US Army Corps of Engineers ${ }_{\circledast}$ Engineer Research and Development Center

\title{
Determination of NRHP Eligibility for 26 Buildings at Fort McCoy, Wisconsin
}

Adam D. Smith and Sunny E. Adams

December 2018
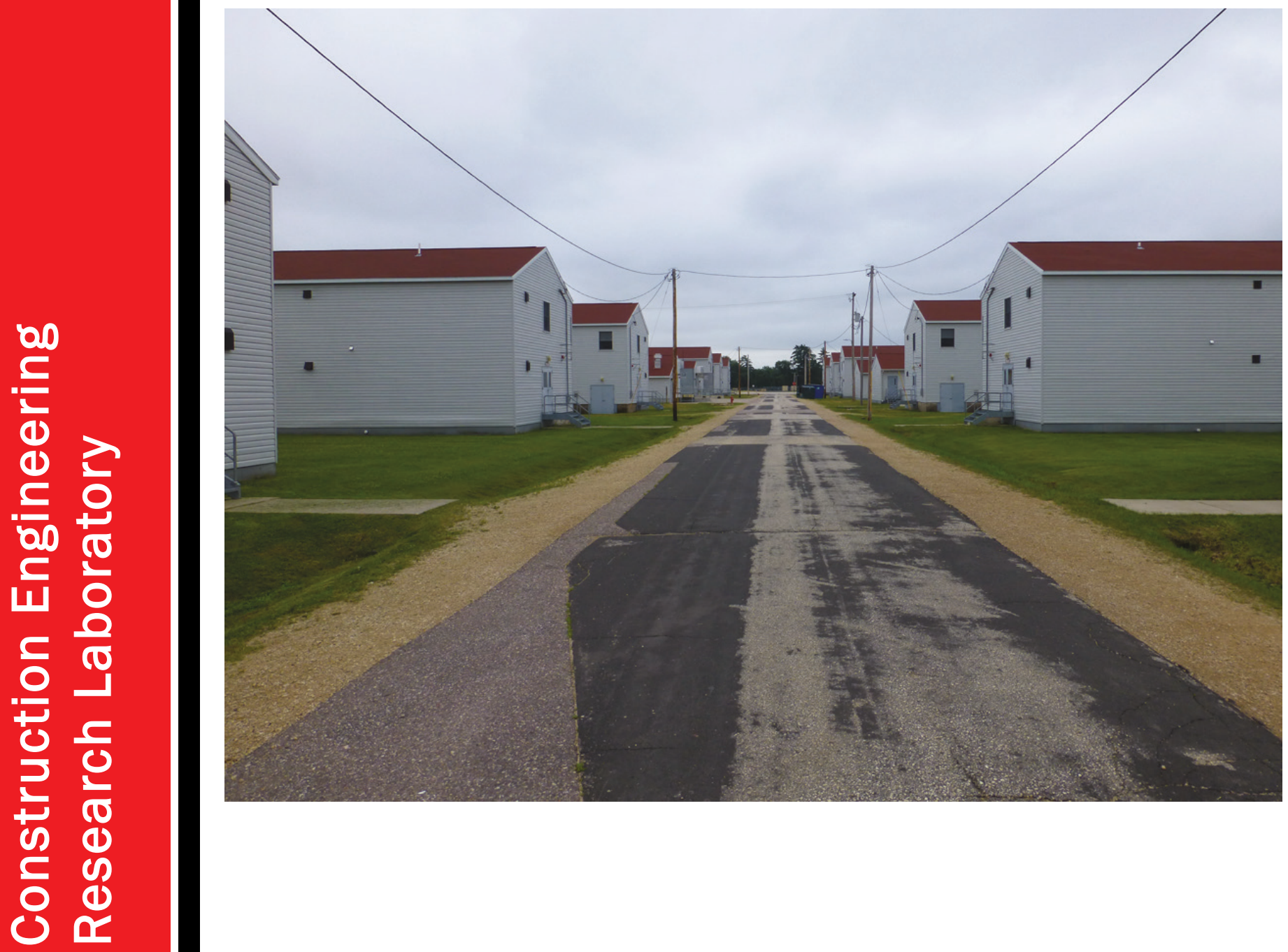
The U.S. Army Engineer Research and Development Center (ERDC) solves the nation's toughest engineering and environmental challenges. ERDC develops innovative solutions in civil and military engineering, geospatial sciences, water resources, and environmental sciences for the Army, the Department of Defense, civilian agencies, and our nation's public good. Find out more at www.erdc.usace.army.mil.

To search for other technical reports published by ERDC, visit the ERDC online library at http://acwc.sdp.sirsi.net/client/default.

Cover Photo: Looking south on South H Street in the 1600 Block at Fort McCoy (ERDC-CERL 2018). 


\title{
Determination of NRHP Eligibility for 26 Buildings at Fort McCoy, Wisconsin
}

\author{
Adam D. Smith and Sunny E. Adams \\ Construction Engineering Research Laboratory \\ U.S. Army Engineer Research and Development Center \\ 2902 Newmark Drive \\ PO Box 9005 \\ Champaign, IL 61826-9005
}

Final Report

Approved for public release; distribution is unlimited.

\footnotetext{
Prepared for Cultural Resources Manager

Directorate of Public Works

Fort McCoy WI 54656

Under Project 474178, "NRHP Integrity Analysis - Fort McCoy"
} 


\section{Abstract}

The U.S. Congress codified the National Historic Preservation Act of 1966 (NHPA), the nation's most effective cultural resources legislation to date, mostly through establishing the National Register of Historic Places (NRHP). The NHPA requires federal agencies to address their cultural resources, which are defined as any prehistoric or historic district, site, building, structure, or object. Section 110 of the NHPA requires federal agencies to inventory and evaluate their cultural resources, and Section 106 requires them to determine the effect of federal undertakings on those potentially eligible for the NRHP.

Fort McCoy is in west-central Wisconsin, entirely within Monroe County. It was first established as the Sparta Maneuver Tract in 1909. The post was renamed Camp McCoy in 1926. Since 1974, it has been known as Fort McCoy. It has one of the largest surviving collections of World War II (WWII) mobilization buildings. This report provides historic context and determinations of eligibility for 26 of those buildings and concludes that only two (fire station and service club) are eligible for the NRHP at the national level, under Criteria A and C. In consultation with the Wisconsin State Historic Preservation Officer, this work fulfills Section 106 and Section 110 processes for these buildings.

DISCLAIMER: The contents of this report are not to be used for advertising, publication, or promotional purposes. Citation of trade names does not constitute an official endorsement or approval of the use of such commercial products. All product names and trademarks cited are the property of their respective owners. The findings of this report are not to be construed as an official Department of the Army position unless so designated by other authorized documents. 


\section{Contents}

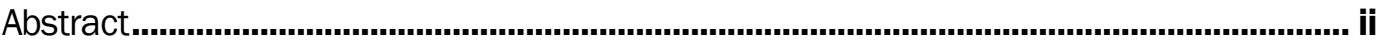

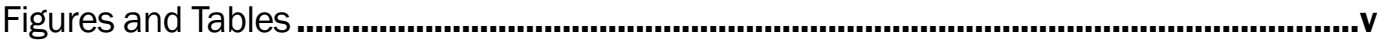

Preface

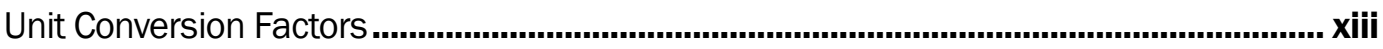

Abbreviations .................................................................................................................xiv

1 Methodology ...................................................................................................................... 1

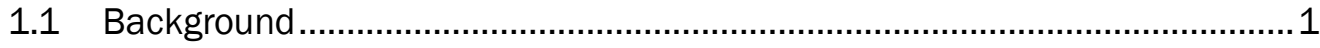

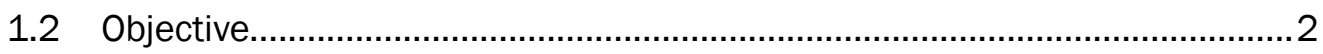

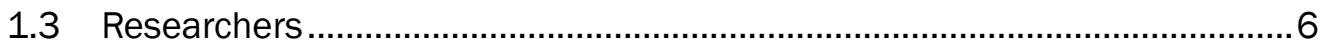

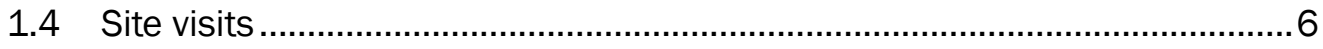

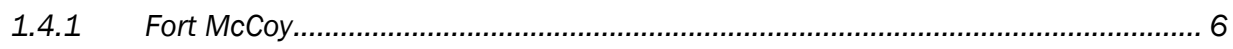

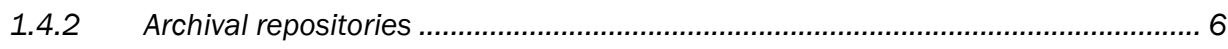

1.4.3 Analysis and evaluation ............................................................................ 6

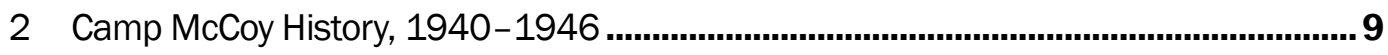

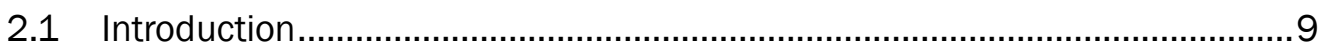

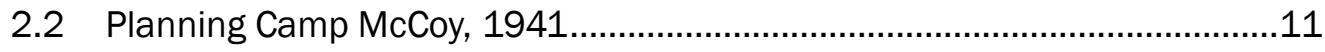

2.3 Constructing Camp McCoy, 1942 .......................................................21

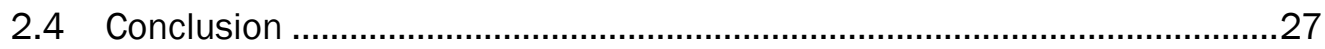

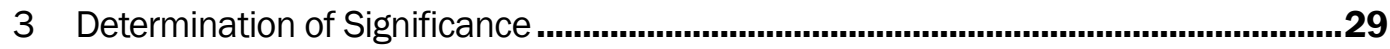

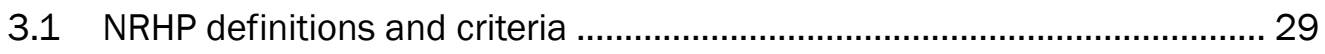

3.2 Final recommendations of significance ...................................................... 30

3.2.1 WWII temporary buildings significance ......................................................... 32

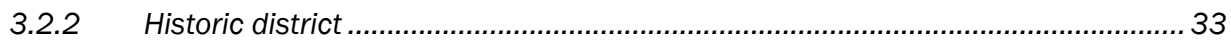

3.2.3 National, state, or local significance.................................................................33

4 World War II Temporary Building Character-defining Features for the 800

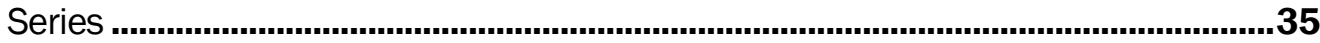

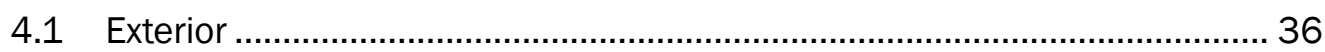

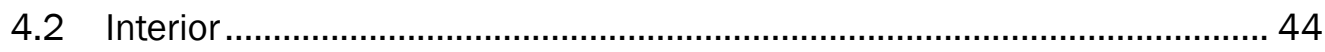

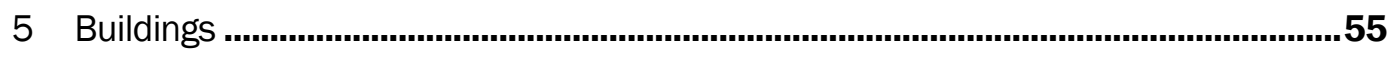

5.1 Fire Station (Building 550).............................................................. 56

5.2 Barracks (Buildings 1602, 1603, 1604, 1607, 1608, 1609, 1610,

$1612,1613,1614,1615,1618,1619,1620$, and 1632)...............................61

5.3 Company Storehouse, Administration, and Recreation (Buildings

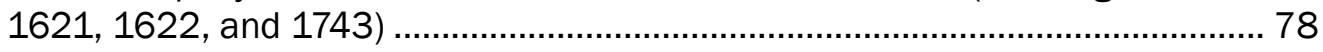

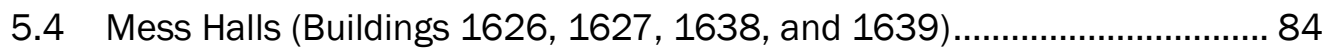

5.5 Service Club (Building 2000) ................................................................ 92 


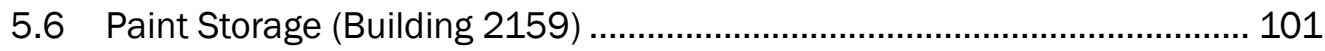

5.7 Administration (Building 2668) ............................................................ 101

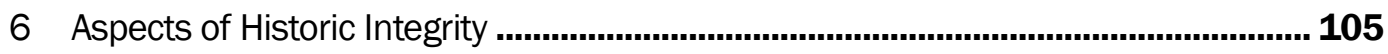

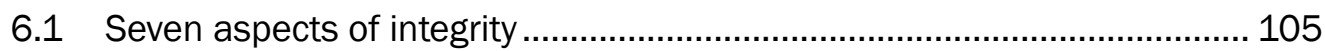

6.2 Integrity determinations ...................................................................... 106

7 Final Recommendations for Eligibility and Conclusion ........................................... 117

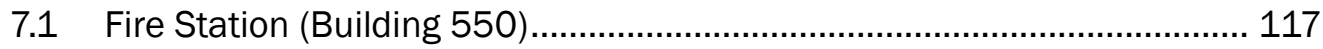

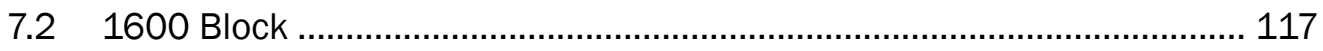

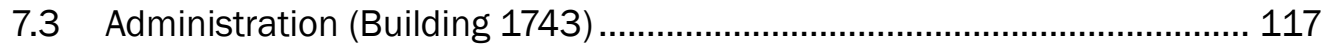

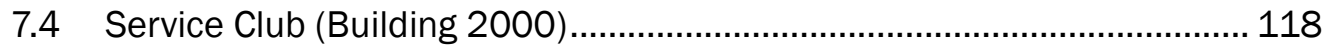

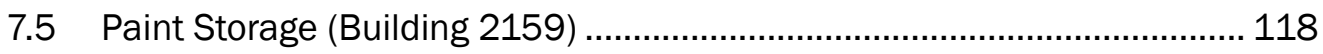

7.6 Administration (Building 2668) ......................................................... 118

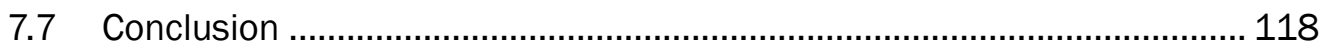

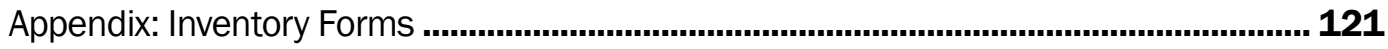

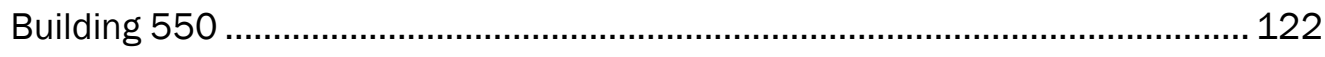

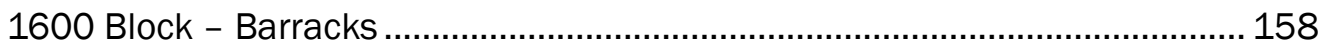

1600 Block (and Building 1743) - Company Storehouse, Administration,

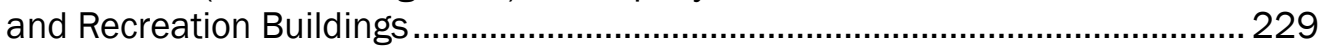

1600 Block - Classroom Buildings (former Mess Halls) ................................... 262

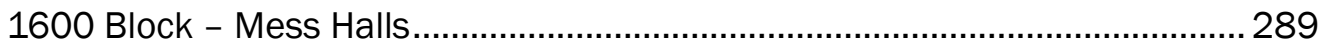

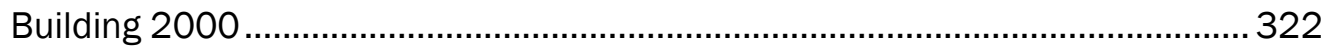

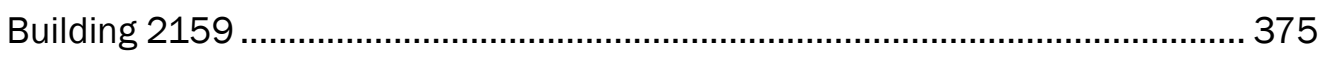

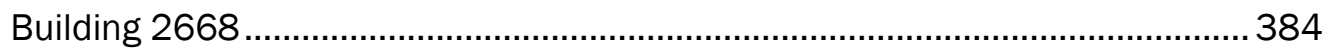

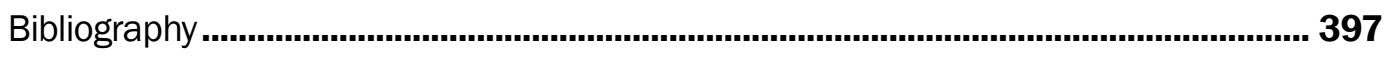

Archival resources - Camp McCoy area........................................................... 400

Archival resources - other ........................................................................ 400

\section{Report Documentation Page}




\section{Figures and Tables}

\section{Figures}

Figure 1. Boundary outline and location of Fort McCoy, in west-central Wisconsin (DPW, Fort McCoy).

Figure 2. Location of the candidate buildings within the Fort McCoy cantonment in 2018 (DPW, Fort McCoy).

Figure 3. Close-up of building locations in the 1600 Block, with planned future action as marked or outlined (Fort McCoy DPW, 2018).

Figure 4. Plan 614-179, dated October 7, 1941, a typical layout for a triangular division prepared by the Site Planning Unit.

Figure 5. "Site Plan A," General Plan of Camp McCoy cantonment prepared by Mead, Ward and Hunt, dated September 27, 1941 and approved by General J. M. Cummins.

Figure 6. Exhibit No. 8 from the March 1942 edition of the Engineering Manual of the Office of the Chief of Engineers, depicting the adaptation of a typical layout at Camp McCoy.

Figure 7. May 1942 plan in 6150 Series, showing the seven construction areas at Camp McCoy and the contractors assigned to each. (Noted that currently the map is missing in the original manuscript, but caption remained; thus, a placeholder used.)

Figure 8. Location of the buildings within the cantonment at Fort McCoy, WI, 2018 (DPW, Fort McCoy). 32

Figure 9. Northwest oblique of Building 2159 (ERDC-CERL, 2018).

Figure 10. Detail from War Department 800 Series plans for mess hall, 1942

(Library of Congress).

Figure 11. Cement asbestos siding with scalloped bottom on Building 550 (ERDC-CERL, 2018).

Figure 12. Close-up of Camp McCoy postcard showing red asphalt roofing, 1942 (ERDC-CERL Collection).

Figure 13. Multipaned window with screen on Building 849 (ERDC-CERL, 2018)............38

Figure 14. Detail of wood window trim on Building 849 (ERDC-CERL, 2018)... 38

Figure 15. Multipaned doors with panels below on Building 849 (ERDC-CERL, 2018) 39

Figure 16. Interior screen door in Building 1129 (ERDC-CERL, 2018).............................39

Figure 17. Wood door trim on Building 849 (ERDC-CERL, 2018). ......................................40

Figure 18. Wood foundation skirting on Building 849 (ERDC-CERL, 2018).......................40

Figure 19. External brick chimney on Building 629 (ERDC-CERL, 2018)........................... 41

Figure 20. Example of an internal brick chimney at Camp McCoy, 1965 (NARA College Park, RG111SC).

Figure 21. Example of wood steps and railing at Camp McCoy, 1951 (NARA

College Park, RG111SC). 
Figure 22. Detail of platform and ladder from War Department 800 Series plans for barracks, 1942 (Library of Congress).

Figure 23. Detail of Camp McCoy postcard showing ladders and platforms, 1942 (ERDC-CERL Collection).

Figure 24. Detail of barracks showing ladders and platforms, 1950 (NARA

College Park, RG111-SC).

Figure 25. Example of an open squad bay in Building 1129 (ERDC-CERL, 2018).

Figure 26. Example of the sink area in a barracks latrine in Building 1129

(ERDC-CERL, 2018).

Figure 27. Example of the toilet area in a barracks latrine in Building 1129 (ERDC-CERL, 2018).

Figure 28. Example of the shower heads in a barracks latrine in Building 1129 (ERDC-CERL, 2018). 46

Figure 29. Example of the NCO room in Building 1129 (ERDC-CERL, 2018)....................46

Figure 30. Open mess hall area in Building 2008 (ERDC-CERL, 2018).............................47

Figure 31. Stove area in Building 2008 (ERDC-CERL, 2018).......................................... 47

Figure 32. Bare wood floor in barracks, Building 1129 (ERDC-CERL, 2018).....................48

Figure 33. Concrete floor in the latrine of Building 550 (ERDC-CERL, 2018)....................48

Figure 34. Fiberboard walls in Building 849 (ERDC-CERL, 2018).....................................49

Figure 35. Fiberboard walls with wainscoting in Building 1866 (ERDC-CERL, 2018). 49

Figure 36. Fiberboard ceiling with in Building 550 (ERDC-CERL, 2018). .........................50

Figure 37. Ceiling vent in Building 550 (ERDC-CERL, 2018). ..........................................51

Figure 38. Metal heater duct in Building 1129 (ERDC-CERL, 2018). ................................51

Figure 39. Former ballroom in Building 2000 (ERDC-CERL, 2018). ..................................52

Figure 40. Exposed wood trusses in library of Building 2000 (ERDC-CERL, 2018)...........52

Figure 41. Brick fireplace in Building 2000 (ERDC-CERL, 2018).......................................53

Figure 42. Aerial view of Fort McCoy cantonment, with the surveyed buildings and areas marked in red, 2018 (DPW, Fort McCoy). 55

Figure 43. Map with location of Building 550, center (Fort McCoy DPW, 2018).................57

Figure 44. 800 Series plan for fire station, Drawing 800-800, 1941 (in drawings

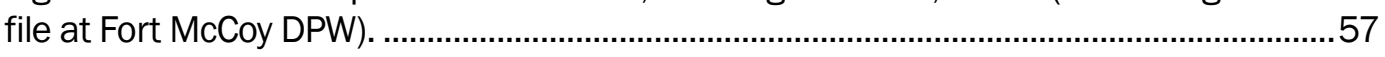

Figure 45. Northwest oblique of Building 550 (ERDC-CERL, 2018).................................58

Figure 46. North side of Building 550 (ERDC-CERL, 2018)............................................58

Figure 47. East side of Building 550 (ERDC-CERL, 2018)..................................................59

Figure 48. South side of Building 550 (ERDC-CERL, 2018)..........................................59

Figure 49. Interior of northernmost fire truck bay on west side of Building 550 (ERDC-CERL, 2018). 60

Figure 50. Original wood floor in former squad bay, Building 550 (ERDC-CERL, 2018). 60

Figure 51. Original latrine in Building 550 (ERDC-CERL, 2018). 
Figure 52. Location of Buildings 1602, 1603, 1604, 1607, 1608, 1609, 1610, $1612,1613,1614,1615,1618,1619,1620$, and 1632 (Fort McCoy DPW, 2018)

Figure 53. 800 Series plan for barracks, Drawing 800-443, 1941 (Library of Congress).

Figure 54. Rear of 800 Series barracks with the original doors, platforms, and ladders, 1950 (NARA College Park, RG111-SC).

Figure 55. Rear of 800 Series barracks with the removal of two doors, 1988 (Library of Congress, HABS WI-308-A-7).

Figure 56. Oblique of 800 Series barracks with the removal of two doors located at the far end of each squad room, 1988 (Library of Congress, HABS WI-308-A-

4).

Figure 57. East side of Building 1602 (ERDC-CERL, 2018)..............................................65

Figure 58. Northeast oblique of Building 1602 (ERDC-CERL, 2018)................................65

Figure 59. Southwest oblique of Building 1602 (ERDC-CERL, 2018)...............................66

Figure 60. West side of Building 1620 (ERDC-CERL, 2018). ..........................................66

Figure 61. Window detail on Building 1602 (ERDC-CERL, 2018)......................................67

Figure 62. Main barracks entrance with metal door and metal steps on Building 1602 (ERDC-CERL, 2018).

Figure 63. Replacement siding on Building 1602 (ERDC-CERL, 2018).....

Figure 64. Replacement siding, foundation covering, and vent on Building 1602 (ERDC-CERL, 2018). 68

Figure 65. Renovated squad room in Building 1602 (ERDC-CERL, 2018). 69

Figure 66. Renovated NCO room in Building 1602 (ERDC-CERL, 2018). 69

Figure 67. Renovated latrine in Building 1602 (ERDC-CERL, 2018)................................70

Figure 68. Replacement doors in Building 1602 (ERDC-CERL, 2018).............................70

Figure 69. Northeast oblique of Building 1603 (ERDC-CERL, 2018).................................71

Figure 70. Southeast oblique of Building 1604 (ERDC-CERL, 2018)................................. 71

Figure 71. Northeast oblique of Building 1607 (ERDC-CERL, 2018). ................................72

Figure 72. Southeast oblique of Building 1608 (ERDC-CERL, 2018). ................................72

Figure 73. Southeast oblique of Building 1609 (ERDC-CERL, 2018)................................73

Figure 74. Southeast oblique of Building 1610 (ERDC-CERL, 2018)................................73

Figure 75. Northwest oblique of Building 1612 (ERDC-CERL, 2018)................................ 74

Figure 76. Northwest oblique of Building 1613 (ERDC-CERL, 2018)................................ 74

Figure 77. Northwest oblique of Building 1614 (ERDC-CERL, 2018)..................................75

Figure 78. Southwest oblique of Building 1615 (ERDC-CERL, 2018).................................75

Figure 79. Southwest oblique of Building 1618 (ERDC-CERL, 2018)................................76

Figure 80. Southwest oblique of Building 1619 (ERDC-CERL, 2018)................................. 76

Figure 81. Southwest oblique of Building 1620 (ERDC-CERL, 2018)................................ 77

Figure 82. North side of Building 1632 (ERDC-CERL, 2018)............................................. 77

Figure 83. Map with location of Buildings 1621, 1622, and 1743 outlined in red (Fort McCoy DPW, 2018). 
Figure 84. 800 Series plan for company storehouse, administration, and recreation buildings, 1943 (Library of Congress).

Figure 85. Southwest oblique of Building 801, Company

Storehouse/Administration and Recreation Building, 1988 (Library of Congress,

HABS WI-208-B).

Figure 86. Building 801 , interior view of recreation area looking north from the

storeroom doorway, 1988 (Library of Congress, HABS WI-208-B).

Figure 87. Southeast oblique of Building 1621 (ERDC-CERL, 2018).

Figure 88. Northeast oblique of Building 1621 (ERDC-CERL, 2018) ...............................81

Figure 89. Northwest oblique of Building 1621 (ERDC-CERL, 2018)..................................82

Figure 90. Southwest oblique of Building 1622 (ERDC-CERL, 2018)...............................82

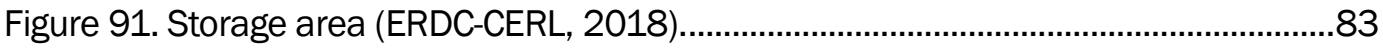

Figure 92. New hallway and latrines (ERDC-CERL, 2018). .............................................83

Figure 93. Former study room space, now office space (ERDC-CERL, 2018).

Figure 94. Map with location of Buildings 1626, 1627, 1638, and 1639 outlined in red (Fort McCoy DPW, 2018). 85

Figure 95. 800 Series plan for a mess hall, Drawing 800-851, 1942 (Library of Congress).

Figure 96. Drawing for connection of two separate mess hall buildings with a hyphen, 2008 (DPW, Fort McCoy) .86

Figure 97. View of mess hall, 1951 (NARA, College Park, RG111SC). 87

Figure 98. Southeast oblique of Building 1626 (ERDC-CERL, 2018). .87

Figure 99. East side of hyphen connecting Buildings 1626 and 1627 (ERDCCERL, 2018). 88

Figure 100. Northeast oblique of Building 1627 (ERDC-CERL, 2018). .88

Figure 101. Interior of mess hall (ERDC-CERL, 2018). .89

Figure 102. Hyphen connecting two mess halls (ERDC-CERL, 2018)................................89

Figure 103. Northwest oblique of Building 1638 (ERDC-CERL, 2018). .90

Figure 104. Building 1606, showing large addition housing latrines similar to 1638 and 1639 (ERDC-CERL, 2018). 90

Figure 105. Interior of classroom [former mess hall] (ERDC-CERL, 2018)........................91

Figure 106. Classroom building (former mess hall) vestibule and latrine addition (ERDC-CERL, 2018). 91

Figure 107. Location of Building 2000 ( Fort McCoy DPW, 2018). .93

Figure 108. 800 Series plan for service club, Drawing 800-517, 1941 (DPW, Fort McCoy). 93

Figure 109. Building 2000, 1952 (NARA, College Park, RG111SC) . .94

Figure 110. Building 2000, 1965 (NARA College Park RG111SC).....................................94

Figure 111. Building 2000, 1978 (NARA, College Park, RG111SC)..................................95

Figure 112. Interior of Building 2000, 1952 (NARA College Park RG111SC).....................95

Figure 113. Interior of Building 2000, 1952 (NARA College Park RG111SC).....................96

Figure 114. Interior of Building 2000, 1978 (NARA College Park RG111SC). .96 


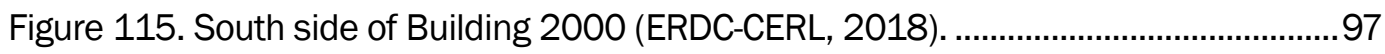

Figure 116. East side of Building 2000 (ERDC-CERL, 2018)..........................................97

Figure 117. North side (ballroom) of Building 2000 (ERDC-CERL, 2018)...........................98

Figure 118. North side of Building 2000 (ERDC-CERL, 2018)...........................................98

Figure 119. Southwest oblique of Building 2000 (ERDC-CERL, 2018)............................99

Figure 120. Interior (ballroom) of Building 2000 (ERDC-CERL, 2018)................................99

Figure 121. Interior (library) of Building 2000 (ERDC-CERL, 2018). ................................ 100

Figure 122. Interior (café) of Building 2000 (ERDC-CERL, 2018).................................. 100

Figure 123. Interior (library and billiard room) of Building 2000 (ERDC-CERL, 2018)

Figure 124. Map with location of Building 2668 outlined in red (Fort McCoy DPW, 2018).

Figure 125. Northwest oblique of Building 2668 (ERDC-CERL, 2018)........................... 103

Figure 126. East side of Building 2668 (ERDC-CERL, 2018) ......................................... 103

Figure 127. Interior of Building 2668 (ERDC-CERL, 2018).............................................. 104

Figure 128. Front elevation of a 74-man barracks with comparison of the original construction, design, and materials from 1950 (left) to 1988 (middle) to 2018 (right). Note, the original wood porch, steps, and handrails have already been removed and replaced with a concrete stoop and metal handrails in middle image (left: NARA; middle: Library of Congress, HABS; right: ERDC-CERL).

Figure 129. Left elevation of a 74-man barracks with comparison of the original construction, design, and materials, as extant in 1988 (left) to 2018 (right) (left: Library of Congress, HABS; right: ERDC-CERL).

Figure 130. Left side and rear oblique of a 74-man barracks with comparison of the original construction, design, and materials, as extant in 1988 (left) to 2018 (right) (left: Library of Congress, HABS; right: ERDC-CERL).

Figure 131. Rear elevation of a 74-man barracks with comparison of the original construction, design, and materials, as extant in 1988 (left) to 2018 (right). Note the original first-floor wood porch, steps, and handrails have been removed and replaced with a concrete stoop and metal handrails; in addition, the left photo shows two of the original fire-exit doors from the squad rooms have been removed, and the door openings have been covered over with newer cement asbestos siding (left: Library of Congress, HABS; right: ERDC-CERL).

Figure 132. Window comparison of the original eight-over-eight wood doublehung window on a 74-man barracks (left) to the current replacement one-overone vinyl window (right) (left: Library of Congress, HABS; right: ERDC-CERL). 109

Figure 133. Original cement asbestos siding with scalloped edge detail and wood foundation skirting (left) compared to current replacement materials of vinyl siding and plywood foundation skirting (right) (left: Library of Congress, HABS; right: ERDC-CERL).

Figure 134. Interior view of the original open-bay entry vestibule with wood screen doors leading to the first floor and to the staircase (left) compared to the modified entry vestibule with partition wall and replacement interior wood door (right) (left: Library of Congress, HABS; right: ERDC-CERL). 
Figure 135. Interior view of an open bay squad room in a 74-man barracks (left) compared to the modified squad room in 2018 (left: Library of Congress, HABS; right: ERDC-CERL).

Figure 136. Interior view of an original NCO room on the second floor of a 74-man barracks (left) compared to a modified NCO room from 2018 (left: Library of Congress, HABS; right: ERDC-CERL).

Figure 137. Interior view of the original sink area in the latrine on the first floor of a 74-man barracks (left) compared to the modified sink area in 2018 (left: Library of Congress, HABS; right: ERDC-CERL).

Figure 138. South elevation comparison of the original construction, design, and materials for the Company Storehouse/Administration and Recreation Building from 1988 (left) to 2018 (right) (left: Library of Congress, HABS; right: ERDCCERL).

Figure 139. Southeast oblique, comparison of the original construction, design, and materials for the Company Storehouse/Administration and Recreation Building from 1988 (left) to 2018 (right) (left: Library of Congress, HABS; right: ERDC-CERL).

Figure 140. Interior view of the original storehouse/administration section looking north toward the recreation section. Comparison of the original construction, design, and materials for the Company Storehouse/Administration and Recreation Building from 1988 (left) to 2018 (right) (left: Library of Congress, HABS; right: ERDC-CERL).

Figure 141. Interior view of the original recreation section looking at the north wall. Comparison of the original construction, design, and materials for the Company Storehouse/Administration and Recreation Building from 1988 (left) to 2018 (right) (left: Library of Congress, HABS; right: ERDC-CERL).

Figure 142. Entry into dining room of a mess hall. Comparison of classroom Building 635 with original design and materials (left) compared to the current condition of Buildings 1605, 1606, 1638, and 1639 (left: Library of Congress, HABS; right: ERDC-CERL).

Figure 143. Entry into kitchen area and long side elevation comparison between the original design and materials compared to the current condition of classroom Buildings 1605, 1606, 1638, and 1639 (left: Library of Congress, HABS; right: ERDC-CERL)

Figure 144. Interior view comparison of the dining room of a mess hall on the left and the interior of it retrofitted into a classroom on the right (left: Library of Congress; right: ERDC-CERL).

Figure 145. Entry into dining room of a mess hall. Building 635 (left) with original design and materials compared to the current condition of Buildings 1616, 1617, 1626, and 1627 (right) (left: Library of Congress; right: ERDC-CERL).

Figure 146. Entry into the kitchen area and long side elevation, with original design and materials (left) compared to the current condition of Buildings 1616, 1617, 1626, and 1627 (right) (left: Library of Congress; right: ERDC-CERL).

Figure 147. Interior view comparison of the dining room of a mess hall on the left and the interior of a renovated mess hall on the right (left: Library of Congress; right: ERDC-CERL).

Figure 148. South (front) elevation of Building 2000 in 1952 (left) compared to 2018 (right) (left: NARA College Park; right: ERDC-CERL). 
Figure 149. Main porch on the south (front) elevation of Building 2000 in 1965 (left) compared to 2018 (right) (left: NARA College Park; right: ERDC-CERL).

Figure 150. Northeast oblique of Building 2000 in 1988 (left) compared to 2018 (right) (left: Library of Congress, HABS; right: ERDC-CERL).

Figure 151. Interior view of the dance hall looking north in Building 2000 in 1952 (left), 1988 (middle) and 2018 (right) (left: NARA, College Park; middle, Library of Congress, HABS; right: ERDC-CERL)

Figure 152. Interior view of the second-floor library, looking east in the east wing of Building 2000 in 1988 (left and center) compared to 2018 (right) (left: Library of Congress, HABS; right: ERDC-CERL).

\section{Tables}

Table 1. List of 26 buildings at Fort McCoy, WI, that were given to ERDC-CERL for evaluation, 2018 (Fort McCoy Real Property Office).

Table 2. List of buildings (DPW, Fort McCoy).

Table 3. List of buildings and determinations of eligibility for the NRHP. 119 


\section{Preface}

This study was conducted for the Cultural Resources Program, Natural Resources Branch, Environmental Division, Directorate of Public Works (DPW) at Fort McCoy, Wisconsin, under Project 474178, "NRHP Integrity Analysis - Fort McCoy." The technical monitor was Dr. Kira E. Kaufmann (Cultural Resources Manager, DPW).

The work was performed by the Land and Heritage Conservation Branch (CNC) of the Installations Divisions (CN), U.S. Army Engineer Research and Development Center - Construction Engineering Research Laboratory (ERDC-CERL). At the time of publication, Dr. Michael S. Hargrave was Chief, CEERD-CNC, and Ms. Michelle J. Hanson was Chief, CEERD-CN. The Deputy Director of ERDC-CERL was Dr. Kirankumar Topudurti, and the Director was Dr. Lance D. Hansen.

COL Ivan P. Beckman was the Commander of ERDC, and Dr. David W. Pittman was the Director. 
ERDC/CERL TR-18-38

xiii

Unit Conversion Factors

\begin{tabular}{|l|l|l|}
\hline Multiply & By & To Obtain \\
\hline acres & \multicolumn{1}{|l|}{$4,046.873$} & square meters \\
\hline feet & 0.3048 & meters \\
\hline inches & 0.0254 & meters \\
\hline miles (U.S. statute) & $1,609.347$ & meters \\
\hline square feet & 0.09290304 & square meters \\
\hline yards & 0.9144 & meters \\
\hline
\end{tabular}




\section{Abbreviations}

\begin{tabular}{|c|c|}
\hline Term & Meaning \\
\hline ACHP & Advisory Council on Historic Preservation \\
\hline AT & annual training \\
\hline $\operatorname{cCC}$ & Civilian Conservation Corps \\
\hline CMTC & Citizens' Military Training Camp \\
\hline $\begin{array}{l}\mathrm{CO} \mathrm{HQ} \\
\mathrm{BLDG}\end{array}$ & Company Headquarters Building \\
\hline CTR & Center \\
\hline DoD & Department of Defense \\
\hline DPW & Directorate of Public Works \\
\hline ENL & Enlisted \\
\hline ERDC-CERL & $\begin{array}{l}\text { Engineer Research and Development Center - Construction } \\
\text { Engineering Research Laboratory }\end{array}$ \\
\hline FACIL & facility \\
\hline $\begin{array}{l}\text { FstFd/ } \\
\text { Snak Bar }\end{array}$ & fast food/snack bar \\
\hline HABS & Historic American Buildings Survey \\
\hline NARA & National Archives and Records Administration \\
\hline NCSHPO & National Council of State Historic Preservation Officers \\
\hline NHPA & National Historic Preservation Act \\
\hline NPS & National Park Service \\
\hline NRHP & National Register of Historic Places \\
\hline PMOA & Programmatic Memorandum of Agreement \\
\hline $\begin{array}{l}\text { RADIOACT } \\
\text { WH INS }\end{array}$ & radioactive storage, warehouse, installation \\
\hline TT & transient training \\
\hline USAR & U.S. Army Reserves \\
\hline $\begin{array}{l}\text { VEH STOR } \\
\text { INST }\end{array}$ & vehicle storage building, installation \\
\hline WWI & World War I \\
\hline WWII & World War II \\
\hline
\end{tabular}




\section{Methodology}

\subsection{Background}

The U.S. Congress codified the National Historic Preservation Act of 1966 (NHPA), the nation's most effective cultural resources legislation to date, in order to provide guidelines and requirements for identifying tangible elements of our nation's past. This legislative requirement was met through creation of the National Register of Historic Places (NRHP). Contained within this piece of legislation (NHPA Sections 110 and 106) are requirements for federal agencies to address their cultural resources, defined as any prehistoric or historic district, site, building, structure, or object. Section 110 requires federal agencies to inventory and evaluate their cultural resources. Section 106 requires the determination of effect of federal undertakings on properties deemed eligible or potentially eligible for the NRHP.

Fort McCoy is located in west-central Wisconsin, east of La Crosse and between the towns of Sparta and Tomah (general area shown in Figure 1). Fort McCoy lies entirely within Monroe County. The U.S. Army first established Sparta Maneuver Tract in 1909 as a field artillery training site. The post was renamed Camp McCoy in 1926, and a Citizens' Military Training Camp (CMTC) ${ }^{1}$ was established at the southern end of the post. A Civilian Conservation Corps (CCC) ${ }^{2}$ was established in 1933 at the former CMTC and existed until 1939. After this, a new cantonment was planned north of the Chicago, Milwaukee, St. Paul and Pacific Railroad utilizing 800 Series War Department mobilization building plans laid out in triangular formation or as the Army referred to it, "triad." The Army deactivated Camp McCoy on 1 February 1953, after which it was utilized for National Guard and Army Reserve training. The Army reactivated the post in 1970, and it was redesignated Fort McCoy in 1974.

\footnotetext{
${ }^{1}$ CMTC was a program that allowed male citizens to obtain basic military training without an obligation to call-up for active duty.

2 The CCC was a public works relief program for environmental projects that operated from 1933 to 1942 for unemployed, unmarried men of ages 17-28. It was one of President Franklin D. Roosevelt's New Deal programs during the Great Depression.
} 
Figure 1. Boundary outline and location of Fort McCoy, in west-central Wisconsin (DPW, Fort McCoy).

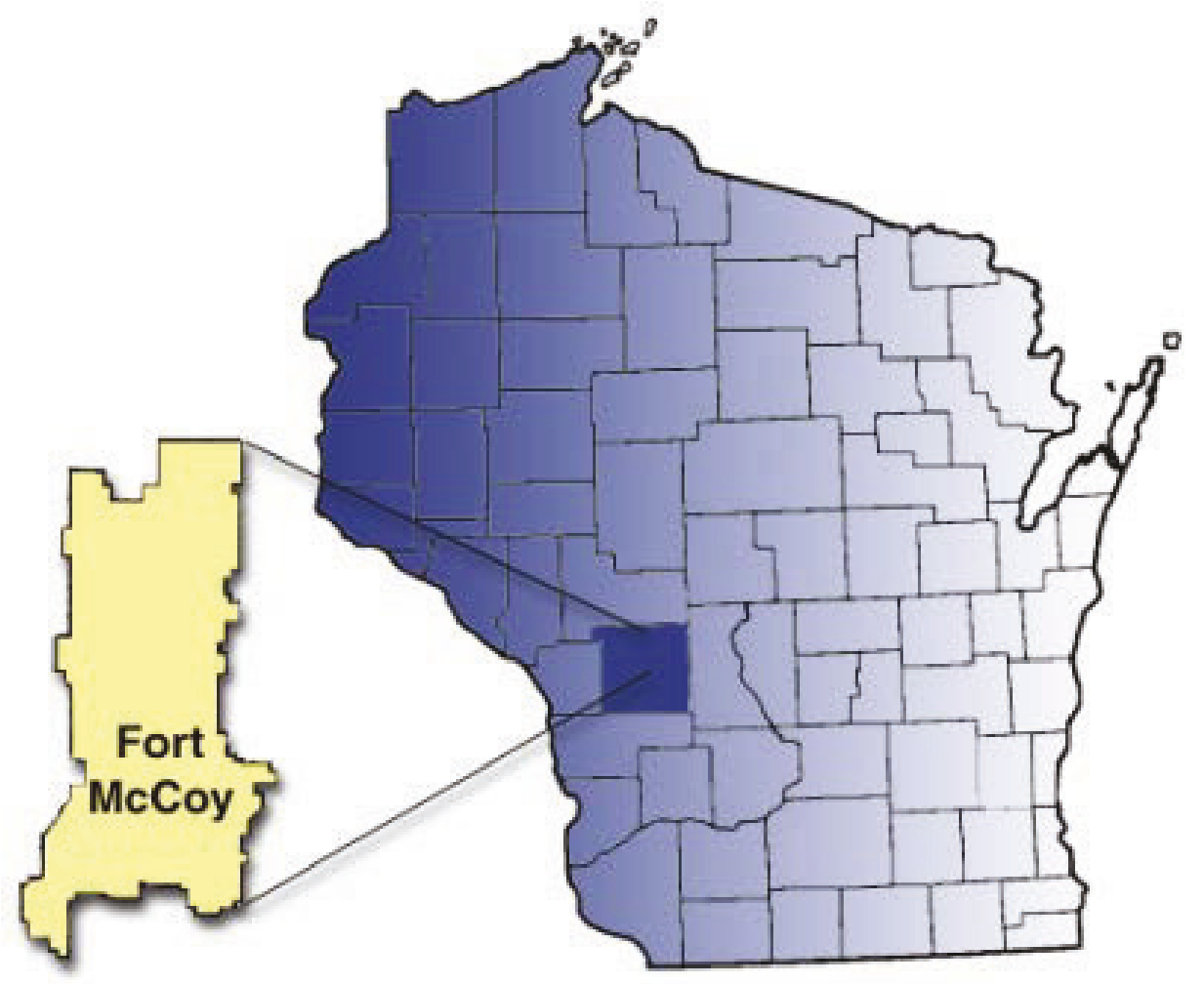

\subsection{Objective}

The objective of this effort was to assess the integrity for listing on the NRHP of 26 buildings at Fort McCoy, Wisconsin. 3 All of these buildings are located within the cantonment of Fort McCoy (Figure 2 and Figure 3). Of the 26 buildings, 25 buildings were constructed as World War II (WWII) temporary buildings in 1942, and 1 building was constructed later in 1947. This survey satisfies Section 110 of the NHPA, and it was used to determine the eligibility of these 26 buildings for inclusion on the NRHP. 
Figure 2. Location of the candidate buildings within the Fort McCoy cantonment in 2018 (DPW, Fort McCoy).

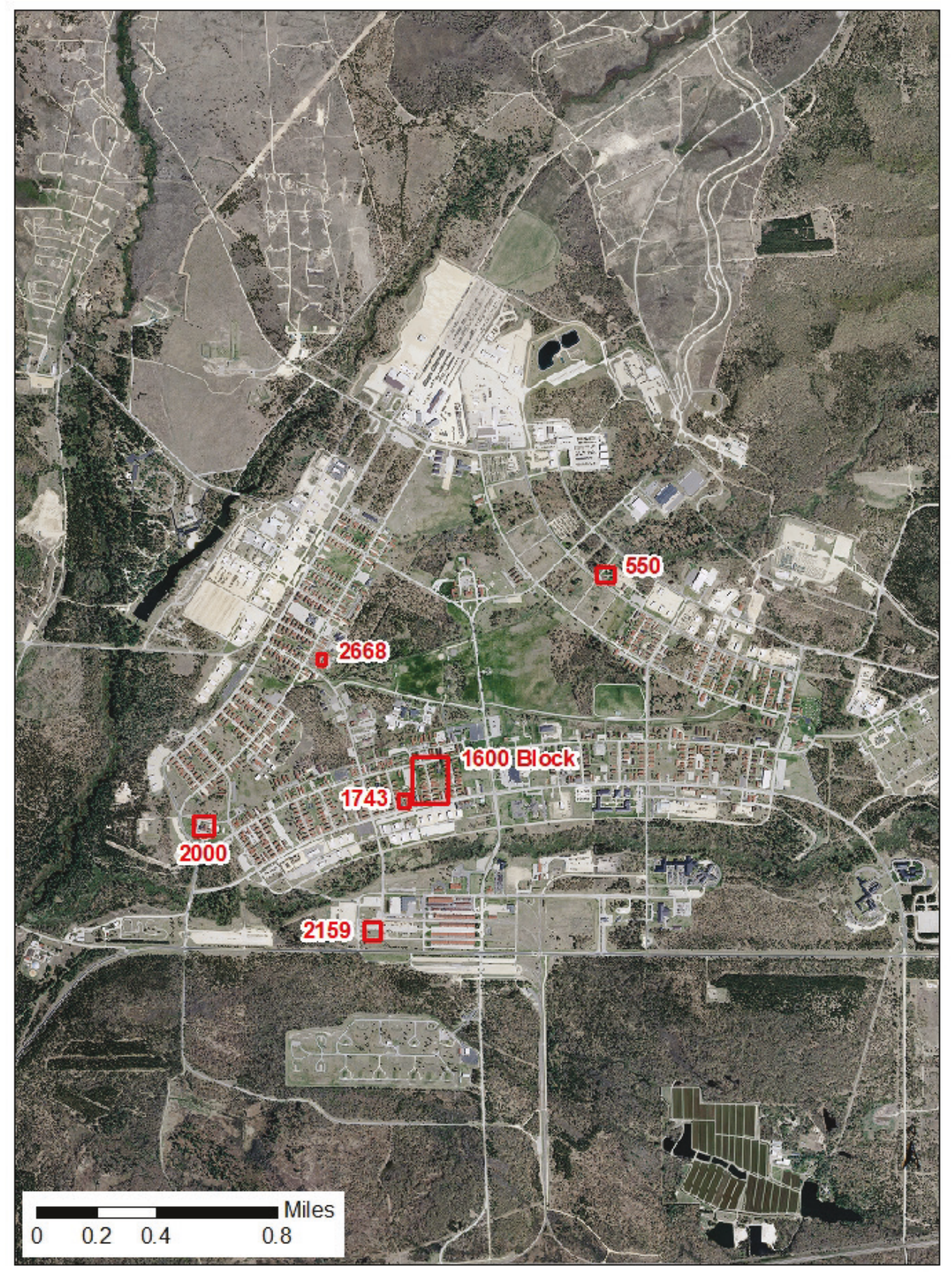


Figure 3. Close-up of building locations in the 1600 Block, with planned future action as marked or outlined (Fort McCoy DPW, 2018). 4

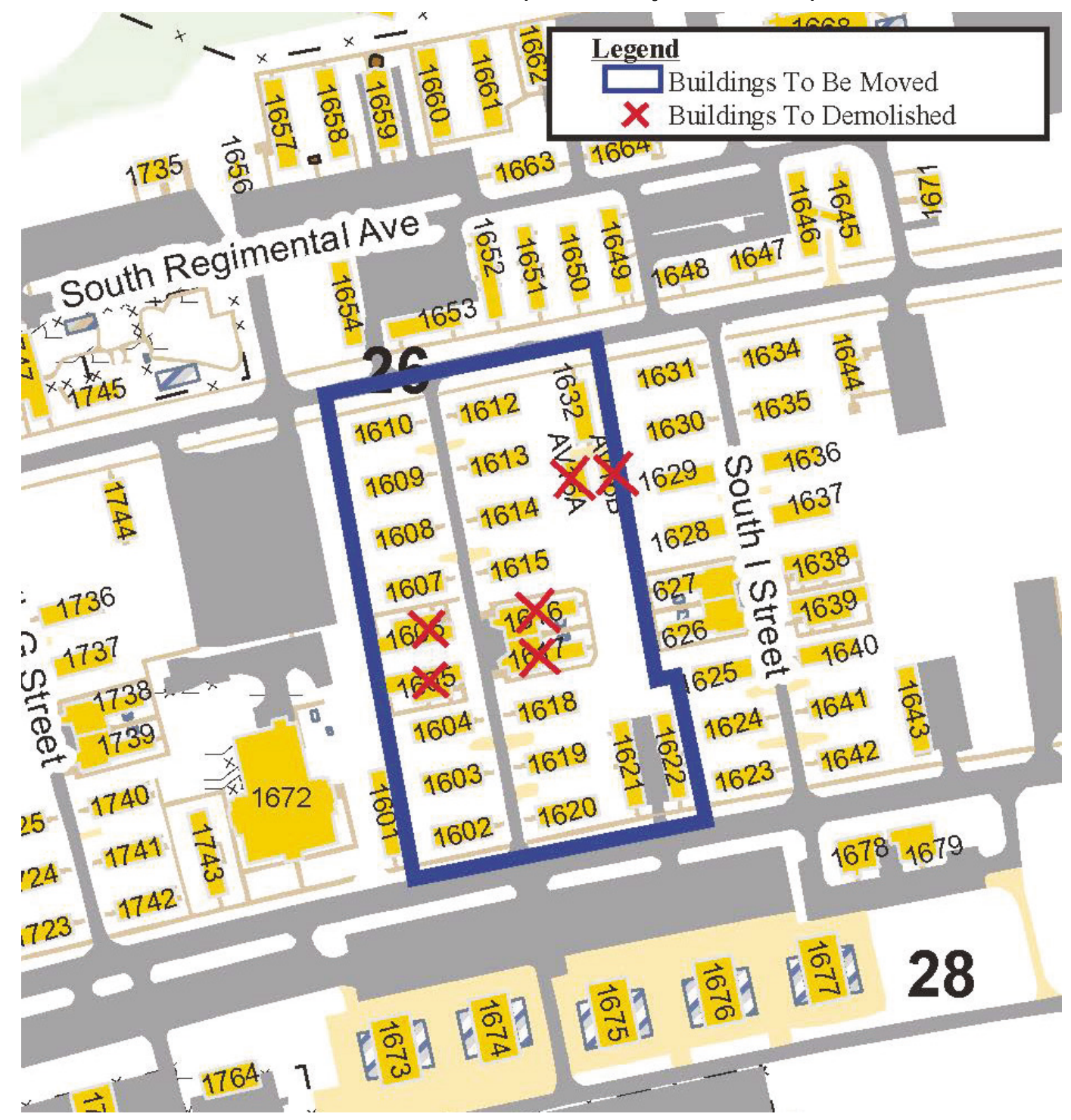

Analyses of the 26 buildings (Table 1) was performed, including basic history and assessment of current conditions. To qualify as eligible for listing on the NRHP, a property must meet at least one of the National Register Criteria for Evaluation as established by the National Park Service, must be significantly associated with an important historic context, and must retain sufficient integrity to convey its significance. 5

\footnotetext{
4 Note that Arms Vaults AV16A and AV16B, constructed in 2011 but scheduled to be demolished, are not part of this report.

5 NPS (National Park Service). National Register Bulletin \#15: How to Apply the National Register Criteria for Evaluation (Washington, DC: U.S. Department of the Interior, National Park Service, 1997).
} 
Table 1. List of 26 buildings at Fort McCoy, WI, that were given to ERDC-CERL for evaluation, 2018 (Fort McCoy Real Property Office).

\begin{tabular}{|c|c|c|c|c|c|}
\hline Facility \# & Built & Historic Use & $\begin{array}{l}\text { Series - } \\
\text { Drawing \# }\end{array}$ & Use in 2000 & $\begin{array}{l}\text { RPI Building } \\
\text { Description }\end{array}$ \\
\hline 550 & Jul-42 & Fire Station & $800-800$ & $\begin{array}{l}\text { Eng/Housing } \\
\text { Maintenance }\end{array}$ & VEH STOR INST \\
\hline 1602 & Jul-42 & 74-Man Barracks & $800-443$ & AT ENL Barracks & TT ENL BARRACKS \\
\hline 1603 & Jul-42 & 74-Man Barracks & $800-443$ & AT ENL Barracks & TT ENL BARRACKS \\
\hline 1604 & Jul-42 & 74-Man Barracks & $800-443$ & AT ENL Barracks & TT ENL BARRACKS \\
\hline 1607 & Oct-42 & 74-Man Barracks & $800-443$ & AT ENL Barracks & TT ENL BARRACKS \\
\hline 1608 & Oct-42 & 74-Man Barracks & $800-443$ & AT ENL Barracks & TT ENL BARRACKS \\
\hline 1609 & Jul-42 & 74-Man Barracks & $800-443$ & AT ENL Barracks & TT ENL BARRACKS \\
\hline 1610 & Jul-42 & 74-Man Barracks & $800-443$ & AT ENL Barracks & TT ENL BARRACKS \\
\hline 1612 & Jul-42 & 74-Man Barracks & $800-443$ & AT ENL Barracks & TT ENL BARRACKS \\
\hline 1613 & Jul-42 & 74-Man Barracks & $800-443$ & AT ENL Barracks & TT ENL BARRACKS \\
\hline 1614 & Jul-42 & 74-Man Barracks & $800-443$ & AT ENL Barracks & TT ENL BARRACKS \\
\hline 1615 & Jul-42 & 74-Man Barracks & $800-443$ & AT ENL Barracks & TT ENL BARRACKS \\
\hline 1618 & Jul-42 & 74-Man Barracks & $800-443$ & AT ENL Barracks & TT ENL BARRACKS \\
\hline 1619 & Jul-42 & 74-Man Barracks & $800-443$ & AT ENL Barracks & TT ENL BARRACKS \\
\hline 1620 & Jul-42 & 74-Man Barracks & $800-443$ & AT ENL Barracks & TT ENL BARRACKS \\
\hline 1621 & Jul-42 & $\begin{array}{l}\text { Company Storehouse, } \\
\text { Admin., \& Recreation }\end{array}$ & $\begin{array}{l}800-661 ; \\
800-460\end{array}$ & Gen Inst Bldg & CO HQ BLDG TT \\
\hline 1622 & Jul-42 & $\begin{array}{l}\text { Company Storehouse, } \\
\text { Admin., \& Recreation }\end{array}$ & $\begin{array}{l}800-661 \\
800-460\end{array}$ & $\begin{array}{l}\text { Company } \\
\text { Storehouse, Admin., } \\
\text { and Recreation }\end{array}$ & GEN INST BLDG \\
\hline 1626 & Jul-42 & 228-Man Mess Hall & $800-851$ & Dining Facility & DINING FACIL TT \\
\hline 1627 & Jul-42 & 228-Man Mess Hall & $800-851$ & Dining Facility & DINING FACIL TT \\
\hline 1632 & Jul-42 & 74-Man Barracks & $800-443$ & AT ENL Barracks & TT ENL BARRACKS \\
\hline 1638 & Jul-42 & 228-Man Mess Hall & $800-851$ & Dining Facility & GEN INST BLDG \\
\hline 1639 & Jul-42 & 228-Man Mess Hall & $800-851$ & Dining Facility & GEN INST BLDG \\
\hline 1743 & Jul-42 & $\begin{array}{l}\text { Company Storehouse, } \\
\text { Admin., \& Recreation }\end{array}$ & $\begin{array}{l}800-661 \\
800-460\end{array}$ & USAR Center & $\begin{array}{l}\text { DEADLINE } \\
\text { HOLDING (Vacant) }\end{array}$ \\
\hline 2000 & Jul-42 & Service Club & $800-517$ & $\begin{array}{l}\text { Fst Fd/Snk Bar } \\
\text { Recreation Ctr }\end{array}$ & RECREATION CTR \\
\hline 2159 & Jul-47 & Paint Storage & $\begin{array}{l}47-018- \\
335\end{array}$ & $\begin{array}{l}\text { Flammable Material } \\
\text { Storage }\end{array}$ & $\begin{array}{l}\text { Old brick hazmat } \\
\text { storage building: } \\
\text { RADIOACT WH INS }\end{array}$ \\
\hline 2668 & Jul-42 & Administration & $800-222$ & Recreation Center & CO HQ BLDG TT \\
\hline \multicolumn{3}{|c|}{ AT = annual training } & \multicolumn{3}{|c|}{ GEN INST BLDG = general instruction building } \\
\hline \multicolumn{3}{|c|}{ CO HQ BLDG = Company Headquarters Building } & \multicolumn{3}{|c|}{ RADIOACT WH INS = radioactive storage } \\
\hline \multicolumn{2}{|c|}{$\mathrm{ENL}=$ enlisted } & & \multicolumn{2}{|c|}{$\mathrm{TT}=$ transient training } & \\
\hline \multicolumn{3}{|c|}{ ENG = engineering } & \multicolumn{2}{|c|}{ USAR = U.S. Army Reserve } & \\
\hline \multicolumn{3}{|c|}{ FACIL = facility, } & \multicolumn{3}{|c|}{$\begin{array}{l}\text { VEH STOR INST = vehicle storage building, } \\
\text { installation }\end{array}$} \\
\hline
\end{tabular}


This final report's main text includes the Fort McCoy WWII historic context and determinations of eligibility for each of the 26 buildings.

\subsection{Researchers}

This project was conducted by the U.S. Army Corps of Engineers, Engineering Research Development Center, Construction and Engineering Research Laboratory (ERDC-CERL) in Champaign, Illinois. The research team included Adam D. Smith, Master of Architecture, as project manager, with 19 years of experience in military architectural history; and Sunny E. Adams, Master of Architecture, as architectural historian, with 15 years of experience.

\subsection{Site visits}

\subsubsection{Fort McCoy}

ERDC-CERL personnel made one trip to Fort McCoy to inventory the buildings in June 2018. During that week, team members evaluated the buildings for their historic architectural integrity.

\subsubsection{Archival repositories}

ERDC-CERL researchers conducted a review of books, archival repositories, and online resources related to Fort McCoy and WWII temporary building construction. The following places were contacted and/or searched:

- NRHP listings and nomination forms (online at https://www.nps.gov/Nr/publications/index.htm);

- Historic drawings, maps, photographs , and information were provided by the Cultural Resources Office of the Directorate of Publics Works (DPW), the Historian's Office, and the Real Property Office's database at Fort McCoy;

- National Archives and Records Administration (NARA), College Park, Maryland (NARA 111-SC and 111-CCS).

\subsubsection{Analysis and evaluation}

After initial research was completed, the team analyzed the gathered information. Archival information and field information were integrated throughout the course of the project. The information available was 
contained in text documents, photographs, and historic maps. Using archival sources, the research team extracted relevant historical information. The material was then combined to tell the story in both text and images.

Using information from a previously published historic context, ${ }^{6}$ the overarching historic integrity was evaluated per the NRHP's definition. A cultural resource can retain or lose its historic integrity, meaning that it either does or does not convey its historic significance. From this evaluation process, a recommendation of eligibility for listing on the NRHP was made. The evaluation followed guidelines published by the National Park Service (NPS) in National Register Bulletin \#15, How to Apply the National Register Criteria for Evaluation; 7 National Register Bulletin \#16A, How to Complete the National Register Registration Form; 8 the National Register Bulletin, How to Prepare National Historic Landmark Nominations; 9 and The Secretary of the Interior's Standards for the Treatment of Historic Properties with Guidelines for the Treatment of Cultural Landscapes. ${ }^{10}$

\footnotetext{
6 HABS No. WI-308. "Fort McCoy (Camp McCoy)," Sparta vicinity Monroe County, Wisconsin, HABS No. WI-308. (Washington, DC: Historic American Buildings Survey, National Park District, Department of the Interior, 1988). Catalogued by Library of Congress as HABS WIS,41-SPAR.V, 1-: https://cdn.loc.gov/master/pnp/habshaer/wi/wi0200/wi0229/data/wi0229data.pdf.

7 NPS, National Register Bulletin \#15: How to Apply the National Register Criteria for Evaluation.

8 NPS, National Register Bulletin \#16A: How to Complete the National Register Registration Form (Washington, DC: U.S. Department of the Interior, National Park Service, 1997).

9 NPS, National Register Bulletin: How to Prepare National Historic Landmark Nominations (Washington, DC: U.S. Department of the Interior, National Park Service, 1999).

10 Anne E. Grimmer, The Secretary of the Interior's Standards for the Treatment of Historic Properties with Guidelines for Preserving, Rehabilitating, Restoring \& Reconstructing Historic Buildings [rev. of 1995 document of same name by Kay D. Weeks and Anne E. Grimmer] (Washington, DC: U.S. Department of the Interior, National Park Service, Technical Preservation Services, 2017). https://www.nps.gov/tps/standards/treatment-guidelines-2017.pdf.
} 
[Intentionally blank.] 


\section{Camp McCoy History, 1940-1946}

The information and some wording in the sections below was extracted from the Historic American Buildings Survey (HABS) of Fort McCoy, ${ }^{11}$ as written in 1988 but edited here for clarity and conciseness. Other documents stored at Camp McCoy were also used and are documented via footnotes herein.

\subsection{Introduction}

During six months in 1942, a greatly enlarged Camp McCoy was constructed near Sparta, Wisconsin, as a mobilization cantonment capable of housing 35,000 U.S. Army soldiers. Although other Army camps and cantonments were built during the early 1940s, none was larger than Camp McCoy. Today, the Wisconsin post is known as Fort McCoy. It claims additional distinction as the site of one of the largest surviving collections of WWII mobilization buildings and structures. An inquiry into the history of the planning and construction of Fort McCoy offers considerable insights into the mobilization effort mounted by the Army between 1940 and 1943 as well as the physical characteristics of the planned communities and architecture that resulted.

Camp McCoy first began in 1909 as Sparta Maneuver Tract, a small, seasonal training ground located four miles southwest of the present McCoy cantonment. Until 1917, regular Army artillery batteries conducted occasional exercises on the grounds of a 14,000-acre military reservation ${ }^{12}$ created from the former McCoy ranch and adjacent tracts, some three and one-half miles northeast of the town of Sparta, Wisconsin. ${ }^{13}$ This area was divided approximately in half by the Chicago, Milwaukee, St. Paul, and Pacific Railroad. North of the tracks was a maneuver camp known as

\footnotetext{
11 Historic American Buildings Survey. “Fort McCoy (Camp McCoy)," Sparta vicinity Monroe County, Wisconsin, HABS No. WI-308. (Washington, DC: Historic American Buildings Survey, National Park District, Department of the Interior, 1988). Catalogued by Library of Congress as HABS WIS,41-SPAR.V, 1-. https://cdn.loc.gov/master/pnp/habshaer/wi/wi0200/wi0229/data/wi0229data.pdf. Some authorship credit to James A. Glass, Ph.D., Field Supervisor, Fort McCoy Project.

12 Reservation is an encompassing term for property (usually a large area) over which the U.S. government has exclusive jurisdiction. It is also separate from the surrounding state in a territorial sense.

13 Post Engineer Office, Camp McCoy, "Historical Data Camp McCoy, Wisconsin" (Camp McCoy, January 15, 1946), 5 [typescript copy of original report in box marked "Historical Engineering Records," in the "Meatlocker" storage room, Building 2145, Fort McCoy]; Martha Sorenson, "Post Becomes a Reality in 1909," The Real McCoy [Fort McCoy newspaper], Vol. 3, No. 11 (May 29, 1986) 2-3.
} 
Camp Emory Upton. An artillery camp known as Camp Robinson was established south of the tracks. ${ }^{14}$

When the United States entered World War I (WWI) in 1917, the War Department (the Cabinet-level agency that oversaw operations of the U. S. Army at that time) decided to build a training camp for draftees in the Upper Midwest region at the McCoy reservation, then known as Camp Robinson. A gridiron plan was quickly laid out, consisting of approximately seven blocks and then barracks, mess halls, warehouses, and stables were erected in parallel rows within the blocks. The buildings were constructed from standard mobilization plans prepared by the Construction Division of the War Department, and these buildings were simple wooden structures, unfinished and hurriedly assembled, and intended for temporary use and removal following the war. During the brief period between the completion of the temporary buildings and the Armistice ending hostilities, field artillery and infantry units occupied the camp and were trained. ${ }^{15}$

Following the conclusion of WWI, the barracks and mess halls were dismantled at Camp Robinson, and the reservation began a 20-year period as a summer training post for regular Army artillery units, Army reserve troops, and National Guard detachments from the western Great Lakes area. During the 1930s, the reservation, now known as Camp McCoy, also became a district headquarters for the Civilian Conservation Corps (CCC), an unemployment relief agency of the New Deal. A few permanent buildings for administering the summer training activities were erected around the perimeters of the World War I cantonment site, which served as a field for the tent camps pitched annually by the visiting troops. ${ }^{16}$

In 1939, as events in Europe moved again toward war, the War Department secured the transfer of 9,500 acres owned by the Department

\footnotetext{
14 U.S. Army Fort McCoy, “Serving America's Armed Forces Since 1909," accessed 29 October 2018: https://home.army.mil/mccoy/index.php/my-fort/all-services/fort-mccoy-guide/history.

15 See the postcard photographs depicting the barracks, mess halls, and stables at Camp Robinson, in the collection of. the Monroe County Local History Room, Sparta, Wisconsin; Post Engineer Office, 5.; Sorenson, 2-3; Lenore Fine and Jesse A. Remington, The Corps of Engineers: Construction in the United States, a volume in the series, United States Army in World War II: The Technical Services (Washington, DC: Office of the Chief of Military History, United States Army, 1972), 7-25.

16 Post Engineer Office, 11; historical photographs of Camp McCoy during the 1920s in the archive of the Public Affairs Office, Fort. McCoy; Post Utilities Office, Camp McCoy, Wisconsin, "Water Supply and Sewage System, Old Camp McCoy \& Prisoner of War Area,"· Plan No. 50-64, dated September 12, 1942, revised to June 26, 1945 [linen drawing in map file, entry hall of Building 2111, Fort McCoy].
} 
of Agriculture to the Camp McCoy reservation. The following year, the Army General Staff decided that the Second Army, composed of 65,000 men, should conduct maneuvers or "war- games" at McCoy. The open, varied terrain of the camp proper and of the surrounding countryside appealed to the commanding officers in the Second Army and other observers as being especially well suited for training exercises involving large numbers of troops. ${ }^{17}$

The maneuvers were conducted successfully in August 1940, and that success apparently contributed to the selection of Camp McCoy as a possible site for a new mobilization cantonment. In the spring of 1941, Major Everett C. Hayden, Zone Constructing Quartermaster for the Sixth Army Corps area, sent Lieutenant Daniel C. Lamoreaux with a real estate appraiser to Wisconsin for an informal survey of the privately-owned land north and northeast of the Camp McCoy reservation. Lamoreaux and the appraiser reported favorably on the suitableness of the adjacent area for a large training cantonment, and Hayden recommended to the Commander of the Sixth Corps that McCoy be considered for expansion. ${ }^{18}$

\subsection{Planning Camp McCoy, 1941}

The investigation of the Wisconsin site was part of a national effort in advance planning ordered by Brigadier General Brehon B. Somervell, Chief of the Construction Division in the Army Quartermaster Corps. Following the passage of the Selective Service Act in October 1940, the War Department had been faced with the immediate planning and construction of camps and cantonments ${ }^{19}$ throughout the United States in less than four months. Sites had to be appraised and acquired; architectengineering firms had to be retained and prepare detailed surveys and plans for layout and road and utility construction; general contractors had to be hired; and construction of the camps and cantonments had to be accomplished. While in civilian projects these planning and construction activities would be carried out sequentially, the almost-immediate need to

\footnotetext{
17 “22 Million Dollar Improvement for McCoy, Monroe County Democrat, July 31, 1941, p 6, col. 4; “Files Tell Events Leading to McCoy Expansion," Monroe County Democrat, July 31, 1941, p 1, col. 5; "Maj. Gen. J.M. Cummins Sees McCoy Possibilities," Monroe County Democrat, August 7, 1941, p 1, col. 3.

18 “Officer Who Helped Build McCoy in '42 Recalls Post's Early Construction Days" [undated, ca. 1950s newspaper clipping, probably either from the Real McCoy (Camp McCoy newspaper) or a Sparta newspaper, found in the archives of the Public Affairs Office, Fort McCoy]; Fine and Remington, 34446.

19 In the mobilization period before World War II, "camps" referred to posts in which the troops lived in tents, and "cantonments" to posts in which the housing was of wooden construction.
} 
house draftees and National Guardsmen forced the Construction Division to conduct them simultaneously. The results were delays, confusion, and large increases in cost. ${ }^{20}$

Somervell, who assumed the construction post at the end of 1940, resolved to avoid the embarrassment of delay and excess cost by erecting the camps and cantonments that would be required for the next wave of draftees. He sent instructions to the Zone Constructing Quartermasters, such as Hayden, to look for suitable sites, and he recruited a first-rate professional staff in Washington to coordinate real estate acquisition, site planning, architectural and engineering design, and construction management. ${ }^{21}$

To direct the efforts of the Zone Constructing Quartermaster to acquire property, Somervell hired John J. O'Brien, a top real estate attorney at the Department of Justice. As Chief of Design in the Engineering Branch, the general appointed Major Hugh J. Casey, a brilliant structural engineer that he borrowed from the U.S. Army Corps of Engineers. To head the Architectural Unit within the Design Section, General Somervell hired George E. Bergstrom, President of the American Institute of Architects. Frederick H. Fowler, President of the American Society of Civil Engineers, was retained as Chief of the Civil Engineering Unit. To lead the site planning effort at the Construction Division, Somervell and Casey recruited Leon $\mathrm{H}$. Zach, a former associate of the Olmsted Brothers, one of the most prominent landscape architecture firms in the nation. These newcomers were to play influential roles in the construction campaign that lay ahead. ${ }^{22}$

Late in May 1941, recommendations for camp and cantonment sites began to arrive at the Construction Division from the commanders of the nine Army Corps areas. Casey and the specialists in the Design Section reviewed each proposal and commented on each with respect to any difficulties in construction or aspects likely to escalate costs. After the Army General Staff reviewed the evaluations of the Construction Division and the field commanders, the Army Chief of Staff, General George C. Marshall, made the final recommendation of sites to Secretary of War

\footnotetext{
20 See the discussion of the planning and construction of the 1940-41 camps and cantonments in Fine and Remington, 198-308.

21 Fine and Remington, 344-54.

22 U.S. Army Corps of Engineers, "Construction Division Expansion," in Civil Engineering, Vol. II, No. 3

(U.S. Army Corps of Engineers, March 1941), 180; Fine and Remington, 333, 347, 401-7.
} 
Henry L. Stimson. In May, the secretary approved nine locations, and in July, he approved fourteen, including Camp McCoy, for preparation of detailed surveys, site plans, and construction drawings. Only advanced planning for the twenty-three sites was to be undertaken; no funds for construction had been sought yet from Congress. General Somervell merely wished to be ready with approved sites and building plans when the next call for mobilization camps came. ${ }^{23}$

In addition to the military and construction advantages the Army found at Camp McCoy, the heavy lobbying of Wisconsin congressmen, senators, and state officials on behalf of the McCoy site undoubtedly influenced the War Department to consider the location favorably. In early 1941, Governor Julius P. Heil instructed the Adjutant General of Wisconsin, Brigadier General Ralph P. Immel, to make the Army aware of the advantages afforded by the western Wisconsin camp for training troops. Simultaneously, U.S. Congressman William H. Stevenson of La Crosse, in whose district McCoy was situated, began to lobby for selection of the camp for expansion by the War Department. The two U.S. Senators from Wisconsin, Alexander Wiley and Robert M. LaFollette Jr., added their influence in Washington. Although Somervell was committed to building only in locations favorable to military training and expeditious construction, he did not object to choosing a site that also enjoyed political backing. Hence, lobbying by state officials and legislators also helped assure the designation of Camp McCoy as an advance planning project. ${ }^{24}$

When Secretary Stimson approved the second group of locations in July, Somervell was ready with a list of architect-engineering firms that Casey's staff had endorsed for carrying out the advance planning tasks. Although several companies had supervised the construction of camps or cantonments in 1940-41, some had experience in civilian projects only. In Wisconsin, the Construction Division sought the services of Mead, Ward and Hunt, a Madison firm falling in the second category. During the last week of July, Clayton N. Ward, senior partner of the company, signed a "cost plus a fixed fee" 25 contract with the War Department for $\$ 100,000$

\footnotetext{
23 Fine and Remington, 353-54.

24 "22 Million Dollar Improvement for McCoy"; “Success at Last” Sparta Herald, August 4, 1941, p 1, col. 6; Fine and Remington, p 377-78.

25 The cost plus a fixed fee contract had been developed by the War Department for emergency construction projects in which the conventional advertisement for bids method was too time consuming. Under a fixed-fee contract, the firm involved agreed to carry out a project for a set fee, and the government paid all expenses.
} 
and the following week, the firm began to hire the first of some 125 engineers who eventually would work on the advance planning for a McCoy cantonment. ${ }^{26}$

At the beginning of August, Ward opened a branch office at Camp McCoy. Topographical surveys, the first task in planning a camp, were started immediately. At the same time, Lieutenant Colonel Hayden, the Zone Constructing Quartermaster, sent two officers from his staff to the camp to establish a local constructing quartermaster office for overseeing the work of Mead, Ward and Hunt. An office from the real estate branch of the zone office arrived to begin appraisals on the private land needed for expanding the McCoy reservation. The proposed project would be immense. News releases at the end of July estimated that the old McCoy reservation would be expanded to approximately 55,000 acres and that a cantonment large enough to house 30,000 men would be built. The total cost of construction was placed at $\$ 22,800,000 .{ }^{27}$

By the end of August, Ward's surveyors completed the topographical field work, and draftsmen at the camp prepared maps for use in other surveys. During the same time, the Mead, Ward and Hunt staff investigated alternate sites within the proposed reservation area for the cantonment proper that would contain barracks, mess halls, administration buildings, service facilities, and social buildings for a training camp. Starting with five locations, the engineers and constructing quartermaster staff narrowed the choice to two possibilities: (a) a relatively level tract between County Trunk Road B (now State Highway 21) and the La Crosse River, or (b) a more compact area between Tarr Creek, which was a small stream flowing roughly east and west to the north of Trunk Road B, and the Northwestern Railroad tracks, which were located south of the road. The engineers also devised tentative layout plans for a cantonment at either of the proposed locations. ${ }^{28}$

\footnotetext{
26 "22 Million Dollar Improvement for McCoy"; “Completion Set for March after Construction Opens," Monroe County Democrat, July 31, 1941, p 1, col. 1.

27 “Construction QM. Office at McCoy," Monroe County Democrat, July 31, 1941, p 1, col. 3; "McCoy Land Appraisal Opens, Begin Activity," Sparta Herald, August 11, 1941, p 1 col. 8; "22 Million Dollar Improvement for McCoy"; "McCoy Survey Project on Schedule, Power Surveyed," Monroe County Democrat, August 21, 1941, p 1, col. 8.

28 "McCoy Survey Project on Schedule, Power Surveyed"; "Triangular McCoy Site Plan Approved by 6th Corps Area," Sparta Herald, September 29, 1941, p 1, col. 1.
} 
As the two layouts took shape in late August and early September, other members of the Mead, Ward and Hunt force began to prepare surveys for the six types of utilities and transportation features that would be constructed in the cantonment: (a) rail spurs from the Northwestern Railroad, (b) water supply sources, (c) water distribution system, (d) sewage disposal plant, (e) roadways, and (f) electrical supply system. As each of the field investigations concluded, draftsmen in the engineering camp office then began to prepare drawings depicting tentative designs for each system. ${ }^{29}$

As September passed, company designers prepared general plans for the cantonment in both of the alternate locations. On September 27, a representative of Mead, Ward and Hunt and Lieutenant Robert K. Sawyer, the Camp McCoy Constructing Quartermaster, presented Site Plan "A," the layout design north of Trunk Road "B," and Site Plan "B," the layout south of Tarr Creek, to Army representatives in Chicago. At the meeting, Major General Joseph M. Cummins, Commanding General of the Sixth Army Corps area, which included Wisconsin, approved the selection of Plan A for construction of the cantonment. $3^{\circ}$ The general's decision followed a field investigation of the two plans and sites the day before by officials of the Quartermaster Corps. The reasons given by Sawyer in a press release for selection of the northern location and layout included the greater room for future expansion available north of Road B and better possibility of adequate drainage. In addition, the more spacious bounds of the north site would allow a layout providing a more pleasing architectural effect. ${ }^{31}$

The plan selected on September 27 was based on the principles set forth in the typical layout plans prepared by Leon Zach and the Site Planning Unit of the Construction Division. Mead, Ward and Hunt used the Zach layout as the basis for designing a cantonment housing a triangular infantry division, the type of Army unit likely to occupy most of the advanced planning sites. The sample design issued by the War Department in the summer of 1941 (Figure 4) ${ }^{32}$ was guided foremost by the training

\footnotetext{
29 "McCoy Survey Project on Schedule, Power Surveyed"; "Complete One McCoy Survey," Monroe County Democrat, September 4, 1941, p 1, col. 7.

30 Among the Army officials present at the meeting and advising the general on his decision were Zone Constructing Quartermaster Hayden; Major G. R. Tyler, representing the Site Planning Unit of the Construction Division in Washington; and supply and medical officers on General Cummins's staff.

31 "Triangular McCoy Site Plan Approved by 6th Corps Area."

32 Figure 4 shows Plan No. 614-179, a "typical layout- diagram” prepared by Zach's staff soon after approval of the Mead, Ward and Hunt plan for McCoy.
} 
requirements of a triangular Army division, the core of which was three infantry regiments. In the diagram, one side of the central parade ground was occupied by six blocks pertaining to the three regiments, which could march to their training areas on the opposite side from the parade field without encountering traffic resulting from the movement of non-infantry troops. The artillery batteries of the division and detachments of special troops were arranged on the other two sides of the parade, allowing them to engage in their training activities without interfering with those of the infantry. 33

Figure 4. Plan 614-179, dated October 7, 1941, a typical layout for a triangular division prepared by the Site Planning Unit.

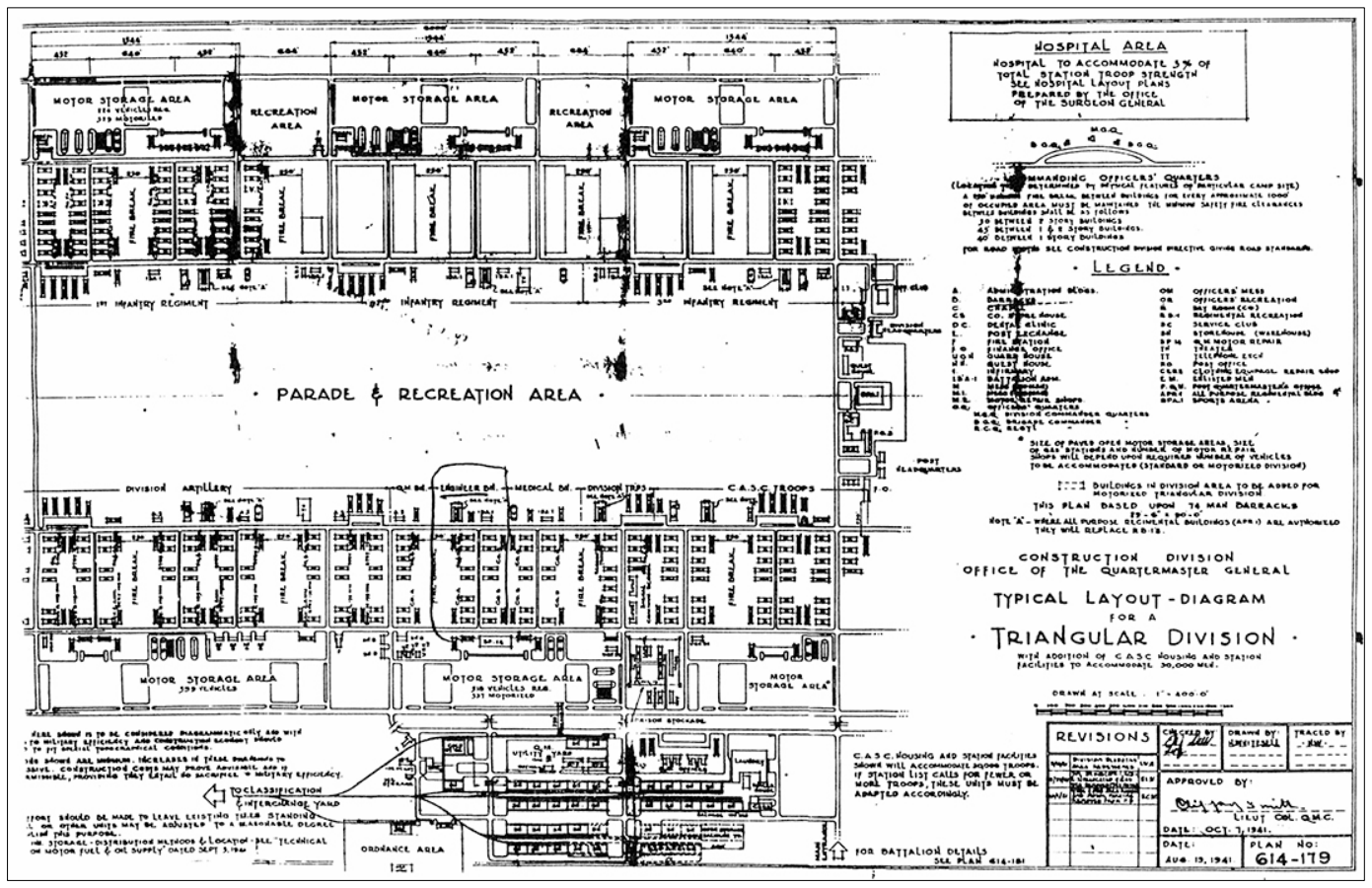

Zach's typical blocks within the general layout were based both on military organizational requirements and city planning principles. Each block was to be occupied by a battalion of troops. Two blocks comprised a regiment. Within a block were six to seven companies, depending on the type of battalion that was involved. Along each street in a block were four mess halls at center, and ten or more barracks, with a company usually occupying three barracks and eating in one of the mess halls. To the rear of the barracks at either end of each street, were company administration

\footnotetext{
33 Also see the discussion of military training requirements in a triangular division plan found in Part IIIArmy Ground Forces Stations, Chapter III-“Site Planning," Engineering Manual, Office of the Chief of Engineers (Washington, DC: War Department, April 1943), sections 3-20 to 3-21.
} 
buildings, one for each company. Zach arrived at the typical block designs after consulting with division officers in the field. 34

The Site Planning chief also invoked city planning precepts in the model layout. Service, social, and cultural buildings, such as infirmaries, service clubs, theaters, and chapels were located within easy reach of each residential block. Incompatible mixtures of land use were avoided: the warehouse and maintenance structures were concentrated in a single block, away from the troop housing areas, and the hospital block, which was not shown on the typical plan, was to be isolated from the cantonment area to reduce the effect of noise and dirt on patients. Traffic circulation for motorized vehicles was carefully considered, with two parallel, main arteries flanking the ends of all troop blocks to avoid congestion and the compactness of the overall configuration reducing travel time. Acknowledging the importance of motorized transport in contemporary warfare, Zach also provided generously for parking areas along the outside of each block. Fire prevention was fostered by placing 250 -foot firebreaks between each block in the cantonment. Finally, as in any civilian community with a population of 30,000 , Zach provided ample open space for recreation and designated the central parade ground for such use. 35

In devising Site Plan A for the new Camp McCoy cantonment, Mead, Ward and Hunt adopted the block and regimental arrangements in the typical layout and observed the city planning principles implied in the model design. The general plan devised by the Madison architectural firm, however, went considerably beyond the Zach layout in offering both an efficient arrangement of blocks and an aesthetically pleasing overall configuration.

In the design approved by General Cummins (Figure 5), the architectengineers arranged three curvilinear segments, each containing from five to nine battalion blocks, in a triangular pattern. The three infantry regiments of the triangular division would occupy the northern segment which was situated close to the infantry training areas in the proposed reservation. The eastern half of the southern segment were intended for the artillery of the division and battalions of special troops attached to the

\footnotetext{
34 See Typical Plan 614-179; Fine and Remington, 351-53.

35 See Figure 4 herein; “Selection of Sites for Structures and Facilities for Economy, Section 3.03 in "Part I--"Selection of Sites, Engineering Manual (February 1943); "Part III - Army Ground Forces Stations," Sections 3-20 through 3-23.
} 
division. The artillery batteries, at the end of the southern segment, were located a short distance north of the firing ranges constructed earlier for artillery practice at the original Camp McCoy. Thus, the two principal groups of troops in a triangular division, the infantry and artillery, could travel quickly and unimpeded to their training areas (Figure 6).

Figure 5. "Site Plan A," General Plan of Camp McCoy cantonment prepared by Mead, Ward and Hunt, dated September 27, 1941 and approved by General J. M. Cummins.

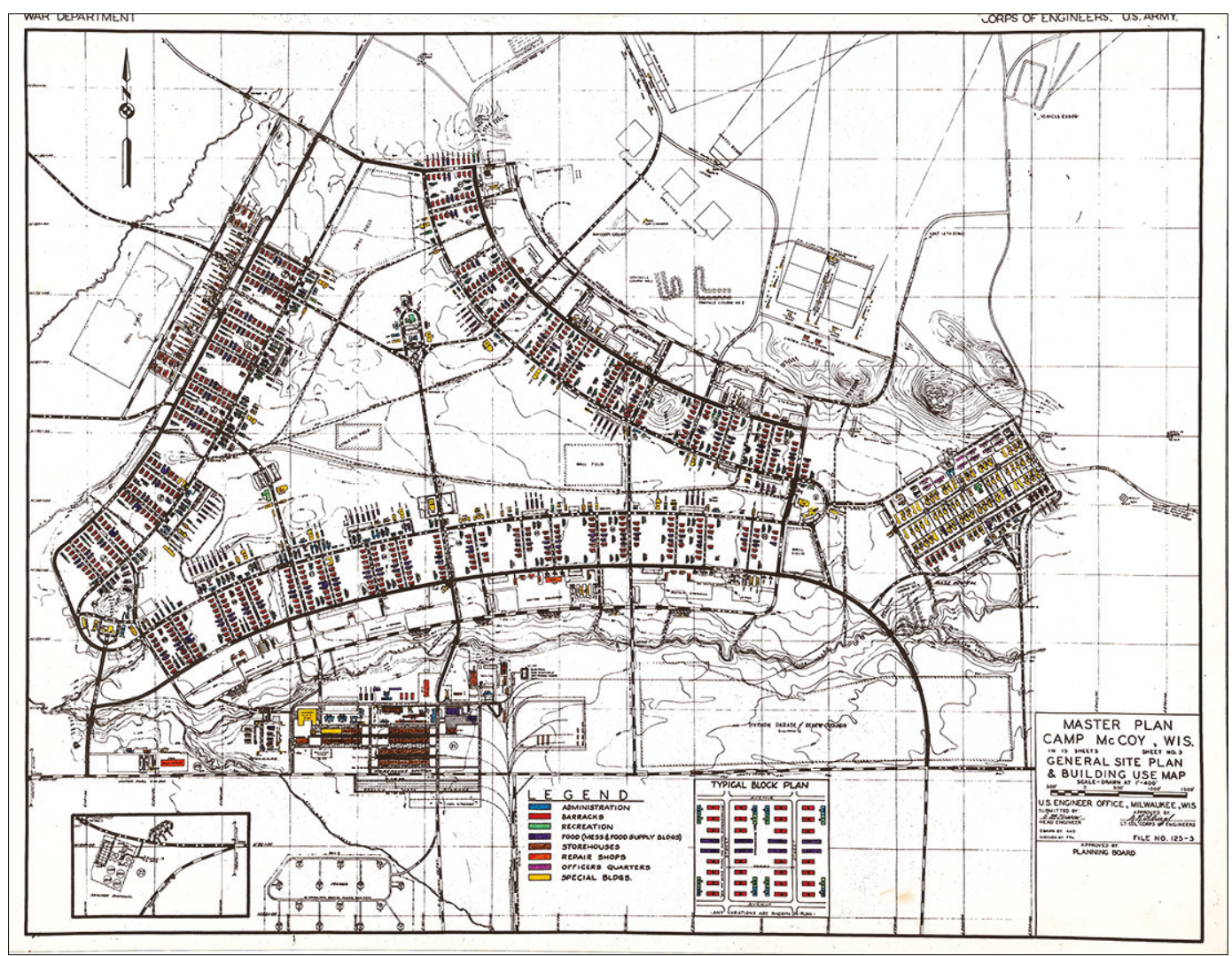

Along the western half of the southern segment and along the entirety of the northwestern segment, the general plan called for occupancy by "nondivisional" troops, which would consist principally of detachments from the various service corps in the Army. The Ordnance Department, Signal Corps, Quartermaster Corps, Medical Corps, tank destroyer detachments, and other non-divisional units would be trained at locations situated away from the division blocks. ${ }^{6}$ Within the triangle formed by the segments was to be built the headquarters of the infantry division, located roughly the same distance from all three segments, for ease of communication.

\footnotetext{
36 See the description of non-divisional troops in "Part III--Army Ground Forces Stations," Section 322(e).
} 
Figure 6. Exhibit No. 8 from the March 1942 edition of the Engineering Manual of the Office of the Chief of Engineers, depicting the adaptation of a typical

layout at Camp McCoy.

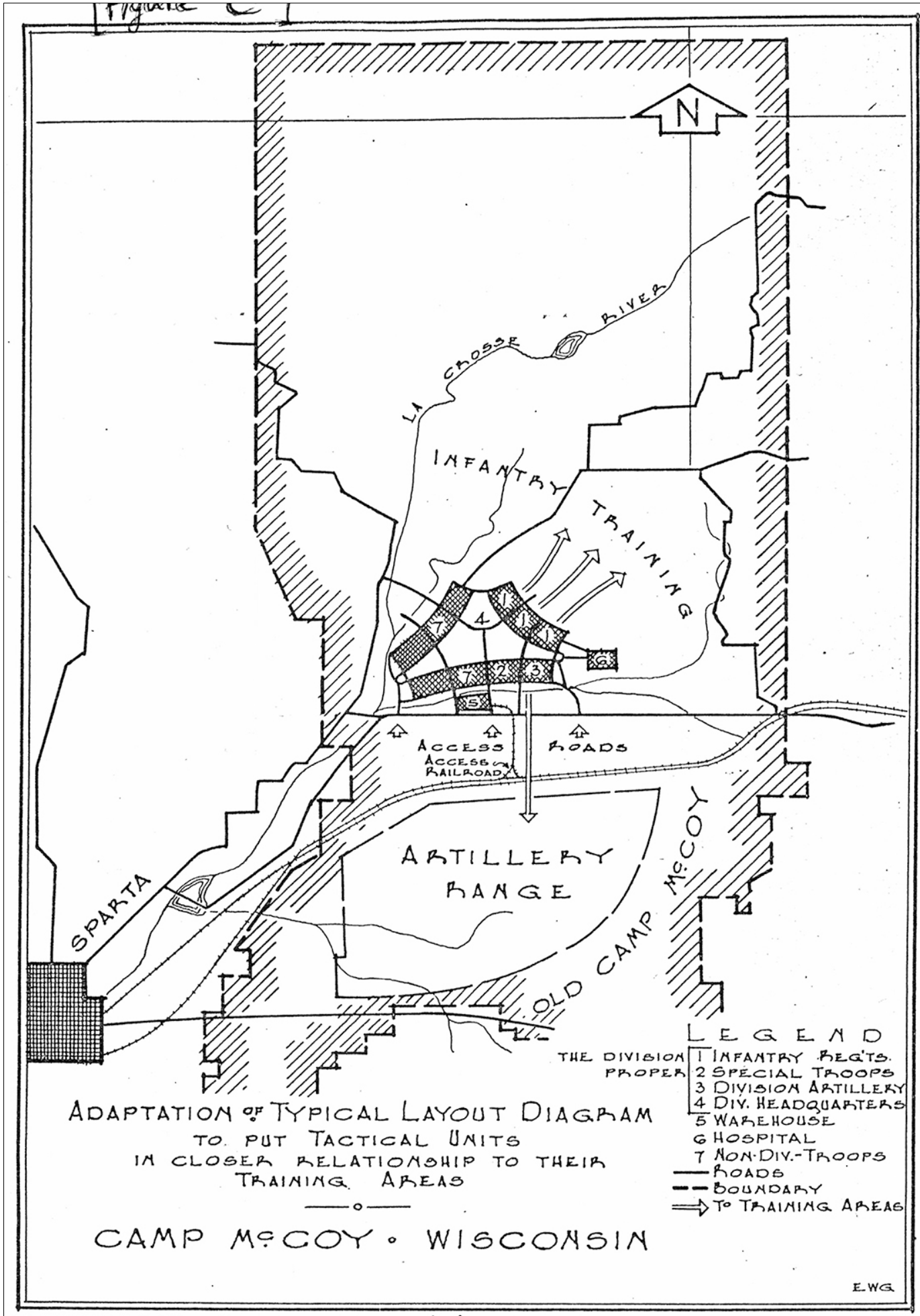

ENGINEERING MANUAL, MARCH 1942, CHAPTER III.

EXHIBIT N: 8 
Mead, Ward and Hunt discarded the gridiron pattern of the typical design and substituted curving lines in all of the north and south segments and in the southern half of the northwest section. The avenues connecting the battalion blocks in troop housing areas would afford constantly-changing perspectives as motorists or pedestrians traveled through the cantonment, counteracting the institutional character of the identical buildings and avoiding the monotony of large numbers of rectilinear blocks present in gridiron plans. The inspiration for the curvilinear design derived from the informal tradition in American city planning, which had begun in the late 19th century with the varied street patterns of suburbs laid out by pioneer landscape architect Frederick Law Olmsted and reached a peak of popularity with model communities planned after World War I, such as Radburn, New Jersey, (1929) and the so-called "green belt" towns built by the federal government (1935-37).37

Mead, Ward and Hunt also worked more formal aesthetic elements into the Camp McCoy plan. The principle of siting monumental buildings at the end of axial streets, widely used in American cities in the early 2oth century as part of the so-called "City Beautiful" movement, found expression in Plan "A" with the location of the division headquarters building at the terminus of the main north-south avenue approaching the center of the triangle from the south. At other locations, the architectengineers placed regimental chapels at the end of battalion streets, providing a pleasing effect with the silhouetted spire (see Figure 5). 38

Mead, Ward and Hunt placed the service areas of the cantonment outside the triangular housing area, much as the Site Planning Unit had recommended. The hospital block, a gridiron section containing over 100 buildings, was to be located about a thousand feet east of the juncture of the northeastern and southern segments of the triangle. The warehouse district and post headquarters were placed in a rectangular block between the south segment and Trunk Road "B." Detention barracks were to be located to the west of the warehouses. The sewage treatment plant and three incinerators were to be erected away from the inhabited sections of the camp, about a mile southwest of the juncture between the northwest and southern segments of the triangle.

\footnotetext{
37 Mel Scott, American City Planning Since 1890 (Berkeley: University of California Press, 1969), 12-13, 259-61, 339-40.

38 Scott 47-65.
} 
With the acceptance by the War Department of the triangular plan at the northern site, Mead, Ward and Hunt were able to complete detailed plans for laying out the cantonment and constructing the necessary roads, railroad spurs, and utilities. By the middle of October, the firm had completed some 58 tracings and completed the advanced planning phase of the Camp McCoy project. 39

Meanwhile, the impetus to begin construction of the Wisconsin cantonment and the other twenty-two "advanced planning" projects diminished. A national emergency requiring immediate construction had not arisen in Europe or the Far East, and Army Chief of Staff Marshall did not wish to request an appropriation from Congress for new cantonments before they were justified. As a consequence, despite the hopefulness of local citizens in towns near Camp McCoy, the Construction Division directed the suspension of activity at the proposed reservation after the architect-engineers finished their work. The constructing quartermaster office at "old" Camp McCoy was closed, and the original post resumed its previous existence as an artillery training ground. 40

\subsection{Constructing Camp McCoy, 1942}

Early in December 1941, the Japanese attacked the United States naval base at Pearl Harbor, Hawaii, and the nation entered World War II. The national emergency justified the mobilization of an additional 500,000 men, and the construction of the advanced planned cantonments. In early January 1942, General Somervell, who had been promoted in December 1941 to Assistant Chief of Staff for Construction (G-4), secured approval from General Marshall for the construction of six cantonments, including

\footnotetext{
39 “Index, Drawings from Area Engineer [Camp McCoy]," February 19, 1944 (in box marked "Historical Engineering Records," "Meatlocker" storage room, Building 2145, Fort McCoy.

40 Fine and Remington, 413-17; "Prospects for McCoy Post Looking Bad," Sparta Herald, October 6, 1941, p 1, col. 1; "184th Field Artillery Unit Arrives at Camp McCoy,". Sparta Herald, October 13, 1942, p. 1, col 8.
} 
the expansion of Camp McCoy. By the end of January, fifteen such projects had been approved or were under construction. ${ }^{41}$

The 1942 cantonments were to be built by the Corps of Engineers, which had assumed responsibility for all Army construction in December 1941. Unlike the camps and cantonments of the 1940-41 construction campaign, in which a single large contractor undertook a complete project under a cost plus a fixed fee arrangement, the 1942 plans would be advertised for bid and awarded to multiple contractors under a fixed price contract. Such an arrangement would control costs, which had greatly exceeded the original estimates for 1940-41 work, and would permit smaller, regional contractors to participate in the immense, multi-billion dollar emergency construction program ahead, even if they lacked sufficient financial backing to undertake a single $\$ 22$ million project. ${ }^{2}$

In Chicago, Lieutenant Colonel Everett C. Hayden, now Assistant Division Engineer for Construction in the Great Lakes Region of the Corps, ordered specifications to be prepared for the Camp McCoy project. The principal volume of specifications, "General Housing, Hospital Boiler House and Steam Distribution," was compiled in late January and early February 1942.43 On February 14, Hayden started taking bids in Chicago for the principal contracts. By February 25, additional specifications had been prepared and released to prospective bidders, covering construction of the sanitary and storm sewerage system, sewage treatment plant, water supply and distribution system, roads, drainage, parking areas, motor fuel storage

\footnotetext{
41 Fine and Remington, 479-82; “Camps Awarded and/or Underway [and] Advanced Planning -- Camps," January 22, 1942 (National Archives, 107-23-894) as quoted in Historic American Building Survey, HABS 41-308, 47; The other advanced planning cantonments constructed in 1942 besides McCoy included Camp Carson, Colorado; Camp Campbell, Kentucky; Camp Atterbury, Indiana; Camp Rucker, Alabama; Camp White, Medford, Oregon; Camp Pickett, Virginia; Camp Swift, Bastrop, Texas; Camp Butner, Durham, North Carolina; Camp Adair, Oregon; Camp Gordon, Georgia; and Camp Beale, California. Busch and Wasch, ibid; "Status of Construction for Divisions to be Activated in 1942," [memorandum written in the G- 4 construction office, Army General Staff], February 25, 1942 (from “Numerical File, 1921 to March, 1942, Director S. S. and P, G-4," National Archives, 165-234-469).

42 Fine and Remington, 474-78, 521, 569-71.

43 “The 'Daddy' of Camp McCoy to New Fields," The Real McCoy, October 16, 1942, p. 8, col 1; "Bids on McCoy Work Started February 14," Sparta Herald, February 16, 1942, p. 1, col 8; and U. S. Engineer Office, Chicago, III. Construction Division, Corps of Engineers, U. S. Army. Specification No. DE-11. "Camp McCoy." Sparta, Wisconsin. Volume I--Specifications for Construction of General Housing, Hospital Boiler House and Steam Distribution and the Utilities Therein," revised February 14, 1942 (original copy in box marked "1942 Specifications," "Meatlocker" storage room, Building 2145, Fort McCoy).
} 
and distribution, pump houses and water storage reservoirs, electric distribution system, and all aspects of the hospital block. 44

News of the revived McCoy cantonment arrived in Sparta, Wisconsin, via a telegram from La Crosse Congressman William H. Stevenson on February 5, 1942. On February9, the U.S. District Attorney in Madison, Wisconsin, filed a motion in federal court to condemn the 9,600-acre site of the cantonment proper. The War Department was to take possession of the site on March 10, so construction could begin as soon as possible. Shortly after the motion was filed, real estate appraisers and negotiators from the Corps of Engineers arrived to begin negotiation with the owners of the private tracts comprising both the cantonment site and the larger reservation. 45

About the middle of February 1942, Colonel Hayden sent Lieutenant Daniel C. Lamoreaux to the cantonment site to establish a field engineering office for directing construction work. Bids were opened and awarded between March 20 and April 2 for most of the contracts. Nine contracts were let for the utilities, roadways, and railroad spurs. The immense work of constructing the 1,487 buildings of the cantonment was split into seven contracts, each pertaining to a different construction area. ${ }^{46}$ All contractors came from the northern Midwest area. The principal contracts went to concerns in St. Paul or Minneapolis, Minnesota, which were the largest nearby cities. Figure 7 shows the location of the seven construction areas in May 1942.

\footnotetext{
44 "Bids on McCoy Work Started February 14"; "Work at McCoy Scheduled to Start About March 20: Bids to Close March 7th,"· Monroe County Democrat, February 26, 1942, p 1, col 8.

45 “U.S. To Receive Bids for Camp McCoy Project, Monroe County Democrat, February 5, 1941, p 1 col 8; "Construction Is Authorized for Camp McCoy - Will Take Over 9600 Acres Land, Monroe County Democrat, February 12, 1942, p 1, col 8; “Work Started on McCoy Building," Monroe County Democrat, February 19, 1942, p 1, col 8.

46 "Bids on McCoy Work Started February 14;" "Work Started on McCoy Building;" "Camp McCoy Cost Is Increased Seven Million," Sparta Herald, March 23, 1942, p 1, col 1; "More Wisconsin Concerns Get Contracts at McCoy," Monroe County Democrat, April 2, 1942, p. 1, col 7.
} 
Figure 7. May 1942 plan in 6150 Series, showing the seven construction areas at Camp McCoy and the contractors assigned to each. (Noted that currently the map is missing in the original manuscript, but caption remained; thus, a placeholder used.)

\author{
Figure 6 \\ could not be \\ located in original \\ manuscript.
}

Early in April, Lieutenant Colonel Hayden assumed full responsibility for overseeing construction of the cantonment, becoming Area Engineer of the McCoy project. Hayden was selected by the Corps of Engineers for the Wisconsin assignment because of his success in 1940, securing the prompt and economical completion of the mobilization cantonment at Fort Custer, Michigan, which was one of the largest projects of the 1940-41 construction campaign. As Area Engineer, Hayden checked on the work of the contractors, overcame difficulties in supplies or logistics, and supplied standard War Department building drawings to the construction firms. He also supervised his own staff's preparation of new tracings based on the plans of Mead, Ward and Hunt to provide guidance to the contractors on the general layout, drainage, utilities, and roadways. 47

The building drawings used by the contractors were nearly all part of the 800 Series of standard War Department plans, prepared the previous spring and summer by George Bergstrom and his Architectural Unit within the Construction Division, for use in the advanced planning cantonments. Despite impending shortages in many construction

\footnotetext{
47 “The 'Daddy' of Camp McCoy to New Fields;" “Index to Drawings from Area Engineer." [NOTE: The drawings prepared by the Area Engineer's office were given numbers beginning with 6150.]
} 
materials, General Somervell persuaded Secretary of War Stimson and General Marshall in January 1942 to allow the Corps of Engineers to proceed with the 800 Series plans, which featured well-constructed wooden buildings with ample structural members and such comforts as indoor plumbing and forced hot-air furnaces. 48

During the previous, peacetime construction campaign in 1940-41, the Construction Division of the Quartermaster Corps had used the 700 Series of standard drawings, which had provided uniform designs for nearly 300 distinct building types needed for the smooth operation of a mobilization cantonment. In the 800 Series, Bergstrom made slight structural improvements, removed superfluous features, and enlarged several basic building types, such as the troop barracks. Otherwise, he retained most of the features of the 1940-41 buildings. At Camp McCoy, Hayden distributed 800 Series plans to the construction area contractors for nearly all the building types to be erected. Where plans in the newer series were not available, 700 Series drawings were employed. 49

There were approximately 100 building types erected at Camp McCoy. ${ }^{50}$ The types including the greatest number of buildings were those devoted to housing, eating, storage and administration, and recreation. There were 469 barracks erected ${ }^{51}-42$ of them as bachelor officer quarters; 172 company mess halls; and 184 combined company storehouse, administration, and recreation buildings. Structures in the troop housing blocks of the triangle were designed for use by certain sizes of Army units. For example, a barracks was intended to house a platoon, and a mess hall or a storehouse-administration-recreation building was intended for use by a company. Two battalion administration buildings and a row of bachelor officer quarters were at the end of each battalion block. At the edge of each regimental area was a cluster of regimental buildings: post

\footnotetext{
48 Fine and Remington, 350-51, 479, 482-83.

49 Diane Shaw Wasch, Perry Bush, Keith Landreth, and James Glass. World War II and the U.S Army Mobilization Program: A History of the 700 and 800 Series Cantonment Program (Washington, DC: Joint effort of HABS/HAER of National Park Service, Department of Interior; and DoD Legacy Resources Management Program of the Department of the Army Engineering and Housing Support Center, 24 March 1992), 12, 42-43, 46; Fine and Remington, 350-51.

50 Footnote in HABS WIS, 41-SPAR.V, 1-(1988): "Some of the building types listed were built between the end of the initial construction campaign and the end of the war. Others were the results of remodeling during the war, such as the Personnel and Separation Centers."

${ }^{51}$ Although 469 were erected, several were remodeled for use as part of the Personnel Center in 1945. See Post Engineer Office, "Historical Data, Camp McCoy, Wisconsin,"· 10.
} 
exchange, chapel, administration building, infirmary, and regimental commanders' quarters.

In areas around the periphery of the triangular section were constructed building types associated with personal services and post maintenance. Block 10, the hospital section, contained several kinds of wards, clinics, and nurses' quarters. Block 21, the warehouse area, included rows of storehouses along rail sidings, a large laundry for cleaning the clothing of the cantonment residents, a bakery, cold food storage, and post headquarters buildings. Along the outer edges of the three segments in the triangle were motor pool and maintenance buildings and fire stations. Service (social) clubs and movie theatres were built at periodic junctures between regimental and detachment groupings.

The structural systems used in Camp McCoy buildings were constructed with either balloon framing or platform framing, entirely composed of wood members. Wall sheathing and flooring were of softwood. The interiors were unfinished, with neither plaster nor paint applied. Instead, tempered pressed wood, fiber insulation board, and gypsum board were used to cover walls and ceilings. The exteriors in the troop housing sections were of uniform appearance: grayish white, asbestos cement siding on the walls, yellow wooden trim, gray wooden foundation skirting, and red asphalt shingle roofs. In the warehouse section, wooden, shiplap siding was employed and painted yellow. The temporary nature of a mobilization cantonment was emphasized by the use of concrete piers for foundations, rather than excavated basement walls. ${ }^{2}$

After the last of the contracts was let in April, the War Department curtailed the release of information to the public regarding construction activities.53 As a consequence, few specifics are known about the efforts mounted during the next four months. Local lore relates that the demand for speedy completion caused Area Engineer Hayden and the contractors

\footnotetext{
52 For detailed analyses of the construction of buildings in the McCoy cantonments, see the Historic American Buildings Survey documentation reports on Buildings 1129, 801, and 635, prepared in September 1988 (see HABS No. WI-308-A, WI-308-B, and WI-308C, respectively - full details at footnotes \#61, \#62, and \#63).

53 No articles can be found in either of the Sparta, Wisconsin, newspapers regarding construction activities at the cantonment between April and August 1942.
} 
to employ some 20,000 construction workers to complete the project on time. 54

In late August, Colonel George MacMullin, post commander of the new camp, hosted an open house for the public of the nearly- completed cantonment. During the next month and a half, units from the old camp gradually occupied sections of the new area, while the contractors finished their work. The finished capacity of the cantonment was 36,836 officers and enlisted men; the total cost at the end of 1942 was $\$ 32,383,000$. In October 1942, the 10oth Infantry Regiment from Hawaii became the first full Army detachment to occupy the McCoy cantonment. 55

\subsection{Conclusion}

In October 1942, the Second Infantry Division of the Army arrived for training at the cantonment, remained for a year and then left for action in the Italian campaign. Subsequently, the 76th Division took over the cantonment for a year and departed for service in the liberation of Western Europe in December 1944. Also in 1944, Camp McCoy became a personnel center for the Army, receiving and redirecting soldiers for new assignments. As the war closed, the personnel center assumed the role of discharging veterans. The personnel center closed in May 1946, and most other functions at the camp halted a year later. 56

After three years of relative inactivity, Camp McCoy was reactivated by the Defense Department for training of regular, reserve, and National Guard units in the Fifth Army area for service in the Korean War. A reassignment and separation center also was opened at the camp during the Korean

\footnotetext{
54 The 20,000 figure was also used by Clayton Ward of Mead, Ward and Hunt in August 1941, as an estimate of the number of workers required to build the cantonment; "Doubled Population Predicted for Sparta, Tomah, Districts, Monroe County Democrat, August 14, 1941, p 1, col 8.

55 "New Camp McCoy Open Sunday, Monroe County Democrat, August 27, 1942, p 1, col 8; “'All Right, You Guys, We're Moving--On to New Site,"- Real McCoy. Vol. 1, No. 6, August 28, 1942, sec. 1, p 1 ; Sgt. Lew Elkin, "Post Headquarters in New Camp Now," Real McCoy, vol. 1, No. 10, September 25, 1942, p 1, col 1; "Picture Taking Now Permitted, But Cautiously,"· Real McCoy, October 9, 1942, p 1; "List of Completed Jobs by Service Command," January 31, 1943 (from collection, "War Construction Program for Period January 31, 1943-April I 30, 1943," National Archives).

56 Post Engineer Office, “Historical Data,". 6-7; handwritten notations on ditto original report, 18.
} 
conflict. Since 1953, the camp has become a center for training reserve units of the Army and National Guard regiments of the Midwest region. 57 


\section{Determination of Significance}

\subsection{NRHP definitions and criteria}

The identification of historically significant properties is achieved only through the evaluation of their position within the larger historic context. According to the NRHP, historic contexts are defined as "...the patterns, themes, or trends in history by which a specific occurrence, property, or site is understood, and its meaning (and ultimately its significance) within prehistory or history is made clear." ${ }^{8} \mathrm{~A}$ historic property is determined significant or not significant based on the application of standardized NRHP criteria within the property's historical context. To qualify as historic, a property must have an association with a relevant historic context as well as having retained its physical integrity through which its historic significance is conveyed.

The NRHP Criteria for Evaluation describe how properties and districts are significant for their association with important events or persons (Criterion A and Criterion B), for their importance in design or construction (Criterion C), or for their information potential (Criterion D). A property may be significant under one or more criteria. The following is a brief description of each of the four NRHP Criteria for Evaluation, excerpted from National Register Bulletin \#15: How to Apply the National Register Criteria for Evaluation: 59

A. Event-associated with events that have made a significant contribution to the broad patterns of our history; or

B. Person-associated with the lives of persons significant in our past; or

C. Design/Construction-embodies the distinctive characteristics of a type, period, or method of construction; or that represents the work of a master; or that possesses high artistic values; or that represents a significant and distinguishable entity whose components may lack individual distinction; or

58 NPS, National Register Bulletin \#15, 7.

59 NPS, National Register Bulletin \#15, 2. 
D. Information Potential-yielded, or may be likely to yield, information important in prehistory or history.

\subsection{Final recommendations of significance}

The temporary wood buildings constructed on Fort McCoy with the War Department's 700 Series or 800 Series plans during the WWII era from 1939-1946 were determined significant for listing on the National Register of Historic Places (NRHP) in 1986. That year is when the Programmatic Memorandum of Agreement (PMOA) was signed between the Department of Defense (DoD), the Advisory Council on Historic Preservation (ACHP), and the National Council of State Historic Preservation Officers (NCSHPO). ${ }^{60}$ In the early 1990 , this significance was reaffirmed by the writing of "World War II and the U.S Army Mobilization Program: A History of the 700 and 800 Series Cantonment Program" 61 and the performance of the Historic American Buildings Survey (HABS) across the country on a variety of the 700 and 800 Series planned buildings. Many of the 800 Series of buildings at Fort McCoy were utilized for the HABS documentation.

The Fort McCoy Real Property database has several of these buildings marked as semi-permanent instead of temporary, but the PMOA is clear in its wording, saying that all 700 and 800 Series of plans are covered.

There are 25 buildings to review that were built during the 1939-1946 period of significance (see Table 2 and Figure 8), and their integrity is addressed in Chapter 6. Building 2159, constructed in 1947, is outside the WWII temporary building period of significance and as a paint storage building, it does not in and of itself have significance as a building type. Further, its design and construction is typical of the era (Figure 9) and is not considered significant for the NRHP; therefore, Building 2159 is not explored further in this report.

\footnotetext{
60 American Council on Historic Preservation, "Demolition of World War II Temporary Buildings," Programmatic Memorandum of Agreement among The United States Department of Defense, The Advisory Council on Historic Preservation, National Conference of State Historic Preservation Officers, and the Historic American Buildings Survey/Historic American Engineering Record (Washington, DC: ACHP, 1986).

61 Wasch, et al., World War II and the U.S Army Mobilization Program.
} 
Table 2. List of buildings (DPW, Fort McCoy).

\begin{tabular}{|c|c|c|c|c|c|}
\hline Facility \# & Built & Historic Use & $\begin{array}{l}\text { Series - } \\
\text { Drawing No. }\end{array}$ & Use in 2000 & $\begin{array}{l}\text { RPI Building } \\
\text { Description }\end{array}$ \\
\hline 550 & Jul-42 & Fire Station & $800-800$ & $\begin{array}{l}\text { Eng/Housing } \\
\text { Maintenance }\end{array}$ & VEH STOR INST \\
\hline 1602 & Jul-42 & 74-Man Barracks & $800-443$ & AT ENL Barracks & TT ENL BARRACKS \\
\hline 1603 & Jul-42 & 74-Man Barracks & $800-443$ & AT ENL Barracks & TT ENL BARRACKS \\
\hline 1604 & Jul-42 & 74-Man Barracks & $800-443$ & AT ENL Barracks & TT ENL BARRACKS \\
\hline 1607 & Oct-42 & 74-Man Barracks & $800-443$ & AT ENL Barracks & TT ENL BARRACKS \\
\hline 1608 & Oct-42 & 74-Man Barracks & $800-443$ & AT ENL Barracks & TT ENL BARRACKS \\
\hline 1609 & Jul-42 & 74-Man Barracks & $800-443$ & AT ENL Barracks & TT ENL BARRACKS \\
\hline 1610 & Jul-42 & 74-Man Barracks & $800-443$ & AT ENL Barracks & TT ENL BARRACKS \\
\hline 1612 & Jul-42 & 74-Man Barracks & $800-443$ & AT ENL Barracks & TT ENL BARRACKS \\
\hline 1613 & Jul-42 & 74-Man Barracks & $800-443$ & AT ENL Barracks & TT ENL BARRACKS \\
\hline 1614 & Jul-42 & 74-Man Barracks & $800-443$ & AT ENL Barracks & TT ENL BARRACKS \\
\hline 1615 & Jul-42 & 74-Man Barracks & $800-443$ & AT ENL Barracks & TT ENL BARRACKS \\
\hline 1618 & Jul-42 & 74-Man Barracks & $800-443$ & AT ENL Barracks & TT ENL BARRACKS \\
\hline 1619 & Jul-42 & 74-Man Barracks & $800-443$ & AT ENL Barracks & TT ENL BARRACKS \\
\hline 1620 & Jul-42 & 74-Man Barracks & $800-443$ & AT ENL Barracks & TT ENL BARRACKS \\
\hline 1621 & Jul-42 & $\begin{array}{l}\text { Company } \\
\text { Storehouse, Admin., } \\
\text { \& Recreation }\end{array}$ & $\begin{array}{l}800-661 ; \\
800-460\end{array}$ & GEN INST BLDG & CO HQ BLDG TT \\
\hline 1622 & Jul-42 & $\begin{array}{l}\text { Company } \\
\text { Storehouse, Admin., } \\
\text { \& Recreation }\end{array}$ & $\begin{array}{l}800-661 ; \\
800-460\end{array}$ & GEN INST BLDG & GEN INST BLDG \\
\hline 1626 & Jul-42 & 228-Man Mess Hall & $800-851$ & Dining Facility & DINING FACIL TT \\
\hline 1627 & Jul-42 & 228-Man Mess Hall & $800-851$ & Dining Facility & DINING FACIL TT \\
\hline 1638 & Jul-42 & 228-Man Mess Hall & $800-851$ & Dining Facility & GEN INST BLDG \\
\hline 1639 & Jul-42 & 228-Man Mess Hall & $800-851$ & Dining Facility & GEN INST BLDG \\
\hline 1632 & Jul-42 & 74-Man Barracks & $800-443$ & AT ENL Barracks & TT ENL BARRACKS \\
\hline 1743 & Jul-42 & $\begin{array}{l}\text { Company } \\
\text { Storehouse, Admin., } \\
\text { \& Recreation }\end{array}$ & $\begin{array}{l}800-661 ; \\
800-460\end{array}$ & USAR Center & $\begin{array}{l}\text { DEADLINE } \\
\text { HOLDING (Vacant) }\end{array}$ \\
\hline 2000 & Jul-42 & Service Club & $800-517$ & $\begin{array}{l}\text { Fst Fd/Snk Bar } \\
\text { Recreation Ctr }\end{array}$ & RECREATION CTR \\
\hline 2159 & Jul-47 & Paint Storage & $47-018-335$ & $\begin{array}{l}\text { Flammable } \\
\text { Material Storage }\end{array}$ & $\begin{array}{l}\text { Old brick hazmat } \\
\text { storage building: } \\
\text { RADIOACT WH INS }\end{array}$ \\
\hline 2668 & Jul-42 & Administration & $800-222$ & Recreation Center & CO HQ BLDG TT \\
\hline
\end{tabular}

$\mathrm{AT}=$ annual training,

CO HQ BLDG = Company Headquarters Building

$\mathrm{Ctr}=$ Center

$\mathrm{ENL}=$ enlisted

$\mathrm{FACIL}=$ facility

FstFd/Snk Bar = Fast Food Snack Bar
GEN INST BLDG = general instruction building RADIOACT WH INS = radioactive storage warehouse, installation

$\mathrm{TT}=$ transient training USAR = U.S. Army Reserve VEH STOR INST = vehicle storage building, installation 
Figure 8. Location of the buildings within the cantonment at Fort McCoy, WI, 2018 (DPW, Fort McCoy).

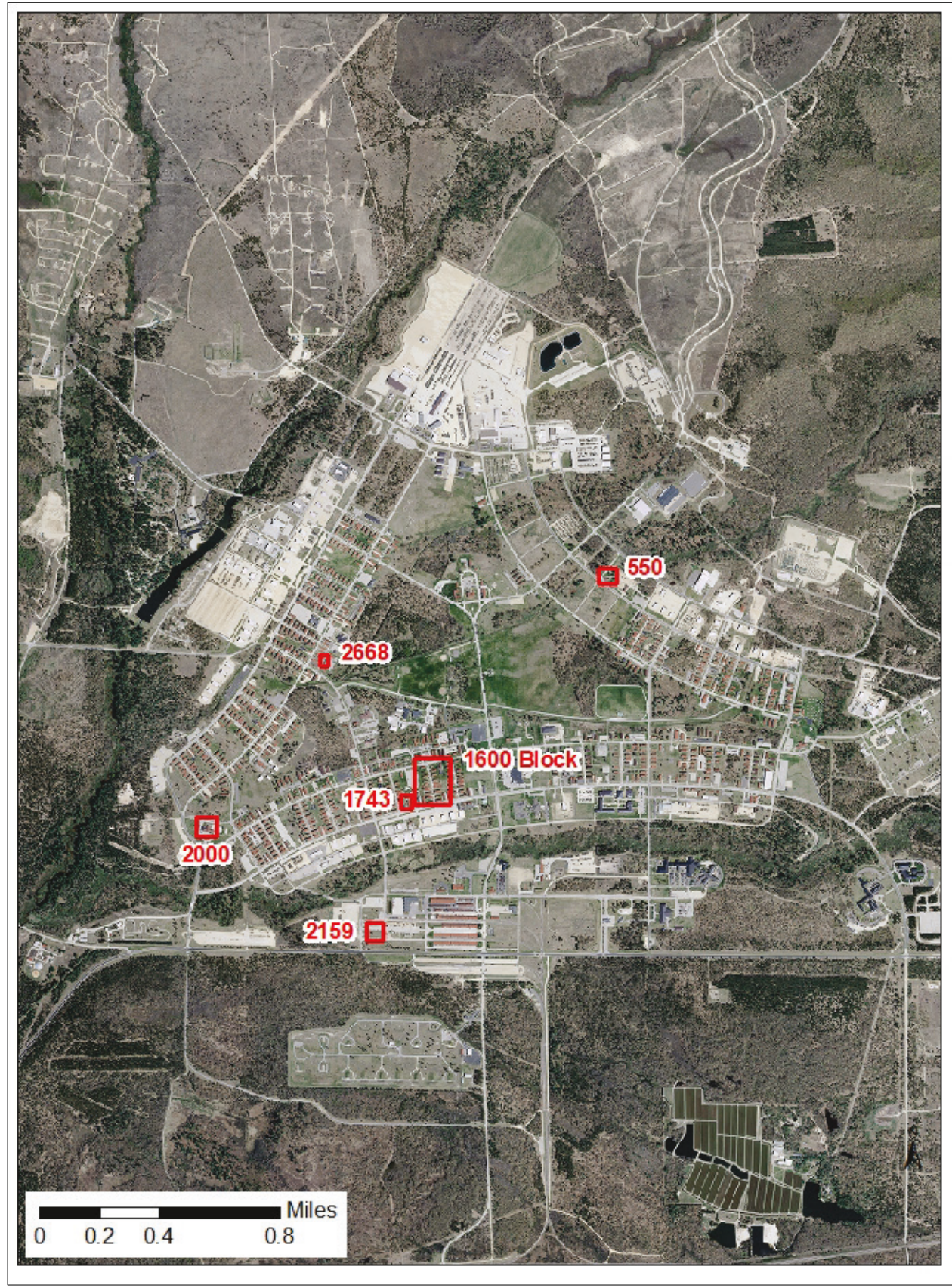

\subsubsection{WWII temporary buildings significance}

The following sections detail findings regarding the historical significance of WWII temporary buildings. 
For Criterion A - Event

The WWII temporary buildings are significant under Criterion A for WWII temporary building construction (1939-1946).

\section{For Criterion $B-$ Person}

There is no significant person associated with WWII temporary buildings.

For Criterion C-Design/Construction

The design and construction of the WWII temporary buildings could not be linked to a specific architect due to their construction from standardized War Department mobilization building plans. They do not possess high artistic values; however, WWII temporary buildings in general were found to be significant for their design, construction, and technological innovation.

For Criterion D - History

The available historical records provided no indication that WWII temporary buildings have yielded, or were likely to yield, any information important in history.

\subsubsection{Historic district}

Buildings 550, 1743, 2000, 2159, and 2668 are physically separated from each other by large distances and cannot be part of a historic district except for one that encompasses all of the Triad. Determining if the Triad is a potential historic district is not part of this project; however, a cursory review was necessary for the buildings located within the 1600 Block. While the WWII-era street system of the Triad appears to be intact, many of the buildings constructed for WWII have been demolished per the 1986 PMOA, and the remaining buildings do not have their integrity from the period of significance.

\subsubsection{National, state, or local significance}

WWII temporary buildings are significant at the national level for their contribution to the war effort during the period 1939-1946. Building 2159 (paint storage) was looked at for local or state significance, but none could 
be found because its design and construction is typical of the era and location (Figure 9).

Figure 9. Northwest oblique of Building 2159 (ERDC-CERL, 2018).

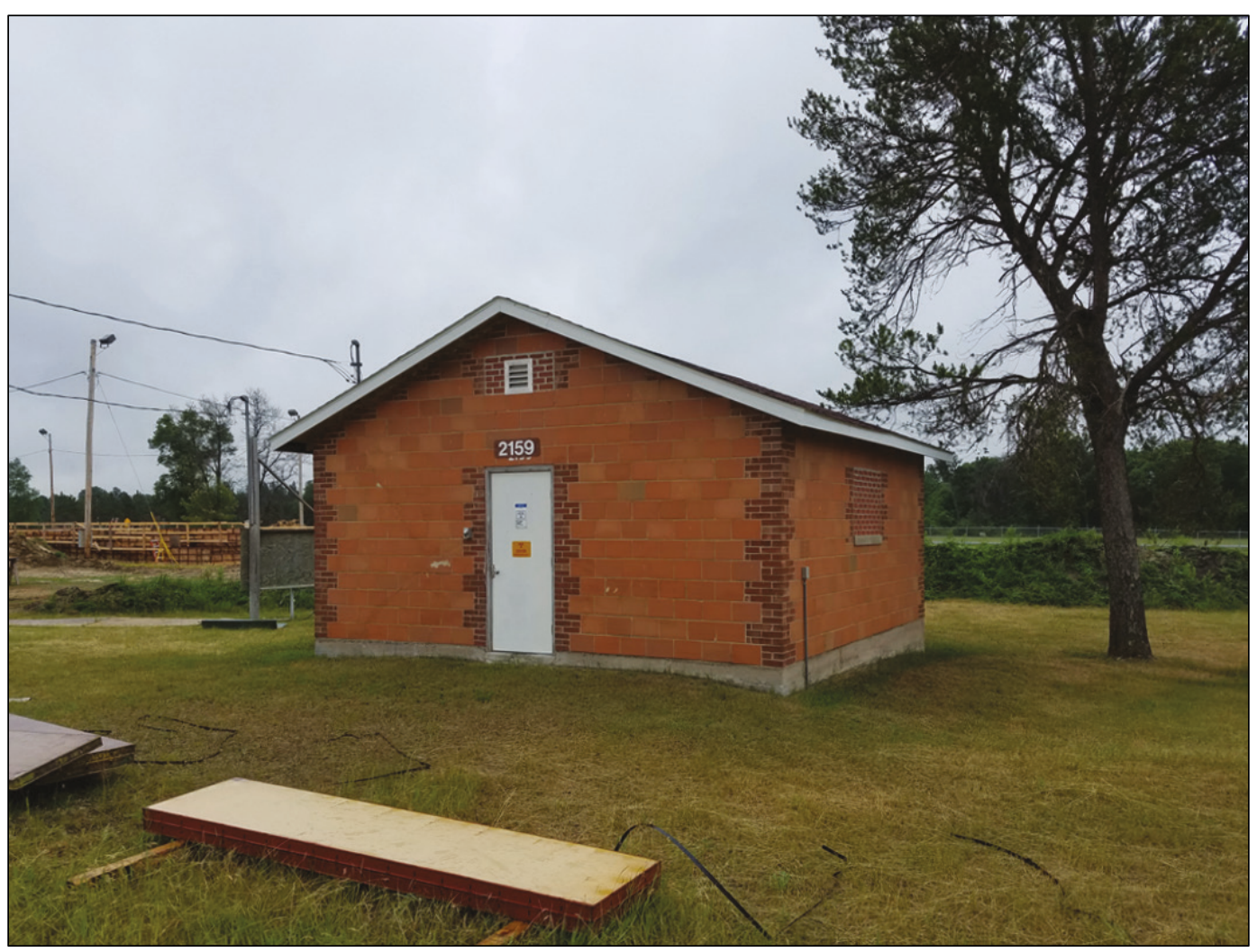




\section{World War II Temporary Building Character-defining Features for the 800 Series}

In Preservation Brief \#17, ${ }^{62}$ Nelson reminds readers that the Secretary of the Interior's Standards for the Treatment of Historic Properties ${ }^{63}$ embodies two important goals: (1) the preservation of historic materials, and (2) the preservation of a building's distinguishing character. Every old building is unique, with its own identity and its own distinctive character. Character refers to all those visual aspects and physical features that comprise the appearance of every historic building. Character-defining elements include the overall shape of the building; its materials, craftsmanship, decorative details, interior spaces, and features; and various aspects of its site and environment.

If the various materials, features, and spaces that give a building its visual character are not recognized and preserved, then essential aspects of its character may be damaged in the process of change.

A building's character can be irreversibly damaged or changed in many ways, and some ways that damage or change can occur are listed below:

- Inappropriate repointing of the brickwork.

- Removal of a distinctive side porch.

- Changes to the window sash.

- Changes to the setting around the building.

- Changes to the major room arrangements.

- Introduction of an atrium.

- Painting previously unpainted woodwork, etc.

62 Lee H. Nelson, National Park Service Preservation Brief 17: Architectural Character-Identifying the Visual Aspect of Historic Buildings as an Aid to Preserving their Character (Washington, DC: U.S. Department of the Interior, National Park Service, 1998), http://www.nps.gov/tps/how-topreserve/briefs/17-architectural-character.htm.

63 Grimmer, Secretary of the Interior's Standards for the Treatment of Historic Properties with Guidelines for the Treatment of Cultural Landscapes. 


\subsection{Exterior}

The following are exterior features of WWII temporary buildings. A combination of historic and contemporary photos of various Fort McCoy buildings show examples.

Massing - generally long rectilinear and 1- or 2-story (Figure 10).

Figure 10. Detail from War Department 800 Series plans for mess hall, 1942 (Library of Congress).

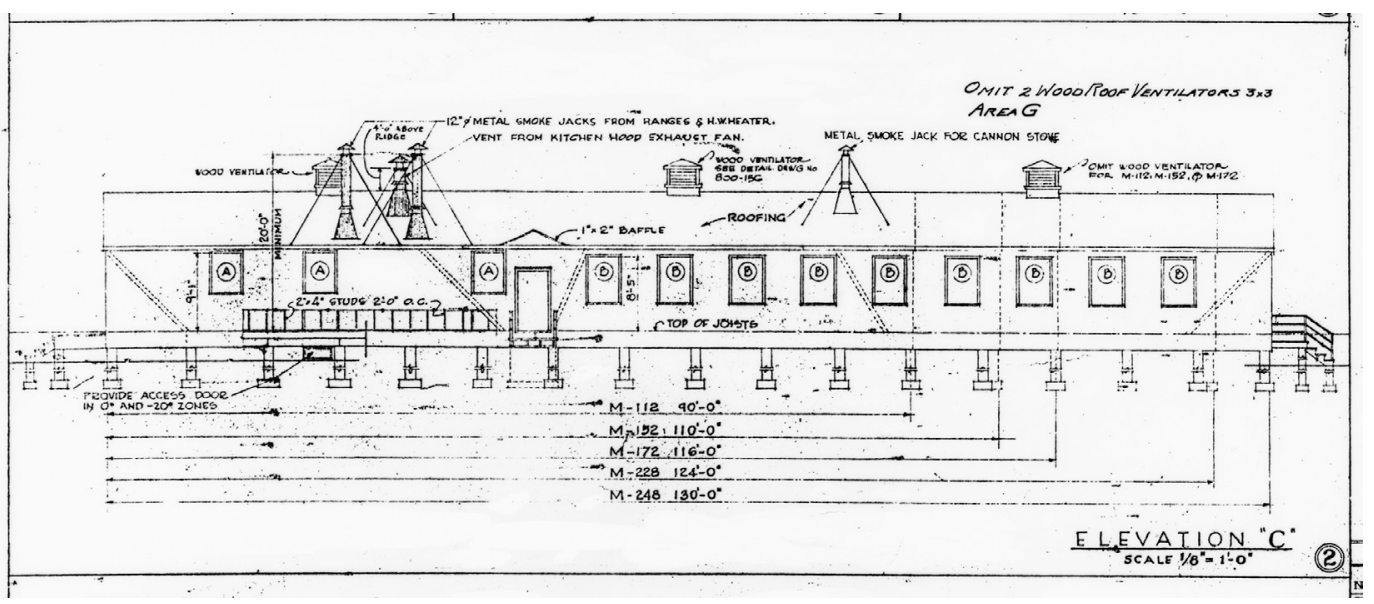


Cladding material - cement asbestos shingles with scalloped bottom edge (Figure 11).

Figure 11. Cement asbestos siding with scalloped bottom on Building 550 (ERDC-CERL, 2018).

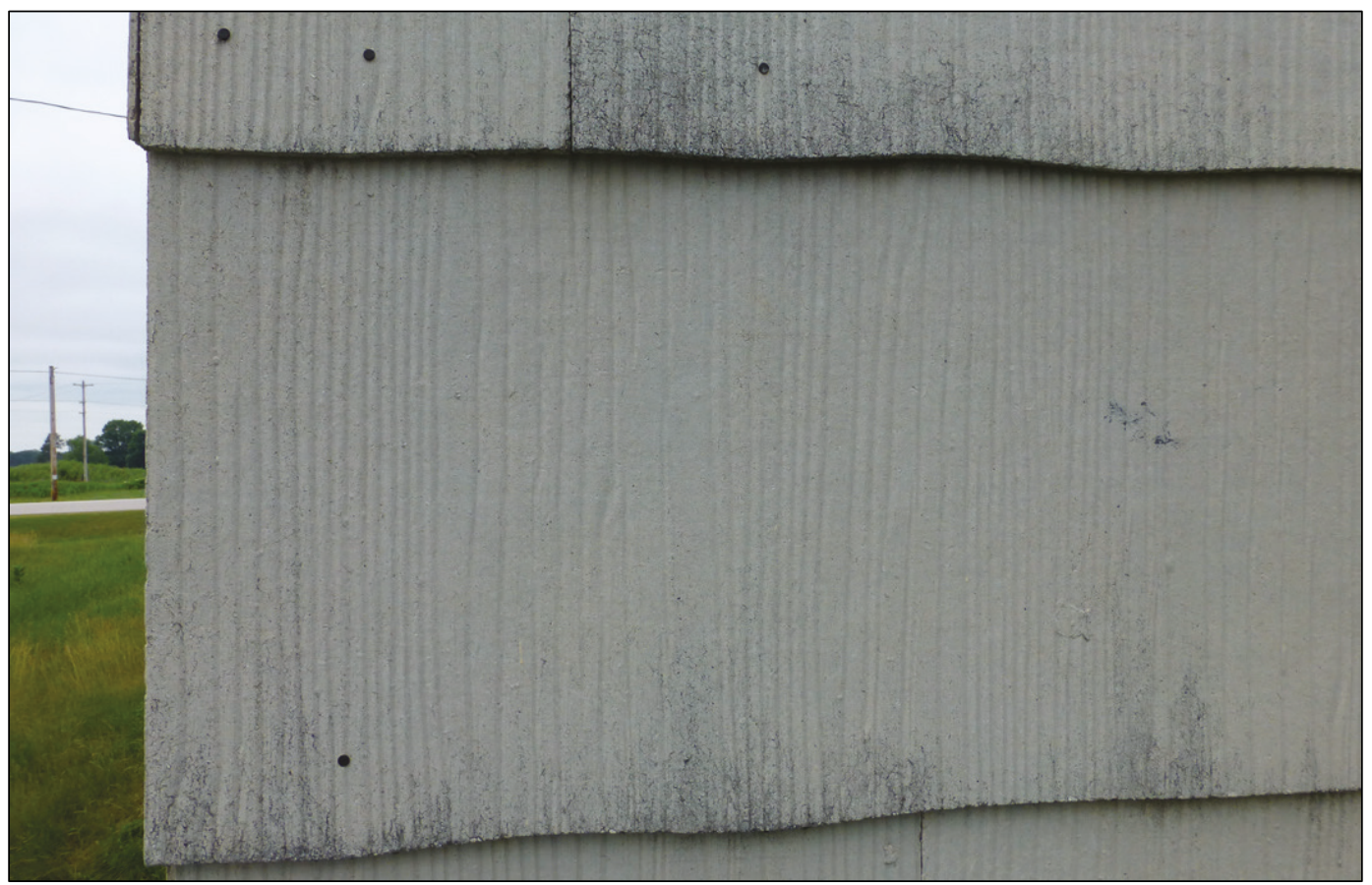

Roofing material - red asphalt shingles (Figure 12).

Figure 12. Close-up of Camp McCoy postcard showing red asphalt roofing, 1942 (ERDC-CERL Collection).

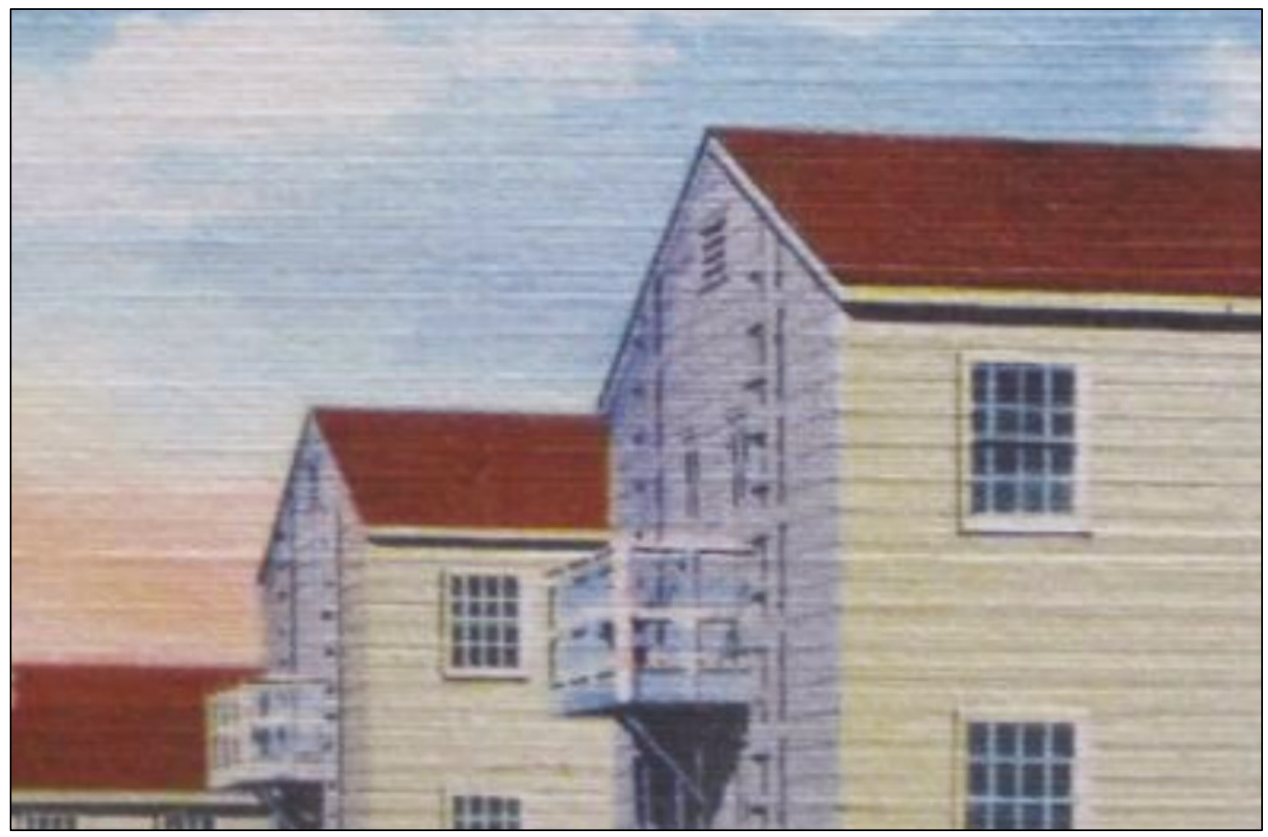


Windows - Wood with multipaned sashes and wood exterior screens (Figure 13).

Figure 13. Multipaned window with screen on Building 849 (ERDC-CERL, 2018).

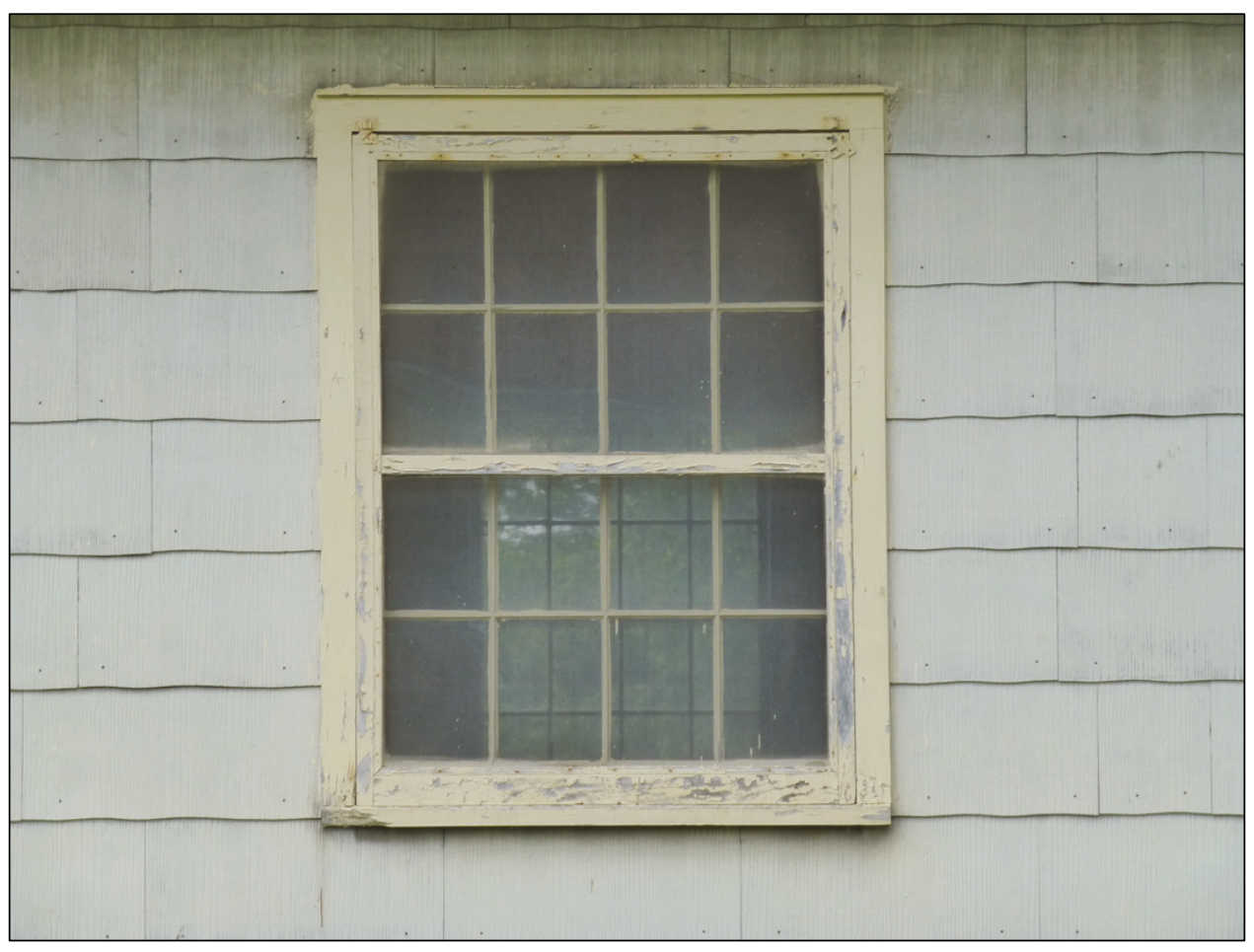

Window trim - wood (Figure 14).

Figure 14. Detail of wood window trim on Building 849 (ERDC-CERL, 2018).

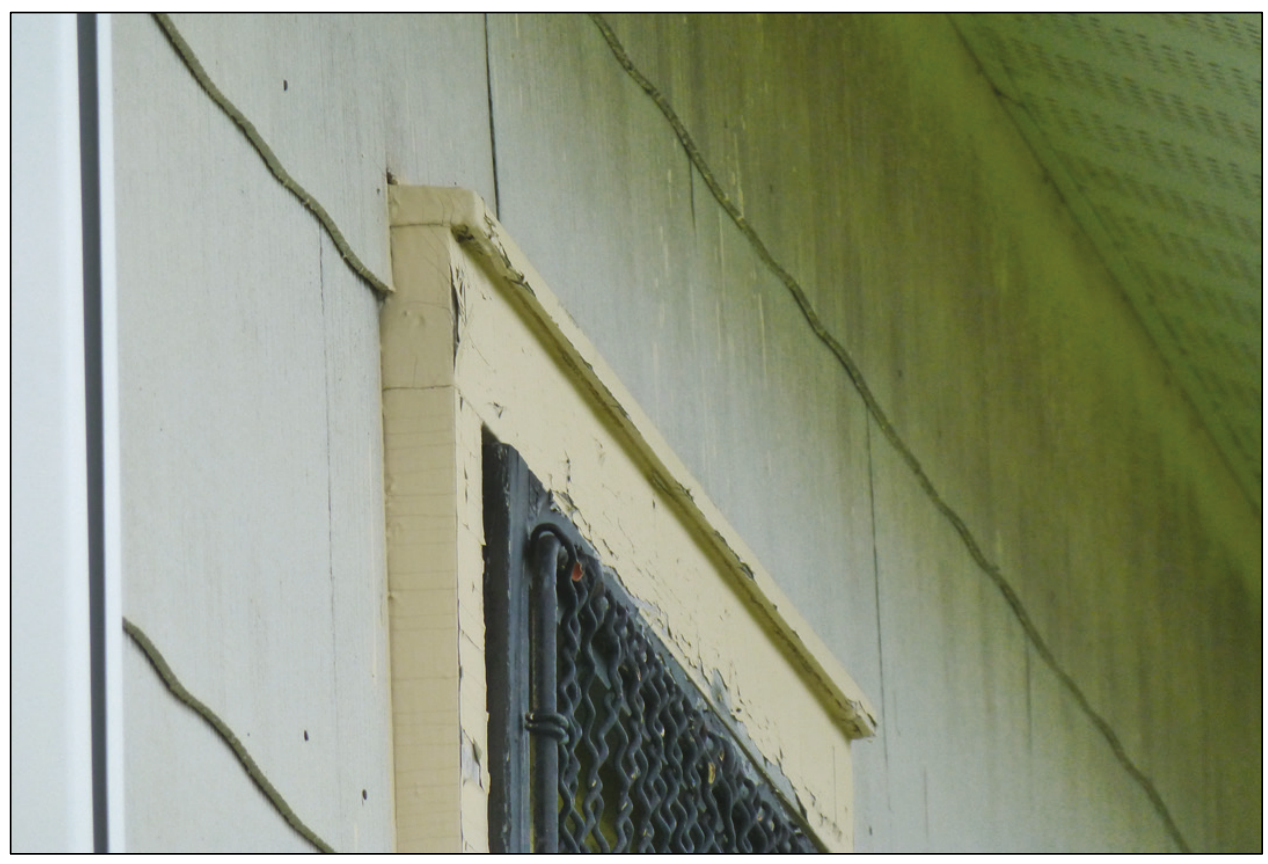


Doors - wood with multipaned lights and wood interior screens (Figure 15 and Figure 16).

Figure 15. Multipaned doors with panels below on Building 849 (ERDC-CERL, 2018).

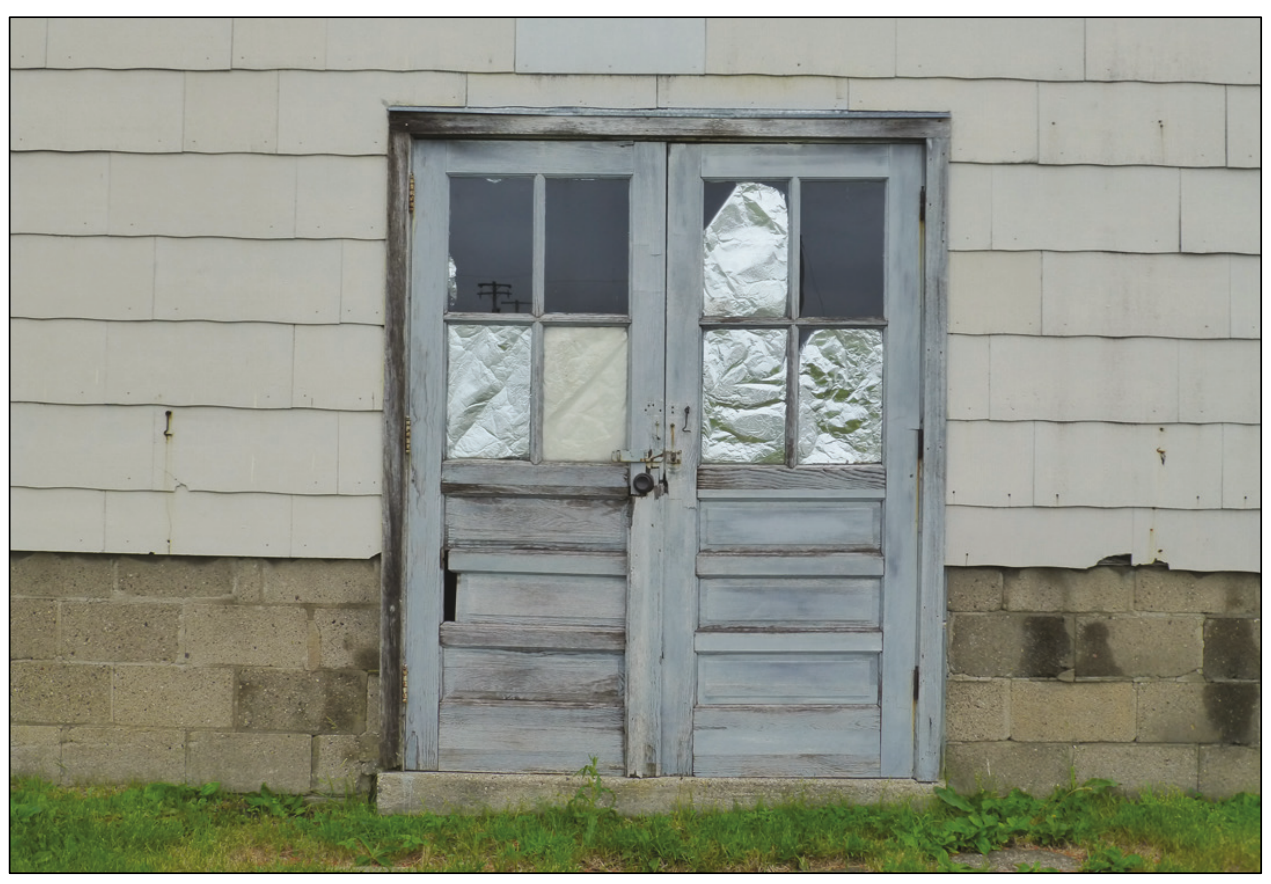

Figure 16. Interior screen door in Building 1129 (ERDC-CERL, 2018).

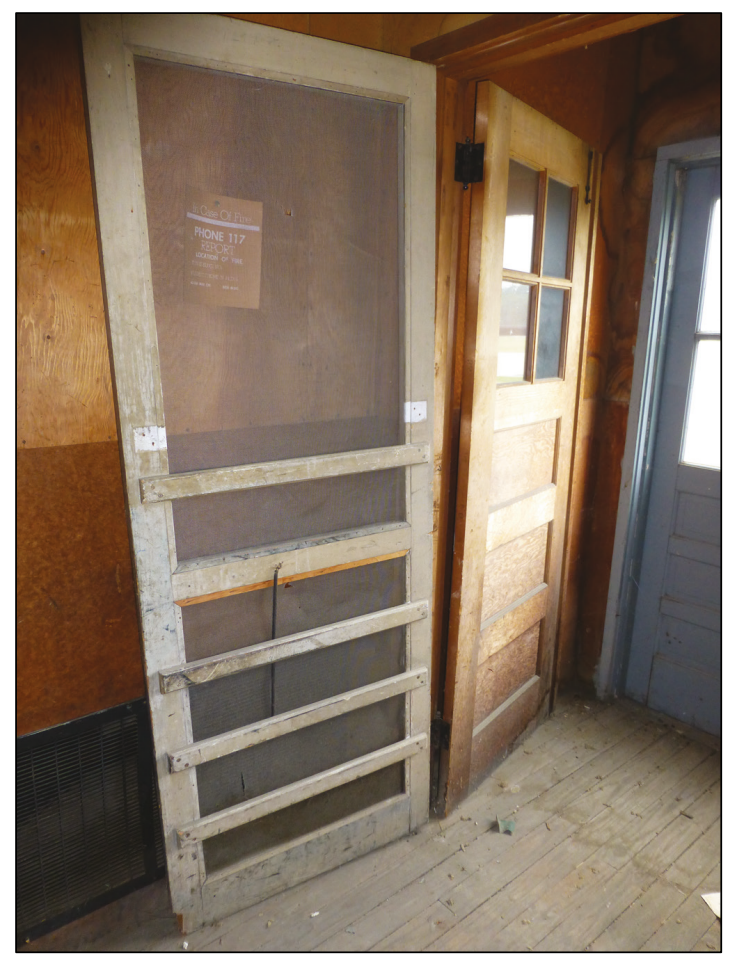


Door trim - wood (Figure 17).

Figure 17. Wood door trim on Building 849 (ERDC-CERL, 2018).

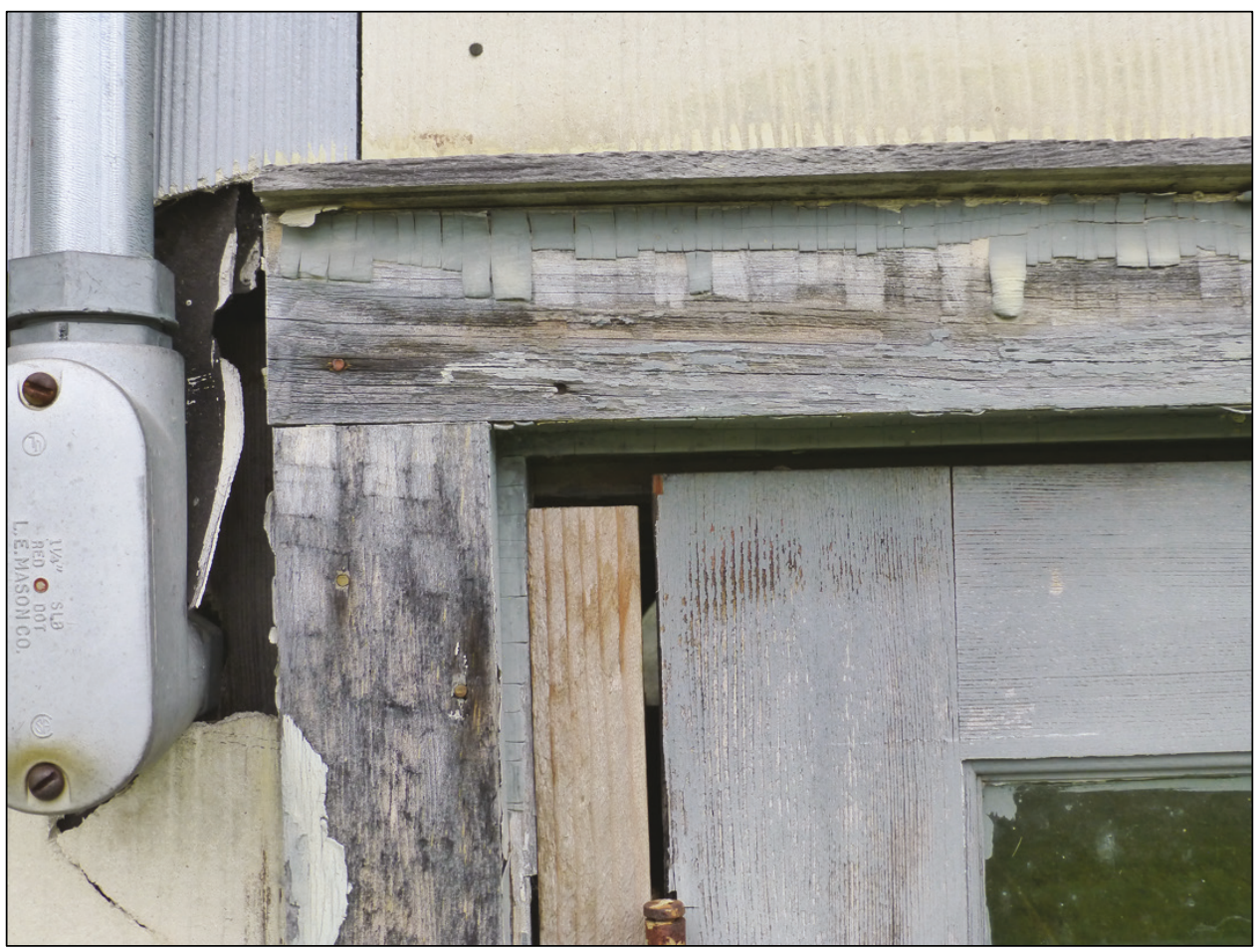

Foundation skirting - wood (Figure 18).

Figure 18. Wood foundation skirting on Building 849 (ERDC-CERL, 2018).

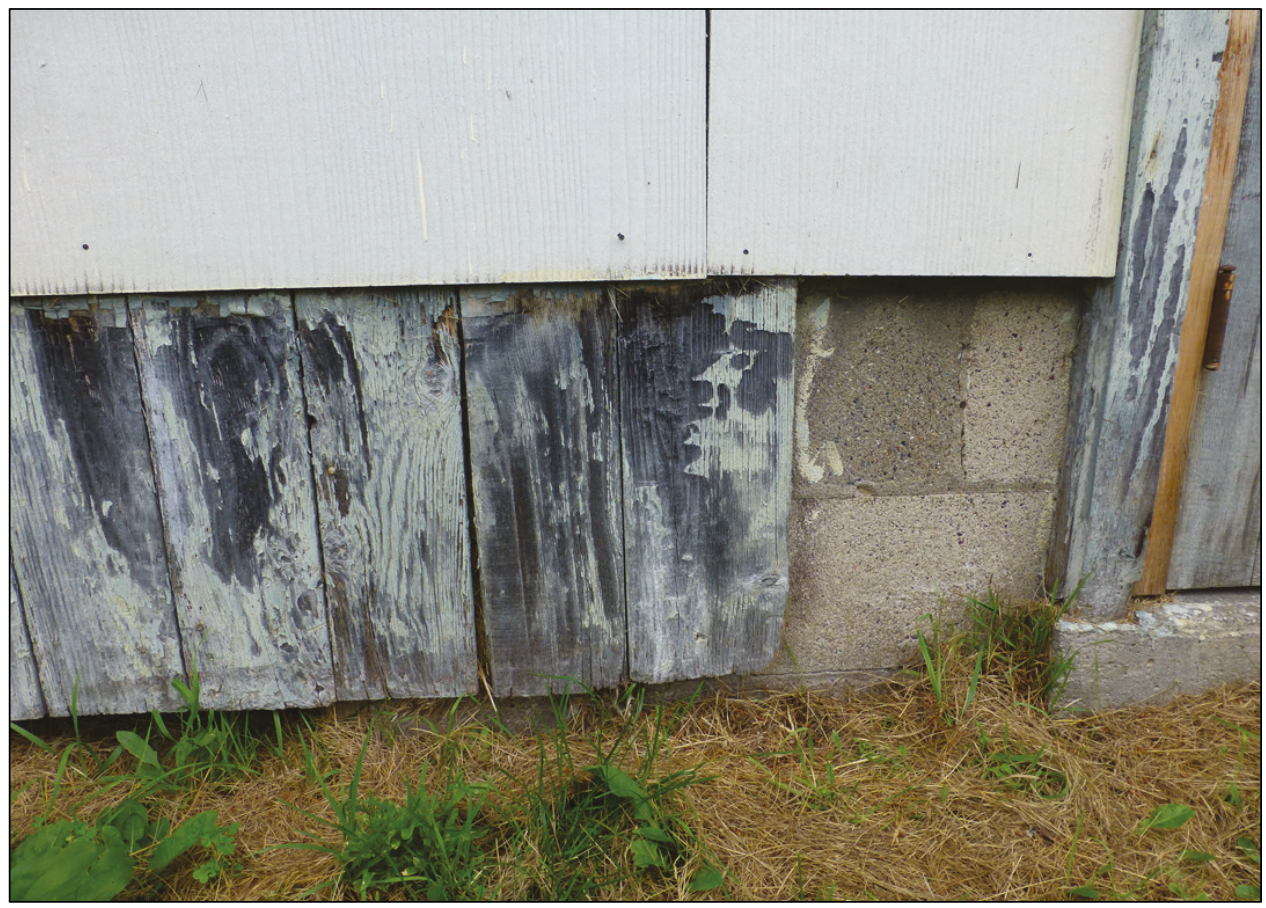


Chimneys (external or internal) - brick (Figure 19 and Figure 20).

Figure 19. External brick chimney on Building 629 (ERDC-CERL, 2018).

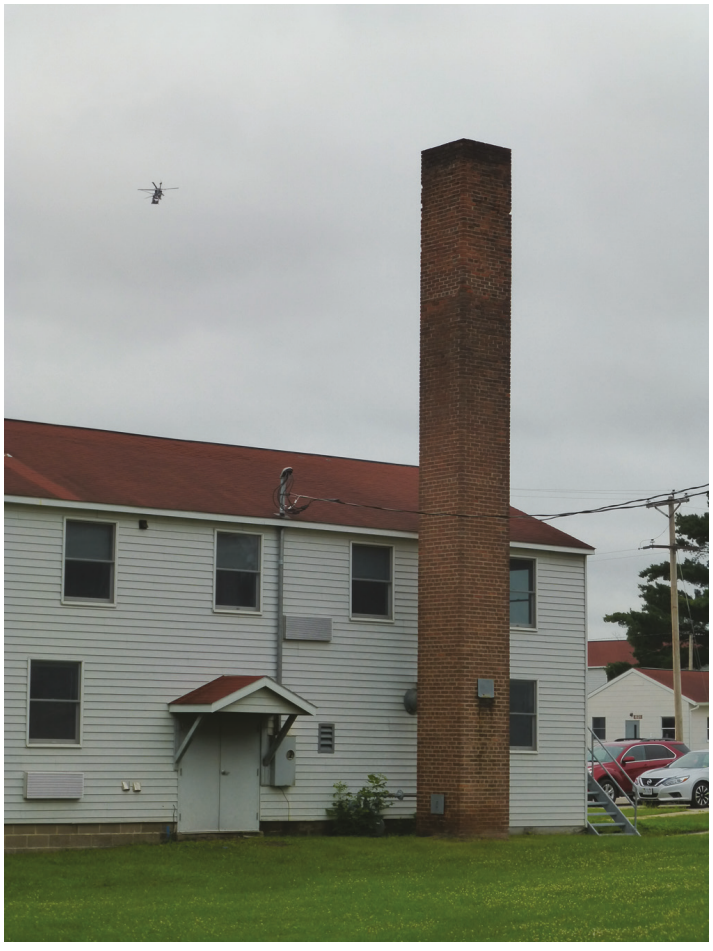

Figure 20. Example of an internal brick chimney at Camp McCoy, 1965 (NARA College Park, RG111SC).

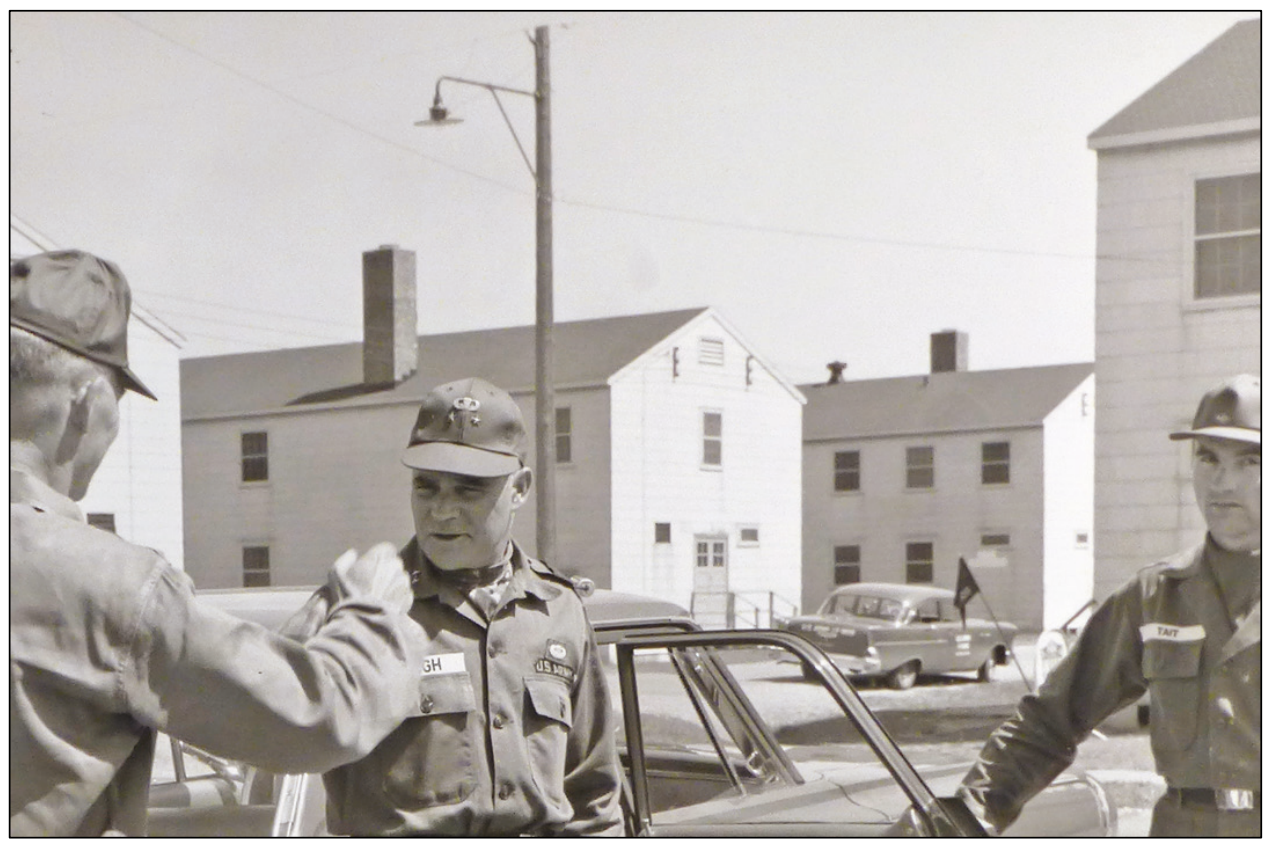


Exterior steps and handrails - wood (Figure 21).

Figure 21. Example of wood steps and railing at Camp McCoy, 1951 (NARA College Park, RG111SC).

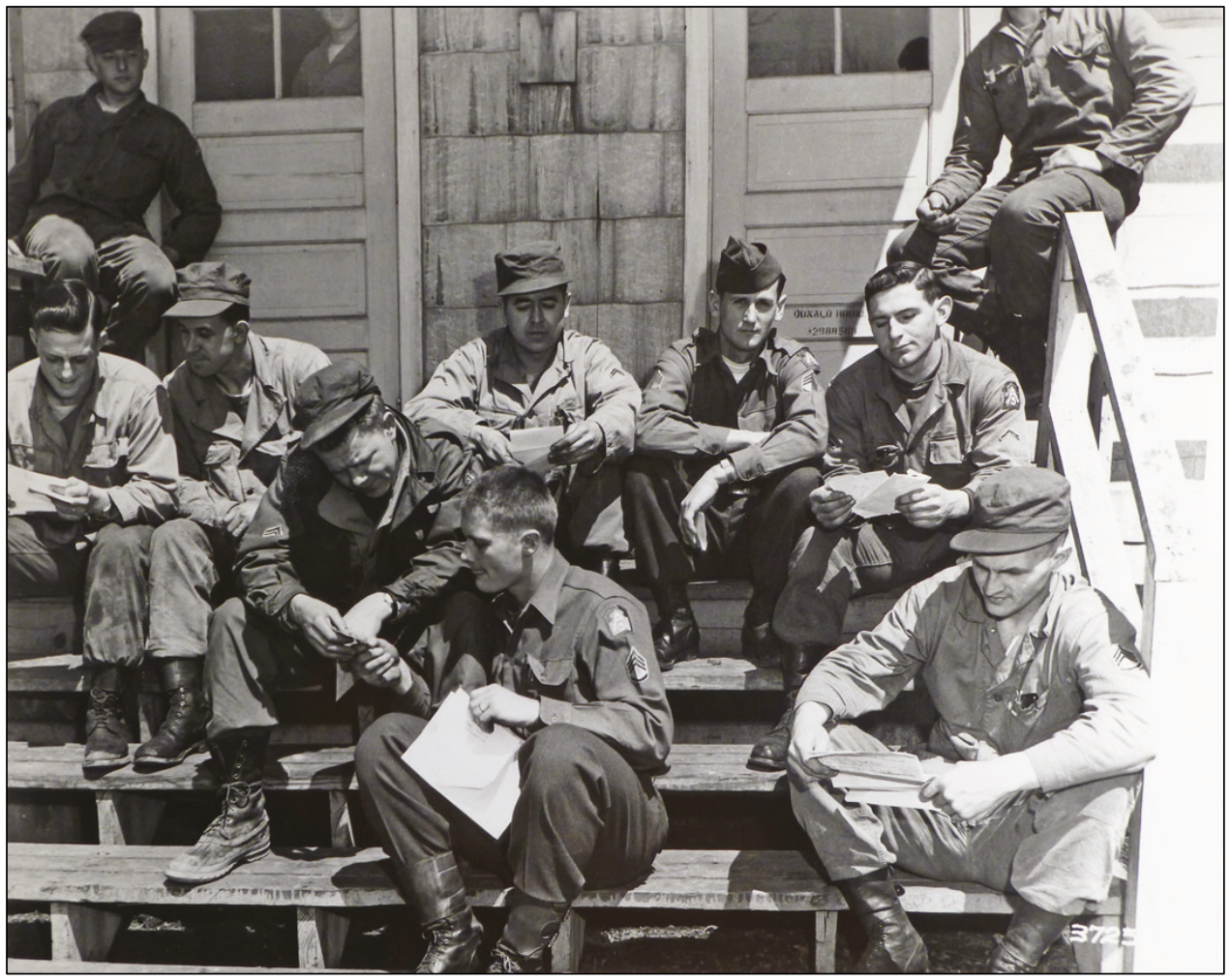

Platforms - wood (Figure 22-Figure 24).

Figure 22. Detail of platform and ladder from War Department 800 Series plans for barracks, 1942 (Library of Congress).

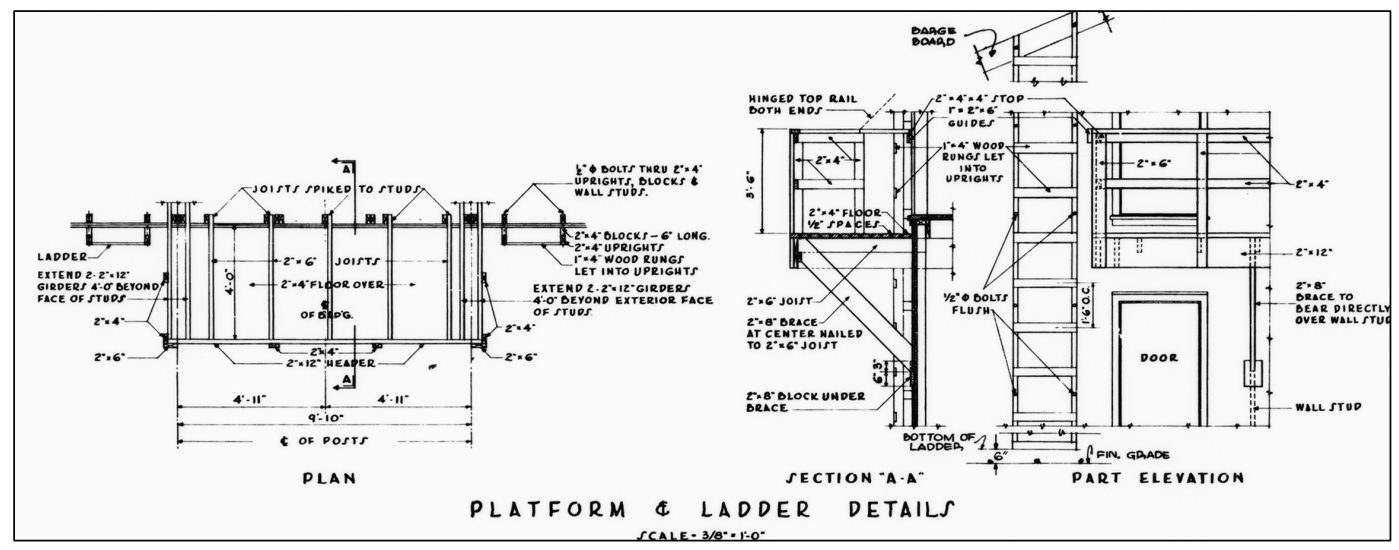


Ladders - wood (Figure 22 and Figure 23).

Figure 23. Detail of Camp McCoy postcard showing ladders and platforms, 1942 (ERDC-CERL Collection).

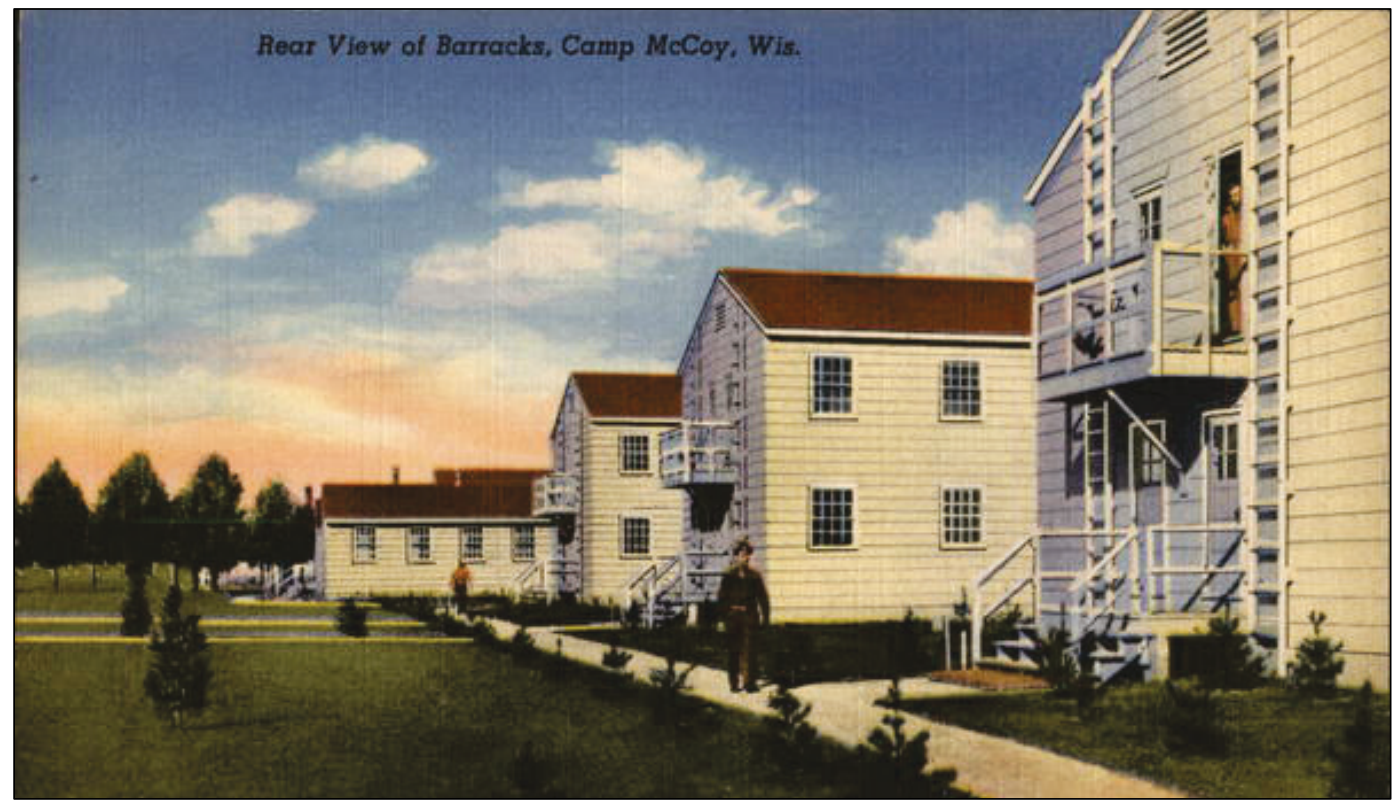

Figure 24. Detail of barracks showing ladders and platforms, 1950 (NARA College Park, RG111-SC).

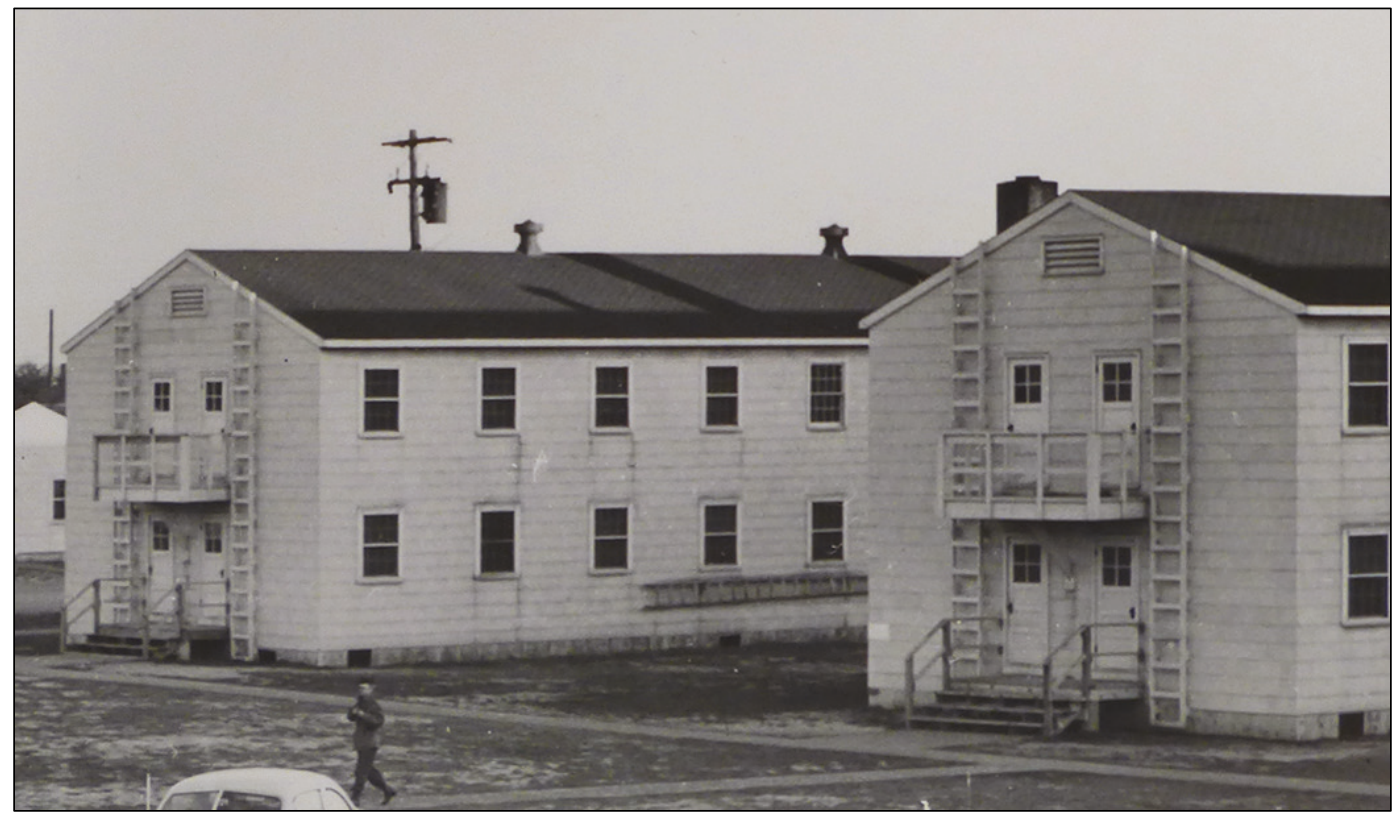




\subsection{Interior}

The following are interior features of various WWII temporary buildings. A combination of historic and contemporary photos of various Fort McCoy buildings are shown as examples.

Squad bays - open on both floors of barracks (Figure 25).

Figure 25. Example of an open squad bay in Building 1129 (ERDC-CERL, 2018).

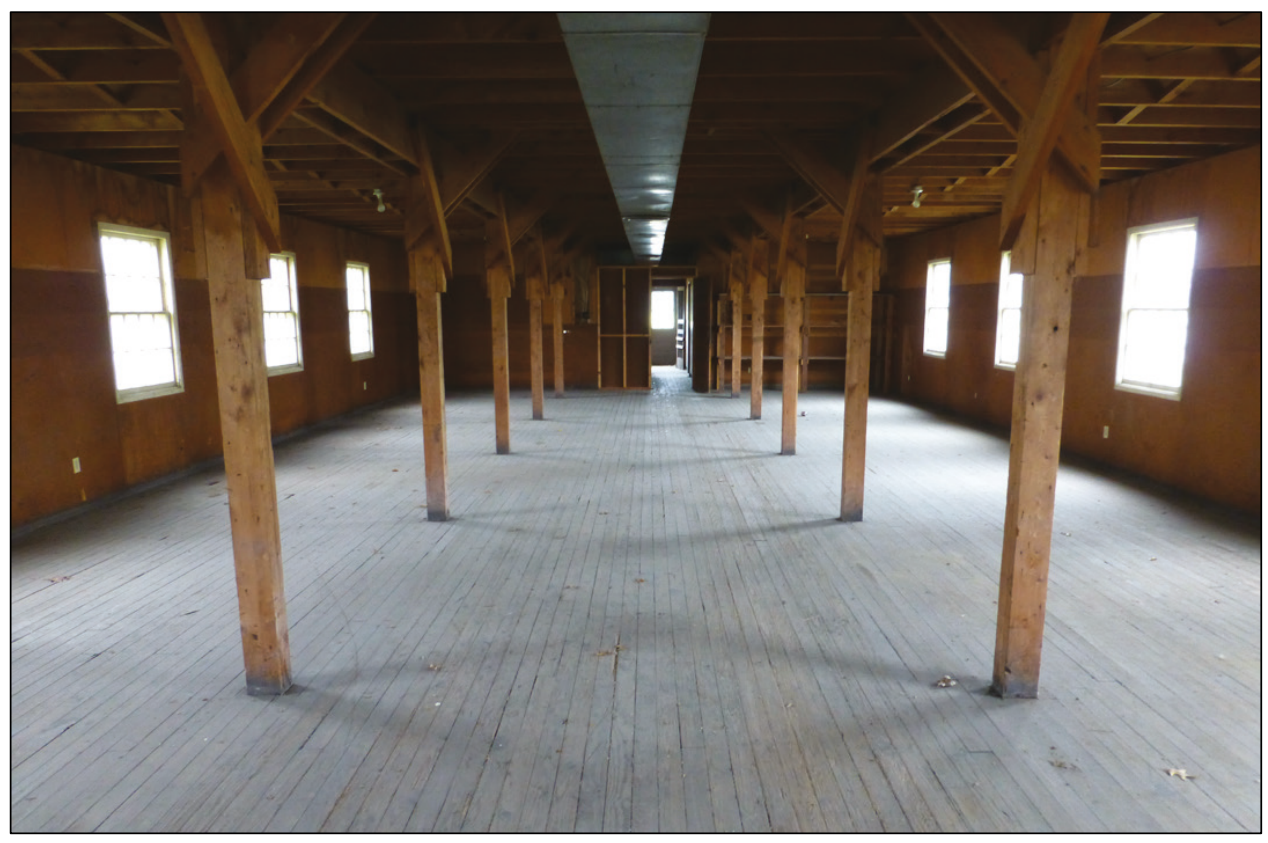

First floor latrines in barracks (Figure 26-Figure 28). 
Figure 26. Example of the sink area in a barracks latrine in Building 1129 (ERDC-CERL, 2018).

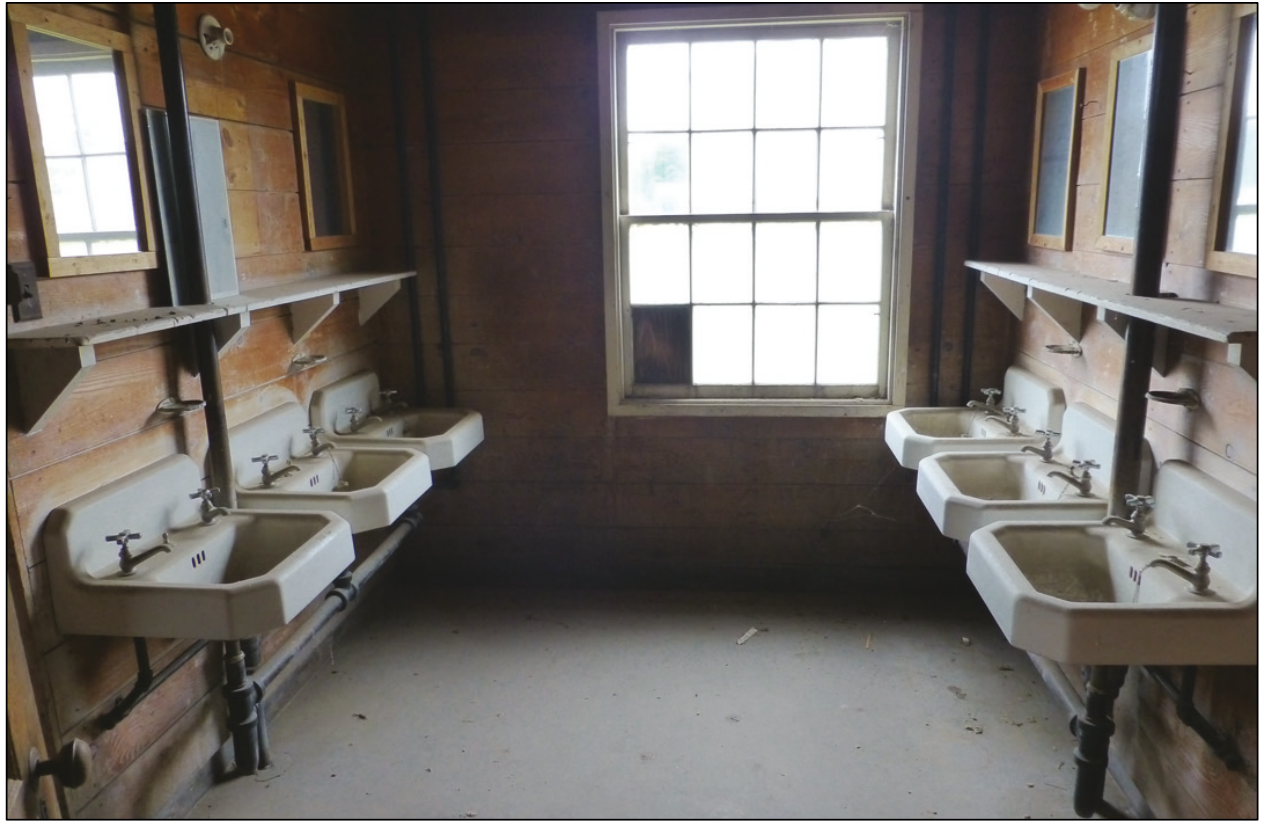

Figure 27. Example of the toilet area in a barracks latrine in Building 1129 (ERDC-CERL, 2018).

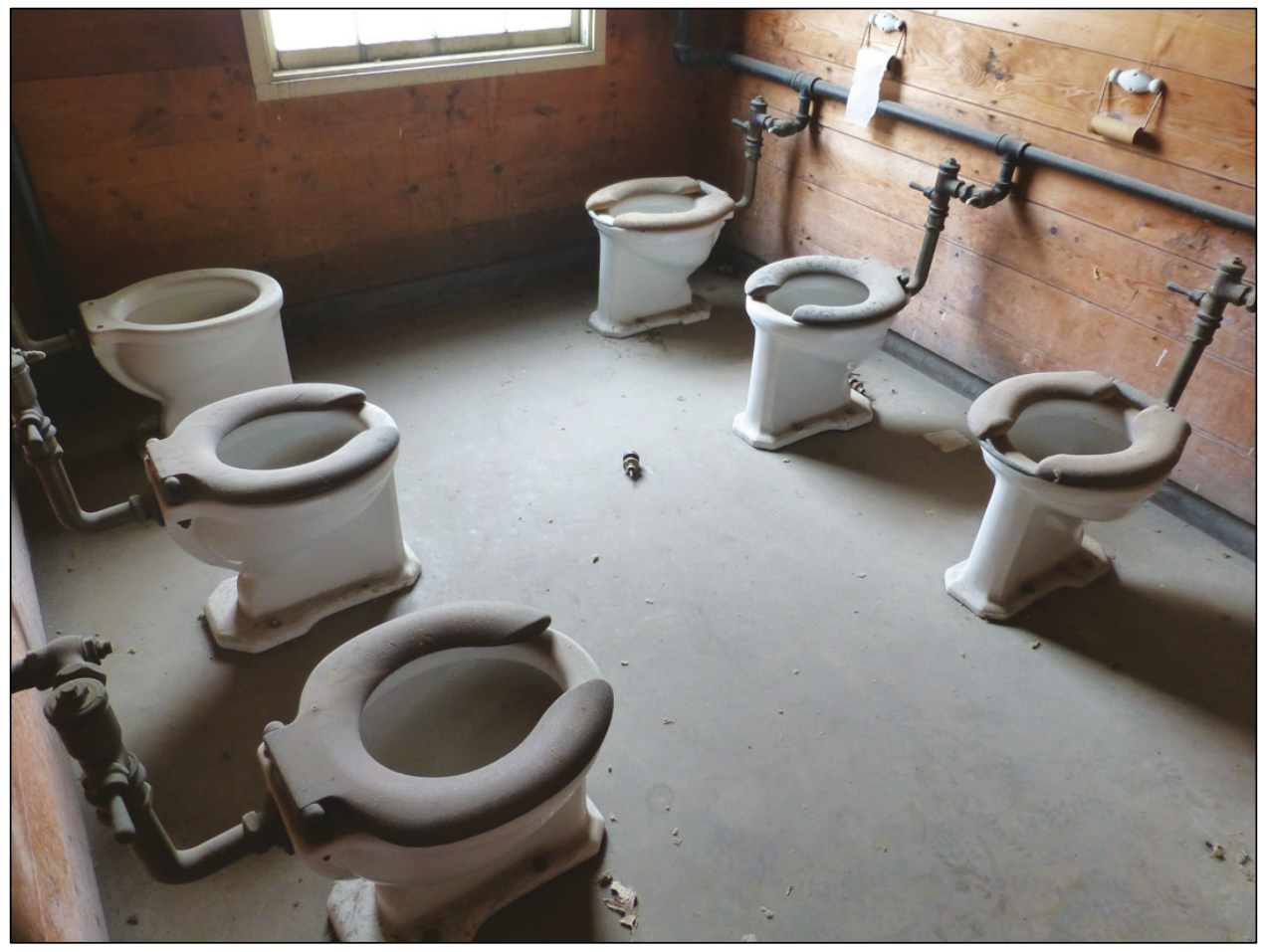


Figure 28. Example of the shower heads in a barracks latrine in Building 1129 (ERDC-CERL, 2018).

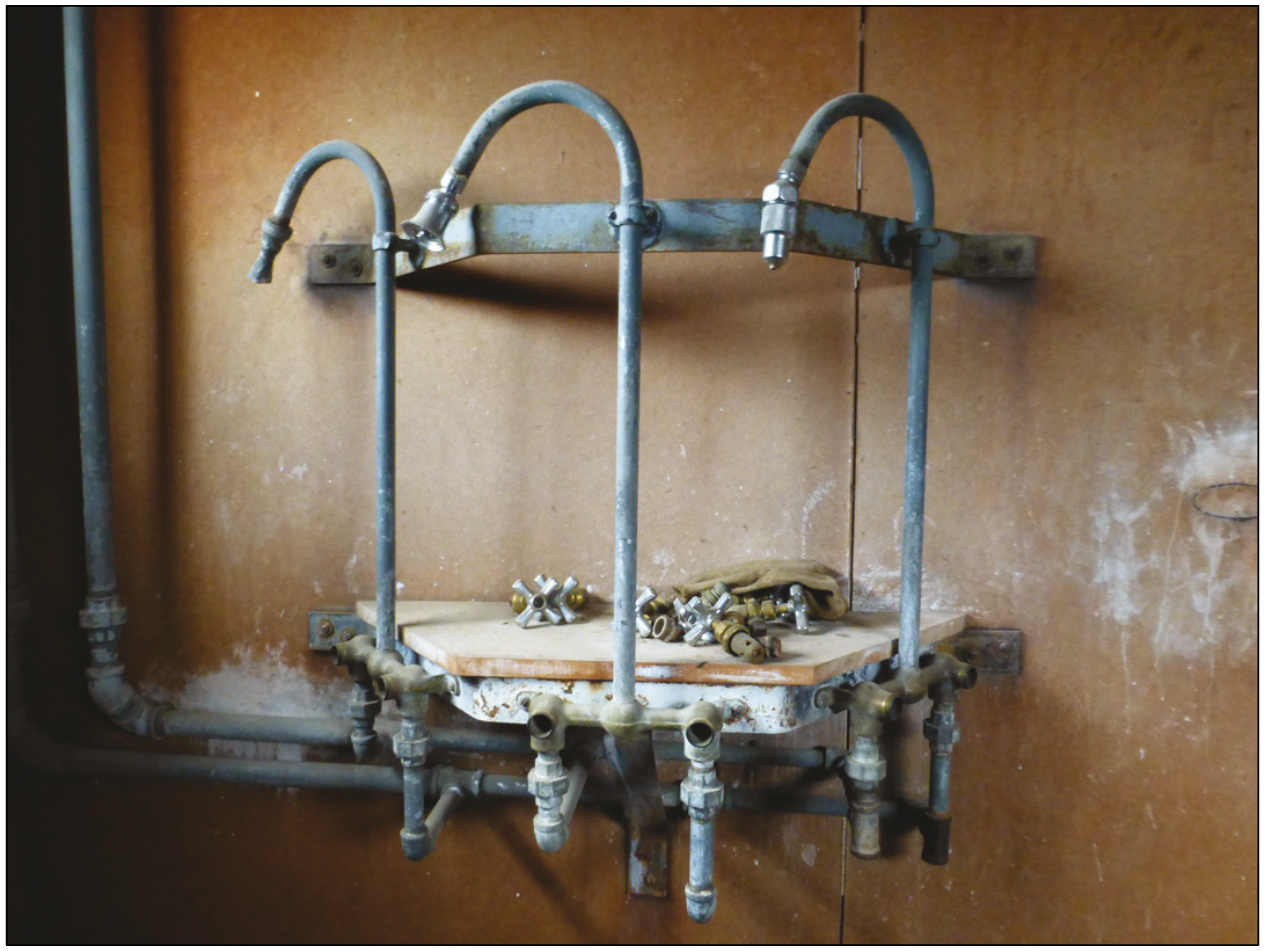

Noncommissioned Officer (NCO) rooms - second floor in barracks (Figure 29).

Figure 29. Example of the NCO room in Building 1129 (ERDC-CERL, 2018).

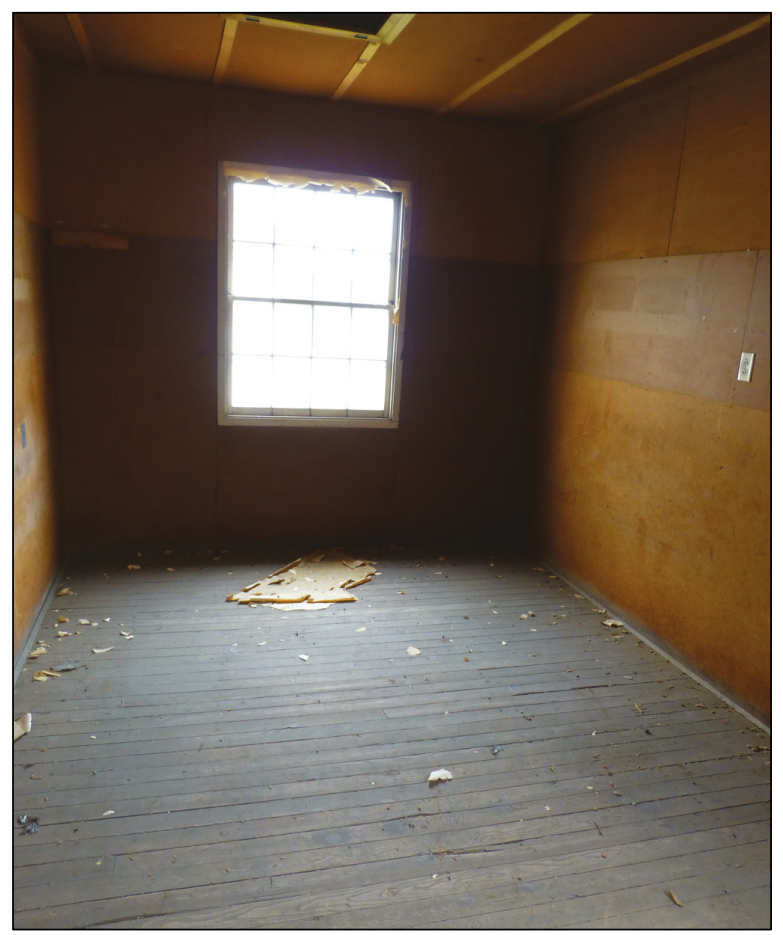


Open bay in mess halls (Figure 30).

Figure 30. Open mess hall area in Building 2008 (ERDC-CERL, 2018).

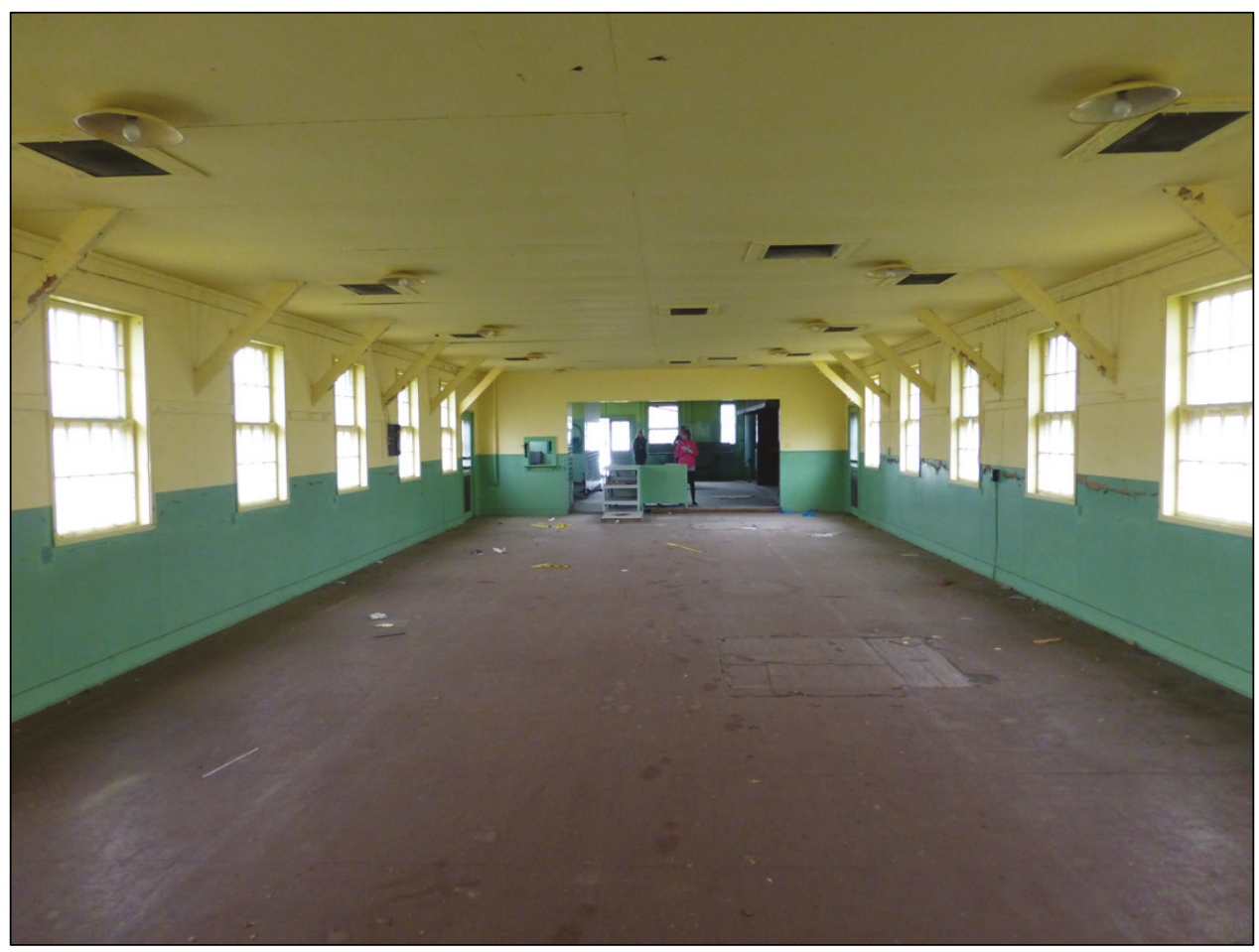

Kitchen in mess halls - including all original aspects like hoods, terra cotta fire tile, sinks, serving counters, etc. (Figure 31).

Figure 31. Stove area in Building 2008 (ERDC-CERL, 2018).

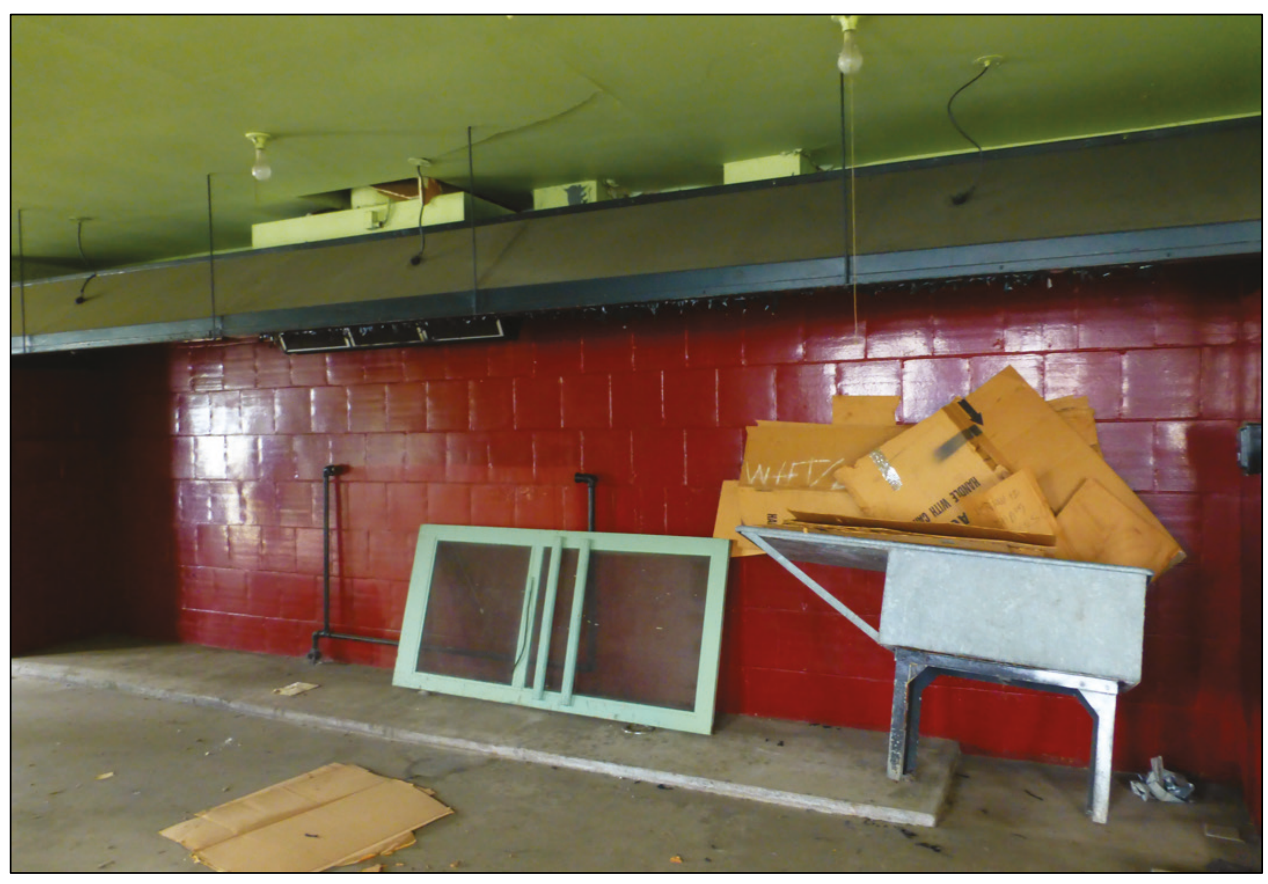


Floors - bare wood floors in most spaces (Figure 32).

Figure 32. Bare wood floor in barracks, Building 1129 (ERDC-CERL, 2018).

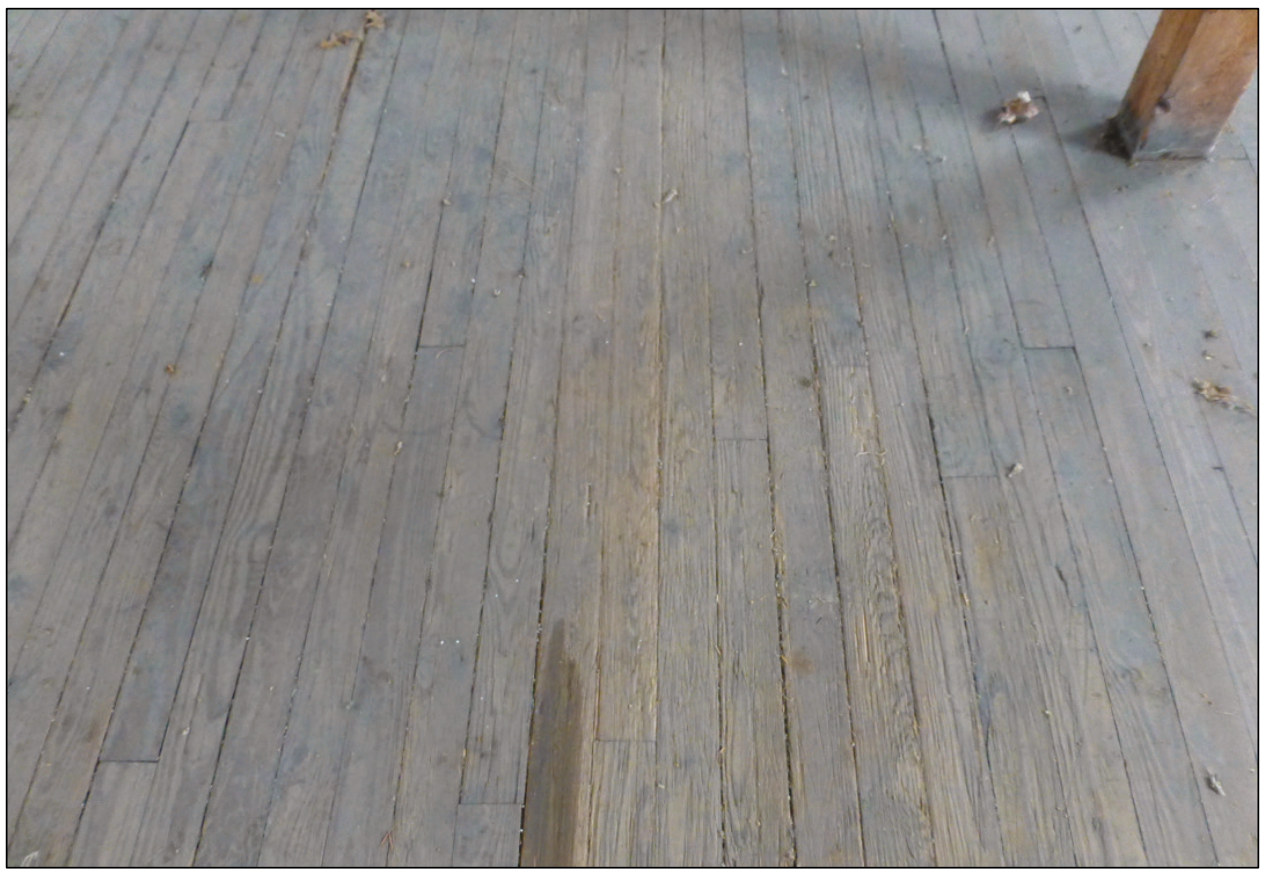

Floors - concrete in latrines, kitchens, and boiler rooms (Figure 33).

Figure 33. Concrete floor in the latrine of Building 550 (ERDC-CERL, 2018).

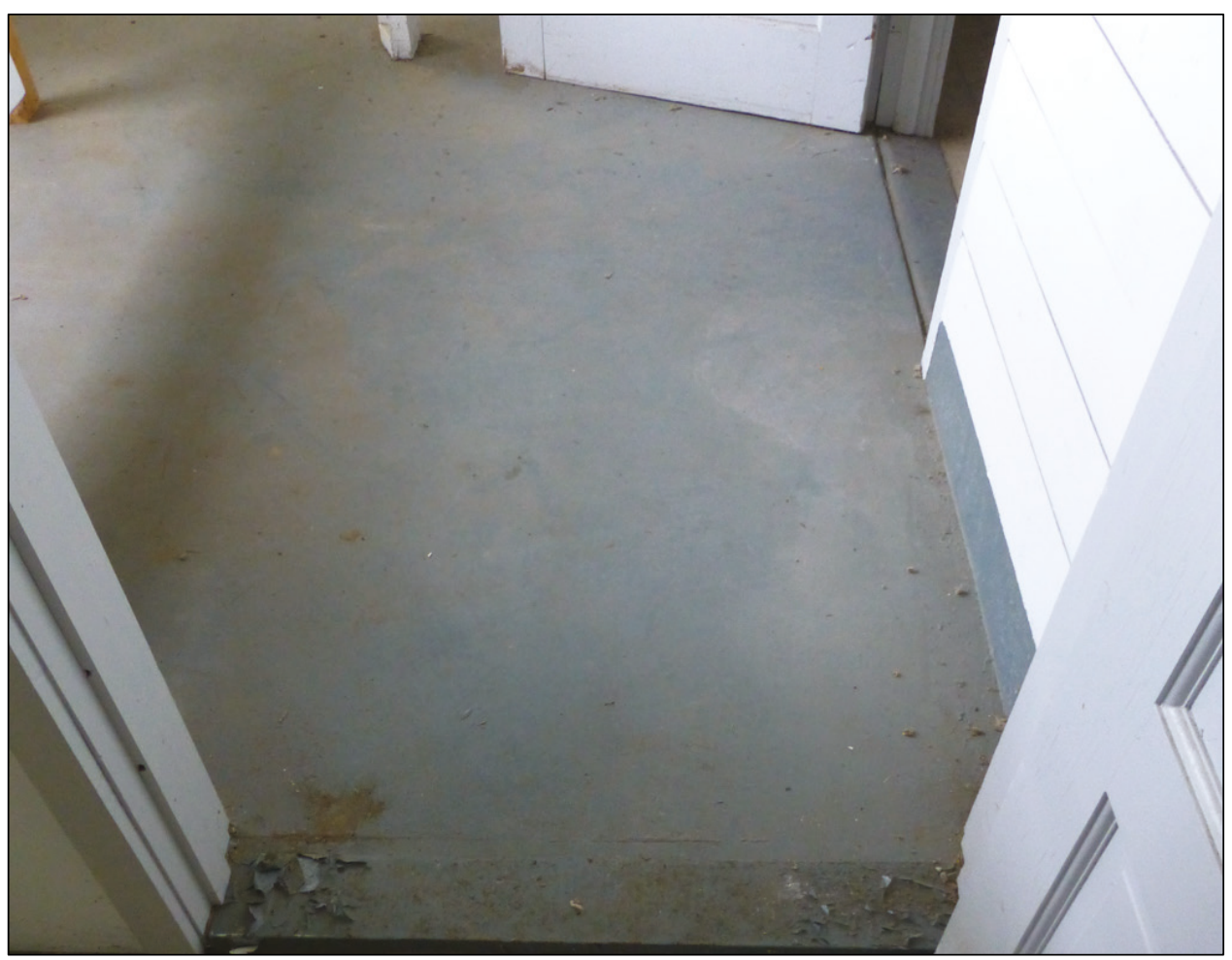


Walls - fiberboard (Figure 34) or fiberboard with a wood tongue-andgroove wainscot (Figure 35).

Figure 34. Fiberboard walls in Building 849 (ERDC-CERL, 2018).

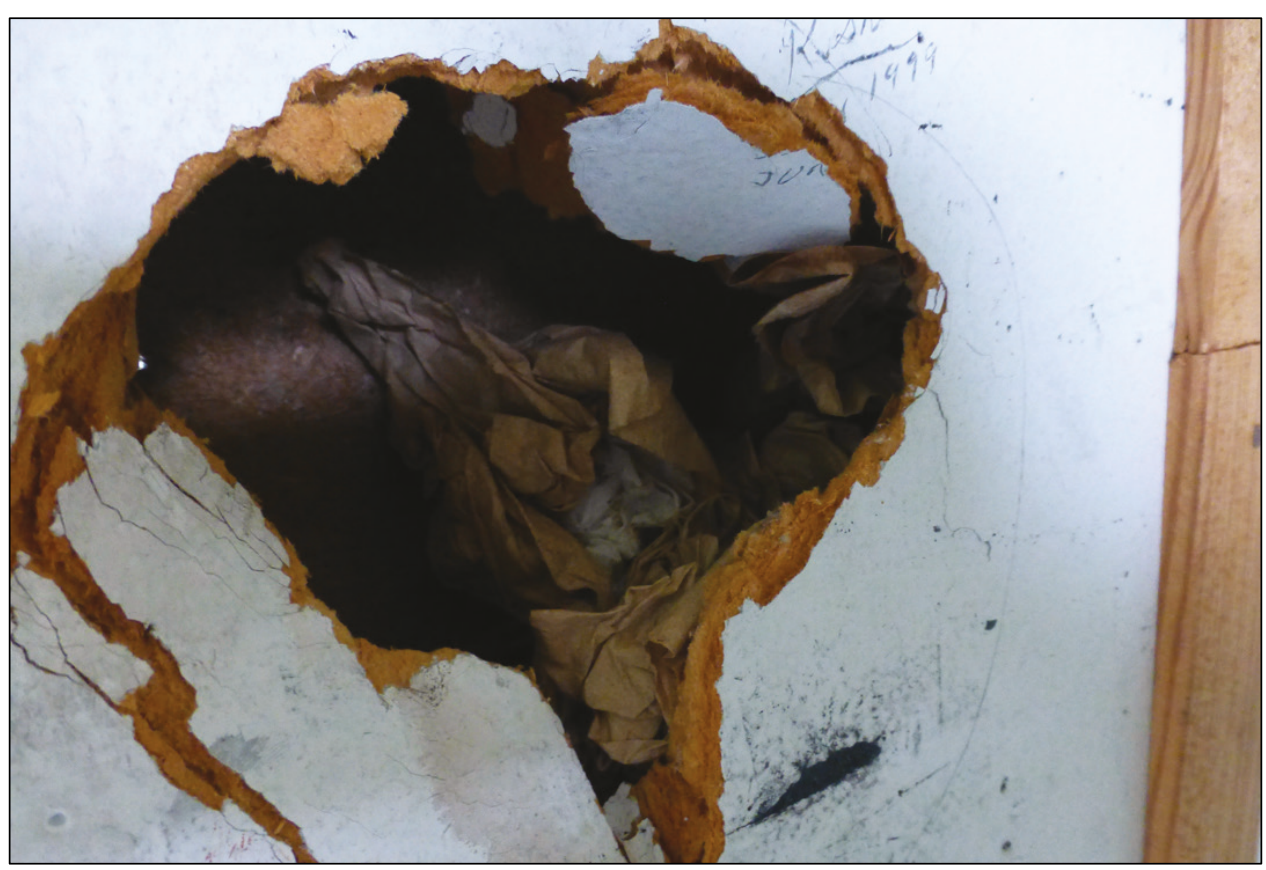

Figure 35. Fiberboard walls with wainscoting in Building 1866 (ERDC-CERL, 2018).

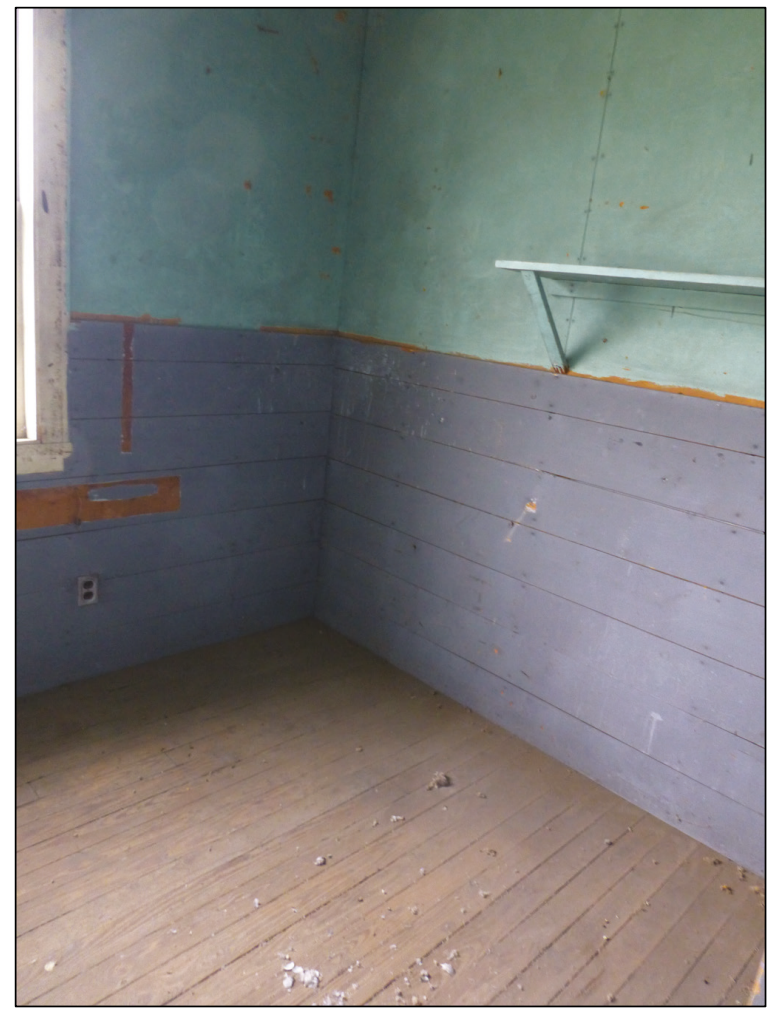


Ceilings - fiberboard with wood trim (Figure 36).

Figure 36. Fiberboard ceiling with in Building 550 (ERDC-CERL, 2018).

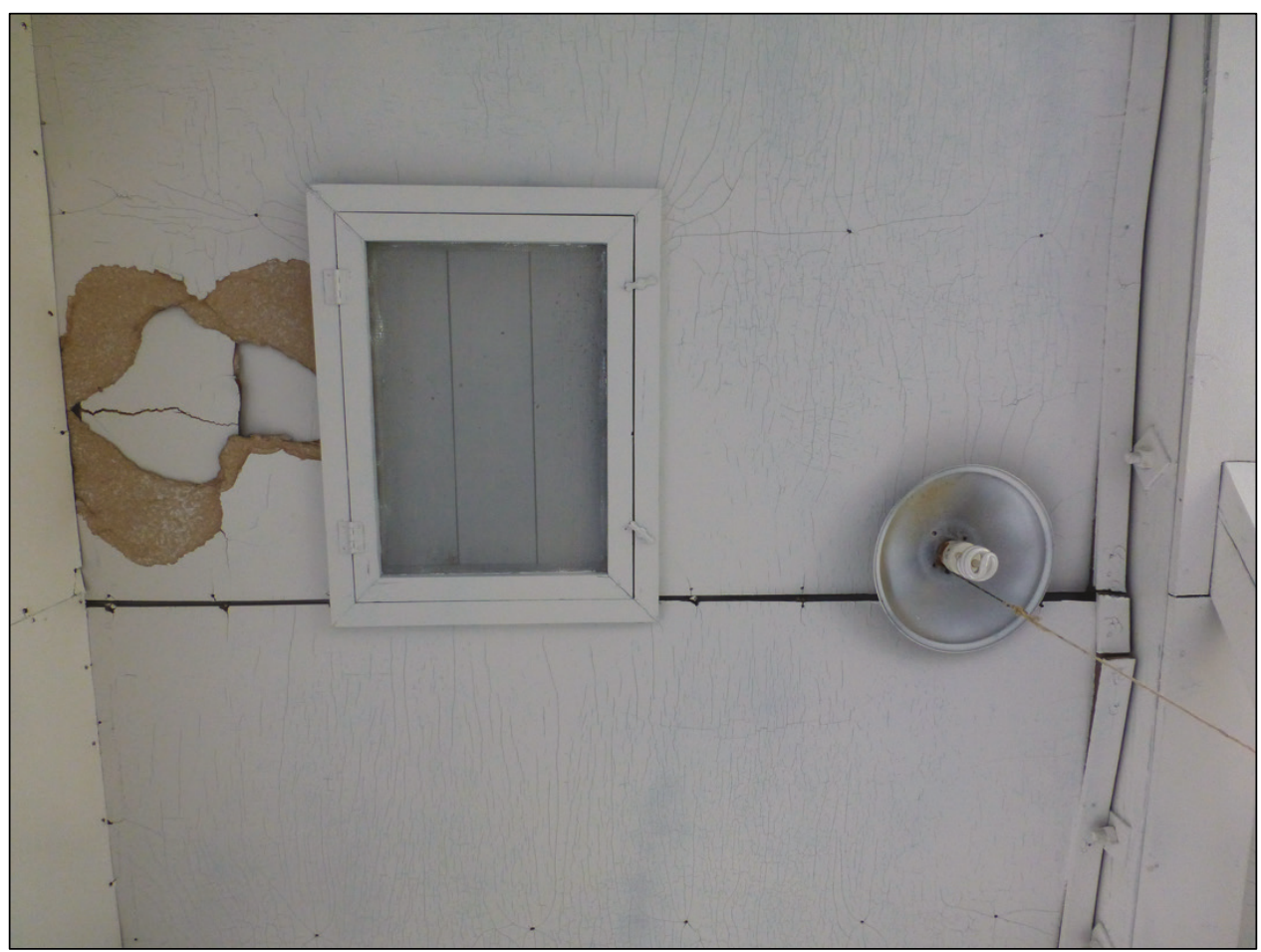

Ceiling vents - (Figure 37).

Ceiling vents consisted of an opening cut into the ceiling material that had a wood hatch-type cover to close it. A screen framed with wood and hinged to a wood frame on the ceiling was used to keep bugs out of the room when the hatch was in the open position. 
Figure 37. Ceiling vent in Building 550 (ERDC-CERL, 2018).

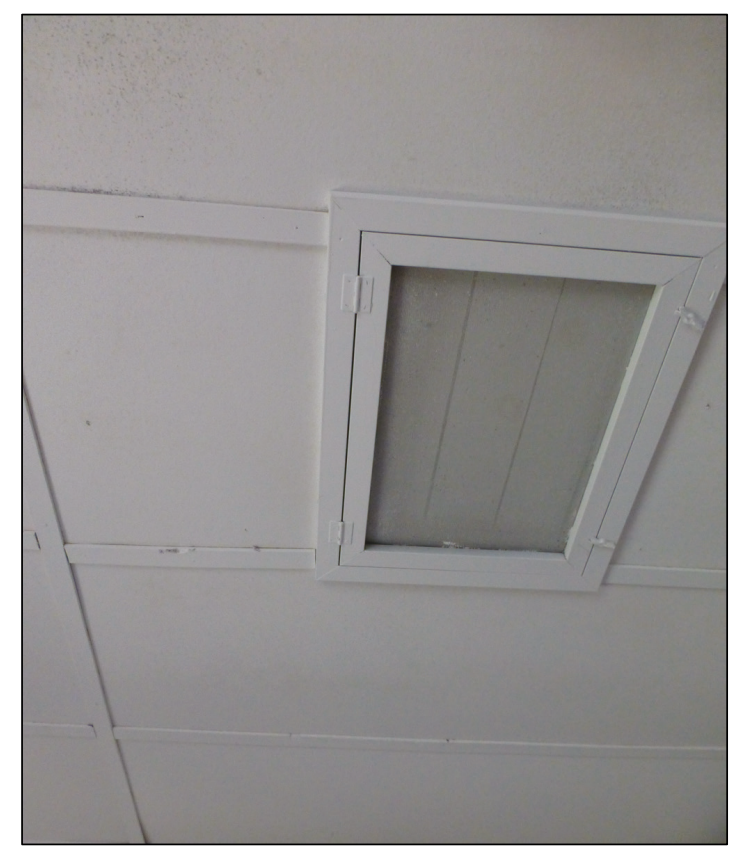

Heater ducts - metal (Figure 38).

Heater ducts consisted of rectangular, galvanized metal hung from the ceiling by galvanized metal strips.

Figure 38. Metal heater duct in Building 1129 (ERDC-CERL, 2018).

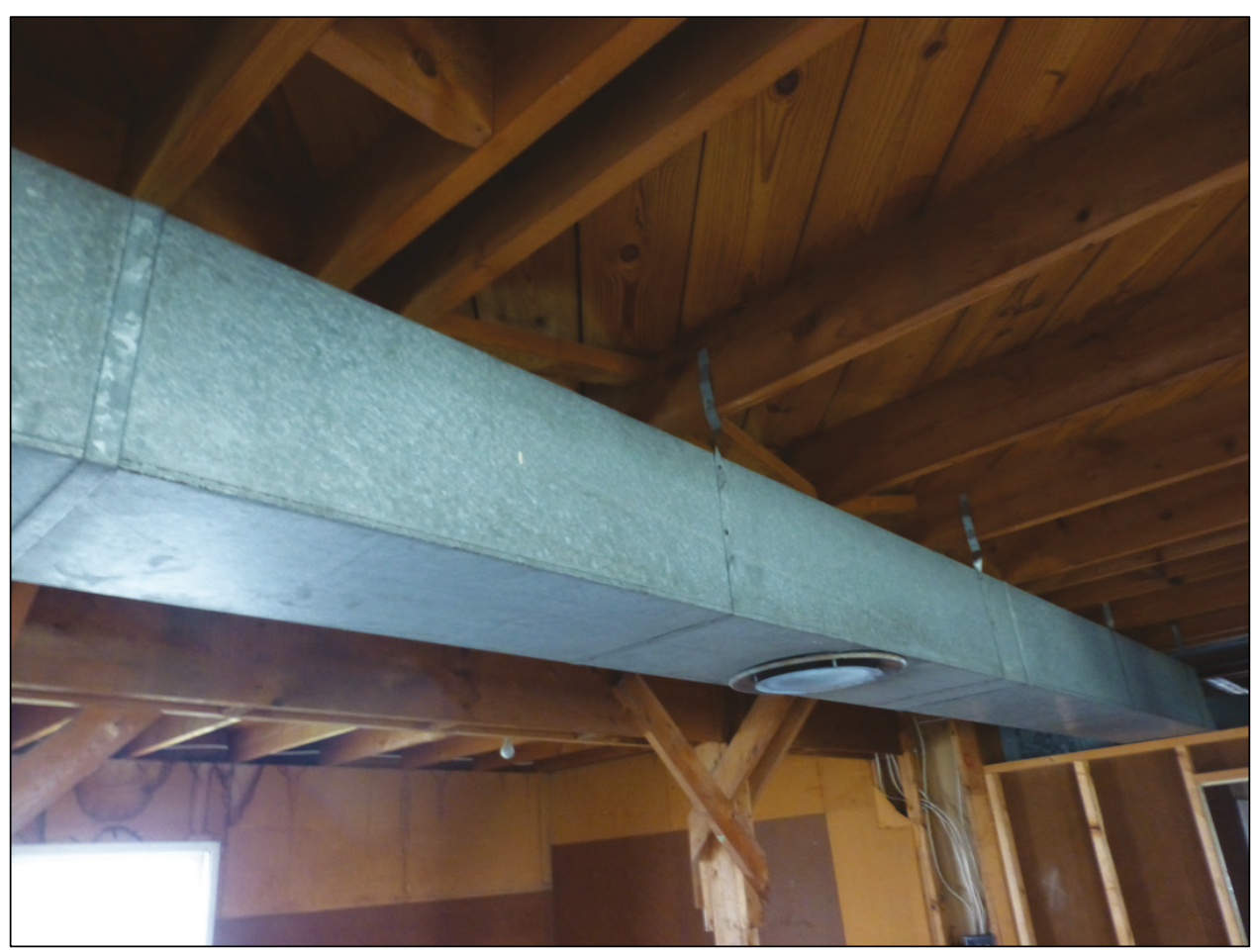


Ballroom - two-story area in service club (Figure 39).

Figure 39. Former ballroom in Building 2000 (ERDC-CERL, 2018).

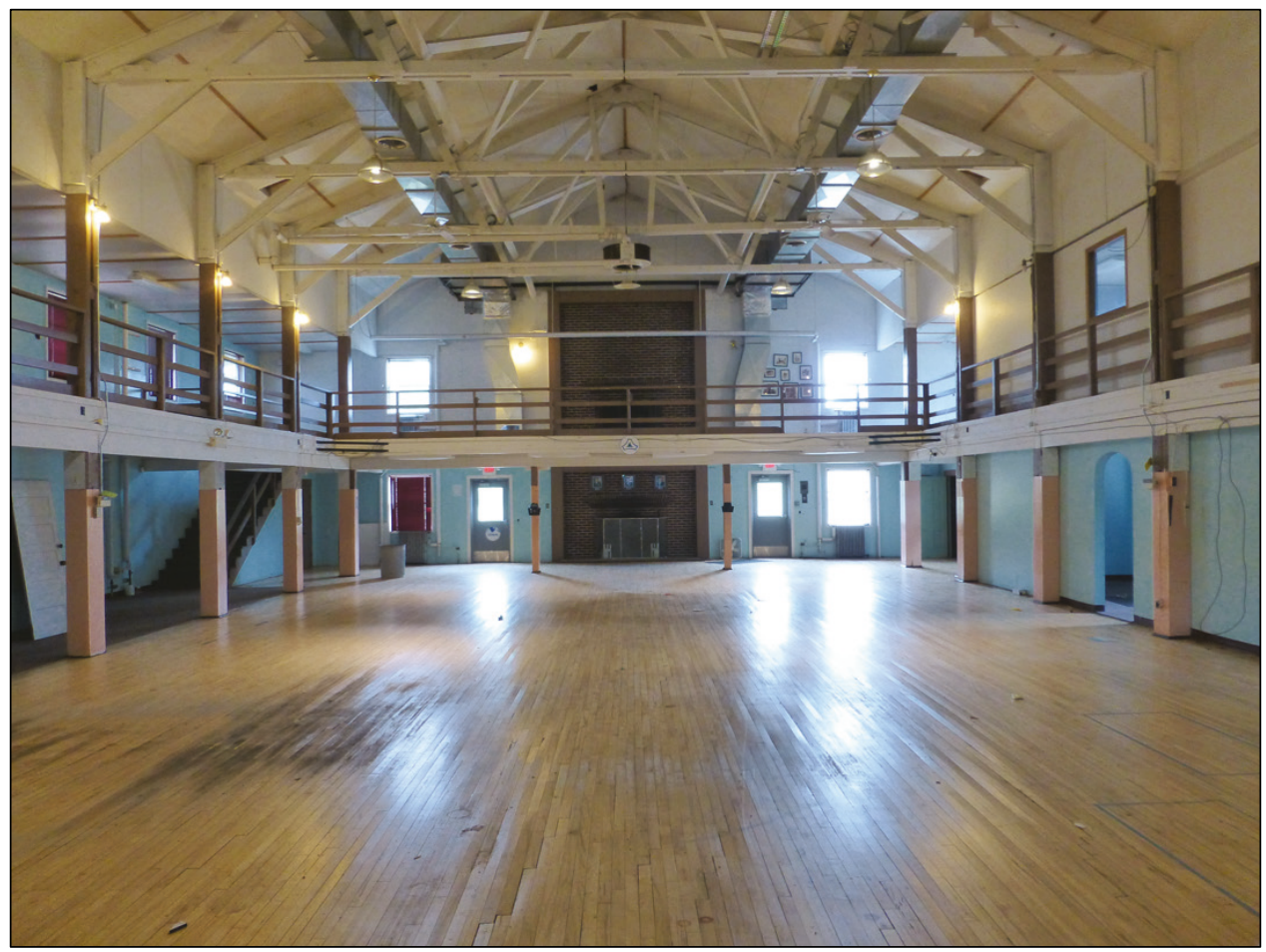

Trusses - exposed wood in service club library and billiard room (Figure 40).

Figure 40. Exposed wood trusses in library of Building 2000 (ERDC-CERL, 2018).

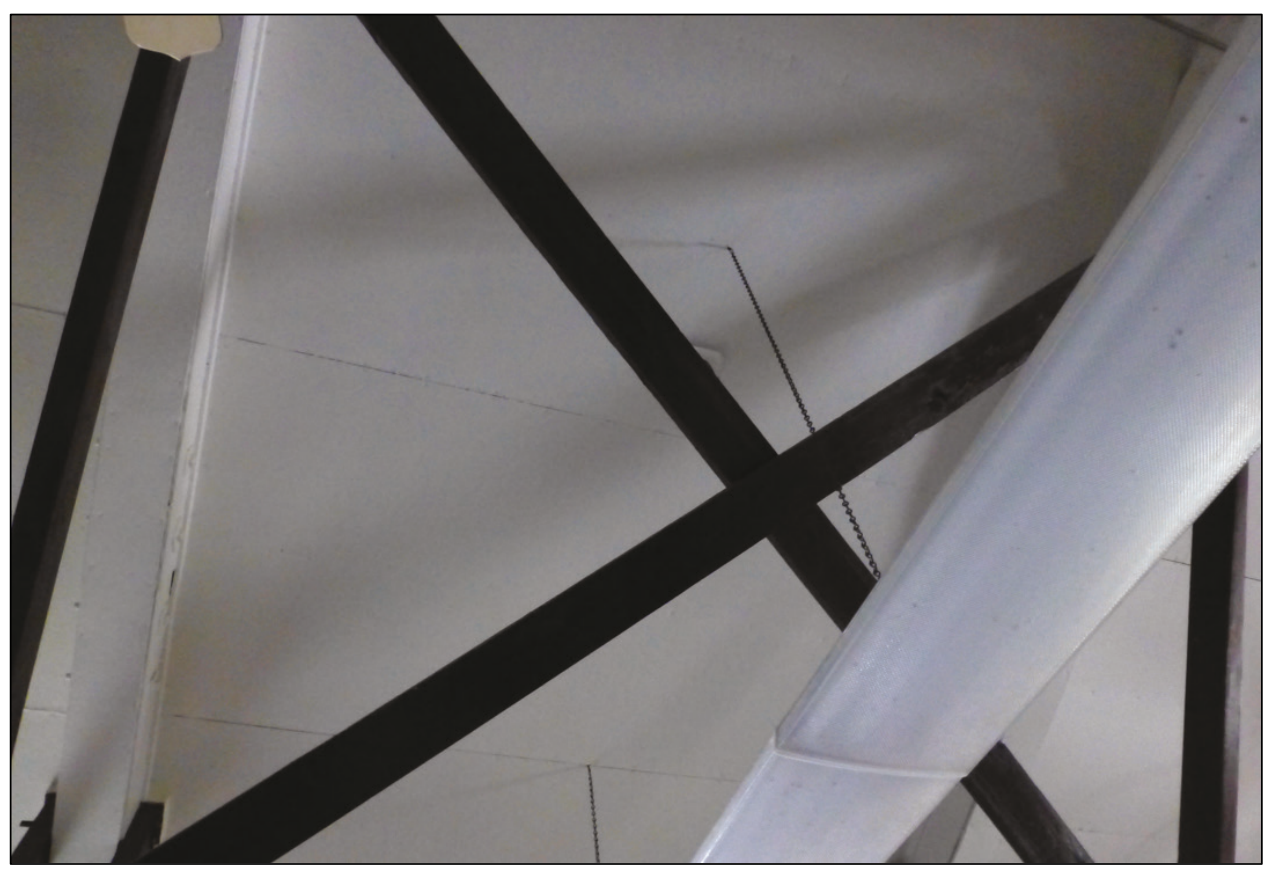


Fireplace - red brick in service club ballroom (Figure 41).

Figure 41. Brick fireplace in Building 2000 (ERDC-CERL, 2018).

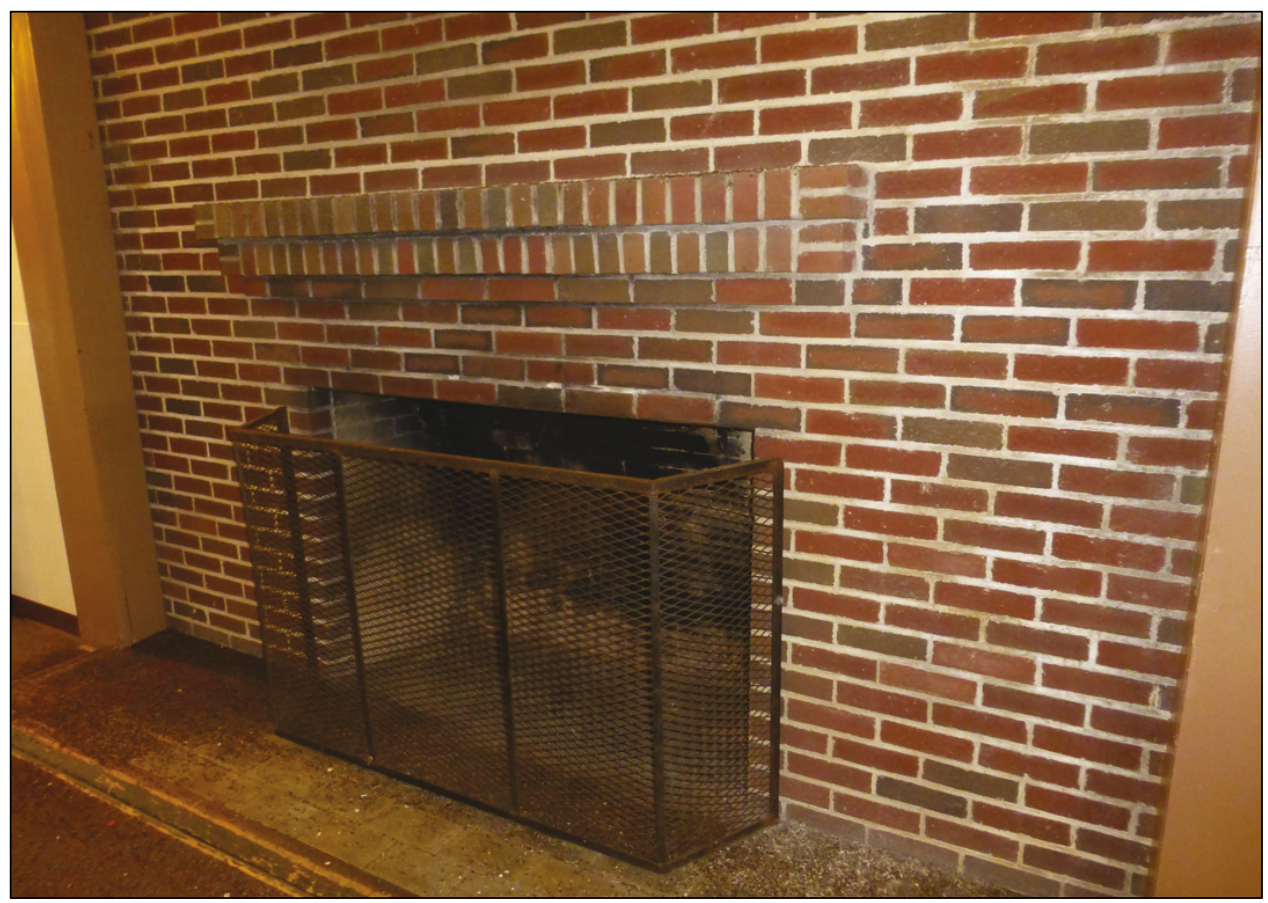


[Intentionally blank.] 


\section{Buildings}

There are 25 buildings constructed during the WWII period on the list given to the researchers; buildings and areas shown in Figure 42. This chapter will group and discuss them as types: fire station; barracks; company storehouse, administration and recreation; mess halls; and service club. There is also one building (Paint Storage Building \# 2159) that is outside the WWII period of significance - see explanation of it in section 5.6. The photos in this chapter will give the reader a general idea of the exterior and interior of the buildings, but please refer to the inventory forms in the appendix for more detailed descriptions and photographs.

Figure 42. Aerial view of Fort McCoy cantonment, with the surveyed buildings and areas marked in red, 2018 (DPW, Fort McCoy).

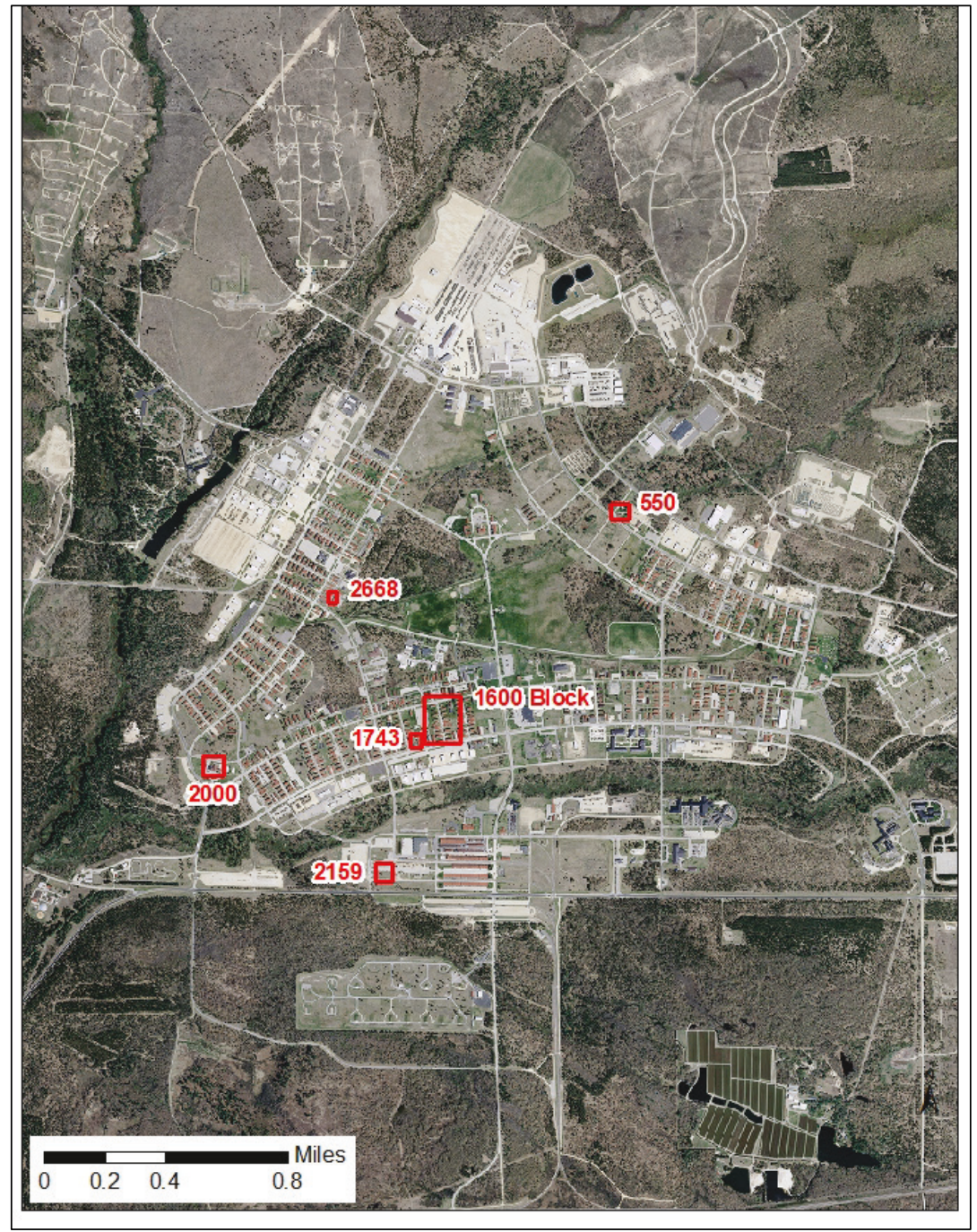




\subsection{Fire Station (Building 550)}

Building 550 is a fire station, constructed in 1942 from the War Department's 800 Series of standard plans (Figure 44)and located on the east side of the Triad (Figure 43). Its category code was changed to a classroom in 1999. The building is not currently in use.

The exterior (Figure 45-Figure 48)retains its character-defining features of overall mass, scalloped asbestos siding, red asphalt shingles, wood windows with multipaned sashes and wood exterior screens, wood window trim, wood doors with multipaned lights and wood interior screens (although the original fire truck bay doors are not extant), and wood skirting.

The interior (Figure 49-Figure 51) has its original plan with its characterdefining features of wood floor in the former squad room and concrete floor in the former fire truck bays, kitchen, and latrine; fiberboard walls, fiberboard ceiling; built-in wood closets; kitchen fixtures, latrine fixtures; and ceiling vents.

HABS was performed on an 800 Series four-bay fire station (Building T1555) at Fort McCoy in 1988, HABS WI-308-FD. 64 This documentation was done as part of the 1986 PMOA for demolition of WWII temporary buildings as approved by DoD, ACHP, and the NCSHPO.

\footnotetext{
64 HABS No. WI-308-FD. “Fort McCoy, Building No. T-1555 (Fire Station)," Intersection of South Tenth Avenue \& South "J" Street, Sparta, Monroe County, Wisconsin," (Denver, CO: Historic American Buildings Survey, National Park Service, Department of the Interior, 1988). Catalogued by Library of Congress as HABS, WIS,41-SPAR.V, 1FD-:

https://cdn.loc.gov/master/pnp/habshaer/wi/wi0500/wi0557/data/wi0557data.pdf.
} 
Figure 43. Map with location of Building 550, center (Fort McCoy DPW, 2018).

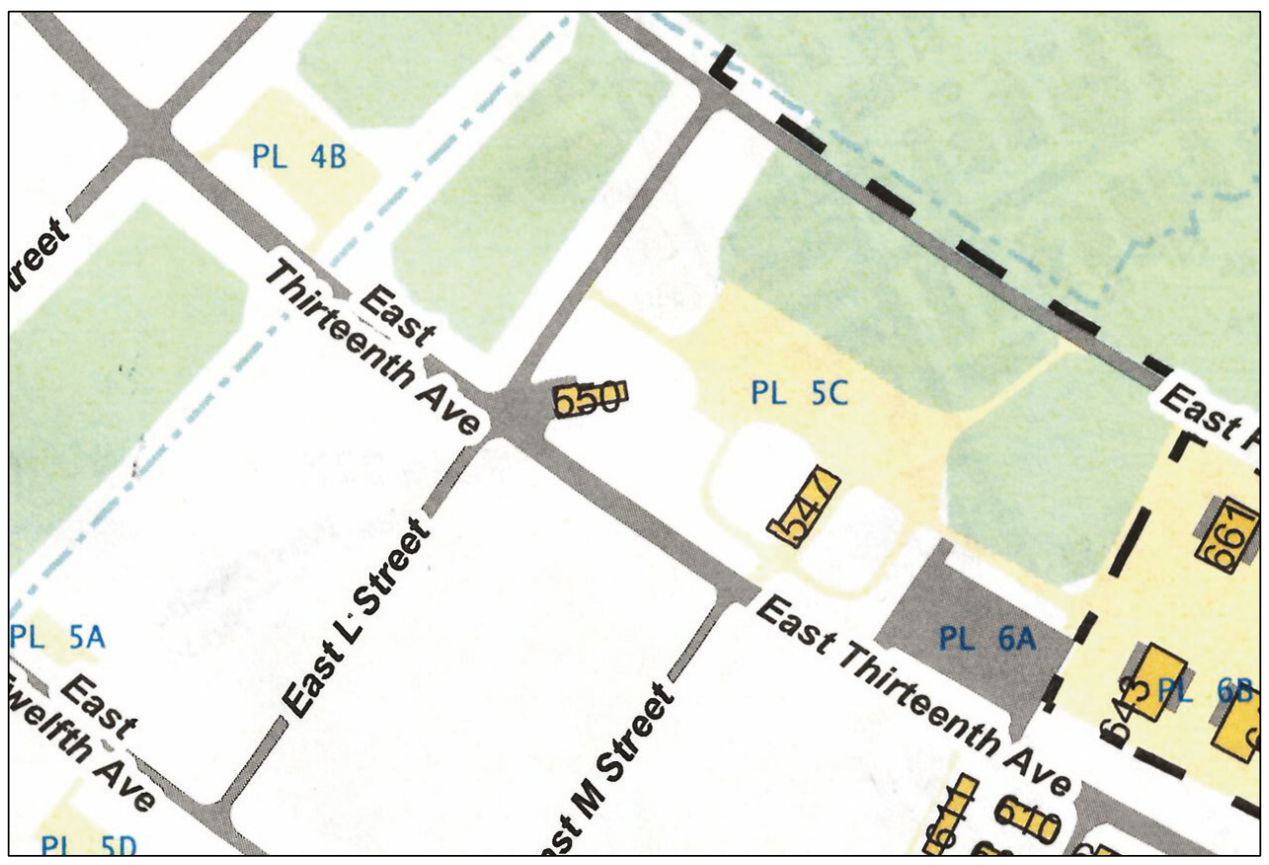

Figure 44. 800 Series plan for fire station, Drawing 800-800, 1941 (in drawings file at Fort McCoy DPW).

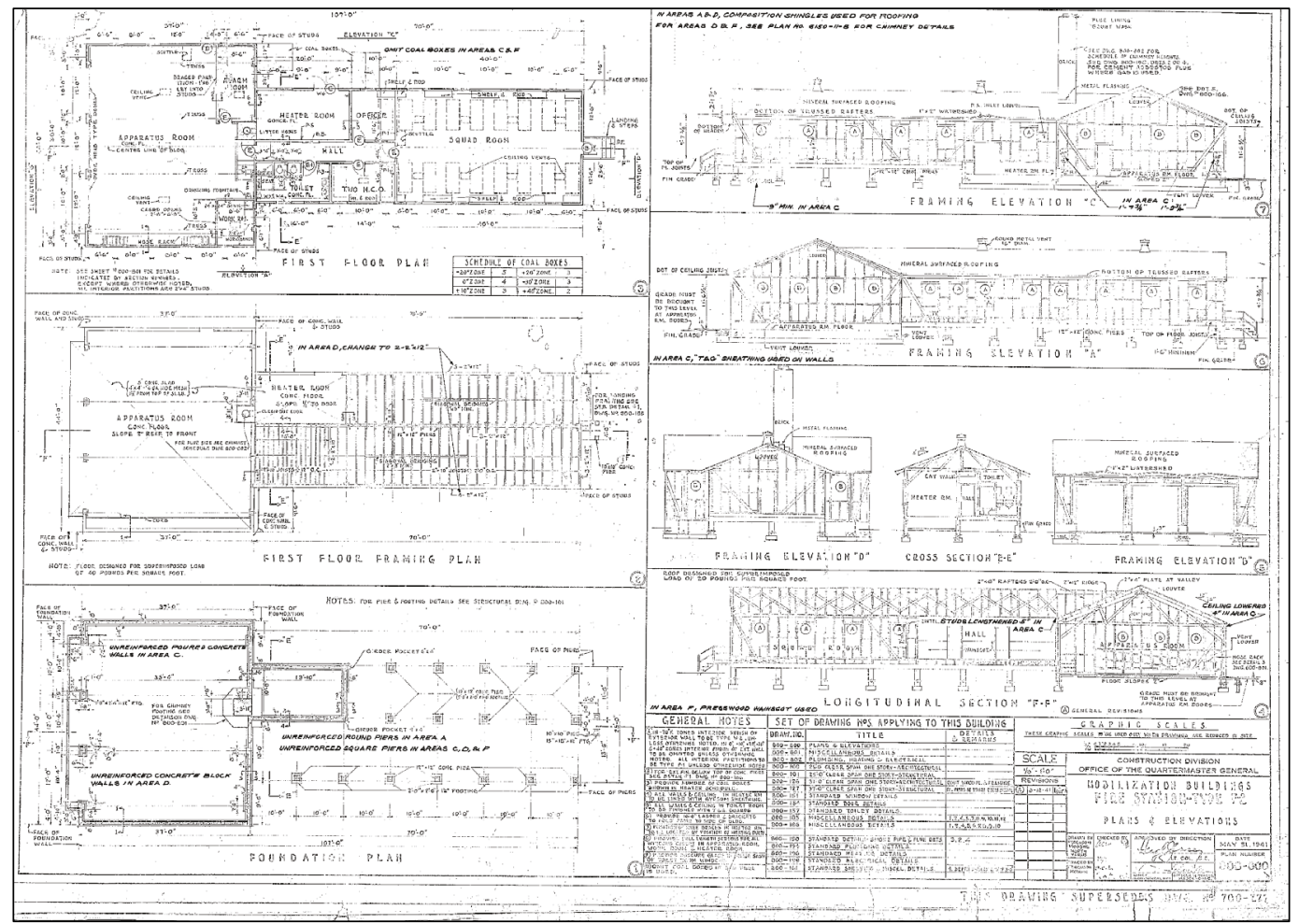


Figure 45. Northwest oblique of Building 550 (ERDC-CERL, 2018).

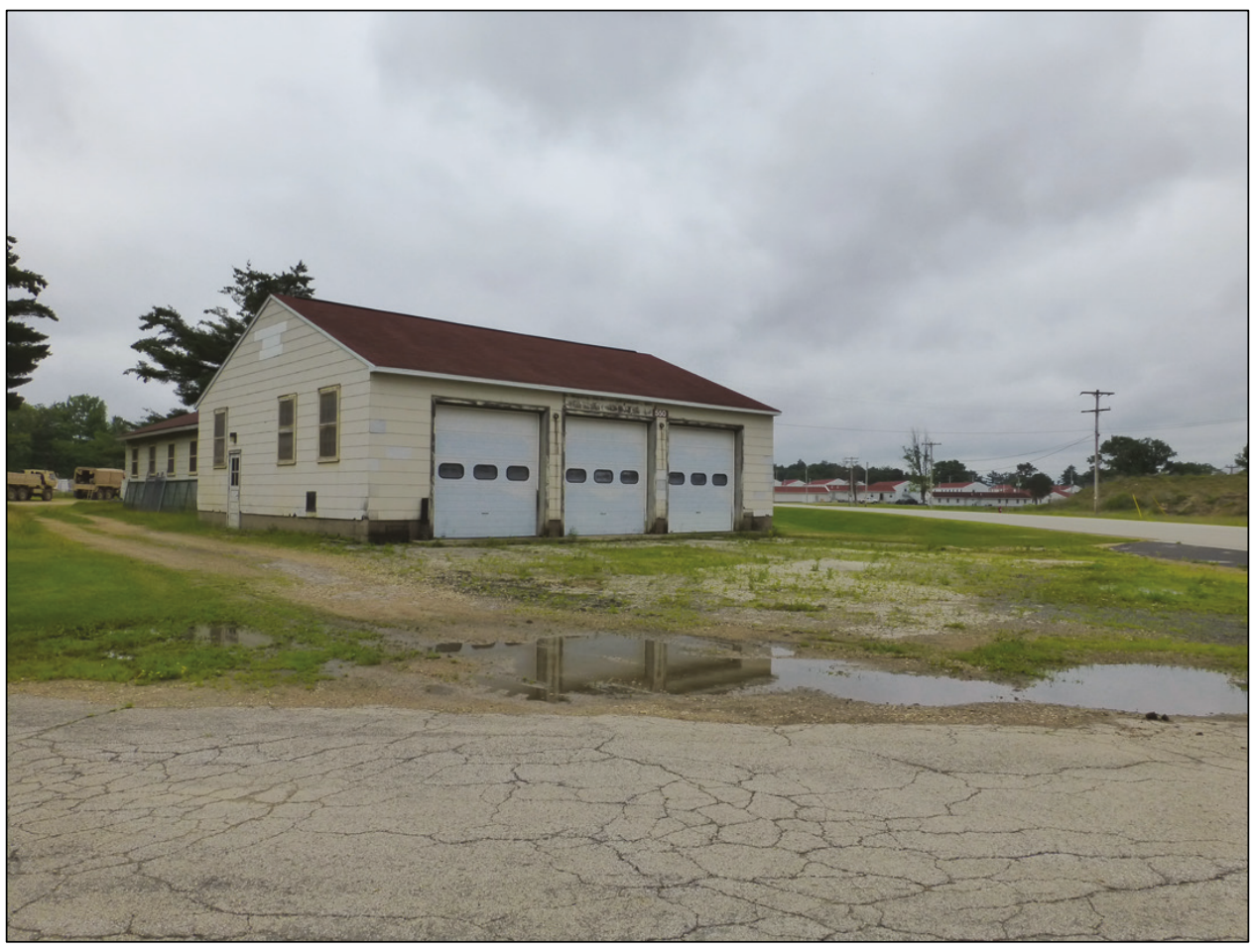

Figure 46. North side of Building 550 (ERDC-CERL, 2018).

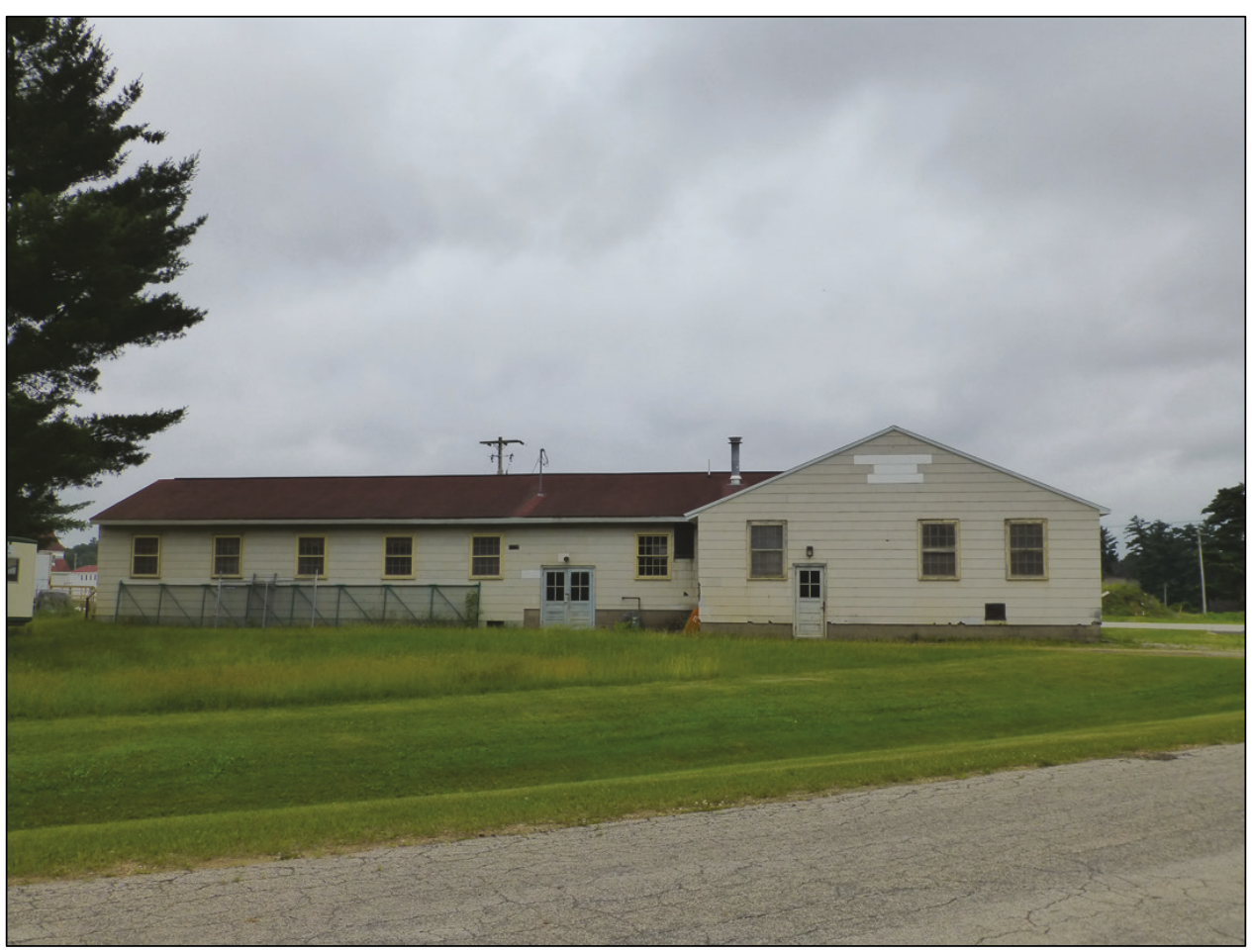


Figure 47. East side of Building 550 (ERDC-CERL, 2018).

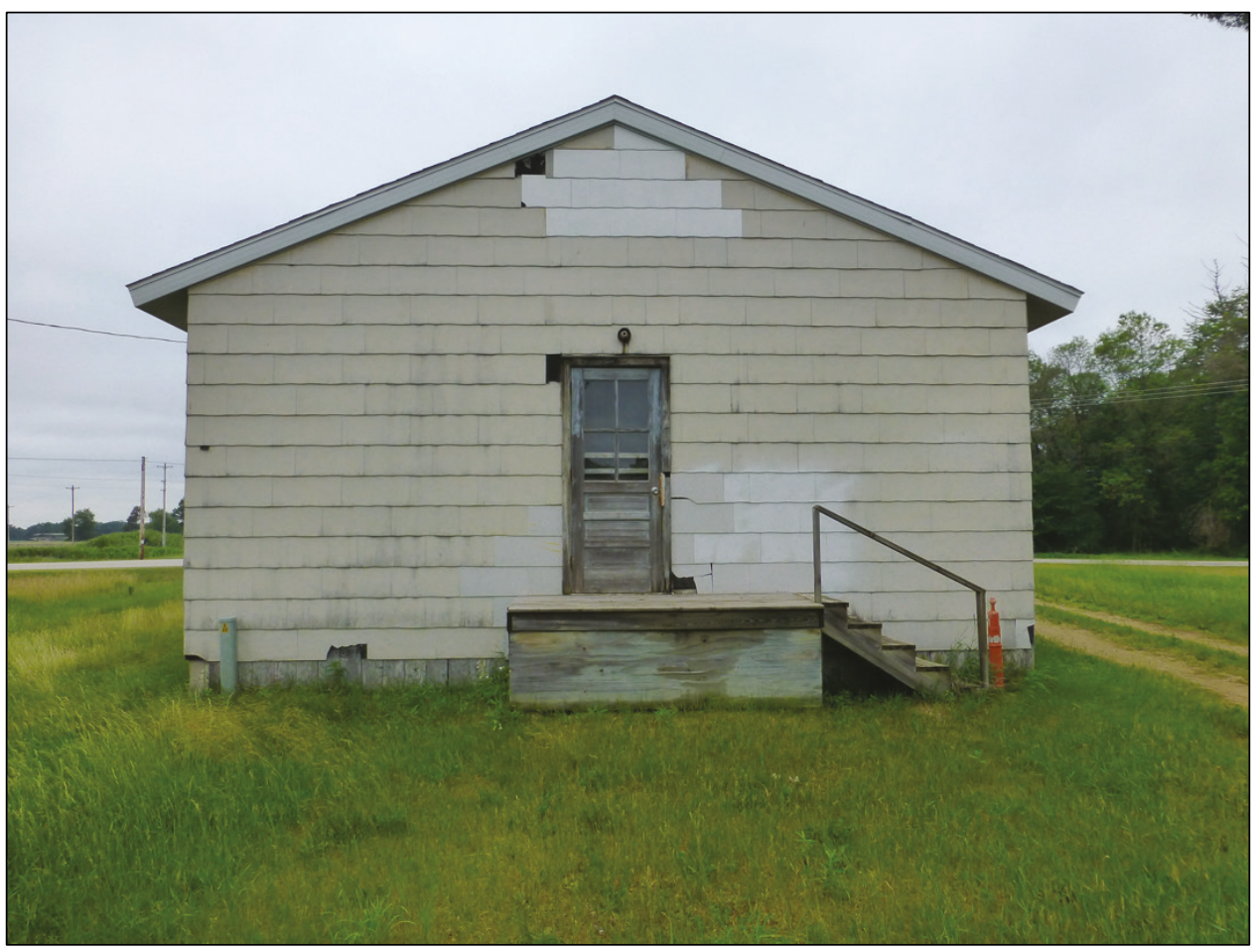

Figure 48. South side of Building 550 (ERDC-CERL, 2018).

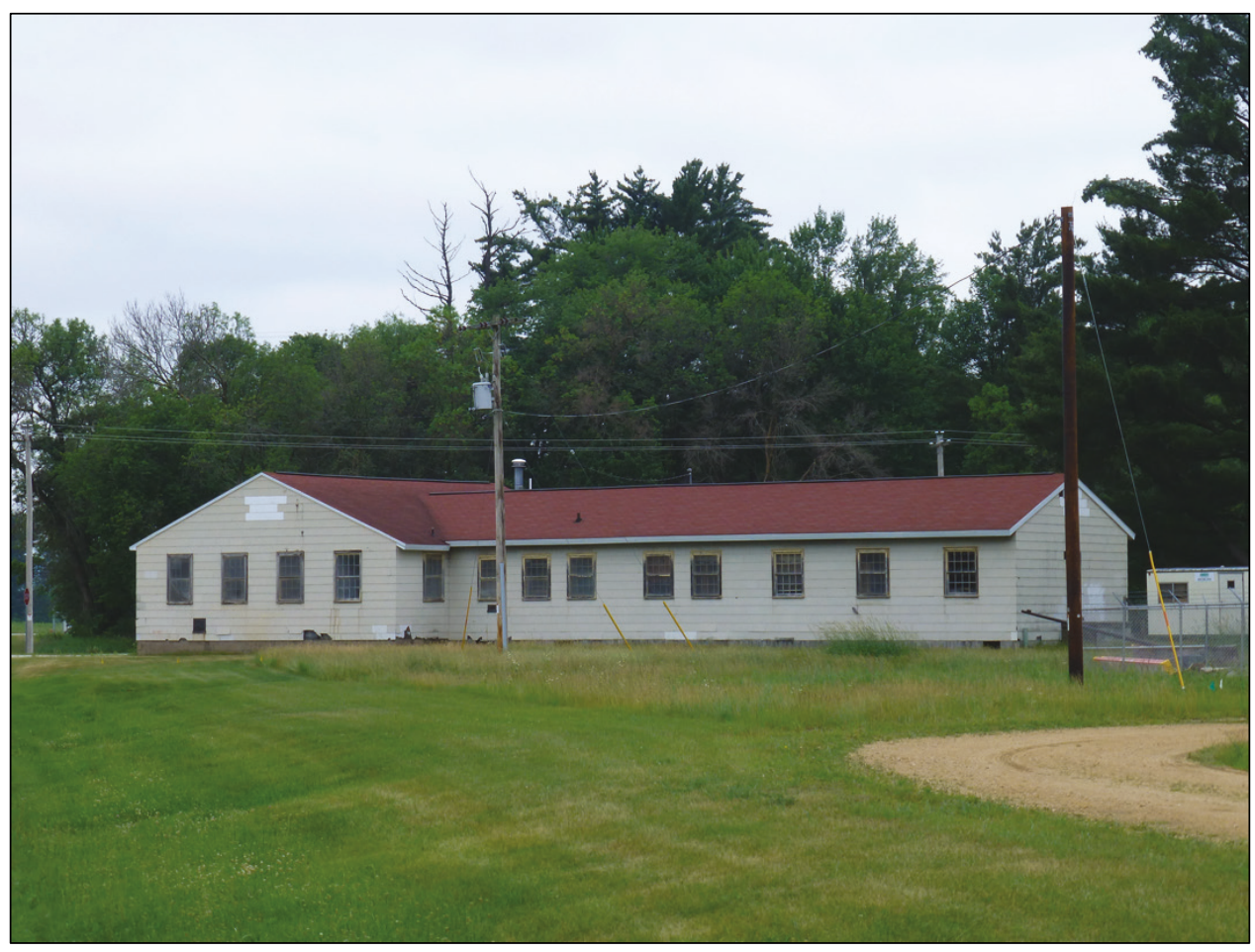


Figure 49. Interior of northernmost fire truck bay on west side of Building 550 (ERDCCERL, 2018).

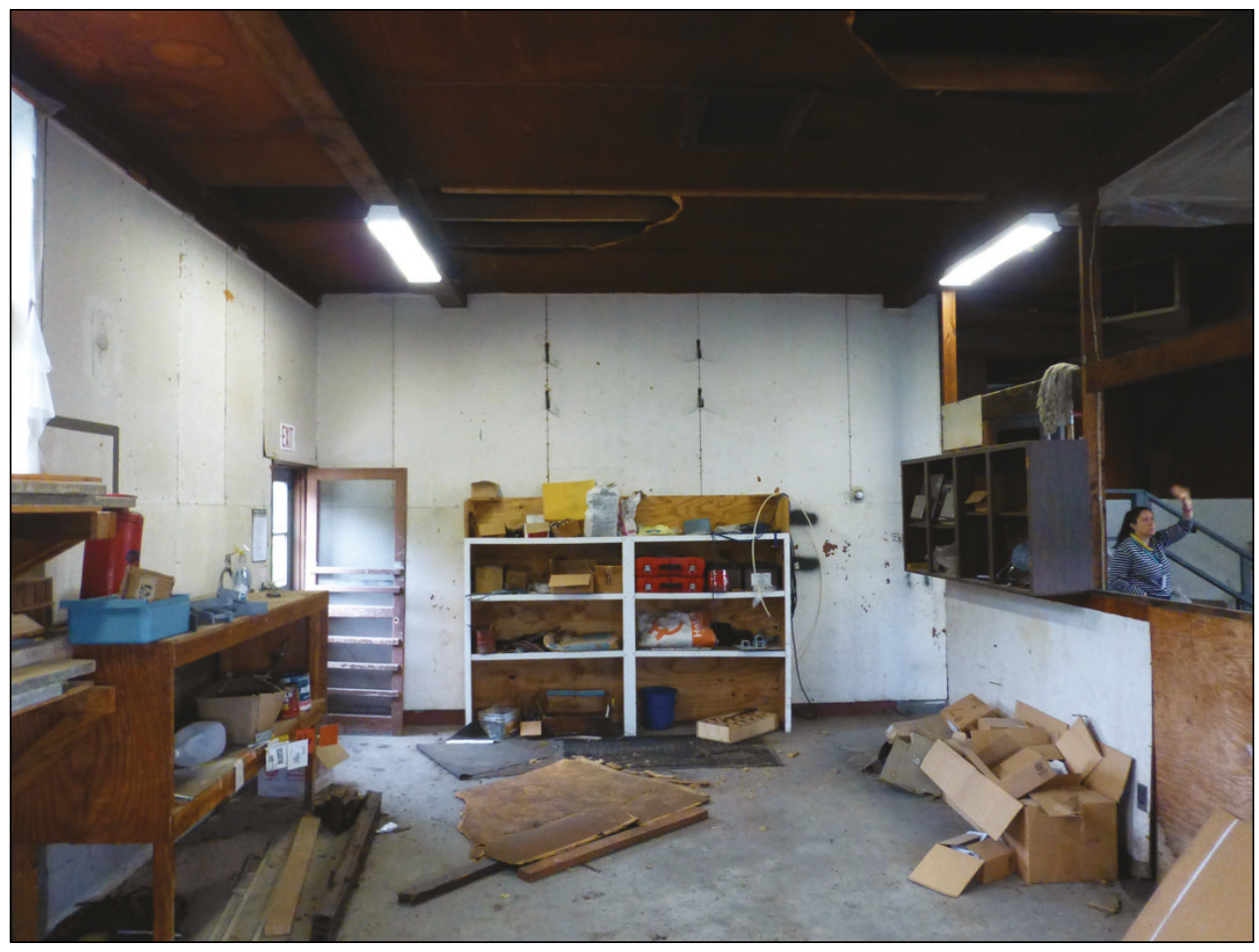

Figure 50. Original wood floor in former squad bay, Building 550 (ERDC-CERL, 2018).

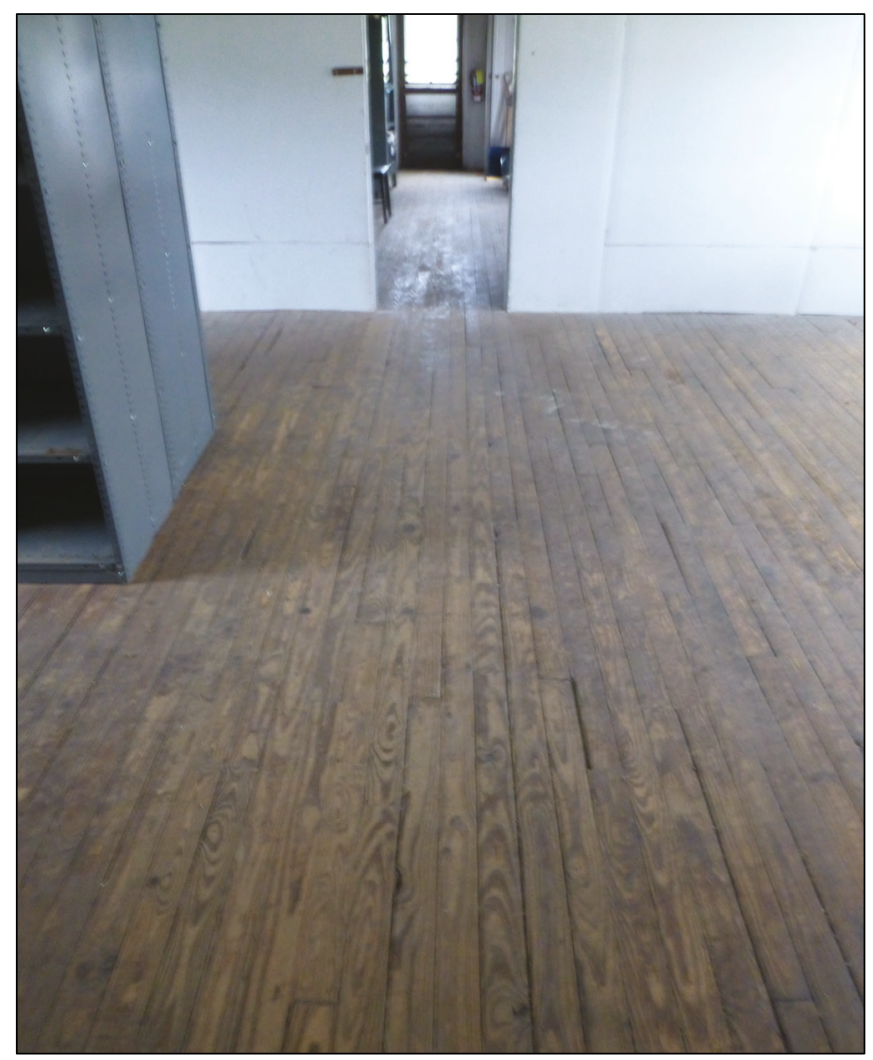


Figure 51. Original latrine in Building 550 (ERDC-CERL, 2018).

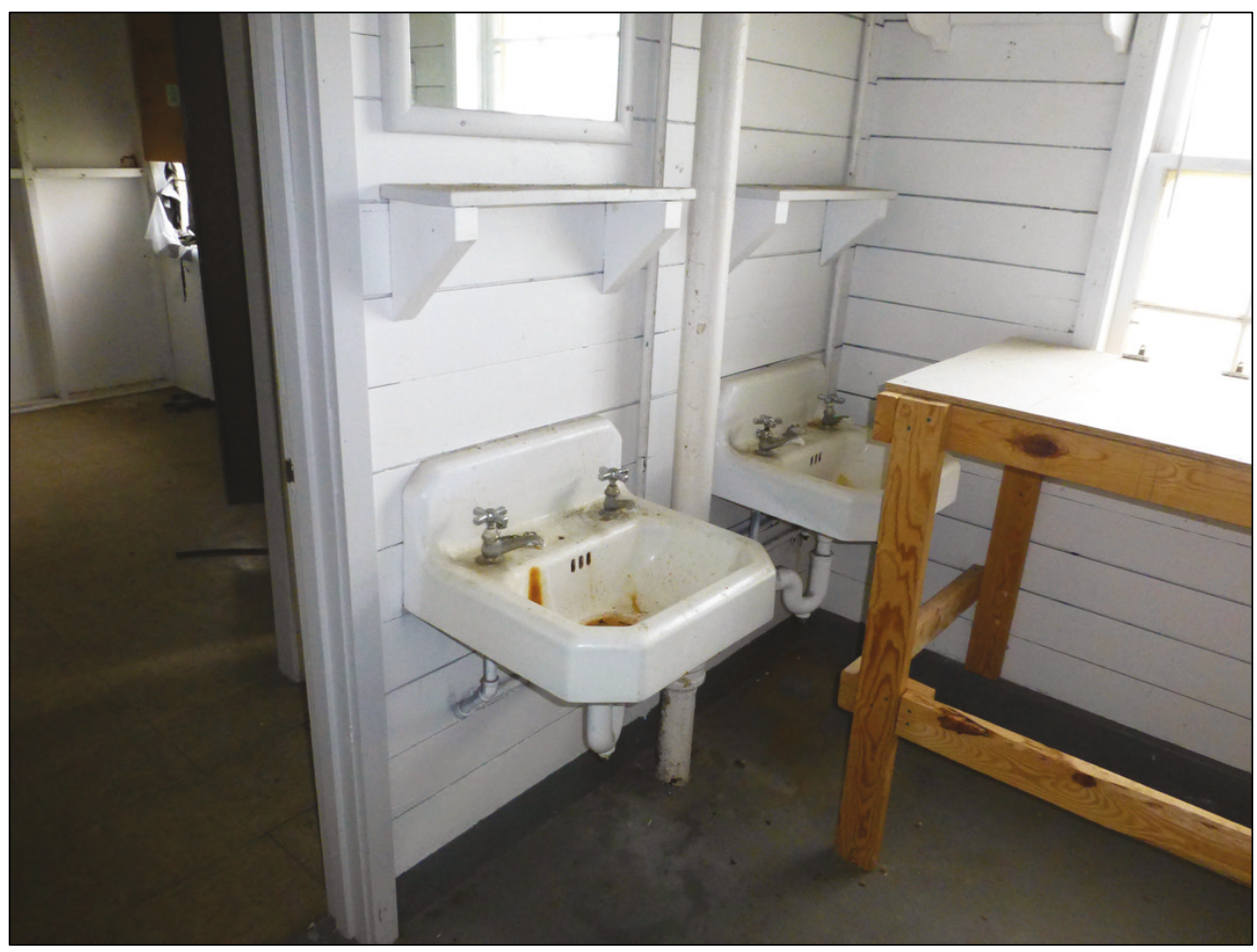

5.2 Barracks (Buildings 1602, 1603, 1604, 1607, 1608, 1609, $1610,1612,1613,1614,1615,1618,1619,1620$, and 1632)

Buildings 1602, 1603, 1604, 1607, 1608, 1609, 1610, 1612, 1613, 1614, 1615, $1618,1619,1620$, and 1632 are all barracks constructed in 1942 from the War Department's 80o Series of standard plans (Figure 53) and located on the south side of the Triad (Figure 52). The buildings are all still barracks and currently in use.

The exterior of the barracks (Figure 54-Figure 64) have no original character-defining features from the period of significance except their overall mass. Two of the four doors on the opposite side from each building's entrance were removed, and the wood platform and ladders were replaced with a steel staircase and platform (Figure 69-Figure 82).

The interior has its original plan, but no other character-defining features are extant (Figure 65-Figure 68). 
HABS was performed on the 800 Series barracks (Building T-1129) at Fort McCoy in 1988, HABS WI-308-A. ${ }^{65}$ This documentation was done as part of the 1986 PMOA for demolition of WWII temporary buildings as approved by DoD, ACHP, and the NCSHPO.

Figure 52. Location of Buildings 1602, 1603, 1604, 1607, 1608, 1609, 1610, 1612, $1613,1614,1615,1618,1619,1620$, and 1632 (Fort McCoy DPW, 2018).

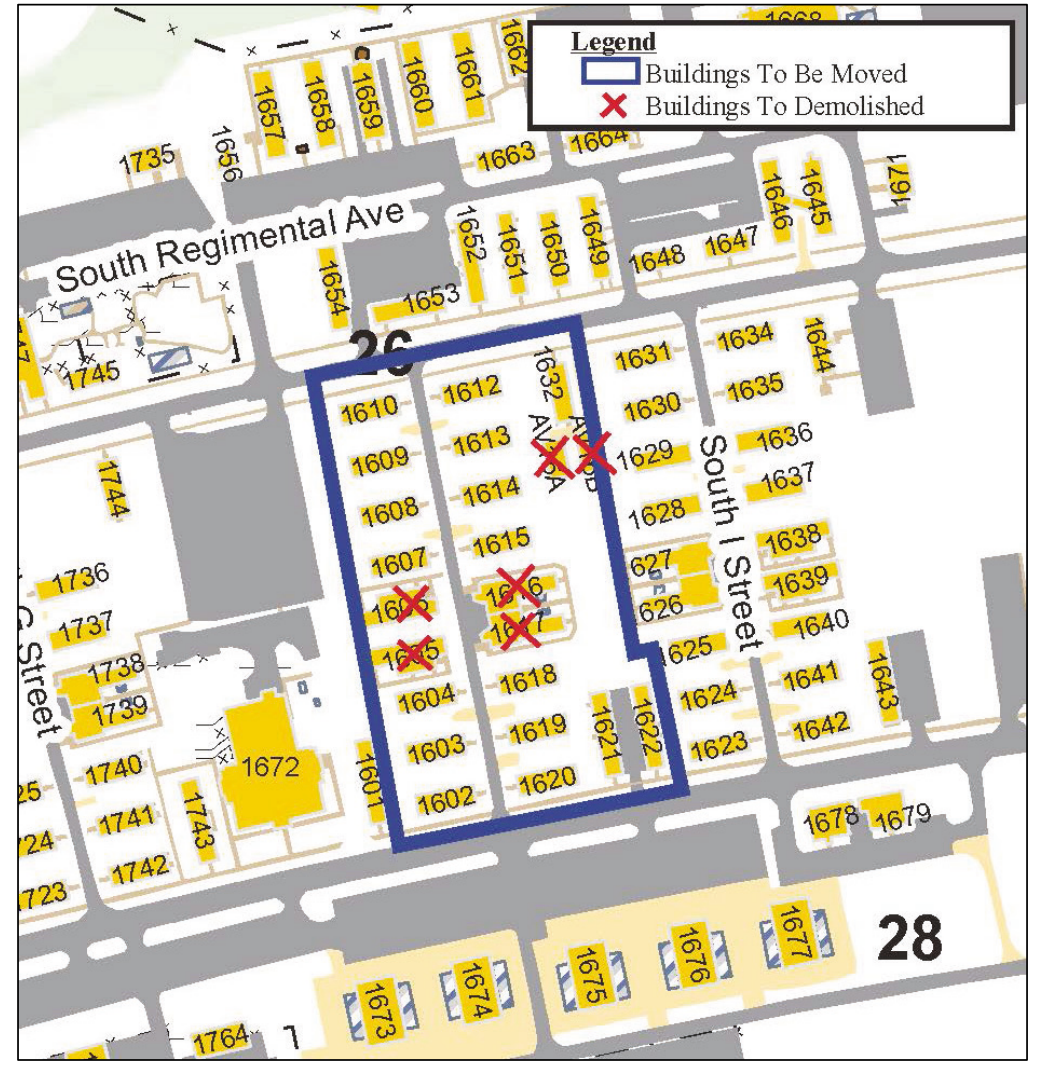

65 HABS WI-308-A, “Fort McCoy, Building T-1129 (Barrack)," Sparta, Monroe County, Wisconsin (Washington, DC: Historic American Buildings Survey, National Park District, Department of the Interior, 1988). Catalogued by Library of Congress as HABS WIS, 41-SPAR.V, 1-A-:

https://cdn.loc.gov/master/pnp/habshaer/wi/wiO200/wi0261/data/wi0261data.pdf. 
Figure 53. 800 Series plan for barracks, Drawing 800-443, 1941 (Library of Congress).

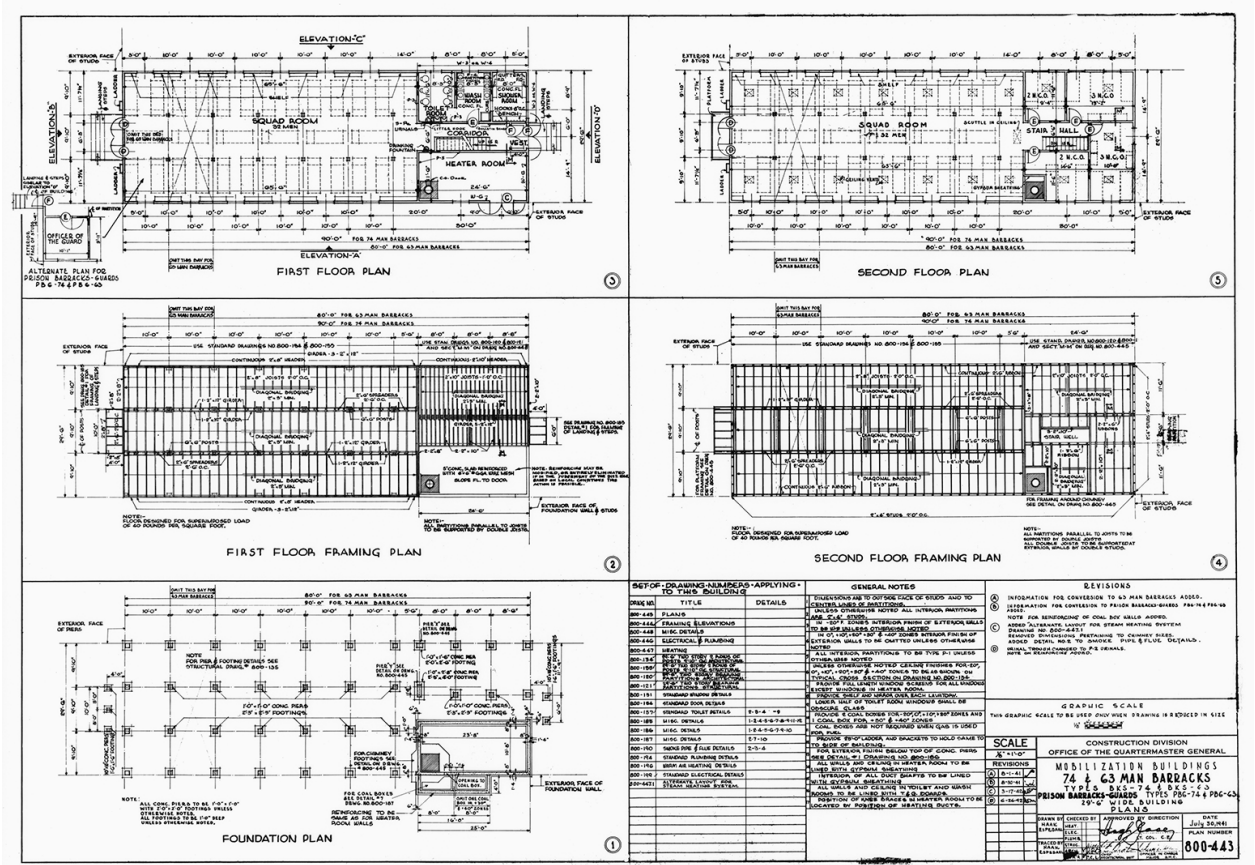

Figure 54. Rear of 800 Series barracks with the original doors, platforms, and ladders, 1950 (NARA College Park, RG111-SC).

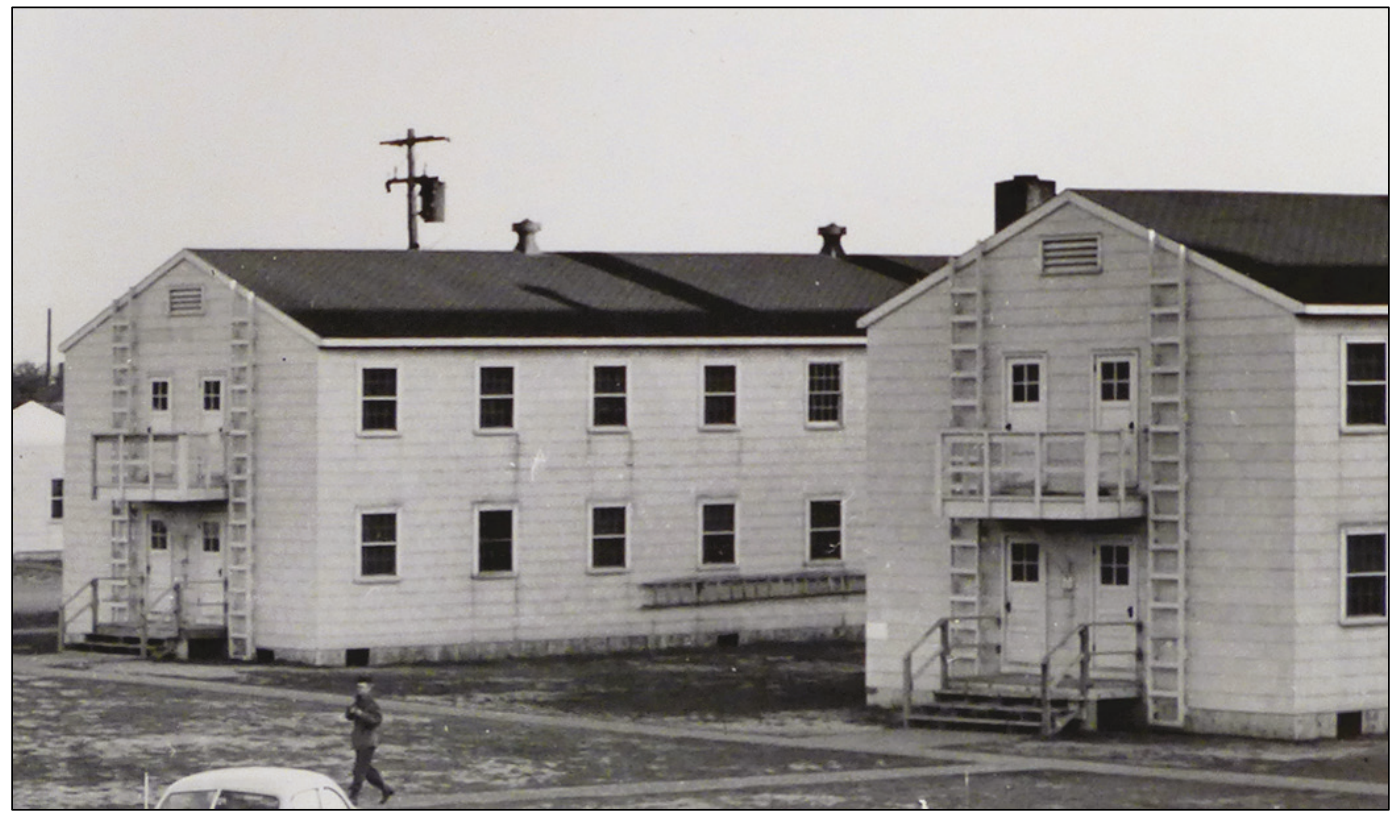


Figure 55. Rear of 800 Series barracks with the removal of two doors, 1988 (Library of Congress, HABS WI-308-A-7).

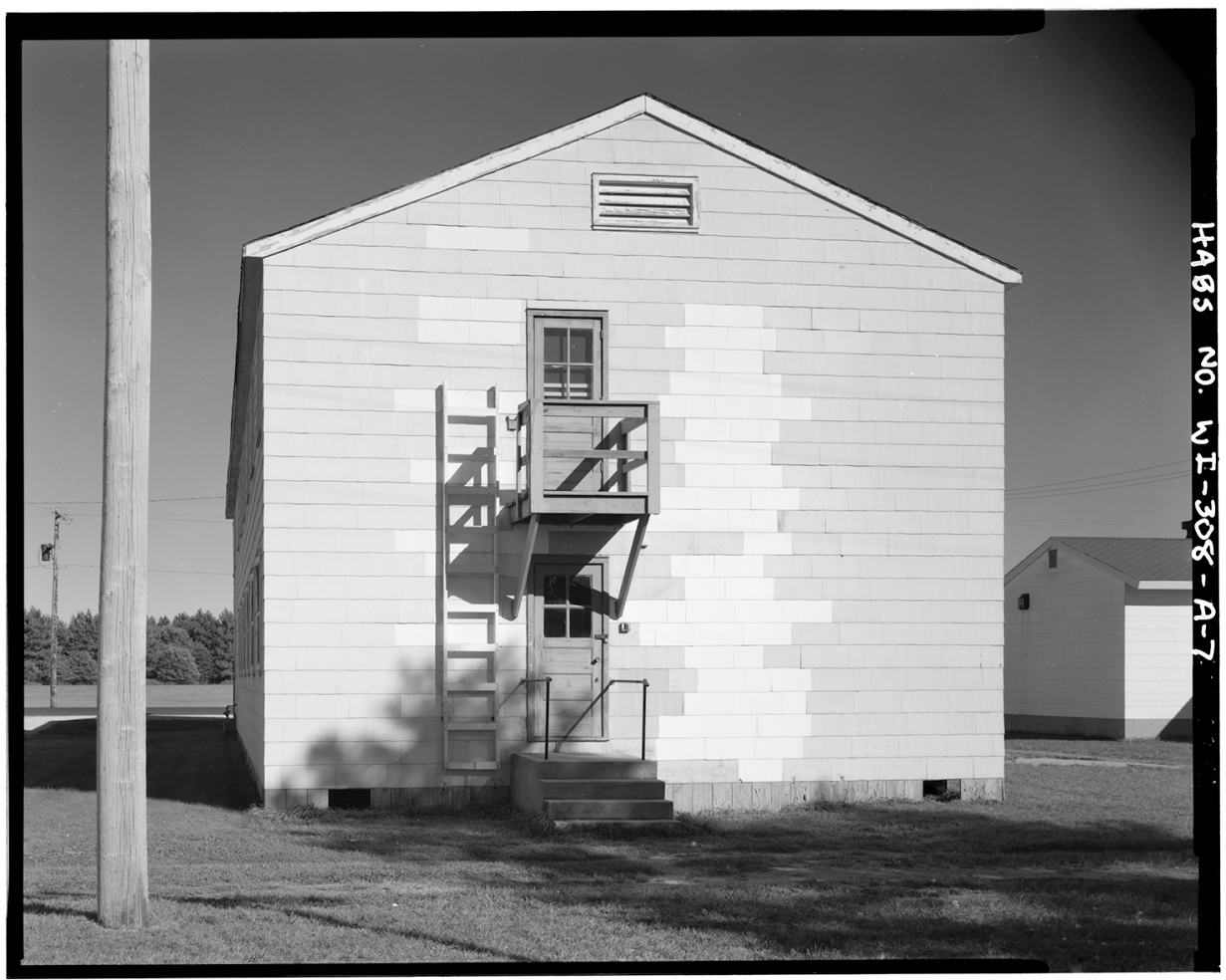

Figure 56. Oblique of 800 Series barracks with the removal of two doors located at the far end of each squad room, 1988 (Library of Congress, HABS WI-308-A-4).

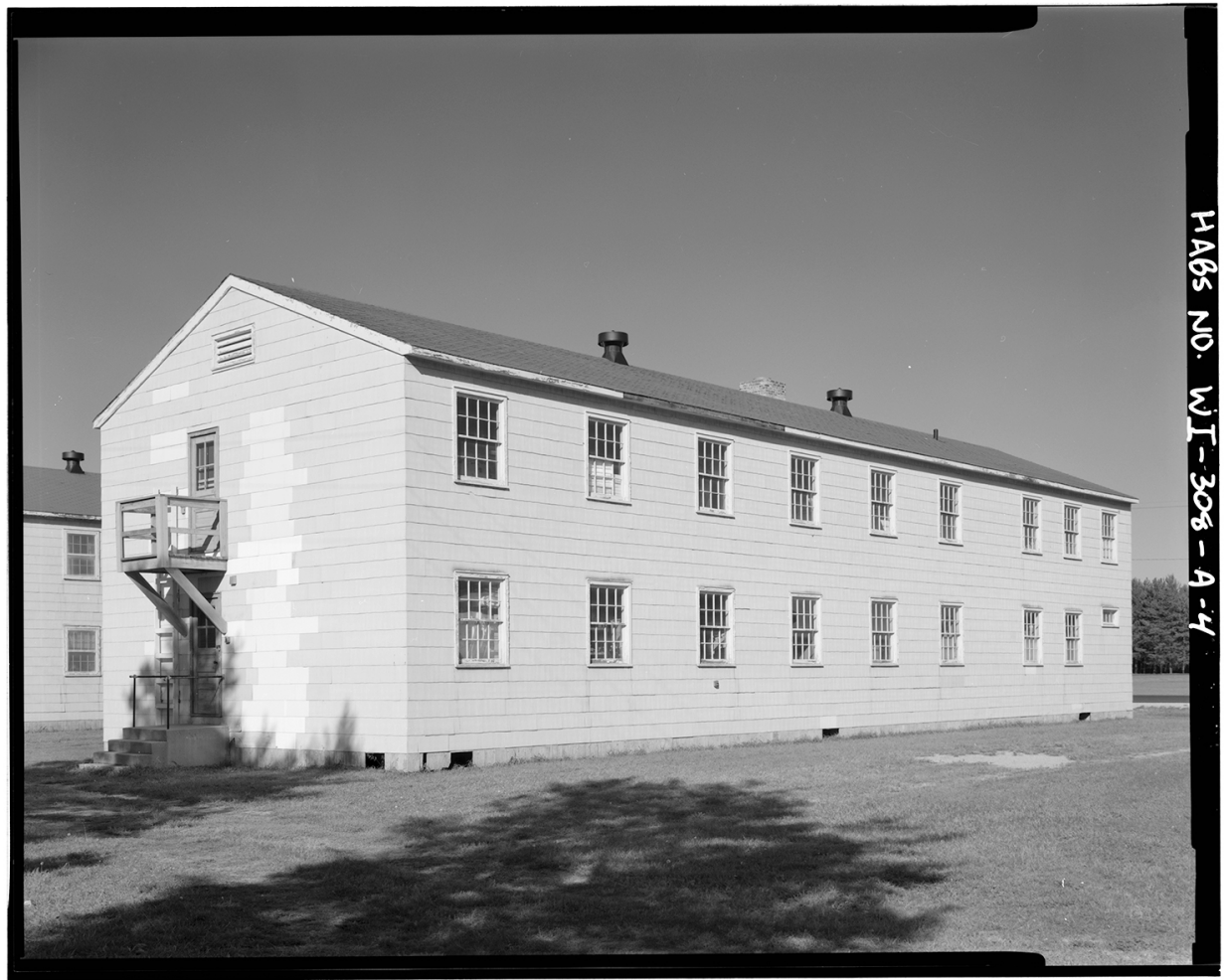


Figure 57. East side of Building 1602 (ERDC-CERL, 2018).

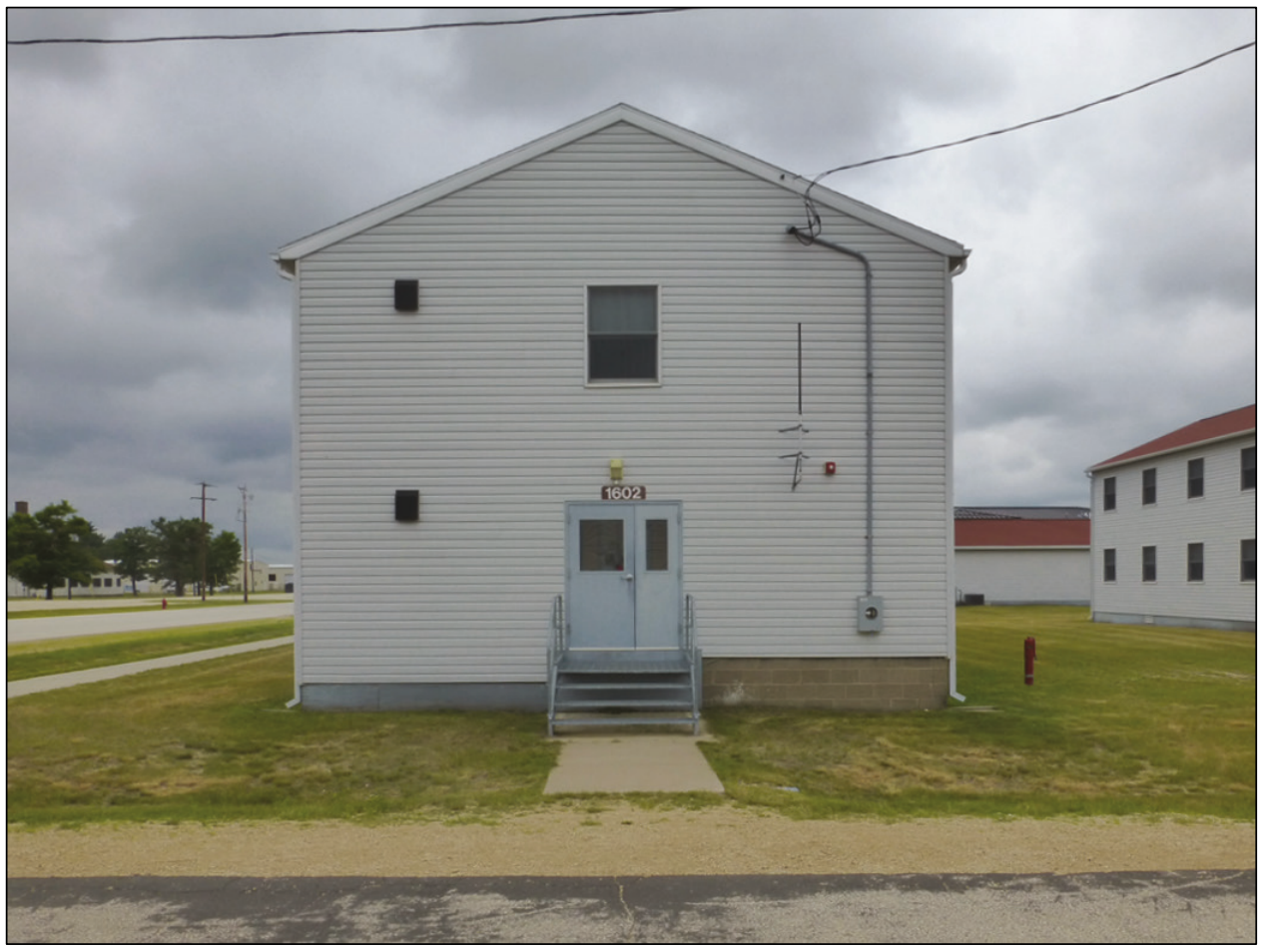

Figure 58. Northeast oblique of Building 1602 (ERDC-CERL, 2018).

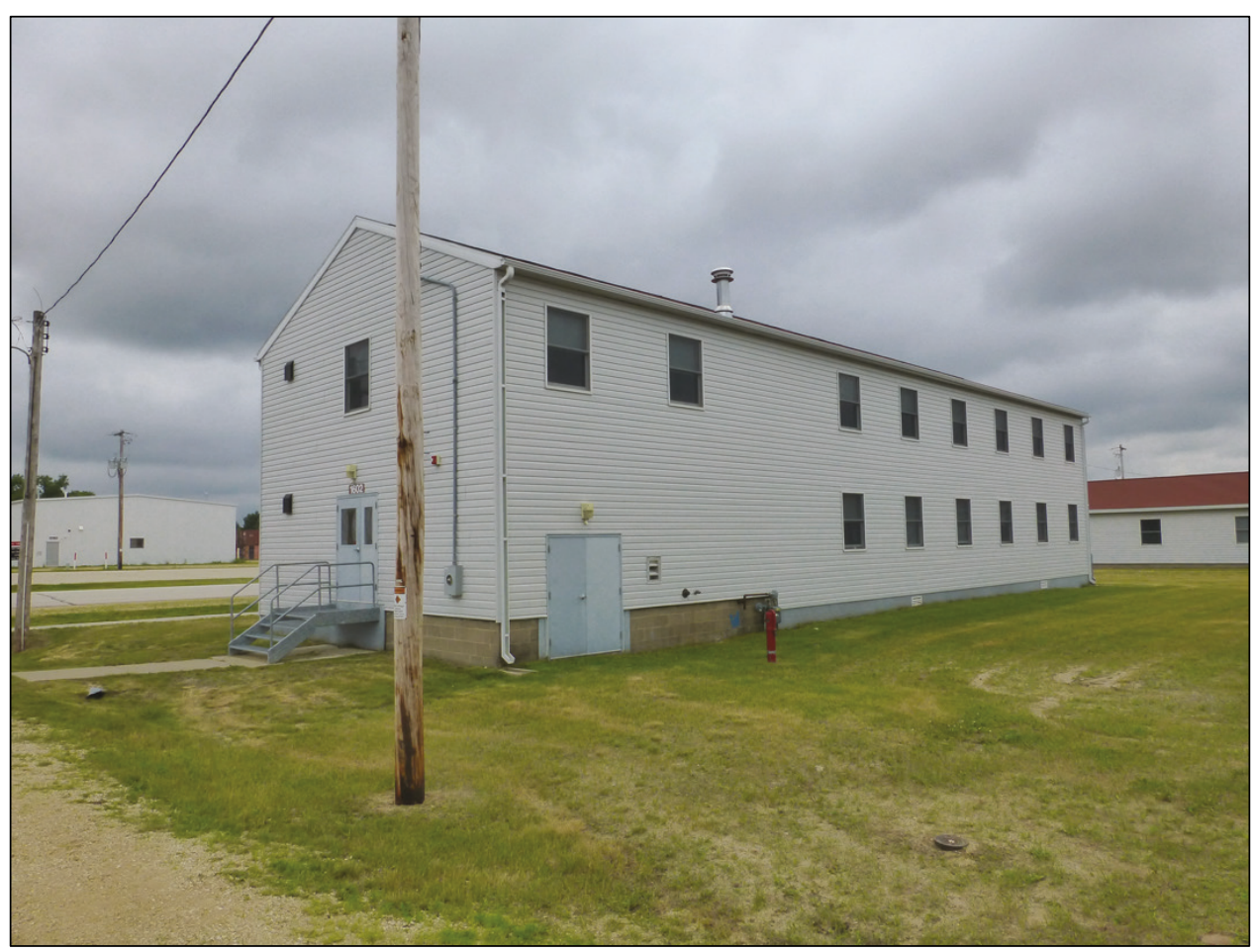


Figure 59. Southwest oblique of Building 1602 (ERDC-CERL, 2018).

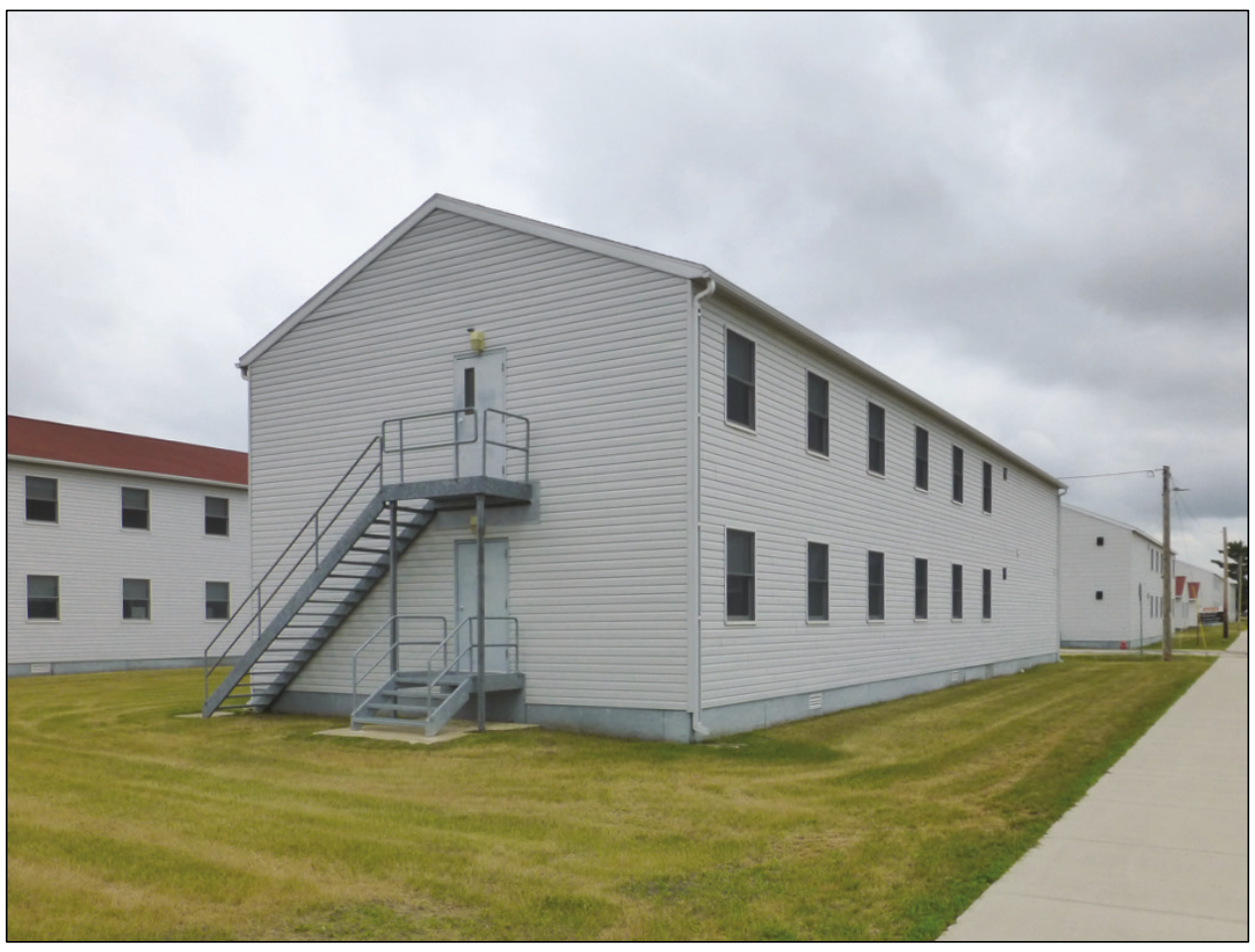

Figure 60. West side of Building 1620 (ERDC-CERL, 2018).

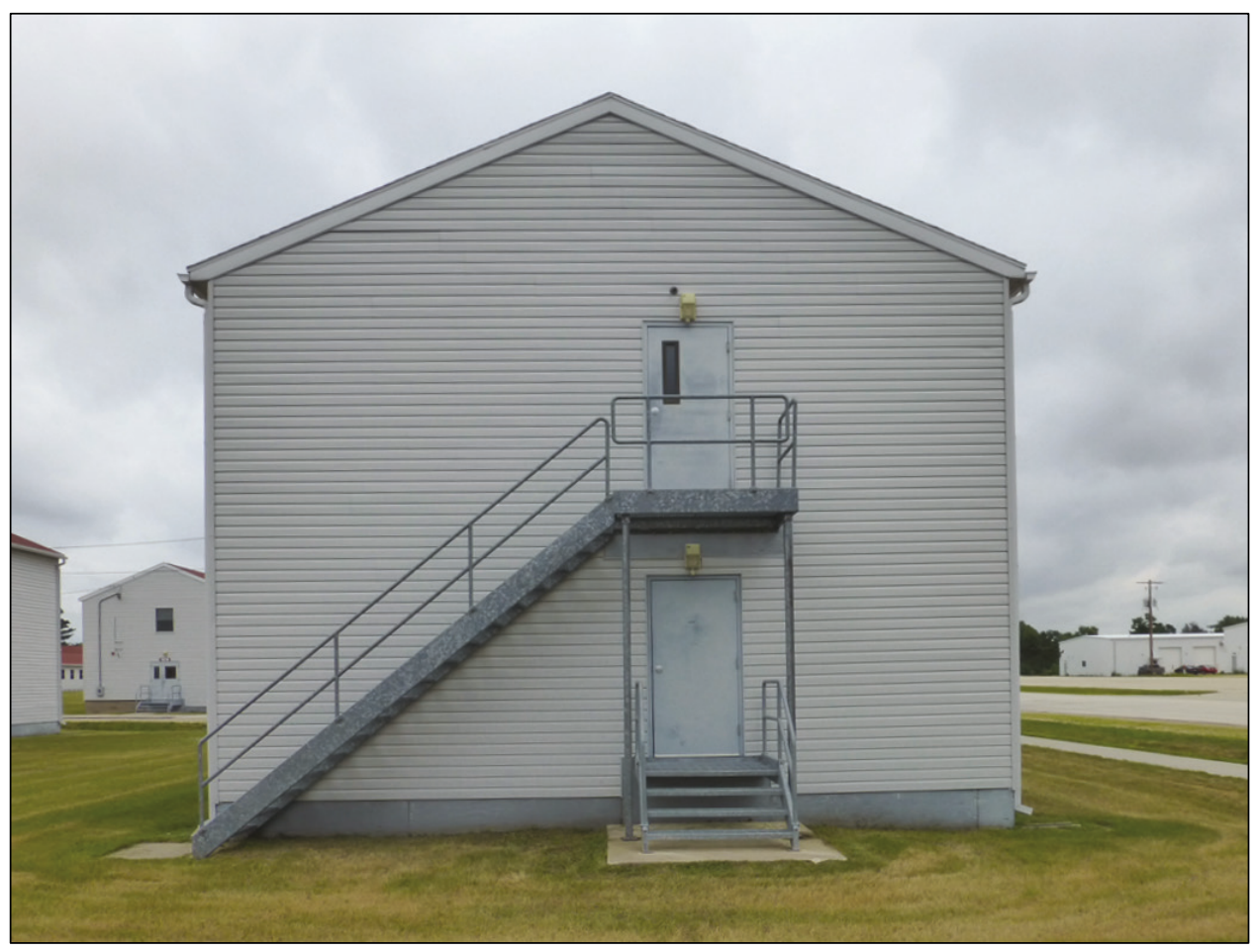


Figure 61. Window detail on Building 1602 (ERDC-CERL, 2018).

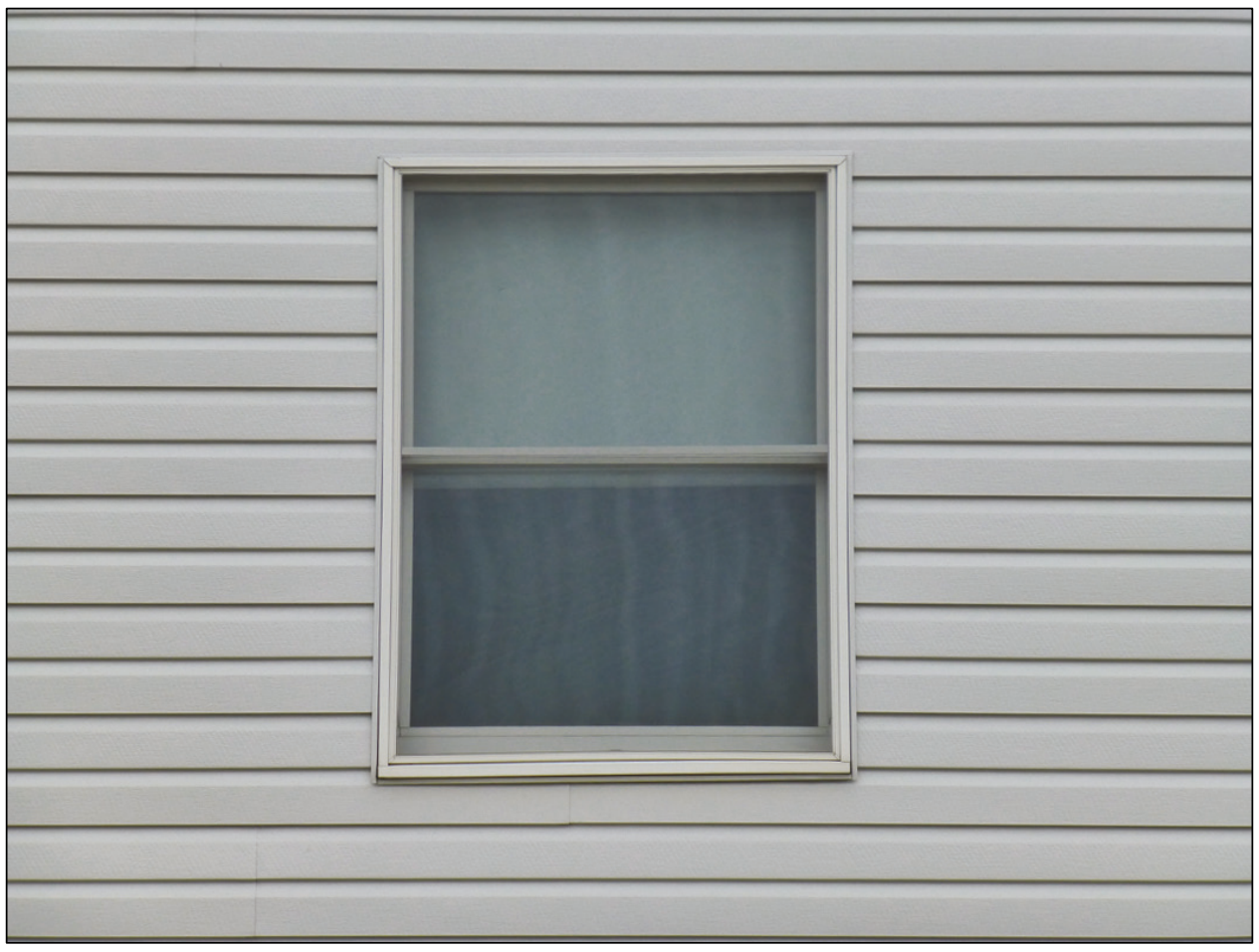

Figure 62. Main barracks entrance with metal door and metal steps on Building 1602 (ERDC-CERL, 2018).

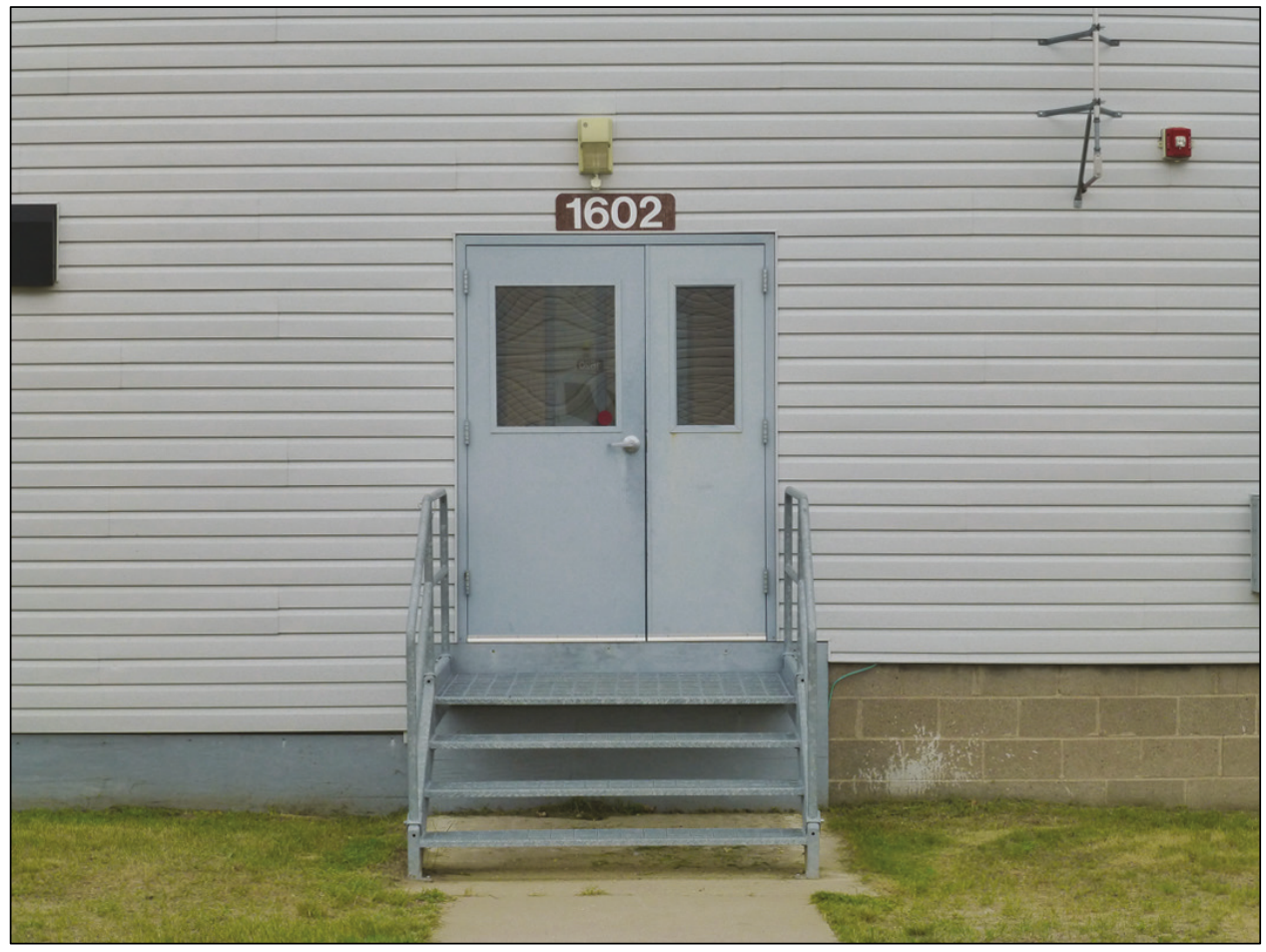


Figure 63. Replacement siding on Building 1602 (ERDC-CERL, 2018).

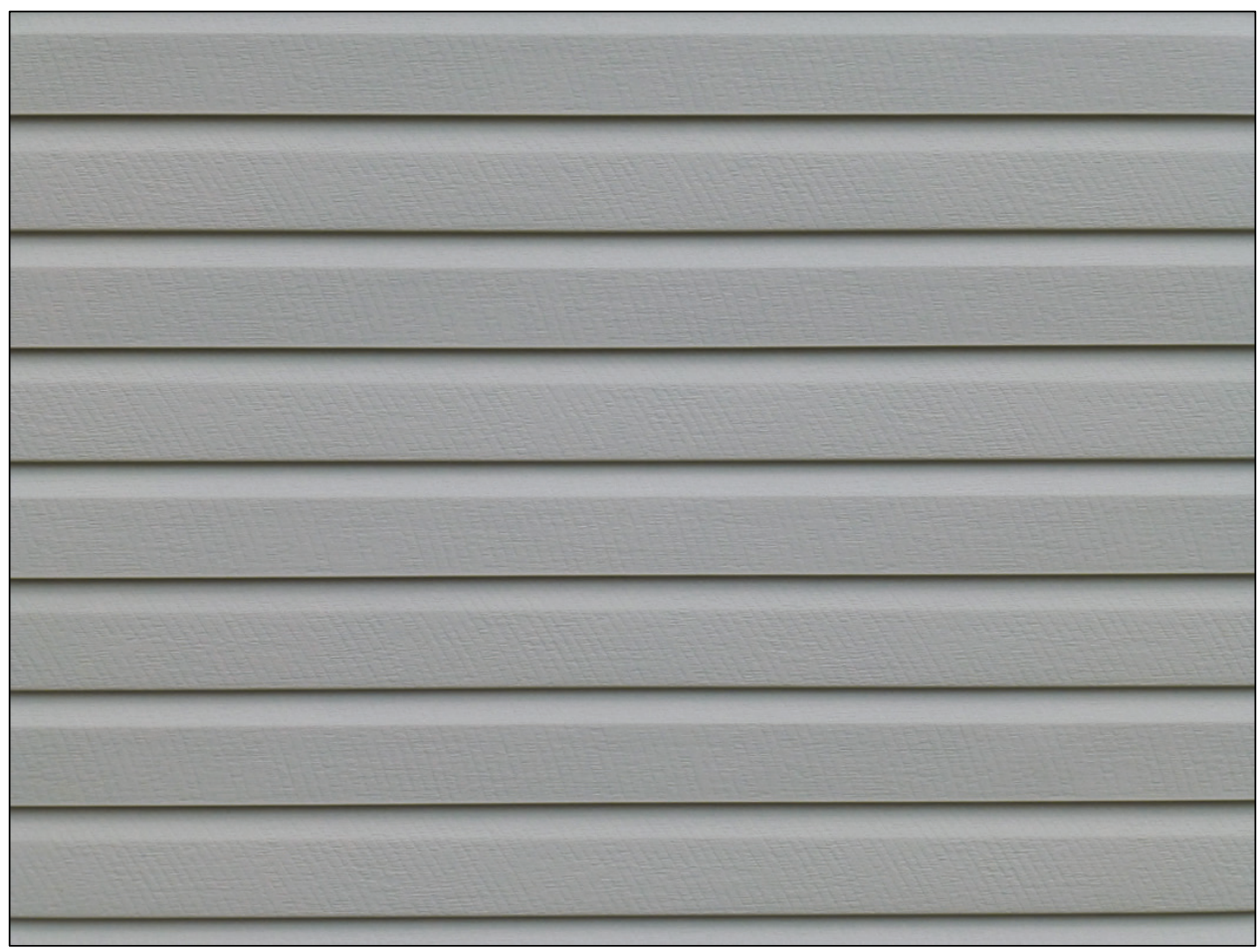

Figure 64. Replacement siding, foundation covering, and vent on Building 1602 (ERDC-CERL, 2018).

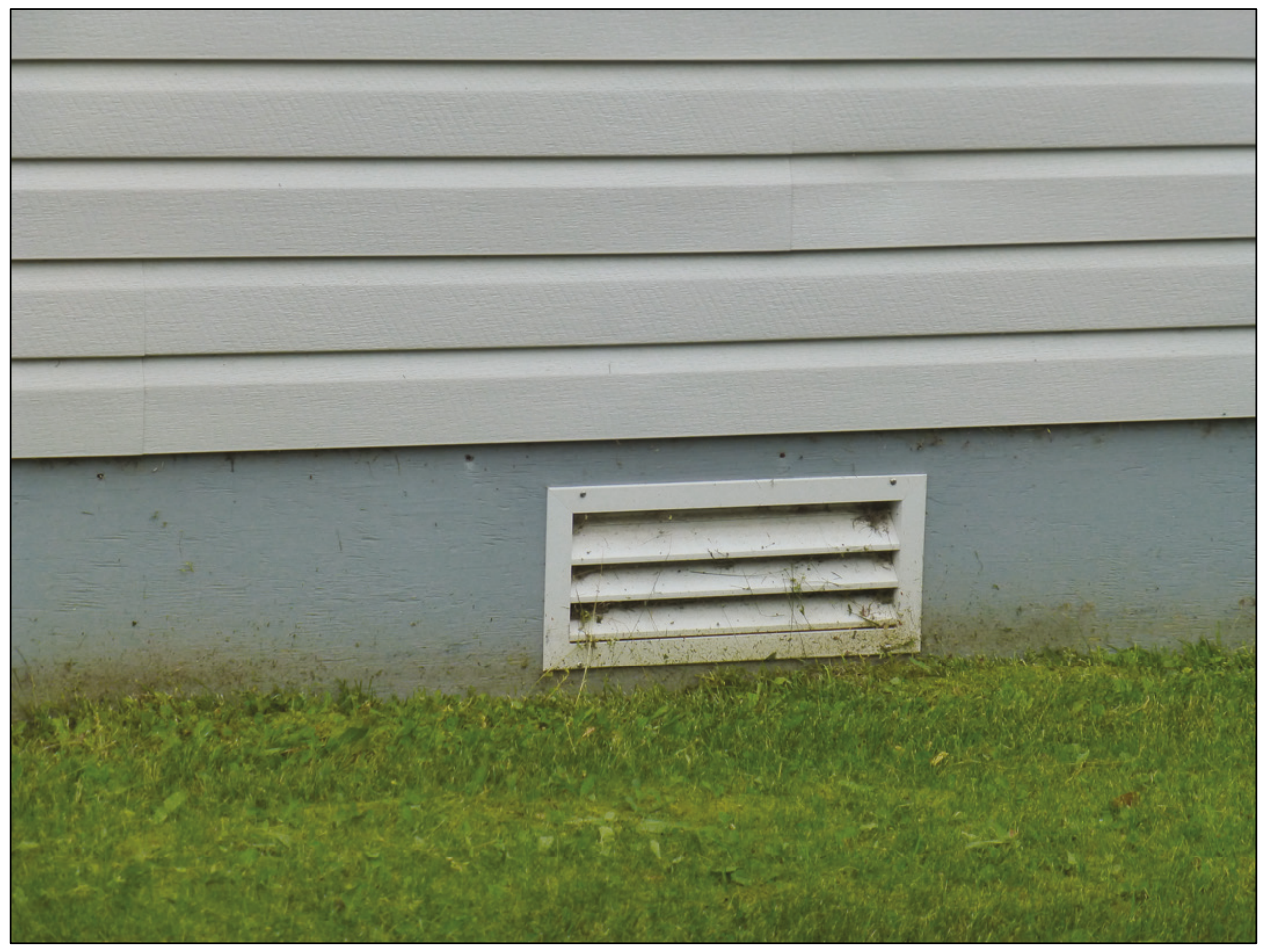


Figure 65. Renovated squad room in Building 1602 (ERDC-CERL, 2018).

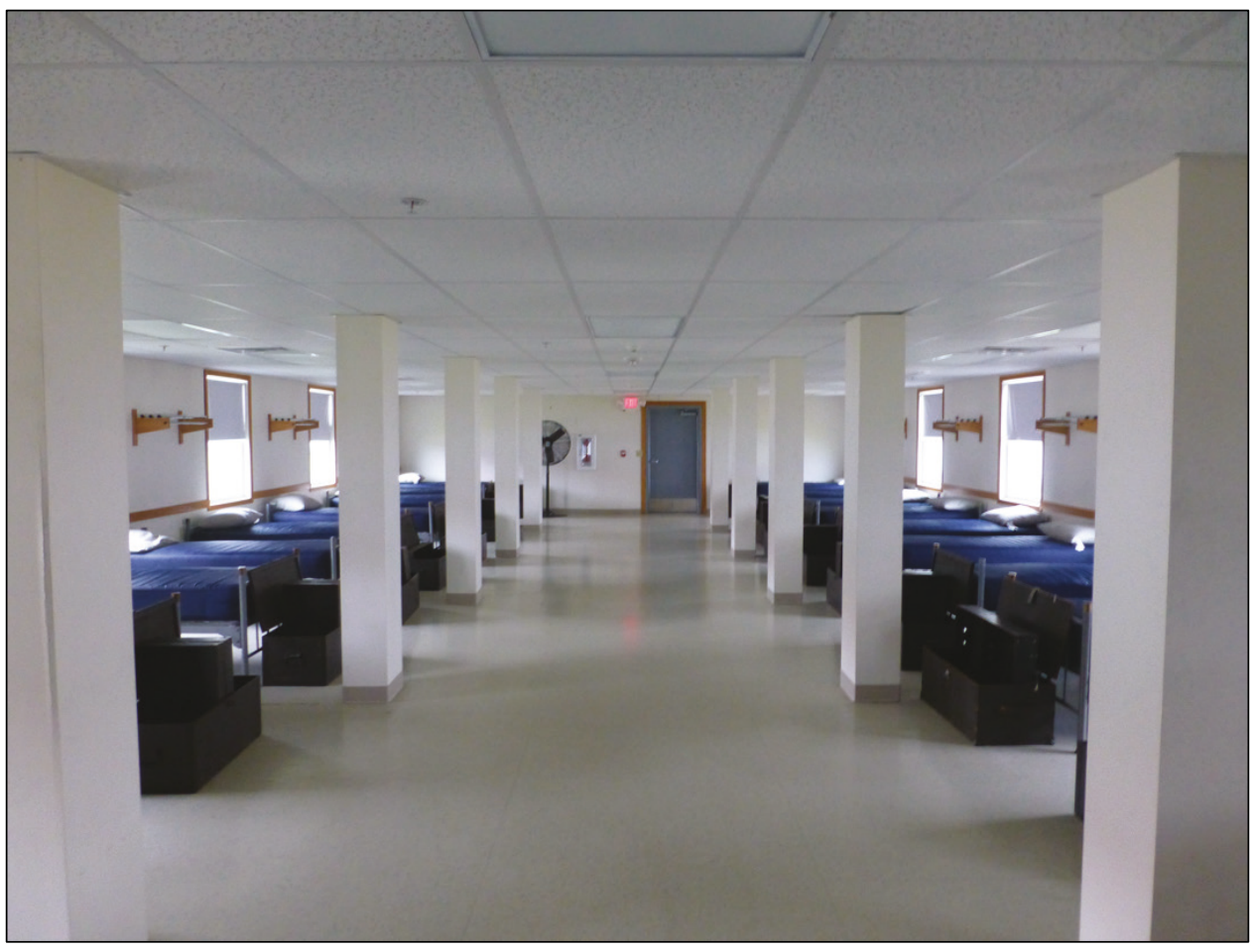

Figure 66. Renovated NCO room in Building 1602 (ERDC-CERL, 2018).

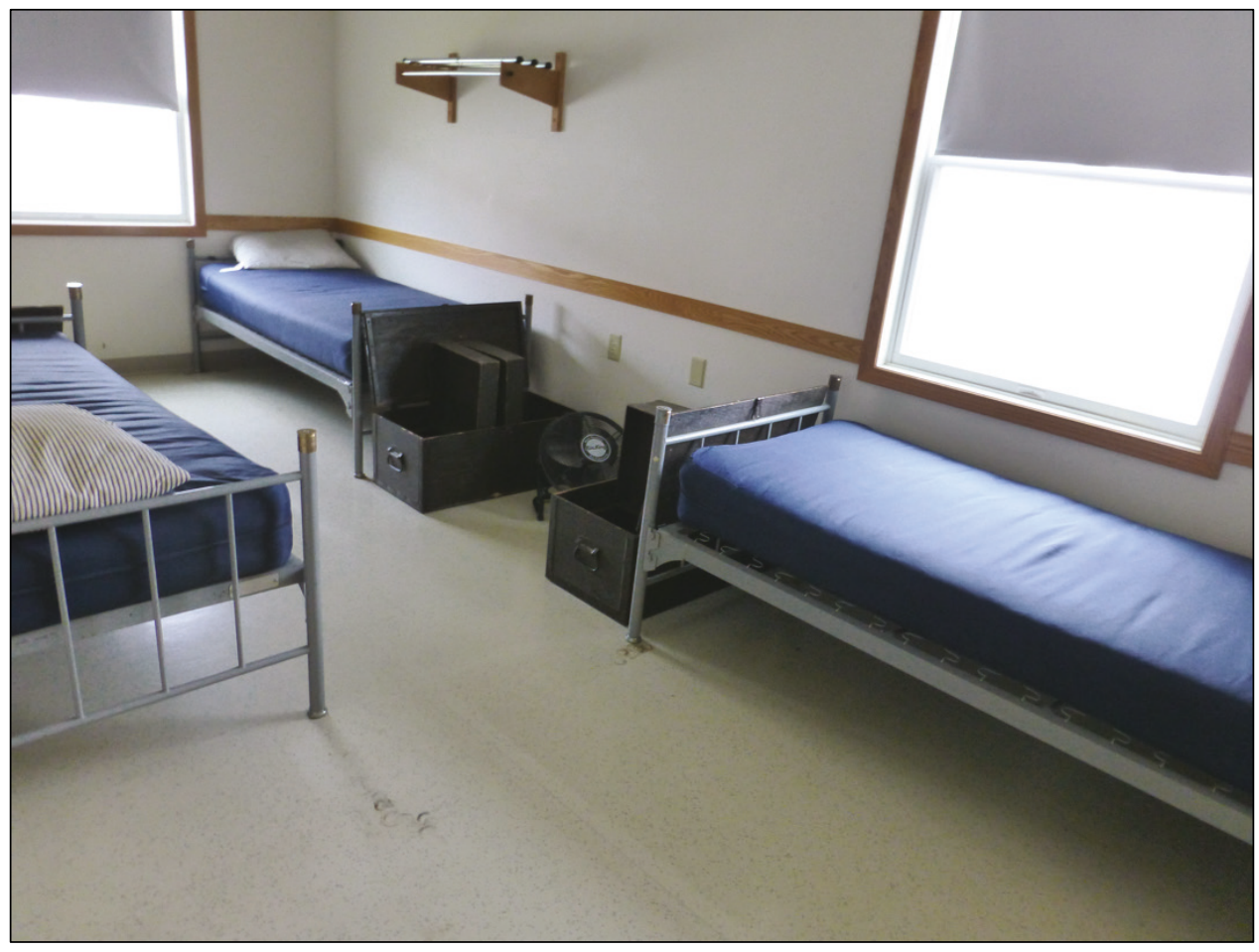


Figure 67. Renovated latrine in Building 1602 (ERDC-CERL, 2018).

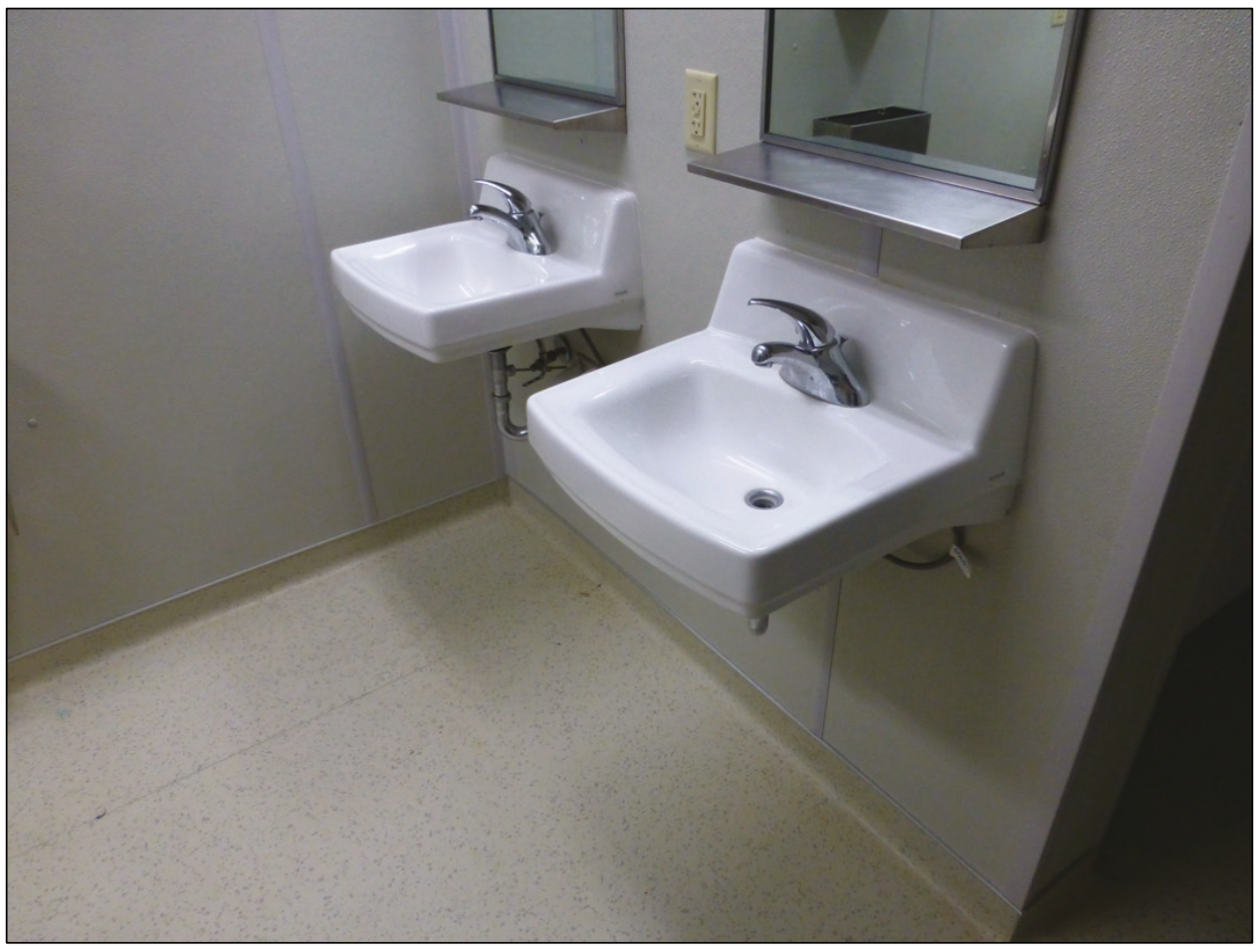

Figure 68. Replacement doors in Building 1602 (ERDC-CERL, 2018).

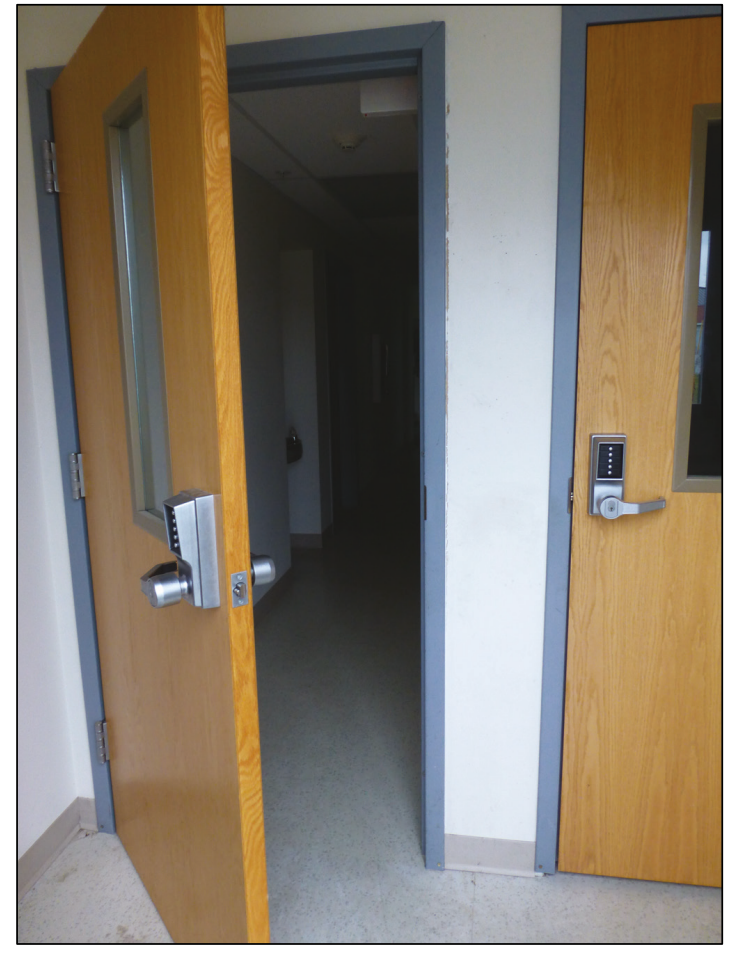


Figure 69. Northeast oblique of Building 1603 (ERDC-CERL, 2018).

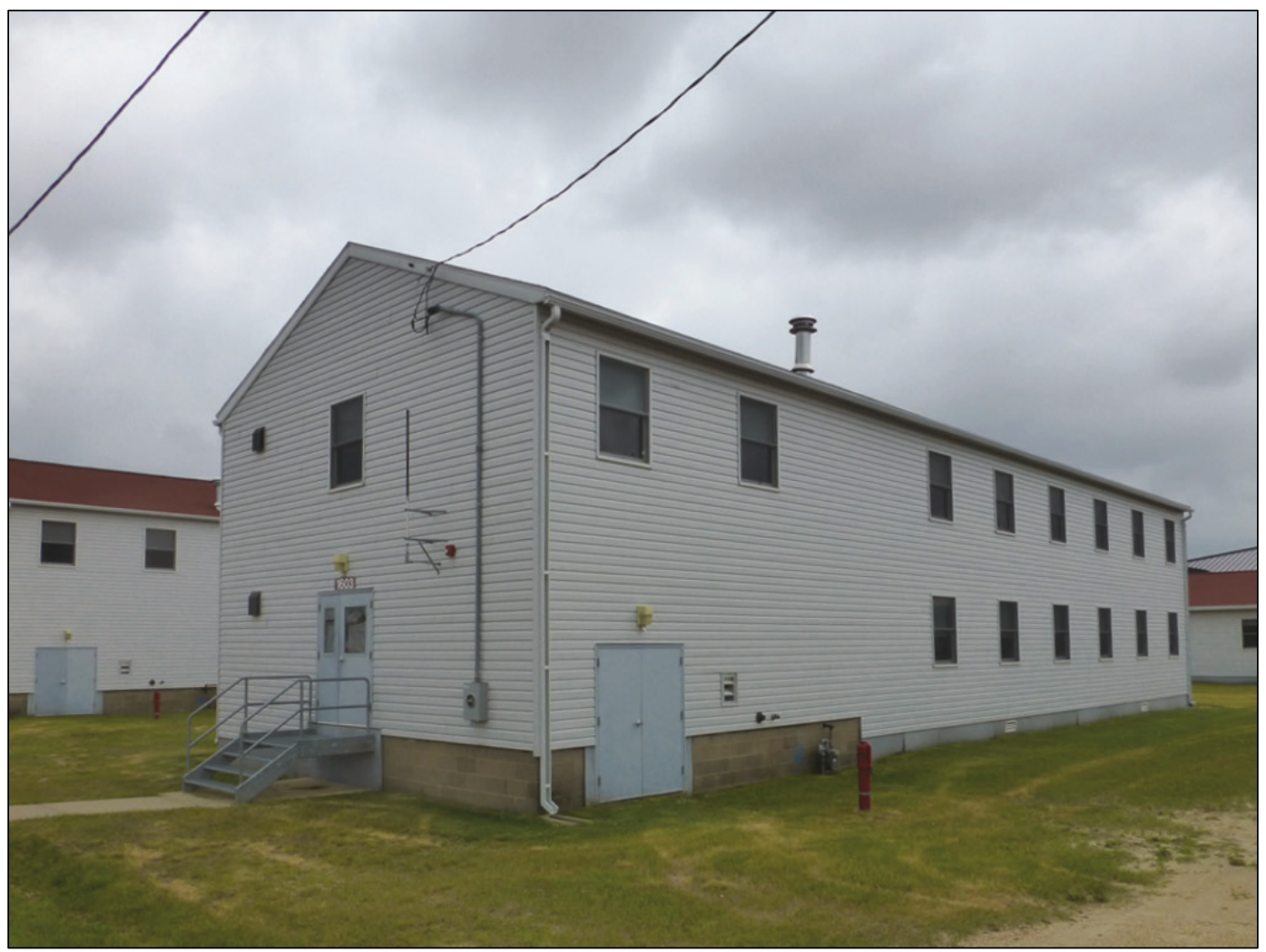

Figure 70. Southeast oblique of Building 1604 (ERDC-CERL, 2018).

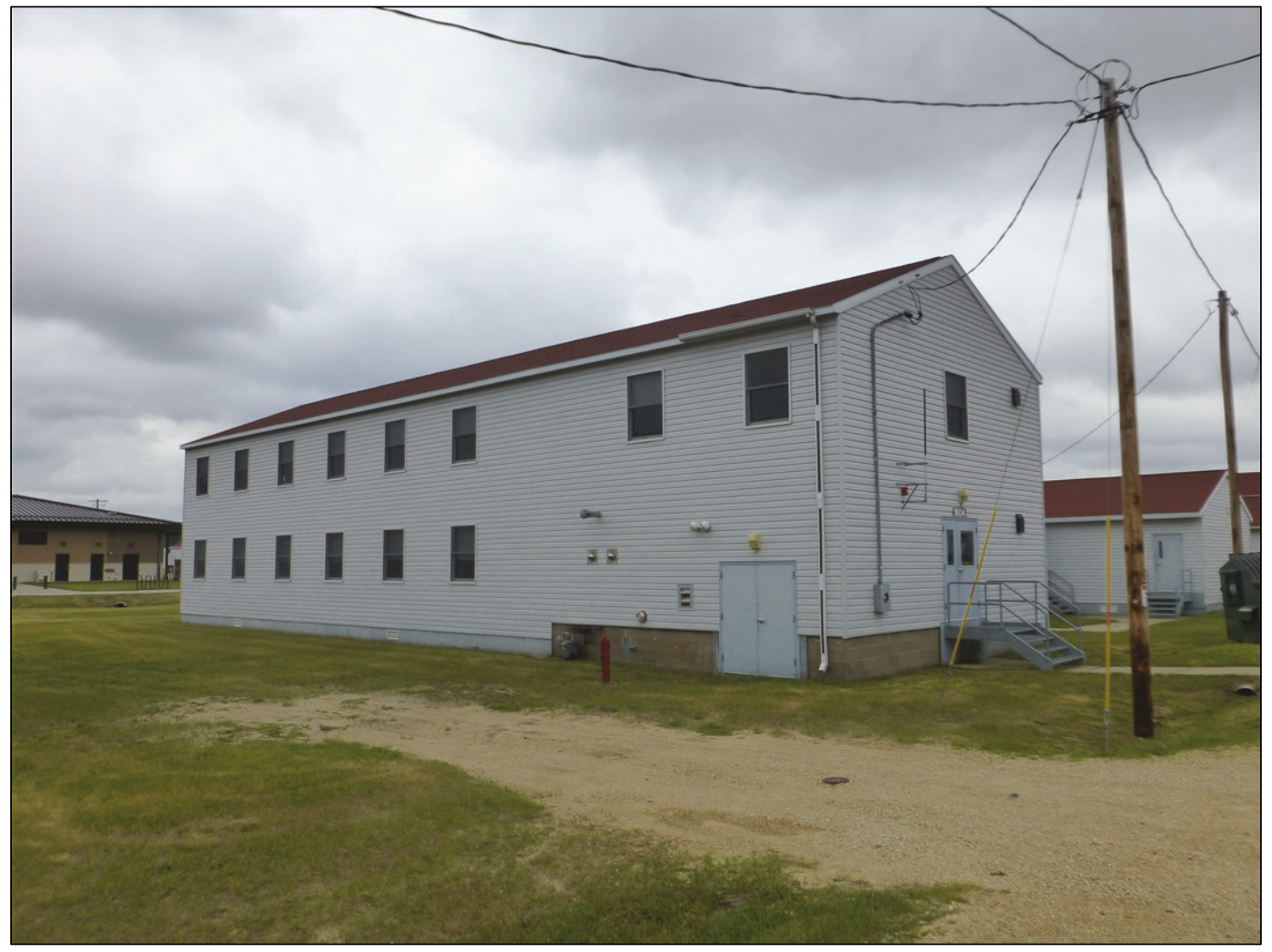


Figure 71. Northeast oblique of Building 1607 (ERDC-CERL, 2018).

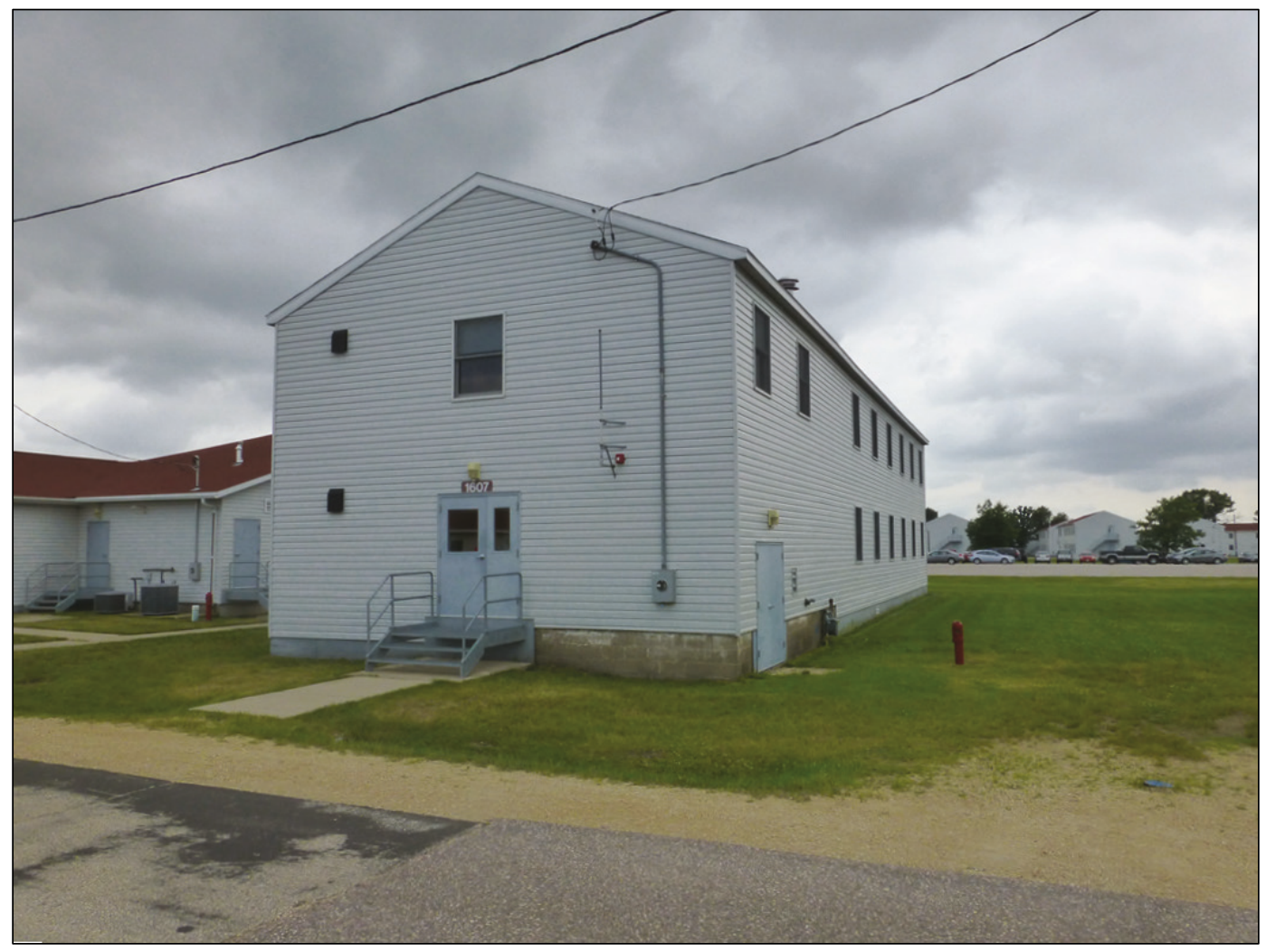

Figure 72. Southeast oblique of Building 1608 (ERDC-CERL, 2018).

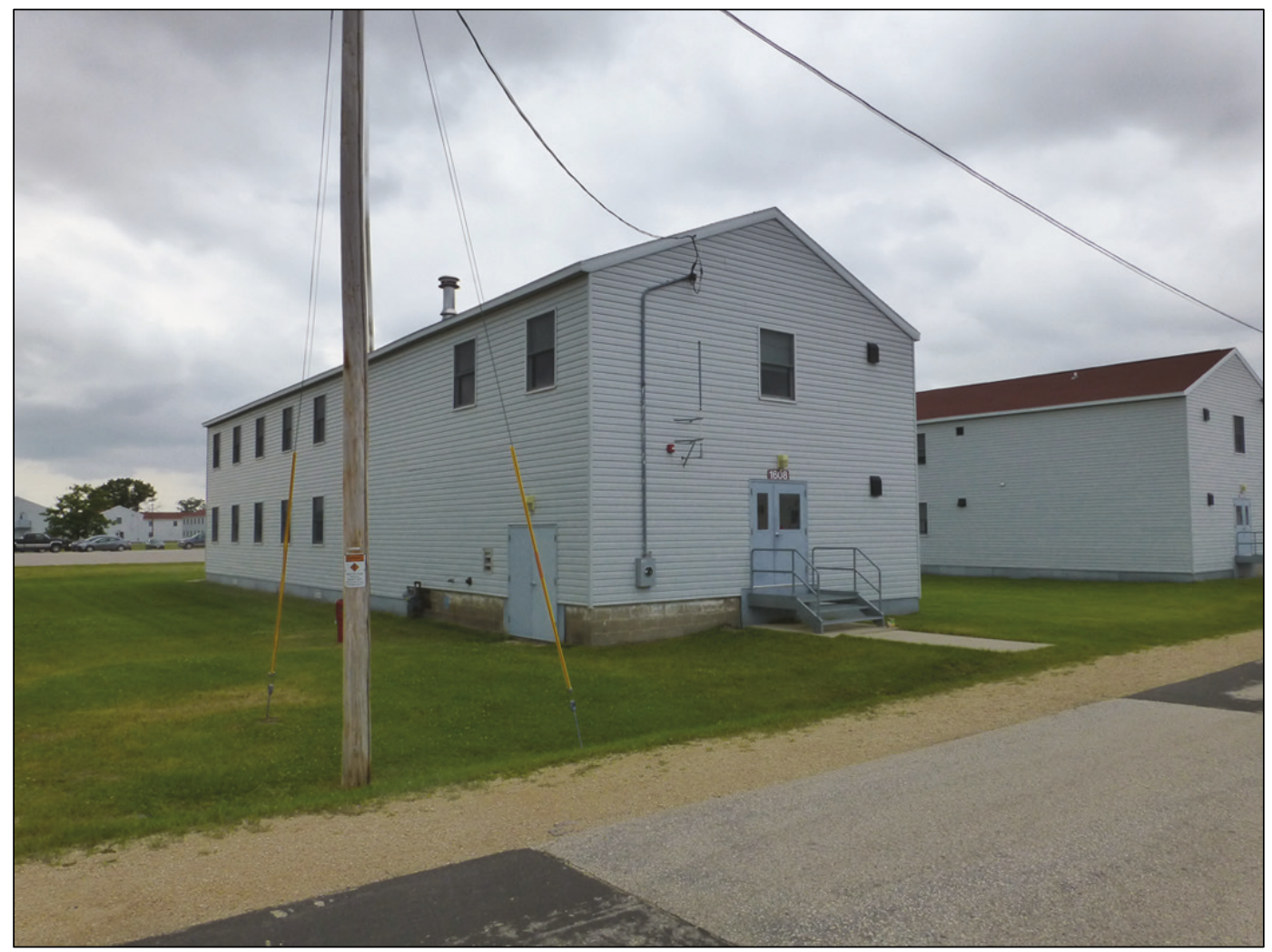


Figure 73. Southeast oblique of Building 1609 (ERDC-CERL, 2018).

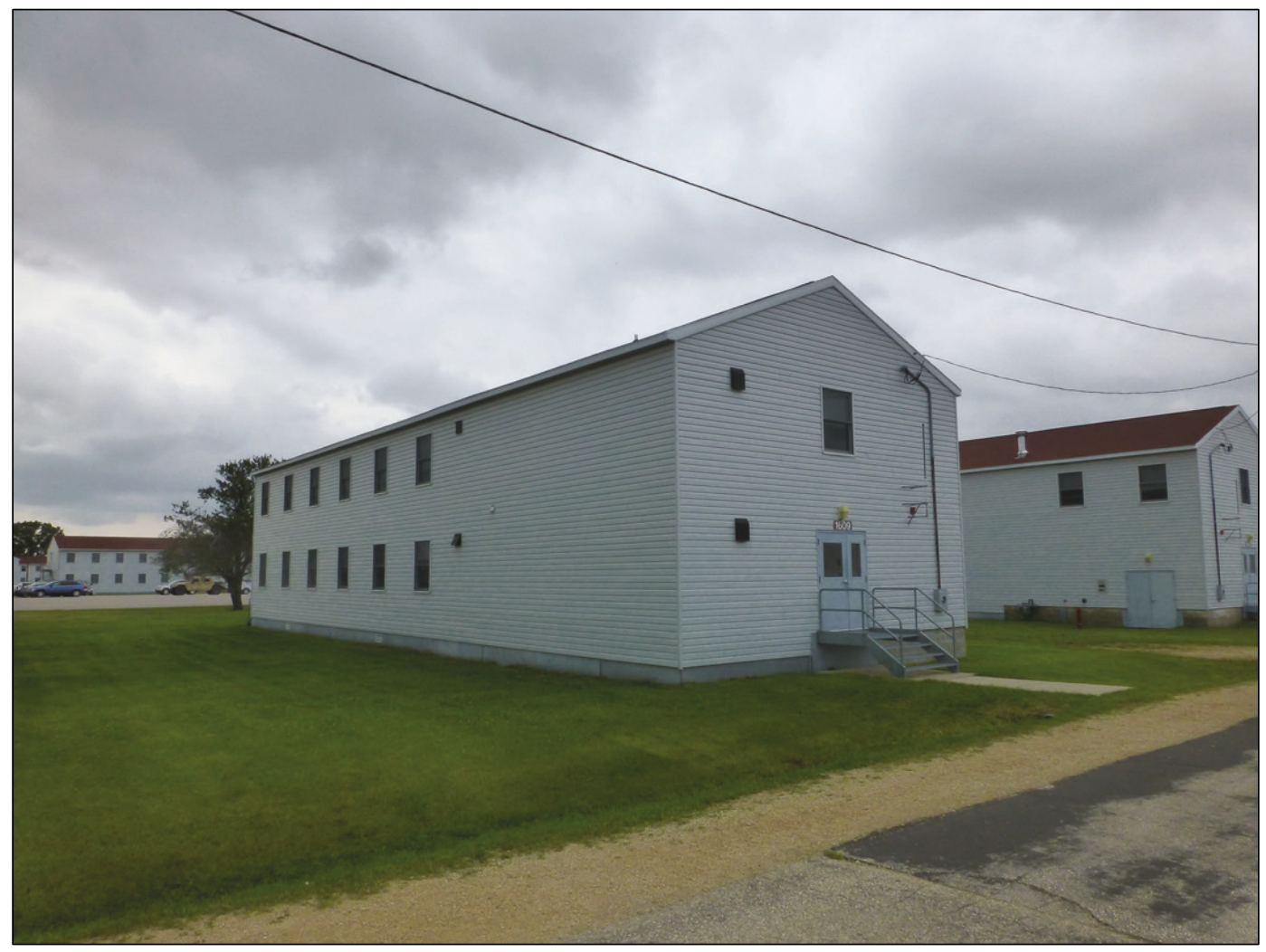

Figure 74. Southeast oblique of Building 1610 (ERDC-CERL, 2018).

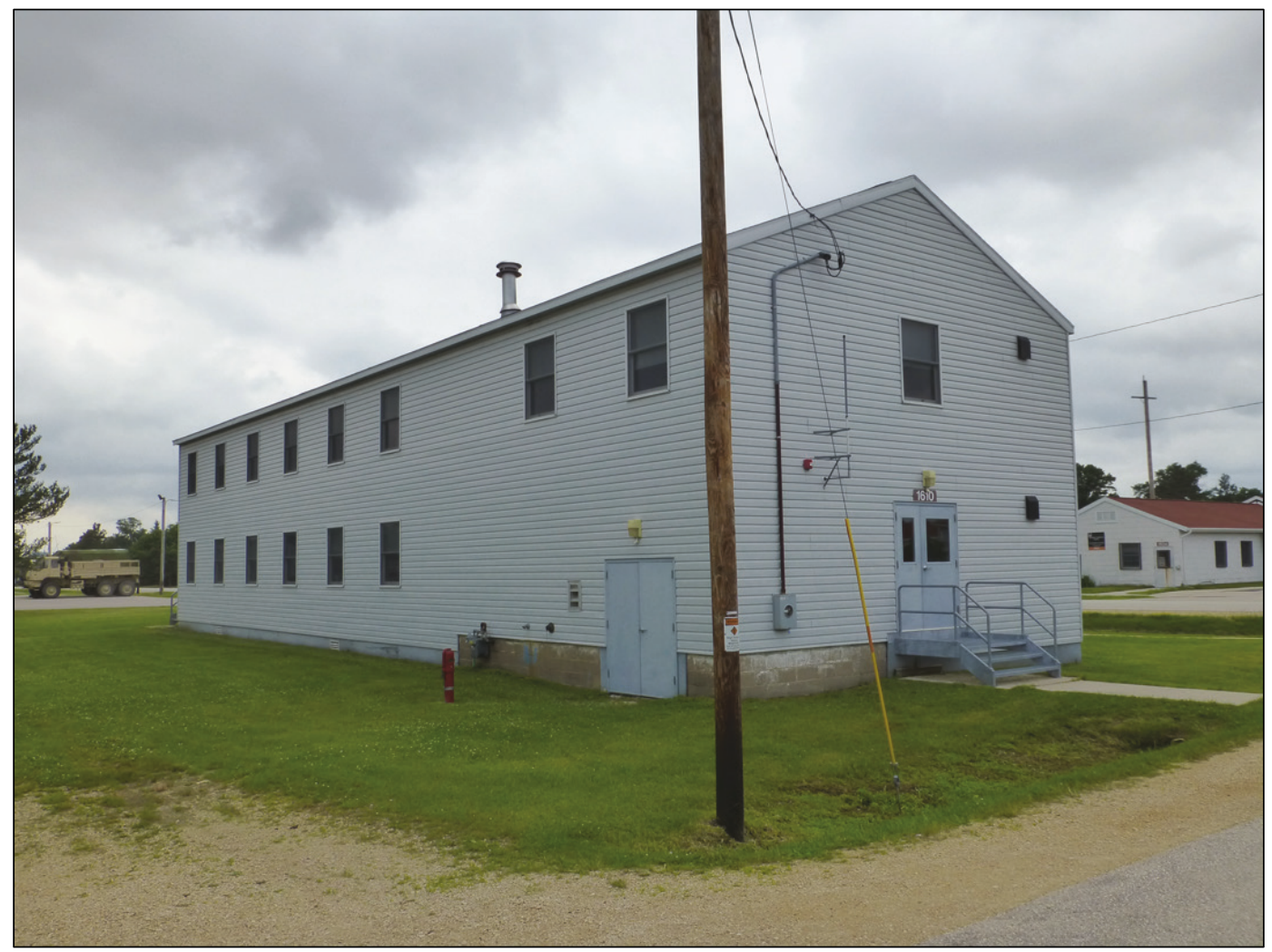


Figure 75. Northwest oblique of Building 1612 (ERDC-CERL, 2018).

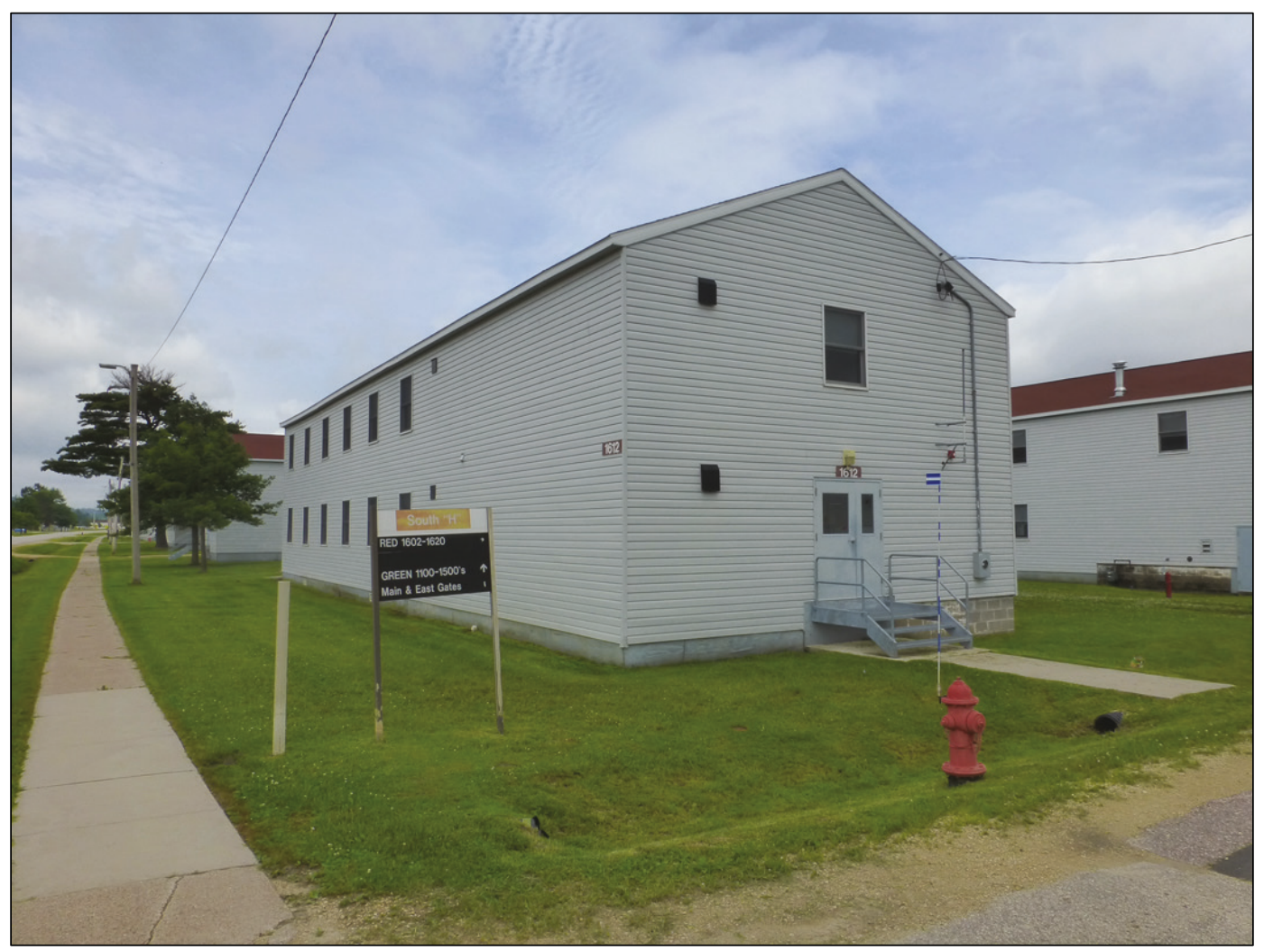

Figure 76. Northwest oblique of Building 1613 (ERDC-CERL, 2018).

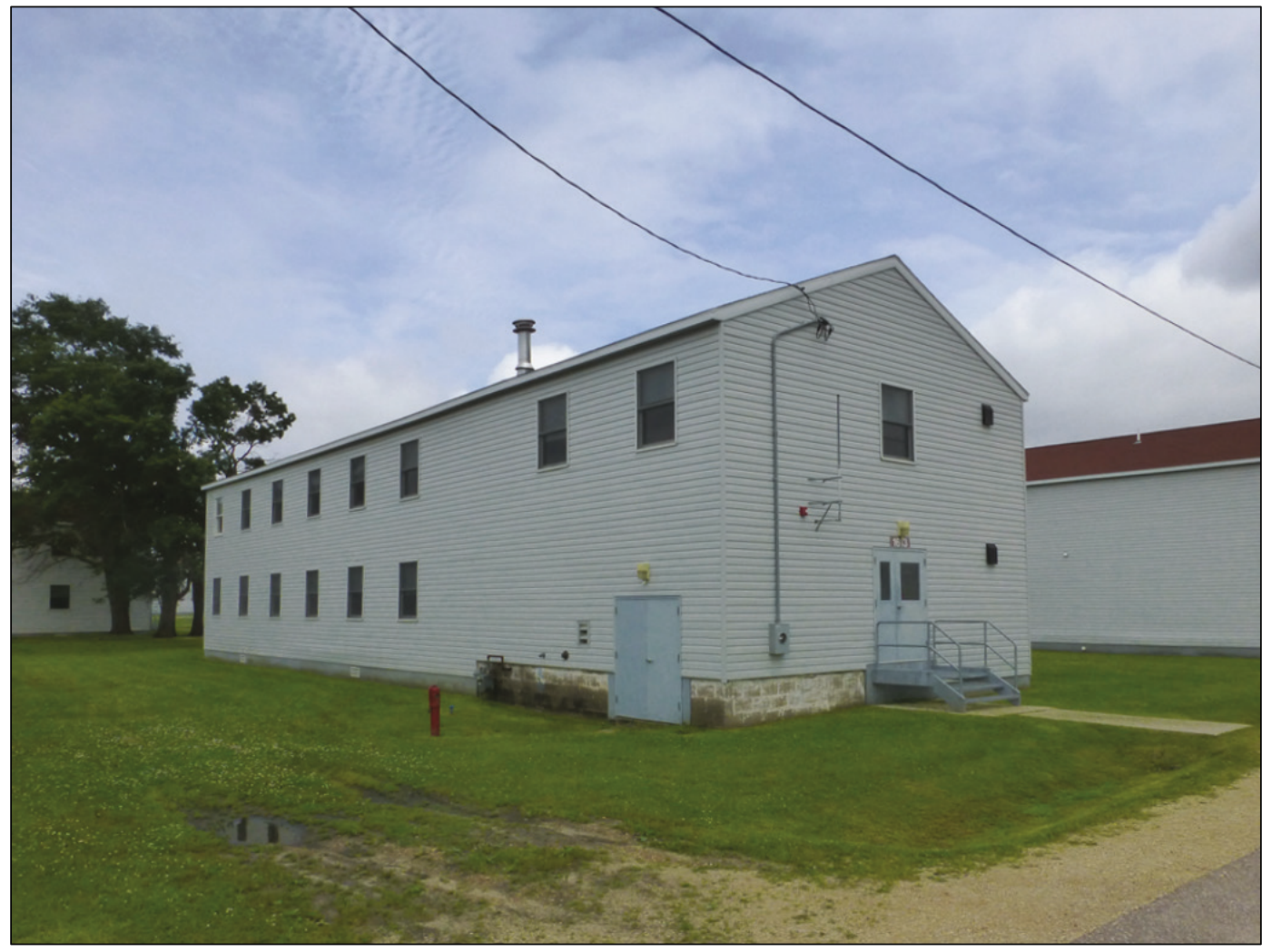


Figure 77. Northwest oblique of Building 1614 (ERDC-CERL, 2018).

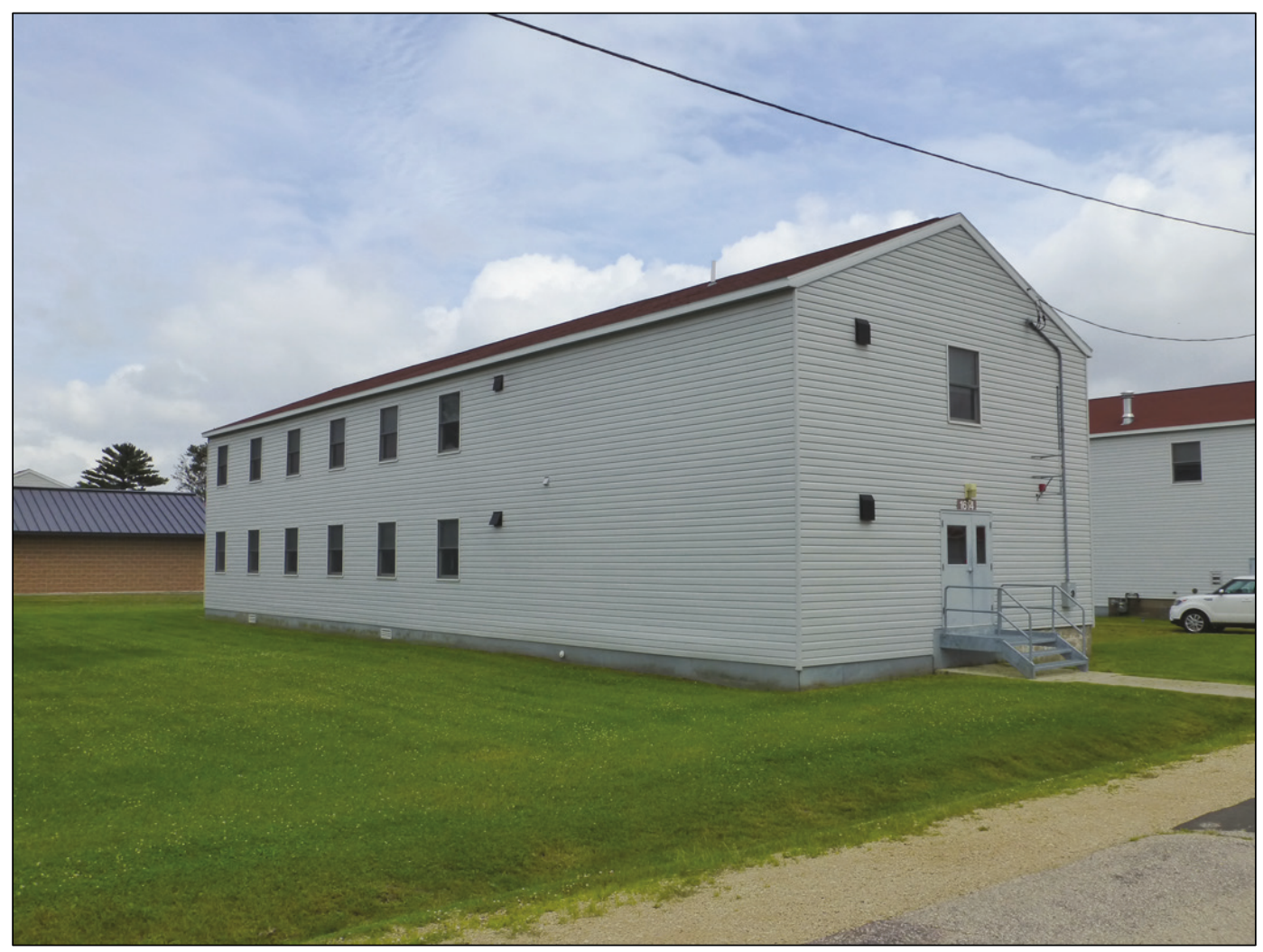

Figure 78. Southwest oblique of Building 1615 (ERDC-CERL, 2018).

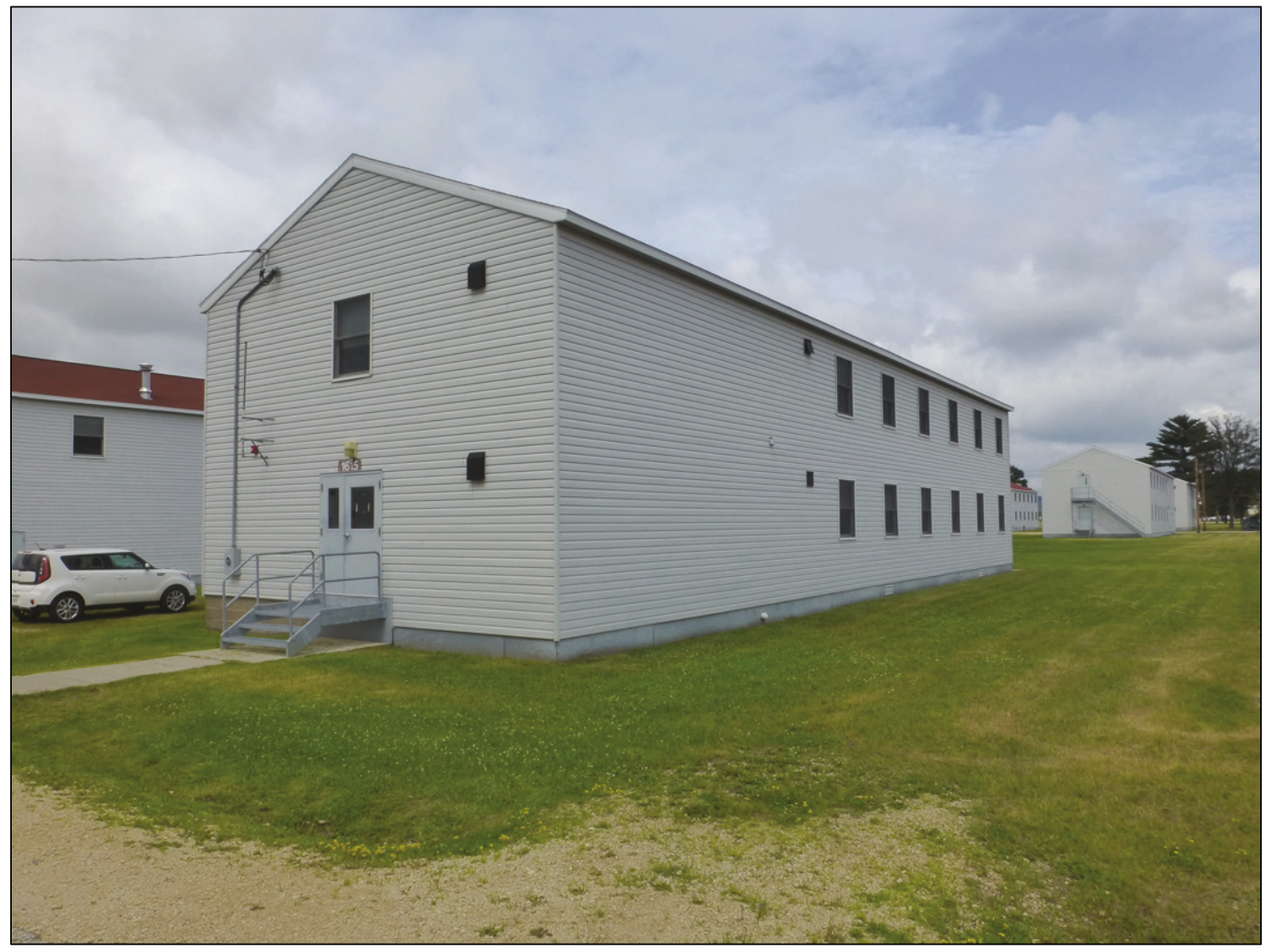


Figure 79. Southwest oblique of Building 1618 (ERDC-CERL, 2018).

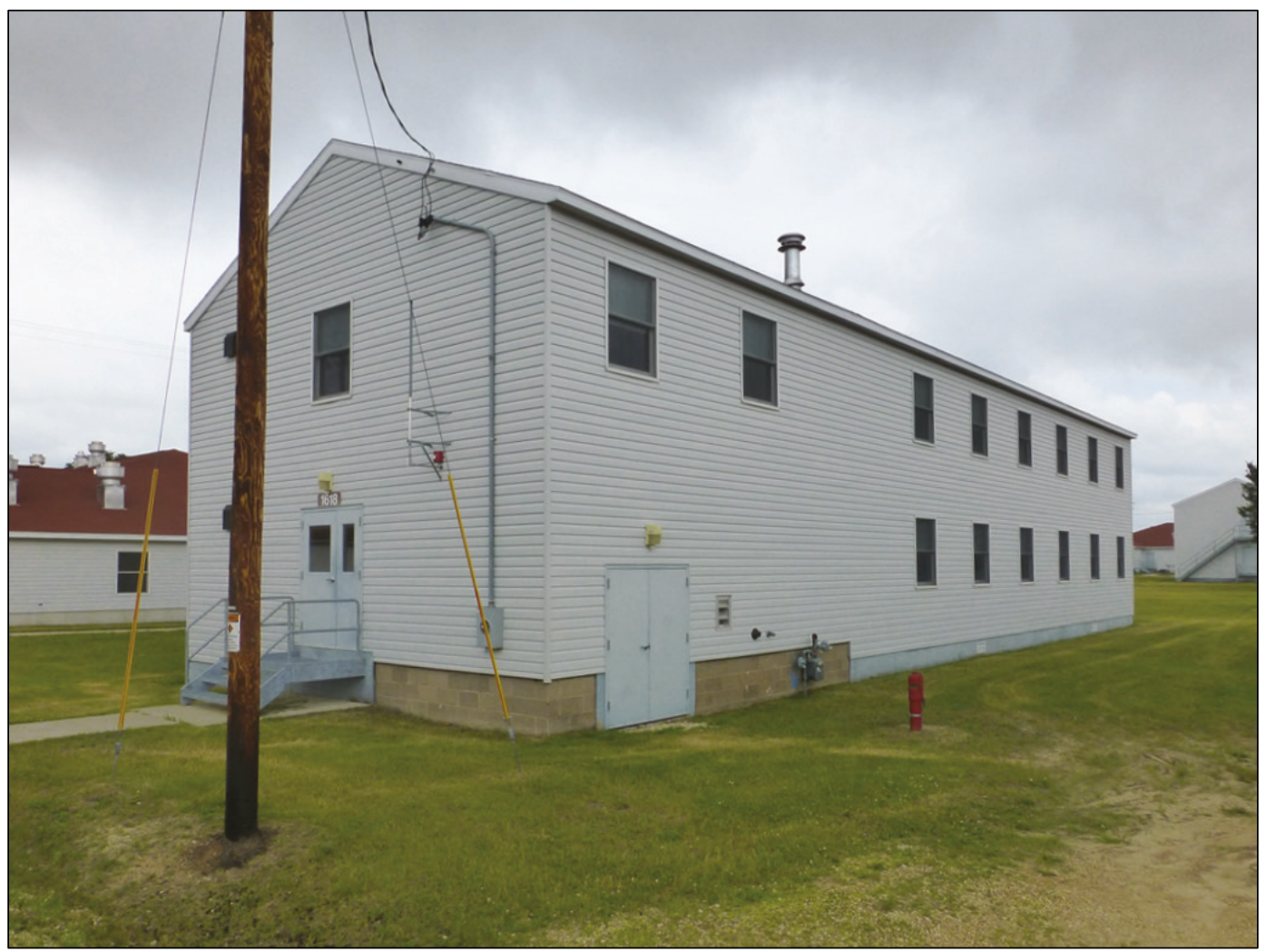

Figure 80. Southwest oblique of Building 1619 (ERDC-CERL, 2018).

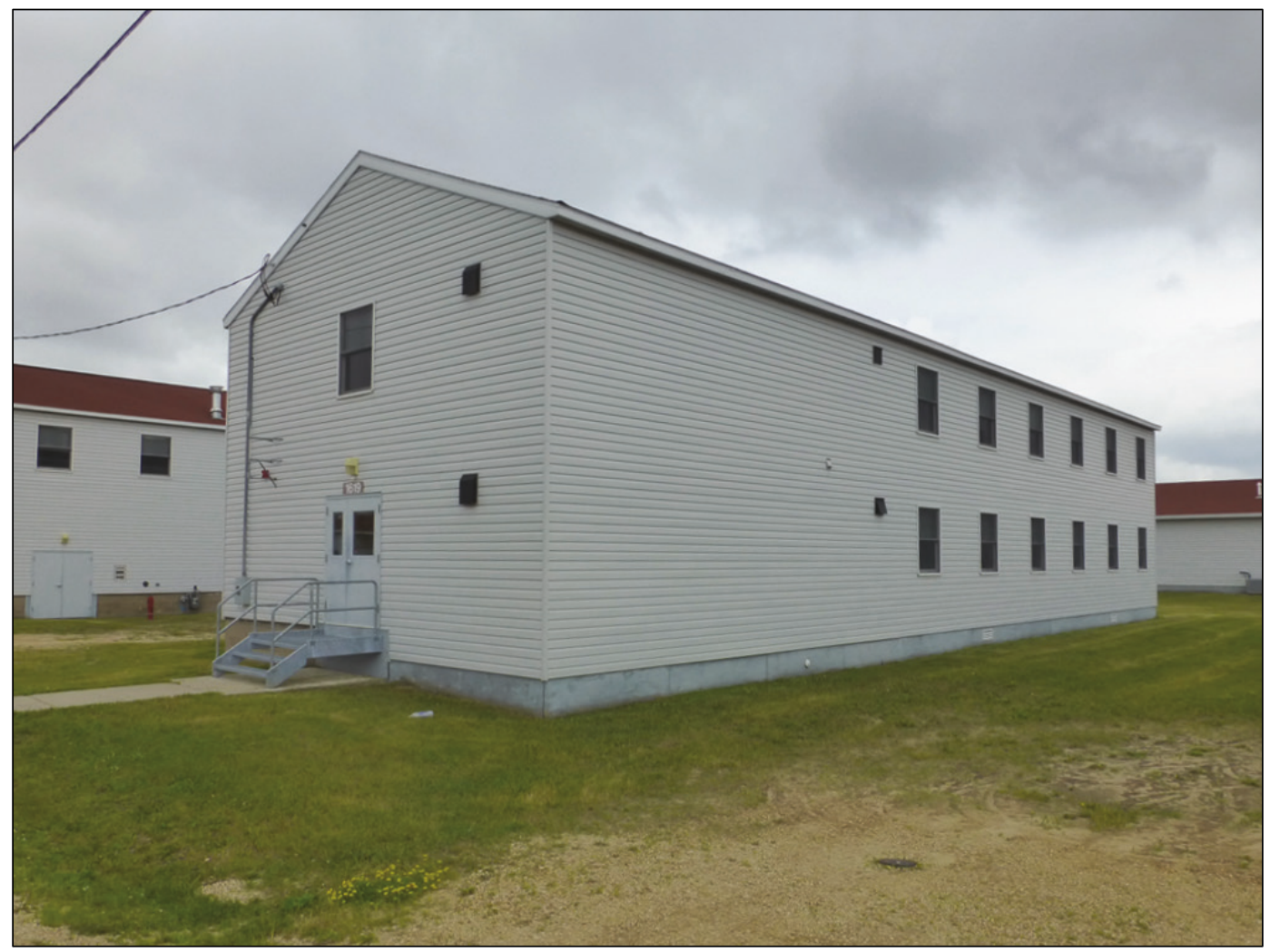


Figure 81. Southwest oblique of Building 1620 (ERDC-CERL, 2018).

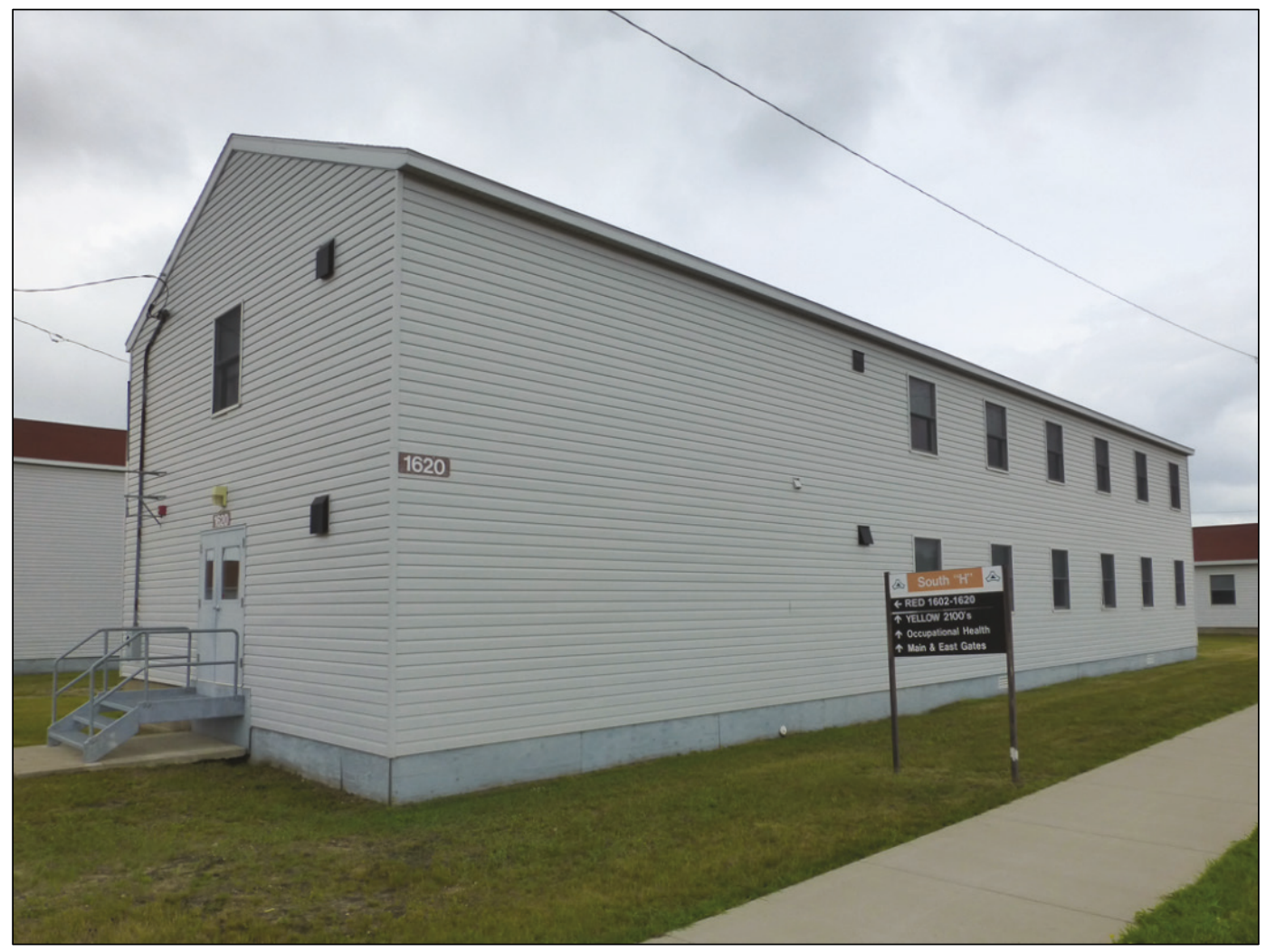

Figure 82. North side of Building 1632 (ERDC-CERL, 2018).

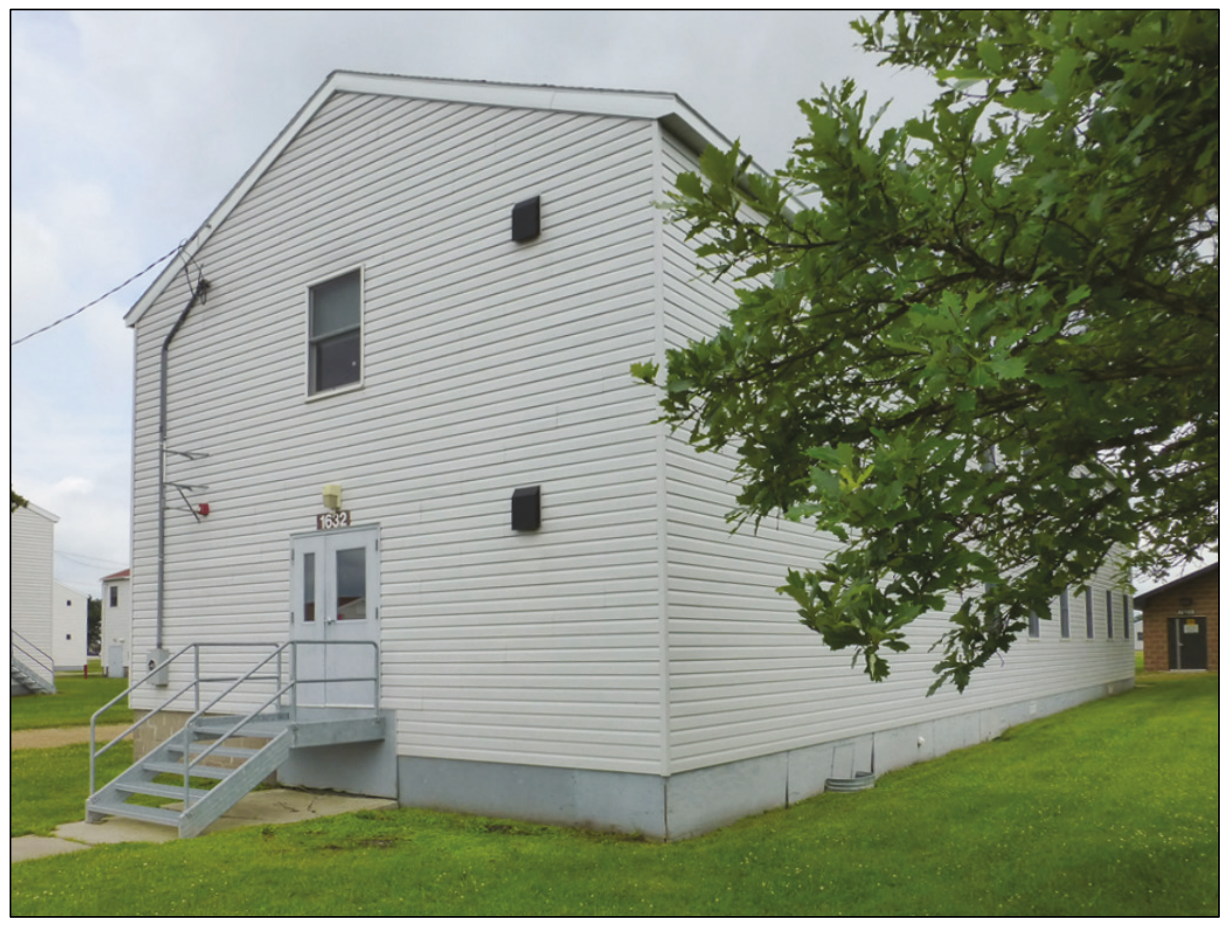




\subsection{Company Storehouse, Administration, and Recreation (Buildings 1621, 1622, and 1743)}

Buildings 1621, 1622, and 1743 were all company storehouse, administration, and recreation buildings constructed in 1942 from the War Department's 800 Series of standard plans (Figure 84) and located on the south side of the Triad (Figure 83). Their category code was changed to General Instruction (classroom) in 1995 (Building 1743 is USAR center). All these buildings are still classrooms and currently in use.

The exterior of these buildings have no original character-defining features from the period of significance except for the overall mass (Figure 85 and Figure 87-Figure 90).

The interiors (Figure 86 and Figure 91-Figure 93) do not have their original plan, and no other character-defining features are extant.

HABS was performed on an 800 Series company storehouse, administration, and recreation building (Building T-801) at Fort McCoy in 1988, HABS WI-308-B. 66 This documentation was done as part of the 1986 PMOA for demolition of WWII temporary buildings as approved by DoD, ACHP, and the NCSHPO.

\footnotetext{
66 HABS No. WI-308-B. "Fort McCoy, Building T-801 (Storehouse, Administration \& Recreation Building)," Sparta vicinity, Monroe County, Wisconsin (Washington, DC: Historic American Buildings Survey, National Park District, Department of the Interior, 1988). Catalogued by Library of Congress as HABS WIS, 41-SPAR.V, 1-B-: https://cdn.loc.gov/master/pnp/habshaer/wi/wi0200/wi0262/data/wi0262data.pdf.
} 
Figure 83. Map with location of Buildings 1621, 1622, and 1743 outlined in red

(Fort McCoy DPW, 2018).

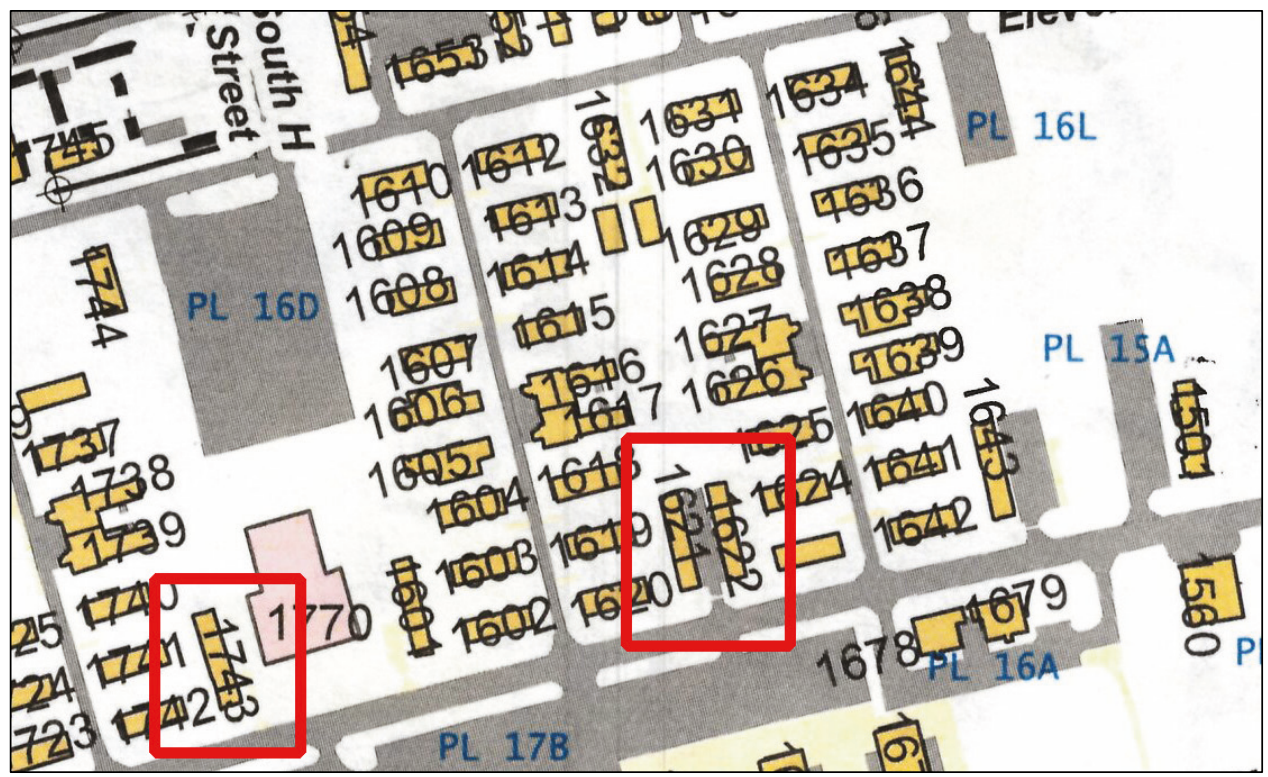

Figure 84. 800 Series plan for company storehouse, administration, and recreation buildings, 1943 (Library of Congress).

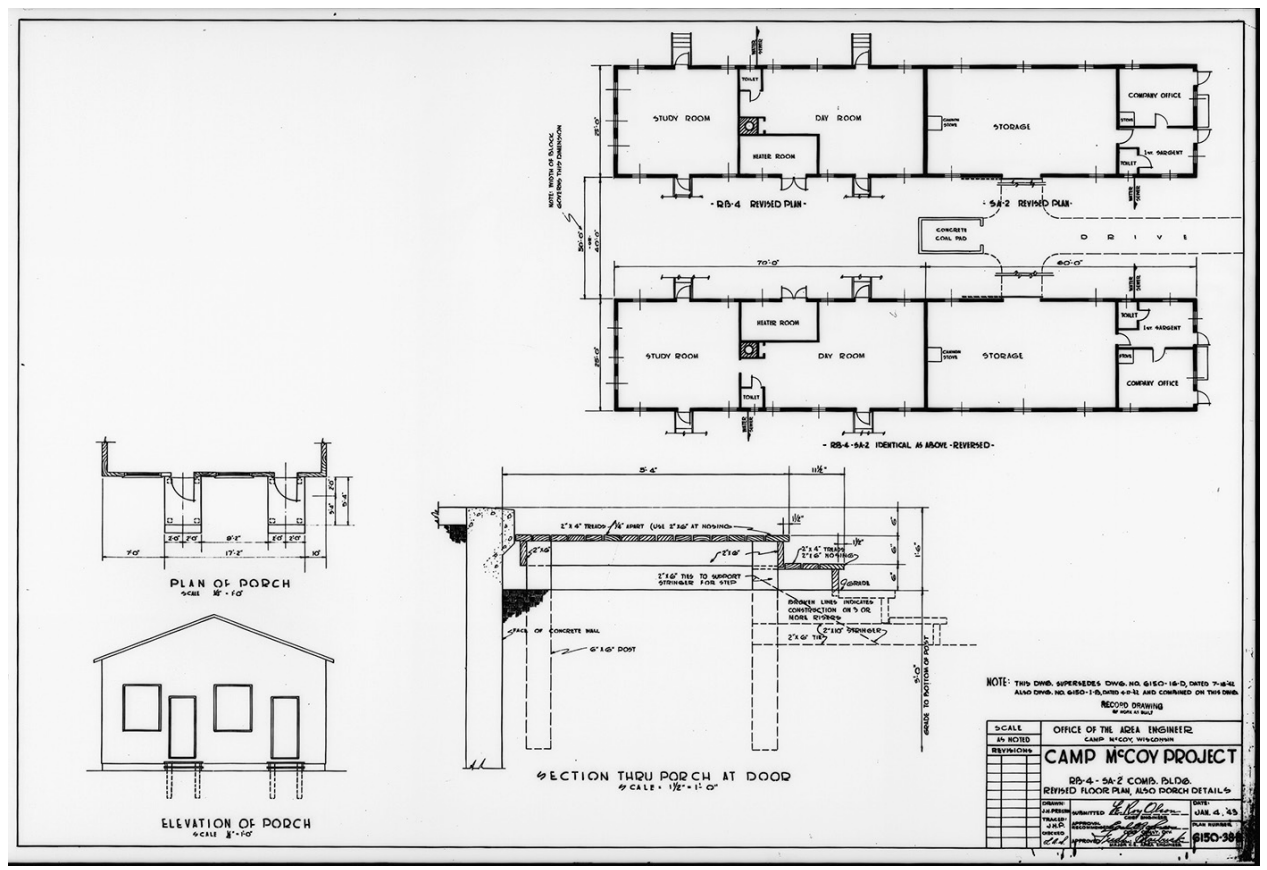


Figure 85. Southwest oblique of Building 801, Company Storehouse/Administration and Recreation Building, 1988 (Library of Congress, HABS WI-208-B).

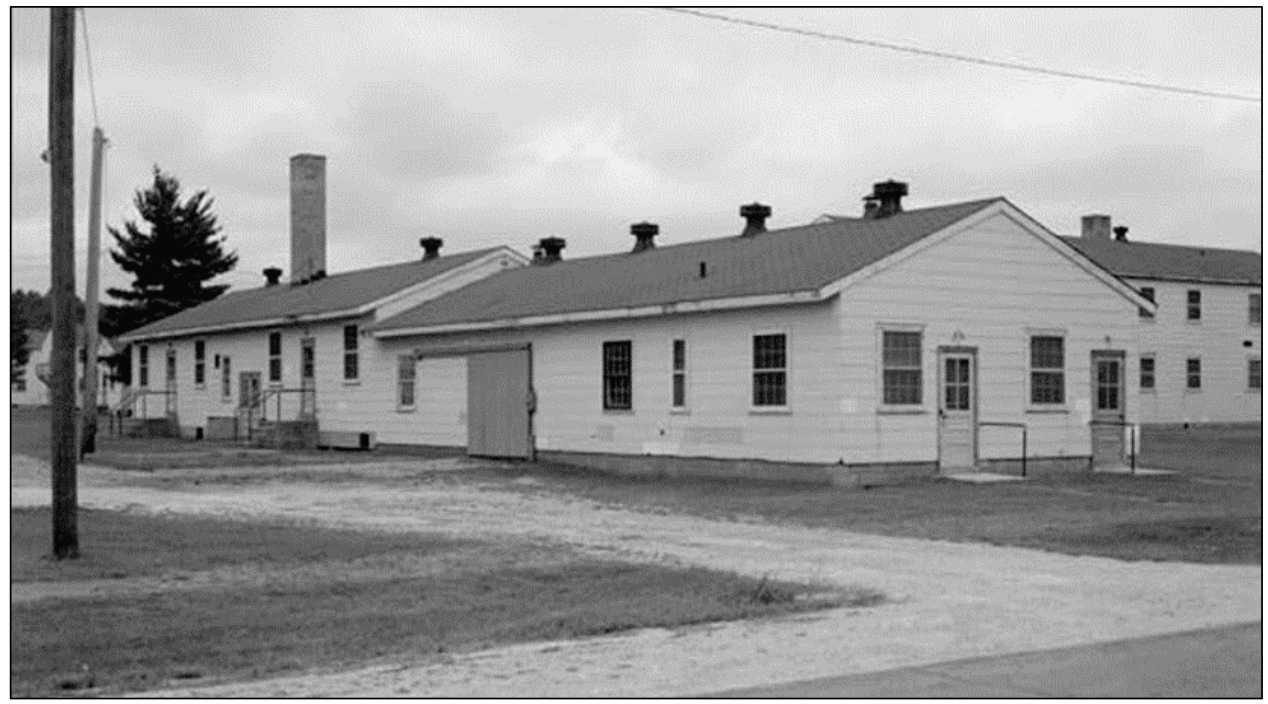

Figure 86. Building 801, interior view of recreation area looking north from the storeroom doorway, 1988 (Library of Congress, HABS WI-208-B).

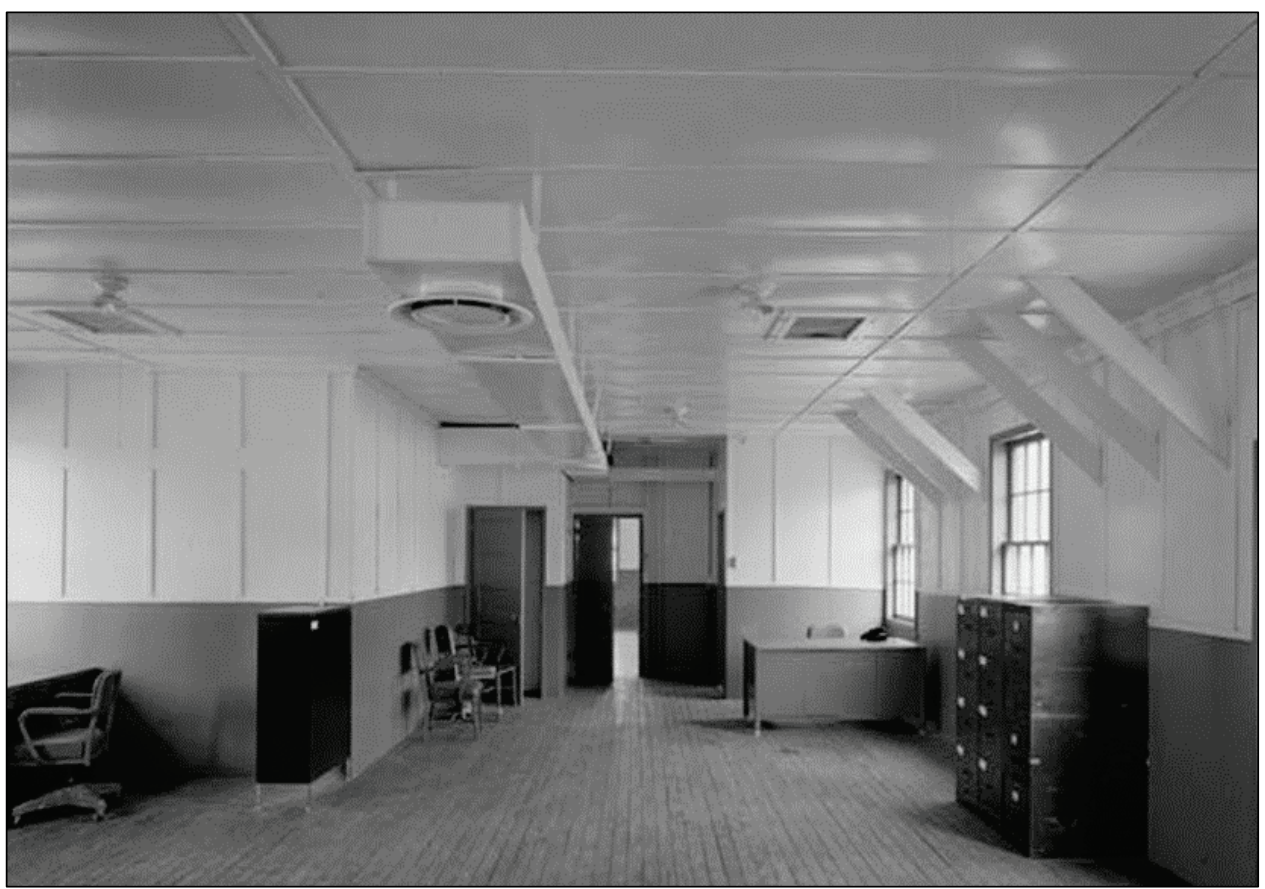


Figure 87. Southeast oblique of Building 1621 (ERDC-CERL, 2018).

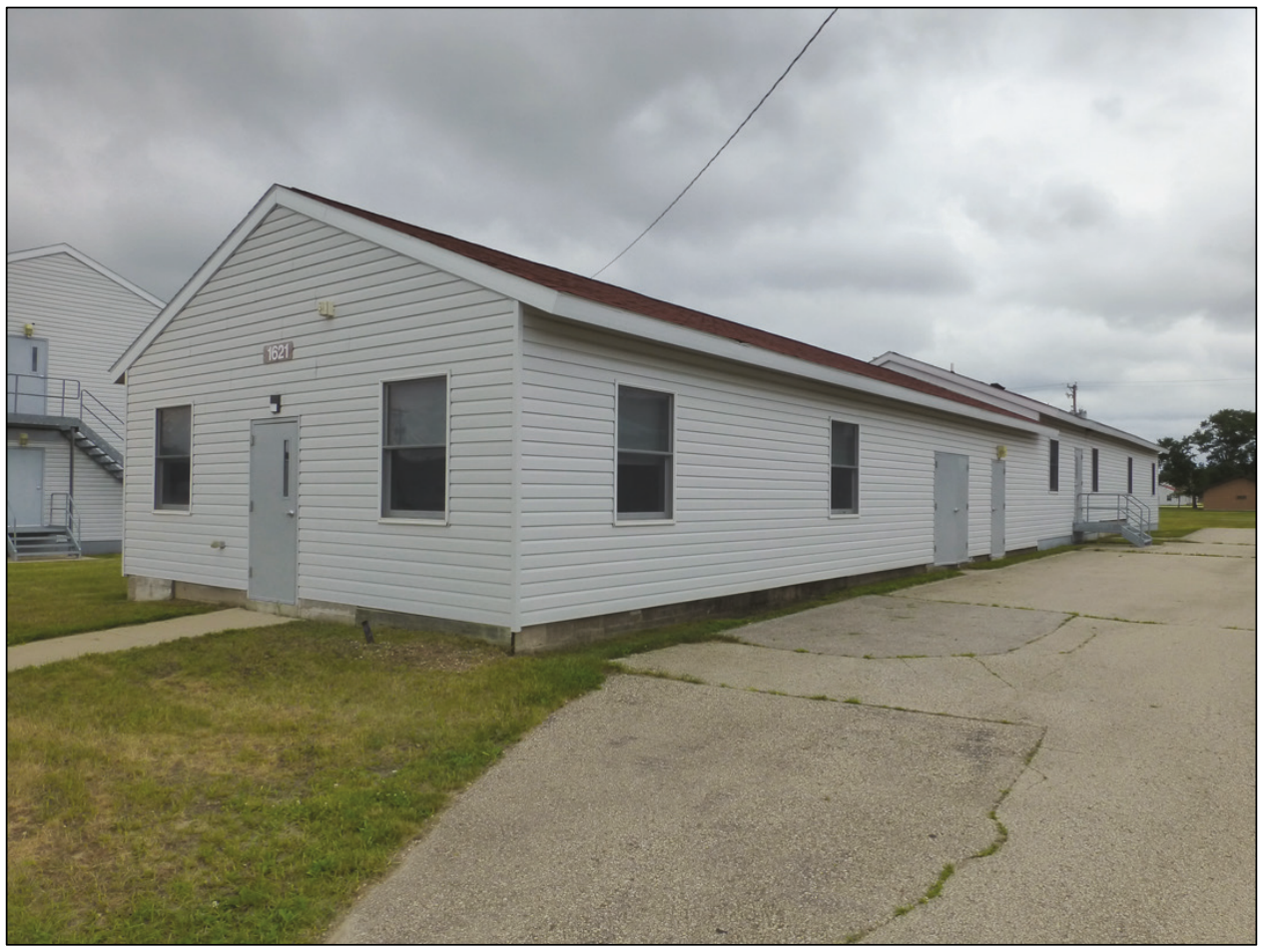

Figure 88. Northeast oblique of Building 1621 (ERDC-CERL, 2018).

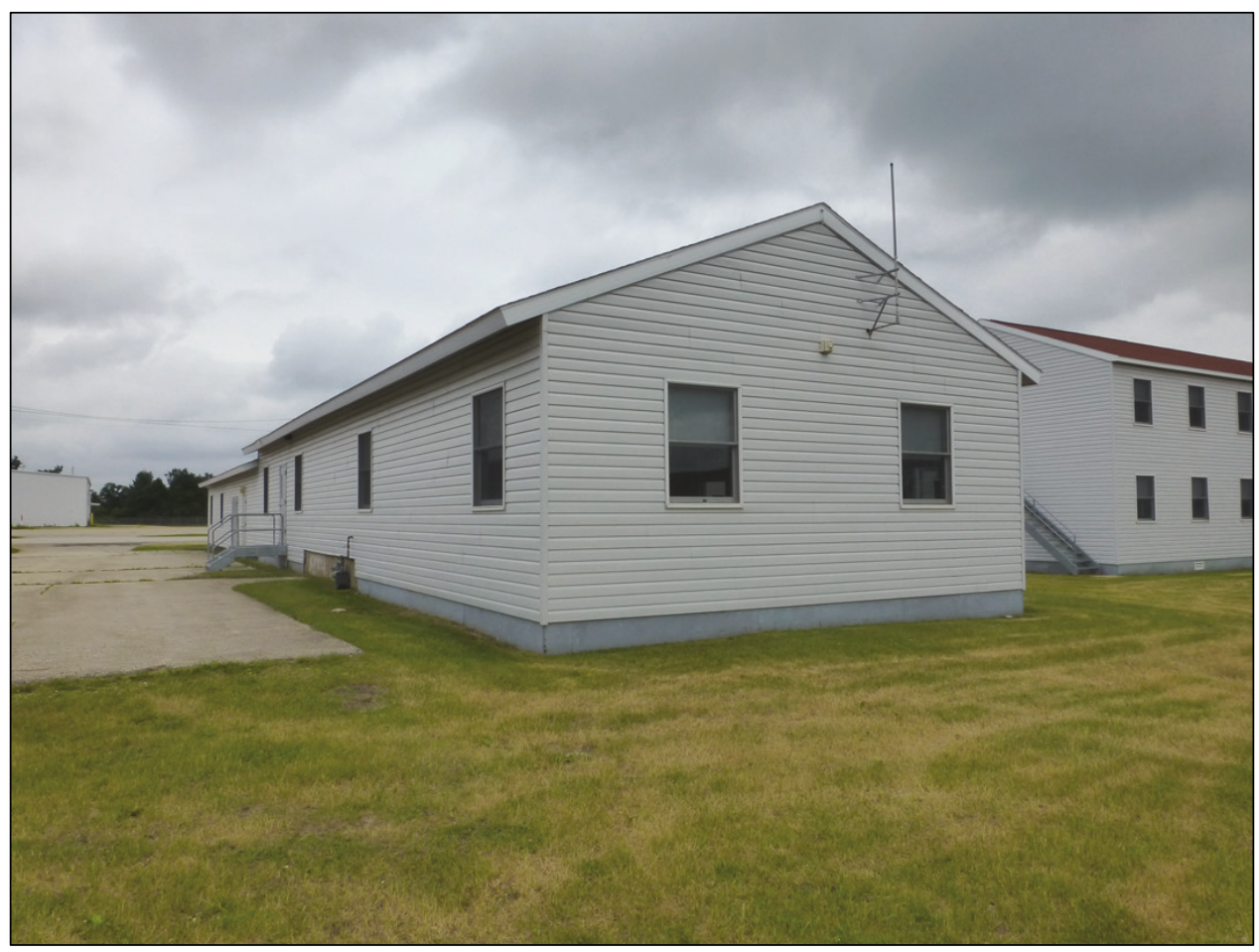


Figure 89. Northwest oblique of Building 1621 (ERDC-CERL, 2018).

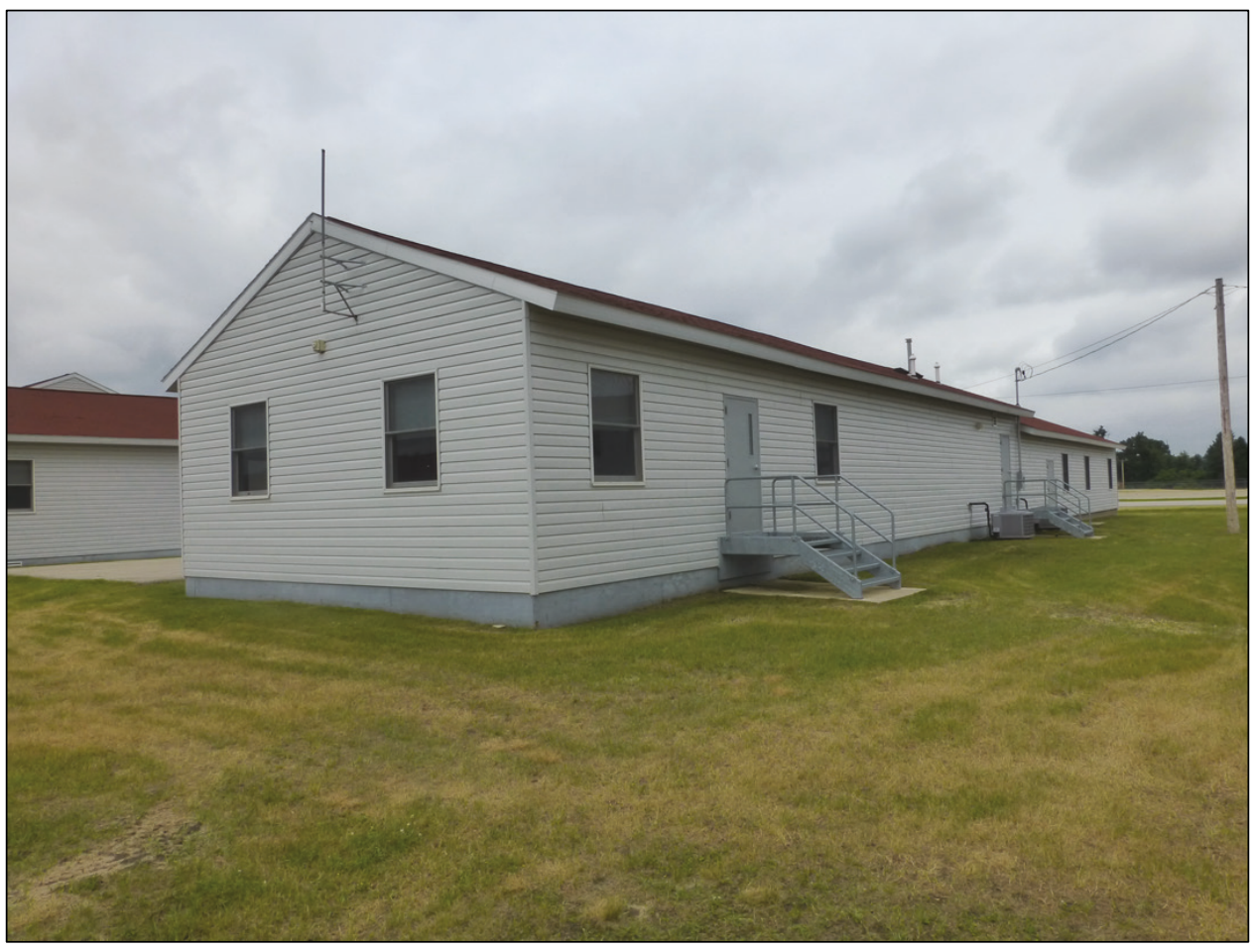

Figure 90. Southwest oblique of Building 1622 (ERDC-CERL, 2018).

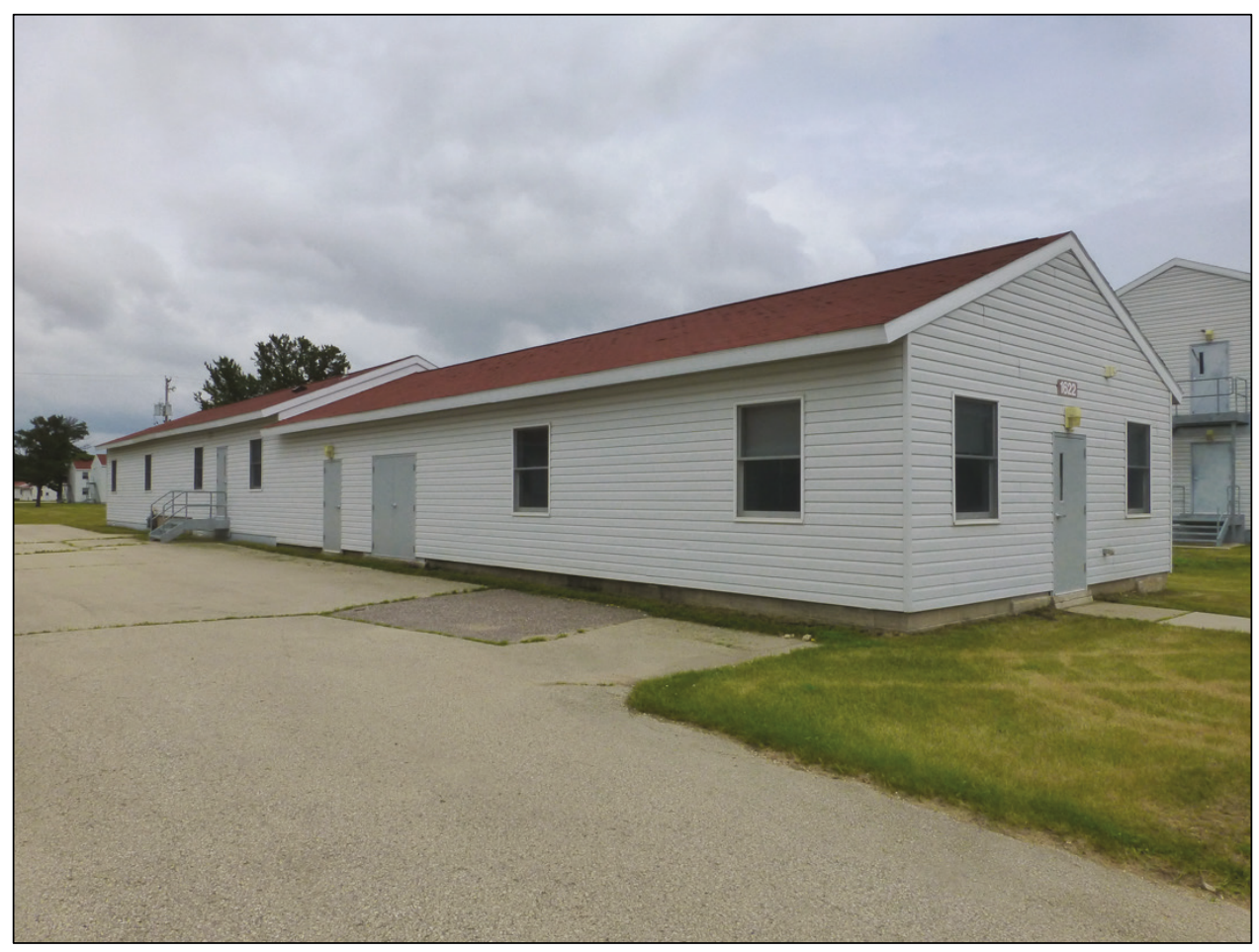


Figure 91. Storage area (ERDC-CERL, 2018).

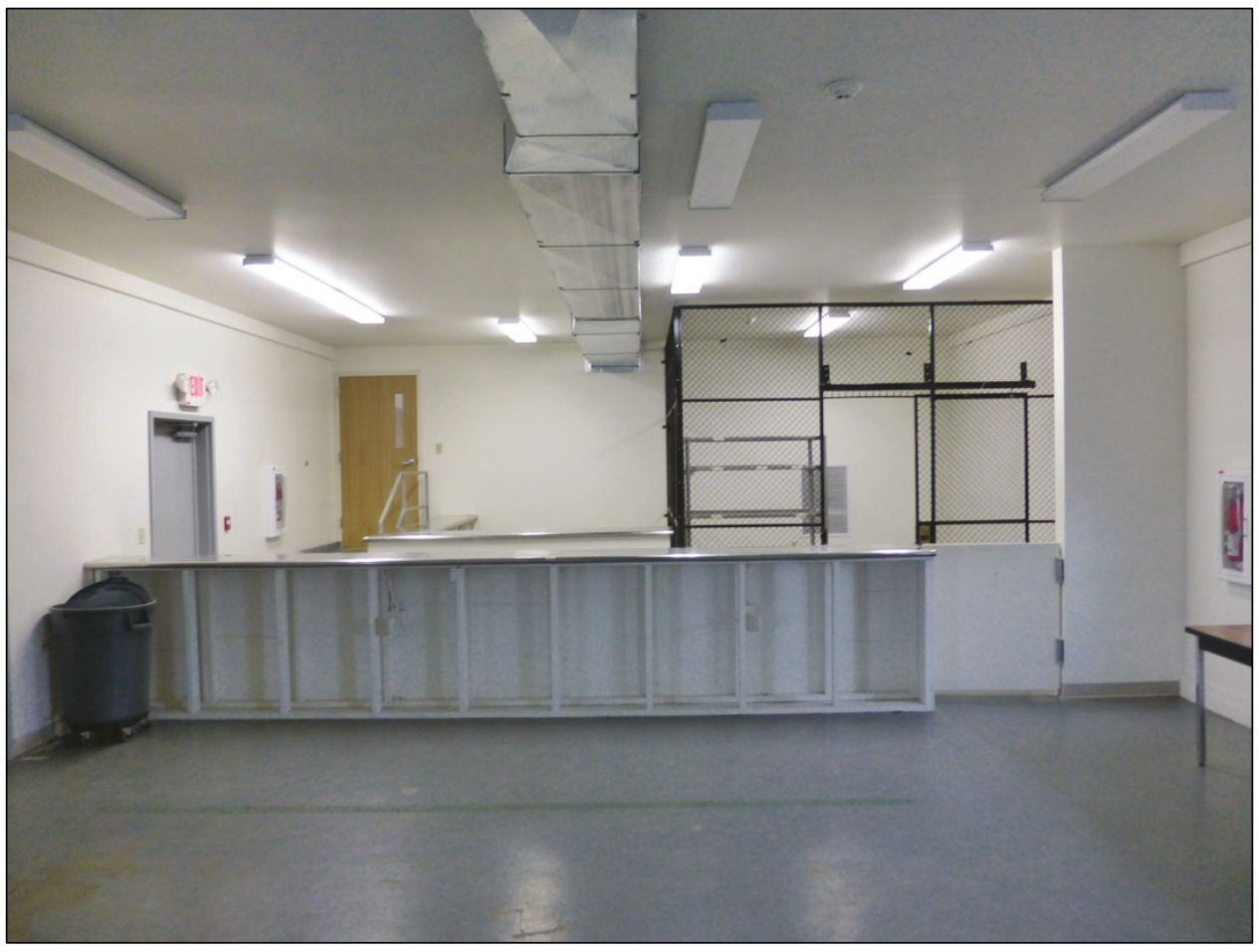

Figure 92. New hallway and latrines (ERDC-CERL, 2018).

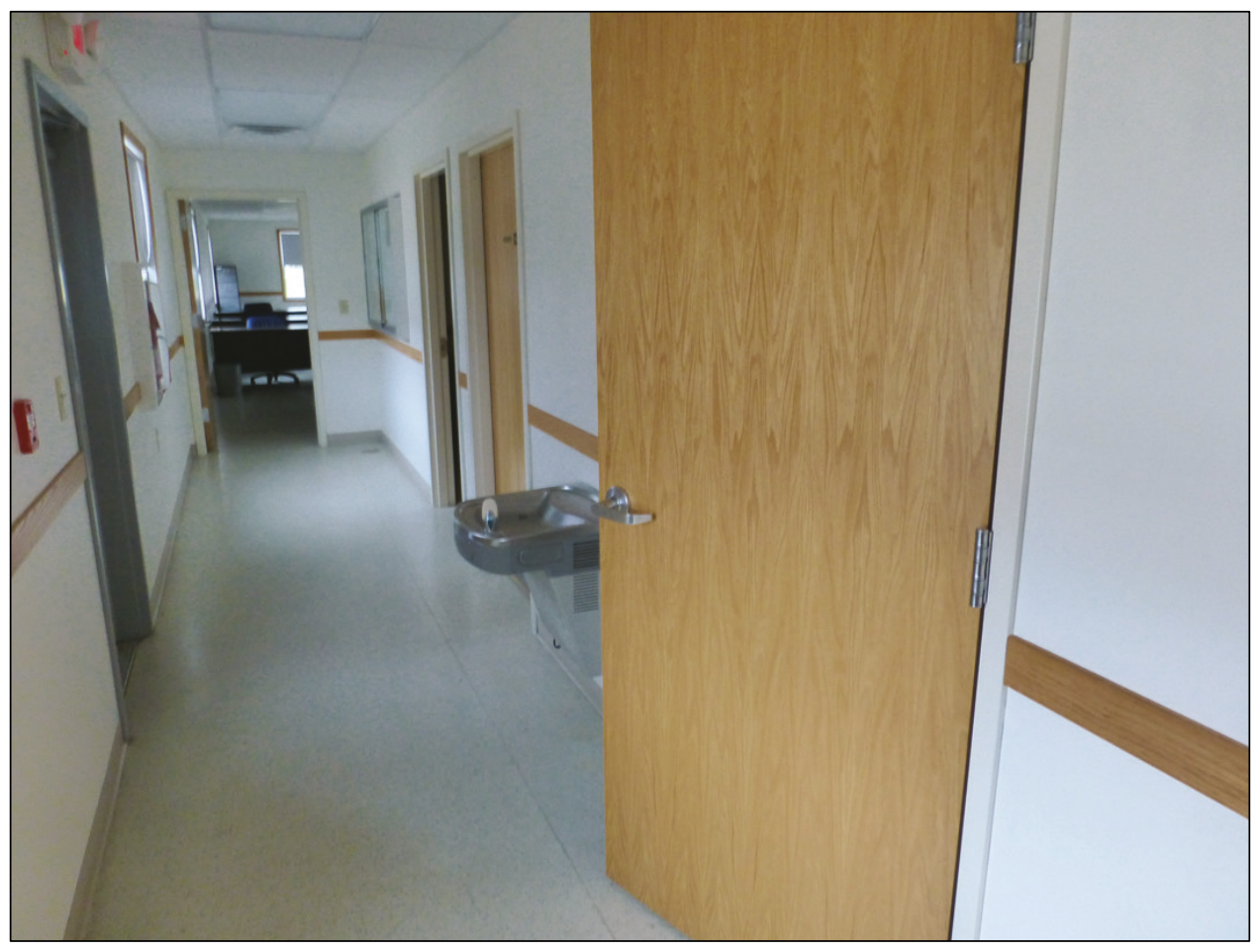


Figure 93. Former study room space, now office space (ERDC-CERL, 2018).

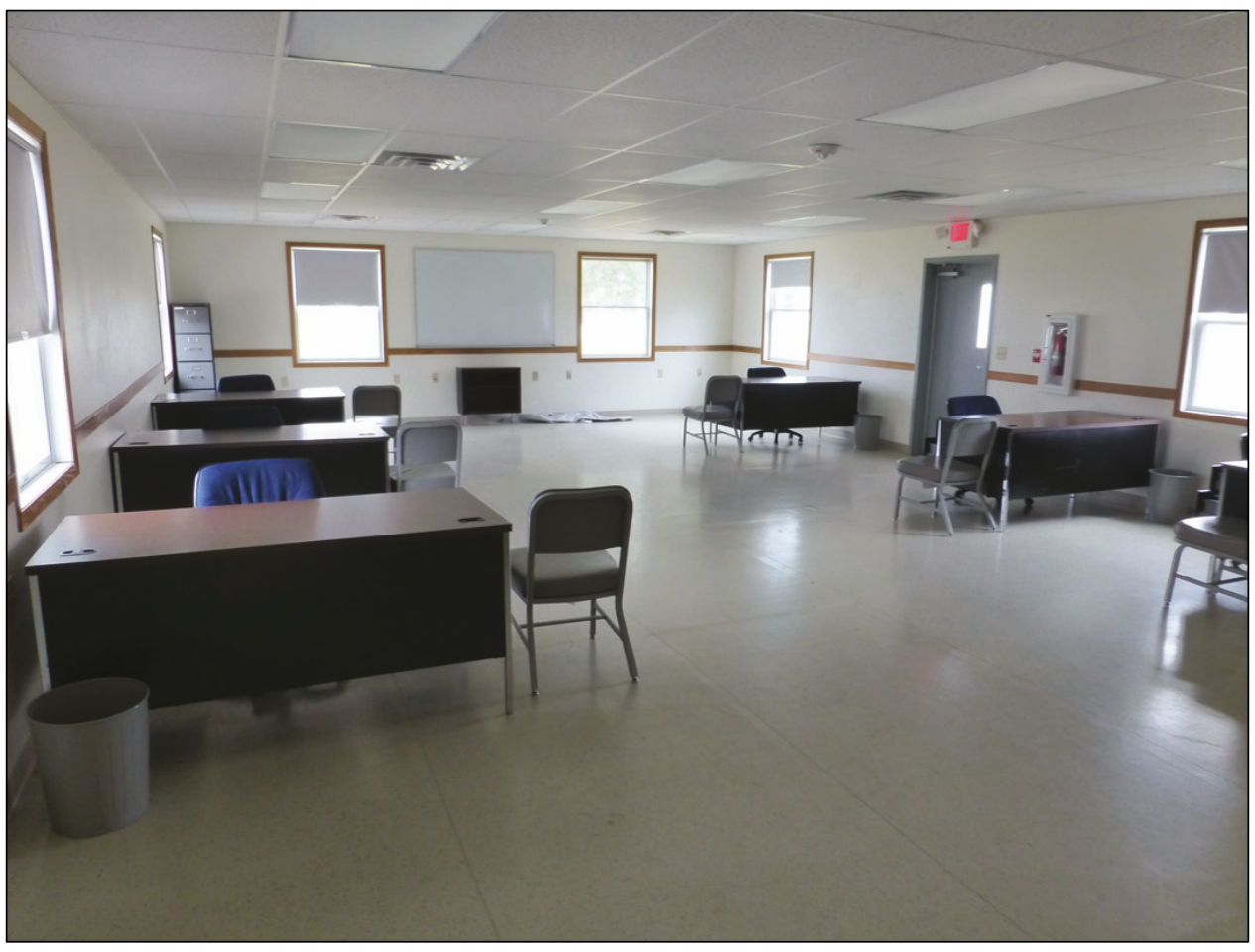

\subsection{Mess Halls (Buildings 1626, 1627, 1638, and 1639)}

Buildings 1626, 1627, 1638, and 1639 are all mess halls constructed in 1942 from the War Department's 800 Series of standard plans (Figure 95) and located on the south side of the Triad (Figure 94). Buildings 1626 and 1627 are currently mess halls. In 2008 these two mess hall buildings, which are located next to each other, were joined by a hyphen that housed latrines and storage areas (Figure 96 and Figure 102). Buildings 1638 and 1639 were changed into classrooms prior to 2003. Each of these two classroom buildings have a large addition that houses latrines (Figure 104).

The exteriors of these buildings have no original character-defining features from the period of significance (Figure 97-Figure 100 and Figure 103).

The interiors do not have their original plan, and no other characterdefining features are extant (Figure 101 and Figure 105). 
HABS was performed on an 800 Series mess hall (Building T-801) at Fort McCoy in 1988, HABS WI-308-C. 67 This documentation was done as part of the 1986 PMOA for demolition of WWII temporary buildings as approved by DoD, ACHP, and the NCSHPO.

Figure 94. Map with location of Buildings $1626,1627,1638$, and 1639 outlined in red (Fort McCoy DPW, 2018).

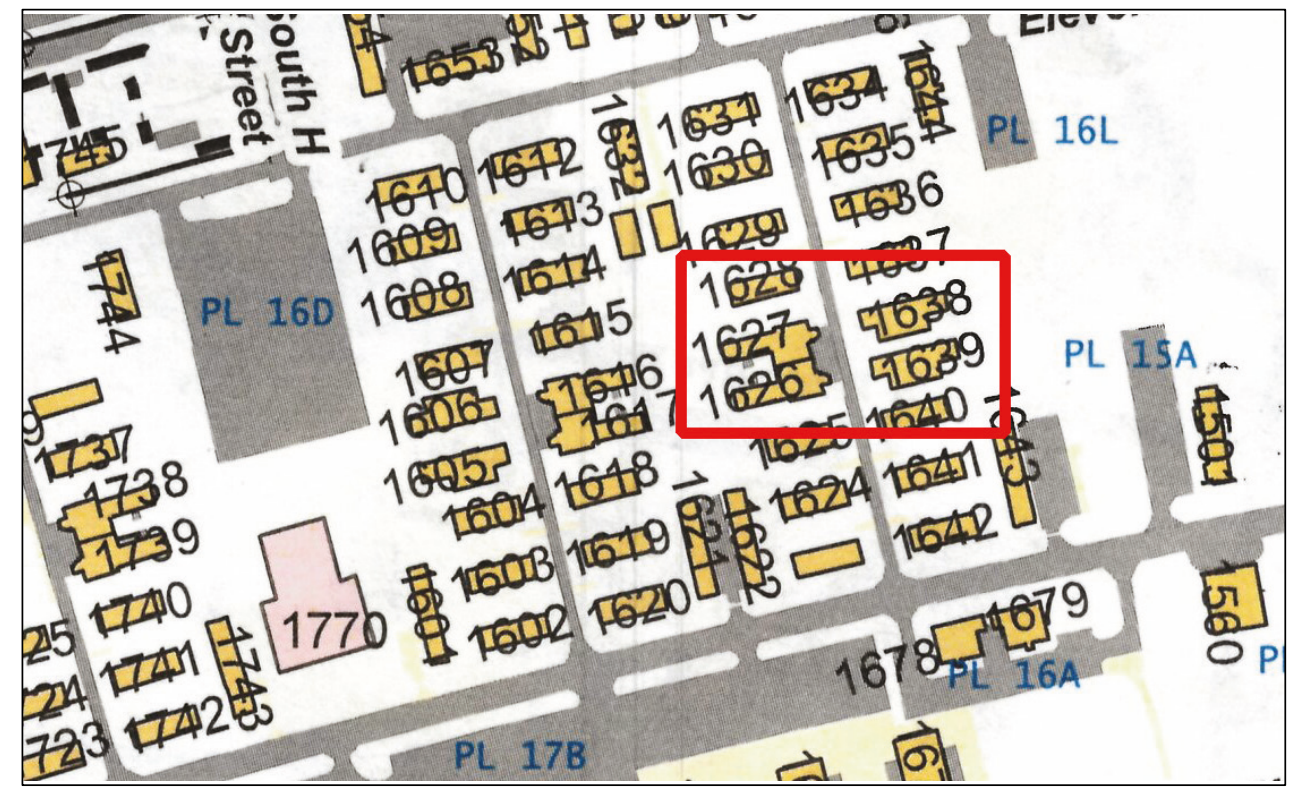

67 HABS No. WI-308-C, “Fort McCoy, Building T-635 (Mess Hall)," Sparta vicinity, Monroe County, Wisconsin (Washington, DC: Historic American Buildings Survey, National Park District, Department of the Interior, 1988). Catalogued by Library of Congress as HABS WIS, 41-SPAR.V, 1-C-: https://cdn.loc.gov/master/pnp/habshaer/wi/wi0200/wi0263/data/wi0263data.pdf. 
Figure 95. 800 Series plan for a mess hall, Drawing 800-851, 1942 (Library of Congress).

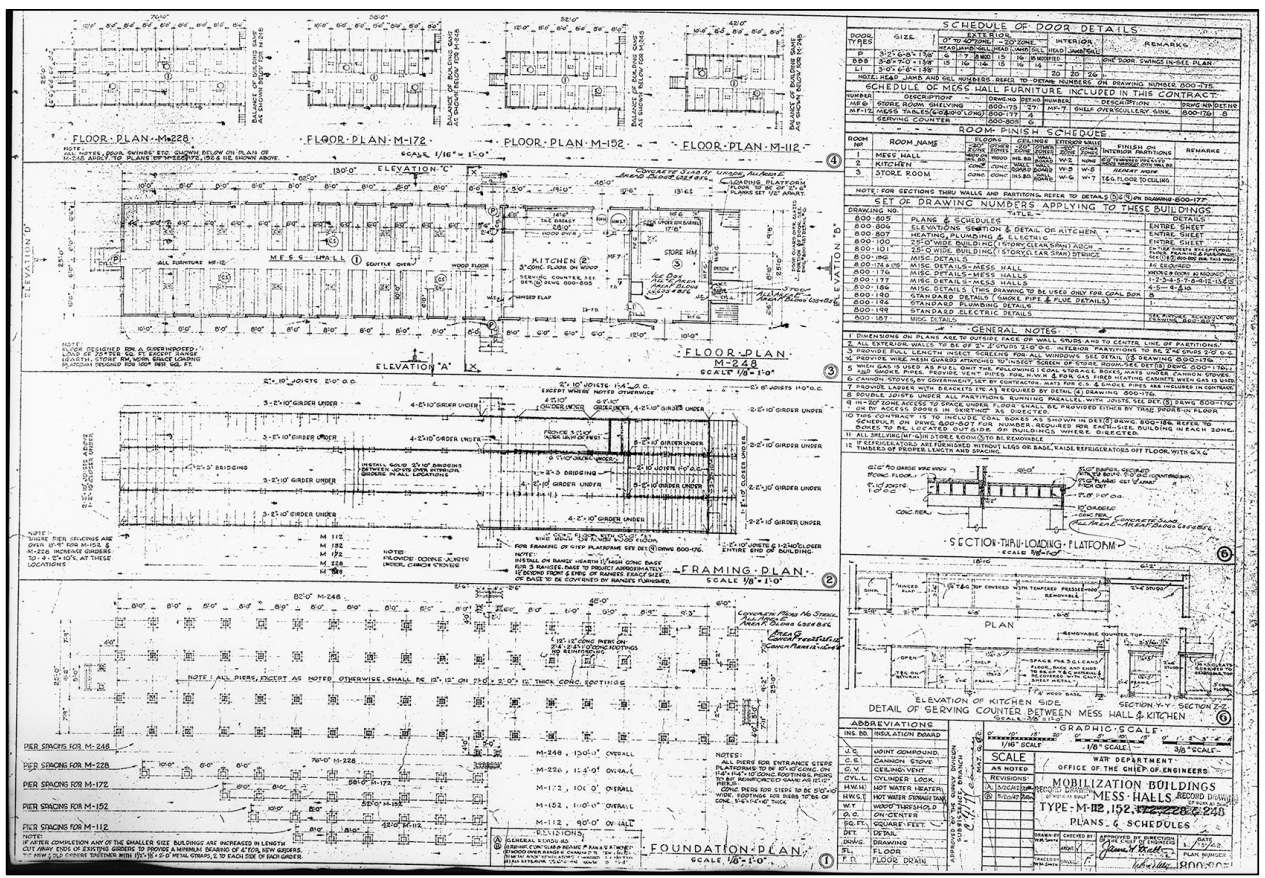

Figure 96. Drawing for connection of two separate mess hall buildings with a hyphen, 2008 (DPW, Fort McCoy).

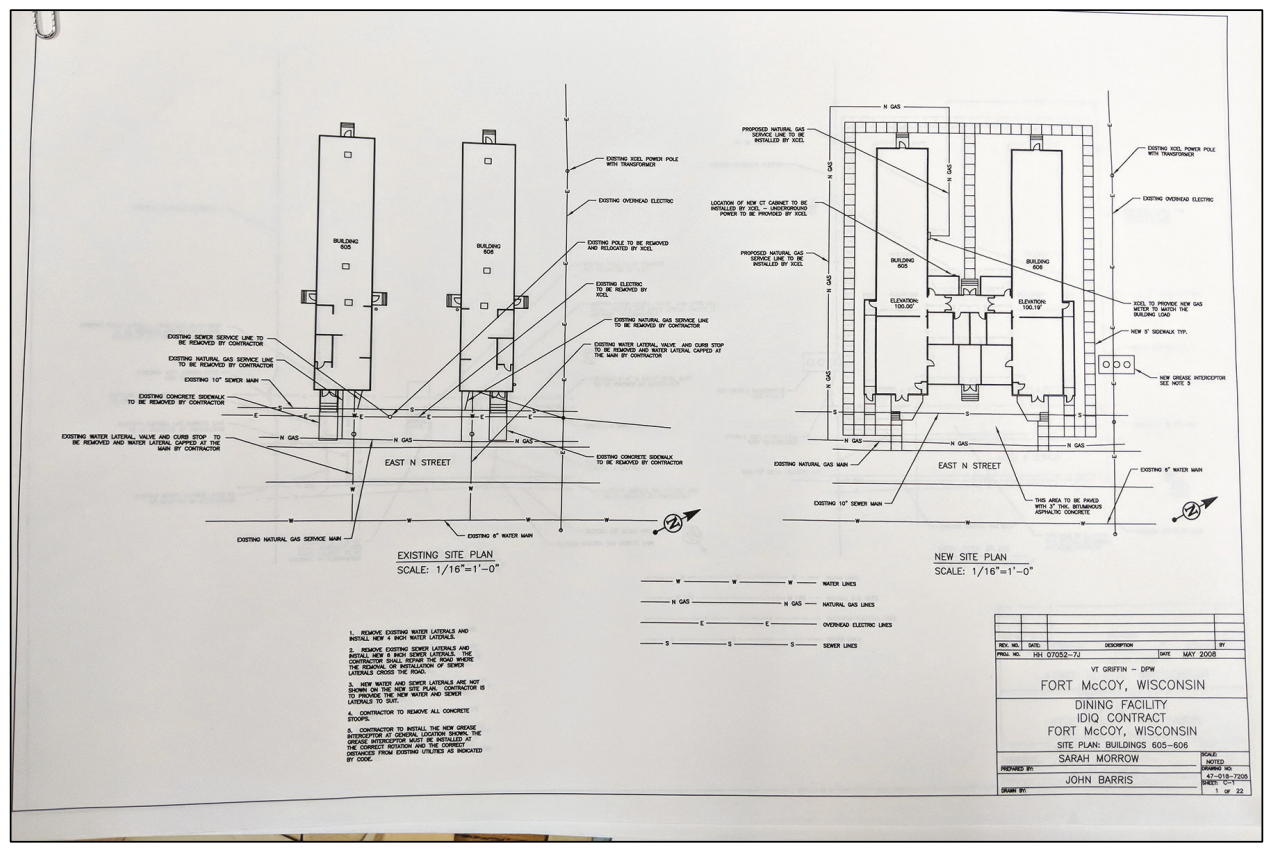


Figure 97. View of mess hall, 1951 (NARA, College Park, RG111SC).

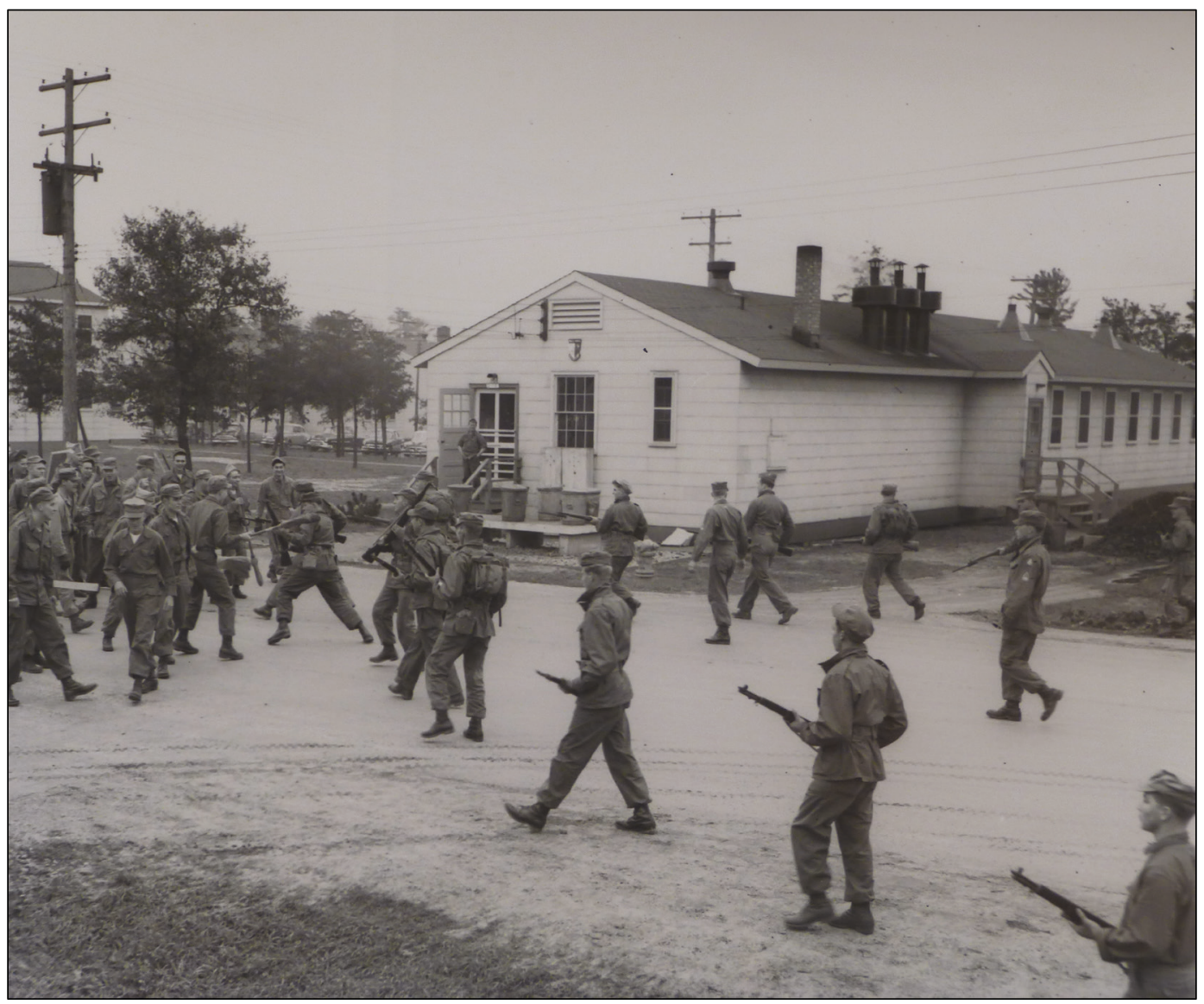

Figure 98. Southeast oblique of Building 1626 (ERDC-CERL, 2018).

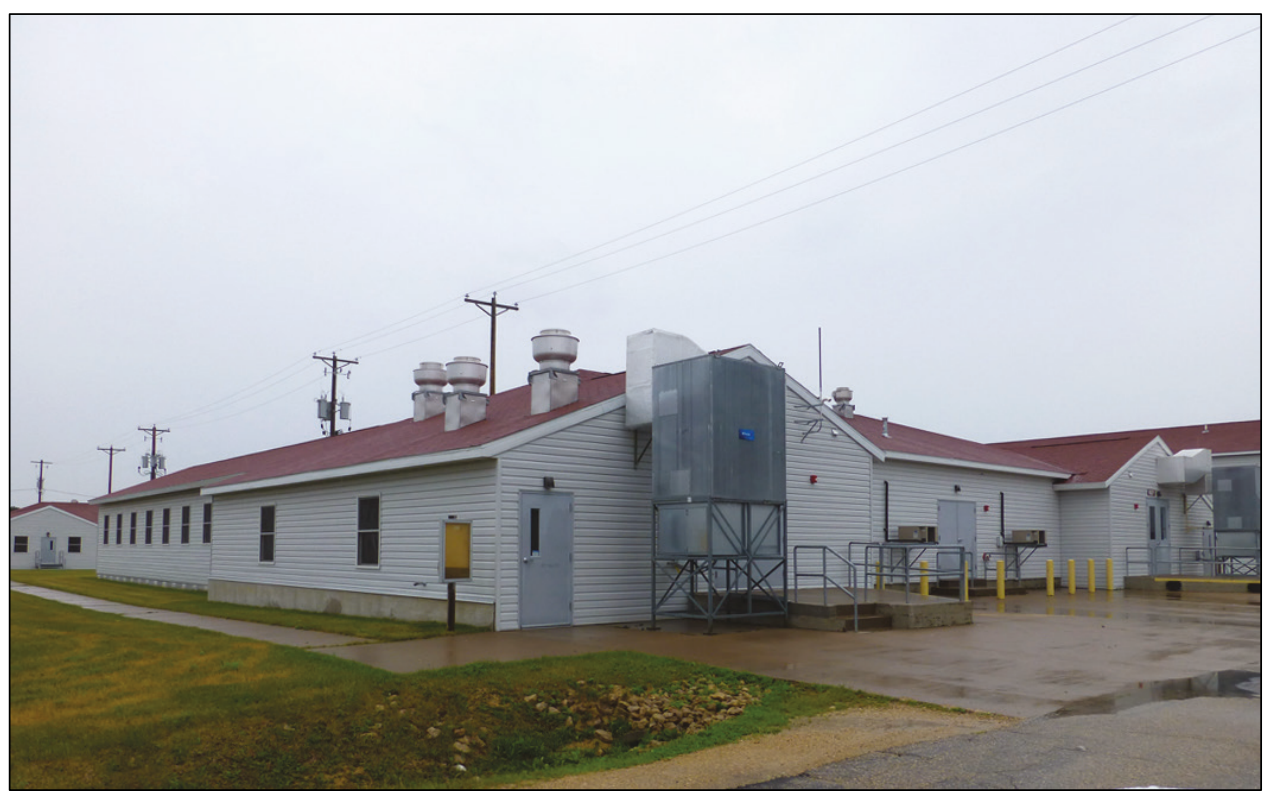


Figure 99. East side of hyphen connecting Buildings 1626 and 1627 (ERDC-CERL, 2018).

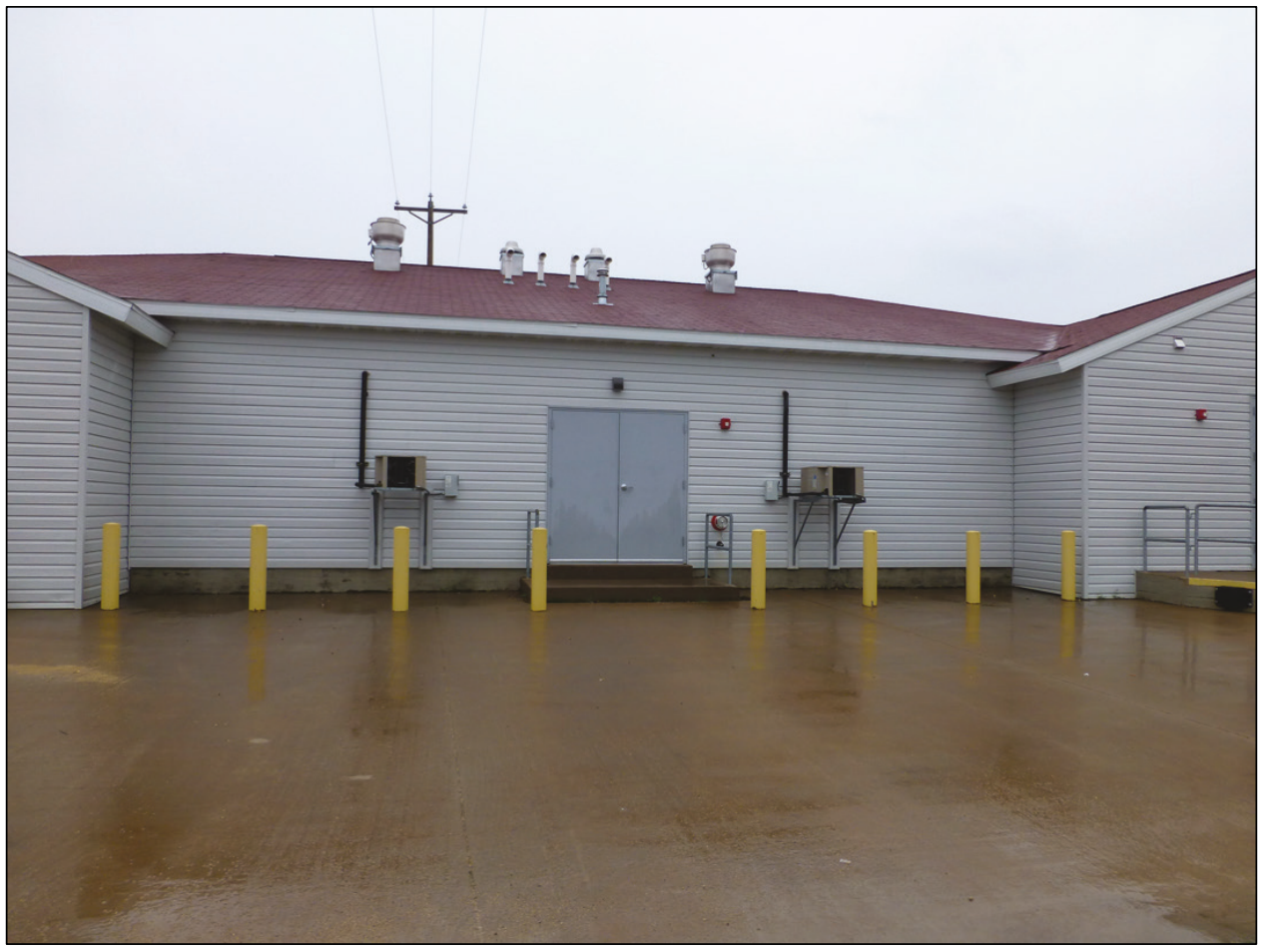

Figure 100. Northeast oblique of Building 1627 (ERDC-CERL, 2018).

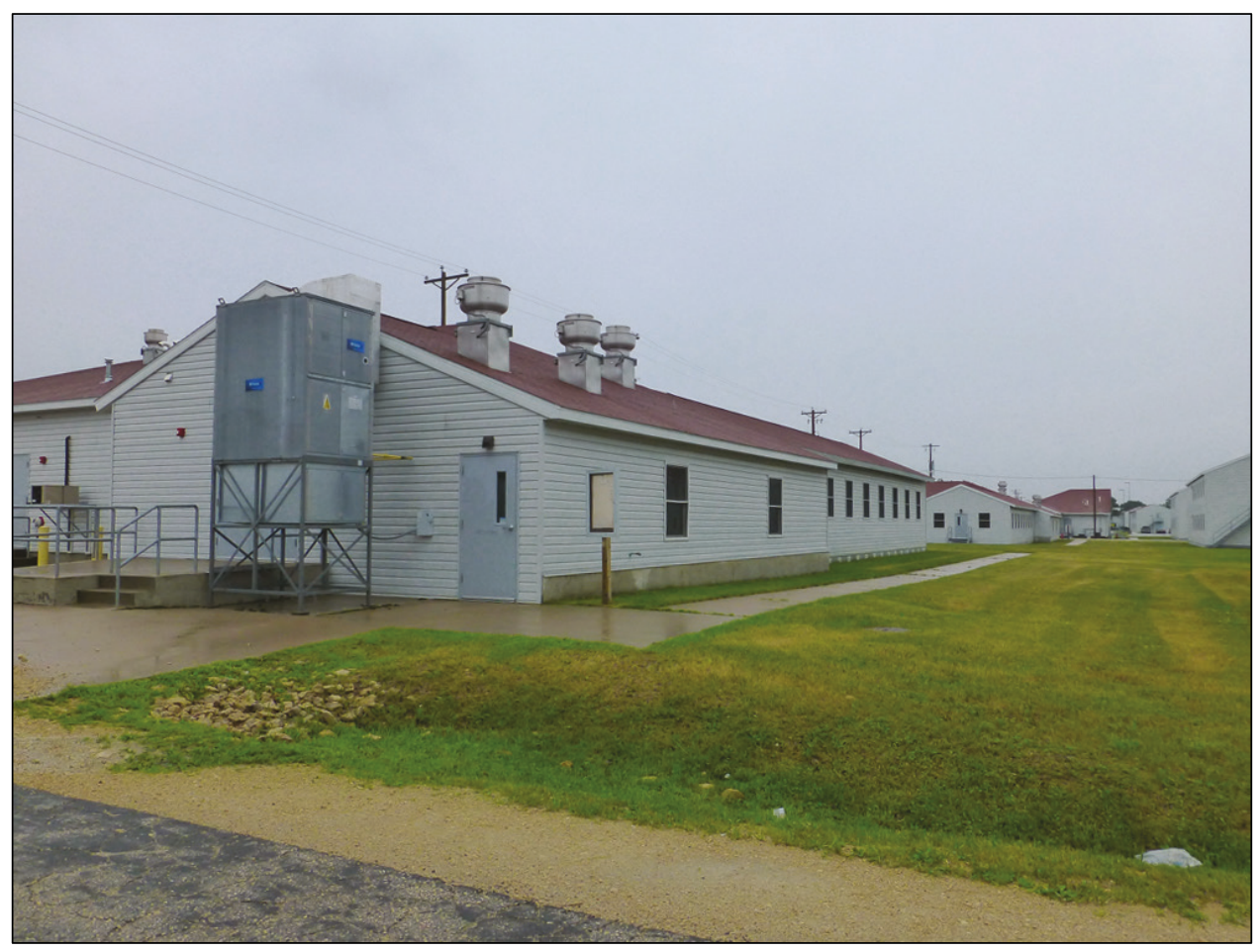


Figure 101. Interior of mess hall (ERDC-CERL, 2018).

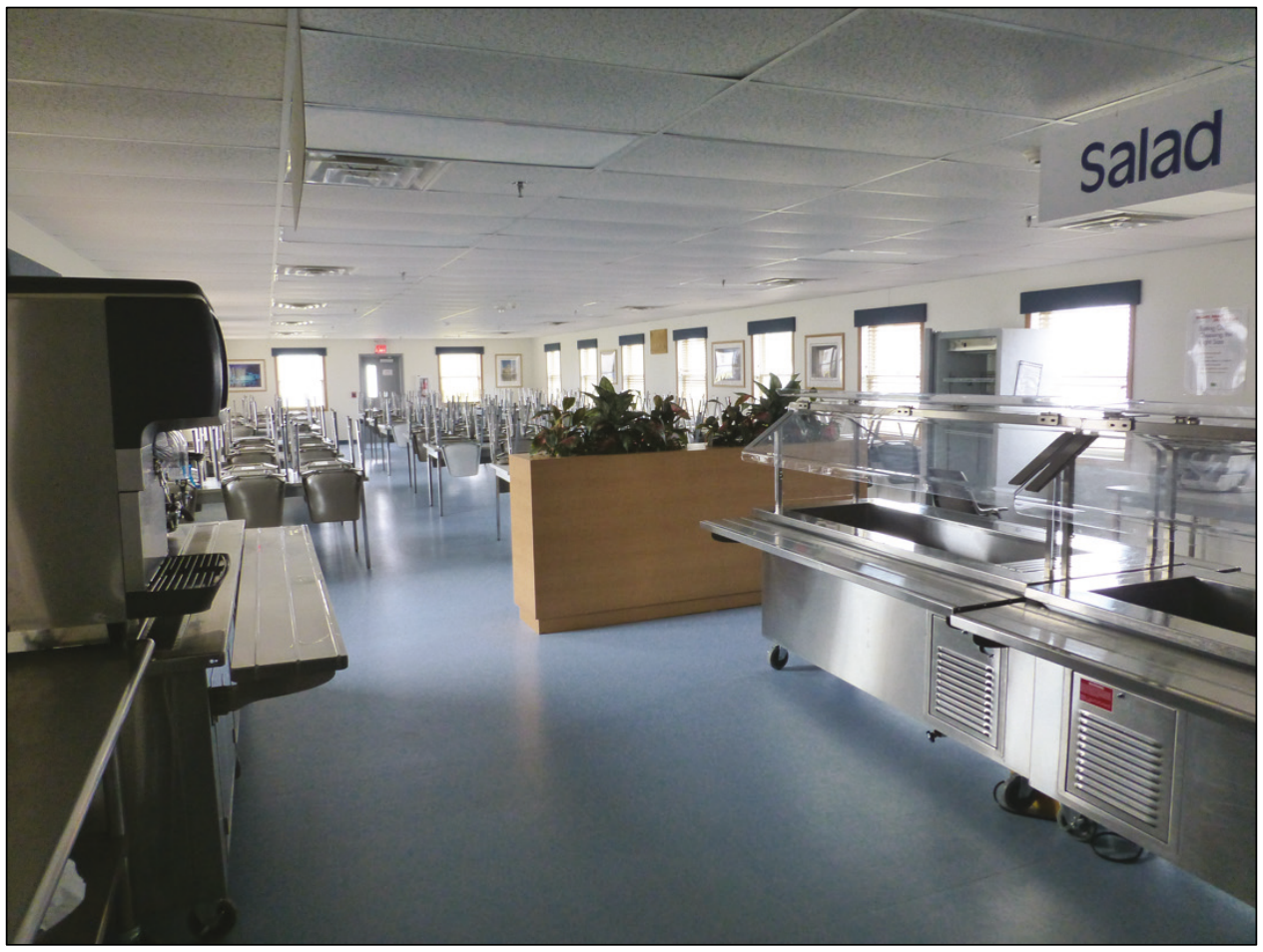

Figure 102. Hyphen connecting two mess halls (ERDC-CERL, 2018).

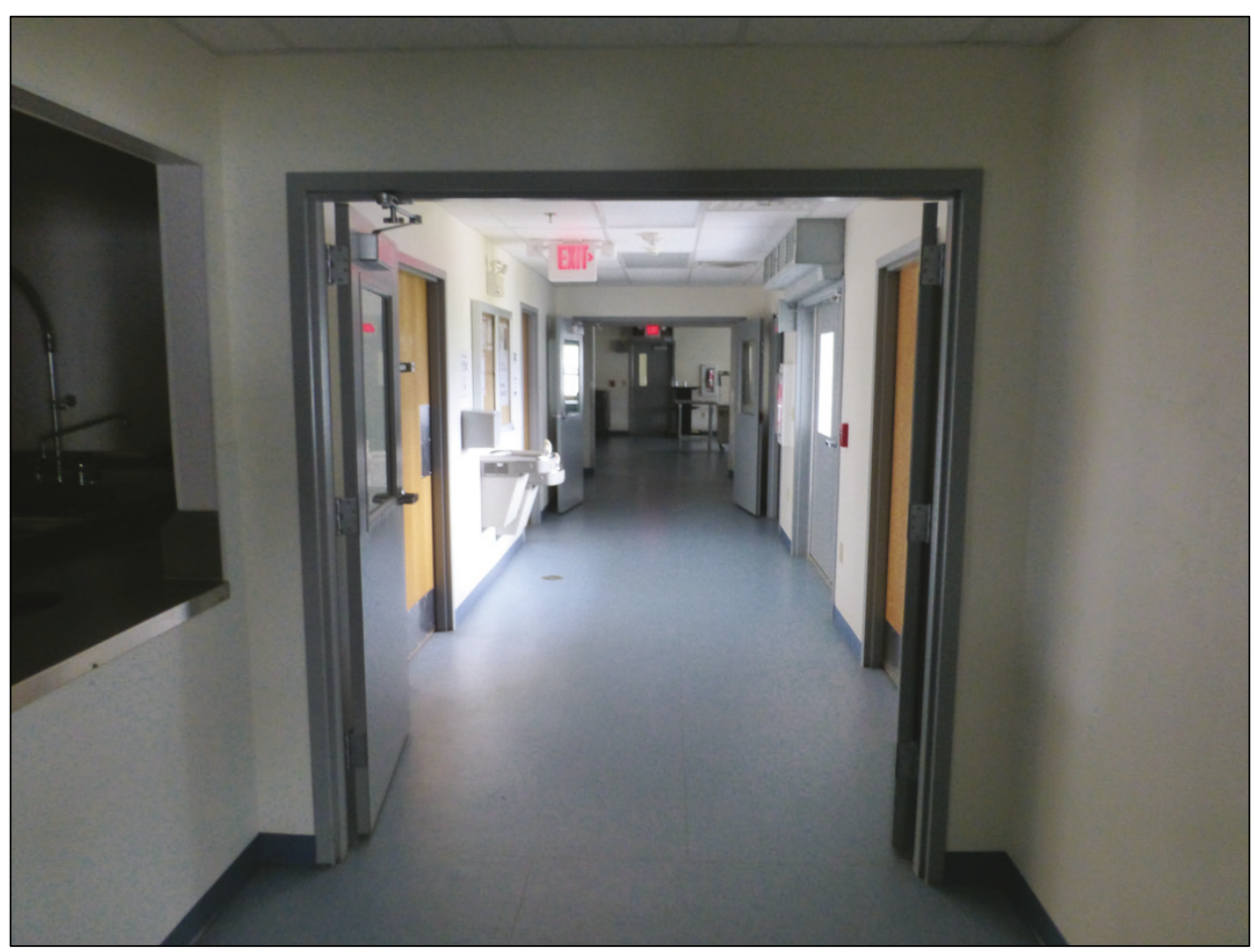


Figure 103. Northwest oblique of Building 1638 (ERDC-CERL, 2018).

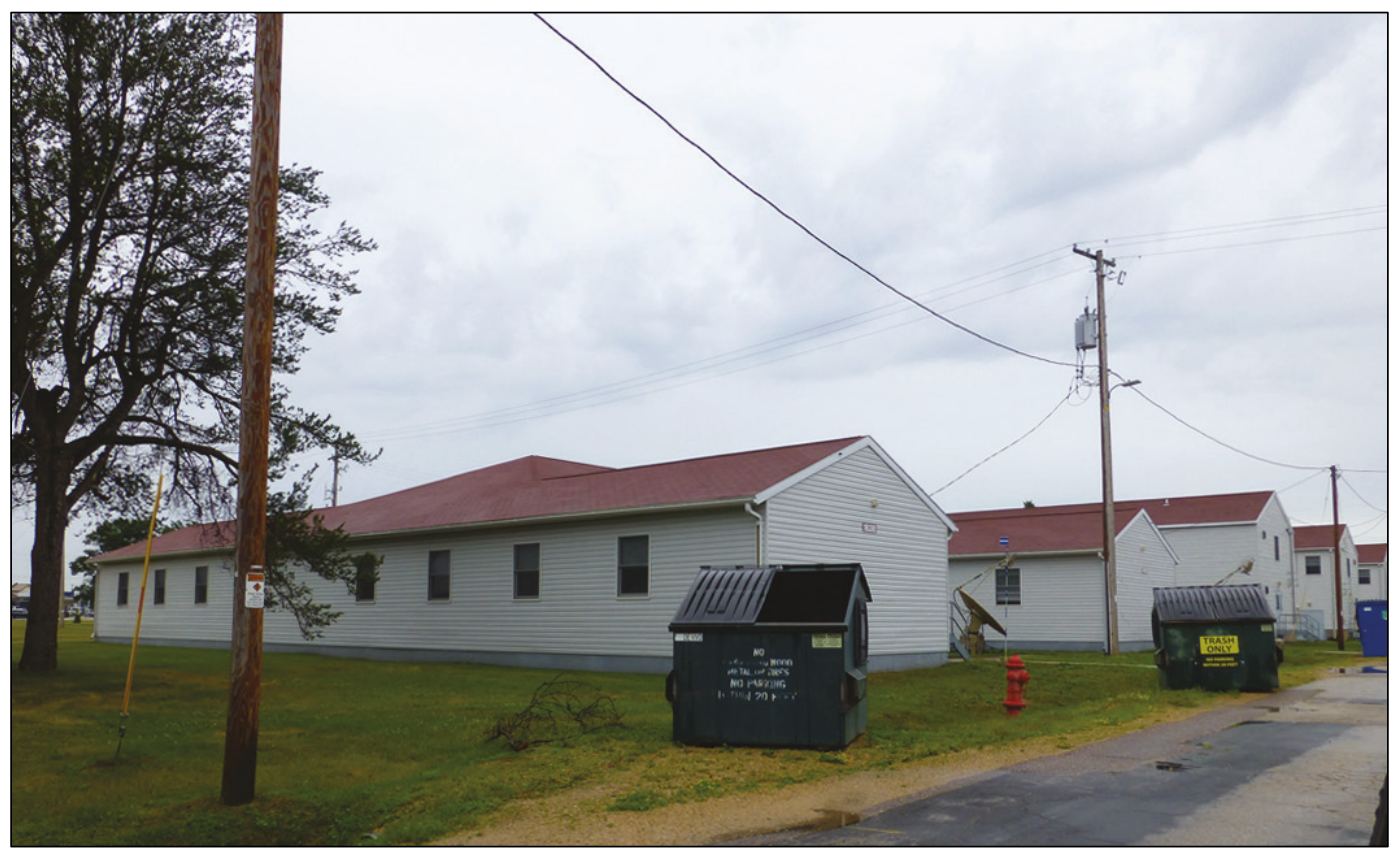

Figure 104. Building 1606, showing large addition housing latrines similar to 1638 and 1639 (ERDC-CERL, 2018).

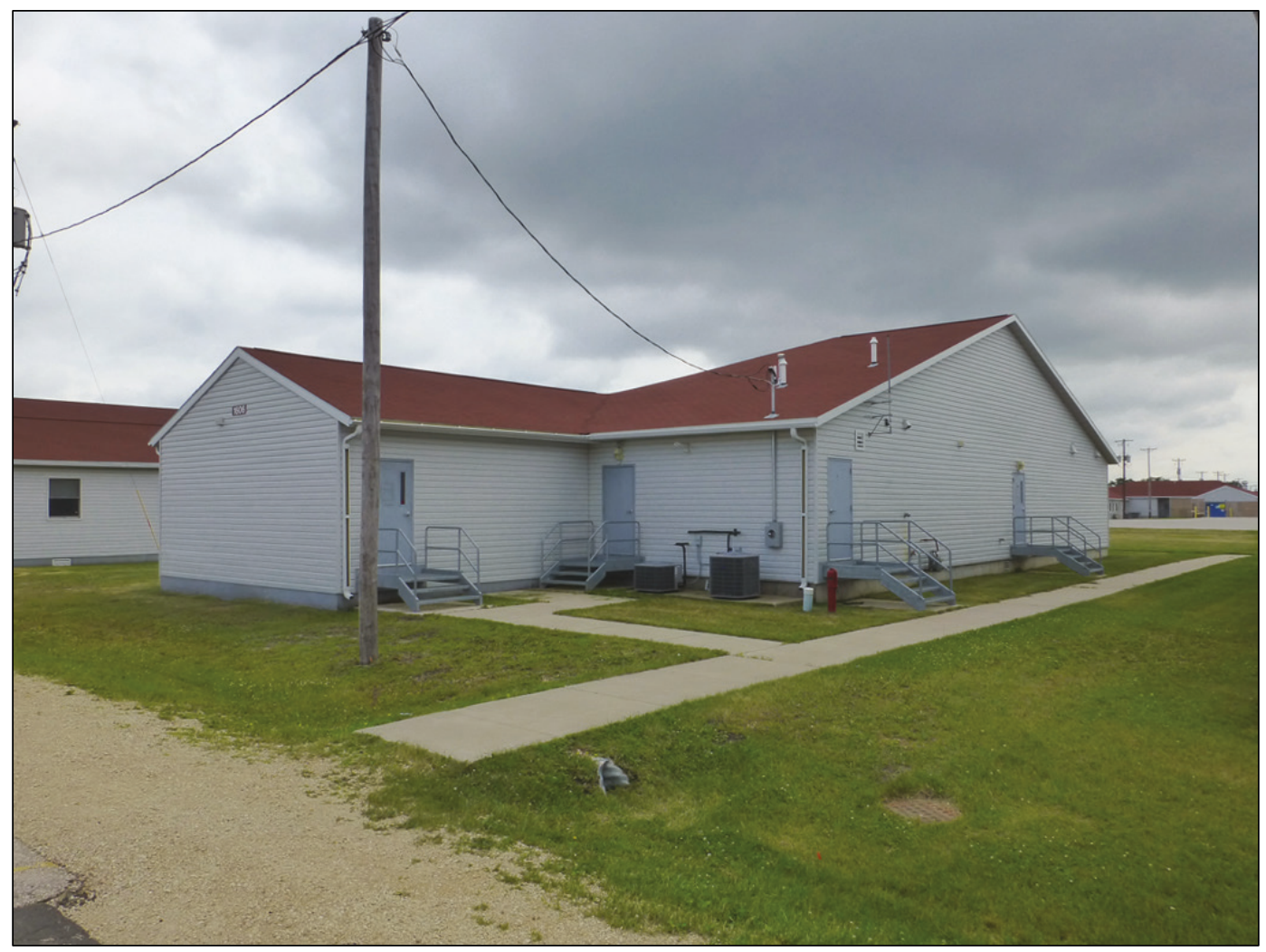


Figure 105. Interior of classroom [former mess hall] (ERDC-CERL, 2018).

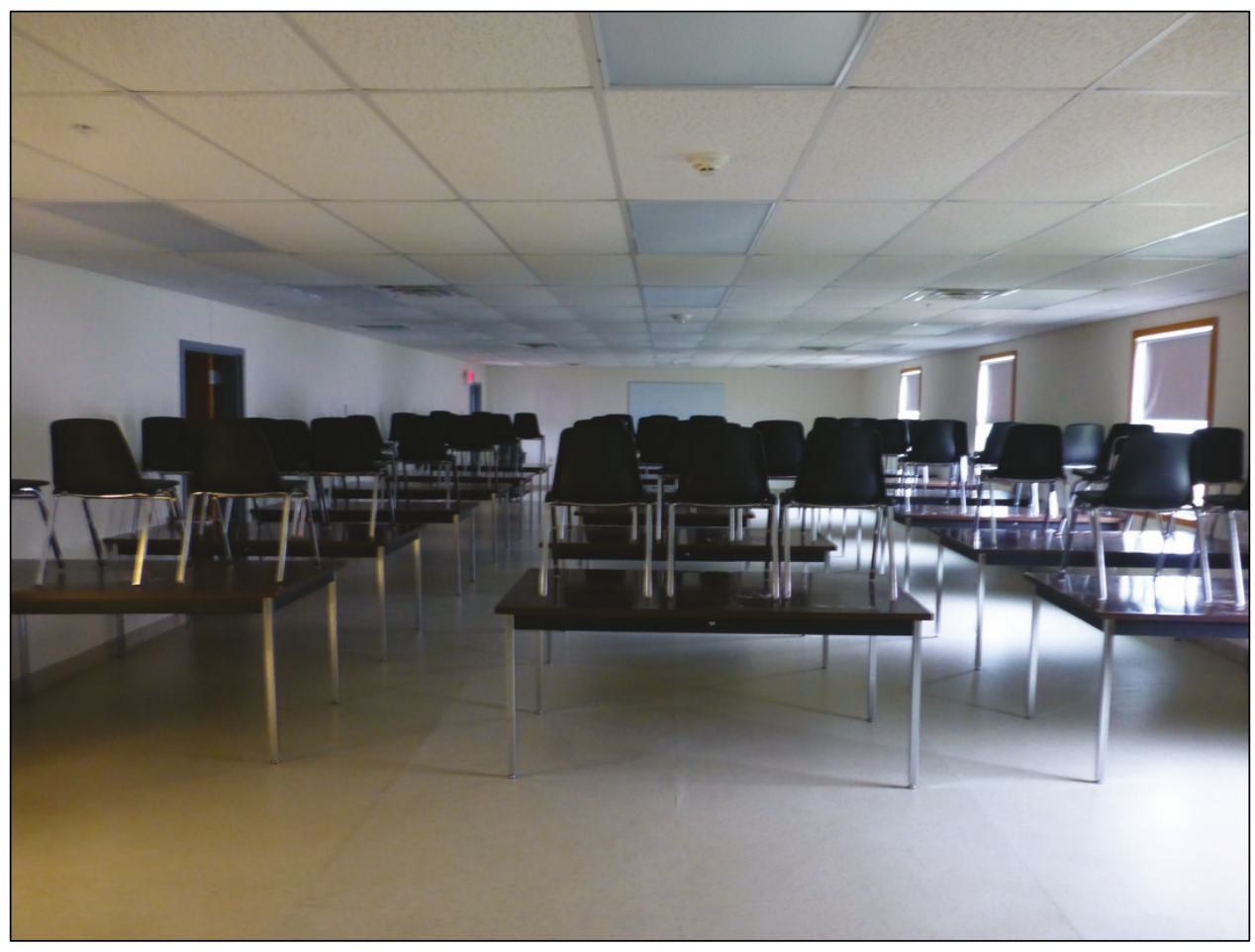

Figure 106. Classroom building (former mess hall) vestibule and latrine addition (ERDC-CERL, 2018).

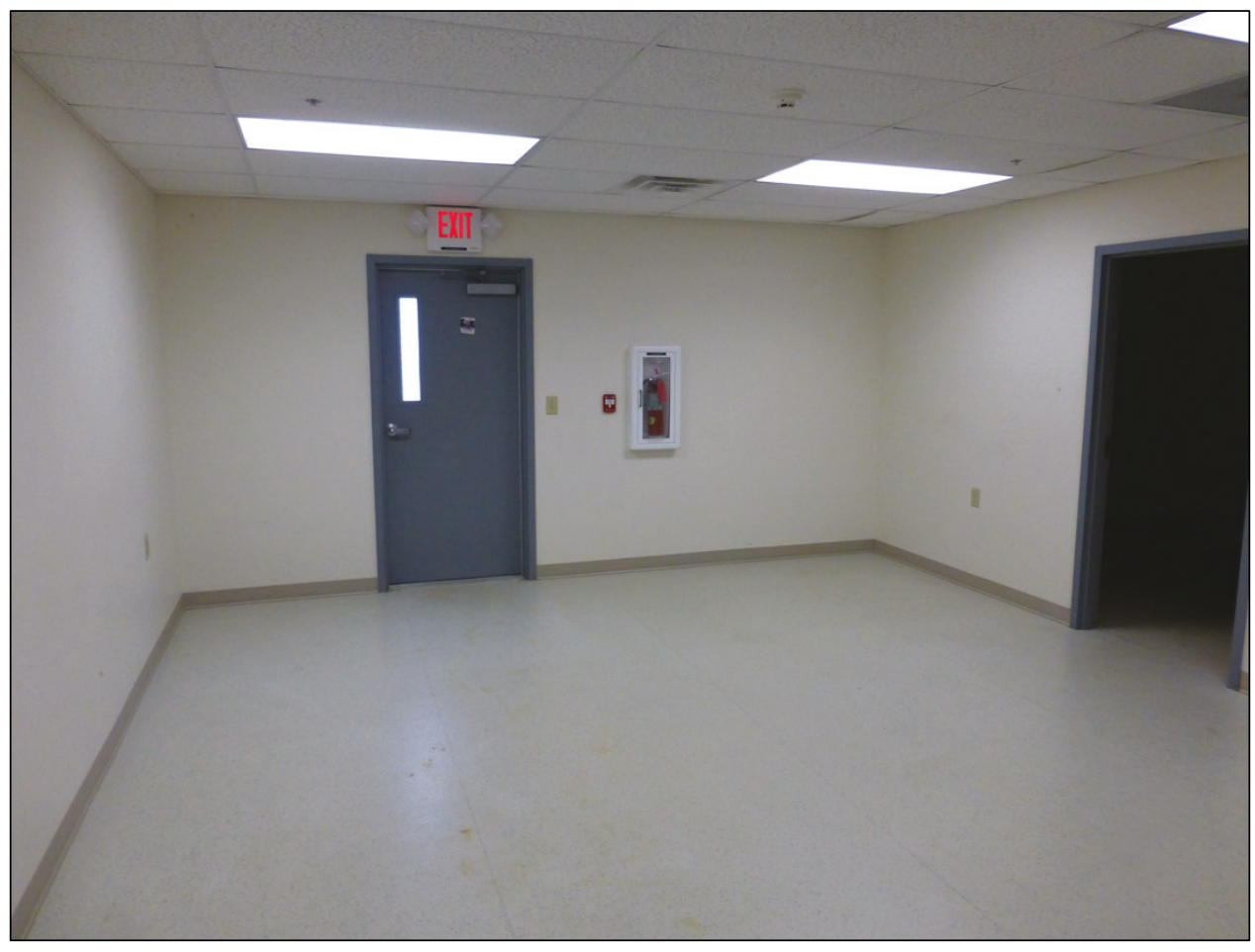




\subsection{Service Club (Building 2000)}

Building 2000 is a service club (recreation center) constructed in 1942 from the War Department's 800 Series of standard plans (Figure 108) and located on the southwest corner of the Triad (Figure 107). Its category code was changed to a multiuse facility in 1999 (fast food, snack bar, recreation). The building is not currently in use.

The exterior has its character-defining features of overall mass, scalloped asbestos siding, red asphalt shingles, but none of the other elements (Figure 109-Figure 111 and Figure 115-Figure 119).

The interior () has its original plan with the exception of the western portion where the café has been thoroughly renovated at least two times. The ballroom, library, and billiard room have most of their characterdefining features, such as wood columns and fireplaces (Figure 112-Figure 114 and Figure 120-Figure 123).

HABS was performed on an 800 Series service club (Building T-2000) at Fort McCoy in 1988, HABS WI-308-J. ${ }^{68}$ This documentation was done as part of the 1986 PMOA for demolition of WWII temporary buildings as approved by DoD, ACHP, and the NCSHPO.

\footnotetext{
68 HABS No. WI-308-J. “Fort McCoy, Building T-2000 (Service Club),” Sparta vicinity, Monroe County, Wisconsin (Washington, DC: Historic American Buildings Survey, National Park District, Department of the Interior, 1988). Catalogued by Library of Congress as HABS WIS, 41-SPAR.V, 1-J-: https://cdn.loc.gov/master/pnp/habshaer/wi/wi0200/wi0270/data/wi0270data.pdf.
} 
Figure 107. Location of Building 2000 ( Fort McCoy DPW, 2018).

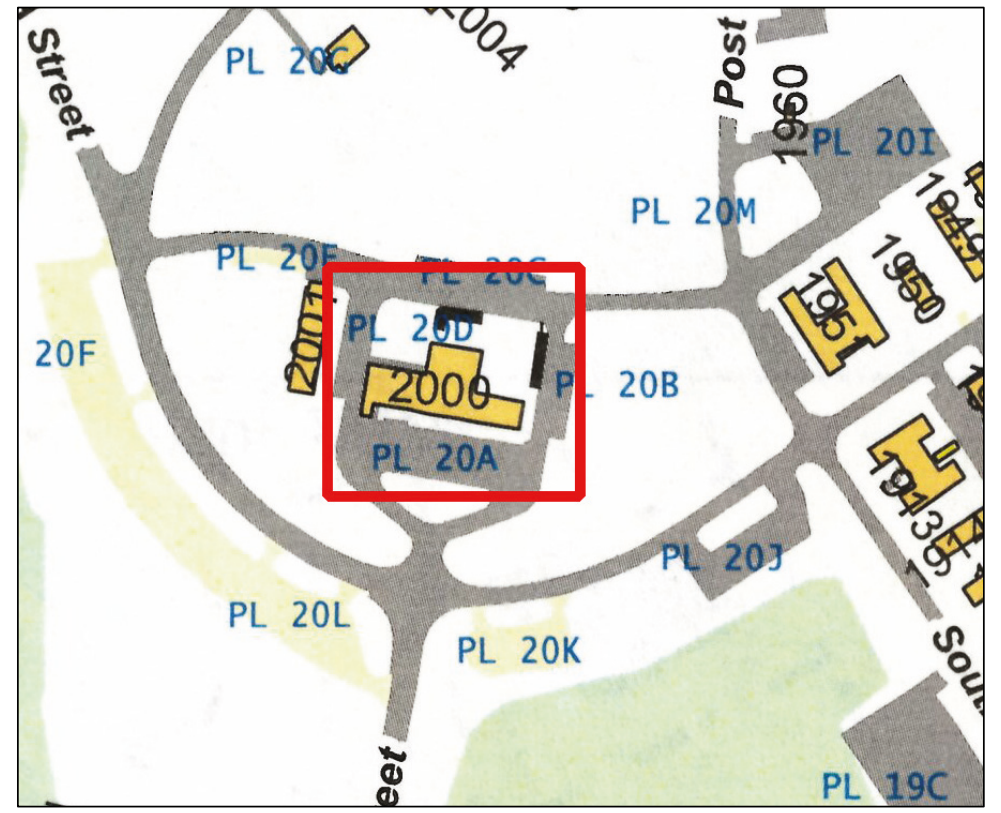

Figure 108. 800 Series plan for service club, Drawing 800-517, 1941 (DPW, Fort McCoy).

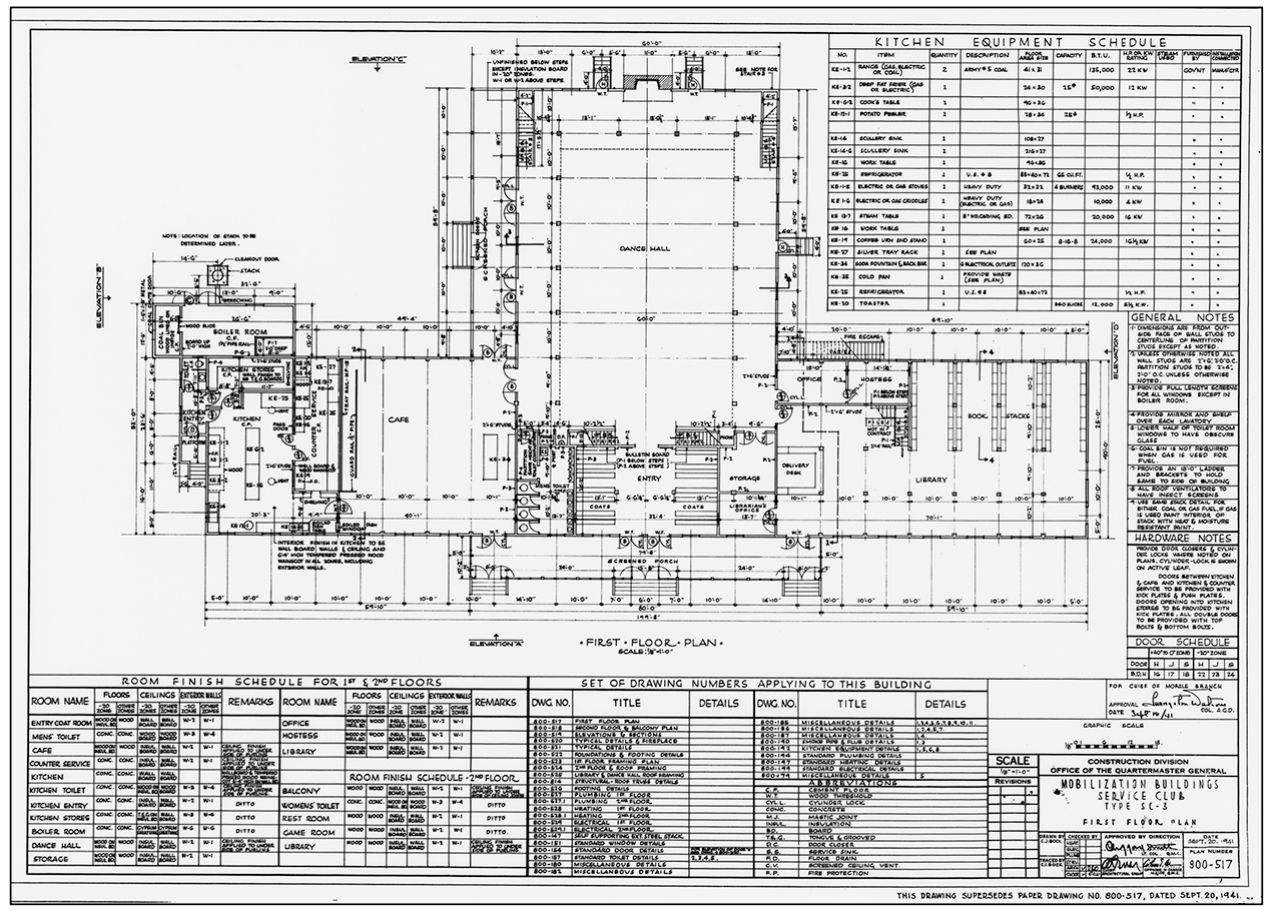


Figure 109. Building 2000, 1952 (NARA, College Park, RG111SC).

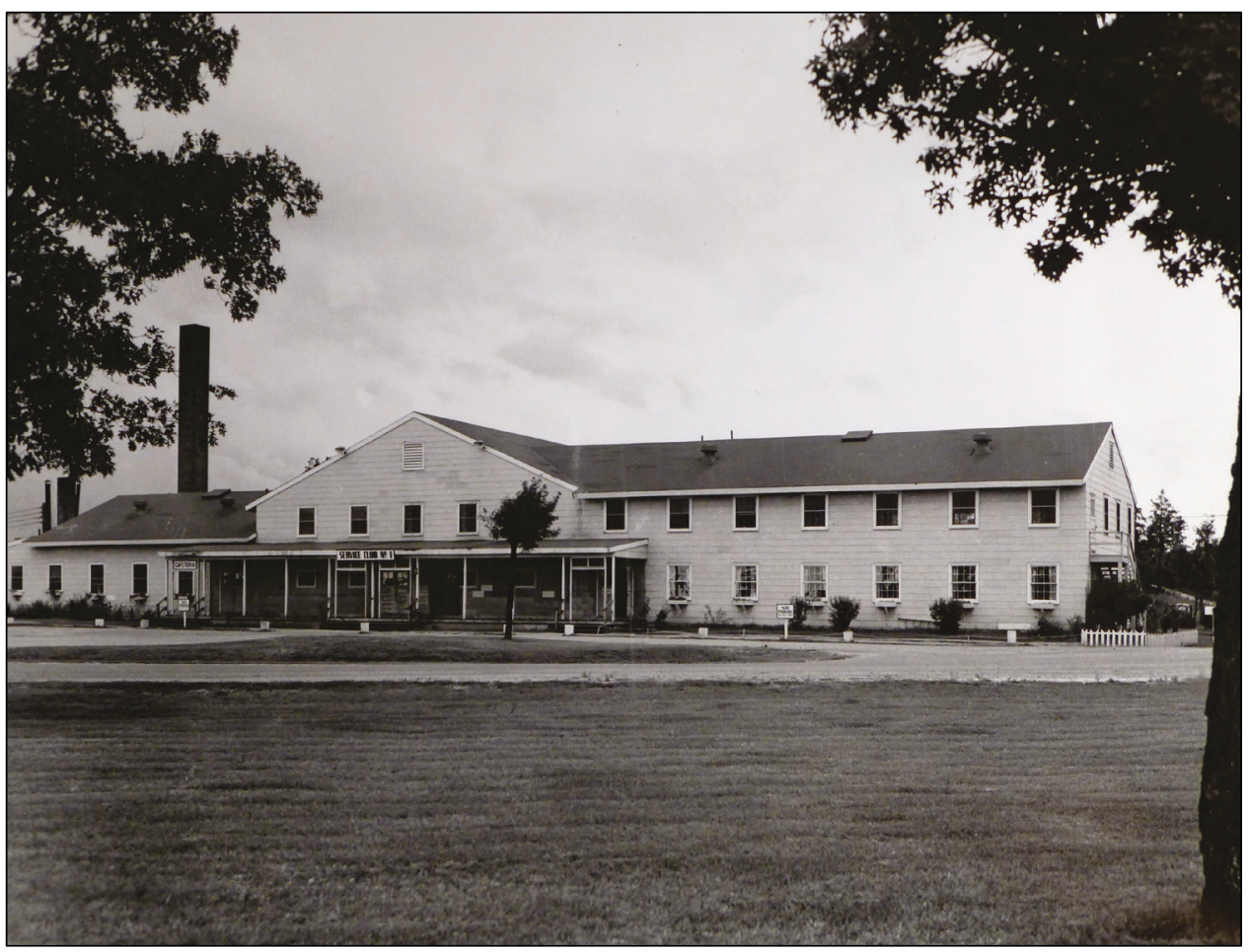

Figure 110. Building 2000, 1965 (NARA College Park RG111SC).

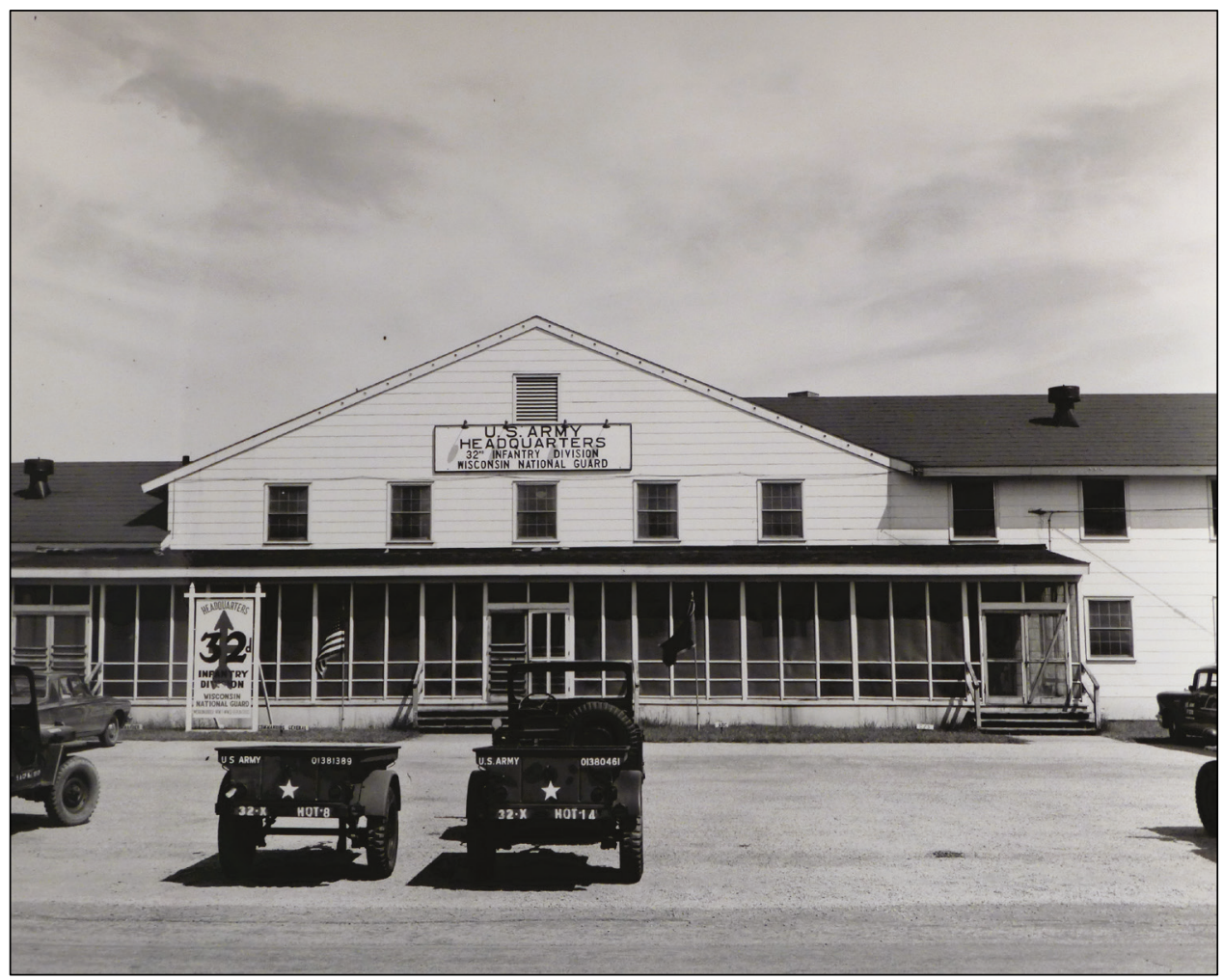


Figure 111. Building 2000, 1978 (NARA, College Park, RG111SC).

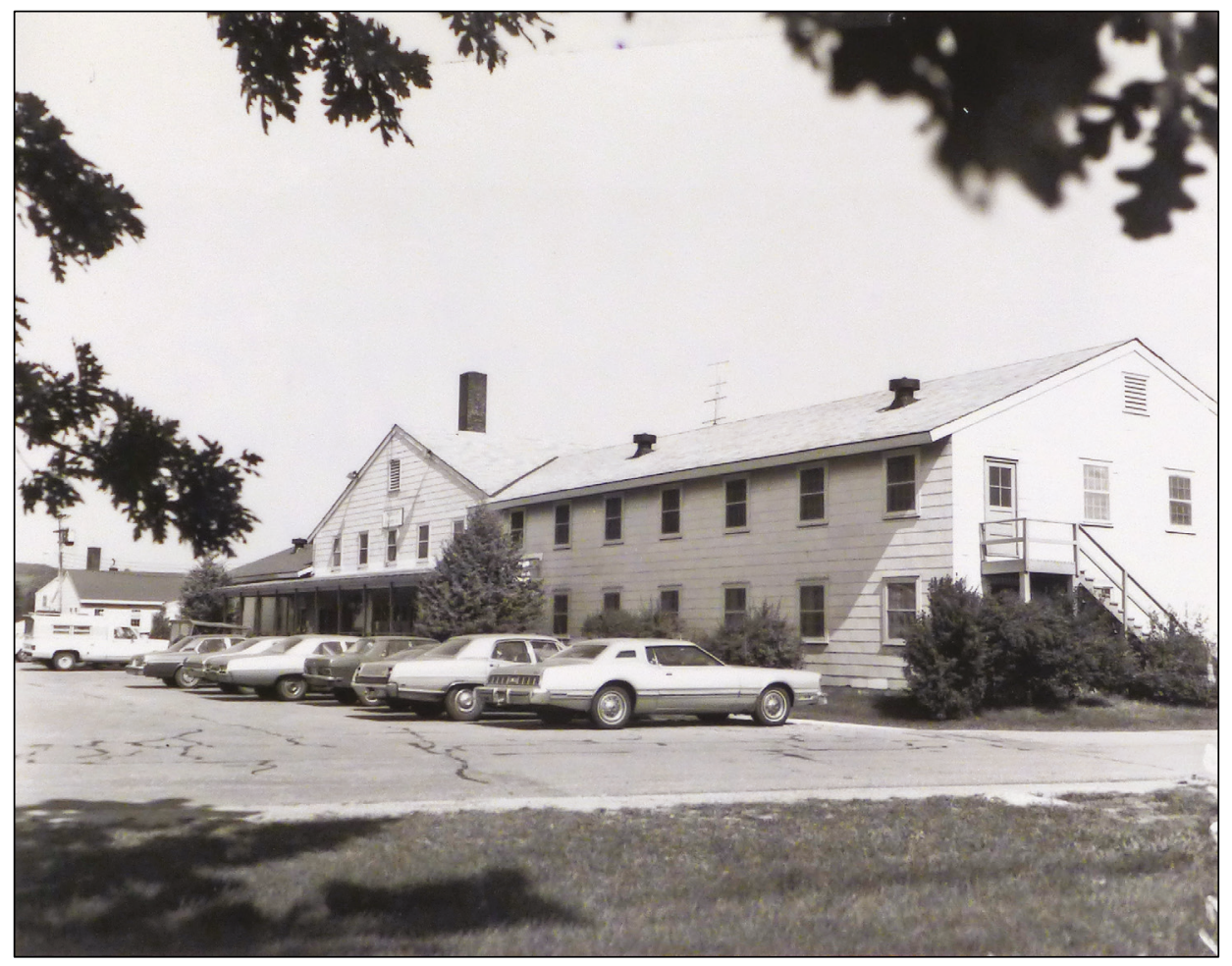

Figure 112. Interior of Building 2000, 1952 (NARA College Park RG111SC).

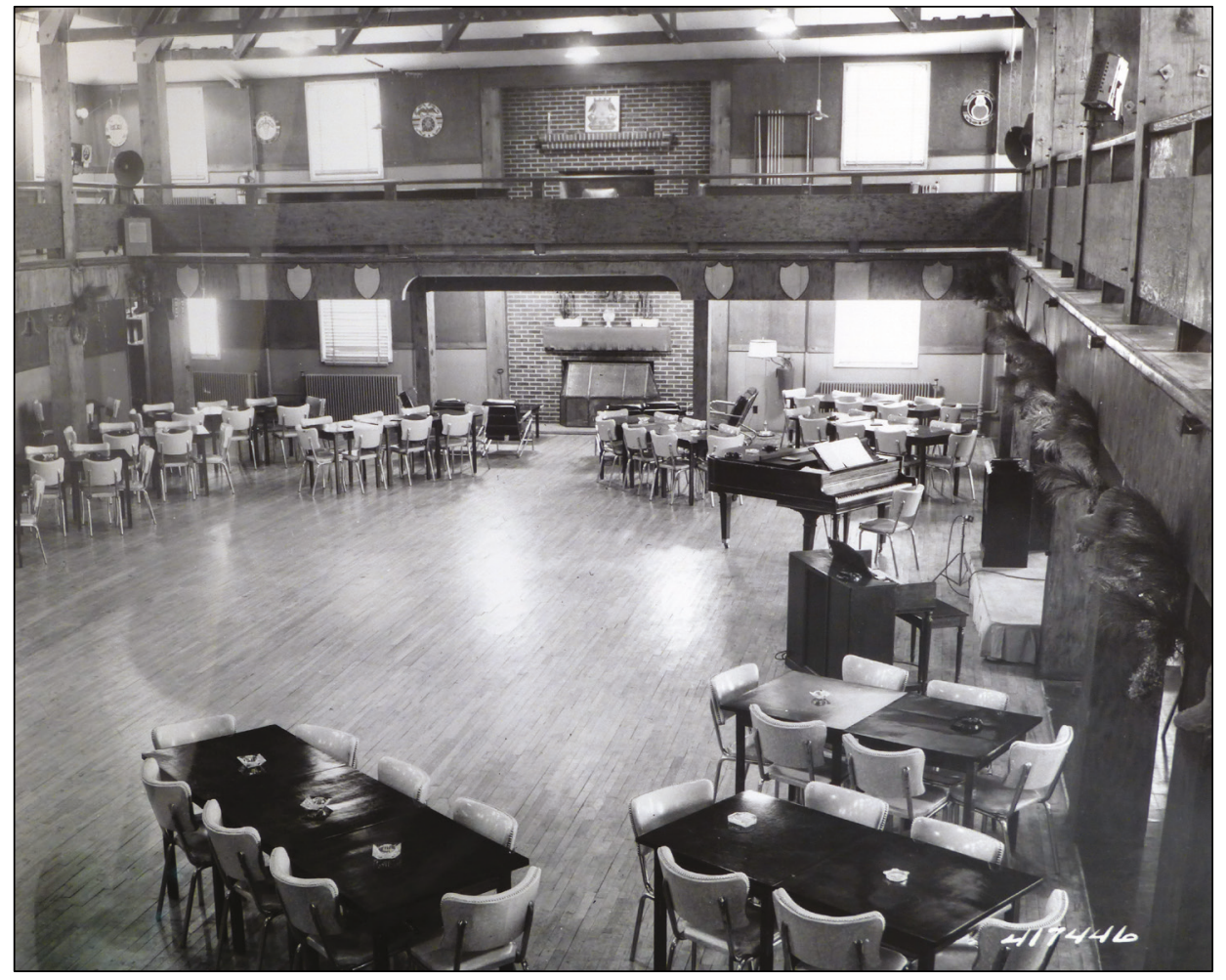


Figure 113. Interior of Building 2000, 1952 (NARA College Park RG111SC).

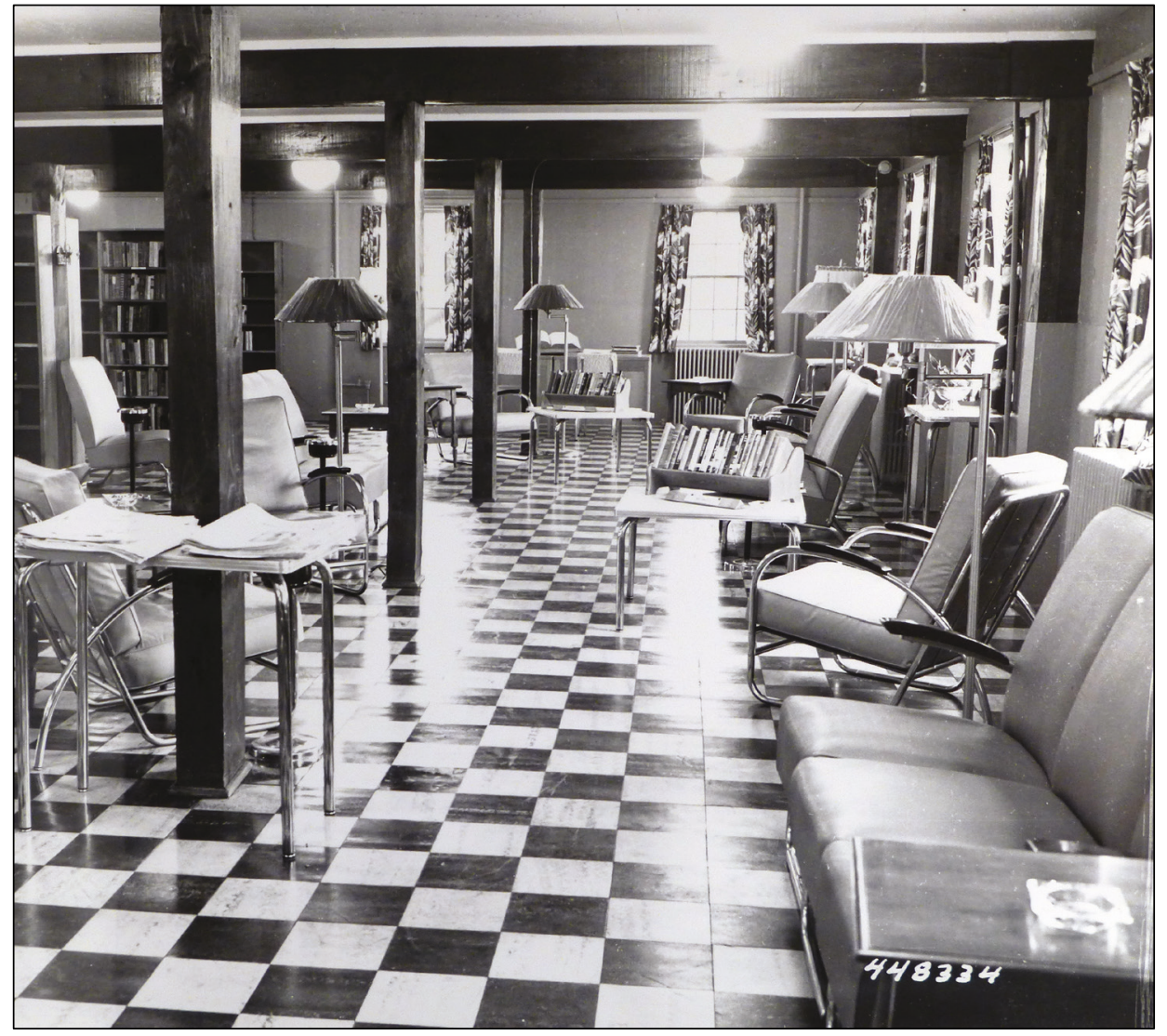

Figure 114. Interior of Building 2000, 1978 (NARA College Park RG111SC).

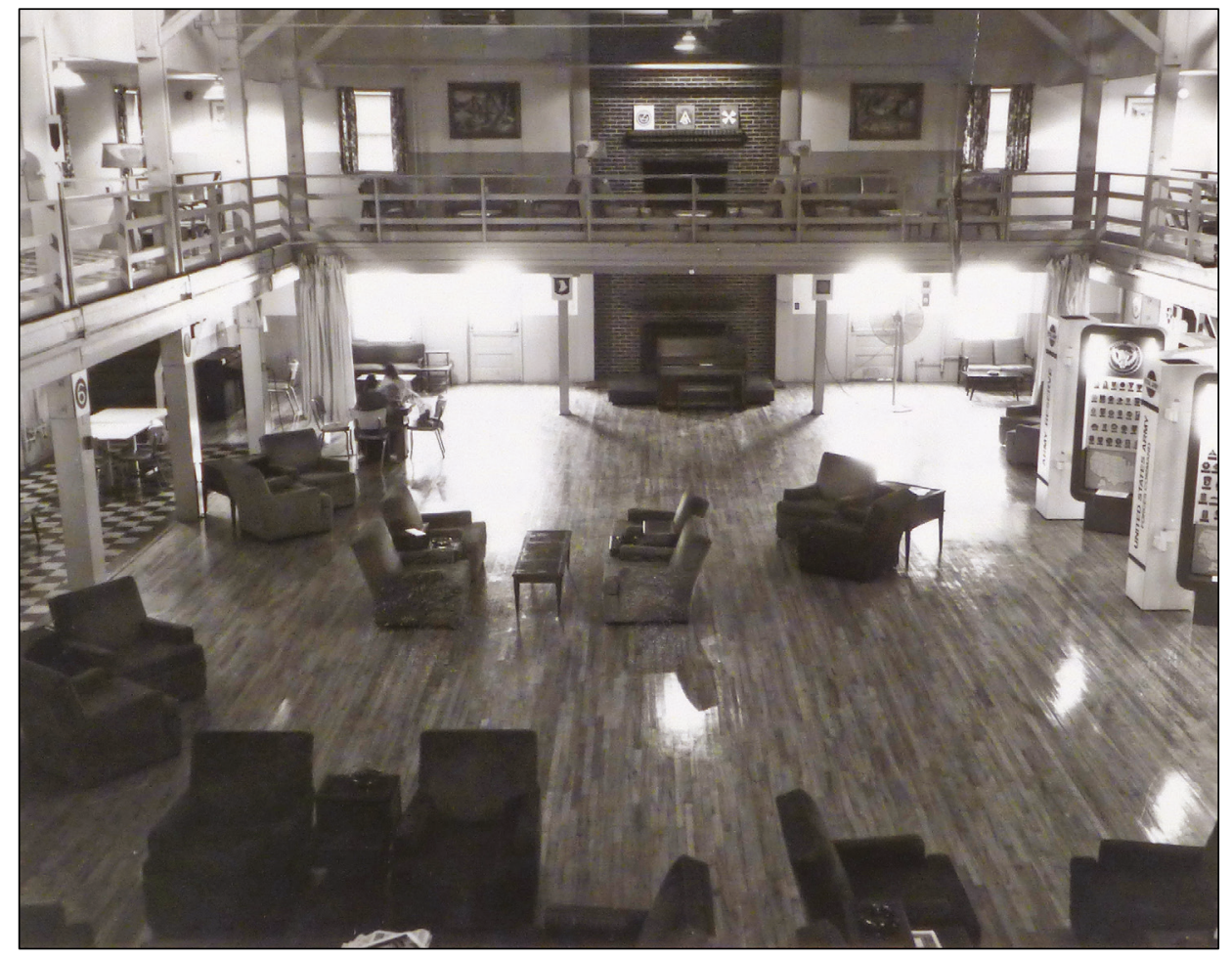


Figure 115. South side of Building 2000 (ERDC-CERL, 2018).

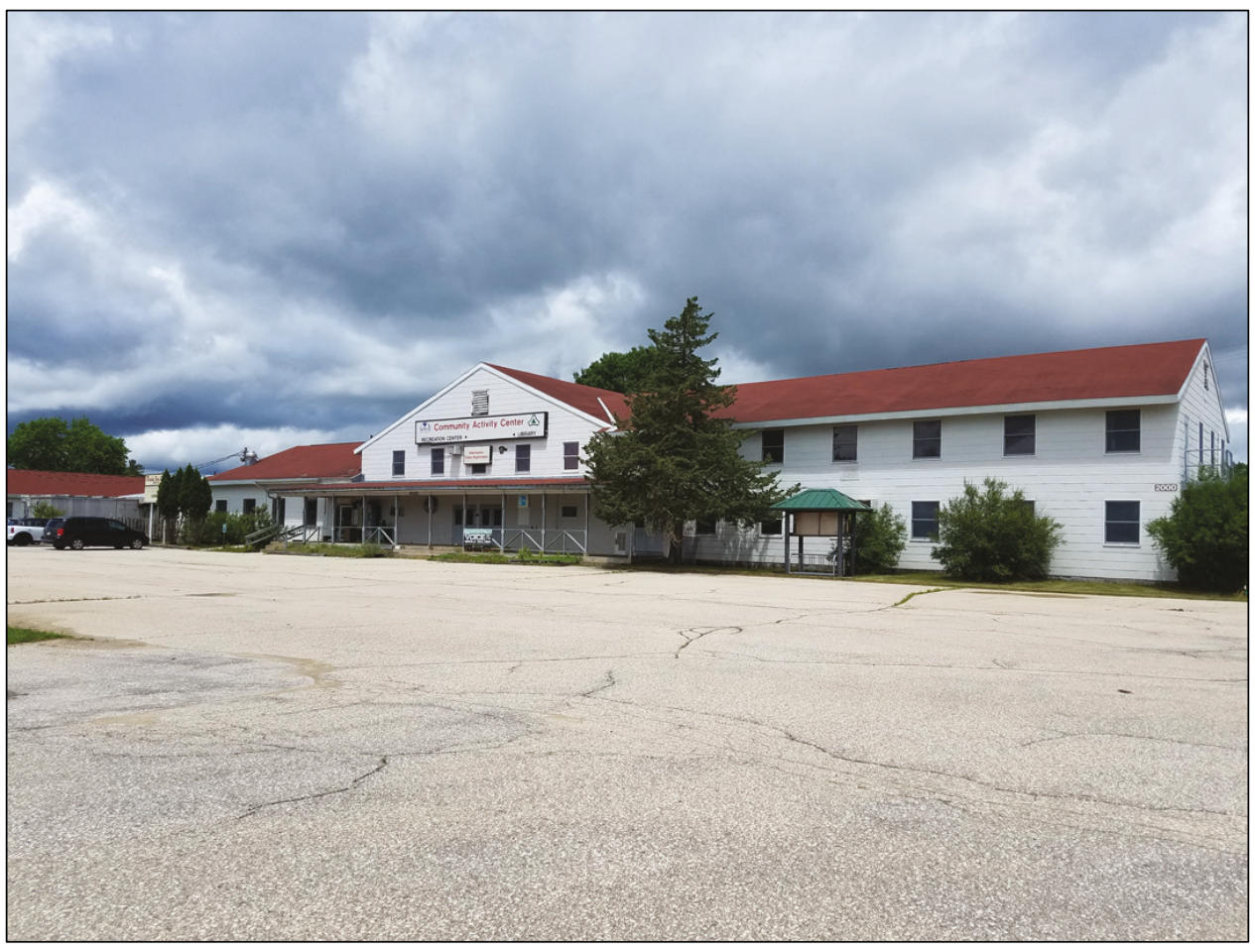

Figure 116. East side of Building 2000 (ERDC-CERL, 2018).

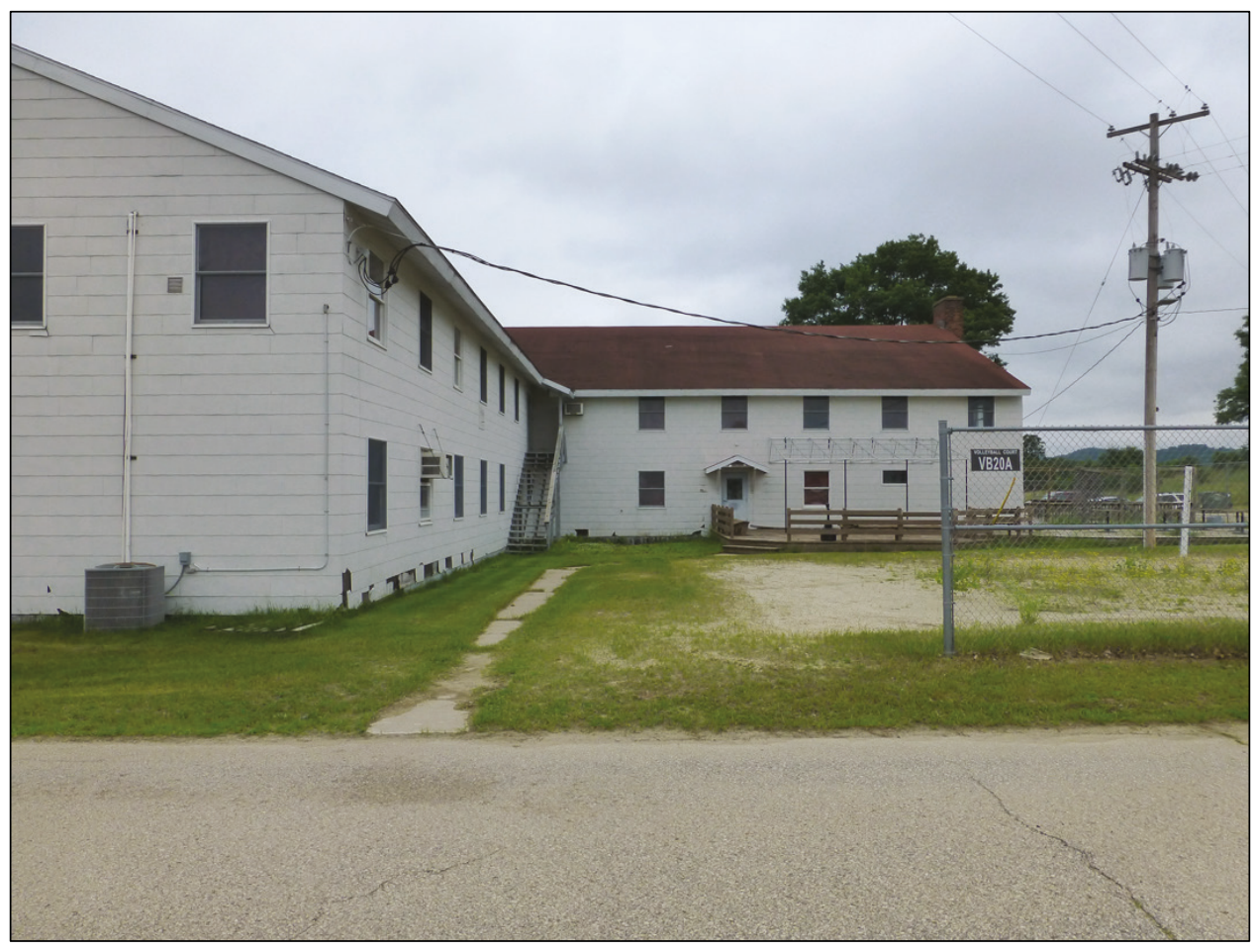


Figure 117. North side (ballroom) of Building 2000 (ERDC-CERL, 2018).

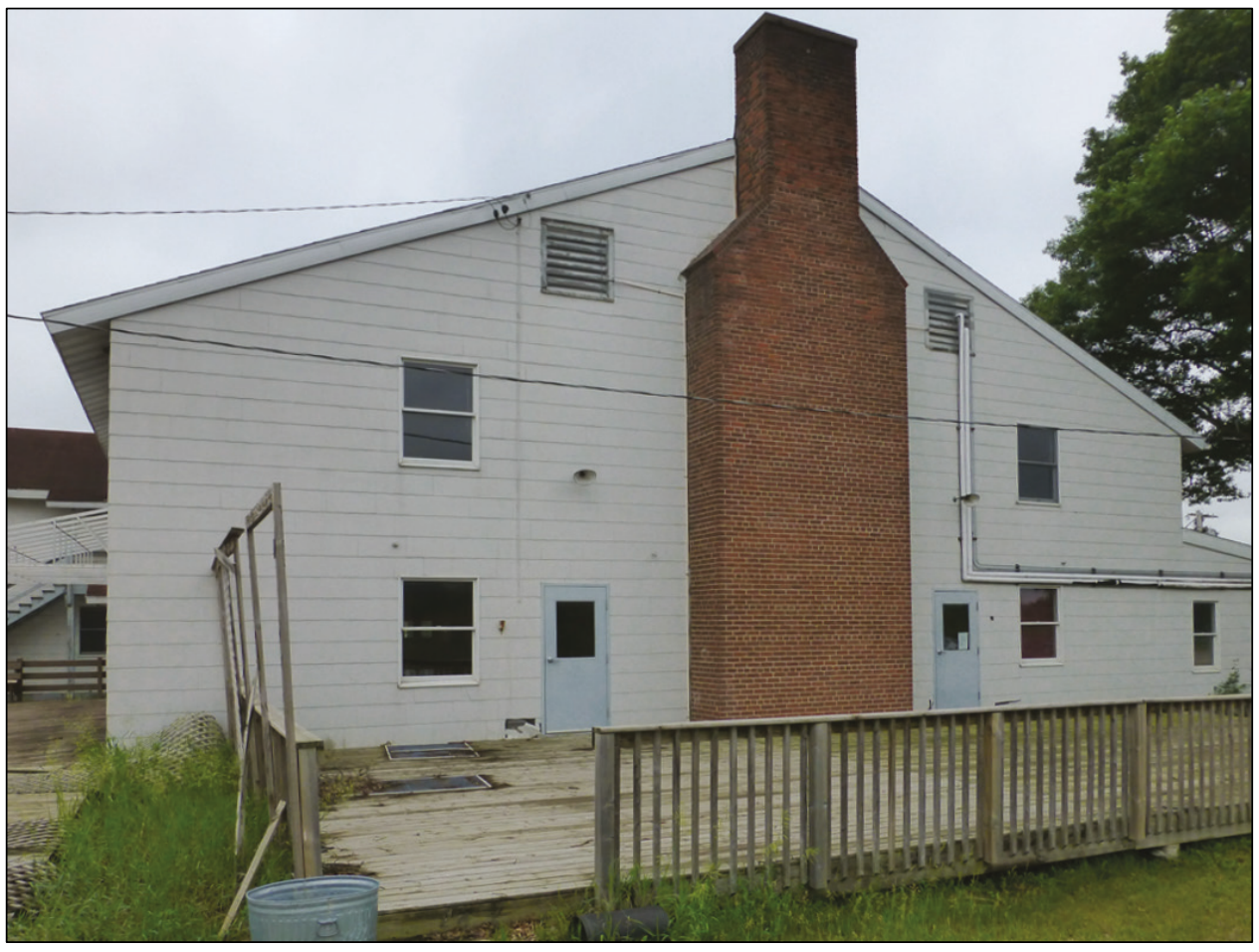

Figure 118. North side of Building 2000 (ERDC-CERL, 2018).

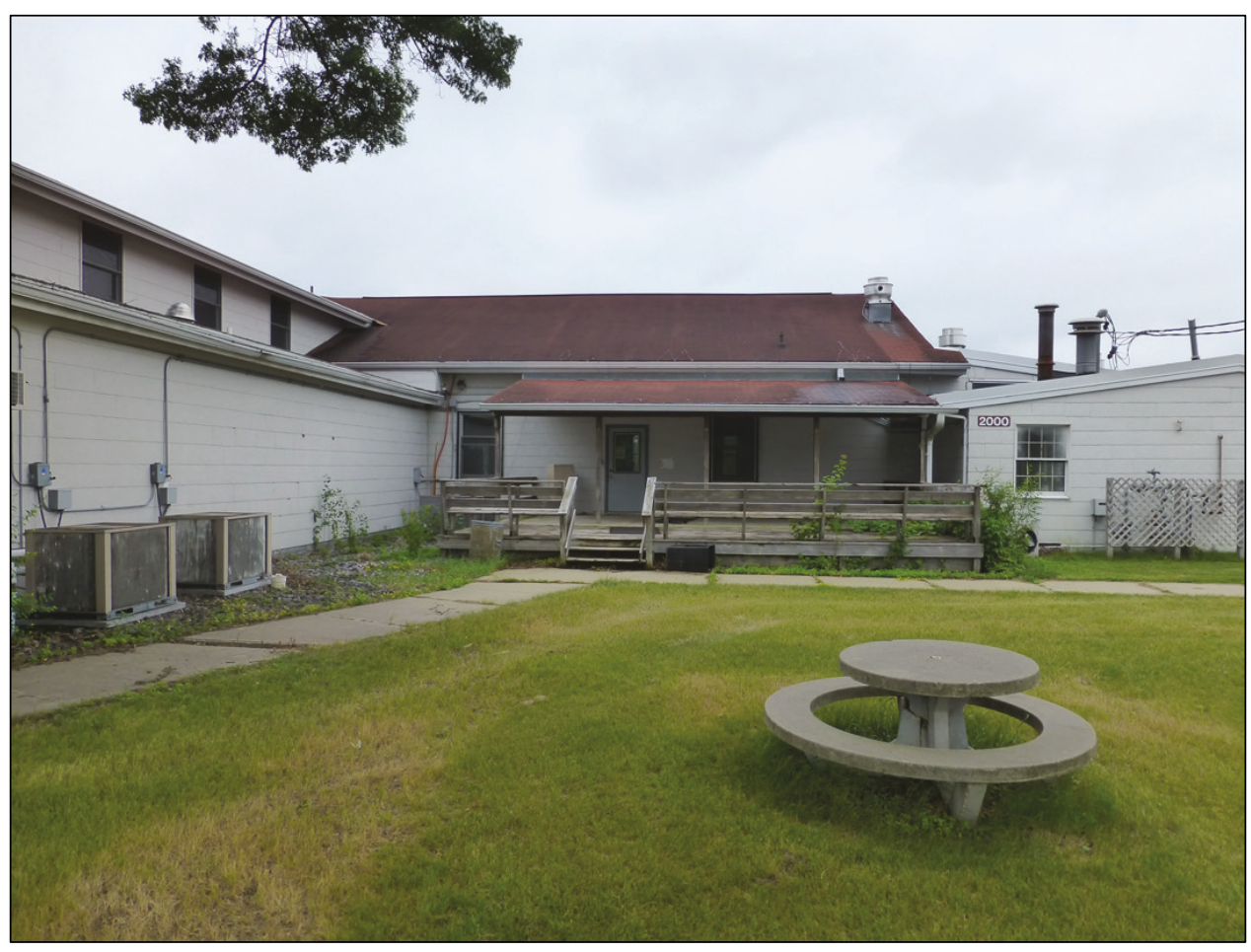


Figure 119. Southwest oblique of Building 2000 (ERDC-CERL, 2018).

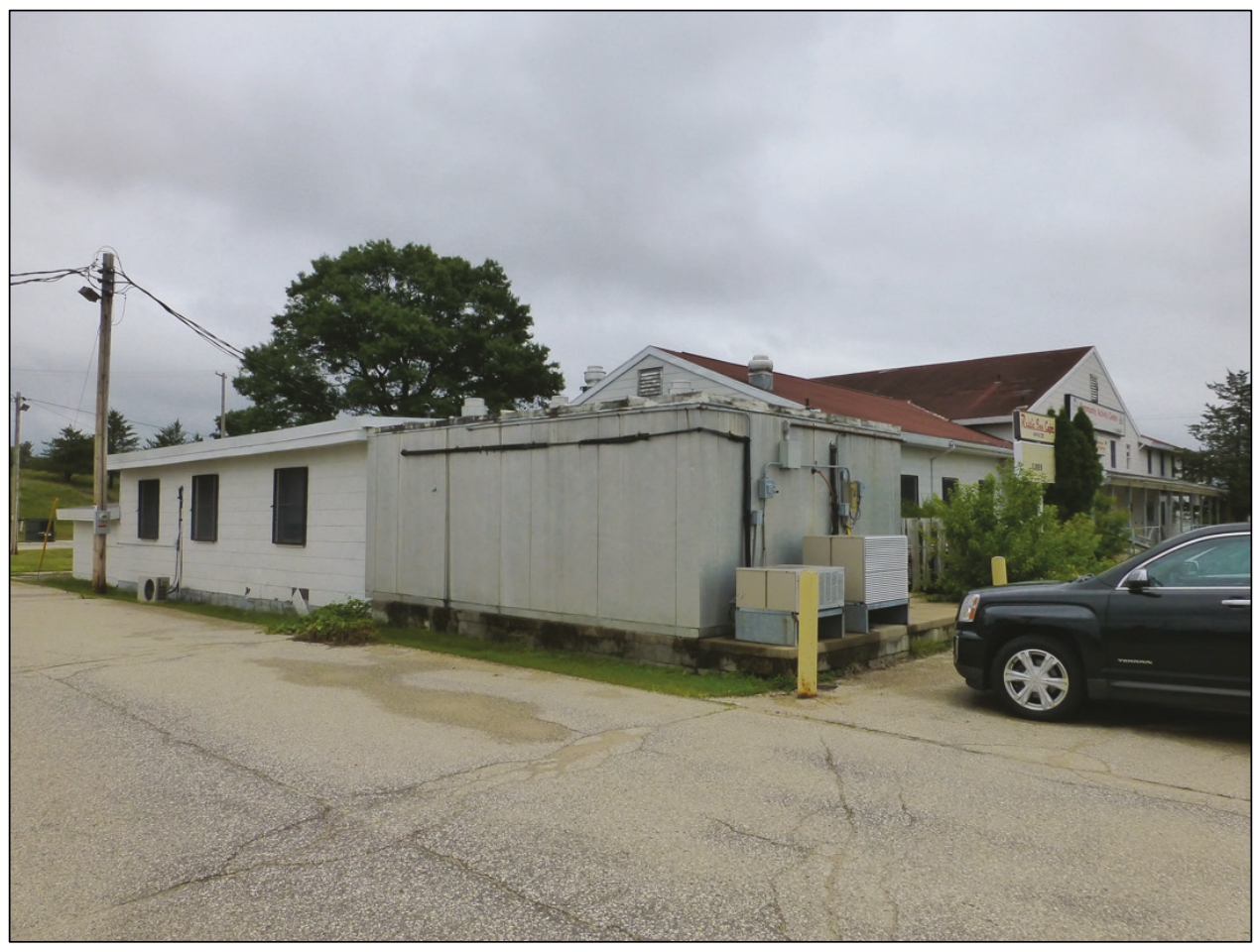

Figure 120. Interior (ballroom) of Building 2000 (ERDC-CERL, 2018).

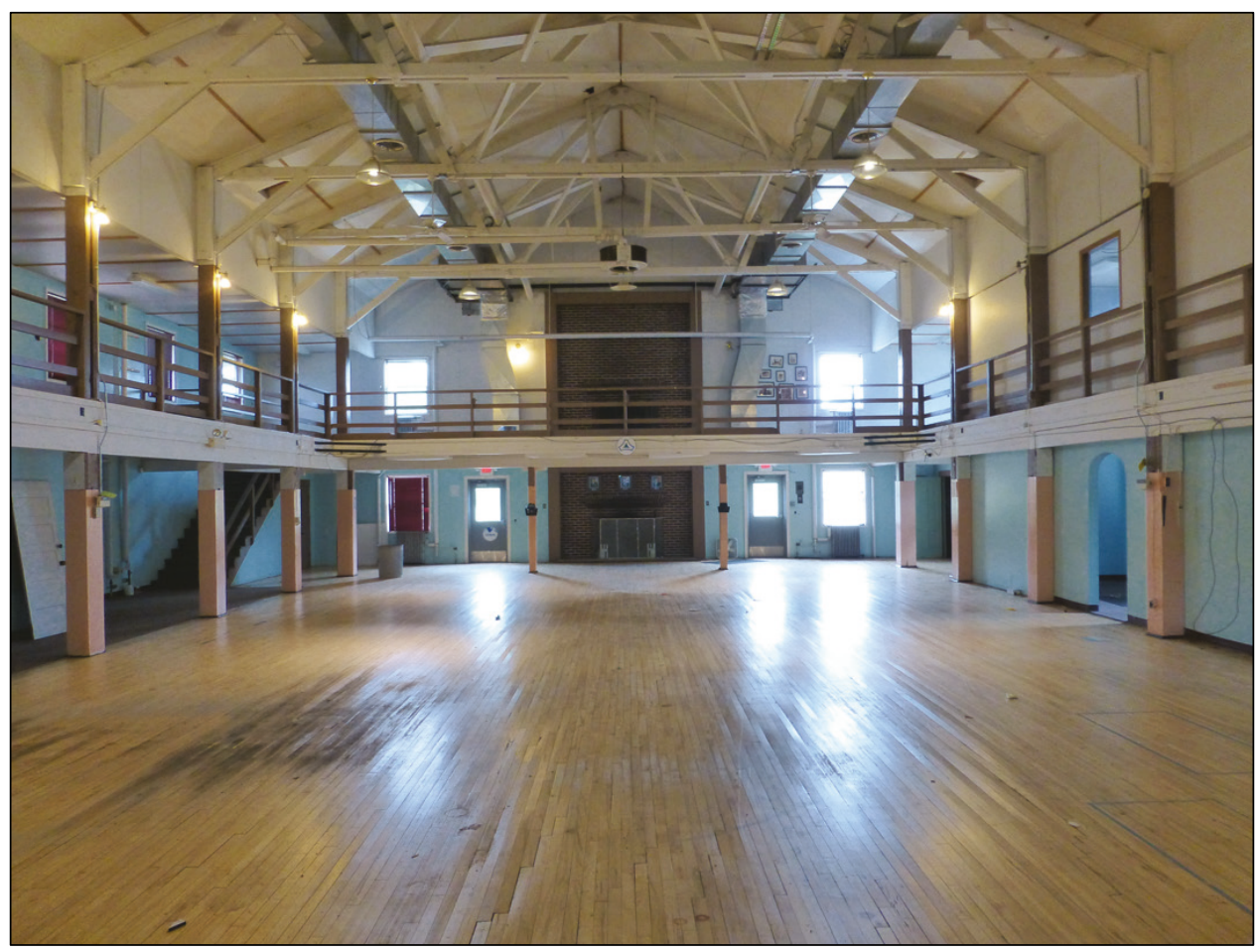


Figure 121. Interior (library) of Building 2000 (ERDC-CERL, 2018).

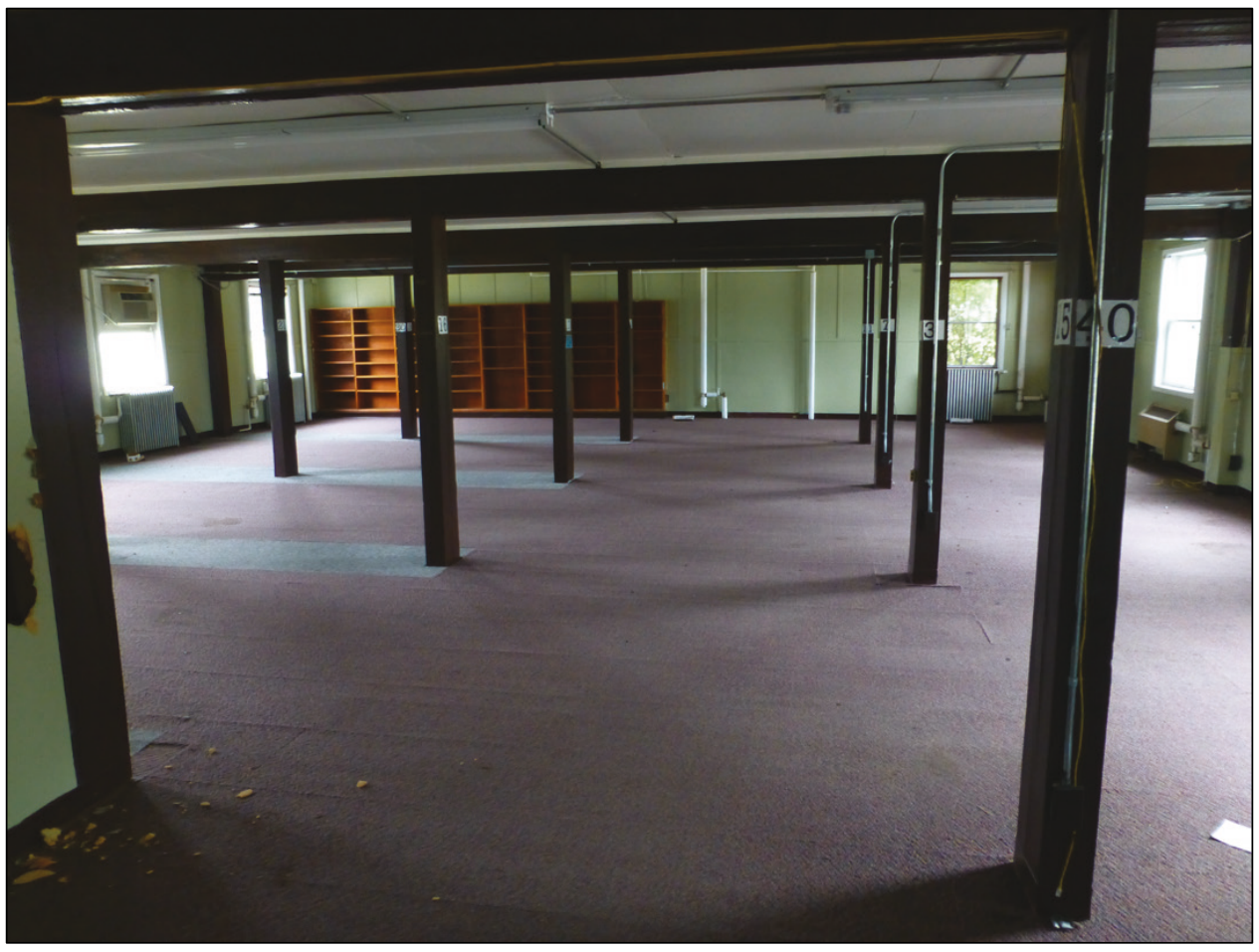

Figure 122. Interior (café) of Building 2000 (ERDC-CERL, 2018).

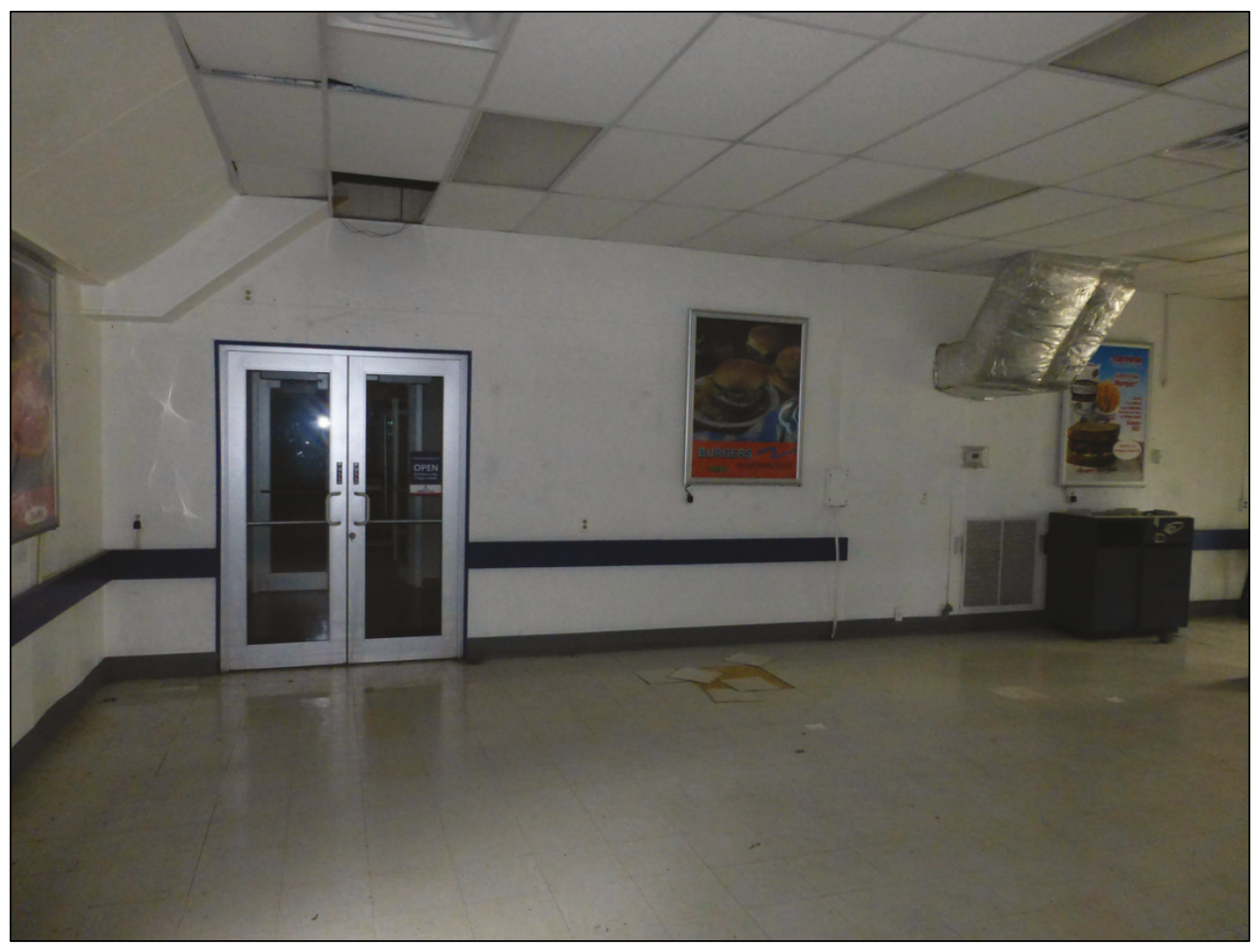


Figure 123. Interior (library and billiard room) of Building 2000 (ERDC-CERL, 2018).

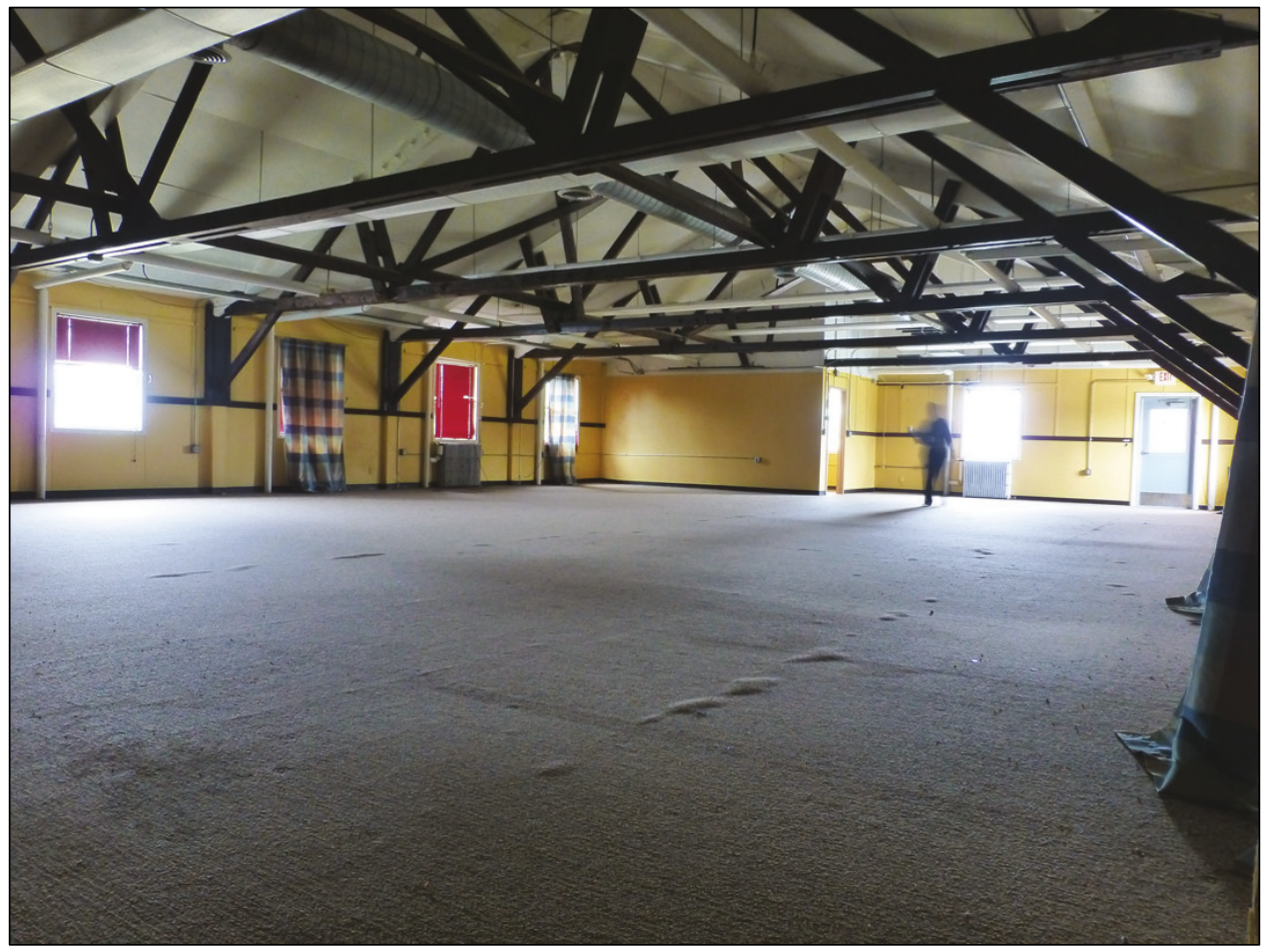

\subsection{Paint Storage (Building 2159)}

Building 2159 was constructed in 1947, so it is outside the period of significance for Fort McCoy's WWII mobilization. For that reason, it is not being covered in this chapter to the extent the other buildings are (with maps and photos). Building 2159 is used now as a flammable materials storage building, similar to its original use. For further detail on this building, please see forms section for it in the appendix of this report.

\subsection{Administration (Building 2668)}

Building 2668 is an administration building constructed in 1942 from the War Department's 800 Series of standard plans on the west side of the Triad (Figure 124). Its category code was changed to a recreation center in 1991. The building is currently again an administration building.

This building has no original character-defining features from the period of significance except for the overall mass (Figure 125-Figure 126).

The interior (Figure 127) does not have its original plan, and no other character-defining features are extant. 
HABS was performed on one of the 800 Series administration buildings (Building 4647) at Aberdeen Proving Ground, Maryland in 1988, HABS MD-1071-A. 69 This documentation was done as part of the 1986 PMOA for demolition of WWII temporary buildings as approved by DoD, ACHP, and the NCSHPO.

Figure 124. Map with location of Building 2668 outlined in red (Fort McCoy DPW, 2018).

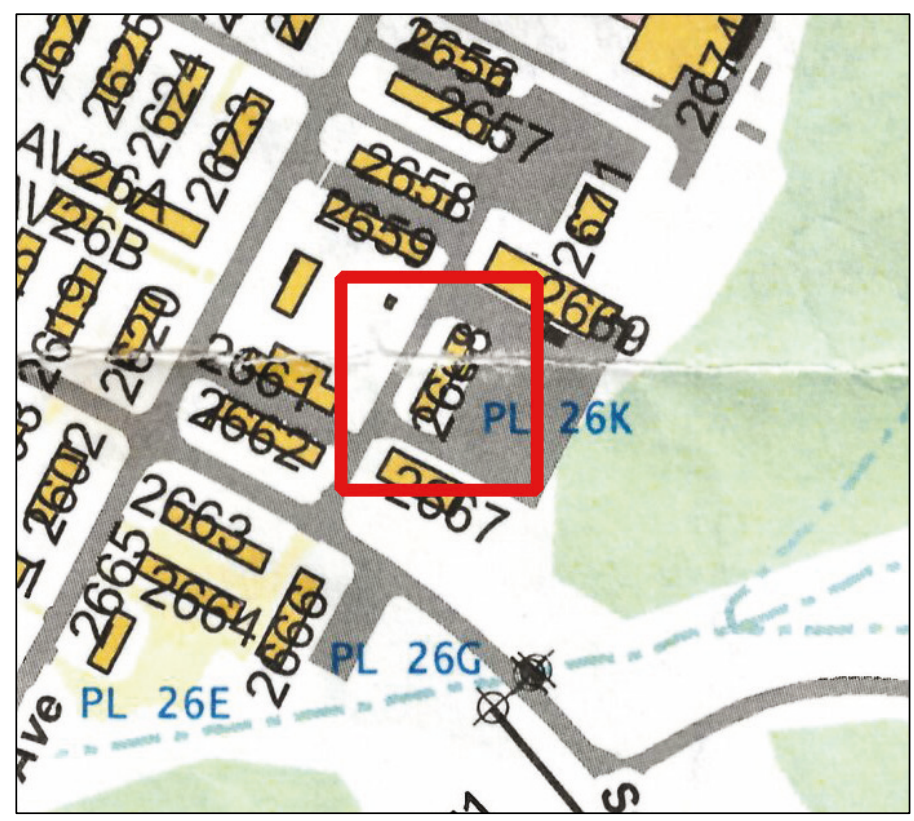

69 HABS MD-1071-A, “Aberdeen Proving Ground, Company Administration Building (Building \#4647)," Flare Loop, Aberdeen, Harford County, Maryland (Philadelphia, PA: Historic American Buildings Survey, National Park Service Northeast Region, Department of the Interior, 1988). Catalogued by Library of Congress as MABS MD 13-ABER, 2A-:

https://cdn.loc.gov/master/pnp/habshaer/md/md1300/md1340/data/md1340data.pdf. 
Figure 125. Northwest oblique of Building 2668 (ERDC-CERL, 2018).

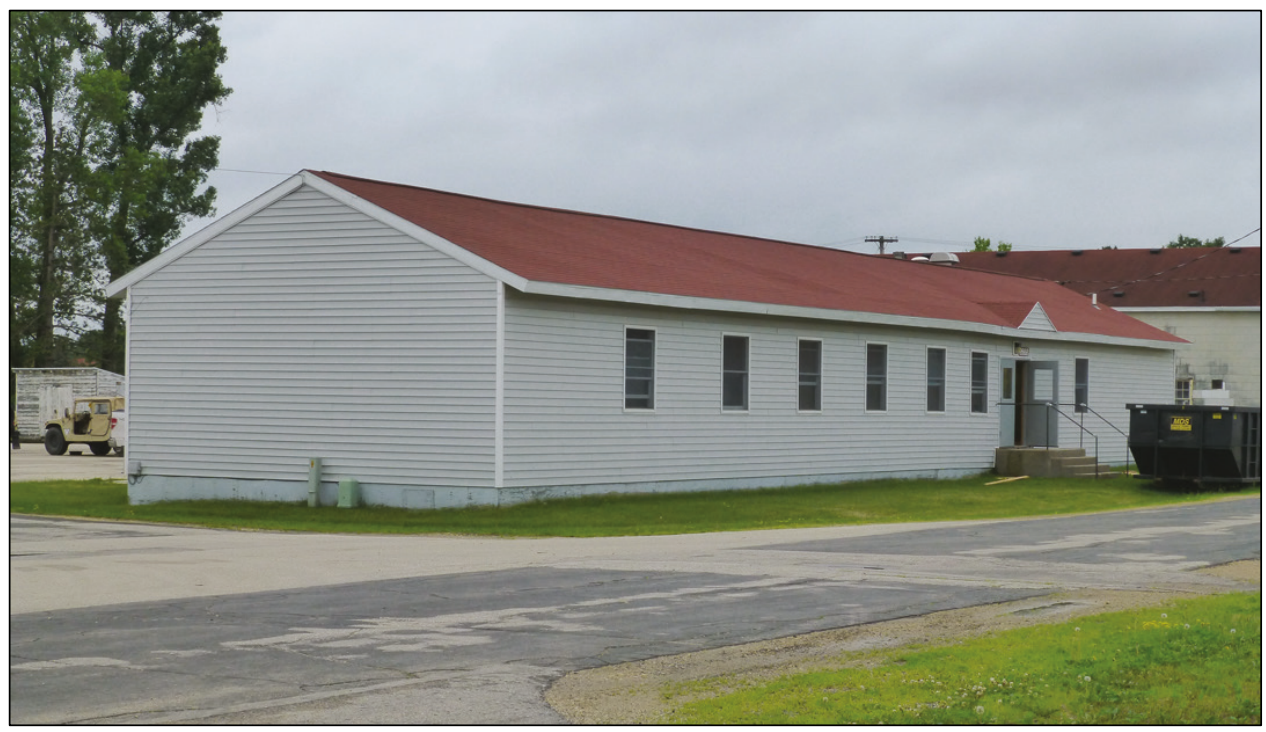

Figure 126. East side of Building 2668 (ERDC-CERL, 2018).

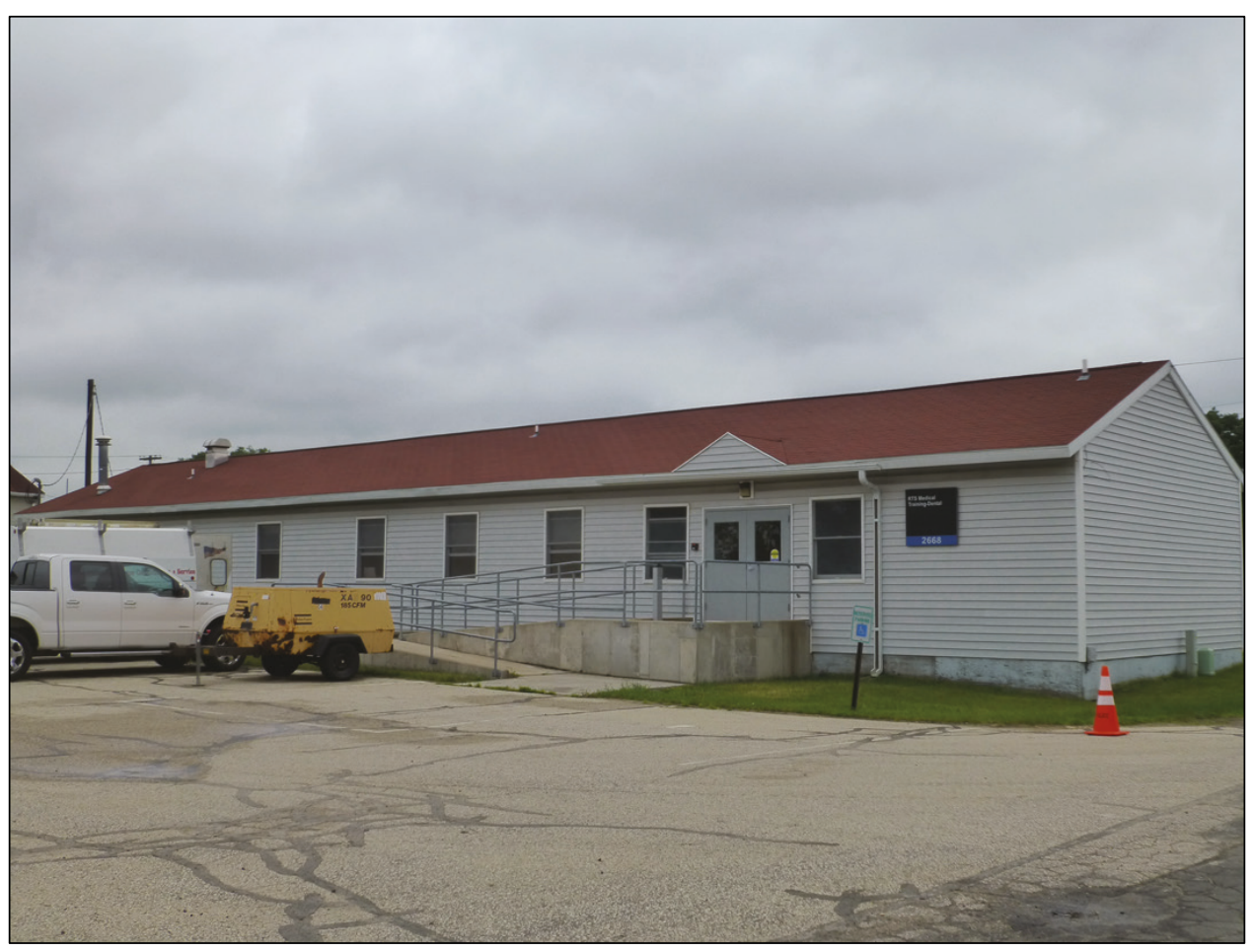


Figure 127. Interior of Building 2668 (ERDC-CERL, 2018).

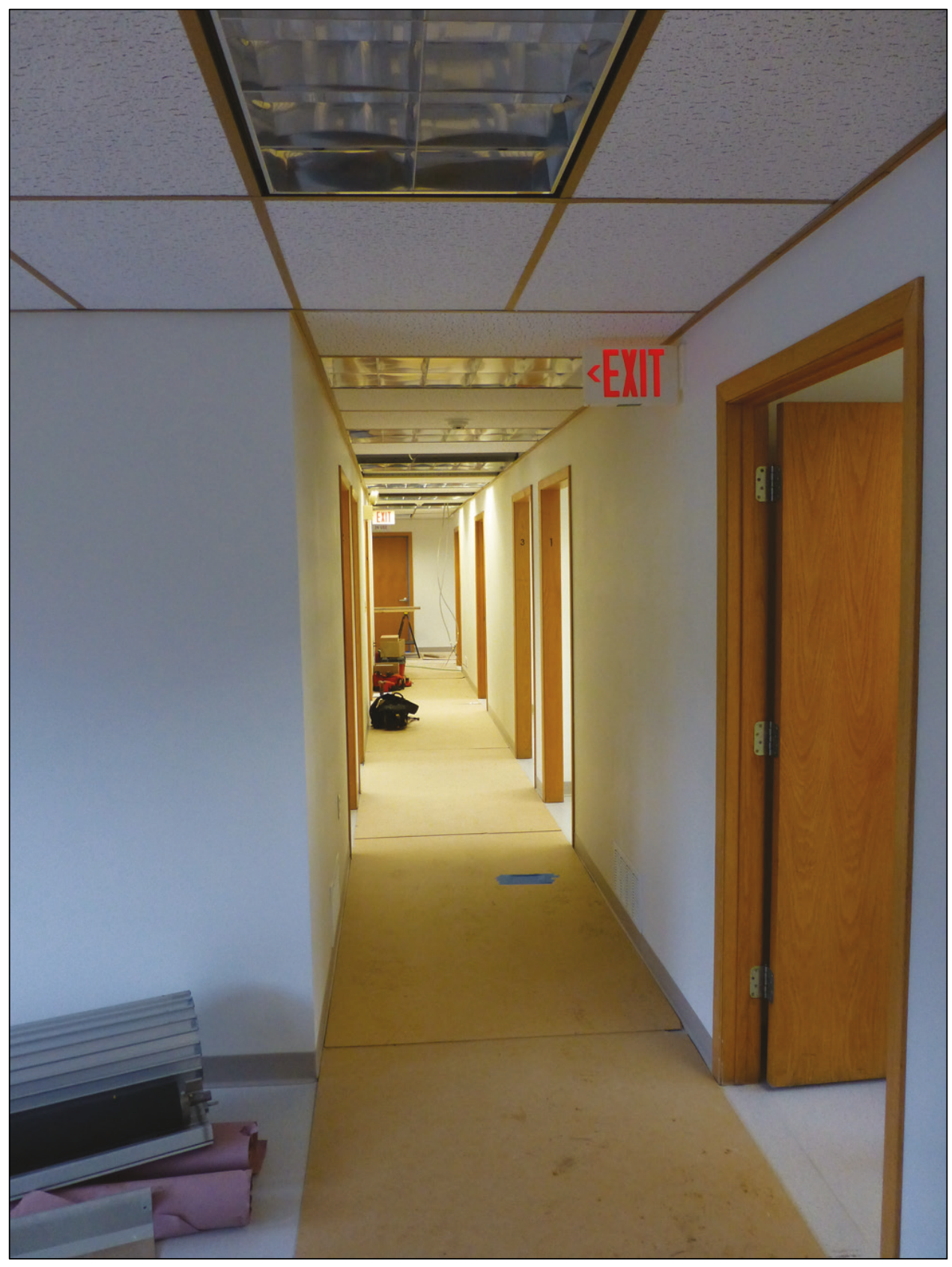




\section{Aspects of Historic Integrity}

In addition to possessing historical significance, a property must also retain sufficient physical integrity of features in order to convey its significance and be eligible for listing on NRHP. ${ }^{\circ}$ Integrity has very specific connotations in defining historic and cultural resources. Integrity is the authenticity of physical characteristics from which resources obtain their significance. Historic properties convey their significance through their integrity. Historic properties both retain integrity and convey their significance, or they do not.

\subsection{Seven aspects of integrity}

The National Register recognizes seven aspects or qualities of a property that define the concept of integrity. To retain historic integrity, a property must possess several, and usually most, of the seven aspects. The retention of specific aspects of historic integrity is paramount for a property to convey its significance. Determining which of these aspects are most important to a particular property requires knowing why, where, and when the property is significant. The seven aspects of integrity are listed in National Register Bulletin \#15: How to Apply the National Register Criteria for Evaluation and summarized below: ${ }^{71}$

1. Location is the place where the historic property was constructed, or the place where the historic event occurred.

2. Design is the combination of elements that create the form, plan, space, structure, and style of a property. It results from conscious decisions made during the original conception and planning of a property (or its significant alteration) and applies to activities as diverse as community planning, engineering, architecture, and landscape architecture. Design includes such elements as organization of space, proportion, scale, technology, ornamentation, and materials.

3. Setting is the physical environment of a historic property. Setting refers to the character of the place in which the property played its

70 NPS, National Register Bulletin \#15, 44-45.

71 NPS, National Register Bulletin \#15, 44-45bid. 
historical role. It involves how, not just where, the property is situated and its relationship to surrounding features and open space.

4. Materials are the physical elements that were combined or deposited during a particular period of time and in a particular pattern or configuration, to form a historic property.

5. Workmanship is the physical evidence of the crafts of a particular culture or people during any given period in history or prehistory.

6. Feeling is a property's expression of the aesthetic or historic sense of a particular time period.

7. Association is the direct link between an important historic event or person and a historic property.

Historic districts and individual resources are considered significant if they possess a majority of the seven aspects outlined above. Properties are classified as either "contributing" or "noncontributing" resources. Contributing resources date from the historic period of significance that has been established. They contribute significance and character through their historical associations and/or architectural values. Noncontributing resources are those that-due to the date of construction, alterations, or other factors-do not contribute to the district's historic significance or character (Figure 128-Figure 152).

\subsection{Integrity determinations}

1. Location is the place where the historic property was constructed, or the place where the historic event occurred.

All 25 buildings from the WWII era retain their integrity of location.

2. Design is the combination of elements that create the form, plan, space, structure, and style of a property. It results from conscious decisions made during the original conception and planning of a property (or its significant alteration) and applies to activities as diverse as community planning, engineering, architecture, and landscape architecture. Design includes such elements as organization of space, proportion, scale, technology, ornamentation, and materials. 
Only Buildings 550 and 2000 retain the key elements of their WWII design (as outlined in Chapter 4) such as layout, scale, door openings, and window openings.

3. Setting is the physical environment of a historic property. Setting refers to the character of the place in which the property played its historical role. It involves how, not just where, the property is situated and its relationship to surrounding features and open space.

All 25 buildings from the WWII era retain their integrity of setting.

4. Materials are the physical elements that were combined or deposited during a particular period of time and in a particular pattern or configuration, to form a historic property.

Only Buildings 550 and 2000 retain the key elements of their WWII architectural materials such as wood doors, wood windows, platforms, chimneys, asbestos siding, wood foundation skirting, asphalt roofs, wood floors, concrete floors in kitchens and bathrooms, fiberboard walls, wood wainscots, plumbing fixtures, and light fixtures.

5. Workmanship is the physical evidence of the crafts of a particular culture or people during any given period in history or prehistory.

Workmanship is not a key part of integrity for WWII temporary buildings.

6. Feeling is a property's expression of the aesthetic or historic sense of a particular time period.

Only Buildings 550 and 2000 retain their feeling of WWII temporary buildings.

7. Association is the direct link between an important historic event or person and a historic property.

All 25 buildings from the WWII era retain their integrity of association. 
Figure 128. Front elevation of a 74-man barracks with comparison of the original construction, design, and materials from 1950 (left) to 1988 (middle) to 2018 (right). Note, the original wood porch, steps, and handrails have already been removed and replaced with a concrete stoop and metal handrails in middle image (left: NARA; middle: Library of Congress, HABS; right: ERDC-CERL).

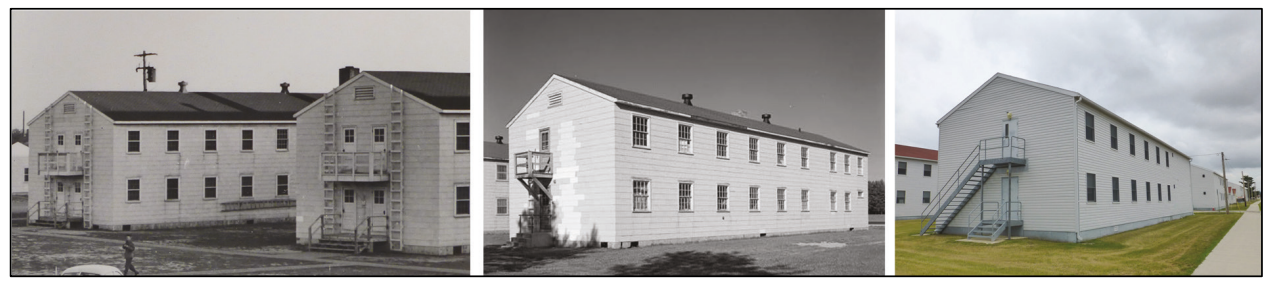

Figure 129. Left elevation of a 74-man barracks with comparison of the original construction, design, and materials, as extant in 1988 (left) to 2018 (right) (left: Library of Congress, HABS; right: ERDC-CERL).

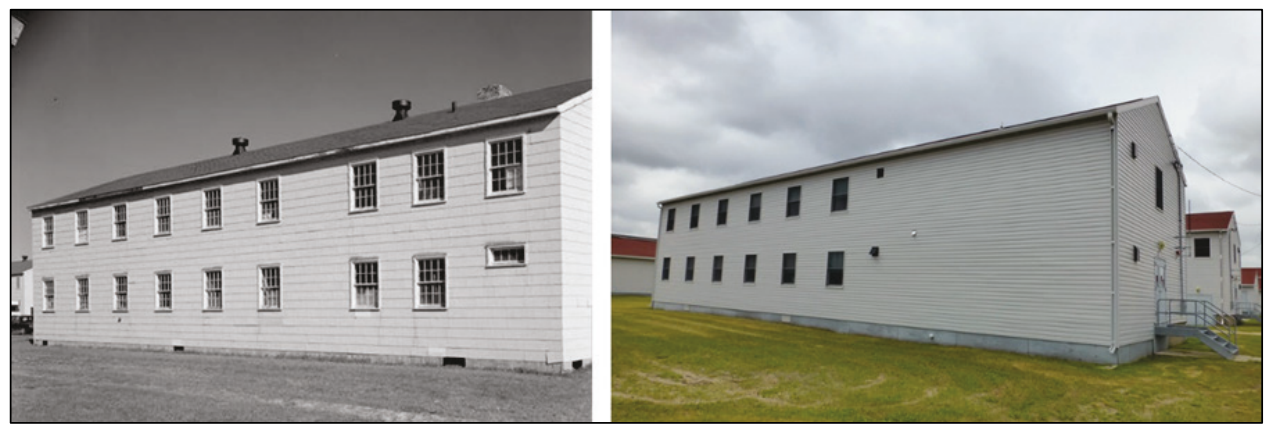

Figure 130. Left side and rear oblique of a 74-man barracks with comparison of the original construction, design, and materials, as extant in 1988 (left) to 2018 (right) (left: Library of Congress, HABS; right: ERDC-CERL).

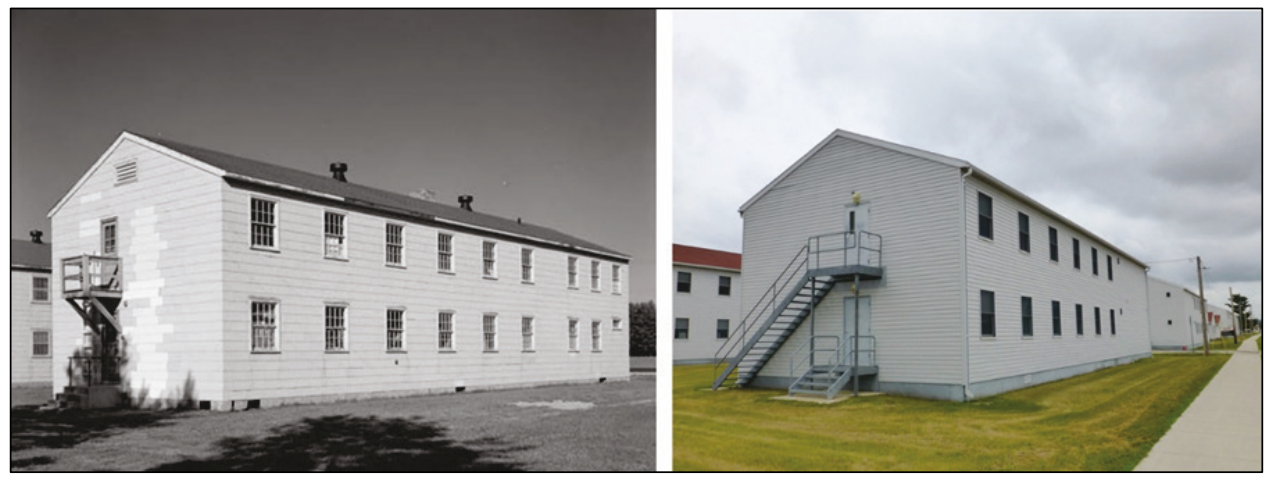


Figure 131. Rear elevation of a 74-man barracks with comparison of the original construction, design, and materials, as extant in 1988 (left) to 2018 (right). Note the original first-floor wood porch, steps, and handrails have been removed and replaced with a concrete stoop and metal handrails; in addition, the left photo shows two of the original fire-exit doors from the squad rooms have been removed, and the door openings have been covered over with newer cement asbestos siding (left: Library of Congress, HABS; right: ERDC-CERL).

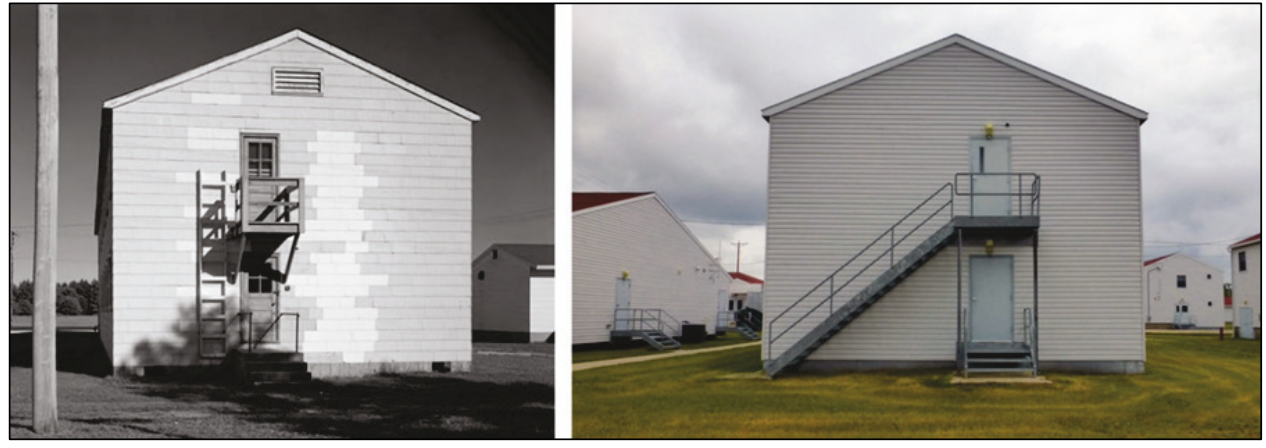

Figure 132. Window comparison of the original eight-over-eight wood double-hung window on a 74-man barracks (left) to the current replacement one-over-one vinyl window (right) (left: Library of Congress, HABS; right: ERDC-CERL).

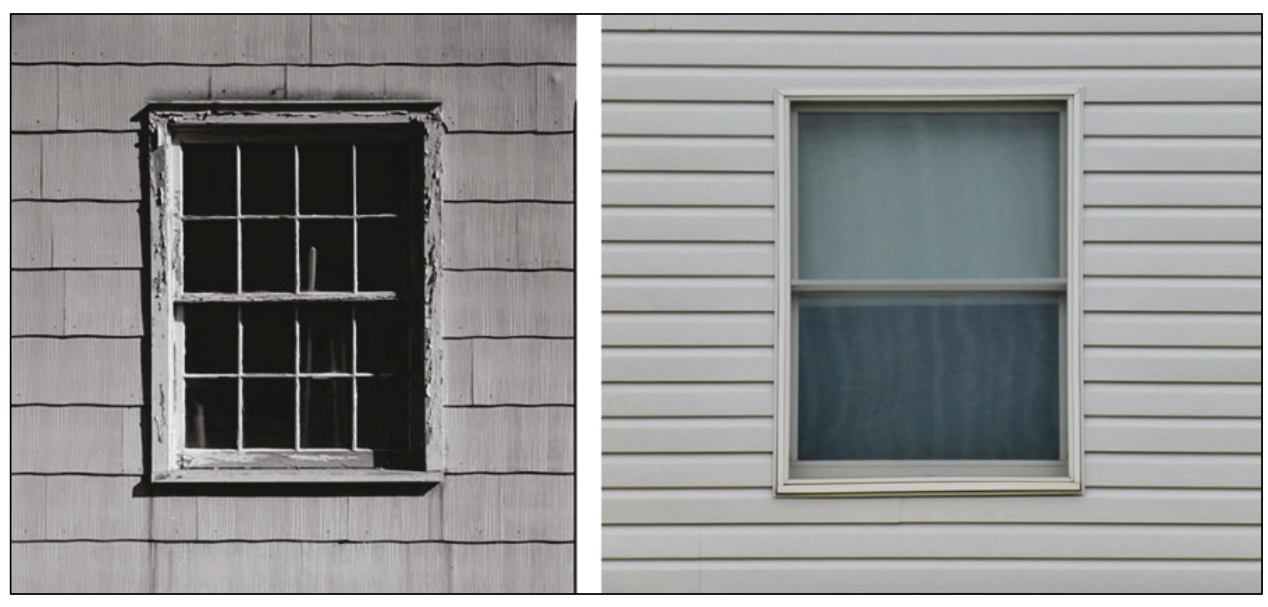


Figure 133. Original cement asbestos siding with scalloped edge detail and wood foundation skirting (left) compared to current replacement materials of vinyl siding and plywood foundation skirting (right) (left: Library of Congress, HABS; right: ERDCCERL).
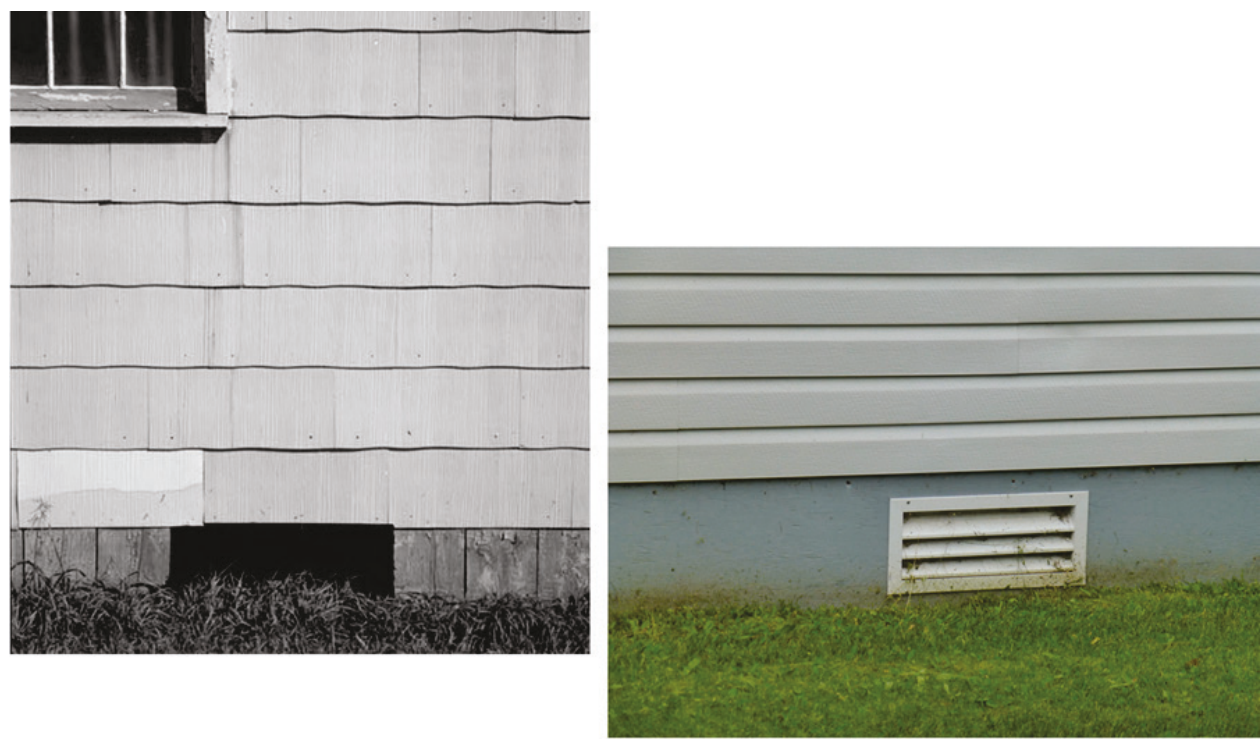

Figure 134. Interior view of the original open-bay entry vestibule with wood screen doors leading to the first floor and to the staircase (left) compared to the modified entry vestibule with partition wall and replacement interior wood door (right) (left: Library of Congress, HABS; right: ERDC-CERL).
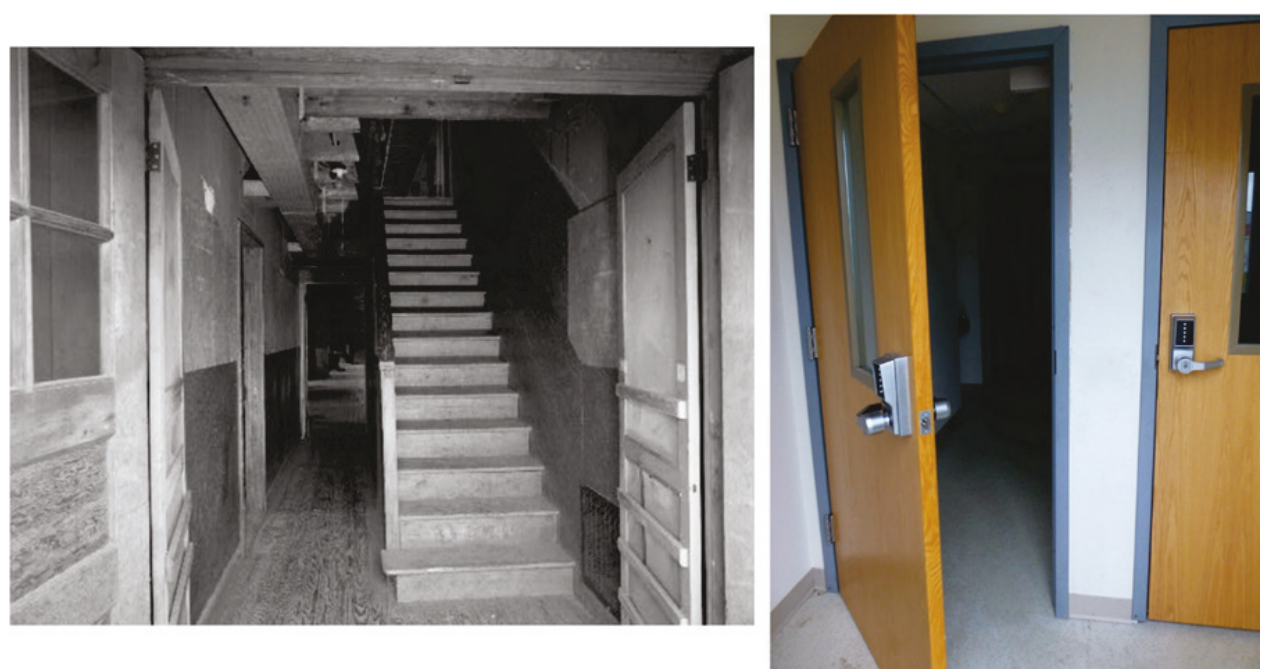
Figure 135. Interior view of an open bay squad room in a 74-man barracks (left) compared to the modified squad room in 2018 (left: Library of Congress, HABS; right: ERDC-CERL).

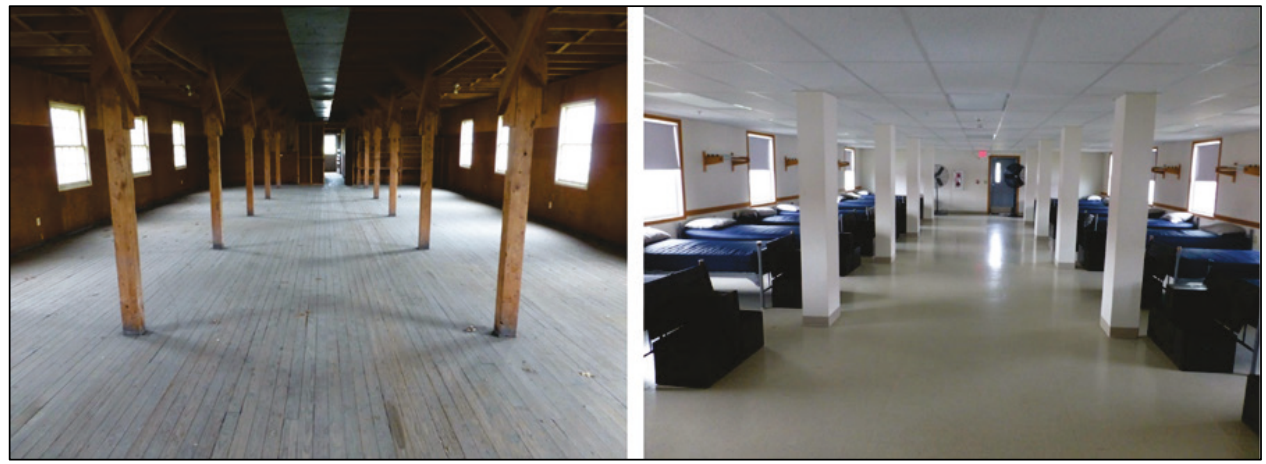

Figure 136. Interior view of an original NCO room on the second floor of a 74-man barracks (left) compared to a modified NCO room from 2018 (left: Library of Congress, HABS; right: ERDC-CERL).

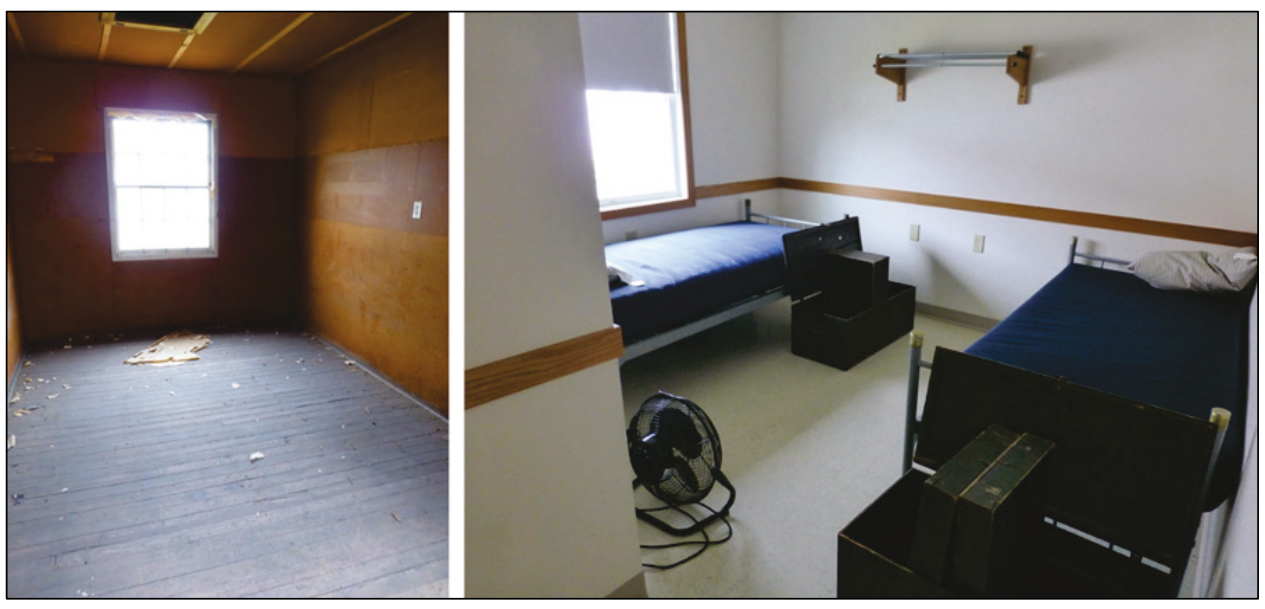

Figure 137. Interior view of the original sink area in the latrine on the first floor of a 74-man barracks (left) compared to the modified sink area in 2018 (left: Library of Congress, HABS; right: ERDC-CERL).

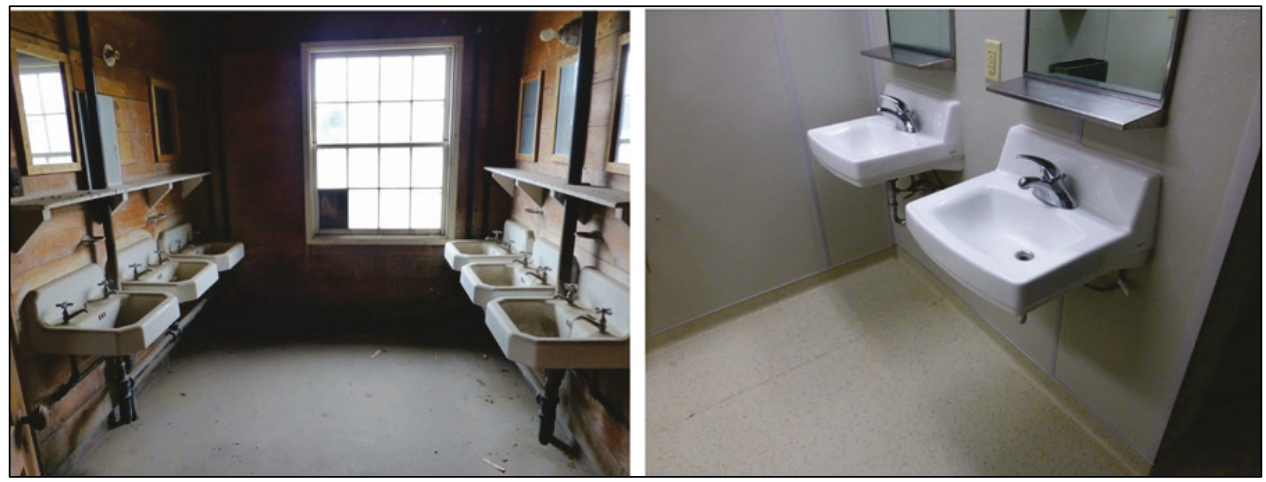


Figure 138. South elevation comparison of the original construction, design, and materials for the Company Storehouse/Administration and Recreation Building from 1988 (left) to 2018 (right) (left: Library of Congress, HABS; right: ERDC-CERL).

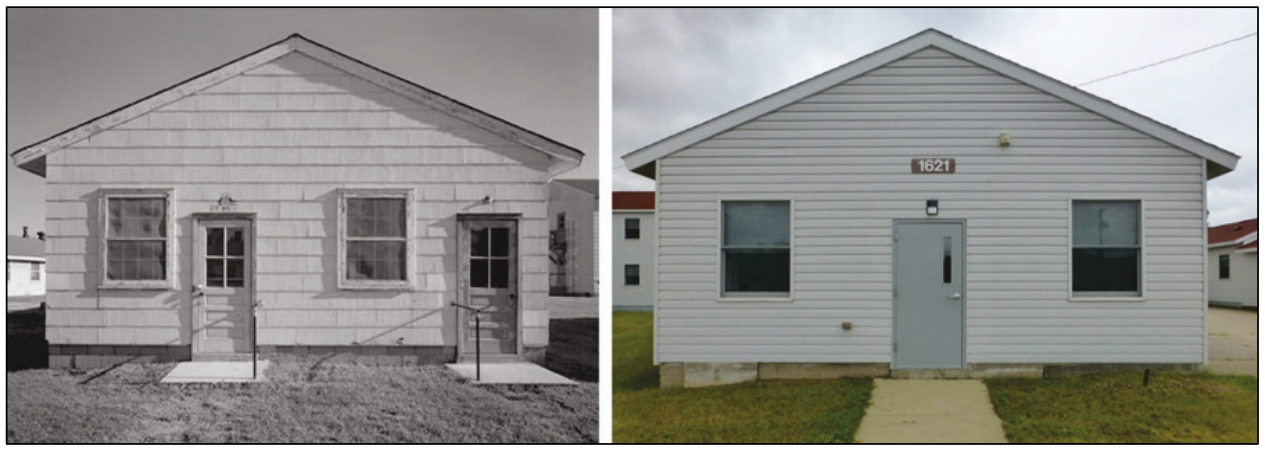

Figure 139. Southeast oblique, comparison of the original construction, design, and materials for the Company Storehouse/Administration and Recreation Building from 1988 (left) to 2018 (right) (left: Library of Congress, HABS; right: ERDC-CERL).

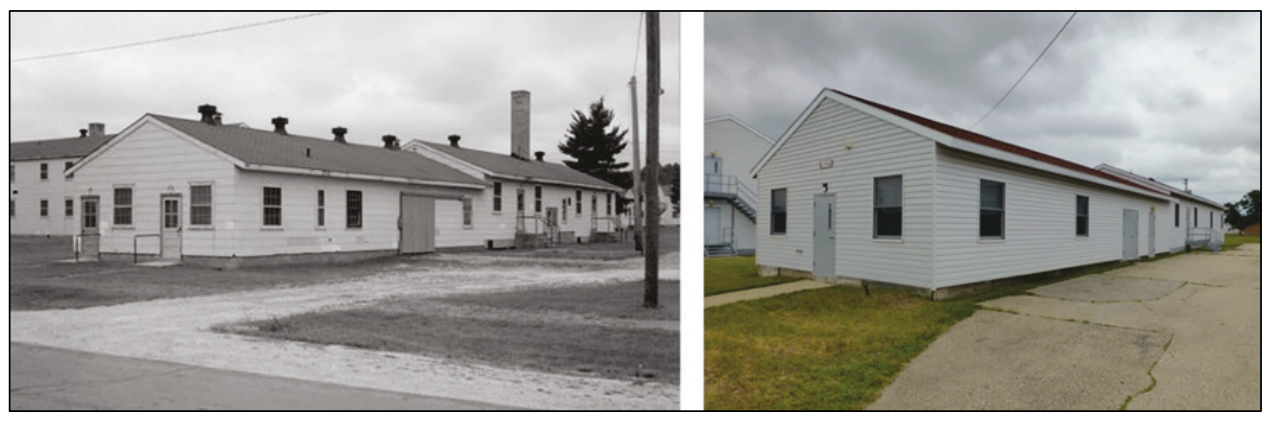

Figure 140. Interior view of the original storehouse/administration section looking north toward the recreation section. Comparison of the original construction, design, and materials for the Company Storehouse/Administration and Recreation Building from 1988 (left) to 2018 (right) (left: Library of Congress, HABS; right: ERDC-CERL).
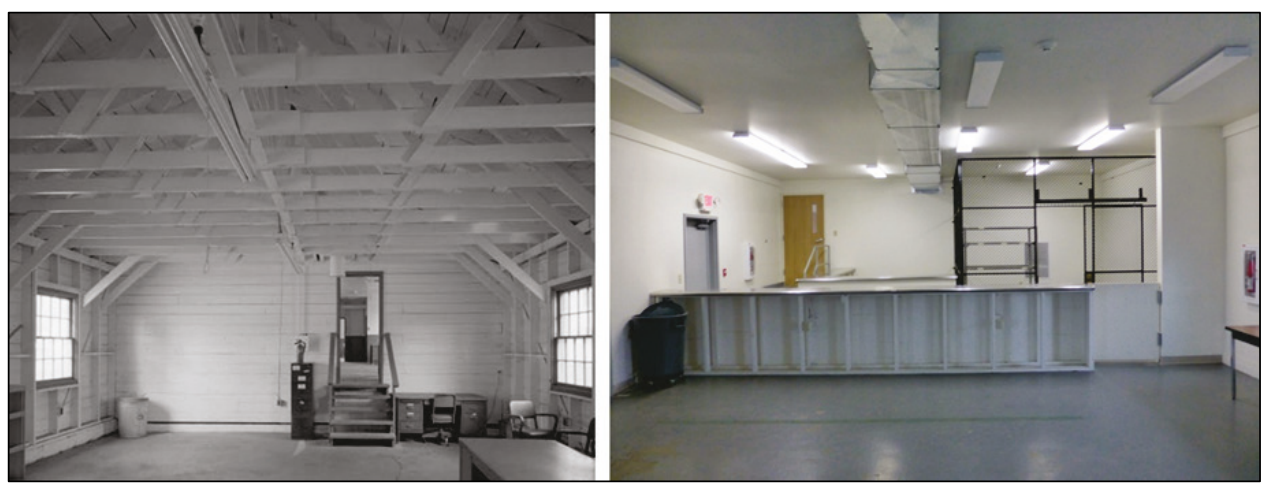
Figure 141. Interior view of the original recreation section looking at the north wall. Comparison of the original construction, design, and materials for the Company Storehouse/Administration and Recreation Building from 1988 (left) to 2018 (right) (left: Library of Congress, HABS; right: ERDC-CERL).
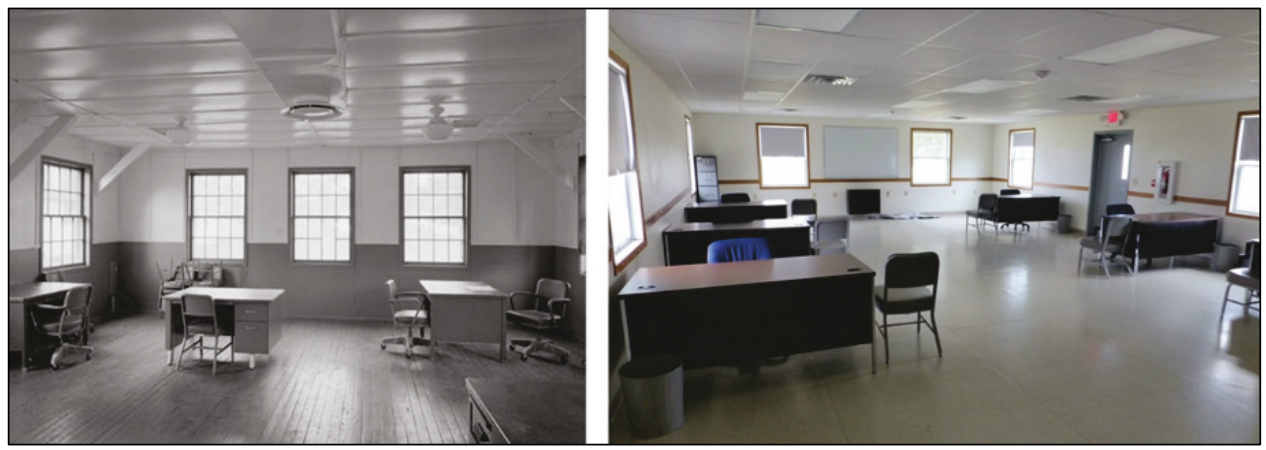

Figure 142. Entry into dining room of a mess hall. Comparison of classroom Building 635 with original design and materials (left) compared to the current condition of Buildings 1605, 1606, 1638, and 1639 (left: Library of Congress, HABS; right: ERDC-CERL).

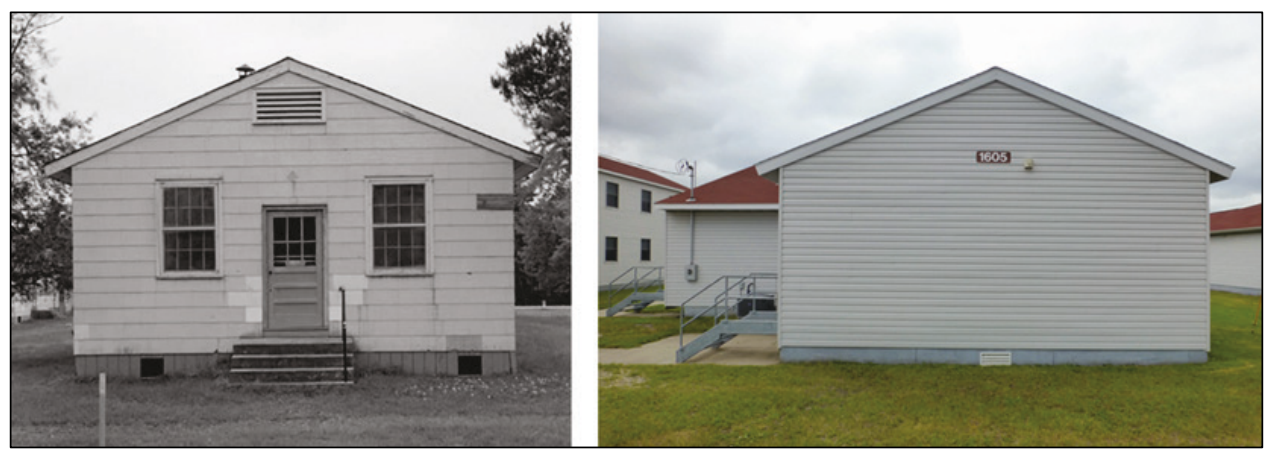

Figure 143. Entry into kitchen area and long side elevation comparison between the original design and materials compared to the current condition of classroom Buildings 1605, 1606, 1638, and 1639 (left: Library of Congress, HABS; right: ERDCCERL).

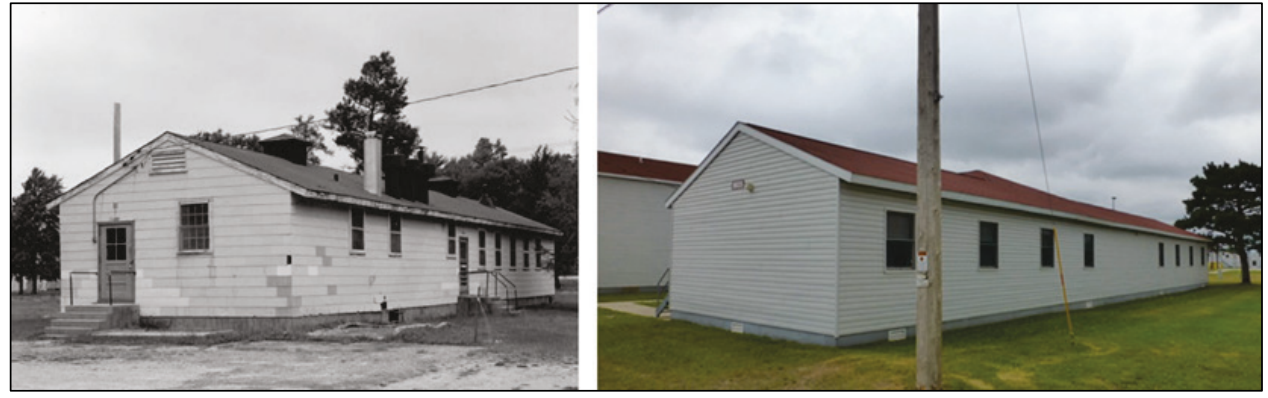


Figure 144. Interior view comparison of the dining room of a mess hall on the left and the interior of it retrofitted into a classroom on the right (left: Library of Congress;

right: ERDC-CERL).

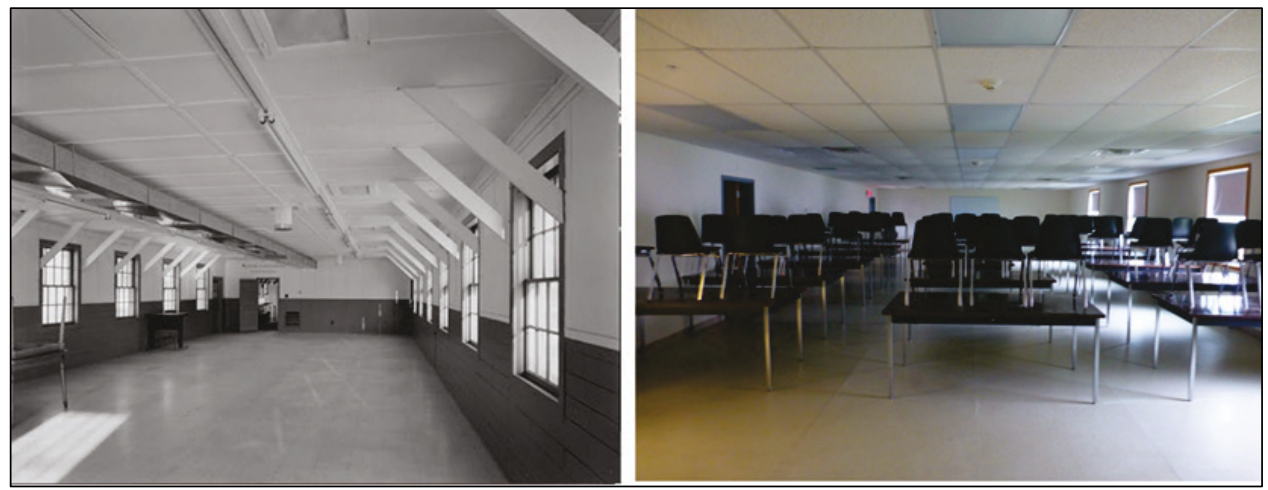

Figure 145. Entry into dining room of a mess hall. Building 635 (left) with original design and materials compared to the current condition of Buildings 1616, 1617, 1626, and 1627 (right) (left: Library of Congress; right: ERDC-CERL).

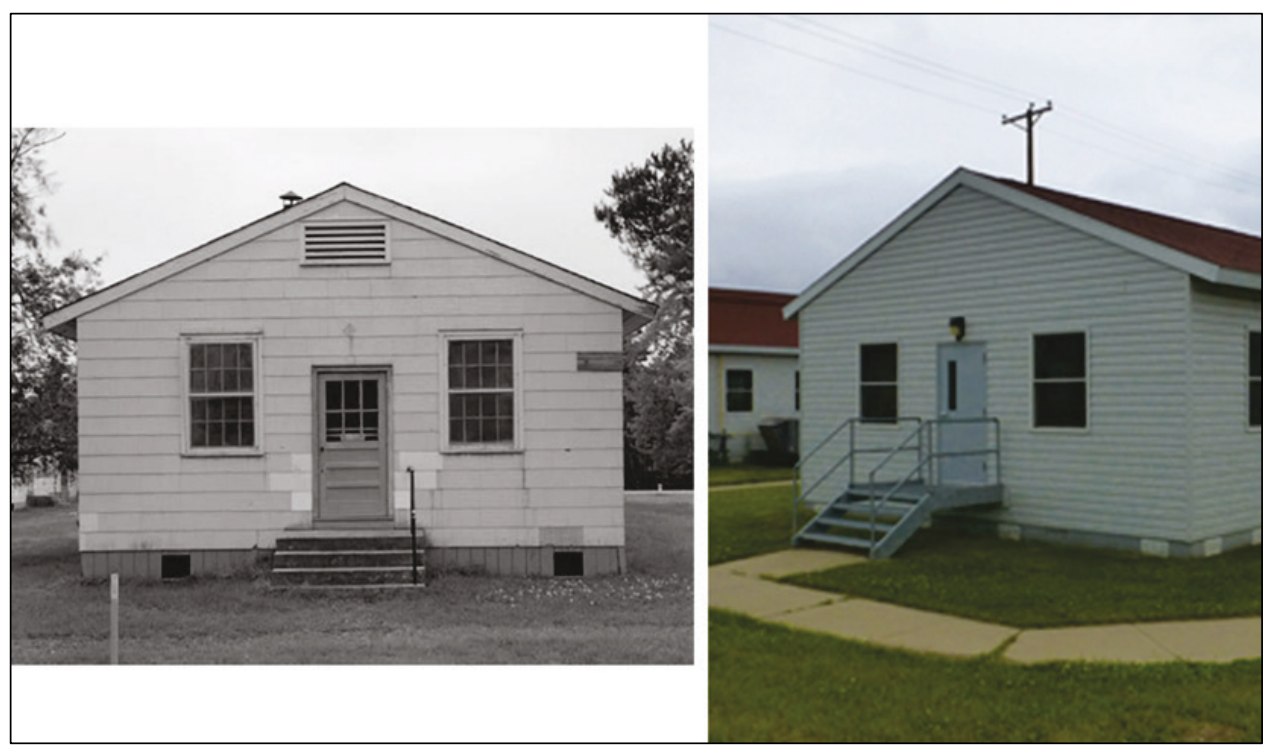

Figure 146. Entry into the kitchen area and long side elevation, with original design and materials (left) compared to the current condition of Buildings 1616, 1617, 1626, and 1627 (right) (left: Library of Congress; right: ERDC-CERL).

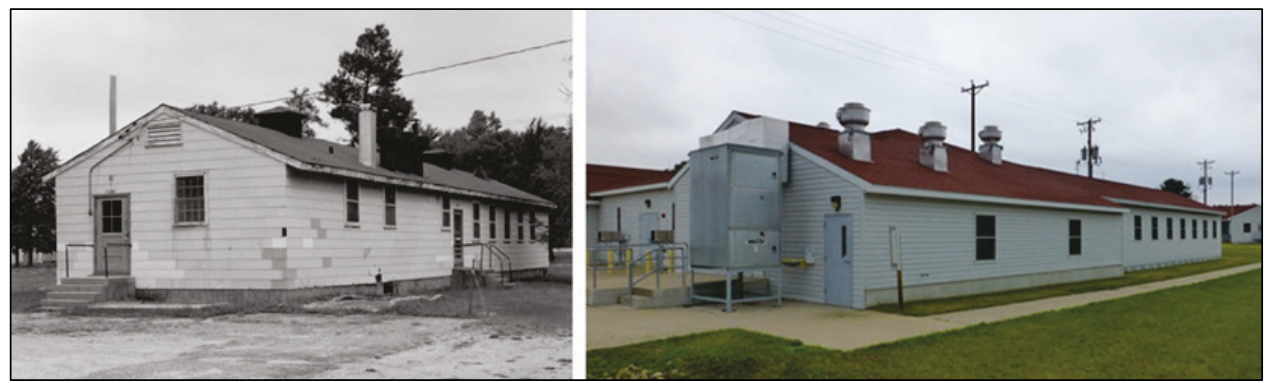


Figure 147. Interior view comparison of the dining room of a mess hall on the left and the interior of a renovated mess hall on the right (left: Library of Congress; right: ERDC-CERL).

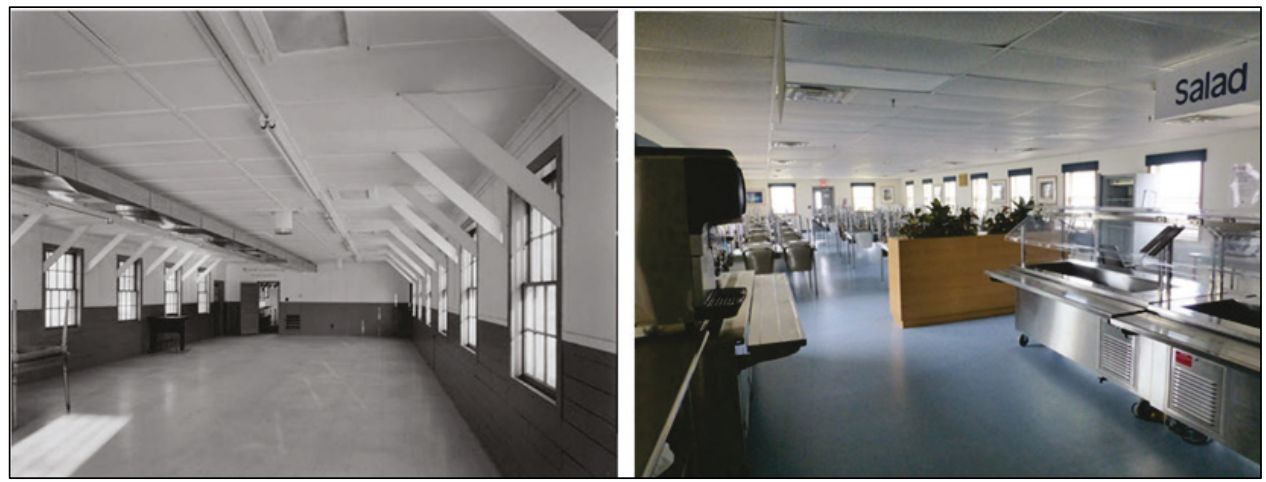

Figure 148. South (front) elevation of Building 2000 in 1952 (left) compared to 2018 (right) (left: NARA College Park; right: ERDC-CERL).

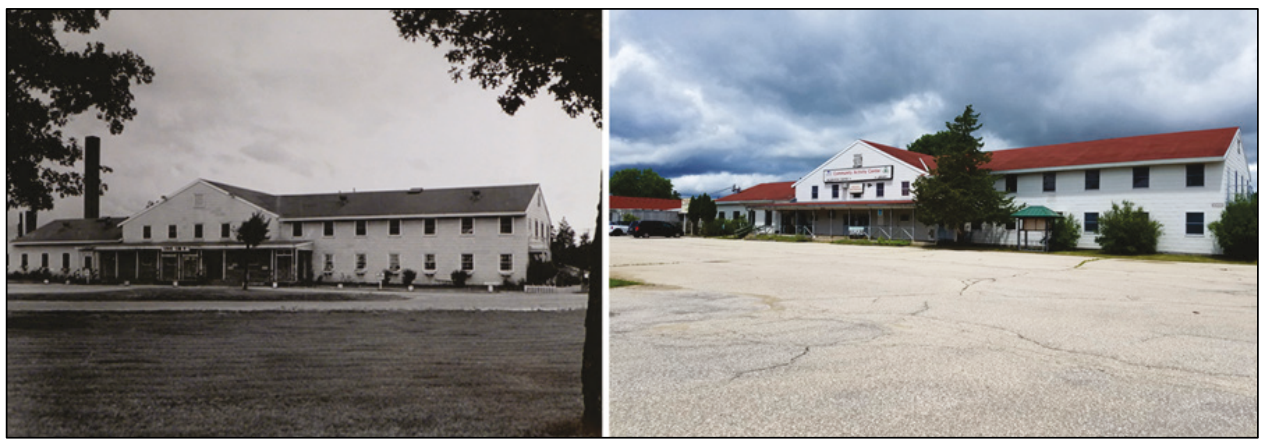

Figure 149. Main porch on the south (front) elevation of Building 2000 in 1965 (left) compared to 2018 (right) (left: NARA College Park; right: ERDC-CERL).

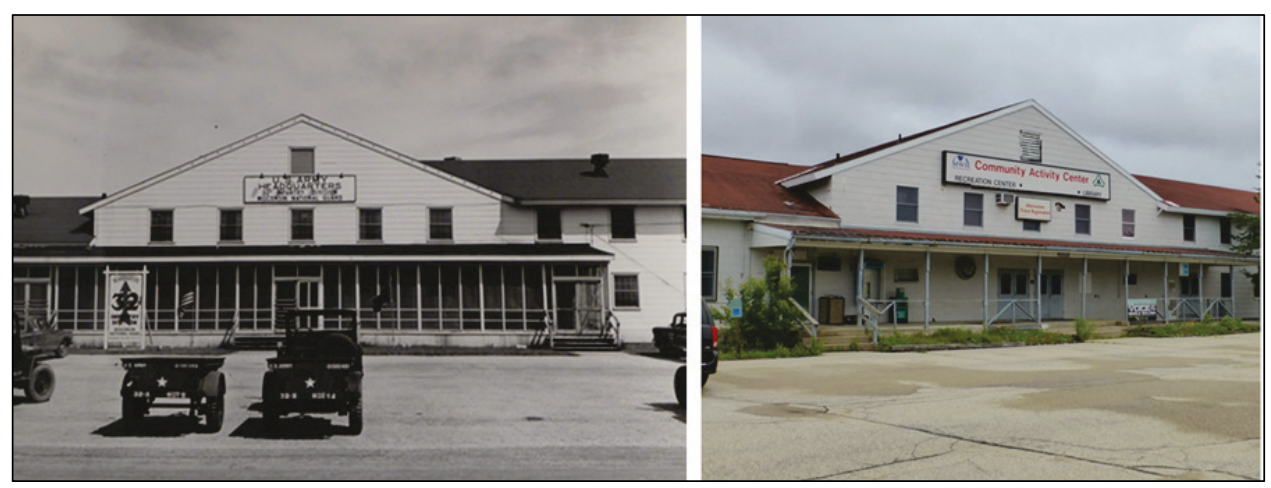


Figure 150. Northeast oblique of Building 2000 in 1988 (left) compared to 2018

(right) (left: Library of Congress, HABS; right: ERDC-CERL).
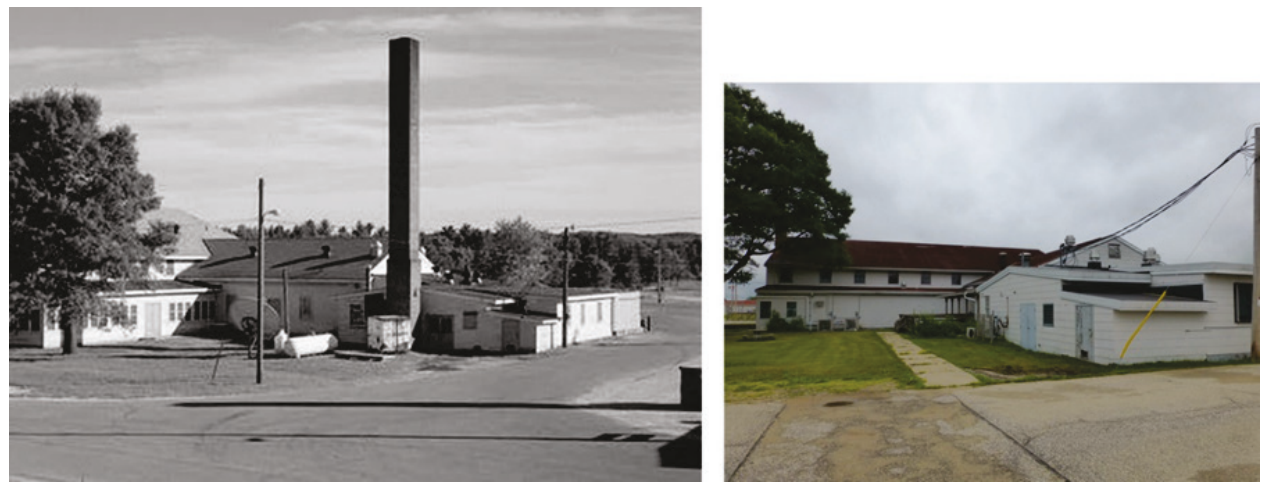

Figure 151. Interior view of the dance hall looking north in Building 2000 in 1952 (left), 1988 (middle) and 2018 (right) (left: NARA, College Park; middle, Library of Congress, HABS; right: ERDC-CERL).

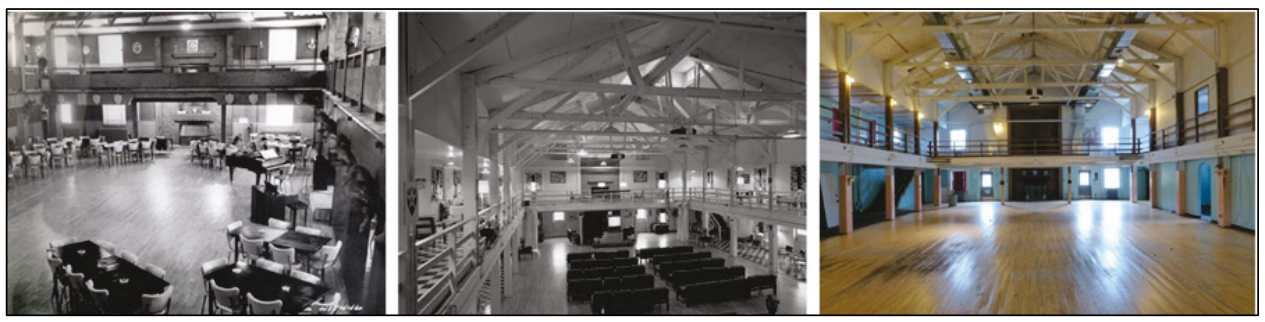

Figure 152. Interior view of the second-floor library, looking east in the east wing of Building 2000 in 1988 (left and center) compared to 2018 (right) (left: Library of Congress, HABS; right: ERDC-CERL).
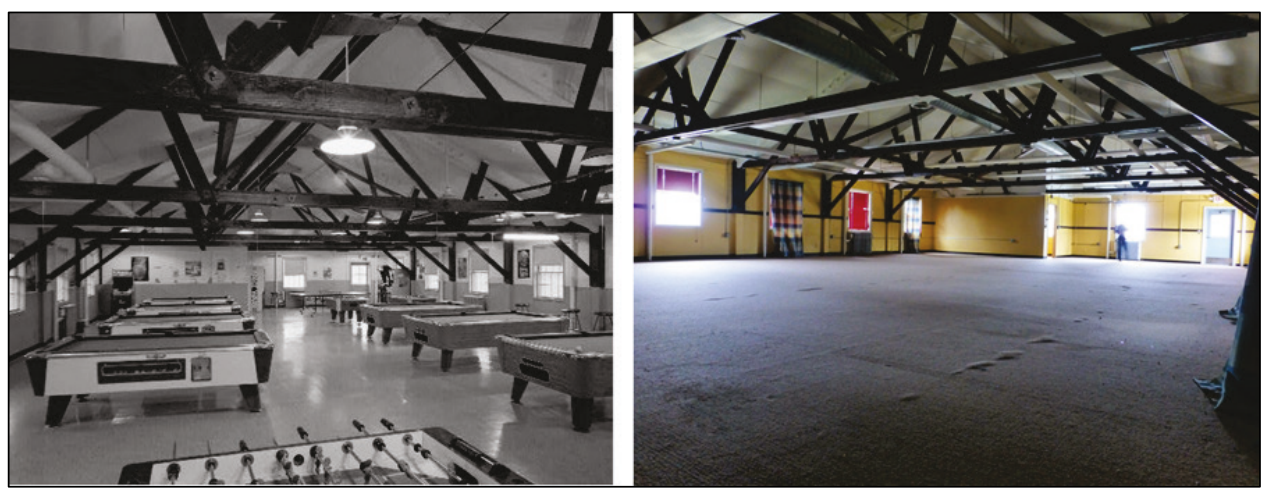


\section{Final Recommendations for Eligibility and Conclusion}

The identification of historically significant properties is achieved only through an evaluation which associates a property within a larger historic context. According to the NRHP, "Historic contexts are those patterns, themes, or trends in history by which a specific occurrence, property, or site is understood and its meaning (and ultimately its significance) within prehistory or history is made clear." 72 Therefore, to qualify as historic, a property must have an association with a relevant historic context as well as having retained its physical integrity through which its historic significance is conveyed.

Sections 7.1 through 7.6 summarize this study's findings regarding the eligibility of the set of 26 buildings given to the researchers (see also Table 3 at end of this chapter).

\subsection{Fire Station (Building 550)}

The researchers determined that Building 550 is eligible for listing on the NRHP at the national level due to its significance under Criteria A and C, and its integrity from the period of significance of 1939 to 1946.

\subsection{Block}

The researchers determined that buildings $(1602,1603,1604,1607,1608$, 1609, 1610, 1612, 1613, 1614, 1615, 1618, 1619, 1620, 1621, 1622, 1626, 1632, 1638, and 1639) studied within the 1600 Block were not eligible for listing on the NRHP at the national level due to a lack of integrity from changes in floor plans; lack of original siding; removal of original window openings, windows, and window trim; removal of original door openings, doors, and door trim; and the complete removal of all interior characterdefining features.

\subsection{Administration (Building 1743)}

The researchers determined that Building 1743 was not eligible for listing on the NRHP at the national level due to a lack of integrity from

\footnotetext{
72 NPS, National Register Bulletin \#15, 7.
} 
changes in floor plan; lack of original siding; removal of original window openings, windows, and window trim; removal of original door openings, doors, and door trim; and the complete removal of all interior characterdefining features.

\subsection{Service Club (Building 2000)}

The researchers determined that Building 2000 is eligible for listing on the NRHP at the national level due to its significance under Criteria A and C and its integrity from the period of significance of 1939 to 1946.

\subsection{Paint Storage (Building 2159)}

The researchers determined that Building 2159 is not eligible for listing on the NRHP at the national level due to its construction outside the period of significance for WWII buildings. It also could not be linked to a significant time period for Fort McCoy, and its design and construction were not significant at the state or local level.

\subsection{Administration (Building 2668)}

The researchers determined that Building 2668 is not eligible for listing on the NRHP at the national level due to a lack of integrity from changes in floor plan; lack of original siding; removal of original window openings, windows, and window trim; removal of original door openings, doors, and door trim; and the complete removal of all interior character-defining features.

\subsection{Conclusion}

This report concludes that only Building 550 (fire station) and Building 2000 (service club) are ELIGIBLE for listing on the NRHP at the national level under Criterion A for their association with World War II temporary building construction (1939-1946) and under Criterion C for their design, construction, and technological innovation.

Table 3 summarizes the above information. 
Table 3. List of buildings and determinations of eligibility for the NRHP.

\begin{tabular}{|c|c|c|c|c|c|}
\hline $\begin{array}{l}\text { Facility } \\
\text { No. }\end{array}$ & Built & Historic Use & $\begin{array}{l}\text { Series } \\
\text { (Drawing } \\
\text { No.) } \\
\end{array}$ & Use in 2000 & $\begin{array}{l}\text { Determination for } \\
\text { NRHP }\end{array}$ \\
\hline 550 & Jul-42 & Fire Station & $800-800$ & $\begin{array}{l}\text { Eng/Housing } \\
\text { Maintenance }\end{array}$ & $\begin{array}{l}\text { ELIGIBLE - Criteria } \\
\mathrm{A} \text { and C }\end{array}$ \\
\hline 1602 & Jul-42 & 74-Man Barracks & $800-443$ & AT ENL Barracks & Not eligible \\
\hline 1603 & Jul-42 & 74-Man Barracks & $800-443$ & AT ENL Barracks & Not eligible \\
\hline 1604 & Jul-42 & 74-Man Barracks & $800-443$ & AT ENL Barracks & Not eligible \\
\hline 1607 & Oct-42 & 74-Man Barracks & $800-443$ & AT ENL Barracks & Not eligible \\
\hline 1608 & Oct-42 & 74-Man Barracks & $800-443$ & AT ENL Barracks & Not eligible \\
\hline 1609 & Jul-42 & 74-Man Barracks & $800-443$ & AT ENL Barracks & Not eligible \\
\hline 1610 & Jul-42 & 74-Man Barracks & $800-443$ & AT ENL Barracks & Not eligible \\
\hline 1612 & Jul-42 & 74-Man Barracks & $800-443$ & AT ENL Barracks & Not eligible \\
\hline 1613 & Jul-42 & 74-Man Barracks & $800-443$ & AT ENL Barracks & Not eligible \\
\hline 1614 & Jul-42 & 74-Man Barracks & $800-443$ & AT ENL Barracks & Not eligible \\
\hline 1615 & Jul-42 & 74-Man Barracks & $800-443$ & AT ENL Barracks & Not eligible \\
\hline 1618 & Jul-42 & 74-Man Barracks & $800-443$ & AT ENL Barracks & Not eligible \\
\hline 1619 & Jul-42 & 74-Man Barracks & $800-443$ & AT ENL Barracks & Not eligible \\
\hline 1620 & Jul-42 & 74-Man Barracks & $800-443$ & AT ENL Barracks & Not eligible \\
\hline 1621 & Jul-42 & $\begin{array}{l}\text { Company } \\
\text { Storehouse, Admin., } \\
\text { \& Recreation }\end{array}$ & $\begin{array}{l}800-661 \\
800-460\end{array}$ & Gen Inst Bldg & Not eligible \\
\hline 1622 & Jul-42 & $\begin{array}{l}\text { Company } \\
\text { Storehouse, Admin., } \\
\text { \& Recreation } \\
\end{array}$ & $\begin{array}{l}800-661 \\
800-460\end{array}$ & Gen Inst Bldg & Not eligible \\
\hline 1626 & Jul-42 & 228-Man Mess Hall & $800-851$ & Dining Facility & Not eligible \\
\hline 1627 & Jul-42 & 228-Man Mess Hall & $800-851$ & Dining Facility & Not eligible \\
\hline 1632 & Jul-42 & 74-Man Barracks & $800-443$ & AT ENL Barracks & Not eligible \\
\hline 1638 & Jul-42 & 228-Man Mess Hall & $800-851$ & Dining Facility & Not eligible \\
\hline 1639 & Jul-42 & 228-Man Mess Hall & $800-851$ & Dining Facility & Not eligible \\
\hline 1743 & Jul-42 & $\begin{array}{l}\text { Company } \\
\text { Storehouse, Admin. } \\
\& \text { Recreation }\end{array}$ & $\begin{array}{l}800-661 \\
800-460 \\
\end{array}$ & USAR Center & Not eligible \\
\hline 2000 & Jul-42 & Service Club & $800-517$ & $\begin{array}{l}\text { Fst Fd/Snk Bar } \\
\text { Recreation Ctr }\end{array}$ & $\begin{array}{l}\text { ELIGIBLE - Criteria } \\
\mathrm{A} \text { and C }\end{array}$ \\
\hline 2159 & Jul-47 & Paint Storage & $\begin{array}{l}47-018- \\
335\end{array}$ & $\begin{array}{l}\text { Flammable } \\
\text { Material Storage }\end{array}$ & Not eligible \\
\hline 2668 & Jul-42 & Administration & $800-222$ & $\begin{array}{l}\text { Recreation } \\
\text { Center }\end{array}$ & Not eligible \\
\hline \multicolumn{6}{|c|}{$\begin{array}{l}\text { AT }=\text { annual training } \\
\mathrm{Ctr}=\text { Center } \\
\text { Eng }=\text { Engineer } \\
\text { ENL = enlisted }\end{array}$} \\
\hline
\end{tabular}


[Intentionally blank.] 


\section{Appendix: Inventory Forms}

The following inventory forms contain detailed architectural descriptions, history, present-day photographs, historic photographs, and construction plans. 


\section{Building 550}

\begin{tabular}{|c|c|c|c|}
\hline \multicolumn{4}{|c|}{$\begin{array}{c}\text { FORT McCOY } \\
\text { HISTORIC PROPERTY INVENTORY FORM }\end{array}$} \\
\hline $\begin{array}{l}\text { PROPERTY BOUNDARIES } \\
\text { - Fort McCoy in the } 500 \text { block } \\
\text { area on the east side of the } \\
\text { triangular cantonment plan } \\
\text { - Sparta vicinity } \\
\text { - Monroe County, Wisconsin }\end{array}$ & \multicolumn{2}{|c|}{$\begin{array}{l}\text { COMMON/HISTORIC NAME } \\
\text { - Building 550 } \\
\text { - Engineering/Housing Maintenance } \\
\text { - Organizational Classroom } \\
\text { - Fire Station }\end{array}$} & $\frac{\text { STATUS }}{\text { Vacant }}$ \\
\hline $\begin{array}{l}\text { ARCHITECT/BUILDER } \\
\text { Construction Division, Office } \\
\text { of the Quartermaster General, } \\
\text { Series } 800-800\end{array}$ & $\begin{array}{l}\text { DATE OF CONSTRUCTION } \\
\text { July } 1942 \\
\text { DATE OF ALTERATIONS } \\
2003 \text { - replaced roof } \\
\text { Unknown - removed brick } \\
\text { furnace stack, removed original } \\
\text { exterior light fixtures, modified } \\
\text { open interior bay with partition } \\
\text { wall }\end{array}$ & $\frac{\text { NO. OF STORIES }}{1}$ & $\frac{\text { FOOTPRINT }}{\text { T-Shaped }}$ \\
\hline$\frac{\text { ROOF FORM }}{\text { Cross-gable }}$ & $\begin{array}{l}\text { FOUNDATION } \\
\text { Concrete pier foundation with } \\
\text { wooden foundation skirting and } \\
\text { concrete block wall foundation } \\
\text { system }\end{array}$ & $\begin{array}{l}\text { WALLS } \\
\text { Wood frame with } \\
\text { asbestos cement } \\
\text { siding }\end{array}$ & $\begin{array}{l}\frac{\text { ROOF }}{\text { Asphalt }} \\
\text { shingles }\end{array}$ \\
\hline \multicolumn{2}{|c|}{ PROPERTY FUNCTION } & \multirow{3}{*}{\multicolumn{2}{|c|}{$\begin{array}{l}\text { NOTABLE FEATURES } \\
\text { - T-shaped temporary wood structure } \\
\text { - Textured asbestos cement siding } \\
\text { with scalloped bottom edge } \\
\text { - Cross-gable roof clad with asphalt } \\
\text { shingles and overhanging eaves } \\
\text { - Concrete pier foundation with } \\
\text { wooden foundation skirting } \\
\text { - Three-bay garage area } \\
\text { - Original multipane wood double- } \\
\text { hung windows } \\
\text { - Original wood exterior and interior } \\
\text { doors } \\
\text { - Original interior features to include } \\
\text { space layout, flooring, wall covering, } \\
\text { exposed ceilings, latrine fixtures, and } \\
\text { suspended mechanical systems } \\
\text { equipment }\end{array}$}} \\
\hline Fire Station & Vacant & & \\
\hline \multicolumn{2}{|c|}{$\begin{array}{l}\text { RELATIONSHIP TO OTHER BUILDINGS } \\
\text { Building } 550 \text { is located east of the intersection of East Thirteenth } \\
\text { Avenue and East L Street in the } 500 \text { block of the cantonment. Only } \\
\text { one other structure, Building } 547 \text {, is located within this block. }\end{array}$} & & \\
\hline
\end{tabular}




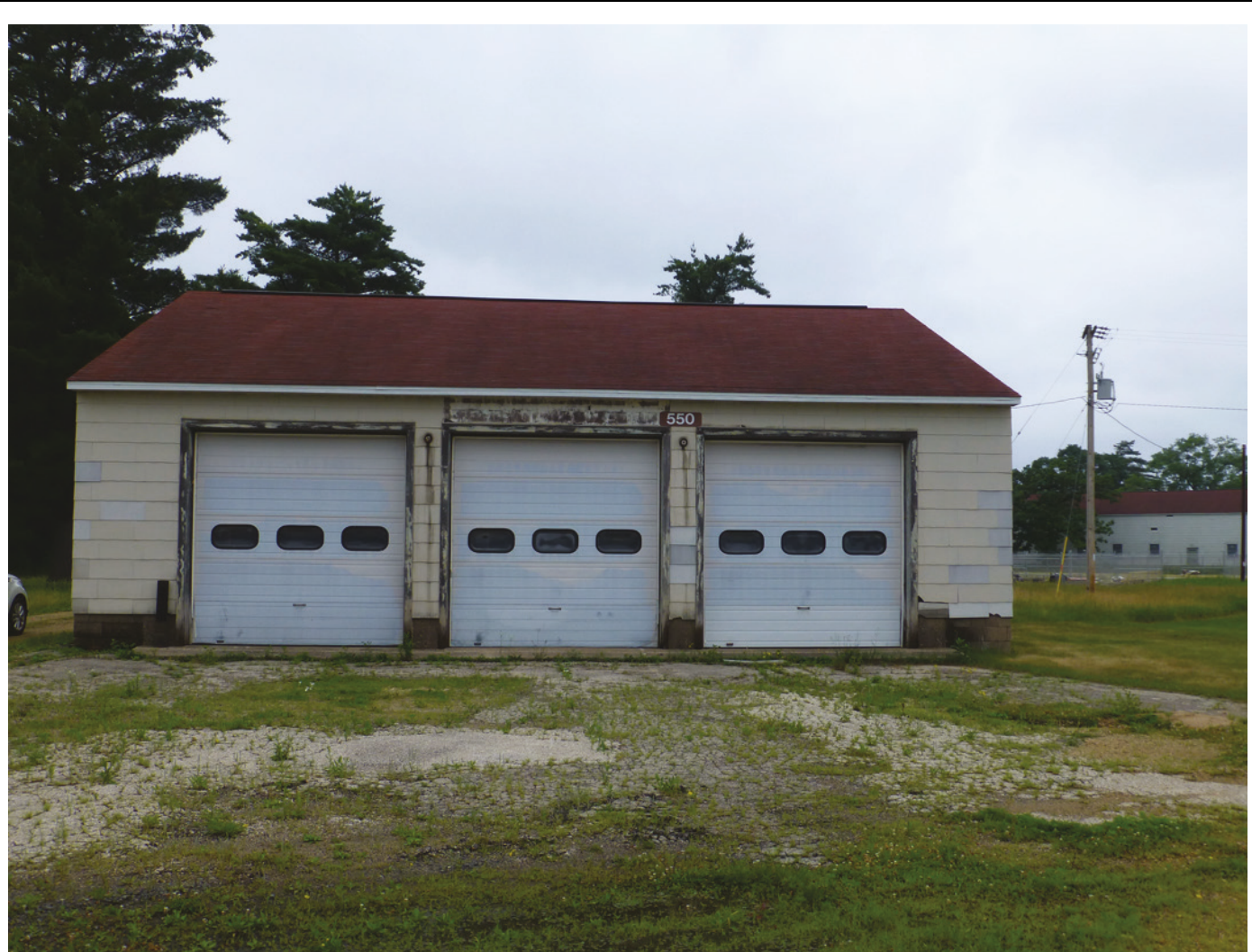

Photo 1. West elevation of the three-bay garage/apparatus room of Building 550 (ERDC-CERL, 2018).

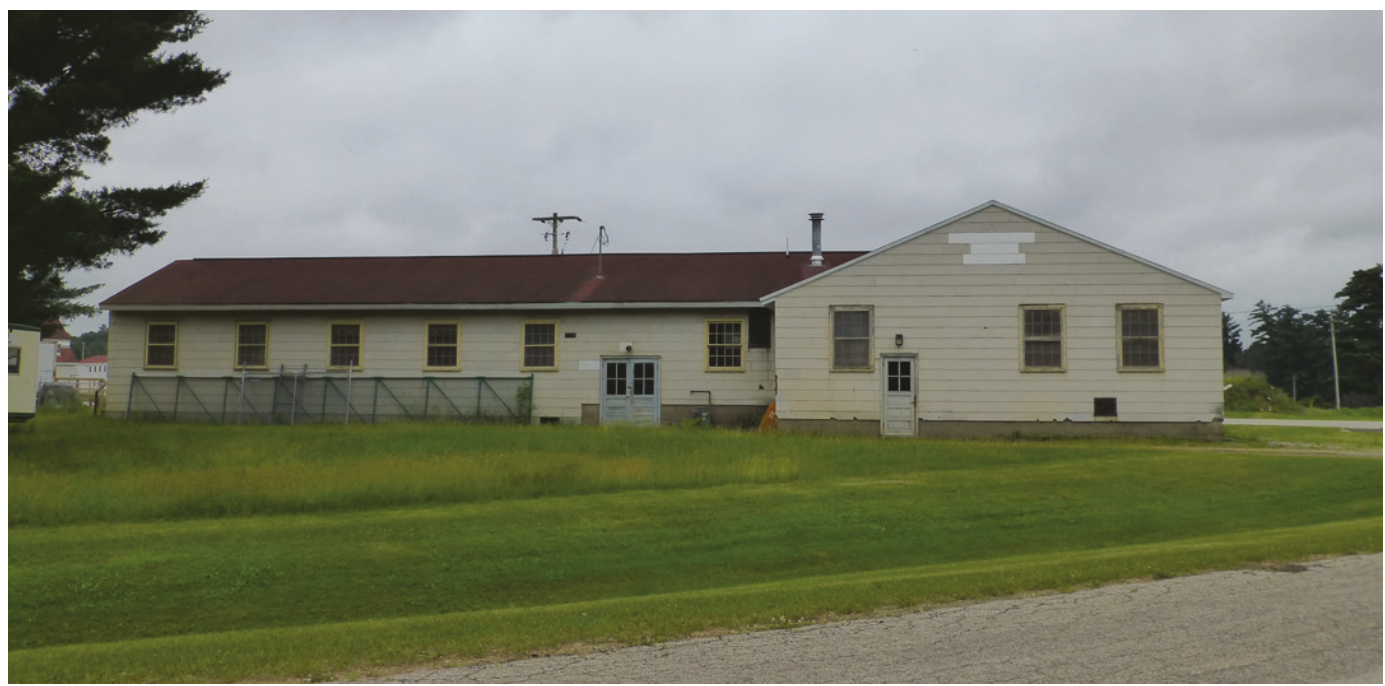

Photo 2. North elevation of Building 550 (ERDC-CERL, 2018). 


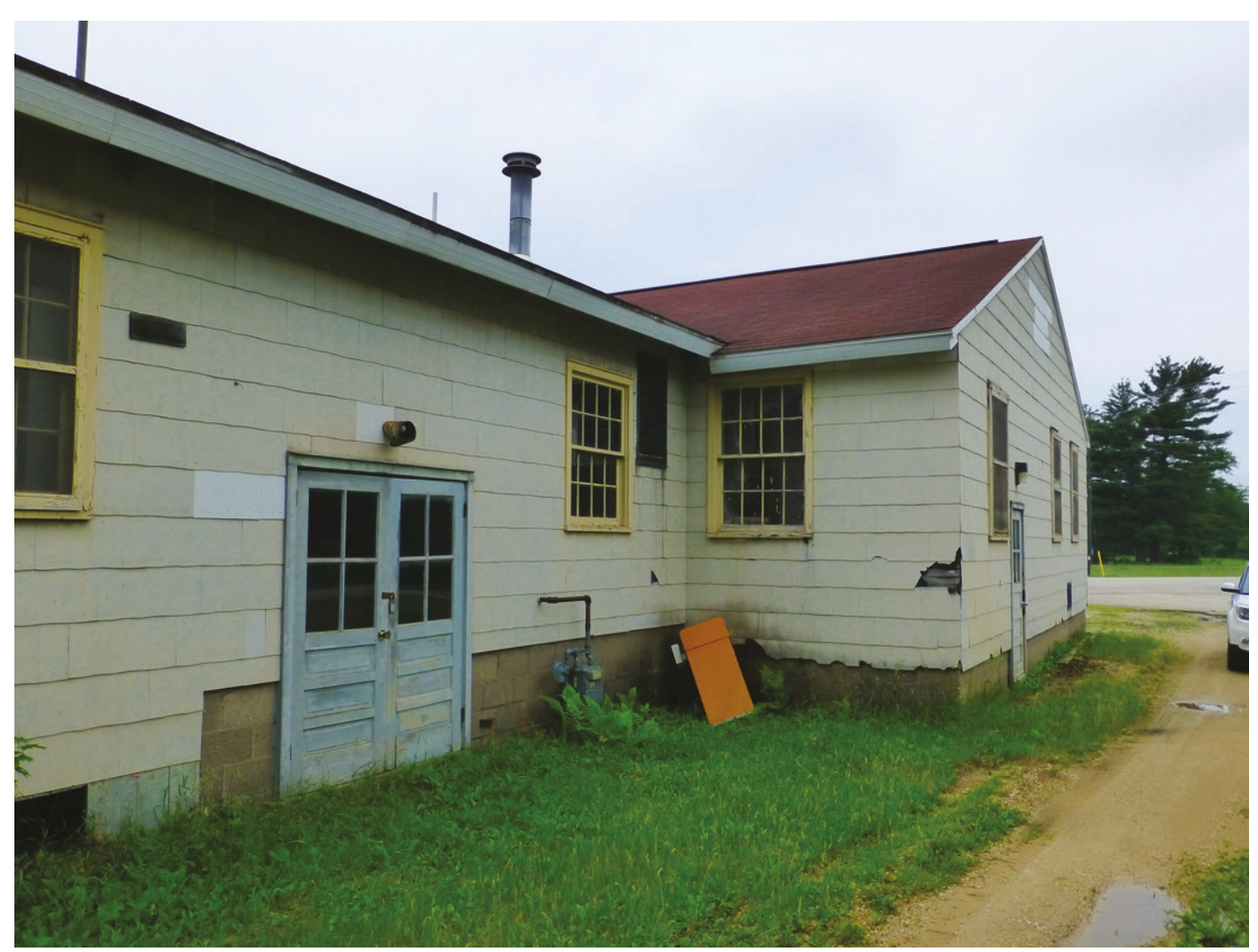

Photo 3. Northeast oblique of the three-bay garage section (right), and north elevation of the administration section (left) of Building 550 (ERDC-CERL, 2018).

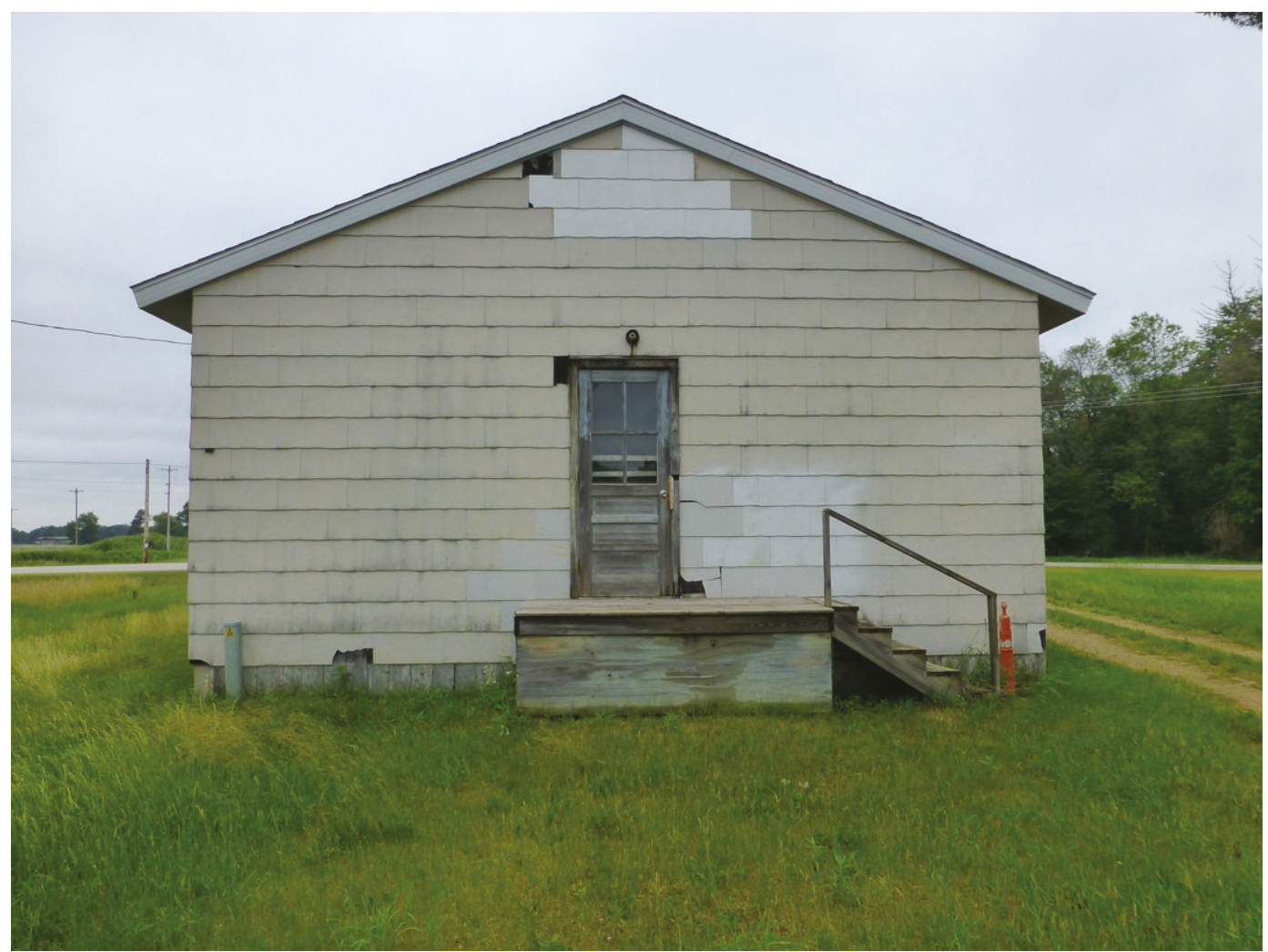

Photo 4. East elevation of the living area of Building 550 (ERDC-CERL, 2018). 


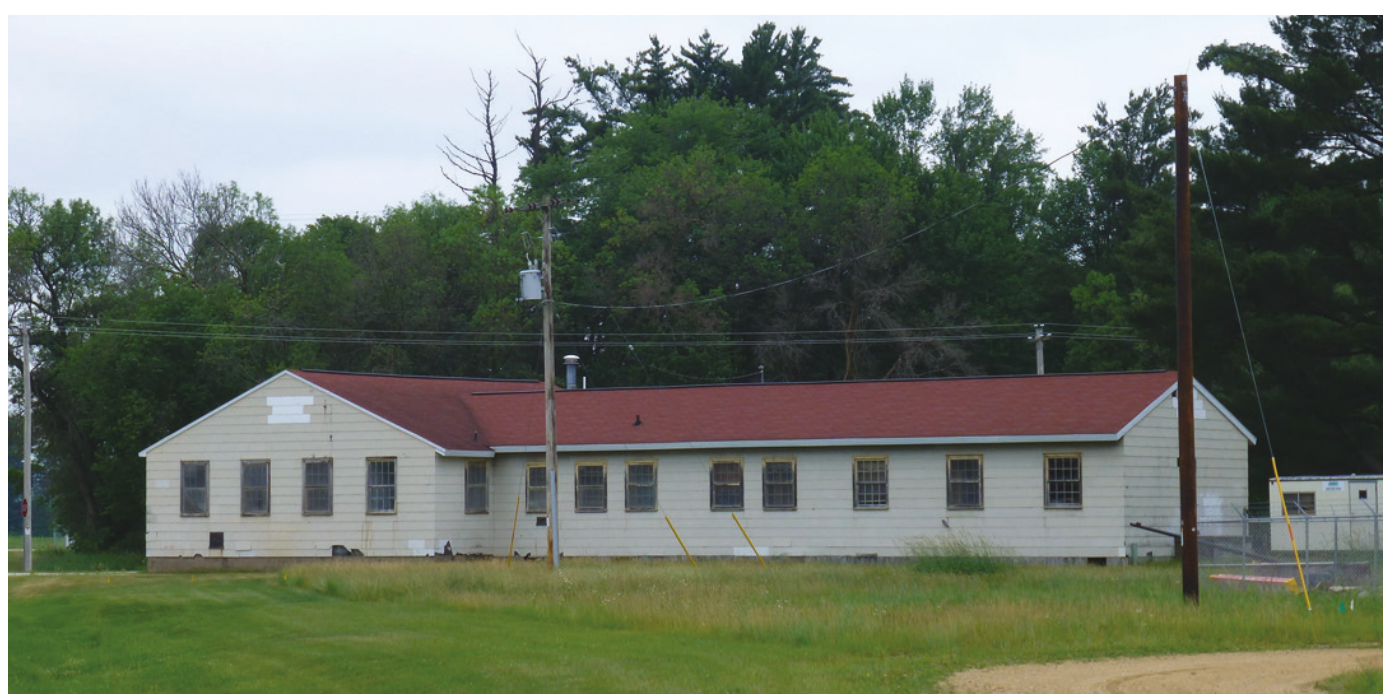

Photo 5. South elevation of Building 550 (ERDC-CERL, 2018).

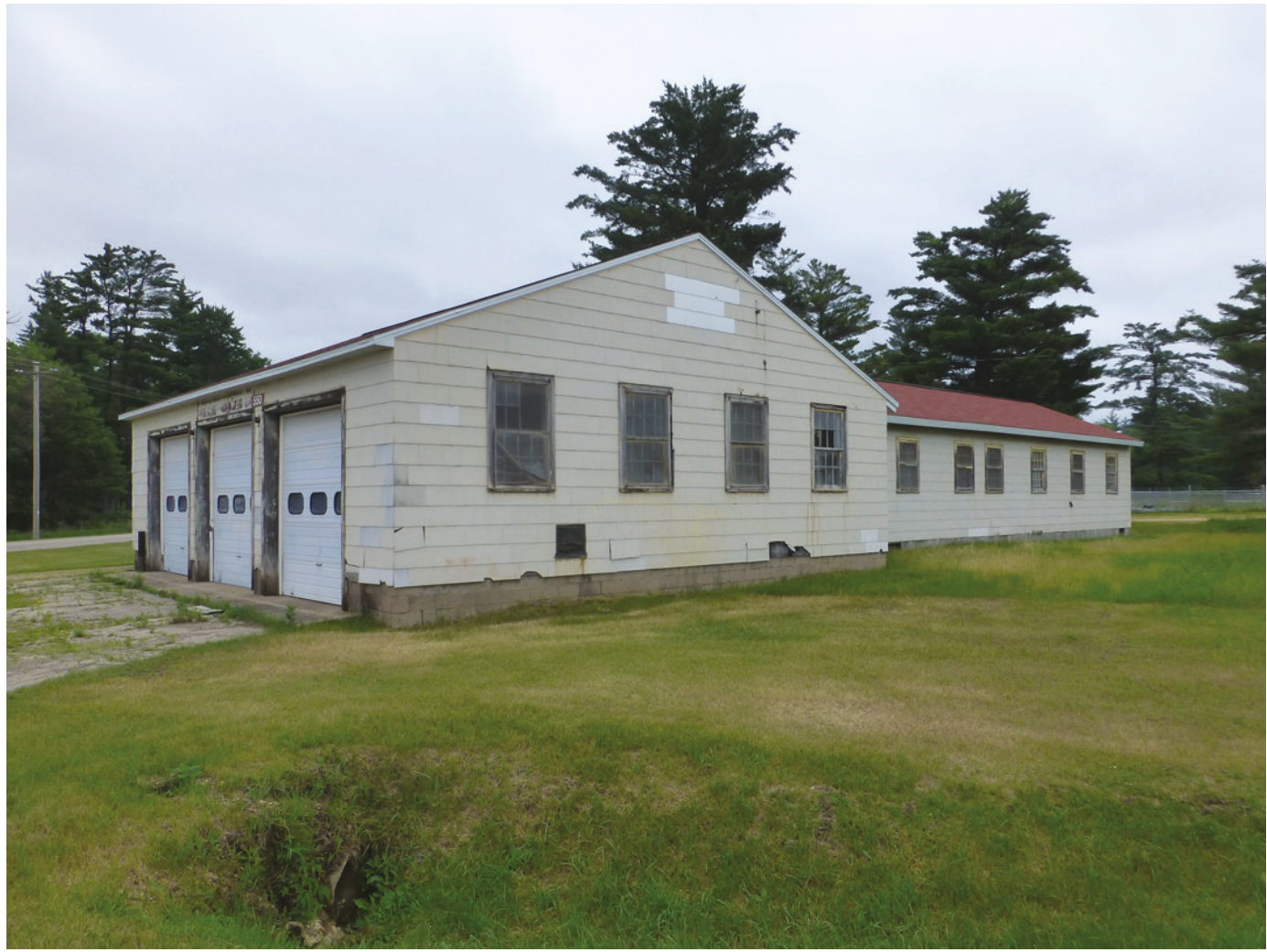

Photo 6. Southwest oblique of the three-bay garage section (left), and south elevation of the administration section (right) of Building 550 (ERDC-CERL, 2018). 


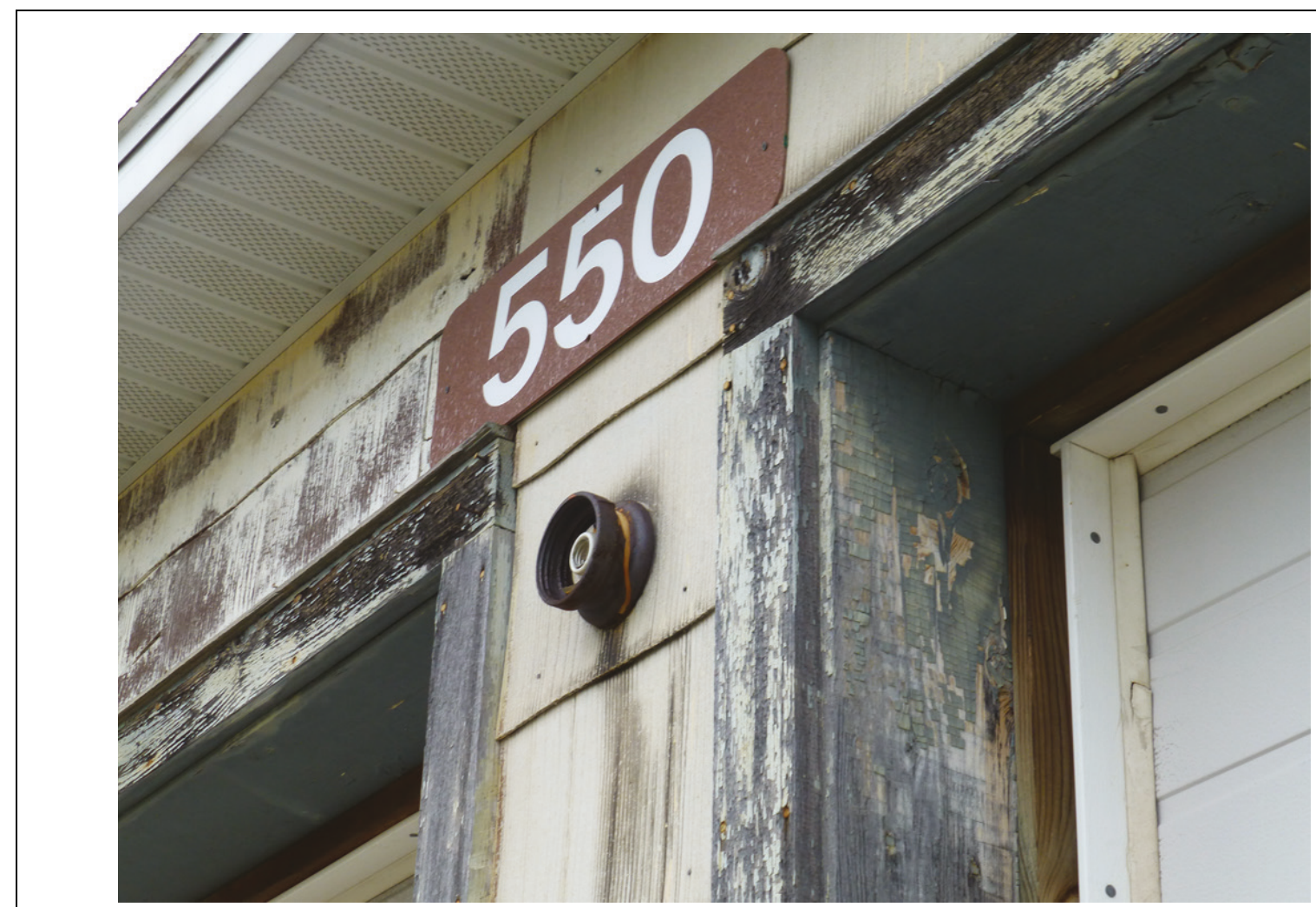

Photo 7. Close-up of the asbestos cement siding, wood trim around door openings, missing light fixture, and replacement metal soffit on Building 550 (ERDC-CERL, 2018).

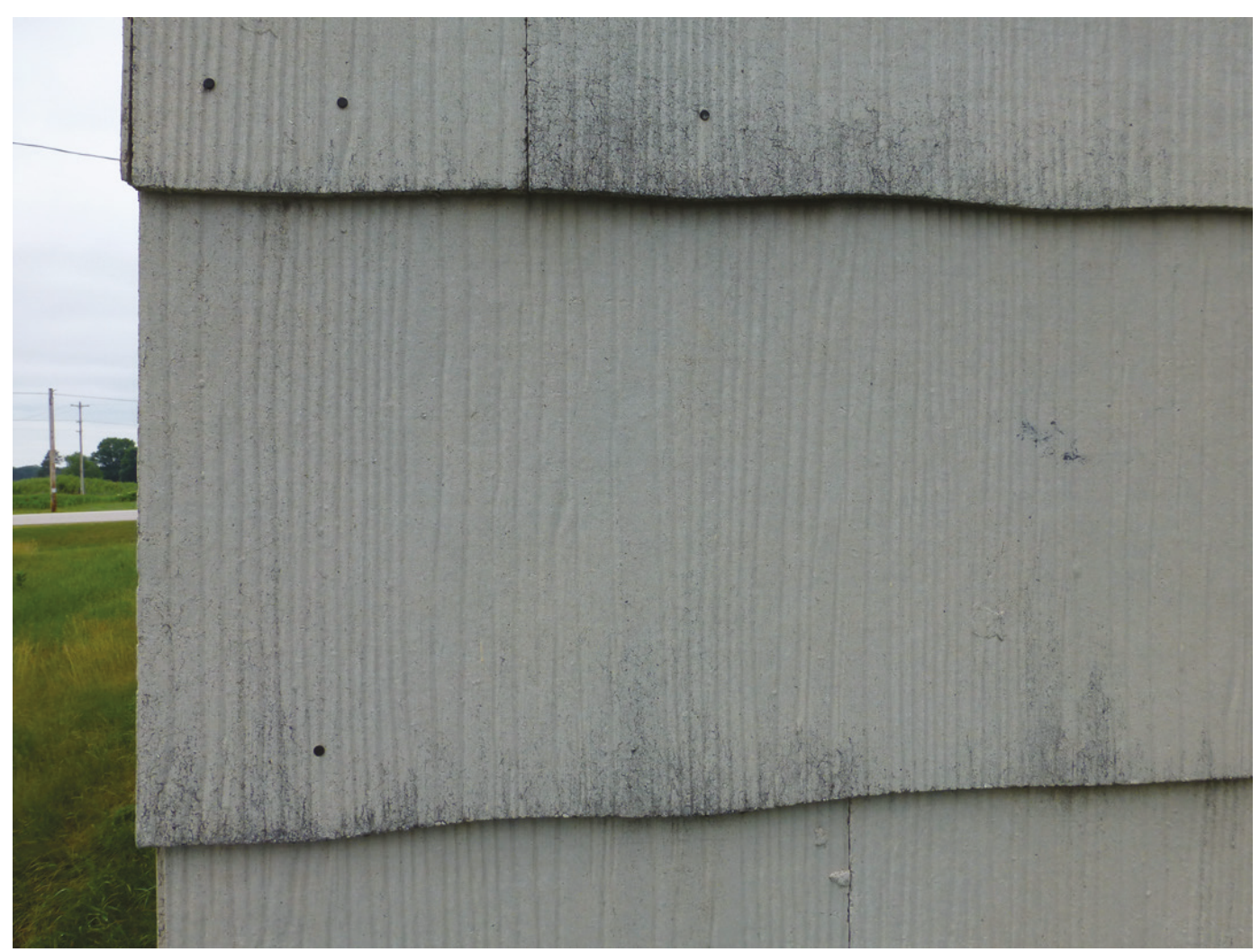

Photo 8. Close-up of the textured asbestos cement siding with scalloped bottom edge on Building 550 (ERDC-CERL, 2018). 


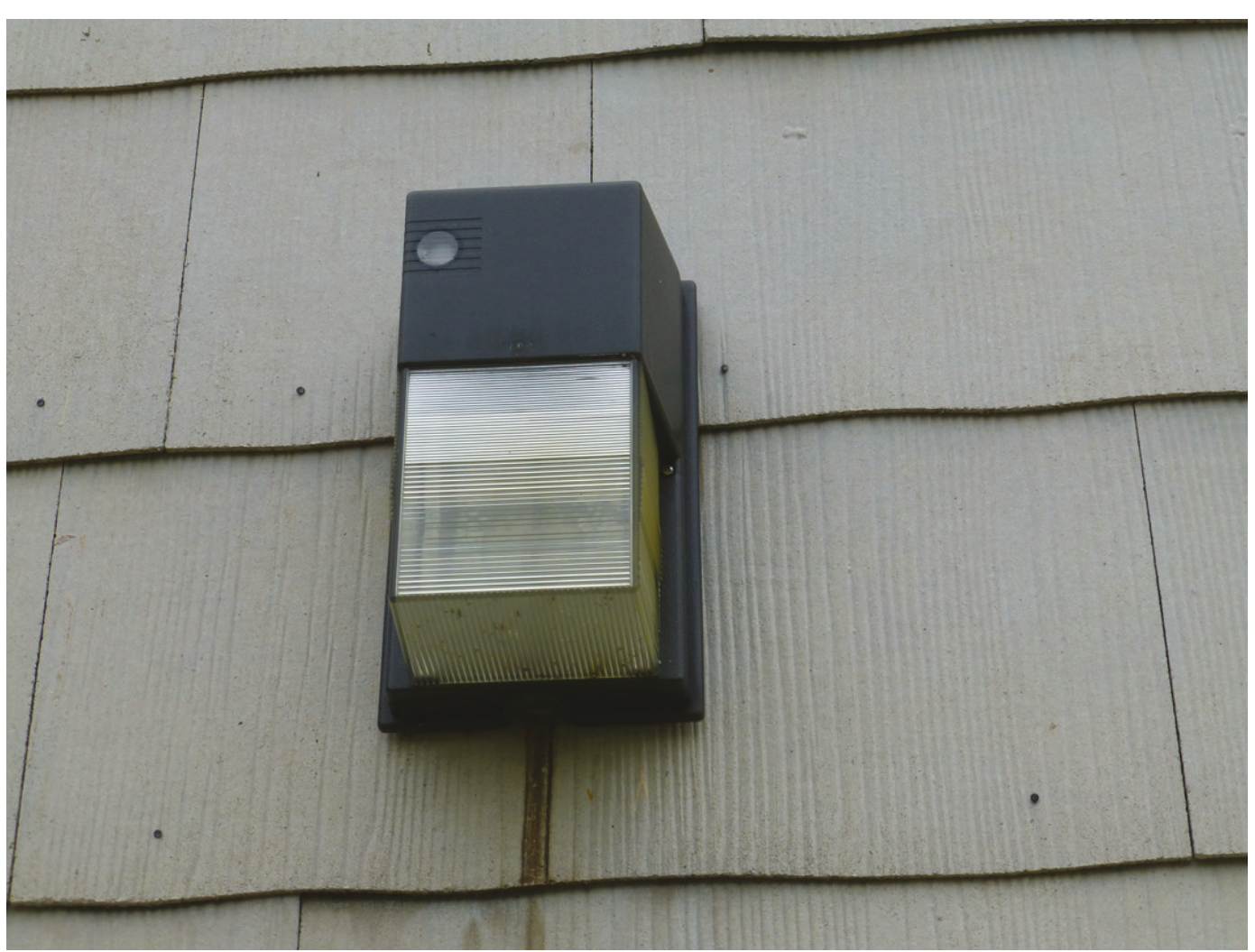

Photo 9. Example of replacement exterior light fixture on Building 550 (ERDC-CERL, 2018).

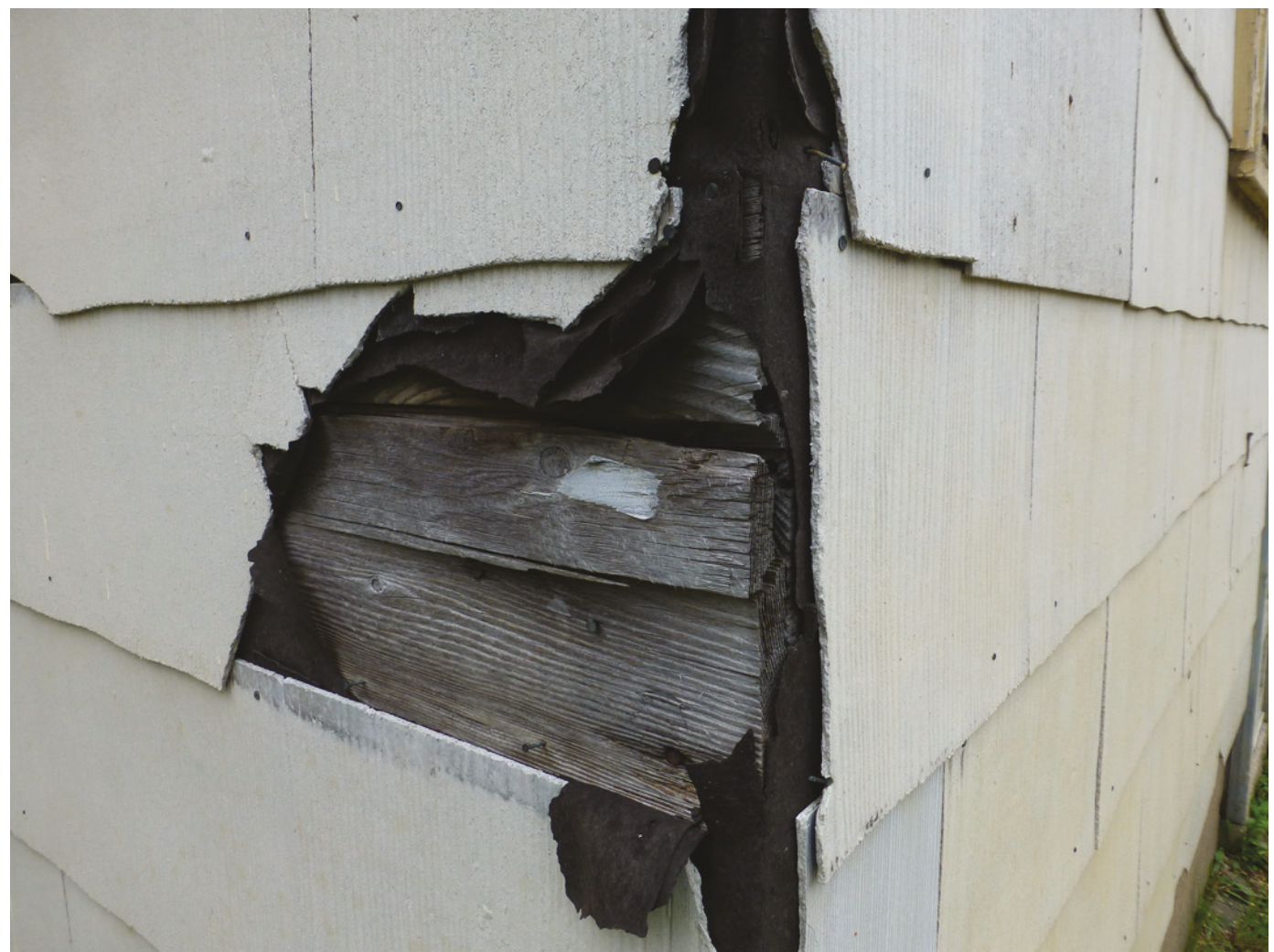

Photo 10. Close-up of damaged asbestos cement siding on Building 550 (ERDC-CERL, 2018). 


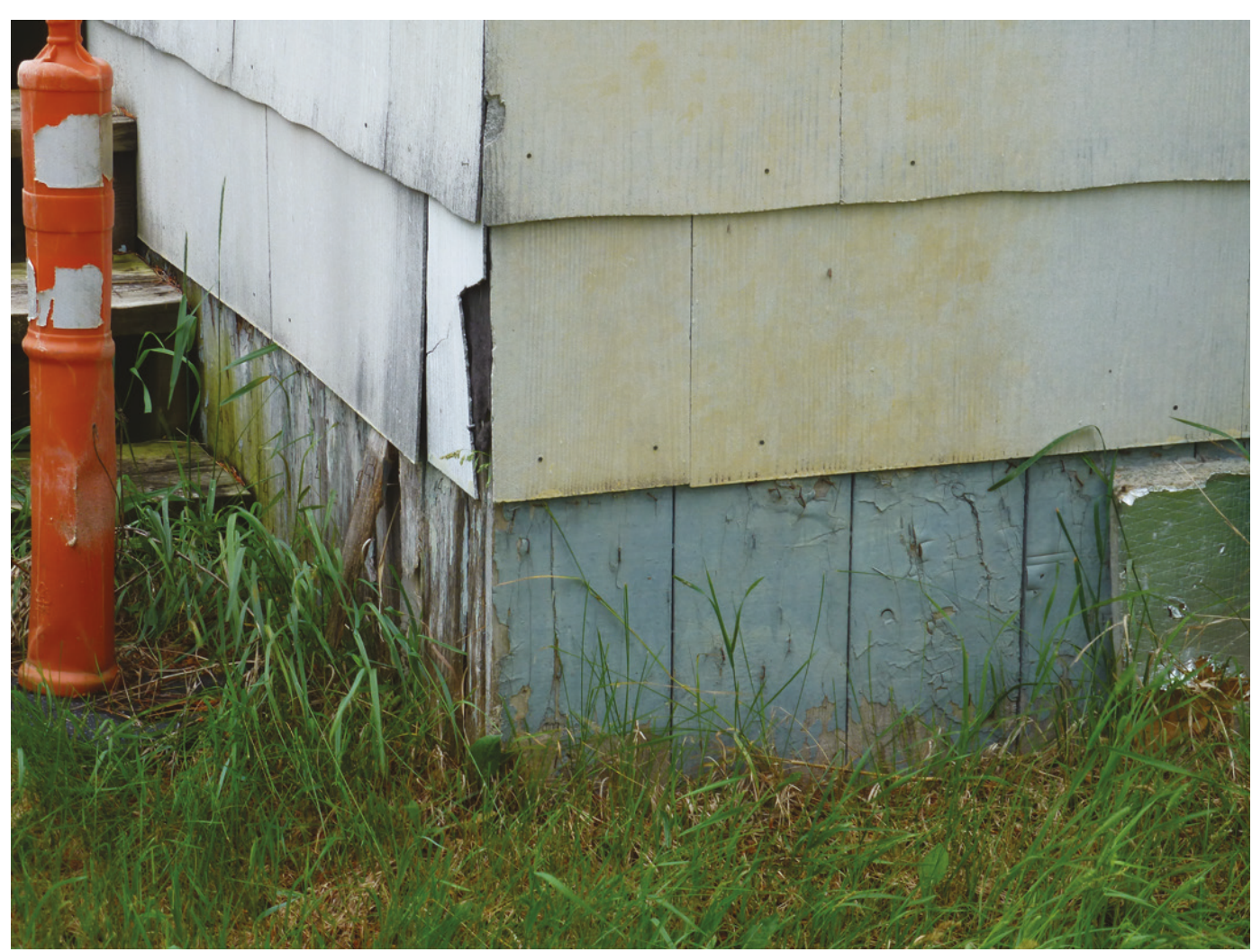

Photo 11. Close-up of the wooden foundation skirting of Building 550 (ERDC-CERL, 2018).

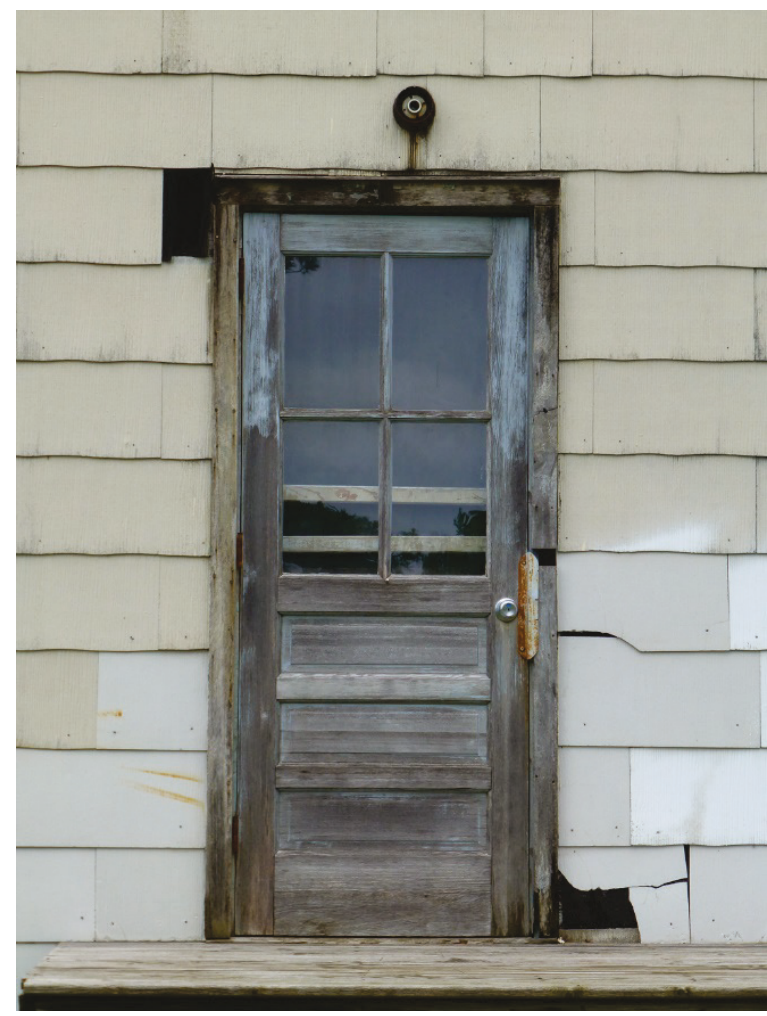

Photo 12. Original wood-panel and divided-light entry door on Building 550 (ERDC-CERL, 2018). 


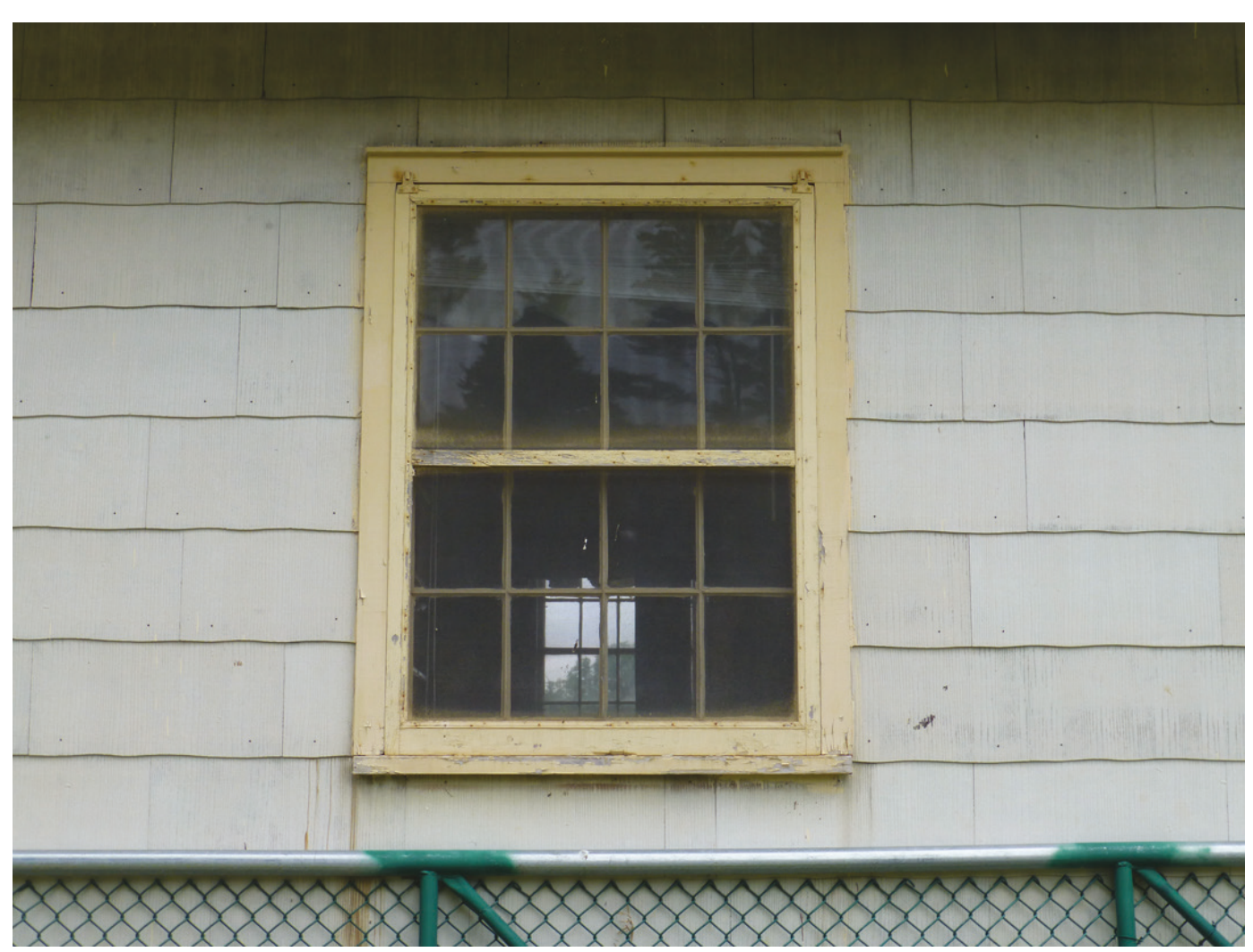

Photo 13. Original multipane wood double-hung window and wood screen on Building 550 (ERDC-CERL, 2018).

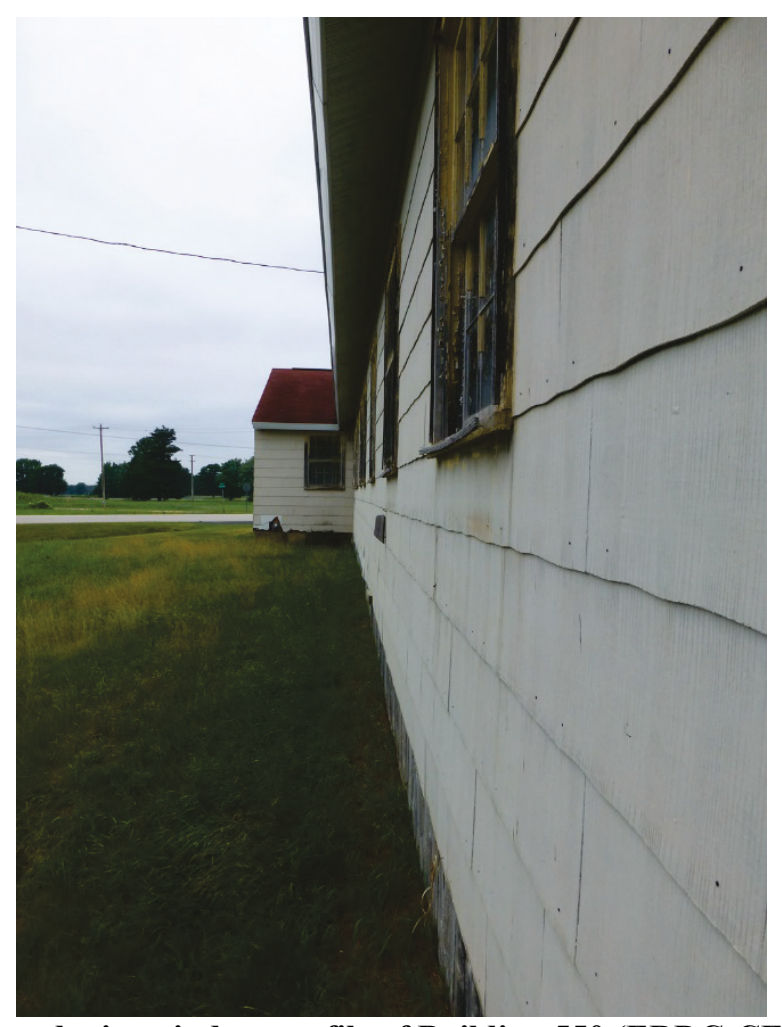

Photo 14. Close-up of the wood trim window profile of Building 550 (ERDC-CERL, 2018). 


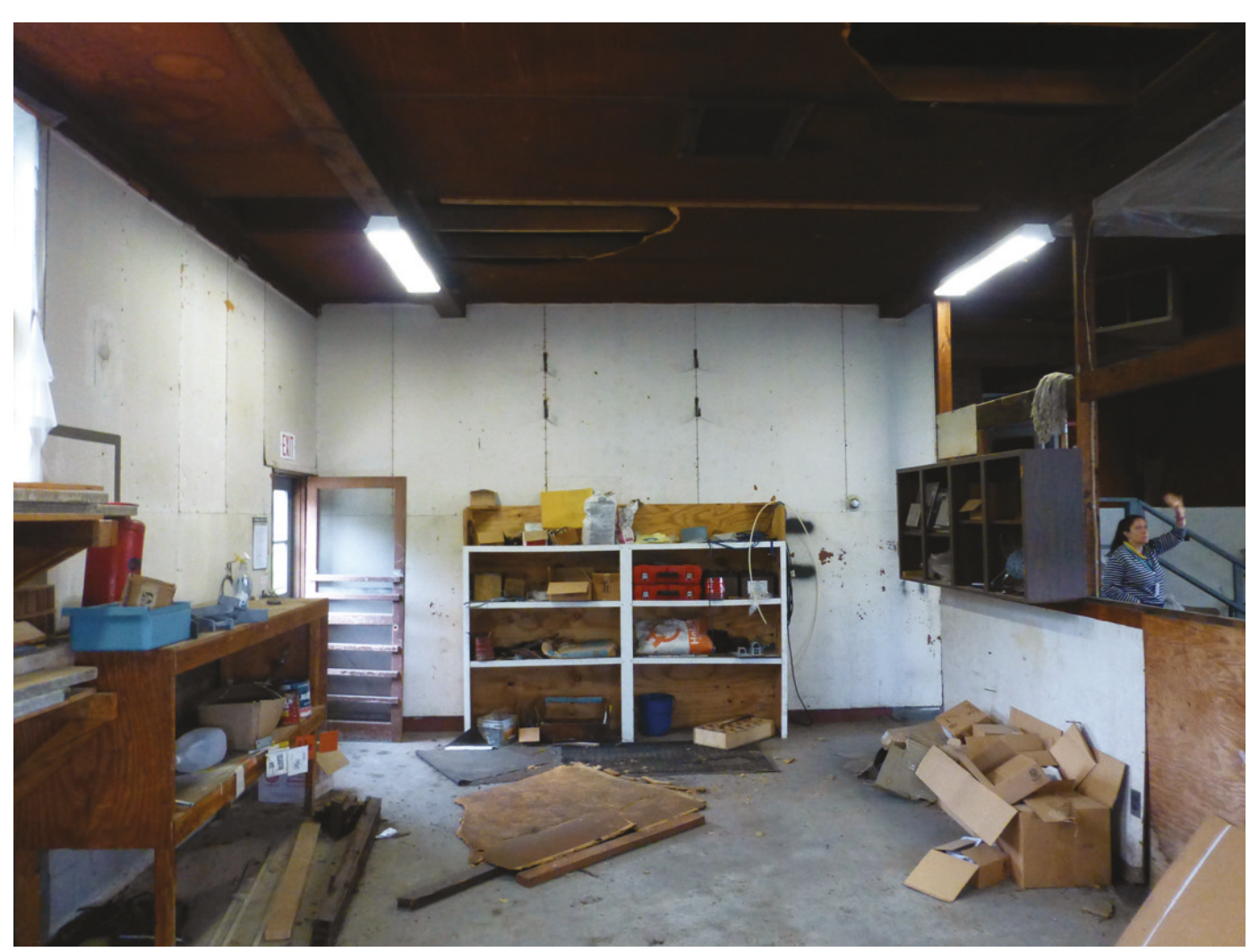

Photo 15. Interior view of the three-bay apparatus room of Building 550, looking east (ERDC-CERL, 2018).

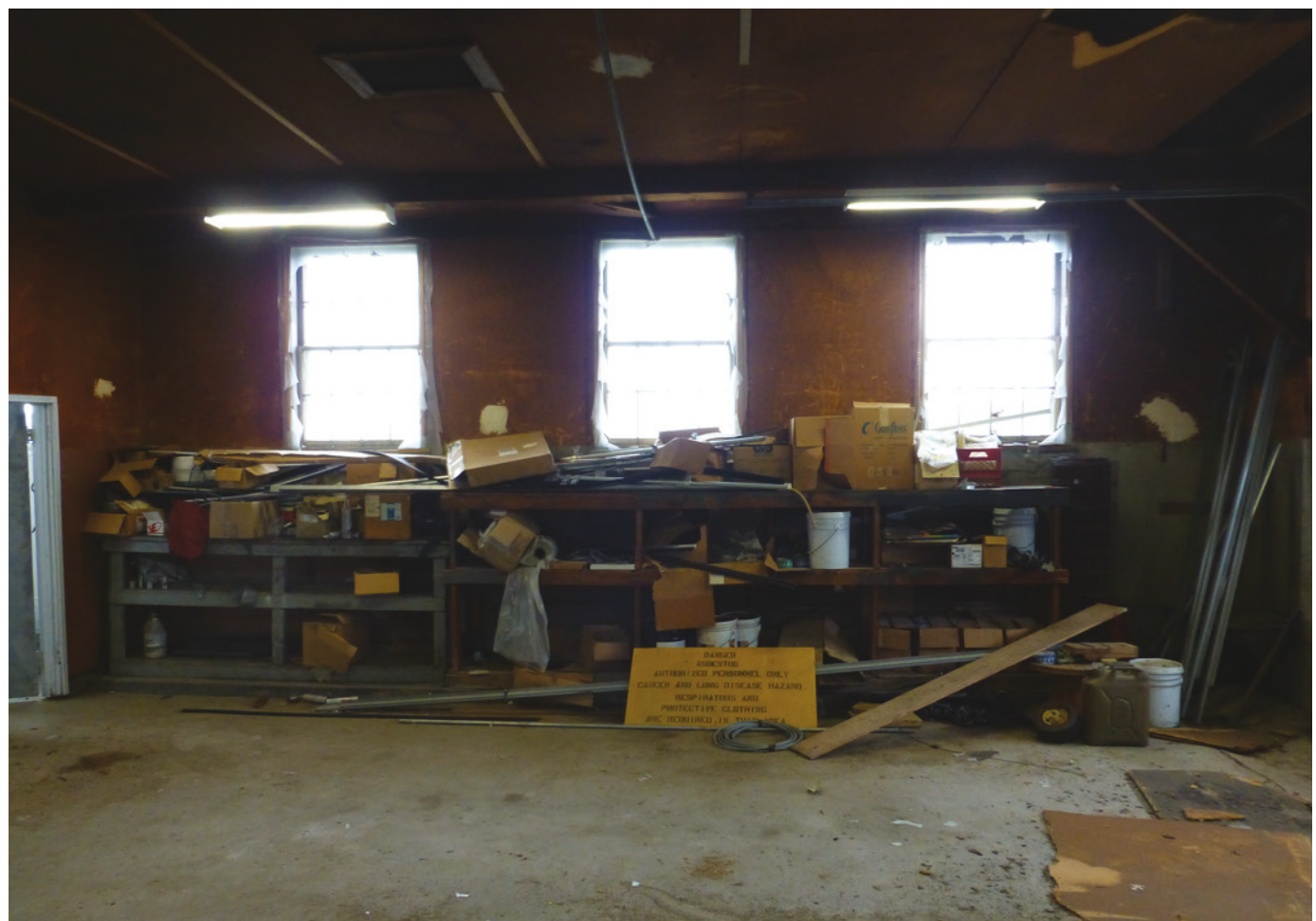

Photo 16. Interior view of the three-bay apparatus room of Building 550, looking south (ERDC-CERL, 2018). 


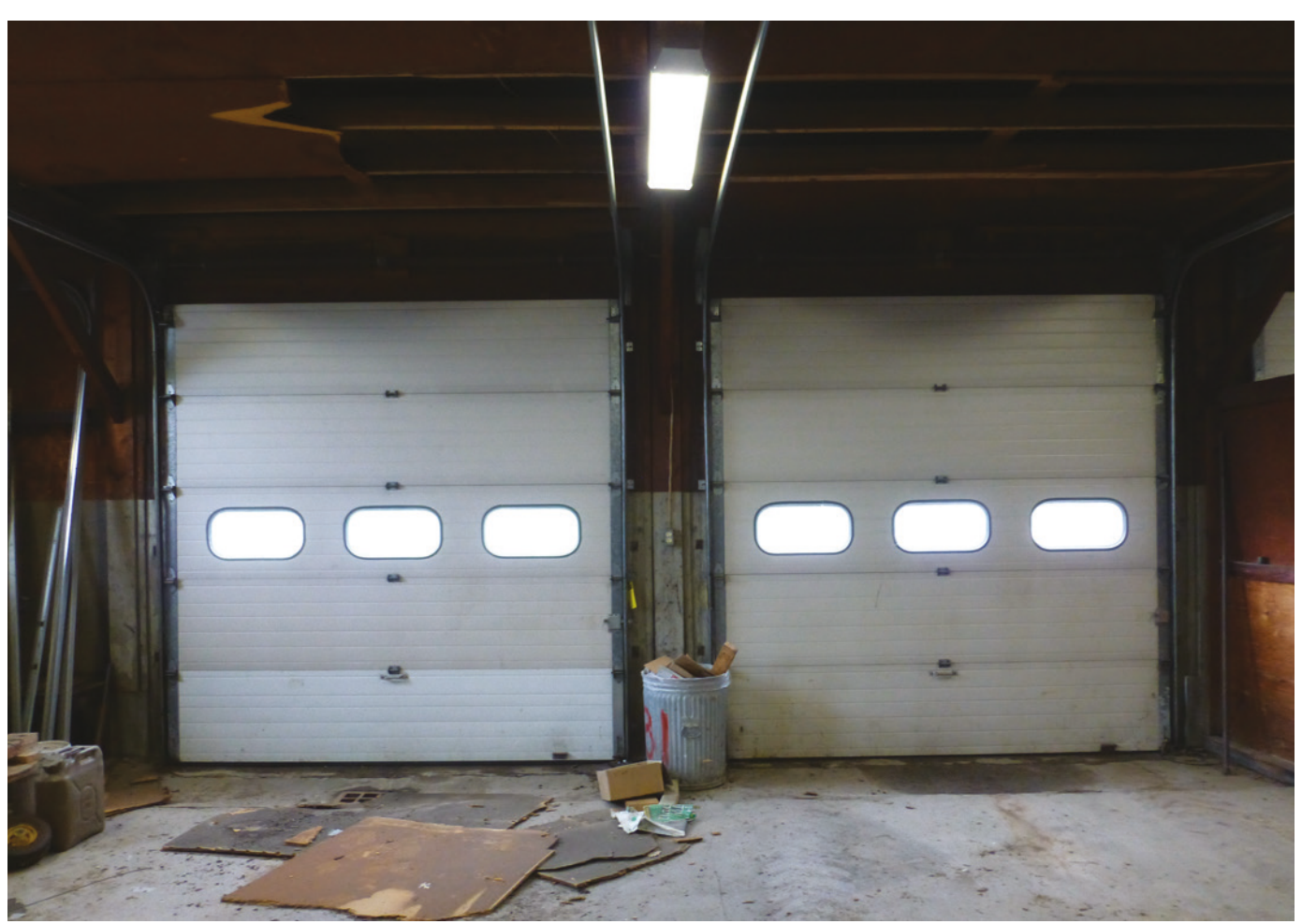

Photo 17. Interior view of the three-bay apparatus room of Building 550, looking west at the replacement overhead doors (ERDC-CERL, 2018).

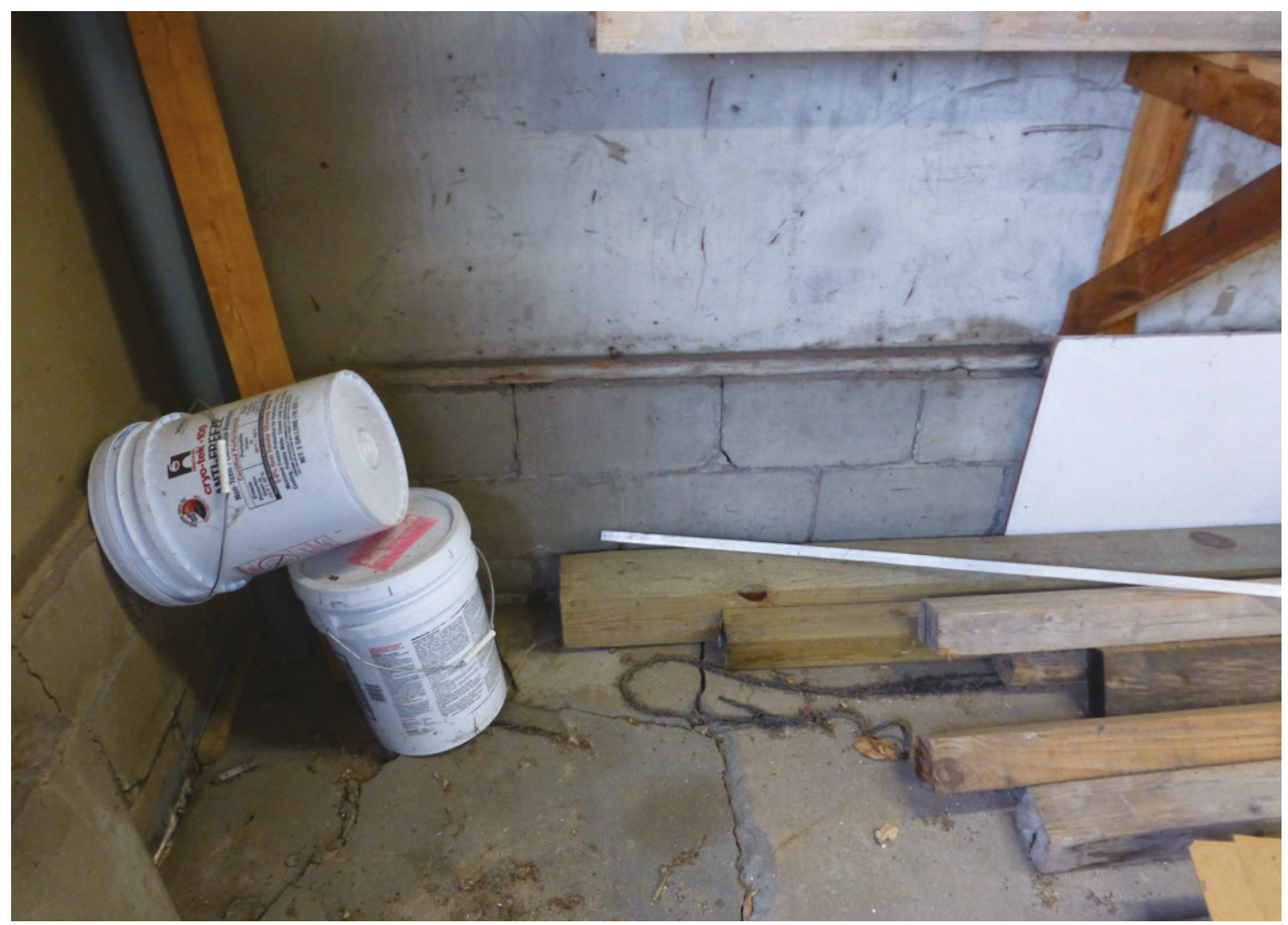

Photo 18. View of the concrete foundation wall of the apparatus room of Building 550 (ERDC-CERL, 2018). 


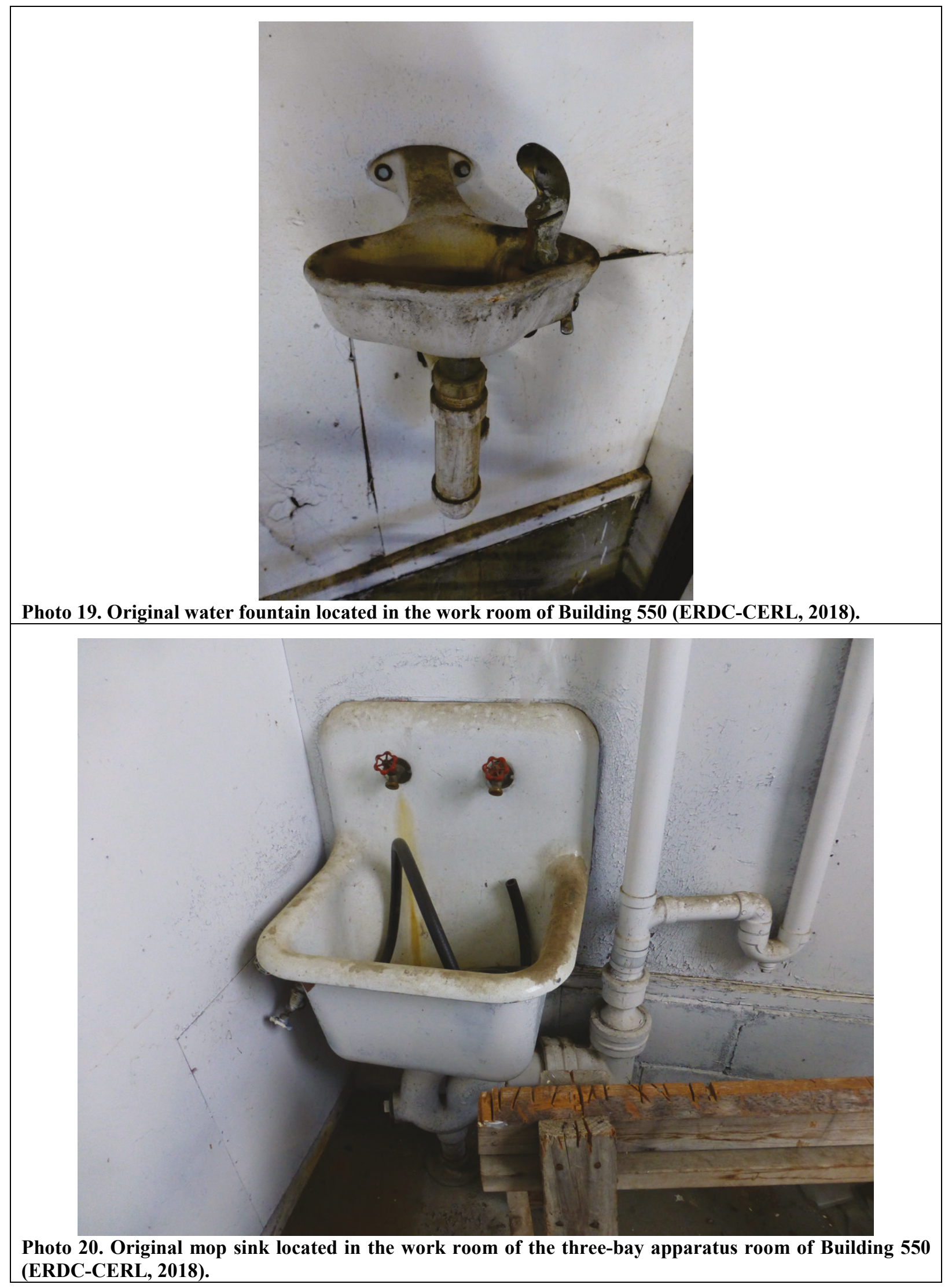




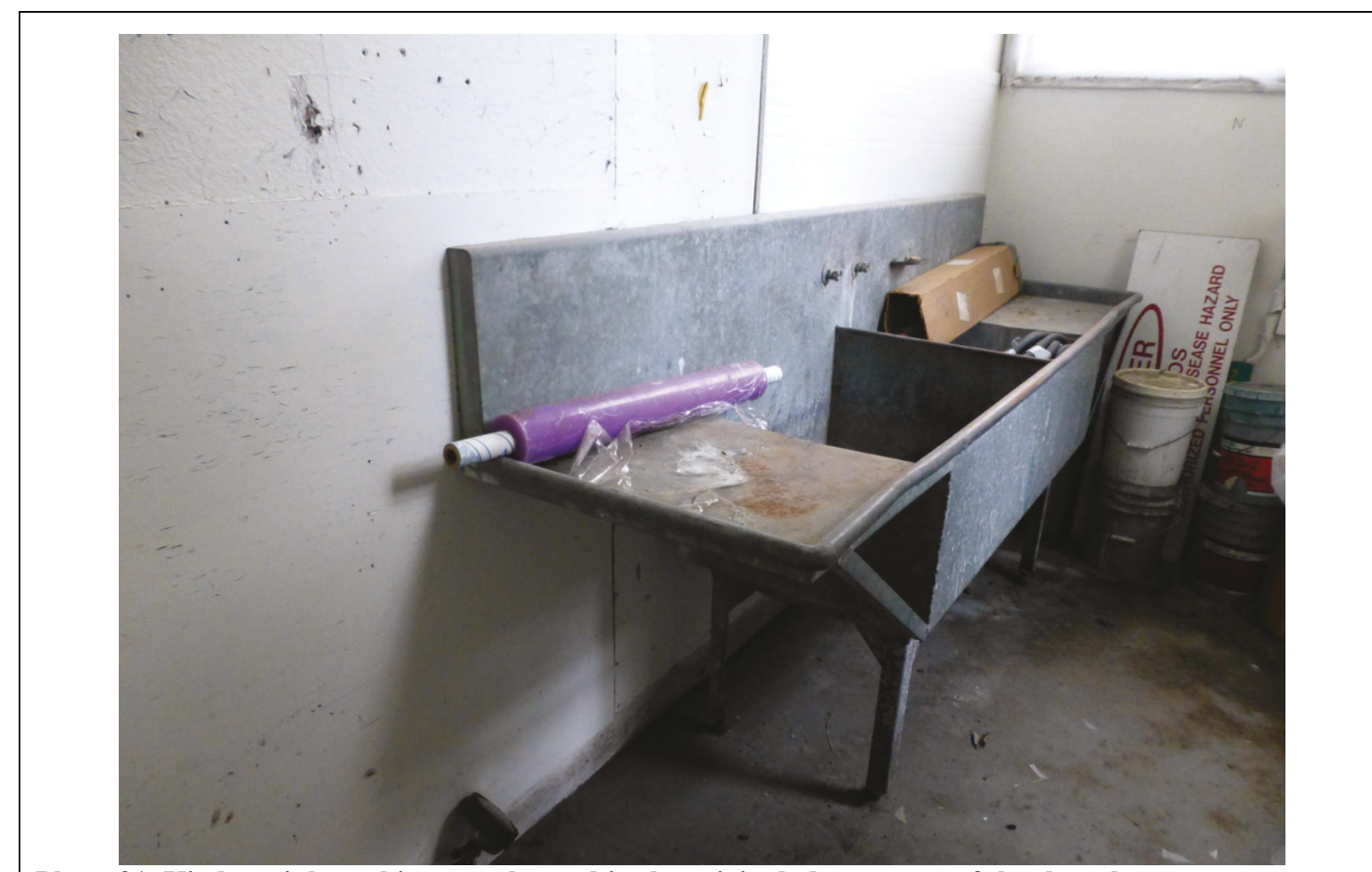

Photo 21. Kitchen sink washing area located in the original alarm room of the three-bay apparatus room in Building 550 (ERDC-CERL, 2018).

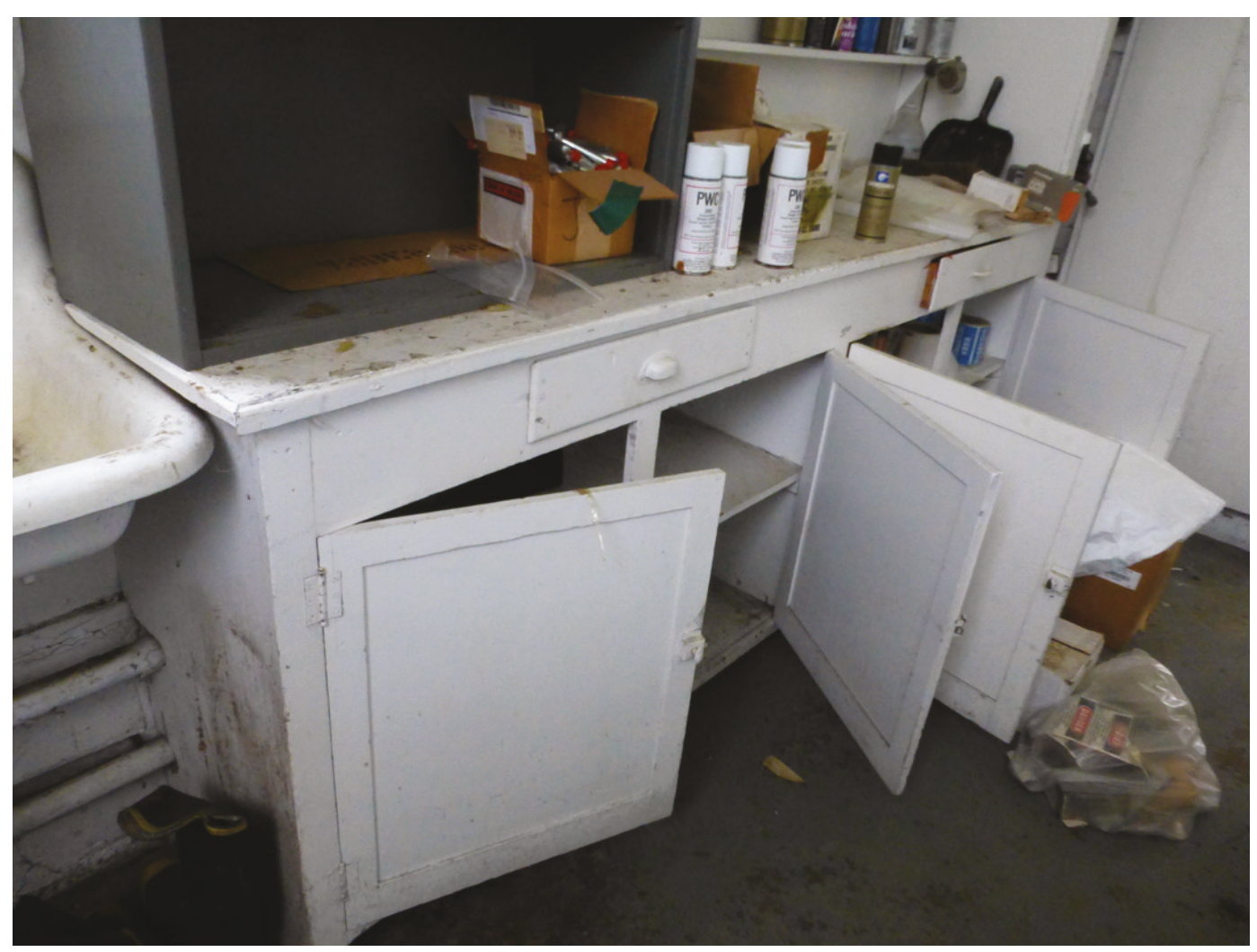

Photo 22. Original cabinetry in the original alarm room of the three-bay apparatus room of Building 550 (ERDC-CERL, 2018). 


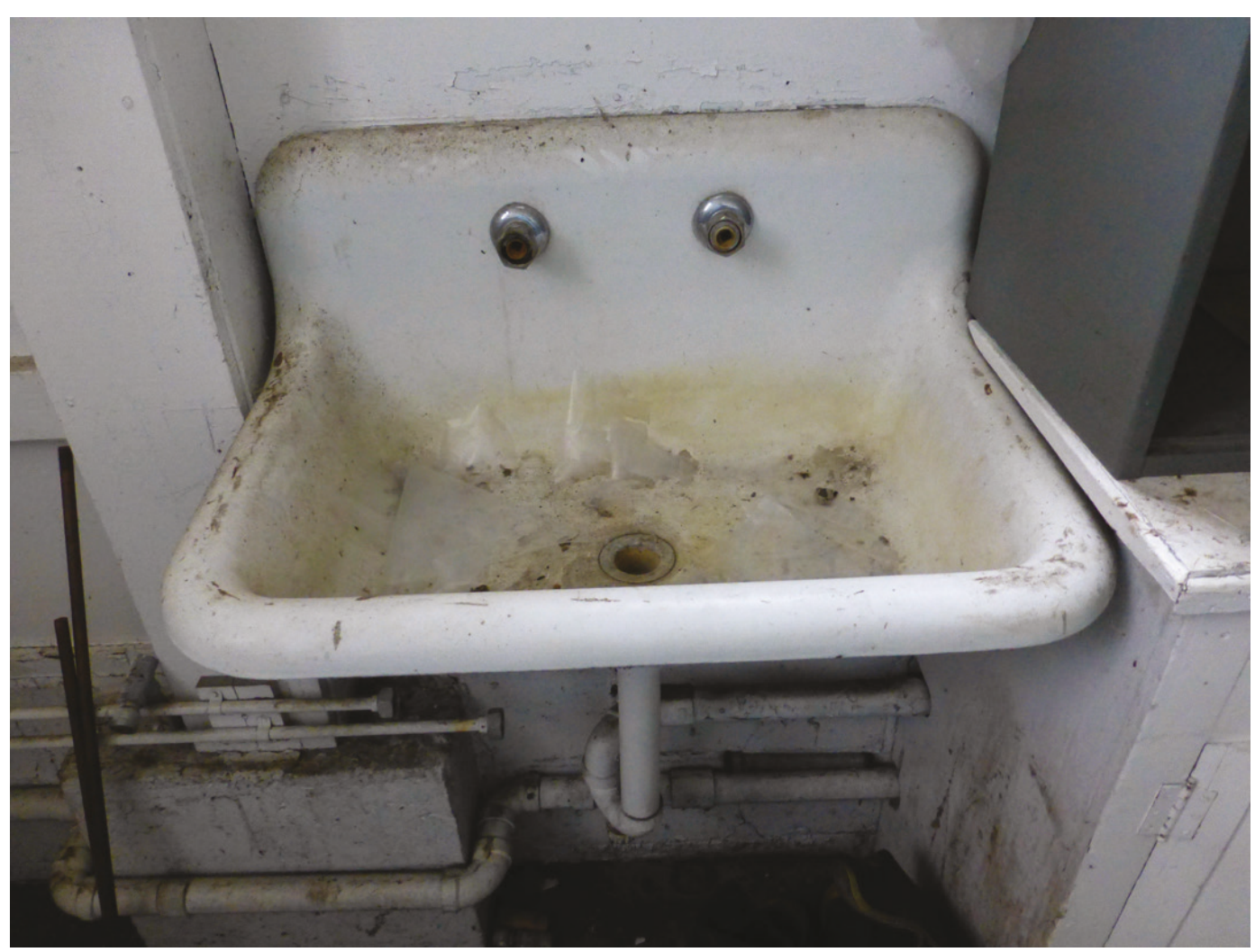

Photo 23. Original mop sink in the original alarm room of the three-bay apparatus room of Building 550 (ERDC-CERL, 2018).

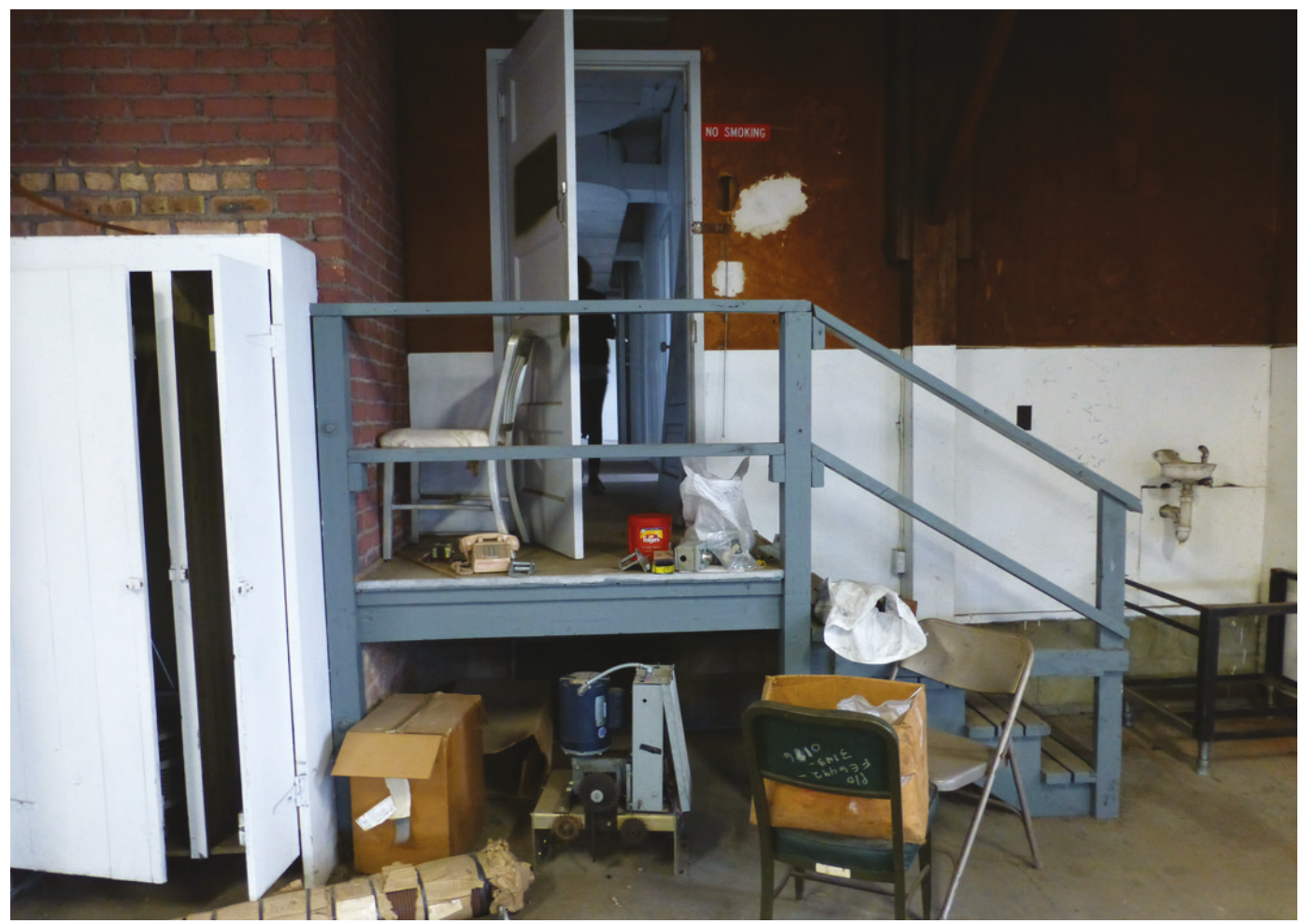

Photo 24. Looking east from the three-bay apparatus room of Building 550 towards the elevated living area of the building (ERDC-CERL, 2018). 


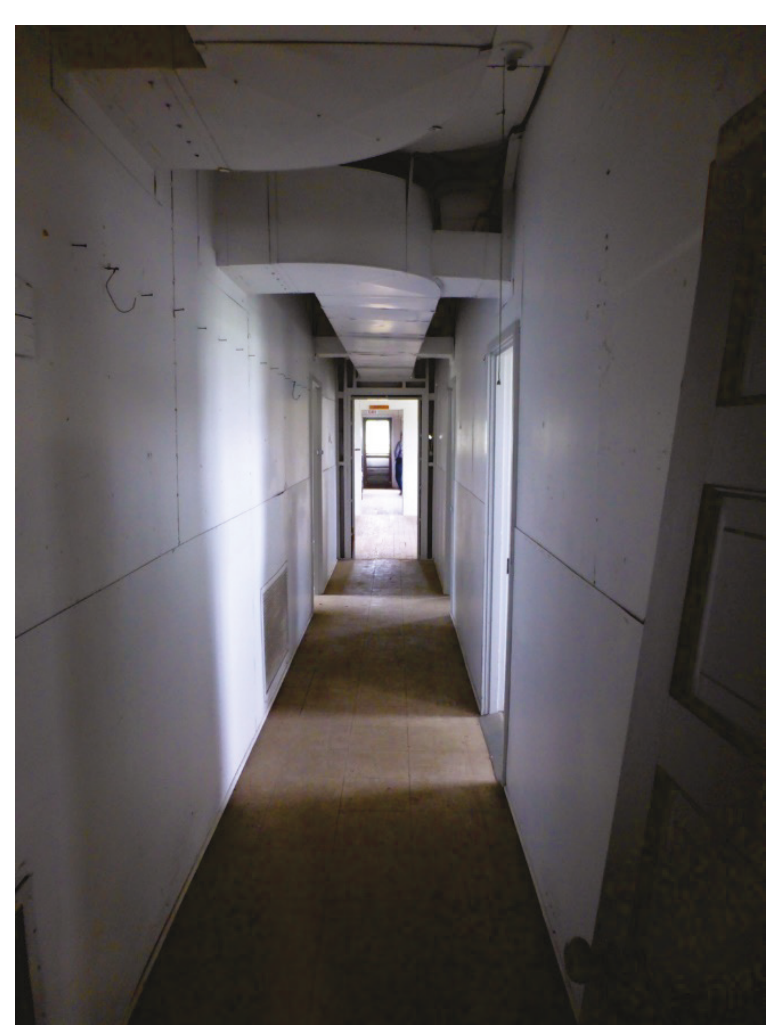

Photo 25. Looking east down the central corridor of the living area of Building 550 (ERDC-CERL, 2018).

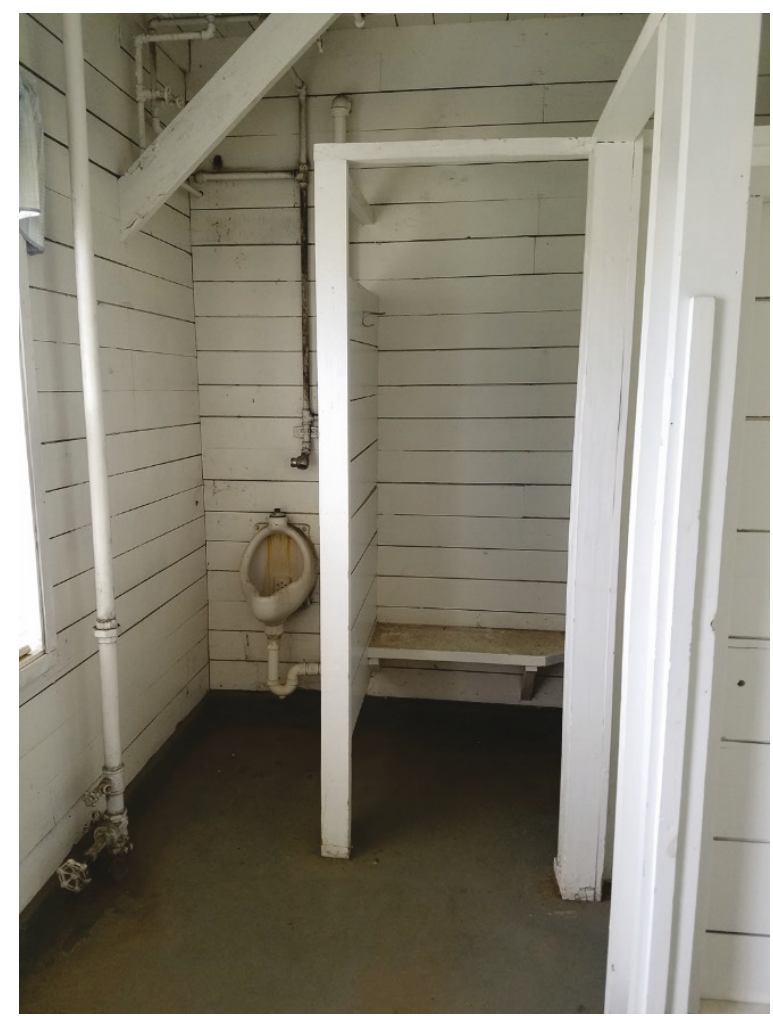

Photo 26. Original latrine area in Building 550 with original wood plank walls, exposed ceiling, concrete floor, and urinal (ERDC-CERL, 2018). 


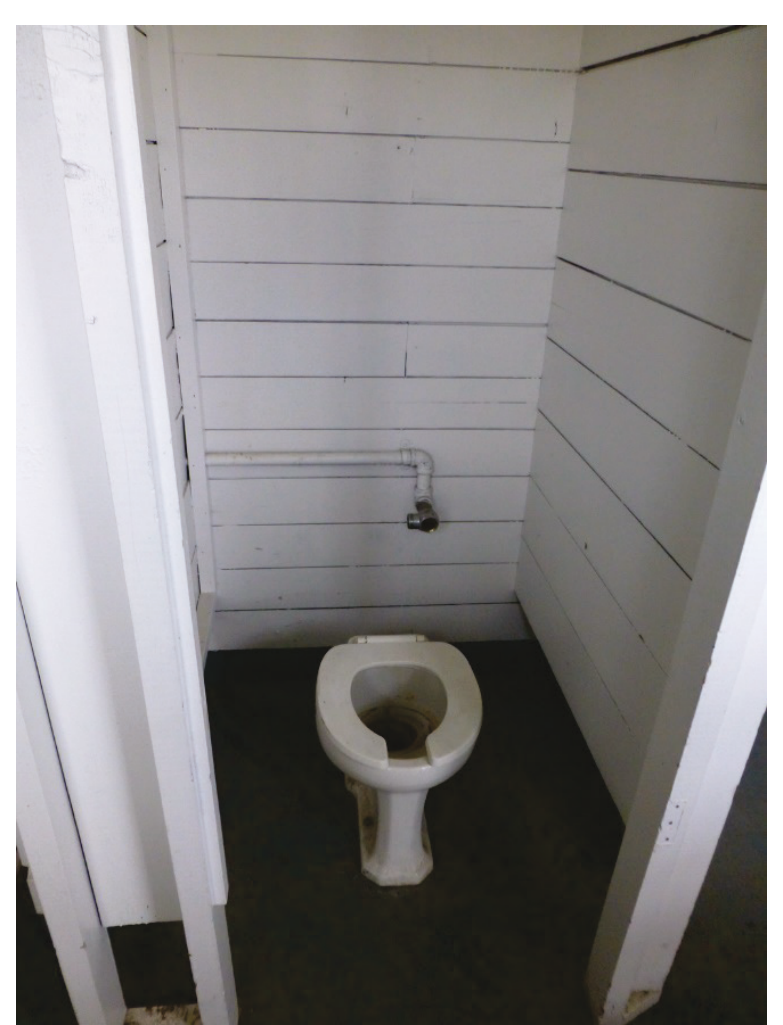

Photo 27. Replacement toilet in the latrine of Building 550 (ERDC-CERL, 2018).

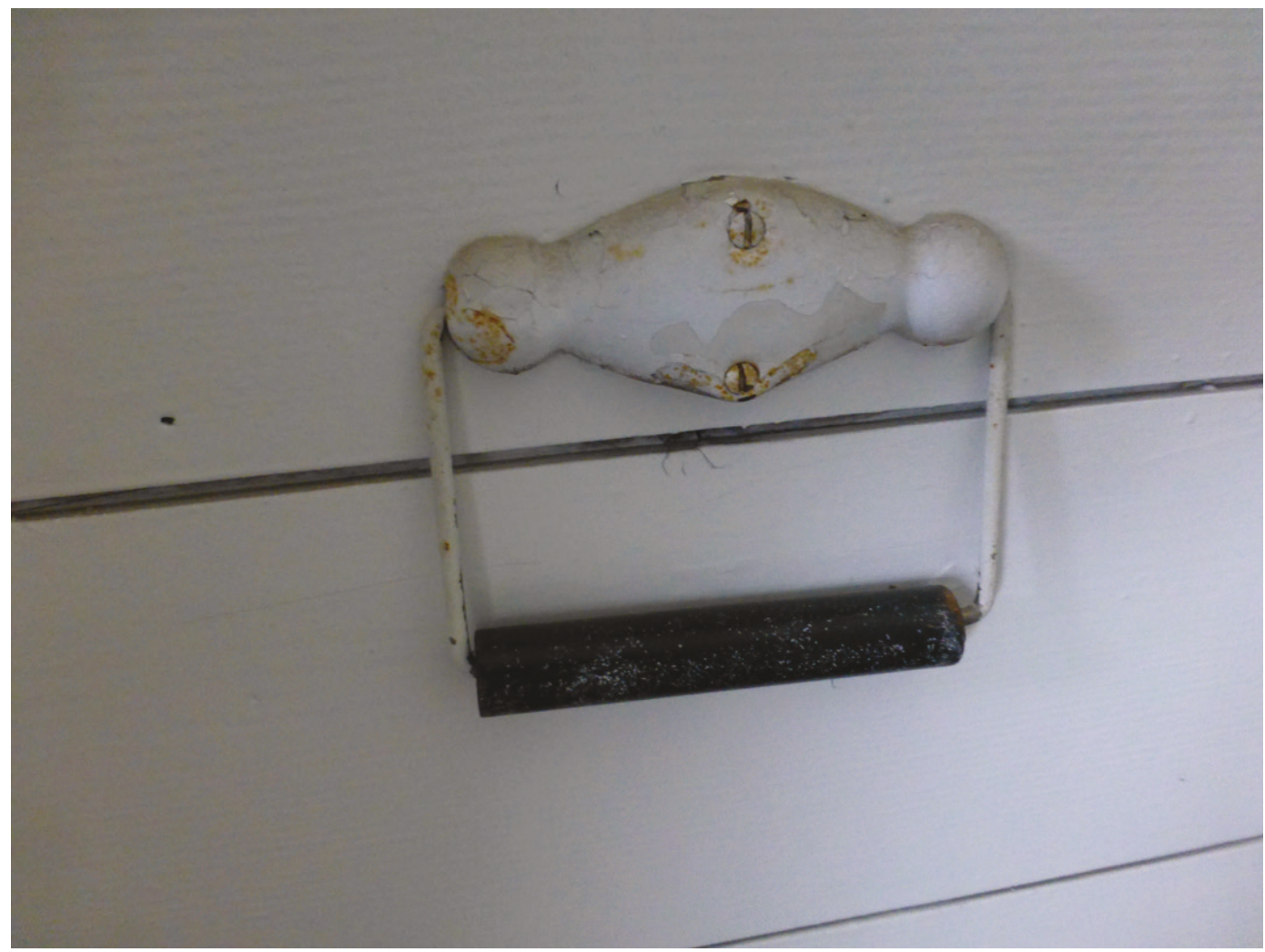

Photo 28. Original toilet paper holder in Building 550 (ERDC-CERL, 2018). 


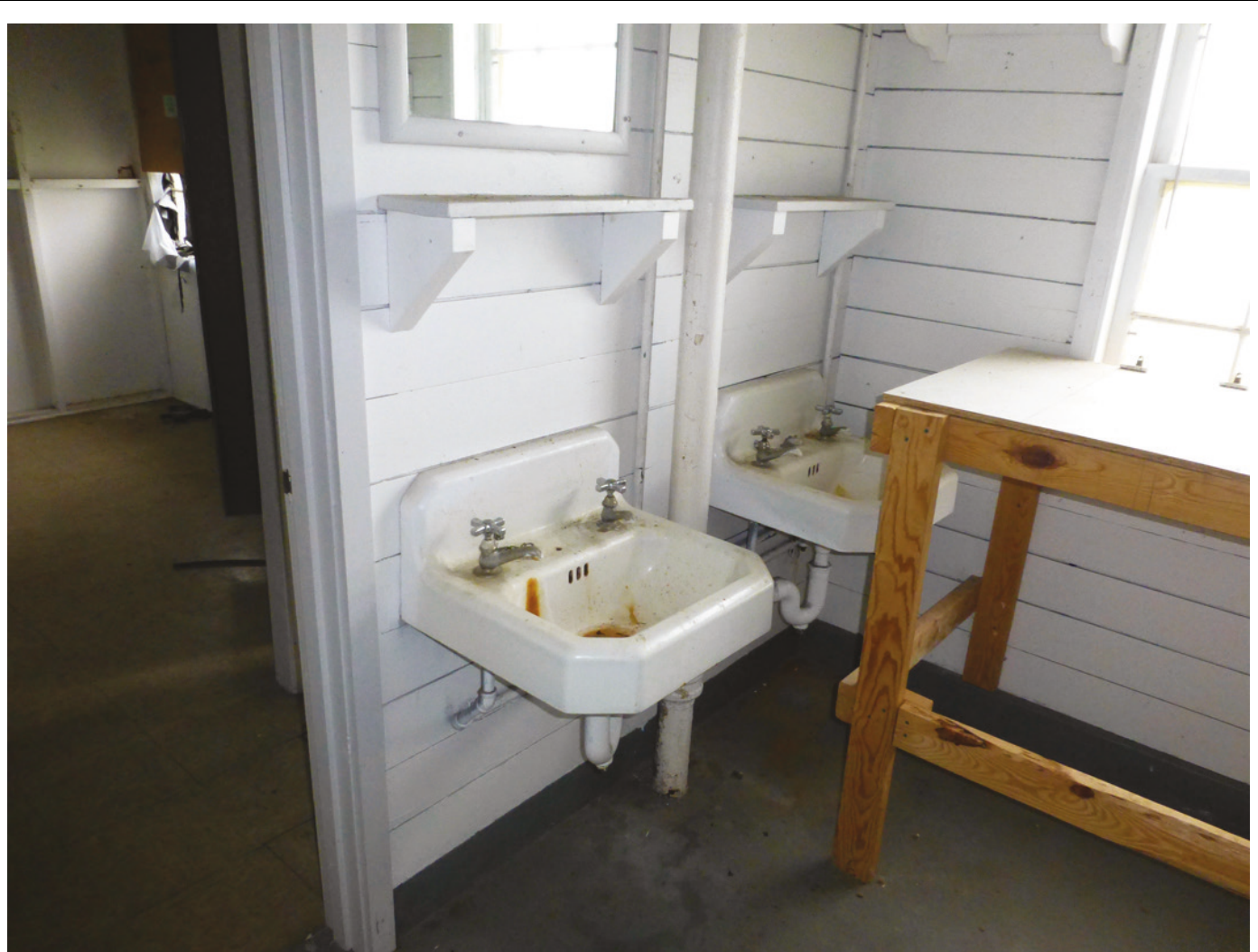

Photo 29. Original sinks, wood plank walls, mirrors, and shelves in Building 550 (ERDC-CERL, 2018).

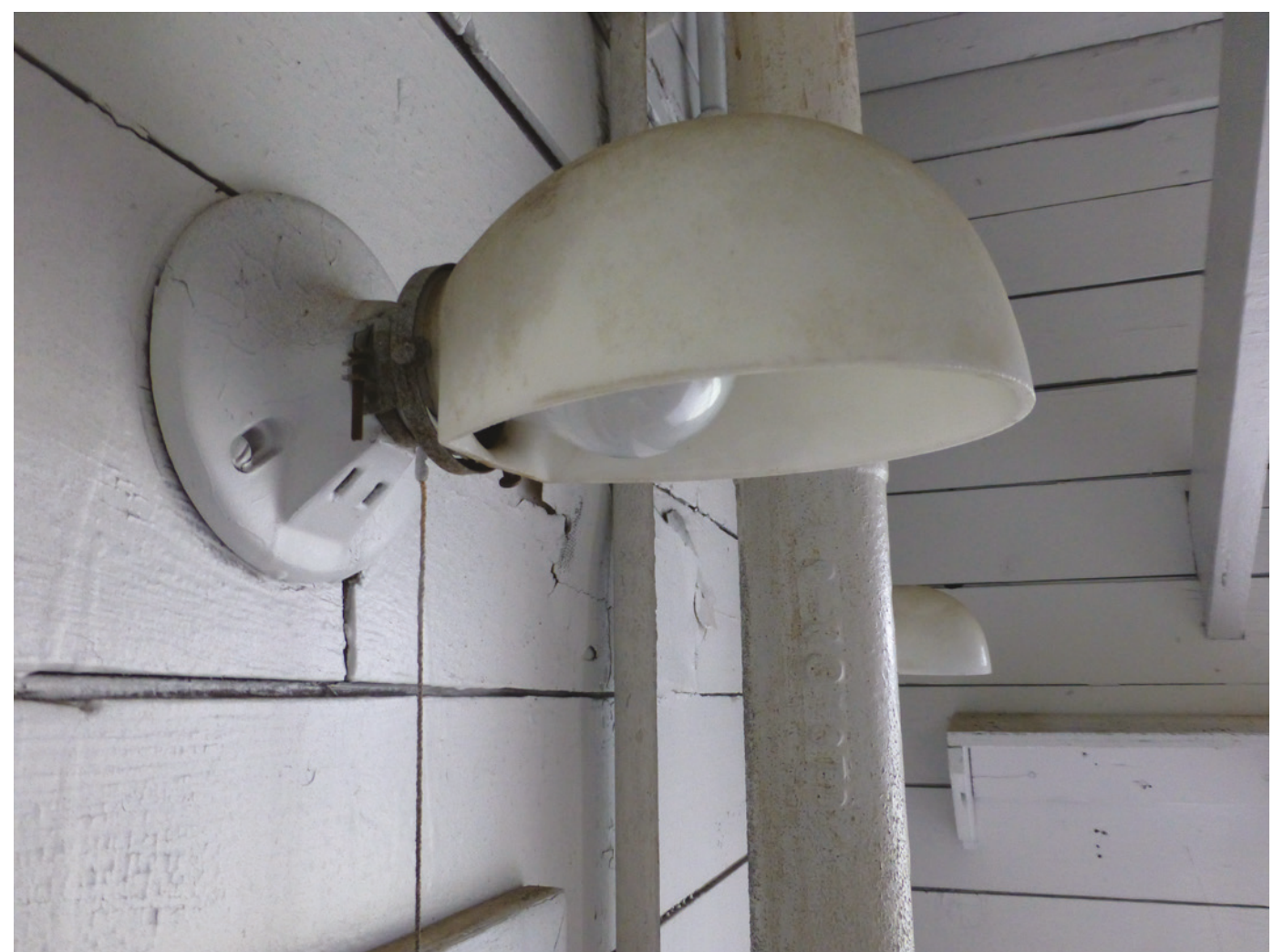

Photo 30. Original light fixture above latrine sinks in Building 550 (ERDC-CERL, 2018). 


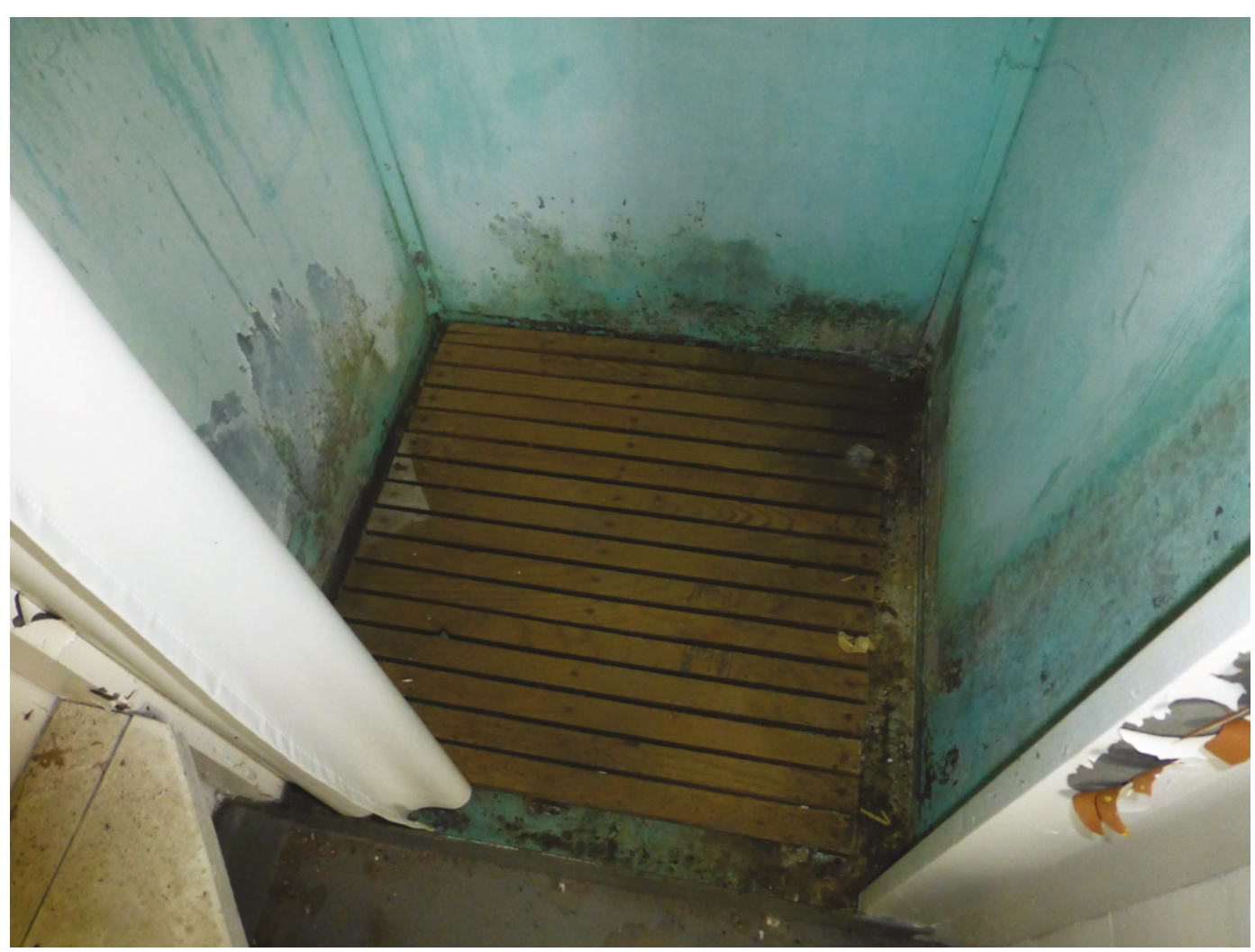

Photo 31. Shower stall in Building 550 with wood plank floor (ERDC-CERL, 2018).

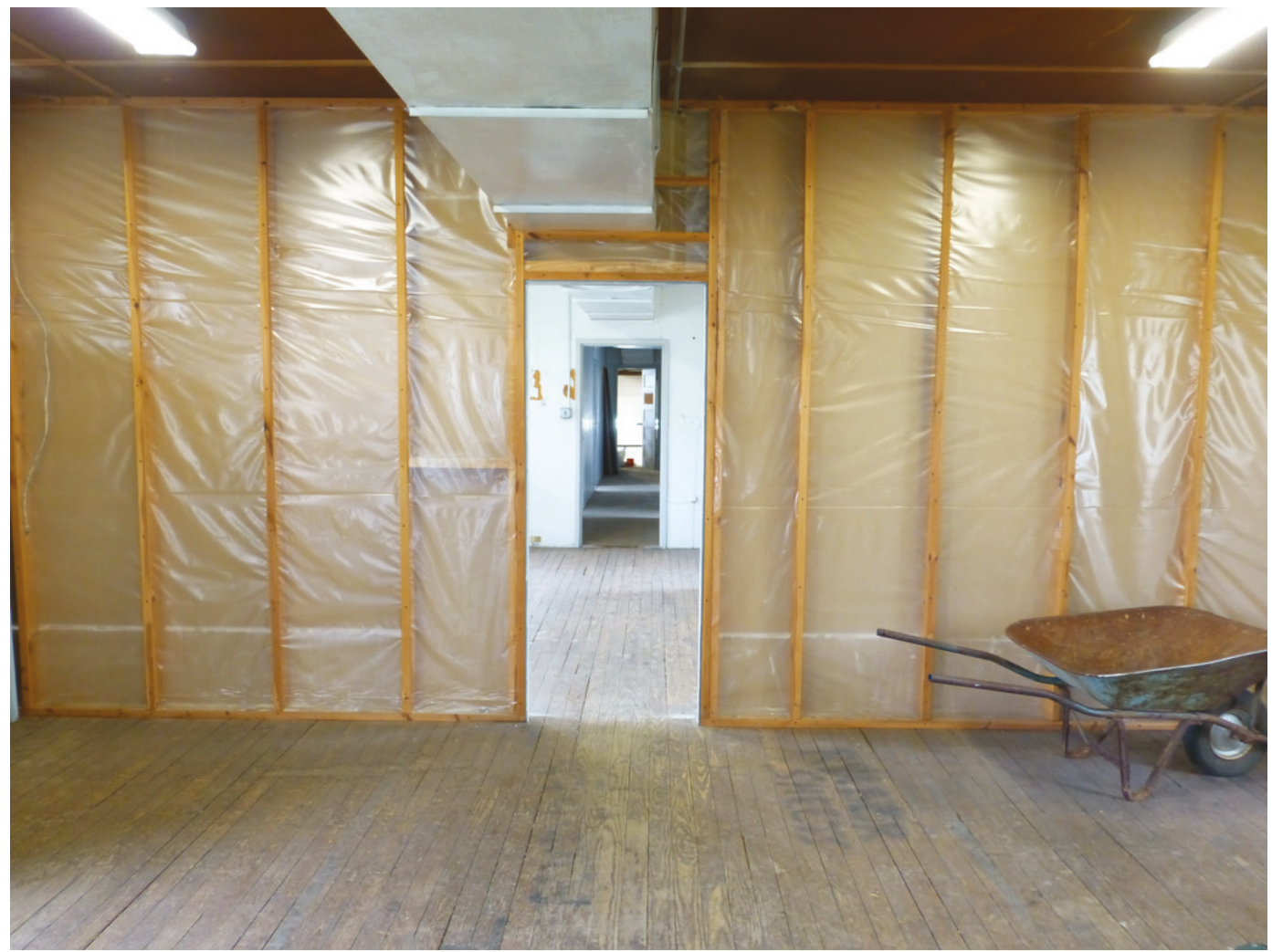

Photo 32. Looking west in the original squad room with original wood floors and modified open bay with new partition wall in Building 550 (ERDC-CERL, 2018). 


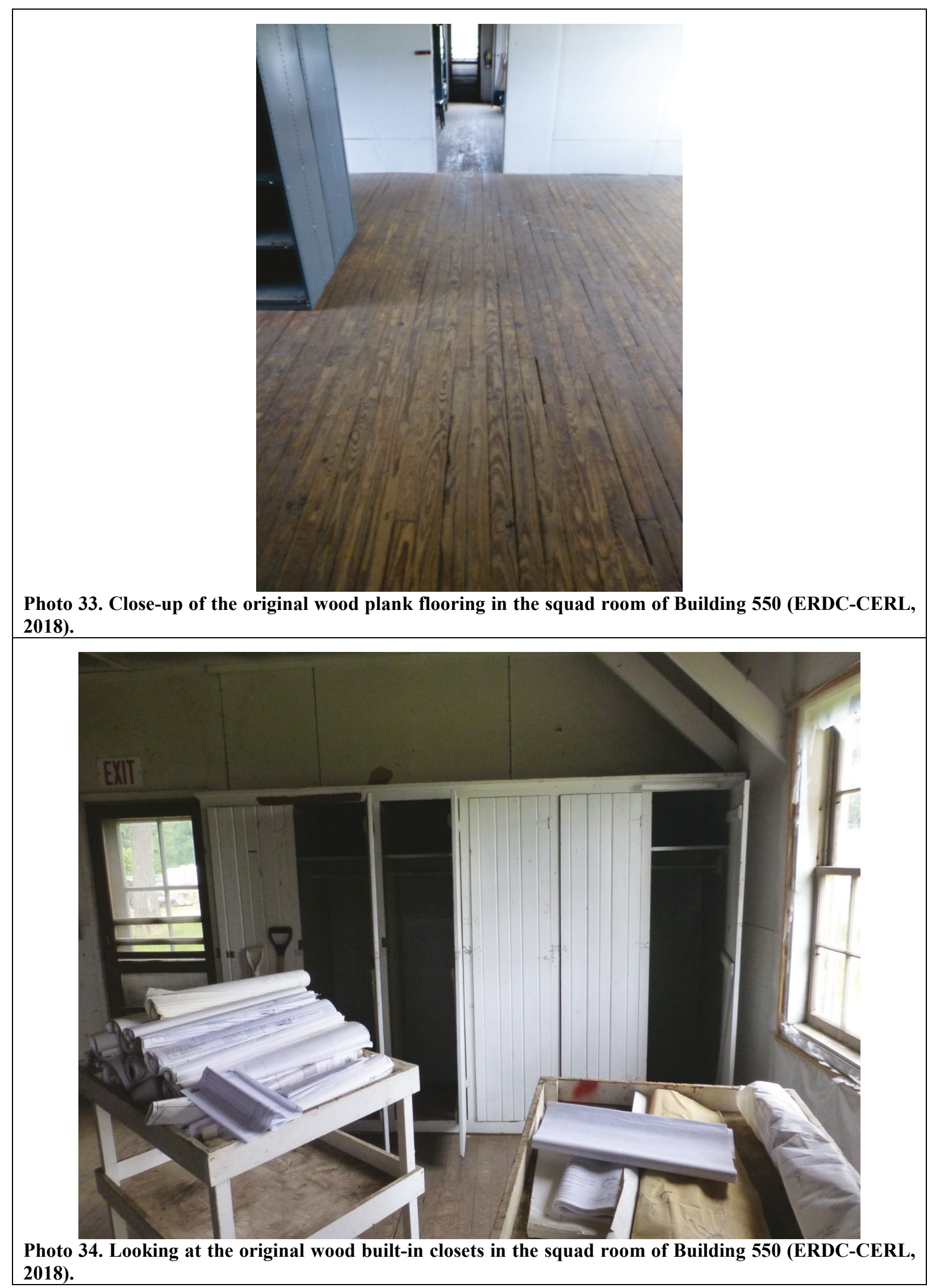




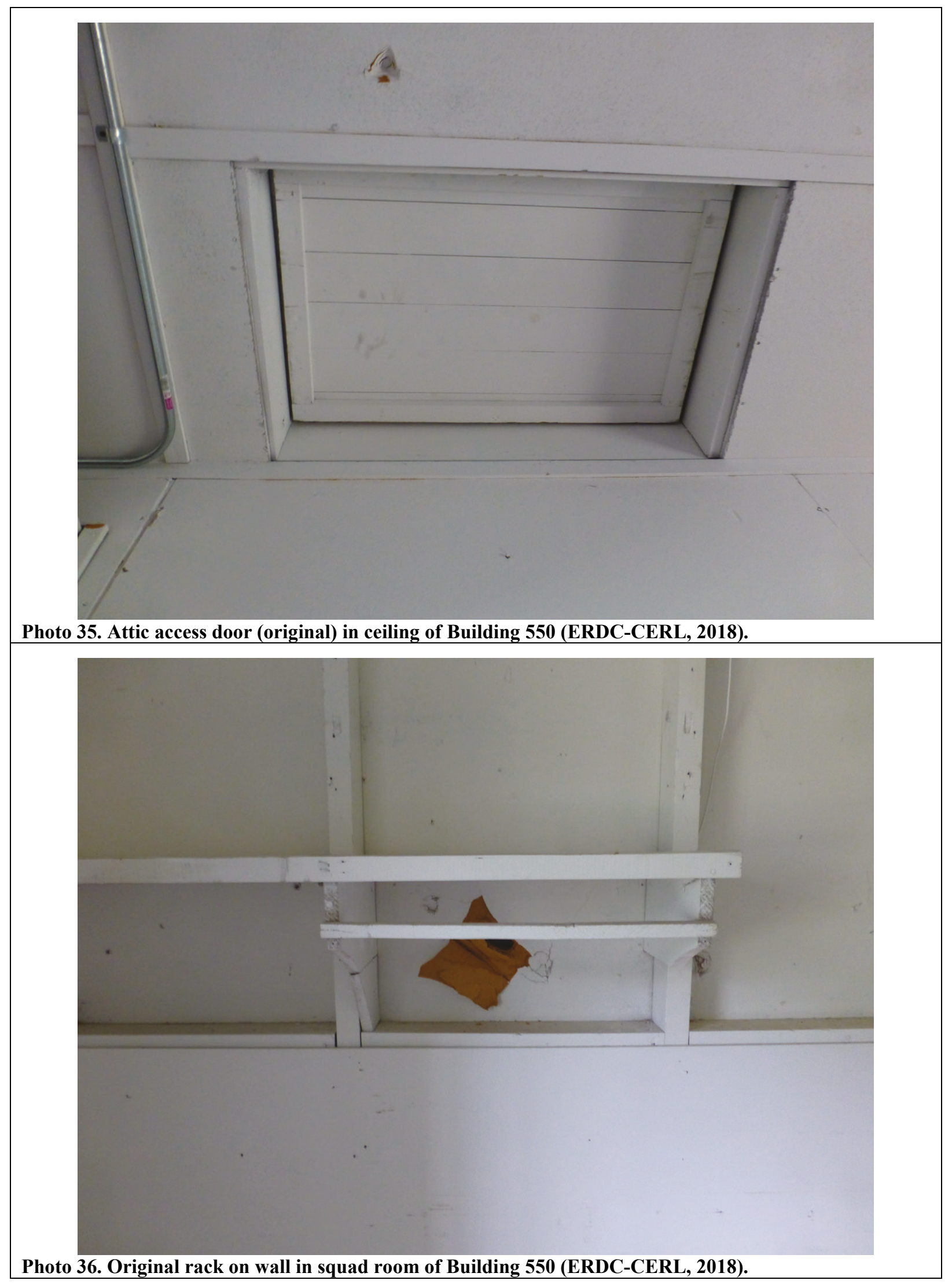




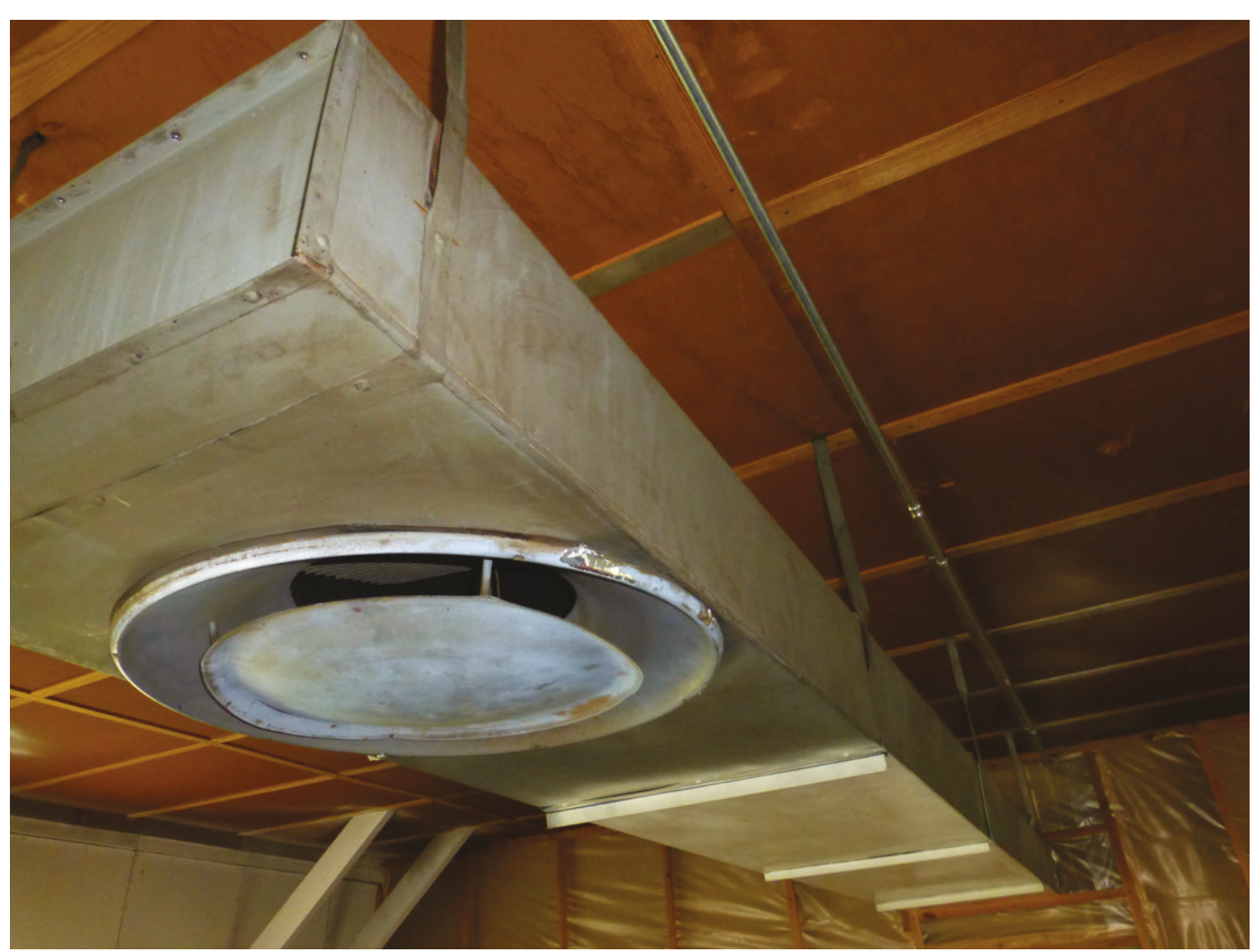

Photo 37. Original suspended mechanical and exhaust system in the squad room of Building 550 (ERDCCERL, 2018).

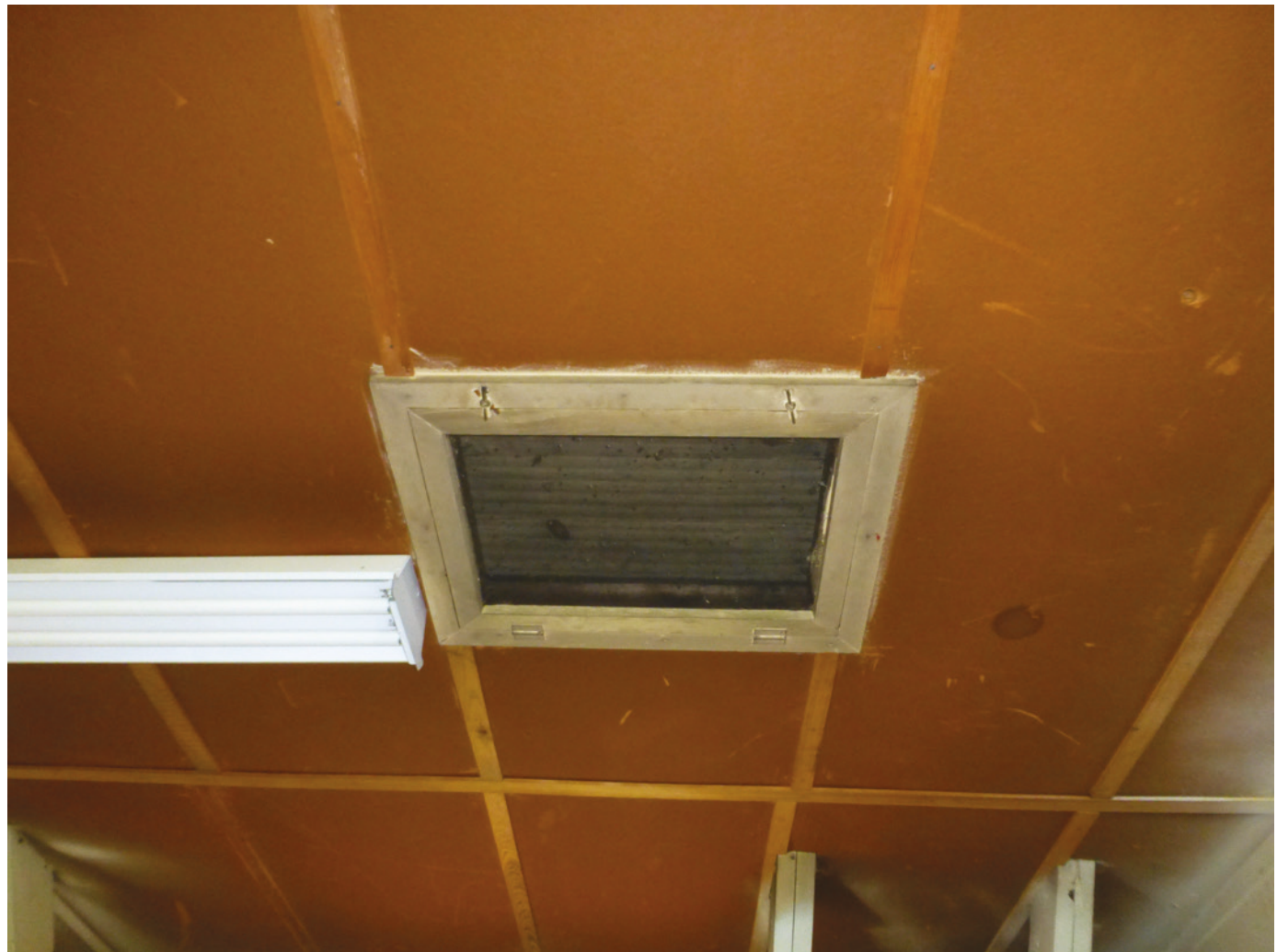

Photo 38. Original ceiling venting system in the squad room of Building 550 (ERDC-CERL, 2018). 


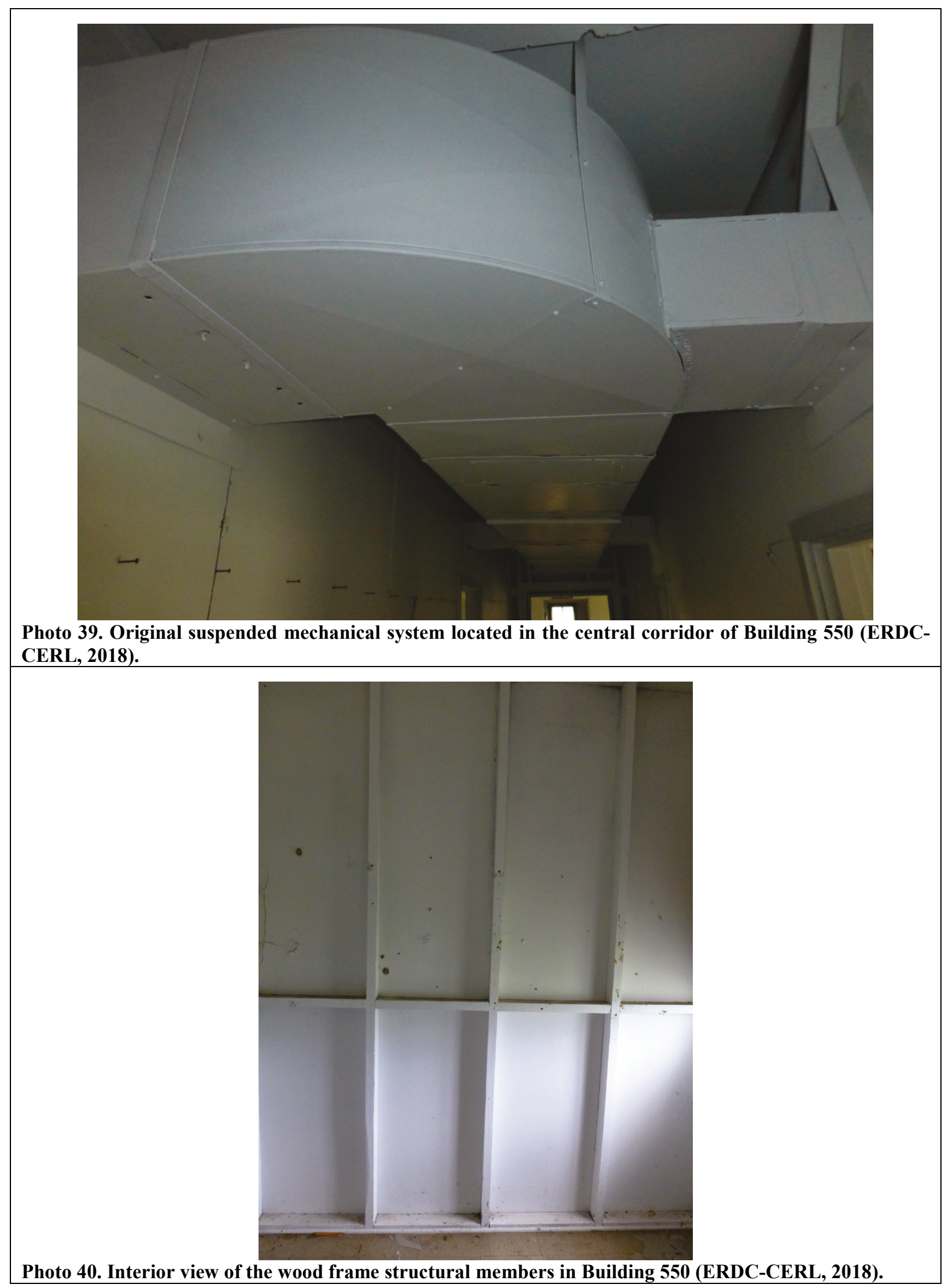




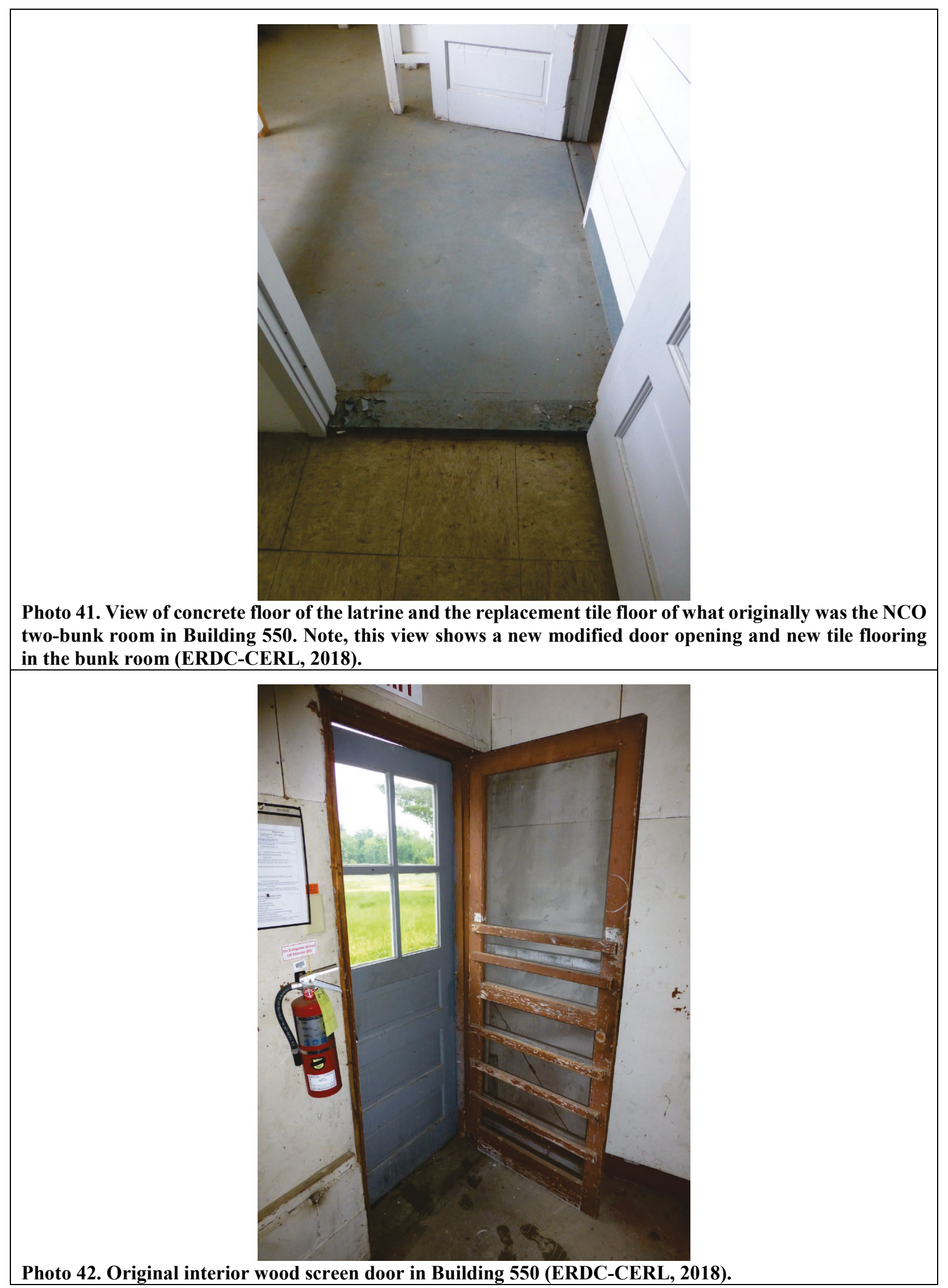




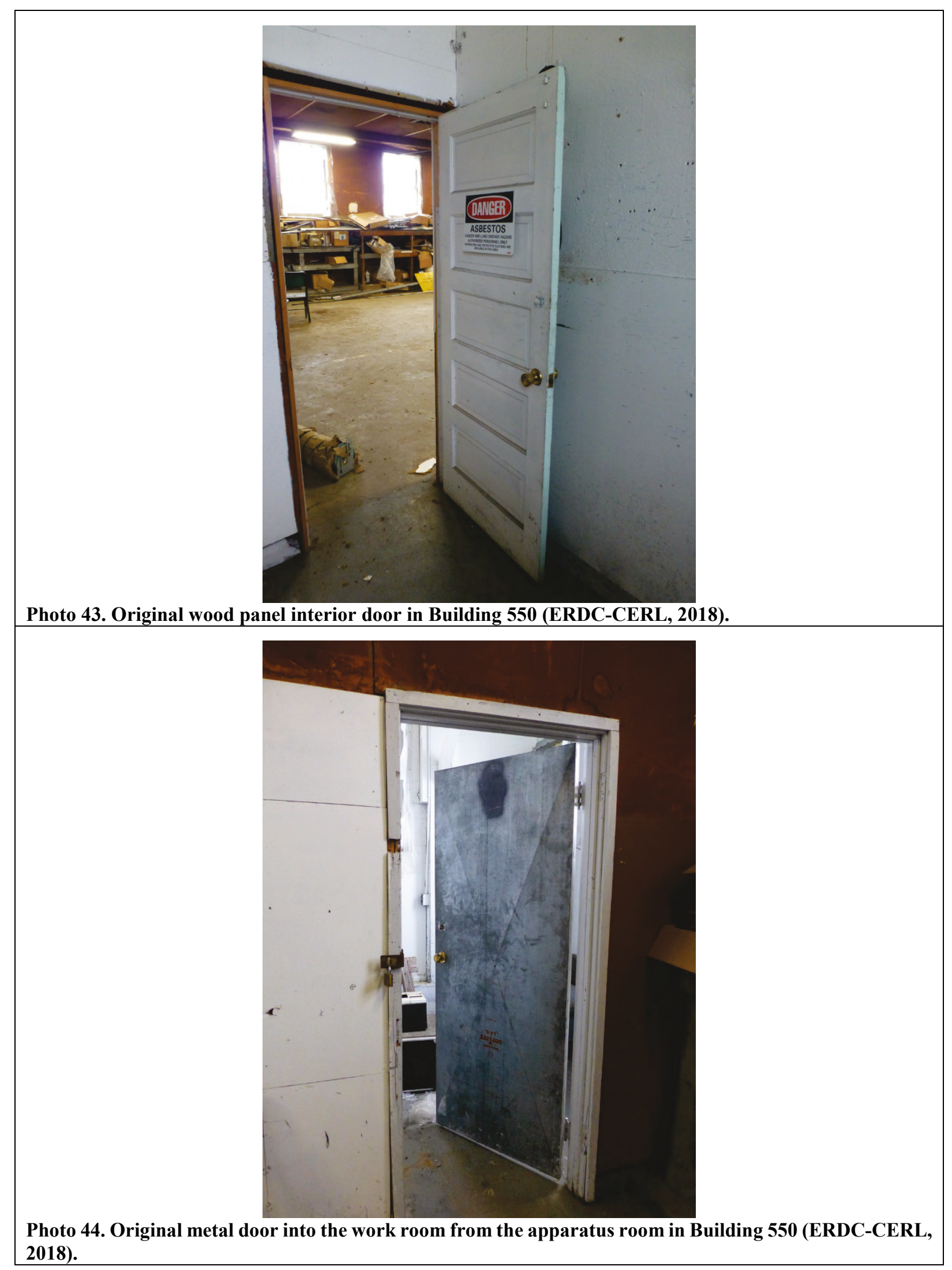




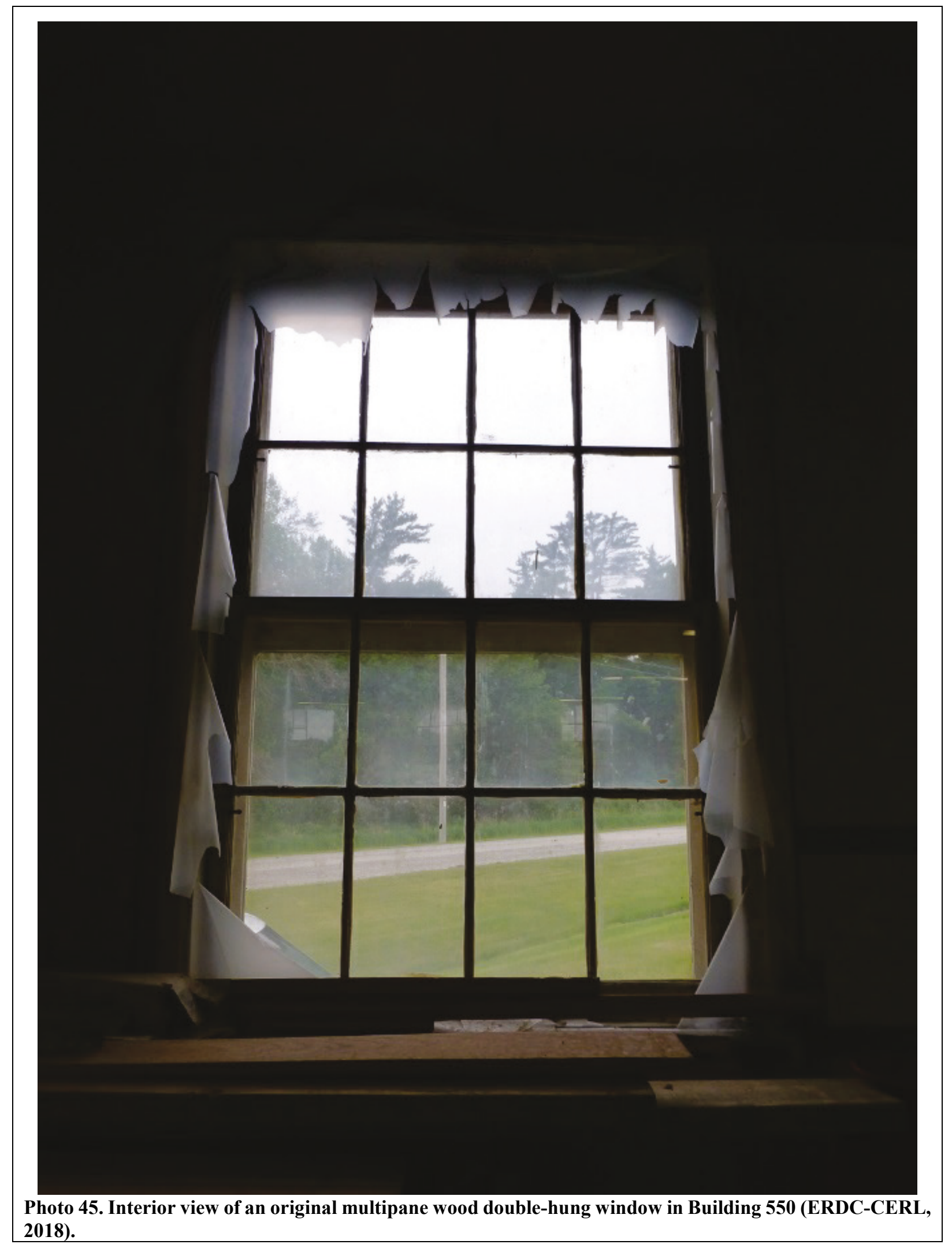




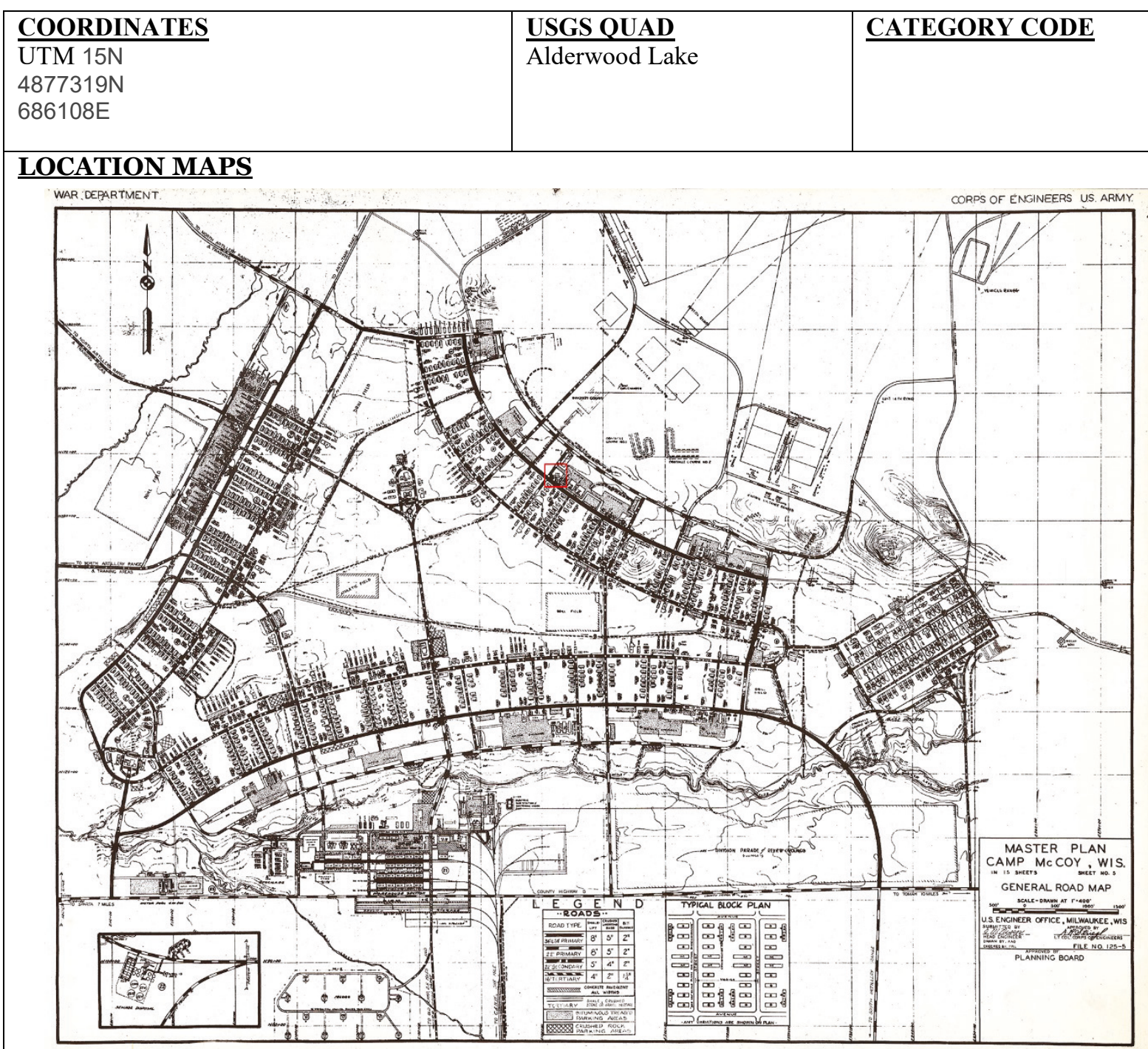

Master plan of Camp McCoy, ca. 1942 with the location of Building 550, Fire Station, indicated by the red box in upper center of the map (Fort McCoy DPW). 


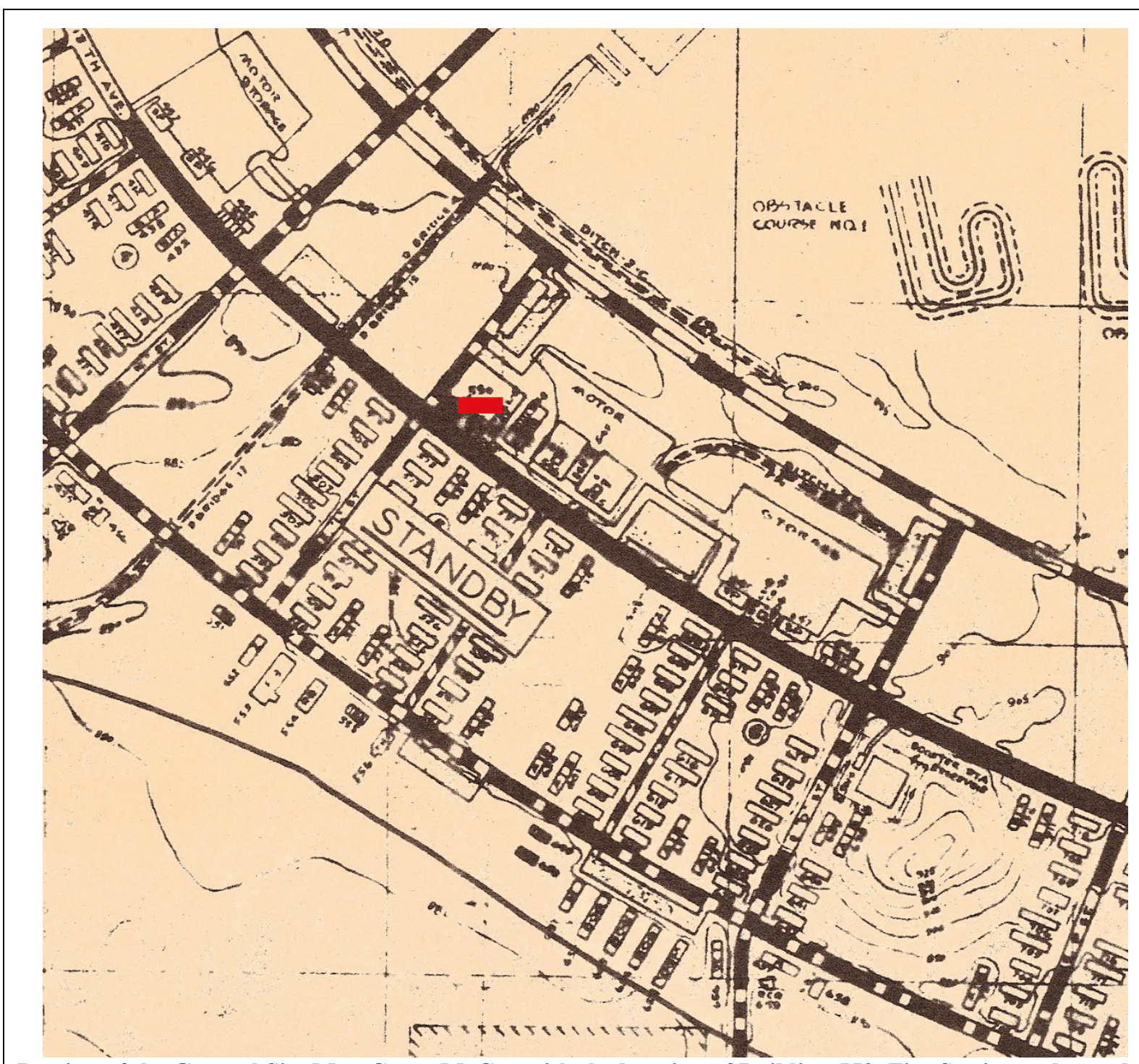

Portion of the General Site Map Camp McCoy with the location of Building 550, Fire Station, color-coded in red, 1947 (Fort McCoy DPW). 


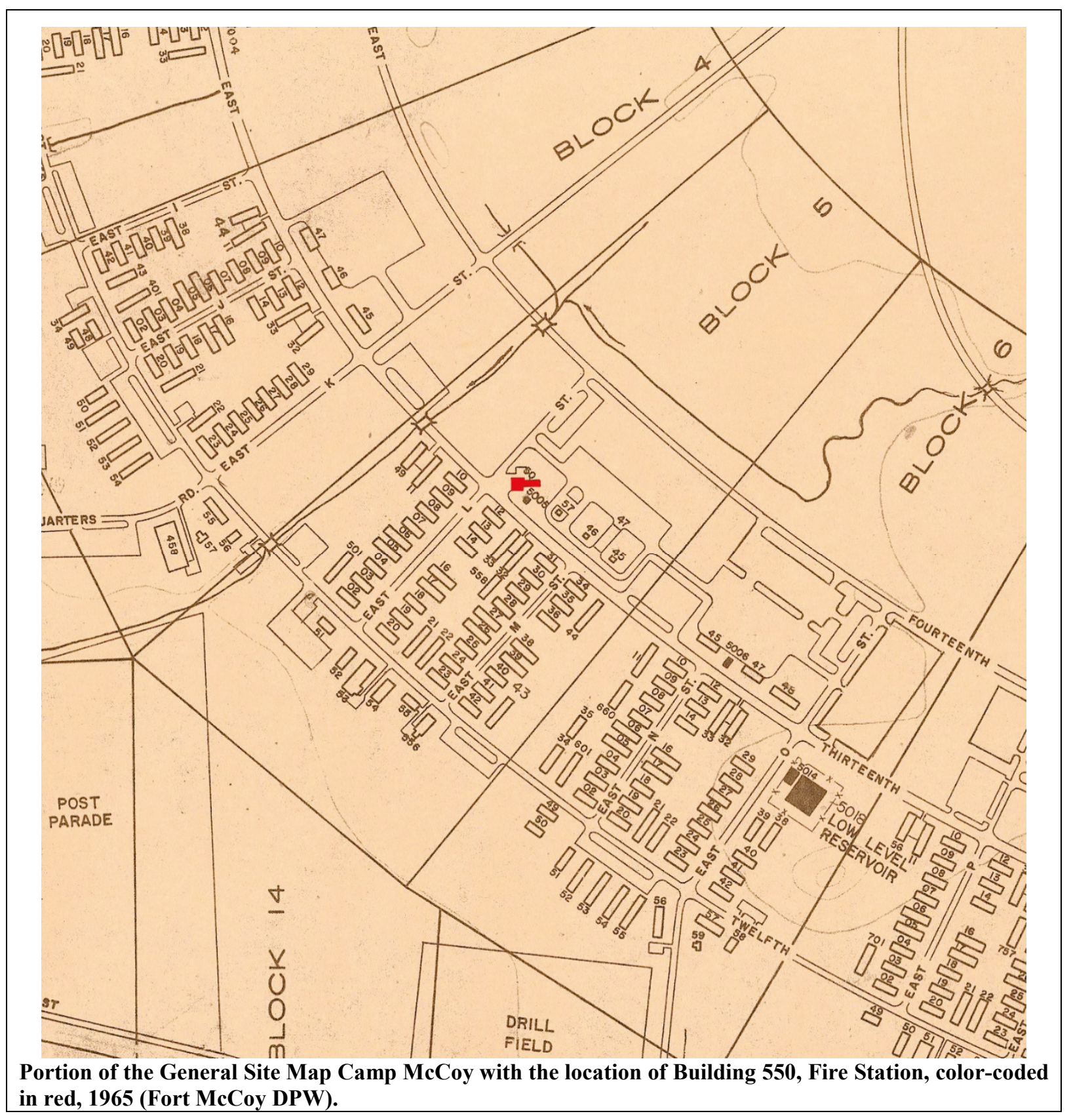




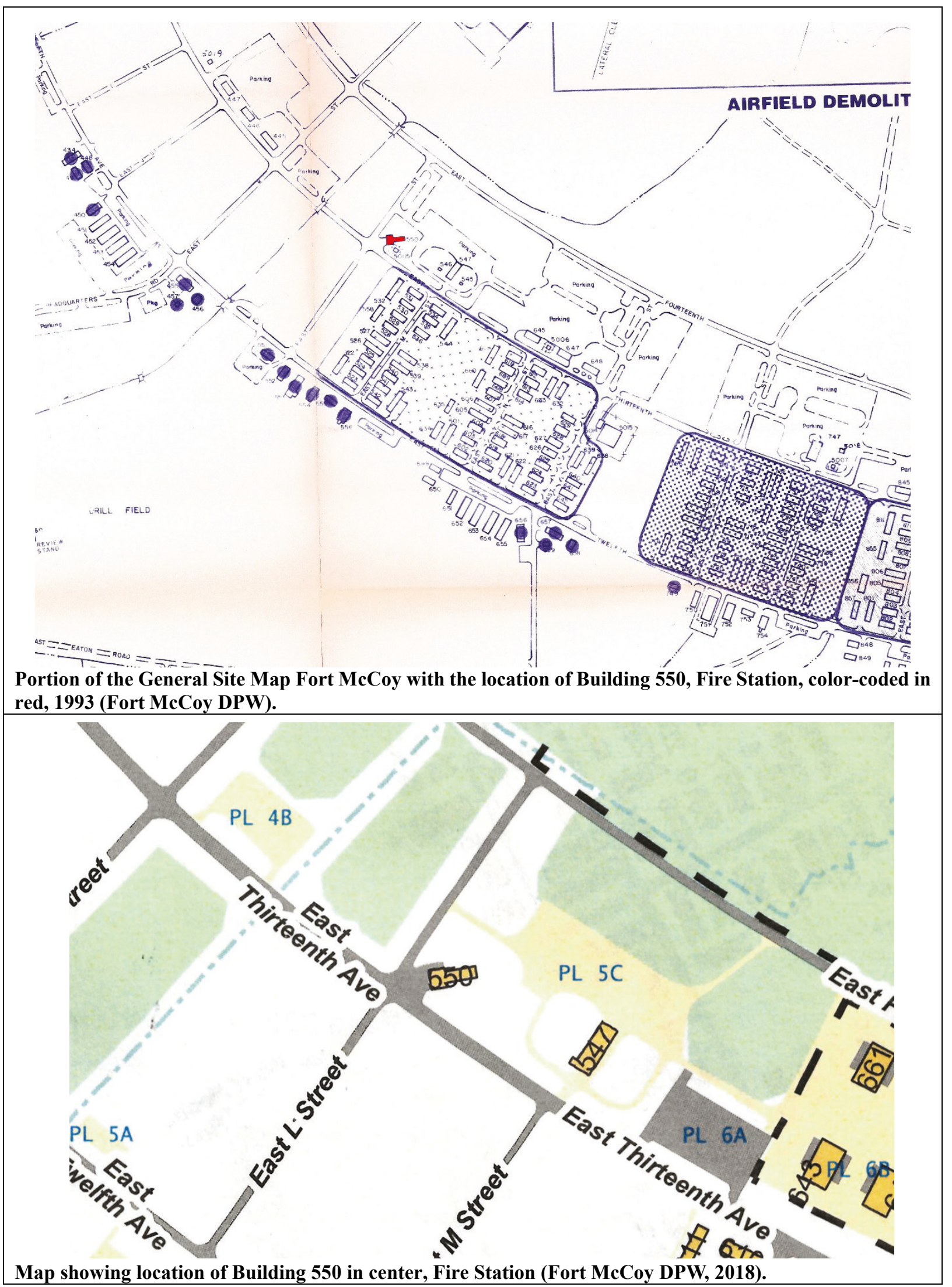




\section{DRAWINGS}

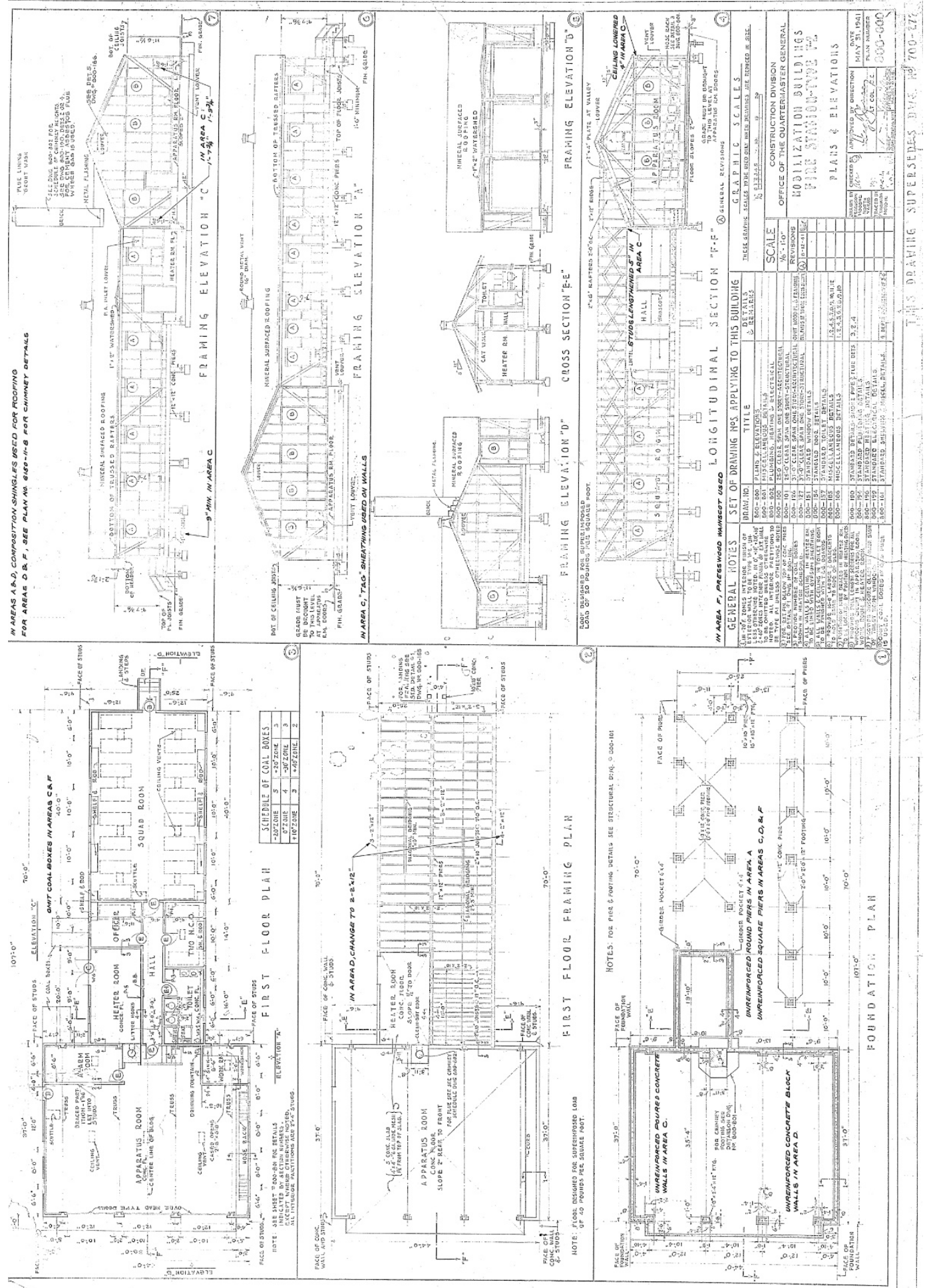

Original construction drawings, Series 800-800, plans and elevations for Building 550, Fire Station, 1941 (Fort McCoy DPW). 


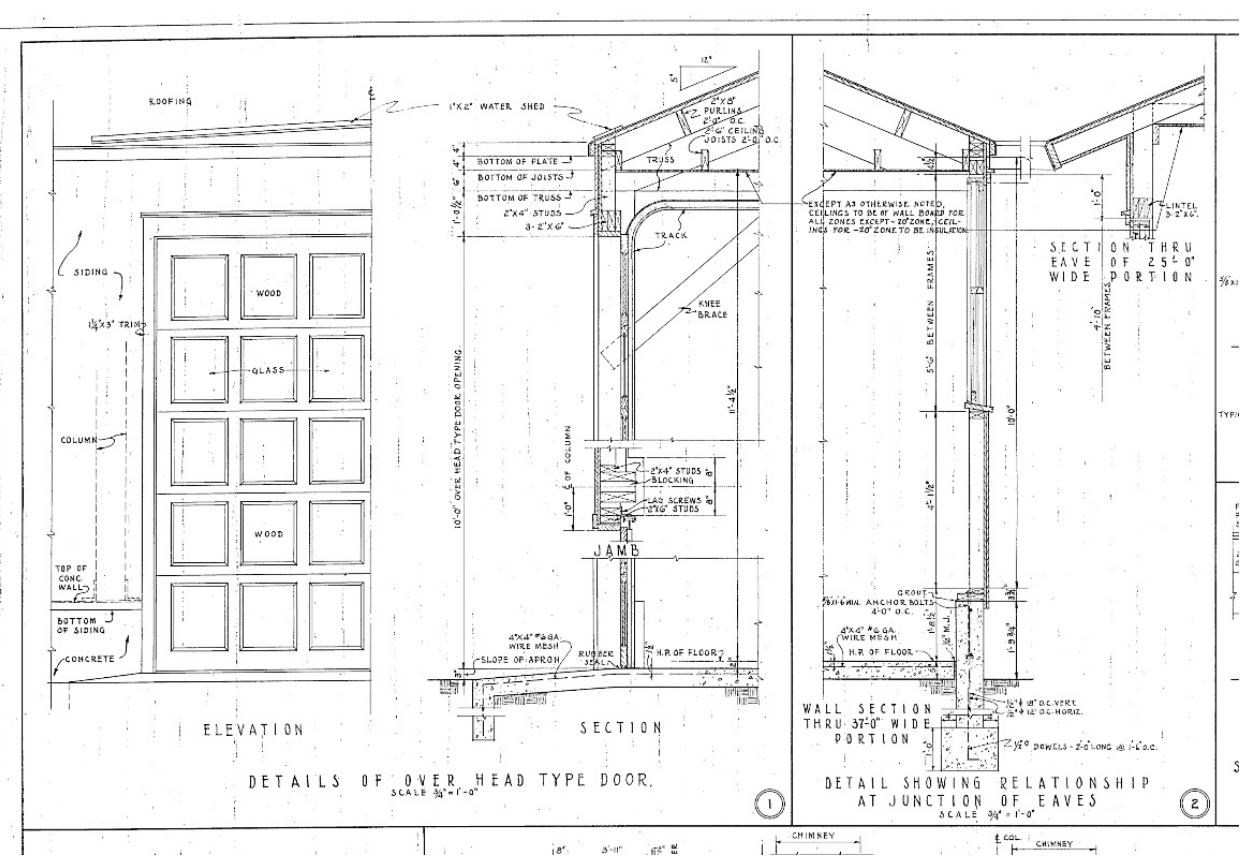

Original construction drawings, Series 800-801, overhead door and overhanging eaves details for Building 550, Fire Station, 1941 (Fort McCoy DPW).

\section{PRESENT OWNER}

Fort McCoy Commander
OWNER ADDRESS

Department of the Army

US Army Garrison, Fort McCoy

100 East Headquarters Road

Fort McCoy, WI 54656

\section{GENERAL CONDITION OF PROPERTY \\ ADDITIONS/ALTERATIONS}

EXCELLENT

GOOD

POOR

YES

NO

IF YES, SEE HISTORY

\section{BIBLIOGRAPHIC SOURCES}

HABS No. WI-308. "Fort McCoy (Camp McCoy)," Sparta vicinity Monroe County, Wisconsin, HABS No. WI308. (Washington, DC: Historic American Buildings Survey, National Park District, Department of the Interior, 1988). Catalogued by Library of Congress as HABS WIS, 41-SPAR.V, 1-:

https://cdn.loc.gov/master/pnp/habshaer/wi/wi0200/wi0229/data/wi0229data.pdf.

\section{ARCHIVAL SOURCES}

Real Property Record Cards on file at Fort McCoy, Wisconsin

Drawing documentation on file at Fort McCoy, Wisconsin

NARA College Park, Maryland 
PRELIMINARY NATIONAL REGISTER DETERMINATION OF ELIGIBILITY

ELIGIBLE/CONTRIBUTING NOT ELIGIBLE/ NON-CONTRIBUTING

\section{FORM PREPARED BY:}

Sunny Adams

Engineer Research and Development Center

Construction Engineering Research Laboratory

2902 Newmark Drive

Champaign, IL 61822

DATE: September 2018 


\section{DESCRIPTION}

Building 550 is located east of the intersection of East Thirteenth Avenue and East L Street in the 500 block of the cantonment. Only one other structure, Building 547, is located within this block.

Building 550 is a one-story structure with a T-shaped footprint, a cross-gable roof clad with red asphalt shingles and overhanging eaves with modified soffits, and exterior walls clad with textured asbestos cement siding with a scalloped bottom edge. The foundation of the three-bay apparatus room and the heater room is concrete block wall, while the foundation of the living area is a concrete pier foundation system. Original, gray wooden foundation "skirting" wraps around perimeter of the living area foundation (see Photo 11). The windows are original multipane wood double-hung windows with wood screens (see Photo 13). The entry doors into the building are wood panel and divided light. The wood trim around the doors and windows are original in width and profile (see Photo 14). The overhead doors are replacement metal doors (see Photo 1). The asbestos cement siding is poor condition. Some areas it is completely missing exposing the wood structural framing system underneath, while some has been replaced with newer cement siding that does not match the original in texture or scalloped edging detail (see Photos 8,10 , and 12). All of the original light fixtures have been modified; either the bulbs or shade removed leaving only the base or have been completely replaced with newer fixtures (see Photos 7 and 9). The building has an approximate square footage of 3,378 square feet.

The west elevation faces the intersection of East Thirteenth Avenue and East L Street and consists of three replacement overhead doors (see Photo1).

The north elevation is two-part. The right side is where the three-bay apparatus room is located and projects slightly out from the left side of the elevation where the living section of the building is located. The right side consists of three original windows and one original entry door. The left side consists of six original windows and a set of original entry doors (see Photos 2 and 3 ).

The east elevation consists of an elevated single entry original door that is accessed by a set of wood steps and wood stoop (see Photo 4).

The south elevation is two-part. The left side is where the three-bay apparatus room is located and projects slightly out from the right side of the elevation where the living section of the building is located. There are four evenly spaced original windows located on the left side of the elevation and eight original windows on the right side of the building (see Photos 5 and 6).

The interior layout and space usage of the building has seen little alteration. The open bay area of the apparatus room with concrete floor and gypsum clad walls and ceiling are intact (see Photos 15-18). The two small rooms within the apparatus room; work room with original mop sink and water fountain is intact (see Photos 19 and 20) and the alarm room with original cabinetry and sinks are intact (see Photos 21-23).

The living section of the building is elevated above the level of the apparatus room and accessed by a set of wood stairs (see Photo 24). A central corridor divides the west end of the space (see Photo 25). A heater room and small open room is located to the north, while a toilet room and small open room is located to the south of the corridor. The toilet room's original fixtures are mostly intact, such as the concrete floor, wood slat walls, shower stall, urinal, sinks, mirrors, light fixtures, and shelves (see Photos 26-31). The toilets have all been replaced (see Photo 27). A new door opening has been cut into the east wall of the toilet room to adjoin it to the adjacent small room (see Photo 41).

At the east end of the corridor is a large open space that has been slightly modified with a newer wood frame partition wall. The open room has original wood floors and walls and ceiling clad with fiber insulation boards (see Photos 32 and 33). Two sets of original wood built-in closet units are located along the east wall of the room (see Photo 34).

The interior doors are original wood panel doors (see Photo 43). There are original wood screen doors leading out to the exterior of the building (see Photo 42). The original suspended mechanical systems and duct work is intact in the open room and central corridor (see Photos 37-39). 


\section{HISTORY}

The construction of Building 550 was part of a massive, nation-wide mobilization program designed to build cantonments in which to house and train the expanded WWII Army.

Building 550 was erected in 1942 using the Construction Division Office of the Quartermaster General, Mobilization Building, Fire Station-Type F-2, Plan Number 800-800a standardized plan of the War Department. The 800 Series plans featured well-constructed wooden buildings with ample structural members and such comforts as indoor plumbing and forced, hot-air furnaces.

The structural systems of Building 550 was platform construction, entirely composed of wood members. The exterior was of uniform appearance; grayish white, asbestos cement siding on the walls, yellow wood trim, gray wooden foundation "skirting," and red asphalt shingle roofs. The building had a cross-gable roof overhanging eaves. A concrete wall foundation was used for the apparatus room, while concrete pier foundation system was used for the living section of the building. A brick furnace stack rose from the roof line at the apex of the apparatus room and living section of the building. The original windows were multipane wood double-hung with mesh screens and wood trim. The original entry doors were wood panel and divided light with interior wood screen doors. The original bay overhead garage doors were wood and glass panel designed. The interiors were unfinished with either plaster or paint. Instead, "tempered pressed wood," fiber insulation board, and gypsum board were used to cover walls and ceilings. Wood flooring was used throughout the living area of the building.

The building was designed with two distinct areas, a three-bay apparatus room, and an elevated living quarters for an officer, two NCOs, and a large open bay squad room. The apparatus room was a high-bay area with concrete floors and walls clad with gypsum board. The room had two small enclosed areas, one as an alarm room and the other as a work room. A set of wood steps led into the elevated living area of the fire house.

The living area was rectangular in shape with a central corridor that separated a heater room and officers bunk area on the north side and a latrine and a room for two NCOs on the south side of the corridor. At the end of the corridor was a large open bay used as the squad room bunks that would sleep sixteen. All walls in toilet room to be finished with tongue and groove boards. The floor of the toilet room was concrete. The room had a toilet, urinal, a shower stall, and two sinks with mirrors and light fixtures above. The squad room had wood slat floor, walls and ceiling clad with fiber insulation board, and a suspended mechanical system.

At an unknown date(s), the original brick furnace stack was dismantled, the three overhead doors were replaced, the original exterior light fixtures were removed, the original exposed wood roof overhanging eaves were modified with metal panel enclosures, and a partition wall was erected in the open squad room. The roof was replaced inkind to the original red asphalt roof in 2003.

The building's category code changed to a classroom in 1999. The building is currently not in use. 


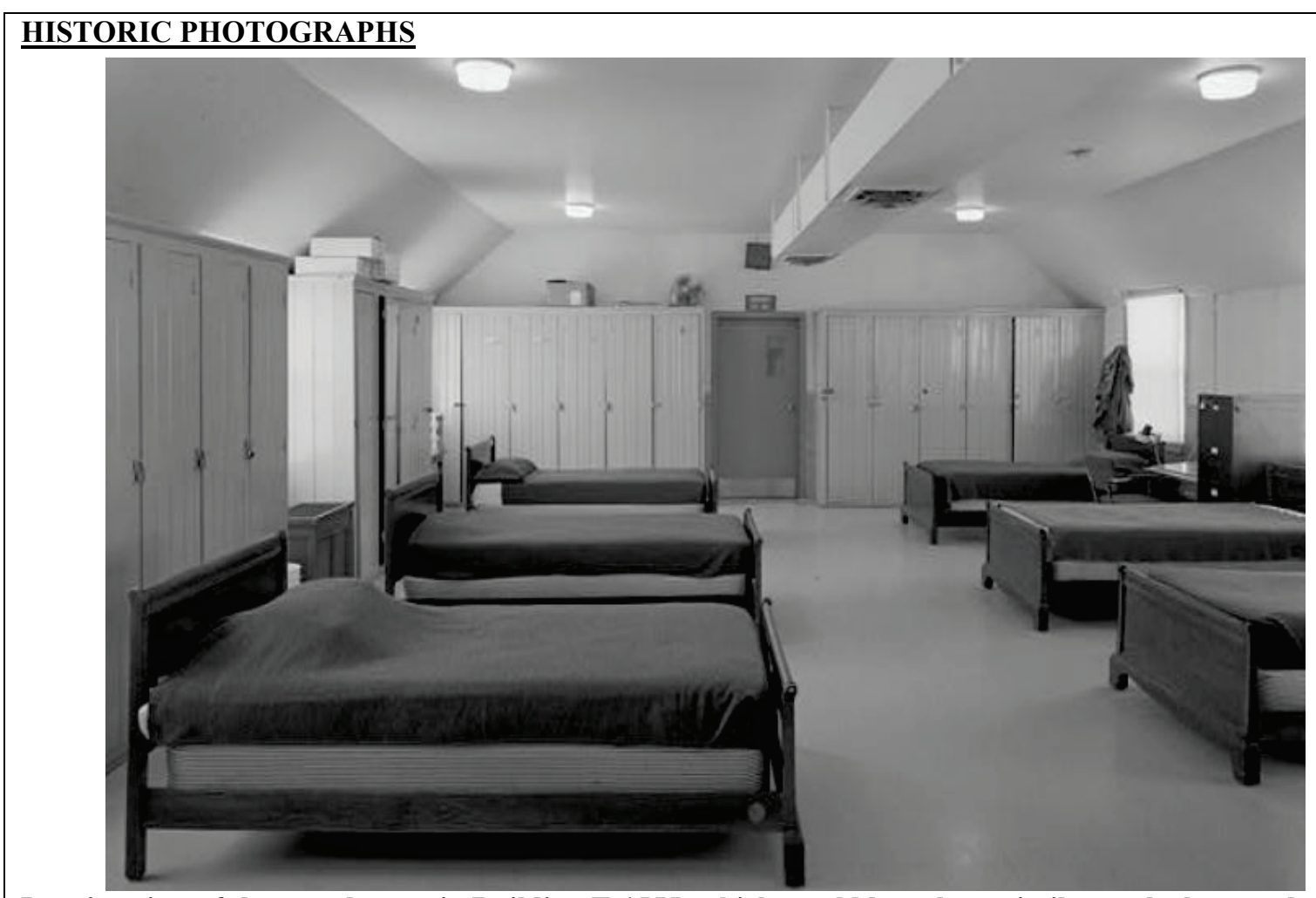

Interior view of the squad room in Building T-1555, which would have been similar to the layout, design, use of the squad room in Building 550, Fire Station, April 1993 (HABS WIS,41-SPAR.V,1FD—6).

\section{CHARACTER-DEFINING FEATURES}

- Massing

- T-shape footprint

- Wood frame structure with textured asbestos cement siding with scalloped bottom edge detail

- Vertical line definition between each siding piece

- Cross-gable roof with red asphalt shingles

- Concrete pier foundation system (living section) and concrete block wall foundation system (heater room and apparatus room

- Multipane wood double-hung windows with wood screens

- $\quad$ Brick furnace stack (demolished)

- Wood trim size and profile around window and door openings

- Wood panel and divided light with wood interior screen doors

- Exterior light fixtures (replaced)

- Open bay apparatus room with concrete floor and walls clad with gypsum board

- Wood and glass overhead doors (replaced with metal overhead doors)

- Living area with central corridor

- Toilet room with fixtures such as urinals, sinks, mirrors, light fixtures, shower stall, concrete floor, and wood plank walls

- Open bay squad room with wood floor and fiber insulated walls and ceiling

- Suspended mechanical system and ductwork in the squad room and central corridor

- Interior wood panel doors

- Interior mop sinks and drinking fountains in the apparatus room 

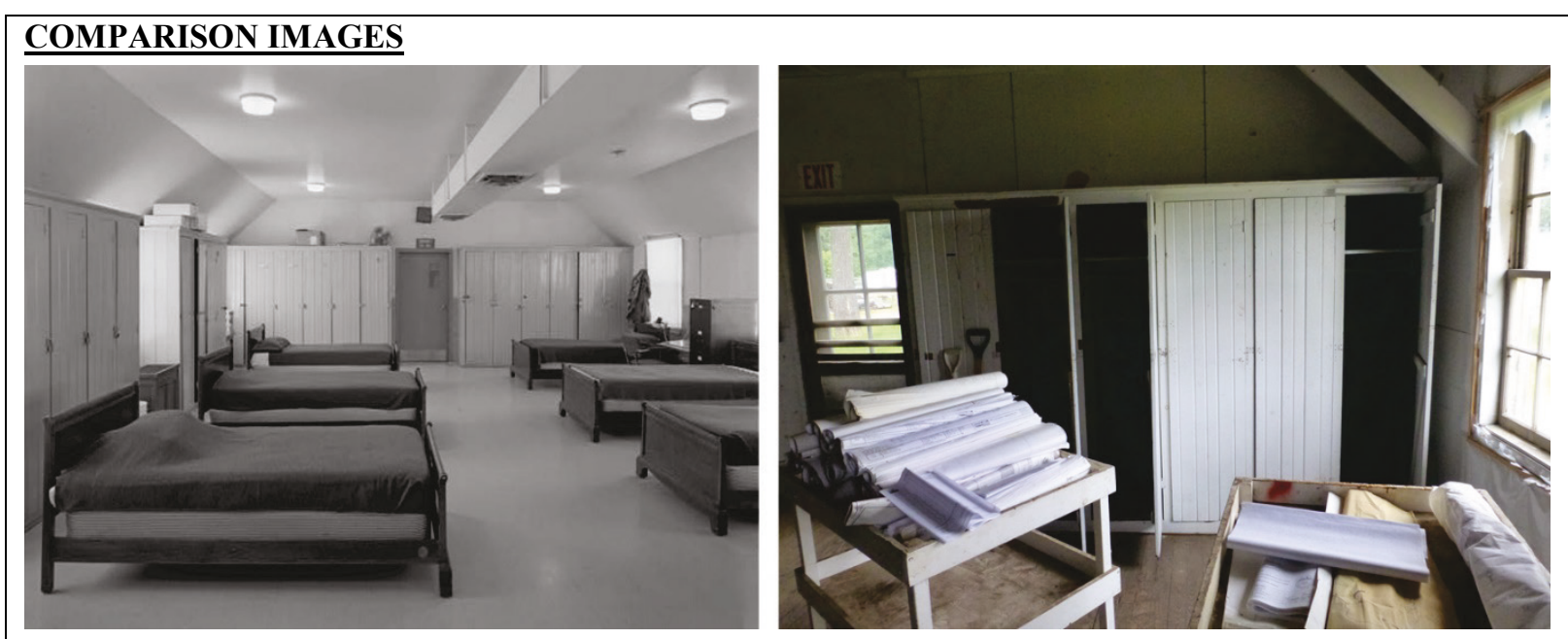

Interior view of the squad room with wood built-in closets. Comparison of the original construction, design, and materials for the Fire Station, Building T-1555 from April 1993 (left) to 2018 (right) (left; Library of Congress, HABS, right: ERDC-CERL).

\section{SIGNIFICANCE}

The 800 Series, and the 700 Series that preceded it, was a comprehensive set of drawings which could be used interchangeably in creating the various building types. War mobilization buildings are significant for their construction and technological innovation. Techniques such as the standardization of plans, prefabrication of units, and assembly-line approach to construction were largely pioneered in the construction of these mobilization structures (FROM THE HABS CAPTION http://www.loc.gov/pictures/collection/hh/item/wi0557/).

The temporary wood buildings constructed with the 700 Series or 800 Series on Fort McCoy during World War II (WWII) between 1939 and 1946 were determined significant for the National Register of Historic Places (NRHP) in 1986 when the Programmatic Memorandum of Agreement (PMOA) was signed between the Department of Defense (DoD), the Advisory Council on Historic Preservation (ACHP), and the National Council of State Historic Preservation Officers (NCSHPO). In the early 1990s, this significance was reaffirmed by the writing of the "World War II and the U.S. Army Mobilization Program: A History of 700 and 800 Series Cantonment Construction" and the performance of the Historic American Buildings Survey (HABS) on a variety of the 700 and 800 Series planned buildings across the country. Many of the 800 Series of buildings at Fort McCoy were utilized for the HABS.

Building 550, WWII temporary building, is significant under Criterion A for WWII temporary building construction (1939-1946).

The design and construction of the WWII temporary buildings could not be linked to a specific architect due to their construction from standardized War Department temporary building plans. They do not possess high artistic values; however, WWII temporary buildings in general were found to be significant for their design, construction and technological innovation under Criterion $\mathrm{C}$.

\section{INTEGRITY DETERMINATIONS}

Location - Building 550 retains its integrity of location.

Design - Building 550 retains the key elements of its WWII design.

Setting - Building 550 retains its integrity of setting. 
Materials - Building 550 retains the key elements of its WWII architectural materials such as doors, windows, exterior cladding material, and asphalt roofing material on the exterior; and wood floors, concrete floors, fiberboard walls, wood wainscots, fiberboard ceilings, plumbing fixtures, and electrical fixtures.

Workmanship - Workmanship is not part of integrity for WWII temporary buildings, including Building 550.

Feeling - Building 550 retains its integrity of a WWII temporary building.

Association - Building 550 retains its integrity of association.

\section{RECOMMENDATION OF CONTRIBUTING/NONCONTRIBUTING STATUS}

It is the recommendation of this report that Building 550, Fire Station, is Eligible for the NRHP at the national level due to its significance under Criteria $A$ and $C$ and its integrity from the period of significance of 1939 to 1946. 


\section{Block - Barracks}

\begin{tabular}{|c|c|c|c|}
\hline \multicolumn{4}{|c|}{$\begin{array}{c}\text { FORT McCOY } \\
\text { HISTORIC PROPERTY INVENTORY FORM }\end{array}$} \\
\hline $\begin{array}{l}\text { PROPERTY BOUNDARIES } \\
\text { - Fort McCoy in the } 1600 \text { block } \\
\text { area on the south side of the } \\
\text { triangular cantonment plan } \\
\text { - Sparta vicinity } \\
\text { - Monroe County, Wisconsin }\end{array}$ & \multicolumn{2}{|c|}{$\begin{array}{l}\text { COMMON/HISTORIC NAME } \\
\text { - Buildings } 1602,1603,1604,1607,1608,1609,1610, \\
1612,1613,1614,1615,1618,1619,1620,1623,1624, \\
1625,1628,1629,1630,1631,1632,1634,1635,1636, \\
\text { 1637, 1641, 1642, 1644 } \\
\text { - AT Enlisted Barracks } \\
\text { - 74-Man Barracks }\end{array}$} & $\frac{\text { STATUS }}{\text { Usable }}$ \\
\hline $\begin{array}{l}\text { ARCHITECT/BUILDER } \\
\text { Construction Division, Office } \\
\text { of the Quartermaster General, } \\
\text { Series } 800-443\end{array}$ & $\begin{array}{l}\text { DATE OF CONSTRUCTION } \\
1942 \\
\text { DATE OF ALTERATIONS } \\
\text { Prior to } 1988 \text { - dismantled } \\
\text { wood stoops } \\
2003 \text { - added metal stoops, } \\
\text { platform and steps, and } \\
\text { removed wood fire escape } \\
\text { ladder } \\
2003 \text { - replaced all windows } \\
\text { and doors } \\
\text { Unknown - added vinyl siding, } \\
\text { replaced foundation skirting, } \\
\text { remodeled entire interior }\end{array}$ & $\frac{\text { NO. OF STORIES }}{2}$ & $\frac{\text { FOOTPRINT }}{\text { Rectangular }}$ \\
\hline$\frac{\text { ROOF FORM }}{\text { Gable }}$ & $\begin{array}{l}\text { FOUNDATION } \\
\text { Concrete pier with wooden } \\
\text { foundation skirting }\end{array}$ & $\begin{array}{l}\text { WALLS } \\
\text { Wood frame with } \\
\text { asbestos cement } \\
\text { siding }\end{array}$ & 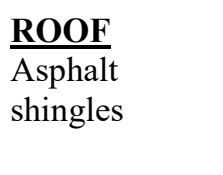 \\
\hline \multicolumn{2}{|c|}{ PROPERTY FUNCTION } & \multirow{3}{*}{\multicolumn{2}{|c|}{$\begin{array}{l}\text { NOTABLE FEATURES } \\
\text { - Mass }\end{array}$}} \\
\hline Barracks & Barracks & & \\
\hline \multicolumn{2}{|c|}{$\begin{array}{l}\text { RELATIONSHIP TO OTHER BUILDINGS } \\
\text { The } 1600 \text { block is located on the south side of the triangular } \\
\text { cantonment layout. South Eleventh Street is to the north, South J } \\
\text { Street is to the east, South Tenth Street is to the south, and South } \\
\text { G Street is to the west. South H and South I Streets cut through the } \\
\text { block. The } 1600 \text { battalion block consists of } 29 \text { barracks, four } \\
\text { company storehouse/administration/recreation buildings (currently } \\
\text { being used as general instruction buildings), and eight mess halls } \\
\text { (four still being used as mess halls and four being used as } \\
\text { classroom buildings). }\end{array}$} & & \\
\hline
\end{tabular}




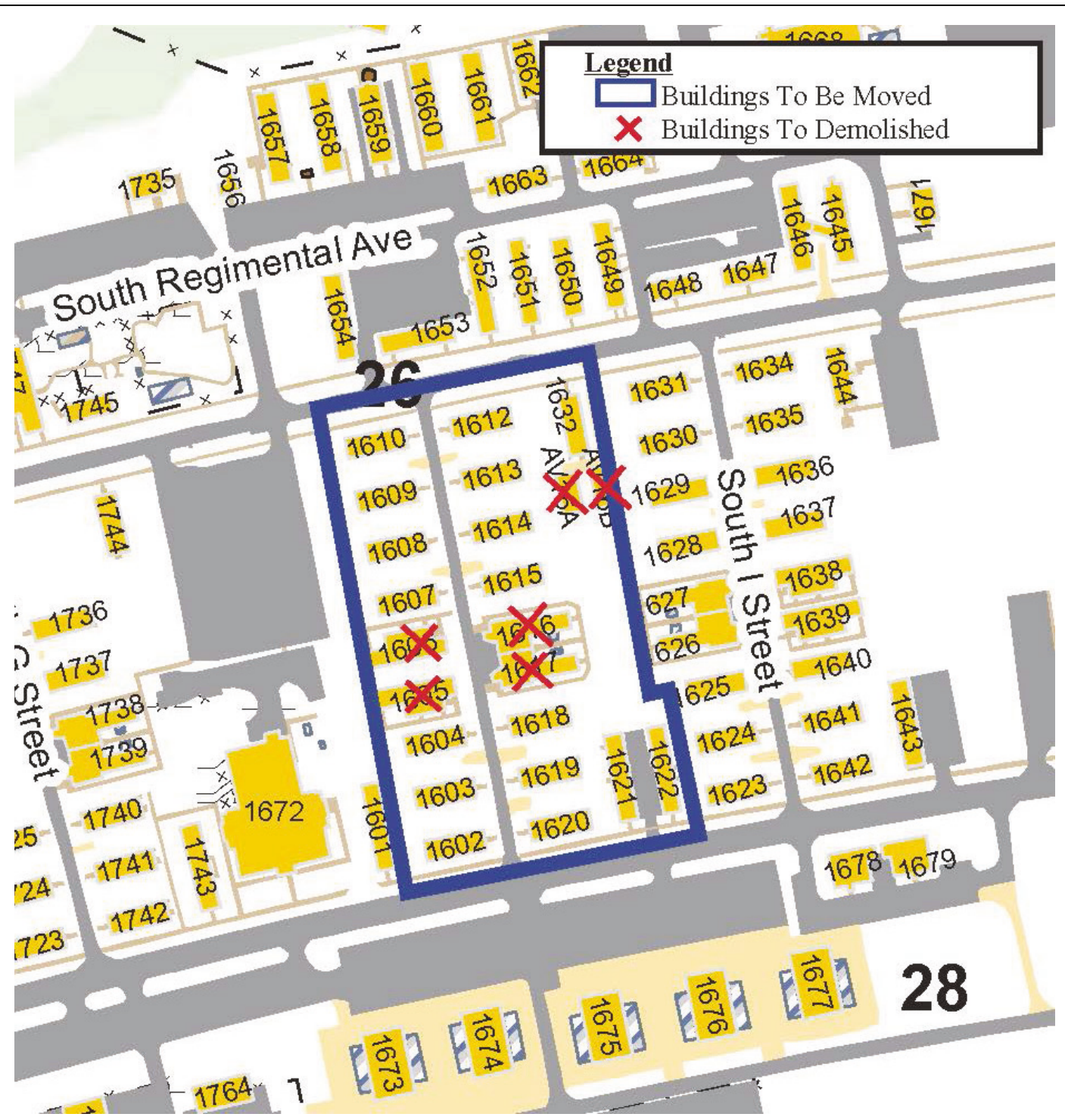

Photo 1. Map showing location of Buildings 1602, 1603, 1604, 1607, 1608, 1609, 1610, 1612, 1613, 1614, 1615, 1618, 1619, 1620, and 1632 (DPW, Fort McCoy, 2018 


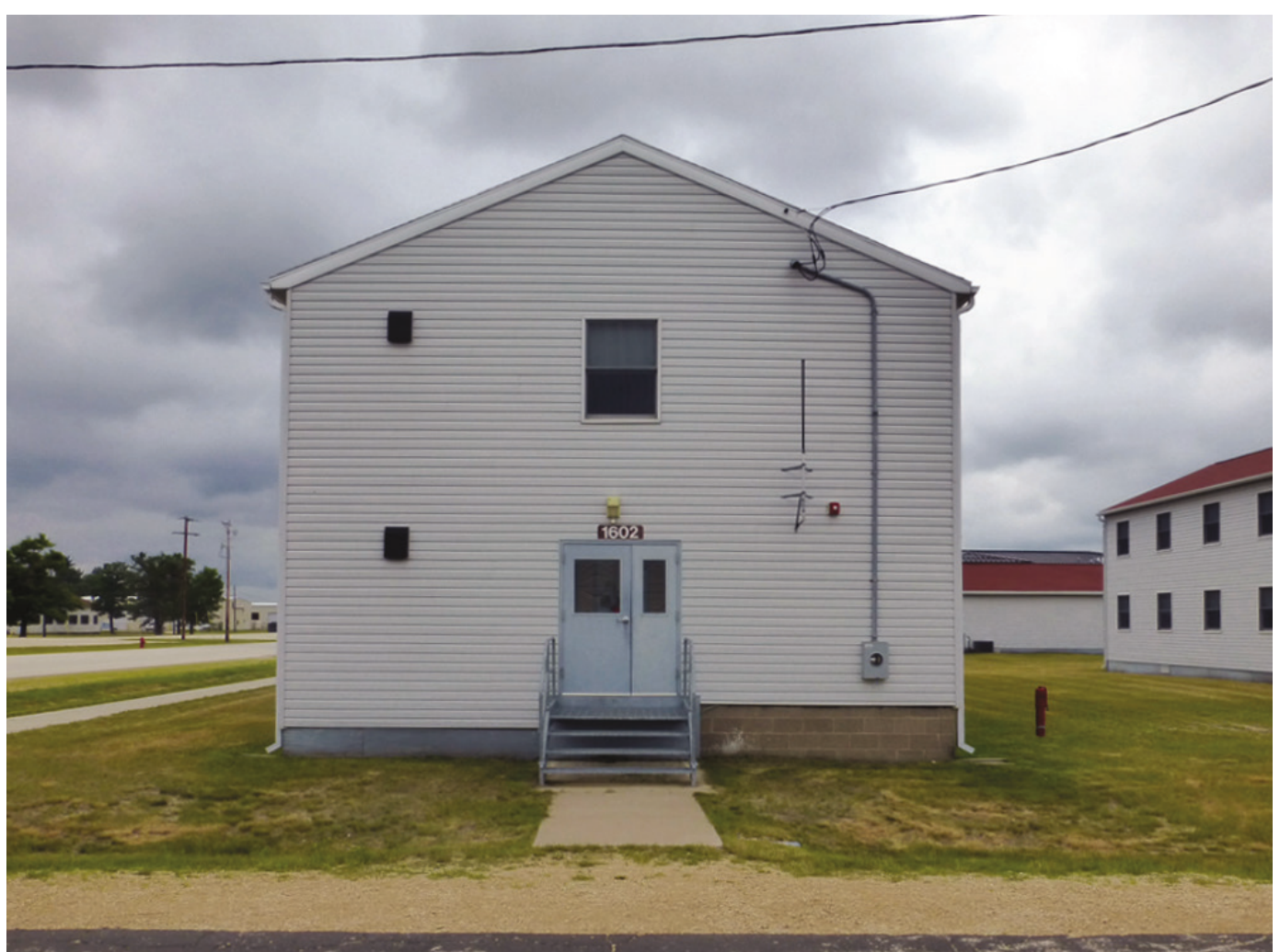

Photo 2. East elevation of Building 1602 (ERDC-CERL, 2018).

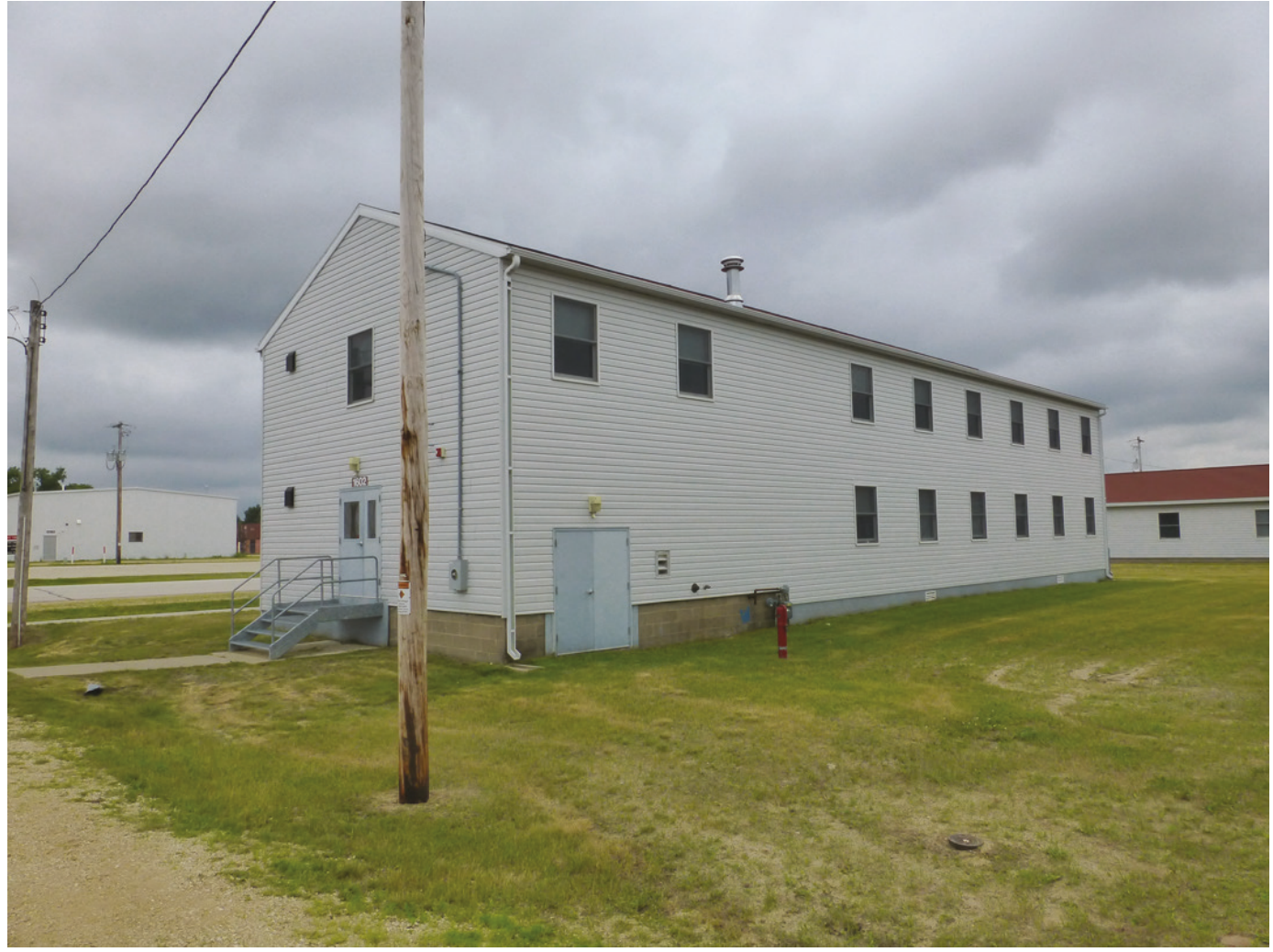

Photo 3. Northeast oblique of Building 1602 (ERDC-CERL, 2018). 


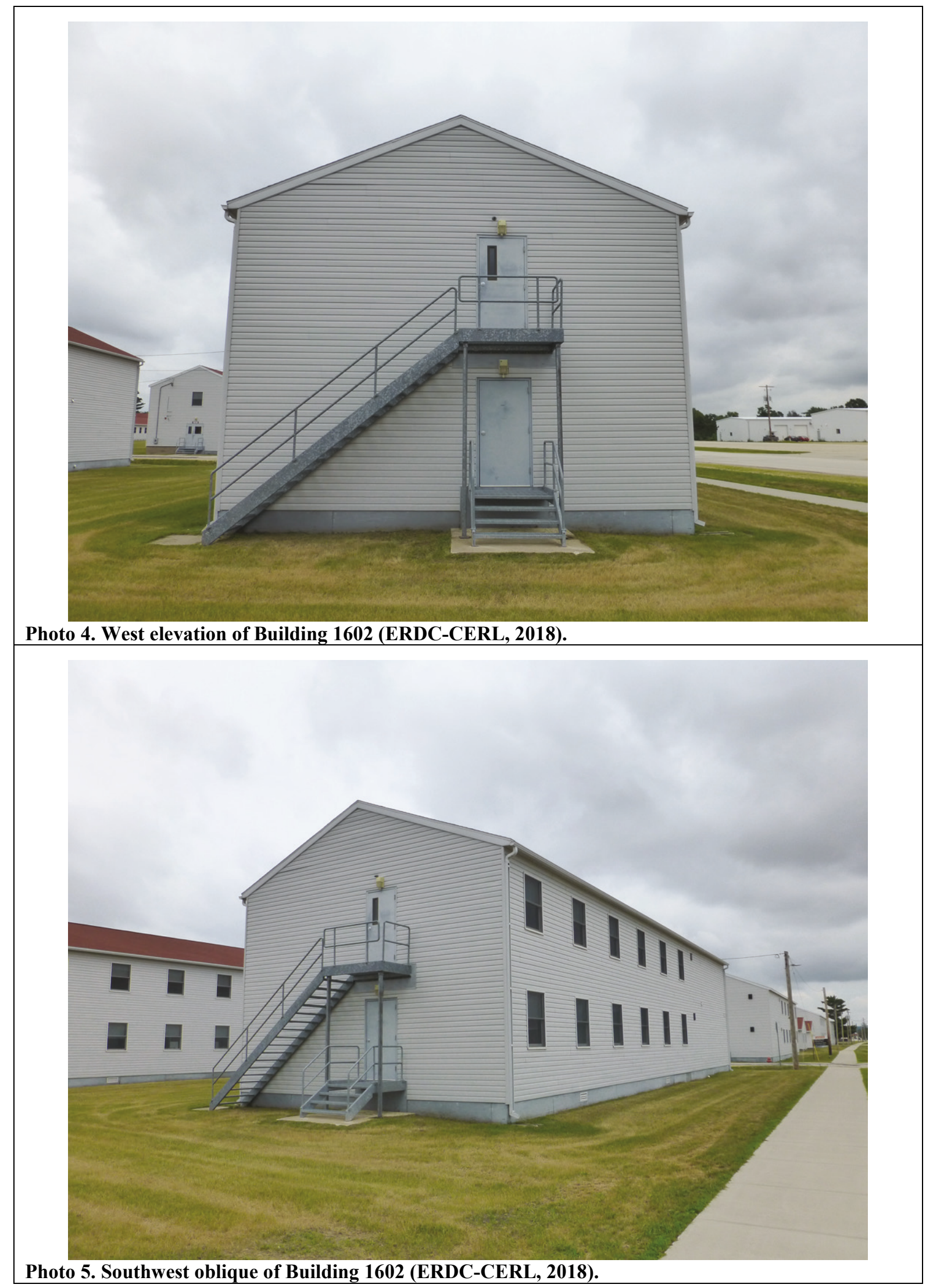




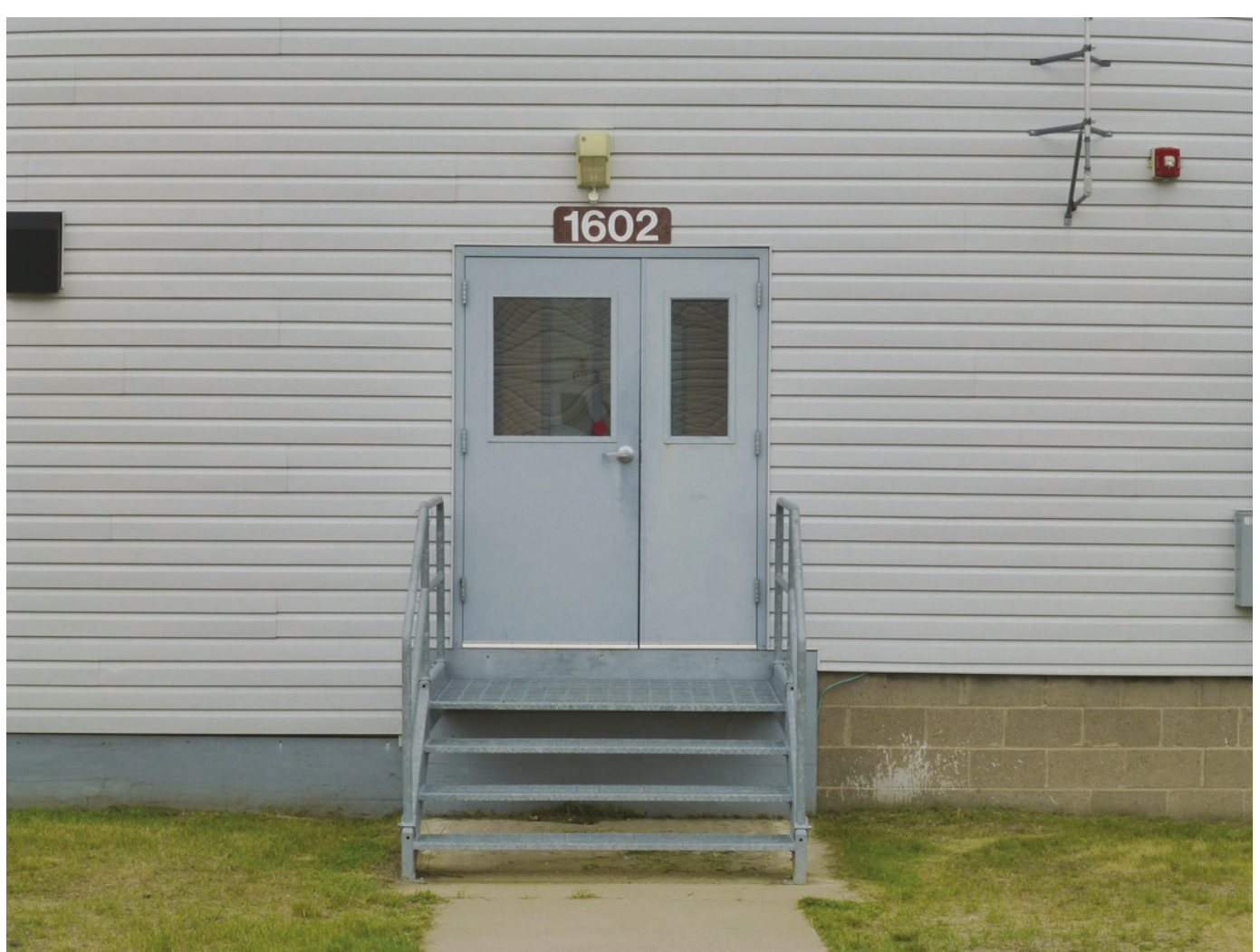

Photo 6. Replacement metal and glass doors, metal steps and metal handrails, vinyl siding, wood foundation skirting, and light fixture of Building 1602 (ERDC-CERL, 2018).

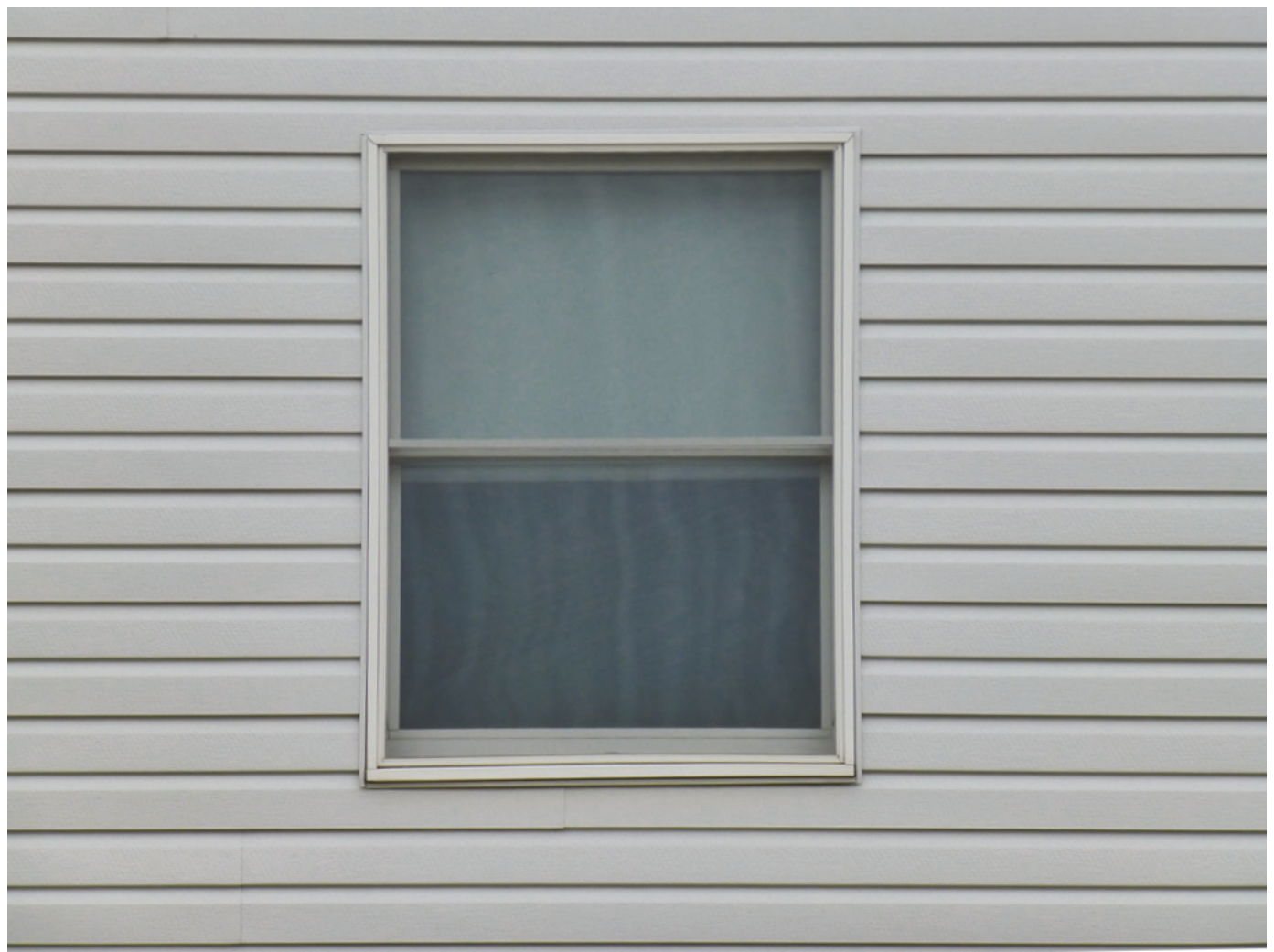

Photo 7. Close-up of replacement one-over-one vinyl window on Building 1602 (ERDC-CERL, 2018). 


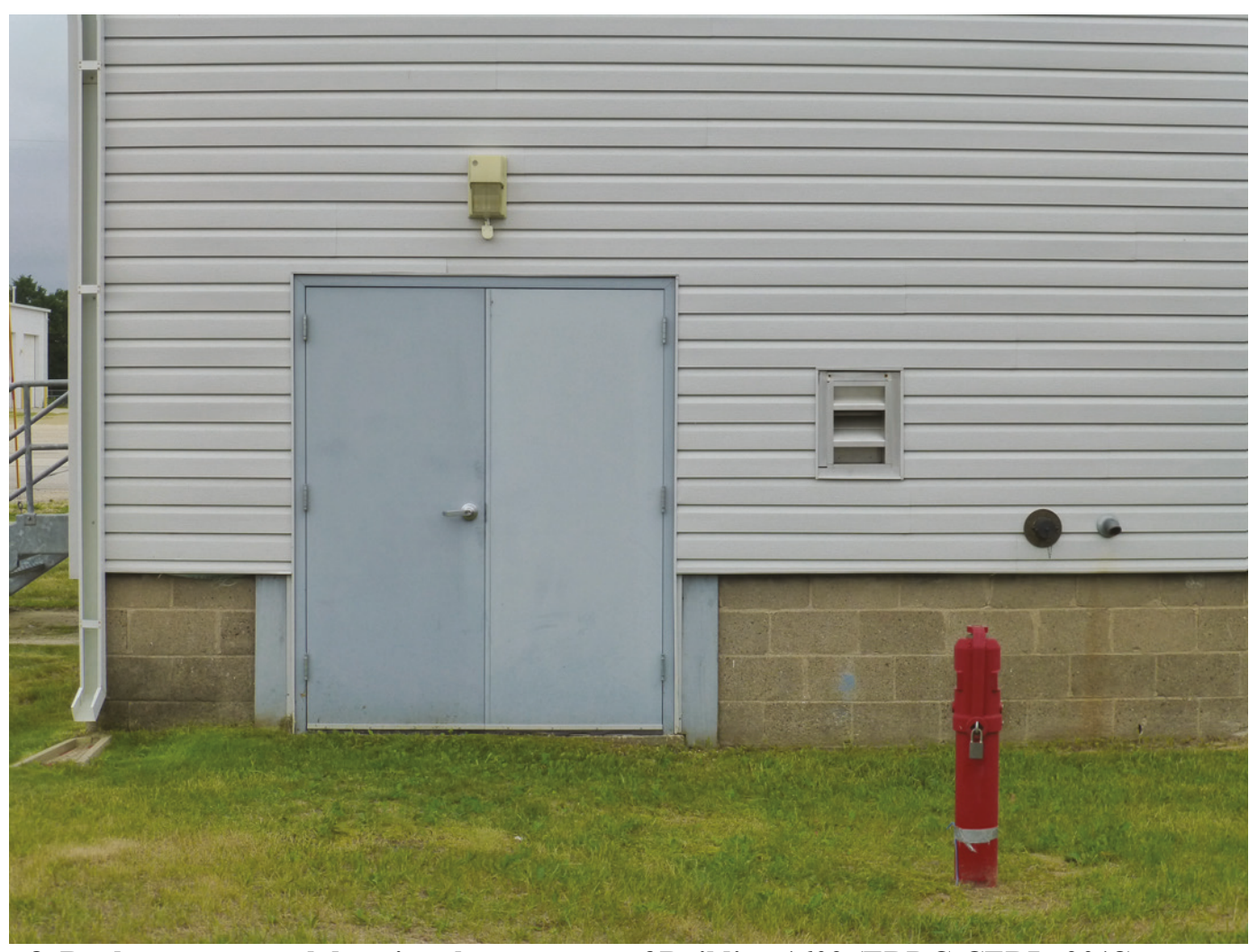

Photo 8. Replacement metal door into heater room of Building 1602 (ERDC-CERL, 2018).

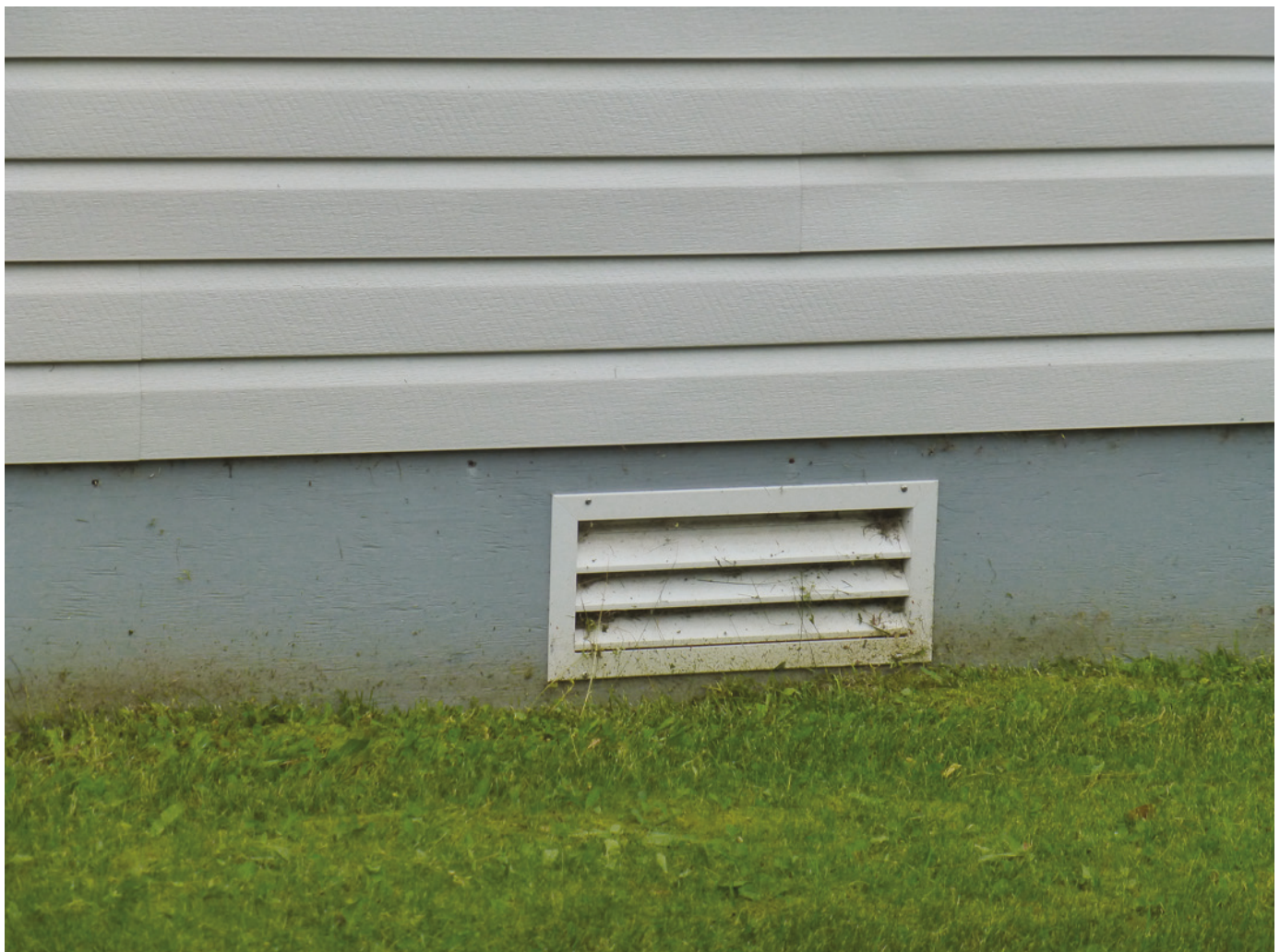

Photo 9. Close-up of replacement wooden foundation skirting on Building 1602 (ERDC-CERL, 2018). 


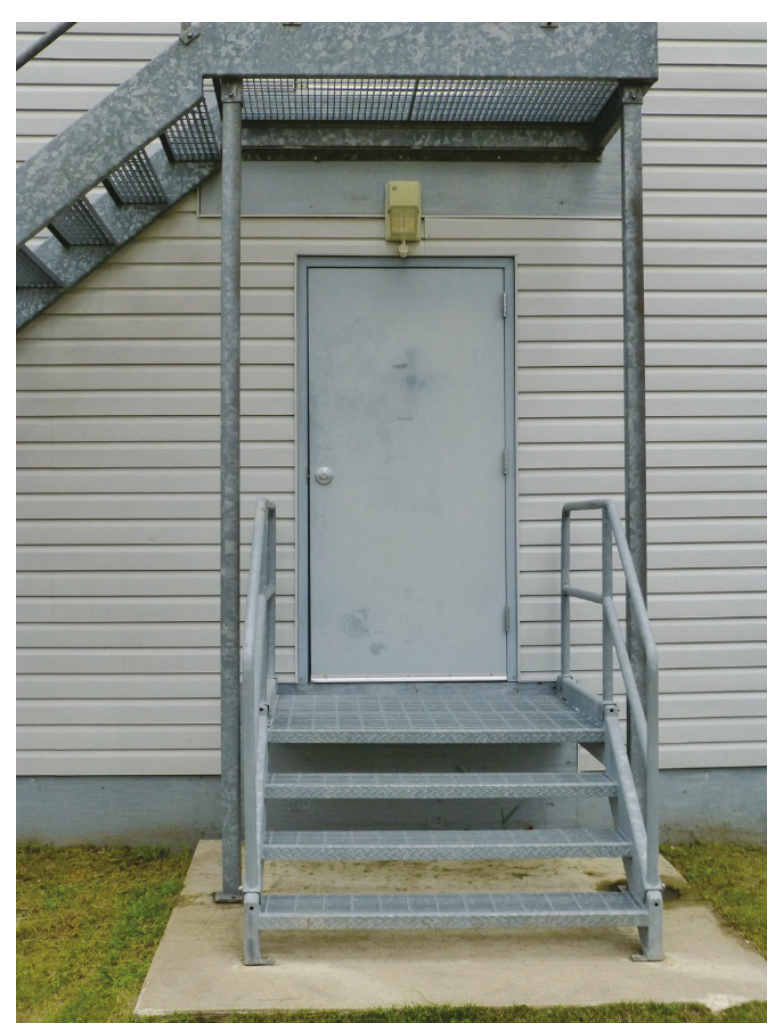

Photo 10. Replacement metal door, metal steps, and metal handrails on Building 1602 (ERDC-CERL, 2018).

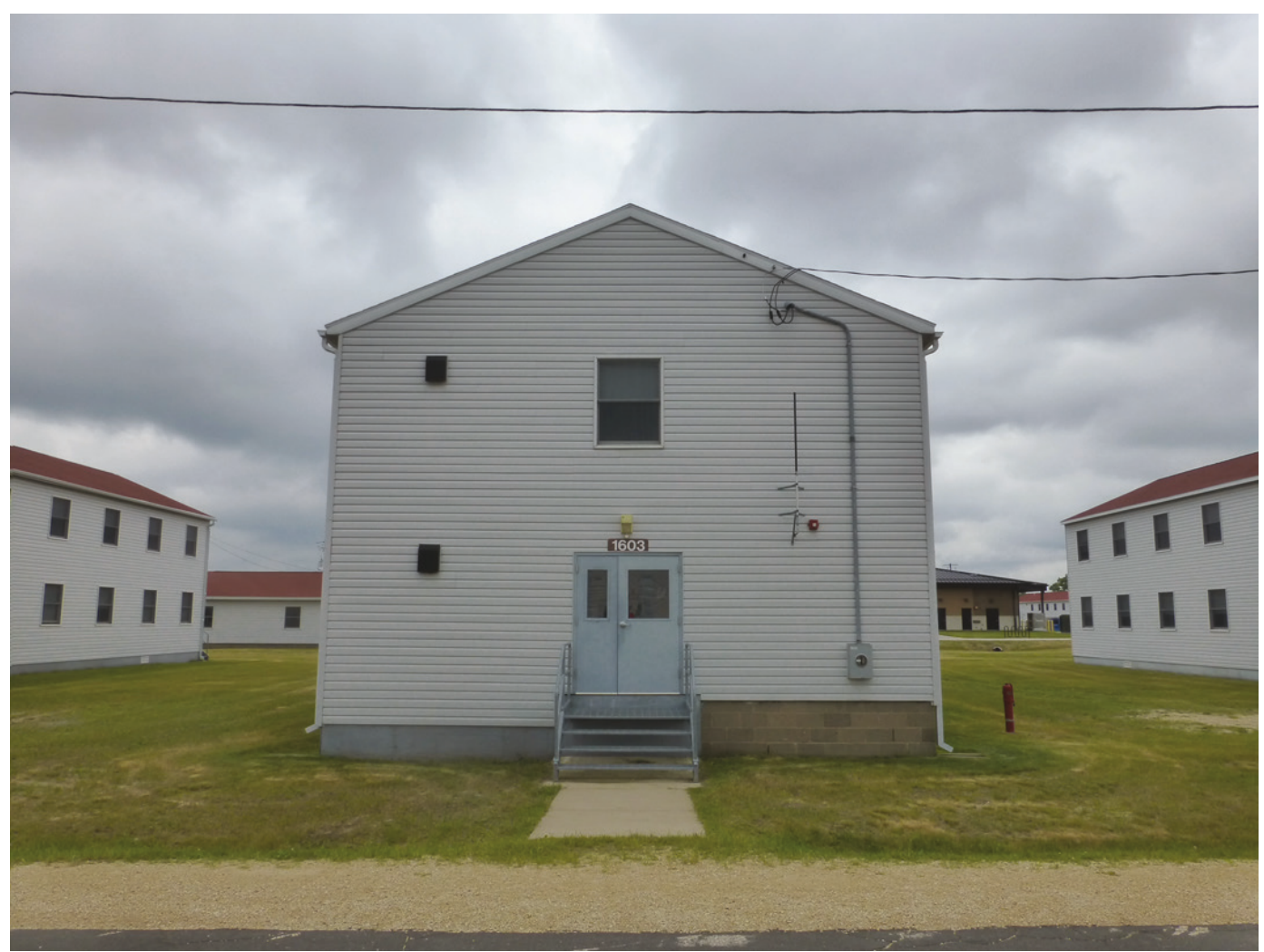

Photo 11. East elevation of Building 1603 (ERDC-CERL, 2018). 


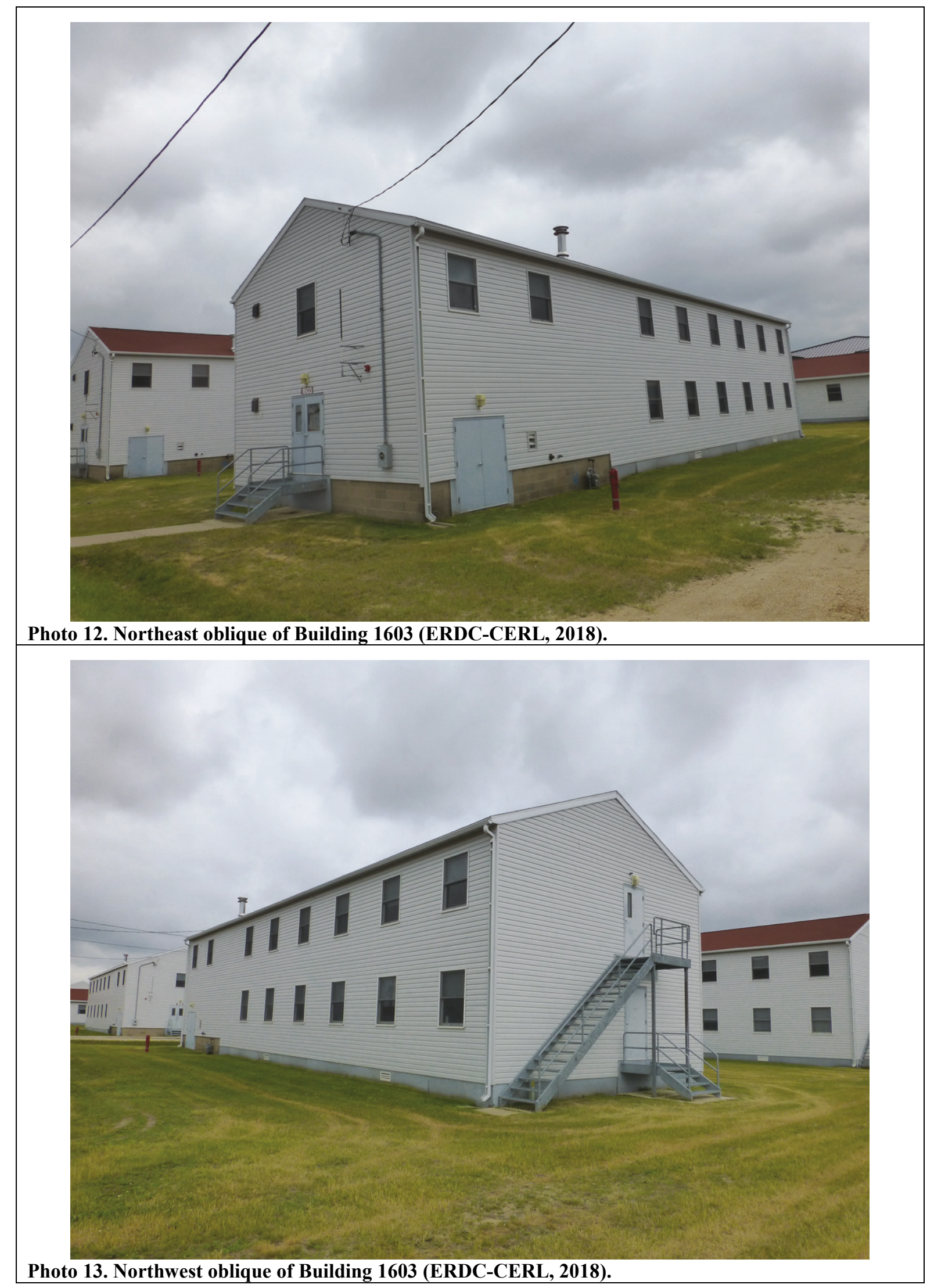




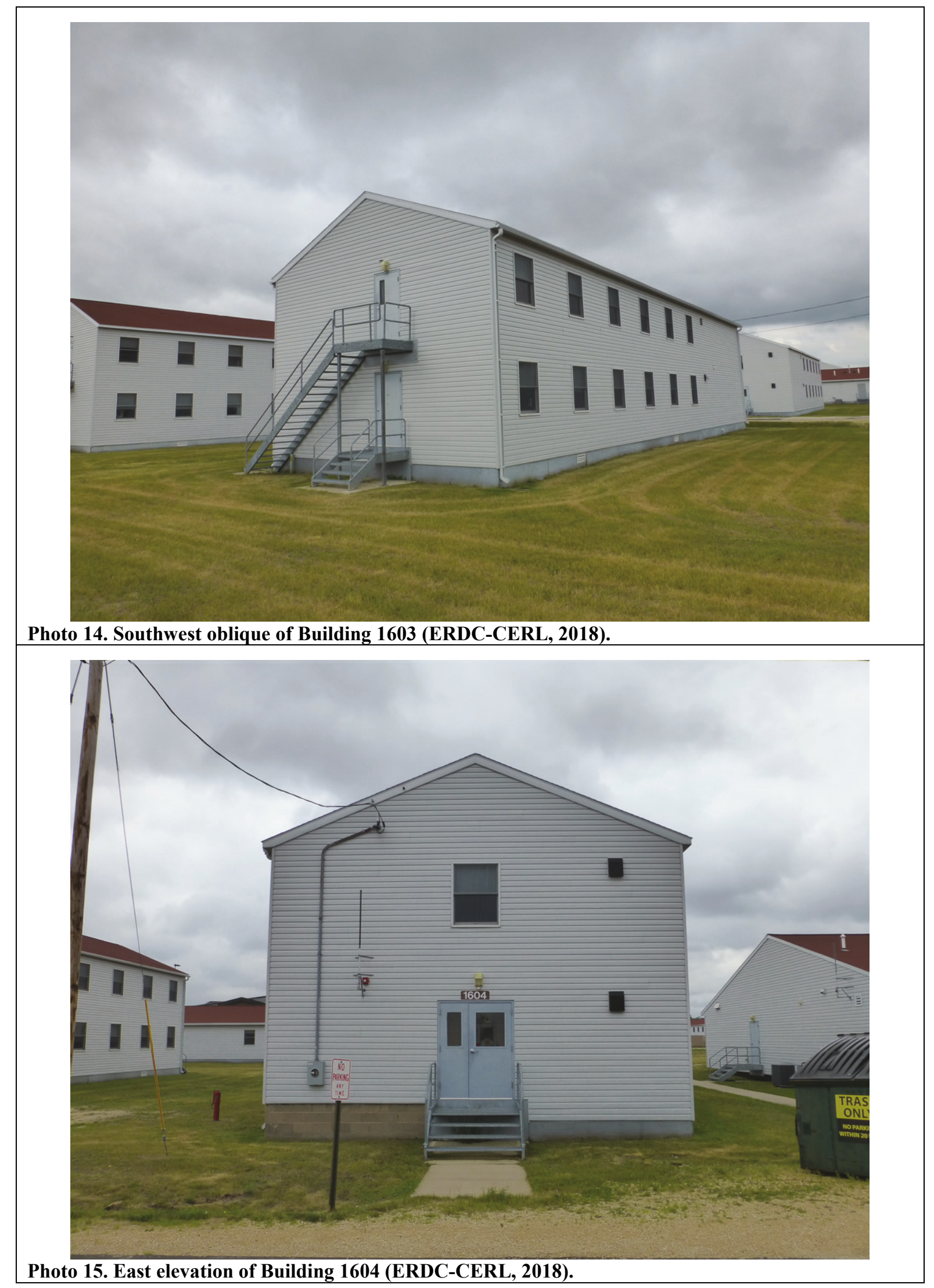




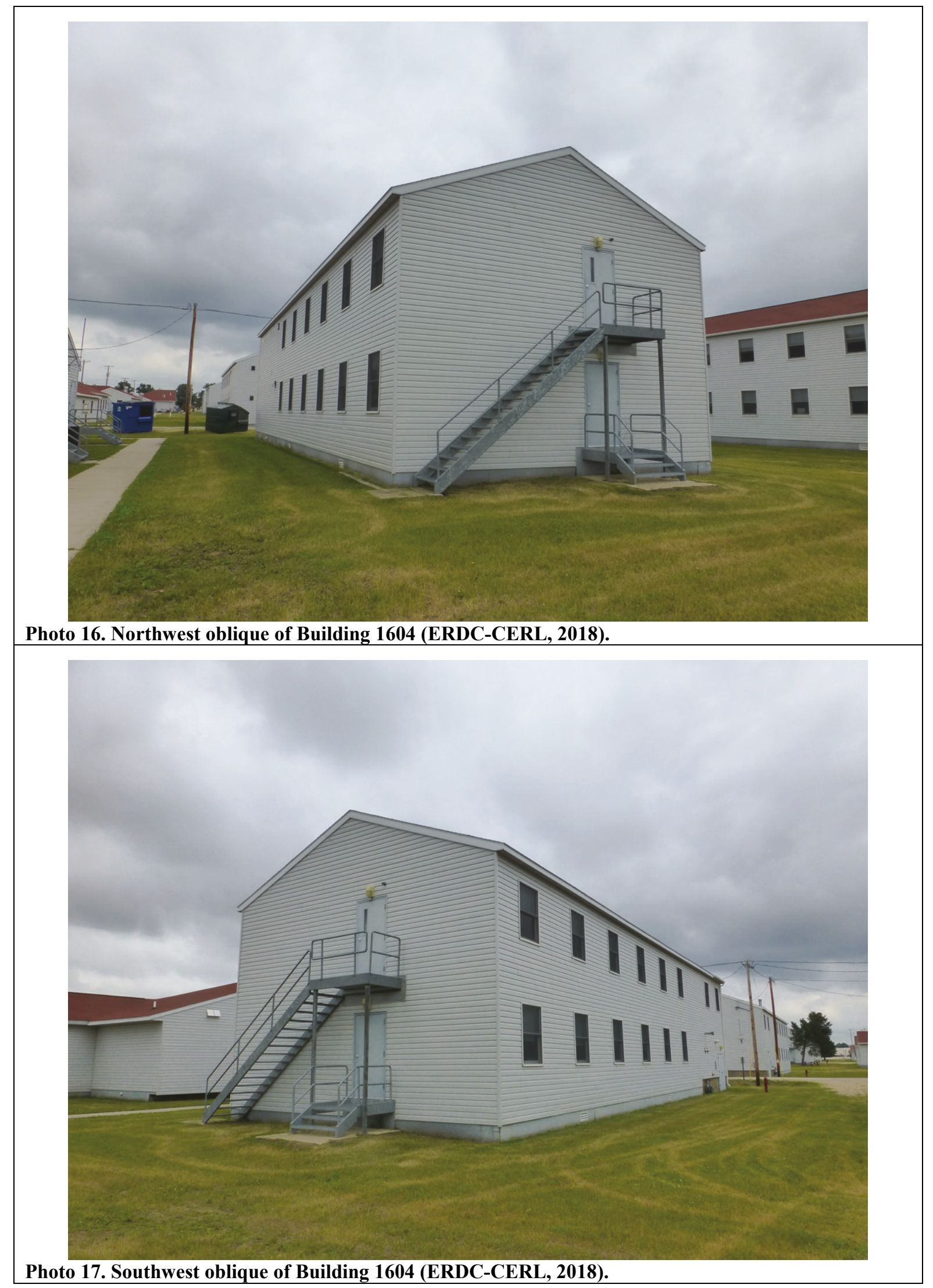




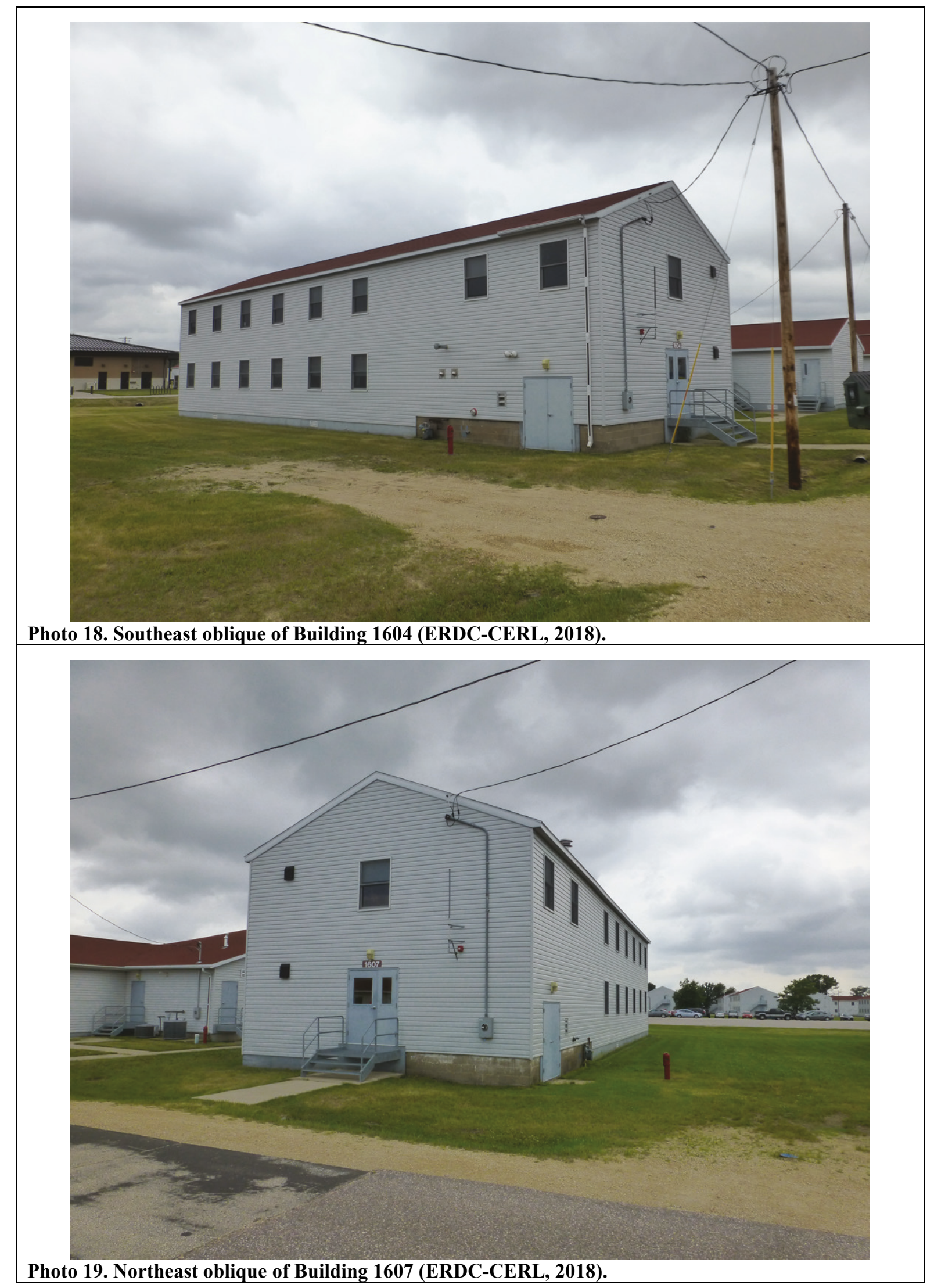




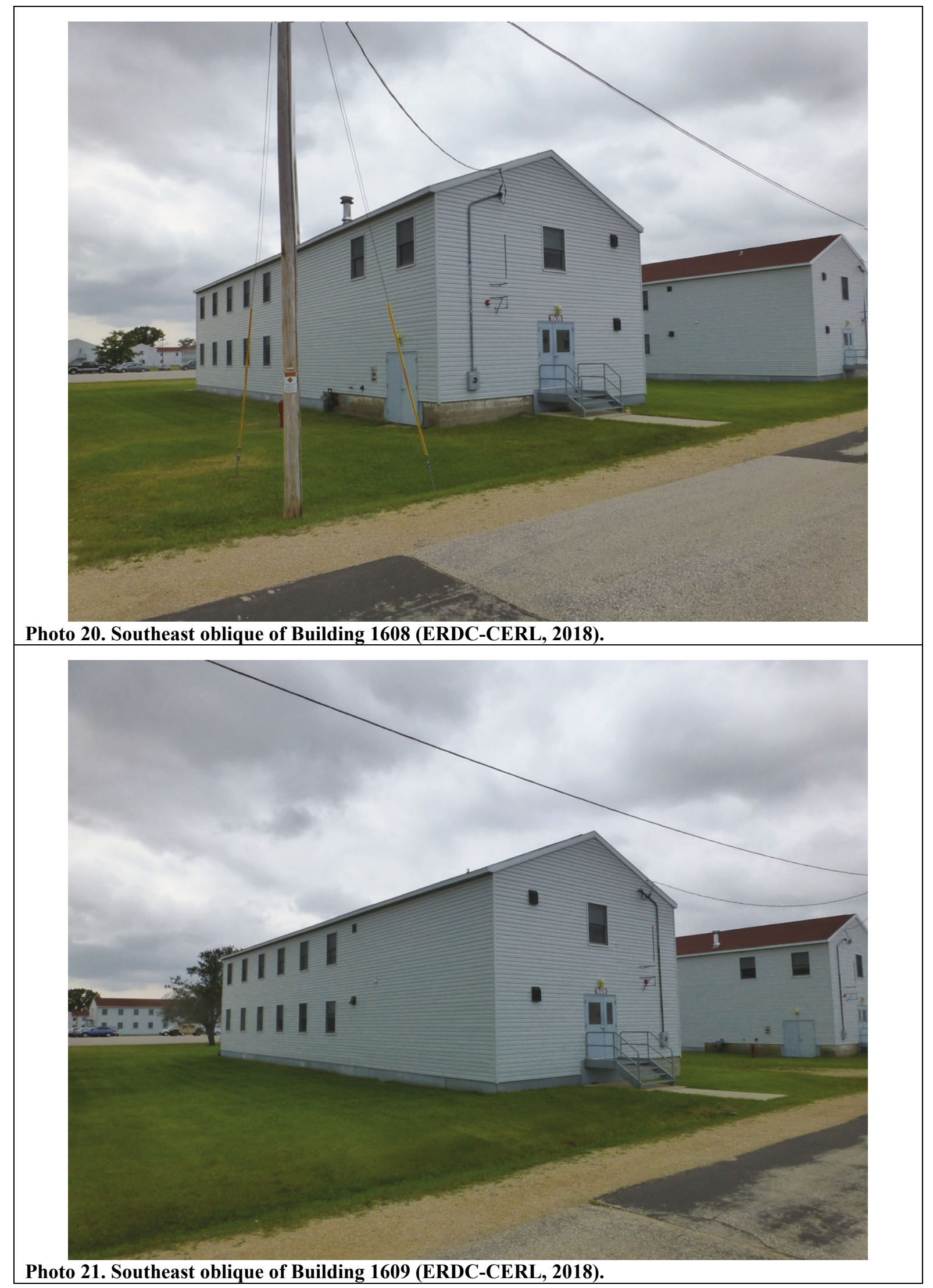




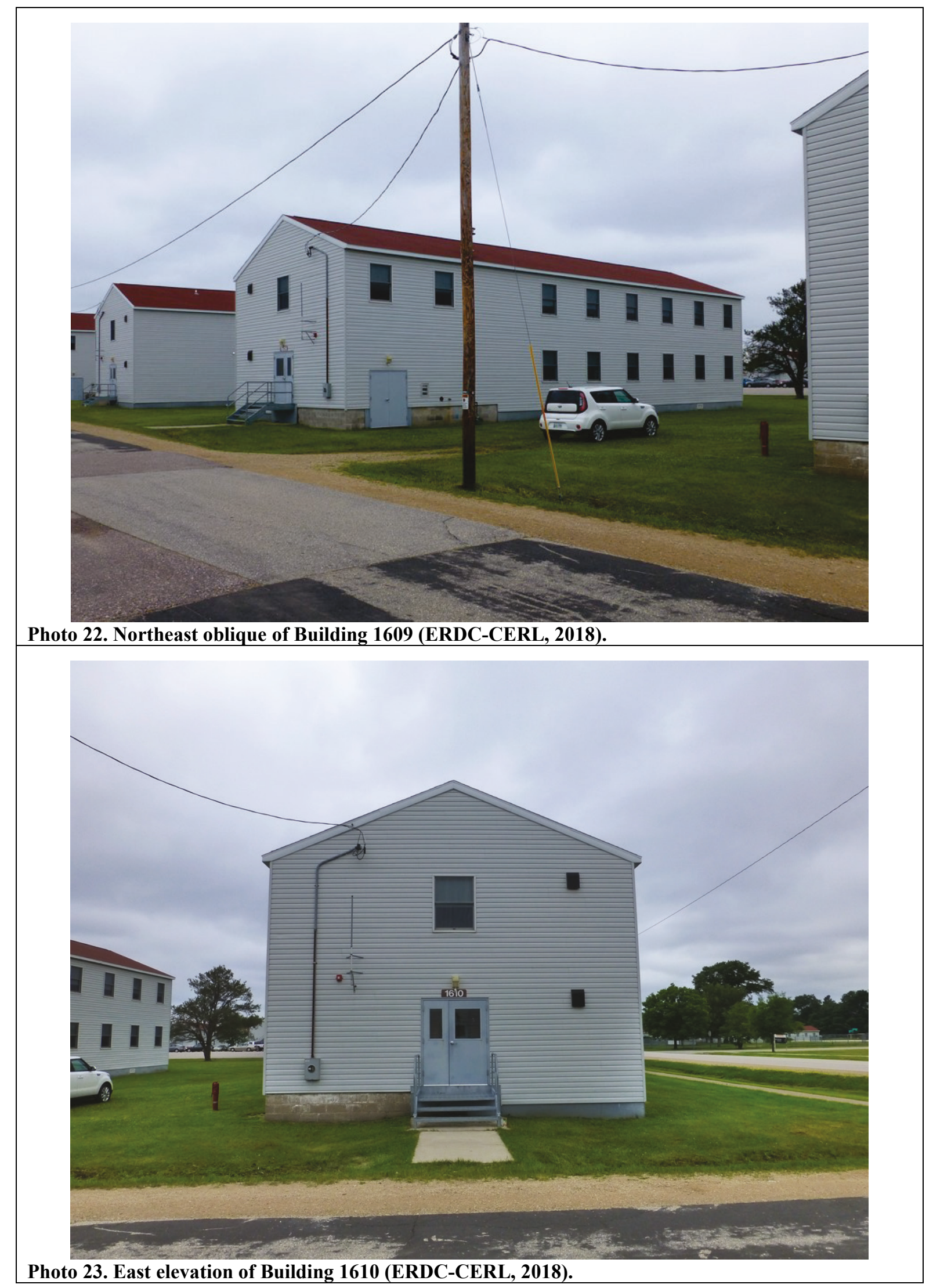




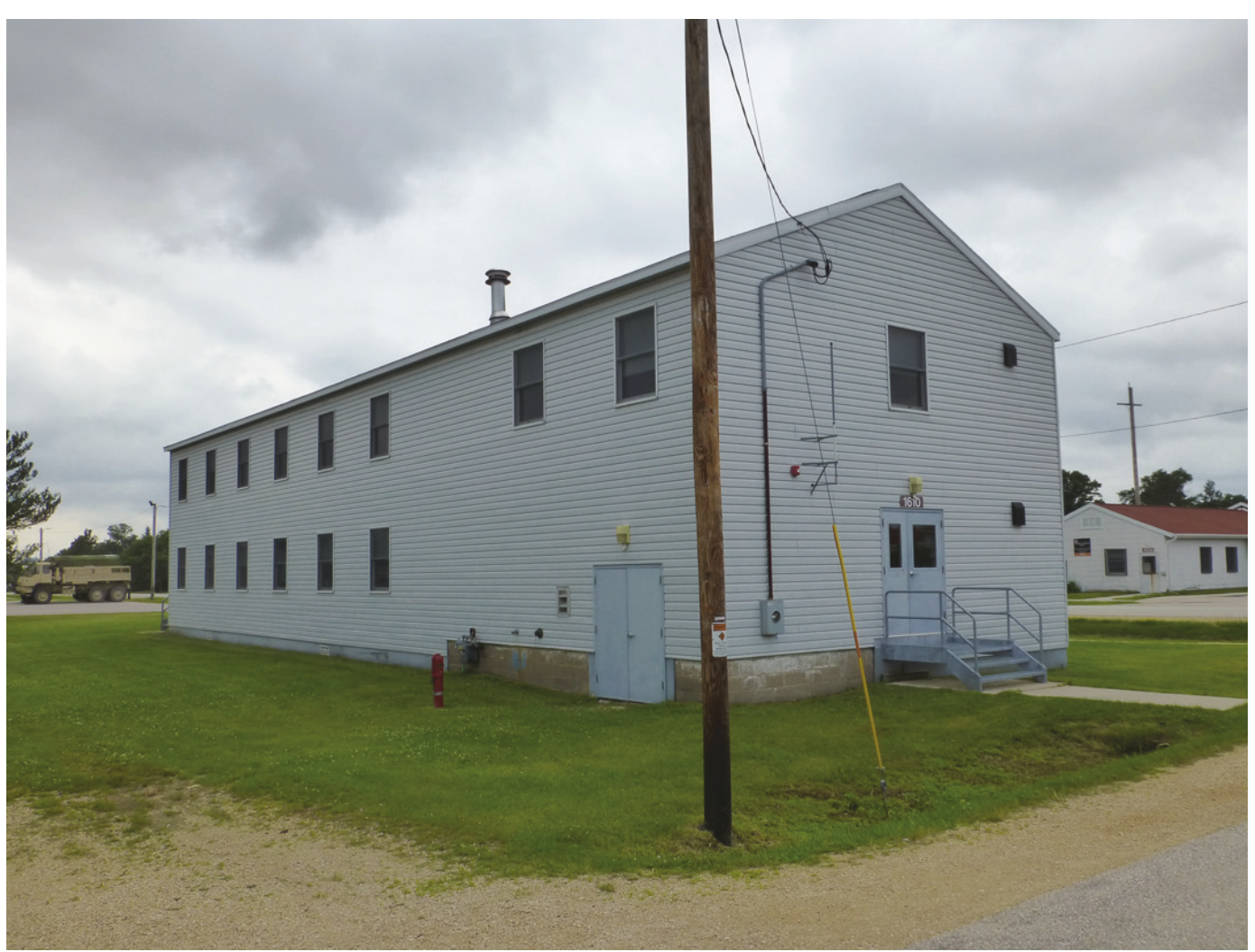

Photo 24. Southeast oblique of Building 1610 (ERDC-CERL, 2018).

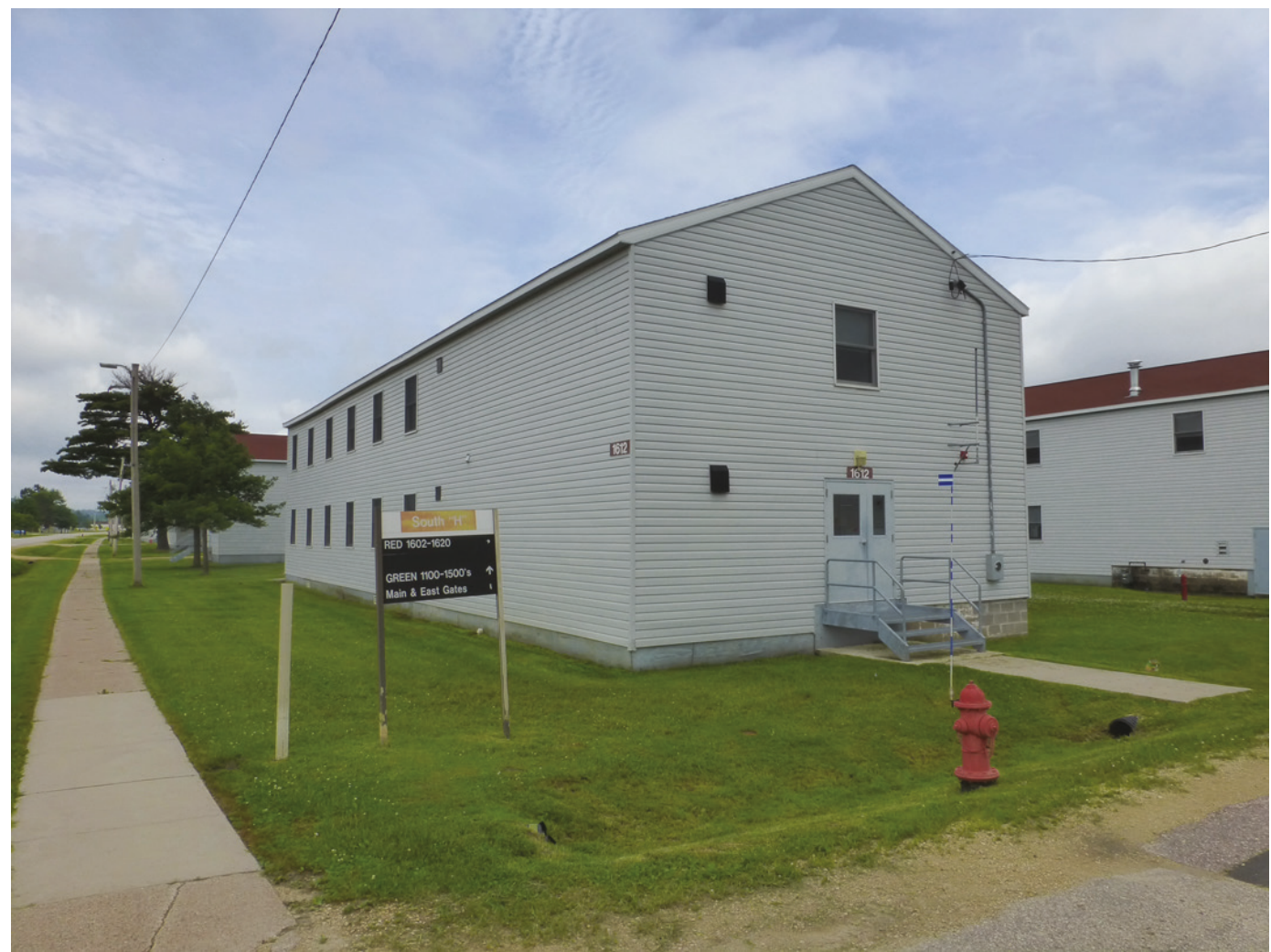

Photo 25. Northwest oblique of Building 1612 (ERDC-CERL, 2018). 


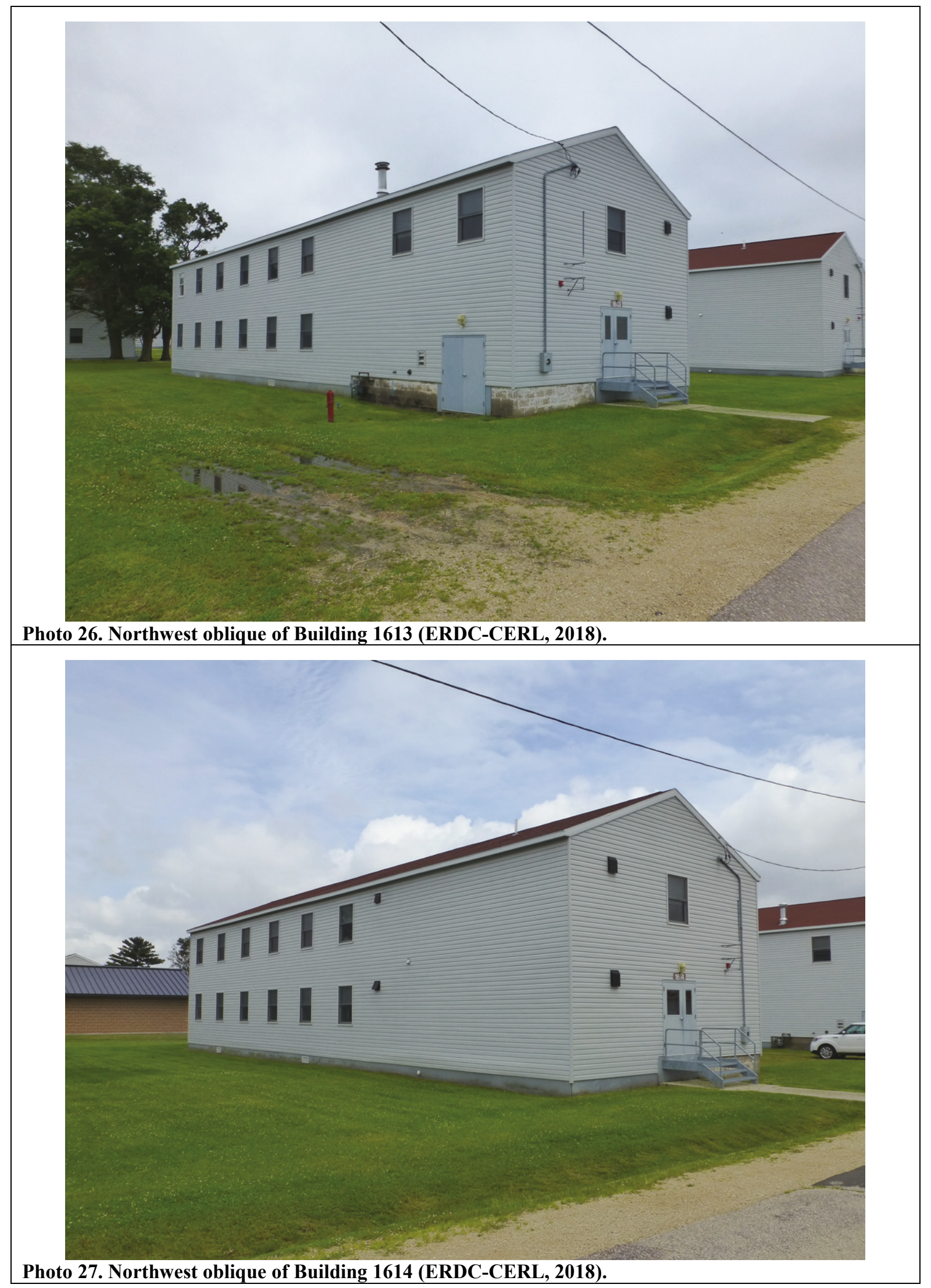




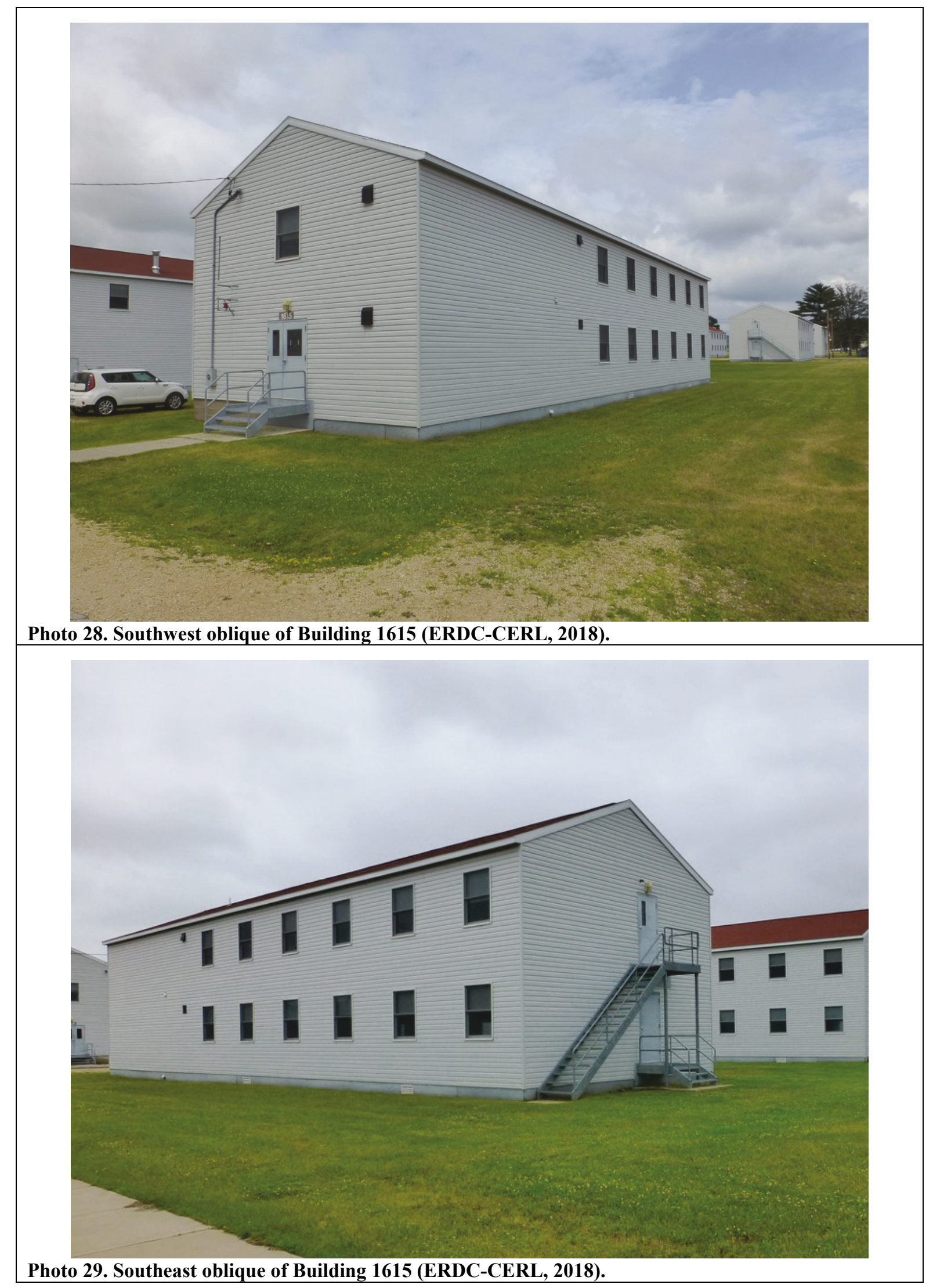




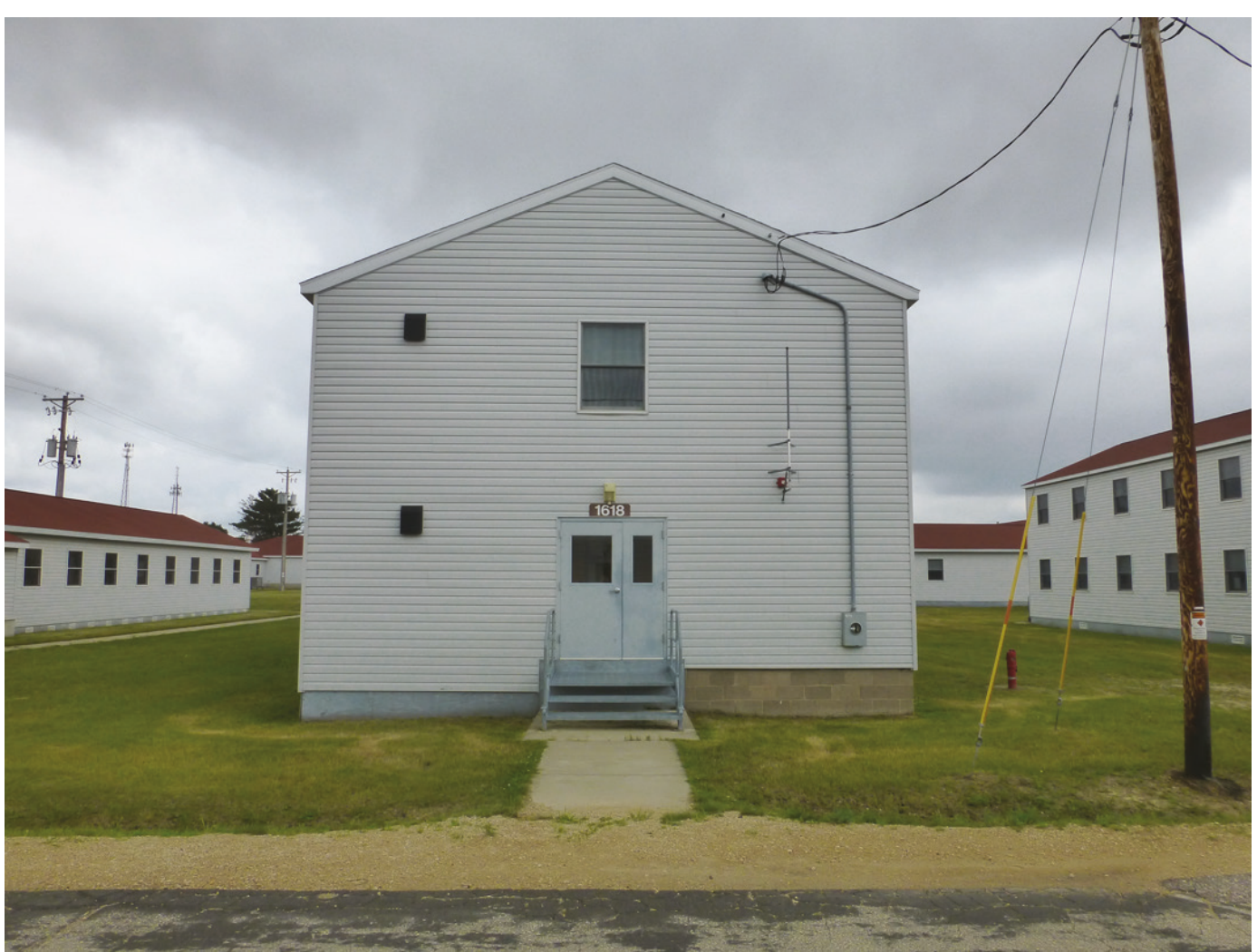

Photo 30. West elevation of Building 1618 (ERDC-CERL, 2018).

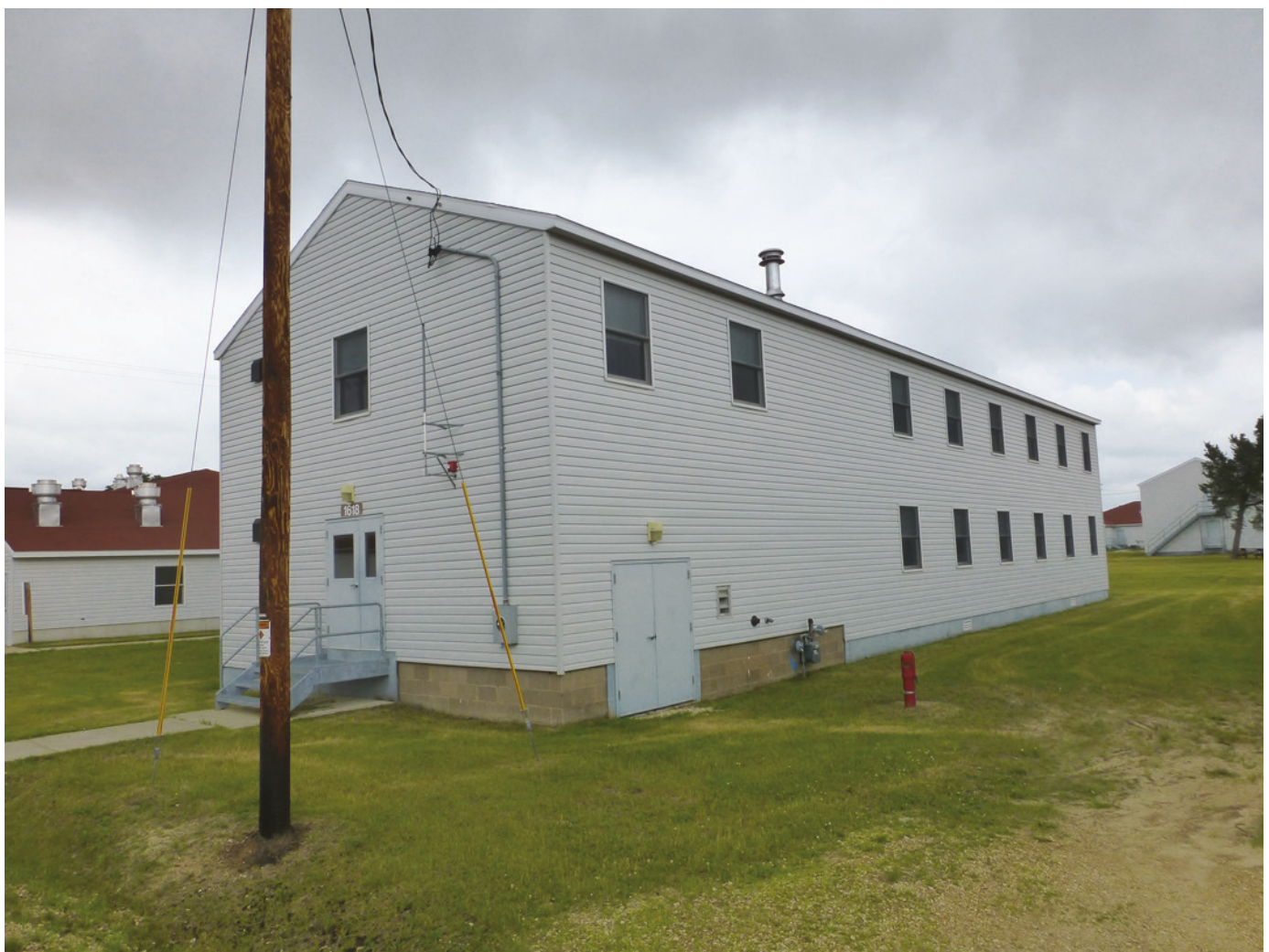

Photo 31. Southwest oblique of Building 1618 (ERDC-CERL, 2018). 


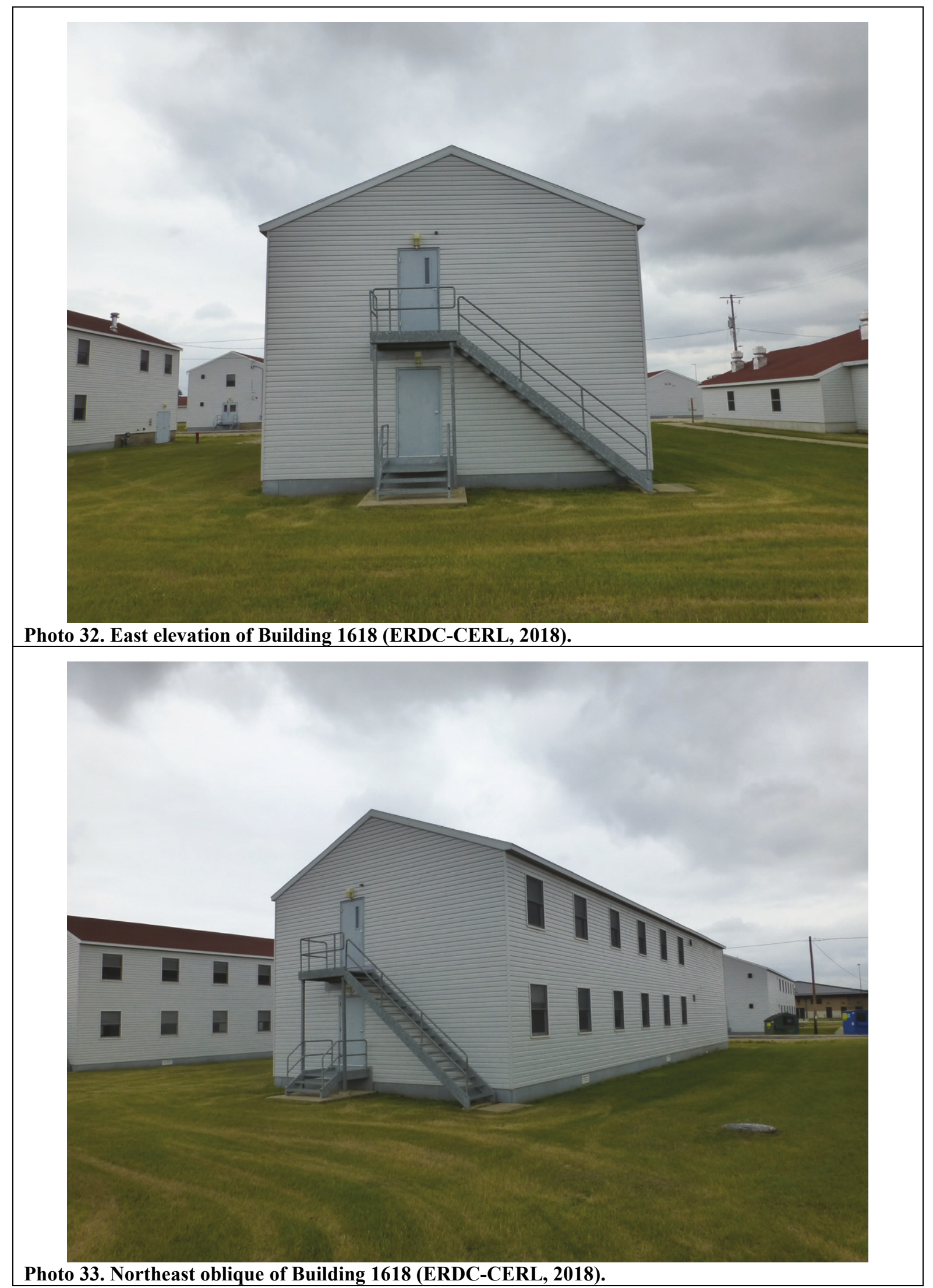




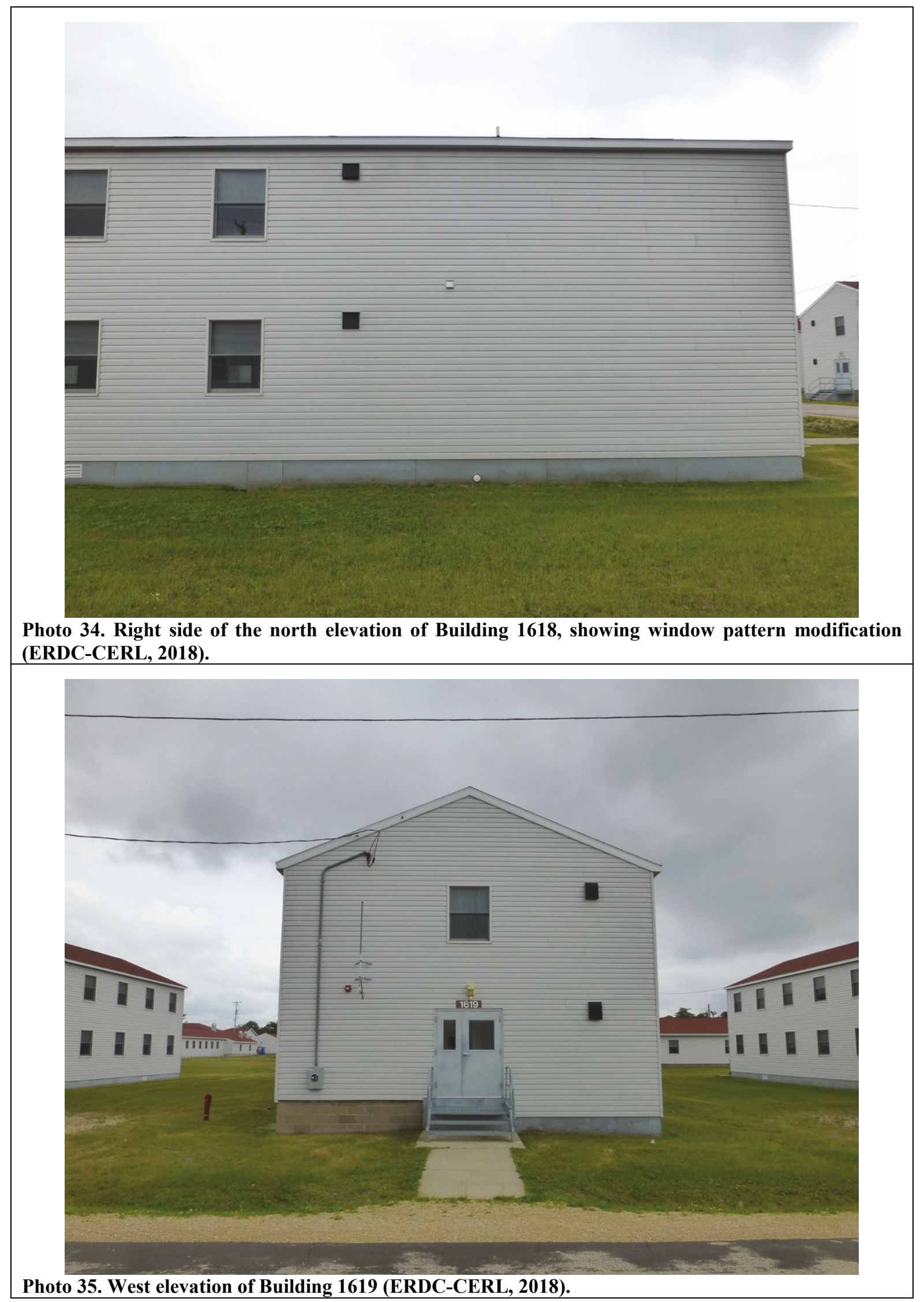




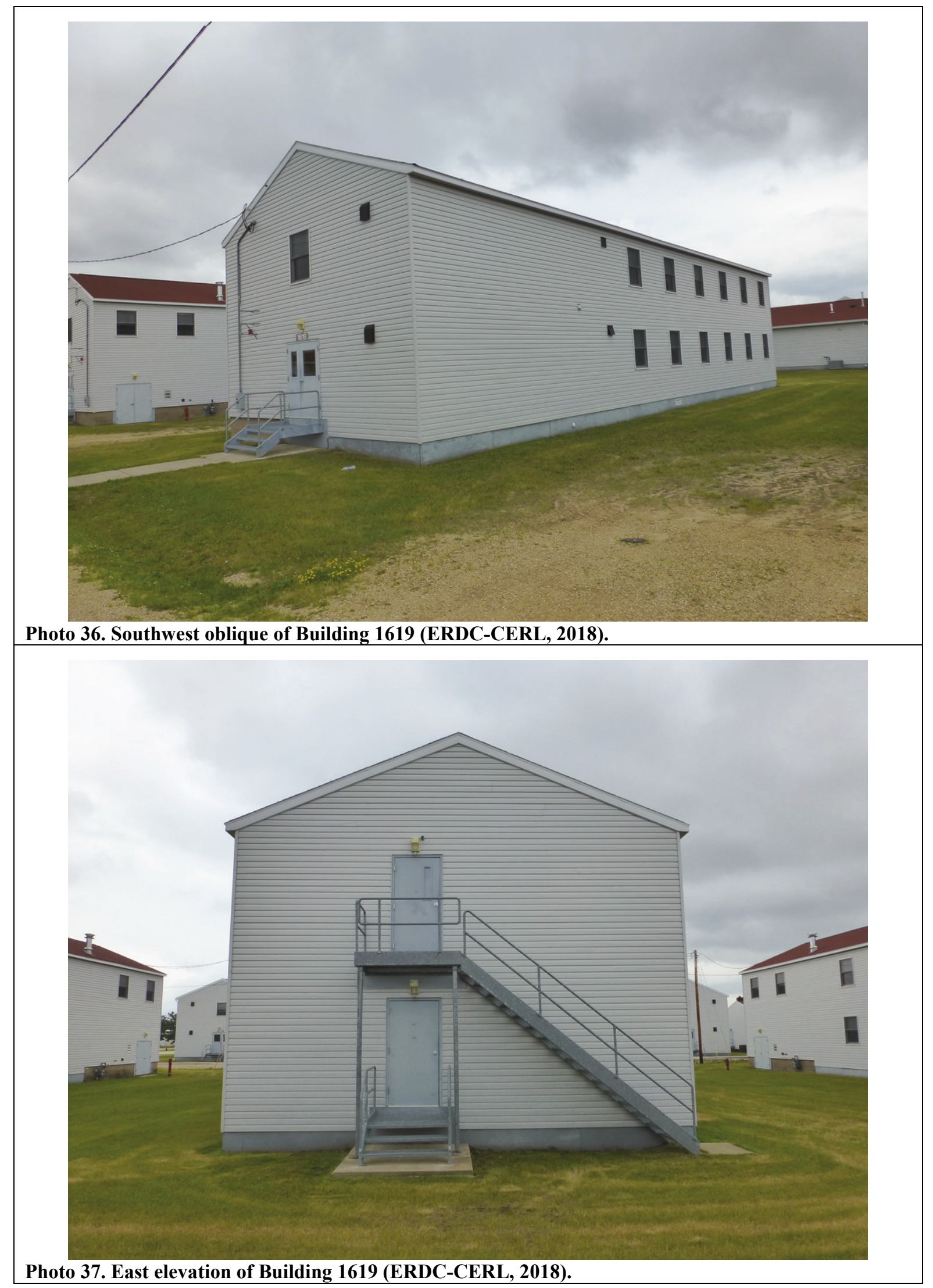




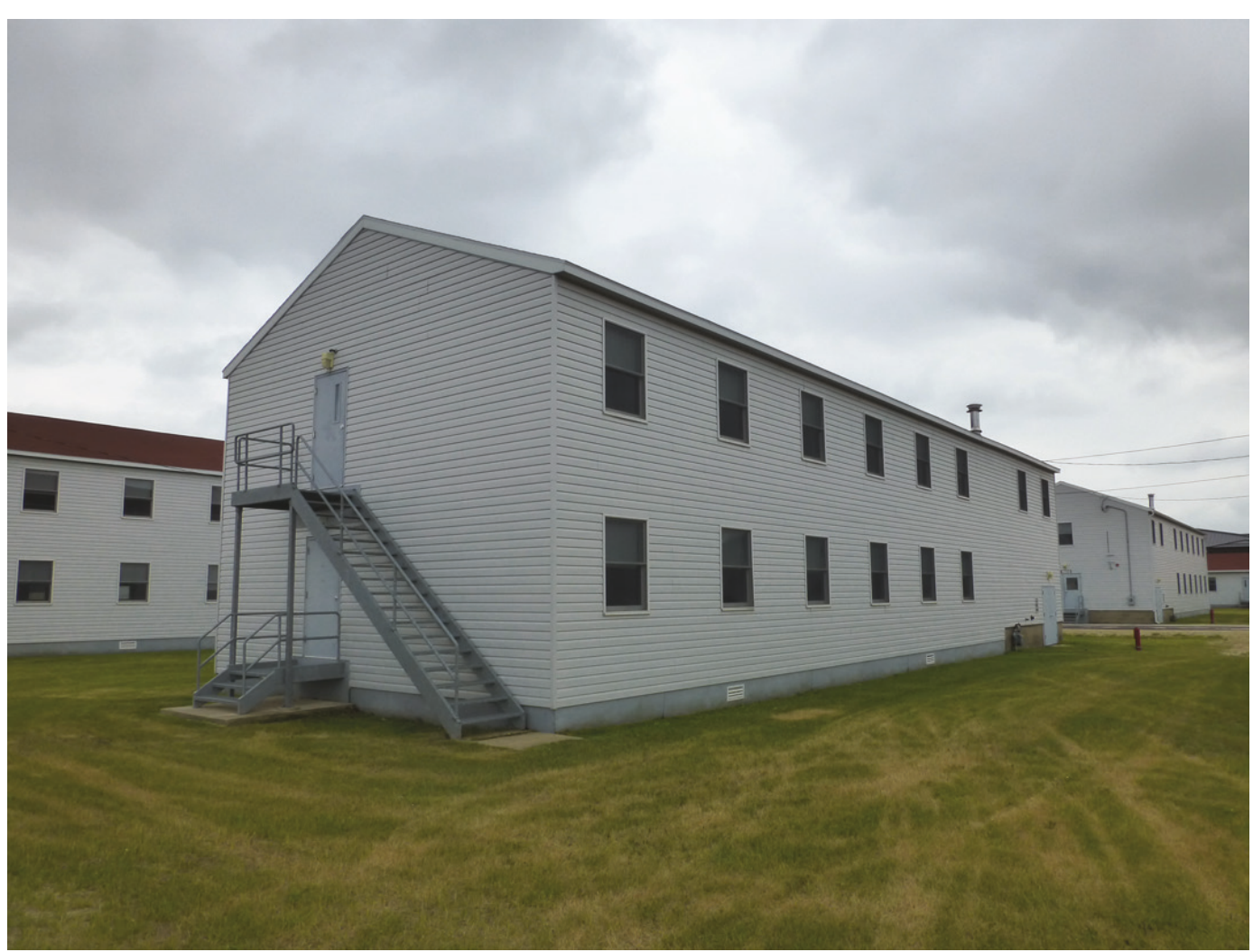

Photo 38. Northeast oblique of Building 1619 (ERDC-CERL, 2018).

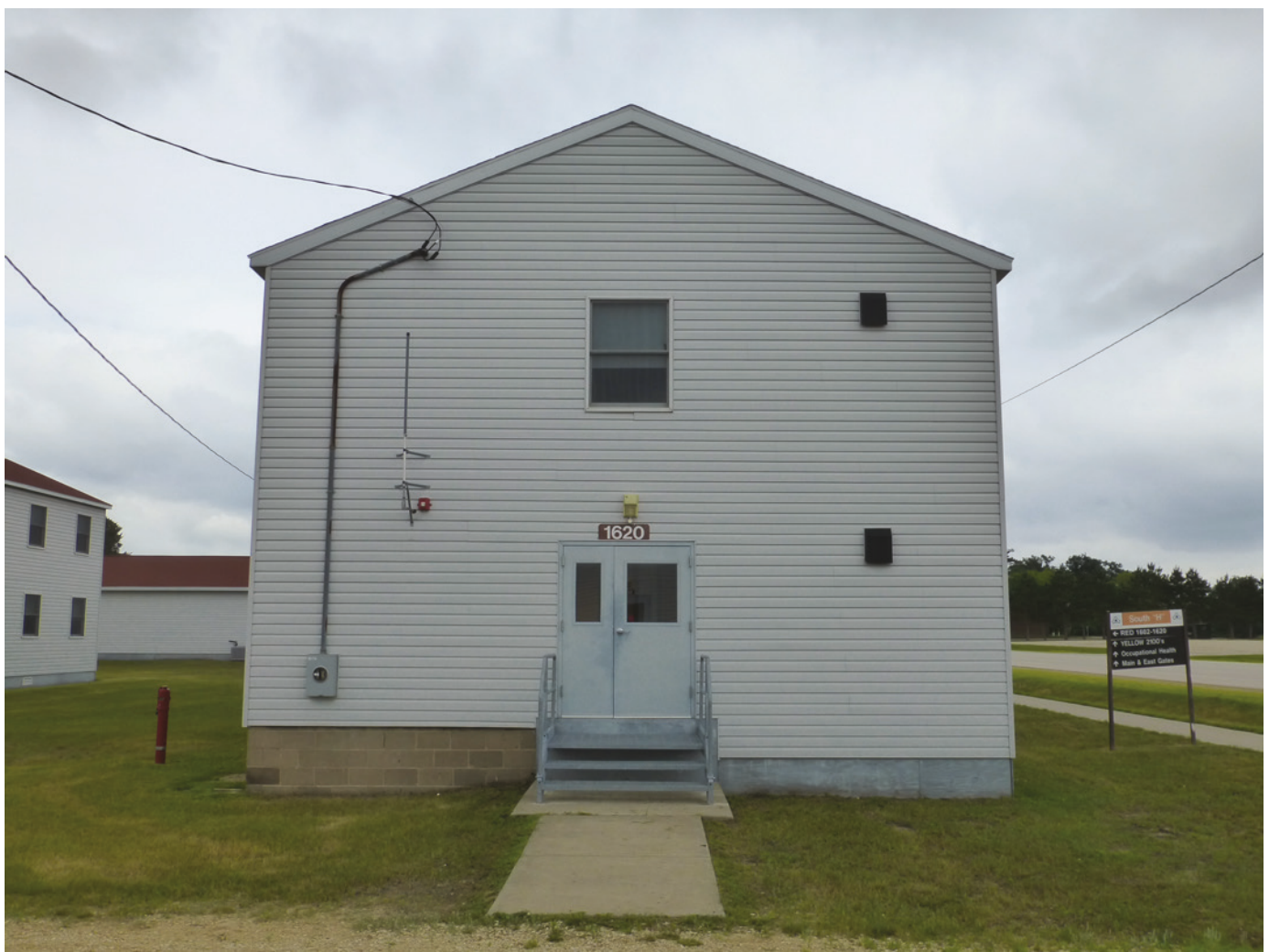

Photo 39. West elevation of Building 1620 (ERDC-CERL, 2018). 


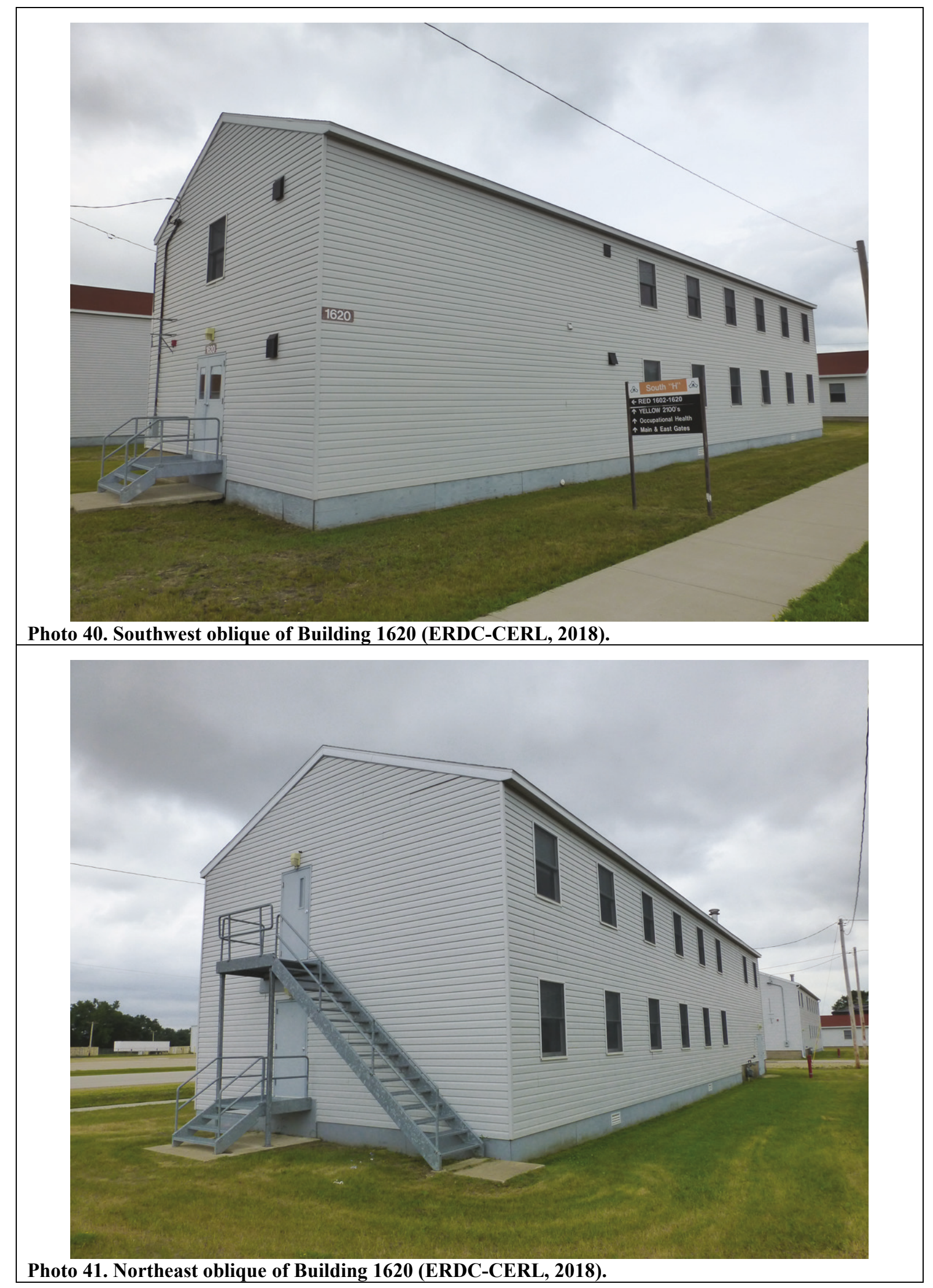




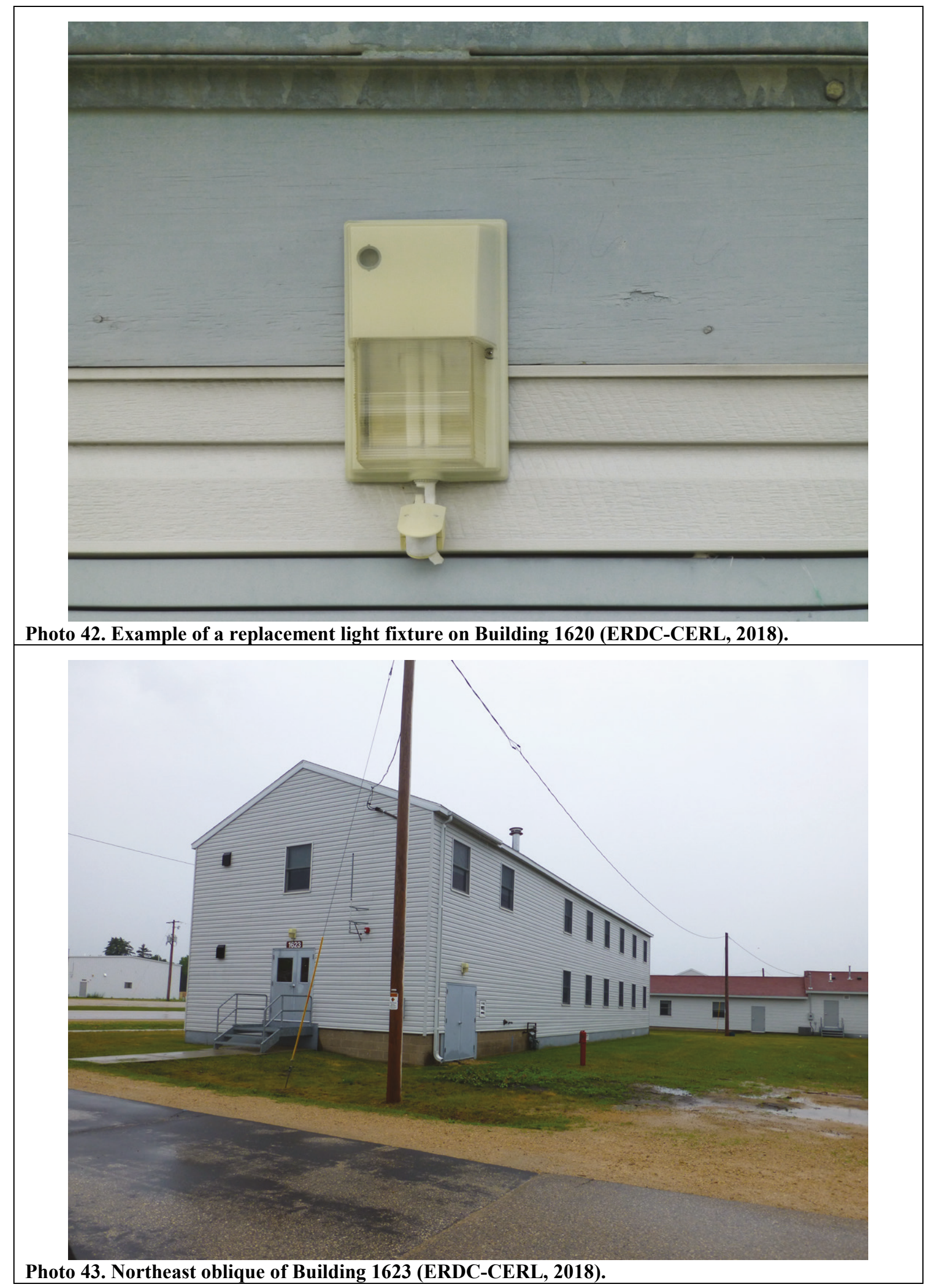




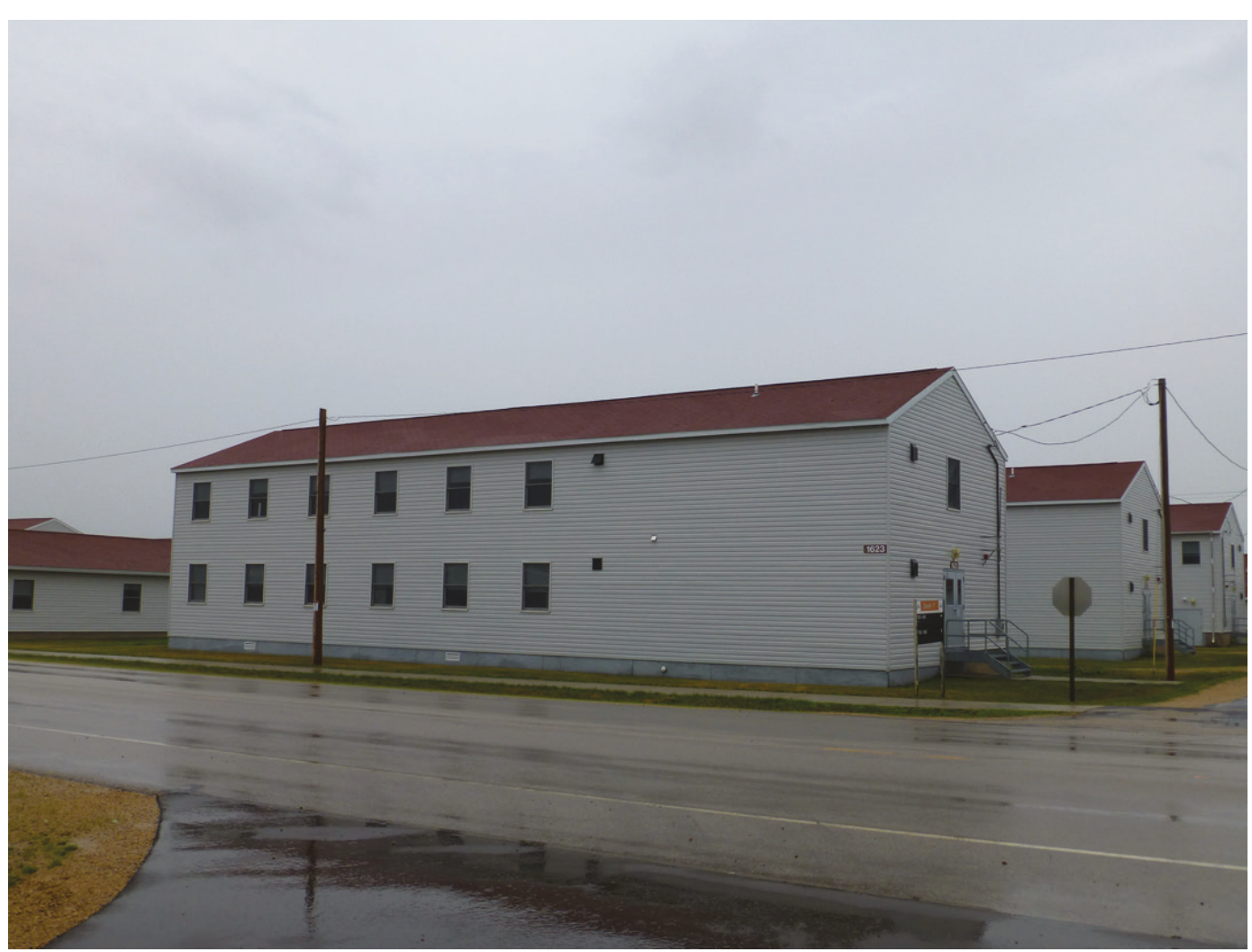

Photo 44. Southeast oblique of Building 1623 (ERDC-CERL, 2018).

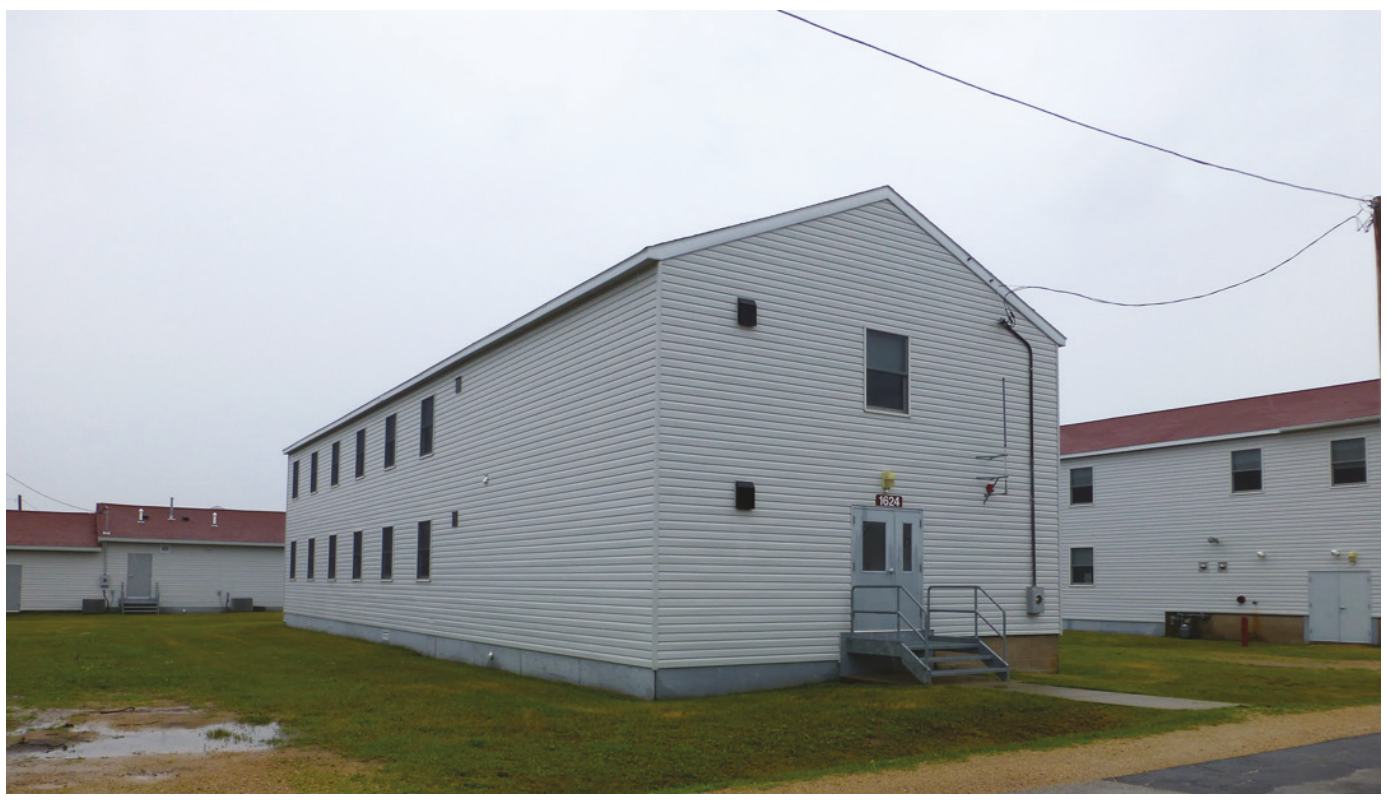

Photo 45. Southeast oblique of Building 1624 (ERDC-CERL, 2018). 


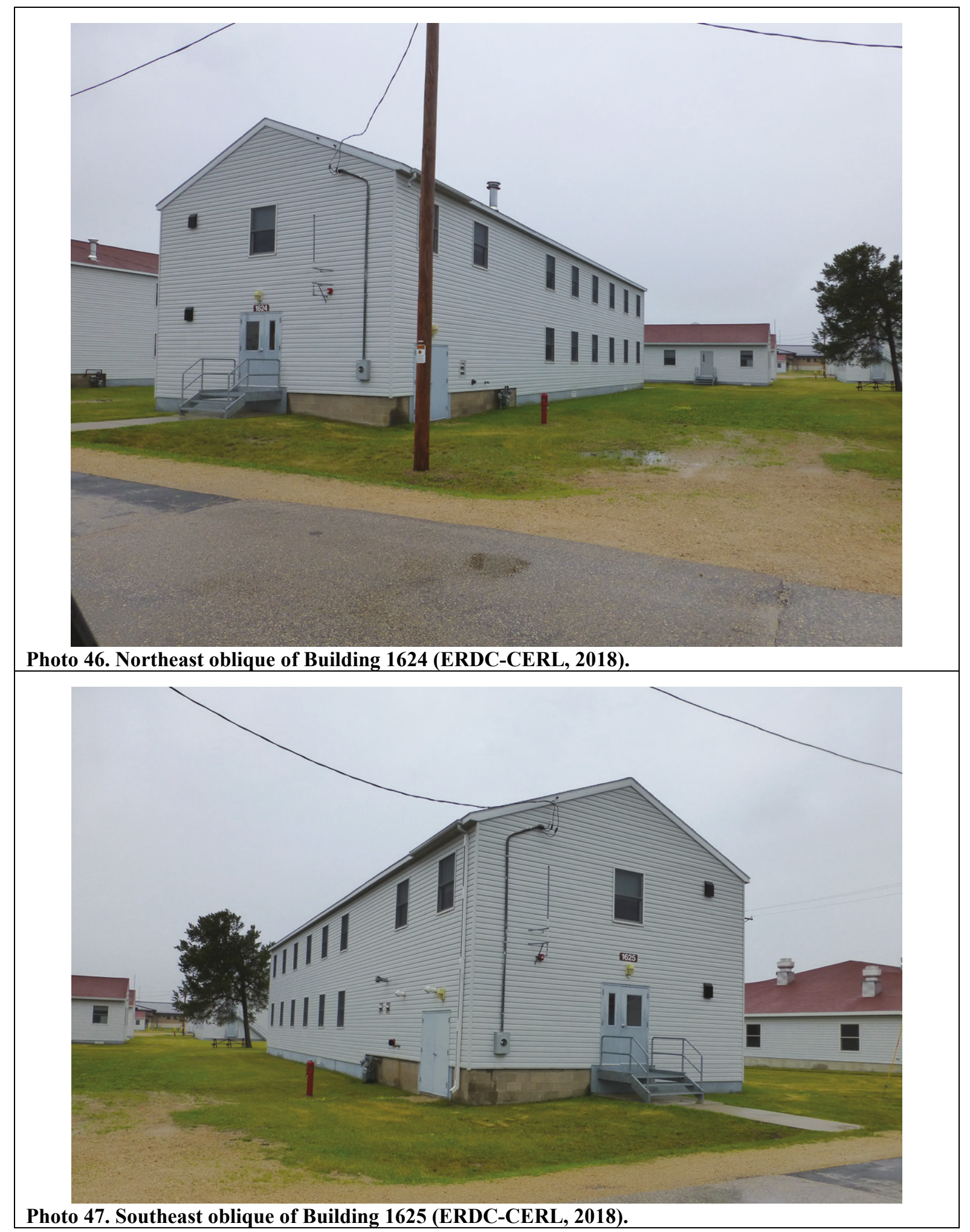




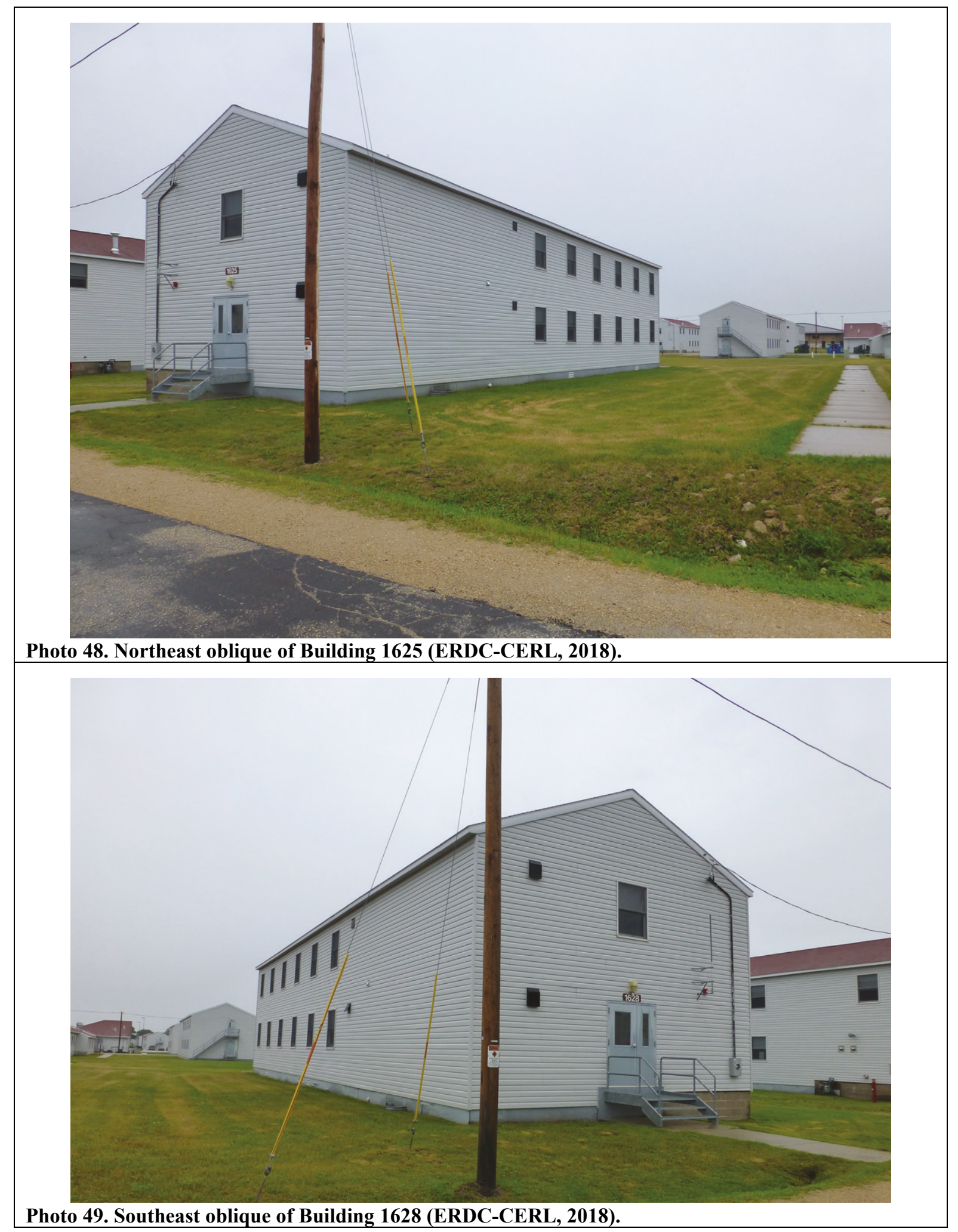




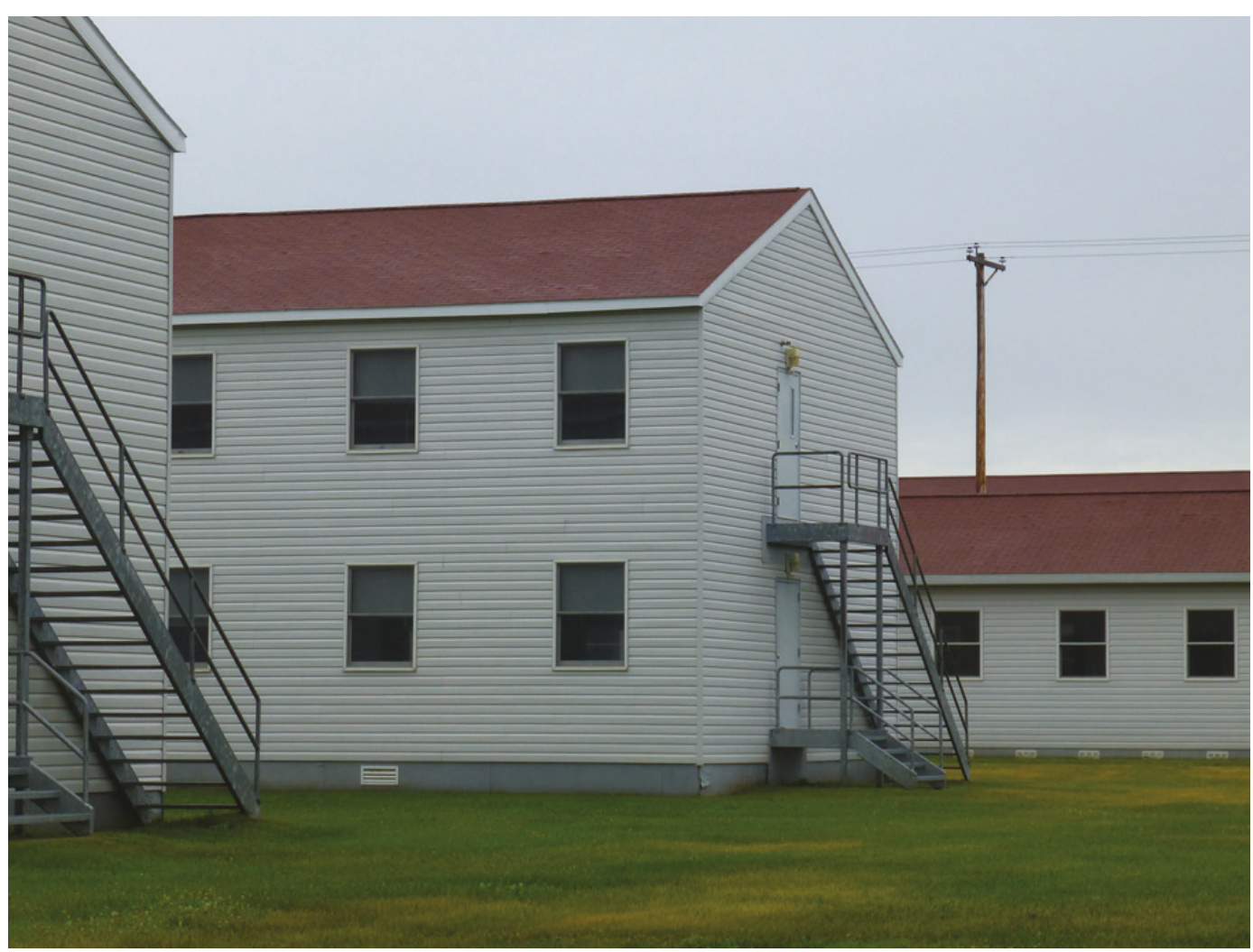

Photo 50. Center portion of photo show oblique of right side of the north elevation and the west elevation of Building 1628 (ERDC-CERL, 2018).

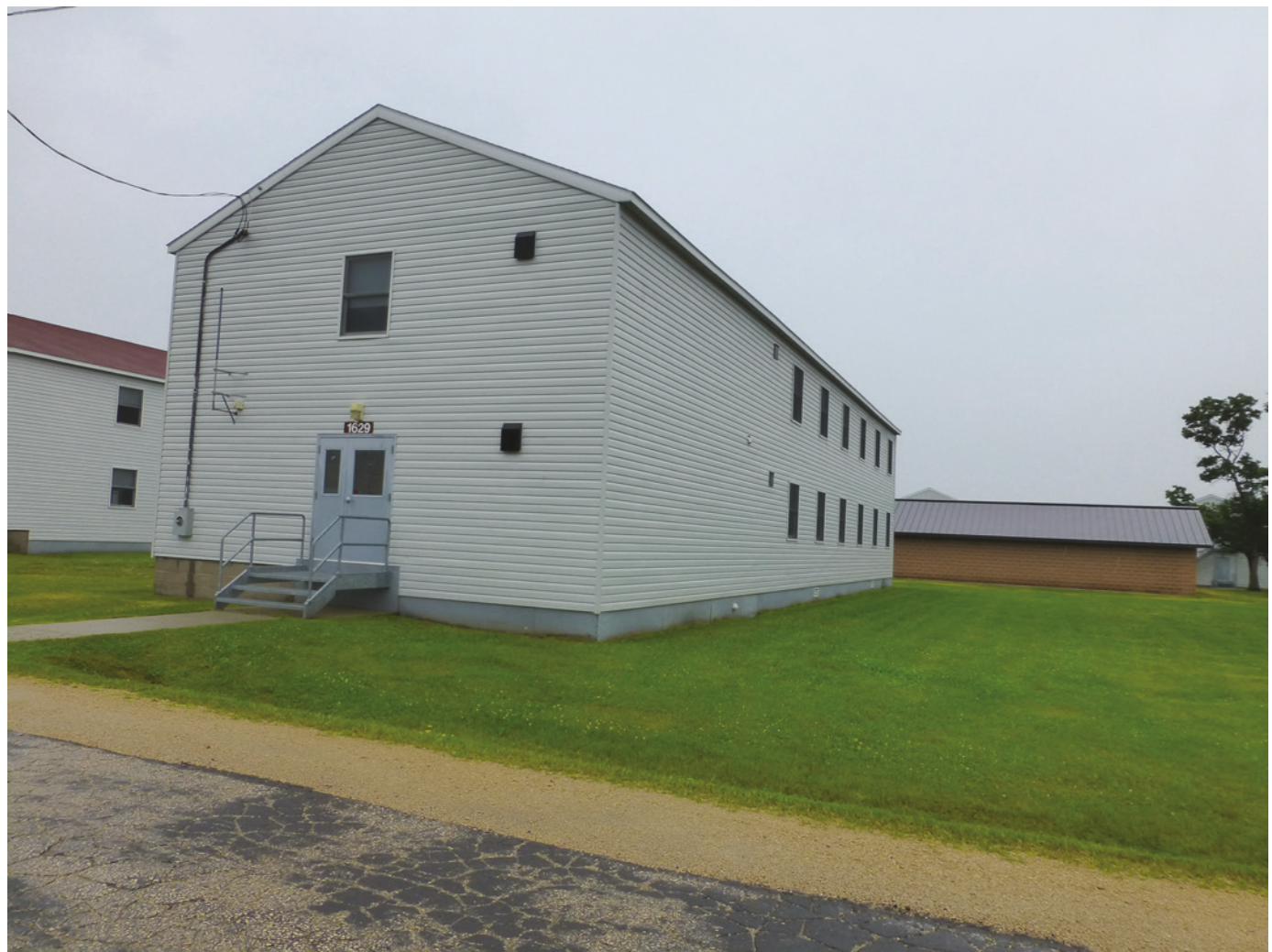

Photo 51. Northeast oblique of Building 1629 (ERDC-CERL, 2018). 


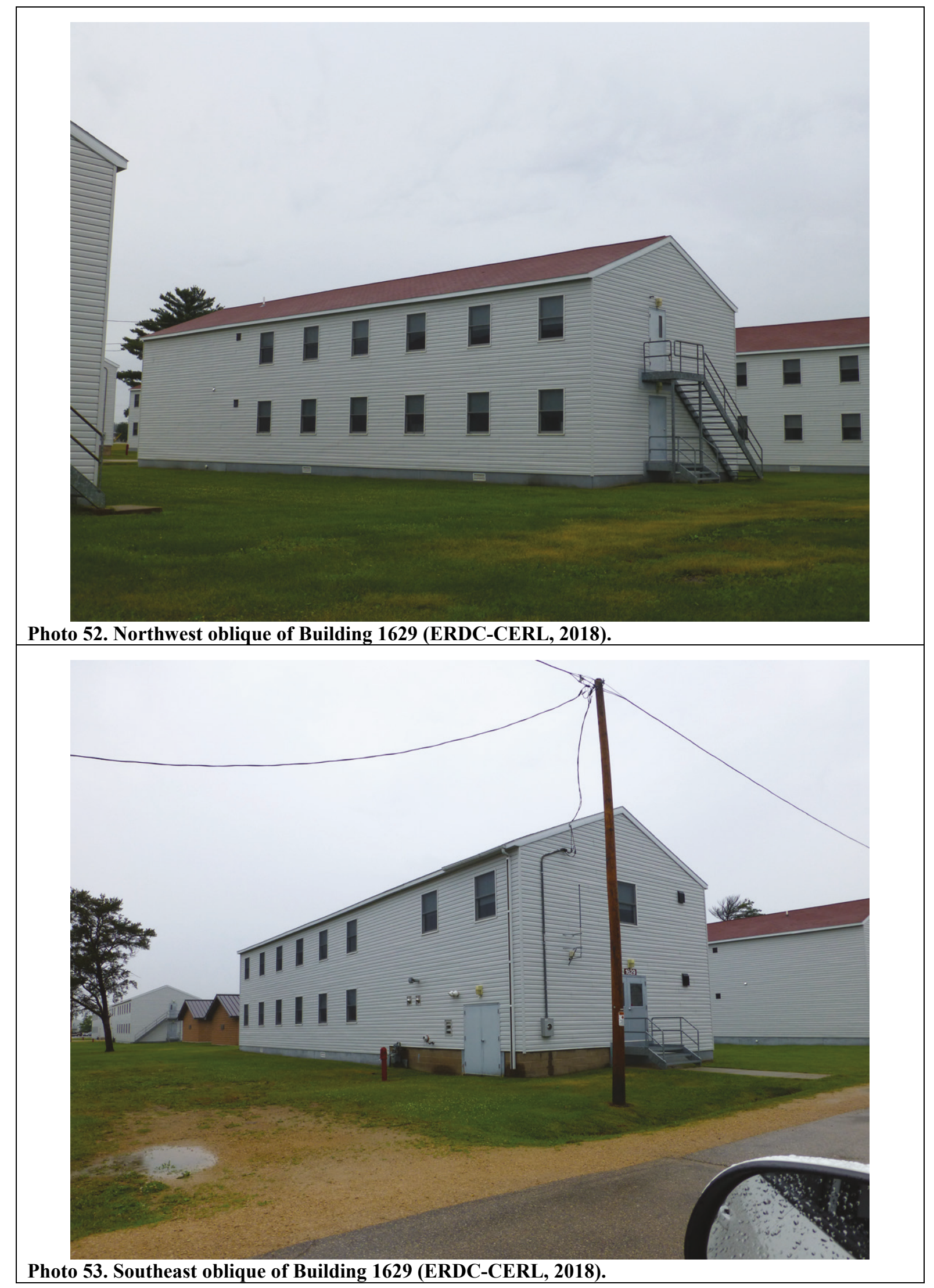




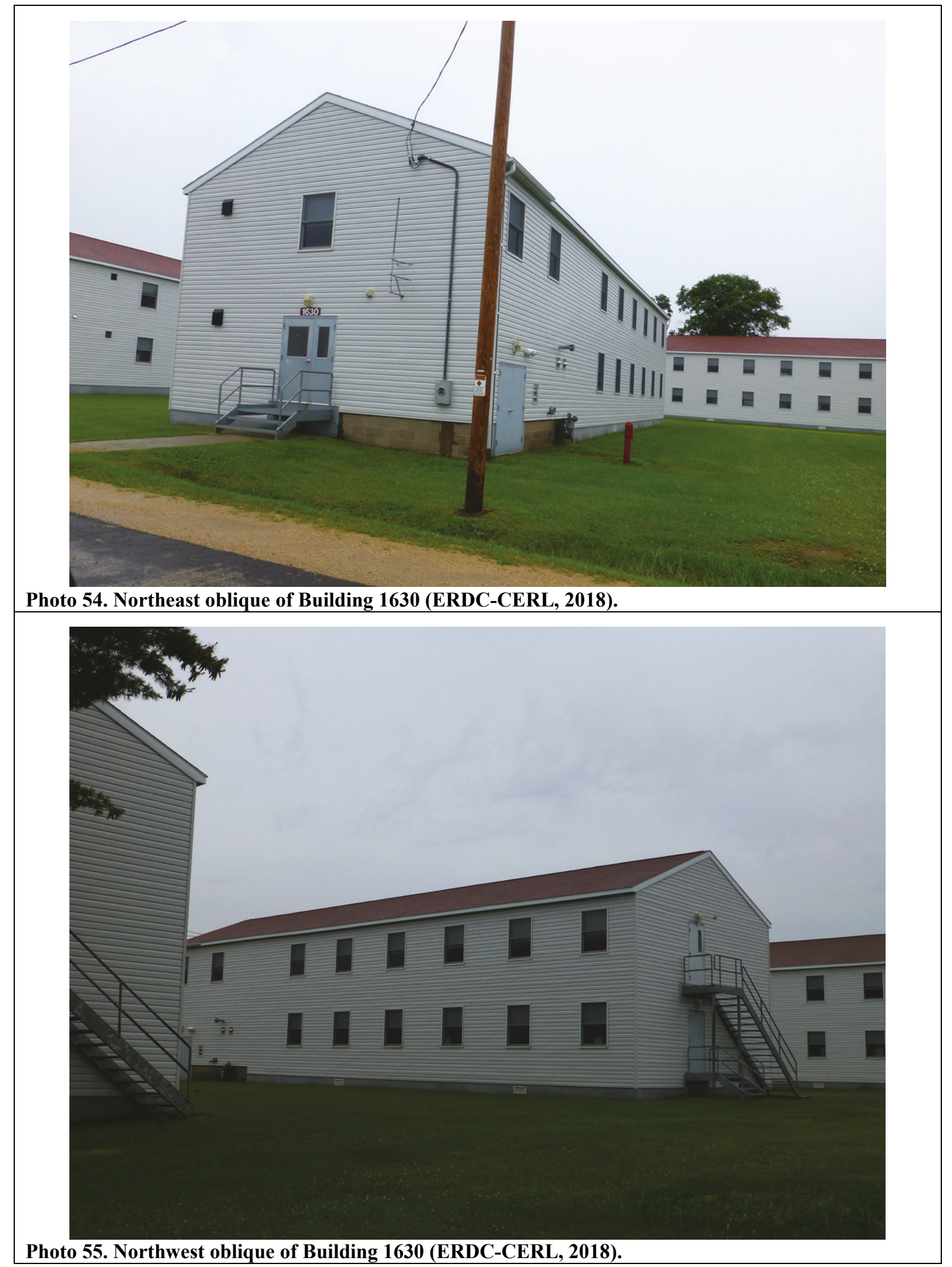




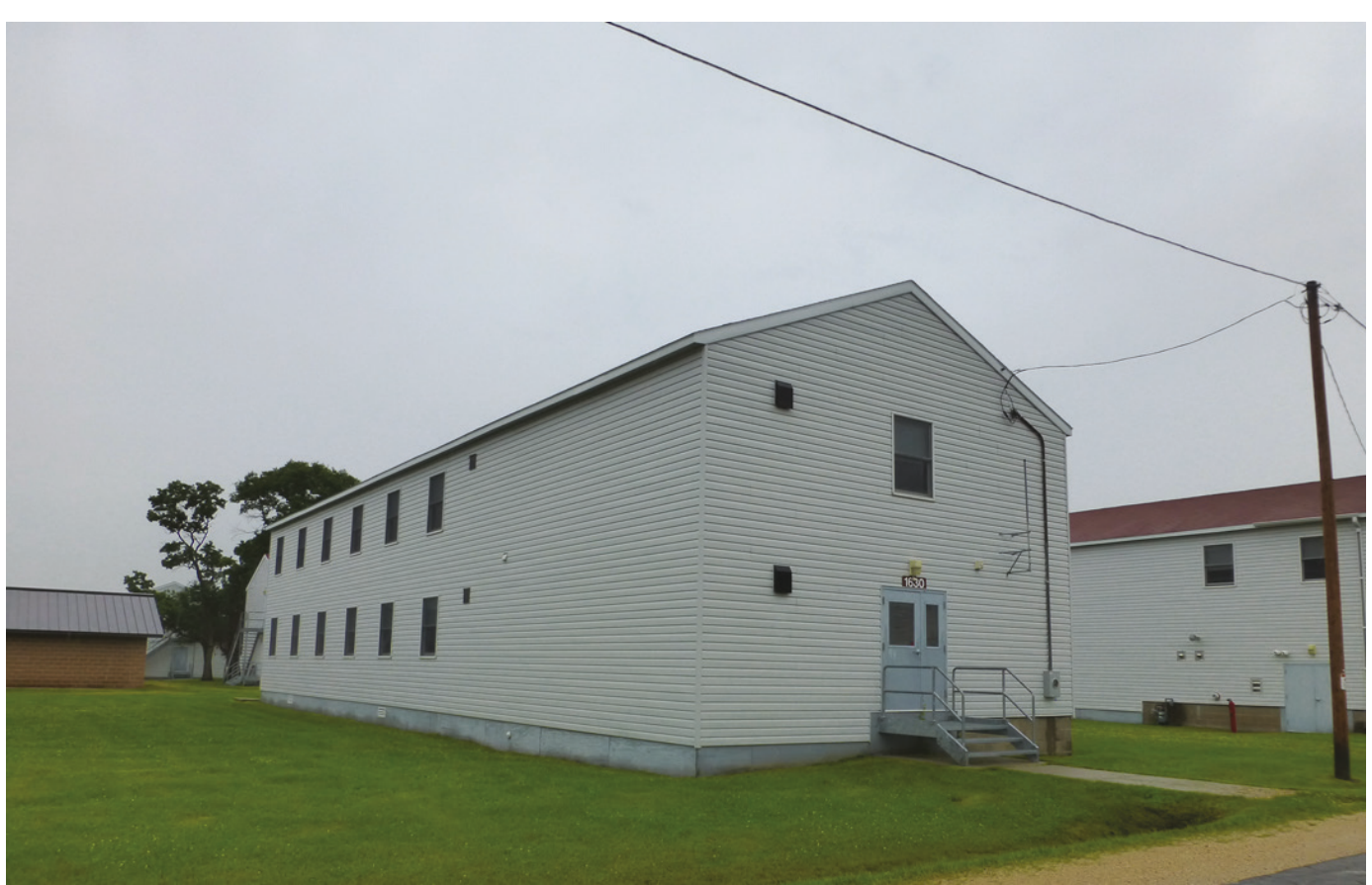

Photo 56. Southeast oblique of Building 1630 (ERDC-CERL, 2018).

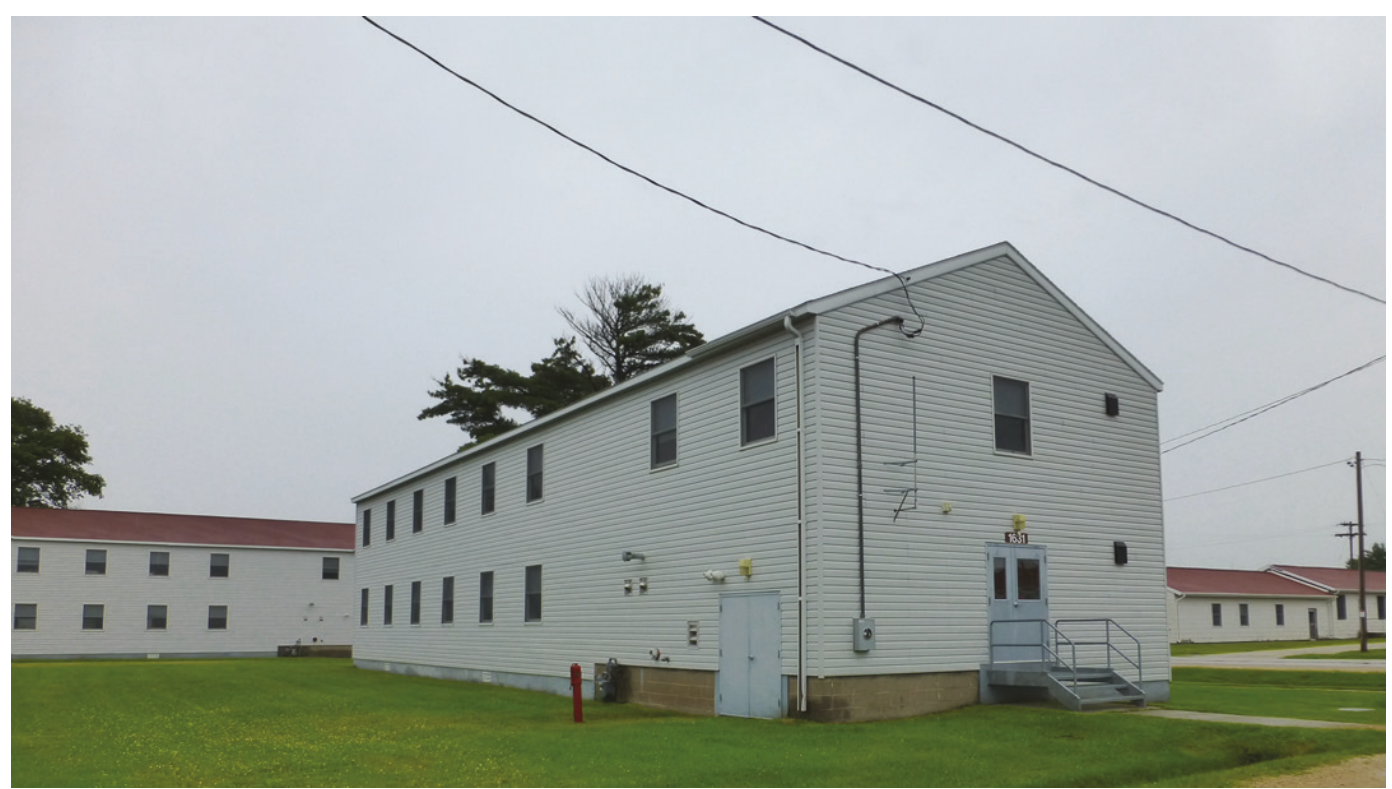

Photo 57. Southeast oblique of Building 1631 (ERDC-CERL, 2018). 


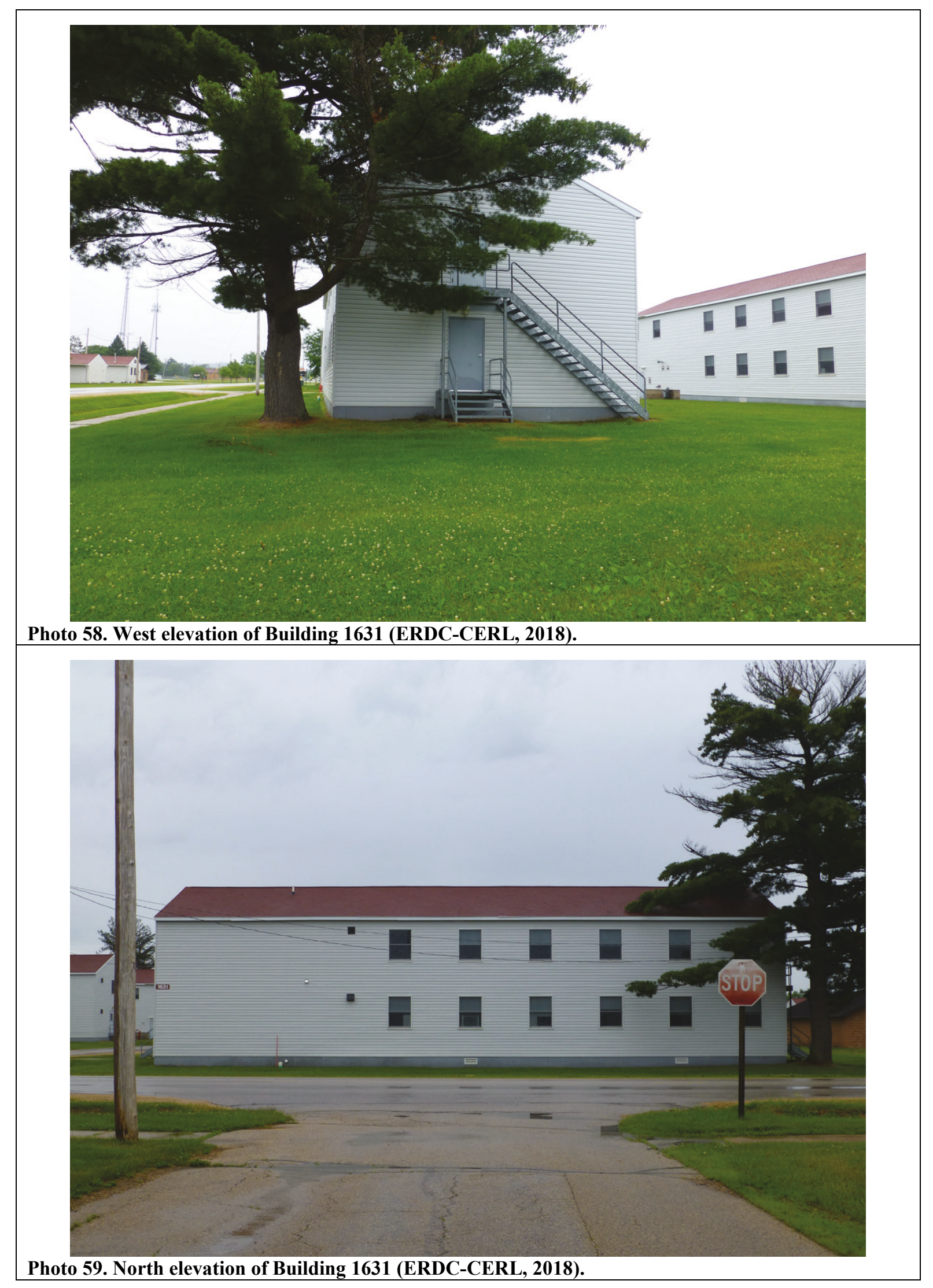




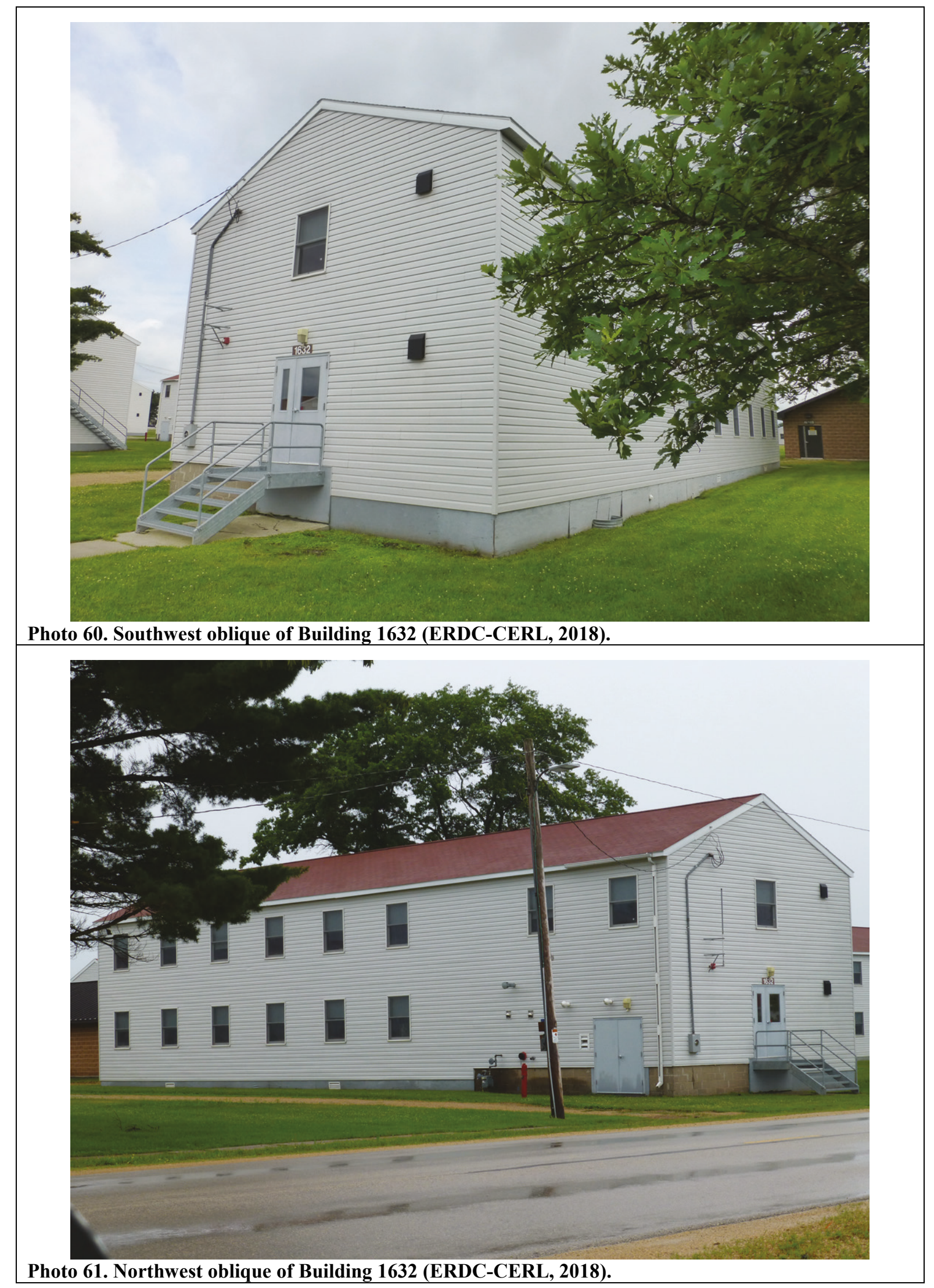




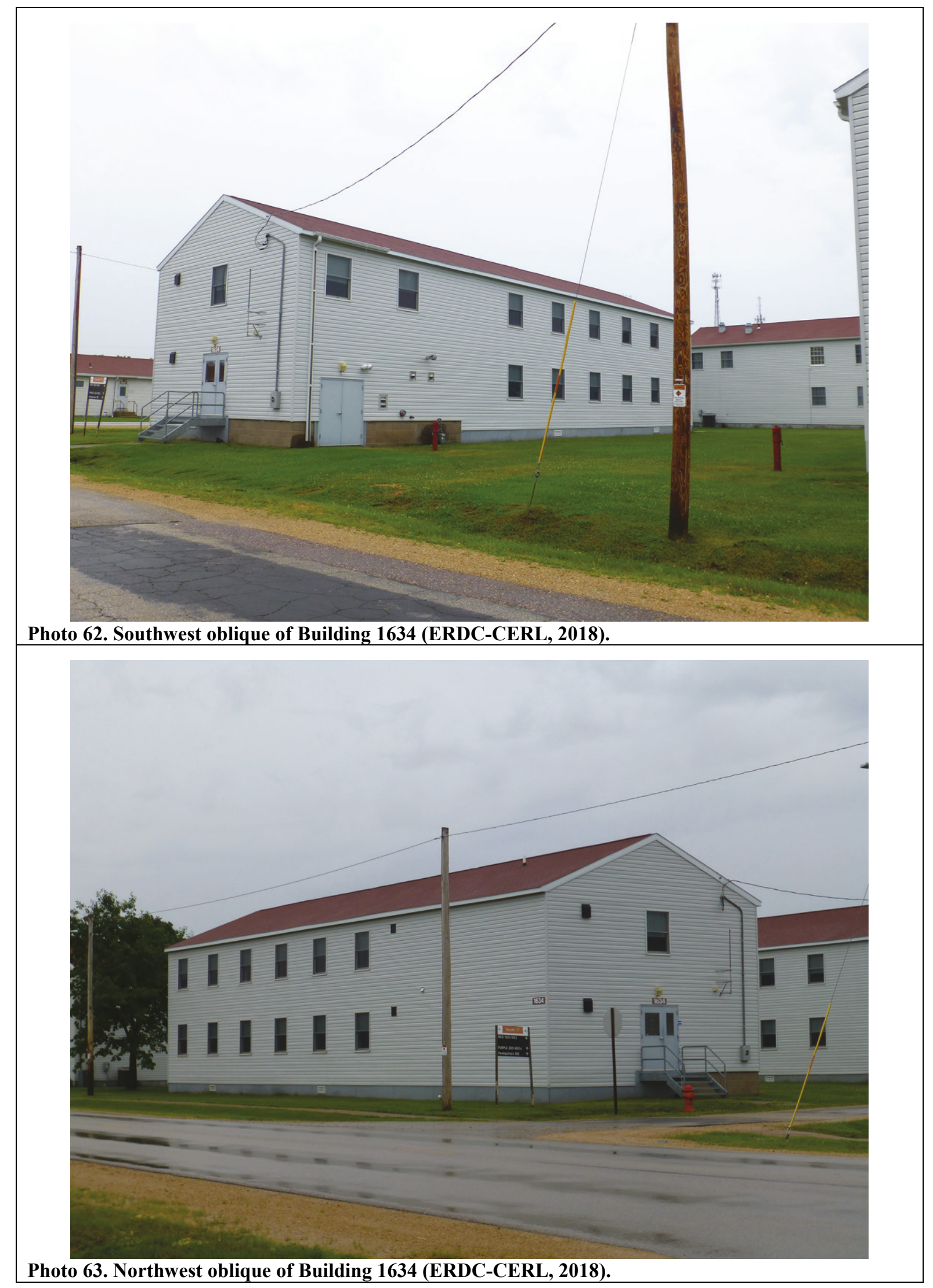




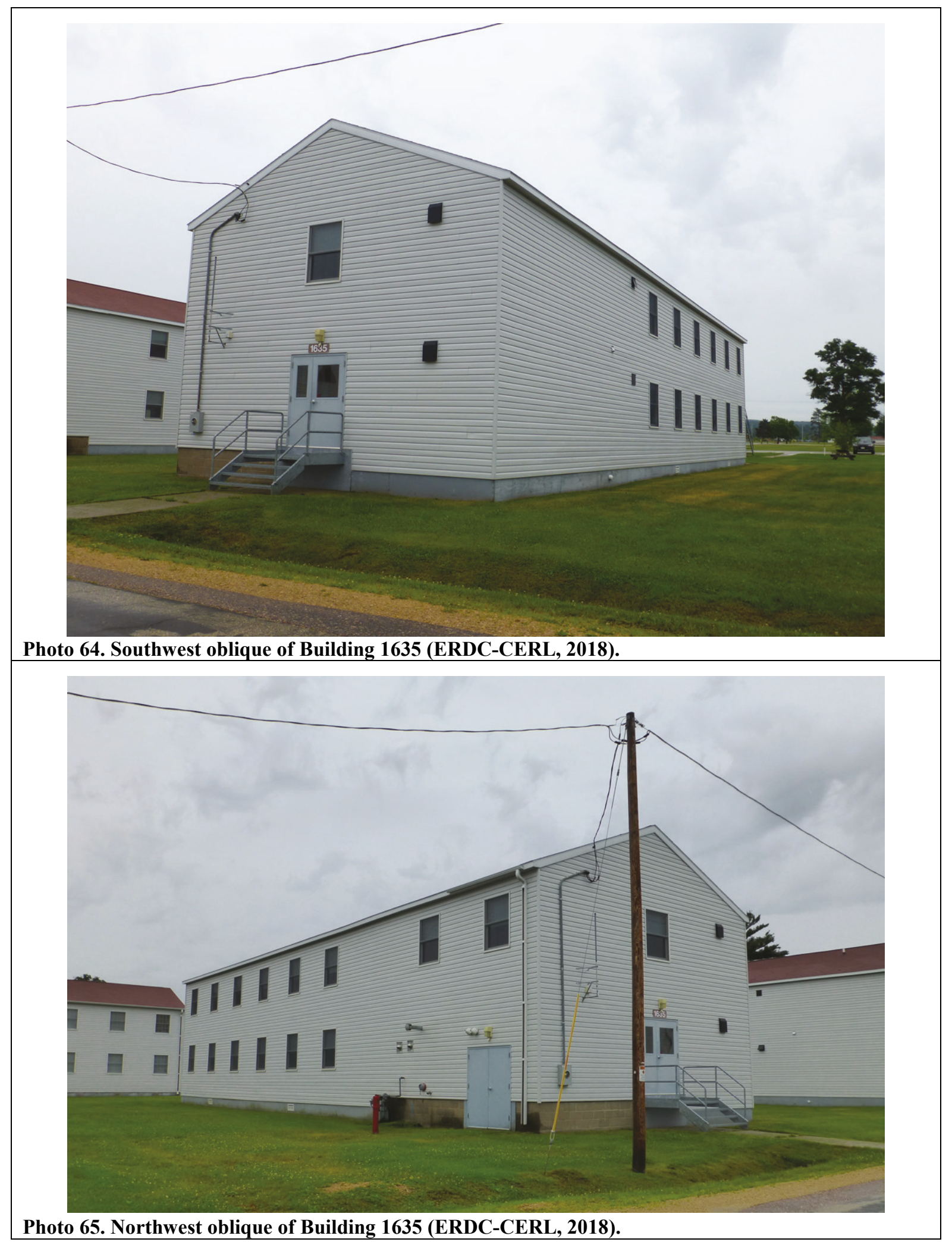




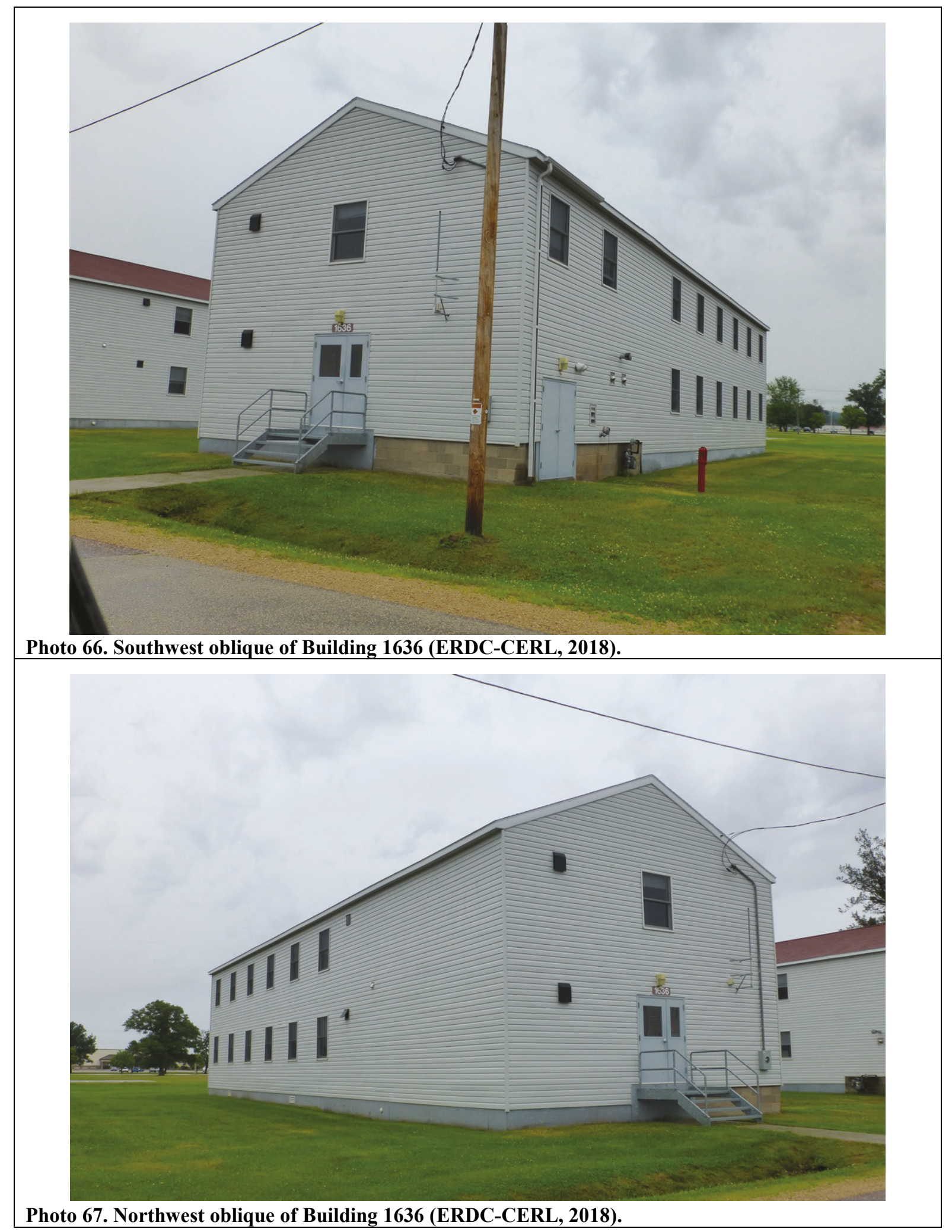




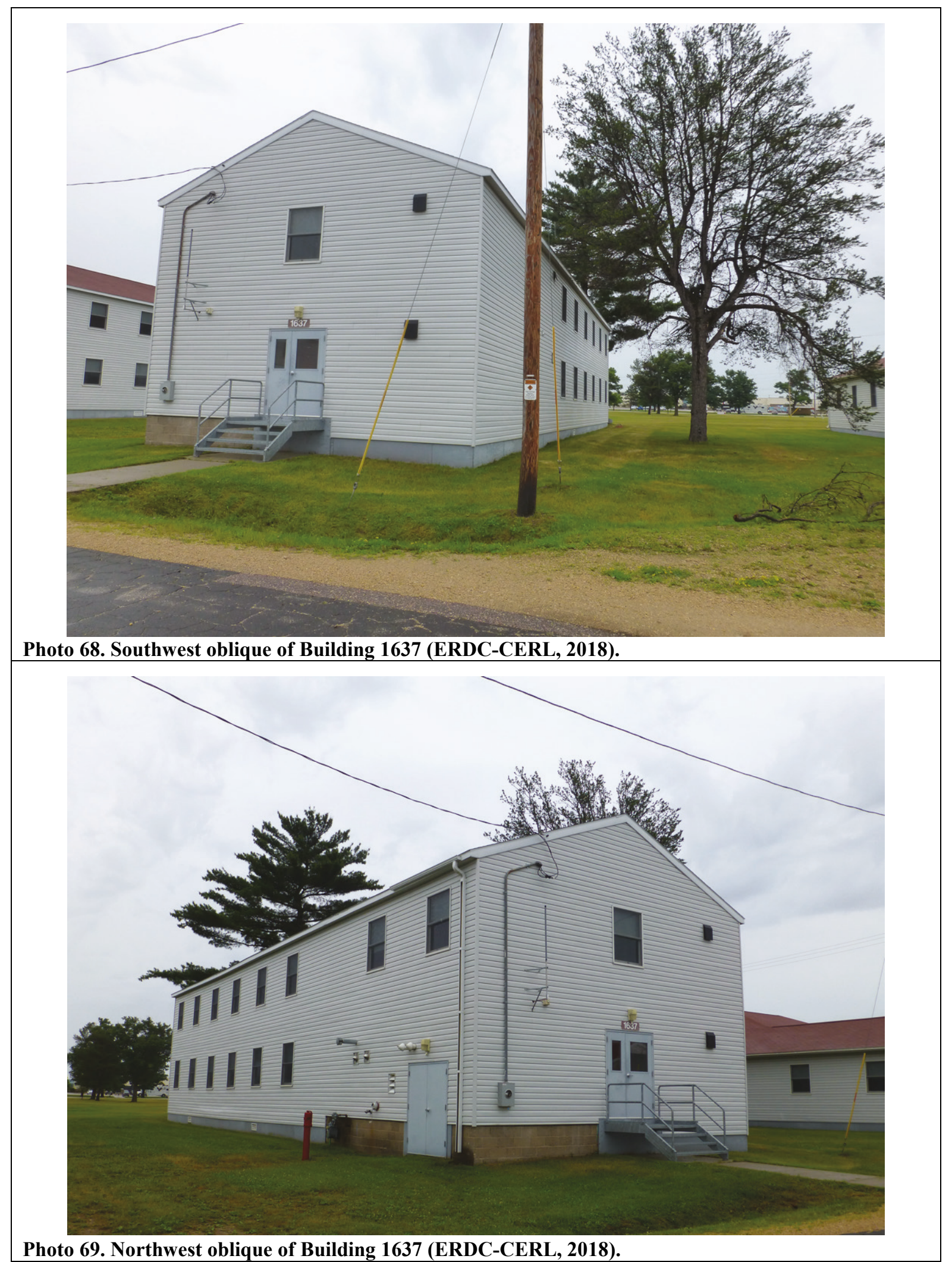




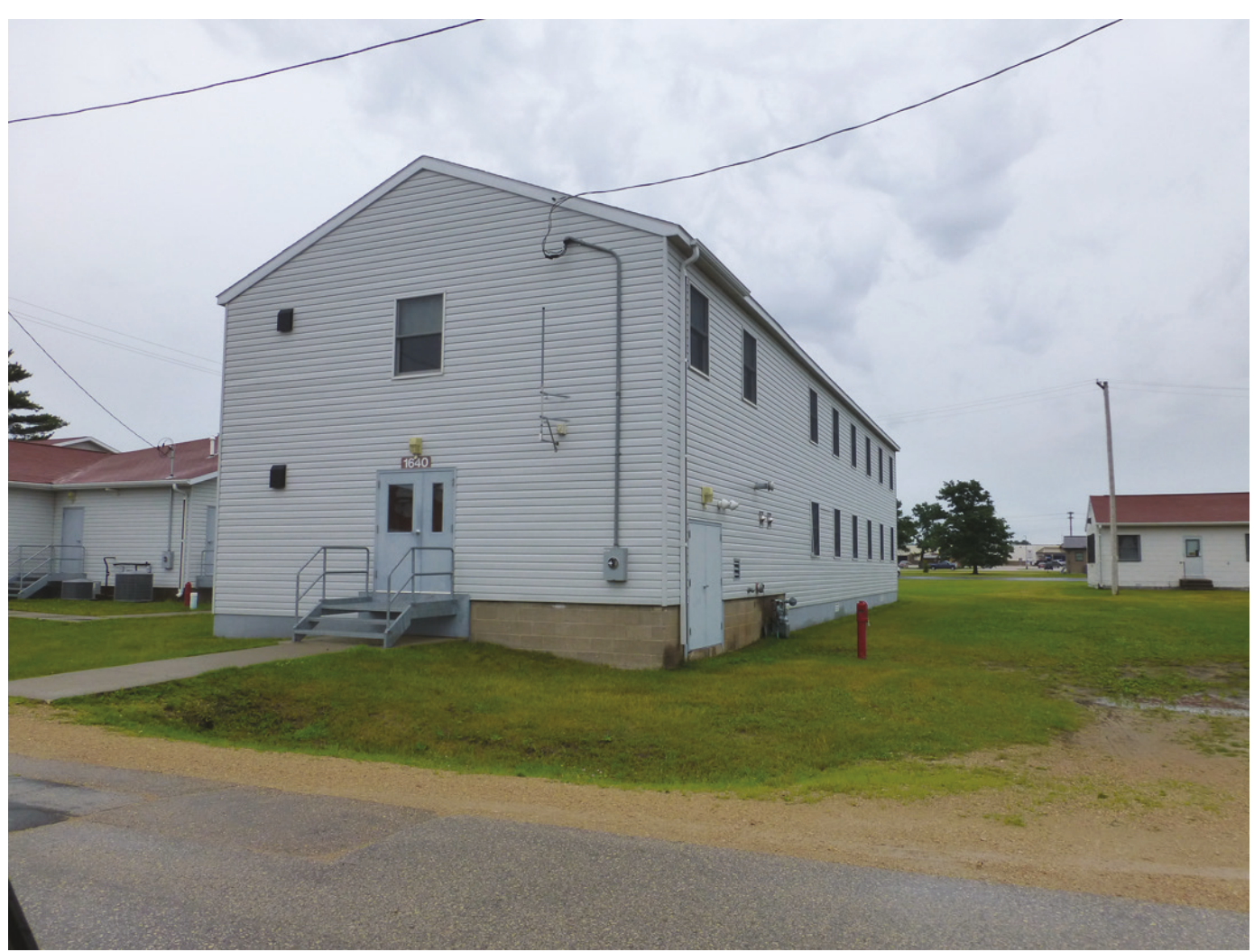

Photo 70. Southwest oblique of Building 1640 (ERDC-CERL, 2018).

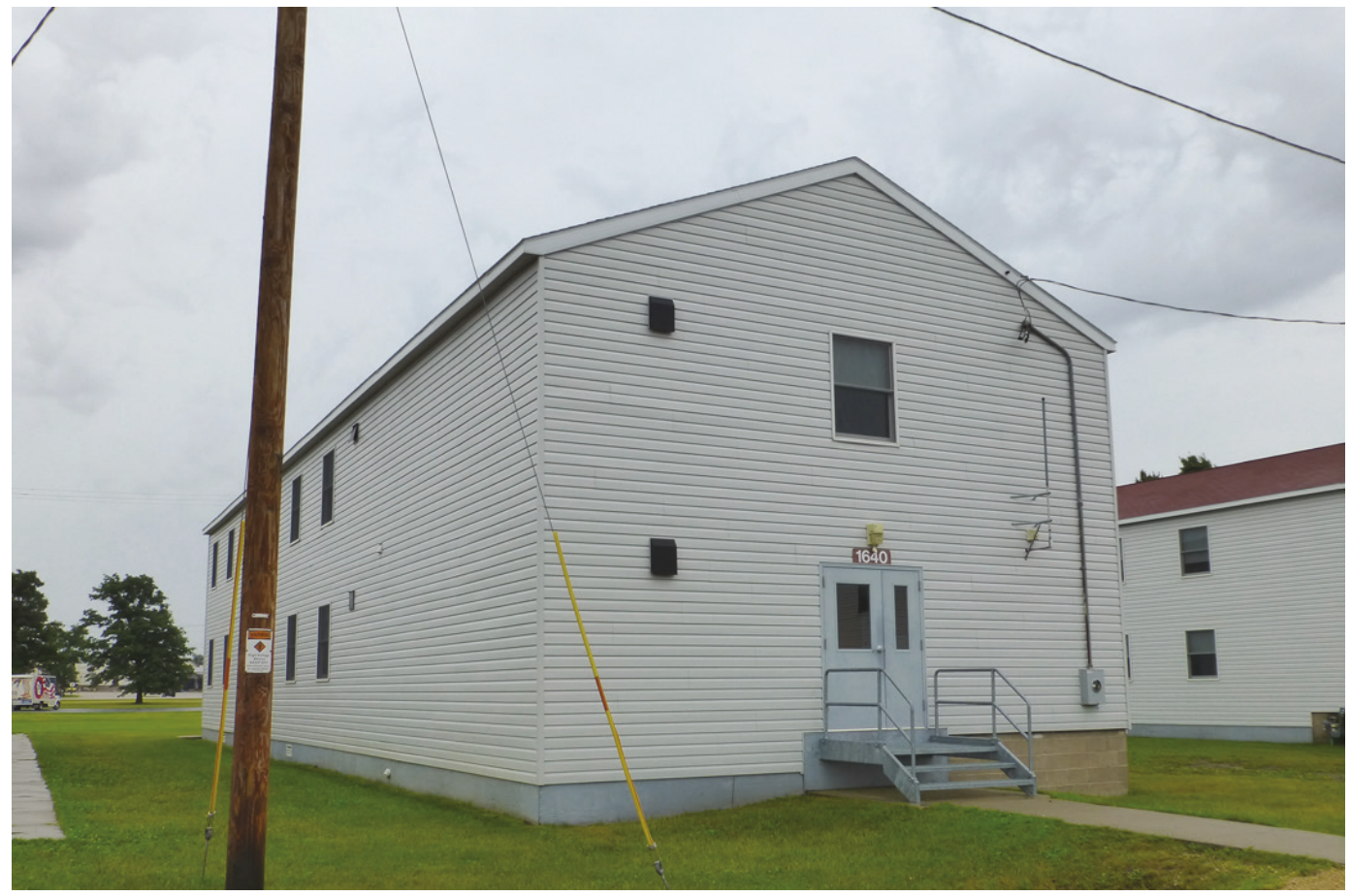

Photo 71. Northwest oblique of Building 1640 (ERDC-CERL, 2018). 


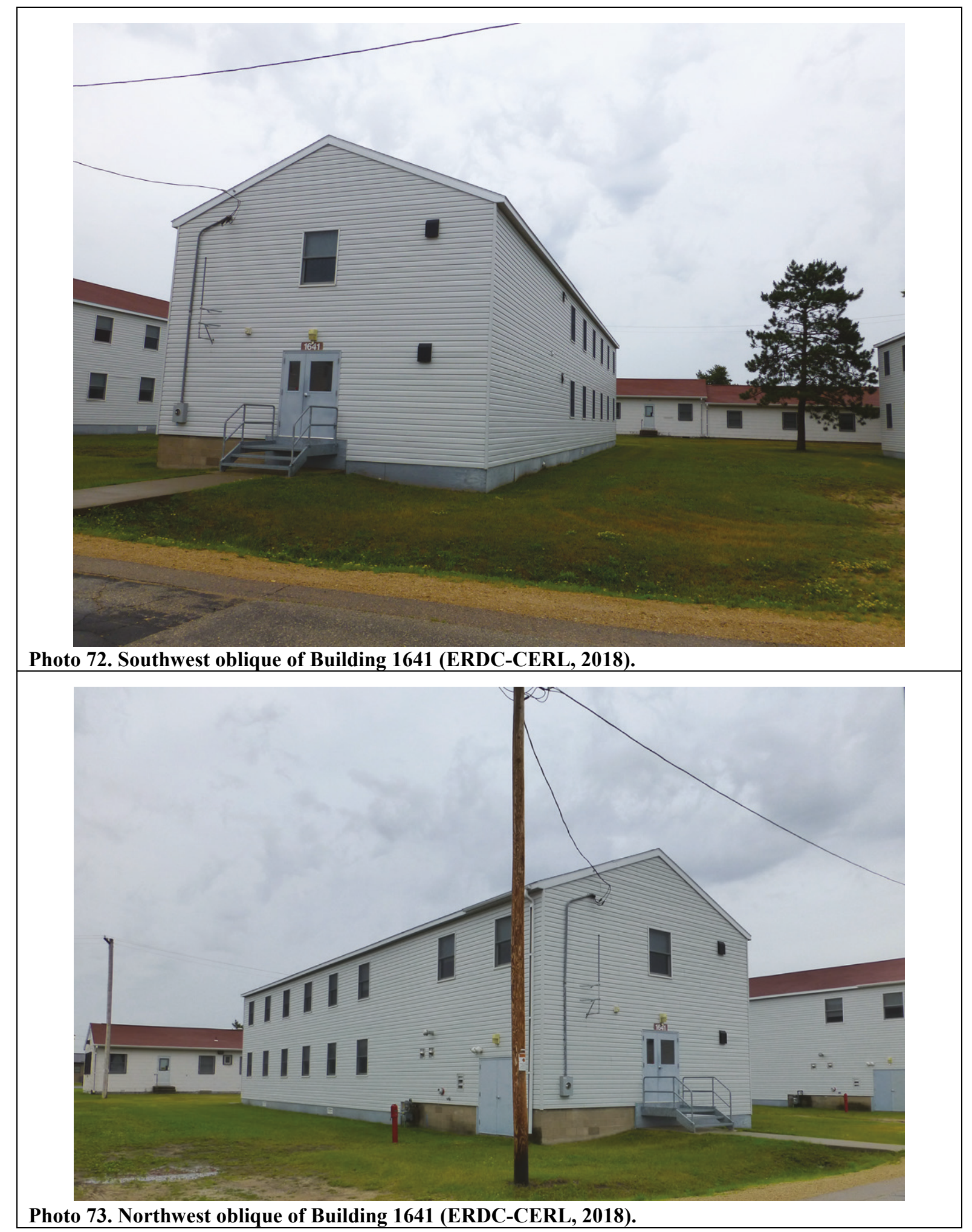




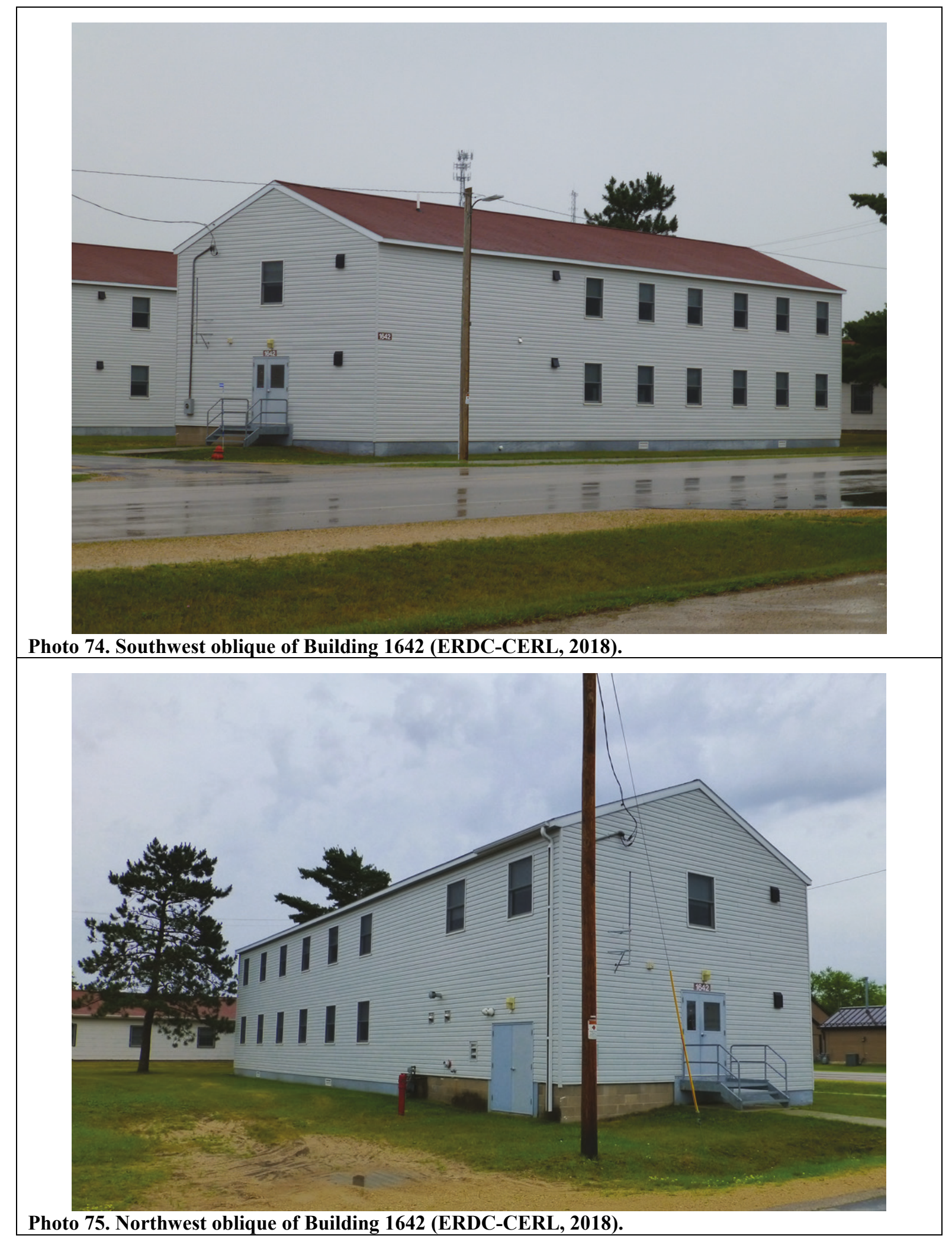




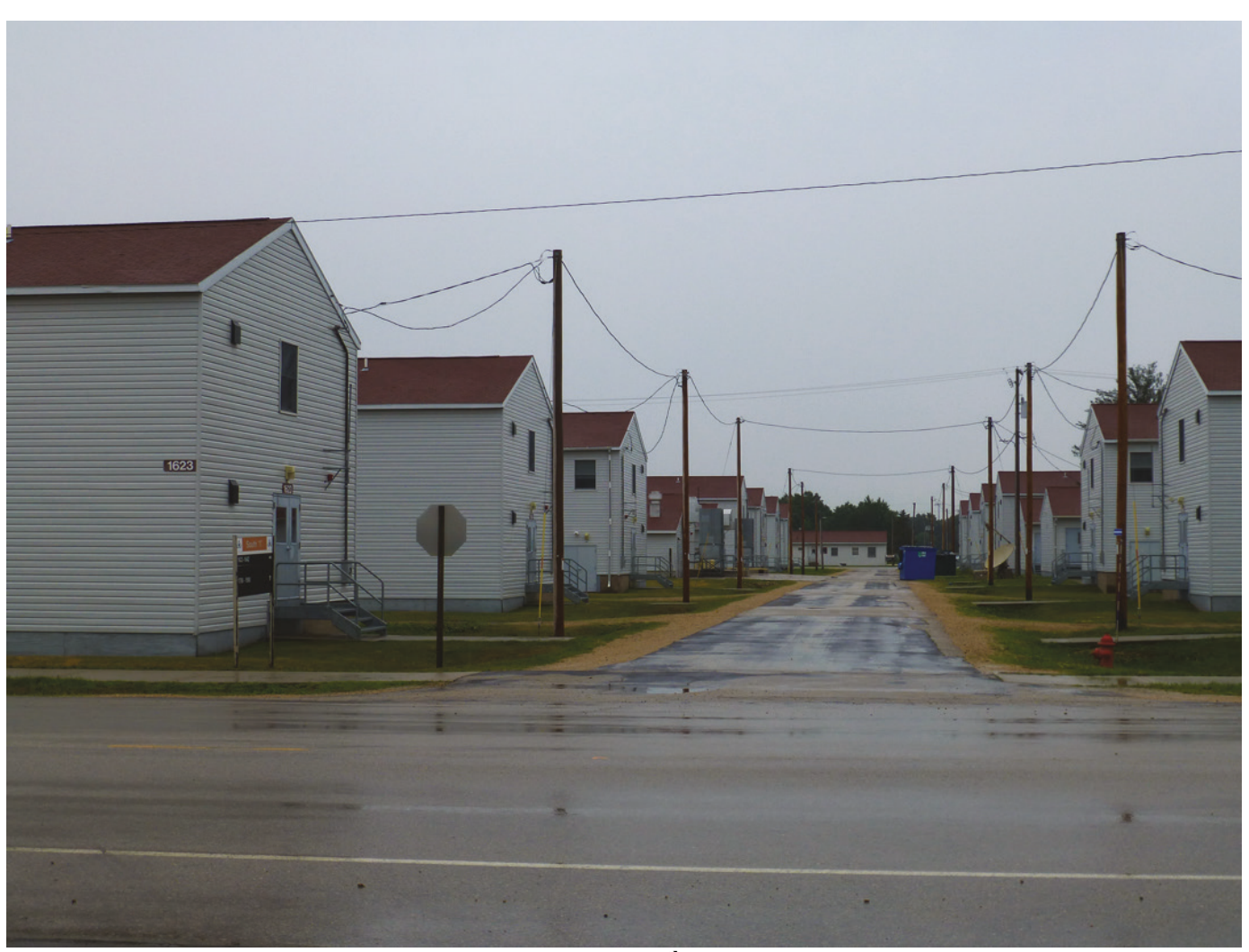

Photo 76. Looking north at the intersection of South $10^{\text {th }}$ Street (foreground) and South I Street (center) (ERDC-CERL, 2018).

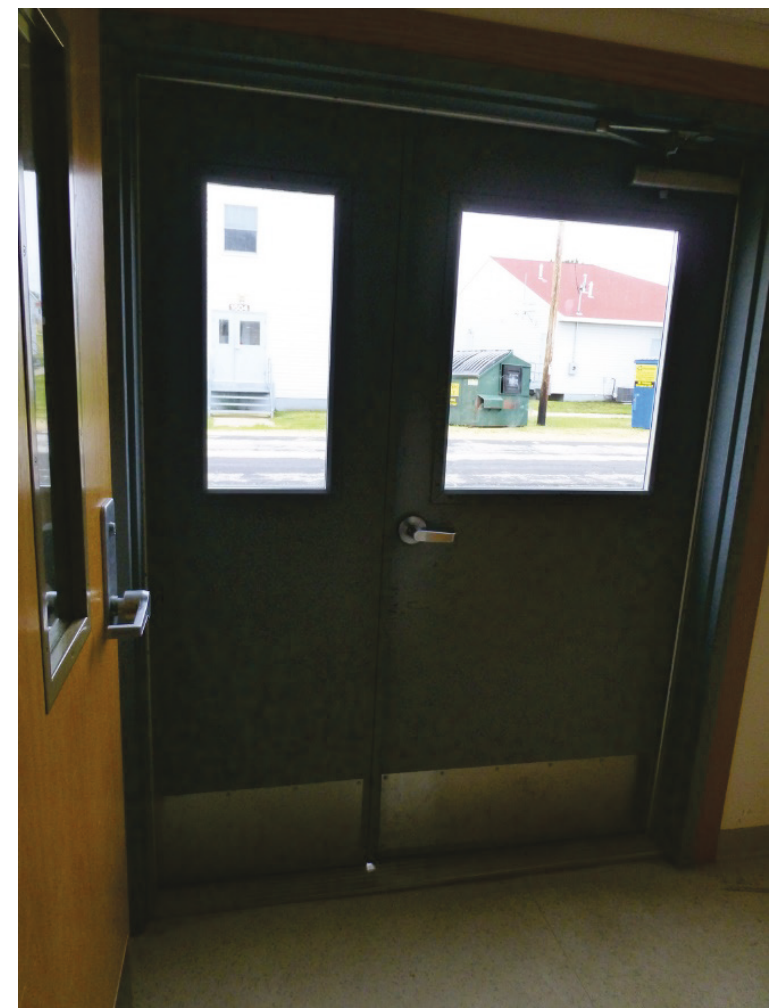

Photo 77. Interior view of the replacement metal and glass entry doors used throughout (ERDC-CERL, 2018). 


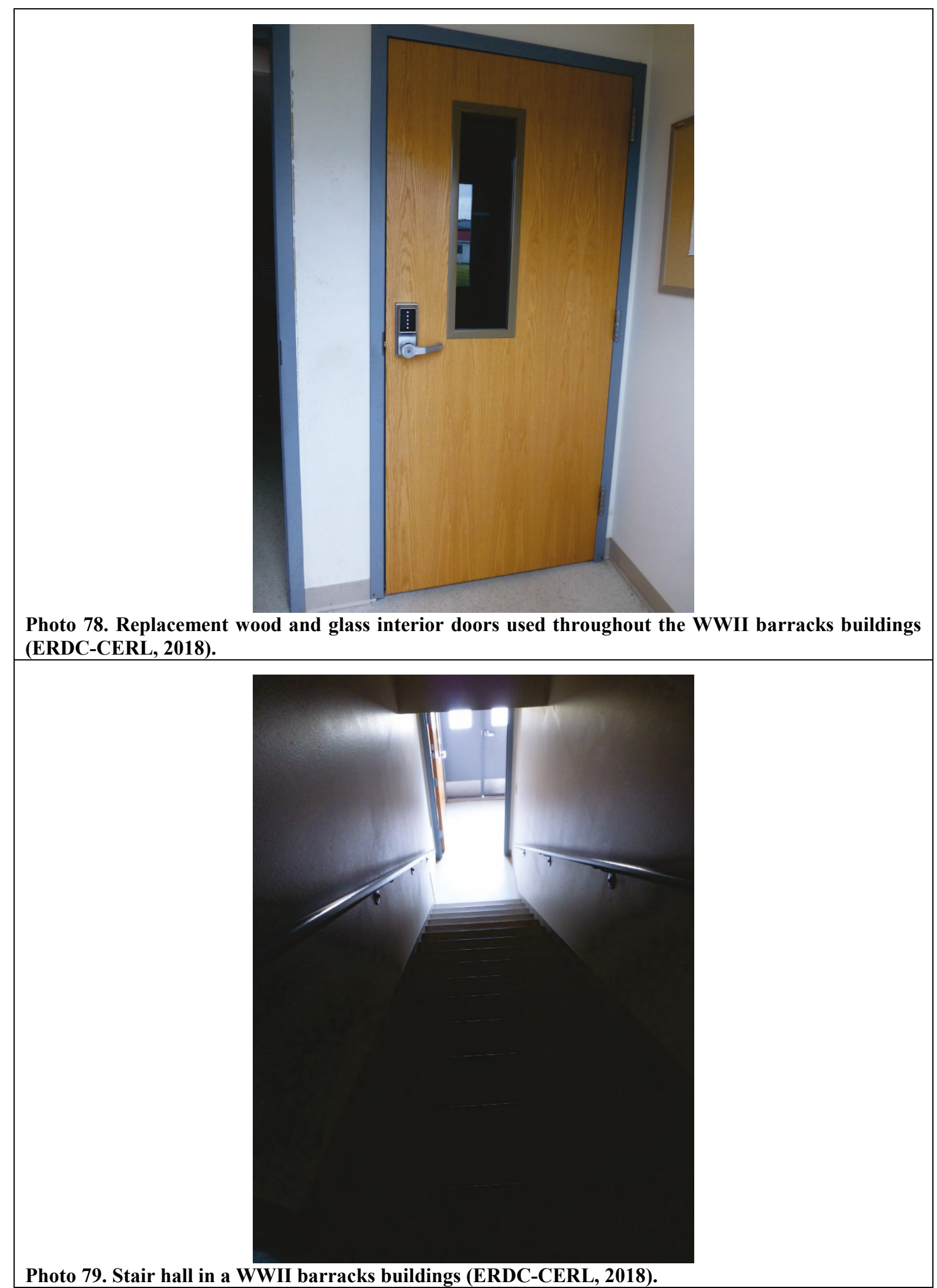




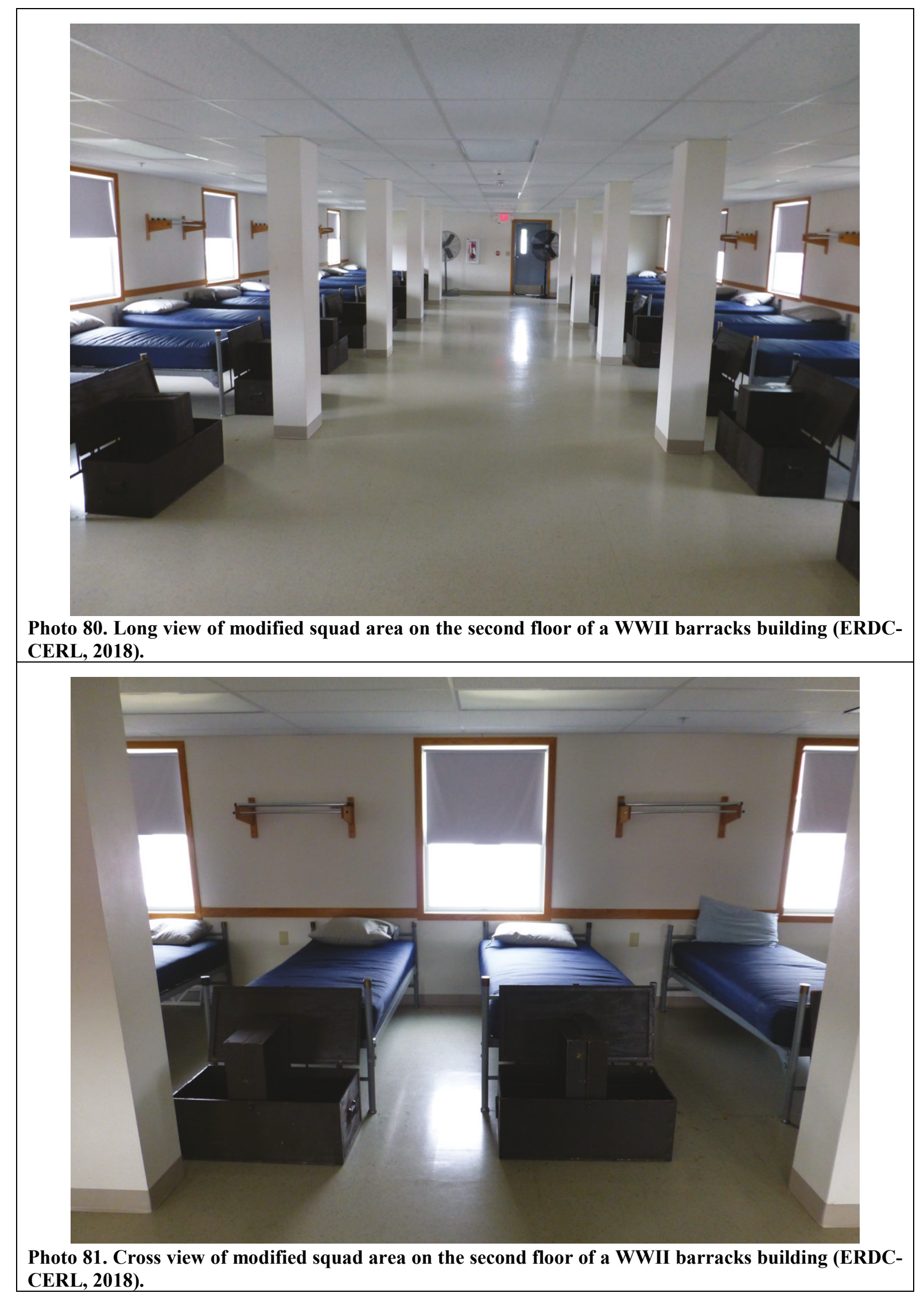




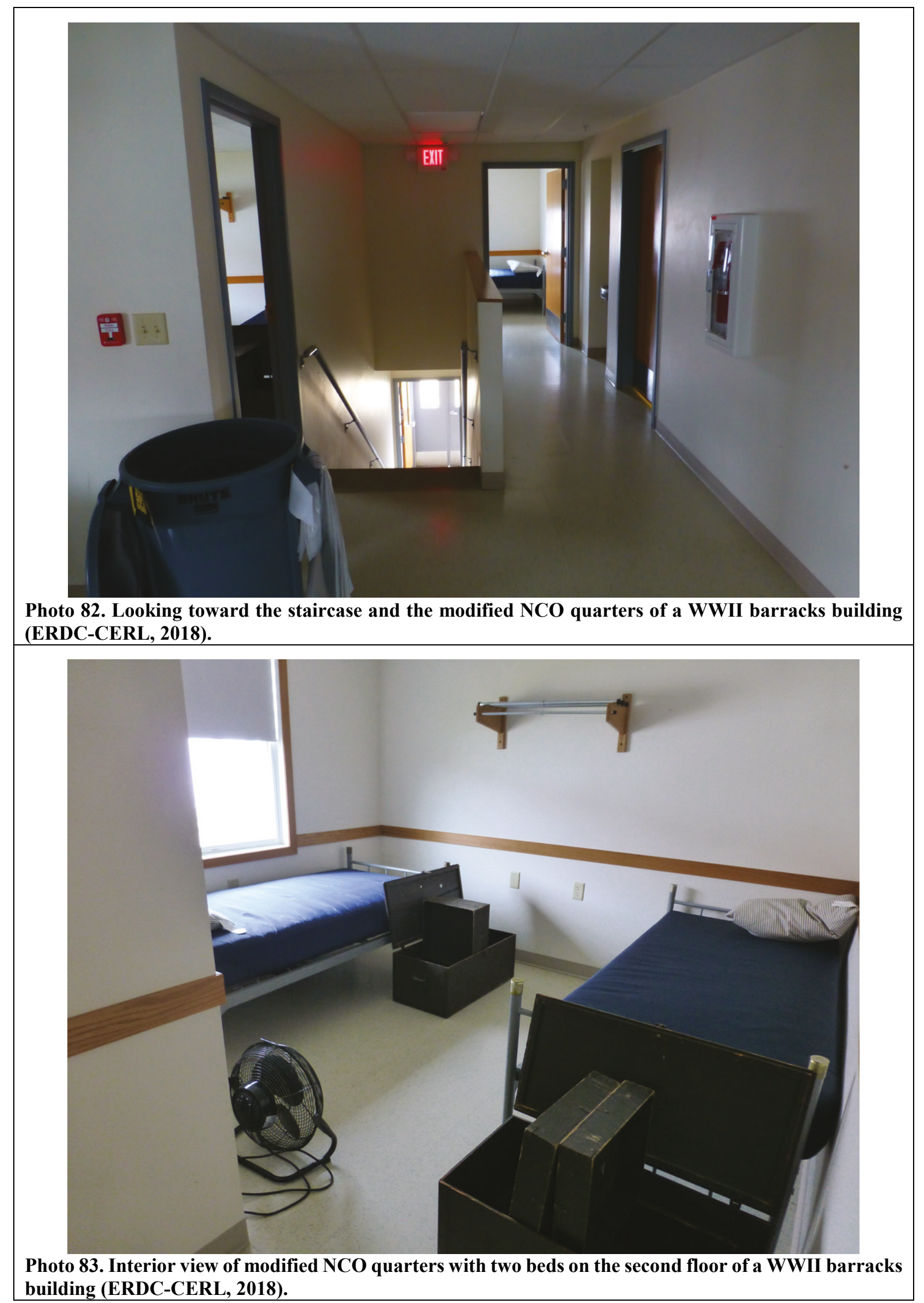




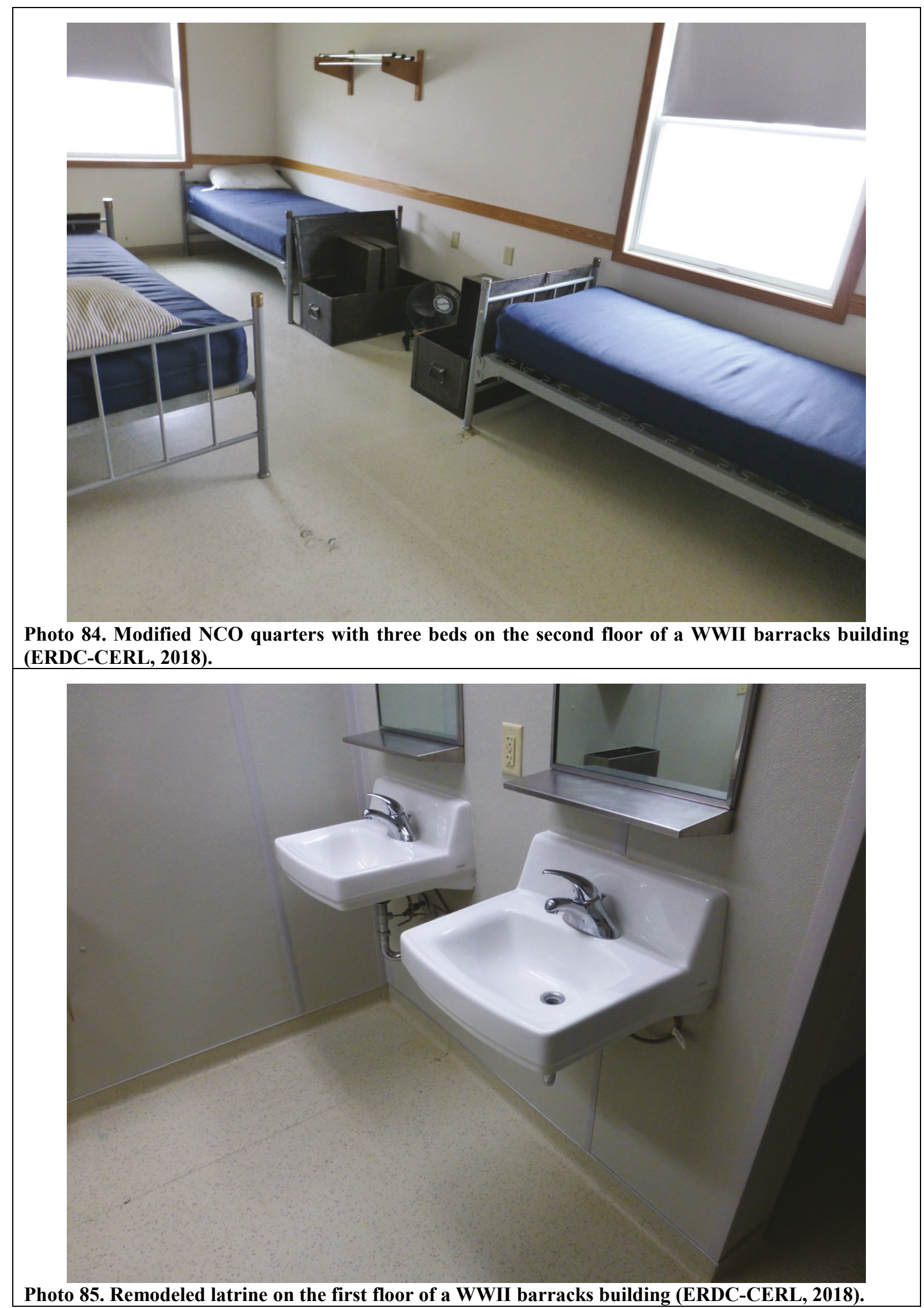




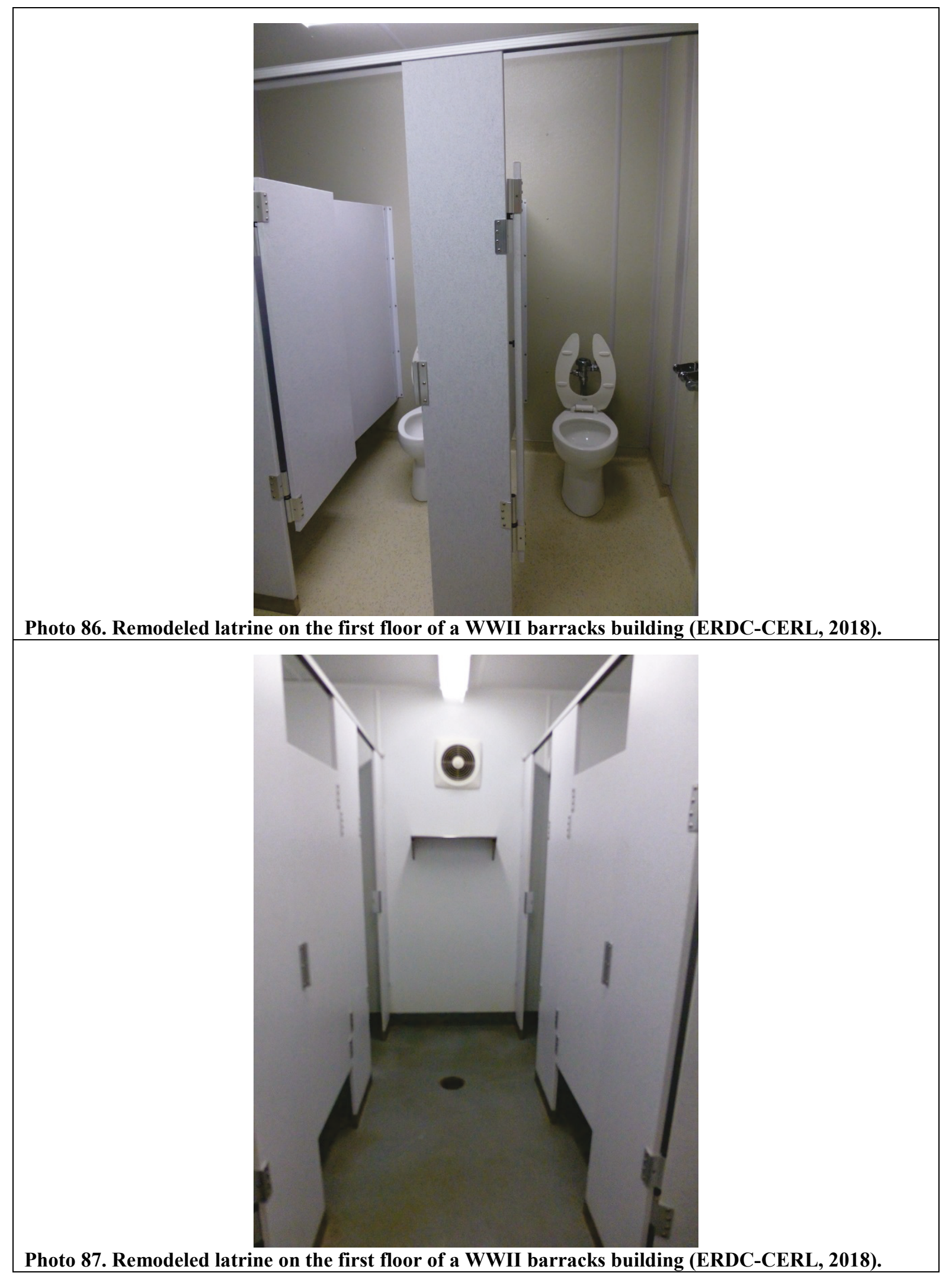




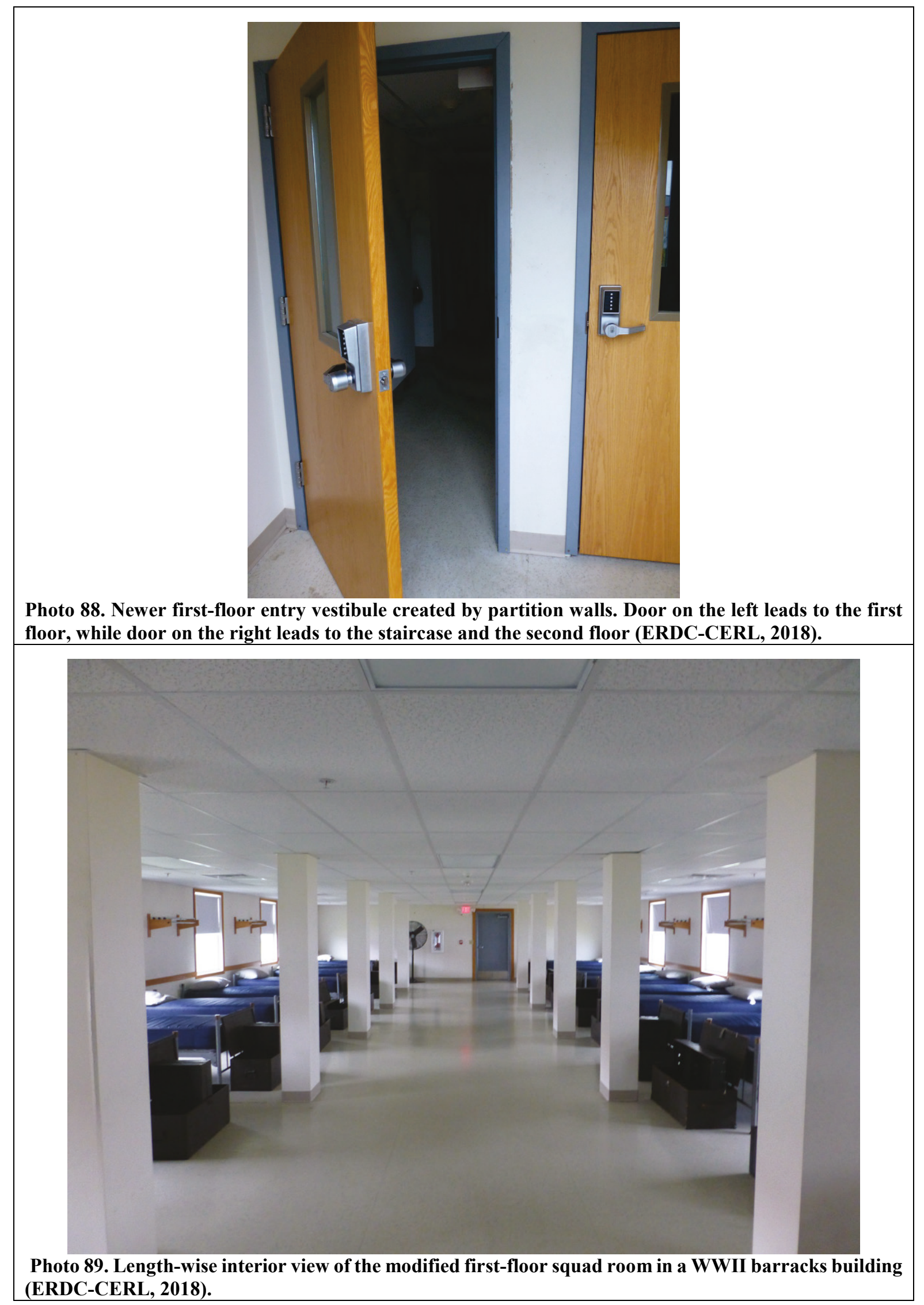




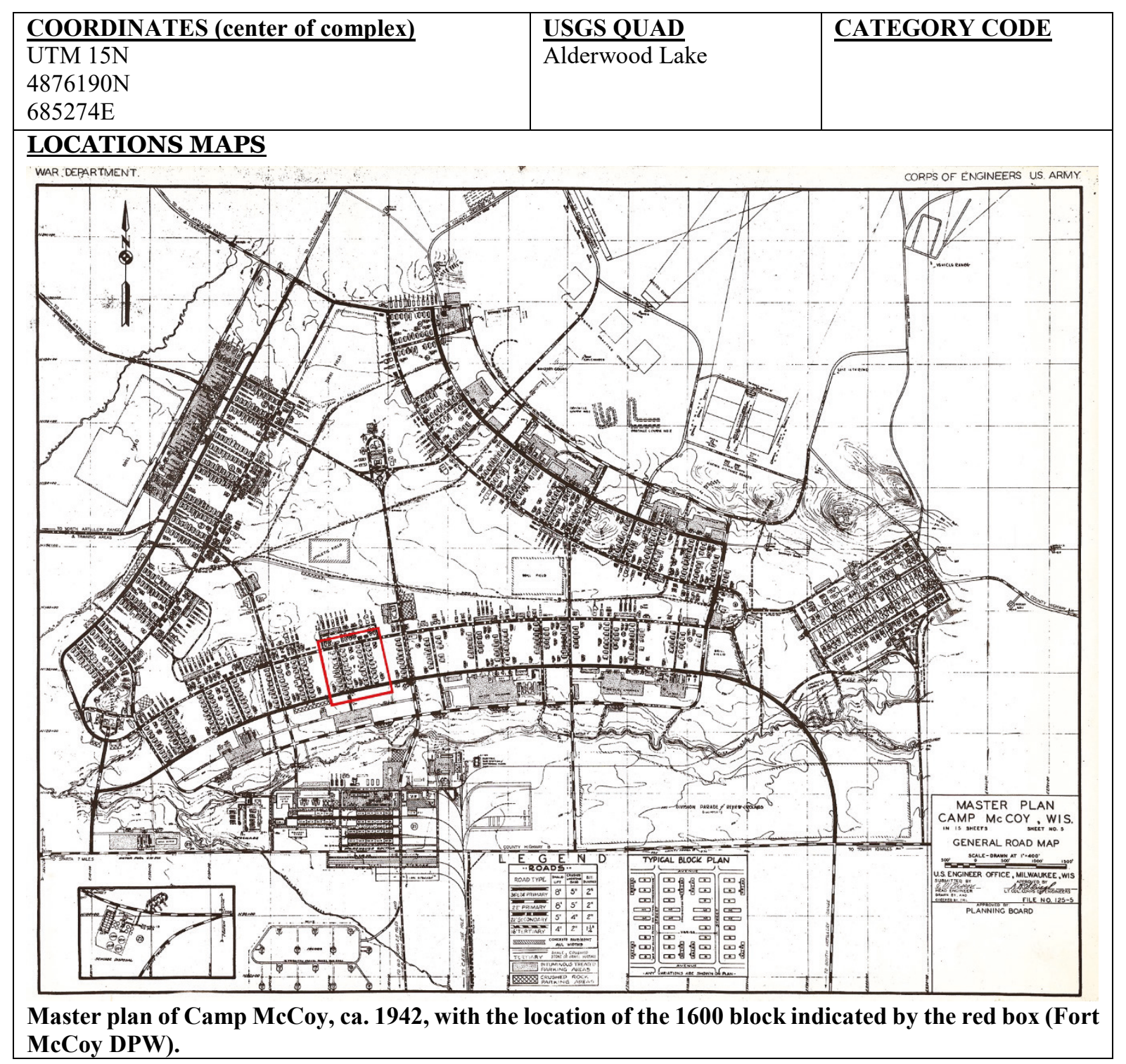




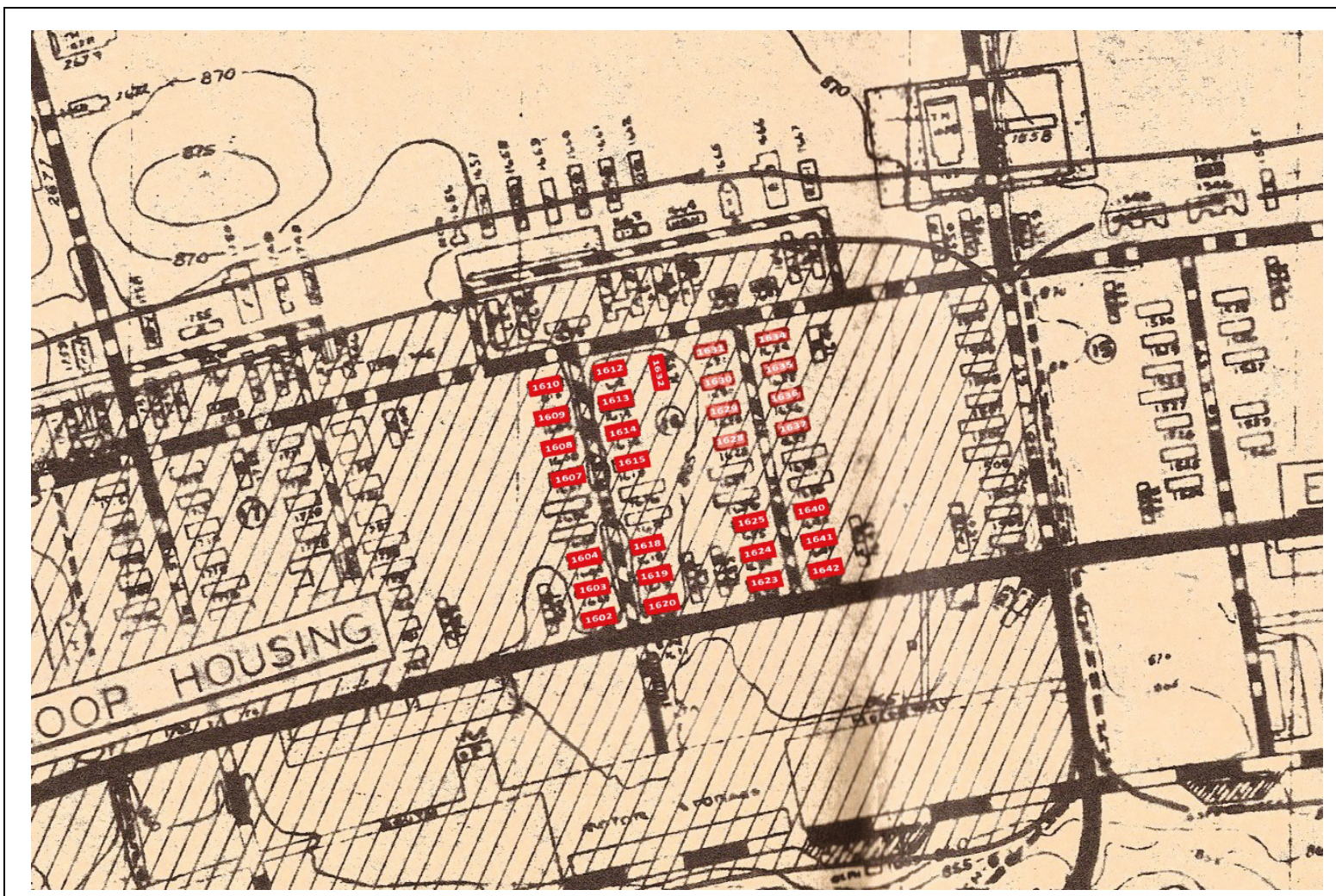

Portion of the General Site Map Camp McCoy with the locations of 1600 Block WWII Barracks Buildings, color-coded in red, 1947 (Fort McCoy DPW). [Researcher's Note: The lighter red-shaded buildings were evaluated on this inventory form, but they were not included on the original inventory list given to the research team to be evaluated at this time.]

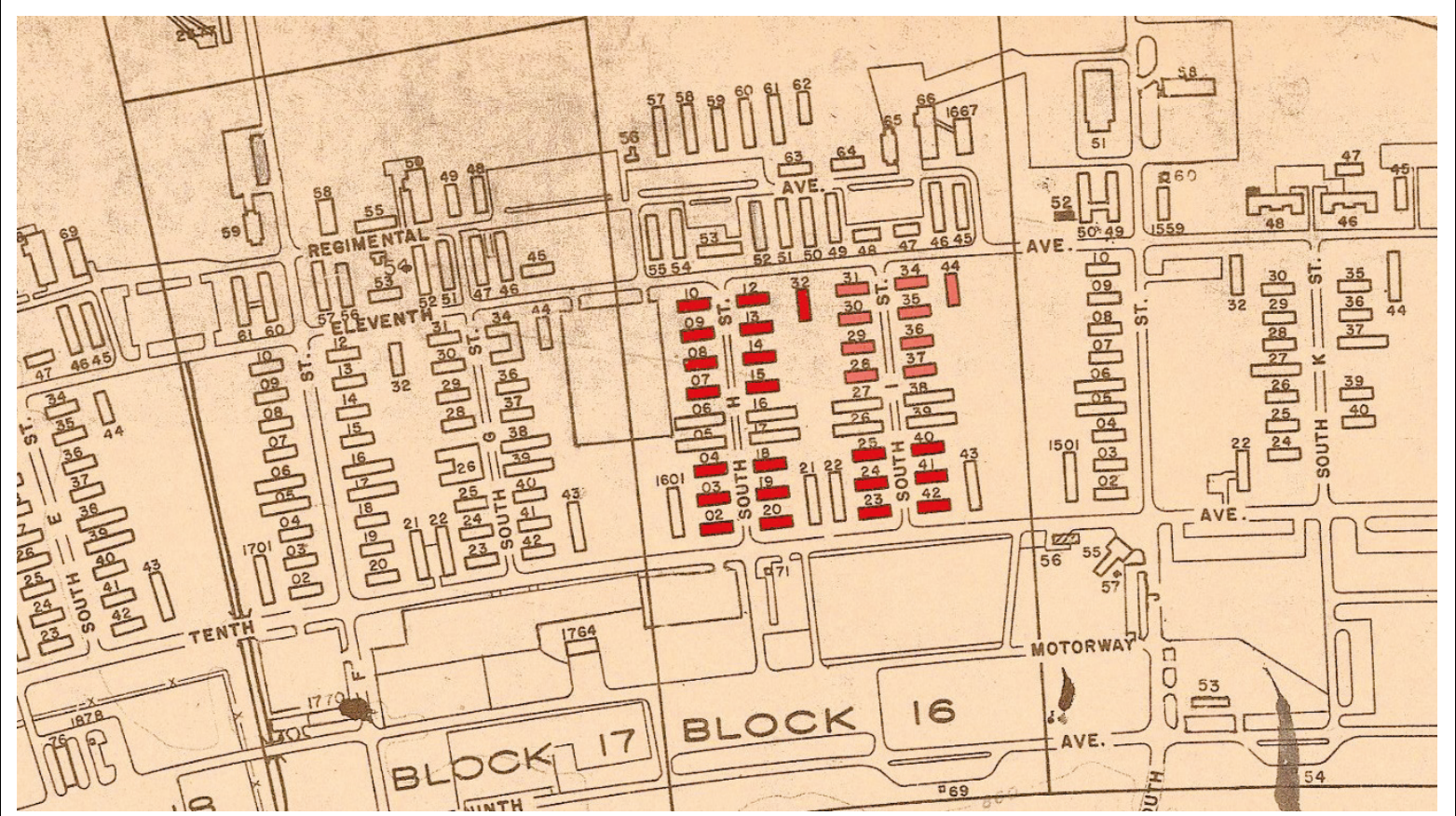

Portion of the General Site Map Camp McCoy with the locations of the 1600 Block WWII Barracks Buildings, color-coded in red, 1965 (Fort McCoy DPW). [Researcher's Note: The lighter red-shaded buildings were evaluated on this inventory form, but they were not included on the original inventory list given to the research team to be evaluated at this time.] 


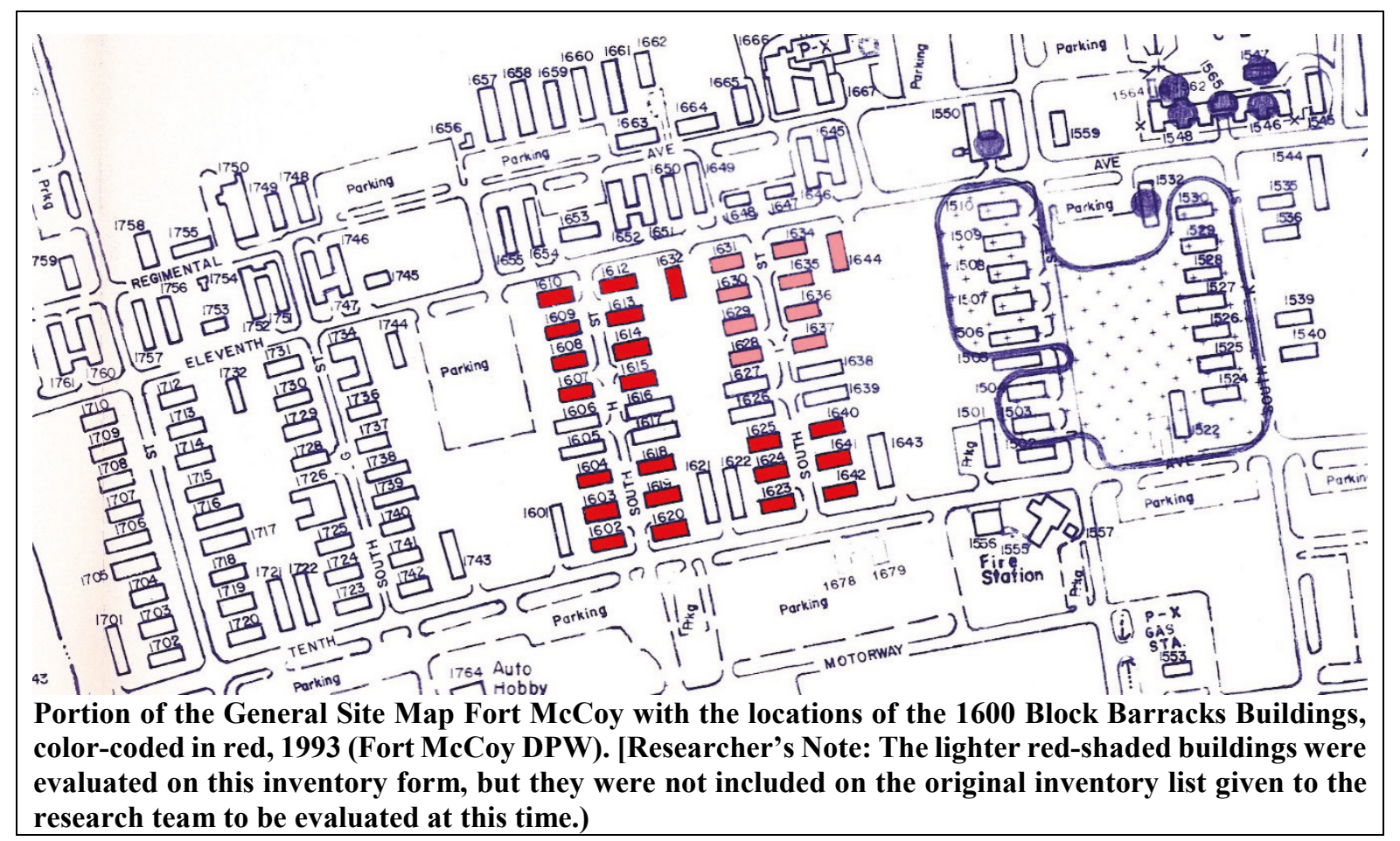




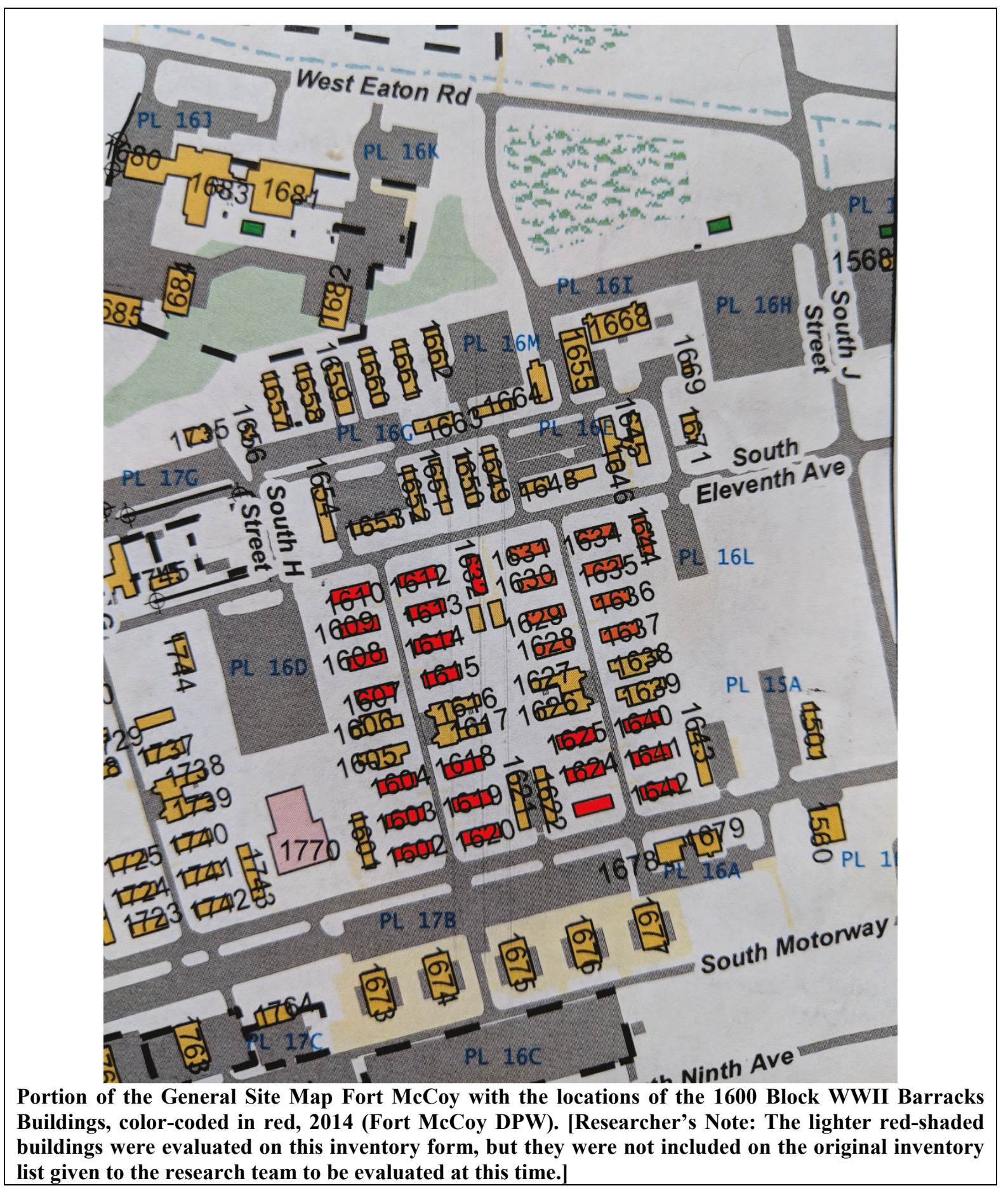




\section{DRAWINGS}

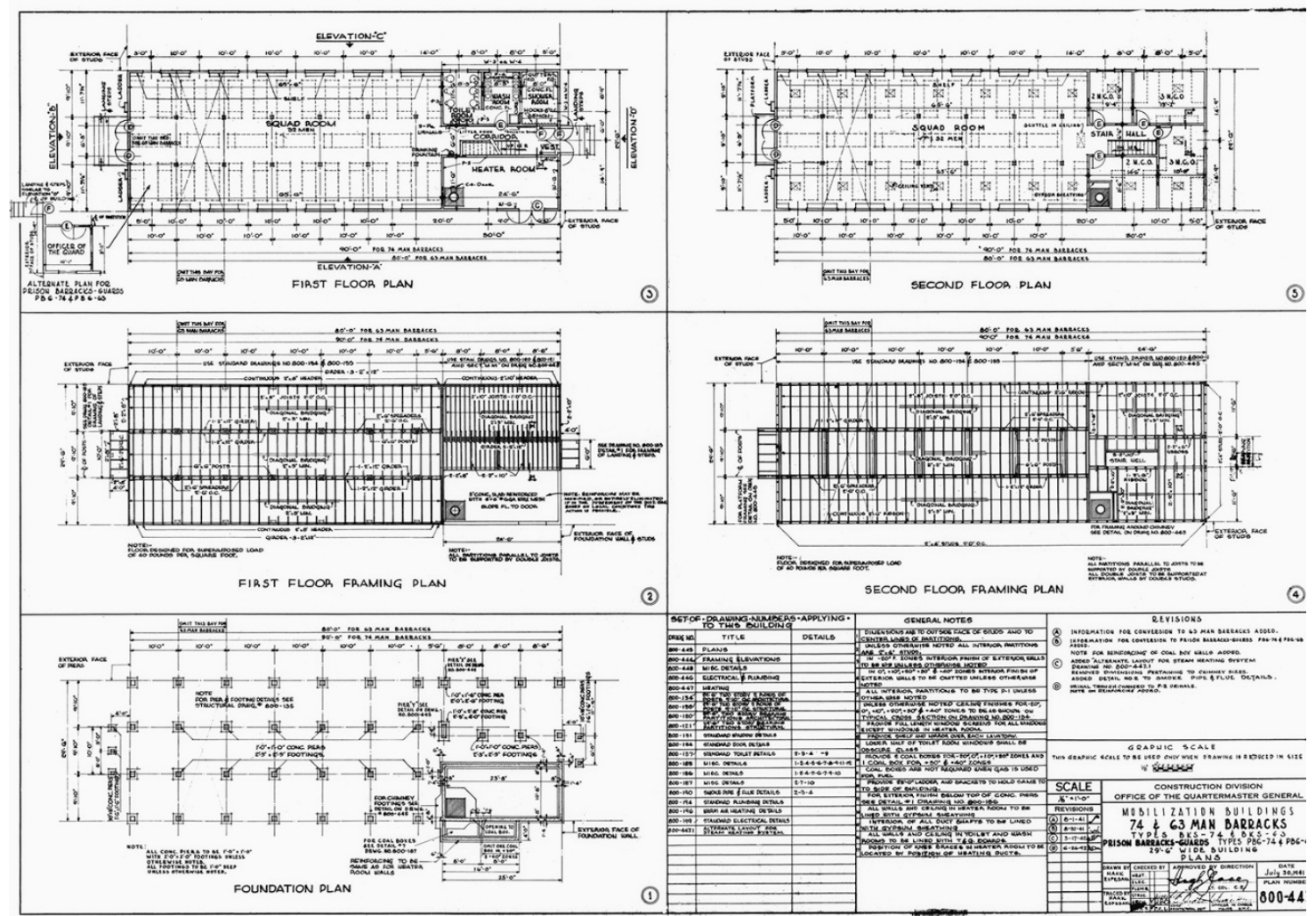

800 Series plan for 74-Man barracks, Drawing 800-443, 1941 (Library of Congress).

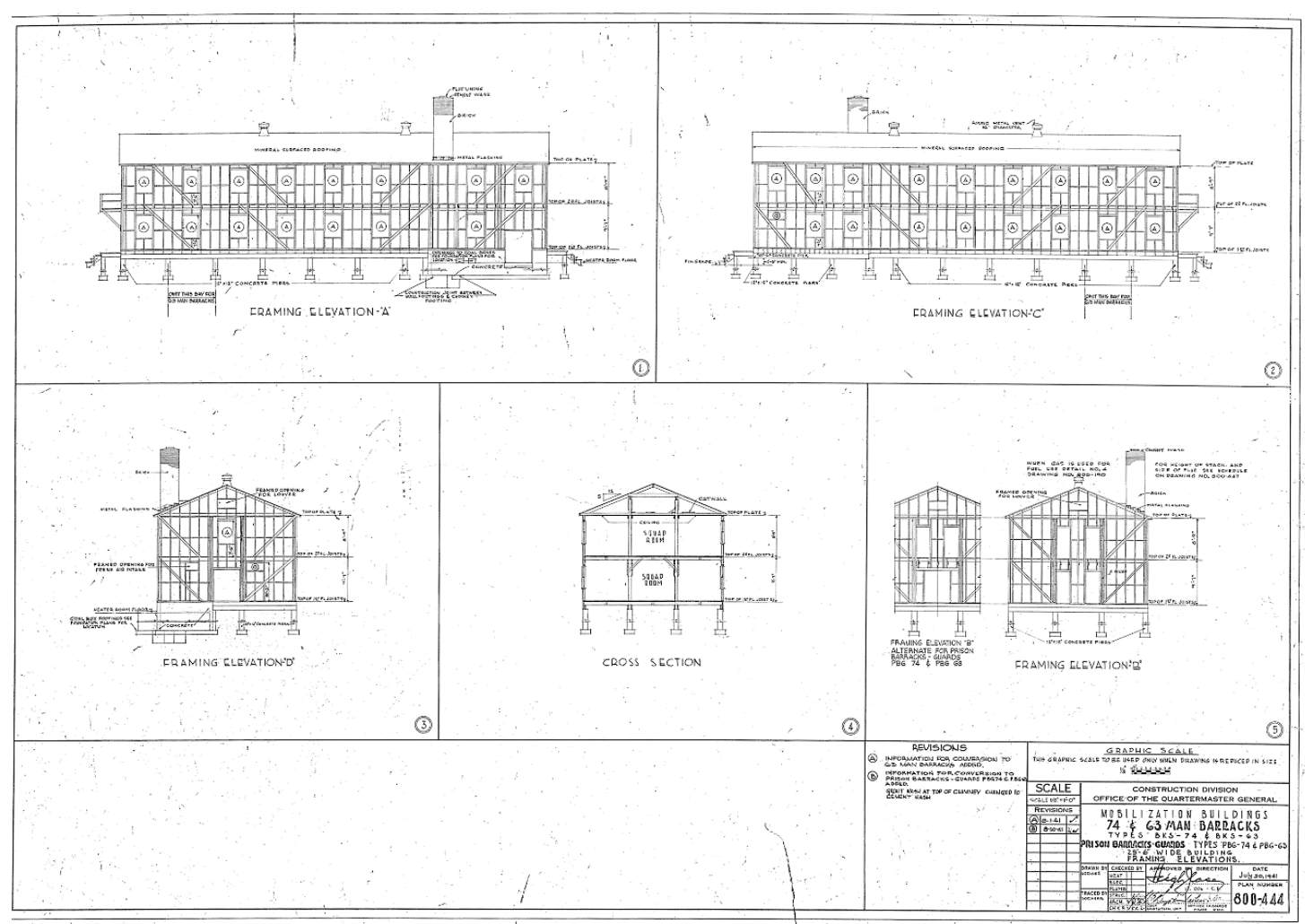

74-Man barracks framing details, Drawing 800-444, 1941 (Fort McCoy DPW). 


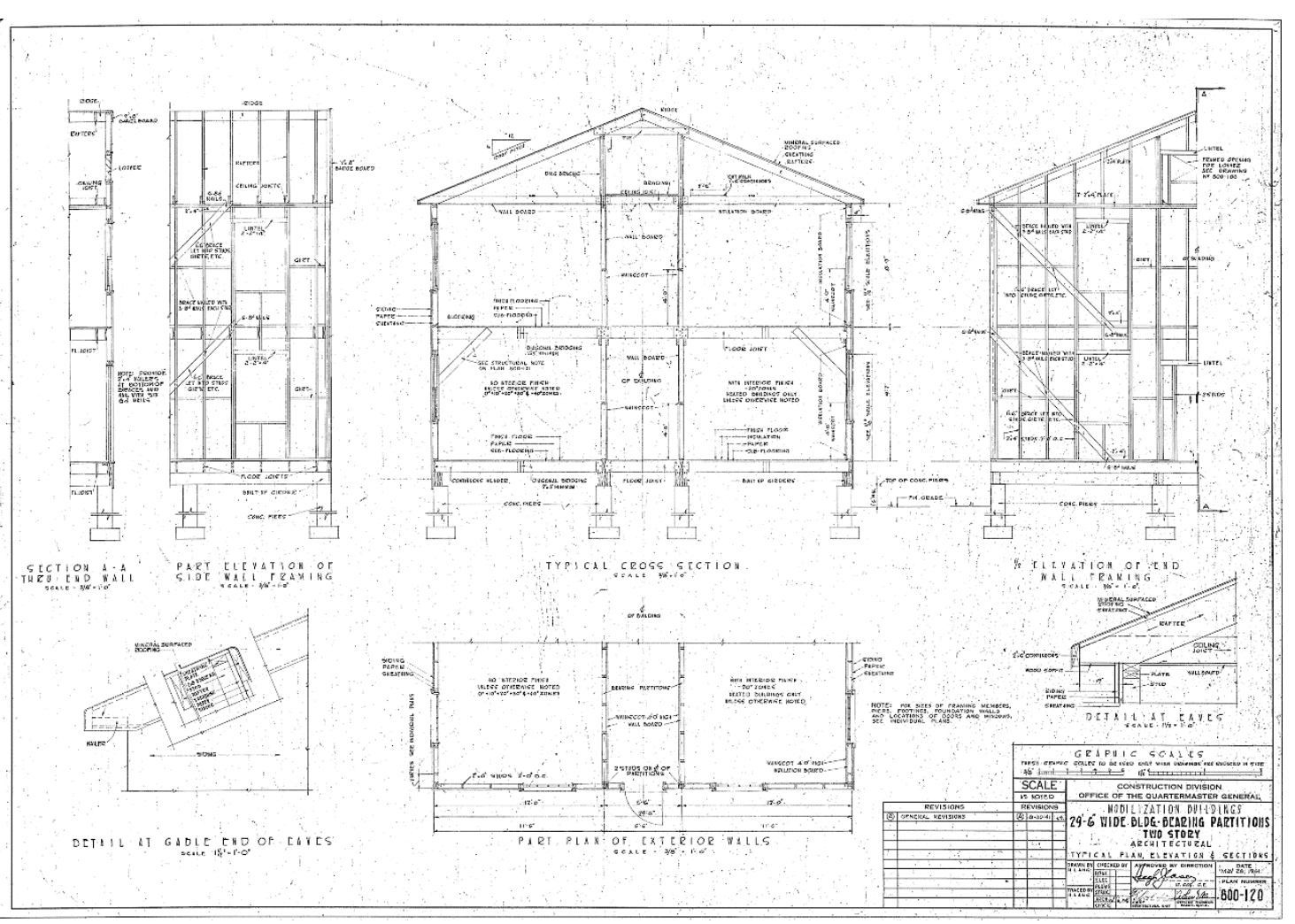

29'-6" wide building bearing partitions, two-story details, Drawing 800-120, 1941 (Fort McCoy DPW).

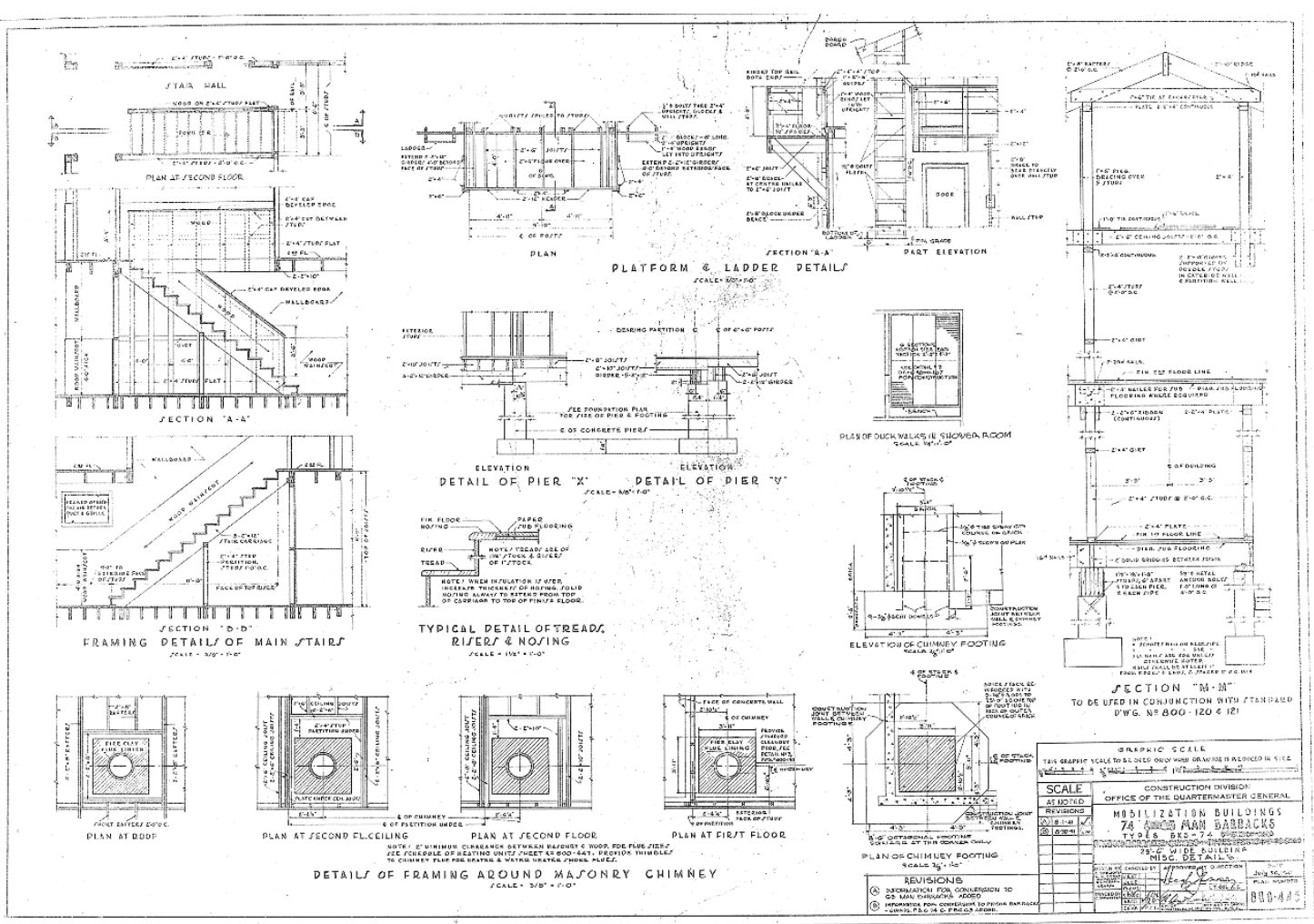

Platform and exterior wooden ladder details, details of framing around masonry chimney, and framing details of main stairs, Drawing 800-445, 1941 (Fort McCoy DPW). 


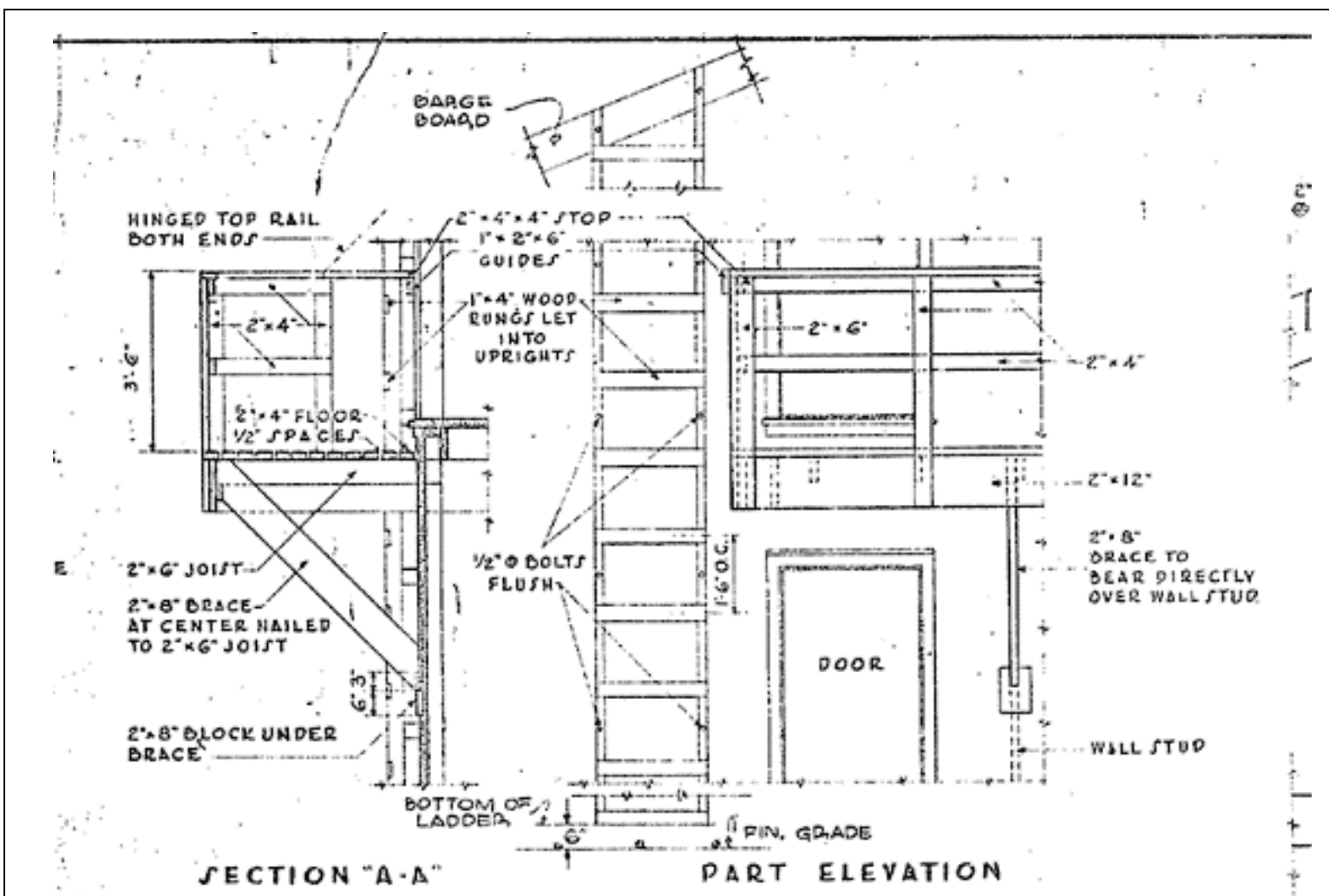

Details of platform and wooden ladder on exterior of barracks, Drawing 800-445, 1941 (Fort McCoy DPW).

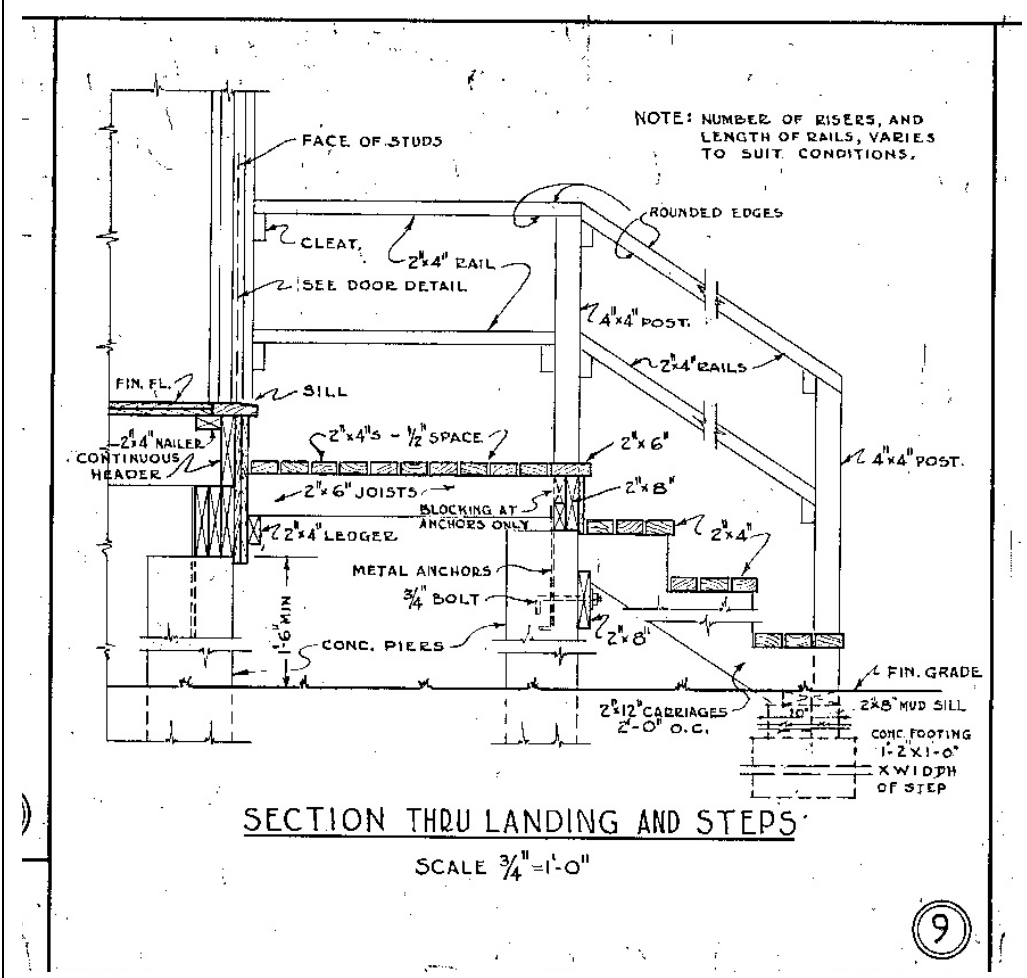

Detail for wood porch stoop and wood handrails used throughout the cantonment on WWII buildings, Drawing 800-176, 1941 (Fort McCoy DPW). 
-

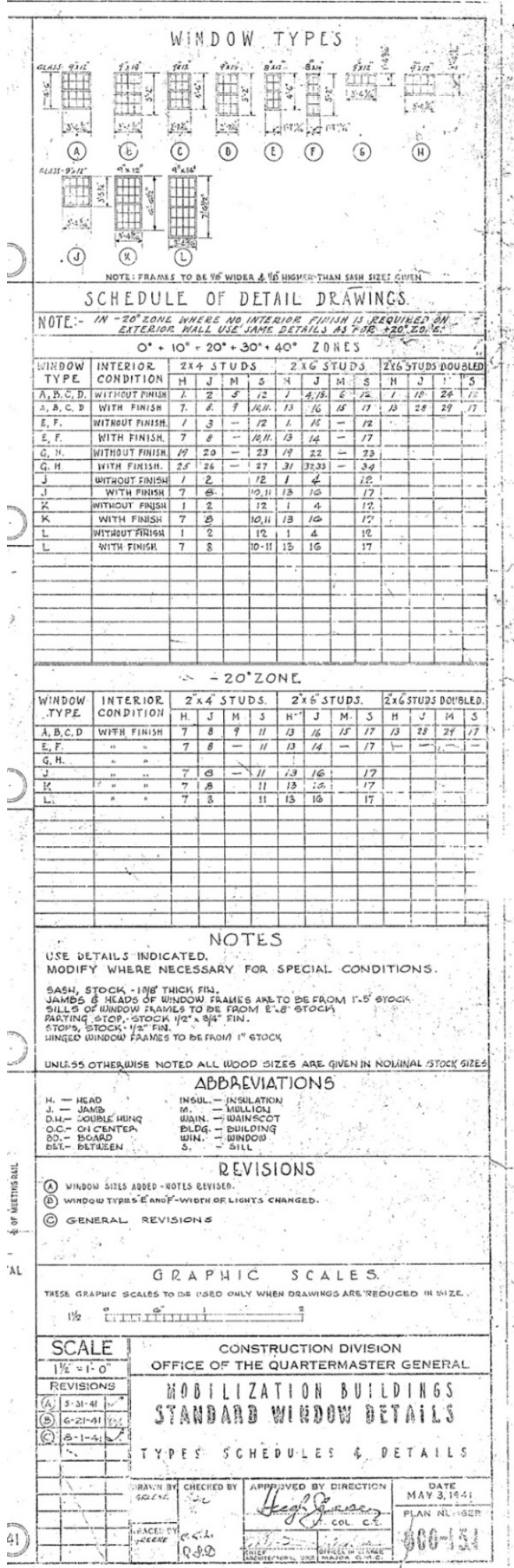

Standard window type details, 1941 (Fort McCoy DPW).

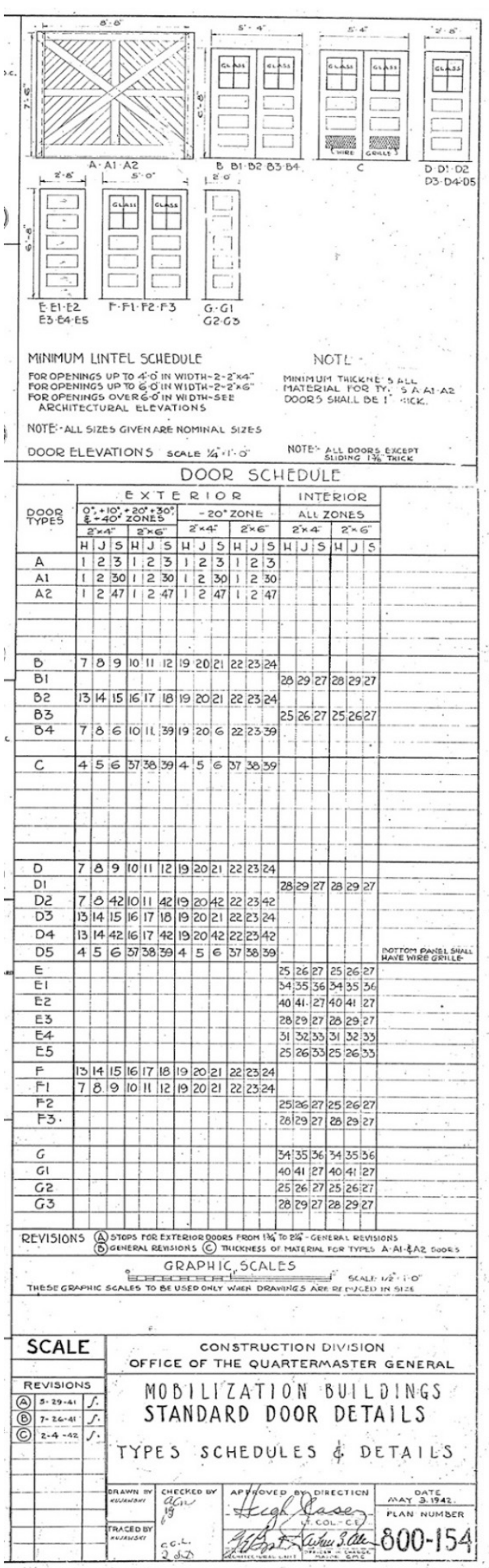

Standard door type details, 1941 (Fort McCoy DPW). 


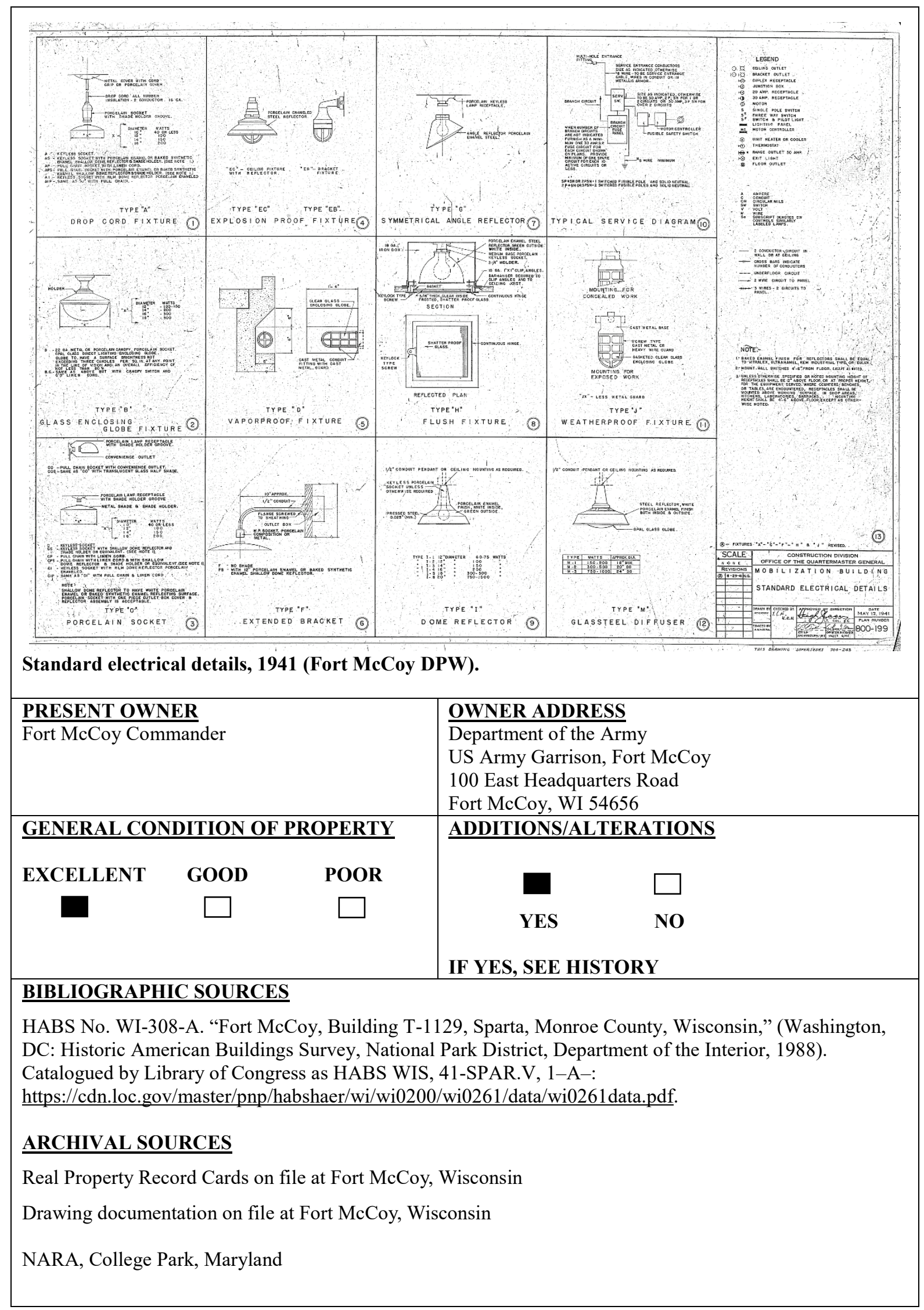




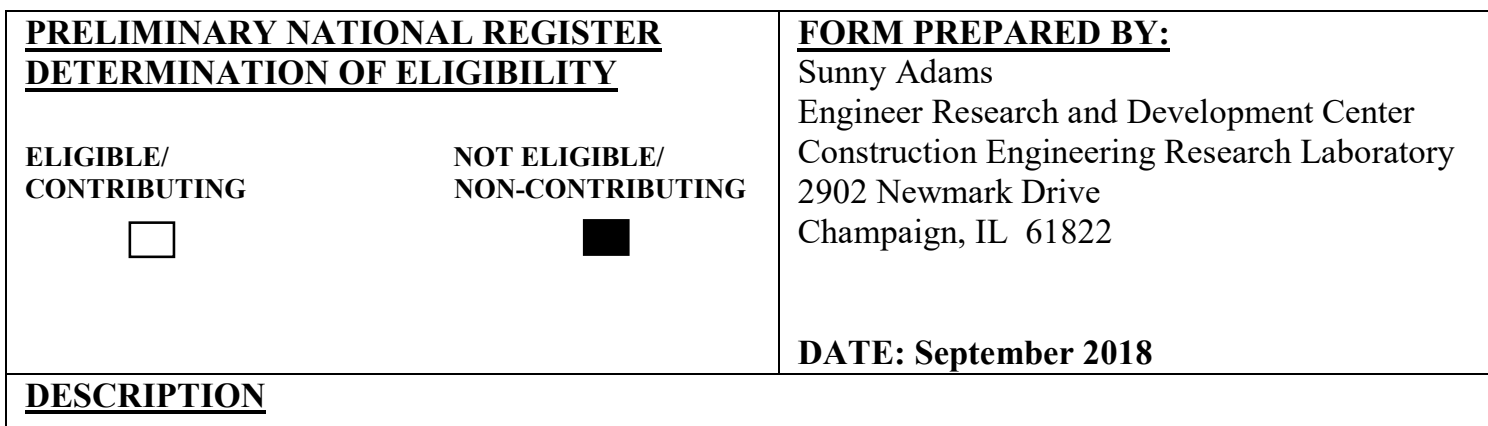

The 1600 block is located on the south side of Fort McCoy's triangular cantonment layout. South Eleventh Street is to the north, South J Street is to the east, South Tenth Street is to the south, and South G Street is to the west. South H and South I Streets cut through the block. The 1600 battalion block consists of 29 barracks, 4 company storehouse/administration/recreation buildings (currently being used as general instruction buildings), and 8 mess halls (with 4 still being used as mess halls and 4 being used as classroom buildings).

The barracks buildings are two-story structures with a front gable roof clad with red asphalt shingles. Each building rests on a concrete pier foundation system encompassed by a plywood foundation skirting, with the exception of the furnace room located in the right front corner of the building that has a concrete block foundation. The exterior walls are clad with replacement vinyl siding. The windows are replacement oneover-one vinyl windows. The soffit and fascia are clad with replacement metal. The doors are replacement metal doors that are either all metal, metal with a narrow light, or metal with a large light. There is a metal set of steps and metal platform on the rear of each elevation, and a metal stoop with metal handrails on both the front and rear elevations. The exterior light fixtures are all replacement. Each building measures 29'-6" x 90'0 ", with an approximate area of 5,310 square feet.

The front elevation faces a street and is defined by a centrally placed entry bay that is accessed by metal stairs and stoop. The entry door is metal with a large light flanked on the right side by a fixed metal and glass sidelight. A replacement window is located above the door on the second level (see Photo 2).

The left side of the right-side elevation is where the furnace room is located, and two replacement solid metal doors provide access to this room. The concrete block foundation is visible here. Above the furnace room, on the second level, are two replacement windows. The right side of the elevation has six replacement windows on both the first and second levels (see Photo 3).

The rear elevation has two entry doors; one per floor. The first-floor entry is accessed by a metal stoop and is a solid metal door, while the second-floor entry is metal with a narrow light and accessed by a set of metal stair and metal platform (see Photo 4).

The left-side elevation has six replacement windows on both the first and second levels (see Photo 5).

The interior of each barracks has been completely remodeled. None of the original materials are intact. The layout of the spaces are intact, however, with the first floor housing a latrine and an open bay squad room and the second floor housing an open bay squad room and three NCO rooms. The front entry bay vestibule has been modified and enclosed with a partition wall with two newer wood interior doors, one leading to the first floor and one leading to the second-floor staircase.

\section{HISTORY (excerpt taken from HABS data sheet)}

Typical blocks within the general layout were based both on military organizational requirements and city planning principles. Each block was to be occupied by a battalion of troops. Two blocks comprised a regiment. Within a block were size to seven companies, depending on the type of battalion involved. Along each street in a block were four mess halls at center, and ten or more barracks, with a company usually occupying three barracks and eating in one of the mess halls. To the rear of the barracks, at either end of each street were company administration buildings, one for each company.

A total of 461 74-man barracks were erected at Camp McCoy in 1942 including Buildings 1602, 1603, 1604, $1607,1608,1609,1610,1612,1613,1614,1615,1618,1619,1620,1623,1624,1625,1628,1629,1630$, $1631,1632,1634,1635,1636,1640,1641,1642$, and 1644, using the 800 Series standard War Department plans, Drawing 800-443. Each barracks during WWII housed a squad. The squad rooms were on the first and 
second floors, three non-commissioned officer (NCO) rooms were on the second floor, and the wash, shower, and toilet rooms were on the first floor.

\section{Exterior:}

Overall dimensions: The barracks were a long rectangular shape measuring 29'-6" wide by 90'-0" long and were two-stories in height rising approximately 27'-0" from grade to the ridge of the roof.

Walls: The exterior wall consists of wooden sheathing composed of 7-1/8" tongue and groove boards, a black construction paper which acts as a vapor barrier, and siding composed of cement asbestos pieces measuring 11 " $\mathrm{x} 24$ ", the standard size used throughout the cantonment.

Foundation: Each barracks rests on a system of poured concrete piers and footings. The crawl space below the barracks was screened by a wooden skirt composed of 1"x10" boards. Originally, the skirts were painted a warm gray. The furnace room, located in one corner of each barracks, had a concrete block foundation that was eight inches thick and rose about 25 -inches above grade.

Structure: The barracks buildings, like all 800 Series mobilization structures, were of light frame construction. The frame of the exterior walls rests on wooden girders built up of three $2^{\prime \prime} \times 12^{\prime \prime}$ borne by the foundation piers and was composed of 2" x 4" studs spaced 2'-0" on center. Diagonal 1" x 6" let-in braces ran between the girders and second-floor girts, and between the girts and plates occurring every other bay on all elevations. The interior structure was borne in the squad room of the first and second floors by wooden posts arranged in two parallel rows directly above the concrete piers of the foundations. The one end of the barracks containing the wash rooms, staircase, and NCO rooms, contained a separate structural system. The walls flanking the staircase on both levels are load-bearing partitions and supported the joists of the second floor.

Roof: The roof of each barracks was a front-gable clad red asphalt shingles. The eaves projected only slightly on the longitudinal elevations and were of wood fascia and soffit.

Porches, balconies: There were two wooden porches with wooden handrails at ground level; one on each short end elevation. A wooden balcony was attached to the end elevation where the squad rooms were located and provided access to two exit doors for the second floor squad room. The balcony consisted of a deck supported by two wooden brackets and balustrade of board rails and posts. An opening on one side of the rail allowed for exit, in case of fire, down a wooden ladder that was attached to the wall adjacent the balcony.

Chimney: There is a furnace room on the right corner of the front portion of the building. It measured $3^{\prime} \mathrm{x}$ 3 'square and sat on a concrete footing. The stack rose approximately 9-feet above the roof line.

Windows: There were two types of windows on the barracks building; a double-hung and a single-sash. The double-hung windows were of the standard design found in all 800 Series mobilization buildings; eight-overeight wood frame. Six of these type windows lined each side of both squad rooms, five were placed on the exterior wall of both NCO rooms, one was placed in the furnace room, one was placed over the main entry doors, and two were located in the latrine room. The single-sash wood hopper window was a small four-light window was located shower room. The architrave of all windows was a simple board construction where the sills and "cornice" boards projected slightly from the face of the surrounds.

Doors: There were six doorways in the exterior of the barracks: (a) the main entrance was defined by a set of double doors; (b) the double-entry door to the furnace room; (c) two single exit doors for the first floor squad room; and (d) two single exit doors for the second-floor squad room. All exterior doorways and doors were of standard design. The architraves consisted of simple wooden boards. The design of the doors all the doors on the barracks was identical; four lights over three horizontal recessed panels. The exterior doorways and doors were painted a warm gray.

\section{Interior:}

Floor plans: The first floor was entered through a set of double doors. There was vestibule, followed by a stair hall. The stairs on the right led up to the second floor. To the left was the door to the washroom, which was the center of a suite of three rooms; showers, wash room, and the toilets and urinal. On the right side of 
the entry hall was the furnace room, which was only accessible through the exterior doors. The majority of the first floor was occupied by the undivided squad room, which measured approximately 65 -feet in length. Originally, this room contained bunk for thirty-two enlisted men. The interior staircase led to the second floor. Near the opening at the top of the staircase were two NCO rooms. Originally, one room housed two men and the other, three. On the other side of the hall was a door to a three-man NCO room and an entrance to a fourth NCO room for two men. Like the first floor, the remaining 65 -feet of the second floor was occupied by a squad room for thirty-two enlisted men.

Stairways. There was a single stairway in the interior of each barracks leading from the first floor to the second floor nearest the main entry into the building.

Flooring: The floor of the furnace room was reinforced concrete, and the floor of the wash and toilet rooms was poured concrete. All other floors in the barracks were of unfinished softwood and were constructed with $3-1 / 4$ " wide boards.

Walls and ceiling finishes: In the wash and toilet rooms, all walls were covered with horizontal, unfinished softwood boards measuring 7-1/8" in width, $3 / 4$ " in thickness, and approximately 11 -feet in length. The samesized boards were used for the ceilings in those two rooms. In the shower room, the hard manufactured wallboard covered the walls and ceiling. The walls of the first floor entry hall consisted of hard wood board used as wainscoting, above are plywood panels and insulation board. In the first floor squad room, a 6'-0" high hard-board wainscot was used, surmounted by insulation board. The joists were exposed in both the entry hall and squad room. In the second floor squad room, the same wall covering as in the room below was used to cover the exterior walls. The ceiling was covered with insulation boards held in place by wooden battens. The same exterior wall and ceiling pattern was used in the NCO rooms.

Doors: There were two types of doors on the interior of the barracks. The more common type was a standard issue, solid door with five horizontal recessed panels, unfinished. This door was found between the entry hall and the first floor squad room, the wash room, and in the doorways of the NCO rooms on the second floor. The other type was of the same design as the exterior doors-four-lights over three panels. The double vestibule doors were of the second type; the wood was unfinished. Original screen doors adjoin the vestibule doors on the outer side.

Sometime before 1988, the original wood porch stoops and handrails on the front and rear elevations were dismantled and replaced with concrete stoops with metal handrails. At this time, two of the original fire exit doors on the rear elevation were removed and the door openings clad over with newer cement asbestos siding. Later in 2003, the concrete stoops and metal handrails were demolished and the wood platform and wood fire escape ladder on the rear elevations were dismantled and replaced with metal stoops, metal handrails, metal platforms, and metal steps leading up to the fire exit doors on the second floor.

In 2003, the original eight-over-eight wood double-hung windows were removed and replaced with oneover-one vinyl windows. The window pattern on the right side of the left elevation was modified when the original small four-pane single-sash hopper windows were removed and their openings were clad over. All of the original simple exterior window trim was removed. The original four-light with three recessed panel exterior doors were replaced with metal entry doors.

At an unknown date(s), the original asbestos cement siding was either removed or simply covered over with vinyl siding. The original wood foundation skirting surrounding the concrete pier foundation system was removed and replaced with plywood. The interior of the buildings were completely remodeled with all new fixtures and finishes such as flooring, doors, trim work, lighting, drywall, drop-ceilings, toilets, showers, sinks, and urinals. 


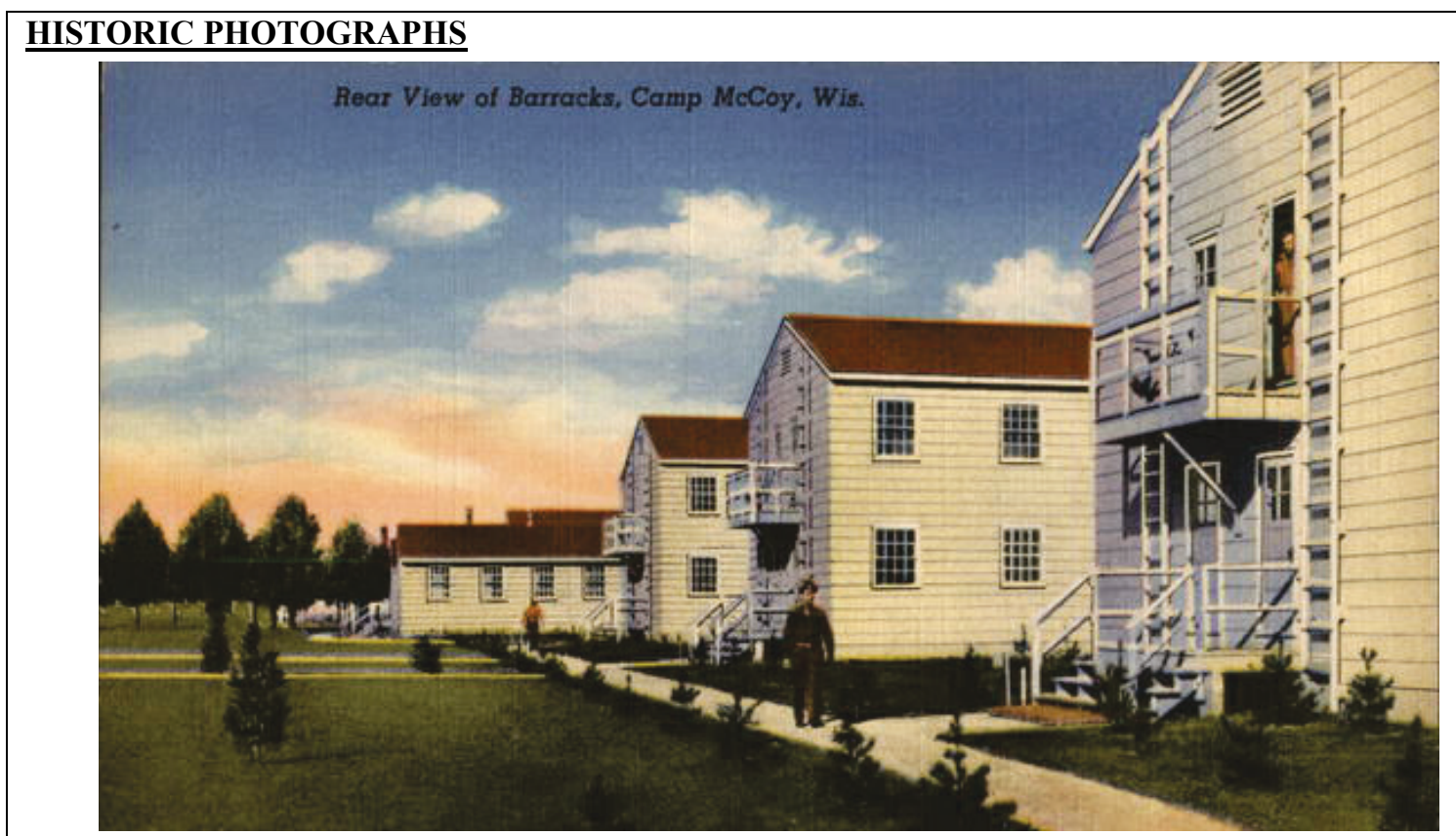

Detail of Camp McCoy postcard showing exterior wood ladders and platforms, 1942 (ERDC-CERL Collection).

\section{NARA PHOTOGRAPHS}

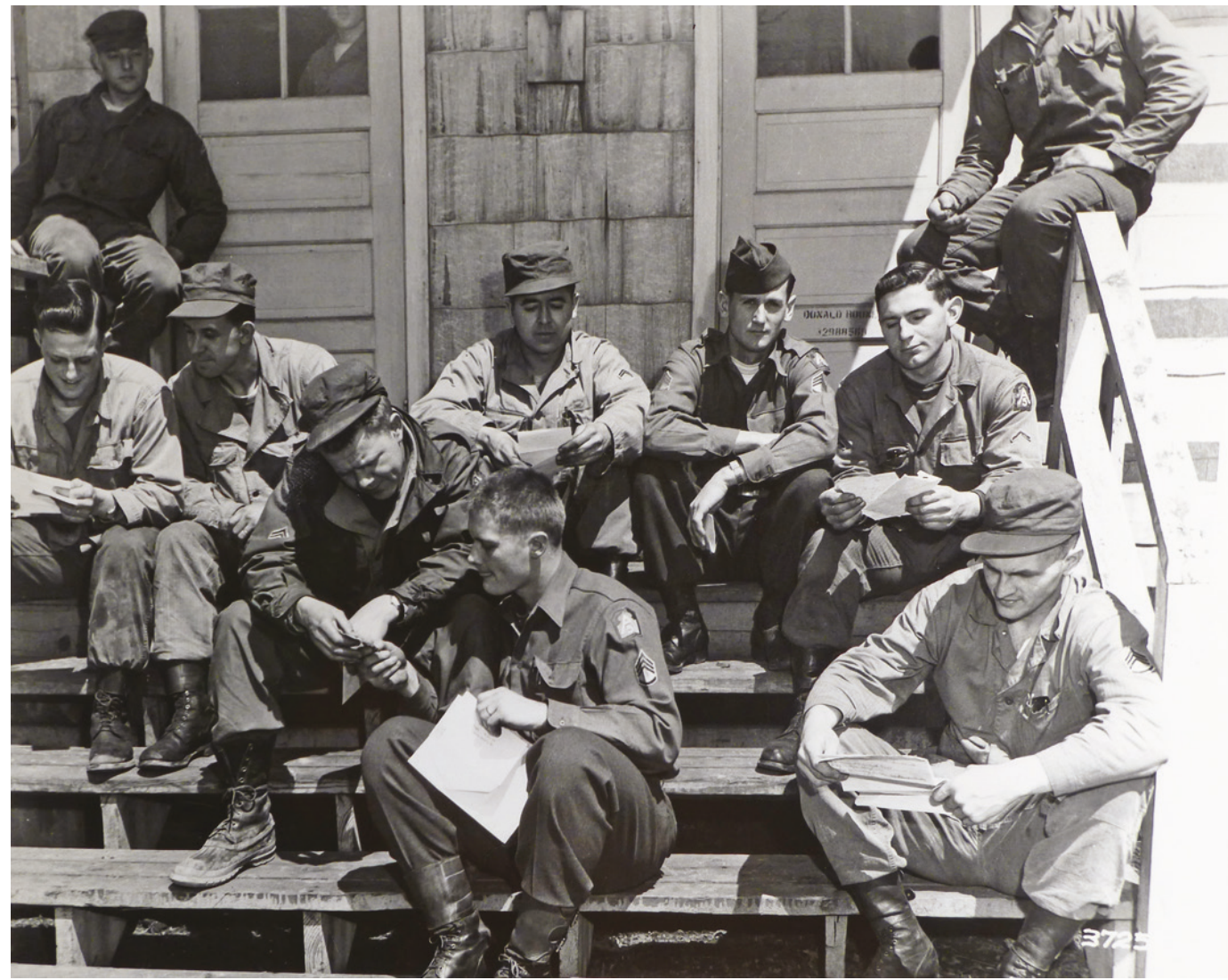

View of doors and wood steps at Fort McCoy barracks in 1951 (NARA College Park, RG111-SC). 


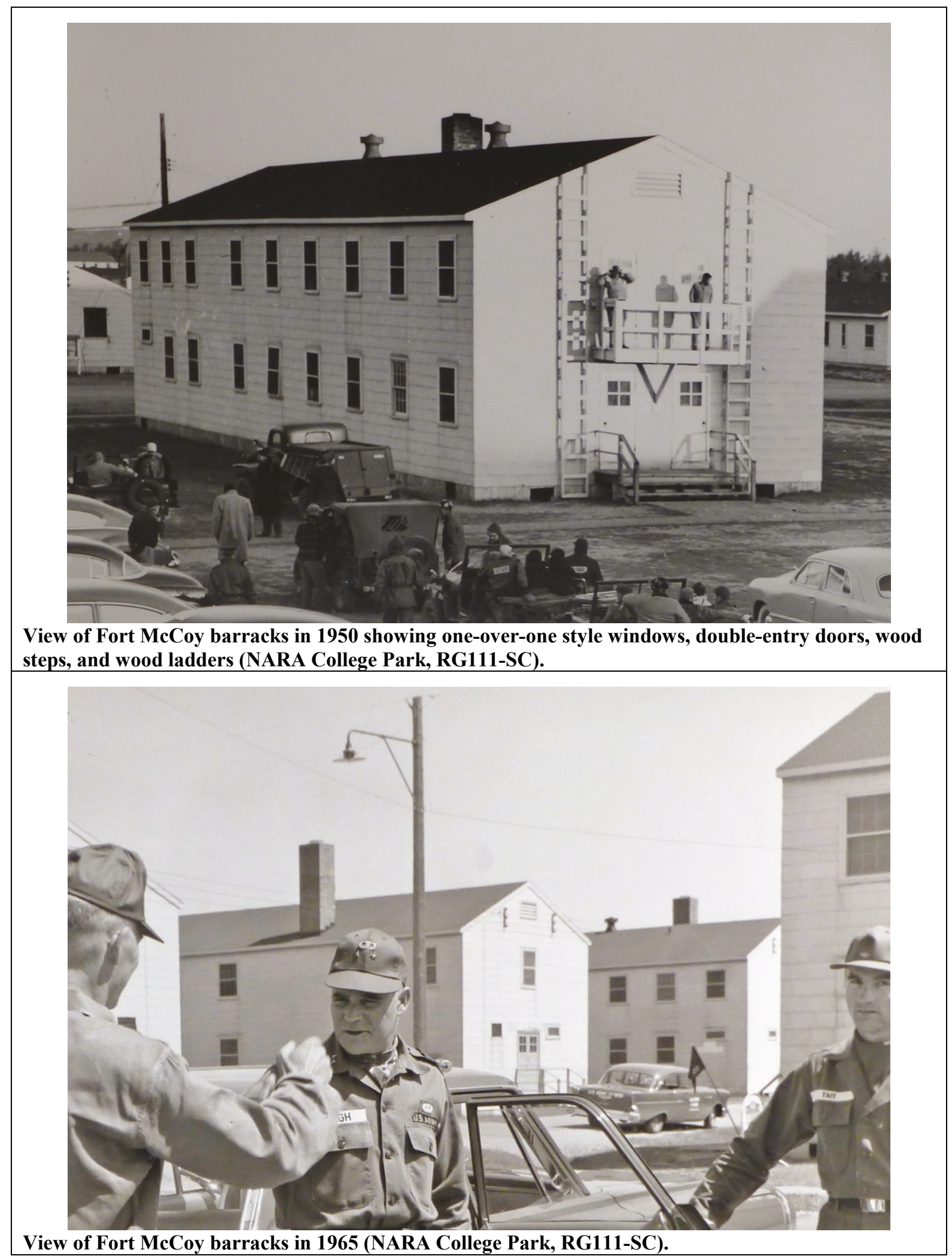




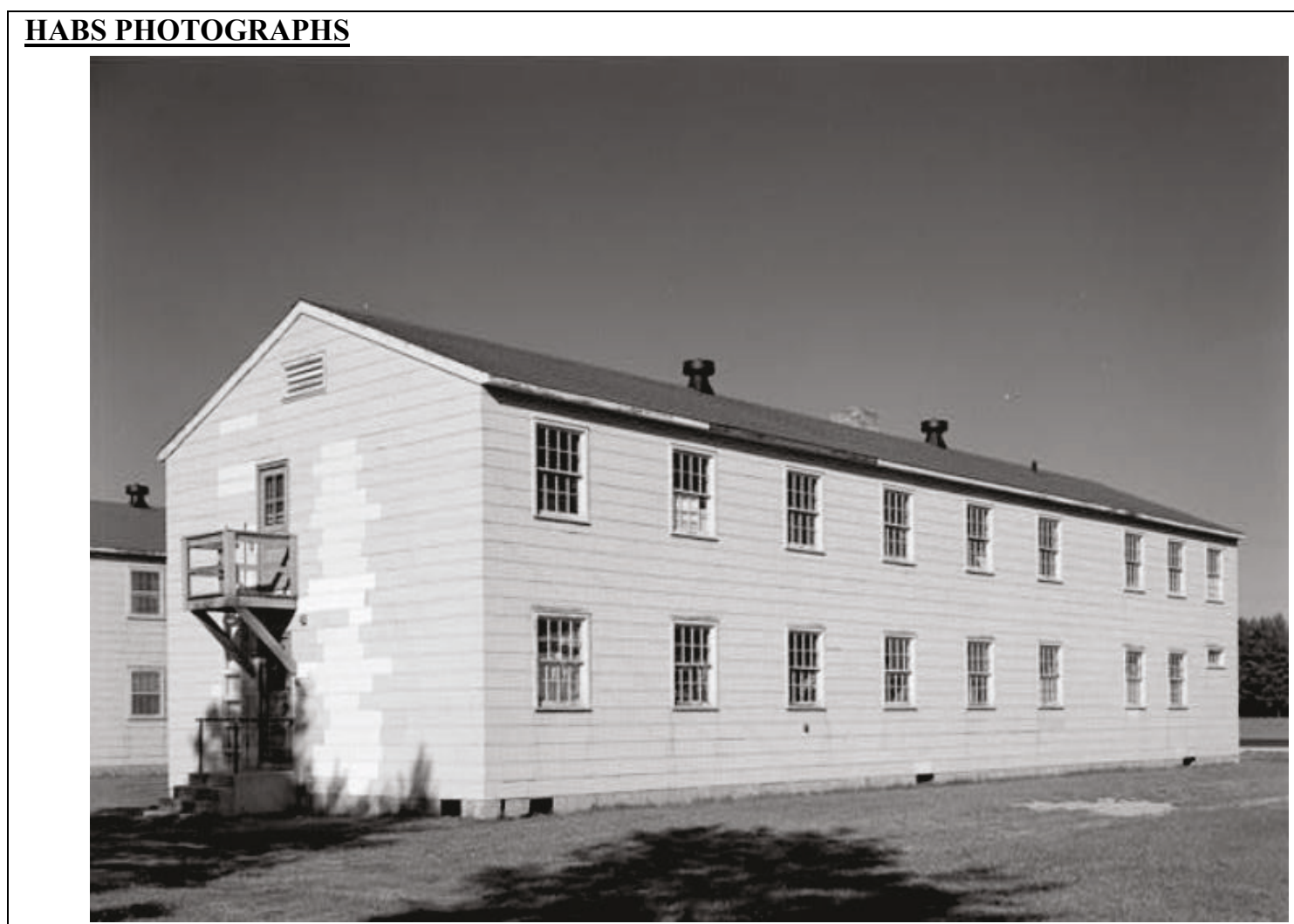

Southwest oblique of Building 1129, a 74-man barracks at Fort McCoy, 1988 (Library of Congress, HABS WIS, 41-SPAR.V, 1-A-4). (Note that HABS was performed on Building 1129 for all barracks.)

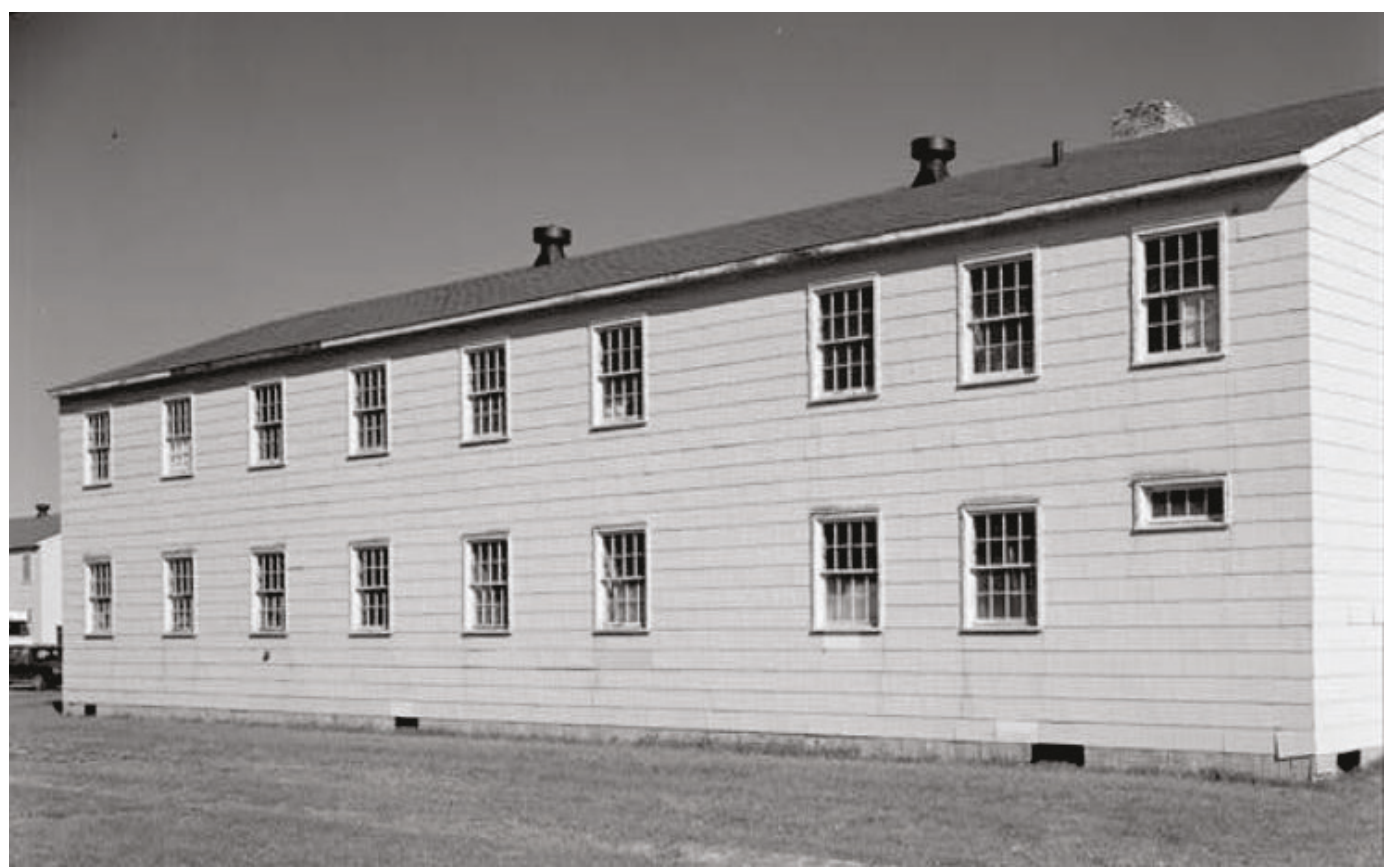

South elevation of Building 1129, a 74-man barracks at Fort McCoy, 1988 (Library of Congress, HABS WIS, 41-SPAR.V, 1-A-3). 


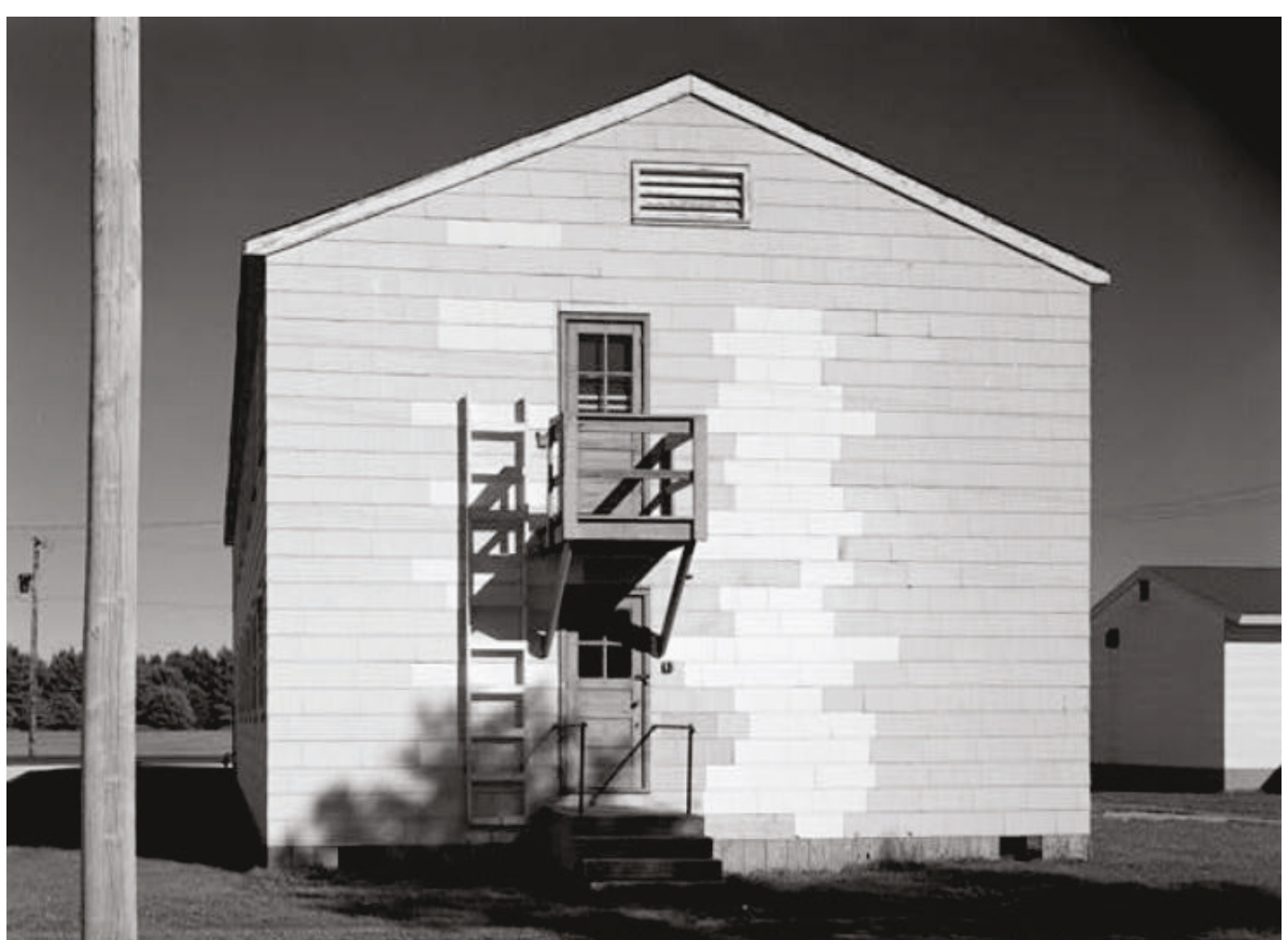

West elevation of Building 1129, a 74-man barracks at Fort McCoy, 1988 (Library of Congress, HABS WIS, 41-SPAR.V, 1-A-7).

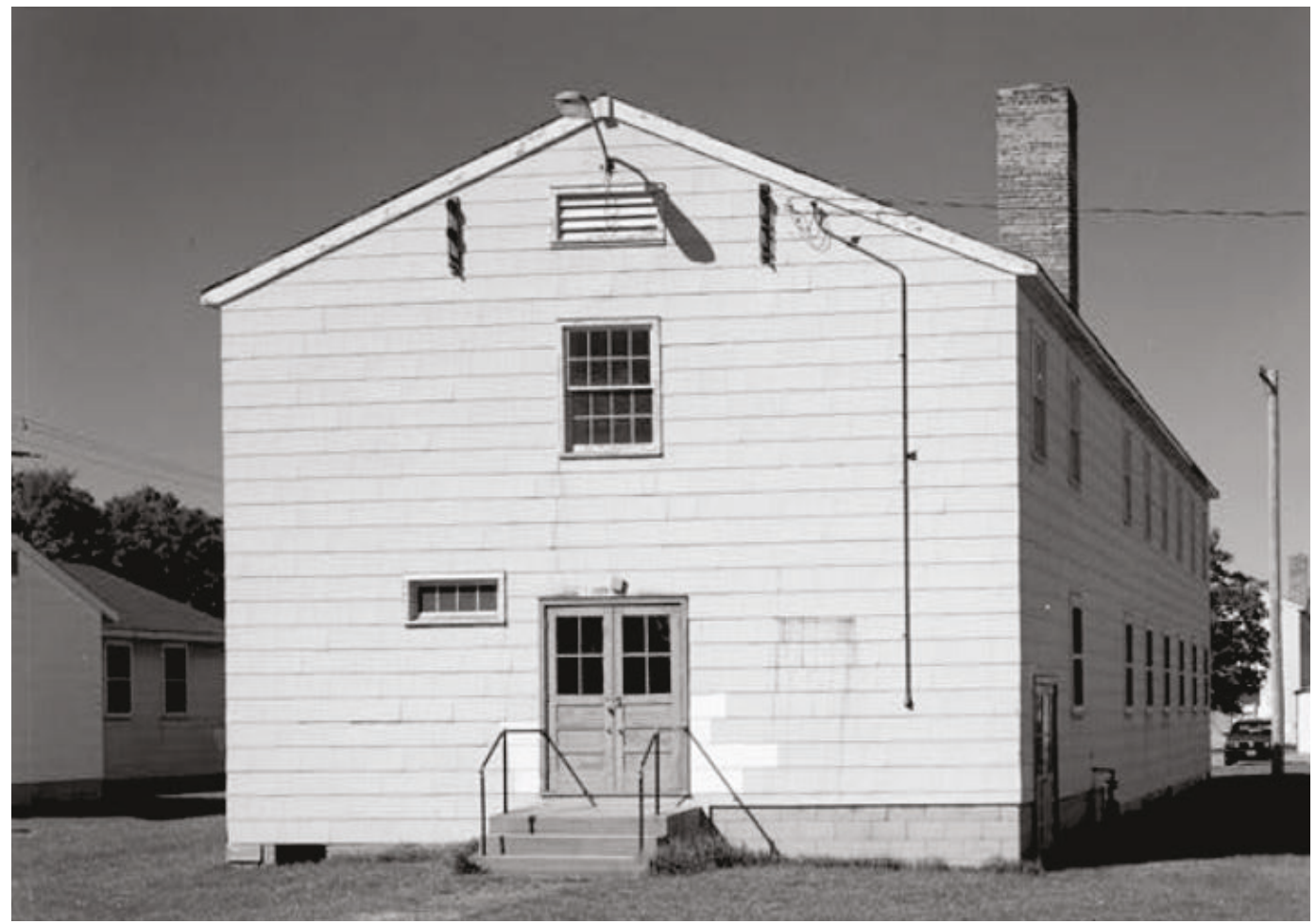

East elevation of Building 1129, a 74-man barracks at Fort McCoy, 1988 (Library of Congress, HABS WIS, 41-SPAR.V, 1-A-6). 


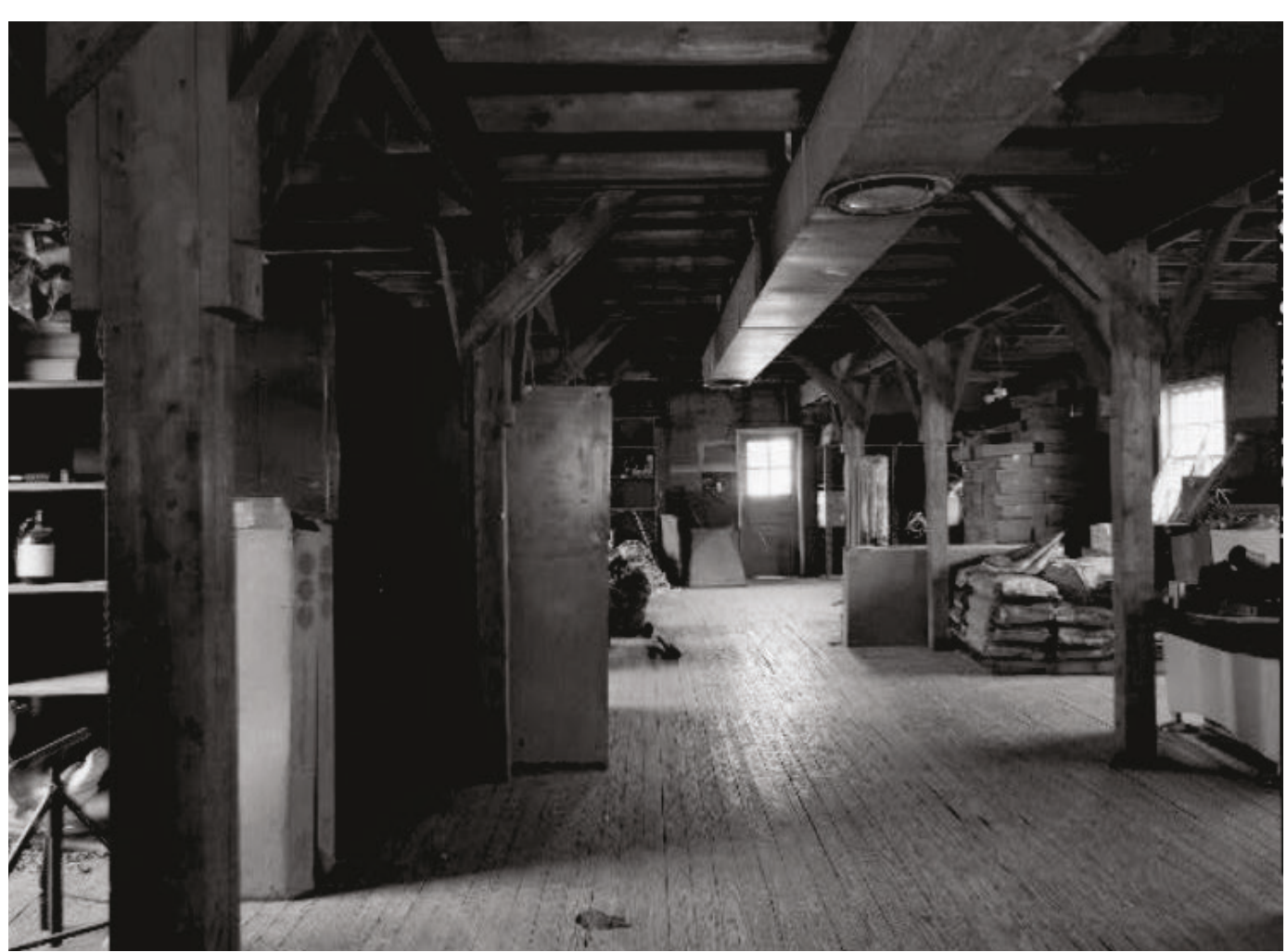

First floor squad room in Building 1129, a 74-man barracks at Fort McCoy, 1988 (Library of Congress, HABS WIS,41-SPAR.V,1-A-15).

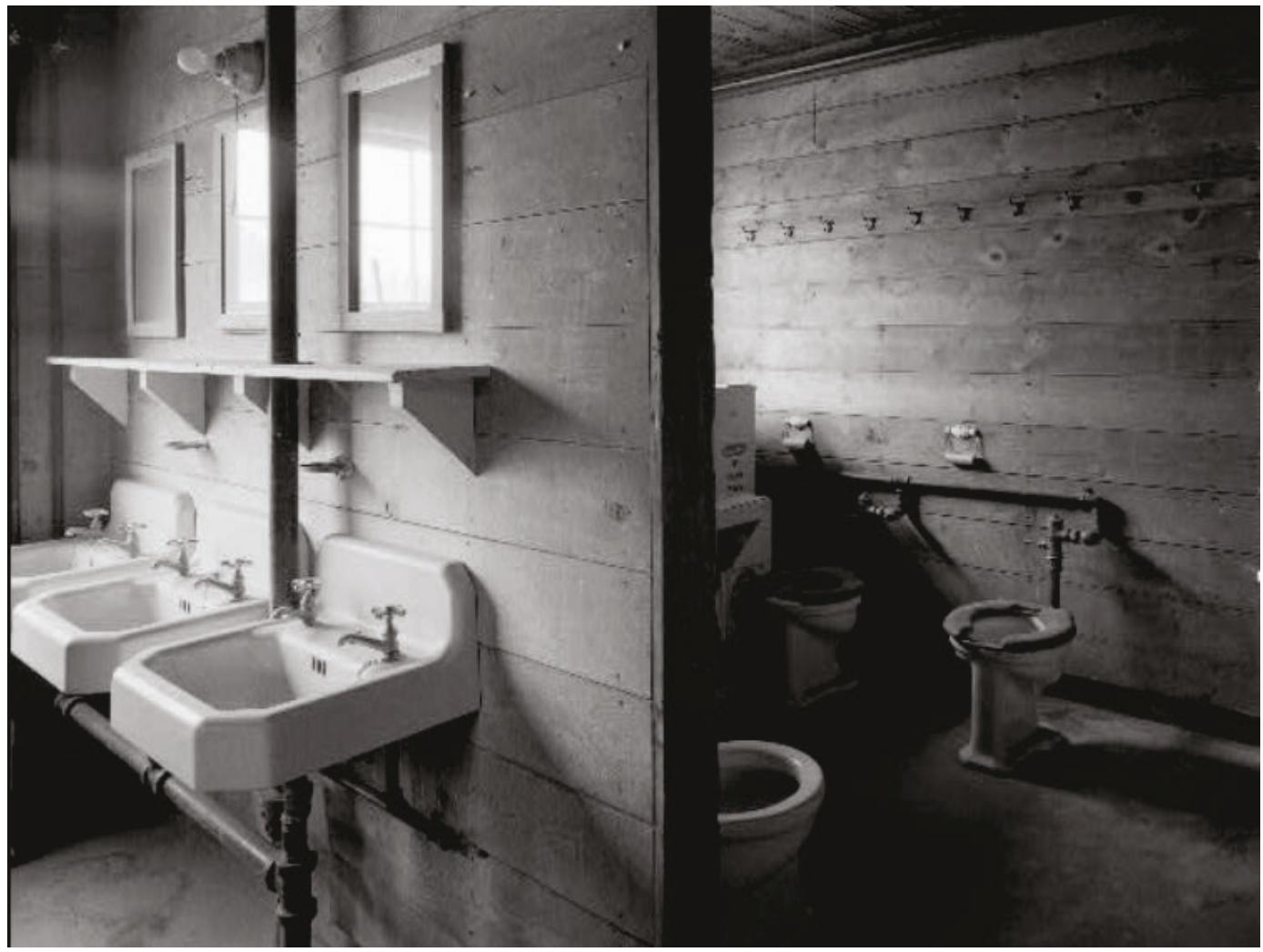

Interior view of the toilet room on the first floor in Building 1129, a 74-man barracks at Fort McCoy, 1988 (Library of Congress, HABS WIS,41-SPAR.V,1-A-13). 


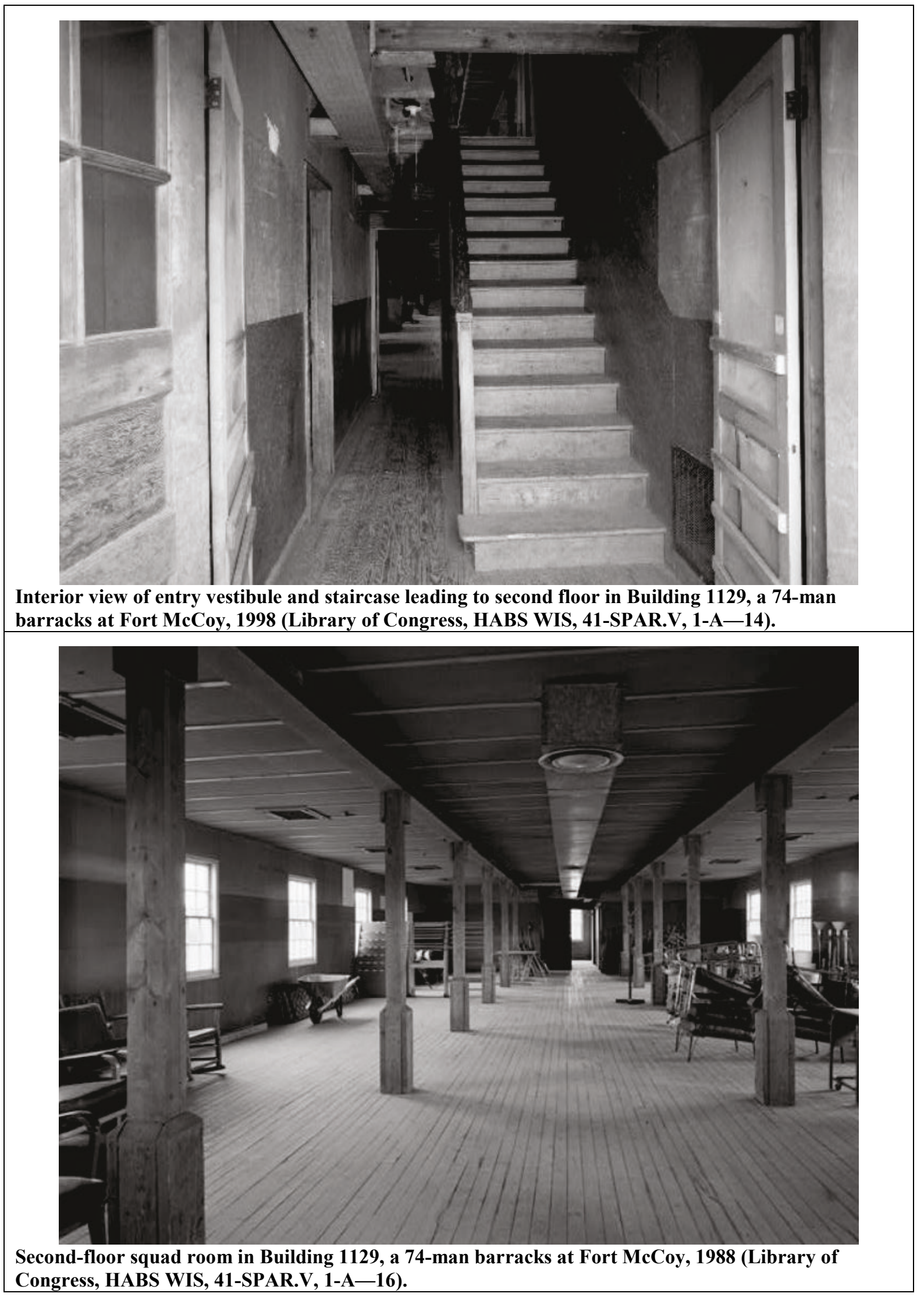




\section{CHARACTER-DEFINING FEATURES}

- Two-story massing

- Rectangular footprint

- Front gable roof clad with red asphalt shingles (replaced roof in-kind)

- Overhanging wood soffit with wood fascia (modified with metal soffits)

- Textured cement asbestos siding with a scalloped bottom edge detail (replaced with vinyl siding)

- Concrete pier foundation with wooden foundation skirting (replaced)

- Concrete block foundation walls, heater room

- Window pattern (modified)

- Multi-pane wood double-hung windows, two different types; $8 / 8$ double-hung and four-pane singlesash hopper (8/8 replaced with one-over-one vinyl windows and four-pane removed and openings covered over)

- Wood trim, surround, and profile of windows (removed)

- Wood panel and divided light doors (replaced with newer metal doors and two were completely removed on the rear elevation at the end of the squad rooms and the openings were covered over)

- Wood steps, stoop, and handrail (dismantled)

- Wood platform and exterior wood ladder attached to the rear wall near squad rooms (dismantled and replaced with metal steps and platform)

- Open bay entry vestibule with interior wood screen doors leading to the first floor and to the staircase (vestibule enclosed with partition wall, screens replaced with newer wood interior doors)

- Room arrangement

- Exposed wood structural system in the first and second floor squad room (encased with newer materials such as a drop-ceiling and drywall panels)

- Insulation board and batten for walls and ceilings in squad rooms and NCO rooms (replaced with drywall)

- Wood floor in squad rooms, entry vestibule, and NCO rooms (removed or covered over with vinyl tiles)

- Concrete floor in latrine and heater room (concrete covered over with vinyl tiles in the latrine)

- Latrine on first floor with sinks, shelves, mirrors, toilets, urinal, shower head fixtures, and wood tongue and groove finished walls (all replaced with newer fixtures and finishes)

- Wood five-panel interior doors (replaced)

- Wood trim around windows (replaced)

- Interior light fixtures (replaced)

\section{COMPARISON IMAGES}
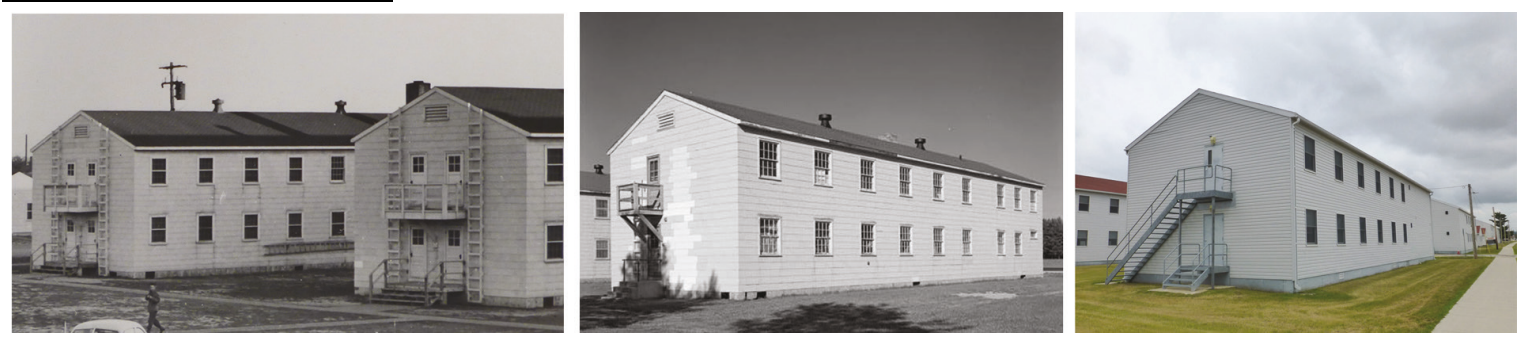

Front elevation of a 74-man barracks with comparison of the original construction, design, and materials from 1950 (left) to 1988 (middle) to 2018 (right). Note the original wood porch, steps, and handrails have already been removed and replaced with a concrete stoop and metal handrails in middle image (Left: NARA; middle: Library of Congress, HABS; right: ERDC-CERL). 


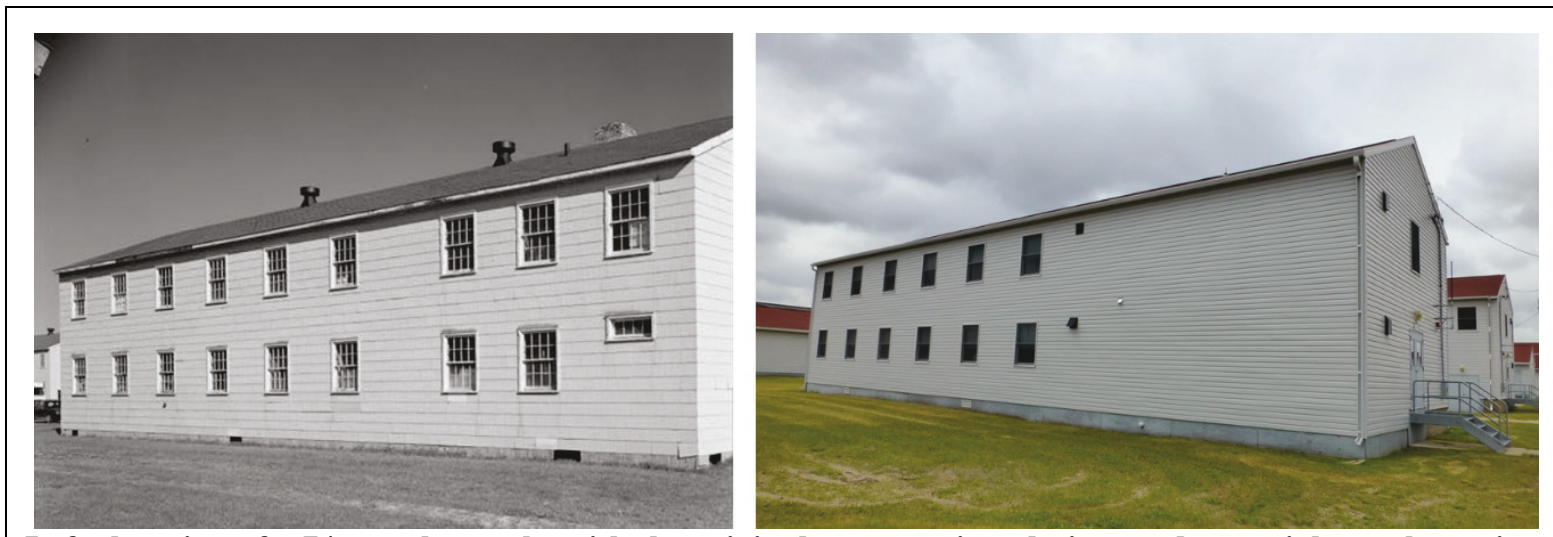

Left elevation of a 74-man barracks with the original construction, design, and materials, as shown in 1988 photo (left) compared to 2018 (right) (left: Library of Congress, HABS; right: ERDC-CERL).

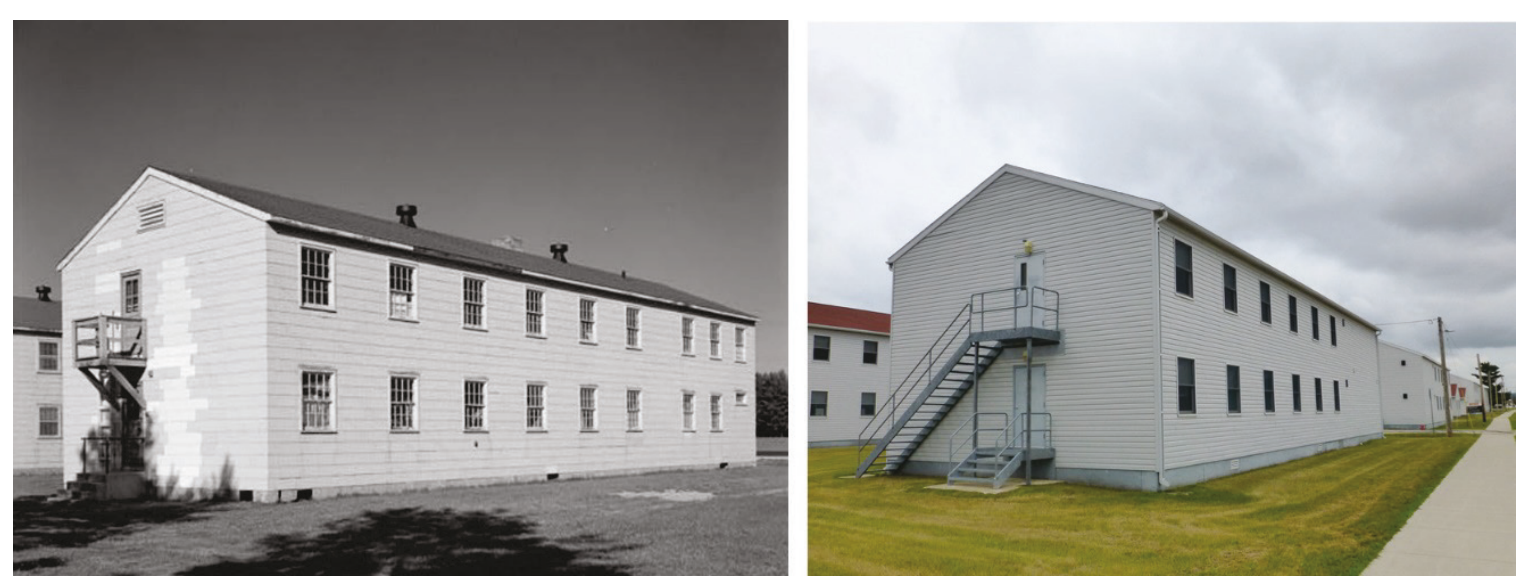

Left and rear oblique of a 74-man barracks with the original construction, design, and materials, as shown in 1988 (left) compare to 2018 (right) (left: Library of Congress, HABS; right: ERDC-CERL).

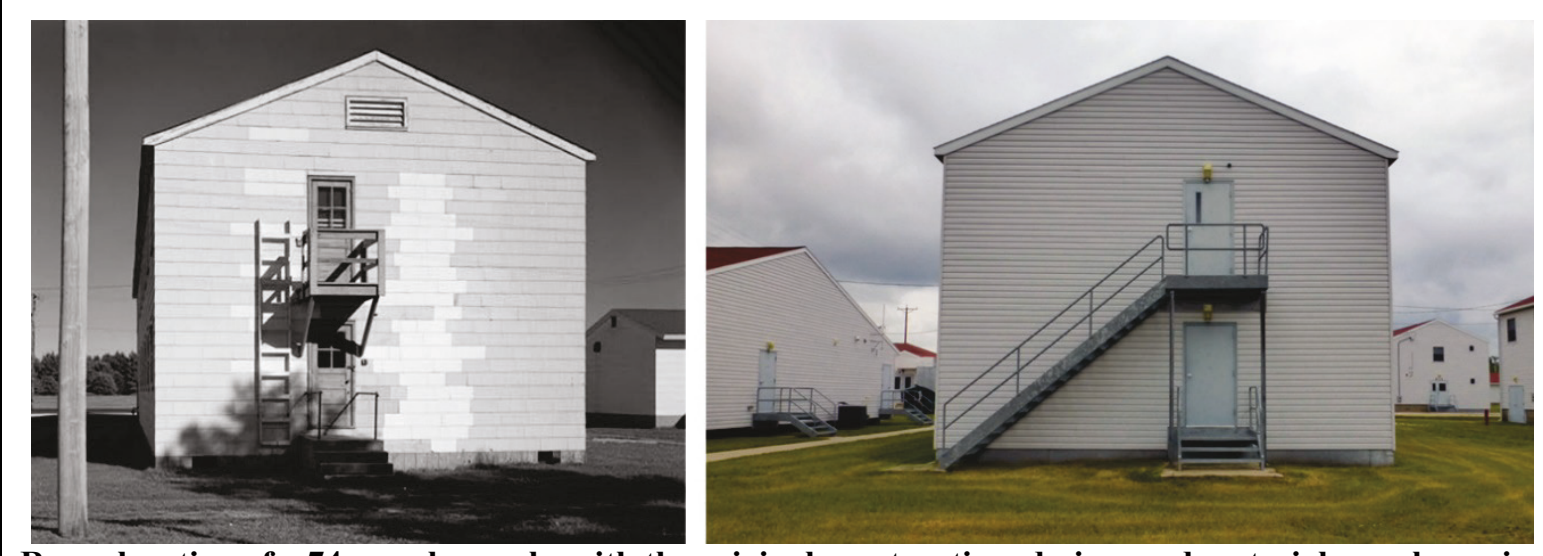

Rear elevation of a 74-man barracks with the original construction, design, and materials, as shown in 1988 photo (left) compared to 2018 (right). Note that the original first-floor wood porch, steps, and handrails have been removed and replaced by 1988 with a concrete stoop and metal handrails, plus the two original fire exit doors have been removed from the squad rooms, and those door openings have been covered with newer cement asbestos siding by 1988 (left: Library of Congress, HABS; right: ERDC-CERL). 


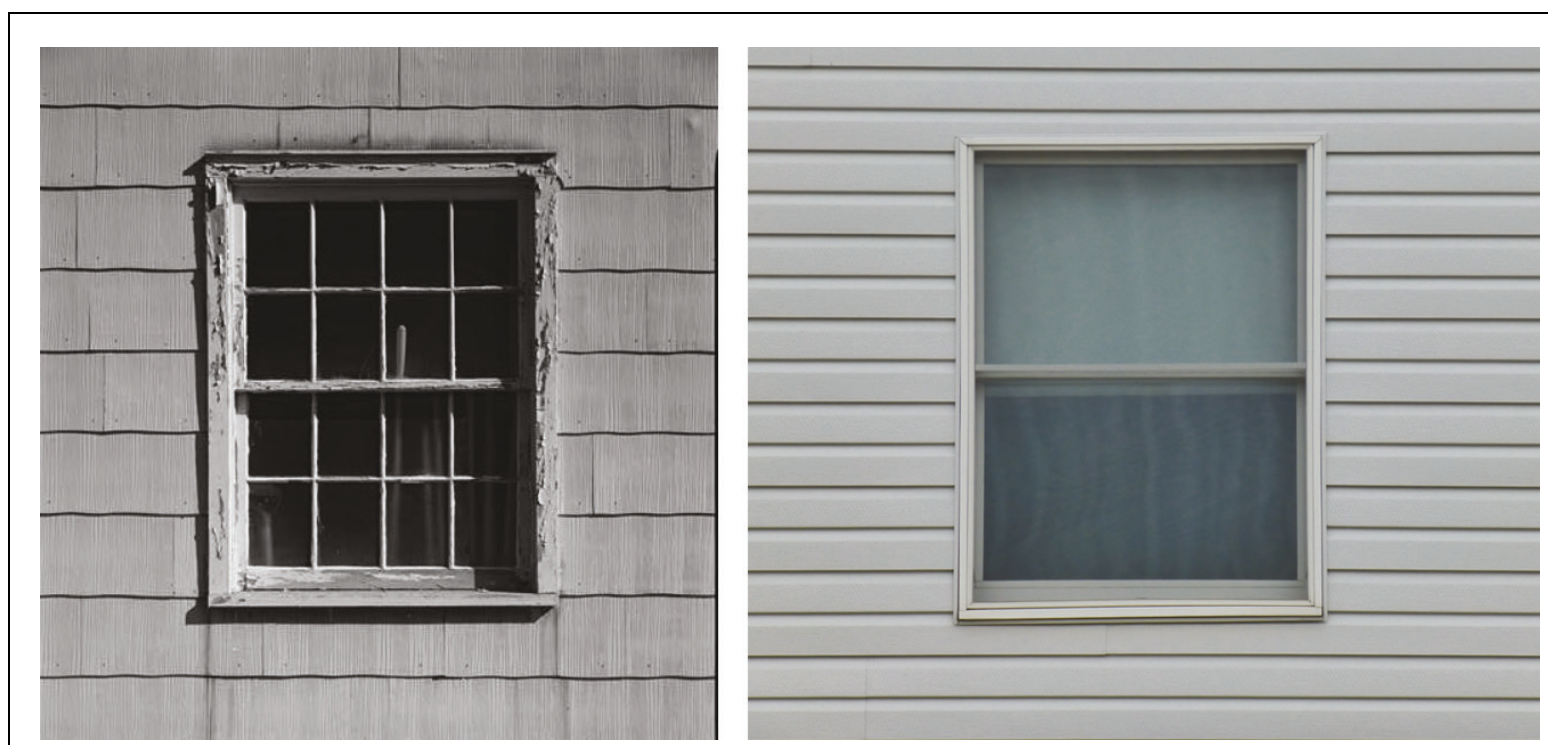

Window comparison of the original eight-over-eight wood double-hung window on a 74-man barracks (left) to the current replacement one-over-one vinyl window (right) (left: Library of Congress, 1988 HABS; right: ERDC-CERL, 2018).
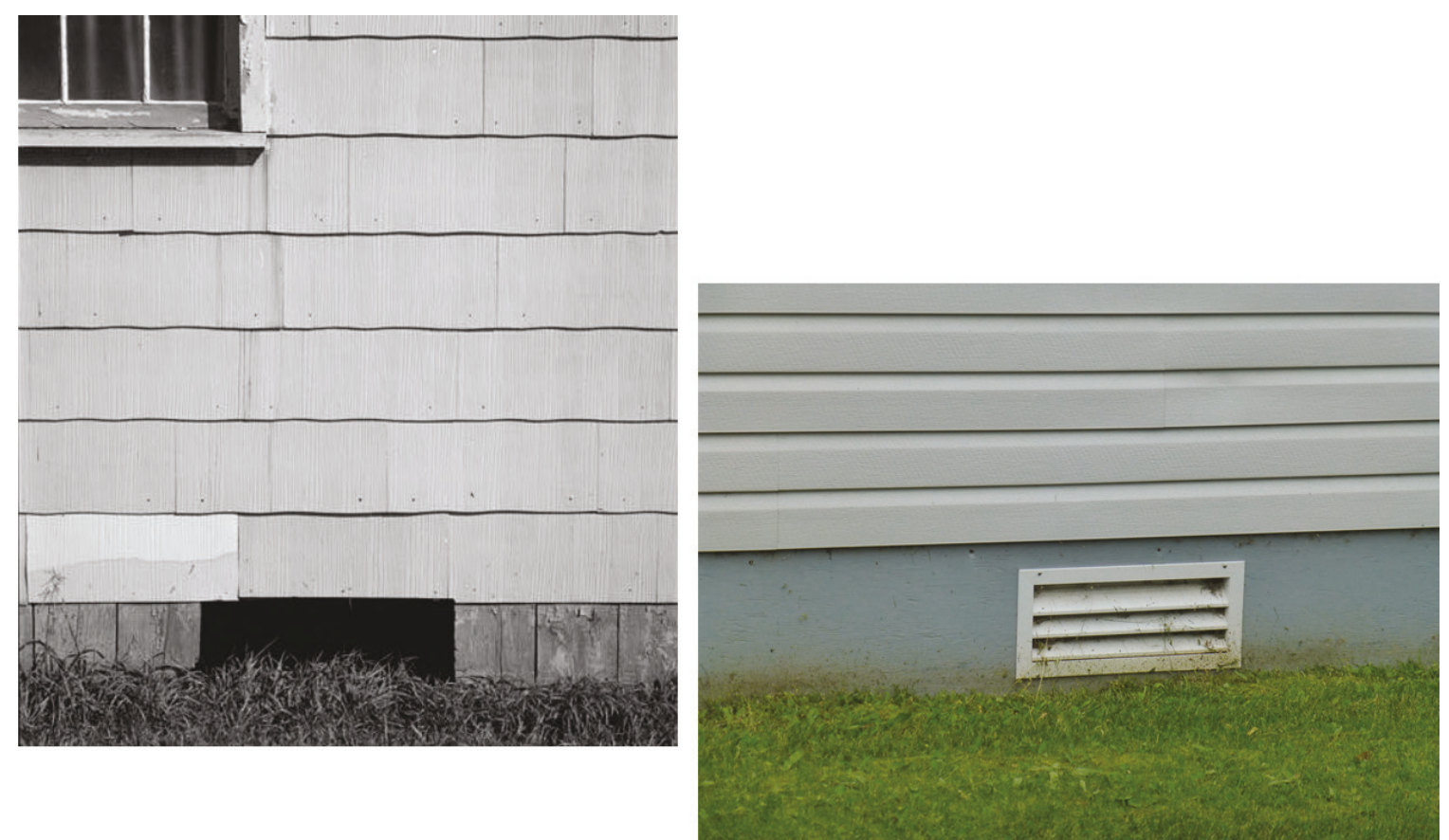

Original cement asbestos siding with scalloped edge detail and wood foundation skirting (left), compared to the replacement materials of vinyl siding and plywood foundation skirting (right) (left: Library of Congress, 1988 HABS; right: ERDC-CERL, 2018). 


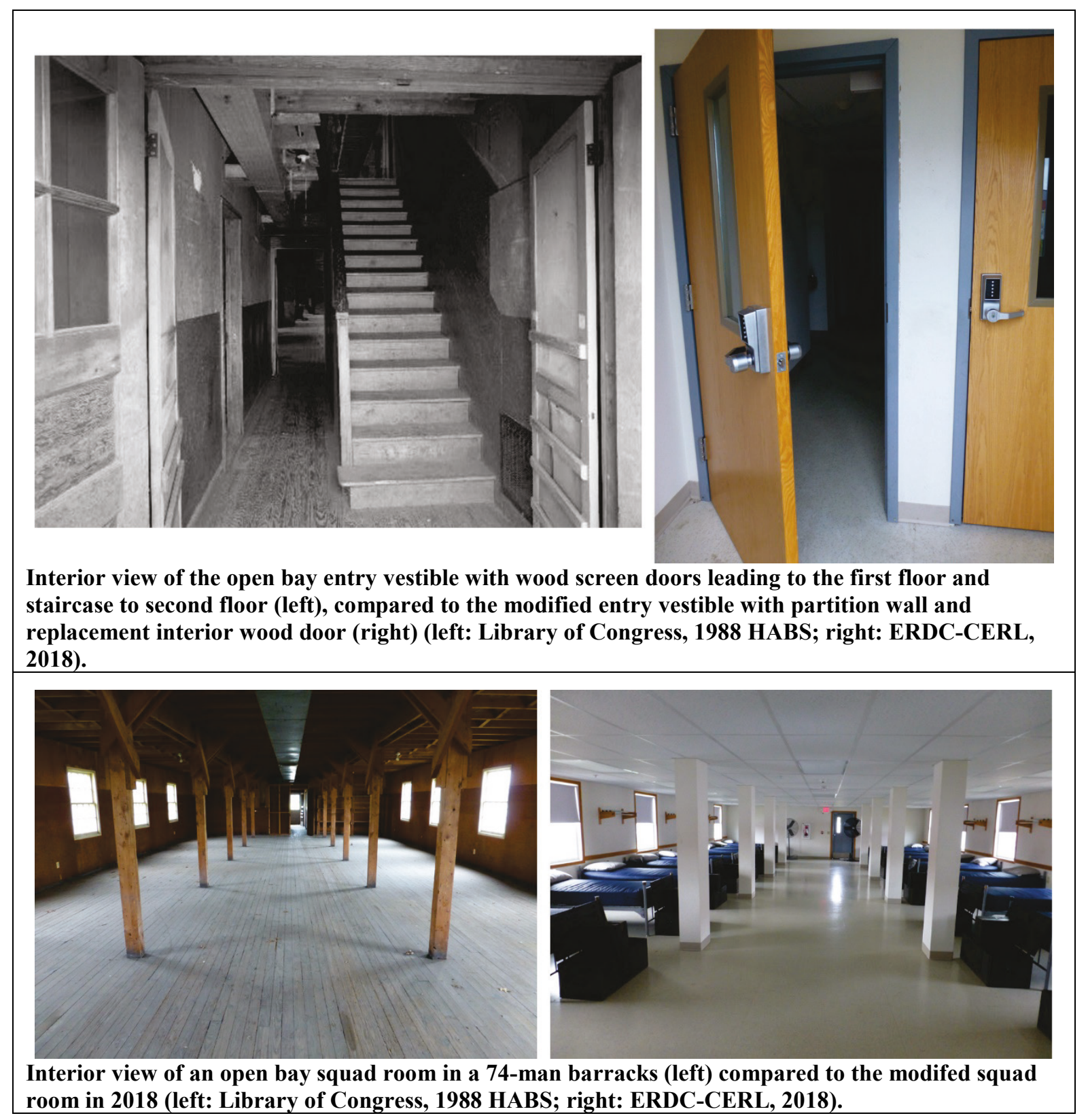



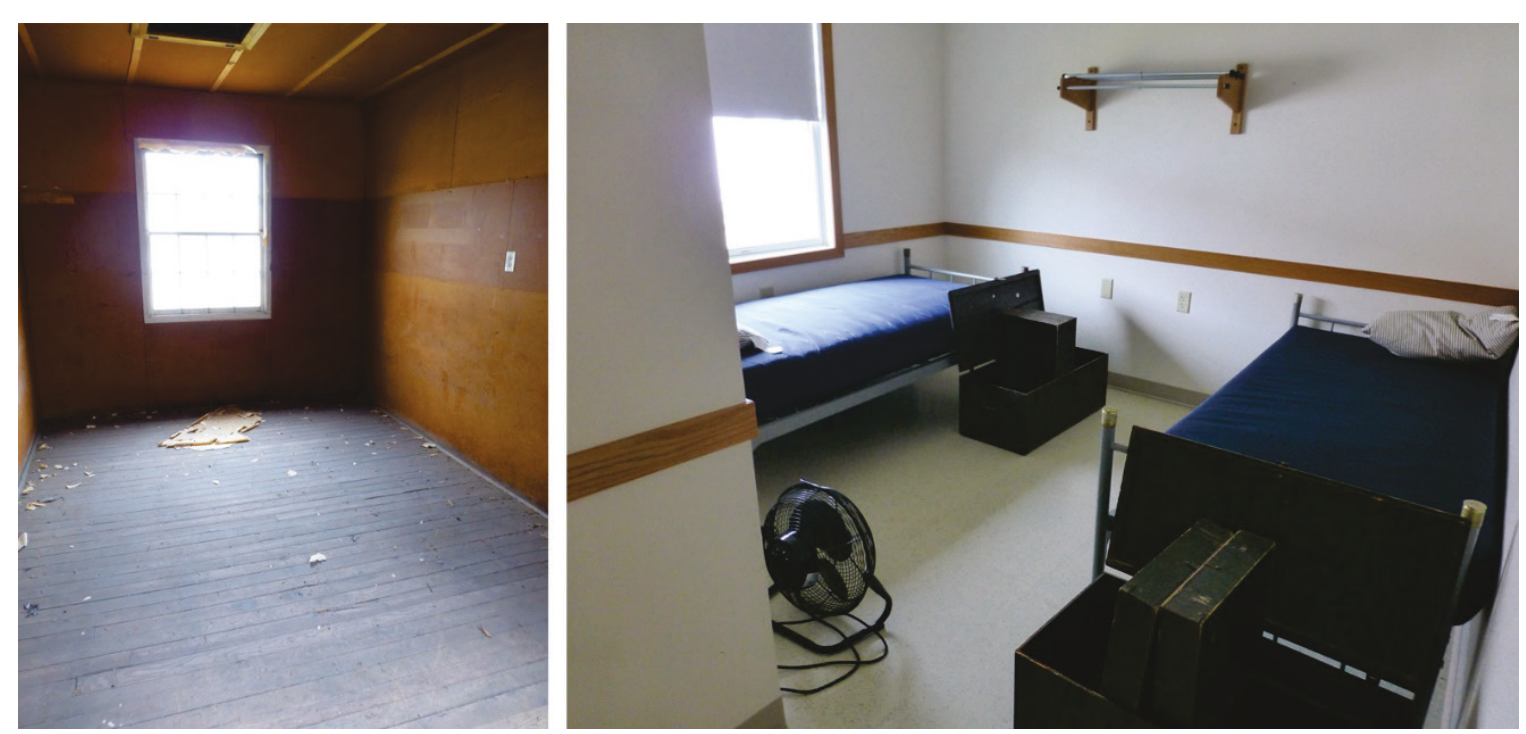

Interior view of an NCO room on the second floor of a 74-man barracks (left), compared to a modified NCO room from 2018 (left: Library of Congress, 1988 HABS; right: ERDC-CERL, 2018).
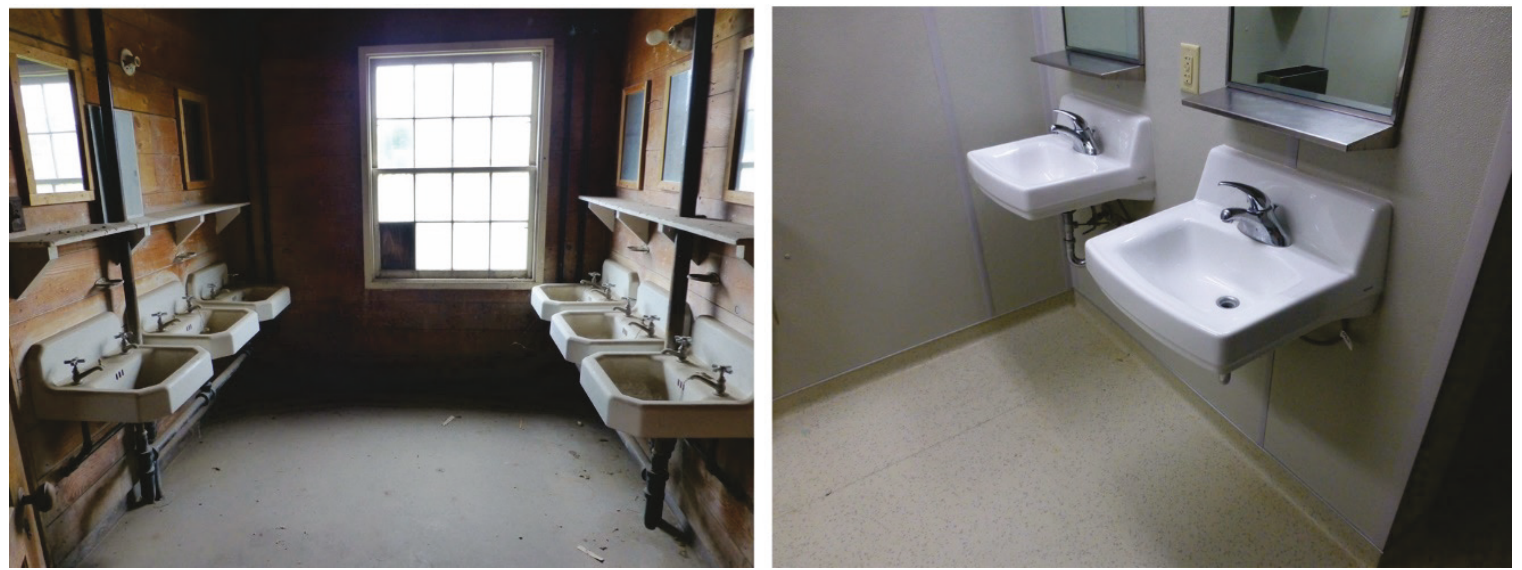

Interior view of the original sink area in the latrine on the first floor of a 74-man barracks (left), compared to the modified sink area in 2018 (left: Library of Congress, 1988 HABS; right: ERDCCERL, 2018). 


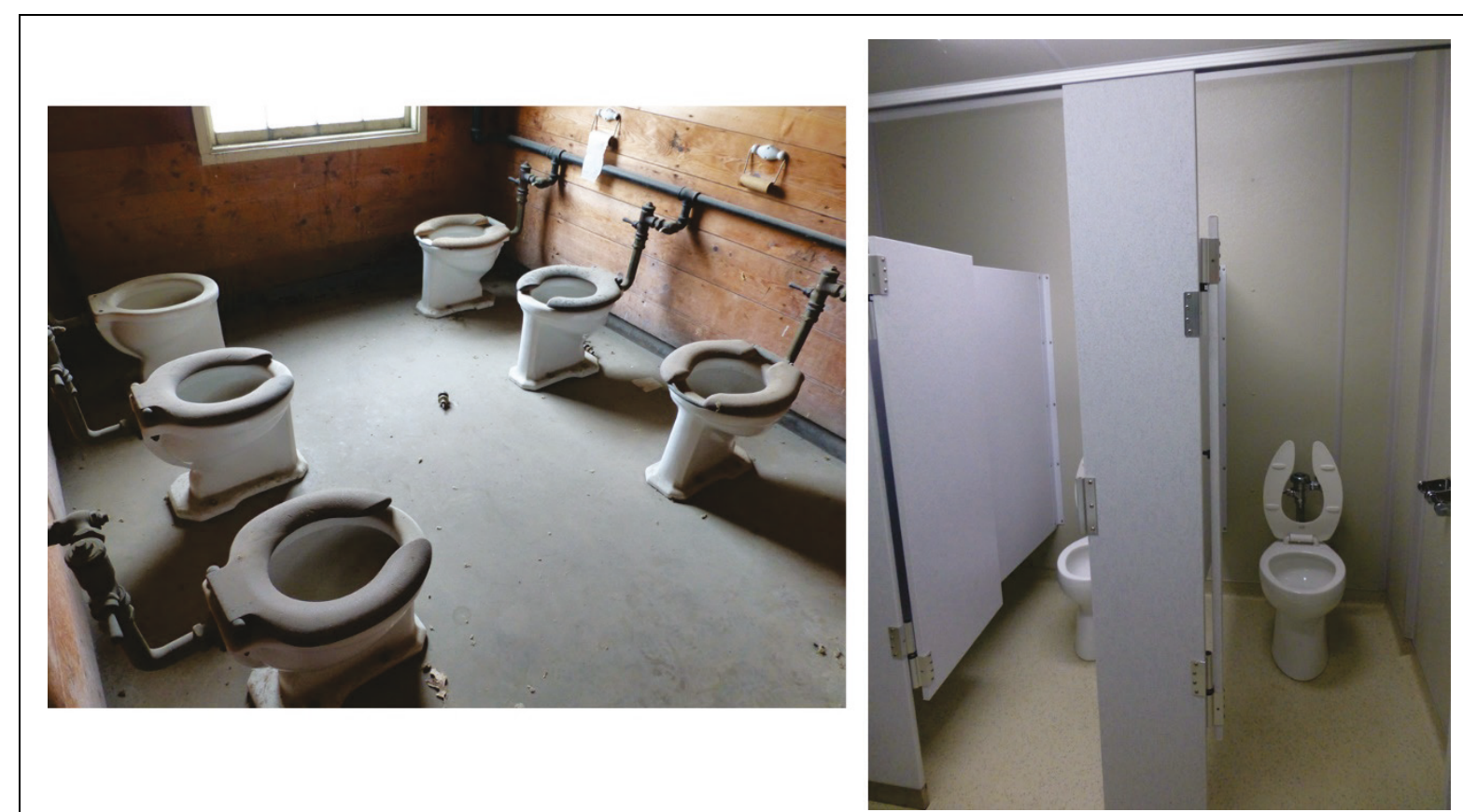

Interior view of the toilet room in the latrine on the first floor of a 74-man barracks (left), compared to the modified toilet room in 2018 (left: Library of Congress, 1988 HABS; right: ERDC-CERL, 2018).

\section{SIGNIFICANCE}

The 800 Series (and the 700 Series that preceded it) was a comprehensive set of drawings which could be used interchangeably in creating various building types. War mobilization buildings are significant for their construction and technological innovation. Techniques such as the standardization of plans, prefabrication of units, and assembly-line approach to construction were largely pioneered in the construction of these mobilization structures.

The temporary wood buildings constructed with the 700 Series or 800 Series on Fort McCoy during World War II (WWII) from 1939-1946 were determined significant for the National Register of Historic Places (NRHP) in 1986, when the Programmatic Memorandum of Agreement (PMOA) was signed between the Department of Defense (DoD), the Advisory Council on Historic Preservation (ACHP), and the National Council of State Historic Preservation Officers (NCSHPO). In the early 1990s, this significance was reaffirmed by the writing of the "World War II and the U.S. Army Mobilization Program: A History of 700 and 800 Series Cantonment Construction" and the performance of the Historic American Buildings Survey (HABS) on a variety of the 700 and 800 Series planned buildings across the country. Many of the 800 Series of buildings at Fort McCoy were utilized for the HABS.

Buildings 1602, 1603, 1604, 1607, 1608, 1609, 1610, 1612, 1613, 1614, 1615, 1618, 1619, 1620, 1623, 1624, $1625,1628,1629,1630,1631,1632,1634,1635,1636,1640,1641,1642$, and 1644-74-man barracks, WWII temporary buildings - are significant under Criterion A for WWII temporary building construction (1939-1946).

The design and construction of the WWII temporary buildings could not be linked to a specific architect due to their construction from standardized War Department temporary building plans. They do not possess high artistic values; however, WWII temporary buildings in general were found to be significant for their design, construction, and technological innovation under Criterion C. 


\section{INTEGRITY}

Location - All 29 WWII barracks buildings retain their integrity of location.

Design - None of the 29 WII barracks retain the key elements of their WWII design.

Setting - All 29 WWII barracks buildings retain their integrity of setting.

Materials - None of the 29 buildings retain their integrity. Each building has been completely modified with newer materials. No original material elements are intact.

Workmanship - is not part of integrity for WWII temporary buildings.

Feeling - All 29 buildings do not retain their integrity of feeling. Each has been heavily modified with modern materials.

Association - All 29 buildings retain their integrity for association.

\section{RECOMMENDATION OF CONTRIBUTING/NONCONTRIBUTING STATUS}

It is the recommendation of this report that Buildings $1602,1603,1604,1607,1608,1609,1610,1612,1613$, $1614,1615,1618,1619,1620,1623,1624,1625,1628,1629,1630,1631,1632,1634,1635,1636,1640$, 1641, 1642, 1644 (all are 74-man barracks) are NOT Eligible for the National Register of Historic Places (NRHP) at the national level due to the lack of integrity from changes in siding, changes in window pattern and type, changes in doors, full interior modifications, and dismantled chimney stack. 


\section{Block (and Building 1743) - Company Storehouse, Administration, and Recreation Buildings}

\begin{tabular}{|c|c|c|c|}
\hline \multicolumn{4}{|c|}{$\begin{array}{c}\text { FORT McCOY } \\
\text { HISTORIC PROPERTY INVENTORY FORM }\end{array}$} \\
\hline $\begin{array}{l}\text { PROPERTY BOUNDARIES } \\
\text { - Fort McCoy in the } 1600 \text { block } \\
\text { area on the south side of the } \\
\text { triangular cantonment plan } \\
\text { - Sparta vicinity } \\
\text { - Monroe County, Wisconsin }\end{array}$ & \multicolumn{2}{|c|}{$\begin{array}{l}\text { COMMON/HISTORIC NAME } \\
\text { - Buildings 1601, 1621, 1622, 1643, and } 1743 \\
\text { - General Instruction Building } \\
\text { - Company Storehouse, Administration, and Recreation } \\
\text { Building }\end{array}$} & $\frac{\text { STATUS }}{\text { Usable }}$ \\
\hline $\begin{array}{l}\text { ARCHITECT/BUILDER } \\
\text { Construction Division, Office of } \\
\text { the Quartermaster General } \\
\text { - Series } 800-661 \text { - Single } \\
\text { Storehouse and Company } \\
\text { Administration-Types SA-1 \& } \\
\text { SA-2, Stockade/Office Building } \\
\text { Type SO-1 } \\
\text { - Series } 800-460 \text { - Recreation } \\
\text { Building type RB-4 }\end{array}$ & $\begin{array}{l}\text { DATE OF CONSTRUCTION } \\
\text { July } 1942 \\
\text { DATE OF ALTERATIONS } \\
2003 \text { - replaced windows and } \\
\text { door } \\
\text { Unknown - added vinyl siding } \\
\text { to exterior walls, replaced the } \\
\text { roof, dismantled brick furnace } \\
\text { stack }\end{array}$ & $\frac{\text { NO. OF STORIES }}{1}$ & $\frac{\text { FOOTPRINT }}{\text { Rectangular }}$ \\
\hline$\frac{\text { ROOF FORM }}{\text { Front gable }}$ & $\begin{array}{l}\text { FOUNDATION } \\
\text { Concrete block walls and } \\
\text { concrete pier }\end{array}$ & $\begin{array}{l}\text { WALLS } \\
\text { Wood frame } \\
\text { structure clad vinyl } \\
\text { siding }\end{array}$ & 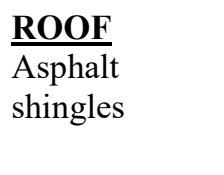 \\
\hline HISTORIC USE(S) & $\frac{\text { FUNCTION }}{\text { CURRENT USE }}$ & \multirow{3}{*}{\multicolumn{2}{|c|}{$\begin{array}{l}\text { NOTABLE FEATURES } \\
\text { - One-story rectangular temporary } \\
\text { structure } \\
\text { - Concrete pier with wooden } \\
\text { foundation skirting on the north end of } \\
\text { the building } \\
\text { - Concrete block foundation on the } \\
\text { south end of the building } \\
\text { - Gable roof clad with red asphalt } \\
\text { shingles } \\
\text { - Two different roof heights }\end{array}$}} \\
\hline $\begin{array}{l}\text { Company Storehouse, } \\
\text { Administration, \& Recreation }\end{array}$ & General Instruction Building & & \\
\hline \multicolumn{2}{|c|}{$\begin{array}{l}\text { RELATIONSHIP TO OTHER BUILDINGS } \\
\text { The } 1600 \text { block is located on the south side of the triangular } \\
\text { cantonment layout. South Eleventh Street is to the north, South J } \\
\text { Street is to the east, South Tenth Street is to the south, and South G } \\
\text { Street is to the west. South H and South I Streets cut through the } \\
\text { block. The } 1600 \text { battalion block consists of } 30 \text { barracks, four } \\
\text { company storehouse/administration/recreation buildings (currently } \\
\text { General Instruction Buildings } 1601,1621,1622 \text {, and } 1643 \text { ), and } \\
\text { eight mess halls. Building } 1743 \text { is located directly to the west of the } \\
1600 \text { block. The four company storehouse/administration/recreation } \\
\text { buildings face south toward South Tenth Street. }\end{array}$} & & \\
\hline
\end{tabular}




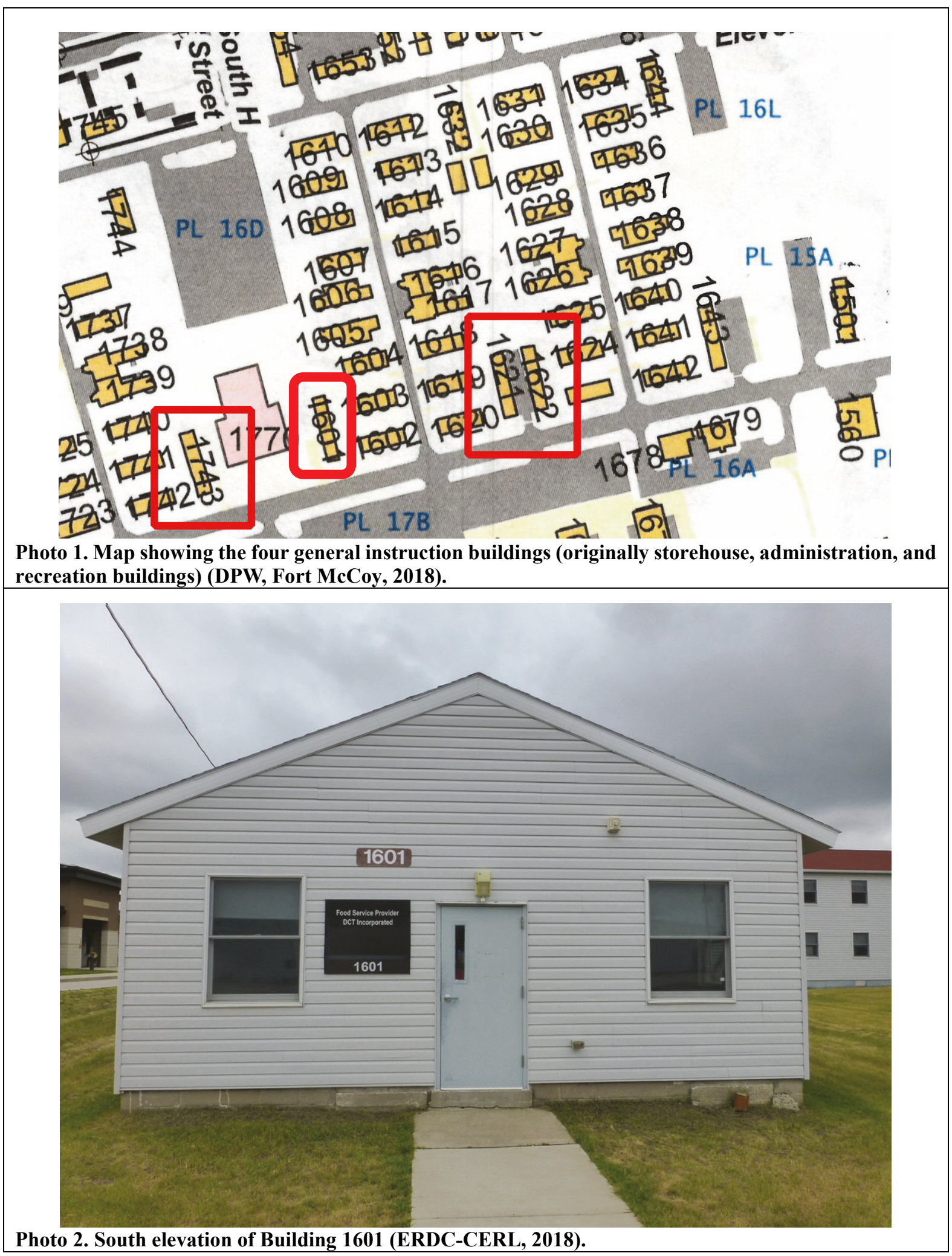




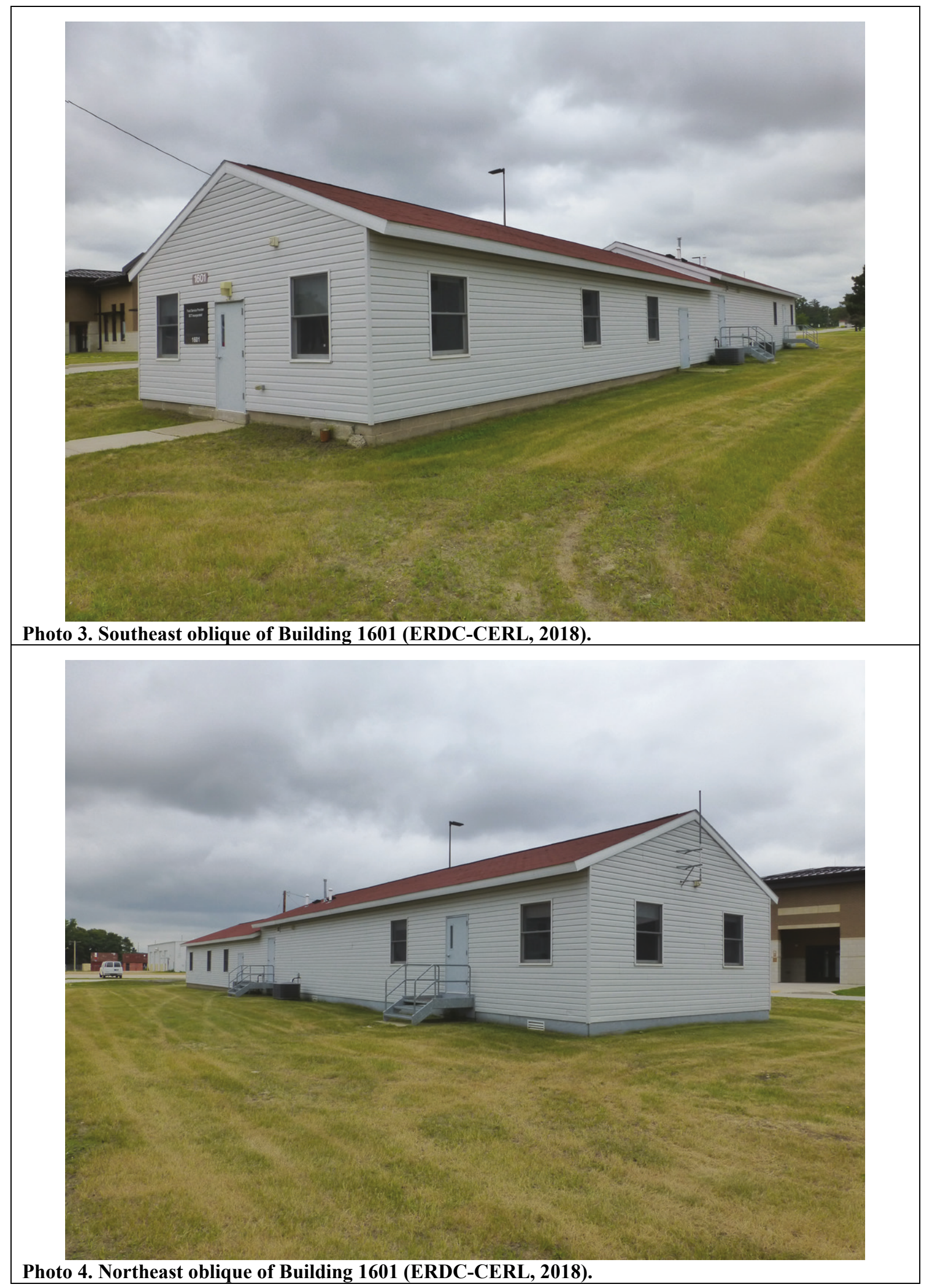




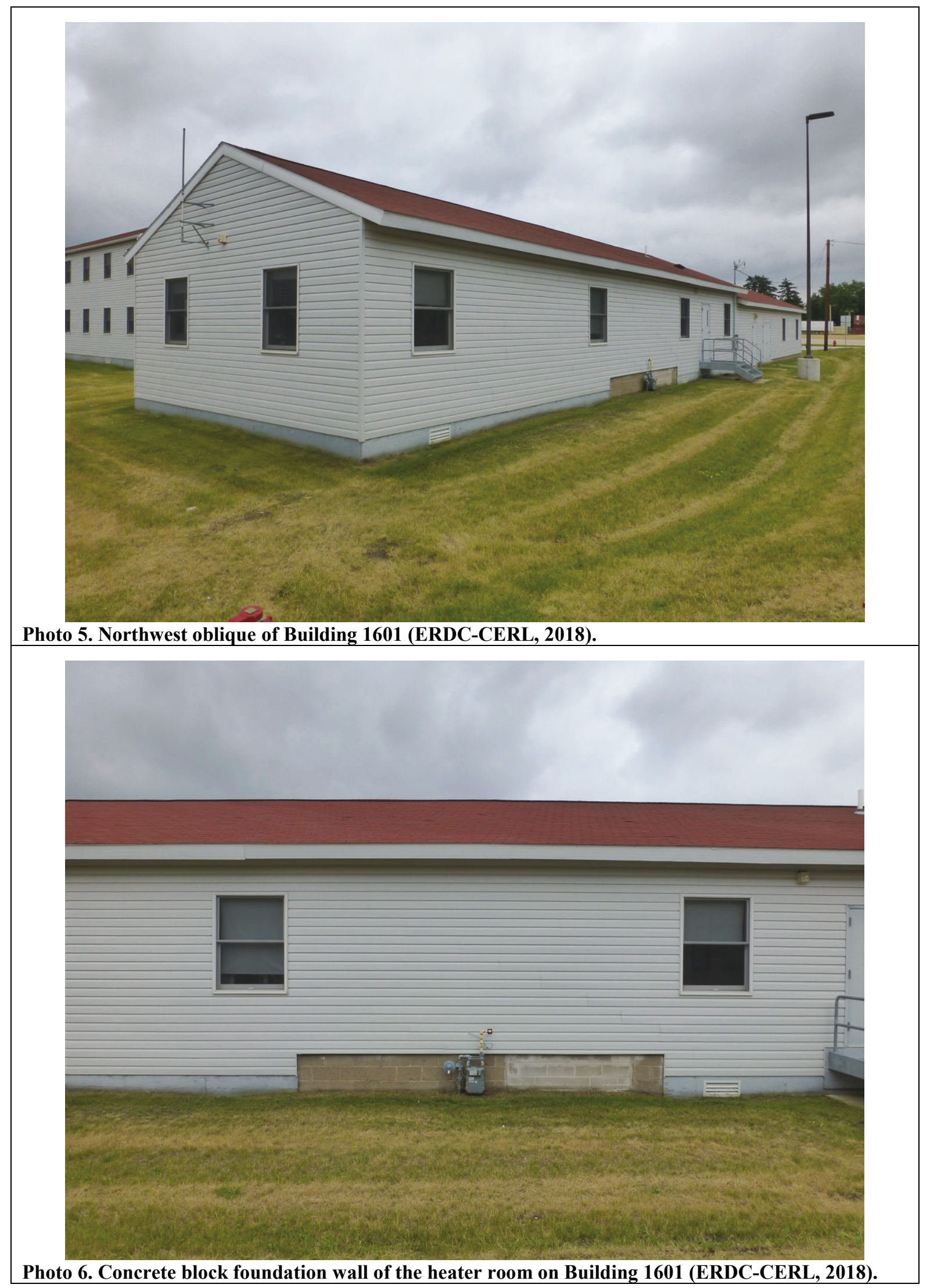



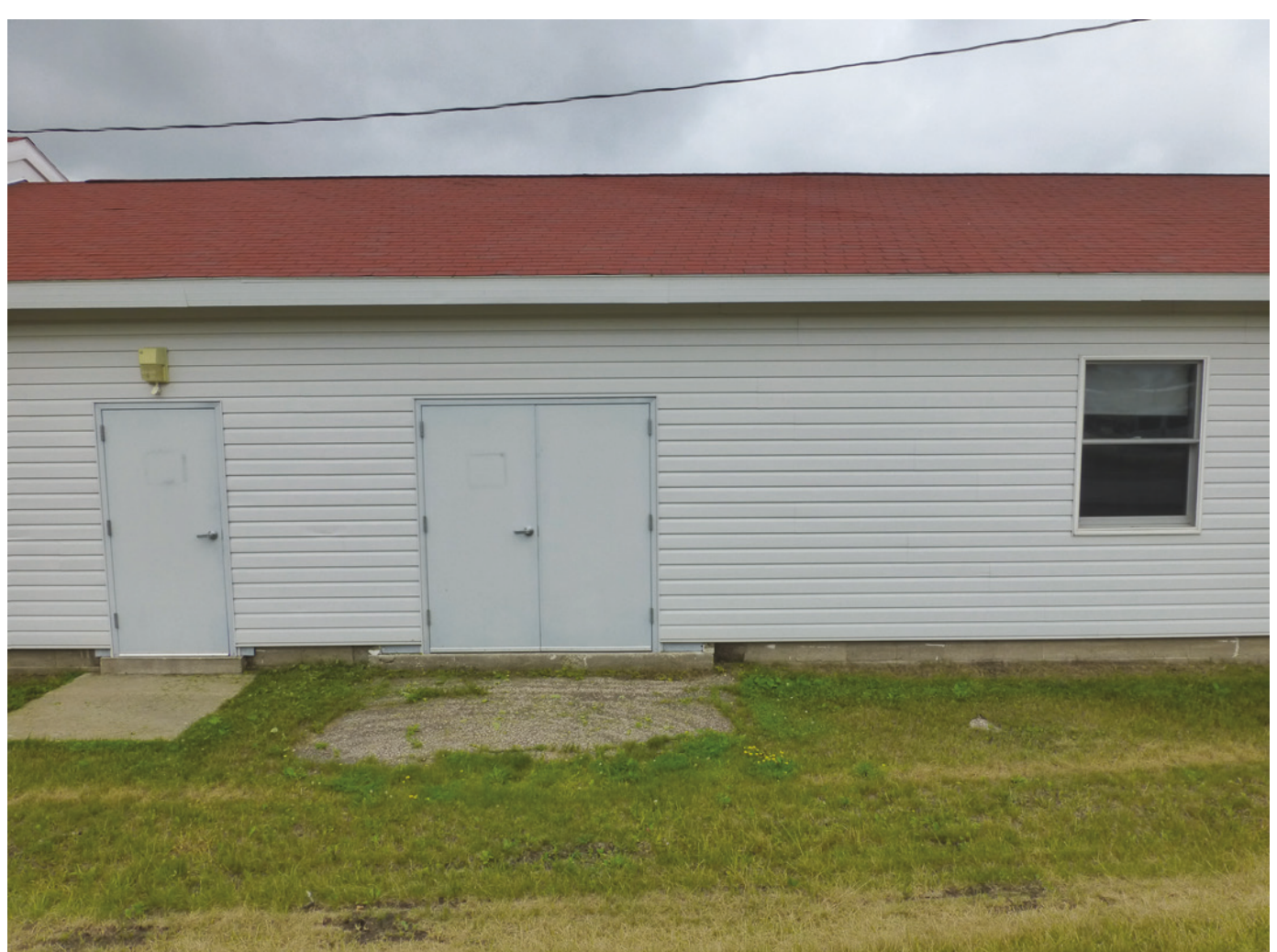

Photo 7. Replacement metal entry doors on the west elevation of Building 1601 (ERDC-CERL, 2018).

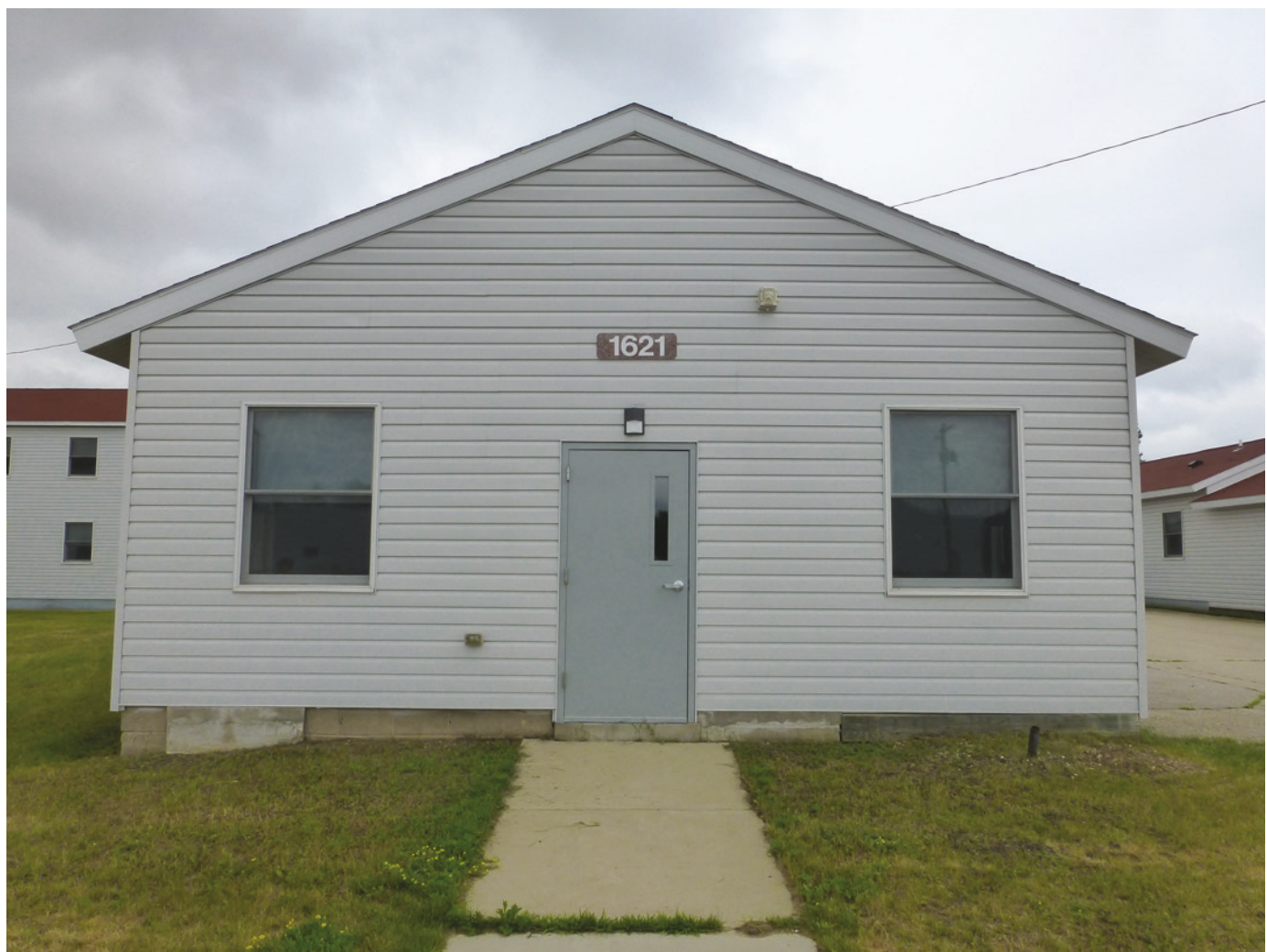

Photo 8. South elevation of Building 1621 (ERDC-CERL, 2018). 


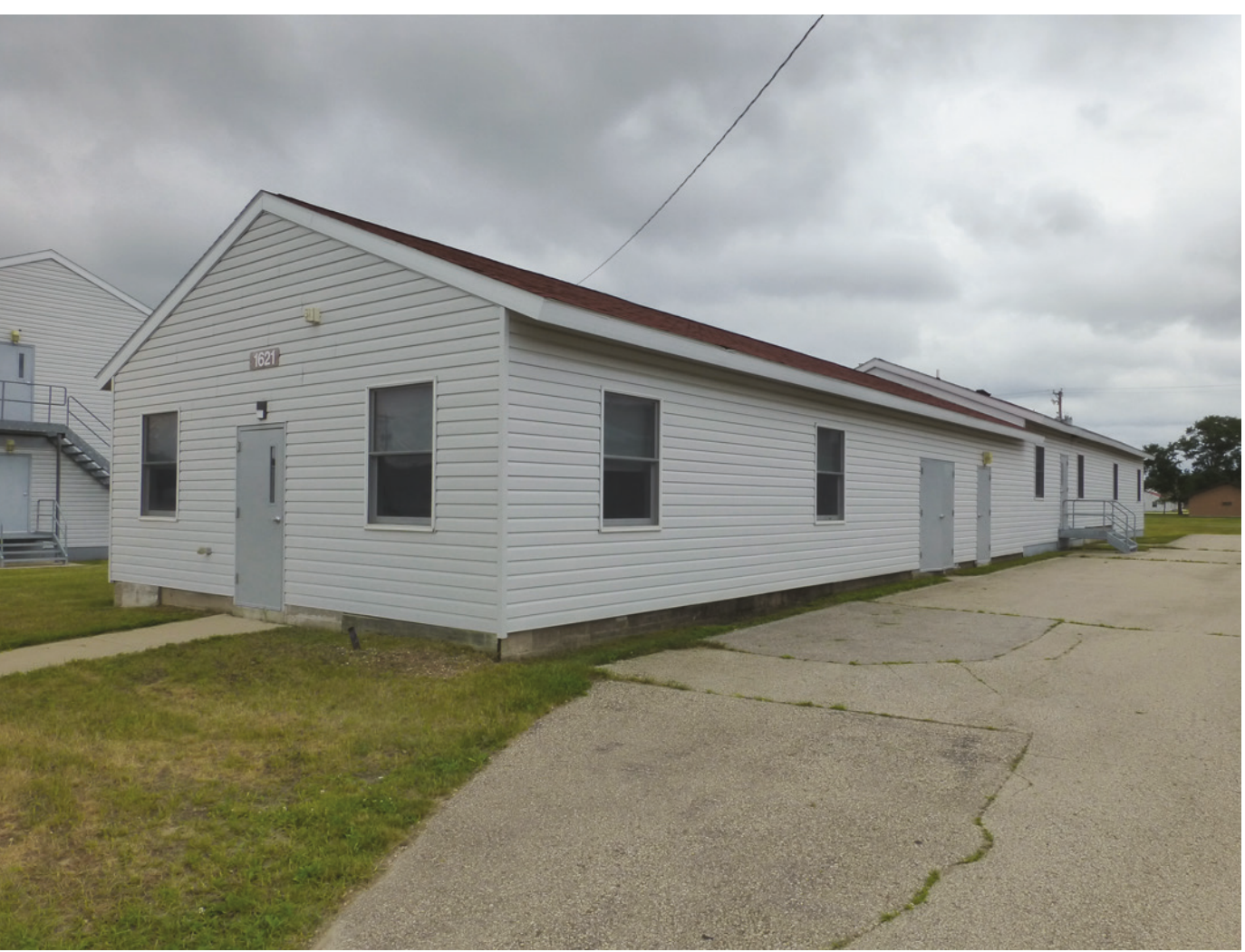

Photo 9. Southeast oblique of Building 1621 (ERDC-CERL, 2018).

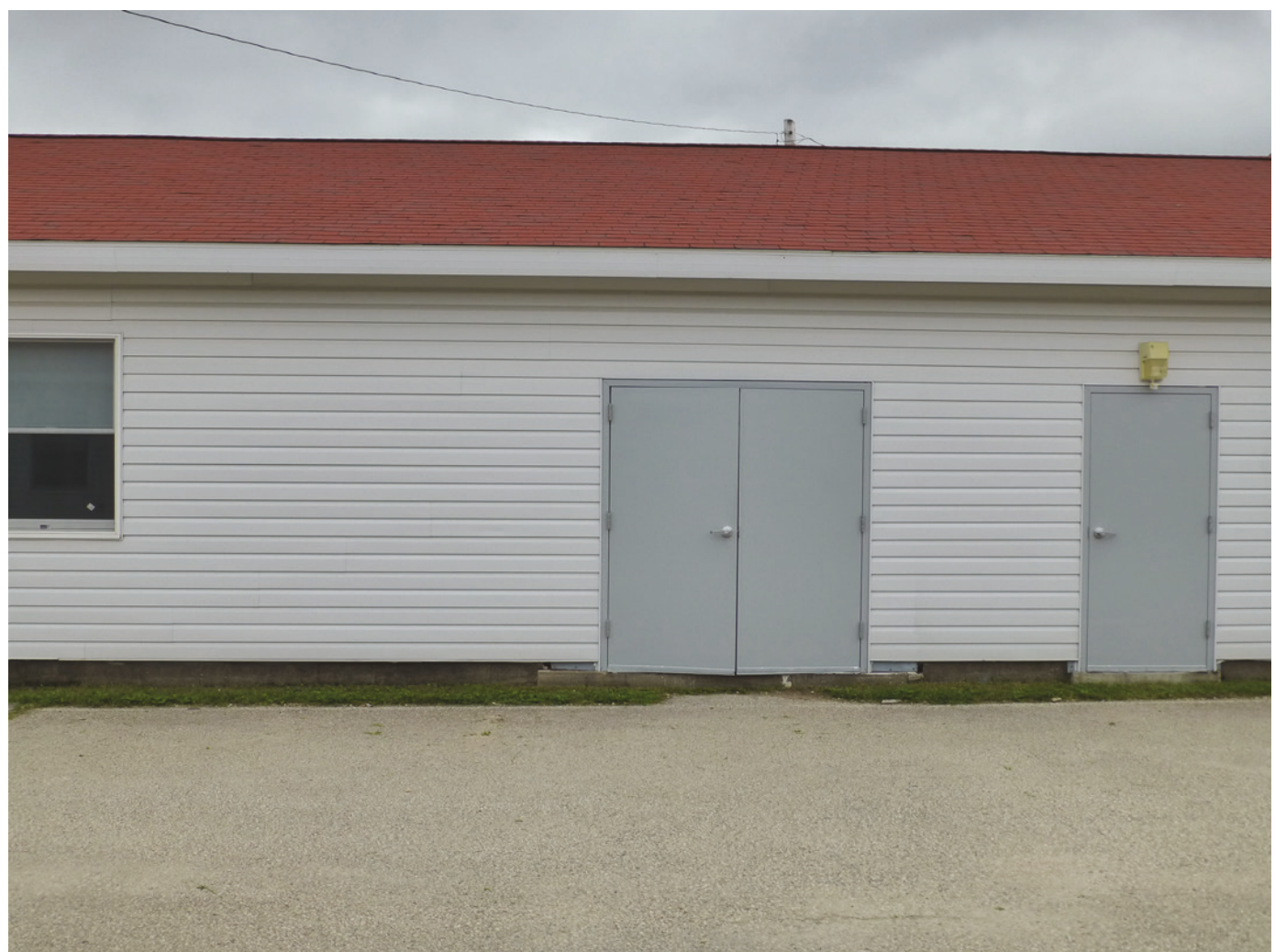




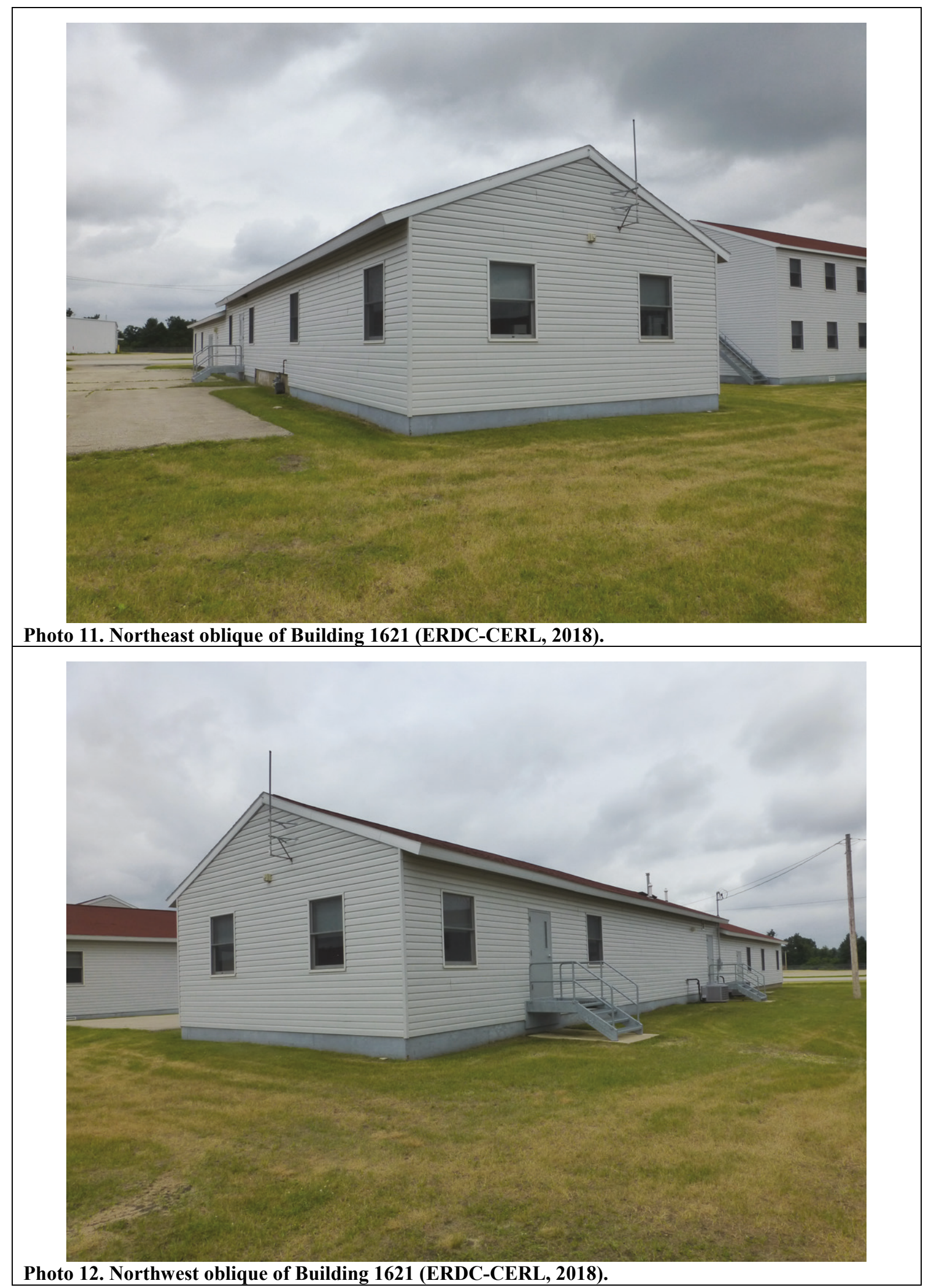




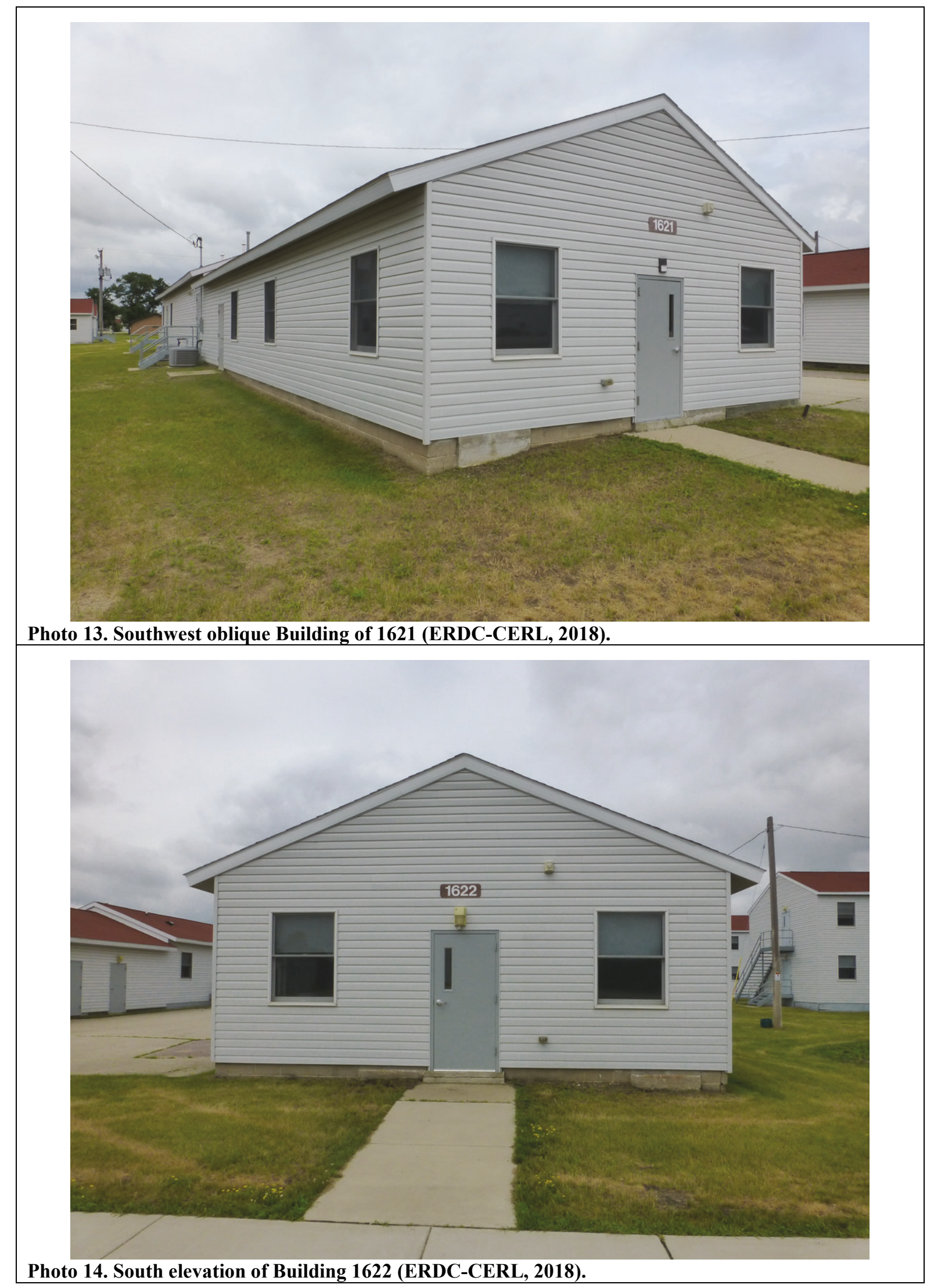




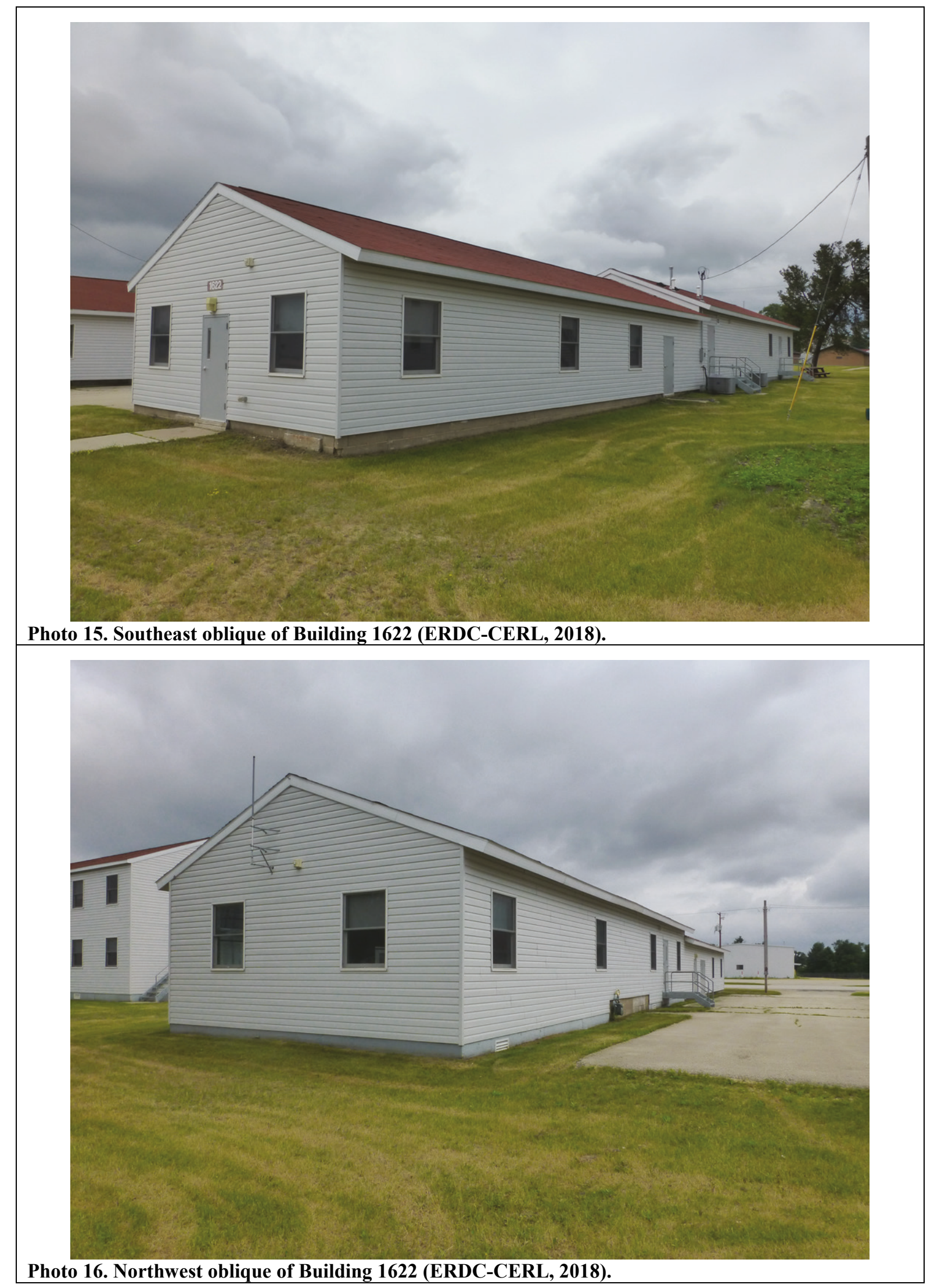




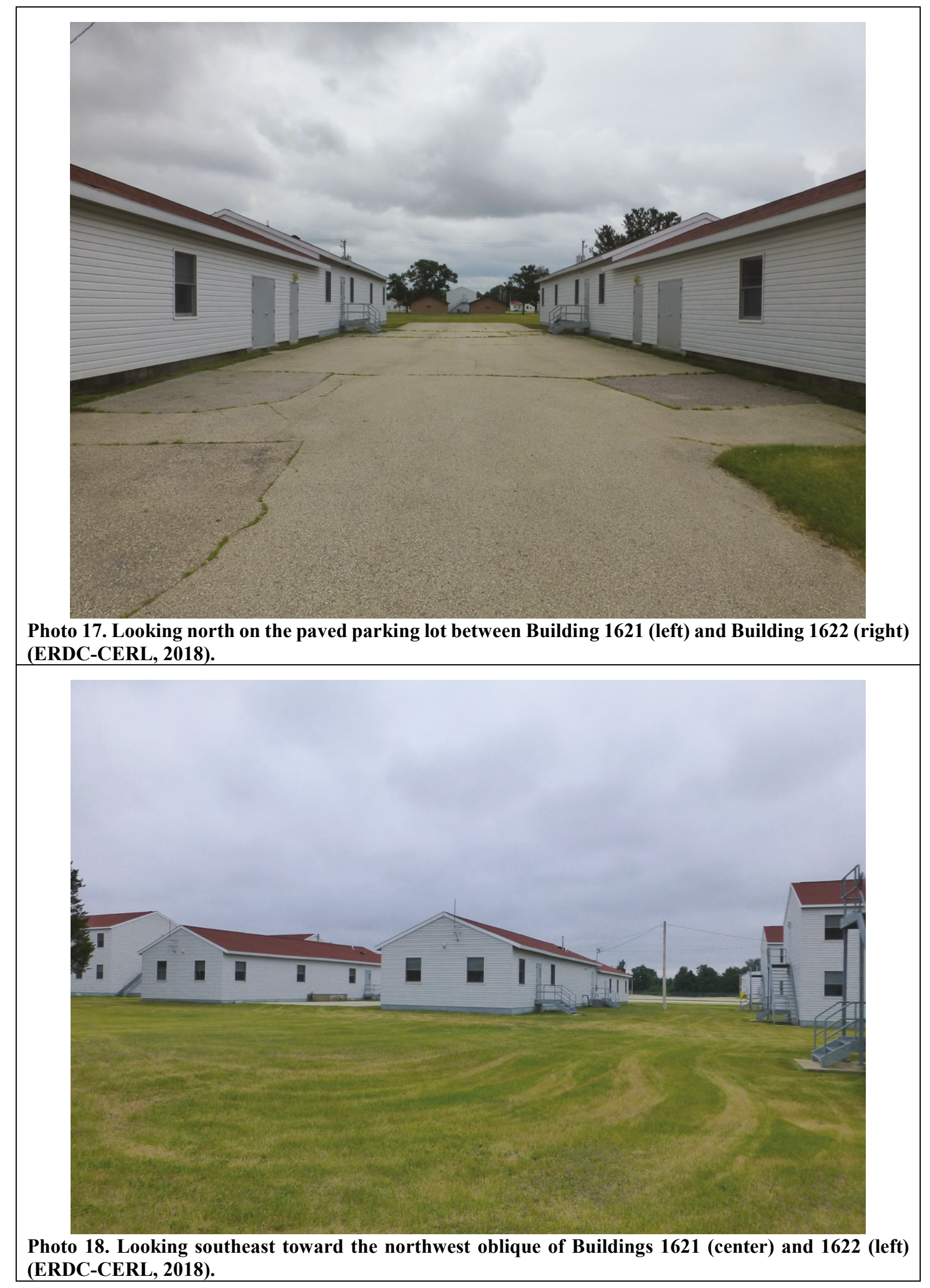




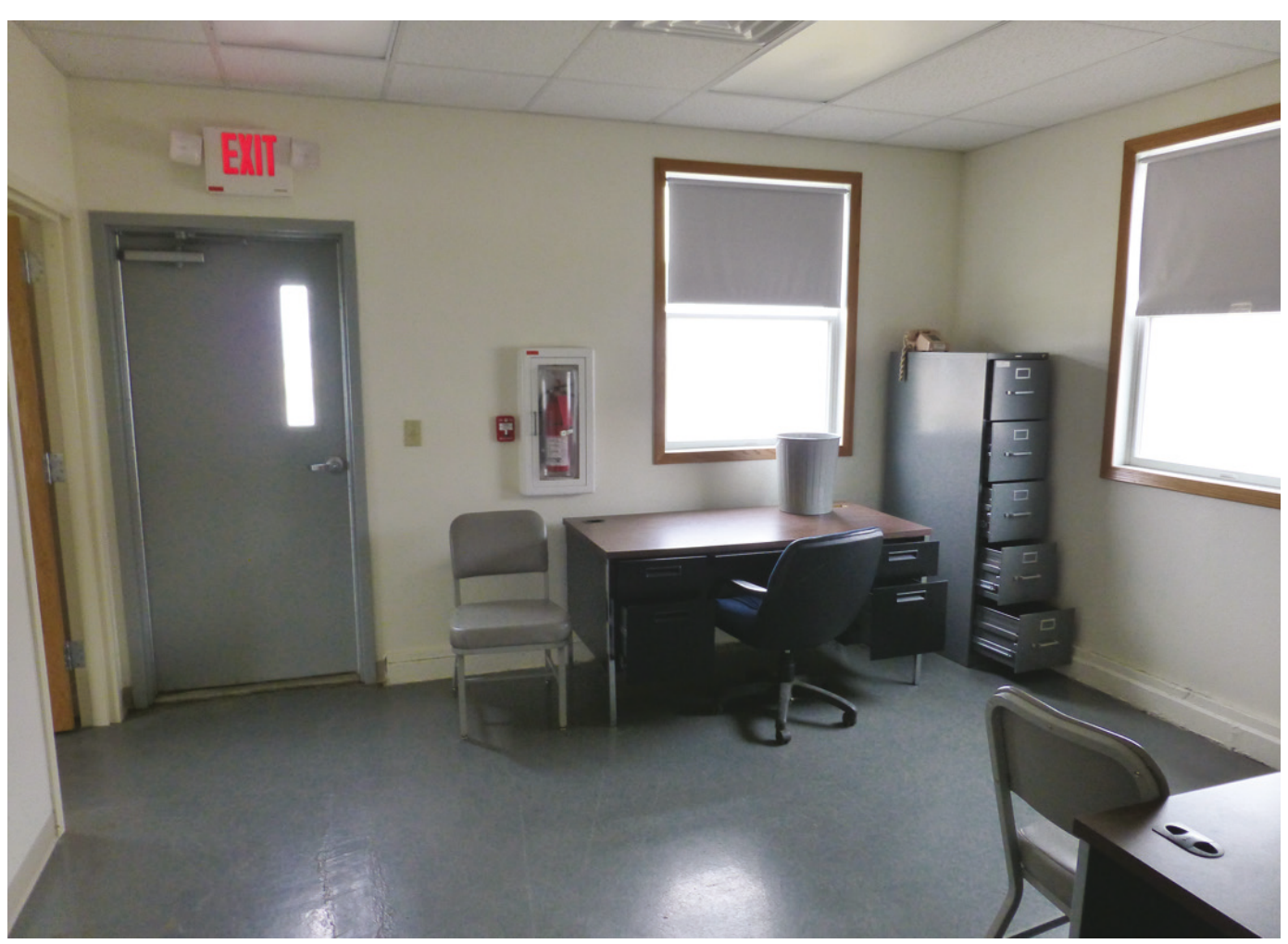

Photo 19. New offices created with the addition of partition walls in the former open area of the storehouse/administration portion (south end) of Building 1621 (ERDC-CERL, 2018).

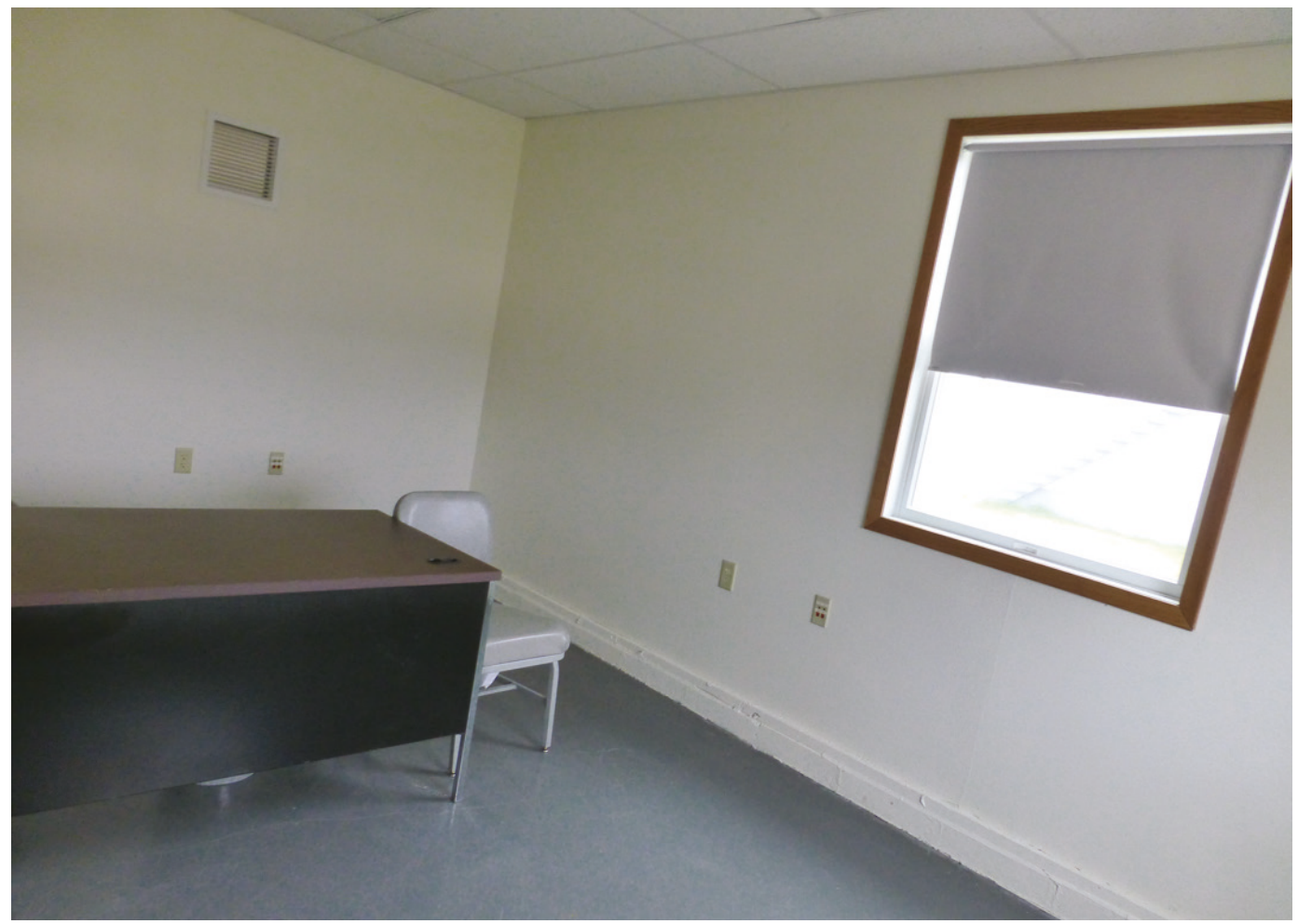

Photo 20. New offices created with the addition of partition walls in the former open area of the storehouse/administration portion (south end) of Building 1621 (ERDC-CERL, 2018). 


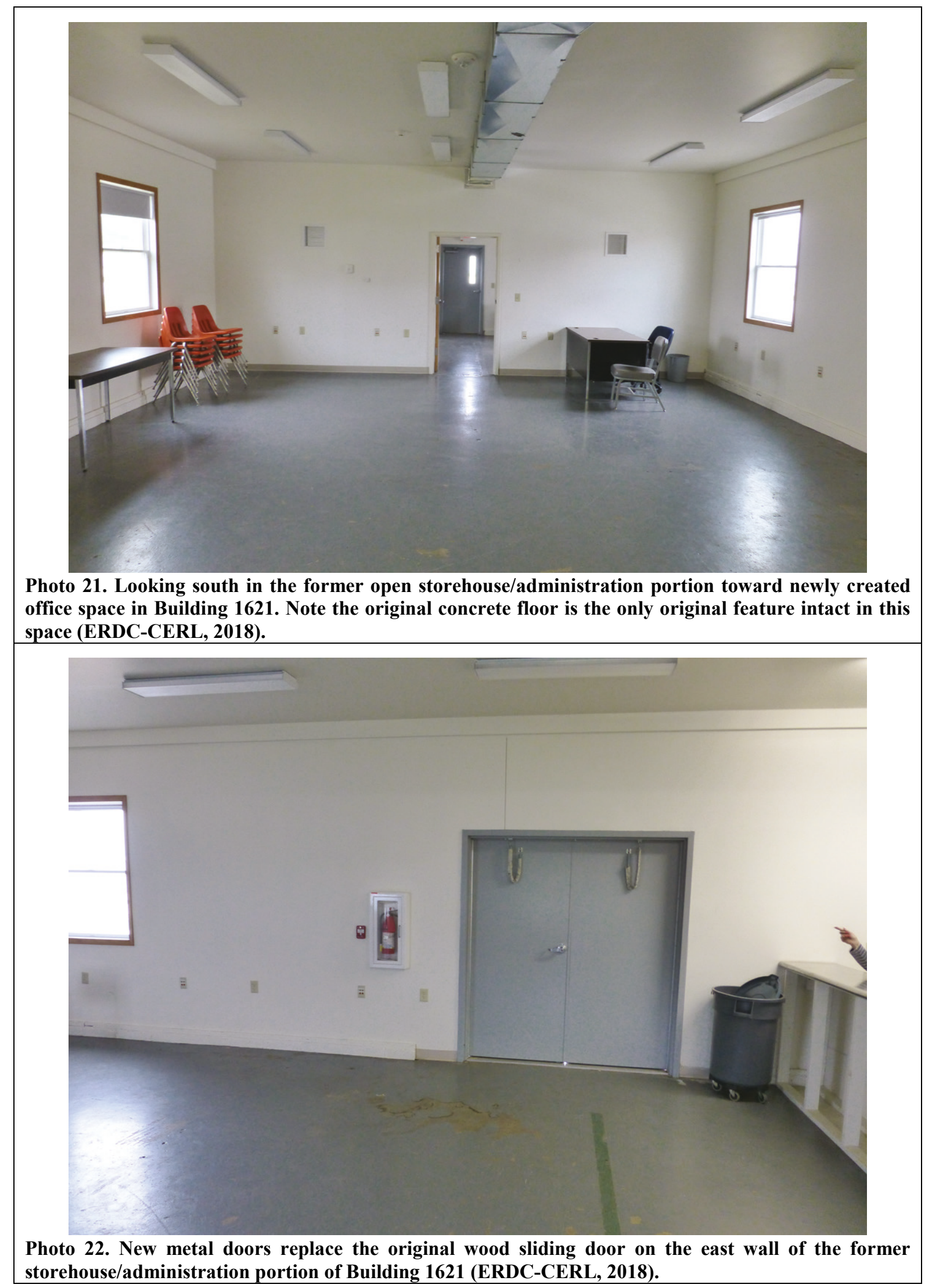




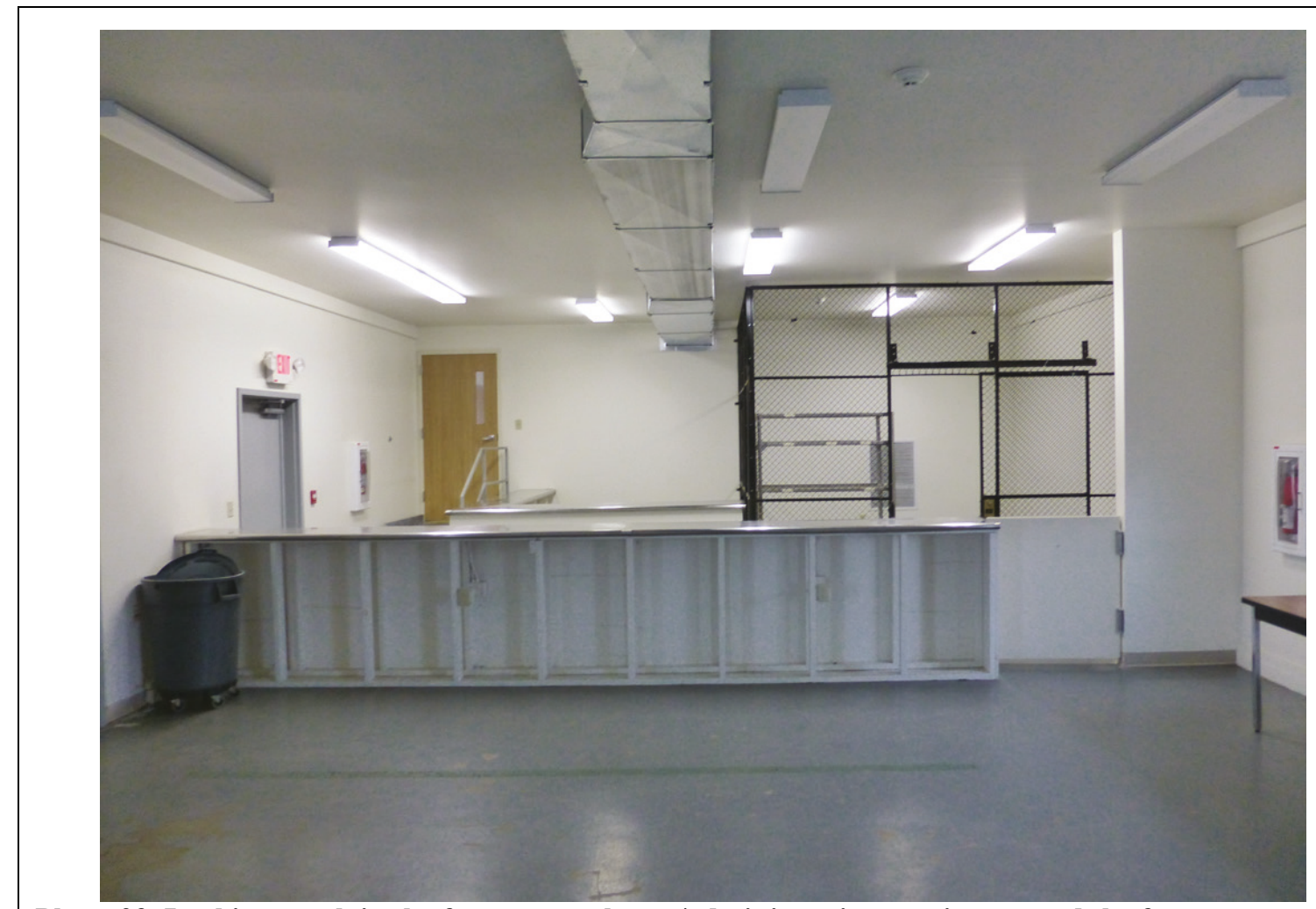

Photo 23. Looking north in the former storehouse/administration portion toward the former recreation portion of Building 1621 (ERDC-CERL, 2018).

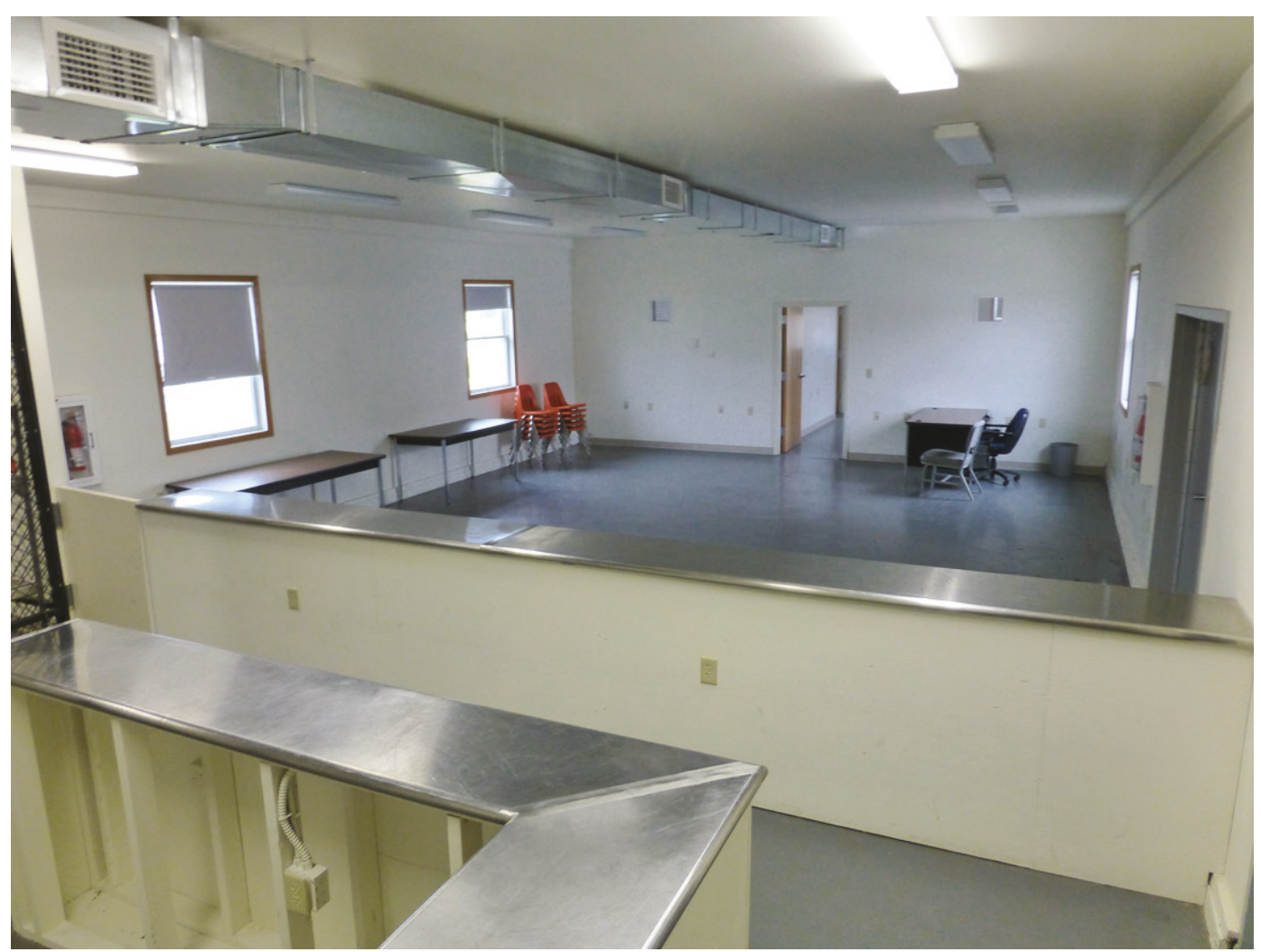

Photo 24. Looking south at the former storehouse/administration portion from the steps leading into the former recreation portion of Building 1621 (ERDC-CERL, 2018). 


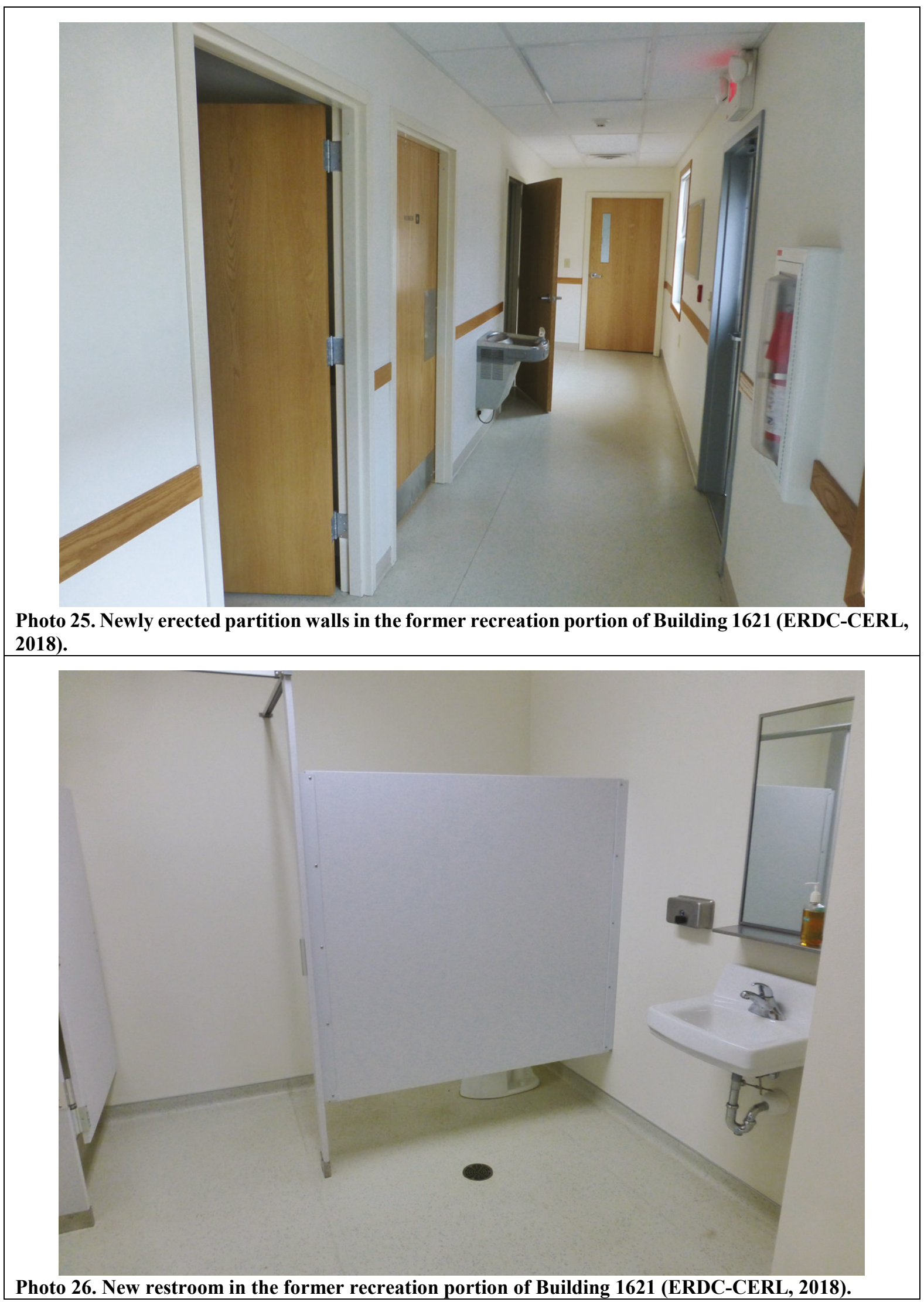




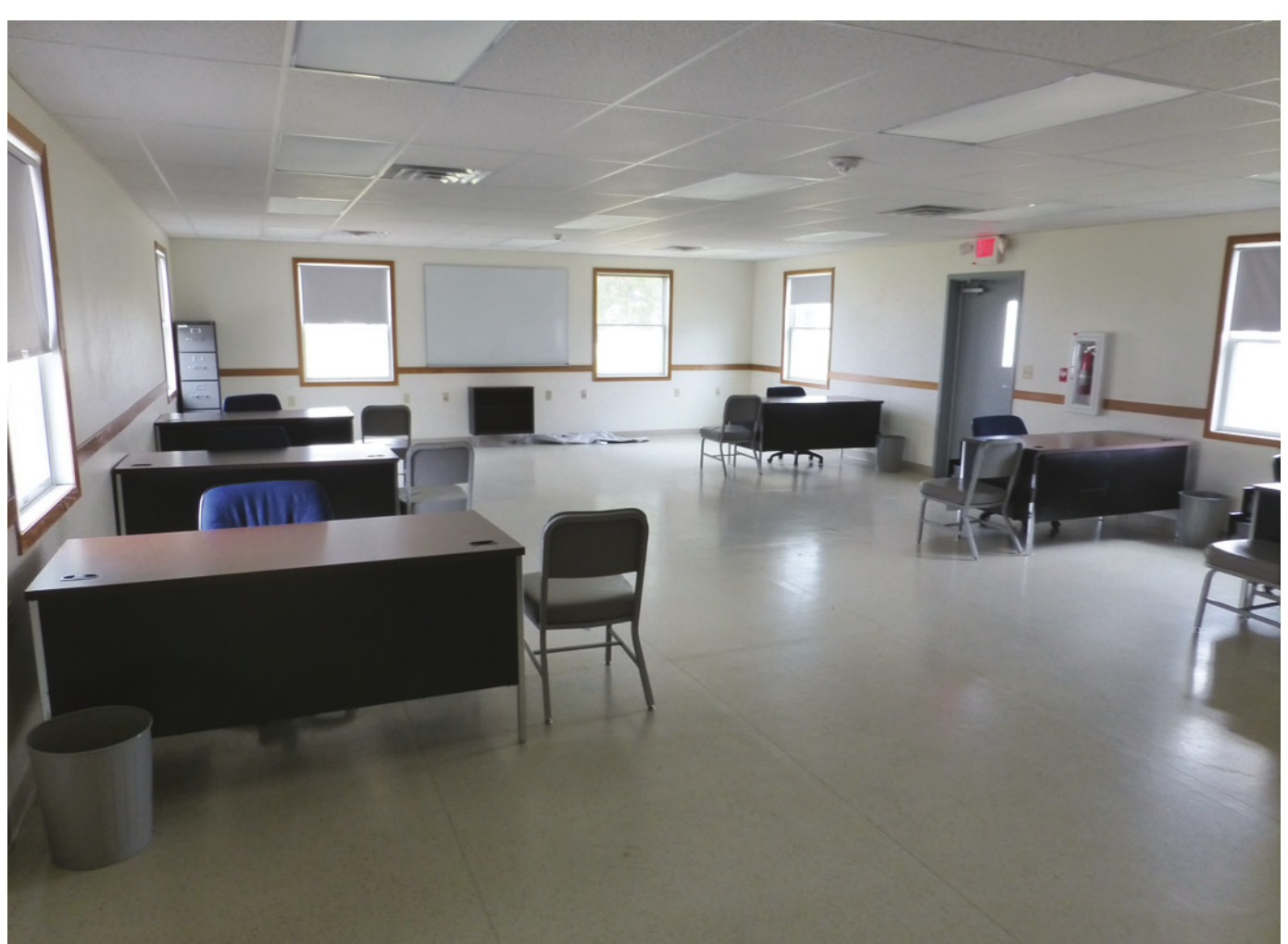

Photo 27. Looking north in the former recreation portion of Building 1621. Note the addition of drywall, drop-ceiling tiles, fluorescent light fixtures, wood trim around the windows, and vinyl tile flooring (ERDC-CERL, 2018).

\section{COORDINATES (center of complex)}

UTM $15 \mathrm{~N}$

$4876190 \mathrm{~N}$

$685274 \mathrm{E}$

\section{USGS QUAD}

Alderwood Lake

\section{CATEGORY}




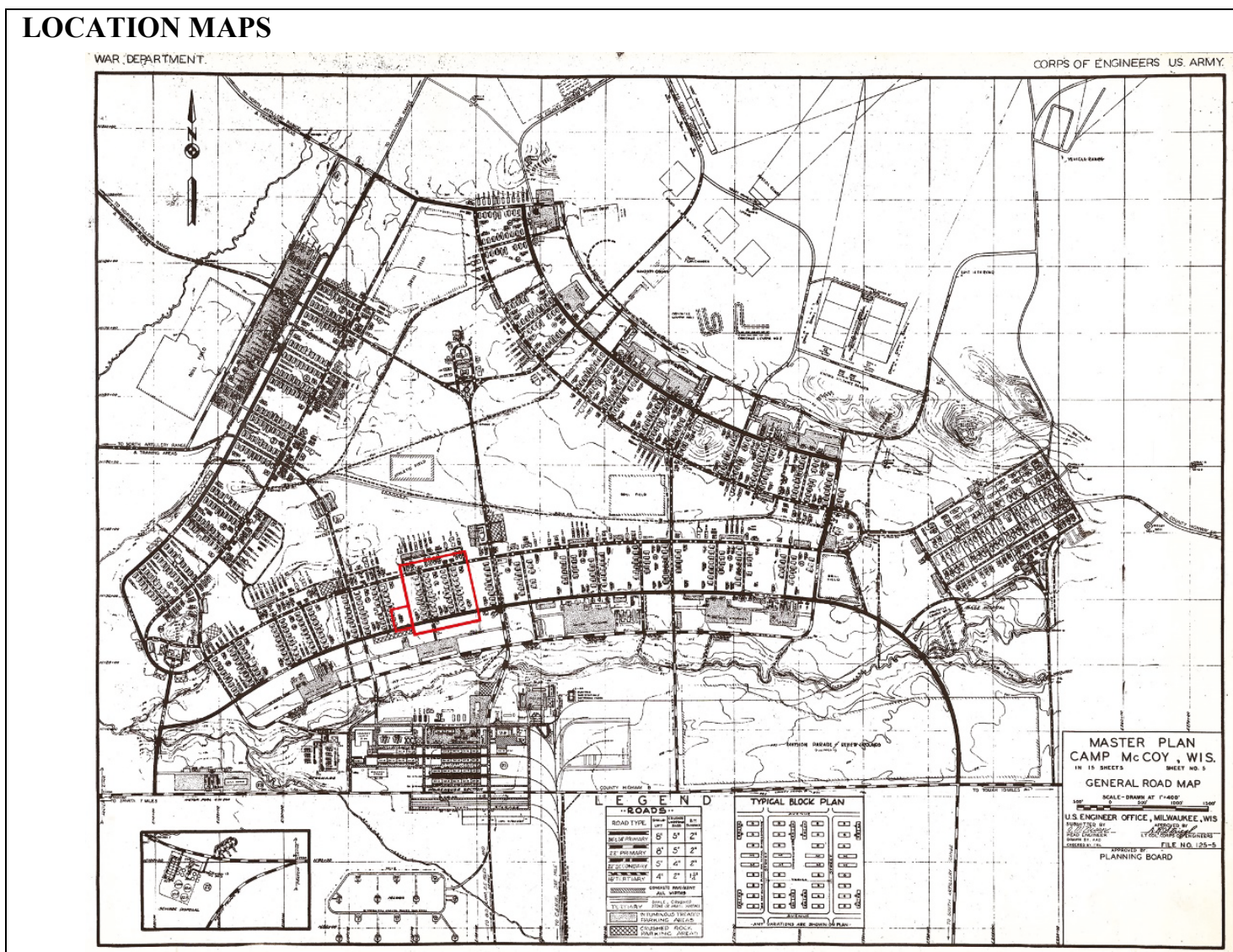

Master plan of Camp McCoy, ca. 1942, with the location of the 1600 block and Building 1743 indicated by the red boxes (Fort McCoy DPW).

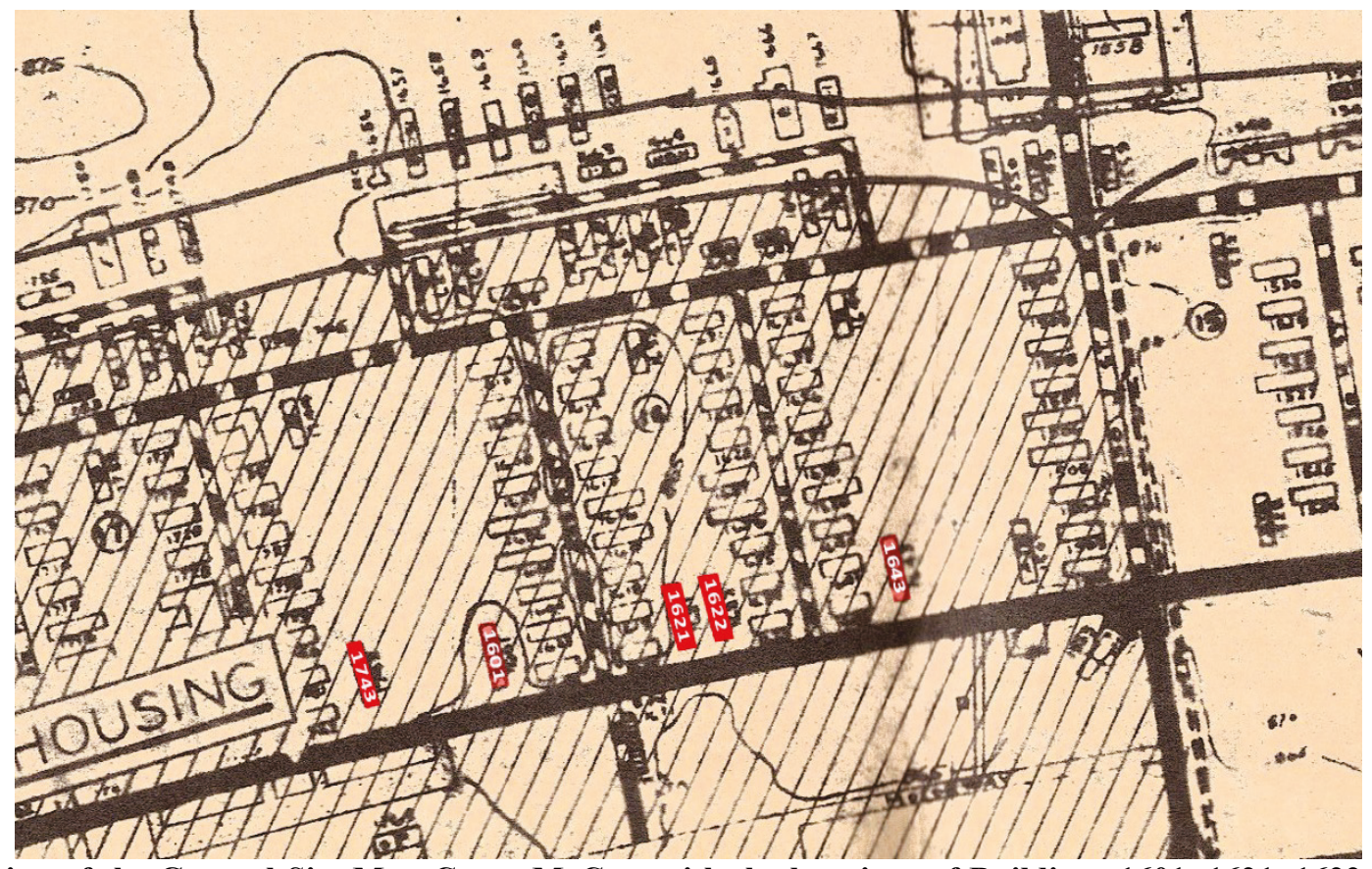

Portion of the General Site Map Camp McCoy, with the locations of Buildings 1601, 1621, 1622, and 1743, Company Storehouse/Administration and Recreation Buildings, color-coded in red, 1947 (Fort McCoy DPW). (Note: The lighter redshaded buildings were evaluated on this inventory form but were not included on the original inventory list given to the research team to be evaluated at this time.) 


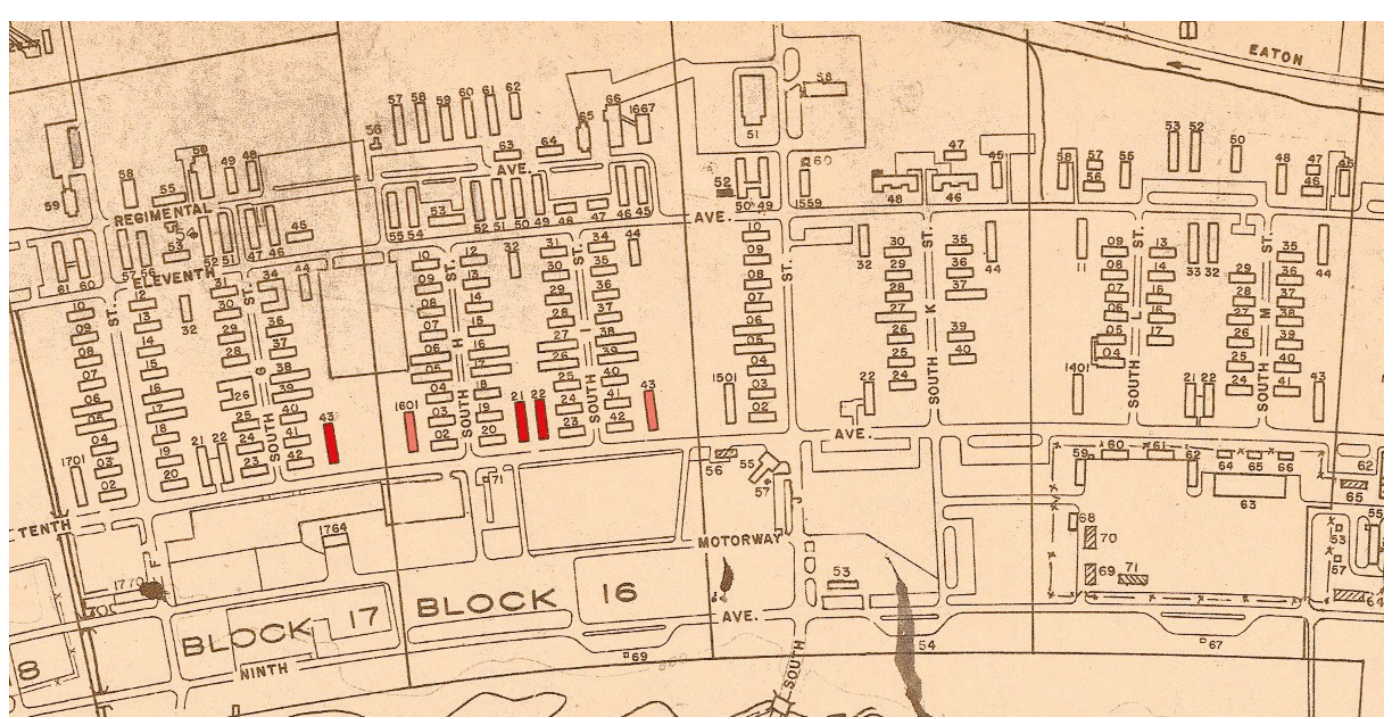

Portion of the General Site Map Camp McCoy with the locations of Buildings 1601, 1621, 1622, and 1743, Company Storehouse/Administration and Recreation Buildings, color-coded in red, 1965 (Fort McCoy DPW). (Note: The light shaded buildings were evaluated on this inventory form but were not included on the original inventory list given to the research team to be evaluated at this time.)

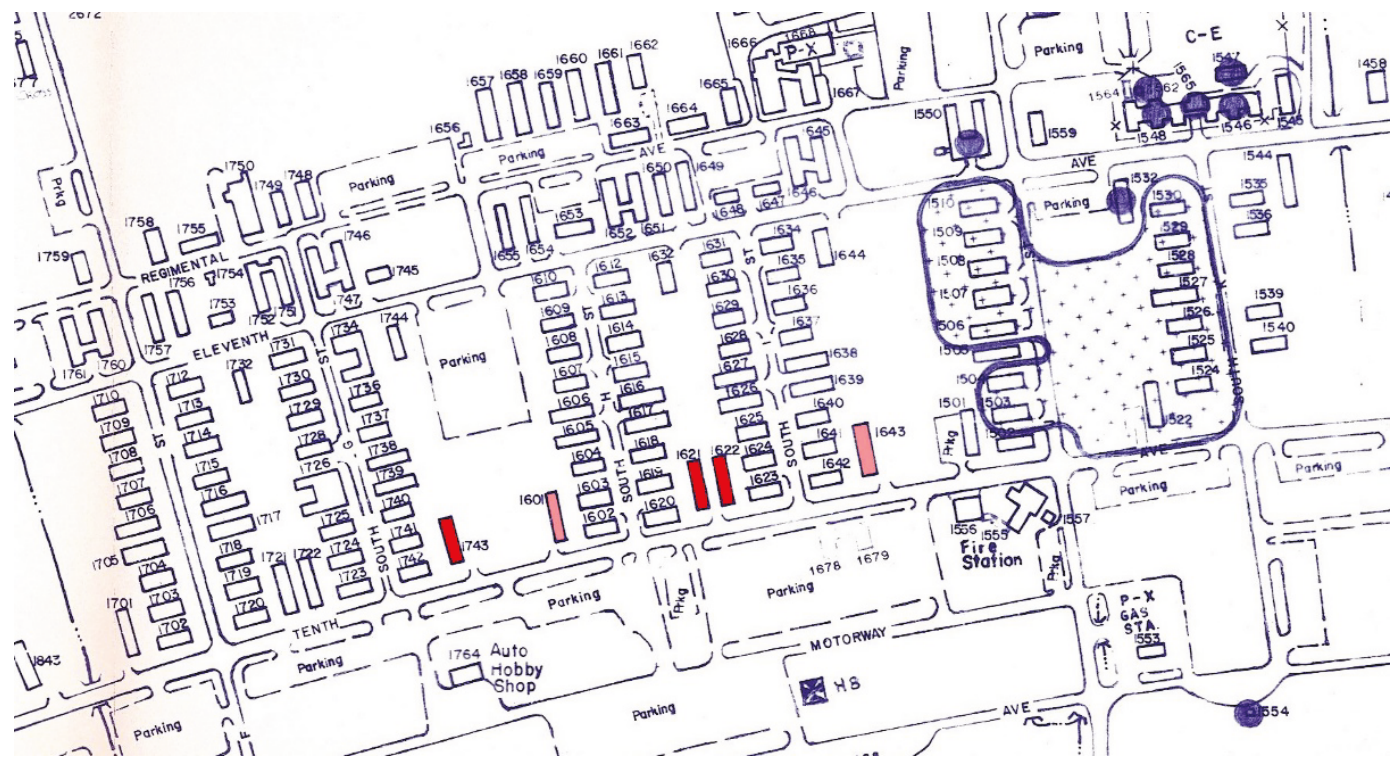

Portion of the General Site Map Fort McCoy with the locations of Buildings 1601, 1621, 1622, and 1743, Company Storehouse/Administration and Recreation Buildings, color-coded in red, 1993 (Fort McCoy DPW). (Note: The light shaded buildings were evaluated on this inventory form but were not included on the original inventory list given to the research team to be evaluated at this time.) 


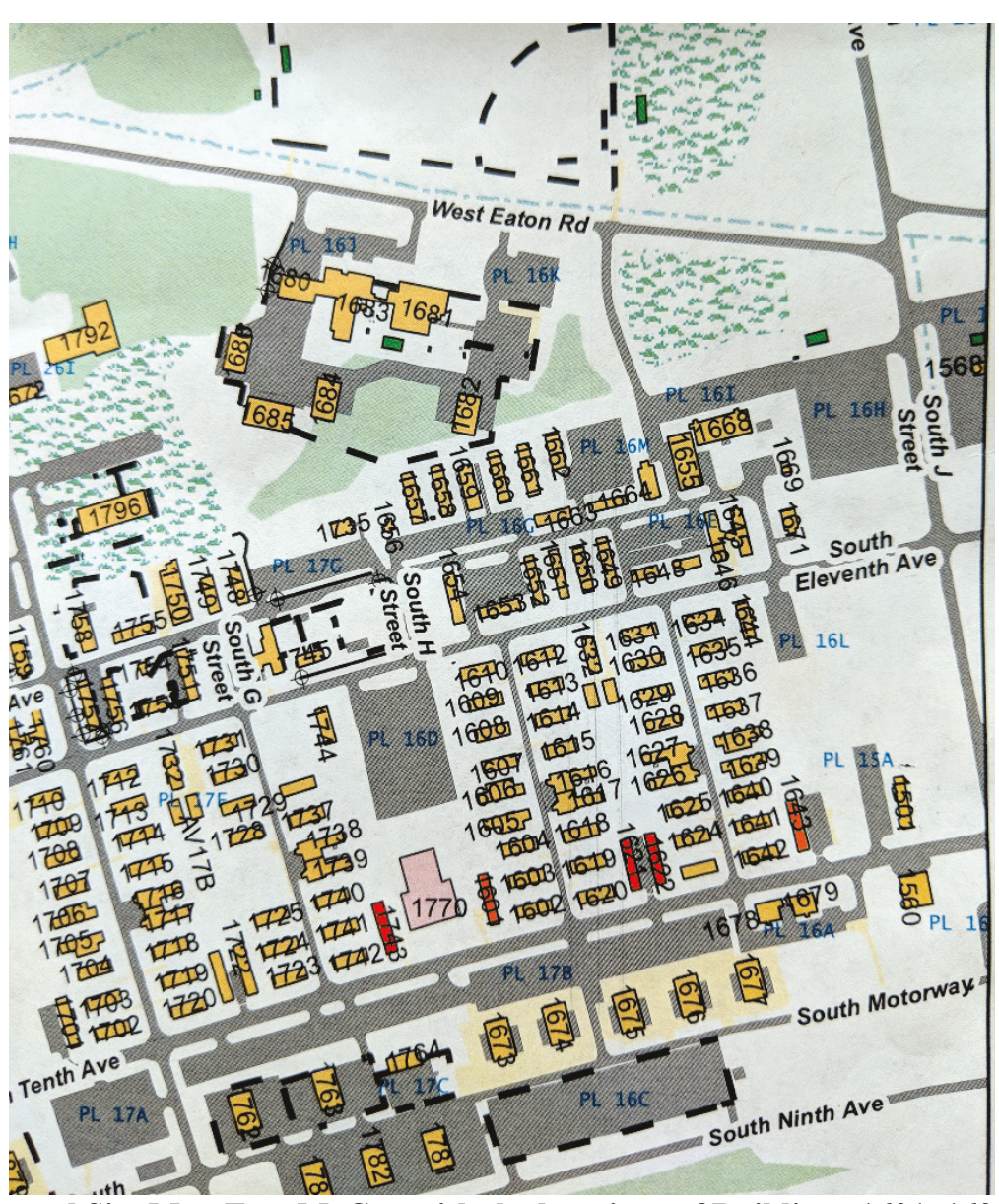

Portion of the General Site Map Fort McCoy with the locations of Buildings 1601, 1621, 1622, and 1743, Company Storehouse/Administration and Recreation Building, color-coded in red, 2014 (Fort McCoy DPW). (Note: The light shaded buildings were evaluated on this inventory form but were not included on the original inventory list given to the research team to be evaluated at this time.) 


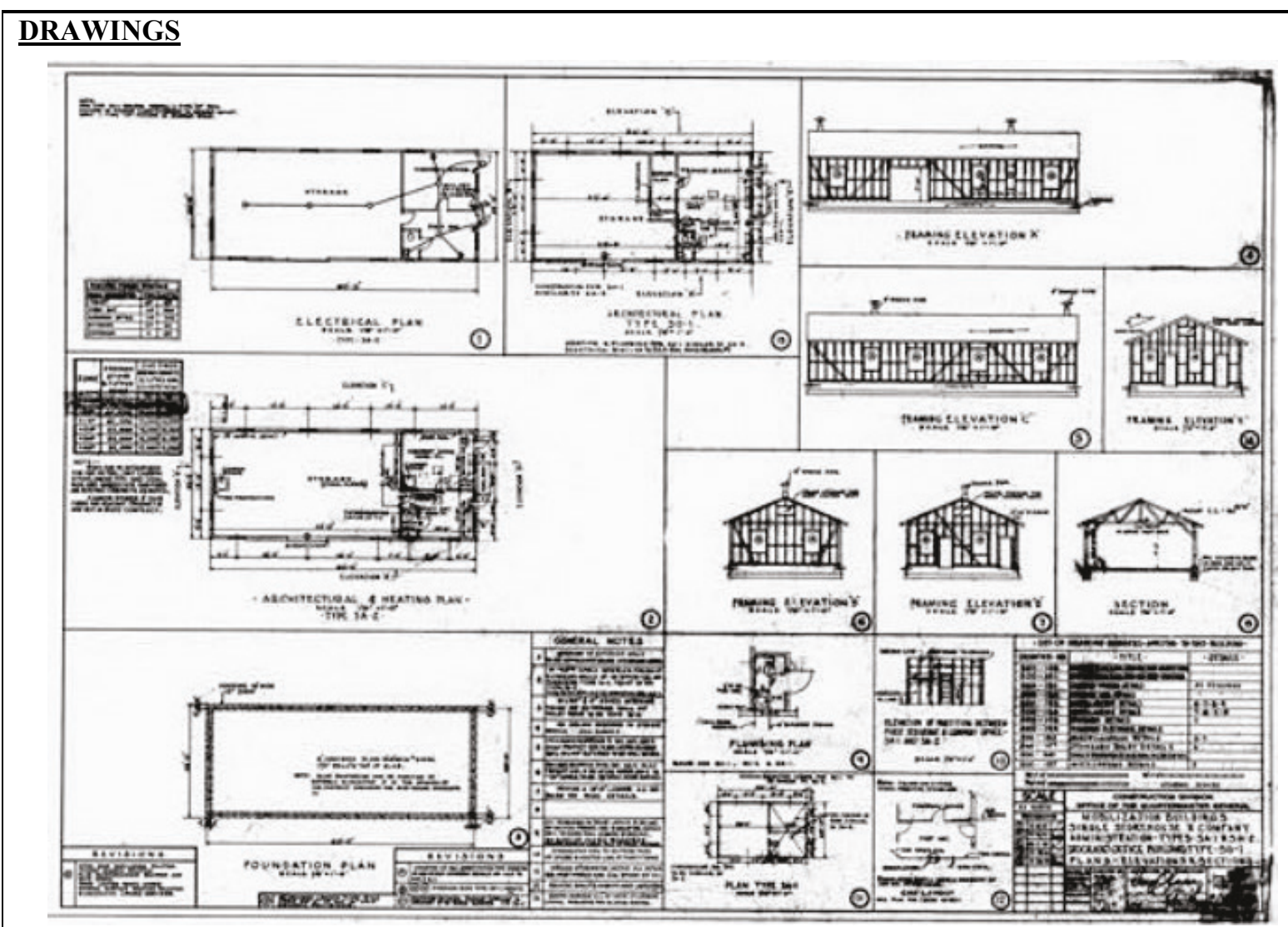

Plan 800-661 (modified at Fort McCoy), Single Storehouse and Company Administration - Types SA-1 and SA-2, Stockade/Office Building Type SO-1. Plans, elevations and sections (Library of Congress, HABS WIS,41-SPAR.V,1-B-13). 


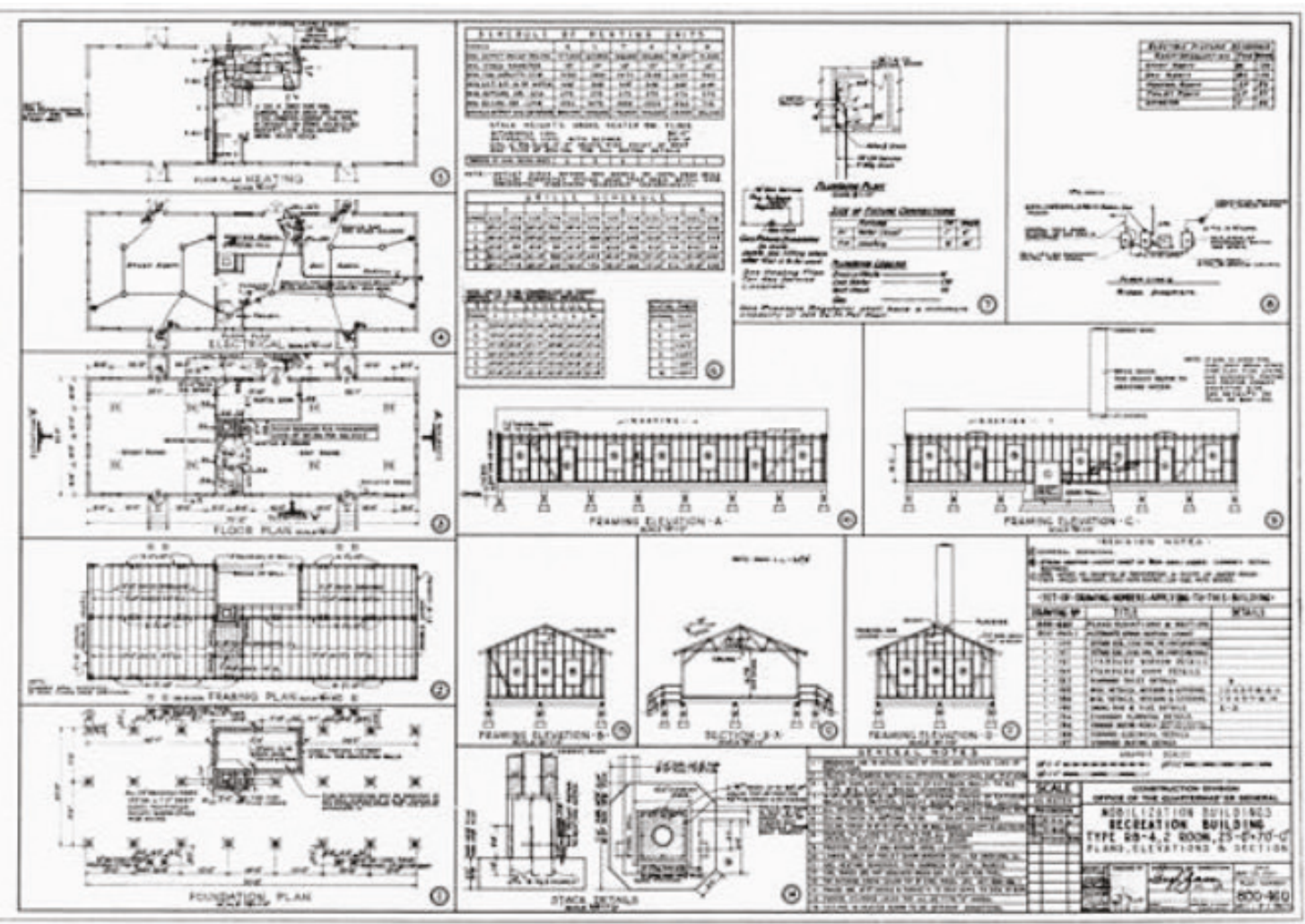

Plan 800-460, Recreation Building Type RB-4 (Library of Congress, HABS WIS,41-SPAR.V,1-B-14).

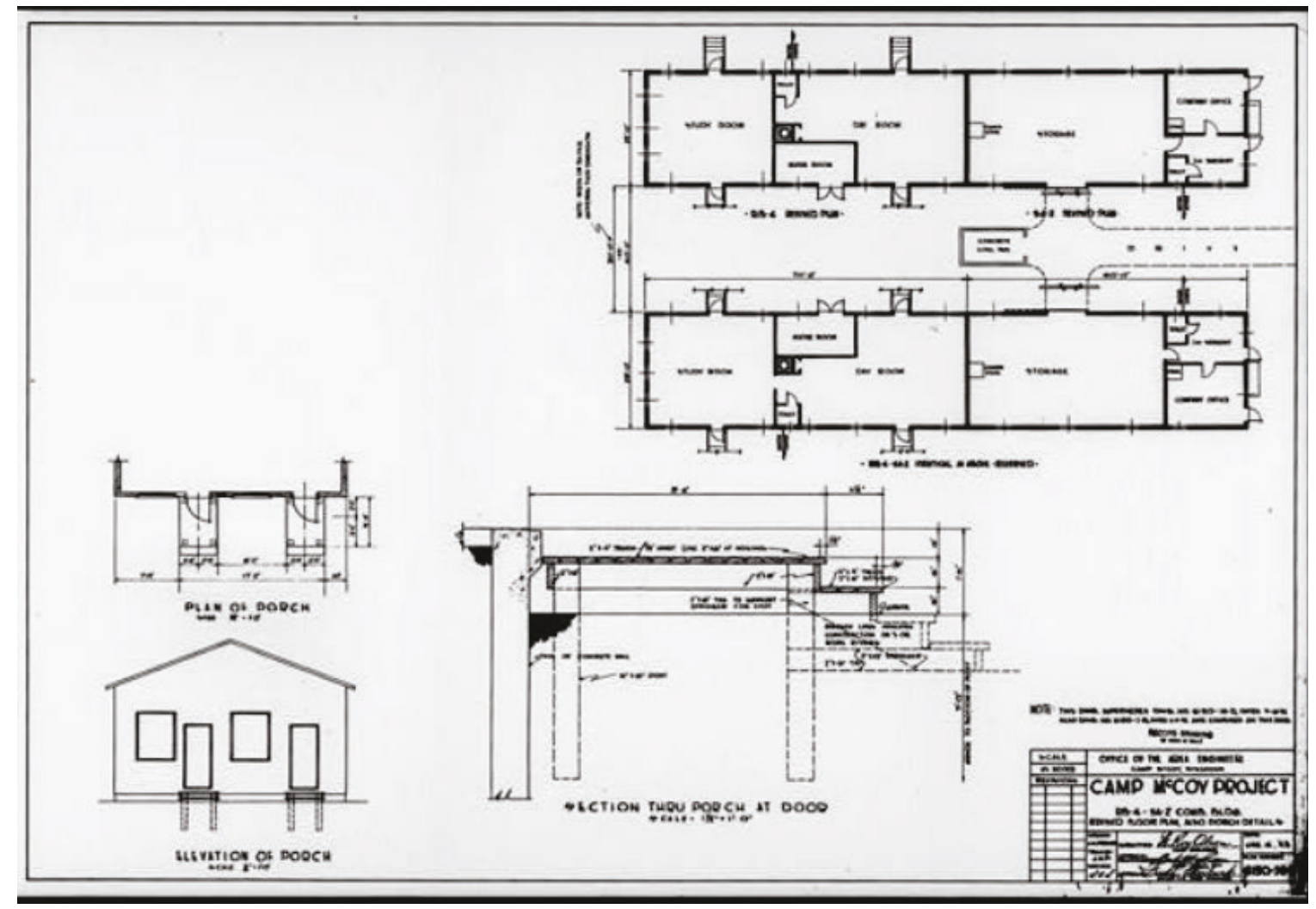

Fort McCoy Drawing 6150-38B. Combined building revised floor plan (Library of Congress, HABS WIS,41-SPAR.V,1-B-12). 
-

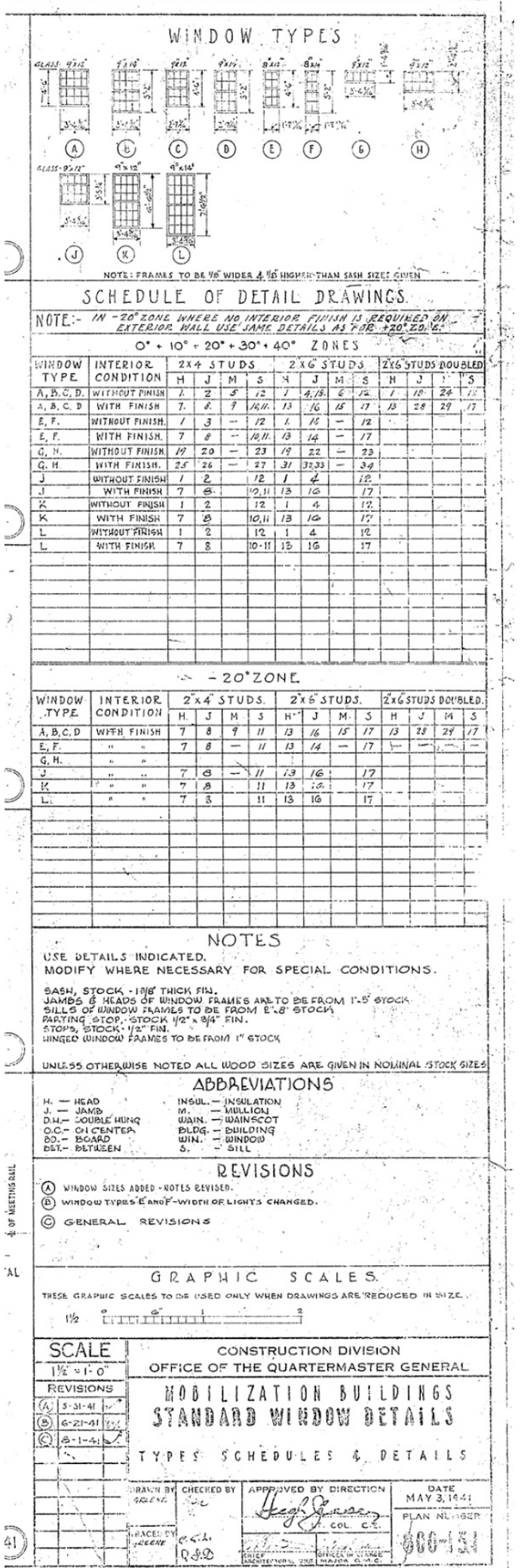

Standard window type details, 1941 (Fort McCoy DPW).

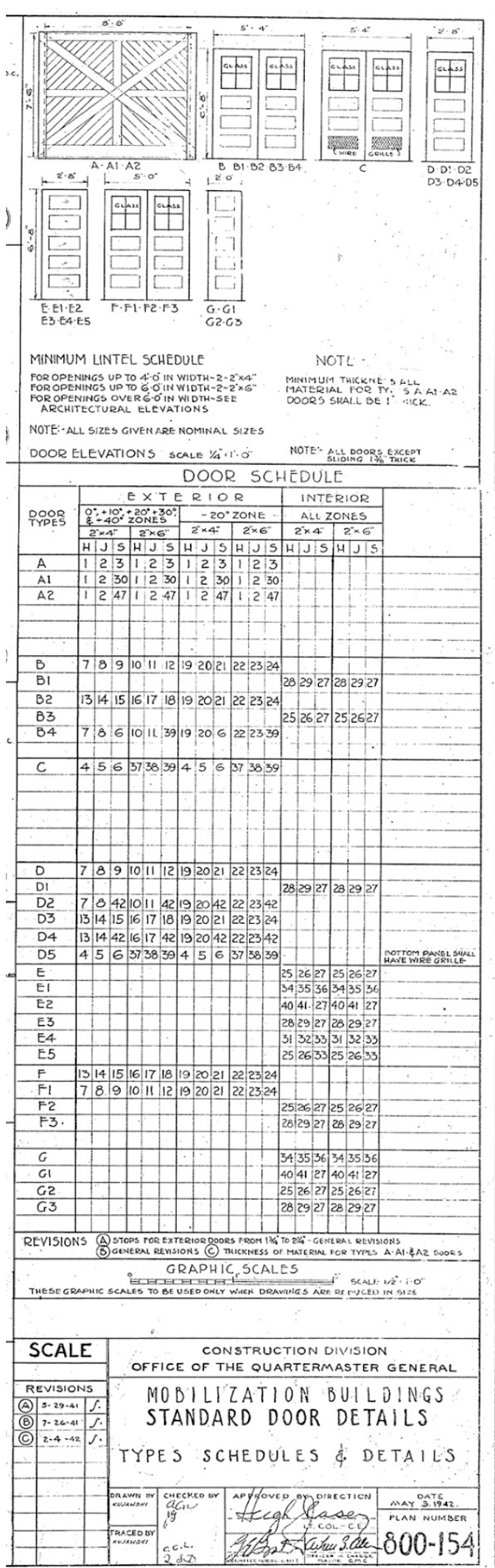

Standard door type details, 1941 (Fort McCoy DPW). 


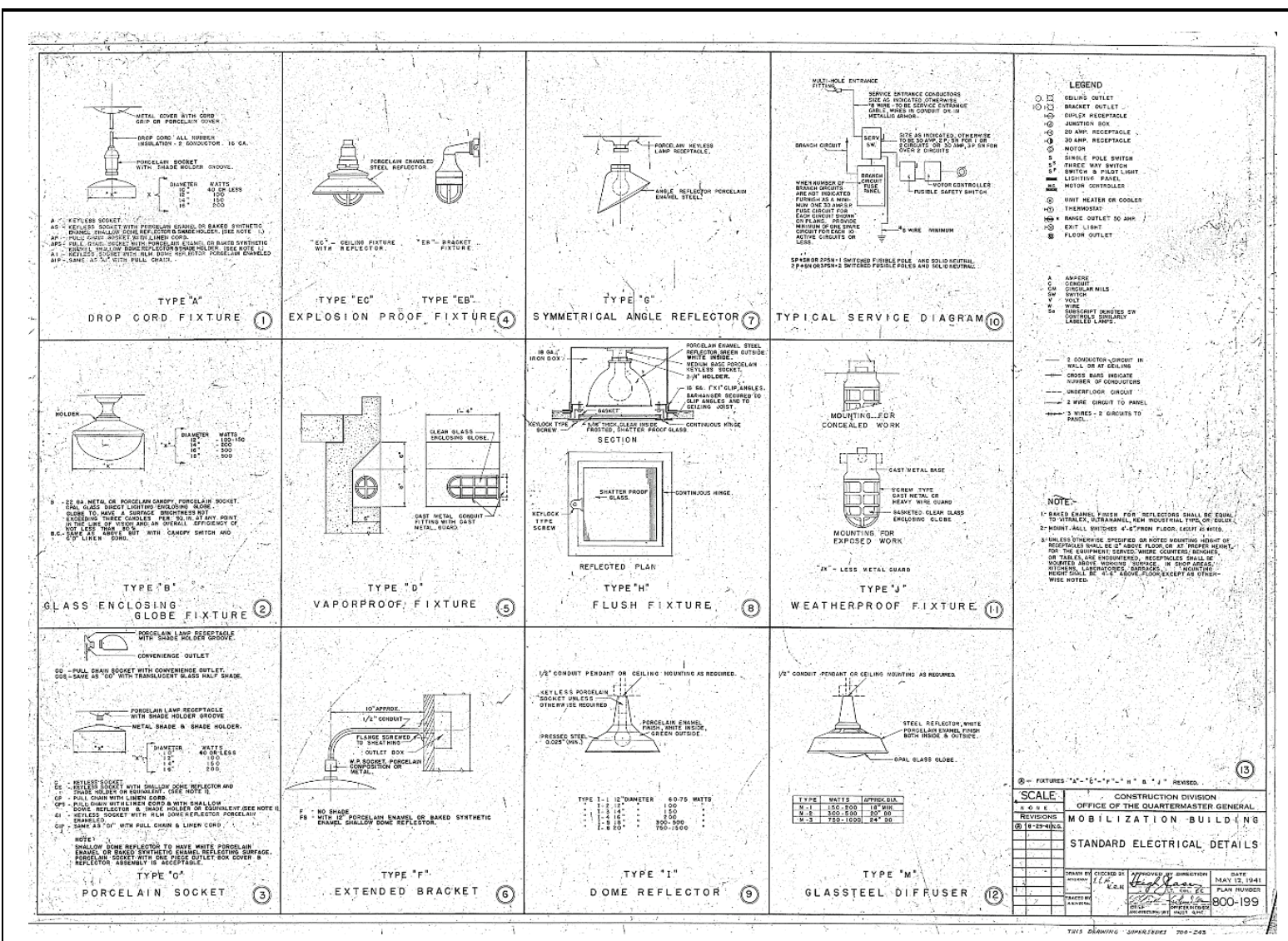

Standard electrical details, 1941 (Fort McCoy DPW).

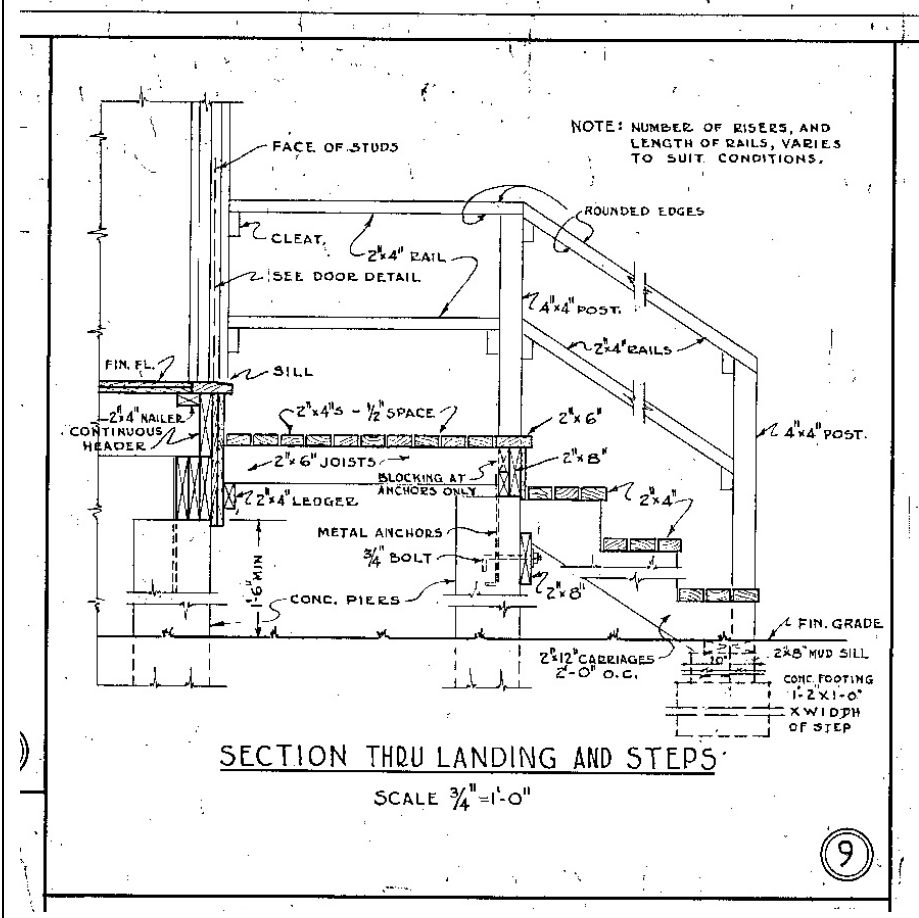

Detail for wood porch stoop and wood handrails used throughout the cantonment on WWII buildings, Drawing 800-176, 1941 (Fort McCoy DPW). 


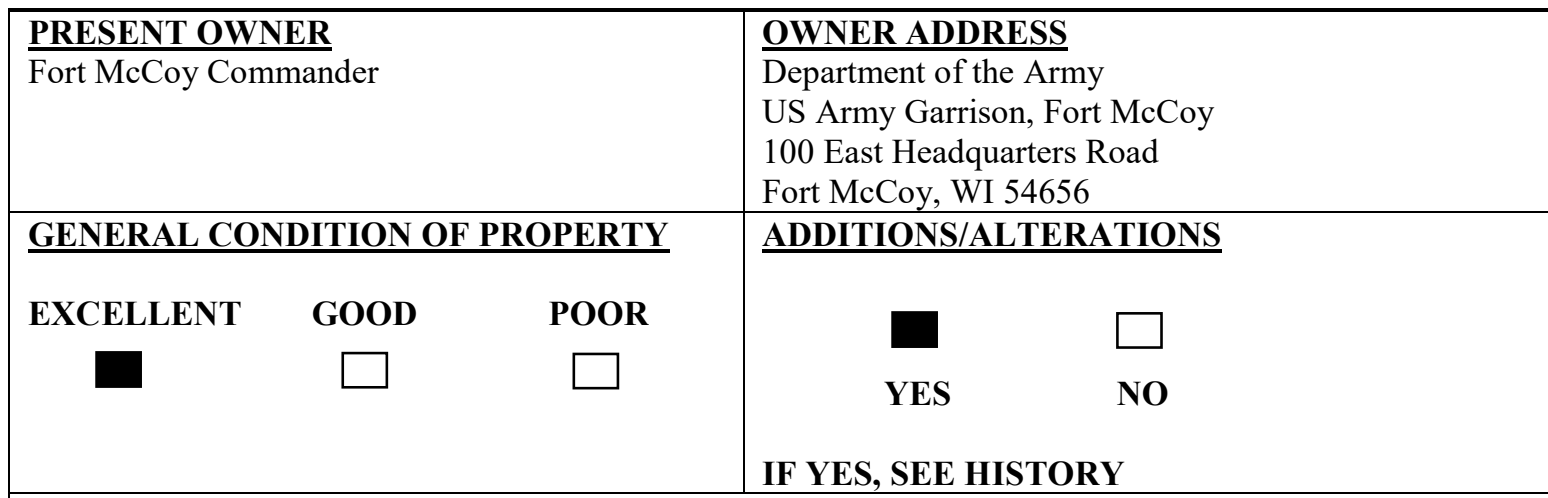

\section{BIBLIOGRAPHIC SOURCES}

HABS No. WI-308-B. "Fort McCoy, Building T-801 (Storehouse, Administration \& Recreation Building), Sparta vicinity, Monroe County, Wisconsin.”(Washington, DC: Historic American Buildings Survey, National Park District, Department of the Interior, 1988). Catalogued by Library of Congress as HABS WIS, 41-SPAR.V, 1-B- : https://cdn.loc.gov/master/pnp/habshaer/wi/wi0200/wi0262/data/wi0262data.pdf.

\section{ARCHIVAL SOURCES}

Real Property Record Cards on file at Fort McCoy, Wisconsin

Drawing documentation on file at Fort McCoy, Wisconsin

NARA College Park, Maryland

\begin{tabular}{|c|c|c|}
\hline \multirow{2}{*}{\multicolumn{2}{|c|}{$\begin{array}{l}\text { PRELIMINARY NATIONAL REGISTER } \\
\text { DETERMINATION OF ELIGIBILITY }\end{array}$}} & FORM PREPARED BY: \\
\hline & & Sunny Adams \\
\hline ELIGIBLE/ & $\begin{array}{l}\text { NOT ELIGIBLE/ } \\
\text { NON_CONTRIBUTING }\end{array}$ & $\begin{array}{l}\text { Engineer Research and Development Center } \\
\text { Construction Engineering Research Laboratory }\end{array}$ \\
\hline$\square$ & & $\begin{array}{l}\text { Champaign, IL } 61822 \\
\text { Cout Newmark Drive }\end{array}$ \\
\hline
\end{tabular}

DATE: September 2018

\section{DESCRIPTION}

The 1600 Block is located on the south side of the triangular cantonment layout. South Eleventh Street is to the north, South J Street is to the east, South Tenth Street is to the south, and South G Street is to the west. South H and South I Streets cut through the block. The 1600 battalion block consists of 29 barracks, four company storehouse/administration/recreation buildings (currently General Instruction Buildings 1601, 1621, 1622 , and 1643), and eight mess halls. Building 1743 is located directly to the west of the 1600 Block. The four company storehouse/administration/recreation buildings face south toward South Tenth Street.

The storehouse/administration and recreation buildings are one-story structures. Overall, the buildings are rectangular in shape and are 25 feet wide and 130 feet long with an approximate area of 3,250 square feet. The storehouse and administration portion of the building is one-story high, and the former recreation section is a story-and-a-half. Each section has a shallow gable roof clad with asphalt shingles. The foundation for the administration section (south end) is concrete block, while the foundation for the former recreation section (north end) is concrete piers. Replacement wood foundation skirting encompasses this foundation area. The fascia and soffits are covered with metal sheathing material. The exterior walls are clad with newer vinyl siding. The windows are replacement vinyl one-over-one, and the entry doors are all replacement metal. All of the exterior light fixtures are replacement.

Buildings 1601,1622, and 1643: The south elevation consists of a centrally located door flanked on either side by a replacement window (see Photos 2 and 14). The left side of the east elevation is the lower portion where the administration section is located (see Photos 3 and 15). There are replacement windows and a 
single-entry door located on this part of the elevation. The right side is slightly taller in height and is where the former recreation section is located (see Photo 4). There are two replacement windows and two elevated replacement doors located on this part of the elevation. Newer metal steps provide access to the doors. The north elevation consists of two replacement windows (see Photos 4, 5, and 16). The left side of the west elevation is slightly taller in roof height and is where the former recreation section is located (see Photos 5 and 16). There are four replacement windows and one elevated replacement door. Metal steps provide access to this entry. A portion of the concrete block foundation wall for the former heater room is visible on this elevation (see Photo 6). The right side of the elevation is where the administration section is located. There are two replacement windows, a single-entry replacement door, and a set of replacement doors (see Photo 7).

Building 1621 and 1743: The south elevation consists of a centrally located door flanked on either side by a replacement window (see Photo 8). The left side of the east elevation is where the administration section is located, with the concrete block foundation (see Photo 9). This section's elevation has two replacement windows, a single-entry replacement door, and a set of replacement doors (see Photo 10). The right side of the elevation is slightly taller in roof height and is where the former recreation section is located (see Photo 11). It consists of four replacement windows and an elevated replacement door. A set of metal steps provides access to this entry. The north elevation consists of two replacement windows (see Photos 11 and 12). The left side is slightly taller in height and is where the former recreation section is located (see Photo 12). There are two replacement windows and two elevated replacement doors located on this part of the elevation. Newer metal steps provide access to the doors. The left side of the east elevation is the lower portion where the administration section is located (see Photo 13). There are three replacement windows and a single-entry door located on the part of the elevation.

The interiors of all four buildings have been completely modified with newer finishes. No original features are left intact expect for the concrete floor of the former storehouse/administration section. Newer drywall, drop-ceilings, light fixtures, interior doors, interior window trim, and partition walls have been added throughout. The original wood floor in the former recreation section has been covered with vinyl tiles.

\section{HISTORY (excerpt taken from the HABS Data Sheet)}

Typical blocks within the general layout were based both on military organizational requirements and city planning principles. Each block was to be occupied by a battalion of troops. Two blocks comprised a regiment. Within a block were size to seven companies, depending on the type of battalion involved. Along each street in a block were four mess halls at center, and ten or more barracks, with a company usually occupying three barracks and eating in one of the mess halls. To the rear of the barracks, at either end of each street were company administration buildings, one for each company.

The construction of Buildings 1601, 1621, 1622, and 1643 were based off two separate standard War Department 800 Series drawings for a company recreation building (Series 800-460 - Recreation Building type RB-4) and a company storehouse and administration building (Series 800-661 - Single Storehouse and Company Administration-Types SA-1 \&SA-2, Stockade/Office Building Type SO-1) dated May 23 and June 3, 1941, respectively. At Camp McCoy the two plans were combined in the early spring of 1942 with the construction of Buildings 1601, 1621, 1622, and 1643.

These four company storehouse, administration, and recreation buildings were approximately four of 124 of that type erected at Camp McCoy. These buildings each served as a headquarters for a company that occupied adjacent barracks.

\section{Exterior:}

Walls: The exterior wall consists of wooden sheathing composed of 7-1/8" tongue and groove boards, a black construction paper which acts as a vapor barrier, and siding composed of cement asbestos pieces measuring 11 " x 24", the standard size used throughout the cantonment. The one-story buildings erected from the 800 Series standard plans are of balloon construction. 
Foundation: The foundation of the company storehouse and administration section was concrete block, along with the foundation and lower wall of the heater room. The recreation portion of the buildings had three longitudinal rows of square concrete piers. A wooden foundation skirting encompassed this end of the buildings.

Roof: The roofs of both sections were low-pitched gables clad red asphalt shingles. The overhanging eaves had wood fascia and soffit.

Exterior Doors: The heavy wooden door into the storehouse slides horizontally along a cast iron track above. The other eight exterior doors are of standard design and each contained four lights in its upper half and three horizontal recessed panels in its lower section.

Windows: There were three types of standard 800 Series window designs used in the combined company storehouse and recreation buildings. Standard Type A consisted of eight-over-eight found on all four elevations, Standard Type C composed of a six-over-six lights and was used one place to provide light into the heater room, and the third was Type E, which consisted of four-over-four lights and appears outside the two water closets. All the windows in the building were wood double-hung sash. The architraves of the opening was of the same simple board design found in the other mobilization building types. The surrounds and sash were both painted a yellow color. Wire insect screen hung on the outside of all the windows except the heater room opening.

Chimney: Rising from near the center of the recreation section of the buildings, from within a concrete block cubicle adjacent to the heater room, a brick chimney ascends to a height of 30 '-0" above grade, approximately 13 feet of which extends above the roof. This feature has since been removed at an unknown date.

\section{Interior:}

Floor Plan: The combination of the storehouse and administration design with the recreation building plan at Camp Coy produced a single headquarters for each company. At the south ends of the buildings was the company office and the office of the first sergeant. Next was a storeroom for company supplies. At the rear (north) end of the combined building was the recreation section, consisting of a day room and study room. The floor plan was a split-level. A short flight of stairs at the end of the storehouse led up into the day room of the recreation section.

Flooring: The storehouse and administration section had a concrete floor, while a wooden floor was in the recreation section.

Walls and ceiling finishes: The storehouse section, the exterior walls and roof structure were left exposed and painted a cream color. In the administration section (two company offices), "insulation board," covered the lower portion of the walls, while wooden batten covers the upper portion of the walls. The roof structure in the company office section was covered with ceiling panels composed of insulation boards secured by wooden battens. In the water closet adjacent to the first sergeant's room, all four walls were of standardsized, tongue and groove boards laid horizontally on the bottom portion of the walls. Above the boards were insulation panels. The same sized tongue and groove boards were used for sheathing the exterior walls of the storehouse. The two main rooms of the recreation section had insulation boards, painted brown, on the lower part of the walls and cream-painted fiber board on the upper portion of these walls. The ceiling panels of the rooms were cream-painted insulation boards nailed in place by battens.

Interior doors: The interior doors were standard-issue solid wood doors constructed in the typical interior pattern: five, horizontal, recessed panels.

Lighting: The original were metal bases with glass globes.

The category code for all four buildings changed in 1995 to a classroom. The buildings are still classroom buildings and currently are in use.

In 2003, all of the original doors and windows were removed. The window pattern was modified when vinyl siding was added to the exterior walls. At an unknown date(s), the brick chimney stack was dismantled, the wooden skirting was replaced with newer material, the wood porch stoops and wood handrails were dismantled, the exposed wood truss system located in the former storehouse/administration portion was covered over with the addition of a drop-ceiling, vinyl tiles were added over the original wood floor of the 
recreation portions. Drywall was added throughout the building replacing the original insulation boards and batten details, all of the original light fixtures have been replaced, all of the wood panel interior doors have been replaced, and new partition walls have been erected throughout the buildings.

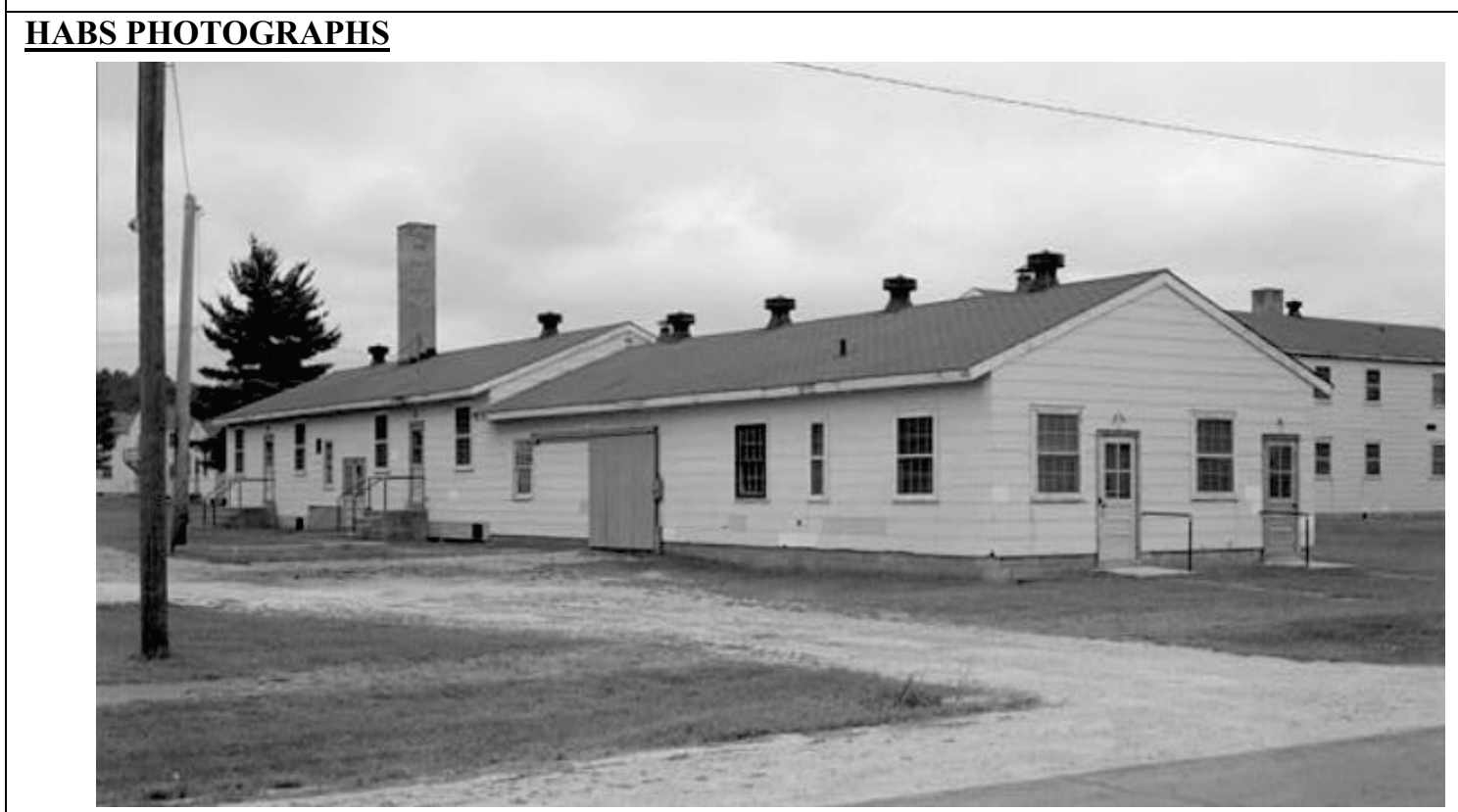

Southwest oblique of Building 801, Company Storehouse/Administration and Recreation Building, September 1988 (Library of Congress, HABS WIS, 41-SPAR.V, 1-B--2).

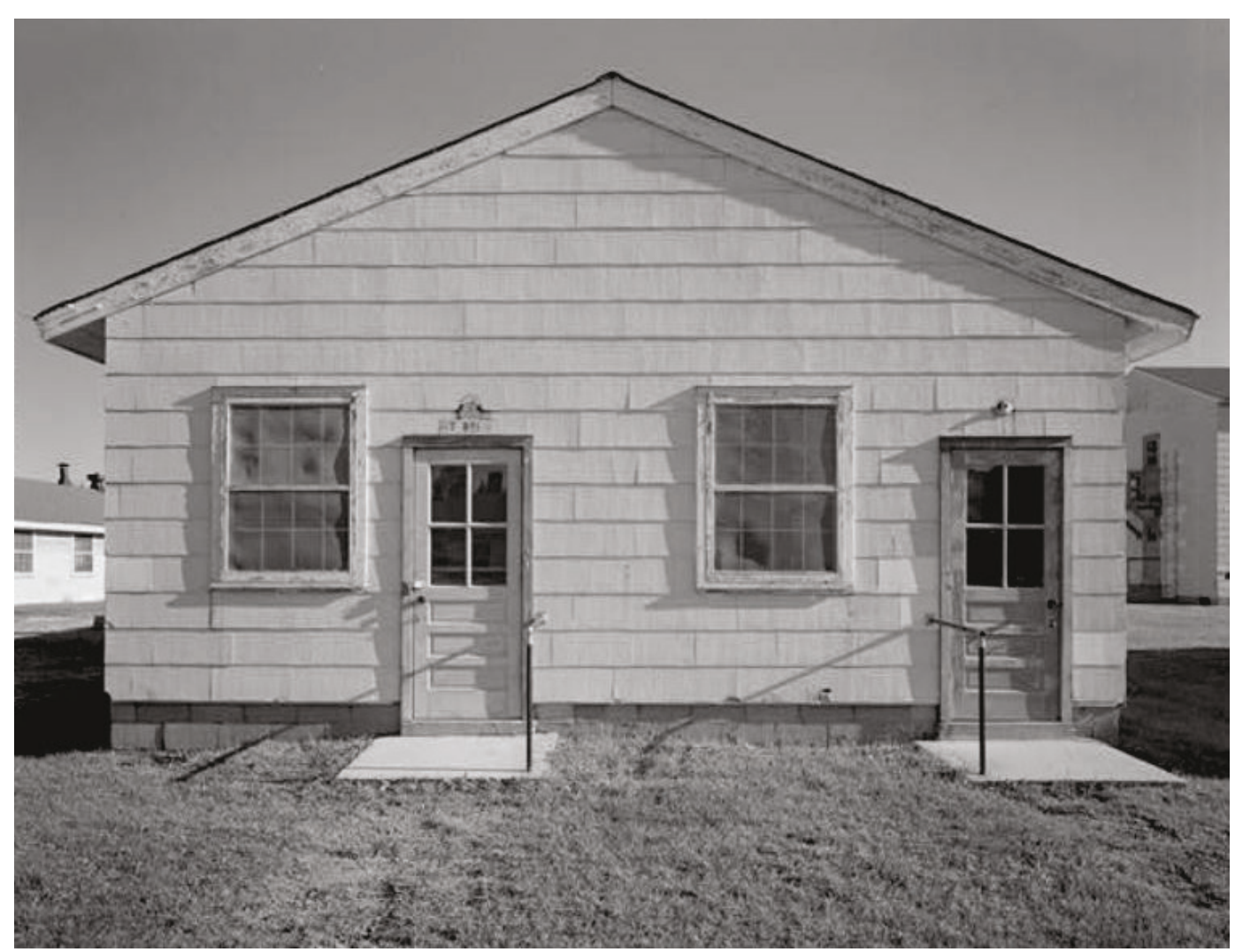

South (front) elevation of Building 801, Company Storehouse/Administration and Recreation Building, September 1988 (Library of Congress, HABS WIS, 41-SPAR.V, 1-B--3). 


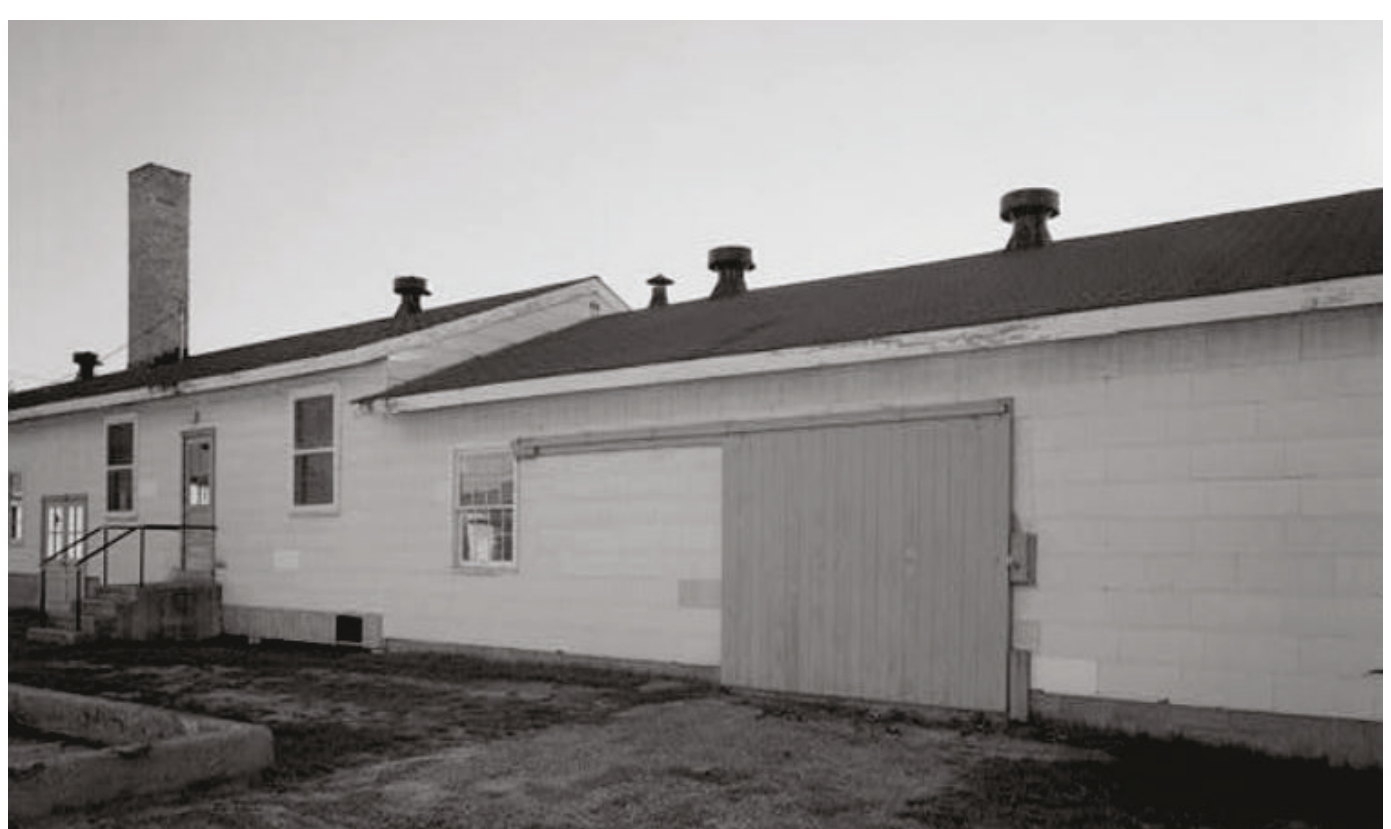

West elevation of Building 801, Company Storehouse/Administration and Recreation Building, September 1988 (Library of Congress HABS WIS, 41-SPAR.V, 1-B-4).

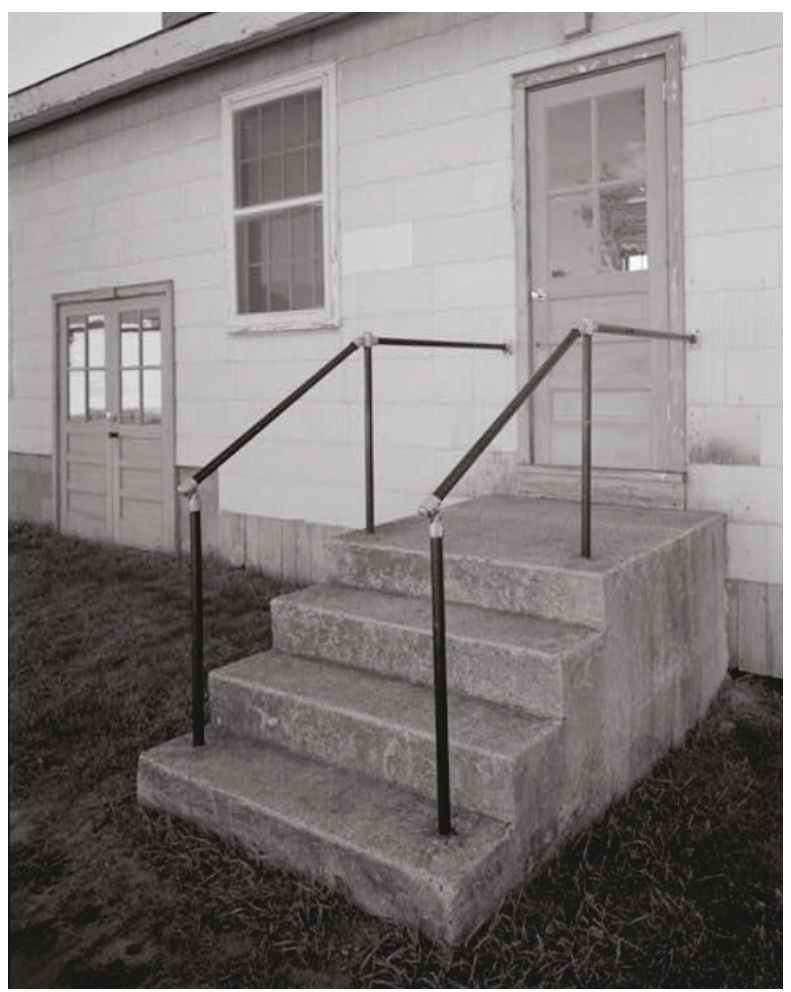

Close-up detail of concrete stoop, cast-iron metal handrails, wood panel and divided light doors, and multi-pane wood window and screen on Building 801, Company Storehouse/Administration and Recreation Building, September 1988 (Library of Congress HABS WIS, 41-SPAR.V, 1-B-5). The original WWII wood steps and handrails were replaced across Fort McCoy between 1965 and 1975. 


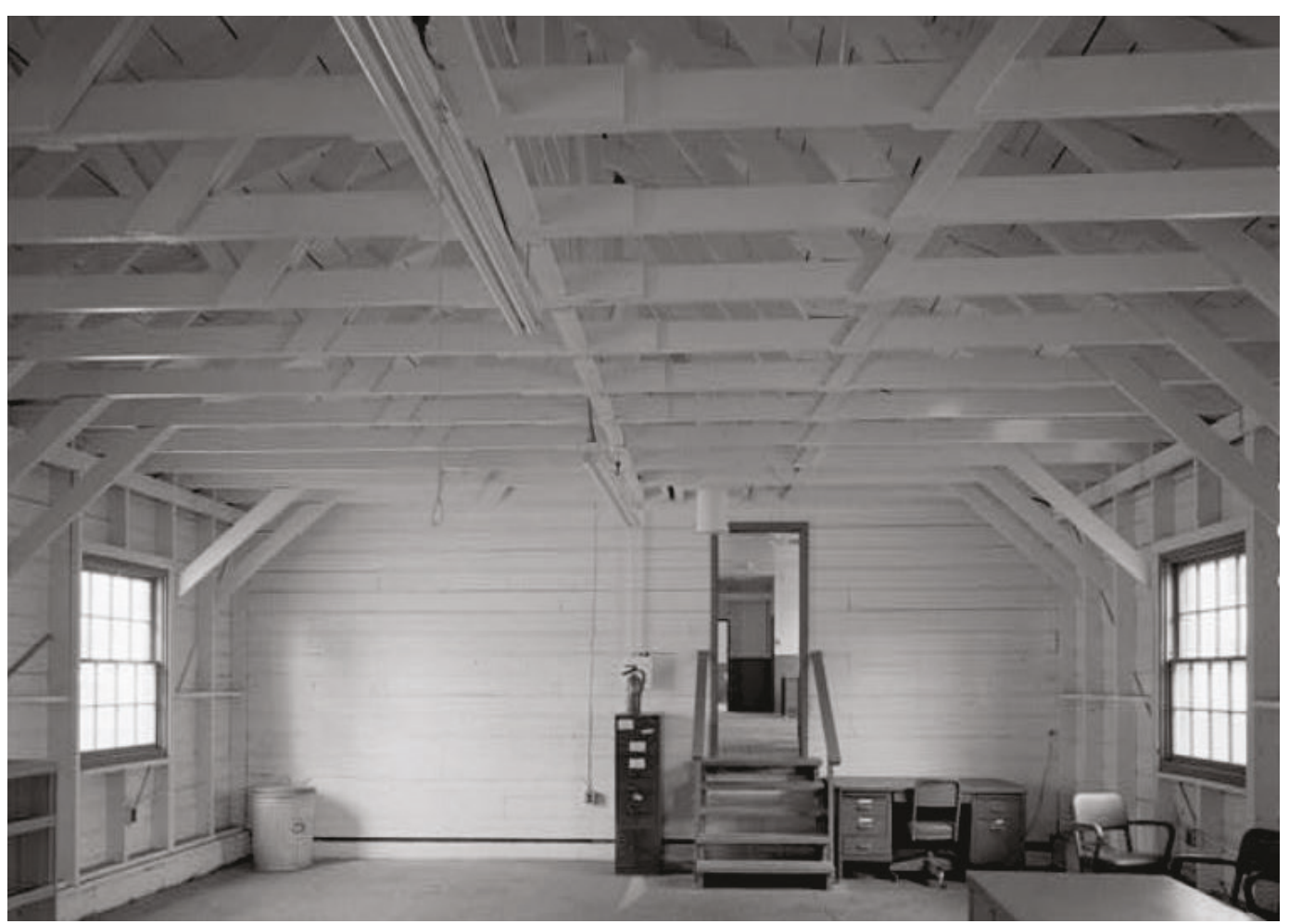

Building 801, interior view of storeroom showing roof trusses and north wall stairs into the recreation area, September 1988 (Library of Congress, HABS WIS, 41-SPAR.V, 1-B-6).

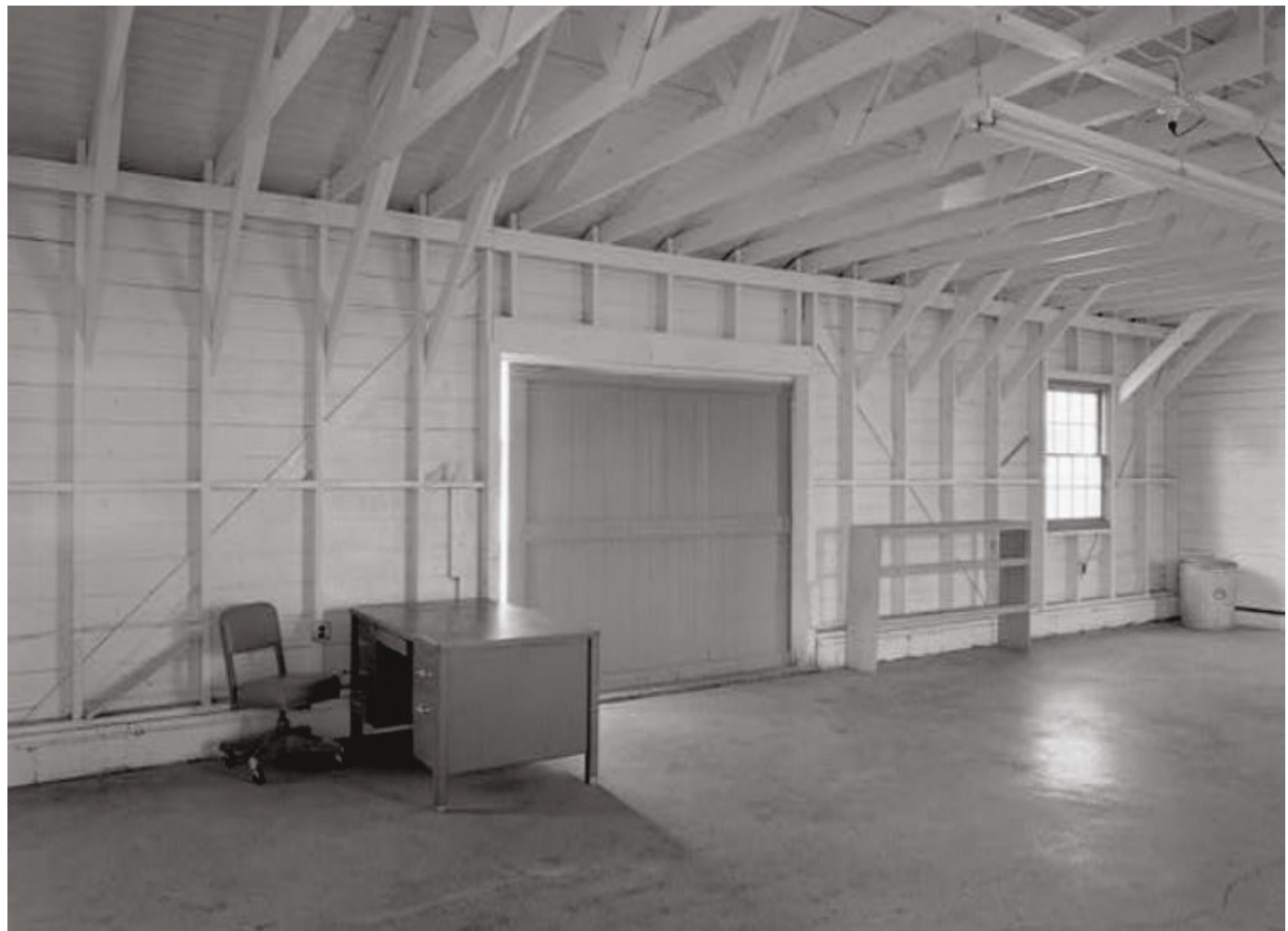

Building 801, interior view of the storeroom showing the wood sliding door on the west wall, September 1988 (Library of Congress, HABS WIS, 41-SPAR.V, 1-B-7). 


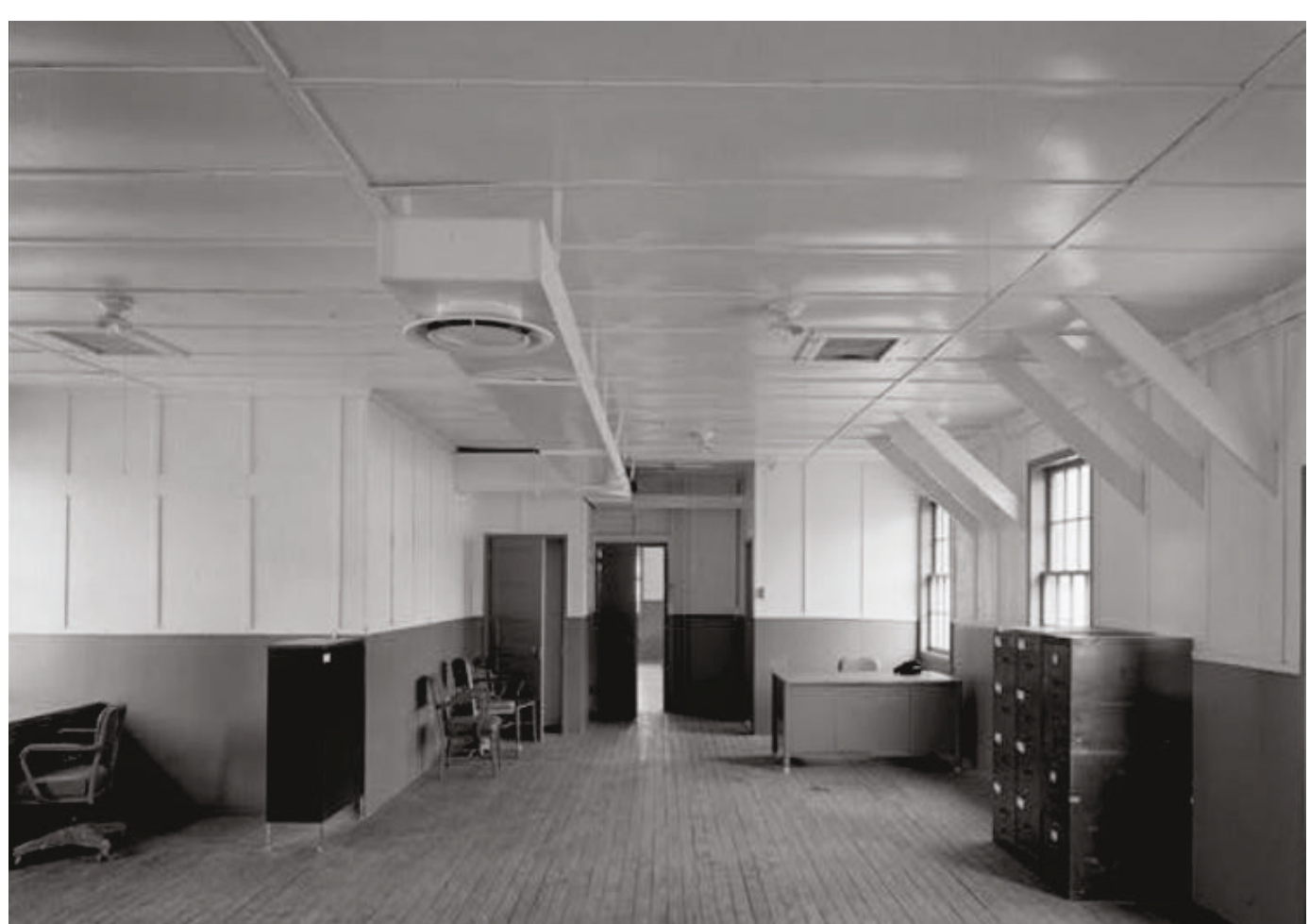

Building 801, interior view of recreation area looking north from the storeroom doorway, September 1988 (Library of Congress, HABS WIS, 41-SPAR.V, 1-B-9).

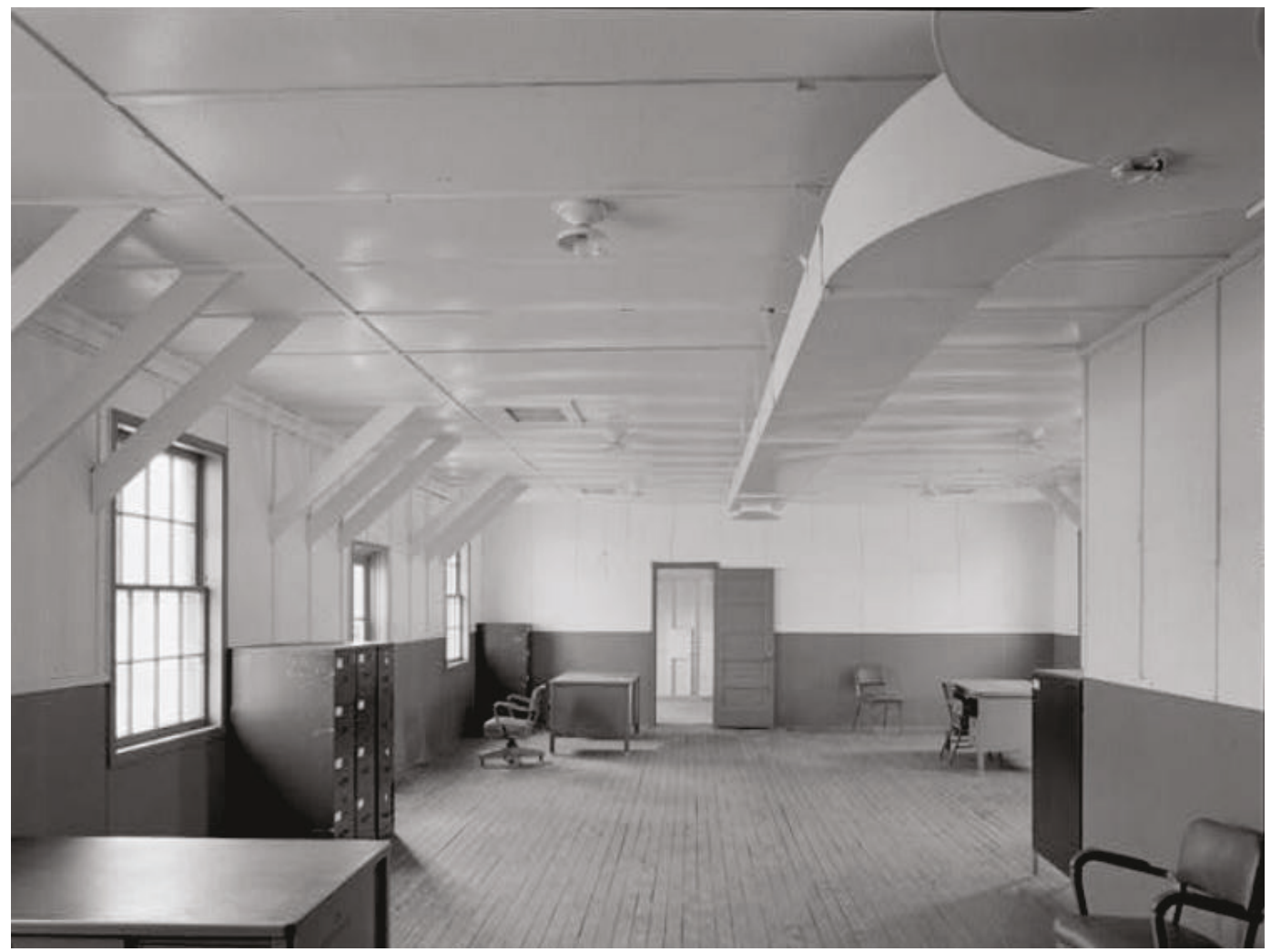

Building 801, interior view of recreation area looking south into storeroom, September 1988 (Library of Congress, HABS WIS, 41-SPAR.V, 1-B-10). 


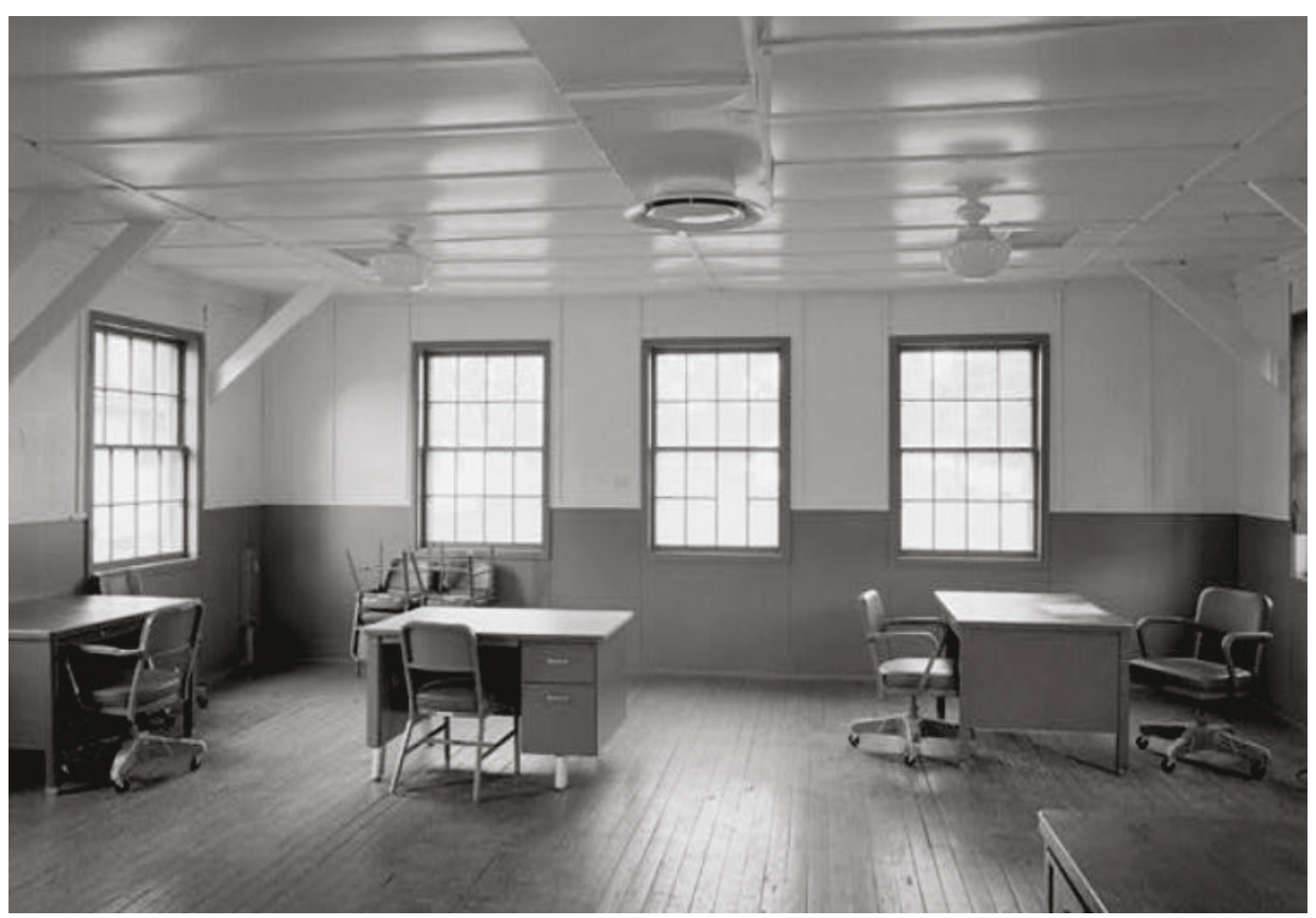

Building 801, interior view looking at the north wall of the recreation area, September 1988 (Library of Congress, HABS WIS, 41-SPAR.V, 1-B-11).

\section{CHARACTER-DEFINING FEATURES}

- One-story massing

- Rectangular footprint

- Front gable roof clad with red asphalt shingles (replaced roof in-kind)

- Overhanging eaves with wood fascia and soffit (modified with metal soffits)

- Textured cement asbestos siding with a scalloped bottom edge detail (replaced with vinyl siding)

- Concrete pier foundation with wooden foundation skirting on the north end, recreation (replaced)

- Concrete block foundation walls, south end, storehouse and administration and heater room

- Window pattern (modified)

- Multi-pane wood double-hung windows, three different types 8/8, 6/6, and 4/4 (replaced with oneover-one vinyl windows)

- Wood trim, surround, and profile of windows (removed)

- Wood panel and divided-light doors (replaced with newer metal doors)

- Wood sliding door (replaced with two metal entry doors)

- Wood steps, stoop, and handrail (dismantled)

- Room arrangement (modified with partition walls)

- Exposed wood truss system in the storehouse and administration section (encased with newer materials such as a drop-ceiling)

- Concrete floor in former storehouse/administration section

- Wood floor in former recreation portion (no longer intact, covered with vinyl tiles)

- Wood 5-panel interior doors (replaced with metal doors)

- Wood trim around windows (replaced by vinyl windows)

- Interior light fixtures (replaced by newer fixtures)

- Insulation board and batten details on walls and ceiling (replaced with drywall) 


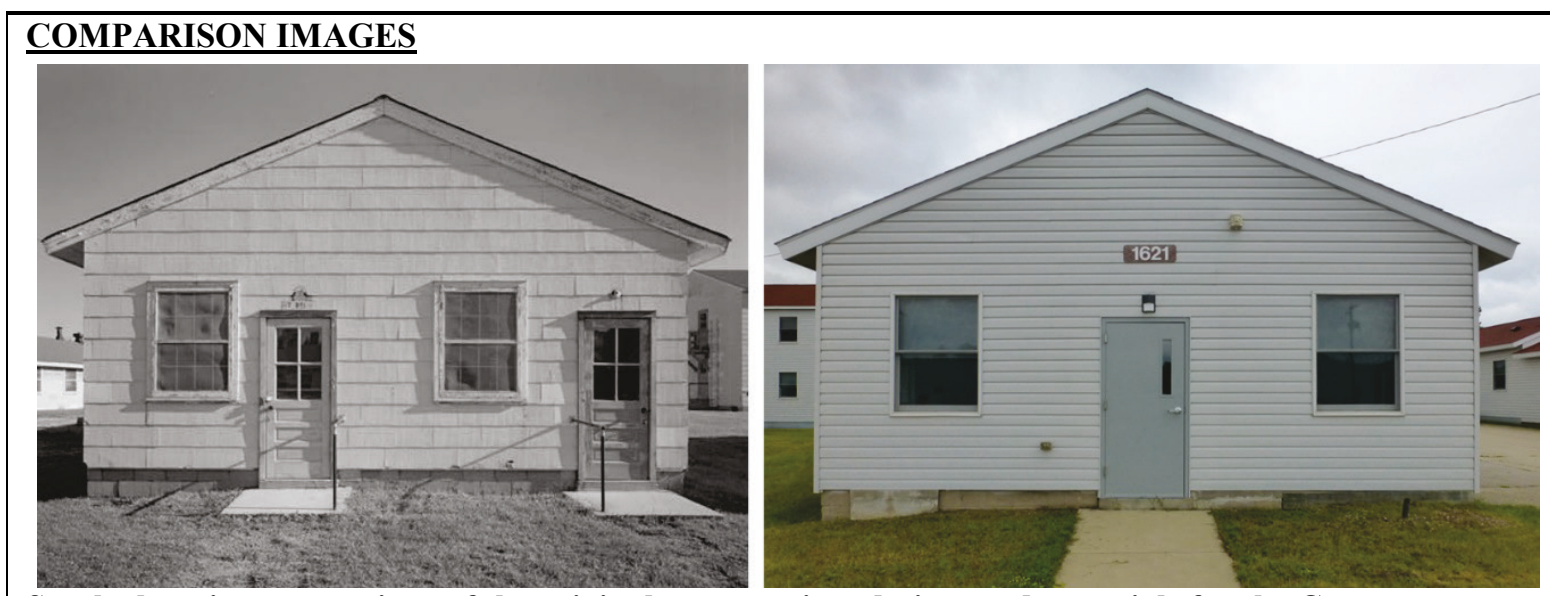

South elevation comparison of the original construction, design, and materials for the Company Storehouse/Administration and Recreation Building from 1988 (left) to 2018 (right) (left: Library of Congress, HABS; right: ERDC-CERL).
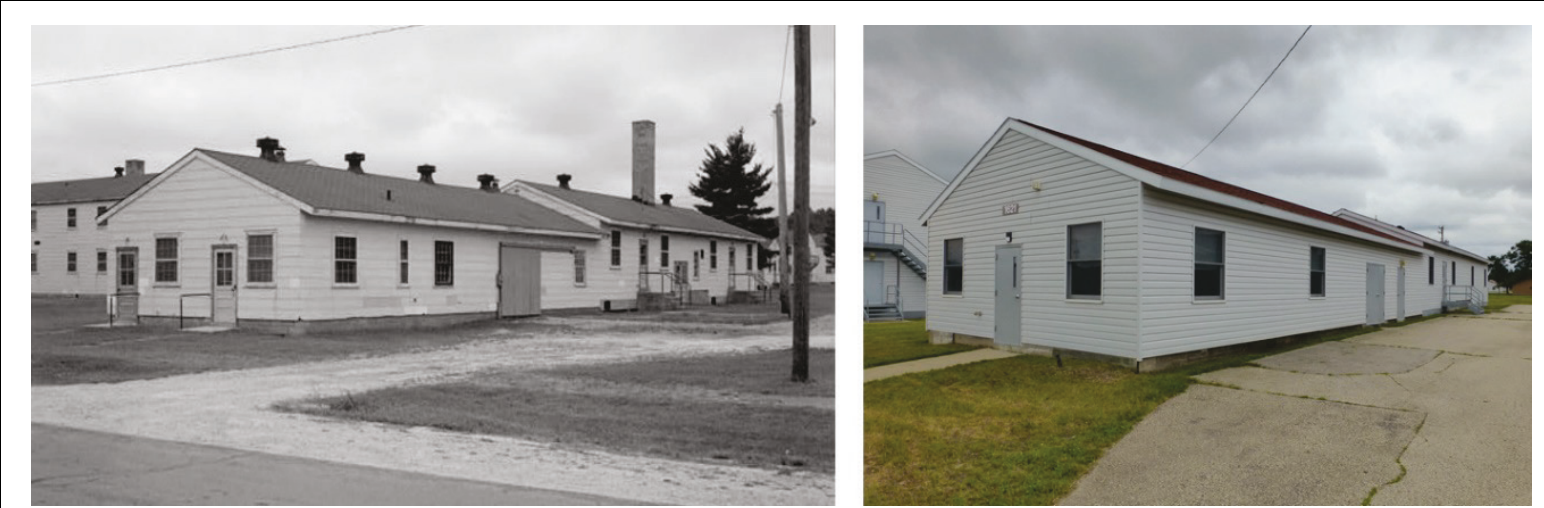

Southeast oblique comparison of the original construction, design, and materials for the Company Storehouse/Administration and Recreation Building from 1988 (left) to 2018 (right) (left: Library of Congress, HABS; right: ERDC-CERL).
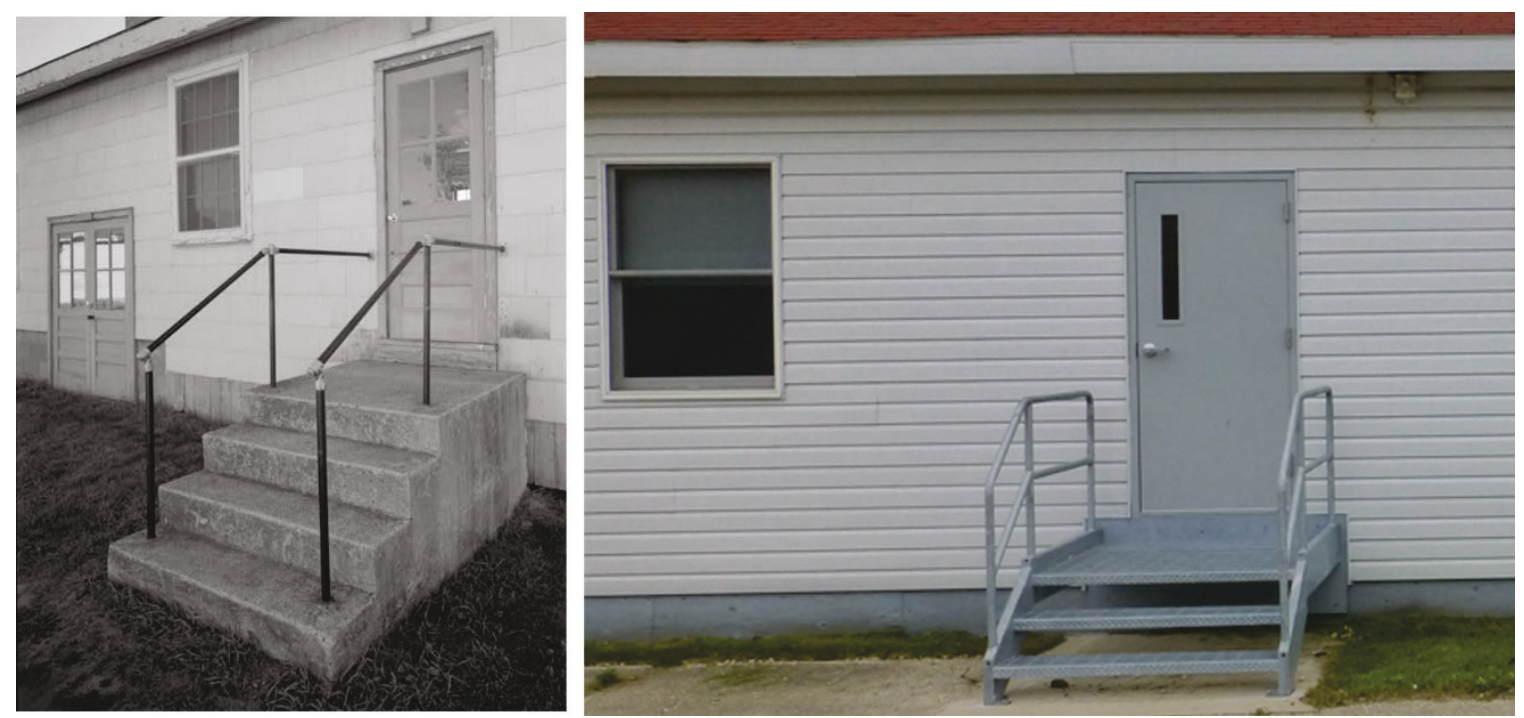

Door, window, and stoop comparison of the original construction, design, and materials for the Company Storehouse/Administration and Recreation Building from 1988 (left) to 2018 (right) (left: Library of Congress, HABS; right: ERDC-CERL). 

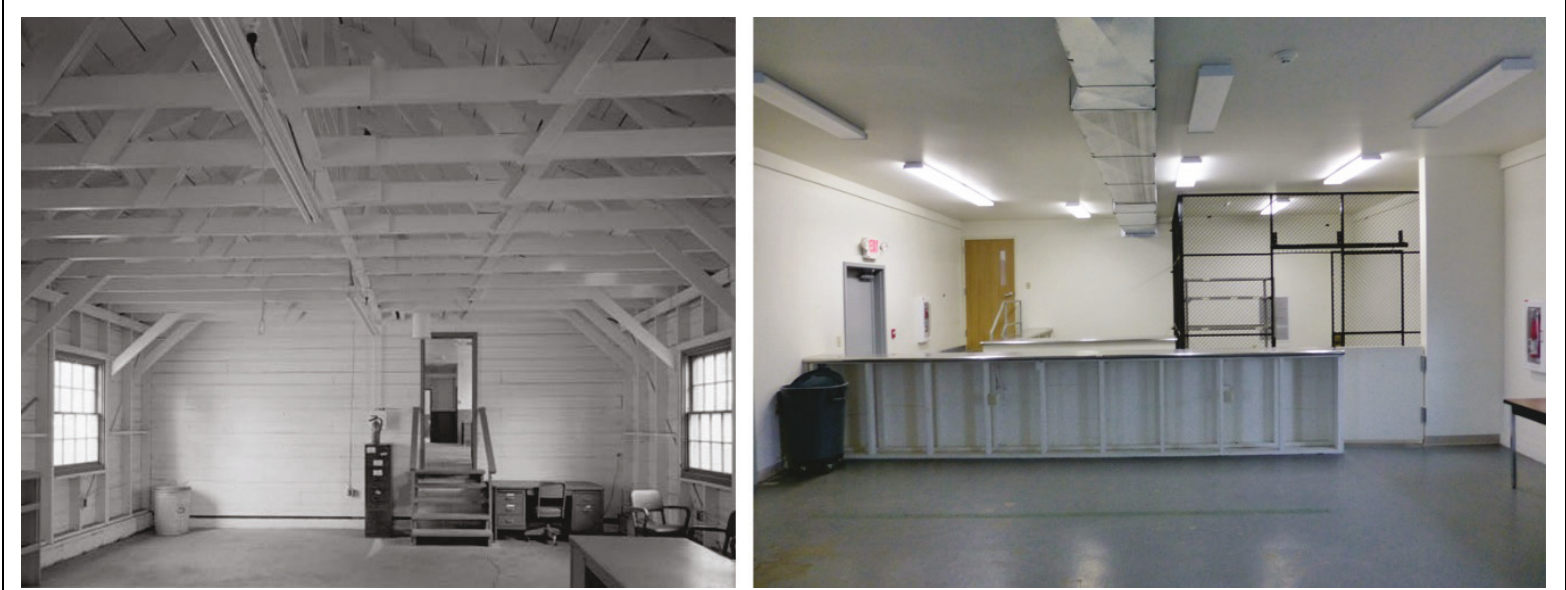

Interior view of the original storehouse/administration section looking north toward the recreation section. Comparison of the original construction, design, and materials for the Company

Storehouse/Administration and Recreation Building from 1988 (left) to 2018 (right) (left: Library of Congress, HABS; right: ERDC-CERL).
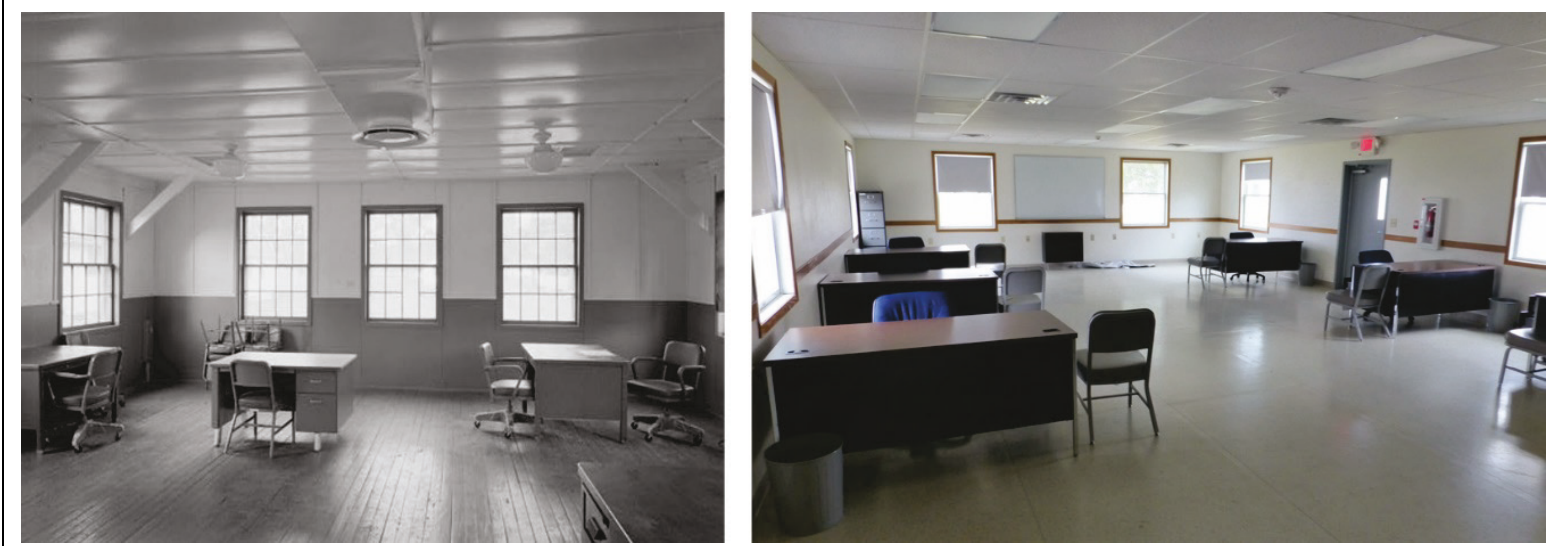

Interior view of the original recreation section, looking at the north wall. Comparison of the original construction, design, and materials for the Company Storehouse/Administration and Recreation Building from 1988 (left) to 2018 (right) (left: Library of Congress, HABS; right: ERDC-CERL).

\section{SIGNIFICANCE}

The 800 Series (and the 700 Series that preceded it) was a comprehensive set of drawings which could be used interchangeably in creating various building types. War mobilization buildings are significant for their construction and technological innovation. Techniques such as the standardization of plans, prefabrication of units, and assembly-line approach to construction were largely pioneered during construction of these mobilization structures.

The temporary wood buildings constructed from 1939-1946 with the 700 Series or 800 Series on Fort McCoy during World War II (WWII) were determined significant for the National Register of Historic Places (NRHP) in 1986 when the Programmatic Memorandum of Agreement (PMOA) was signed between the Department of Defense (DoD), the Advisory Council on Historic Preservation (ACHP), and the National Council of State Historic Preservation Officers (NCSHPO). In the early 1990s, this significance was reaffirmed by the writing of "World War II and the U.S. Army Mobilization Program: A History of 700 and 800 Series Cantonment Construction" and performance of the Historic American Buildings Survey (HABS) on a variety of the 700 and 800 Series planned buildings across the country. Many of the 800 Series of buildings at Fort McCoy were utilized for the HABS. 
Buildings 1601, 1621, 1622, and 1743, Company Storehouse/Administration and Recreation Buildings, WWII temporary buildings, are significant under Criterion A for WWII temporary building construction (1939-1946).

The design and construction of the WWII temporary buildings could not be linked to a specific architect due to their construction from standardized War Department temporary building plans. They do not possess high artistic values; however, WWII temporary buildings in general were found to be significant for their design, construction, and technological innovation under Criterion $\mathrm{C}$.

\section{INTEGRITY}

Location - All four WWII buildings retain their integrity of location.

Design - All four buildings retains the key elements of their WWII design.

Setting - All four WWII buildings retain their integrity of setting.

Materials - None of the four buildings retain their integrity of materials. Each building has been completely modified with newer materials. No original material elements are intact.

Workmanship - Workmanship is not part of integrity for WWII temporary buildings, including these four buildings.

Feeling - All four buildings do not retain their integrity of feeling. They have all been heavily modified with modern materials.

Association - All four buildings retain their integrity of association.

\section{RECOMMENDATION OF CONTRIBUTING/NONCONTRIBUTING STATUS}

It is the recommendation of this report that Buildings 1601, 1621, 1622, and 1743, Company Storehouse/Administration and Recreation Buildings, are NOT Eligible for the NRHP at the national level due to the lack of integrity from changes in floor plan, changes in siding, changes in window pattern and type, changes in doors, and dismantled chimney stack. 


\section{Block - Classroom Buildings (former Mess Halls)}

\begin{tabular}{|c|c|c|c|}
\hline \multicolumn{4}{|c|}{$\begin{array}{c}\text { FORT McCOY } \\
\text { HISTORIC PROPERTY INVENTORY FORM }\end{array}$} \\
\hline $\begin{array}{l}\text { PROPERTY BOUNDARIES } \\
\text { - Fort McCoy in the } 1600 \text { block } \\
\text { area on the south side of the } \\
\text { triangular cantonment plan } \\
\text { - Sparta vicinity } \\
\text { - Monroe County, Wisconsin }\end{array}$ & \multicolumn{2}{|l|}{$\begin{array}{l}\text { COMMON/HISTORIC NAME } \\
\text { - Building 1605 } \\
\text { - Classroom Building } \\
\text { - 228-Man Mess Hall } \\
\text { - Building } 1606 \\
\text { - Classroom Building } \\
\text { - 228-Man Mess Hall } \\
\text { - Building 1638 } \\
\text { - Classroom Building } \\
\text { - 228-Man Mess Hall } \\
\text { - Building 1639 } \\
\text { - Classroom Building } \\
\text { - 228-Man Mess Hall } \\
\end{array}$} & $\frac{\text { STATUS }}{\text { Usable }}$ \\
\hline $\begin{array}{l}\text { ARCHITECT/BUILDER } \\
\text { Construction Division, Office of } \\
\text { the Quartermaster General, } \\
\text { Series } 800-851\end{array}$ & $\begin{array}{l}\text { DATE OF CONSTRUCTION } \\
1942 \\
\text { DATE OF ALTERATIONS } \\
1953 \text { - added enclosed side entries } \\
\text { with vestibules } \\
2003 \text { - an appendage was } \\
\text { constructed on one of the long } \\
\text { elevations of each building that } \\
\text { altered the original footprint, vinyl } \\
\text { siding was added, windows were } \\
\text { removed, window and door } \\
\text { openings were modified, and the } \\
\text { interior was completely remodeled }\end{array}$ & $\frac{\text { NO. OF }}{\frac{\text { STORIES }}{1}}$ & $\frac{\text { FOOTPRINT }}{\text { L-shaped }}$ \\
\hline$\frac{\text { ROOF FORM }}{\text { Cross-gable }}$ & $\begin{array}{l}\text { FOUNDATION } \\
\text { Concrete pier (original) } \\
\text { Poured concrete slab (addition) }\end{array}$ & $\begin{array}{l}\text { WALLS } \\
\text { Wood structure } \\
\text { frame clad with } \\
\text { vinyl siding }\end{array}$ & $\begin{array}{l}\text { ROOF } \\
\text { Asphalt } \\
\text { shingles }\end{array}$ \\
\hline HISTORIC USE(S) & FUNCTION & \multirow{3}{*}{\multicolumn{2}{|c|}{$\frac{\text { NOTABLE FEATURES }}{\text { - None }}$}} \\
\hline Mess Hall & Classroom & & \\
\hline \multicolumn{2}{|c|}{$\begin{array}{l}\text { RELATIONSHIP TO OTHER BUILDINGS } \\
\text { The } 1600 \text { Block is located on the south side of Fort McCoy's } \\
\text { triangular cantonment layout. South Eleventh Street is to the north, } \\
\text { South J Street is to the east, South Tenth Street is to the south, and } \\
\text { South G Street is to the west. South H and South I Streets cut through } \\
\text { the block. The } 1600 \text { battalion block consists of } 29 \text { barracks, four } \\
\text { company storehouse/administration/recreation buildings (currently } \\
\text { being used as general instruction buildings), and eight mess halls (four } \\
\text { still being used as mess halls and four being used as classroom } \\
\text { building). Buildings } 1605 \text { and } 1606 \text { are adjacent each other, while } \\
\text { Buildings } 1638 \text { and } 1639 \text { are adjacent each other. }\end{array}$} & & \\
\hline
\end{tabular}




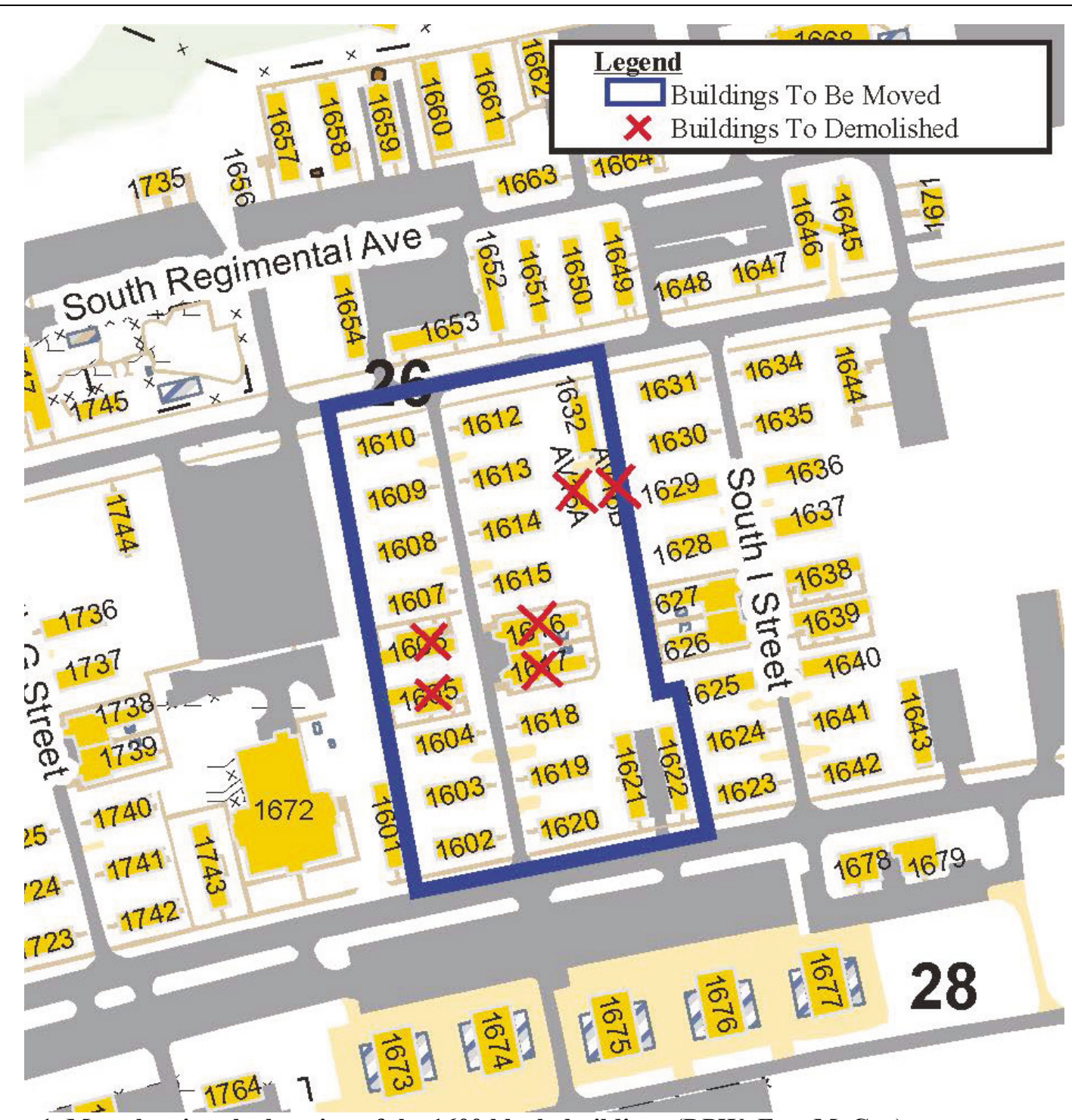

Photo 1. Map showing the location of the 1600 block buildings (DPW, Fort McCoy). 


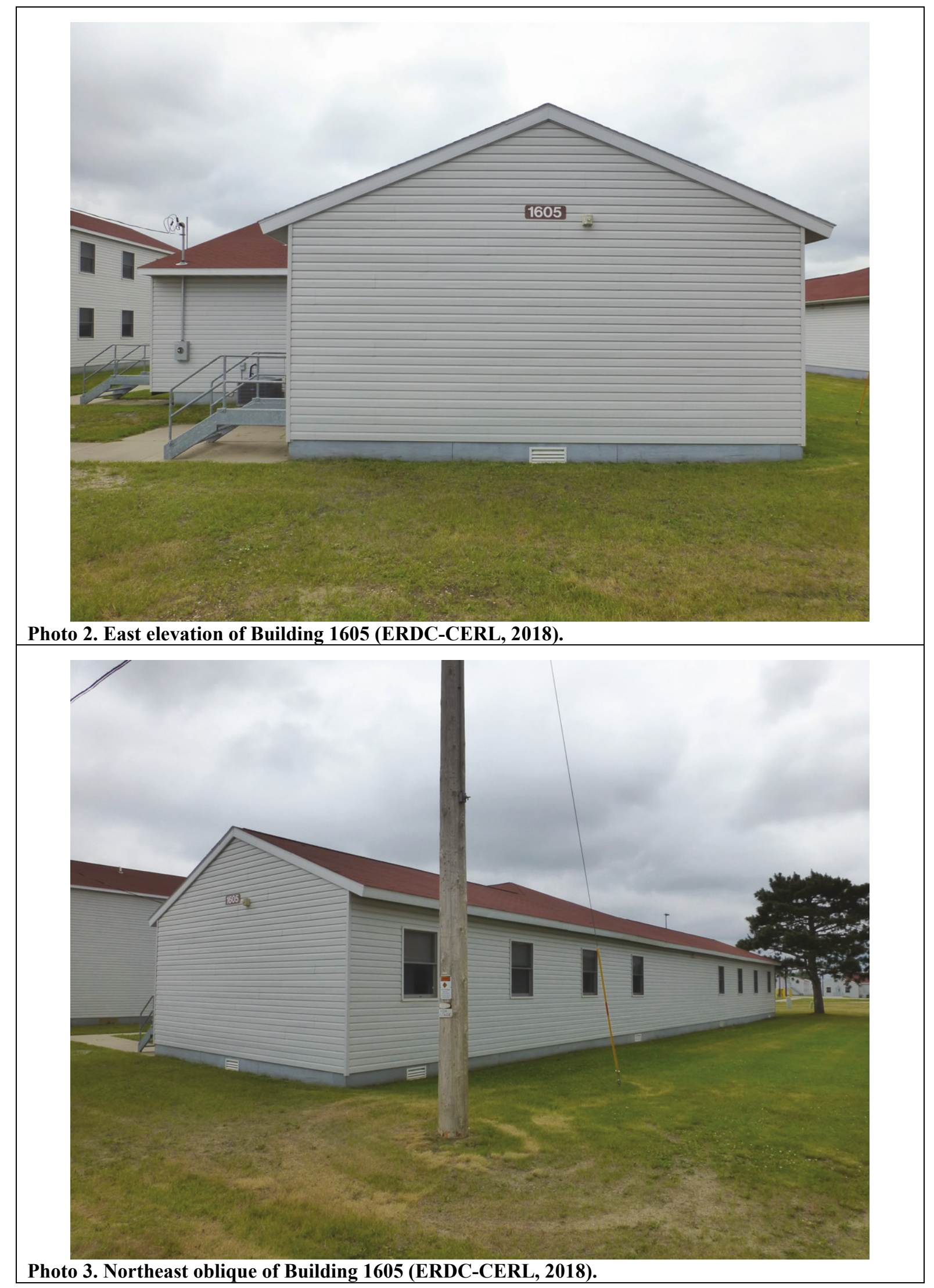




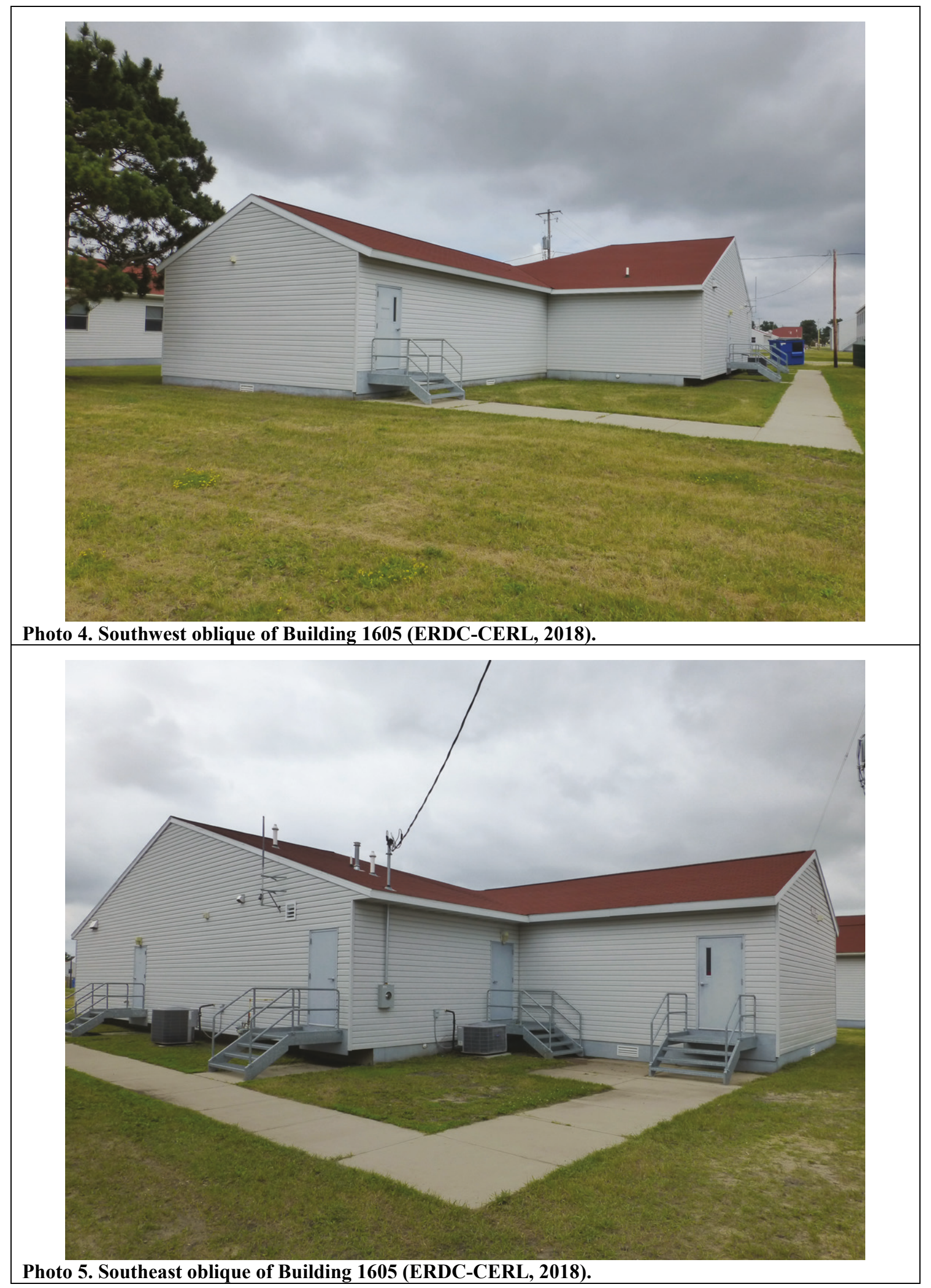




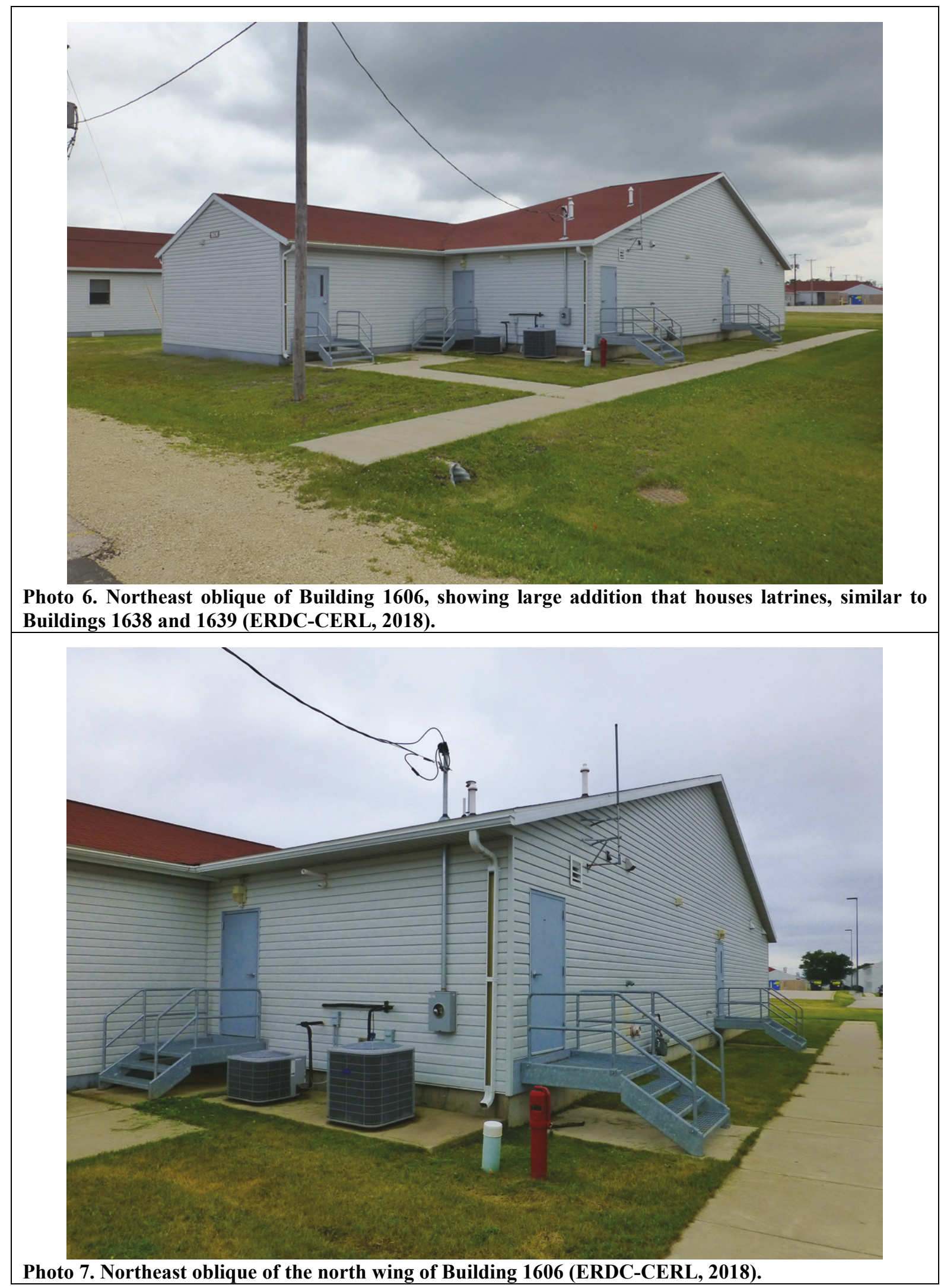




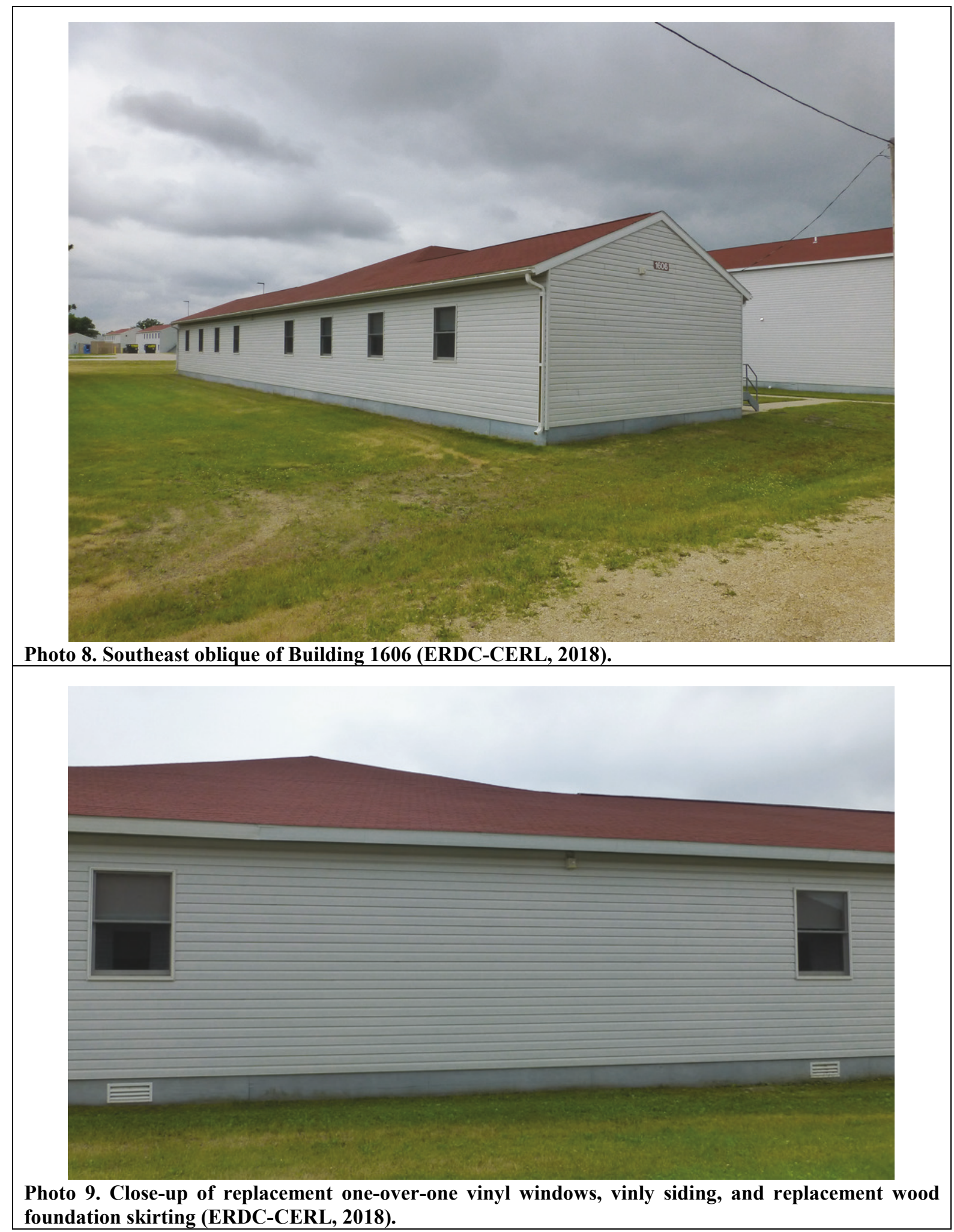




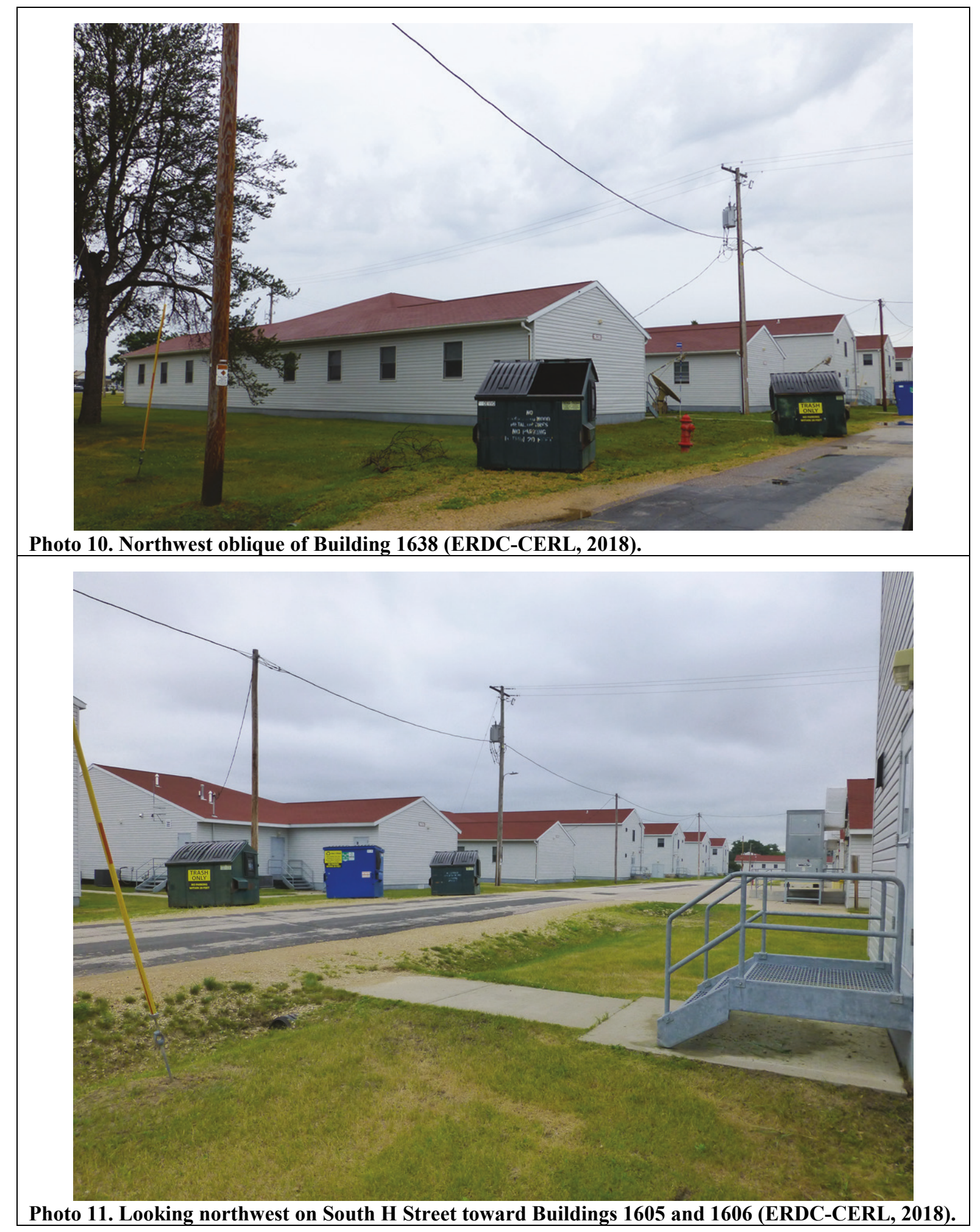




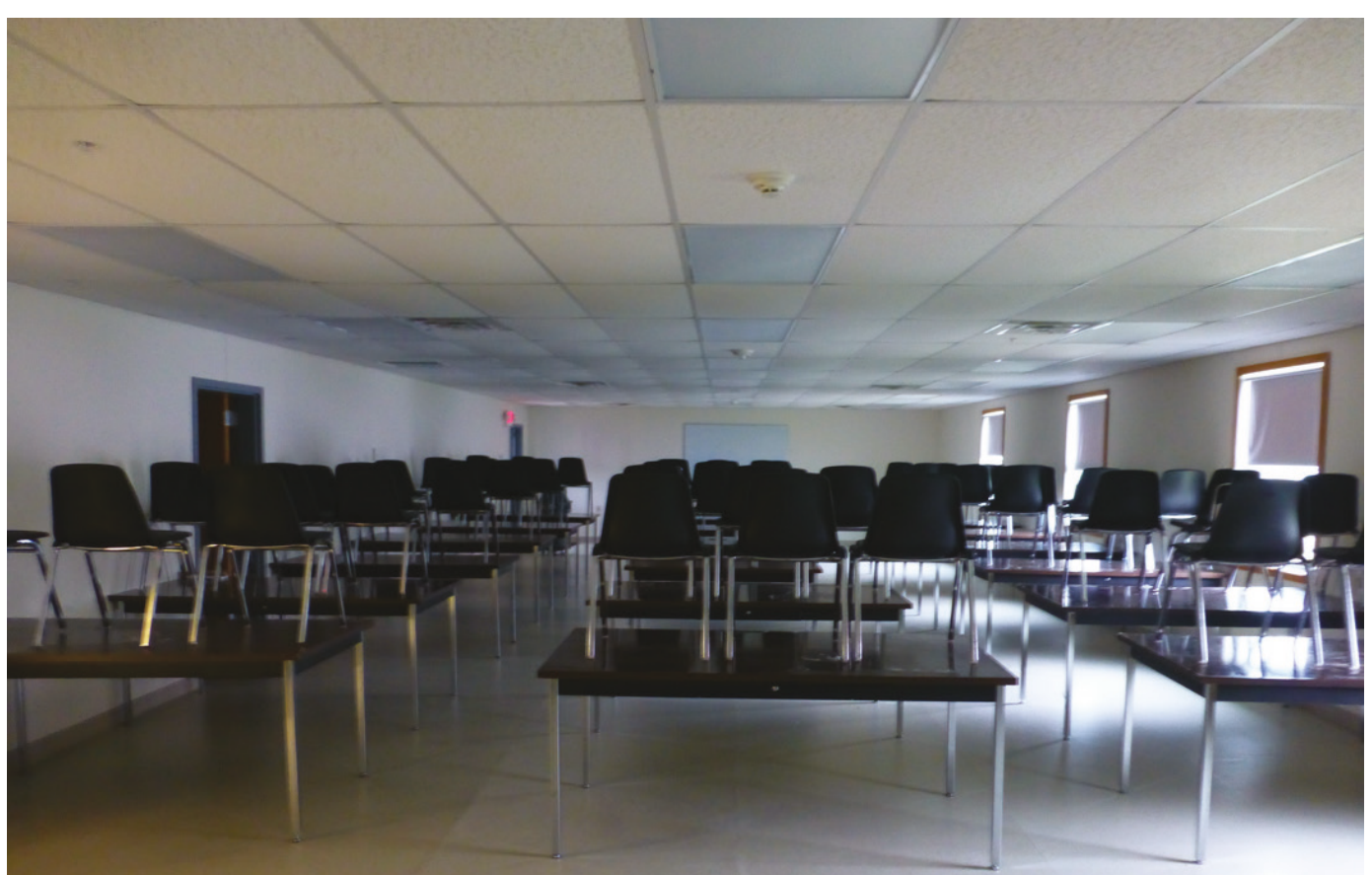

Photo 12. Interior view of the former mess hall with all new finishes such as flooring, drop-ceiling, light fixtures, drywall (ERDC-CERL, 2018).

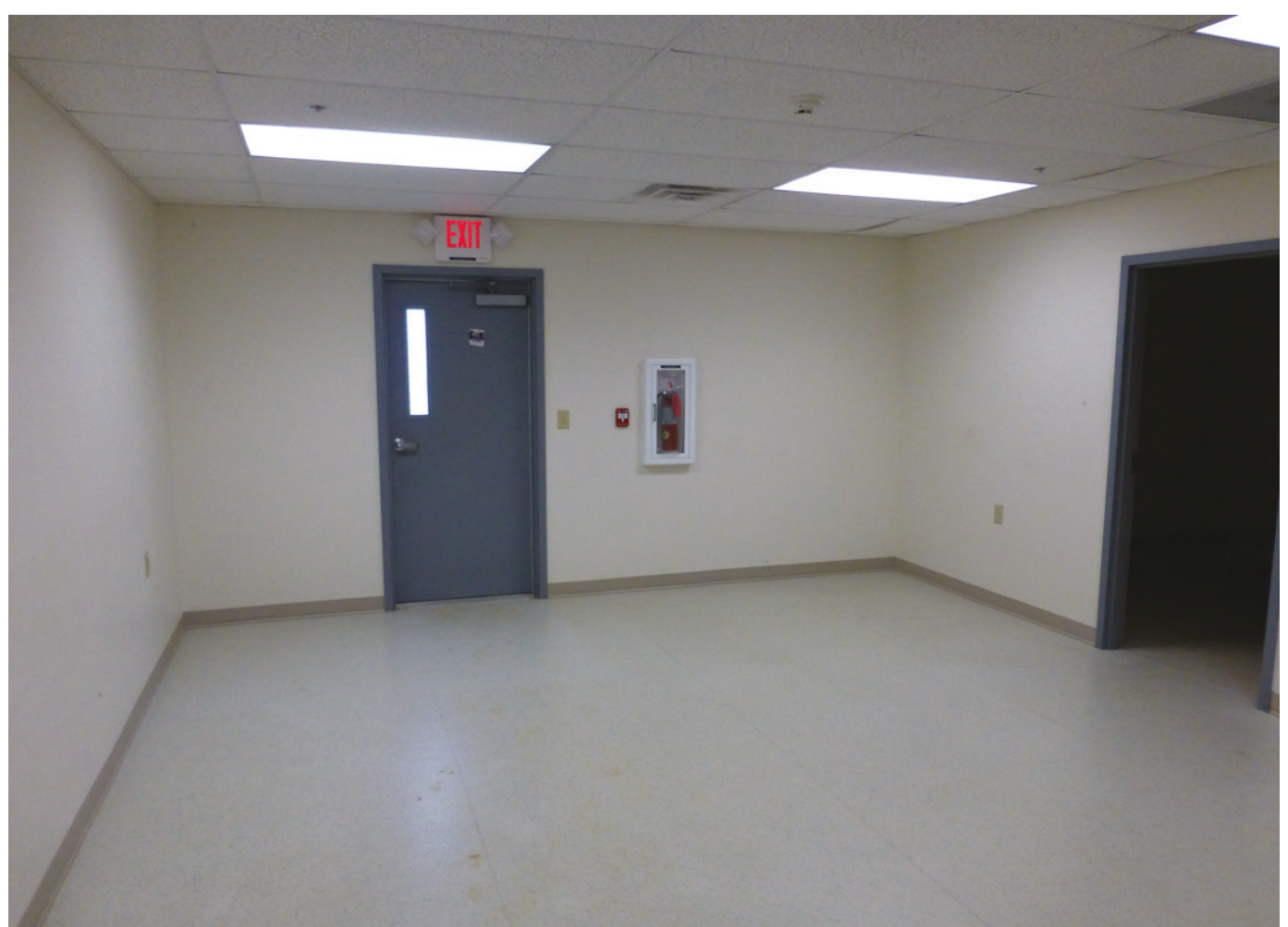




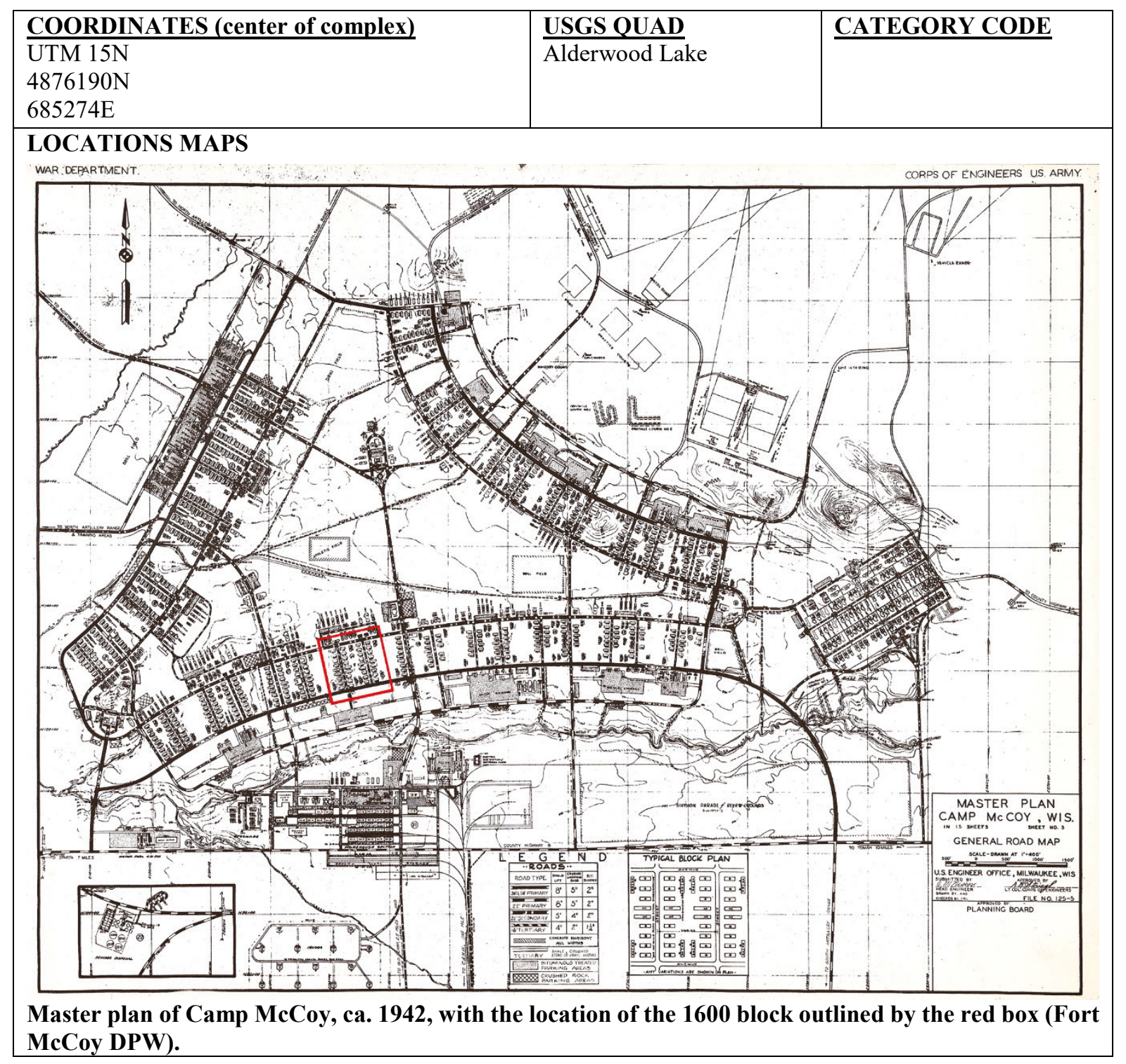




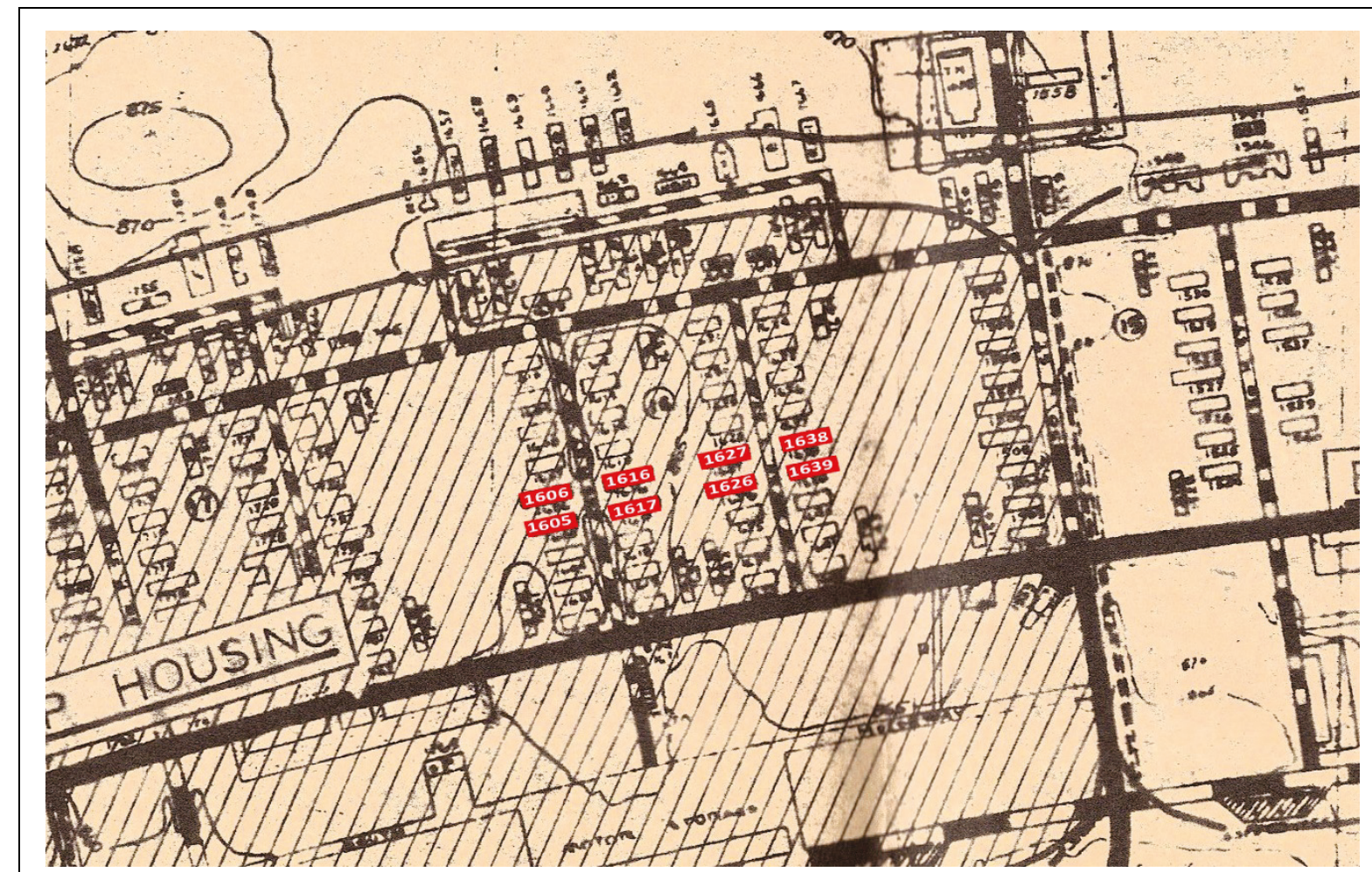

Portion of the General Site Map Camp McCoy, with the location of the 1600 Block Mess Halls colorcoded in red, 1947 (Fort McCoy DPW).

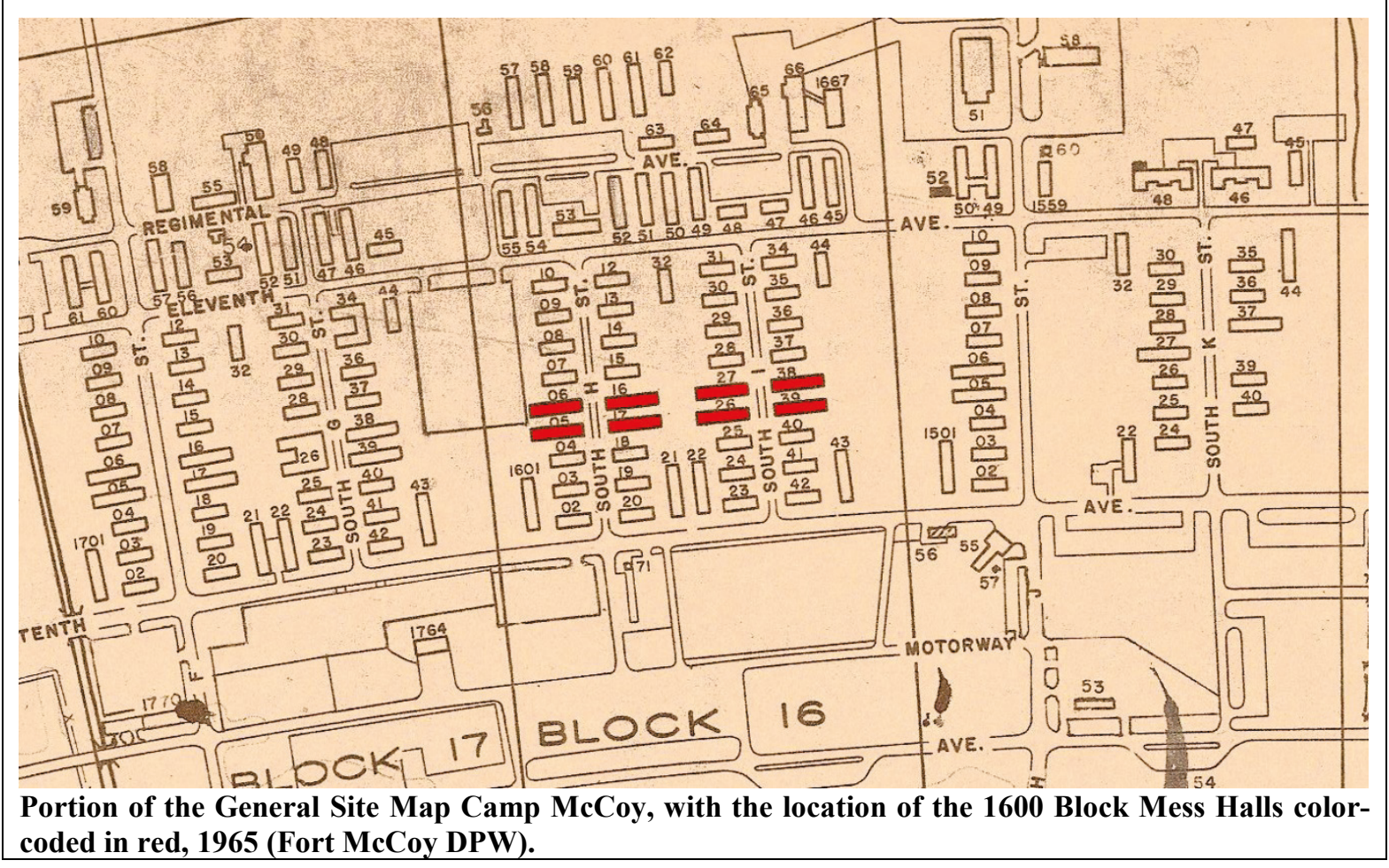




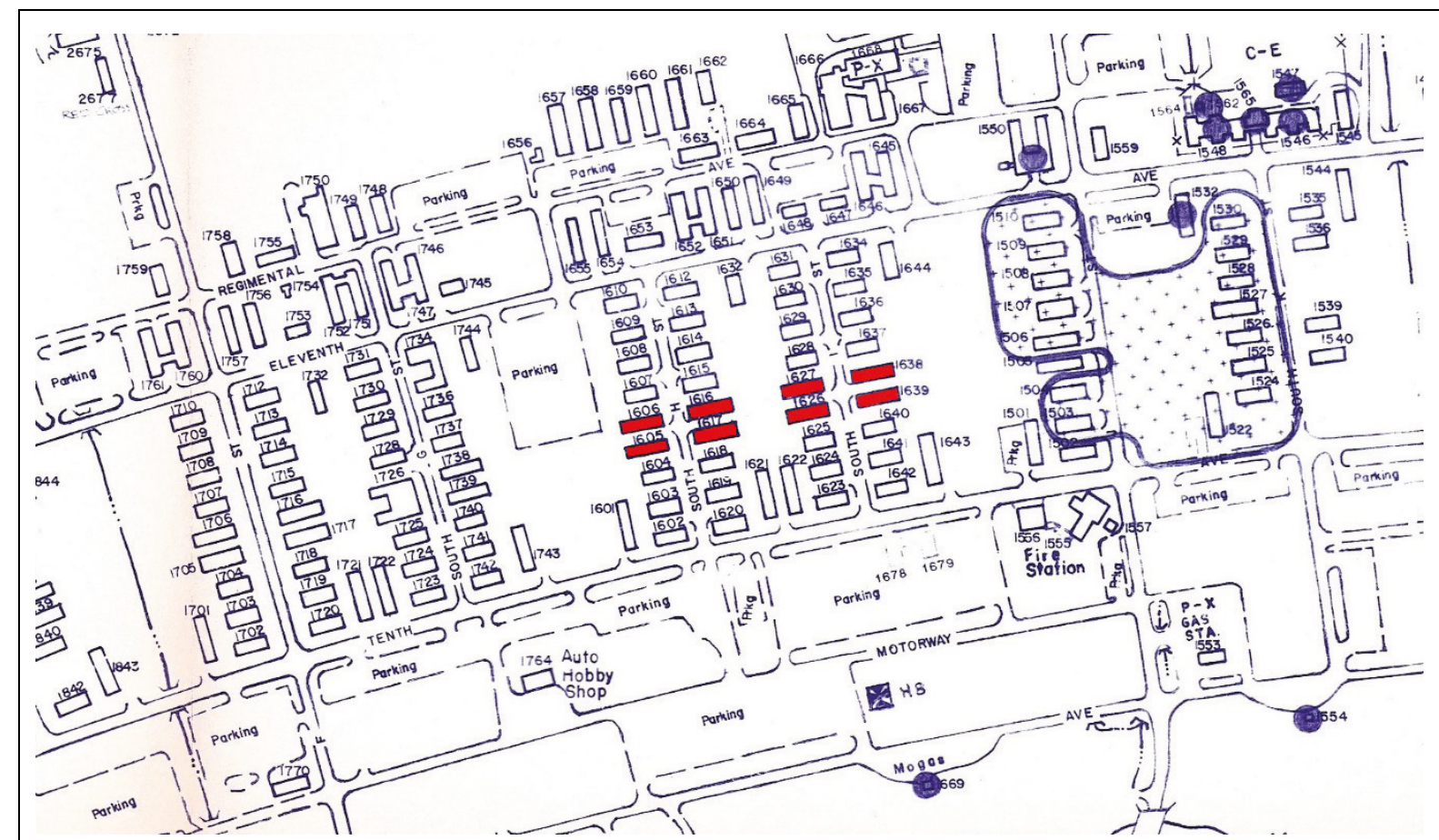

Portion of the General Site Map Fort McCoy with the location of the 1600 Block Mess Halls color-coded in red, 1993 (Fort McCoy DPW).

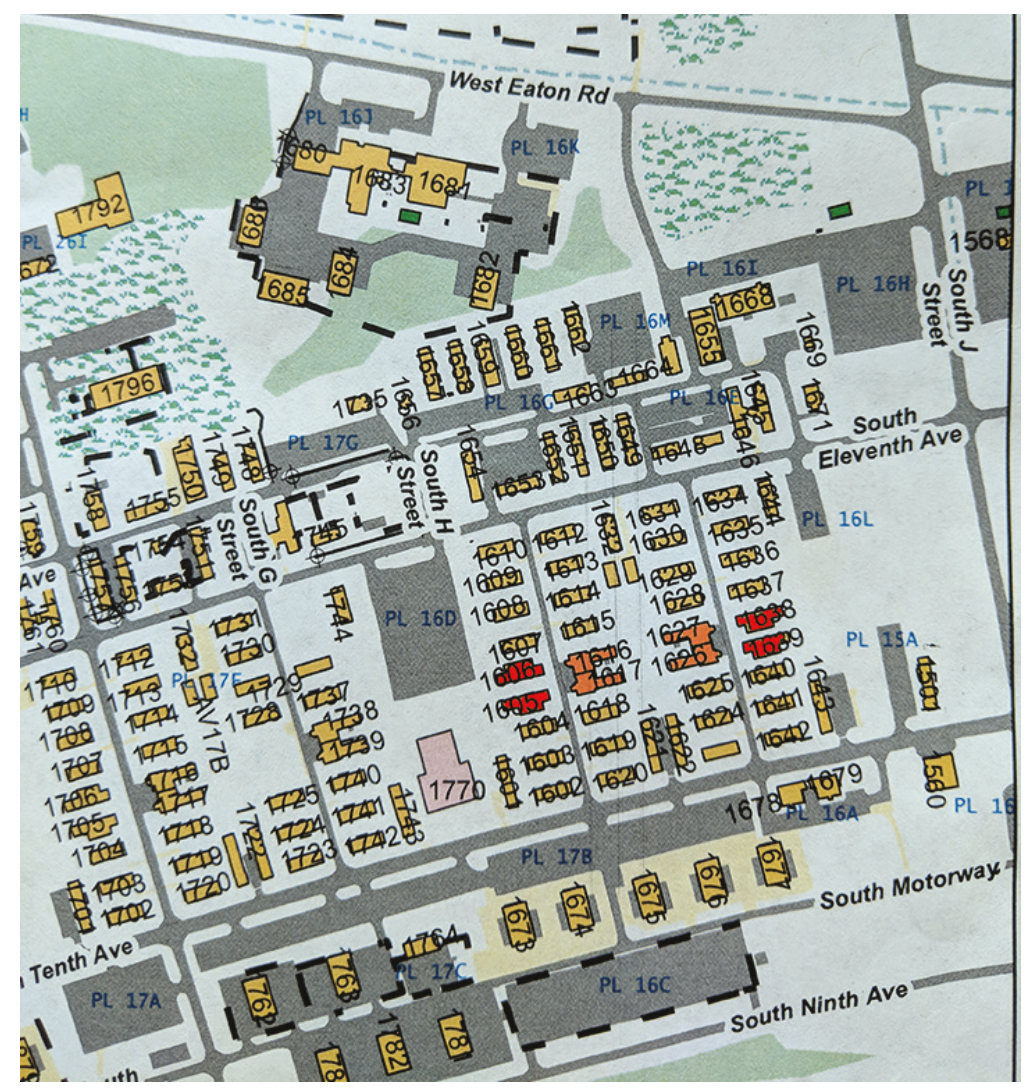

Portion of the General Site Map Fort McCoy with the location of Buildings 1605, 1606, 1638, and 1639, Mess Halls, color-coded in red, 2014. (Buildings 1616, 1617, 1626, and 1627 are also mess halls and colored in lighter-red shading.) (Fort McCoy DPW). 


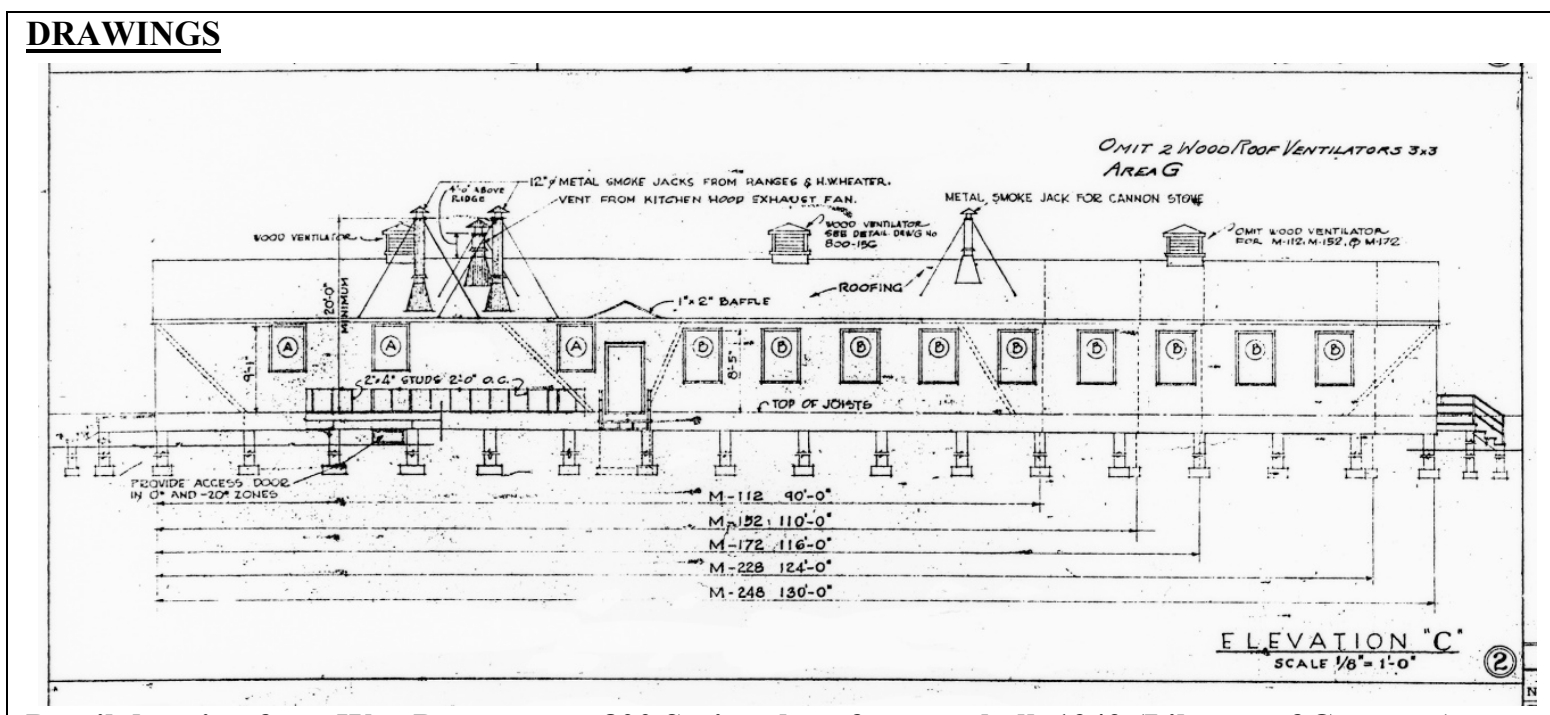

Detail drawing from War Department 800 Series plans for mess hall, 1942 (Library of Congress).

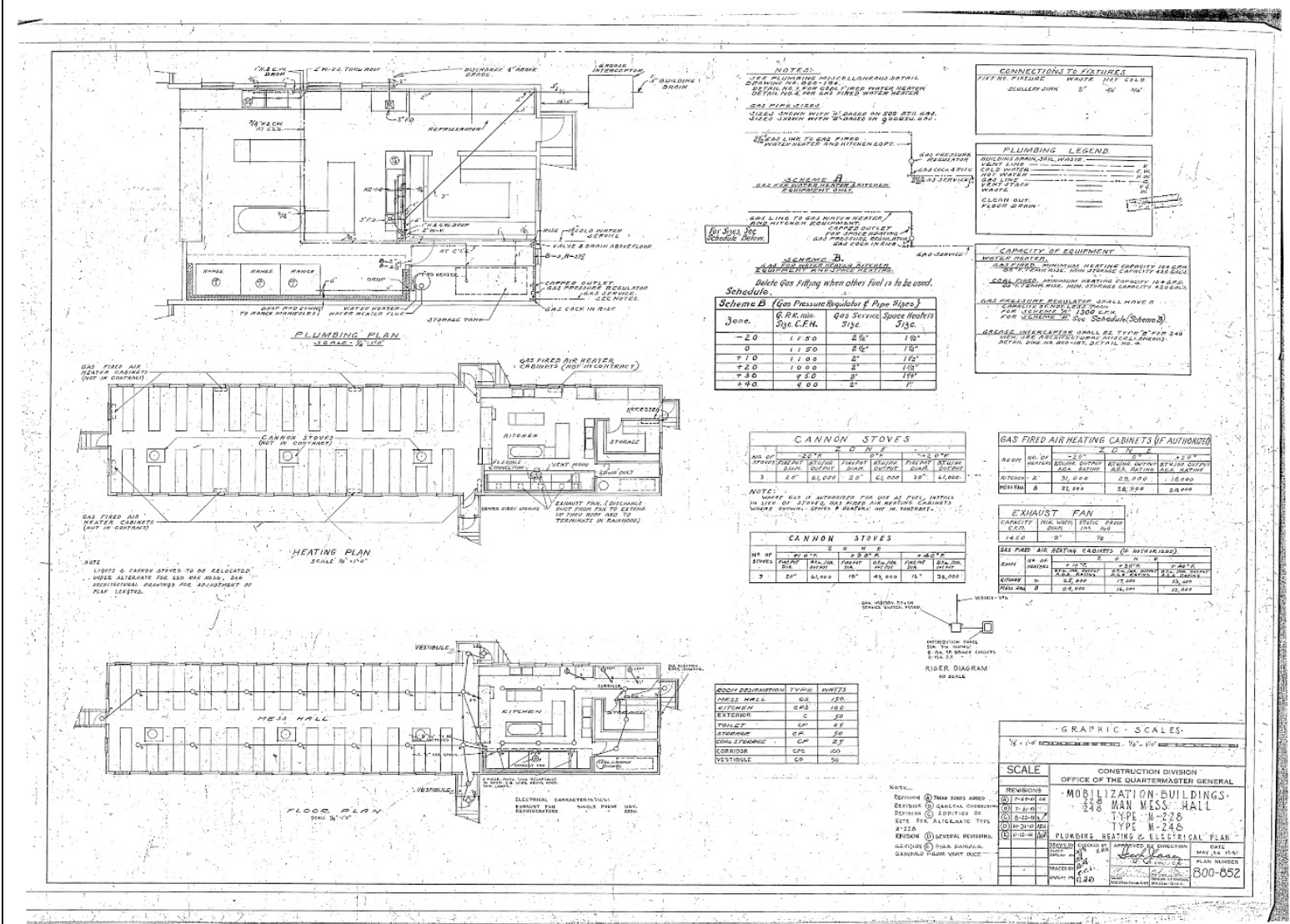

228-Man Mess Hall floor plan and details, Drawing 800-852, 1941 (Fort McCoy DPW). 


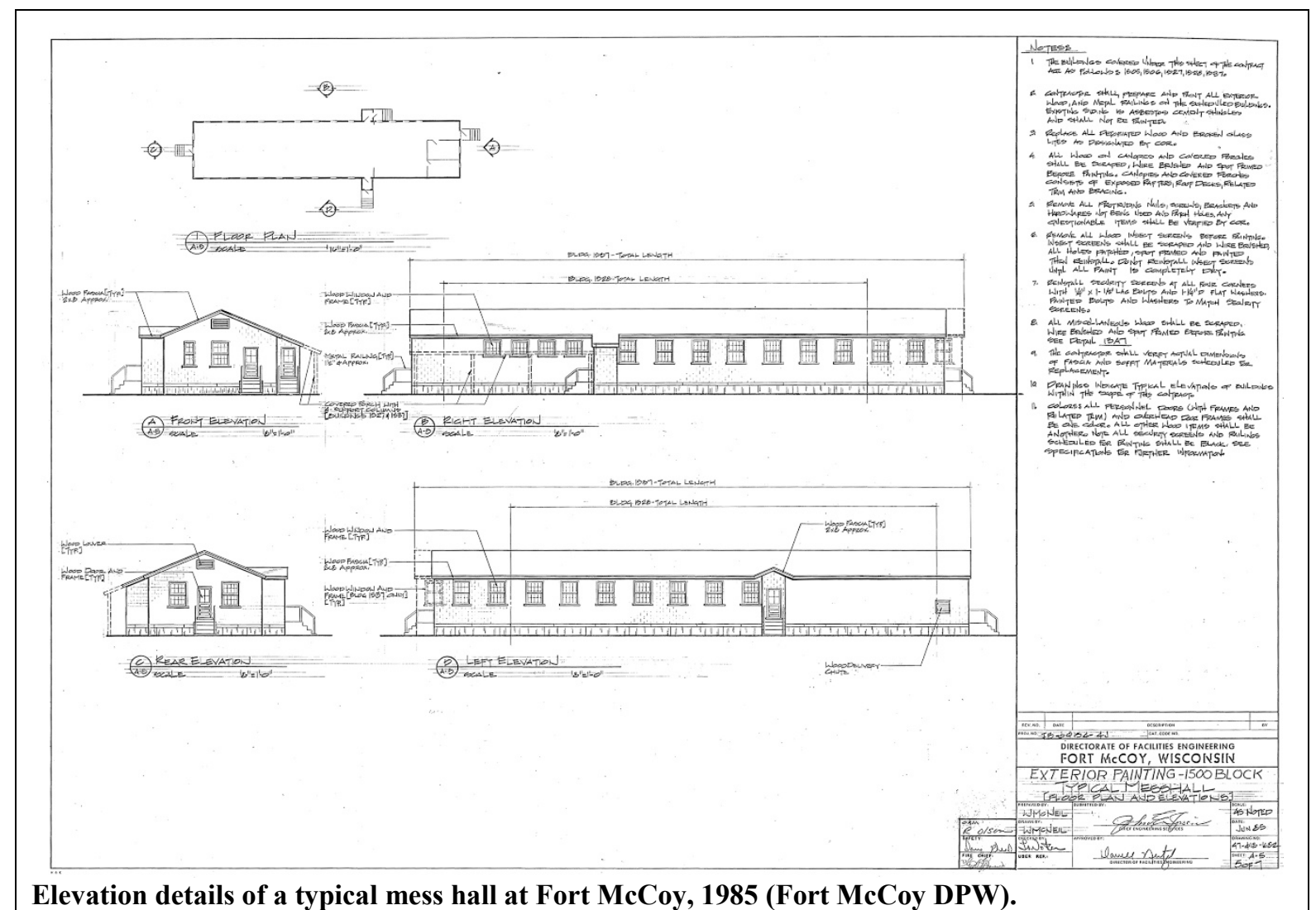


-

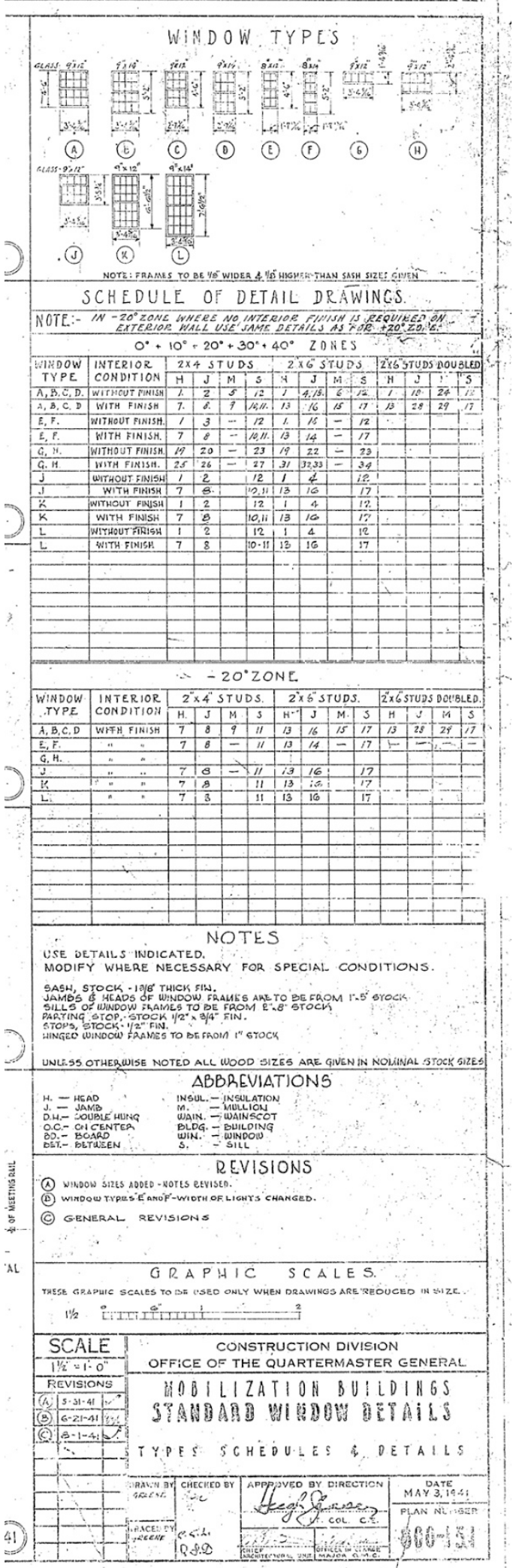

Standard window type details, Drawing 800-151, 1941 (Fort McCoy DPW).

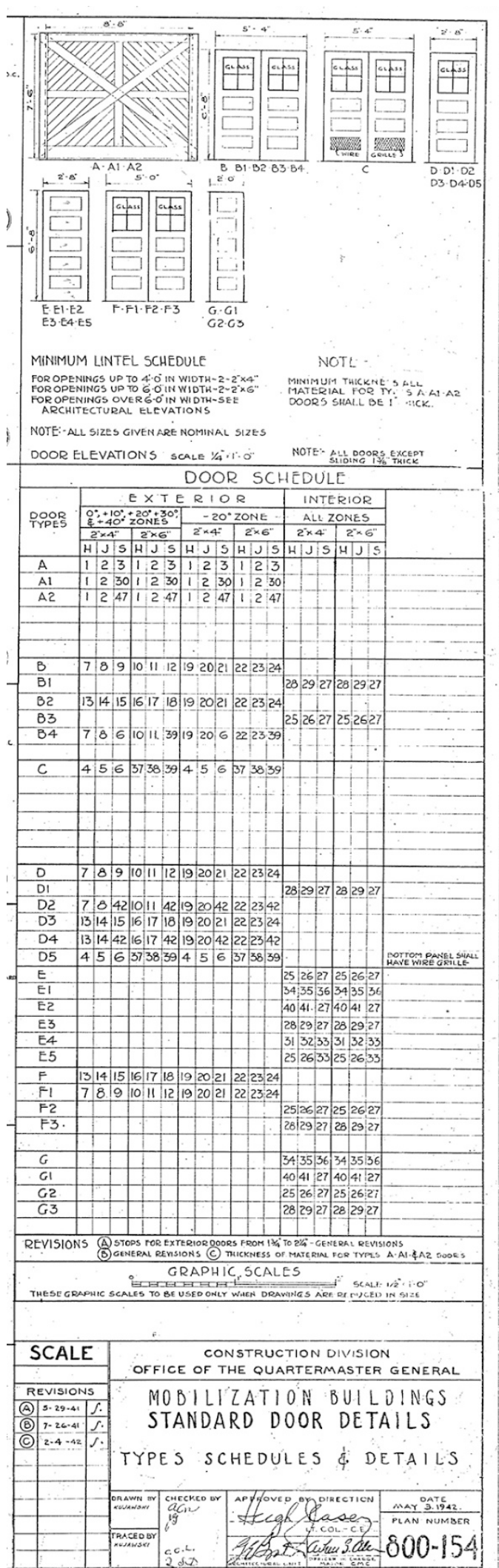

Standard door type details, Drawing 800-151, 1941 (Fort McCoy DPW). 


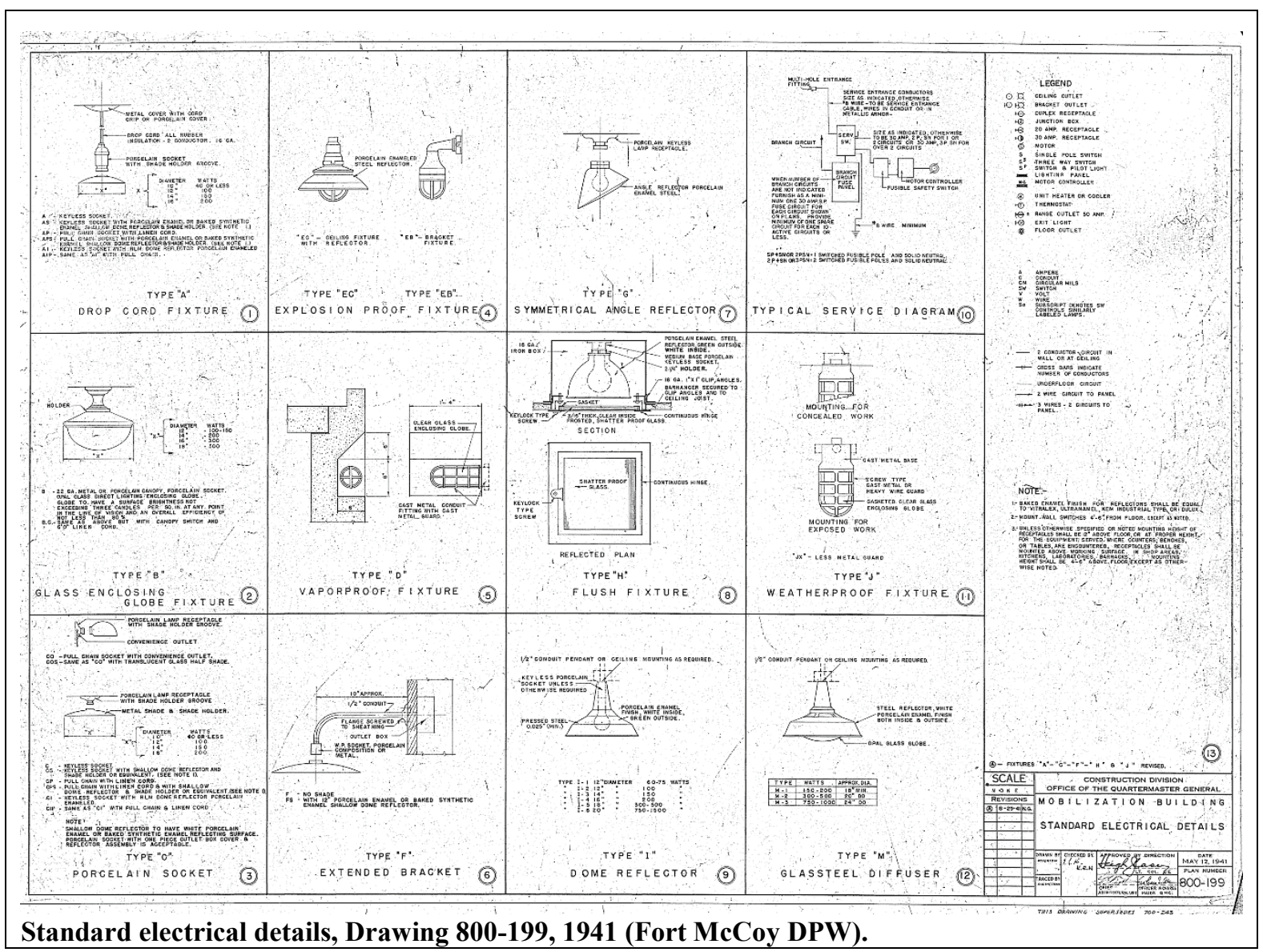




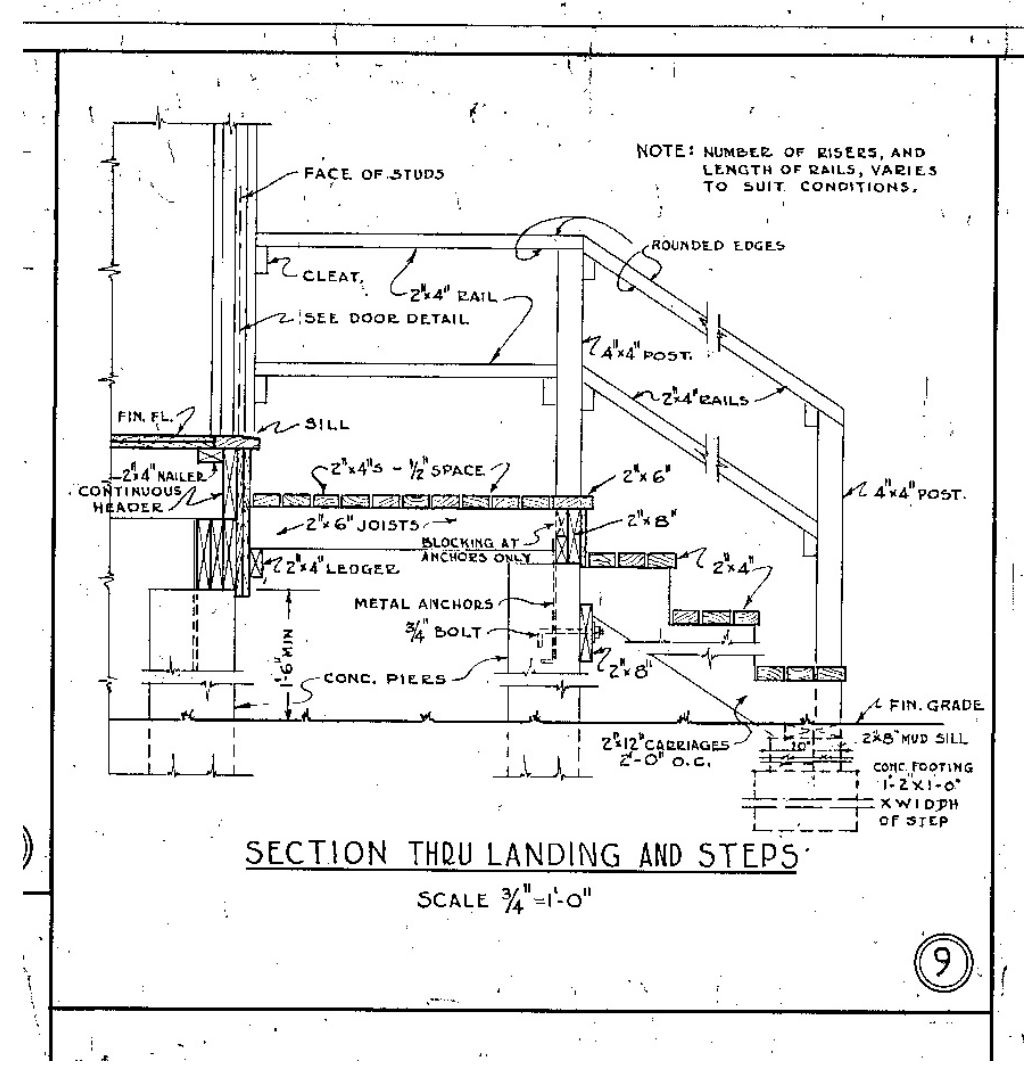

Detail for wood porch stoop and wood handrails used throughout the cantonment on WWII buildings, Drawing 800-176, 1941 (Fort McCoy DPW).

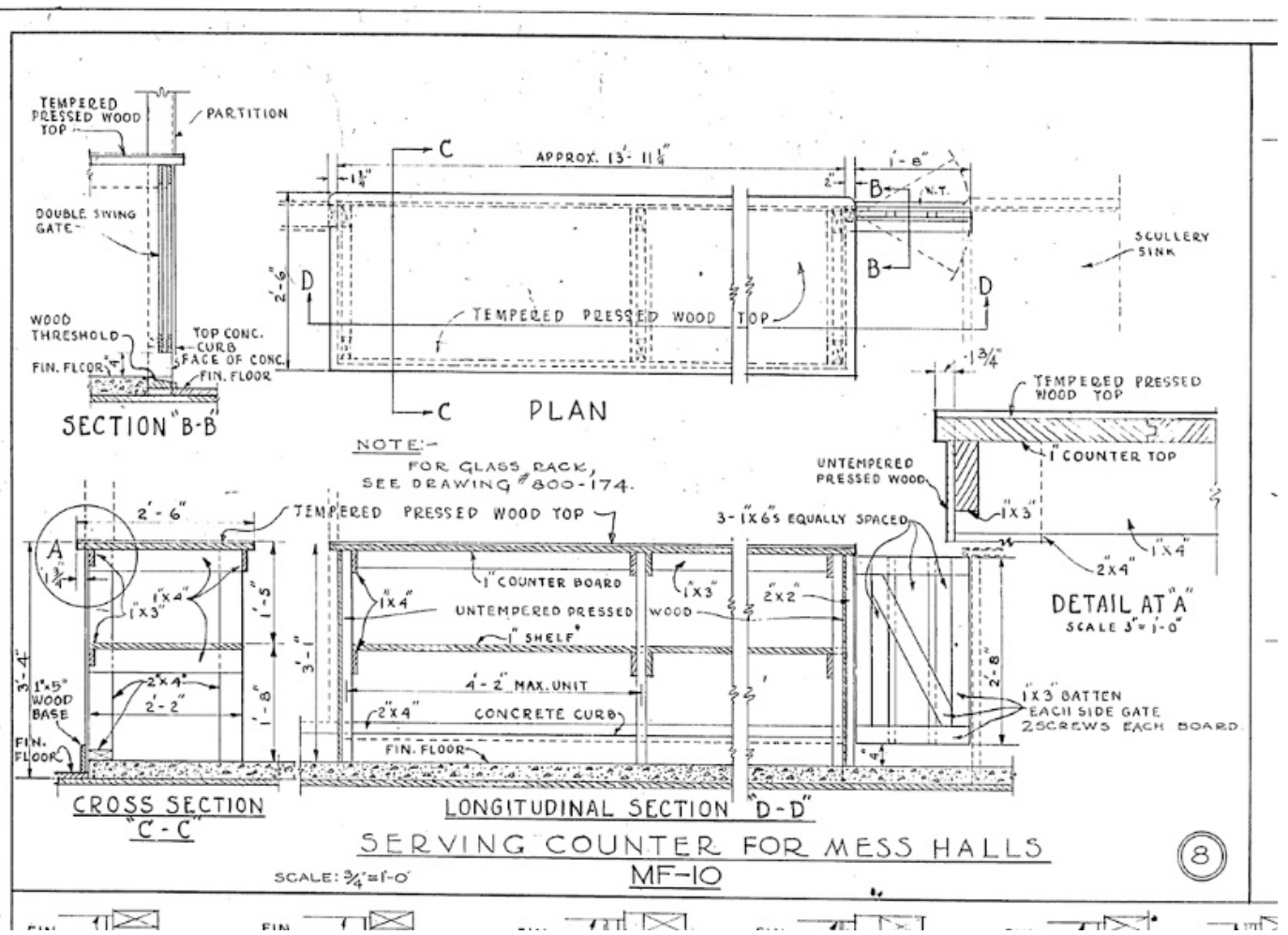

Serving counter details for mess halls, Drawing 800-177, 1941 (Fort McCoy DPW). 


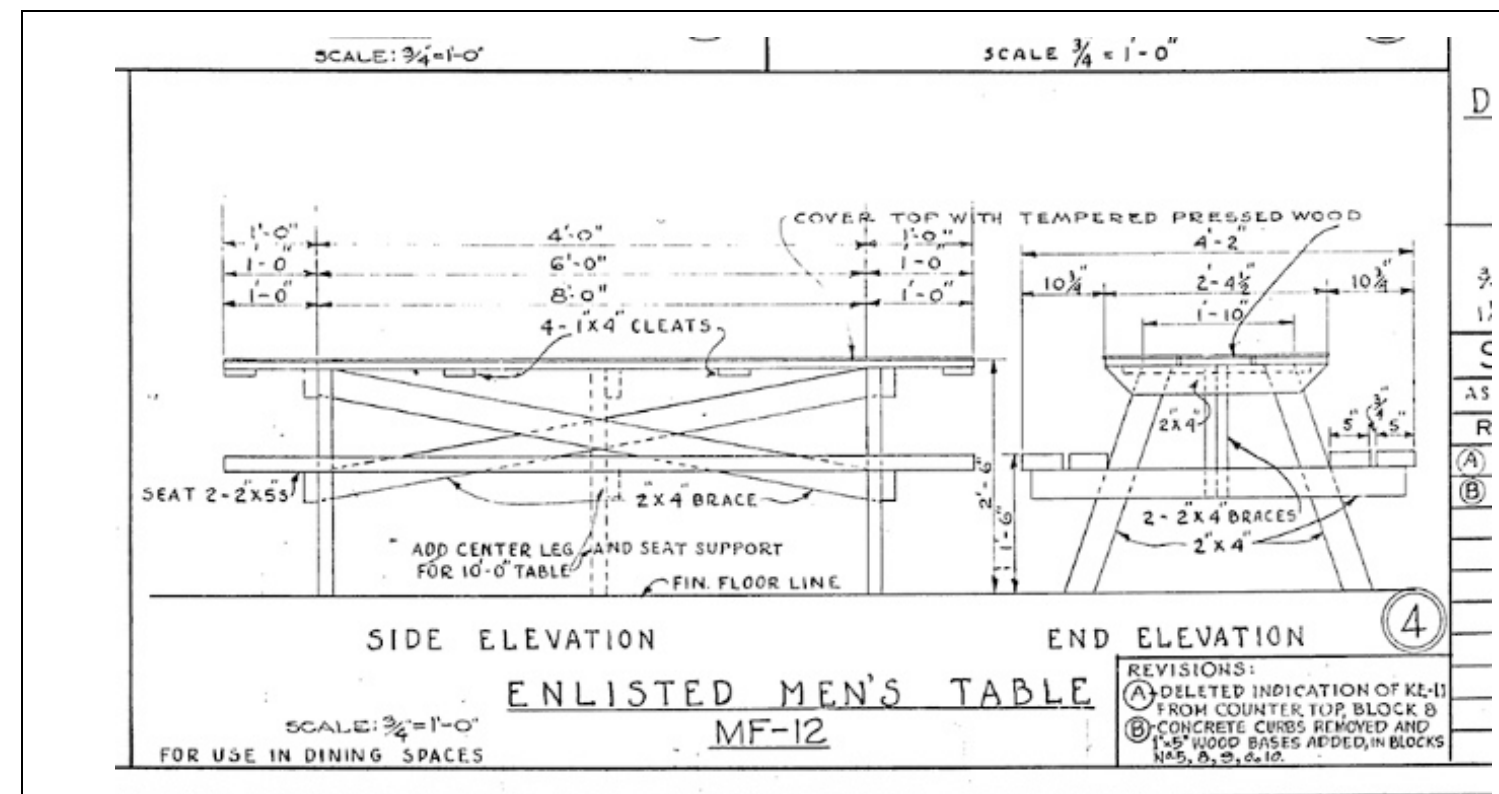

Dining table details for mess halls, Drawing 800-177, 1941 (Fort McCoy DPW).

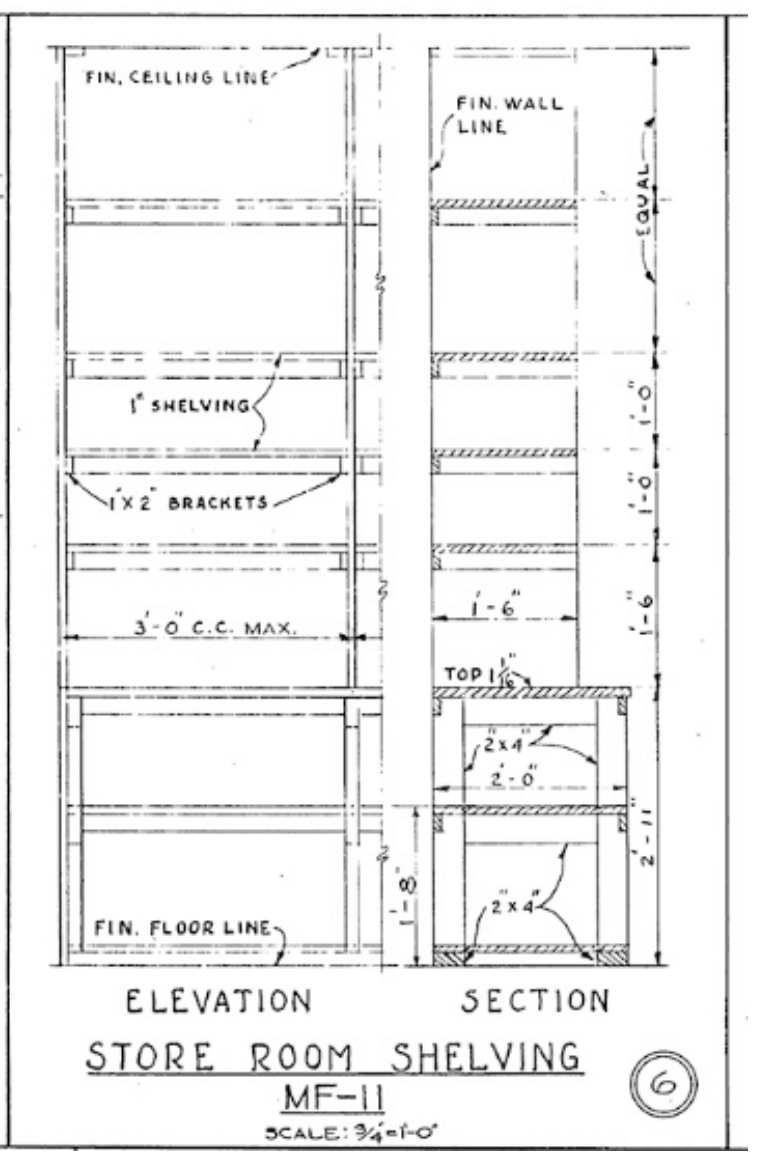

Detail of built-in for the storeroom in the mess halls, Drawing 800-177, 1941 (Fort McCoy DPW). 


\begin{tabular}{|c|c|}
\hline$\frac{\text { PRESENT OWNER }}{\text { Fort McCoy Commander }}$ & $\begin{array}{l}\text { OWNER ADDRESS } \\
\text { Department of the Army } \\
\text { US Army Garrison, Fort McCoy } \\
100 \text { East Headquarters Road } \\
\text { Fort McCoy, WI } 54656\end{array}$ \\
\hline $\begin{array}{l}\text { GENERAL CONDITION OF PROPERTY } \\
\text { EXCELLENT } \\
\text { GOOD }\end{array}$ & $\begin{array}{cc}\text { ADDITIONS/ALTERATIONS } \\
\\
\text { YES } \\
\text { IF YES, SEE HISTORY }\end{array}$ \\
\hline $\begin{array}{l}\text { BIBLIOGRAPHIC SOURCES } \\
\text { HABS No. WI-308-C. "Historic American Building } \\
\text { Sparta vicinity, Monroe County, Wisconsin." (Wash } \\
\text { National Park District, Department of the Interior, } 1 \\
\text { 41-SPAR.V, 1-C-: https://cdn.loc.gov/master/pnp/h } \\
\text { ARCHIVAL SOURCES } \\
\text { NARA, College Park, Maryland } \\
\text { Real Property Record Cards on file at Fort McCoy, } \\
\text { Drawing documentation on file at Fort McCoy, Wisc }\end{array}$ & $\begin{array}{l}\text { s Survey. Fort McCoy, Building T-635 (Mess Hall), } \\
\text { ington, DC: Historic American Buildings Survey, } \\
\text { 988). Catalogued by Library of Congress as HABS WIS, } \\
\text { abshaer/wi/wi0200/wi0263/data/wi0263data.pdf. }\end{array}$ \\
\hline $\begin{array}{ll}\text { ELIGIBLE/ } & \text { NOT ELIGIBLE/ } \\
\text { CONTRIBUTING } & \text { NON-CONTRIBUTING } \\
\square & \end{array}$ & $\begin{array}{l}\text { FORM PREPARED BY: } \\
\text { Sunny Adams } \\
\text { Engineer Research and Development Center } \\
\text { Construction Engineering Research Laboratory } \\
\text { 2902 Newmark Drive } \\
\text { Champaign, IL } 61822 \\
\text { DATE: September } 2018 \\
\end{array}$ \\
\hline \multicolumn{2}{|l|}{ DESCRIPTION } \\
\hline \multicolumn{2}{|c|}{$\begin{array}{l}\text { The } 1600 \text { block is located on the south side of the triangular cantonment layout. South Eleventh Street is to } \\
\text { the north, South J Street is to the east, South Tenth Street is to the south, and South G Street is to the west. } \\
\text { South H and South I Streets cut through the block. The } 1600 \text { battalion block consists of } 30 \text { barracks, four } \\
\text { company storehouse/administration/recreation buildings (currently being used as general instruction } \\
\text { buildings), and eight mess halls (four still being used as mess halls and four being used as classroom } \\
\text { building). Buildings } 1605 \text { and } 1606 \text { are adjacent each other, while Buildings } 1638 \text { and } 1639 \text { are adjacent each } \\
\text { other. } \\
\text { The buildings have an L-shaped footprint due to the construction of an addition off of one long side } \\
\text { elevation. The appendage was built to include restrooms and storage areas for the building when it was } \\
\text { converted into classrooms. The buildings have a cross-gable roof clad with asphalt shingles and metal fascia } \\
\text { and soffit. The exterior walls are clad with vinyl siding. The windows are replacement one-over-one vinyl } \\
\text { windows and the doors are replacement metal with a narrow light. All elevated entries are accessed by a set } \\
\text { of metal steps with metal handrails. The original rectangular portion of the building has a concrete pier } \\
\text { foundation system with replacement wood foundation skirting. }\end{array}$} \\
\hline & 1 \\
\hline
\end{tabular}


The north elevation consists of eight replacement windows (see Photo 3). The left side of the west elevation is the original portion of the building and the recessed right is where the appendage is located (see Photo 4). This elevation is void of any fenestration. The south elevation is where the appendage is located and projects off the middle of the original south wall (see Photos 4 and 5). There is one replacement elevated door on the left side of the original portion of the building and one replacement elevated door on the right side of the original portion of the building. There are two metal doors on the south elevation of the appendage.

Building 1606: The east elevation (former kitchen area) faces South H Street. The left side of the elevation is the original portion of the building and the recessed right side is where the appendage was added (see Photo 6). There is a replacement elevated entry door on the east elevation of the appendage. The north elevation is where the appendage is located and projects off the middle of the original north wall. There is one replacement elevated door on the left side of the original portion of the building and one replacement elevated door on the right side of the original portion of the building. There are two metal doors on the north elevation of the appendage (see Photo 7). The right side of the west elevation is the original portion of the building and the recessed left is where the appendage is located. This elevation is void of any fenestration. The south elevation has eight replacement windows (see Photo 8).

Buildings 1638 and 1639: The west elevation (former kitchen area) faces South H Street. The left side of the elevation is the original portion of the building and the recessed right side is where the appendage was added. There is a replacement elevated entry door on the west elevation of the appendage. The north elevation consists of eight replacement windows. The right side of the east elevation is the original portion of the building and the recessed left is where the appendage is located. This elevation is void of any fenestration. The south elevation is where the appendage is located and projects off the middle of the original south wall. There is one replacement elevated door on the left side of the original portion of the building and one replacement elevated door on the right side of the original portion of the building. There are two metal doors on the south elevation of the appendage.

The interior of all four buildings has been completely remodeled and nothing of the original layout and finishing materials exists (see Photos 12 and 13). All new materials including drywall, flooring, partition walls, drop-ceilings, lighting, doors, and window trim have replaced the original.

\section{HISTORY (excerpt taken from the HABS Data Sheet)}

Typical blocks within the general layout were based both on military organizational requirements and city planning principles. Each block was to be occupied by a battalion of troops. Two blocks comprised a regiment. Within a block were size to seven companies, depending on the type of battalion involved. Along each street in a block were four mess halls at center, and ten or more barracks, with a company usually occupying three barracks and eating in one of the mess halls. To the rear of the barracks, at either end of each street were company administration buildings, one for each company.

Architecturally, this type of mess was one of five variations available in the 800 Series of standard plans for mess halls. Buildings 1605, 1606, 1638, and 1639 were four of 172 mess halls erected in 1942 using Standard War Department Drawing 800-851 prepared for the construction of a 228-Man mess hall.

\section{Exterior:}

Over-all dimensions: The mess halls are rectangular in shape and are $25^{\prime}-0 "$ wide and $118^{\prime}-0^{\prime}$ long with an approximate area of 2,950 square feet. The buildings are one story, and the height from grade to the roof ridge is approximately $15^{\prime}$.

Foundation: The foundations of the mess halls were concrete piers. The crawl space below each building was screened by a wooden skirting composed of vertical boards.

Walls: The exterior walls consisted of three layers: (a) wooden sheathing, (b) black construction paper, and (c) siding composed of cement asbestos pieces measuring 11" x 24", the standard size used throughout the cantonment. The siding pieces had a scalloped bottom edge detail. The one-story buildings erected from the 800 Series standard plans are of balloon construction.

Roof: The roofs were low-pitched gables clad red asphalt shingles. The overhanging eaves had wood fascia and soffit. 
Chimney: There was no brick chimney stack. There were three large circular metal vent stacks that projected from the slope of the roof over the kitchen area where the range was located.

Porches, stoops: The original drawing version of standard Plan 800-851 shows wooden stairs and porches at each of the four entries on the exterior of the mess halls.

Windows: There were two types of standard 800 window designs used in the mess halls. Type "A," measuring 4'-6" x 3'-4 5/16" was located near the kitchen and storeroom. Type "B," measuring 5'-2" x 3'-4 5/16" was placed along the dining room section of the halls. The kitchen and storeroom windows were set higher in the walls and are shorter than the dining room windows. Both types of windows followed the same standard design: eight-over-eight light, double-hung sash, constructed of wood with a simple wooden architrave. Wood-frame screens were placed over each window.

Doors: The doors of the mess halls are wider than other doors found in the 800 Series. Two sizes of doors were used on the mess halls. Standard door type "BBB," measuring 7'-0" x 3'-0" was installed in the entry to the storeroom. Standard door type "P," measuring 8'-0" x 3'-2", was used in the three doorways leading into the dining room. The door designs were all of the standard type used at Camp McCoy; four lights over three horizontal recessed panels. The standard simple doorway surround was used for all entries. Standard screen doors, composed of wooden frames and wire mesh screens were placed at the entry doors.

\section{Interior:}

Floor plan: The interior of the buildings depicted the activities carried on in all 172 mess halls at Camp McCoy; a dining room in one half, in which the troops sat at tables, and a kitchen and storeroom in the other half, where foot was prepared, served, and stored. During WWII, the enlisted men assigned to each mess hall entered the dining room through the exterior doorways. They received their food at the serving counter between the mess hall section and the kitchen and ate at standard issue tables placed in rows. Through an opening in the counter was the kitchen, where the cooks and "K.P." staff prepared the food and cleaned up following each meal. They stored foodstuffs on shelves in the storeroom and placed perishable items in the large cooler. The kitchen staff entered and exited the mess hall through the rear of the building.

Flooring: Originally, there were softwood floors in the dining rooms of all the mess halls erected at Camp McCoy, laid on foundations of construction paper and wooden sub-flooring. Following WWII, linoleum tile was installed in apparently all of the dining room in the cantonment. There are two 5'-0" x 4'-6" concrete platforms in the mess section of the buildings. These were intended for Cannon Stoves that originally heated the room. The kitchen and storeroom had concrete floors.

Walls and ceiling finishes: In the dining room, there was a wainscoting of manufactured board, called "tempered pressed wood" in the standard plans that was used on the bottom three feet of the walls.

"Insulation board" was used on the upper six feet of the walls above the wainscoting. The ceiling was insulation board. Pairs of exposed structural knee braces ran between the upper walls into the attic between each bay. In the kitchen, there was 6'-0" high wainscoting composed of pressed wood. Insulation board was installed above the wainscoting. A fourteen foot wide ceramic tile surface was used along the kitchen wall to provide fireproof backing for the cooking ranges. The storeroom walls were composed of standard-sized 5-1/4" wide tongue and groove boards nailed horizontally across the studs. On three of the walls were built-in shelves and counters. The ceiling in the storeroom was composed of insulation board.

Doors: There was one interior door located between the kitchen and the storeroom and it was standard type "L-I," consisting of five horizontal recessed panels.

Windows: The same, simple board architraves found in the barracks and company storehouse, administration, and recreation buildings framed the interior mess hall windows.

Lighting: The original light fixtures in the dining room were metal-shade screwed onto porcelain sockets attached to the ceiling.

Original furnishings: Wooden tables and benches were used in the dining room. A work/prep table stood in the center of the kitchen. A serving counter placed on top of partition walls between the kitchen and dining room had a pressed-board top. There were two detached "scullery sinks" made of galvanized steel and both consisting of double sinks, and side counters were located in the kitchen. Also in the one corner of the kitchen was a 6'-0" high wooden pie safe. 
In 1951, two vestibule additions were constructed at the two side entries into the dining area.

At an unknown date, but prior to 1985 (according to drawing documentation), the original wood porch stoops and wood handrails were removed and replaced with concrete stoops and cast-iron metal handrails.

In 2003, the original construction materials such as the cement asbestos siding, multi-pane wood doublehung windows, wood panel and divided light entry doors, exterior light fixtures, wooden foundation skirting, and wood porch stoops and wood handrails were all removed and replaced with newer materials and finishes. The window and door patterns were modified at this time. Buildings 1605, 1606, 1638, and 1639 were changed into classrooms prior to 2003. Each of the classroom buildings has a large addition housing latrines. The construction of the addition altered the original rectangular footprint to an L-shaped footprint.

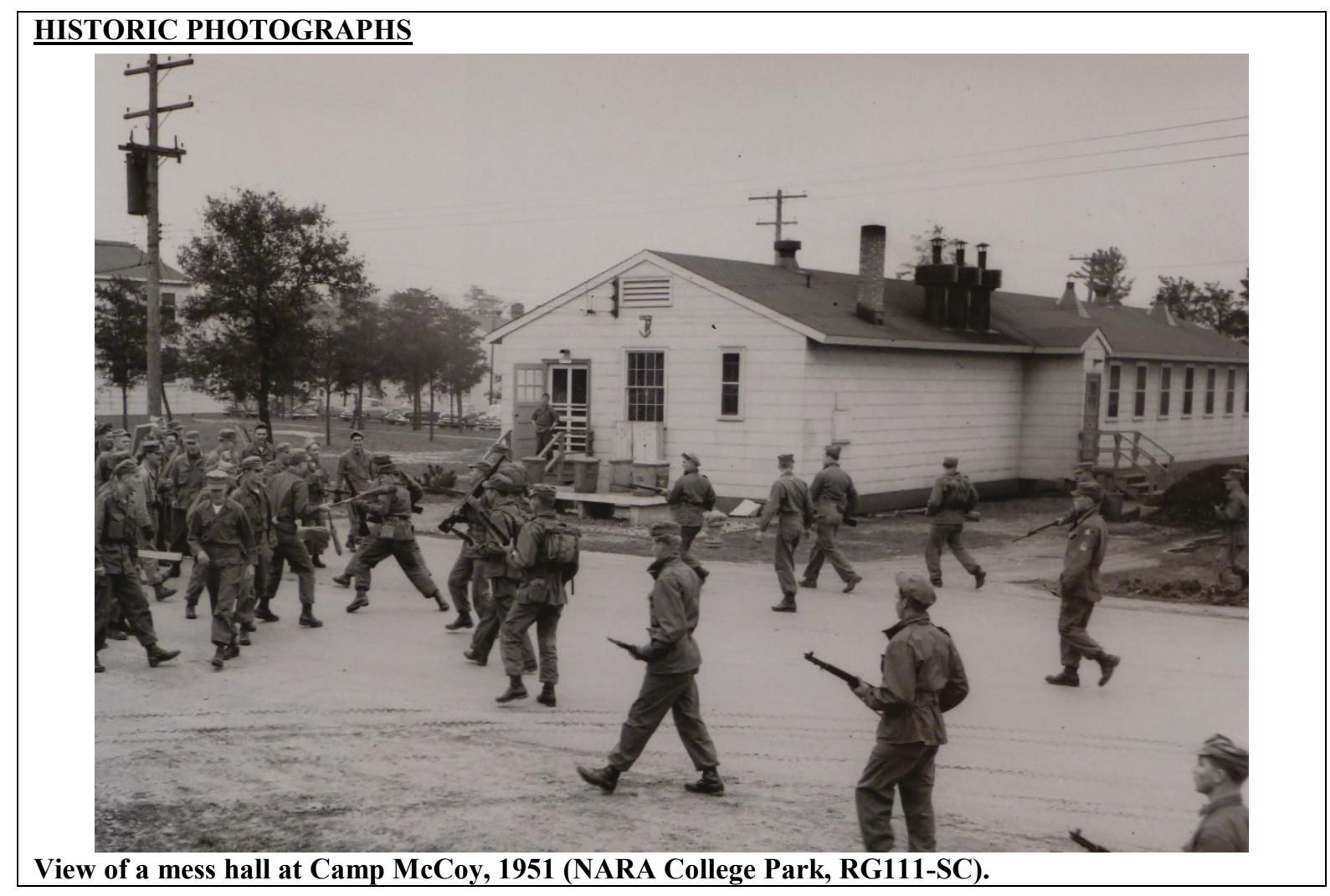




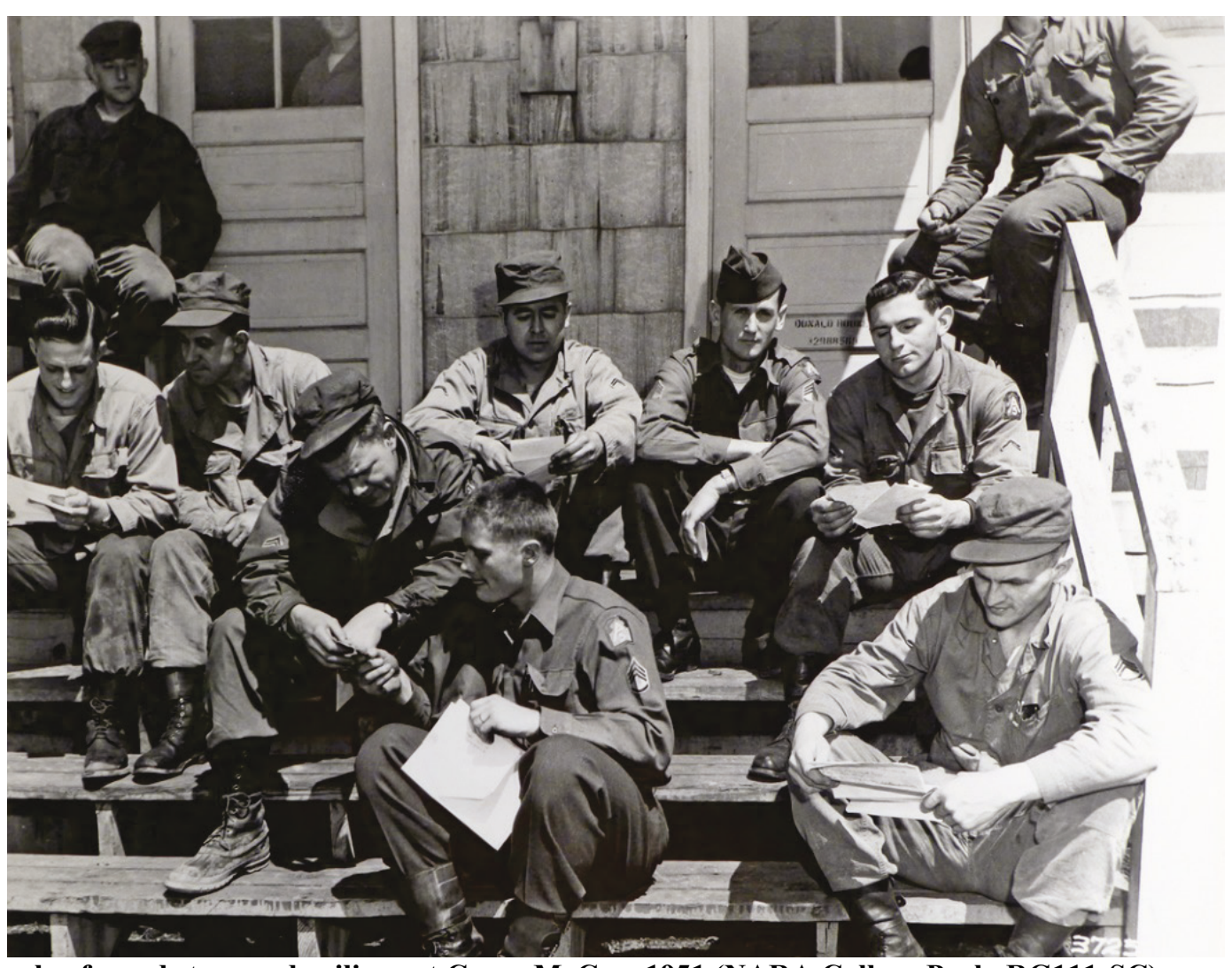

Example of wood steps and railings at Camp McCoy, 1951 (NARA College Park, RG111-SC).

\section{HABS PHOTOGRAPHS}

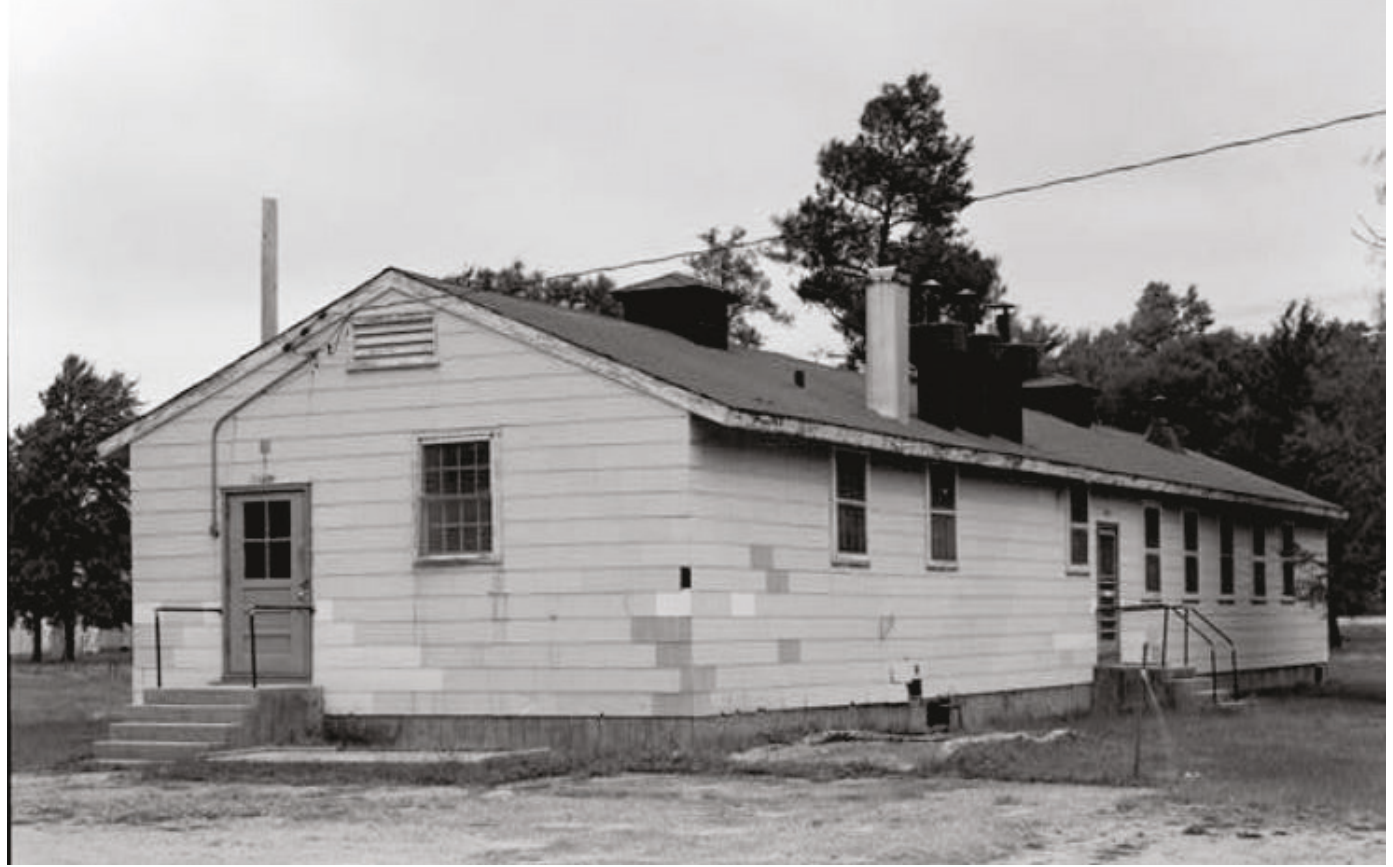

Perspective view of the rear (kitchen and storehouse entry) and side elevations of Building 635, Mess Hall, September 1988 (Library of Congress, HABS WIS,41-SPAR.V,1-C-2). 


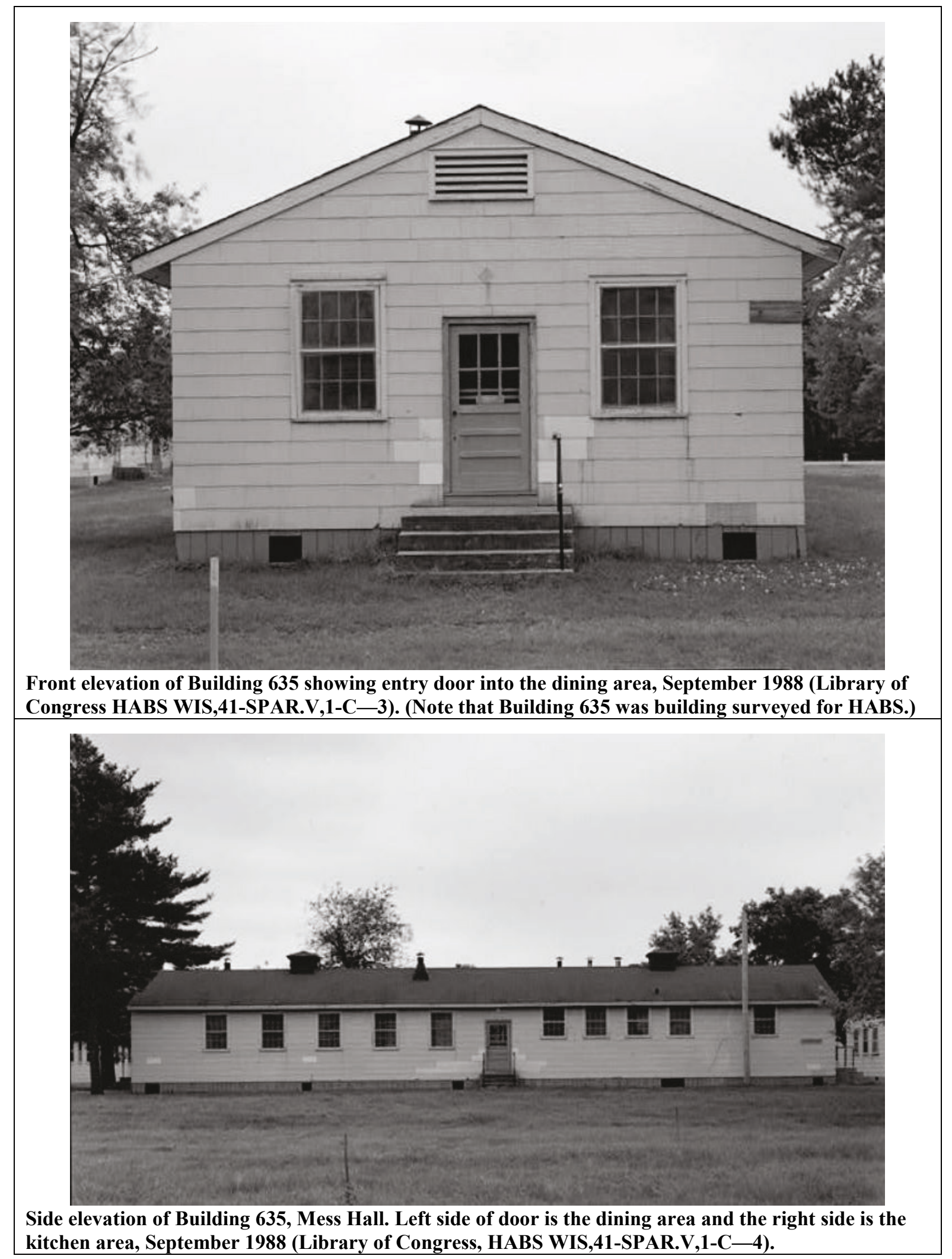




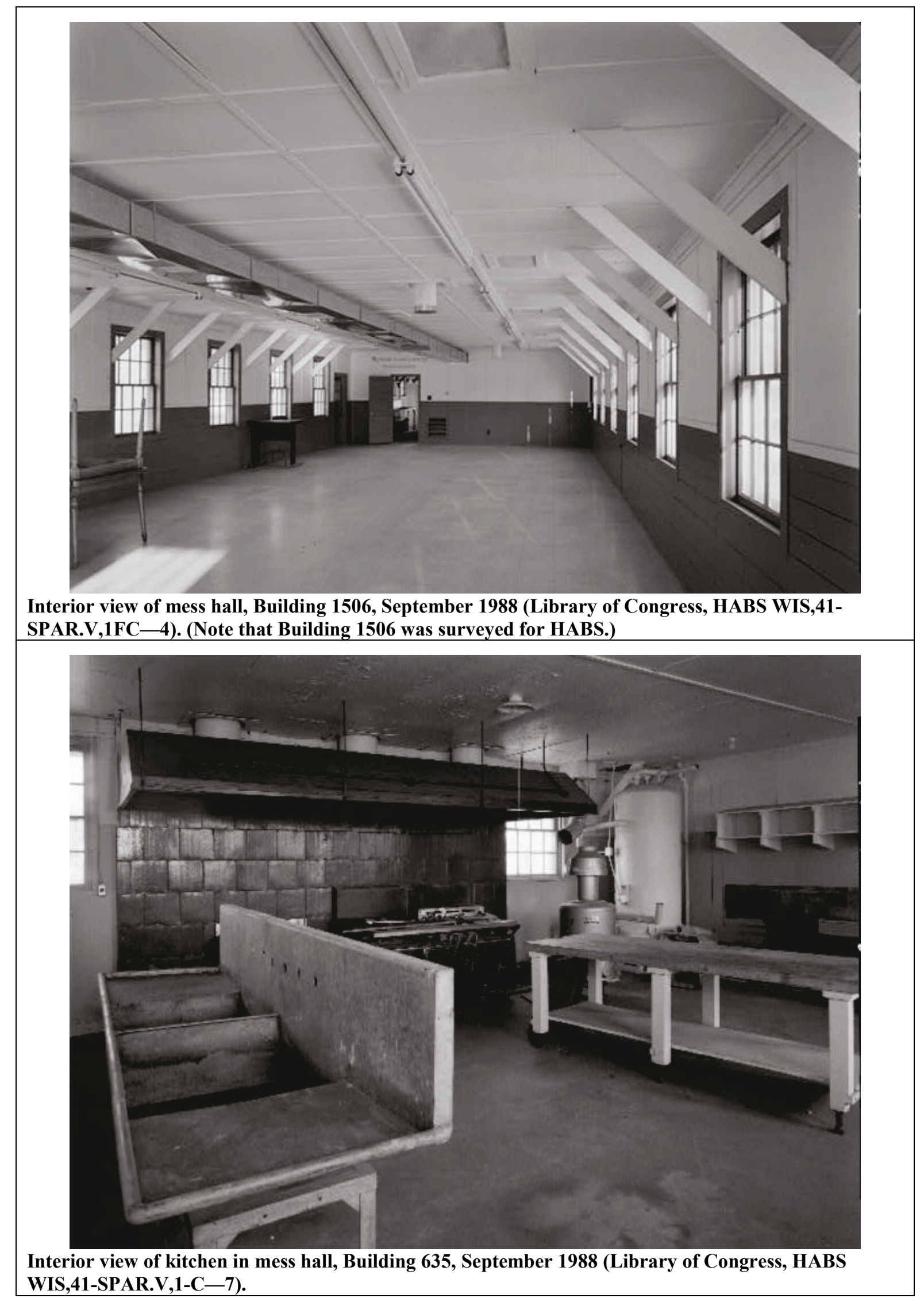




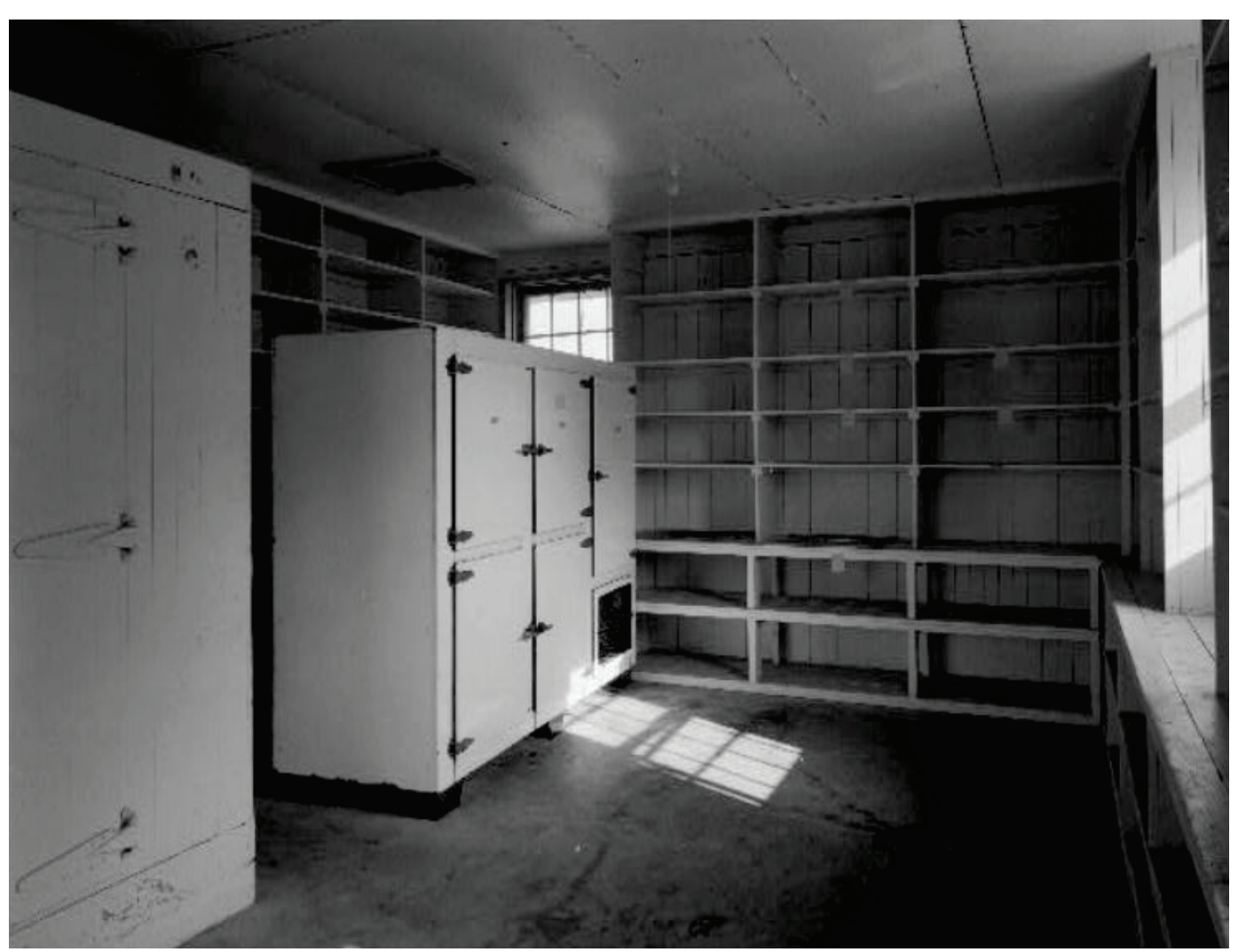

Interior view of the storeroom in Building 635, Mess Hall, September 1988 (Library of Congress, HABS WIS,41-SPAR.V,1-C-8).

\section{CHARACTER-DEFINING FEATURES}

- One-story massing

- Rectangular footprint (modified with construction of an appendage that houses restrooms and storage)

- Front gable roof clad with red asphalt shingles (replaced roof in-kind)

- Overhanging eaves with wood fascia and soffit (modified with metal soffits)

- Textured cement asbestos siding with a scalloped bottom edge detail (replaced with vinyl siding)

- Concrete pier foundation with wooden foundation skirting (replaced)

- Window pattern (modified)

- Multi-pane wood double-hung windows, two different types (replaced with one-over vinyl windows)

- Wood trim, surround, and profile of windows (removed)

- Wood panel and divided light doors (replaced with newer metal doors)

- Wood porch stoop and handrails (removed and replaced with concrete stoop and metal handrails)

- Three large, circular, metal roof vents for ventilation of the kitchen ranges (removed)

- Room arrangement (modified with partition walls)

- Wood floor in dining room (covered with newer materials)

- Concrete floor in kitchen and storeroom (covered with newer materials)

- Serving counter, scullery sinks, pie rack, glazed tile wall, and ranges in kitchen area (all removed)

- Built-in cabinets and shelves in storeroom (removed)

- Pressed wood and insulation board clad walls (covered with drywall)and ceilings (replaced with drop ceiling) throughout

- Wood 5-panel interior doors (replaced with metal doors)

- Simple architrave around windows on interior (replaced by vinyl)

- Interior light fixtures (replaced with newer fixtures) 


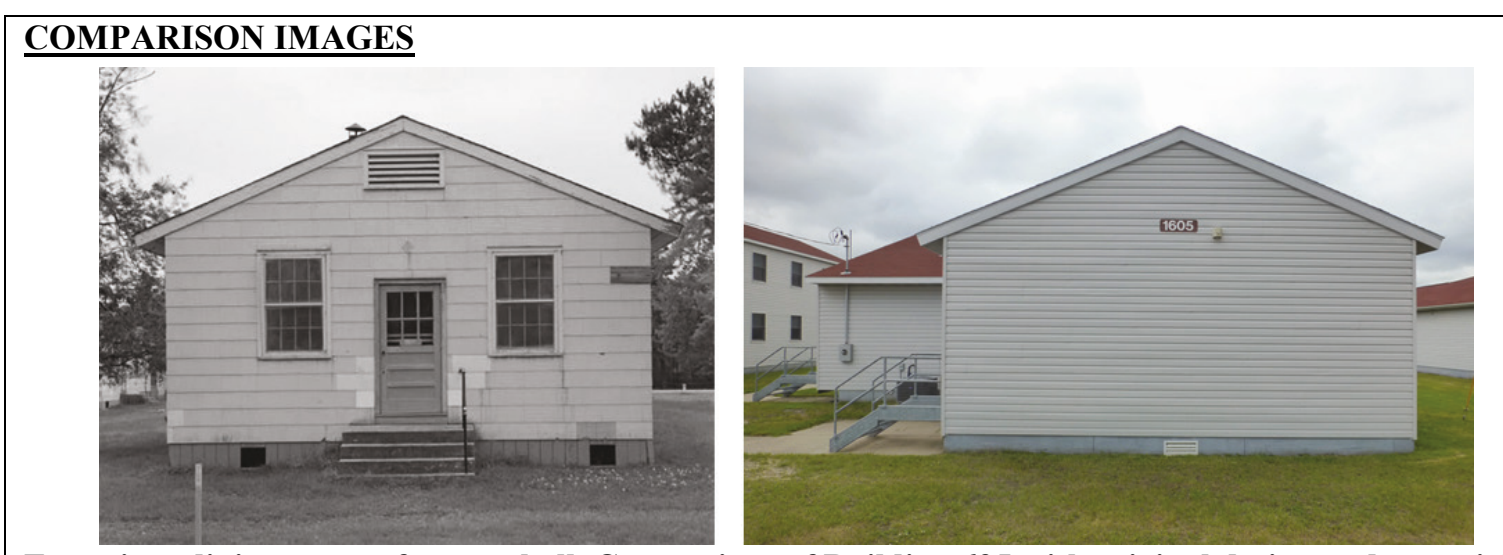

Entry into dining room of a mess hall. Comparison of Building 635 with original design and materials (left) compared to the current condition of Buildings 1605, 1606, 1638, and 1639 (left: Library of Congress, 1988 HABS; right: ERDC-CERL, 2018).
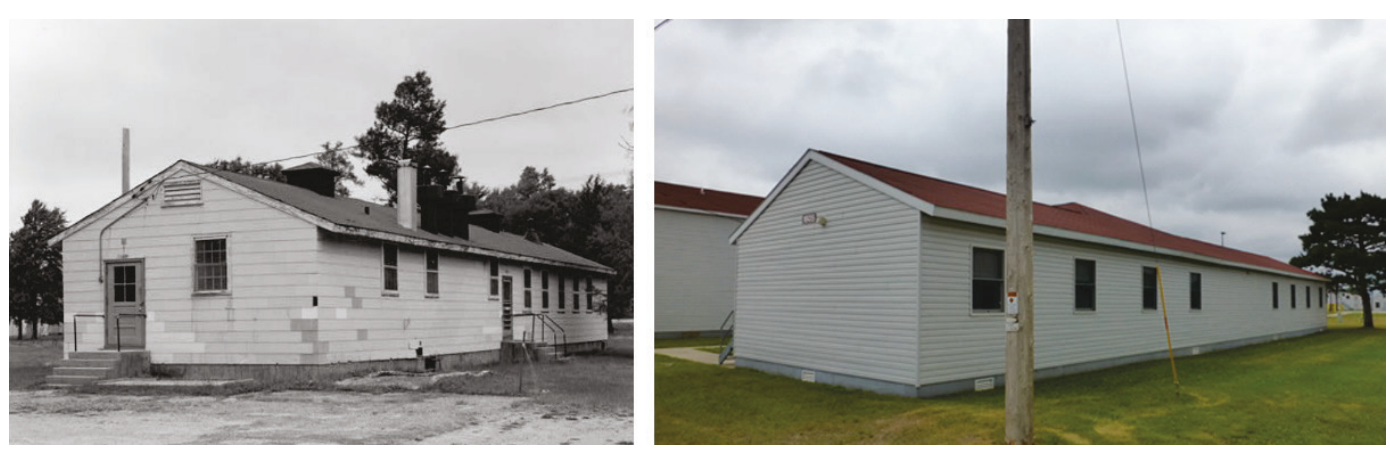

Entry into kitchen area and long-side elevation comparison between the original design and materials (left) to the current condition of Buildings 1605, 1606, 1638, and 1639 (left: Library of Congress, 1988 HABS; right: ERDC-CERL, 2018).
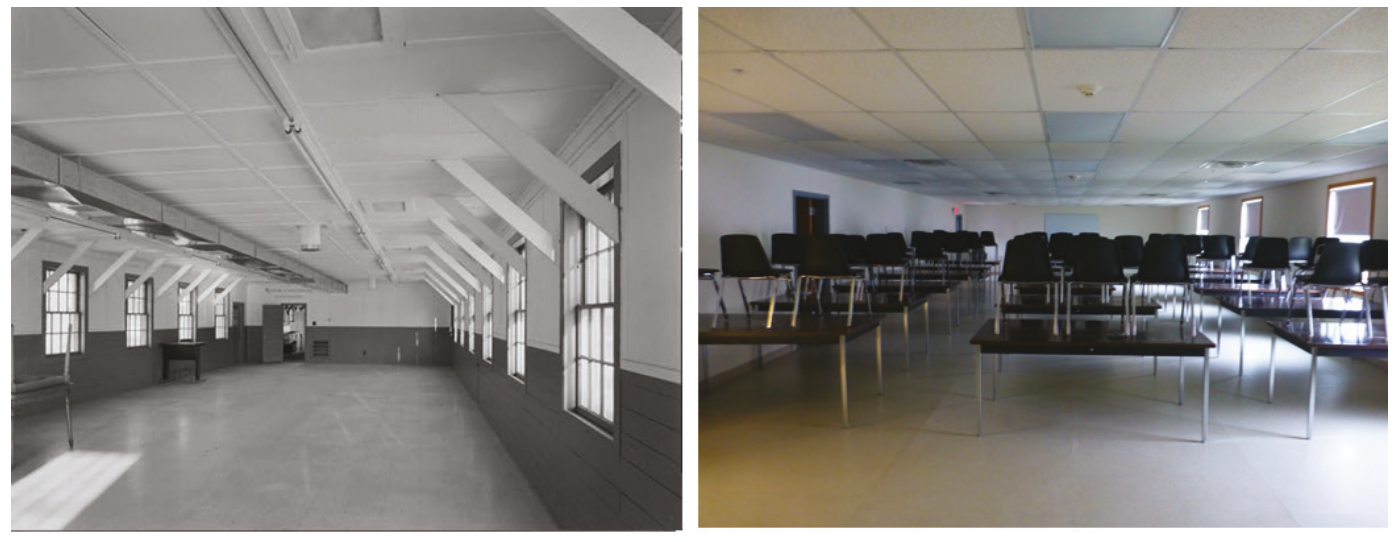

Interior view comparison of the dining room of a mess hall on the left and its interior retrofitted into a classroom on the right (left: Library of Congress, 1988 HABS; right: ERDC-CERL, 2018). 


\section{SIGNIFICANCE}

The 800 Series (and the 700 Series that preceded it) were a comprehensive set of drawings which could be used interchangeably in creating the various building types. War mobilization buildings are significant for their construction and technological innovation. Techniques such as the standardization of plans, prefabrication of units, and assembly-line approach to construction were largely pioneered during construction of these mobilization structures.

The temporary wood buildings constructed with the 700 Series or 800 Series on Fort McCoy during World War II (WWII) between 1939 and 1946 were determined significant for the National Register of Historic Places (NRHP) in 1986 when the Programmatic Memorandum of Agreement (PMOA) was signed between the Department of Defense (DoD), the Advisory Council on Historic Preservation (ACHP), and the National Council of State Historic Preservation Officers (NCSHPO). In the early 1990s, this significance was reaffirmed by the writing of "World War II and the U.S. Army Mobilization Program: A History of 700 and 800 Series Cantonment Construction" and performance of a Historic American Buildings Survey (HABS) on a variety of the 700 and 800 Series planned buildings across the country. Many of the 800 Series of buildings at Fort McCoy were utilized for the HABS.

Buildings 1605, 1606, 1638, and 1639, Mess Hall, WWII temporary buildings, are significant under Criterion A for WWII temporary building construction (1939-1946).

The design and construction of the WWII temporary buildings could not be linked to a specific architect due to their construction from standardized War Department temporary building plans. They do not possess high artistic values; however, WWII temporary buildings in general were found to be significant for their design, construction, and technological innovation under Criterion $\mathrm{C}$.

\section{INTEGRITY}

Location - All four WWII buildings retain their integrity of location.

Design - All four buildings retain the key elements of their WWII design.

Setting - All four WWII buildings retain their integrity of setting.

Materials - None of the four buildings retain their integrity. Each building has been completely modified with newer materials. No original material elements are intact.

Workmanship - Workmanship is not part of integrity for WWII temporary buildings.

Feeling - All four buildings do not retain their integrity of feeling. They have all been heavily modified with modern materials.

Association - All four buildings retain their integrity of association.

\section{RECOMMENDATION OF CONTRIBUTING/NONCONTRIBUTING STATUS}

It is the recommendation of this report that Buildings 1605, 1606, 1638, and 1639 are NOT Eligible for the NRHP at the national level due to the lack of integrity from changes in floor plan, changes in siding, changes in window pattern and type, and changes in doors. 
1600 Block - Mess Halls

\begin{tabular}{|c|c|c|c|}
\hline \multicolumn{4}{|c|}{$\begin{array}{c}\text { FORT McCOY } \\
\text { HISTORIC PROPERTY INVENTORY FORM }\end{array}$} \\
\hline $\begin{array}{l}\text { PROPERTY BOUNDARIES } \\
\text { - Fort McCoy in the } 1600 \text { block } \\
\text { area on the south side of the } \\
\text { triangular cantonment plan } \\
\text { - Sparta vicinity } \\
\text { - Monroe County, Wisconsin }\end{array}$ & \multicolumn{2}{|l|}{$\begin{array}{l}\text { COMMON/HISTORIC NAME } \\
\text { - Building } 1616 \\
\text { - Dining Facility } \\
\text { - 228-Man Mess Hall } \\
\text { - Building 1617 } \\
\text { - Dining Facility } \\
\text { - 228-Man Mess Hall } \\
\text { - Building 1626 } \\
\text { - Dining Facility } \\
\text { - 228-Man Mess Hall } \\
\text { - Building 1627 } \\
\text { - Dining Facility } \\
\text { - 228-Man Mess Hall }\end{array}$} & $\frac{\text { STATUS }}{\text { Usable }}$ \\
\hline $\begin{array}{l}\text { ARCHITECT/BUILDER } \\
\text { Construction Division, Office of } \\
\text { the Quartermaster General } \\
\text { - Series } 800-851\end{array}$ & $\begin{array}{l}\text { DATE OF CONSTRUCTION } \\
1942 \\
\text { DATE OF ALTERATIONS } \\
1953 \text { - added enclosed side } \\
\text { entries with vestibules } \\
2003 \text { - upgraded windows and } \\
\text { doors } \\
2008 \text { - buildings that were next } \\
\text { to each other were joined by a } \\
\text { hyphen }(1617 / 1617 \text { and } \\
1626 / 1627) \\
\text { Unknown - added vinyl siding } \\
\text { to exterior, removed original } \\
\text { wood steps and handrails, } \\
\text { remodeled interior }\end{array}$ & $\frac{\text { NO. OF }}{\frac{\text { STORIES }}{1}}$ & $\frac{\text { FOOTPRINT }}{\text { U-shaped }}$ \\
\hline$\frac{\text { ROOF FORM }}{\text { Cross-gable }}$ & $\begin{array}{l}\text { FOUNDATION } \\
\text { Concrete pier (original) } \\
\text { Poured concrete slab (addition) }\end{array}$ & $\begin{array}{l}\text { WALLS } \\
\text { Wood structure } \\
\text { frame clad with } \\
\text { vinyl siding }\end{array}$ & $\begin{array}{l}\text { ROOF } \\
\text { Asphalt } \\
\text { shingles }\end{array}$ \\
\hline HISTORIC USE(S) & $\frac{\text { FUNCTION }}{\text { CURRENT USE }}$ & \multirow{2}{*}{\multicolumn{2}{|c|}{$\frac{\text { NOTABLE FEATURES }}{\text { - None }}$}} \\
\hline Mess Hall & Dining Hall & & \\
\hline
\end{tabular}




\section{RELATIONSHIP TO OTHER BUILDINGS}

The 1600 block is located on the south side of the triangular cantonment layout. South Eleventh Street is to the north, South J Street is to the east, South Tenth Street is to the south, and South G Street is to the west. South H and South I Streets cut through the block. The 1600 battalion block consists of 30 barracks, four company storehouse/administration/recreation buildings (currently being used as general instruction buildings), and eight mess halls (four still being used as mess halls and four being used as classroom buildings). Buildings 1616 and 1617 are connected to each other, and Buildings 1626 and 1627 are connected to each other.

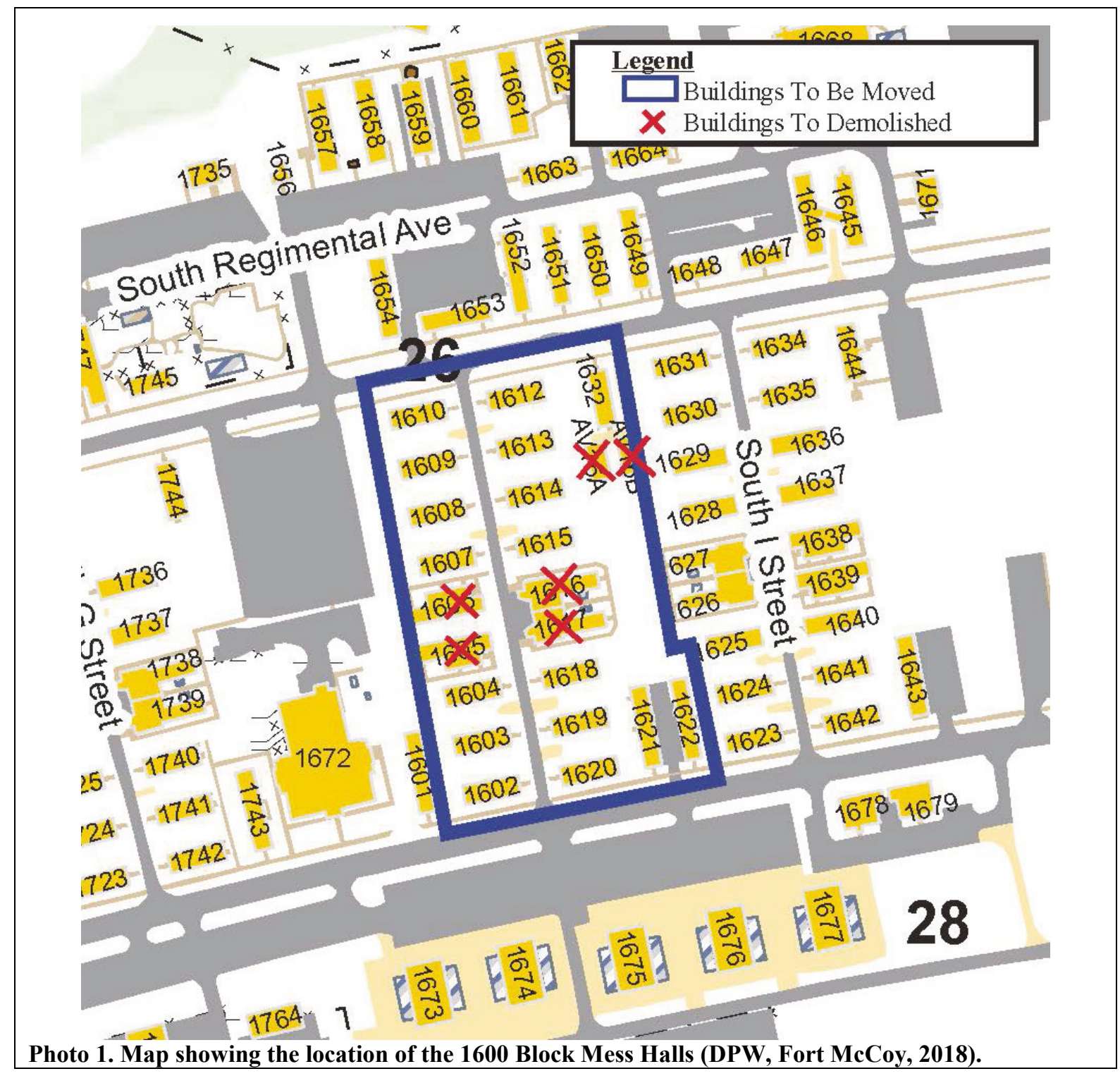




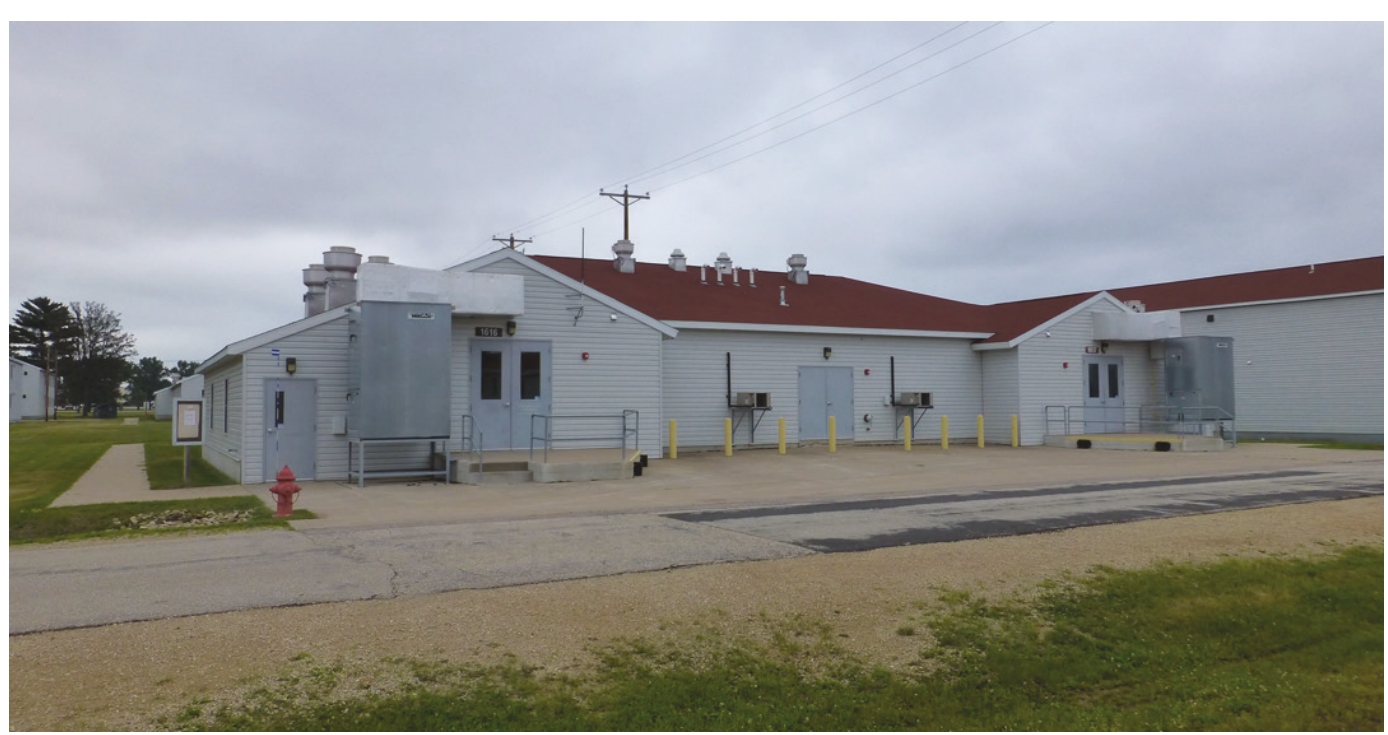

Photo 2. West elevation of Buildings 1616 (left) and 1617 (right) (ERDC-CERL, 2018).

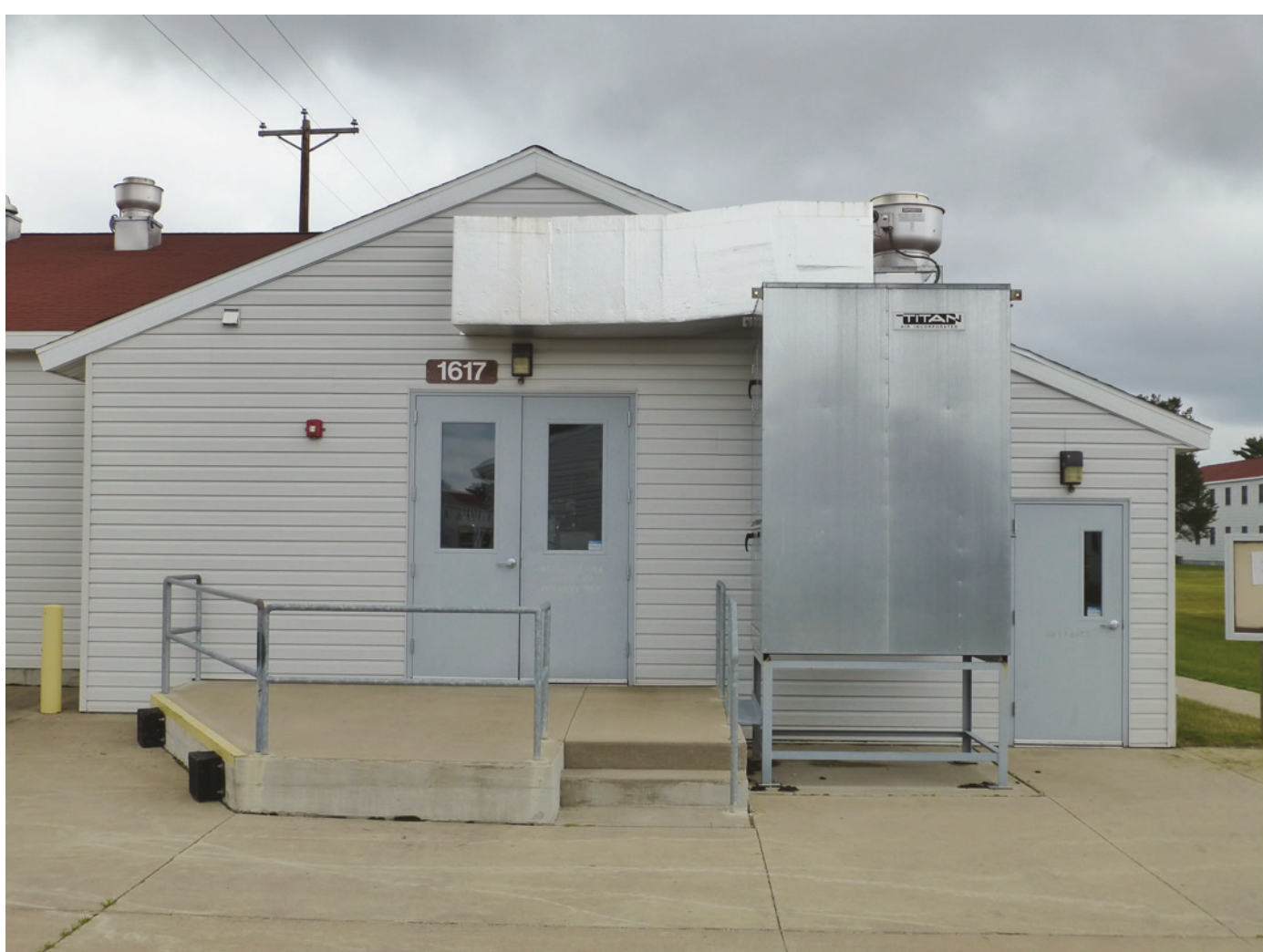

Photo 3. West elevation of Building 1617 (ERDC-CERL, 2018). 


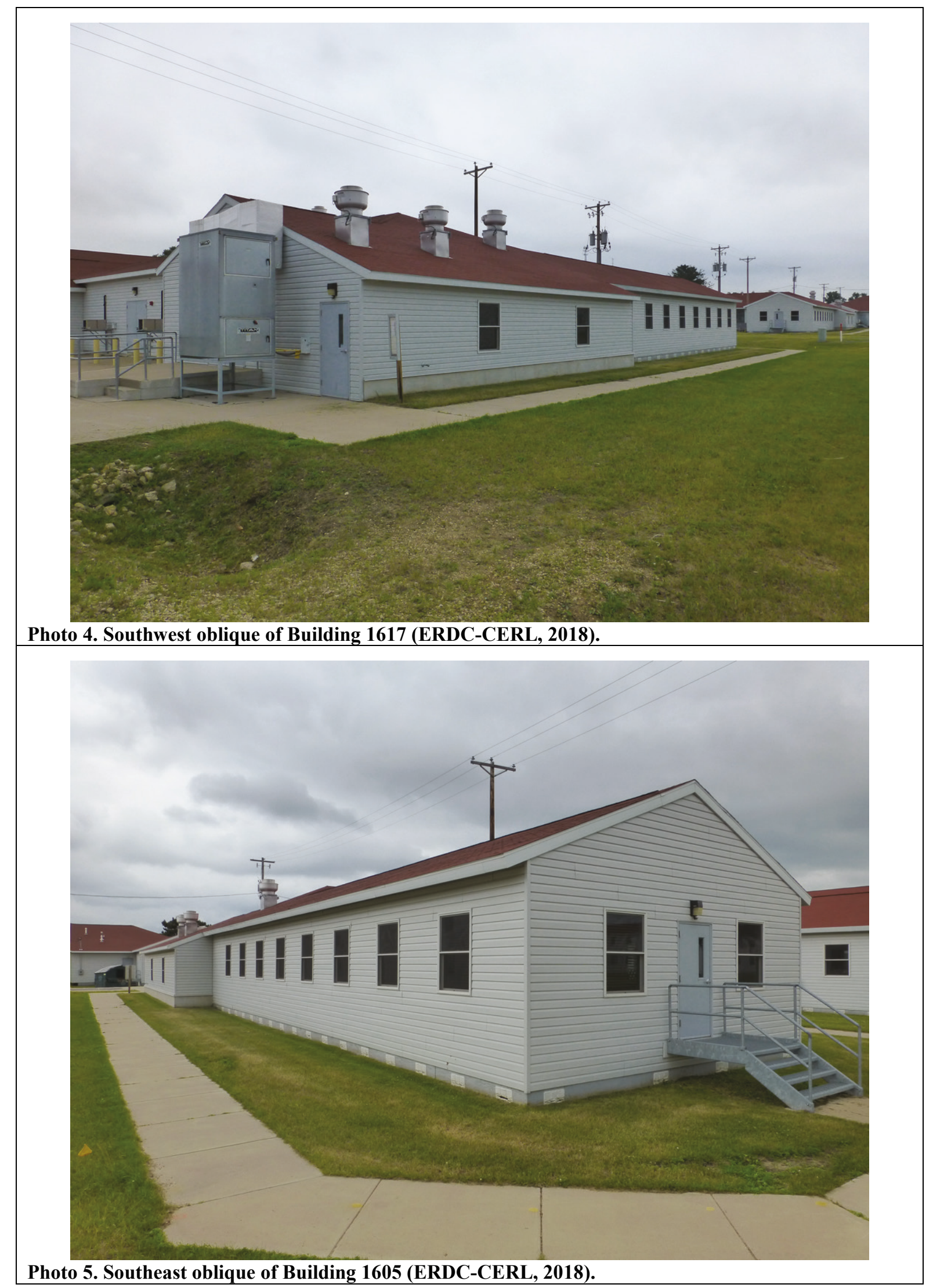




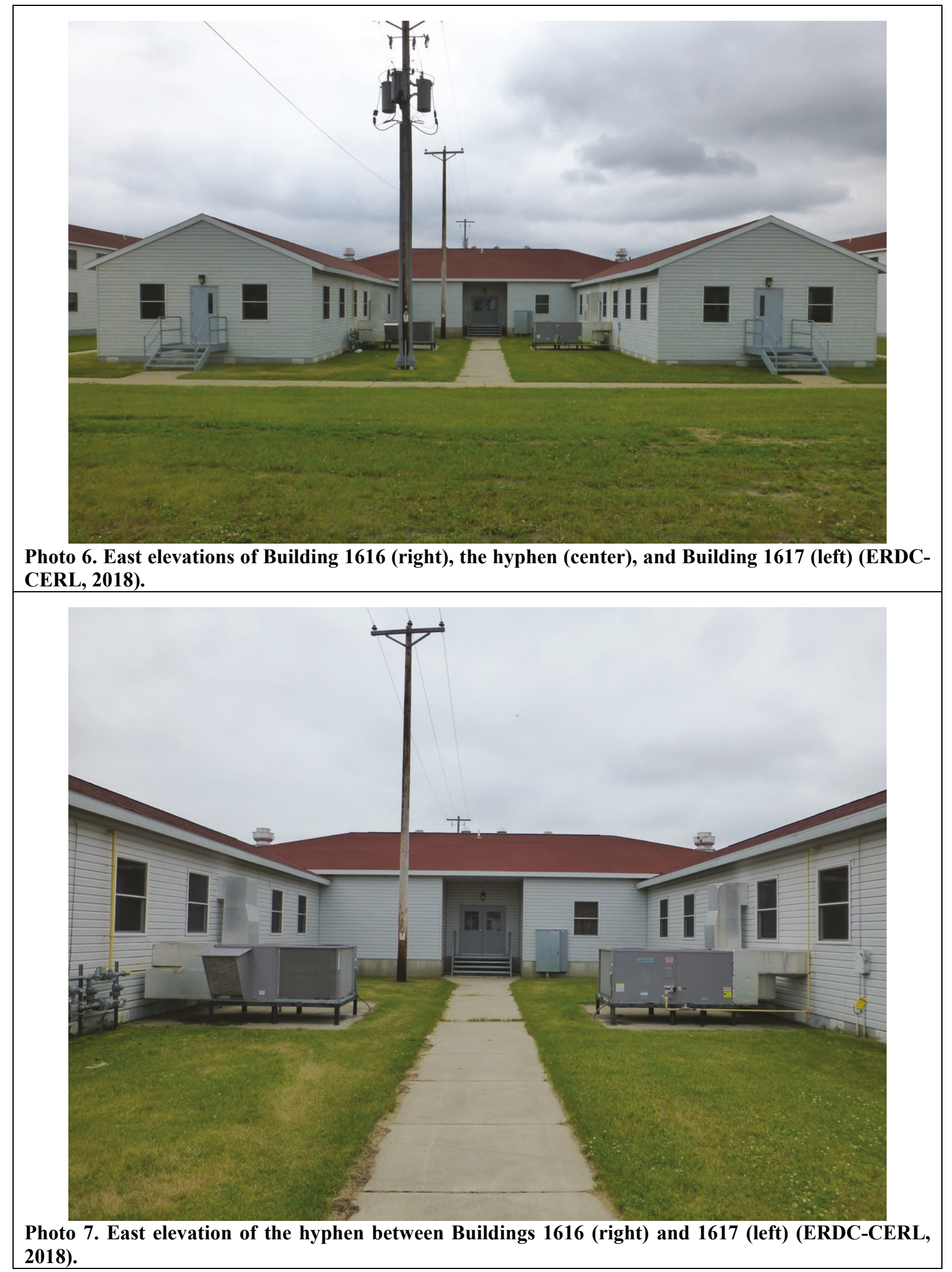




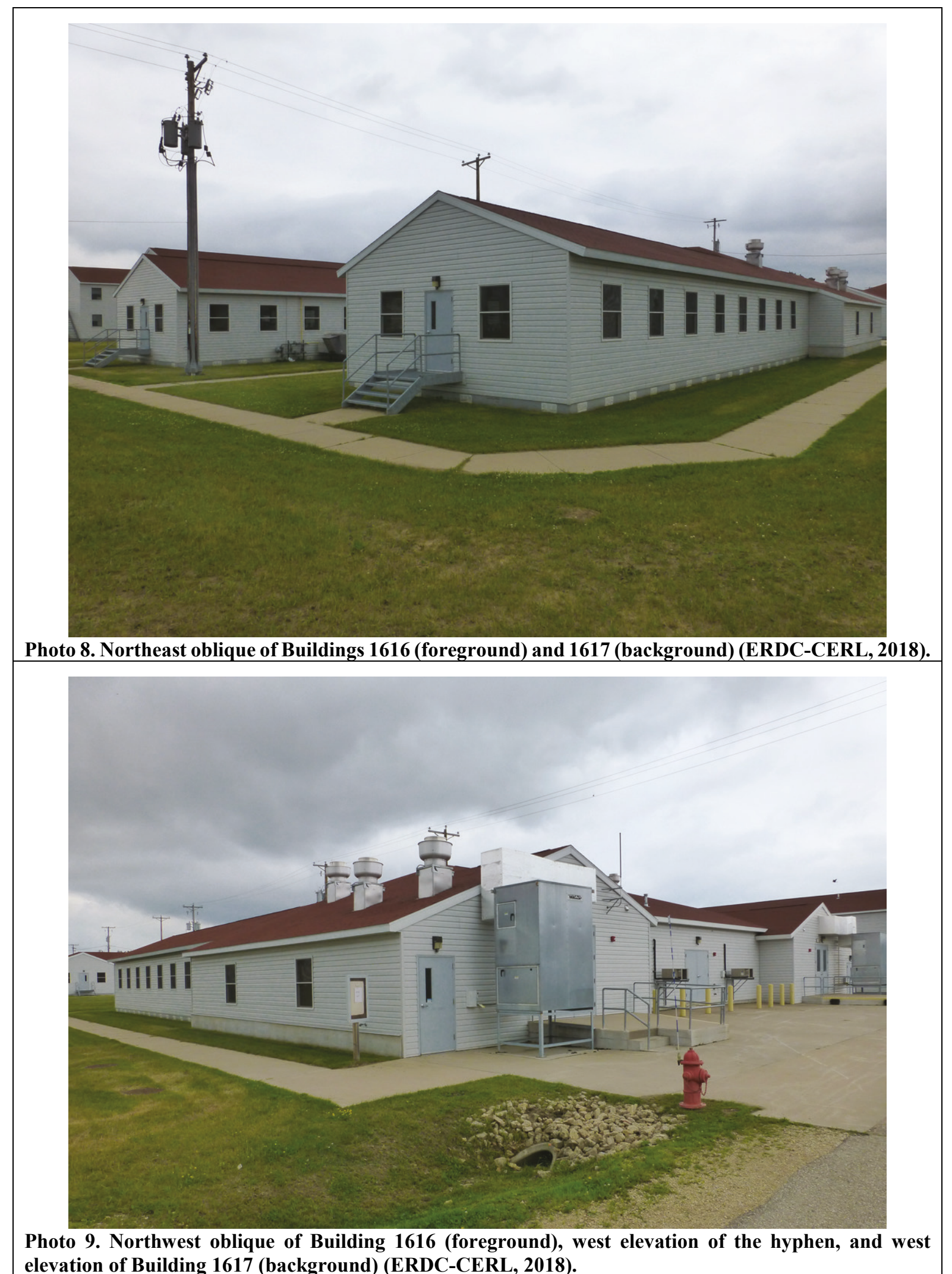




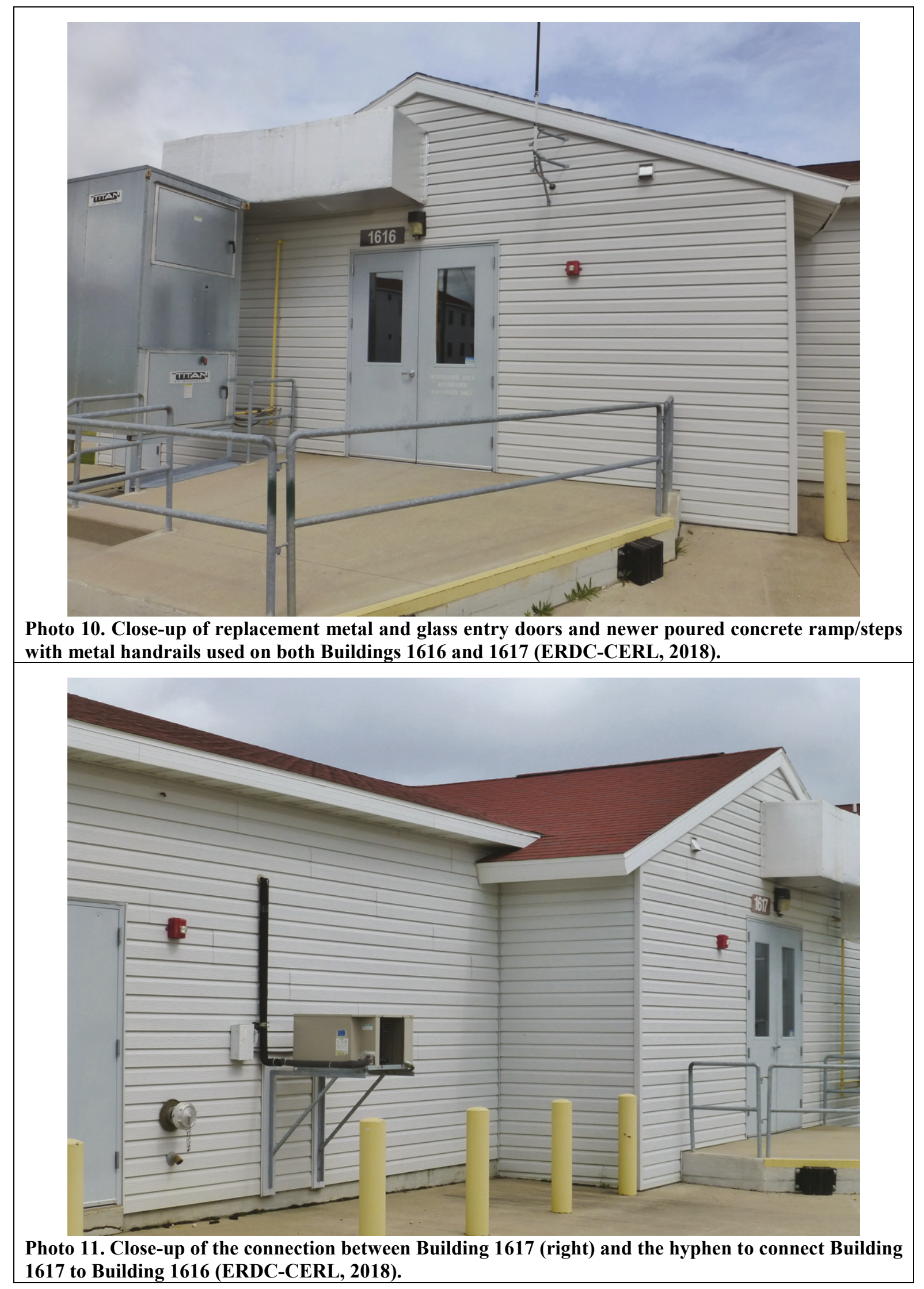




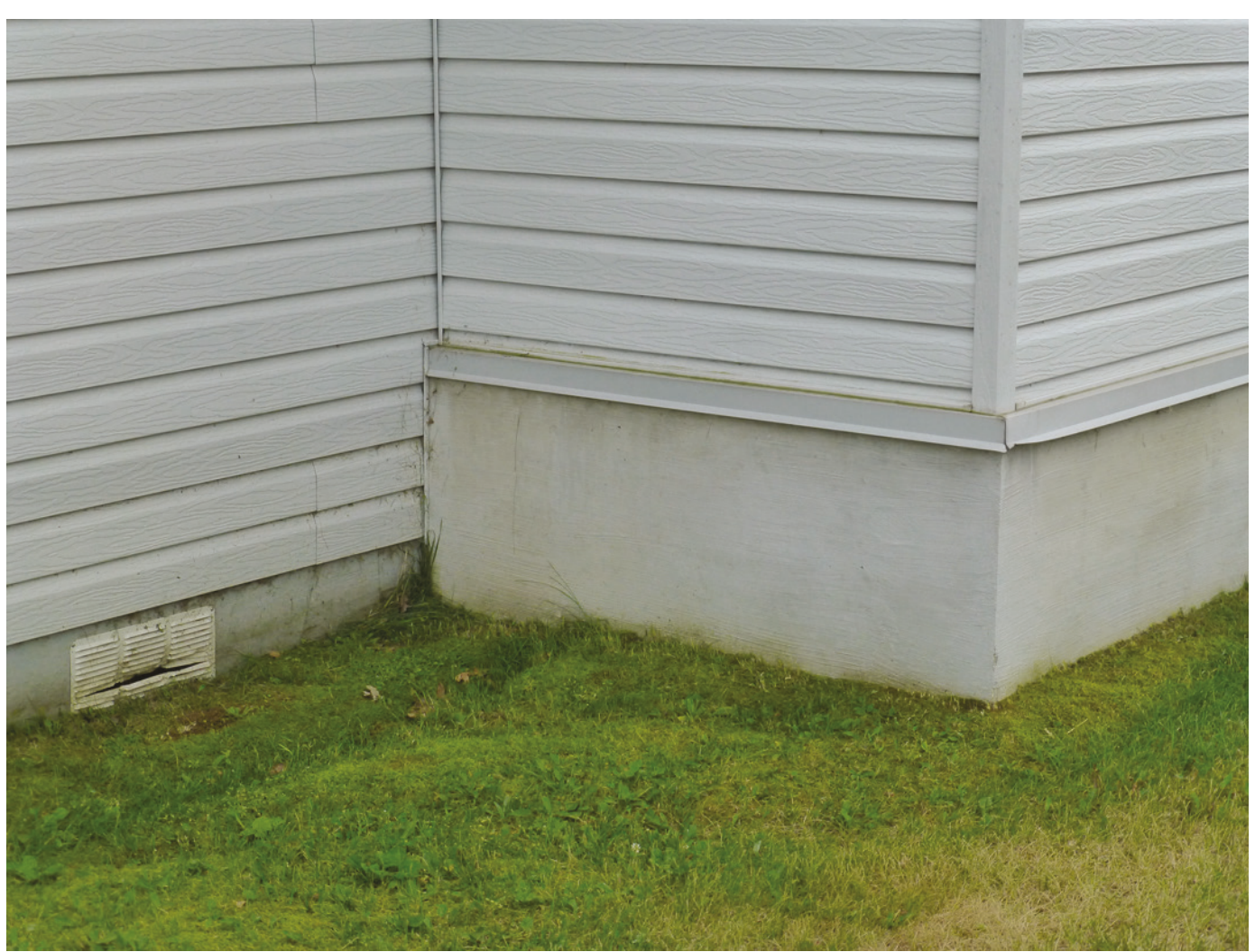

Photo 12. Close-up of foundation skirting on original part of the structure (left) compared to the poured concrete foundation of an appendage that was constructed at a later date (right) (ERDC-CERL, 2018).

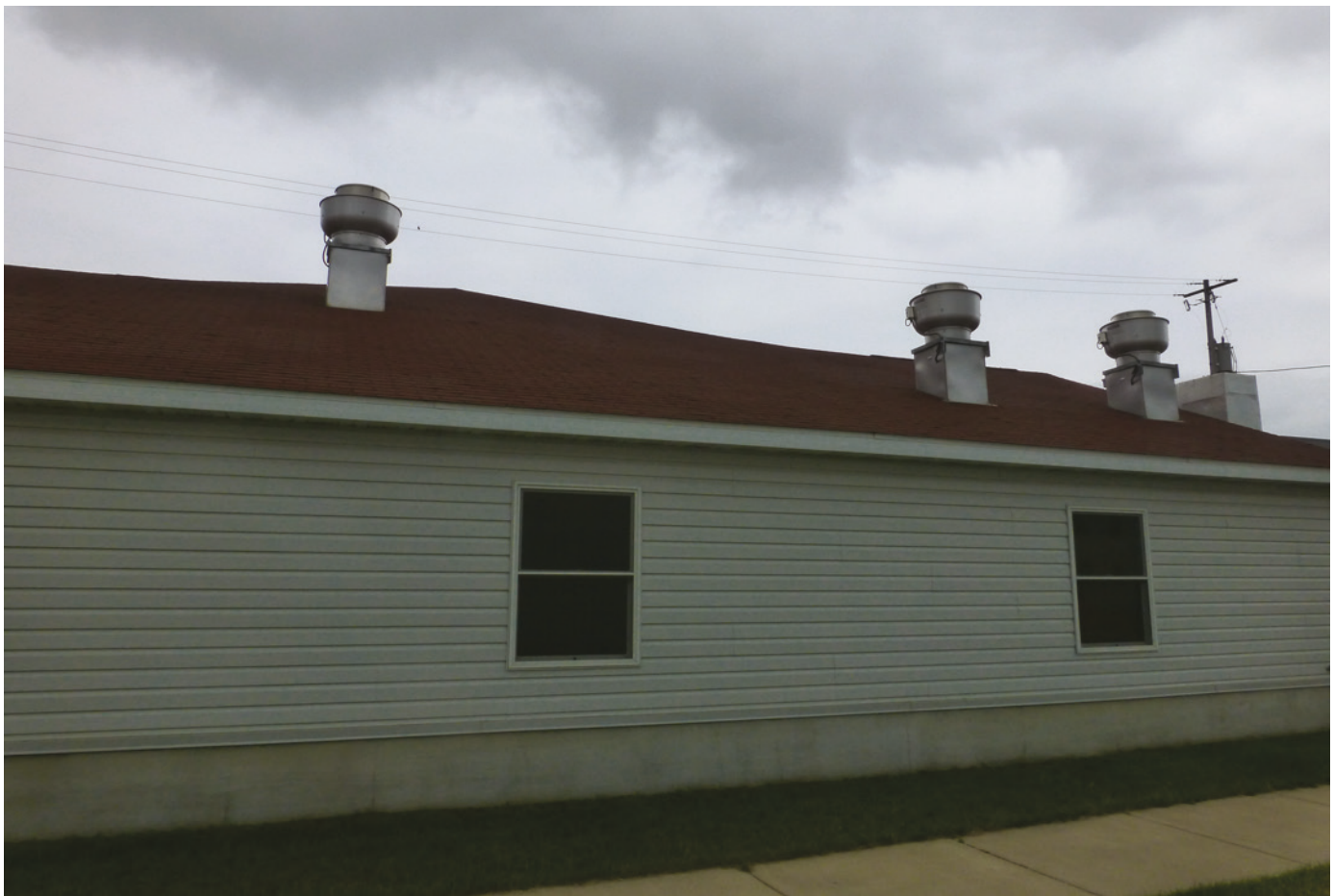

Photo 13. Close-up of replacement windows, vinyl siding, and newer roof ventilators (ERDC-CERL, 2018). 


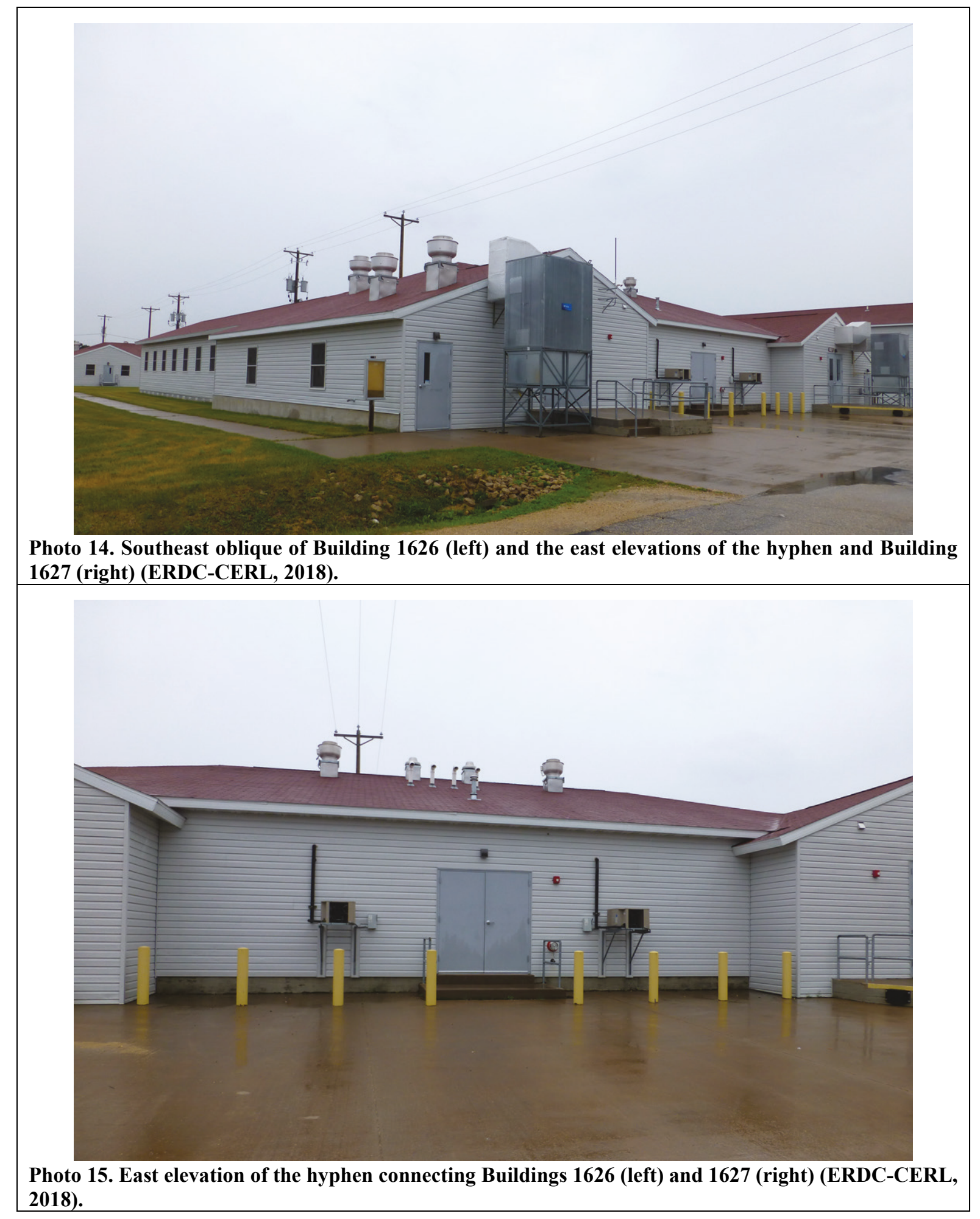




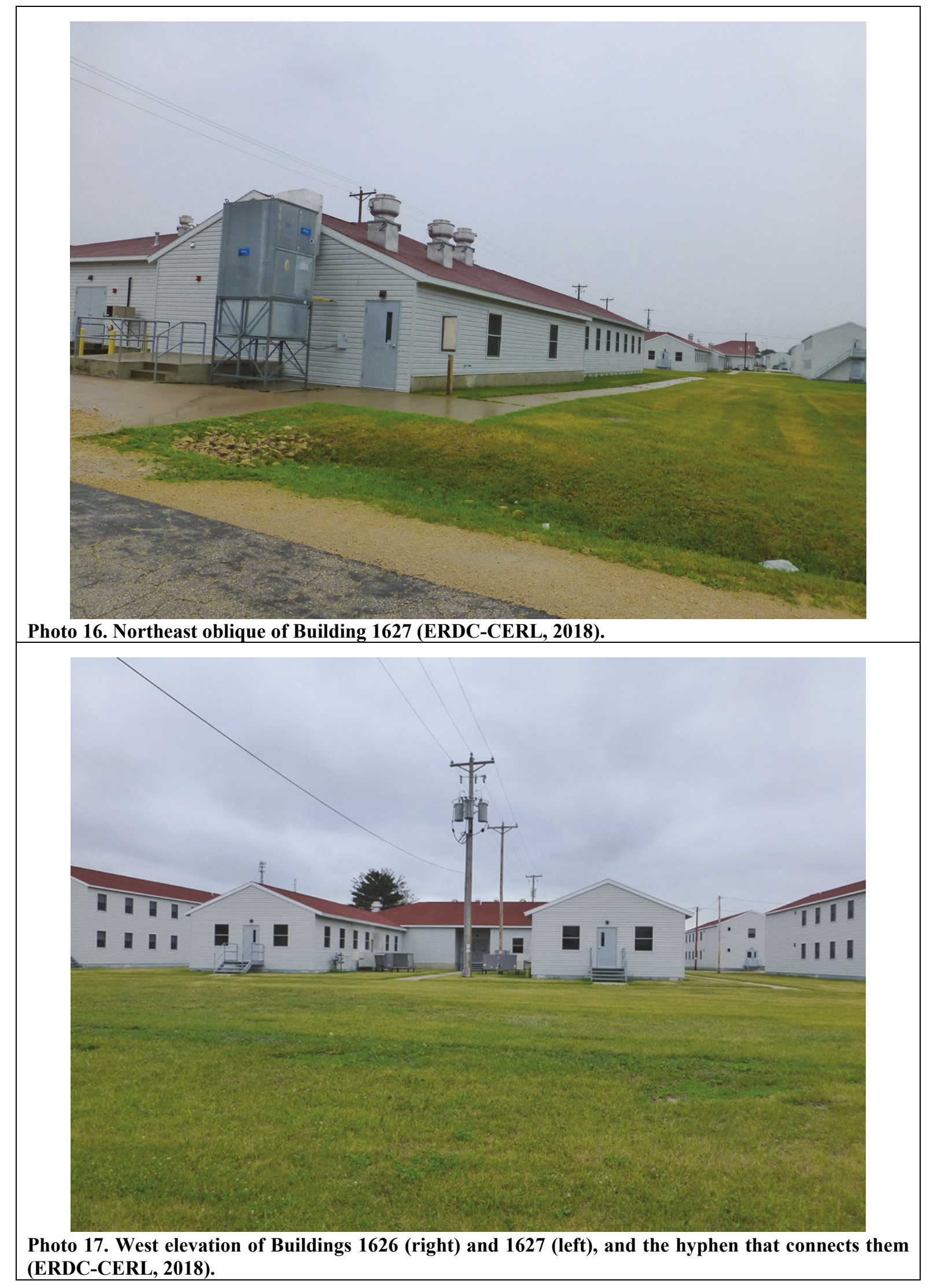




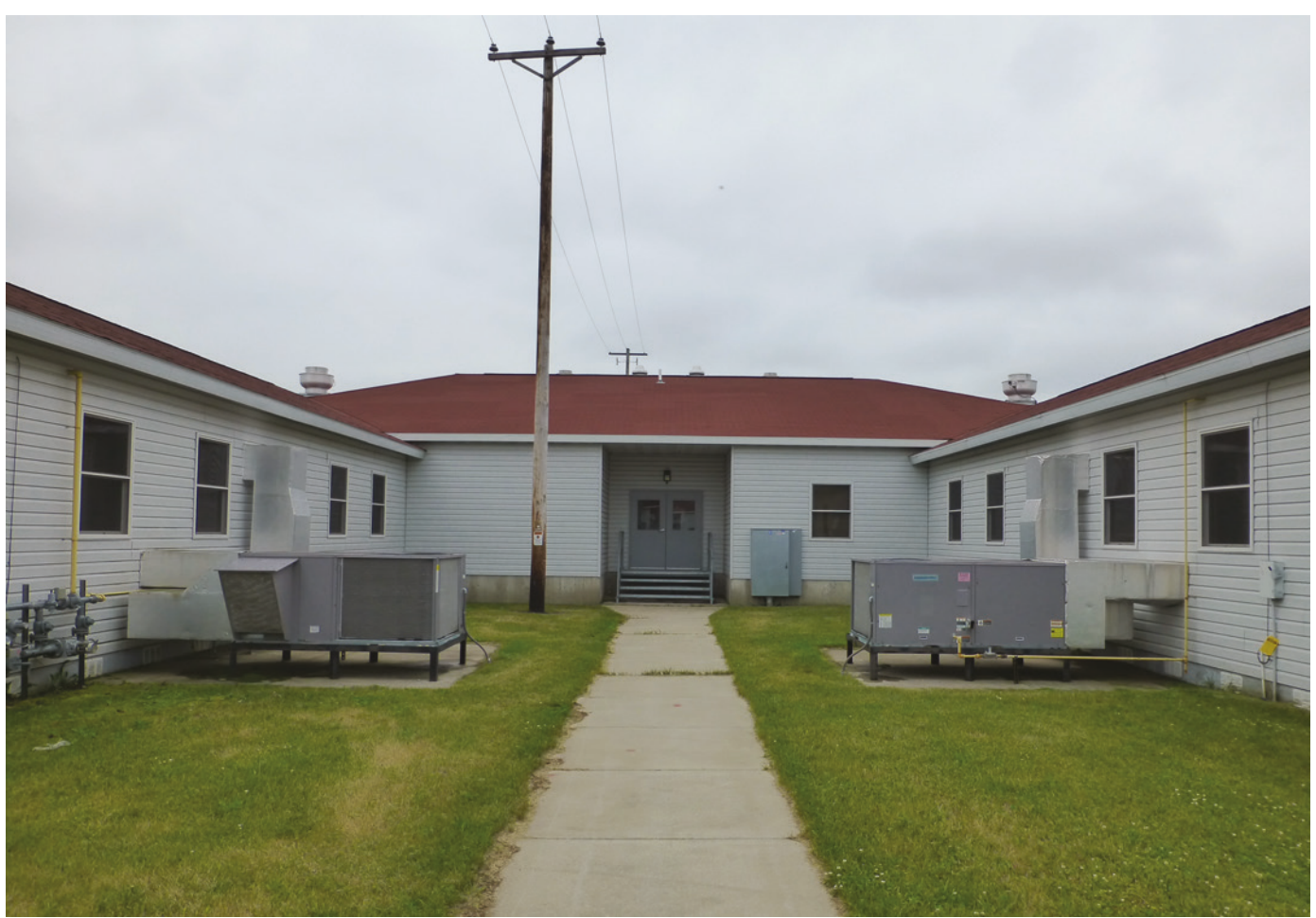

Photo 18. Looking west at east elevation of the hyphen connecting Building 1616 (right) and Building 1617 (left) (ERDC-CERL, 2018).

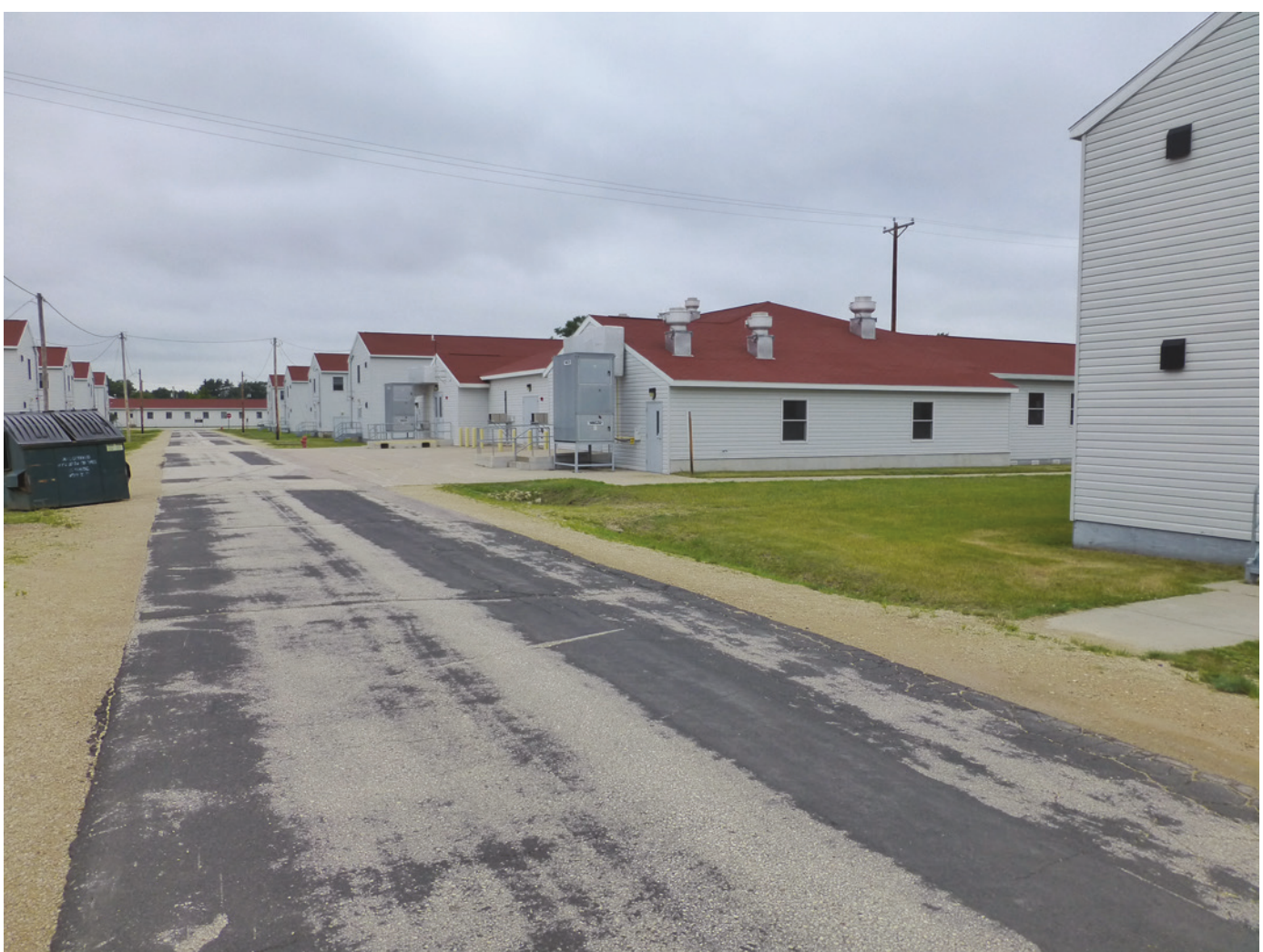

Photo 19. Looking north on South H Street toward Buildings 1616 and 1617 (center right of photo) (ERDC-CERL, 2018). 


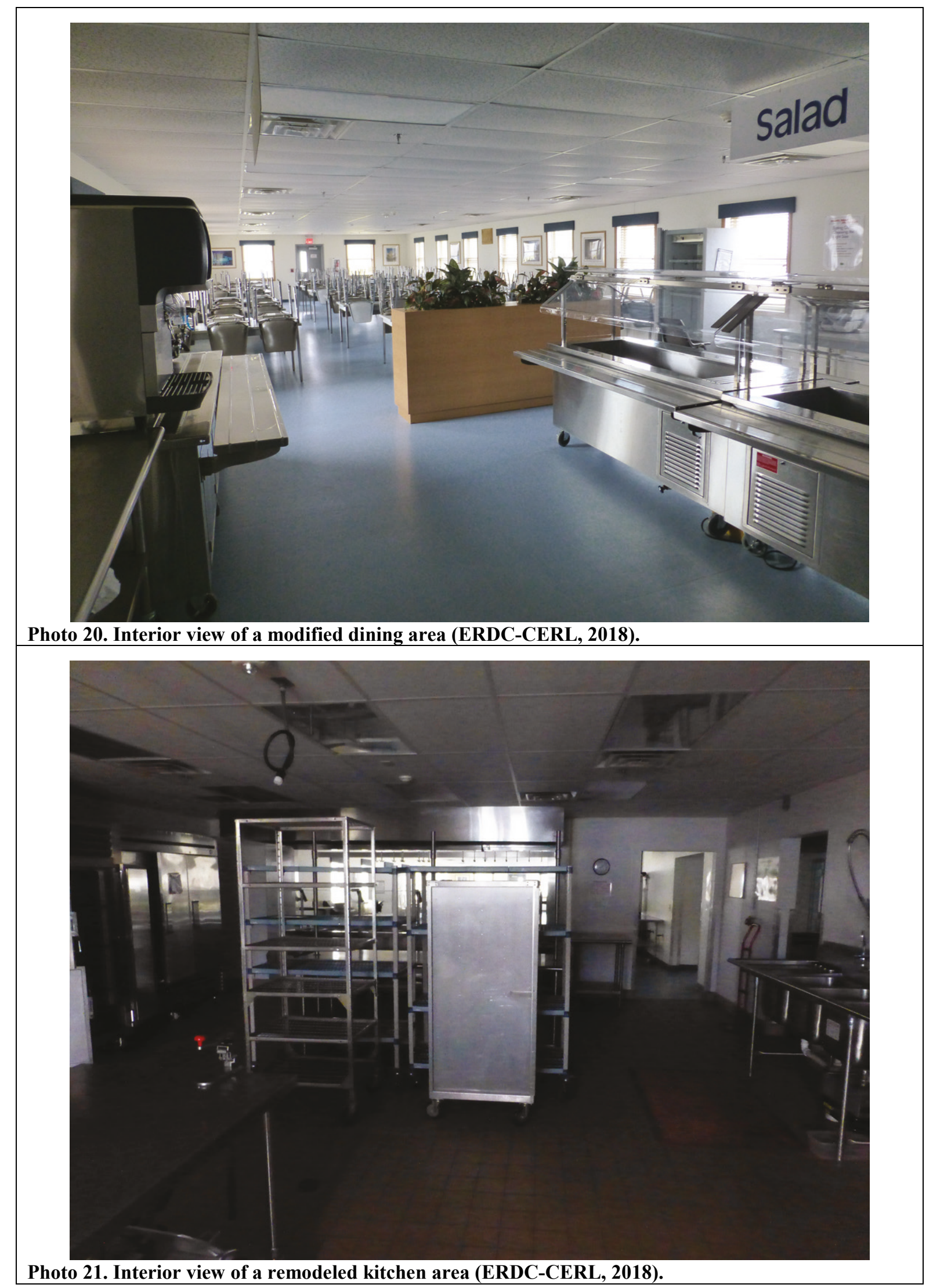




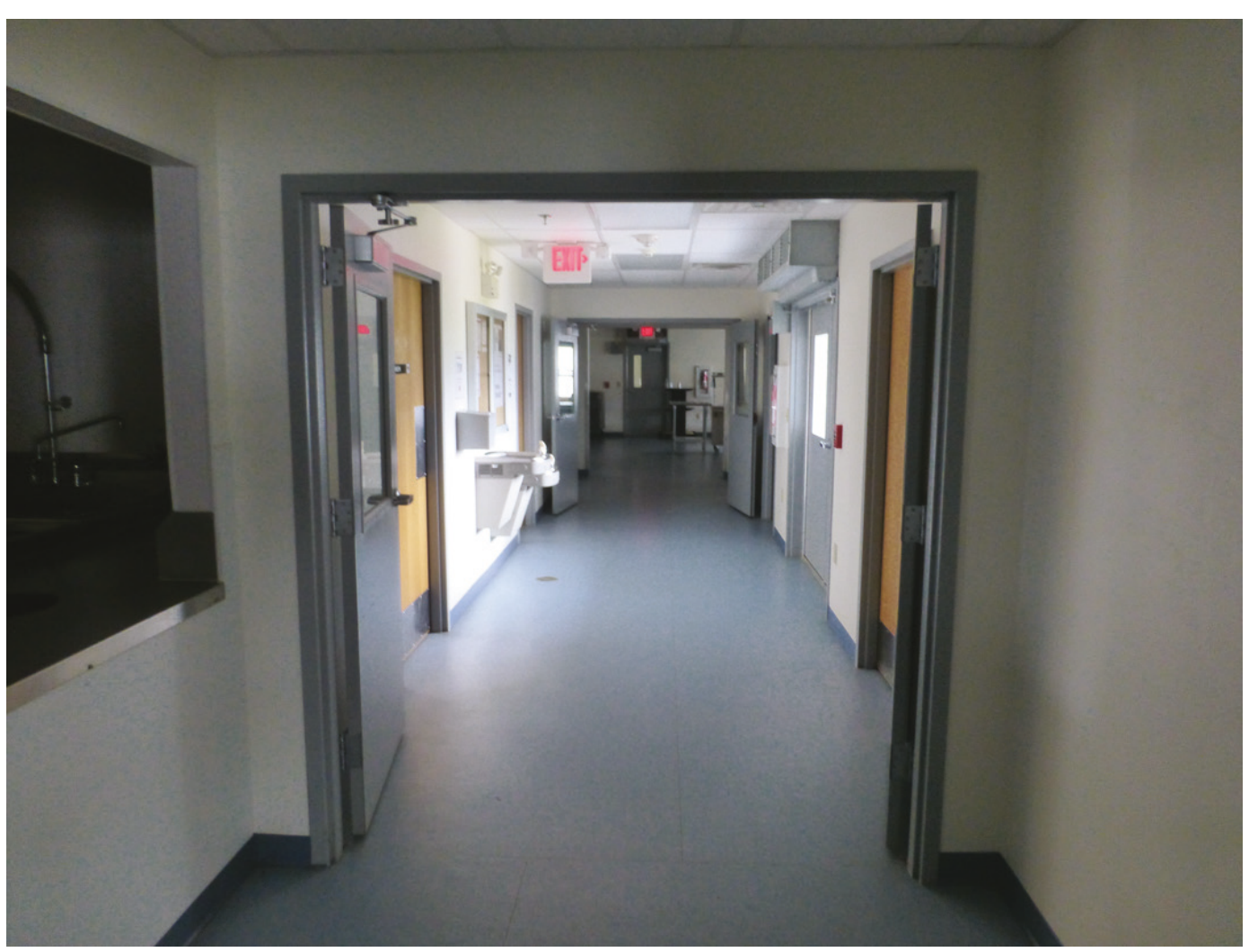

Photo 22. Interior view of corridor in the hyphen that connects Buildings 1616/1617 and Building 1626/1627 (ERDC-CERL, 2018). 


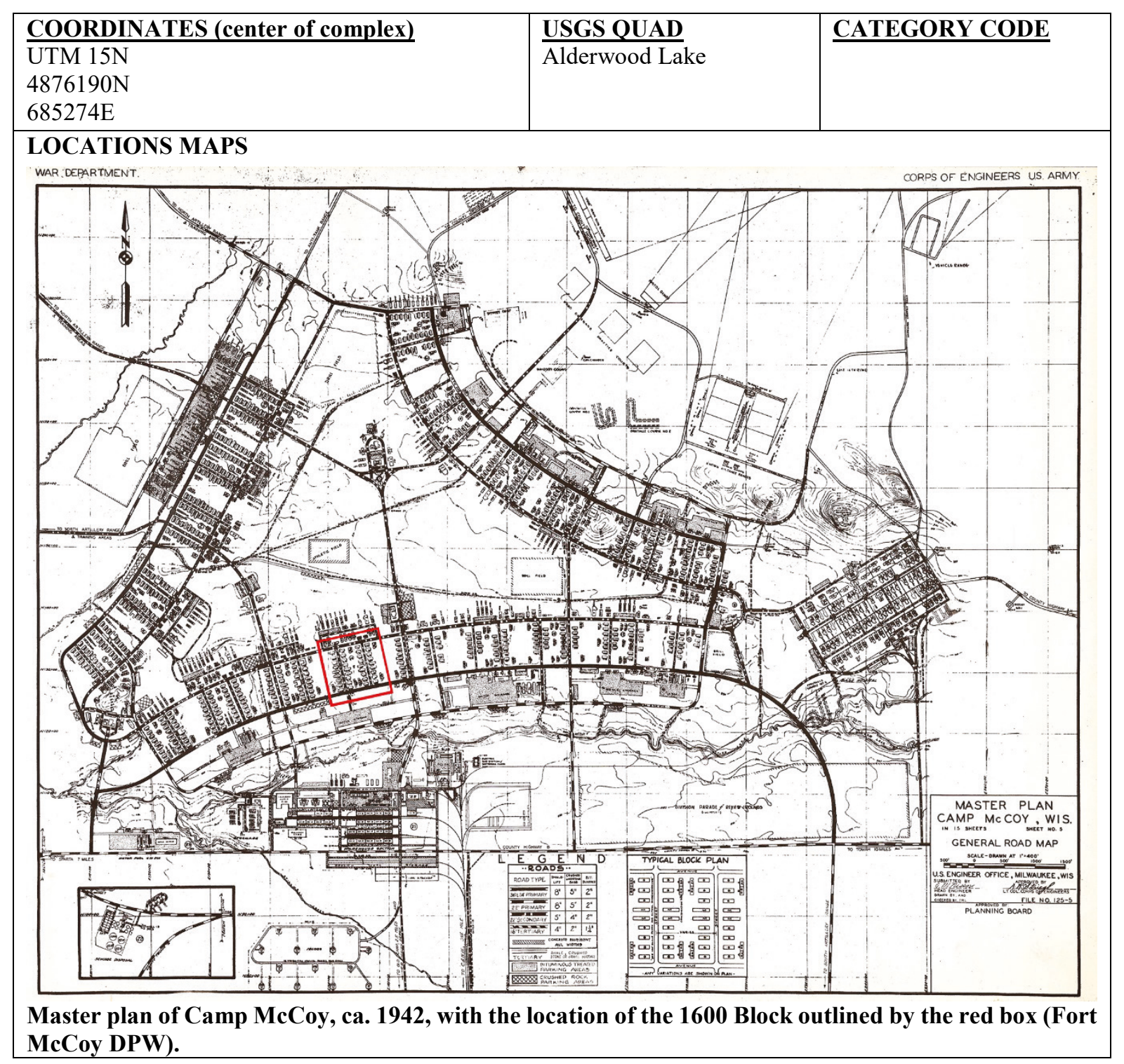




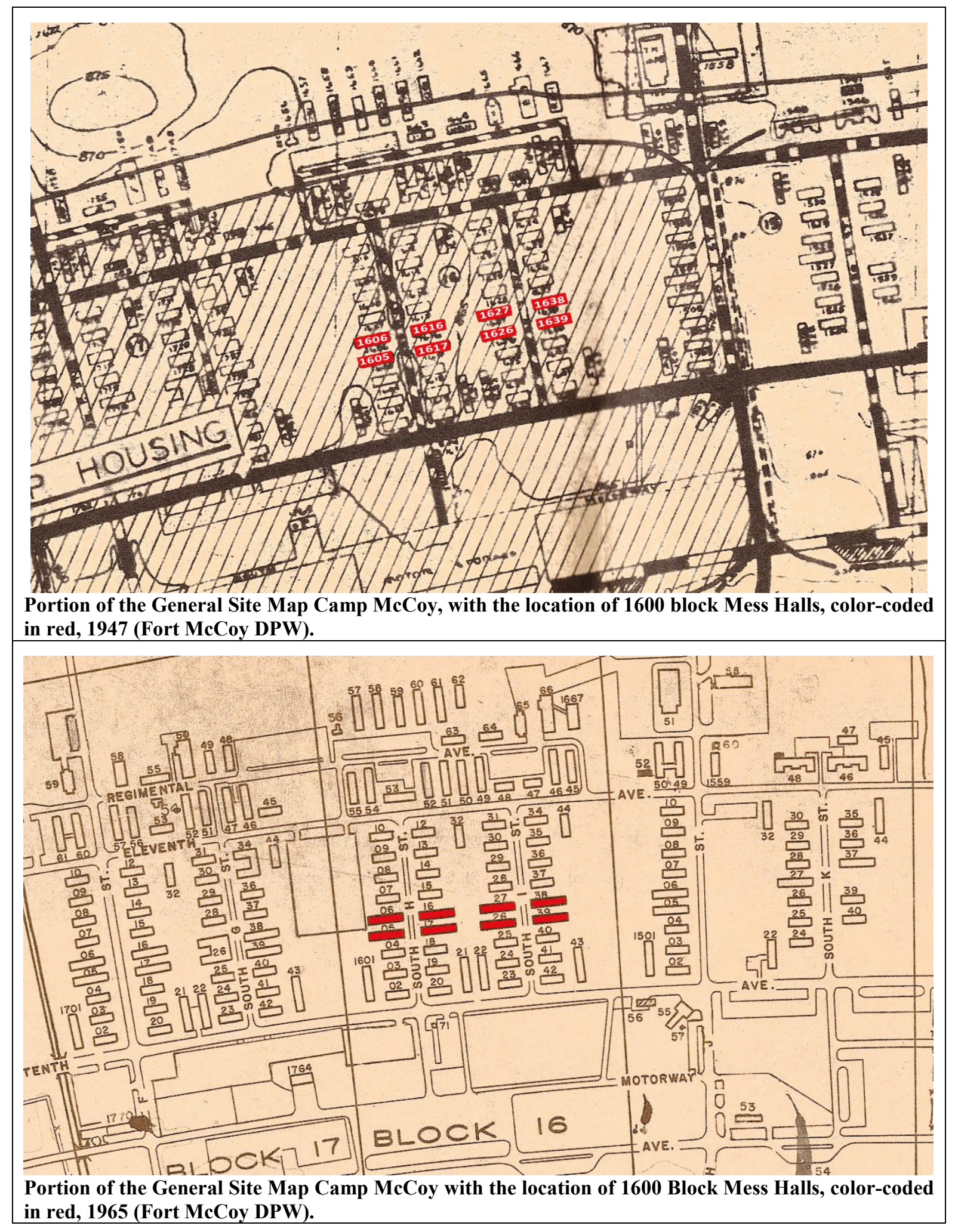




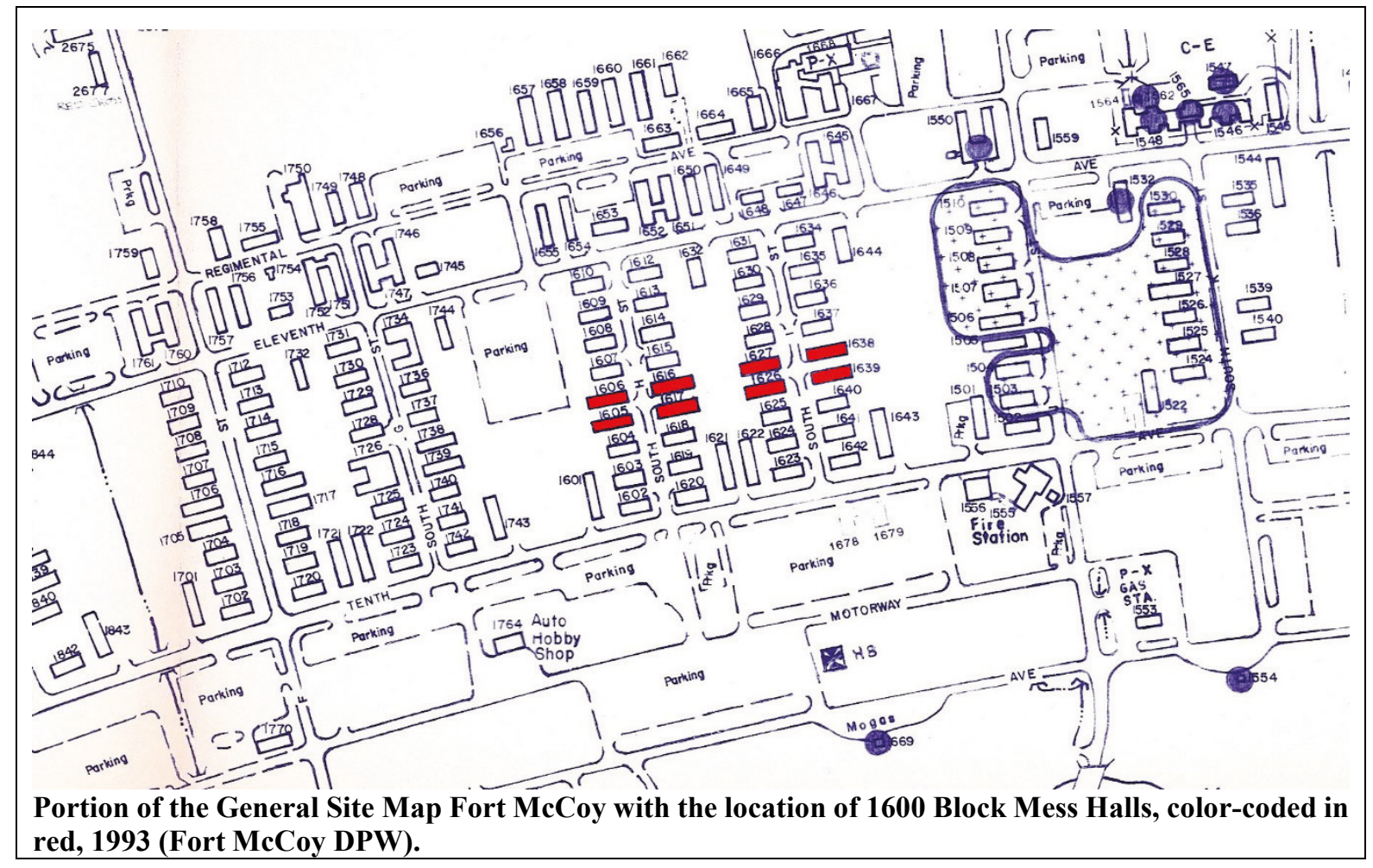




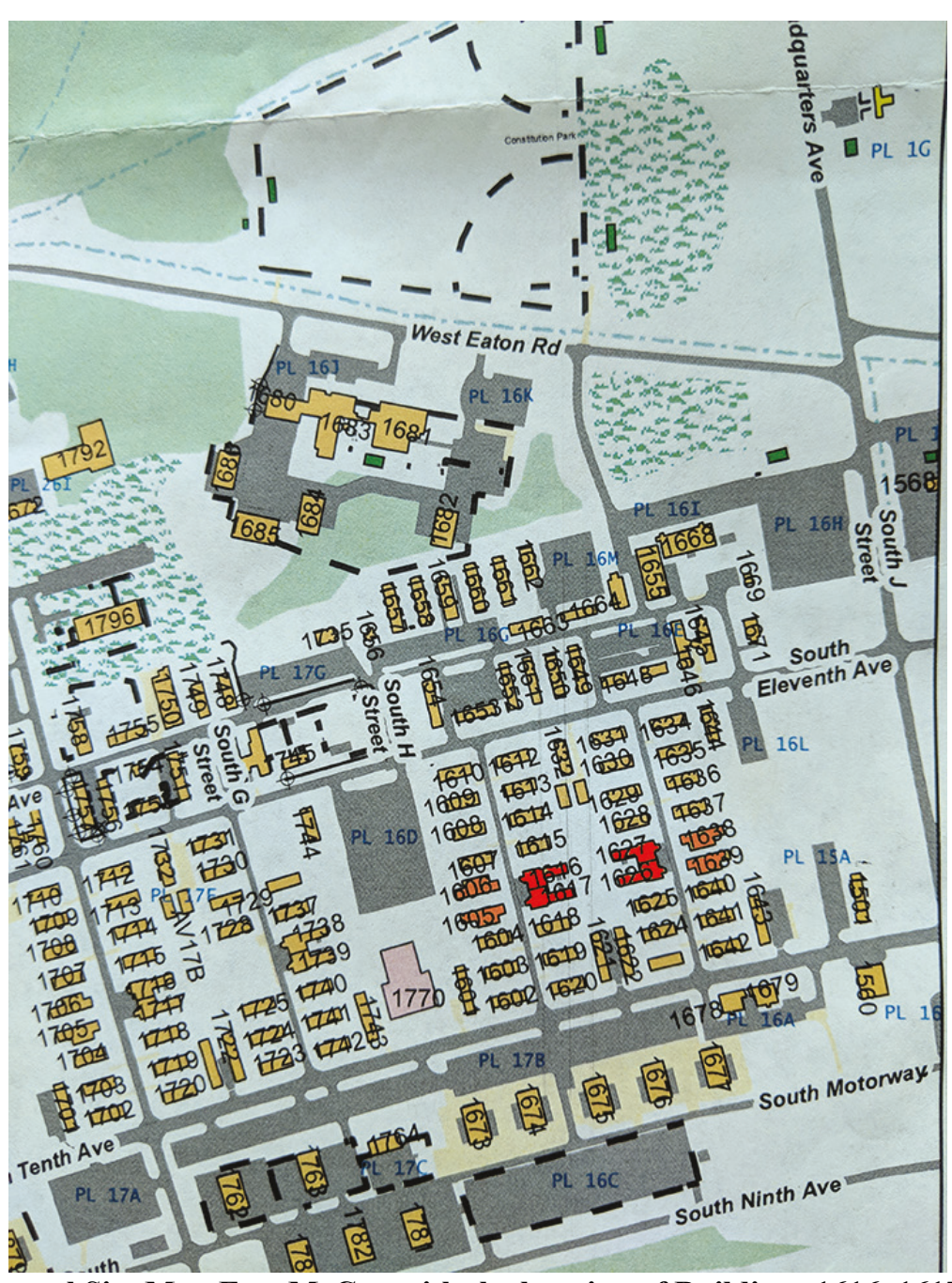

Portion of the General Site Map Fort McCoy with the location of Buildings 1616, 1617, 1626, and 1627, Mess Halls, color-coded in red, 2014. (Buildings 1605, 1606, 1638, and 1639 are also mess halls.) (Fort McCoy DPW). 


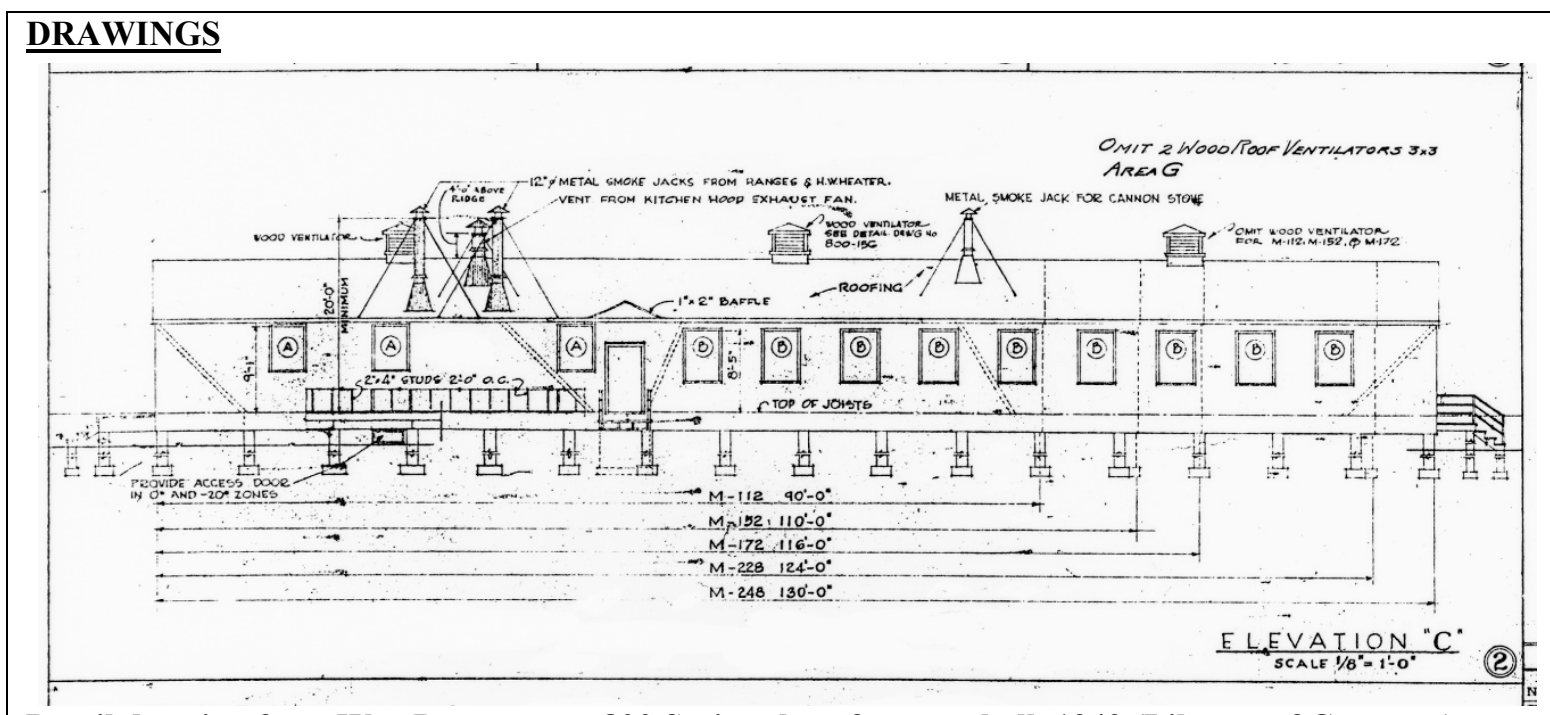

Detail drawing from War Department 800 Series plans for mess hall, 1942 (Library of Congress).

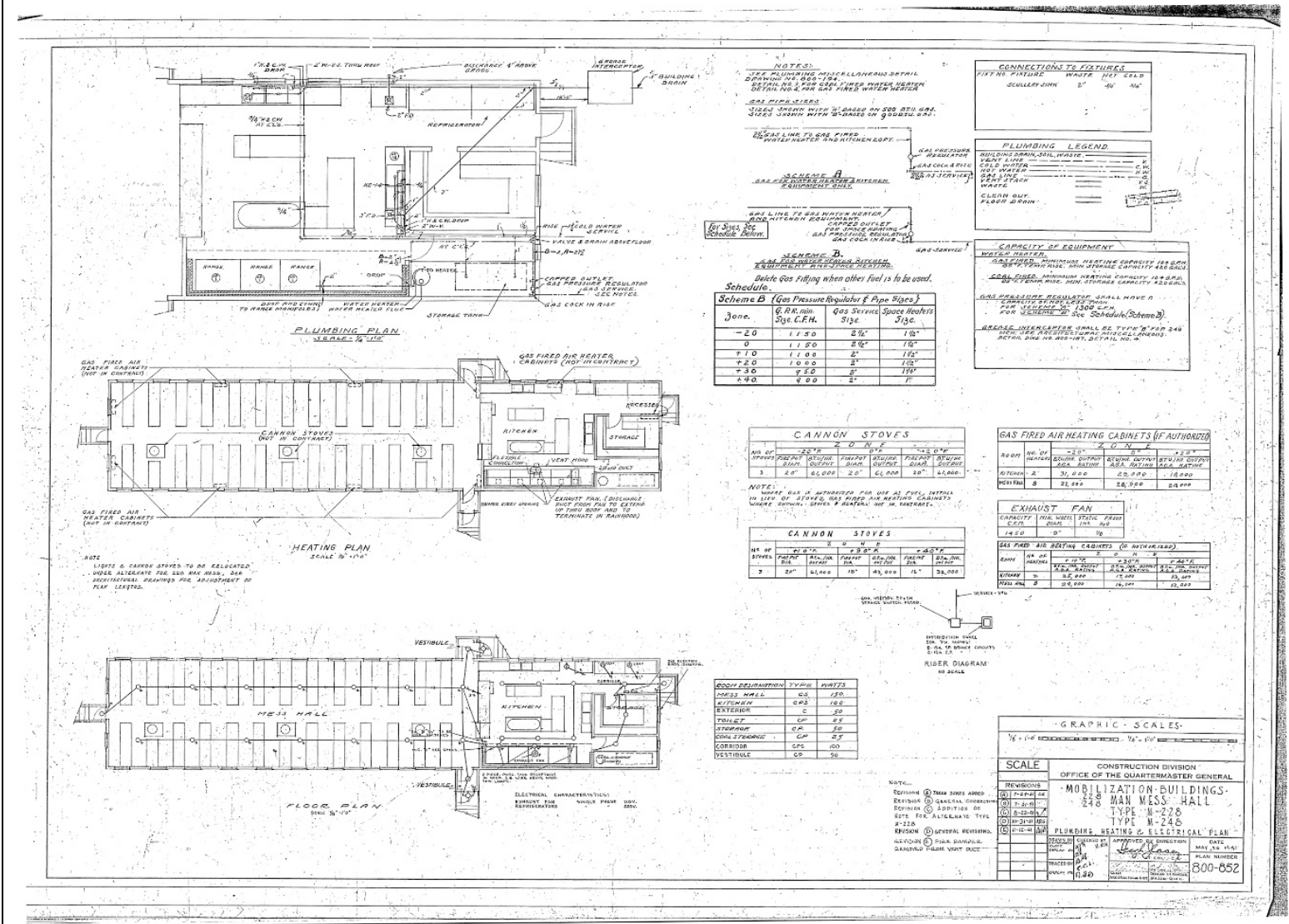

228-Man Mess Hall floor plan and details, Drawing 800-852, 1941 (Fort McCoy DPW). 


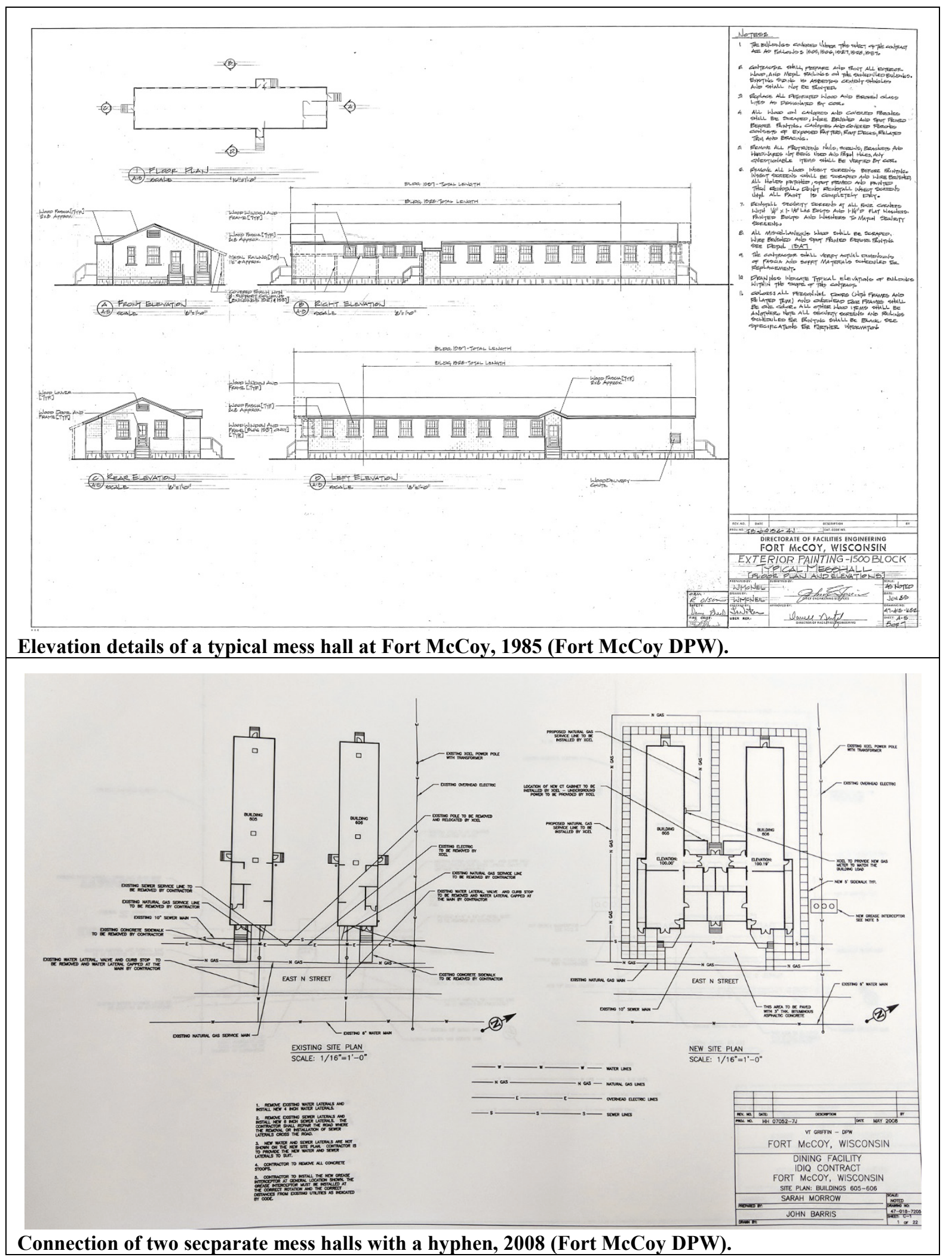


-

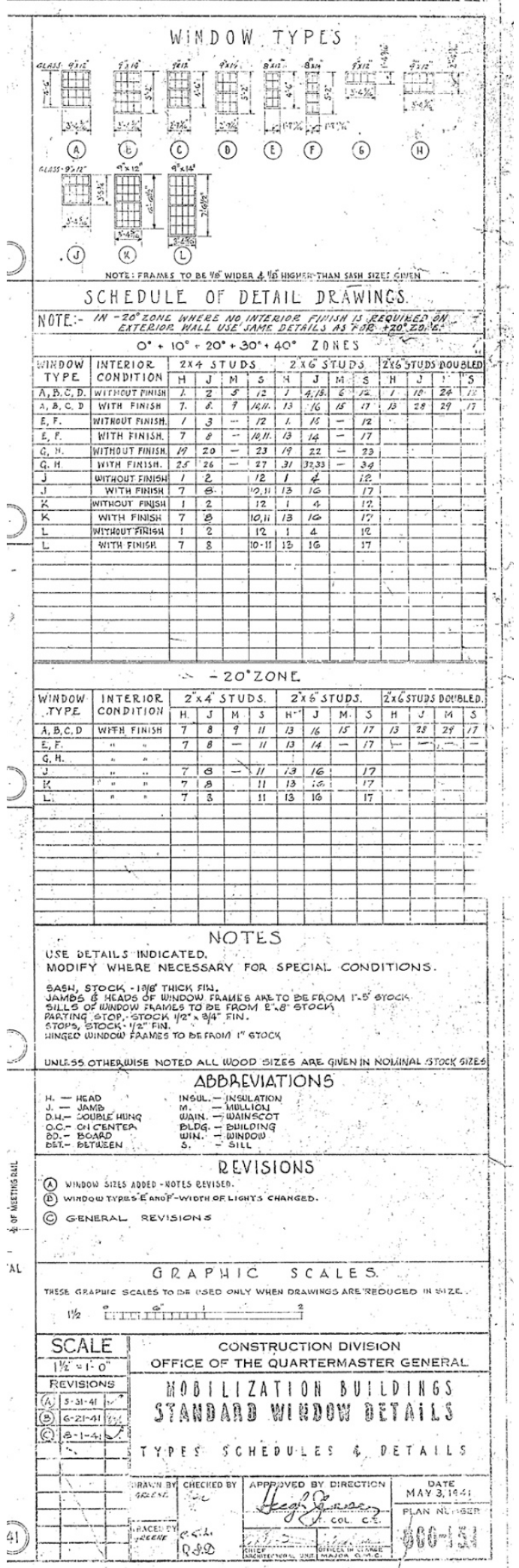

Standard window type details, Drawing 800-151, 1941 (Fort McCoy DPW).

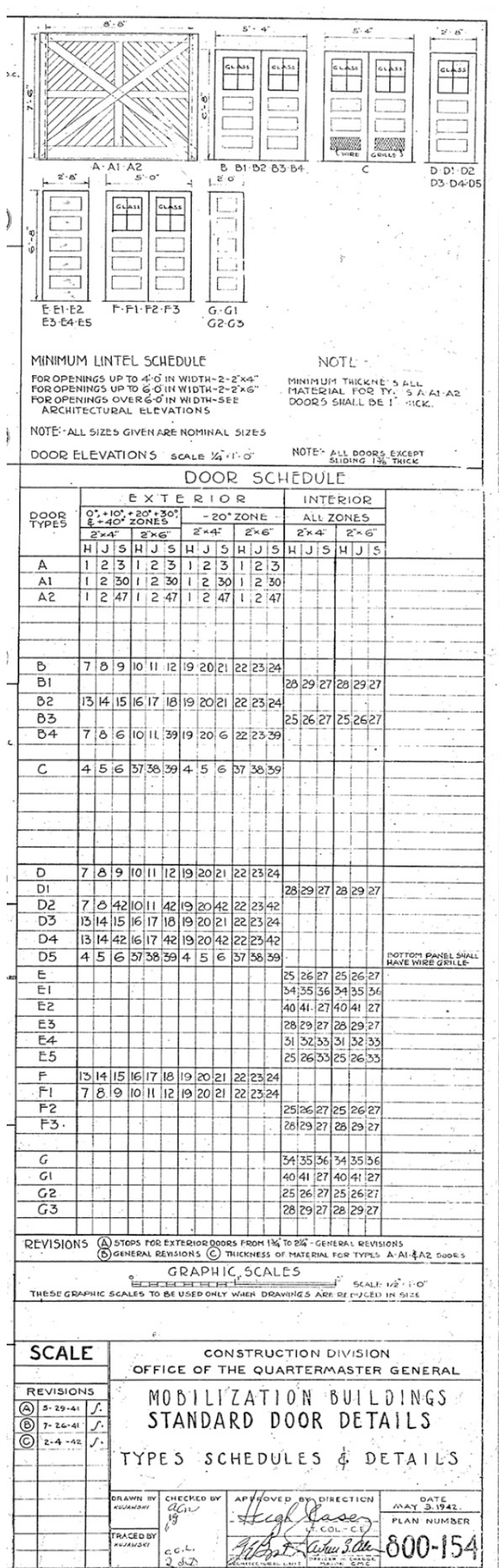

Standard door type details, Drawing 800-151, 1941 (Fort McCoy DPW). 


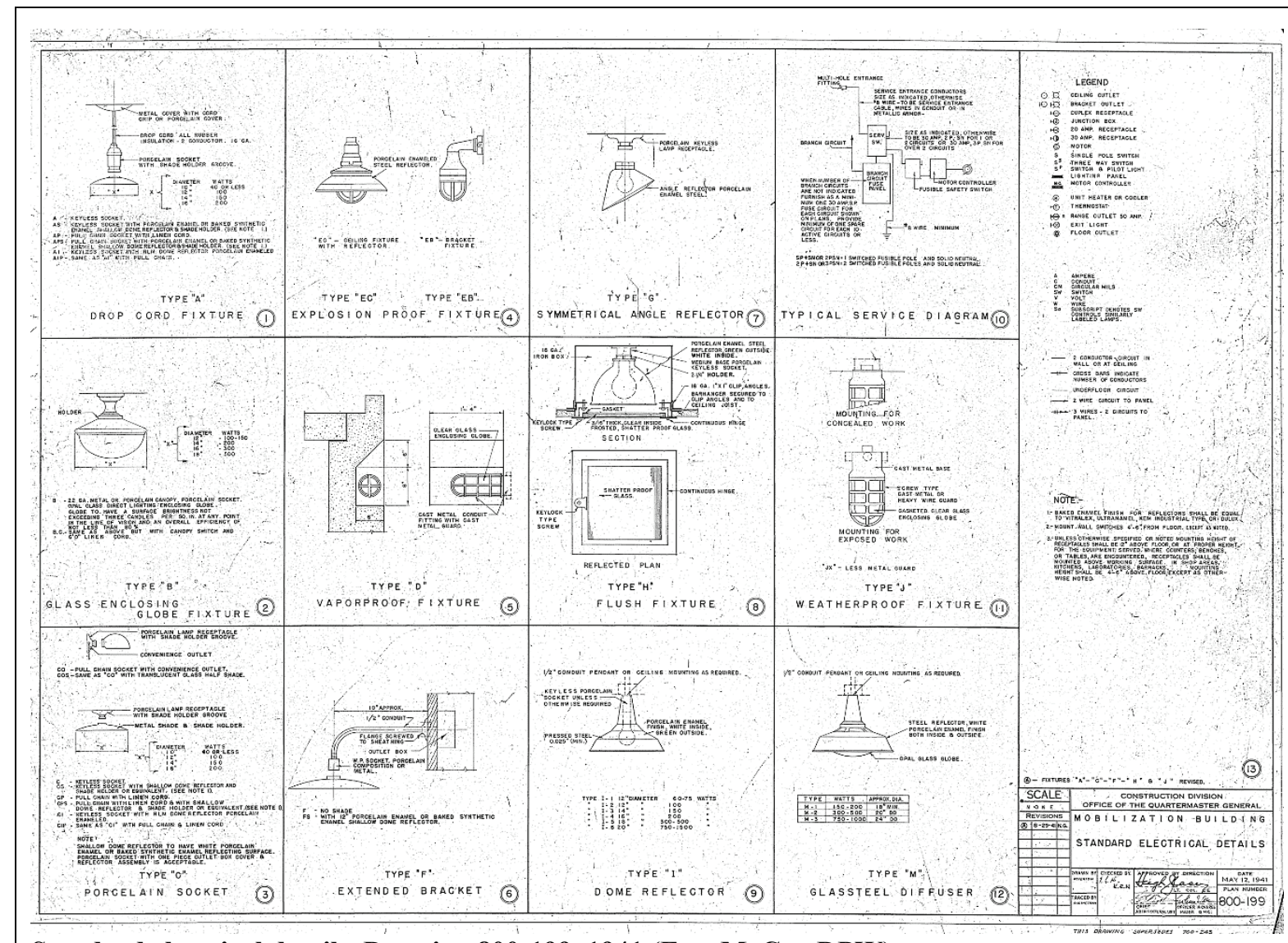

Standard electrical details, Drawing 800-199, 1941 (Fort McCoy DPW).

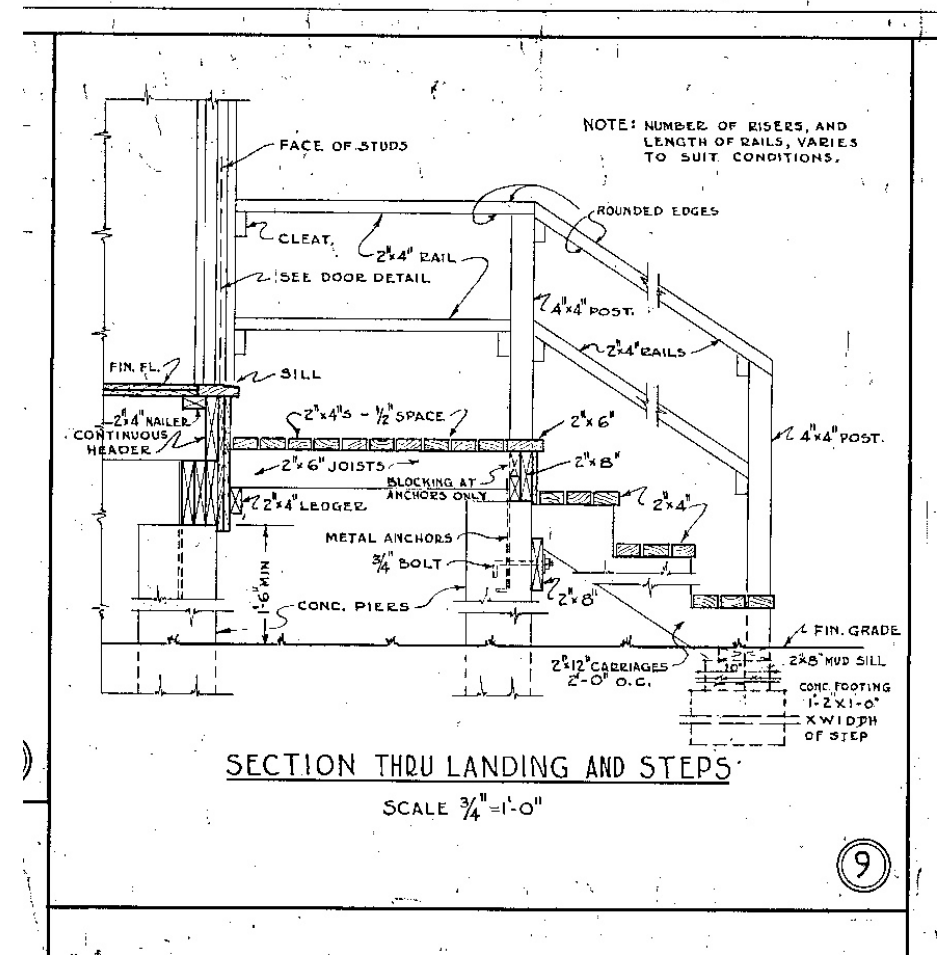

Detail for wood porch stoop and wood handrails used throughout the cantonment on WWII buildings, Drawing 800-176, 1941 (Fort McCoy DPW). 


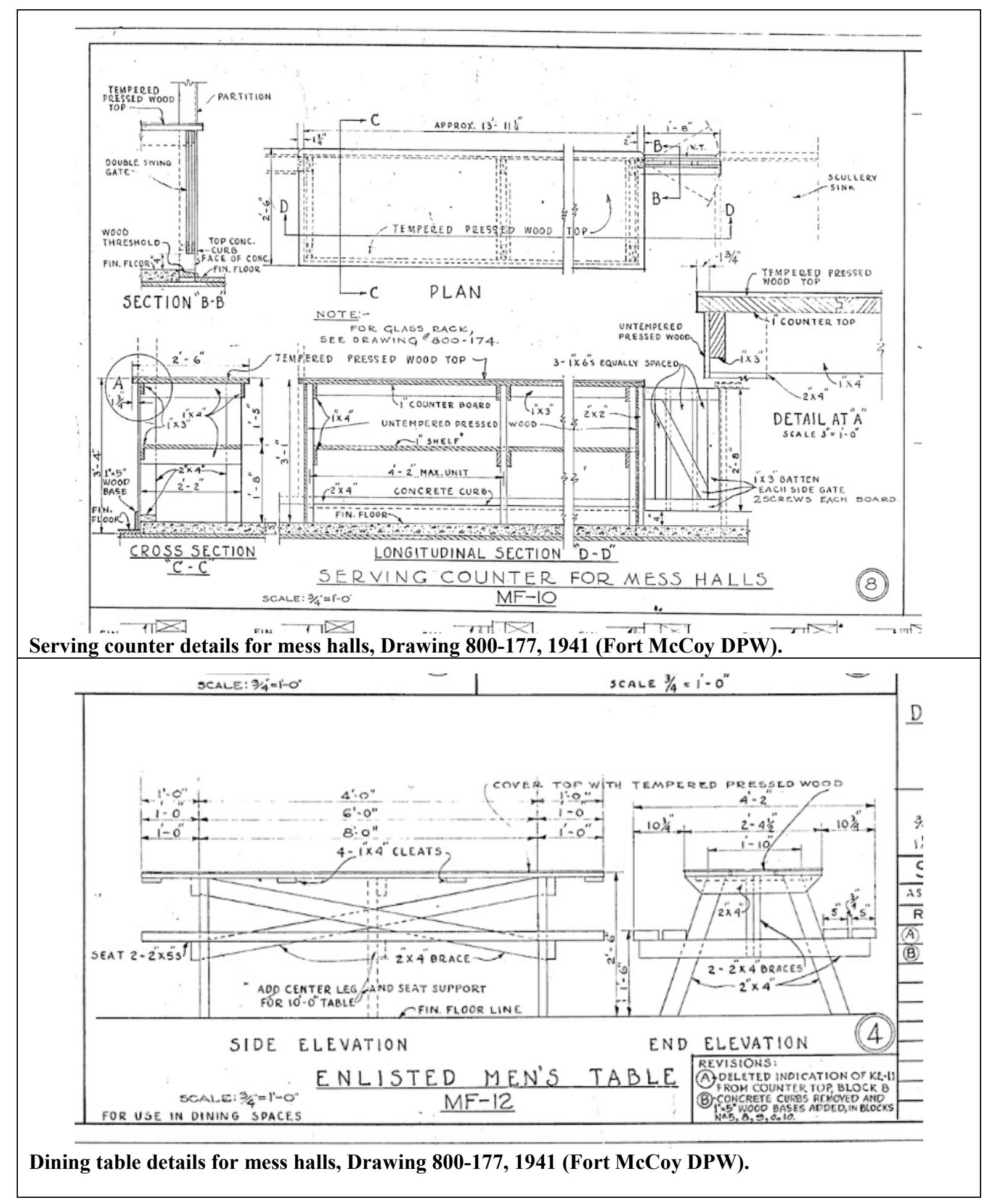




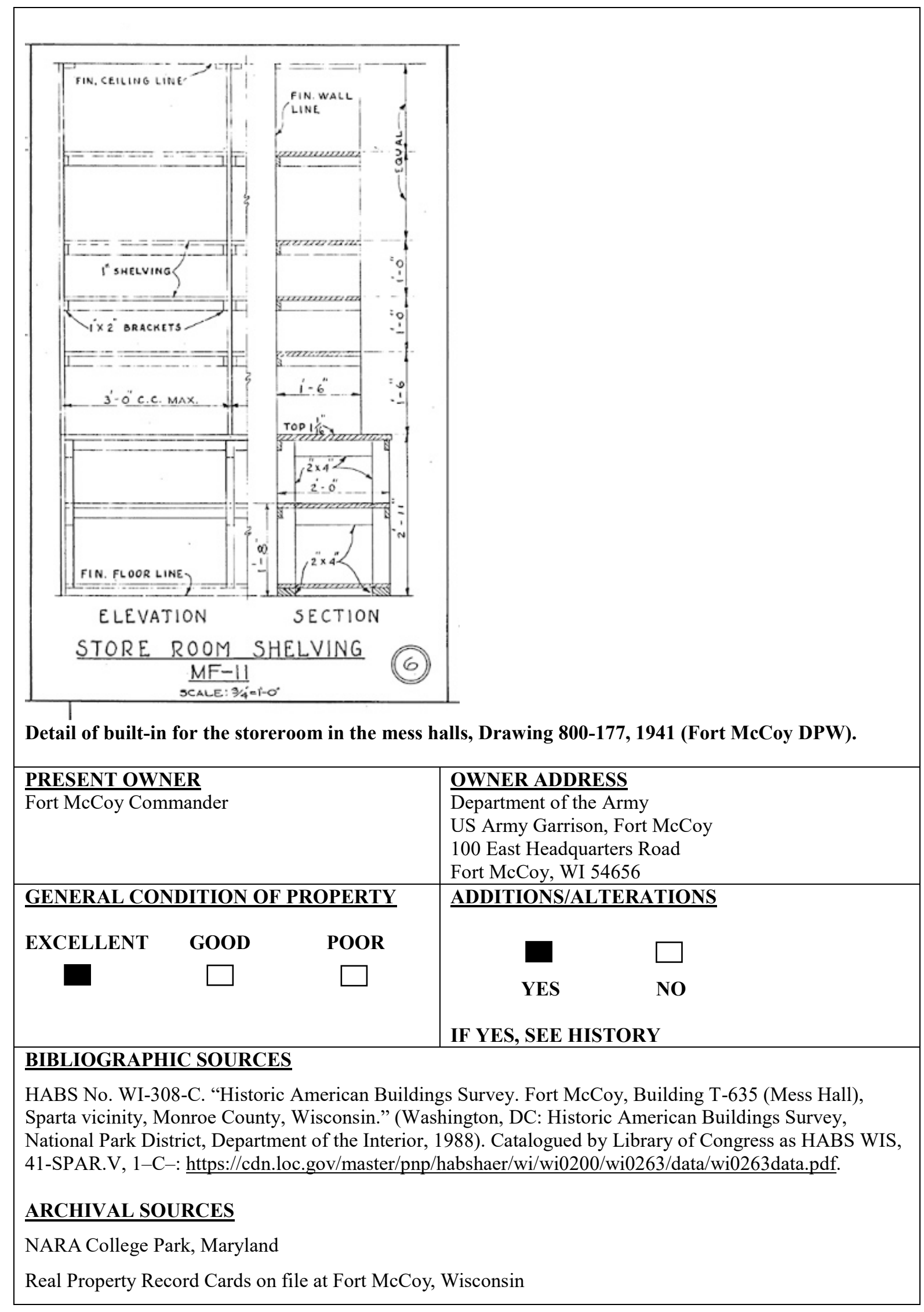




\begin{tabular}{|c|c|}
\hline \multicolumn{2}{|l|}{ Drawing documentation on file at Fort McCoy, Wisconsin } \\
\hline $\begin{array}{lc}\text { PRELIMINARY NATIONAL REGISTER } \\
\text { DETERMINATION OF ELIGIBILITY } \\
\text { ELIGIBLE/ } \\
\begin{array}{c} \\
\text { CONTRIBUTING }\end{array} \\
\square & \text { NOT ELIGIBLE/ } \\
\end{array}$ & $\begin{array}{l}\text { FORM PREPARED BY: } \\
\text { Sunny Adams } \\
\text { Engineer Research and Development Center } \\
\text { Construction Engineering Research Laboratory } \\
\text { 2902 Newmark Drive } \\
\text { Champaign, IL } 61822 \\
\text { DATE: September } 2018\end{array}$ \\
\hline
\end{tabular}

\section{DESCRIPTION}

The buildings have an overall U-shaped footprint due to the construction of hyphens that connect Buildings 1616 and 1617 together and connect Buildings 1626 and 1627 together. The hyphens were built to include restrooms and storage areas for the buildings they connect. Each hyphen has concrete slab foundation, exterior walls clad with vinyl siding, and a side gable roof that is clad with red asphalt shingles. Also, located on the outside wall of each U-footprint, the buildings have been widened to include a long enclosed corridor vestibule, and the slope of the original gable roof line was just extended over this addition. Each addition has a poured concrete foundation. The original rectangular buildings have front-gable roofs clad with asphalt shingles and metal fascias and soffits. The exterior walls are clad with vinyl siding. The windows are replacement one-over-one vinyl windows, and the doors are replacement metal with a light. The original rectangular portion of the building has a concrete pier foundation system with replacement wood foundation skirting. All exterior light fixtures are replacement.

Buildings 1617 and 1617: The hyphen that connects Buildings 1616 and 1617 is located on the west end of the original rectangular structures (see Photo 2). The west elevation faces South H Street and Buildings 1605 and 1606 (two other former mess halls). This elevation is symmetrical. The left side of the elevation is Building 1616. The far left side is where the later enclosed vestibule corridor is located, and it is defined by a single-entry metal door with a narrow light. The west elevation of Building 1616 has a set of replacement metal doors, each with a large light, and it is accessed by a poured concrete porch with metal handrails (see Photo 10). A large mechanical system unit is located to the left of the doors. The middle of the west elevation is the hyphen. A set of metal doors is located in the middle of the west elevation of the hyphen. The right side of the west elevation is Building 1617 (see Photo 3), and it mirrors the left side. The south elevation is Building 1617. The left side projects slightly out from the right side, and that is where the long corridor vestibule addition is located (see Photo 4). There are two windows located on this part of the elevation. The right side has eight replacement windows (see Photo 5). The east elevation is the inside view of the "Ushaped" footprint (see Photo 6). The left side of the east elevation is Building 1617, and it consists of a centrally placed replacement door accessed by metal steps with metal handrails (see Photos 5 and 6). The middle of the east elevation is the hyphen. A recessed entry bay is nestled under the roofline in the middle of the east elevation. A set of metal doors, each with a large light, is accessed by a set of metal steps (see Photo 7). A one-over-one window is located to the right of the entry bay (see Photo 7). The right side of the east elevation is Building 1616, and it mirrors Building 1617 on the left side of the elevation (see Photos 6 and 8). Thus, the building to the north is Building 1616. The left side of the east elevation has eight replacement windows, while the right side projects slightly outward and is where the long corridor vestibule addition is located (see Photo 8). There are two one-over-one windows on this part of the elevation (see Photo 9). The inside view of the U-shape shows the south elevation of Building 1616 facing the north elevation of Building 1617. These elevations mirror each other, and both have six replacement windows (see Photos 6 and 7).

Buildings 1626 and 1627: The hyphen that connects Buildings 1626 and 1627 is located between the east ends of the original rectangular structures (see Photo 2). The east elevation faces South I Street and Buildings 1638 and 1639 (two former mess halls). This elevation is symmetrical. The left side of the elevation is Building 1626. The far left side is where the later, enclosed vestibule corridor is located and defined by a single entry metal door with a narrow light (see Photo 14). The east elevation of Building 1626 has a set of replacement metal doors, each with a large light, and it is accessed by a poured concrete porch with metal 
handrails. A large mechanical system unit is located to the left of the doors. The middle of the east elevation is the hyphen. A set of metal doors is located in the middle of the east elevation of the hyphen (see Photo 15). The right side of the east elevation is Building 1627 (see Photo 16). It mirrors the left side, which is Building 1626. The left side projects slightly outward from the right side and is where the long corridor vestibule addition is located (see Photo 16). There are two windows are located on this part of the elevation. The right side has eight replacement windows. The west elevation consists of the inside view of the U-shaped footprint (see Photo 17). The left side is Building 1627 and consists of a centrally placed replacement door accessed by metal steps with metal handrails (see Photo 17). The middle of the west elevation is the hyphen. A recessed entry bay is nestled under the roofline in the middle of the elevation. A set of metal doors, each with a large light, is accessed by a set of metal steps (see Photo 18). A one-over-one window is located to the right of the entry bay (see Photo 18). The right side of the west elevation is Building 1626 and it mirrors Building 1627 at the left side of the west elevation (see Photo 17). The south elevation is Building 1627. The left side has eight replacement windows, while the right side projects slightly outward and is where the long corridor vestibule addition is located (see Photo 14). There are two one-over-one windows on this part of the elevation (see Photo 9). The inside of the U-shape: The north elevation of Building 1626 faces the south elevation of Building 1627. These facing elevations mirror each other, and both have six replacement windows (see Photos 17 and 18).

The interior of all four buildings has been completely remodeled and no original finishing materials exist (see Photos 20 and 21). All new materials, including drywall, flooring, drop-ceilings, lighting, doors, and window trim, have replaced the original. The original layout of spaces for dining area, kitchen area, and storeroom are intact (see Photos 20 and 21). The interior of the hyphen has a corridor with restrooms and storage rooms accessible from it (see Photo 22).

\section{HISTORY (excerpt taken from the HABS Data Sheet)}

Typical blocks within the general layout were based both on military organizational requirements and city planning principles. Each block was to be occupied by a battalion of troops. Two blocks comprised a regiment. Within a block were size to seven companies, depending on the type of battalion involved. Along each street in a block were four mess halls at center, and ten or more barracks, with a company usually occupying three barracks and eating in one of the mess halls. To the rear of the barracks, at either end of each street were company administration buildings, one for each company.

Architecturally, this type of mess was one of five variations available in the 800 Series of standard plans for mess halls. Buildings 1616, 1617, 1626, and 1627 formerly were four of 172 mess halls erected in 1942 by using Standard War Department Drawing 800-851 prepared for the construction of a 228-man mess hall.

\section{Exterior:}

Over-all dimensions: The mess halls are rectangular in shape and are 25'-0" wide and 118'-0" long with an approximate area of 2,950 square feet. The buildings are one story, and the height from grade to the roof ridge is approximately $15^{\prime}$.

Foundation: The foundations of the mess halls were concrete piers. The crawl space below each building was screened by a wooden skirting composed of vertical boards.

Walls: The exterior walls consisted of three layers: (a) wooden sheathing, (b) black construction paper, and (c) siding composed of cement asbestos pieces measuring 11" x 24", the standard size used throughout the cantonment. The siding pieces had a scalloped bottom edge detail. The one-story buildings erected from the 800 Series standard plans are of balloon construction.

Roof: The roofs were low-pitched gables clad with red asphalt shingles. The overhanging eaves had wood fascia and soffit.

Chimney: There was no brick chimney stack. There were three large circular metal vent stacks that projected from the slope of the roof over the kitchen area where the range was located.

Porches, stoops: The original drawing version of standard Plans 800-851 show wooden stairs and porches at each of the four entries on the exterior of the mess halls.

Windows: There were two types of standard 800 window designs used in the mess halls. Type "A," measuring 4'-6" x 3'-4 5/16" was located near the kitchen and storeroom. Type "B," measuring 5'-2" x 
3-4 5/16" was placed along the dining room section of the halls. The kitchen and storeroom windows were set higher in the walls and are shorter than the dining room windows. Both types of windows followed the same standard design: eight-over-eight light, double-hung sash, and constructed of wood with a simple wooden architrave. Wood-frame screens were placed over each window.

Doors: The doors of the mess halls are wider than other doors found in the 800 Series. Two sizes of doors were used on the mess halls. Standard door type "BBB," measuring 7'-0" x 3'-0" was installed in the entry to the storeroom. Standard door type "P," measuring 8'-0" x 3'-2", was used in the three doorways leading into the dining room. The door designs were all of the standard type used at Camp McCoy; four lights over three horizontal recessed panels. The standard simple doorway surround was used for all entries. Standard screen doors, composed of wooden frames and wire mesh screens were placed at the entry doors.

\section{Interior:}

Floor plan: The interior of the buildings depicted the activities carried on in all 172 mess halls at Camp McCoy; a dining room in one half, in which the troops sat at tables, and a kitchen and store room in the other half, where foot was prepared, served, and stored. During WWII, the enlisted men assigned to each mess hall entered the dining room through the exterior doorways. They received their food at the serving counter between the mess hall section and the kitchen and ate at standard issue tables placed in rows. Through an opening in the counter was the kitchen, where the cooks and "K.P." staff prepared the food and cleaned up following each meal. They stored foodstuffs on shelves in the storeroom and placed perishable items in the large cooler. The kitchen staff entered and exited the mess hall through the rear of the building.

Flooring: Originally, there were softwood floors in the dining rooms of all the mess halls erected at Camp McCoy, laid on foundations of construction paper and wooden sub-flooring. Following WWII, linoleum tile was installed in apparently all of the dining rooms in the cantonment. There are two 5'-0" x 4'-6" concrete platforms in the mess section of the buildings. These were intended for Cannon Stoves that originally heated the room. The kitchen and storeroom had concrete floors.

Walls and ceiling finishes: In the dining room, there was a wainscoting of manufactured board, called "tempered pressed wood" in the standard plans and was used on the bottom three feet of the walls.

"Insulation board" was used on the upper six feet of the walls above the wainscoting. The ceiling was insulation board. Pairs of exposed structural knee braces ran between the upper walls into the attic between each bay. In the kitchen, there was 6'-0" high wainscoting composed of pressed wood. Insulation board was installed above the wainscoting. A fourteen foot wide ceramic tile surface was used along the kitchen wall to provide fireproof backing for the cooking ranges. The storeroom walls were composed of standard-sized 5-1/4" wide tongue and groove boards nailed horizontally across the studs. On three of the walls were built-in shelves and counters. The ceiling in the storeroom was composed of insulation board.

Doors: There was one interior door located between the kitchen and the storeroom, and it was standard type "L-I," consisting of five horizontal recessed panels.

Windows: The same, simple board architraves found in the barracks and company storehouse, administration, and recreation buildings framed the interior mess hall windows.

Lighting: The original light fixtures in the dining room were metal-shades screwed onto porcelain sockets attached to the ceiling.

Original furnishings: Wooden tables and benches were used in the dining room. A work/prep table stood in the center of the kitchen. A serving counter placed on top of partition walls between the kitchen and dining room had a pressed board top. There were two detached "scullery sinks" made of galvanized steel and both consisting of double sinks and side counters were located in the kitchen. Also in the one corner of the kitchen was a 6'-0" high wooden pie safe.

In 1951, two vestibule additions were constructed at the two side entries into the dining area.

At an unknown date, but prior to 1985 (according to drawing documentation), the original wood porch stoops and wood handrails were removed and replaced with concrete stoops and cast-iron metal handrails.

In 2003, the original construction materials such as the cement asbestos siding, multi-pane wood doublehung windows, wood panel and divided light entry doors, exterior light fixtures, wooden foundation skirting, and wood porch stoops and wood handrails were all removed and replaced with newer materials and finishes. 


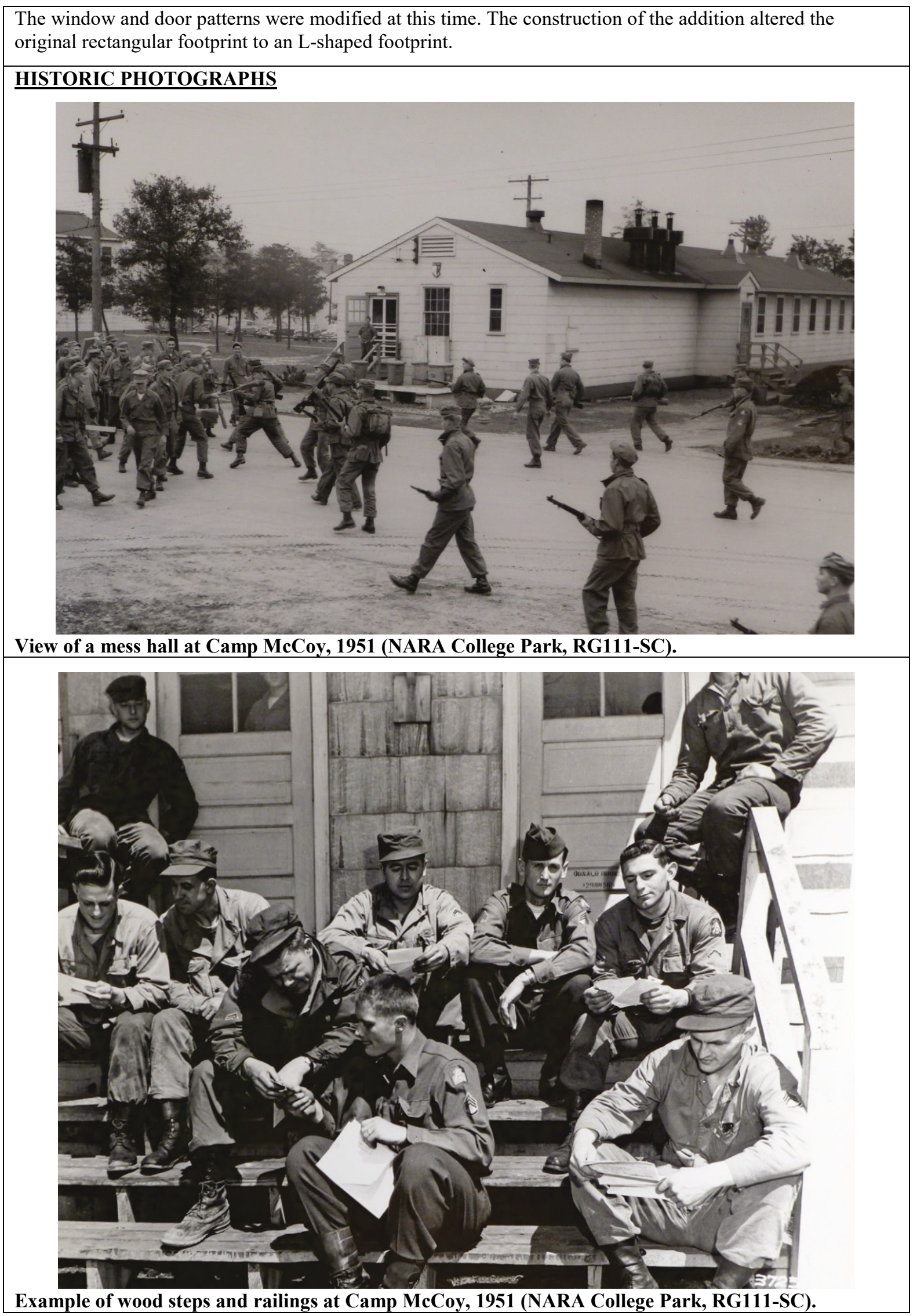




\section{HABS PHOTOGRAPHS}

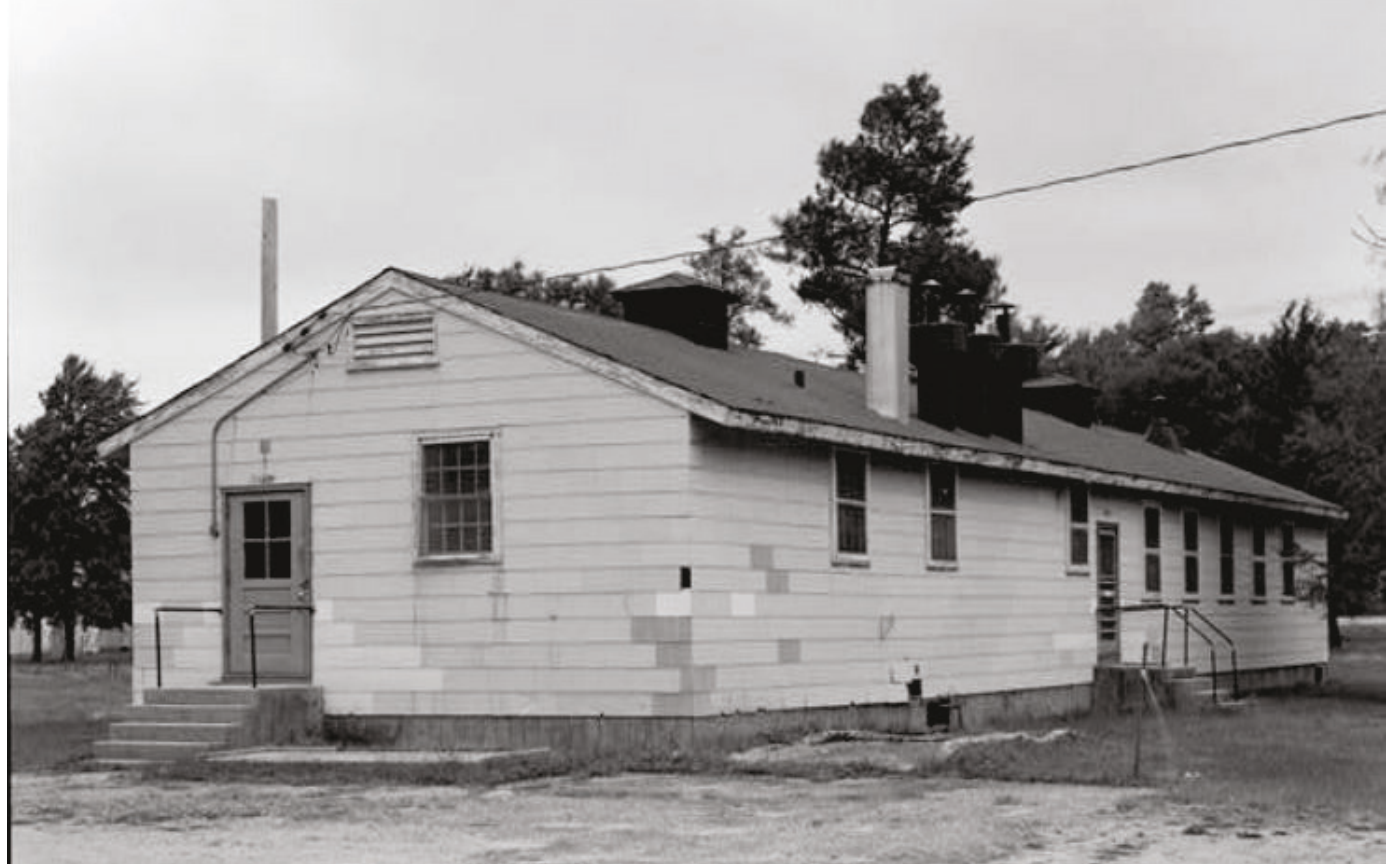

Perspective view of the rear (kitchen and storehouse entry) and side elevations of Building 635, Mess Hall, September 1988 (Library of Congress, HABS WIS, 41-SPAR.V, 1-C-2). (Note that Building 6135 was chosen for HABS.)

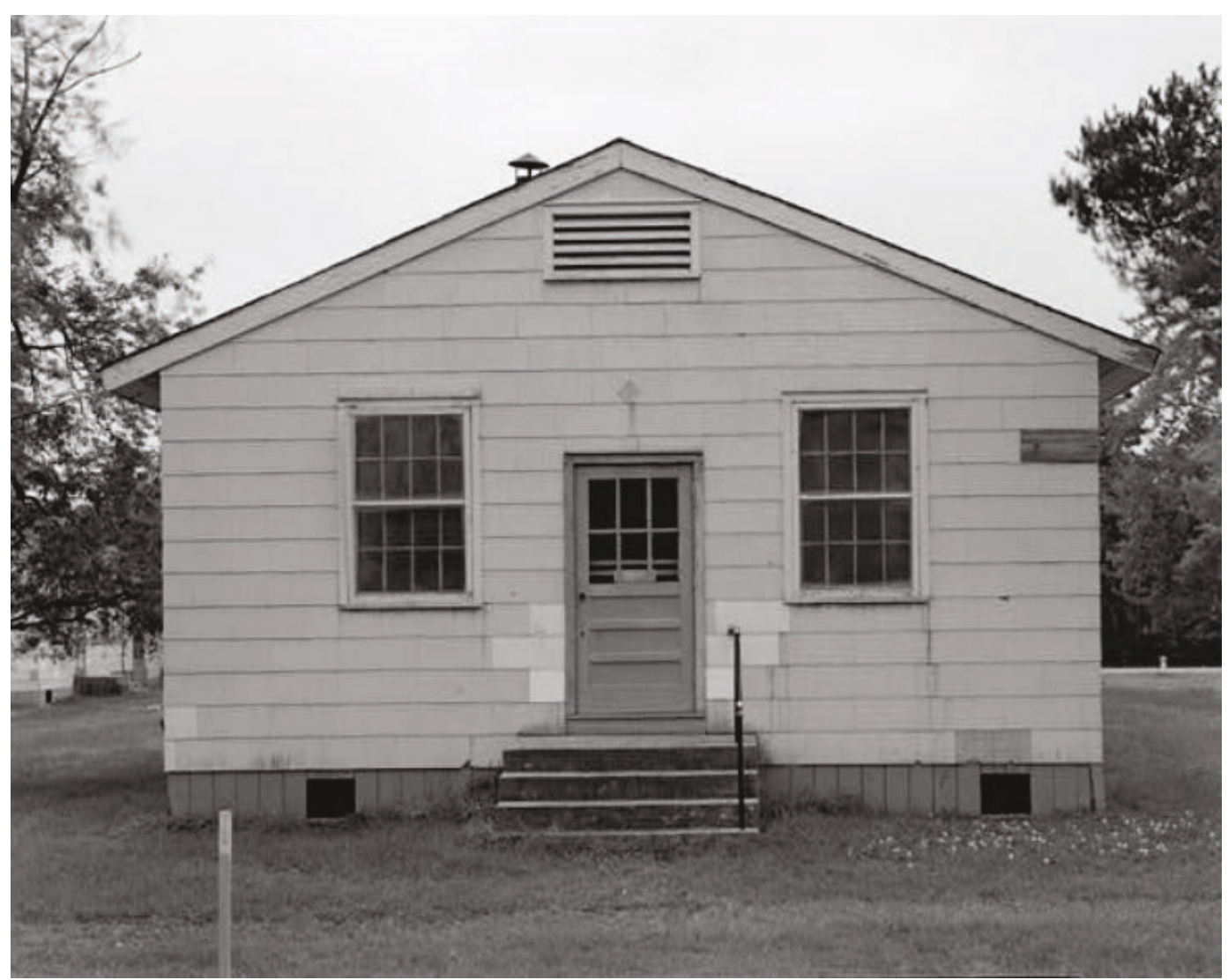

Front elevation of Building 635 showing entry door into the dining area, September 1988 (Library of Congress HABS WIS, 41-SPAR.V, 1-C-3). 


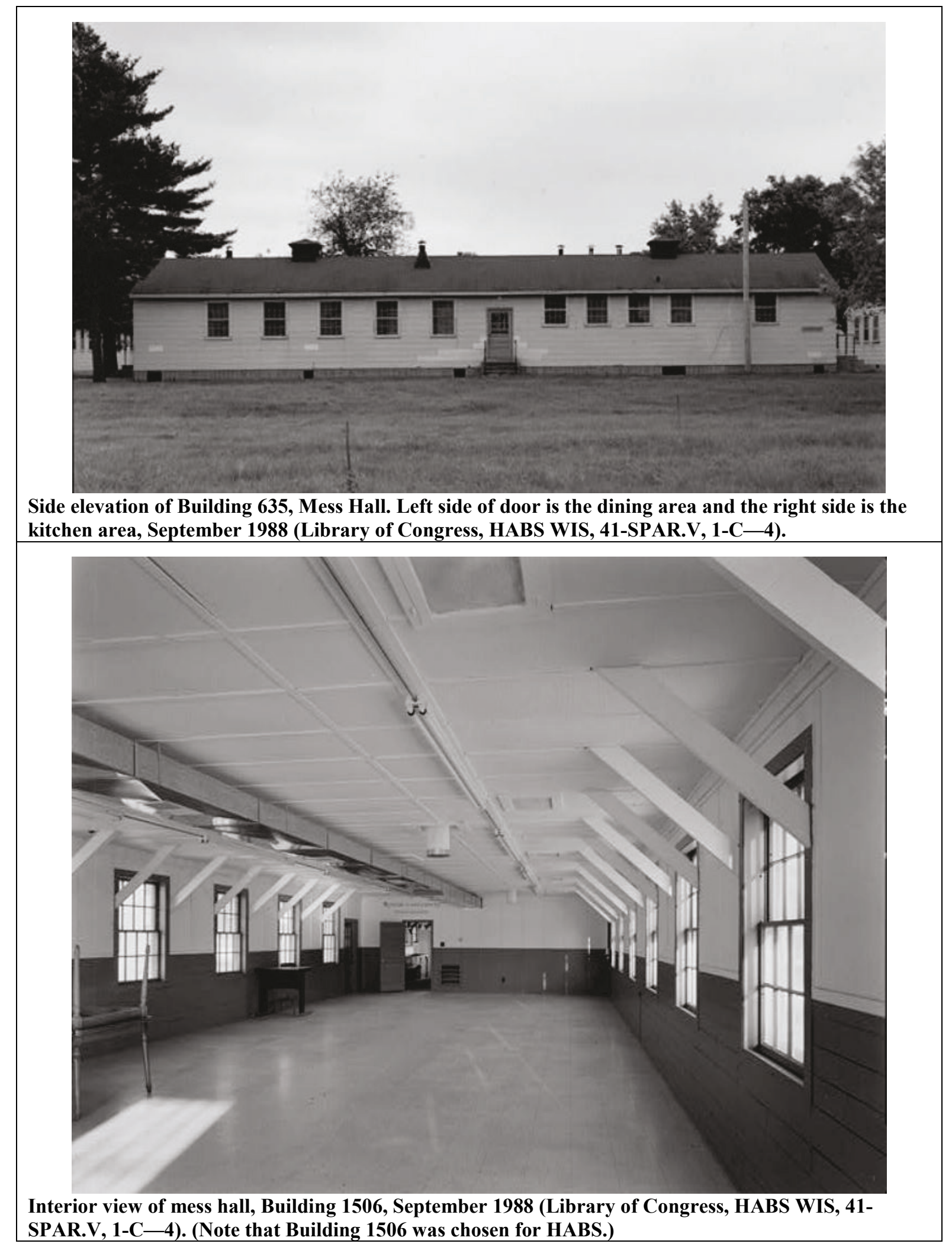




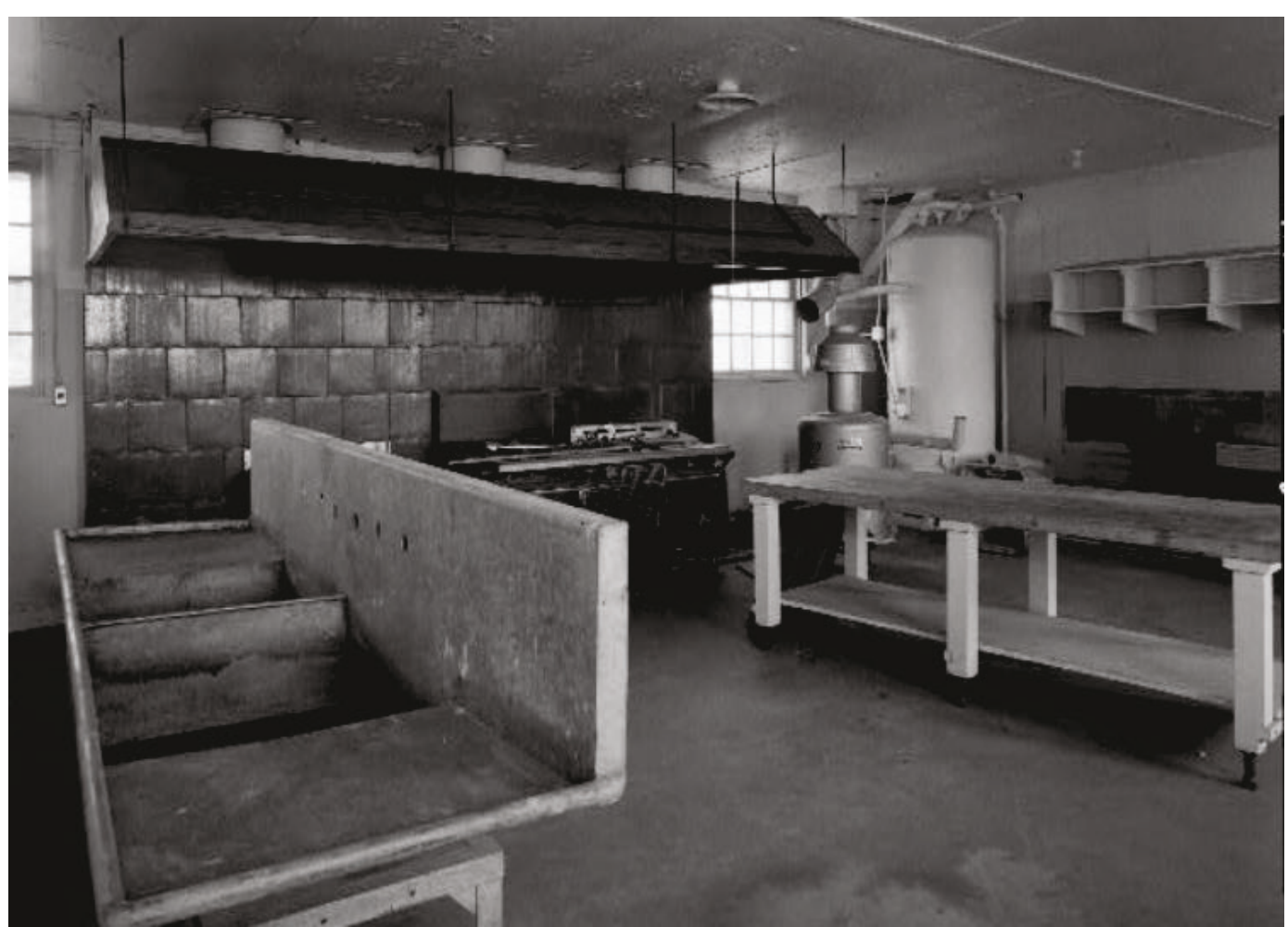

Interior view of kitchen in mess hall, Building 635, September 1988 (Library of Congress, HABS WIS, 41-SPAR.V, 1-C-7).

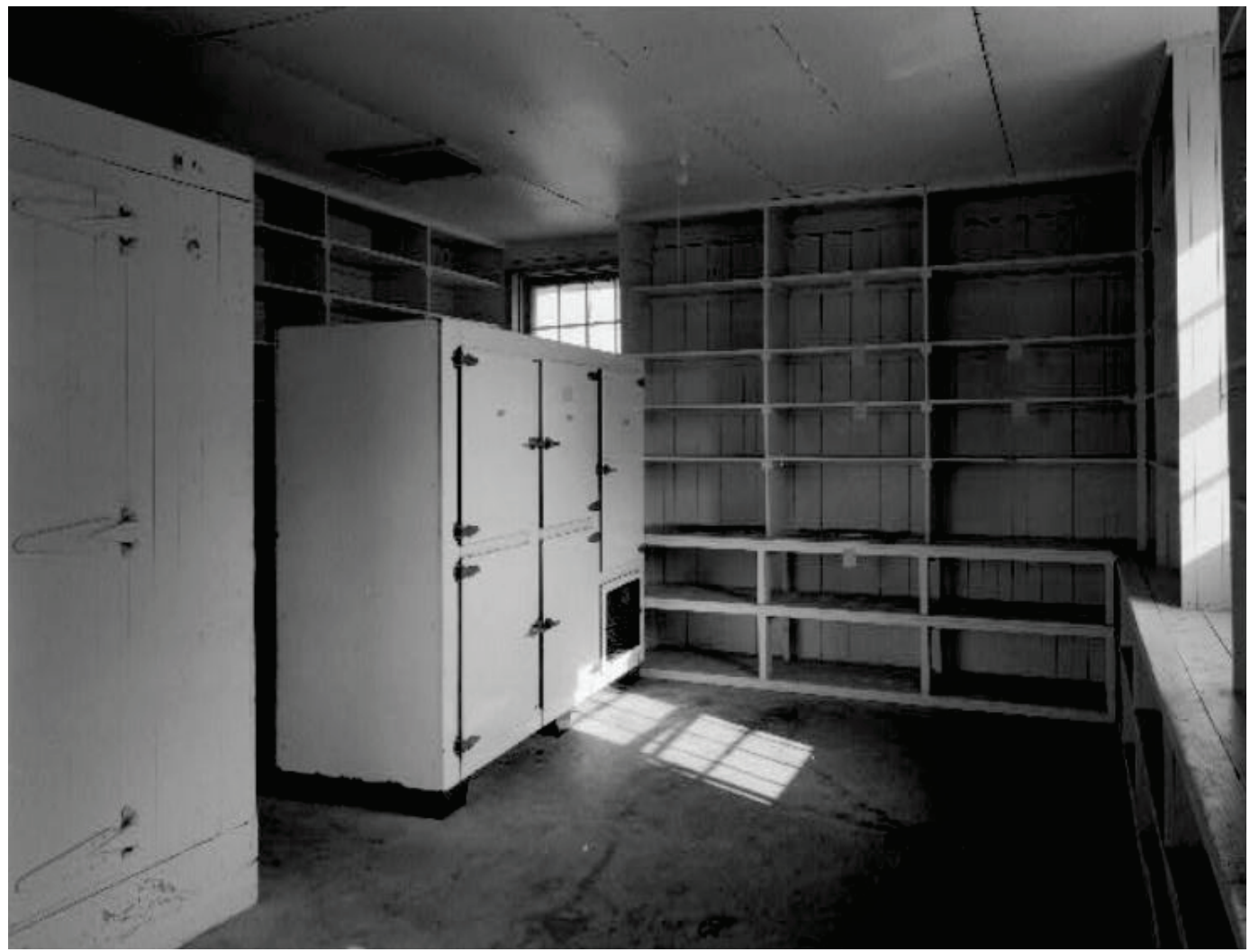

Interior view of the storeroom in Building 635, Mess Hall, September 1988 (Library of Congress, HABS WIS, 41-SPAR.V, 1-C-8). 


\section{CHARACTER-DEFINING FEATURES}

- One-story massing

- Rectangular footprint (modified with construction of a hyphen that connects Buildings 1616/1617 and 1626/1627 that houses restrooms and storage)

- Front gable roof clad with red asphalt shingles (replaced roof in-kind)

- Overhanging eaves with wood fascia and soffit (modified with metal soffits)

- Textured cement asbestos siding with a scalloped bottom edge detail (replaced with vinyl siding)

- Concrete pier foundation with wooden foundation skirting (replaced)

- Window pattern (modified)

- Multi-pane wood double-hung windows, two different types (replaced with one-over vinyl windows)

- Wood trim, surround, and profile of windows (removed)

- Wood panel and divided light doors (replaced with newer metal doors)

- Wood porch stoop and handrails (removed)

- Room arrangement

- Wood floor in dining room (covered with newer materials)

- Concrete floor in kitchen and storeroom (covered with newer materials)

- Serving counter, scullery sinks, pie rack, glazed tile wall and ranges in kitchen area (all removed)

- Built-in cabinets and shelves in storeroom (removed)

- Pressed wood and insulation board clad walls (covered with drywall) and ceilings (replaced with drop-ceiling) throughout

- Wood 5-panel interior doors (replaced with metal doors)

- Simple architrave around windows on interior (replaced by vinyl replacement windows)

- Interior light fixtures (replaced with newer fixtures) 


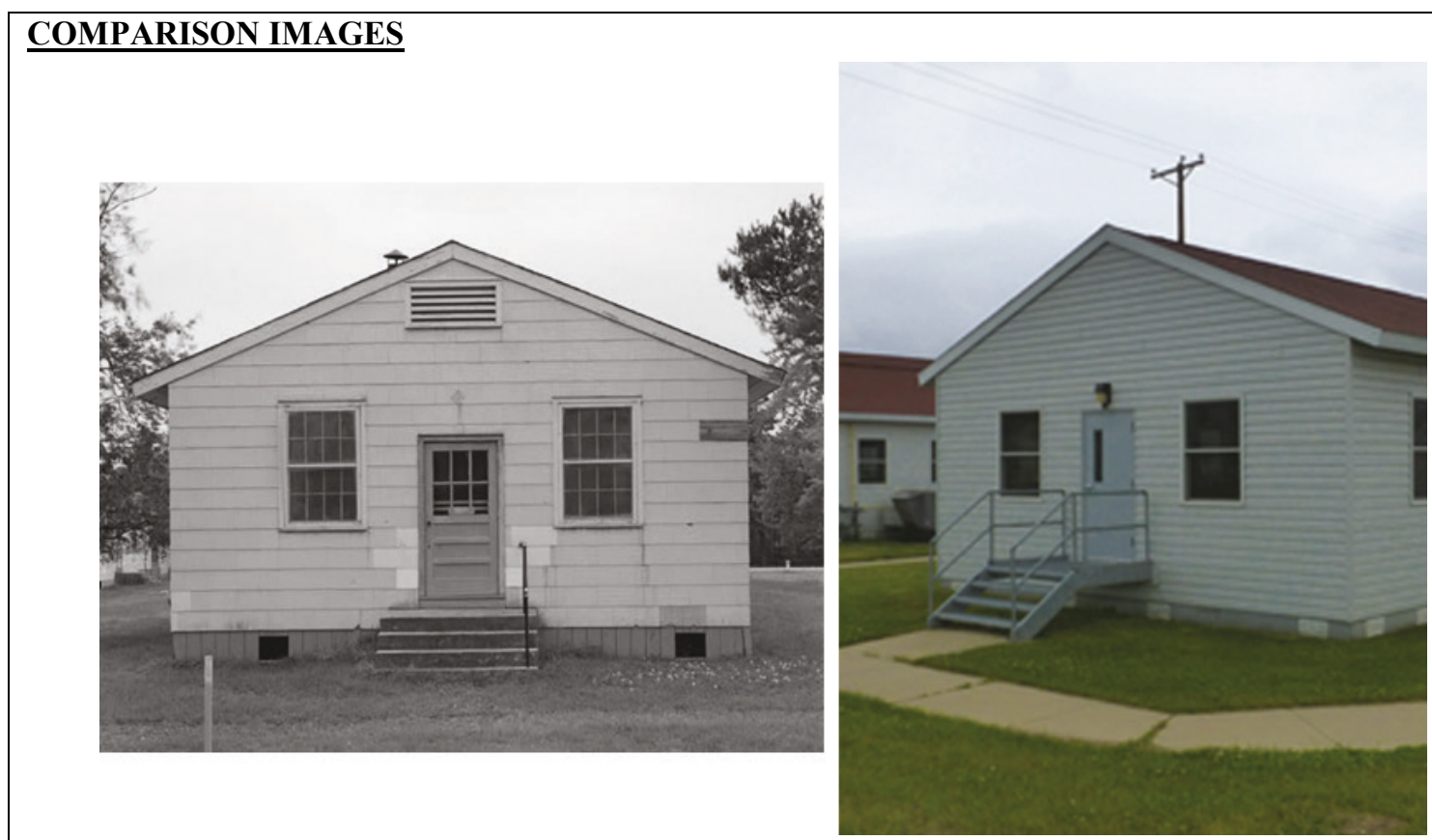

Entry into dining room of a mess hall. Comparison of Building 635 (left) with original design and materials to the current condition of Buildings 1616, 1617, 1626, and 1627 (left: Library of Congress, 1988 HABS; right: ERDC-CERL, 2018).
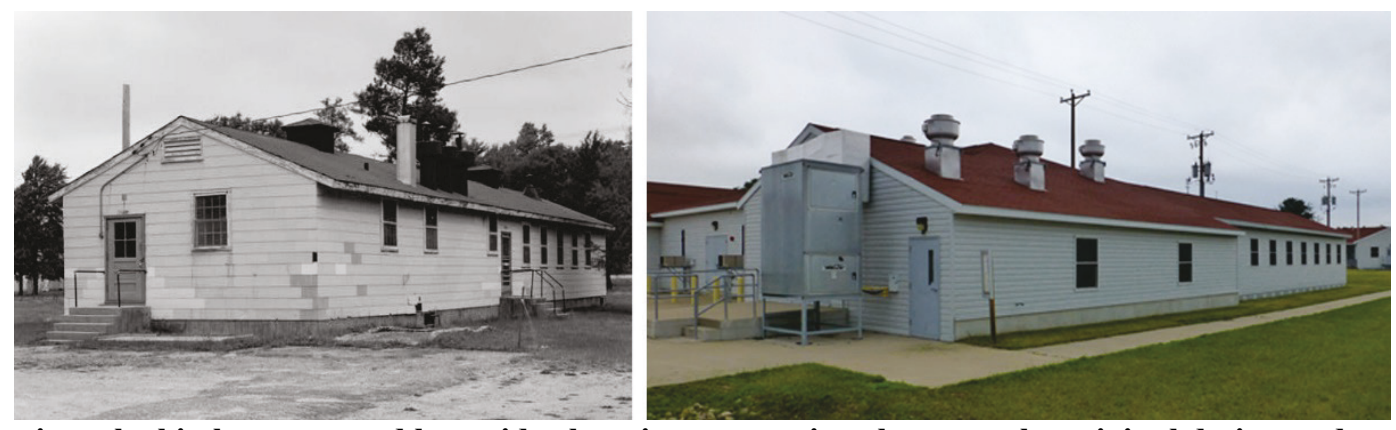

Entry into the kitchen area and long side elevation comparison between the original design and materials (left) compared to the current condition of Buildings 1616, 1617, 1626, and 1627 (right) (left: Library of Congress, 1988 HABS; right: ERDC-CERL, 2018).
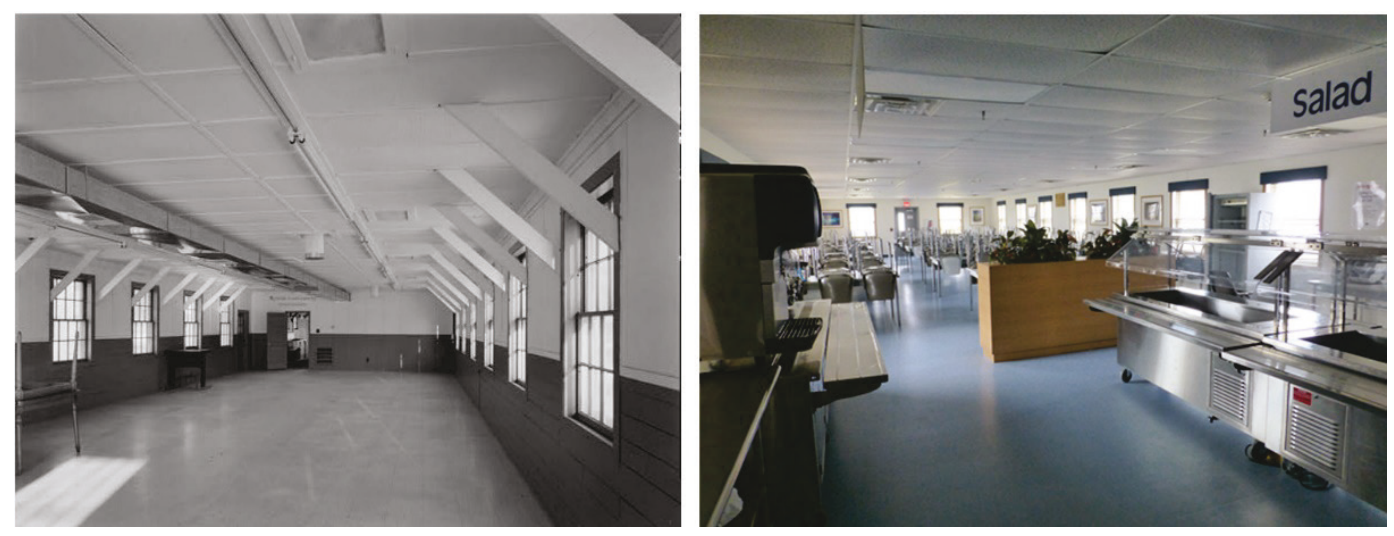

Interior view comparison of the dining room of an original mess hall on the left with the interior of a renovated mess hall on the right (left: Library of Congress, 1988 HABS; right: ERDC-CERL, 2018). 


\section{SIGNIFICANCE}

The 800 Series (and the 700 Series that preceded it) was a comprehensive set of drawings that could be used interchangeably in creating various building types. War mobilization buildings are significant for their construction and technological innovation. Techniques such as the standardization of plans, prefabrication of units, and assembly-line approach to construction were largely pioneered in the construction of these mobilization structures.

The temporary wood buildings constructed with the 700 Series or 800 Series on Fort McCoy during World War II (WWII) from 1939-1946 were determined significant for the National Register of Historic Places (NRHP) in 1986 when the Programmatic Memorandum of Agreement (PMOA) was signed between the Department of Defense (DoD), the Advisory Council on Historic Preservation (ACHP), and the National Council of State Historic Preservation Officers (NCSHPO). In the early 1990s, this significance was reaffirmed by the writing of "World War II and the U.S. Army Mobilization Program: A History of 700 and 800 Series Cantonment Construction" and the performance of the Historic American Buildings Survey (HABS) on a variety of the 700 and 800 Series planned buildings across the country. Many of the 800 Series of buildings at Fort McCoy were utilized for the HABS.

Buildings 1616, 1617, 1626, and 1627 Mess Hall, WWII temporary buildings, are significant under Criterion A for WWII temporary building construction (1939-1946).

The design and construction of the WWII temporary buildings could not be linked to a specific architect due to their construction from standardized War Department temporary building plans. They do not possess high artistic values; however, WWII temporary buildings in general were found to be significant for their design, construction and technological innovation under Criterion C.

\section{INTEGRITY}

Location - All four WWII buildings retain their integrity of location.

Design - All four buildings retain the key elements of their WWII design.

Setting - All four WWII buildings retain their integrity of setting.

Materials - None of the four buildings retain their integrity. Each building has been completely modified with newer materials. No original material elements are intact.

Workmanship - Workmanship is not part of integrity for WWII temporary buildings.

Feeling - All four buildings do not retain their integrity of feeling. They have all been heavily modified with modern materials.

Association - All four buildings retain their integrity of association.

\section{RECOMMENDATION OF CONTRIBUTING/NONCONTRIBUTING STATUS}

It is the recommendation of this report that Buildings 1616, 1617, 1626, and 1627 are NOT Eligible for the NRHP at the national level due to the lack of integrity due to changes in floor plan, changes in siding, changes in window pattern and type, and changes in doors. 


\section{Building 2000}

\begin{tabular}{|c|c|c|c|}
\hline \multicolumn{4}{|c|}{$\begin{array}{c}\text { FORT MCCOY } \\
\text { HISTORIC PROPERTY INVENTORY FORM }\end{array}$} \\
\hline $\begin{array}{l}\text { PROPERTY BOUNDARIES } \\
\text { - Fort McCoy in the } 2000 \text { block } \\
\text { area on the west side of the } \\
\text { triangular cantonment plan } \\
\text { - Sparta vicinity } \\
\text { - Monroe County, Wisconsin }\end{array}$ & \multicolumn{2}{|l|}{$\begin{array}{l}\text { COMMON/HISTORIC NAME } \\
\text { - Building } 2000 \\
\text { - Multi-purpose Recreation Center } \\
\text { - Service Club }\end{array}$} & $\frac{\text { STATUS }}{\text { Vacant }}$ \\
\hline $\begin{array}{l}\text { ARCHITECT/BUILDER } \\
\text { Construction Division, Office } \\
\text { of the Quartermaster General, } \\
\text { Series } 800-517 \text {, Service Club } \\
\text { Type SC-3 }\end{array}$ & $\begin{array}{l}\text { DATE OF CONSTRUCTION } \\
\text { July } 1942 \\
\text { DATE OF ALTERATIONS } \\
1943 \text { - one-story addition on } \\
\text { west wing } \\
1951 \text { - enclosed screen porch on } \\
\text { west wing and added tile } \\
\text { flooring in library and balcony } \\
\text { Ca. } 1970 \text { - removed the screens } \\
\text { on the south porch } \\
2003 \text { - replaced all windows and } \\
\text { exterior doors } \\
\text { Unknown - demolished boiler } \\
\text { room chimney stack, added two } \\
\text { door openings on north side, } \\
\text { modified interior spaces with } \\
\text { carpet, paint, and fixtures, and } \\
\text { dismantled south (front) wood } \\
\text { porch floor and replaced with a } \\
\text { concrete porch floor }\end{array}$ & $\frac{\text { NO. OF STORIES }}{2}$ & $\frac{\text { FOOTPRINT }}{\text { T-shape }}$ \\
\hline$\frac{\text { ROOF FORM }}{\text { Cross-gable }}$ & $\begin{array}{l}\text { FOUNDATION } \\
\text { Concrete pier foundation system } \\
\text { with wood foundation skirting }\end{array}$ & $\begin{array}{l}\text { WALLS } \\
\text { Wood frame with } \\
\text { cement asbestos } \\
\text { siding }\end{array}$ & 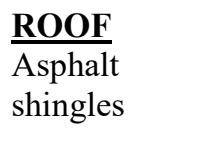 \\
\hline PROPERTI & FUNCTION & \multirow{4}{*}{\multicolumn{2}{|c|}{$\begin{array}{l}\text { NOTABLE FEATURES } \\
\text { - Overall mass } \\
\text { - Cement asbestos siding with a } \\
\text { scalloped edge detail } \\
\text { - Red asphalt shingled roof } \\
\text { - Original interior plan (except } \\
\text { western portion where the café has } \\
\text { been renovated) } \\
\text { - Dance hall, library, and billiards } \\
\text { rooms have most of their original } \\
\text { features }\end{array}$}} \\
\hline HISTORIC USE(S) & CURRENT USE & & \\
\hline Service Club & Vacant & & \\
\hline \multicolumn{2}{|c|}{$\begin{array}{l}\text { RELATIONSHIP TO OTHER BUILDINGS } \\
\text { Building } 2000 \text { is located in the southwest corner of the triangular } \\
\text { cantonment layout just north of where South A Street intersects } \\
\text { with West A Street and South Eleventh Avenue. A paved circular } \\
\text { drive is located on the south side of the building. Open, mowed lots } \\
\text { are located on the east and west sides of the building, and Building } \\
2001 \text { is adjacent Building } 2000 \text { on the west side. }\end{array}$} & & \\
\hline
\end{tabular}




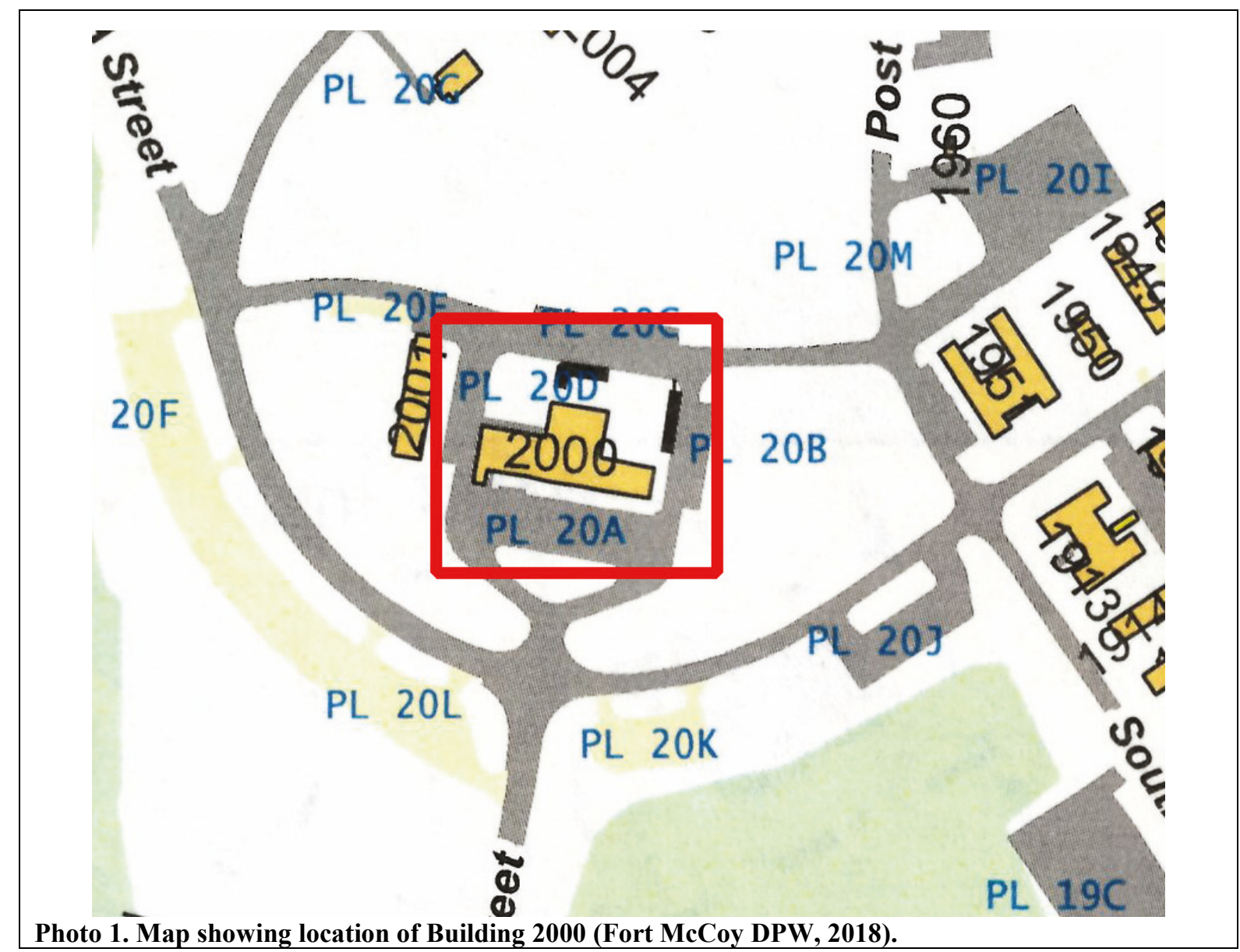




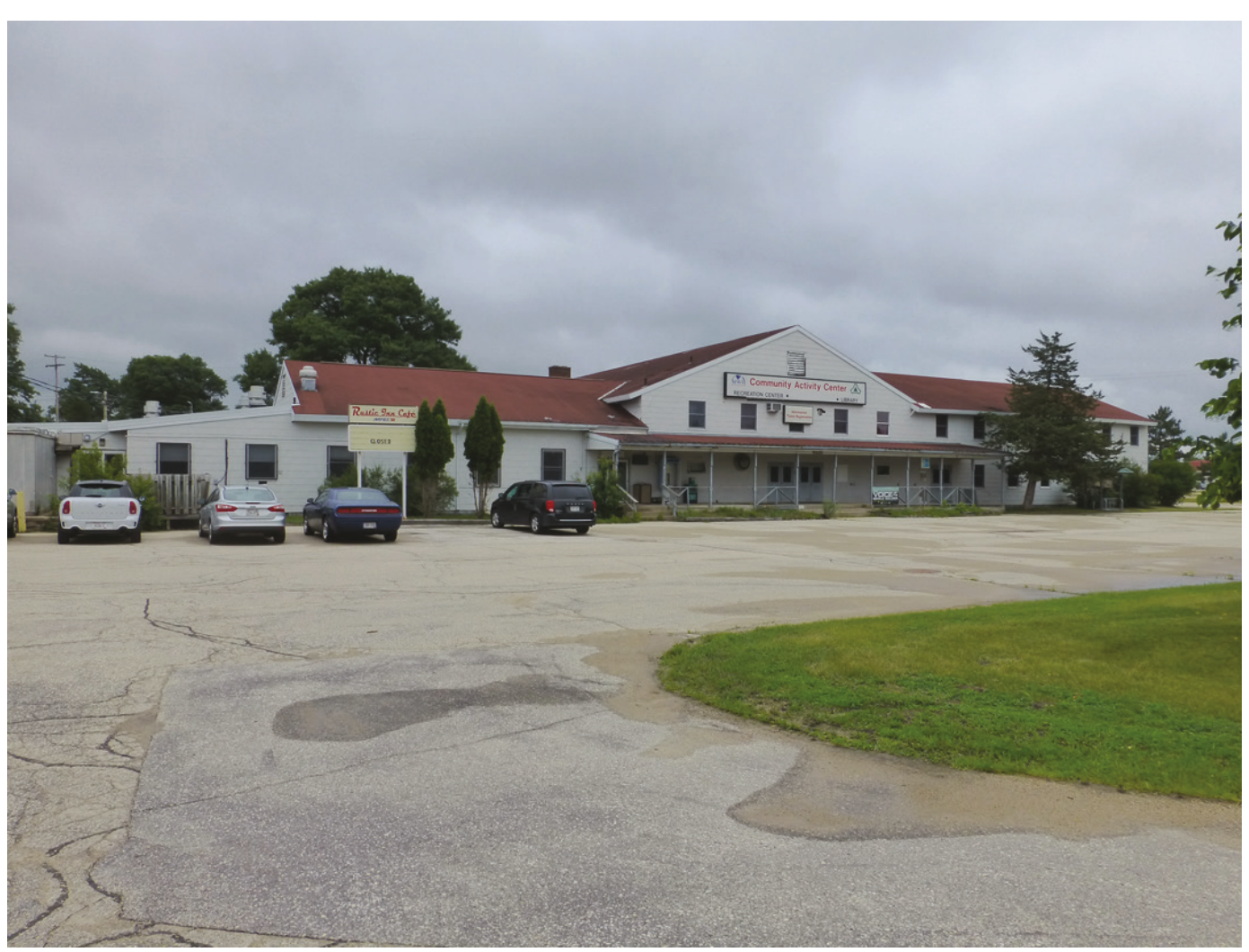

Photo 2. South elevation of Building 2000 (ERDC-CERL, 2018).

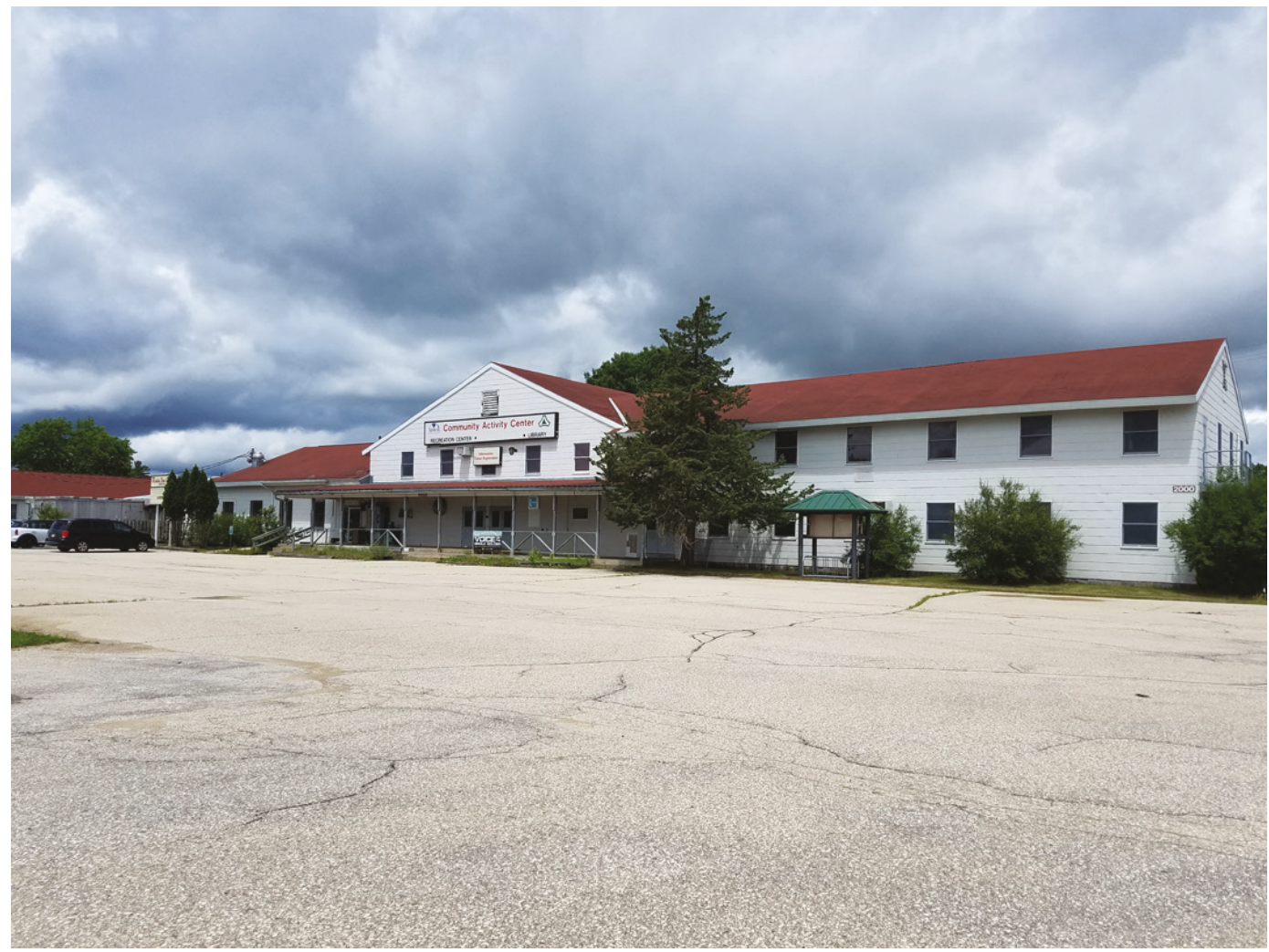

Photo 3. South elevation of Building 2000 (ERDC-CERL, 2018). 


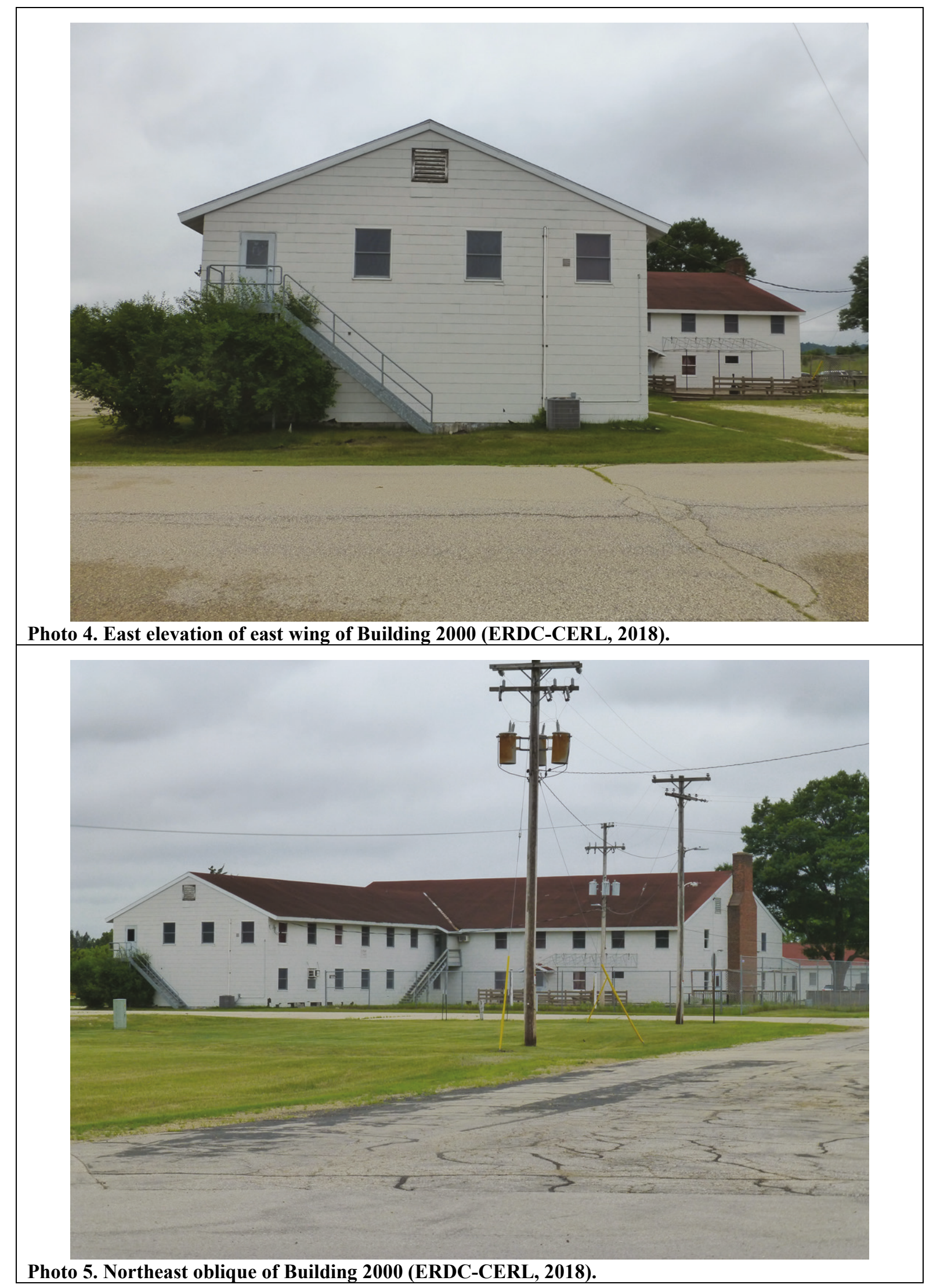




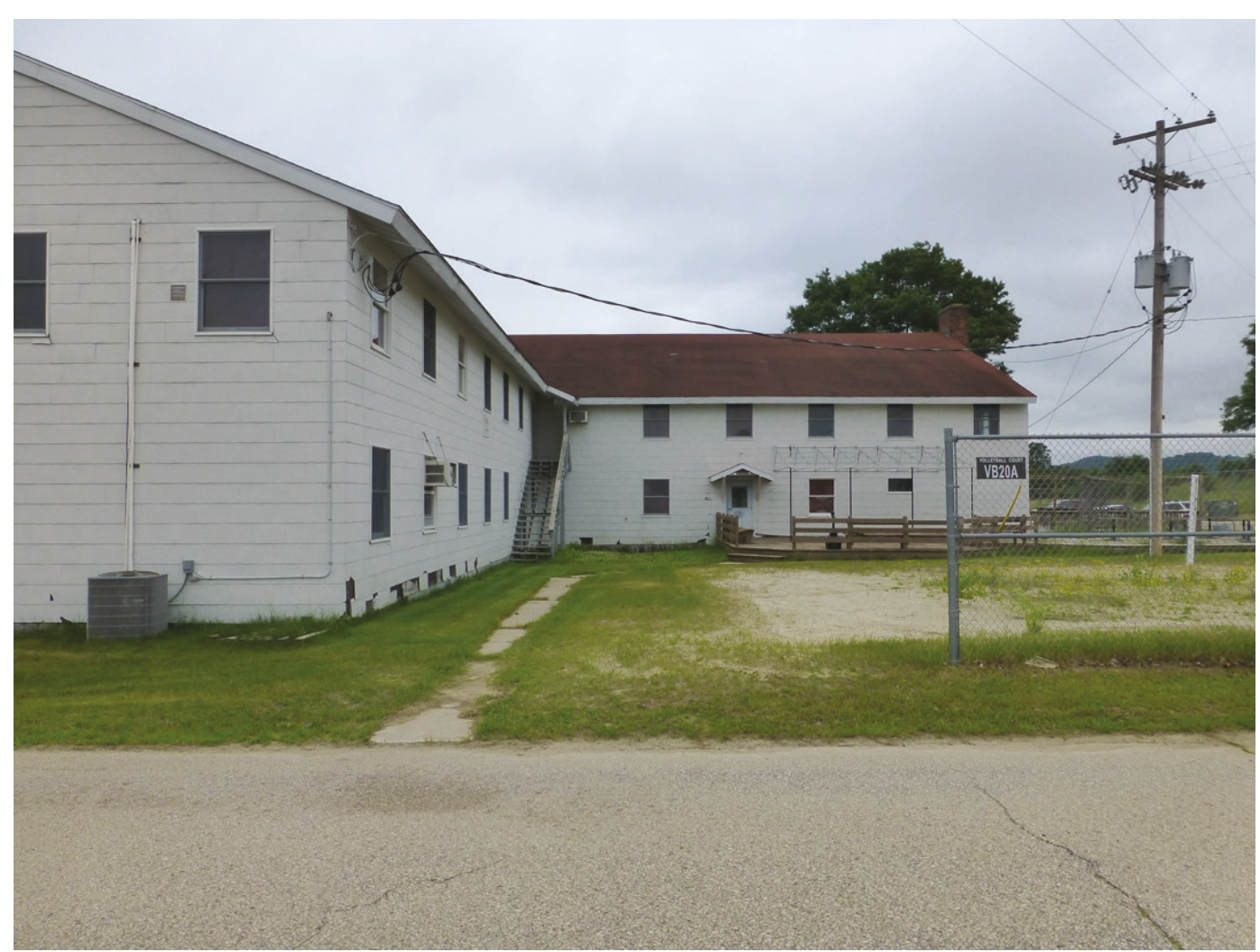

Photo 6. North elevation of east wing (left side) and east elevation of north wing (right side) of Building 2000 (ERDC-CERL, 2018).

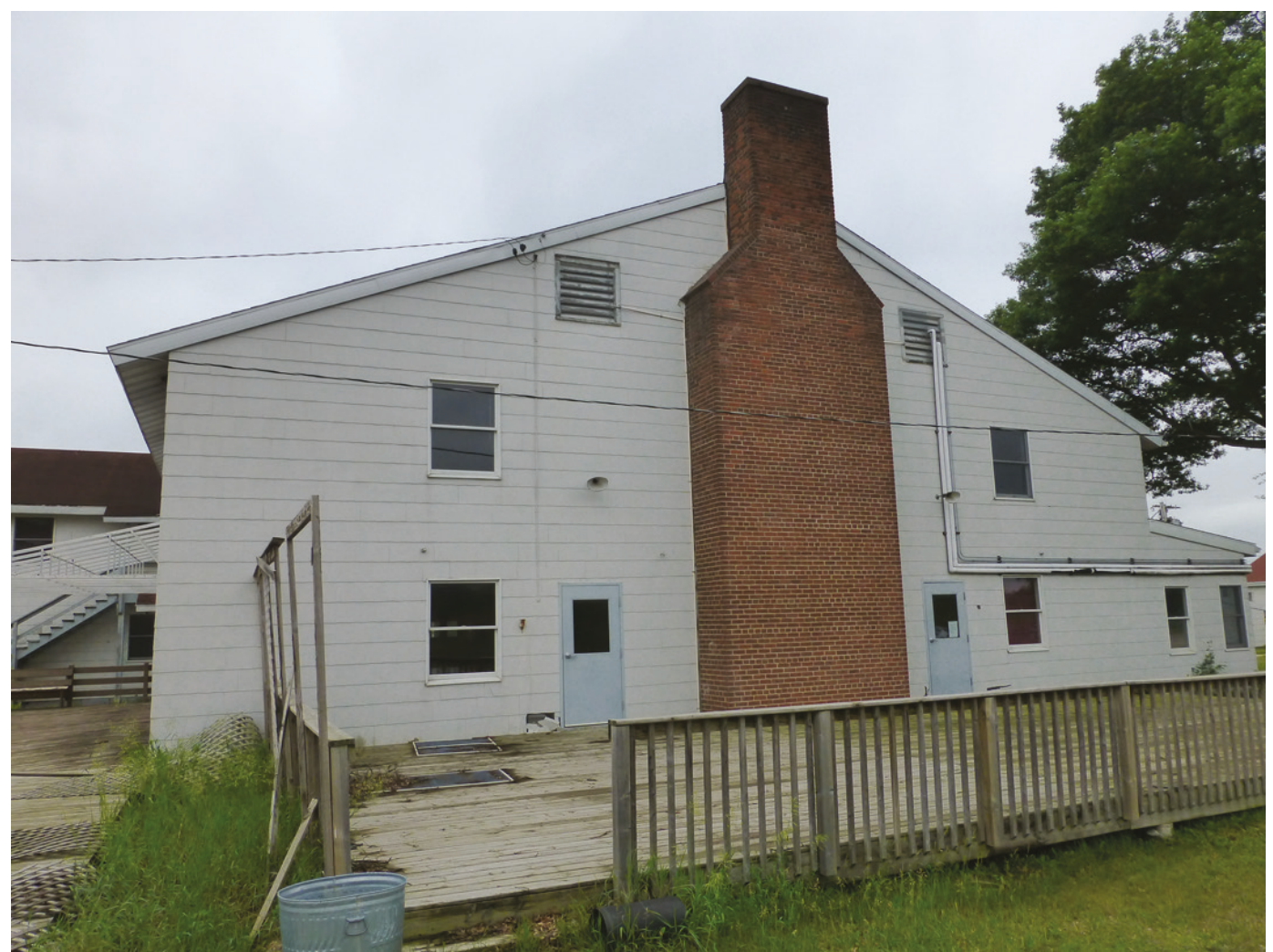

Photo 7. North elevation of north wing of Building 2000 (ERDC-CERL, 2018). 


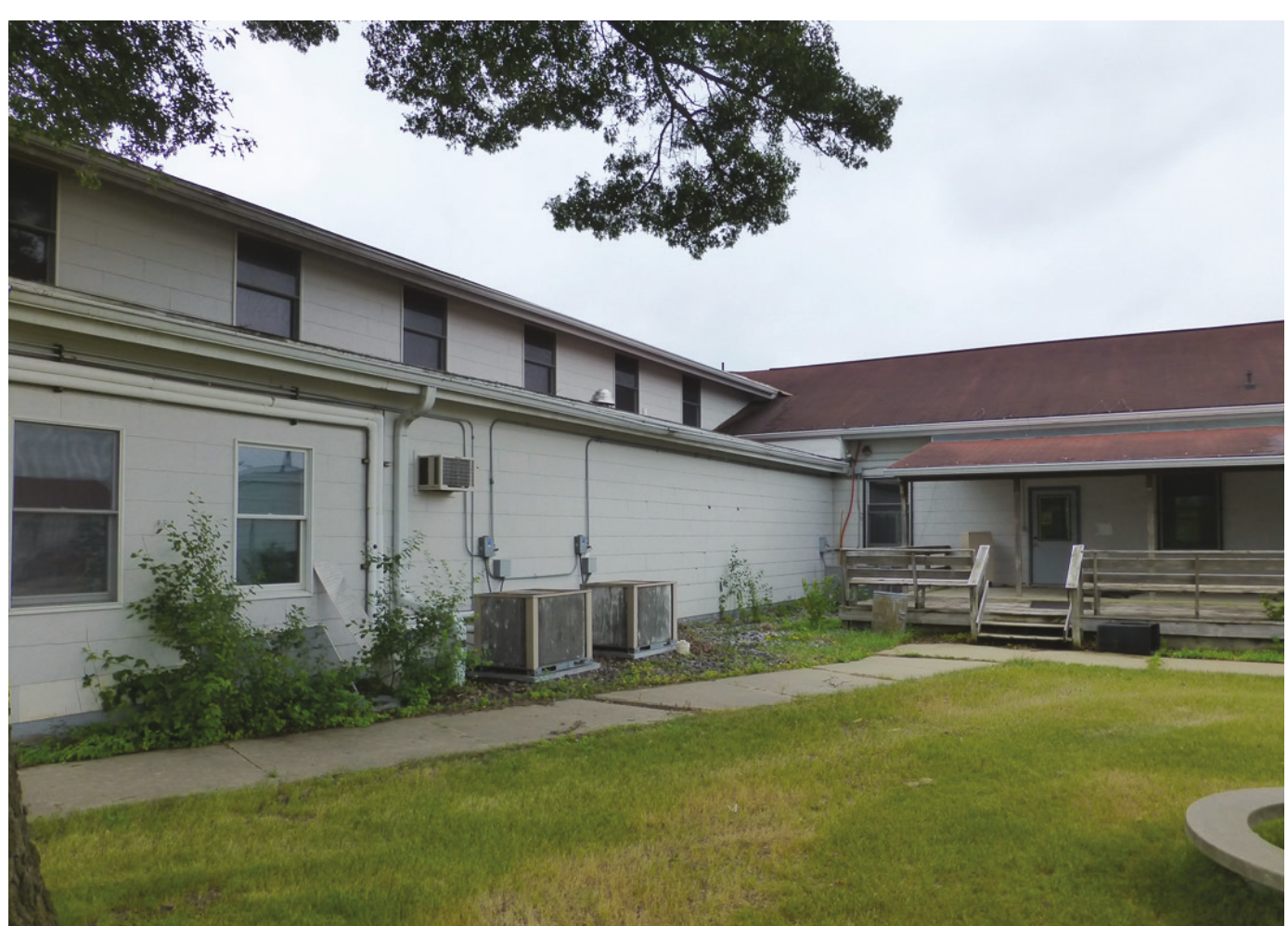

Photo 8. West elevation of north wing (left) and left side of north elevation of west wing (right) of Building 2000 (ERDC-CERL, 2018).

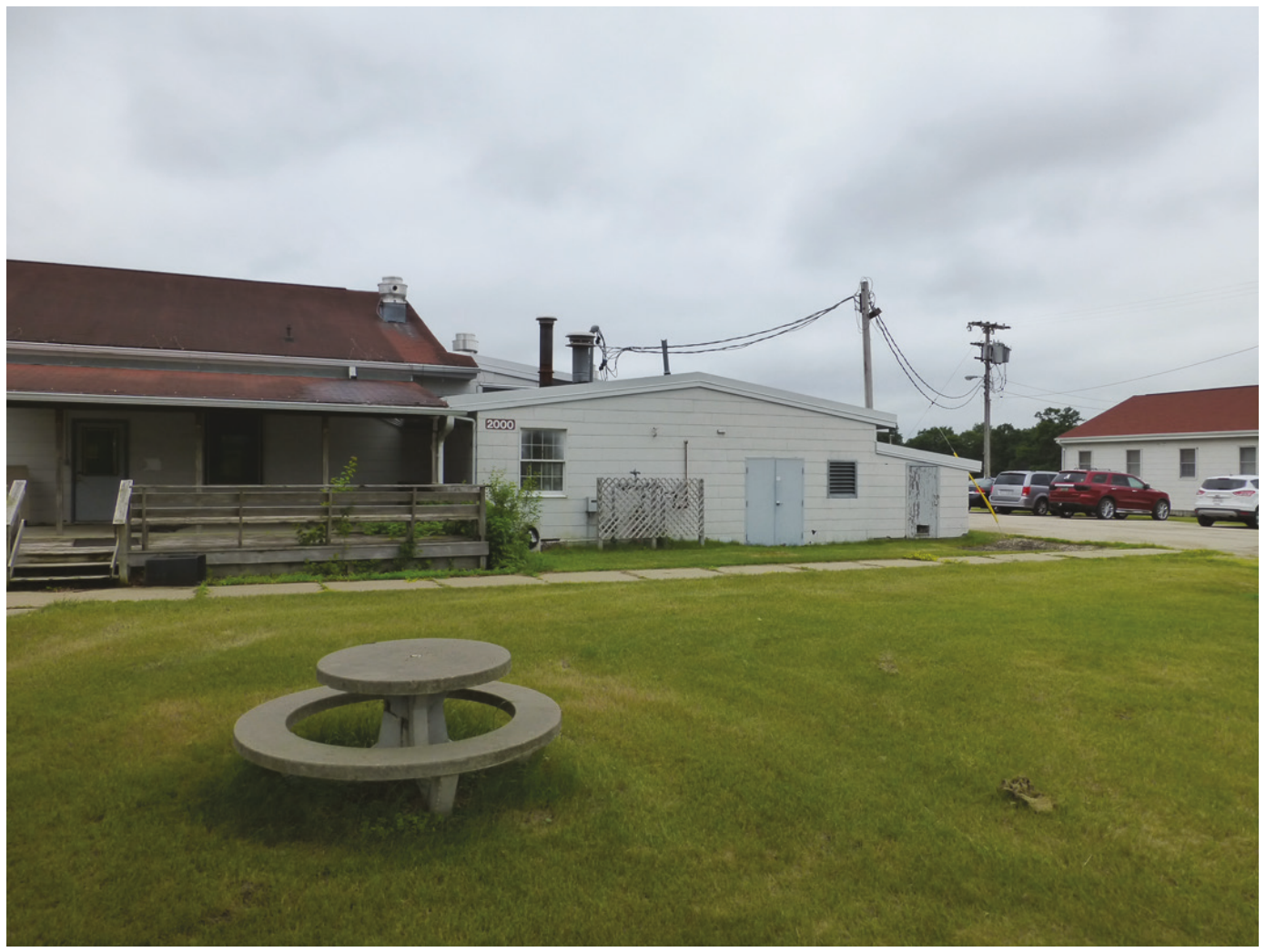

Photo 9. Right side of the north elevation of the west wing (left) and 1943 addition (right) of Building 2000 (ERDC-CERL, 2018). 


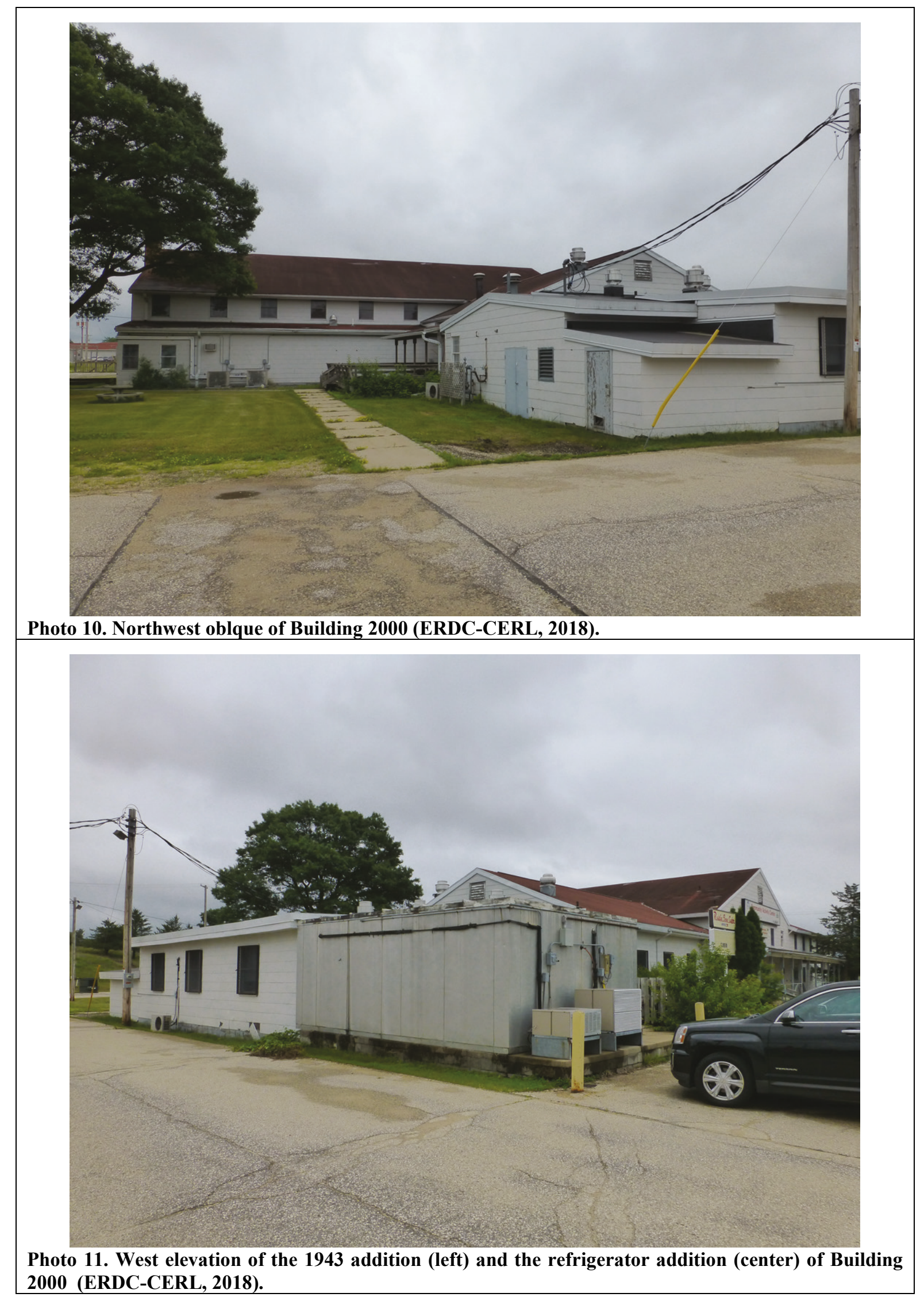




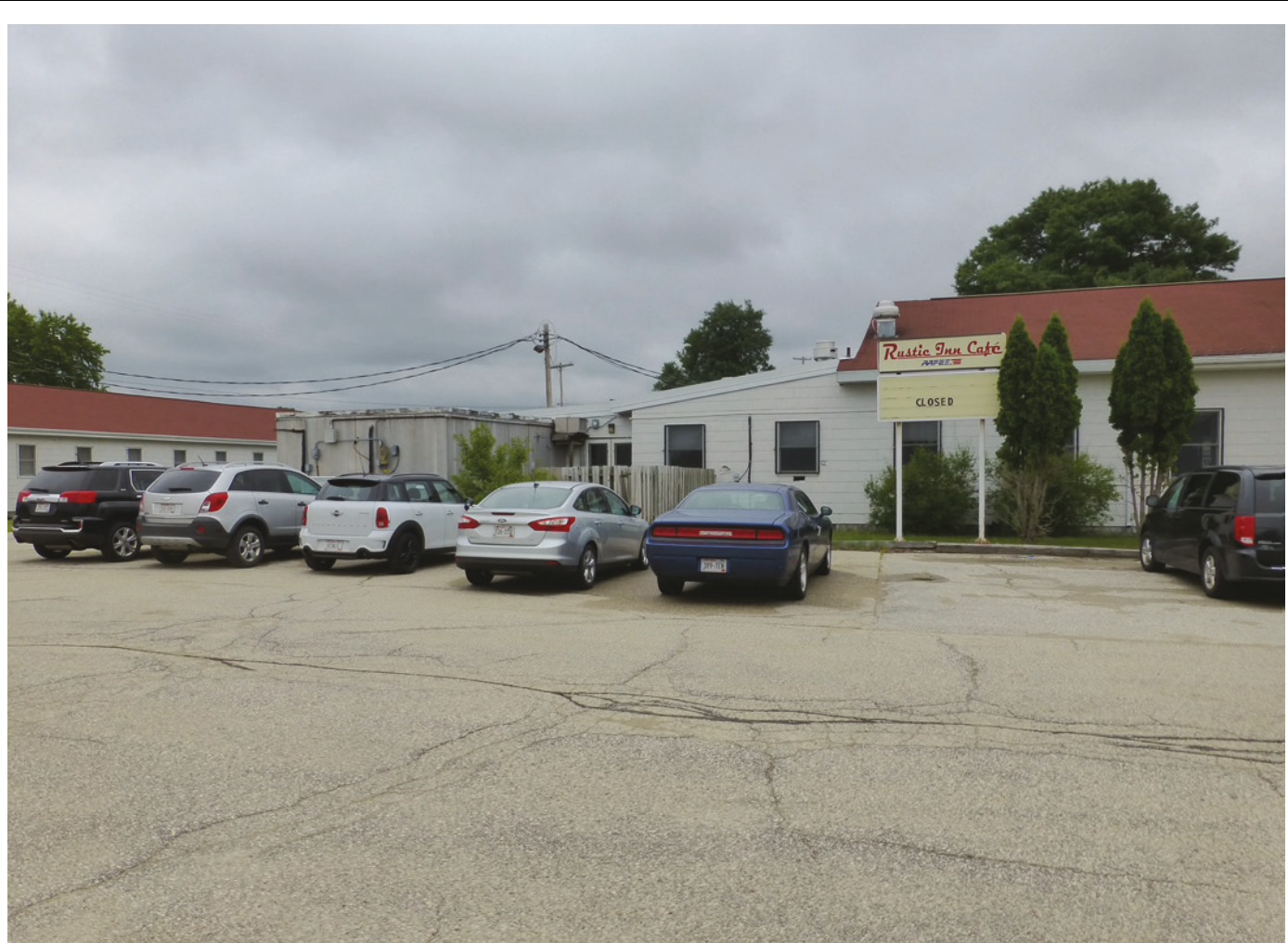

Photo 12. Left side of the south elevation of 1943 addition to Building 2000 (ERDC-CERL, 2018).

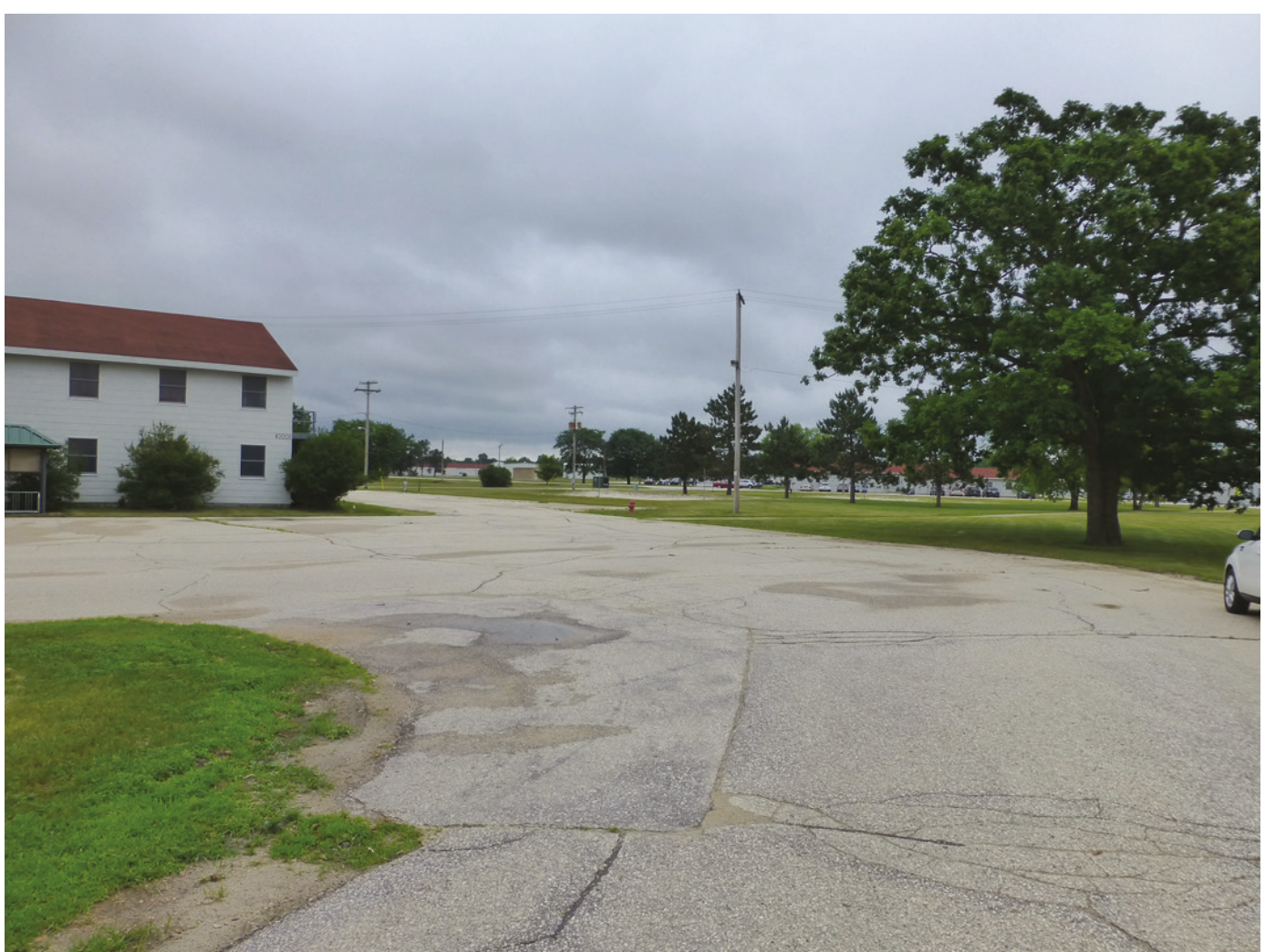

Photo 13. Looking northeast from the paved circular drive in front of Building 2000 (ERDC-CERL, 2018). 


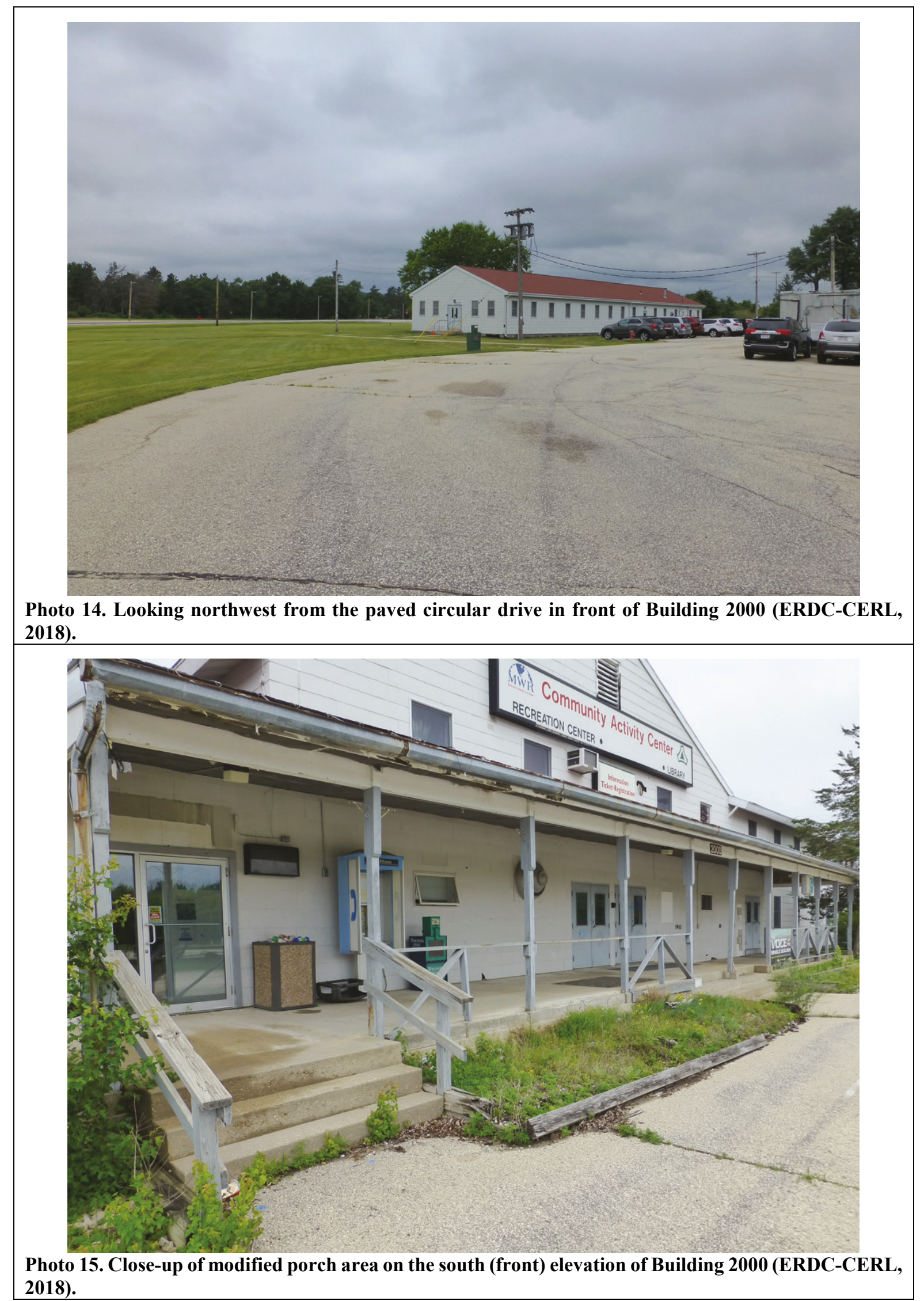




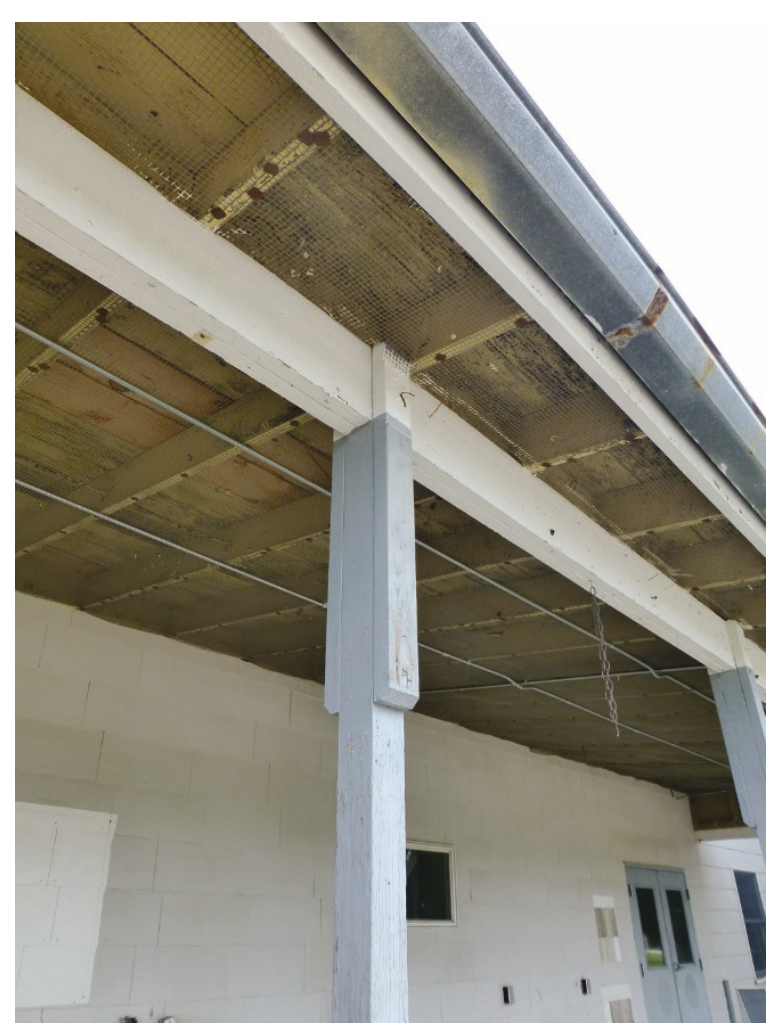

Photo 16. Close-up of the porch wood overhang and supports of Building 2000 (ERDC-CERL, 2018).

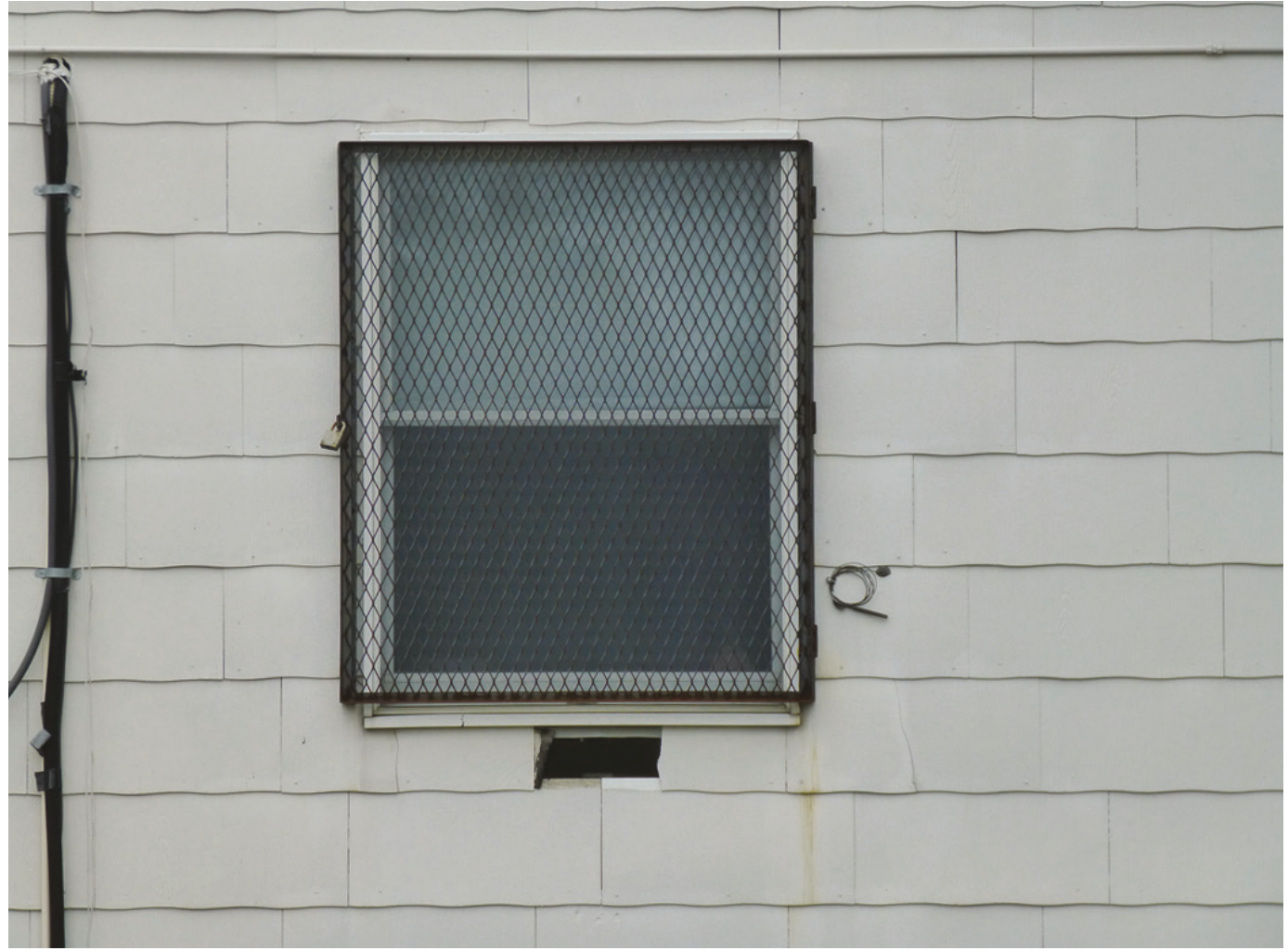

Photo 17. Close-up of replacement one-over-one vinyl window with new metal security screen and closeup of original cement asbestos siding of Building 2000 (ERDC-CERL, 2018). 


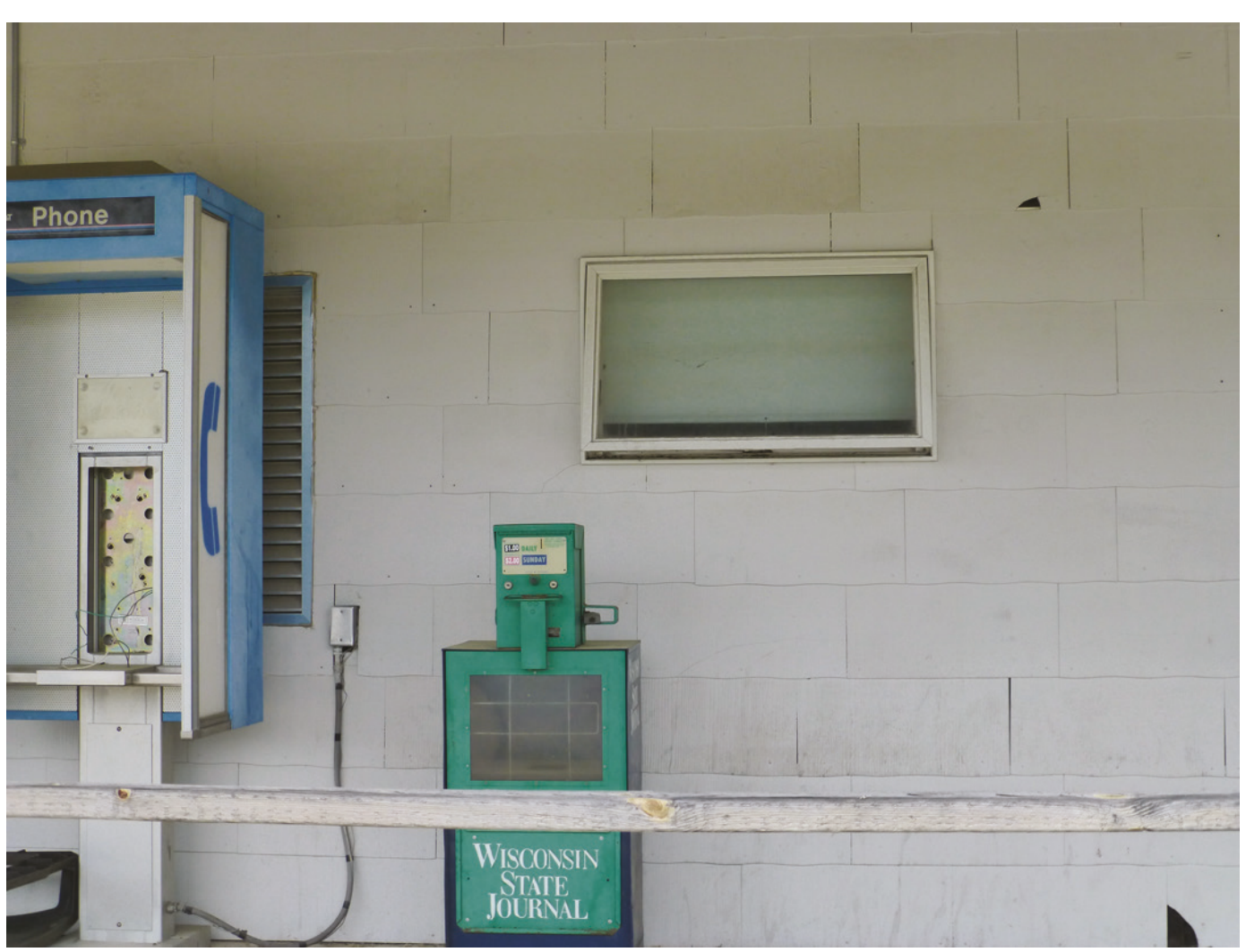

Photo 18. Small replacement one-pane window on the south (front) elevation of Building 2000 (ERDCCERL, 2018).

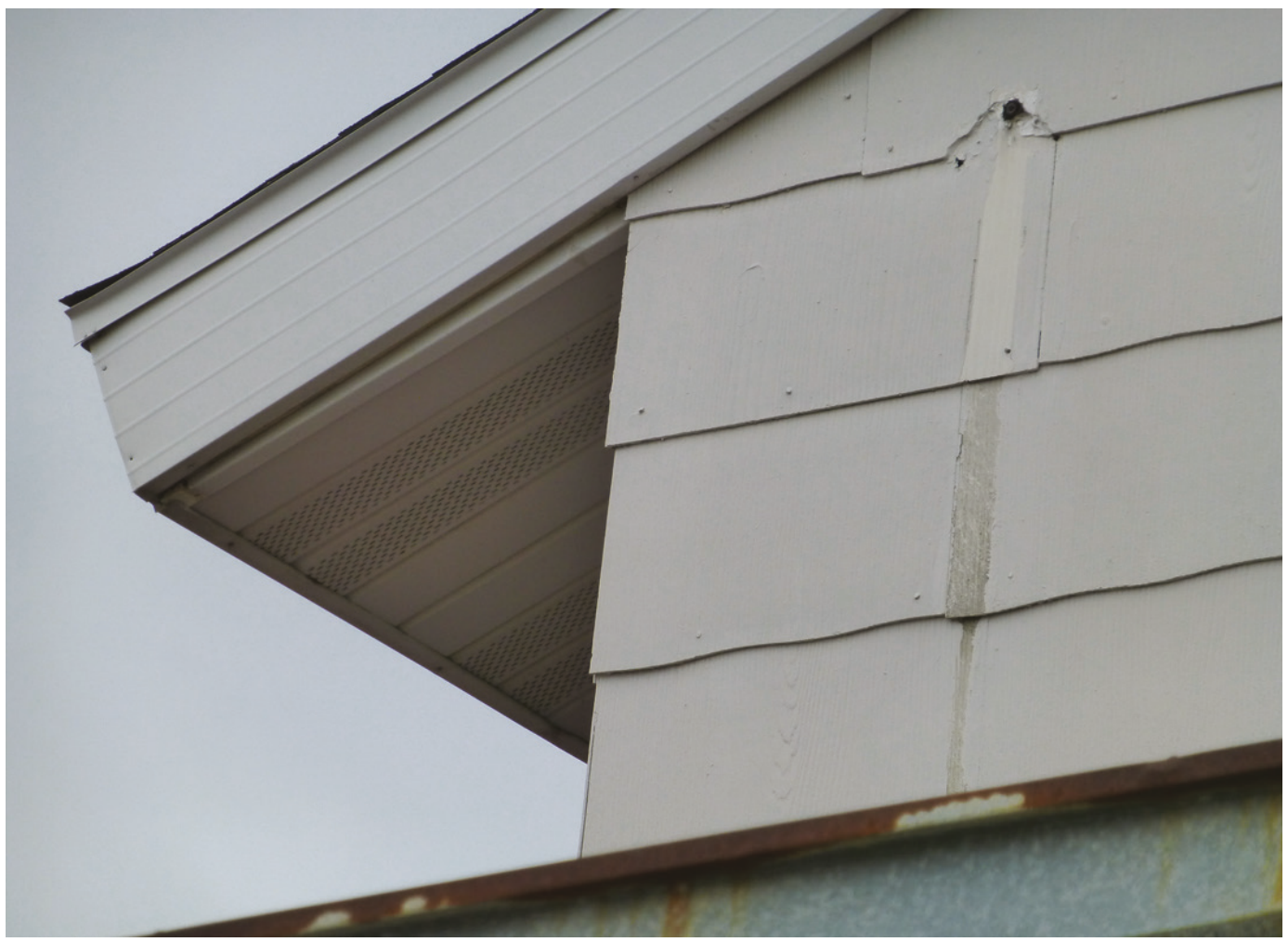

Photo 19. Close-up of modified roof overhang with replacement metal soffit and fascia on Building 2000 (ERDC-CERL, 2018). 


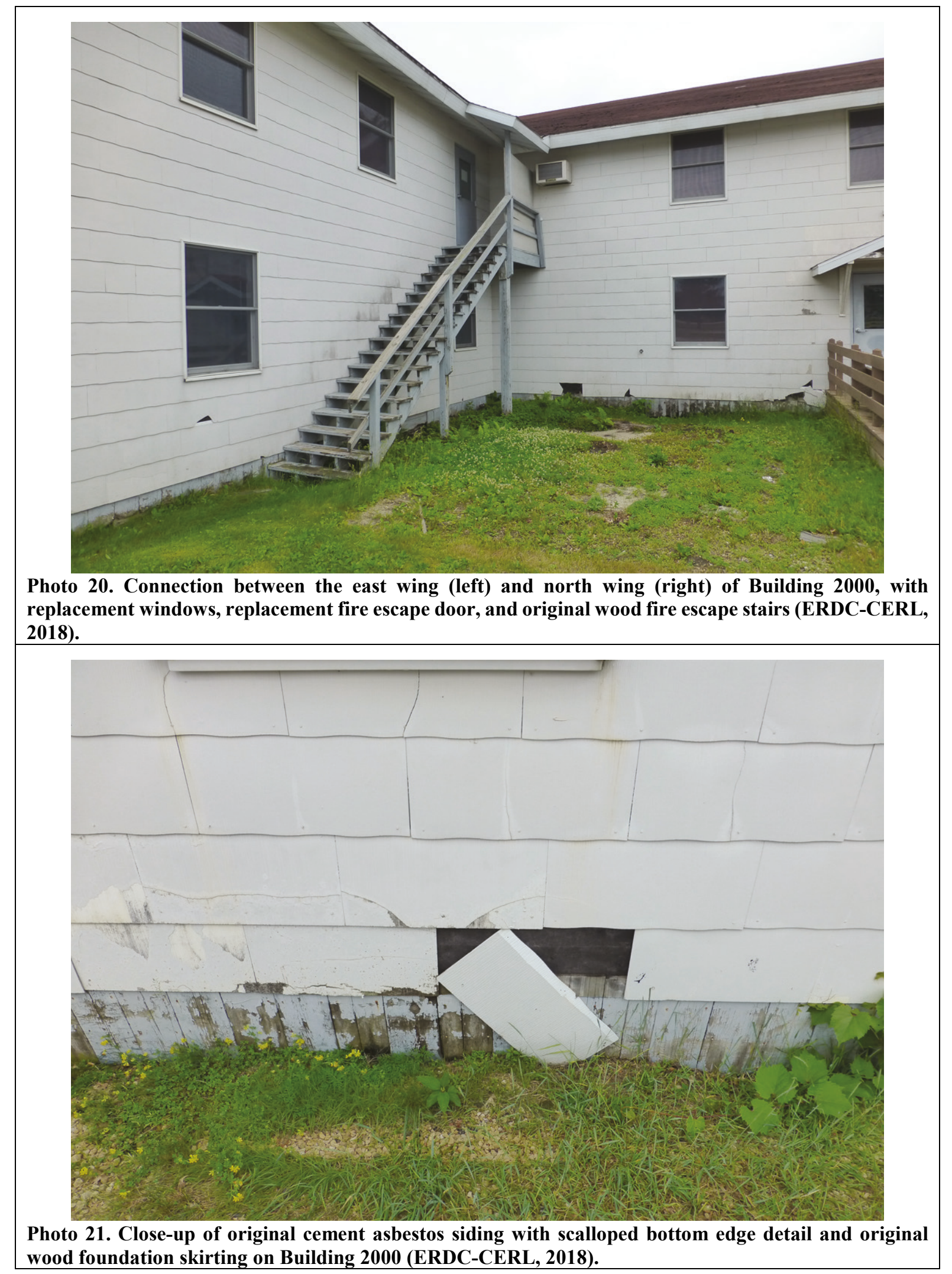




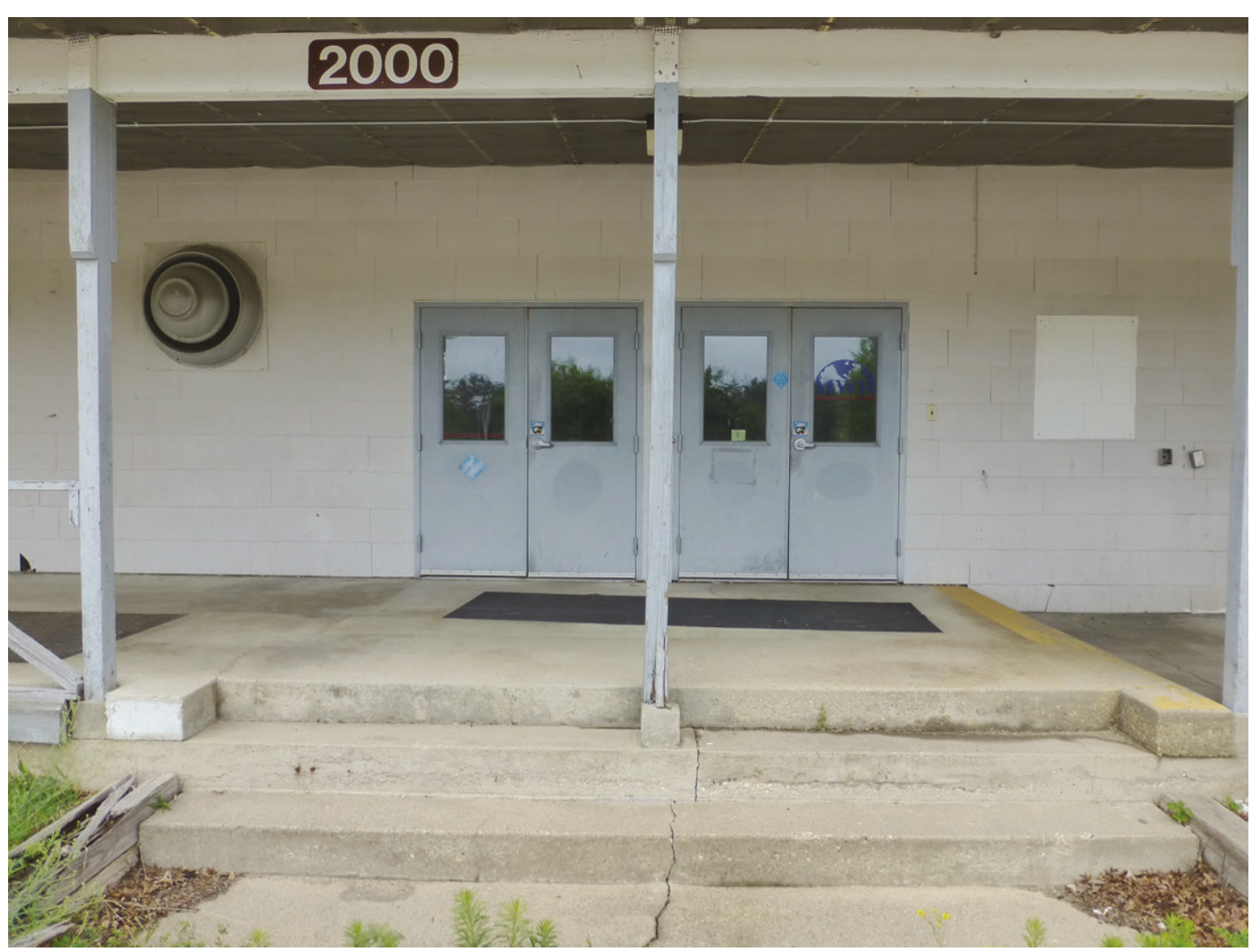

Photo 22. Two sets of main entry replacement metal and glass doors on the south (front) elevation of Building 2000 (ERDC-CERL, 2018).

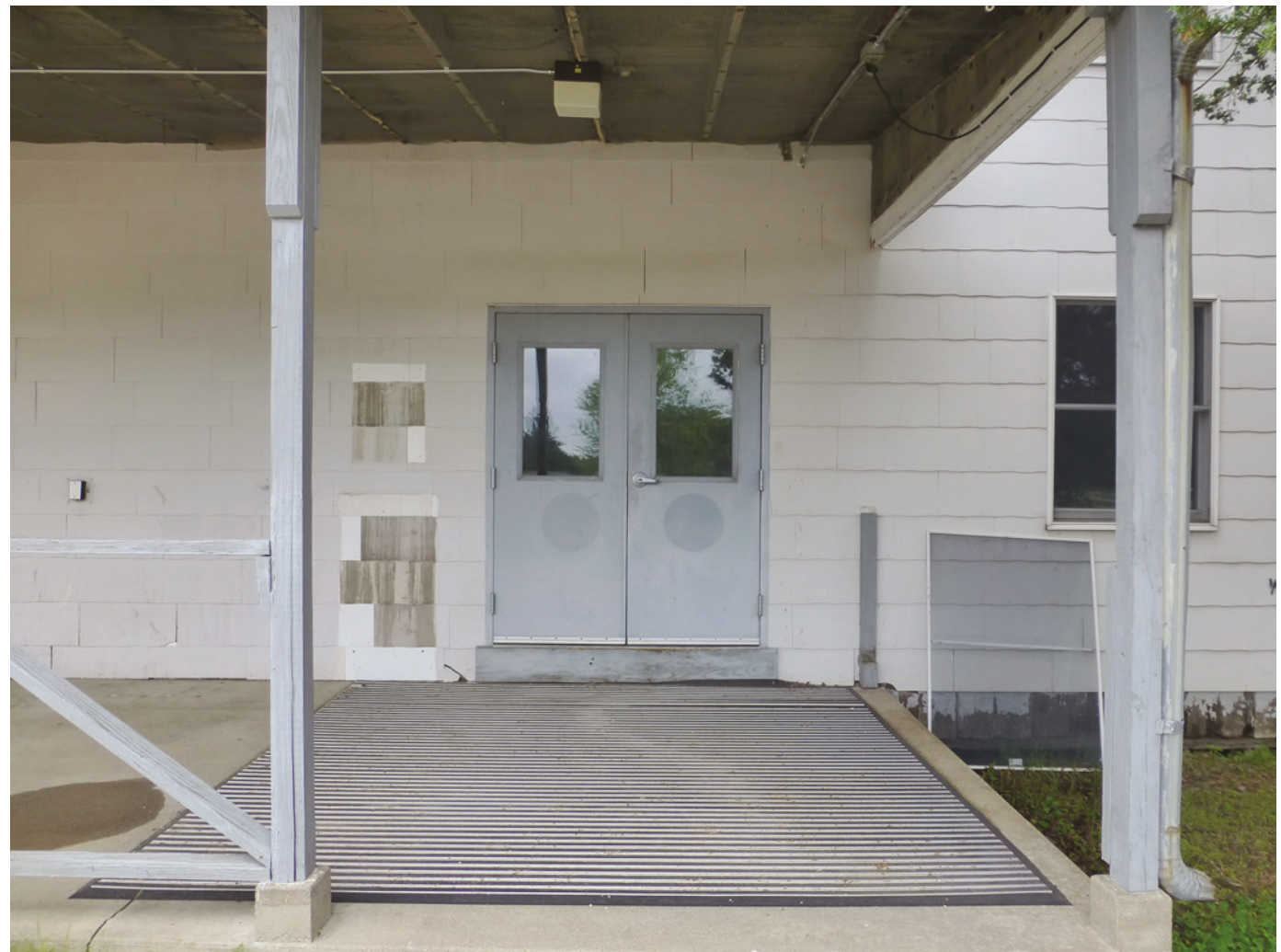

Photo 23. Typical replacement metal door with large pane on Building 2000 (ERDC-CERL, 2018). 


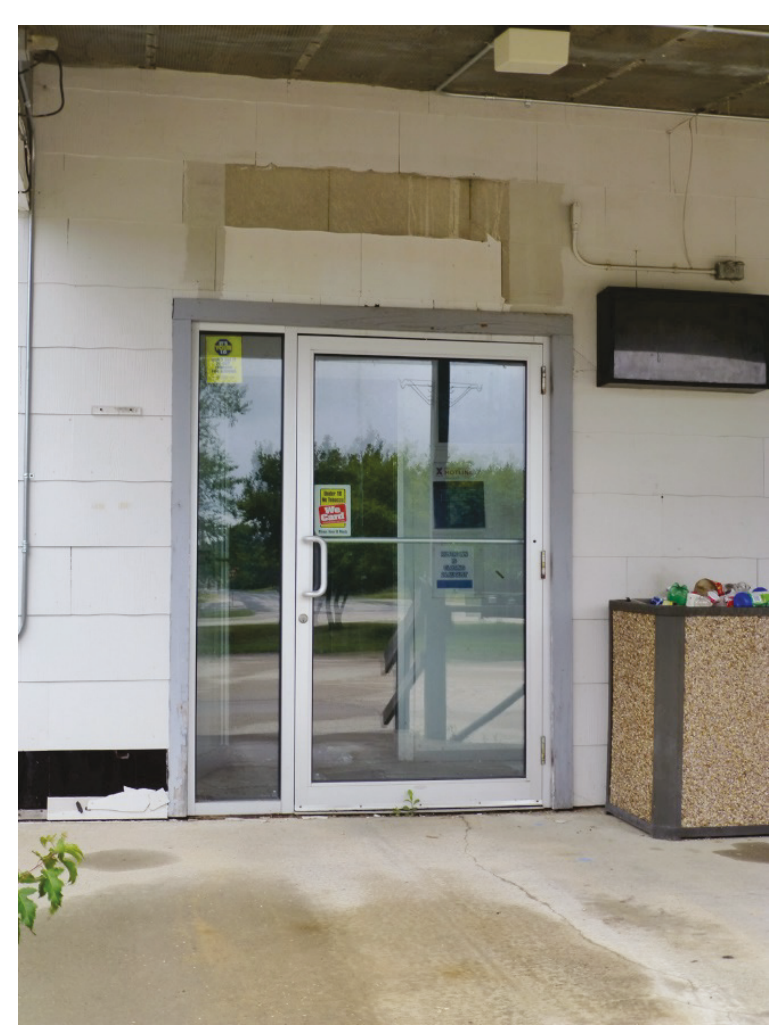

Photo 24. Replacement plate glass and metal door and sidelight into the original café wing (west) of Building 2000 (ERDC-CERL, 2018).

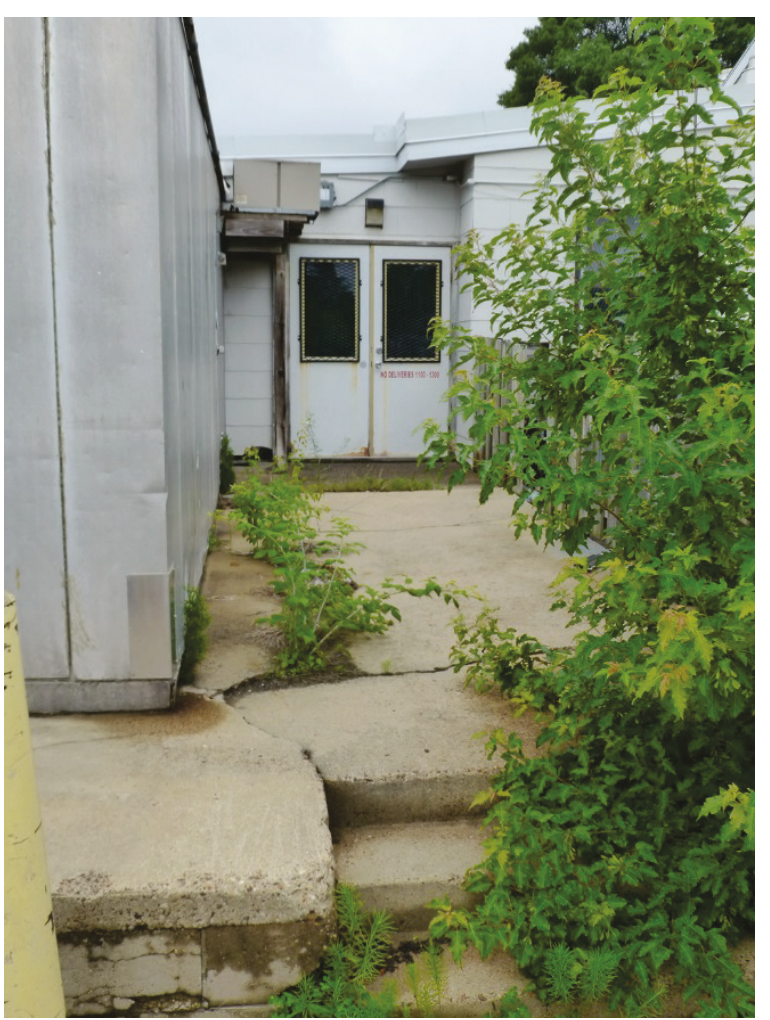

Photo 25. Replacement metal doors leading into the kitchen from the south side of Building 2000 (ERDCCERL, 2018). 


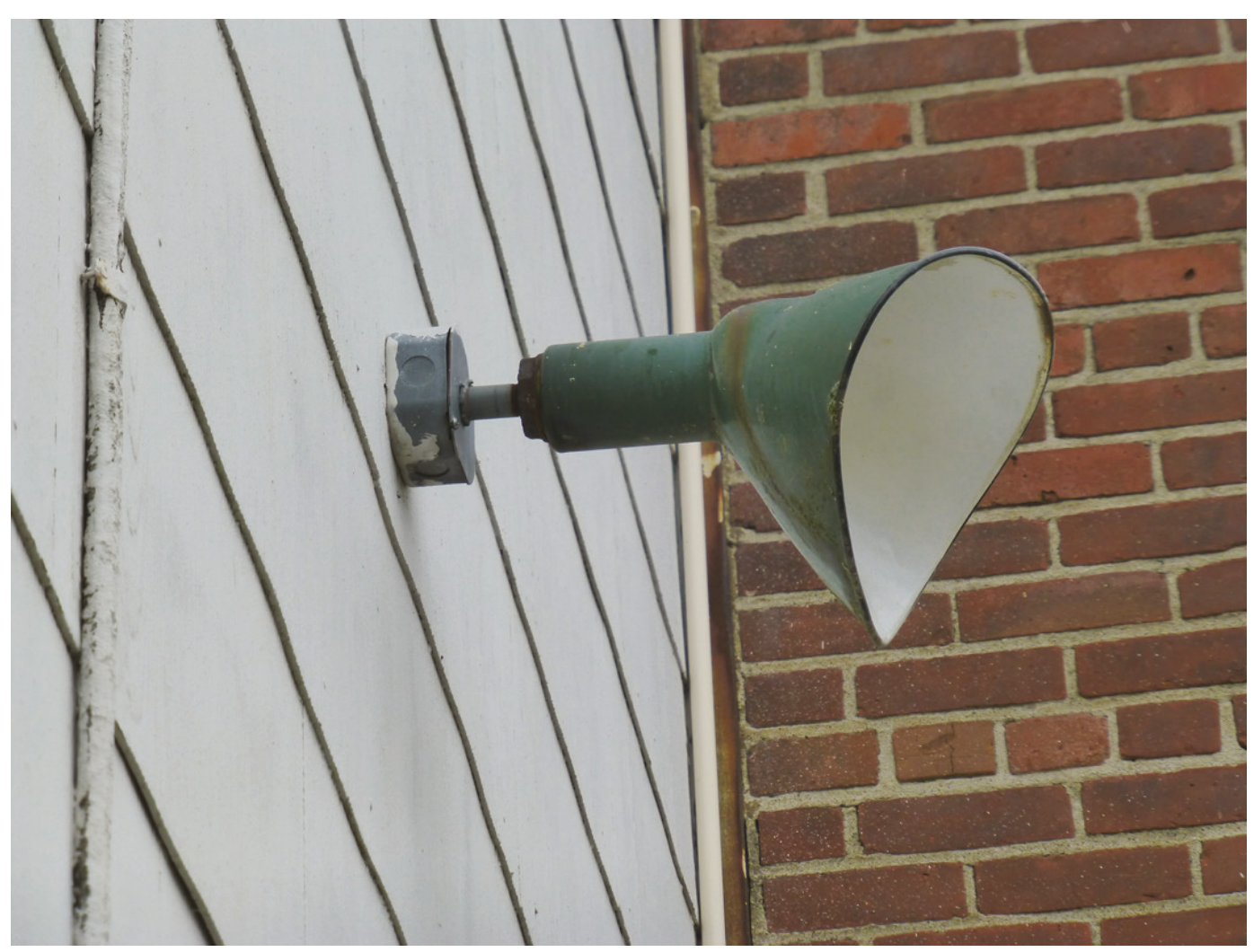

Photo 26. Original exterior light fixture located on the north elevation of the north wing of Building 2000, near the chimney (ERDC-CERL, 2018).

Photo 27. Interior view of the entry hall looking east toward the staircase leading up to the second floor (left) and toward the library on the first floor (right) (ERDC-CERL, 2018).

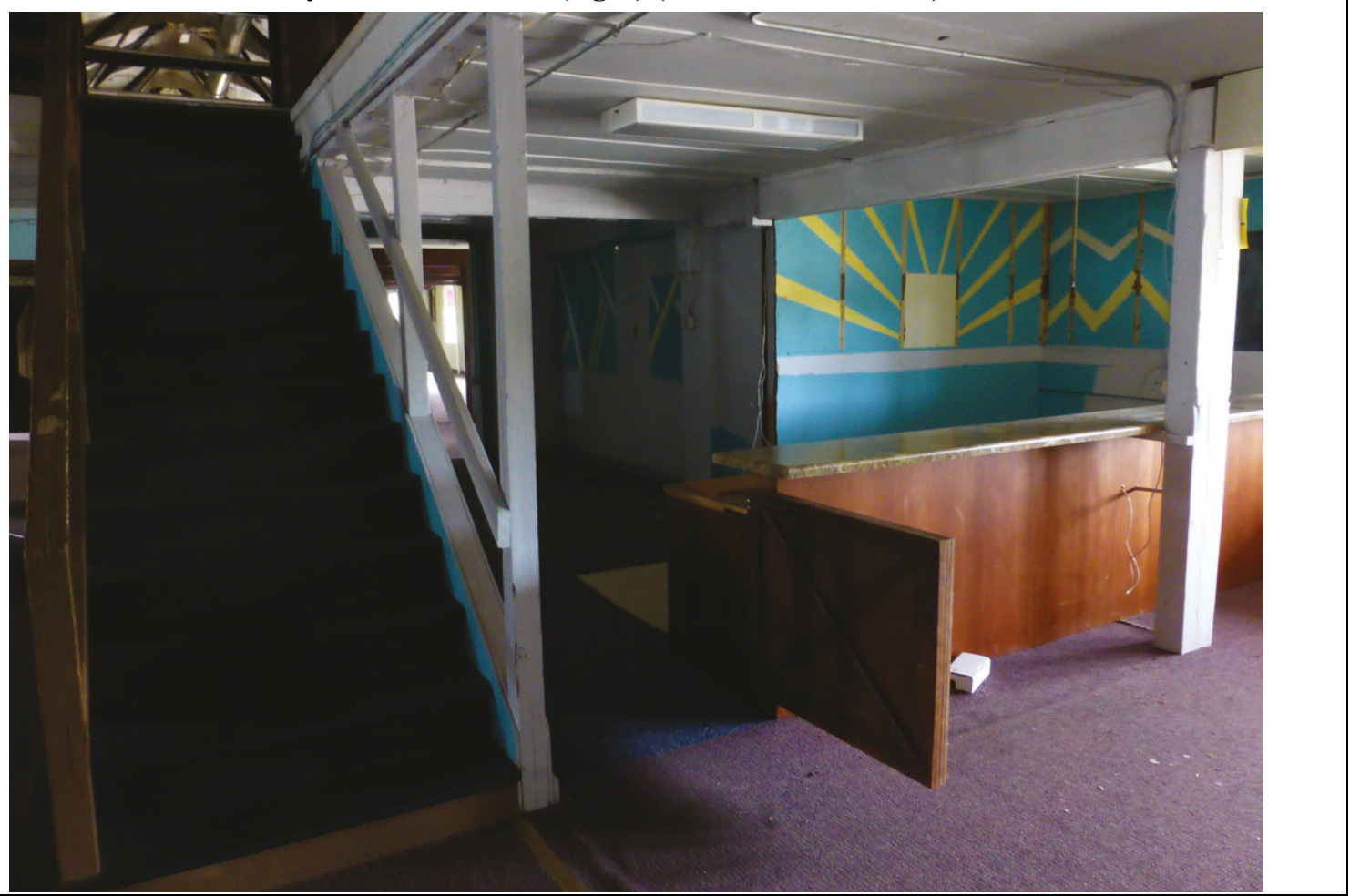




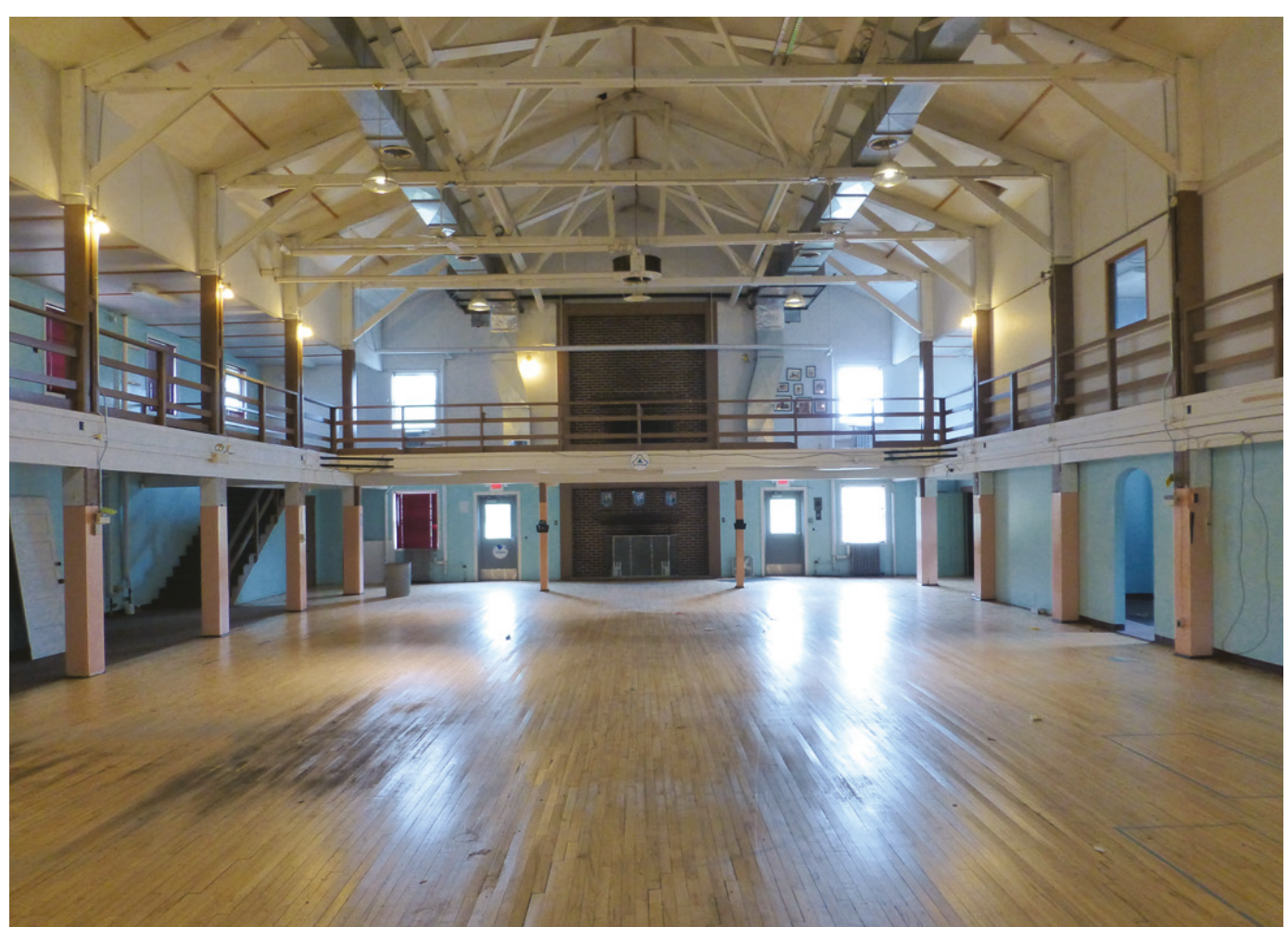

Photo 28. Interior view of the dance hall in Building 2000, looking at the north wall and fireplaces (ERDC-CERL, 2018).

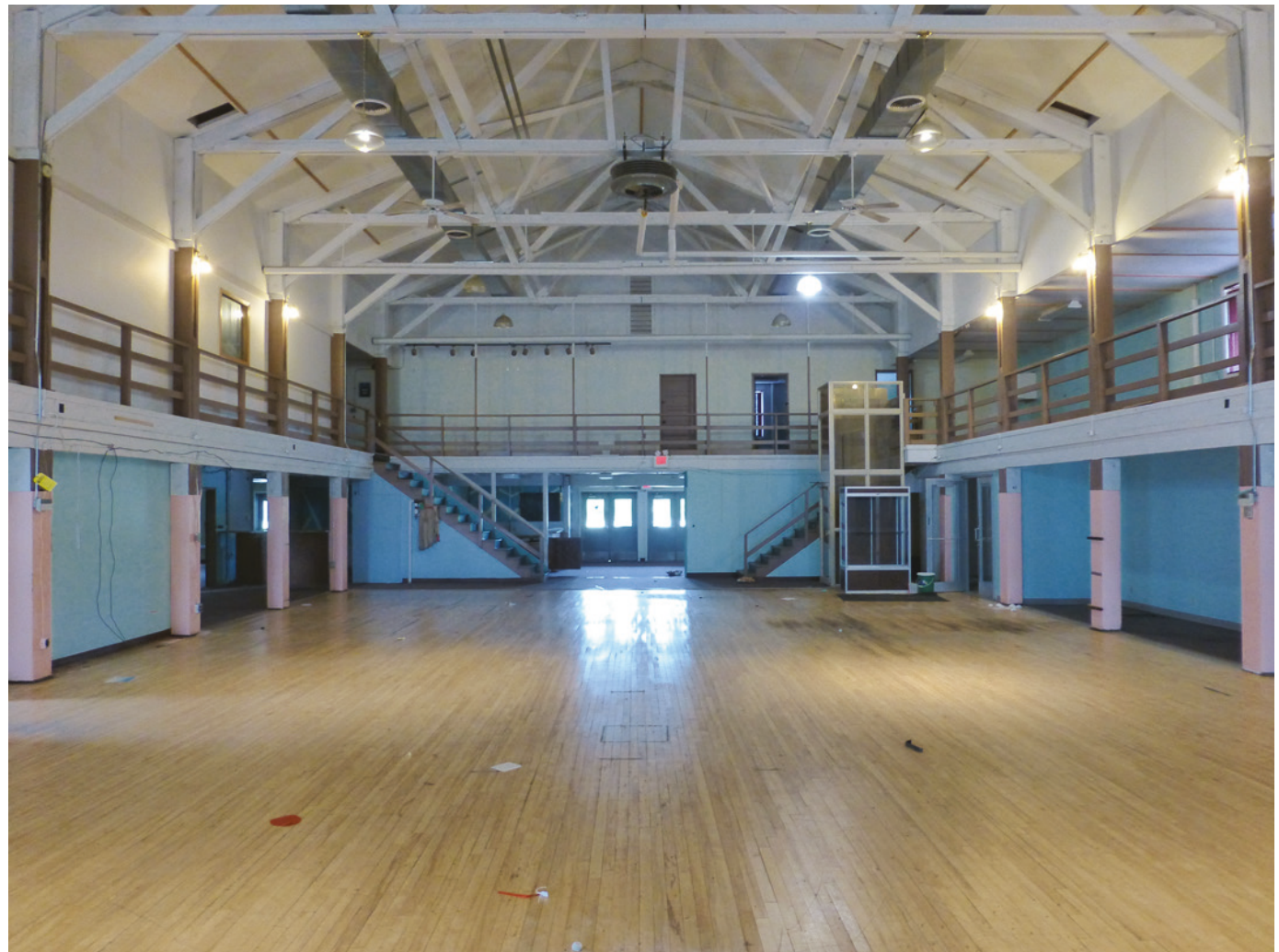

Photo 29. Interior view of the dance hall of Building 2000, looking south toward the entry hall (ERDCCERL, 2018). 


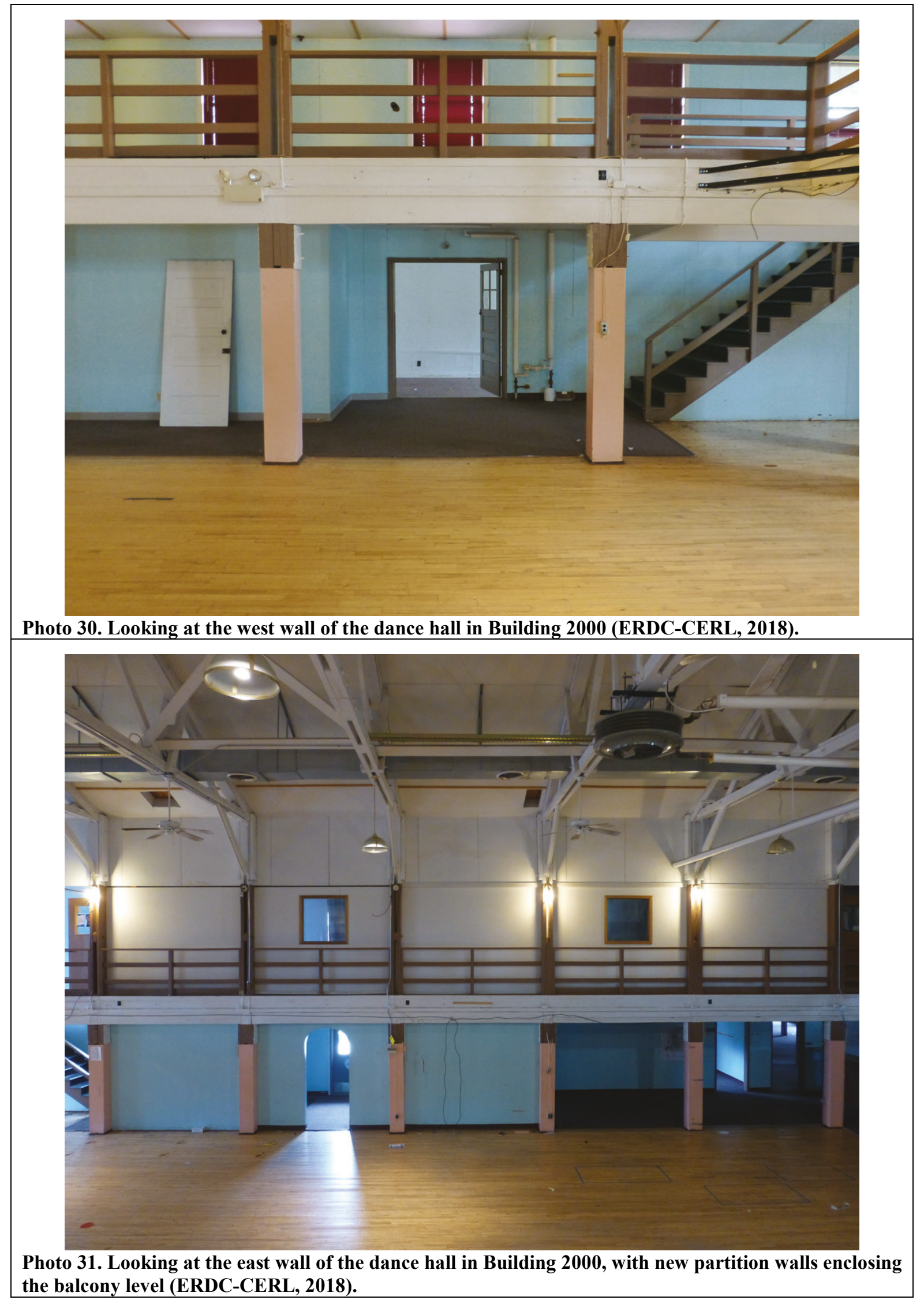




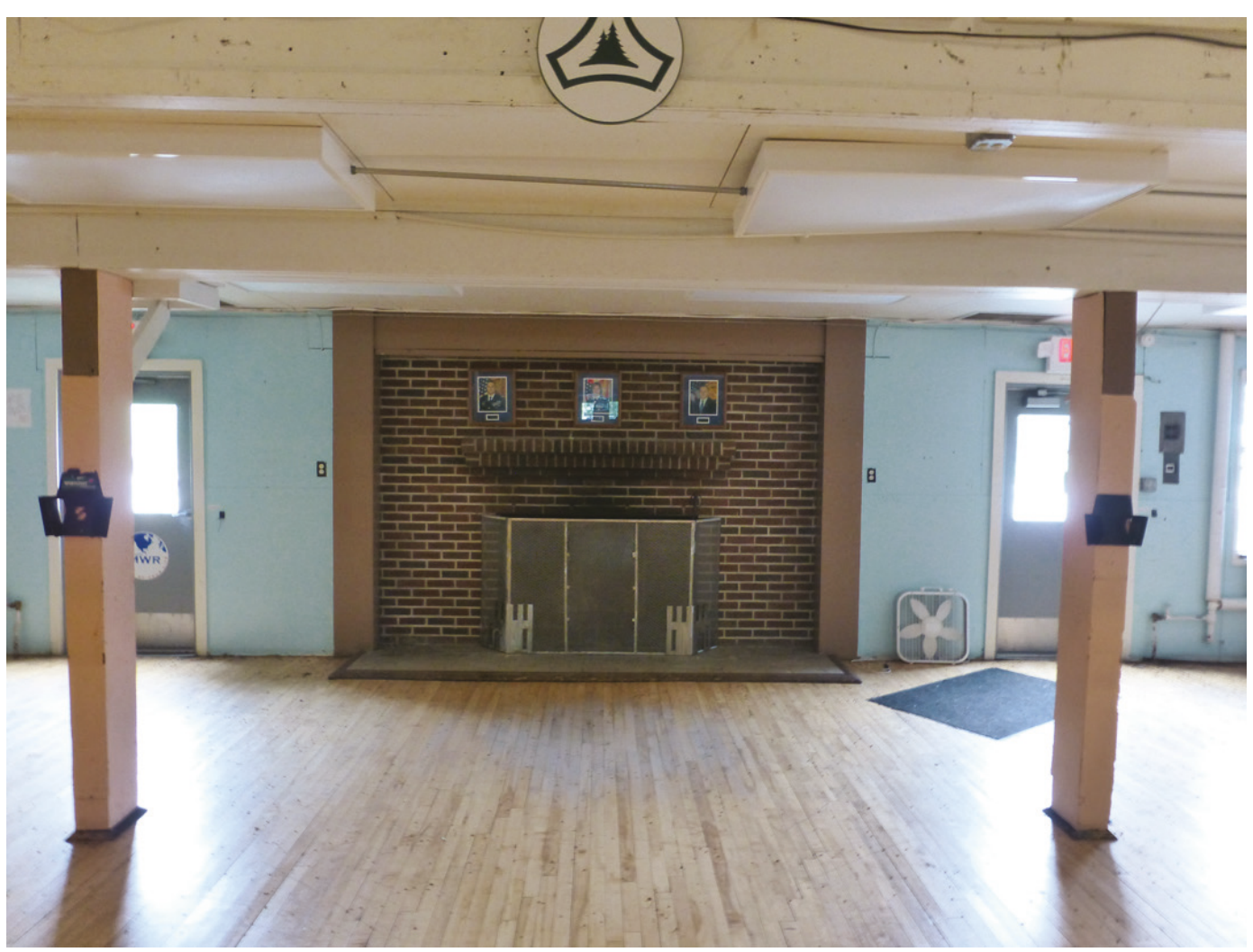

Photo 32. Firstfloor fireplace in the dance hall of Building 2000 (ERDC-CERL, 2018).

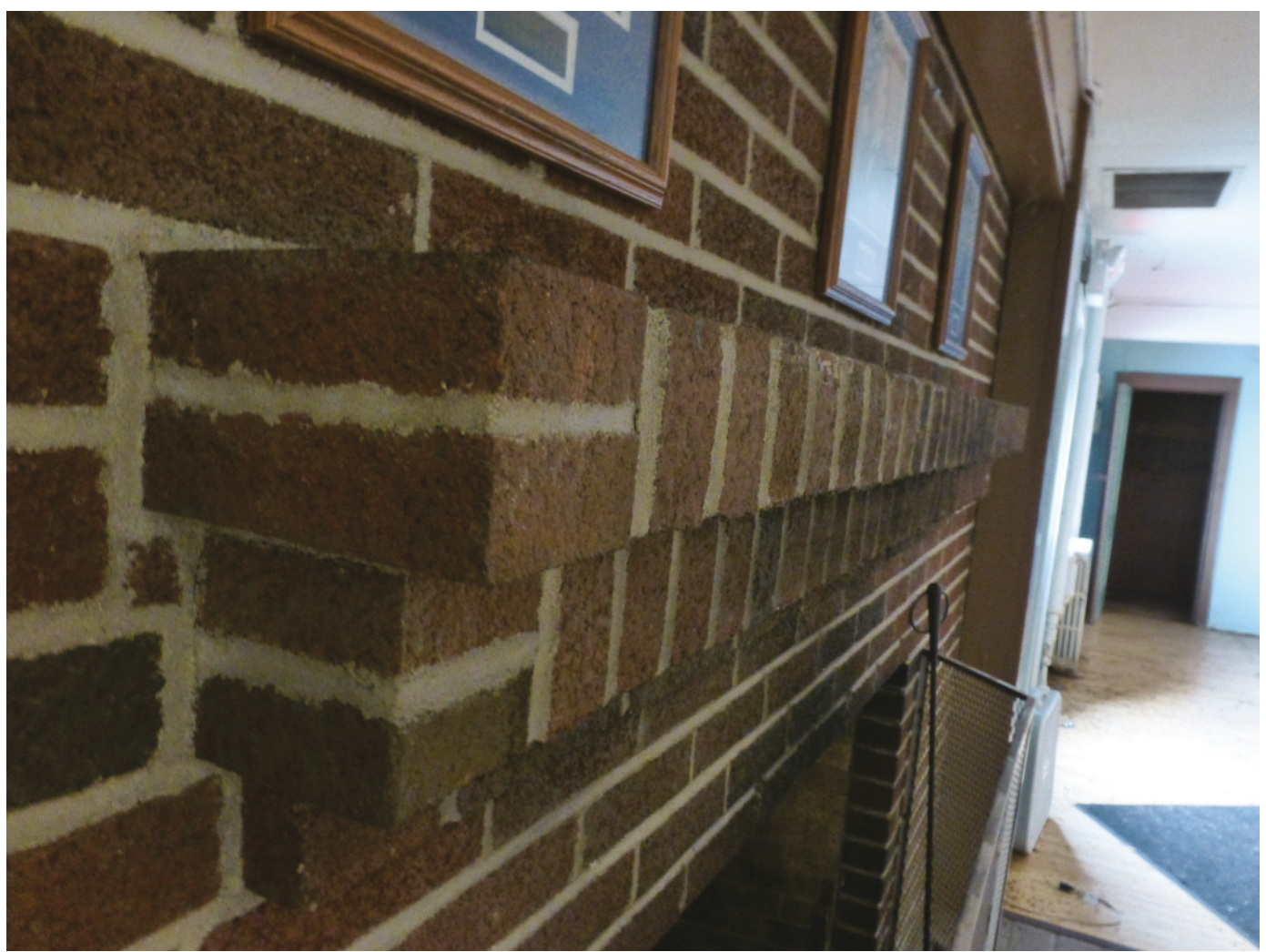

Photo 33. Close-up detail of the first-floor fireplace in the dance hall of Building 2000 (ERDC-CERL, 2018). 


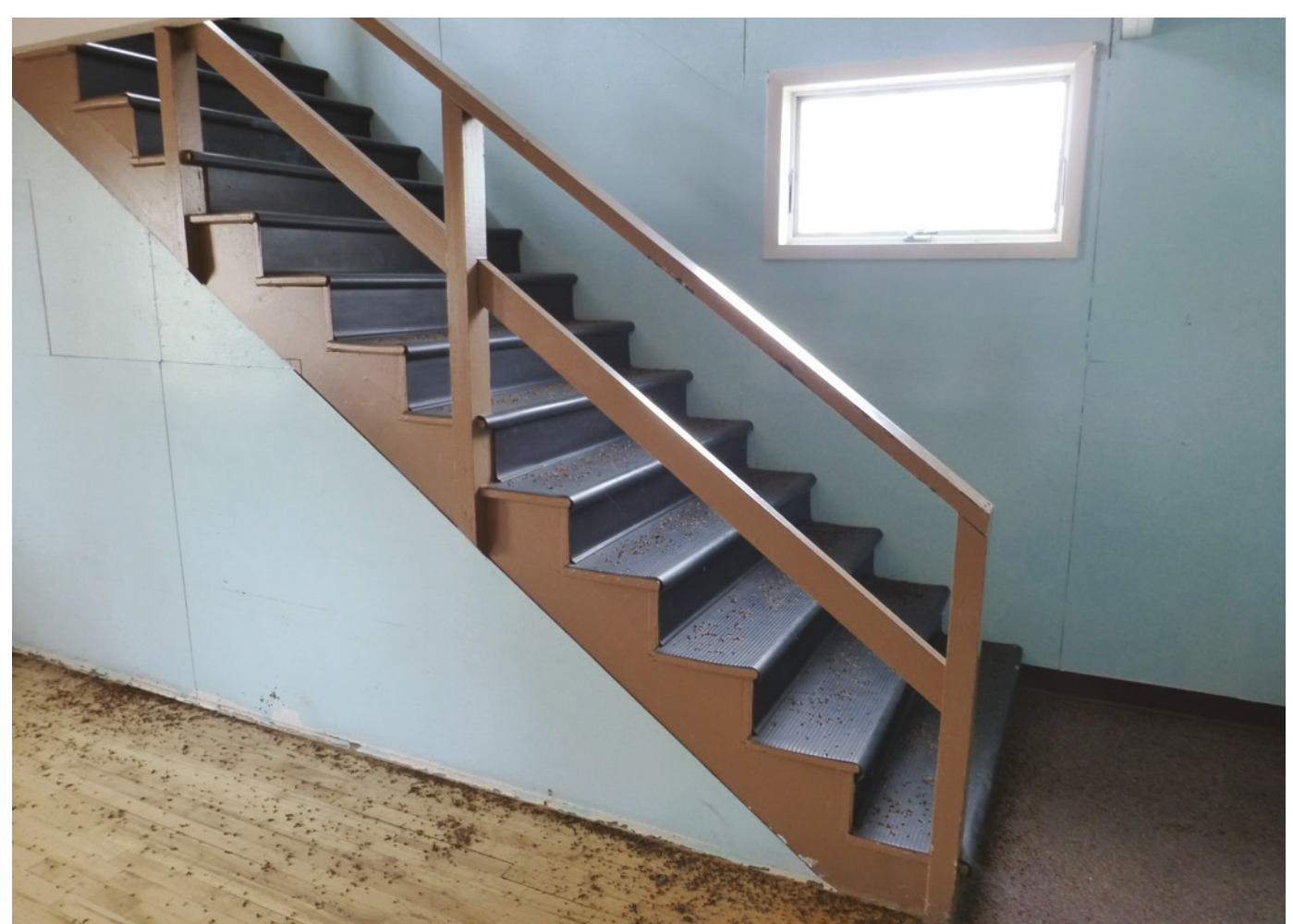

Photo 34. Northeast staircase in the dance hall of Building 2000, leading to the balcony level (ERDCCERL, 2018).

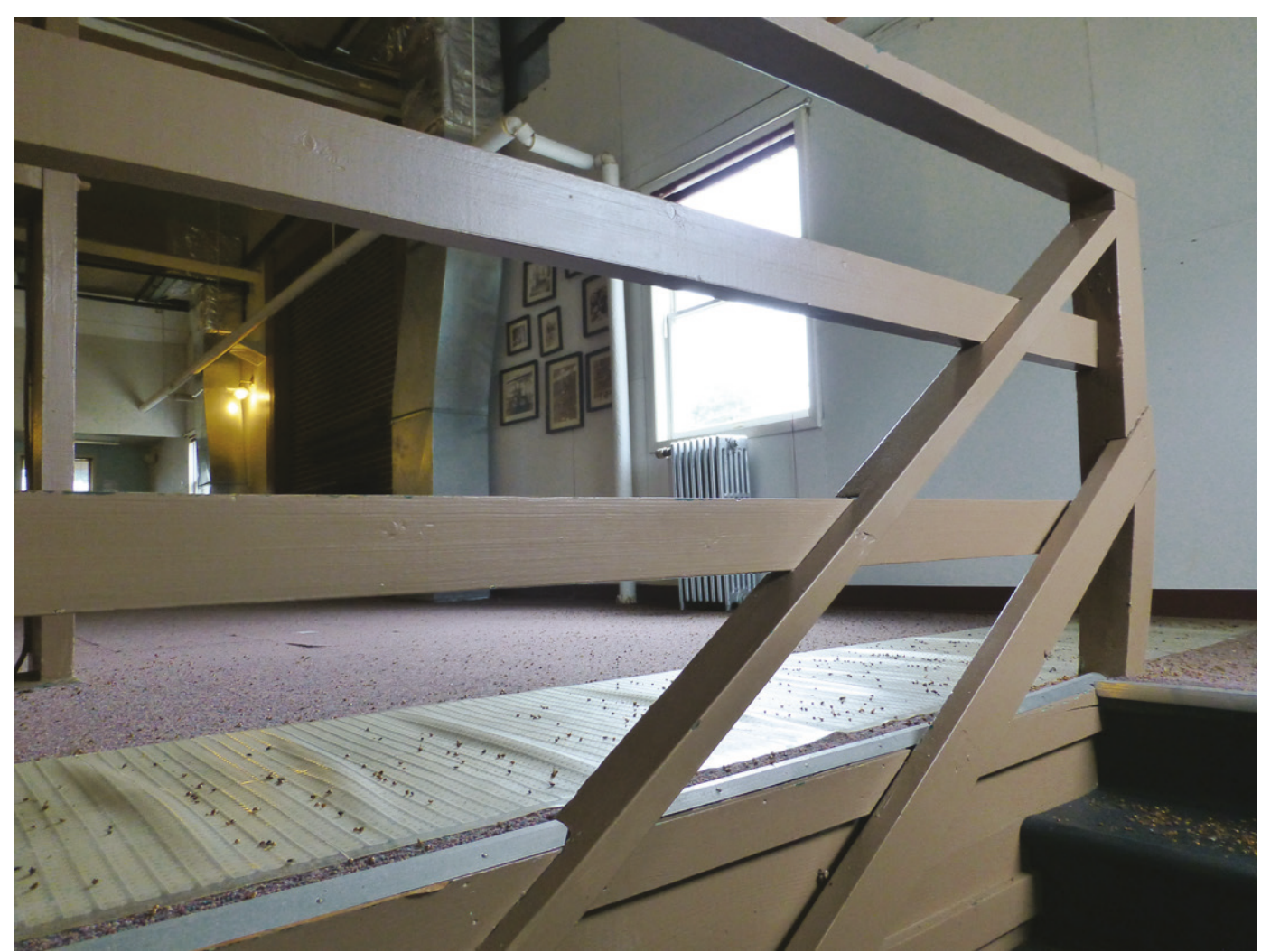

Photo 35. Close-up detail of the wood banister and railing of the northeast staircase in Building 2000 (ERDC-CERL, 2018). 


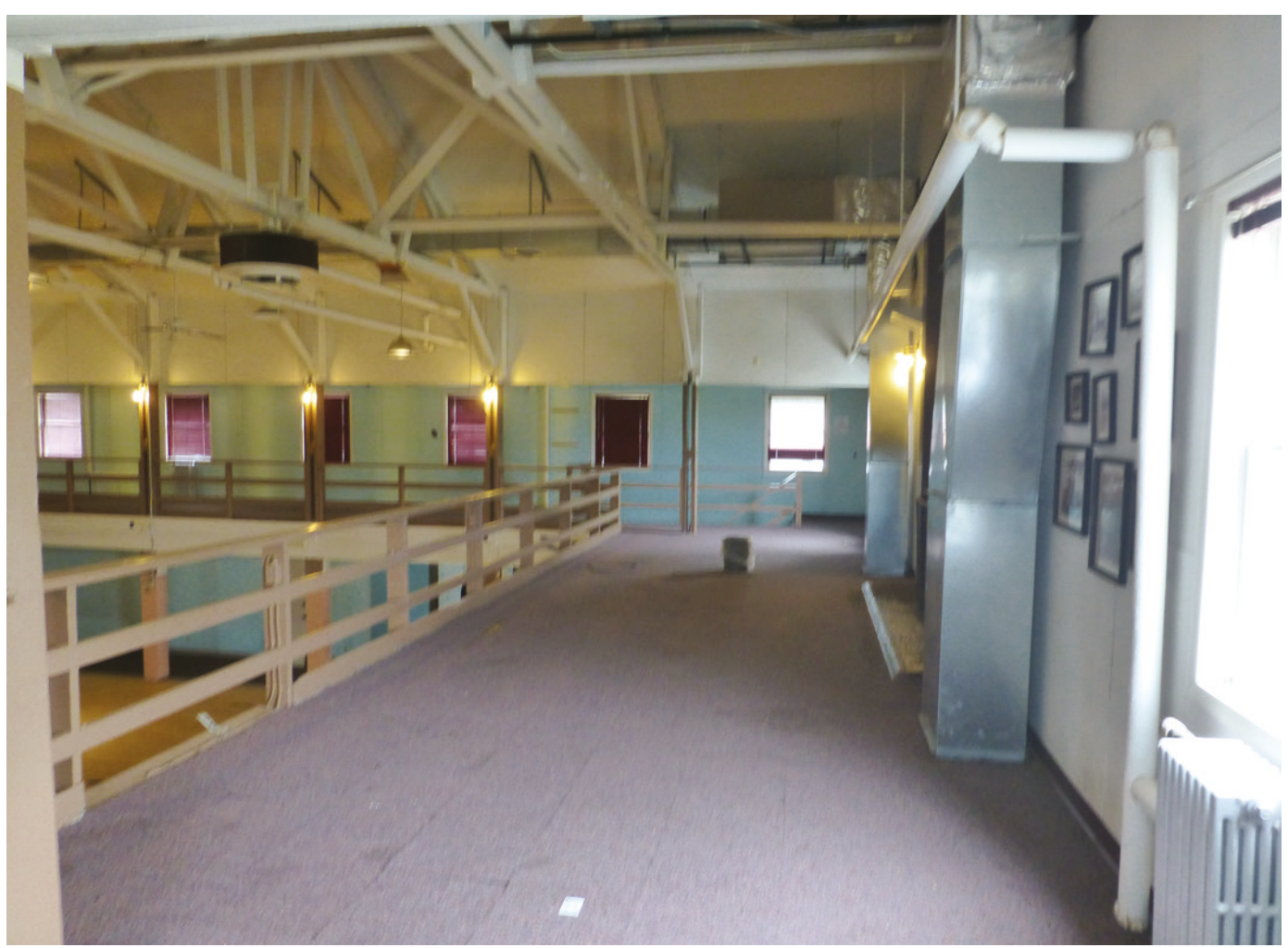

Photo 36. Looking west from the northeast corner of the balcony that surrounds dance floor in Building 2000 (ERDC-CERL, 2018).

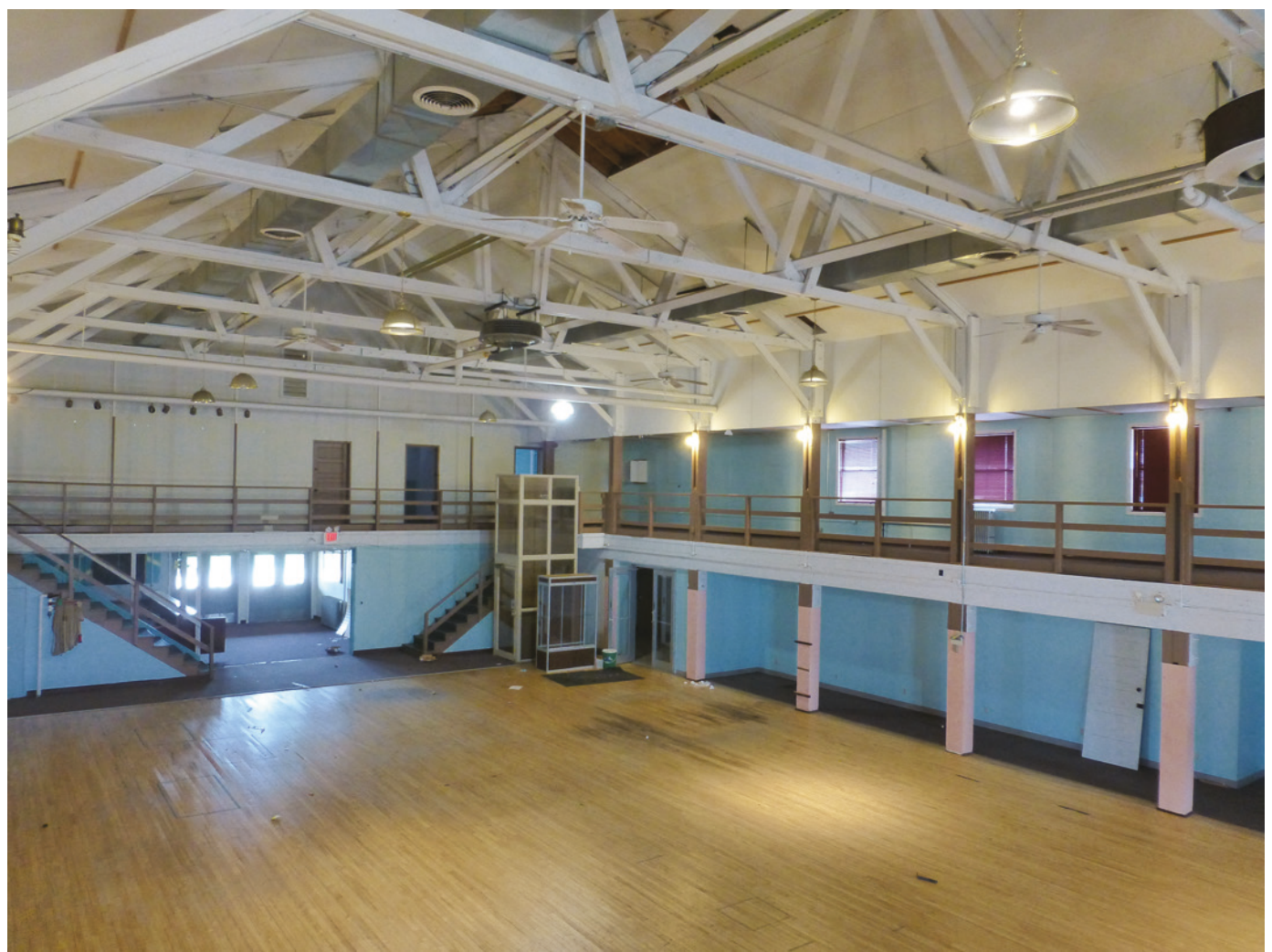

Photo 37. Looking southwest from the northeast corner of the balcony in Building 2000 (ERDC-CERL, 2018). 


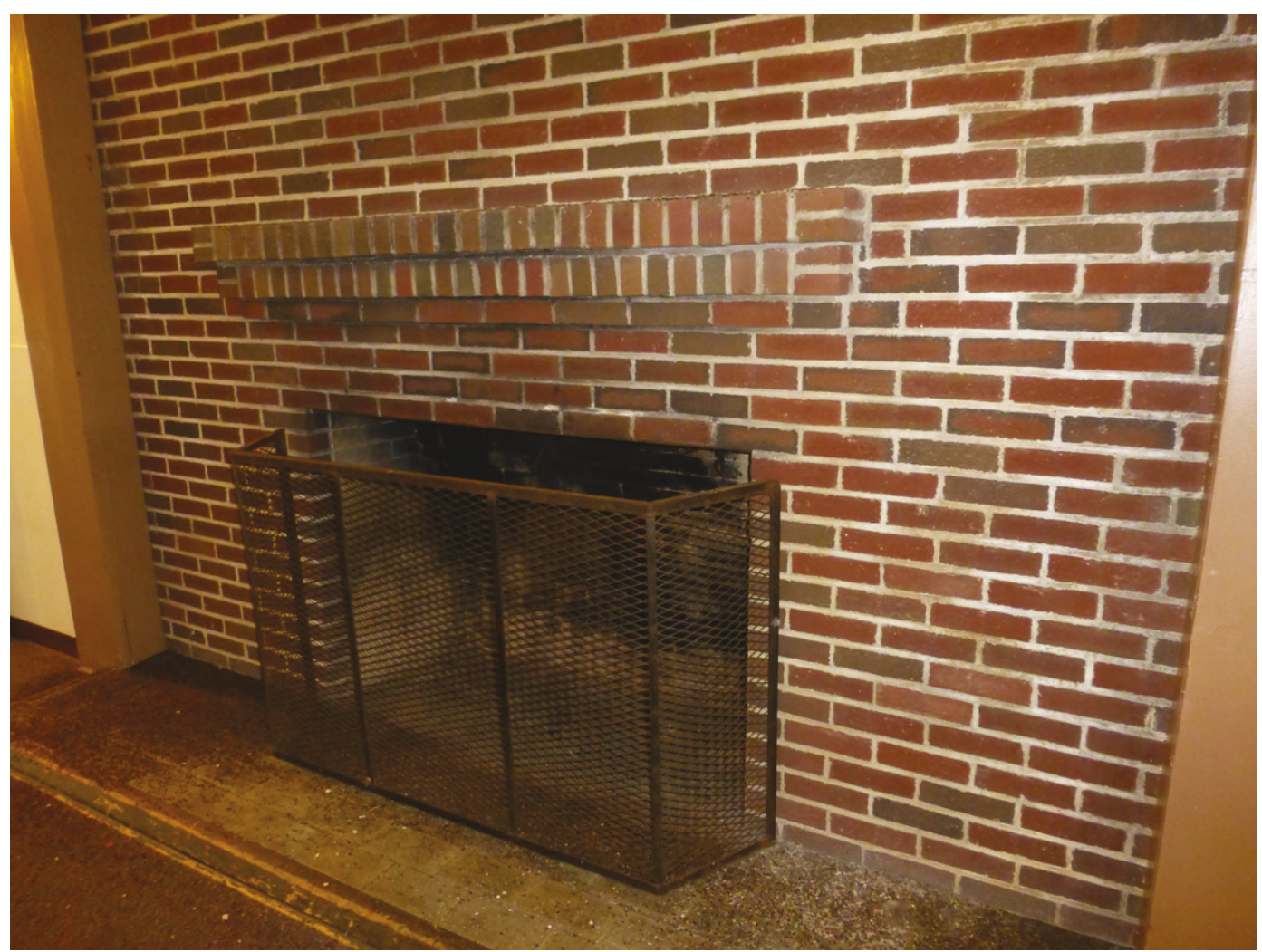

Photo 38. Fireplace on the balcony level of Building 2000 (ERDC-CERL, 2018).

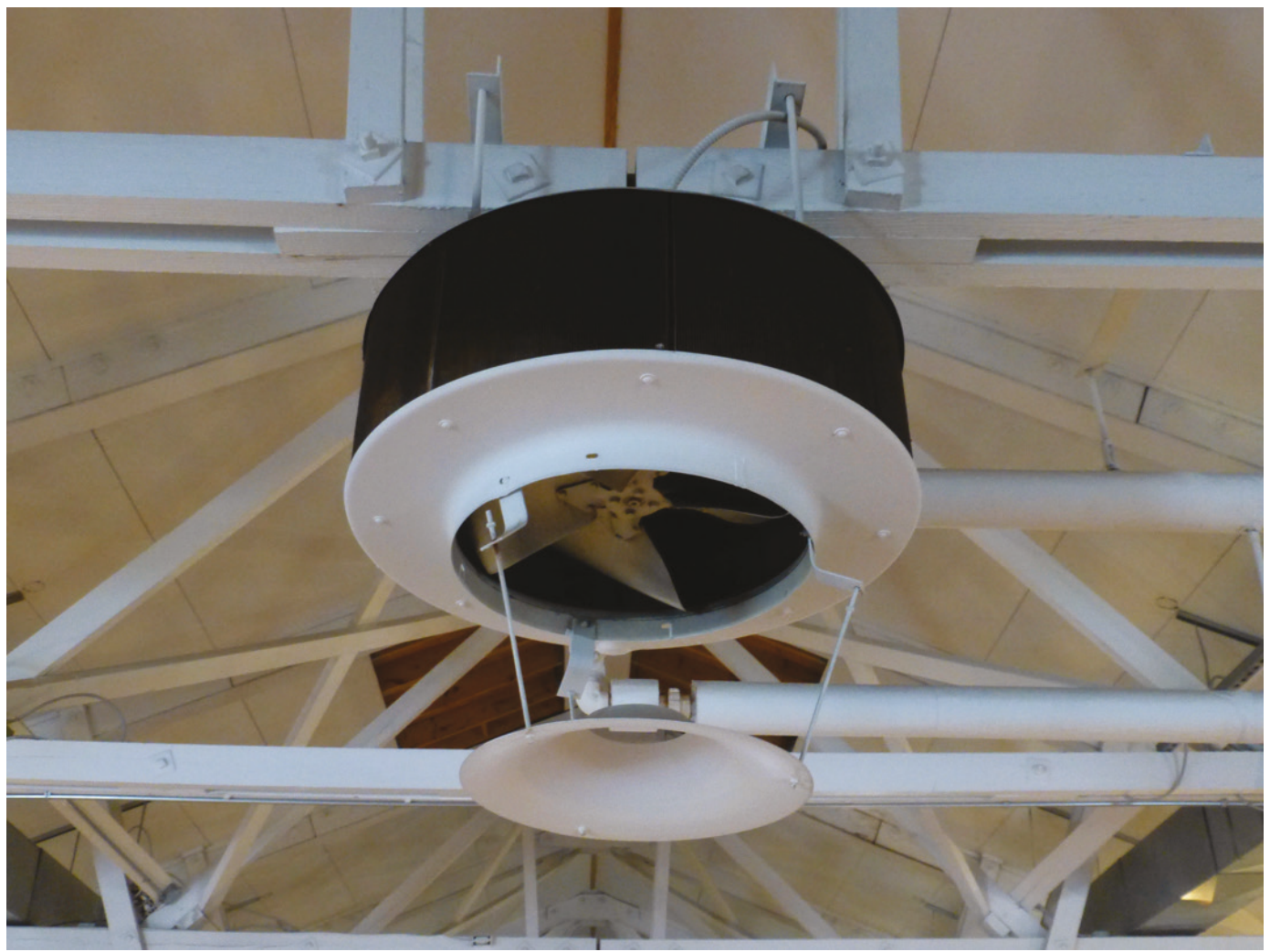

Photo 39. Close-up detail of the an original heater with diffuser that is supended from the truss system over the dance hall in Building 2000 (ERDC-CERL, 2018). 


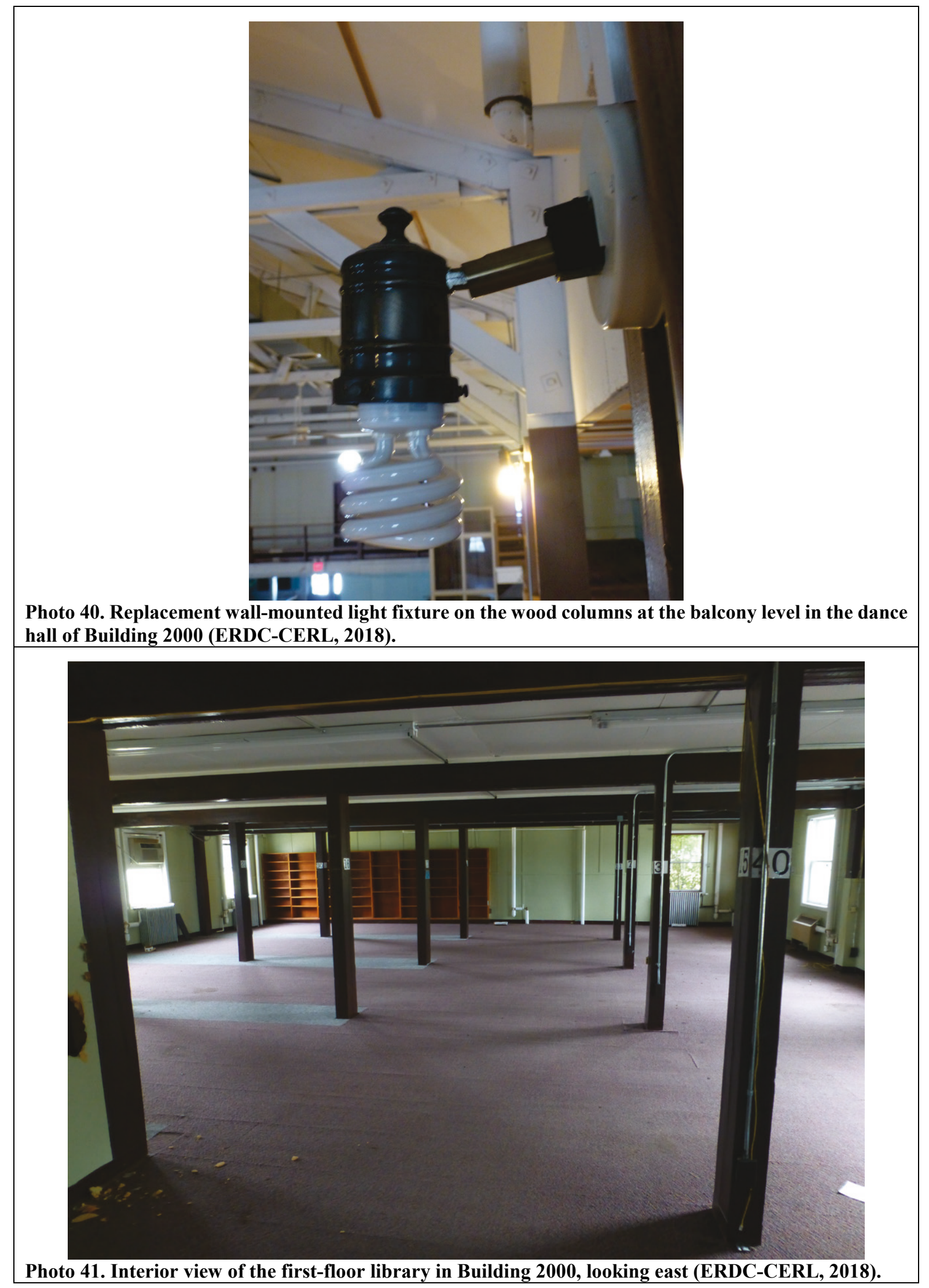




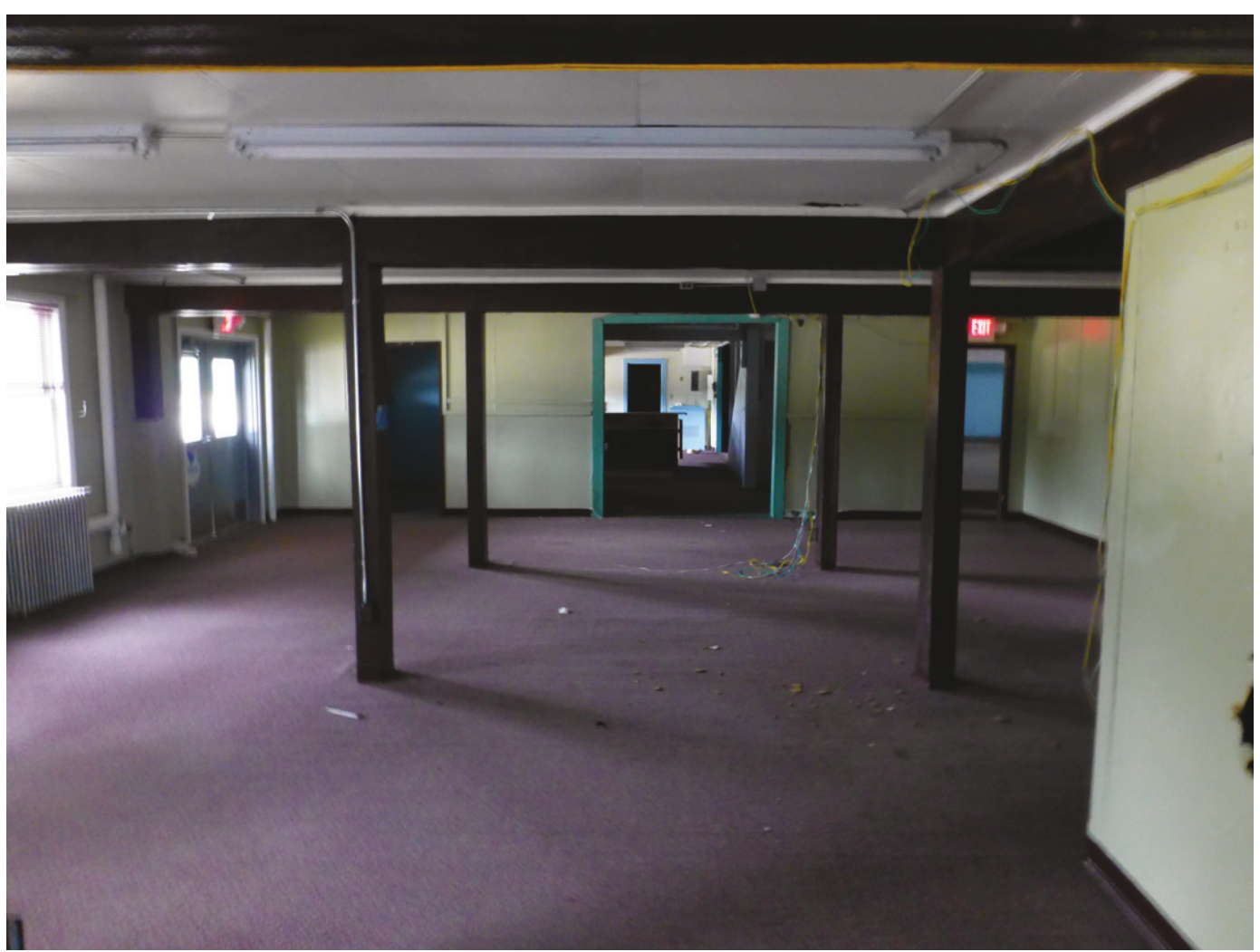

Photo 42. Interior view of the first-floor library in Building 2000, looking west (ERDC-CERL, 2018).

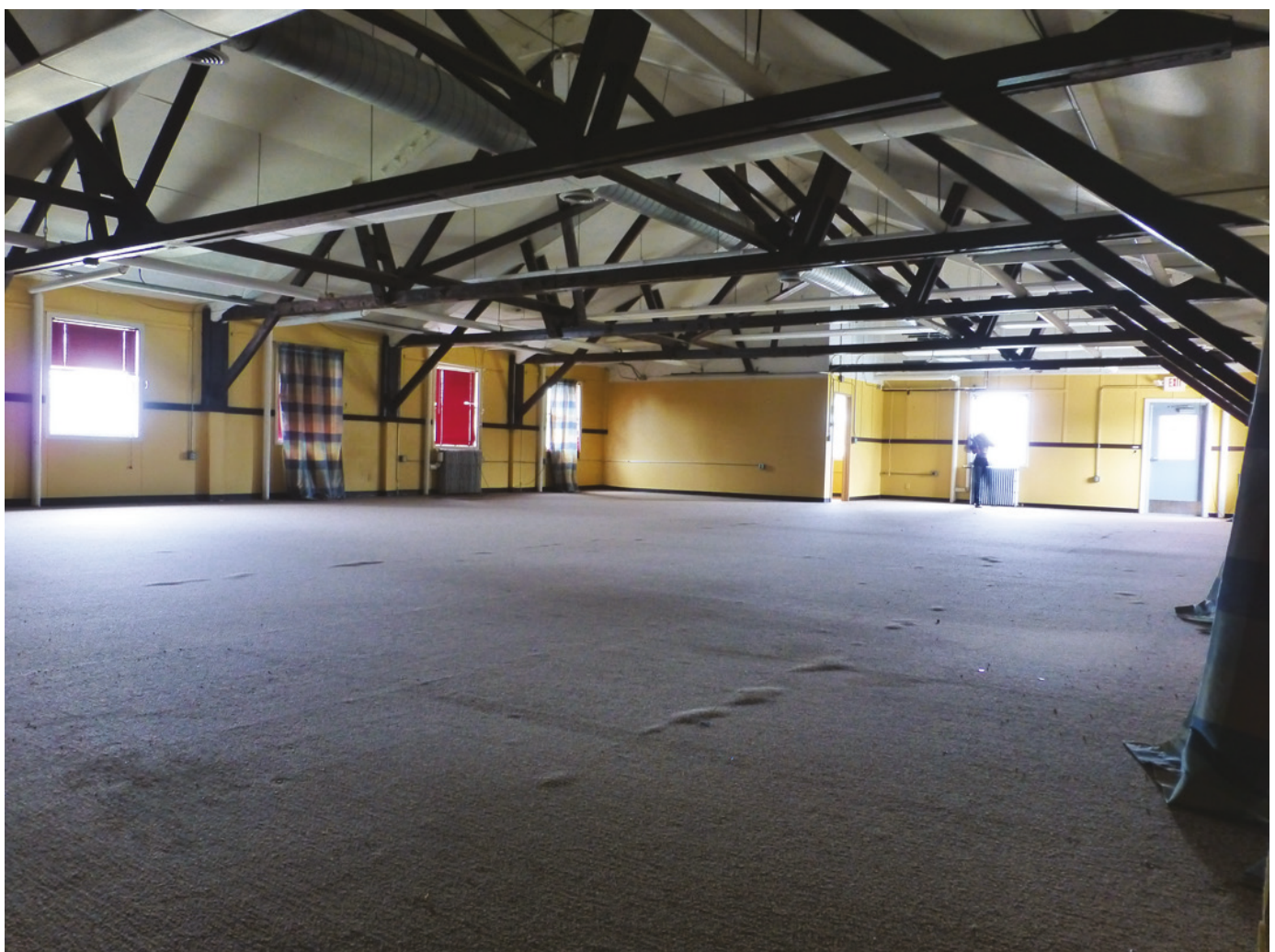




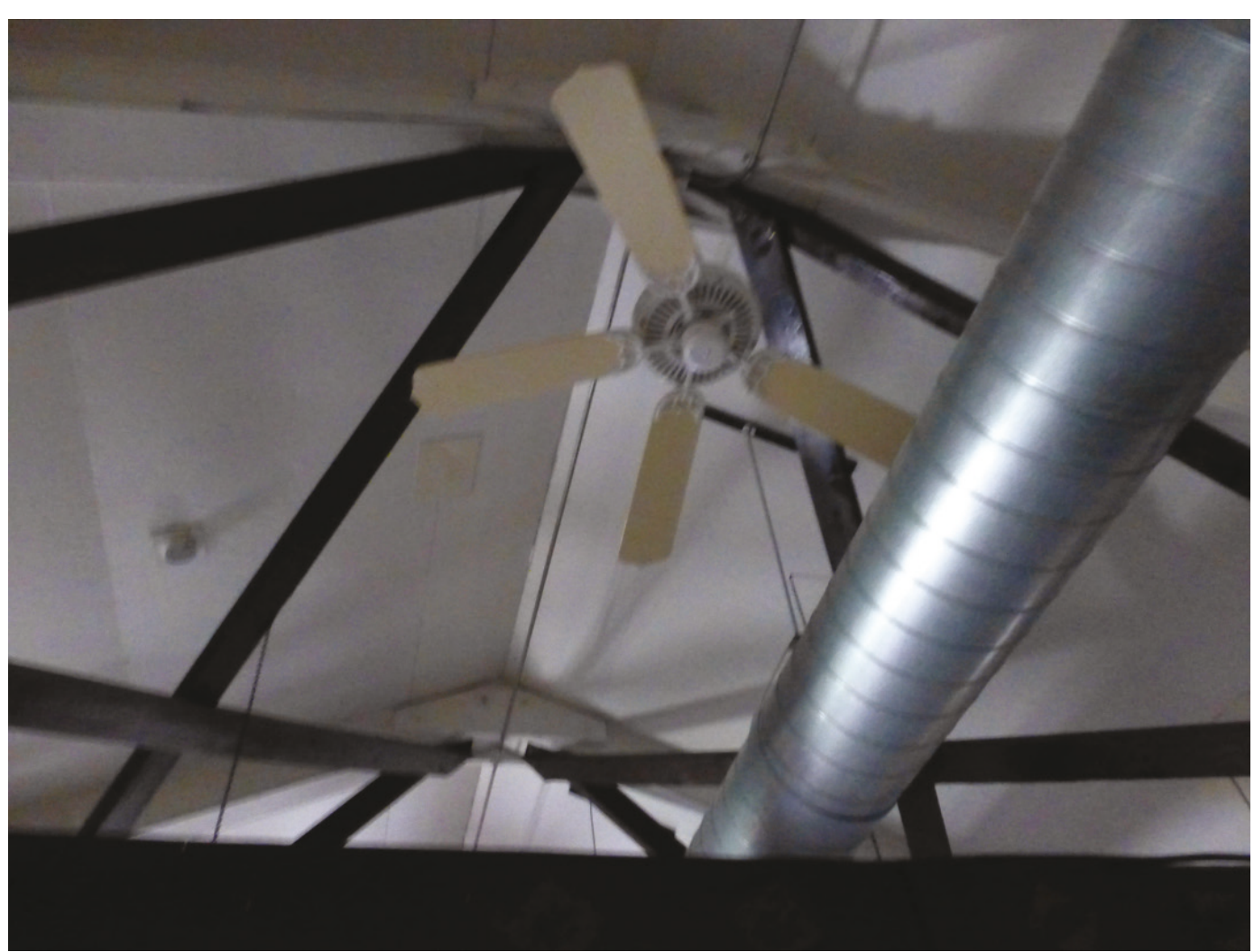

Photo 44. Close-up view of the interior truss system of the second floor in Building 2000 (used for billiards) (ERDC-CERL, 2018).

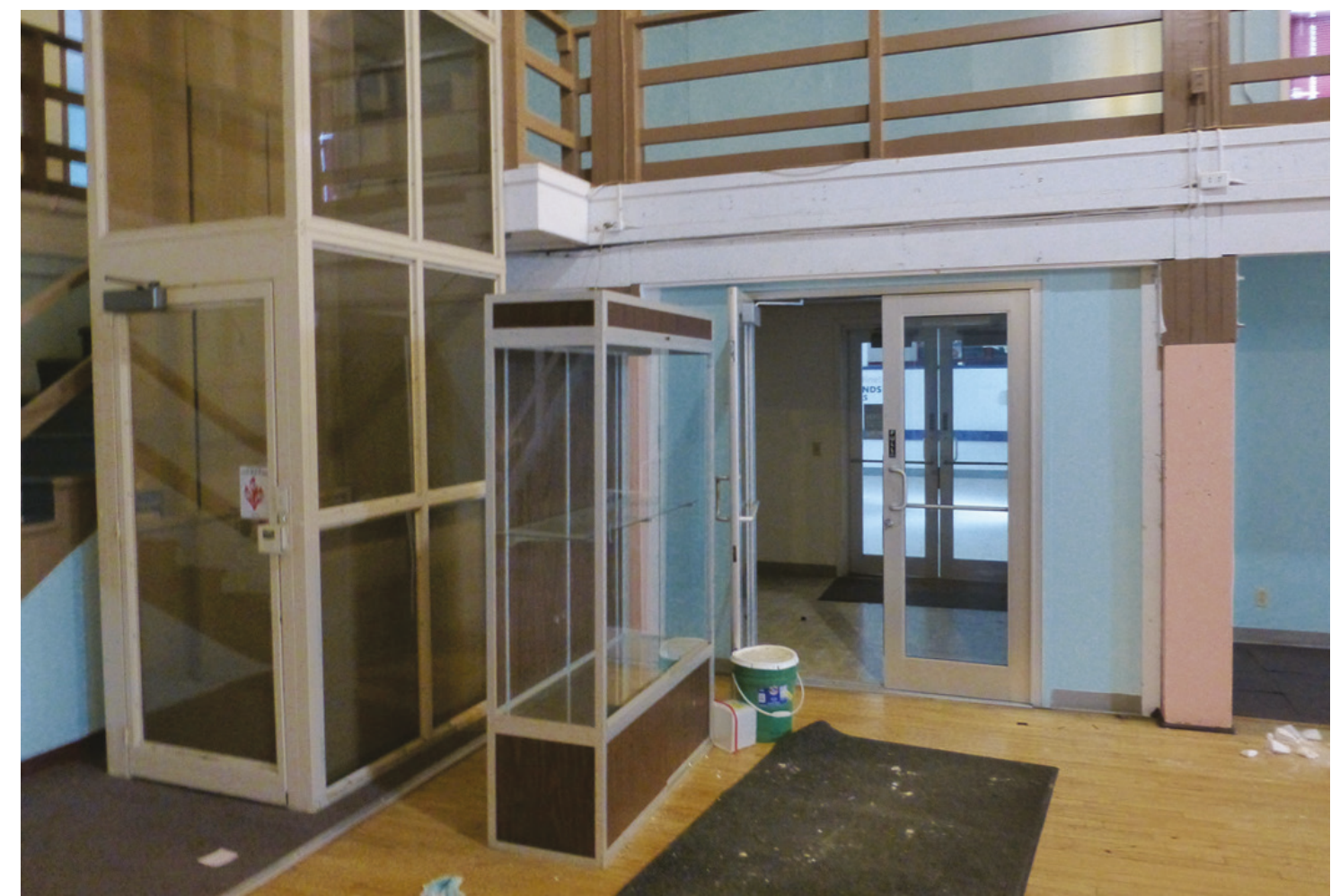

Photo 45. Entry into café space from dance hall (center) and ADA elevator addition (left) (ERDC-CERL, 2018). 


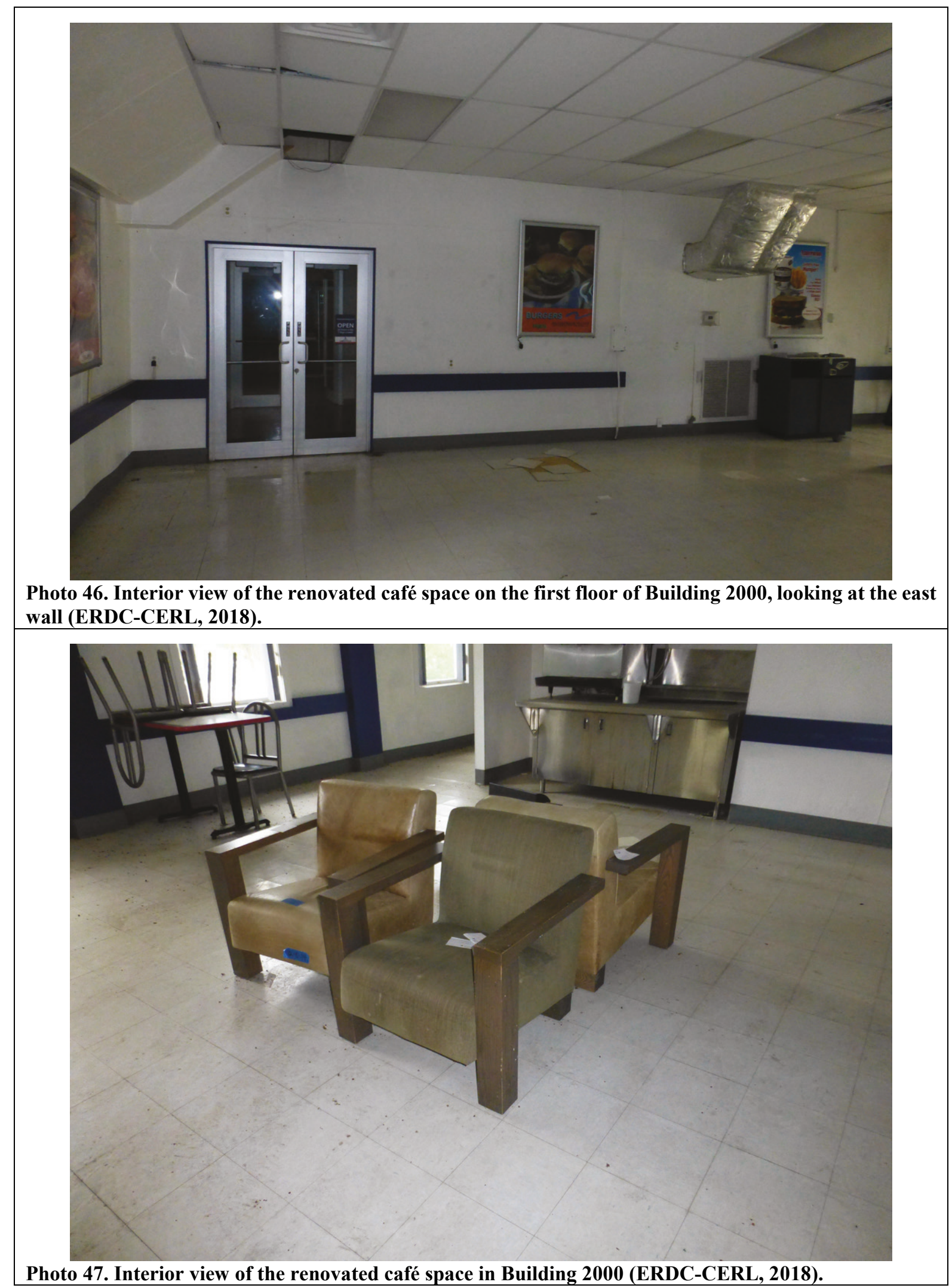




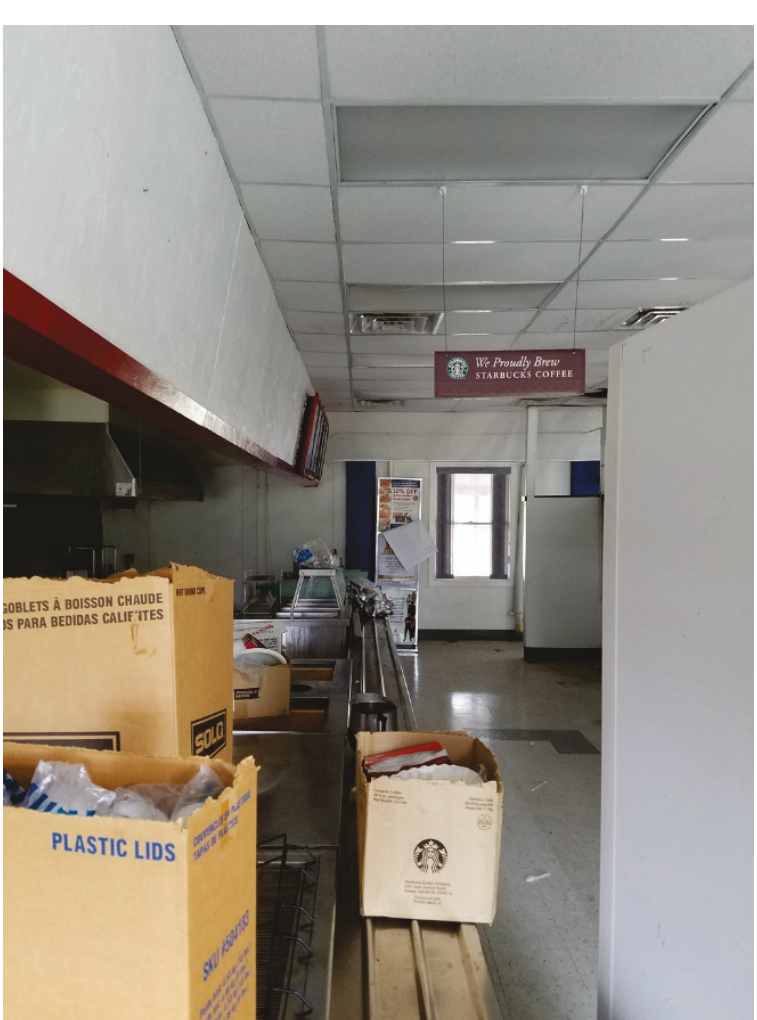

Photo 48. Interior view of the 1943 addition to Building 2000 (ERDC-CERL, 2018).

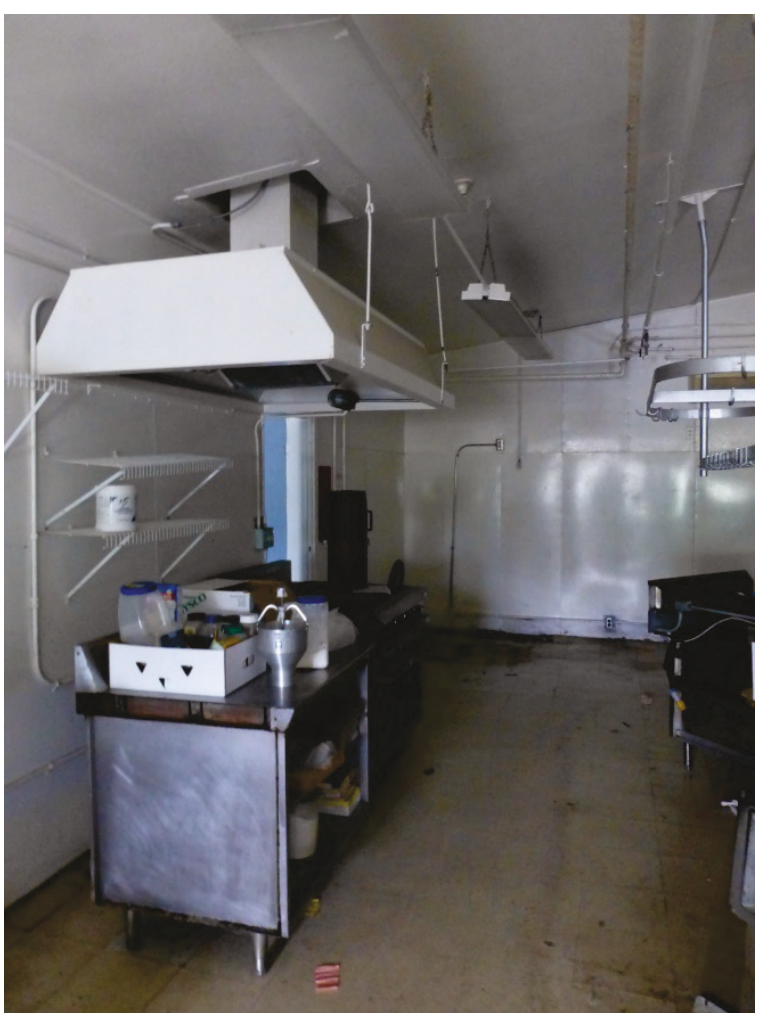

Photo 49. Interior view of the 1943 addition to Building 2000 (ERDC-CERL, 2018). 


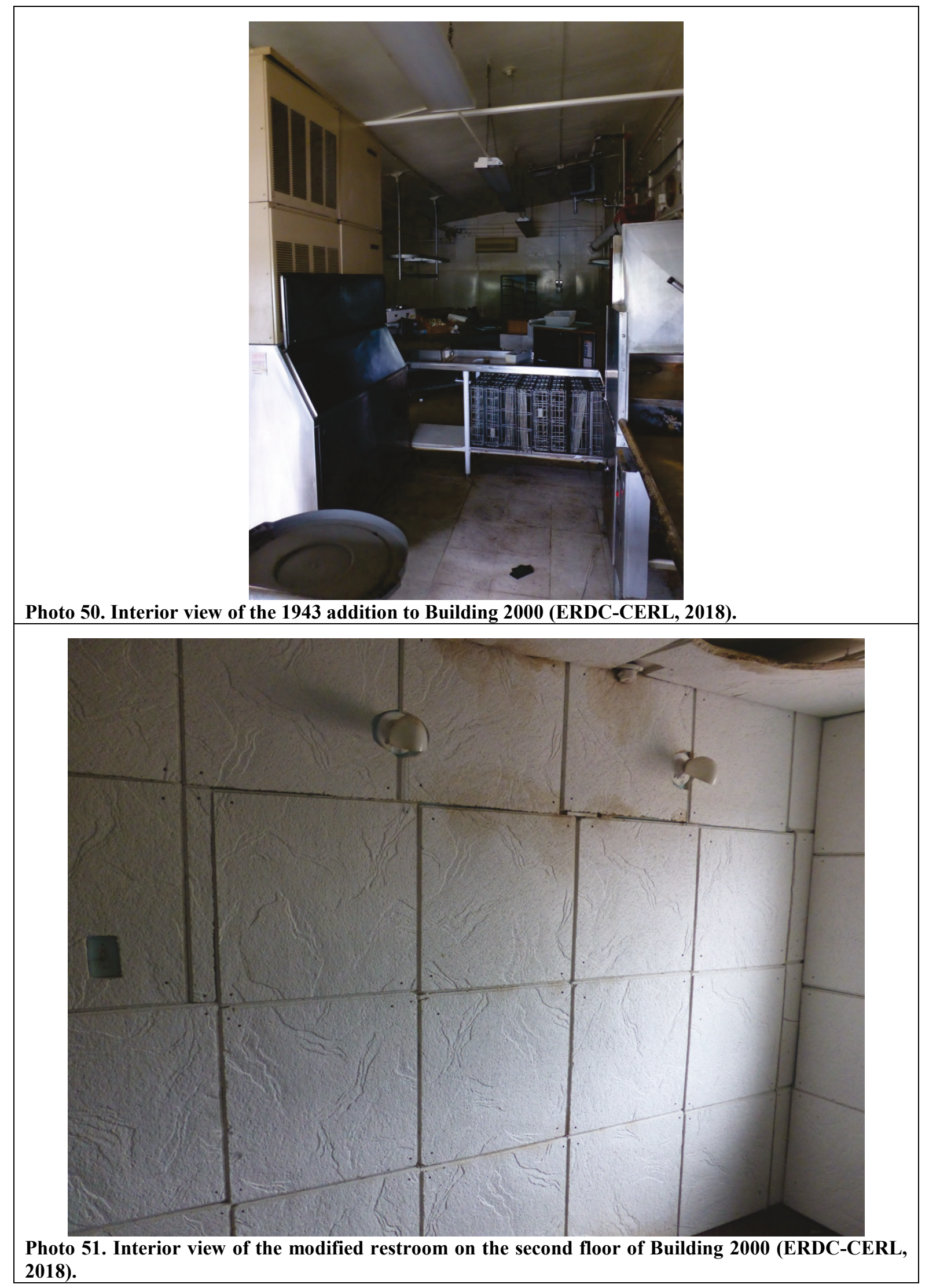




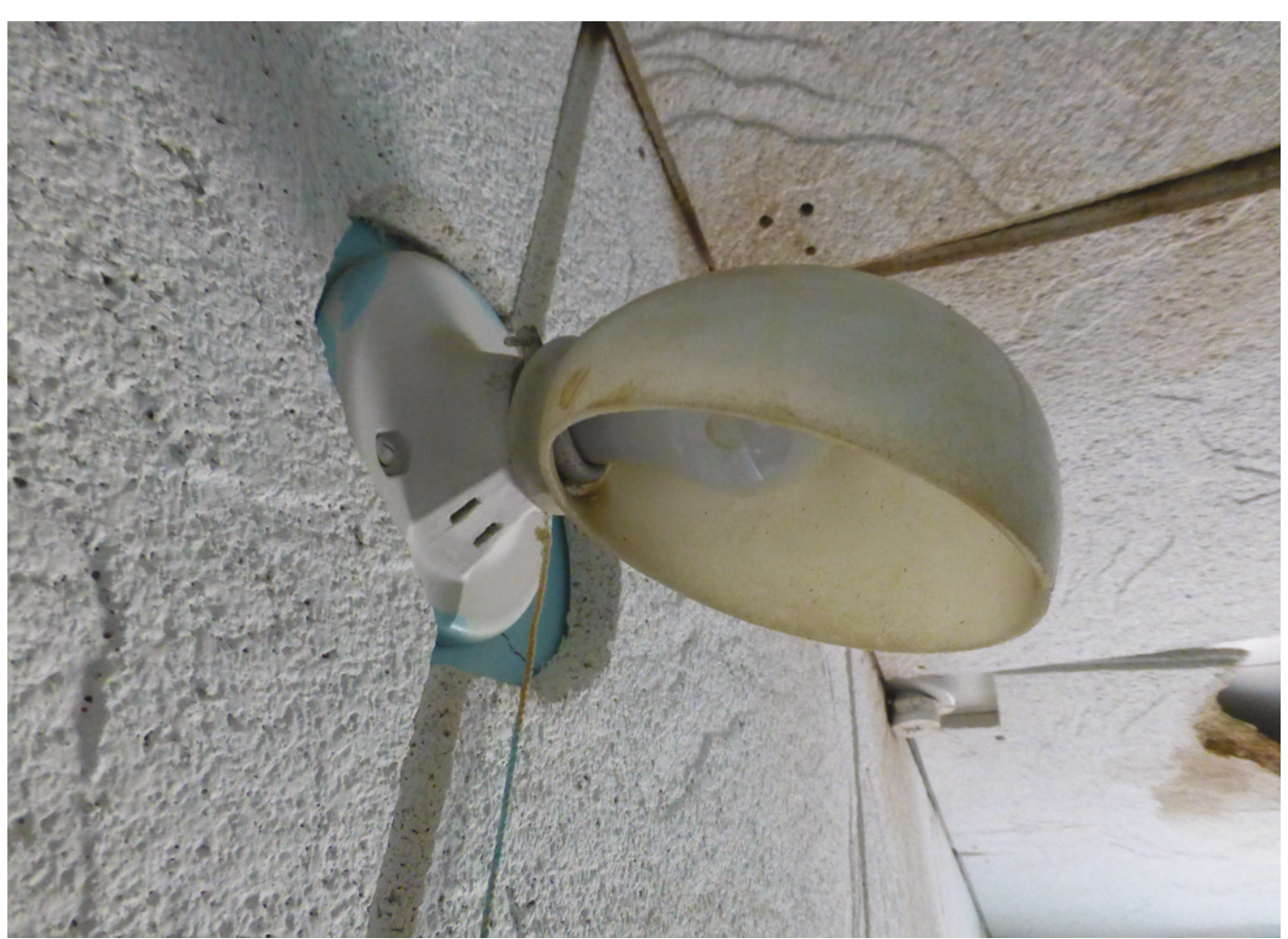

Photo 52. Original light fixture that would have been above the sinks in the secondfloor restroom in Building 2000 (ERDC-CERL, 2018).

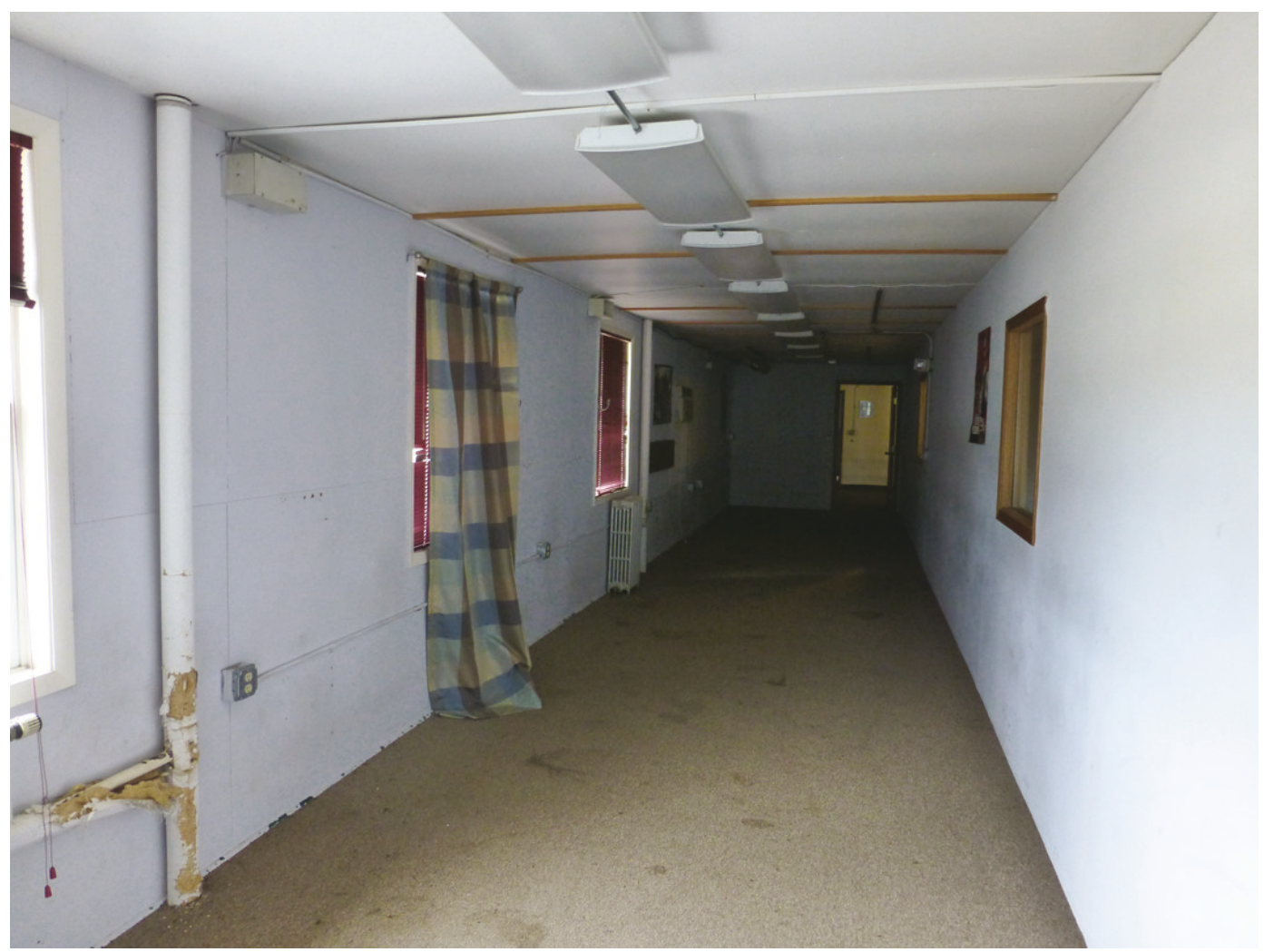

Photo 53. Interior view of the modified east balcony space in Building 2000, with enclosed partition walls (ERDC-CERL, 2018). 


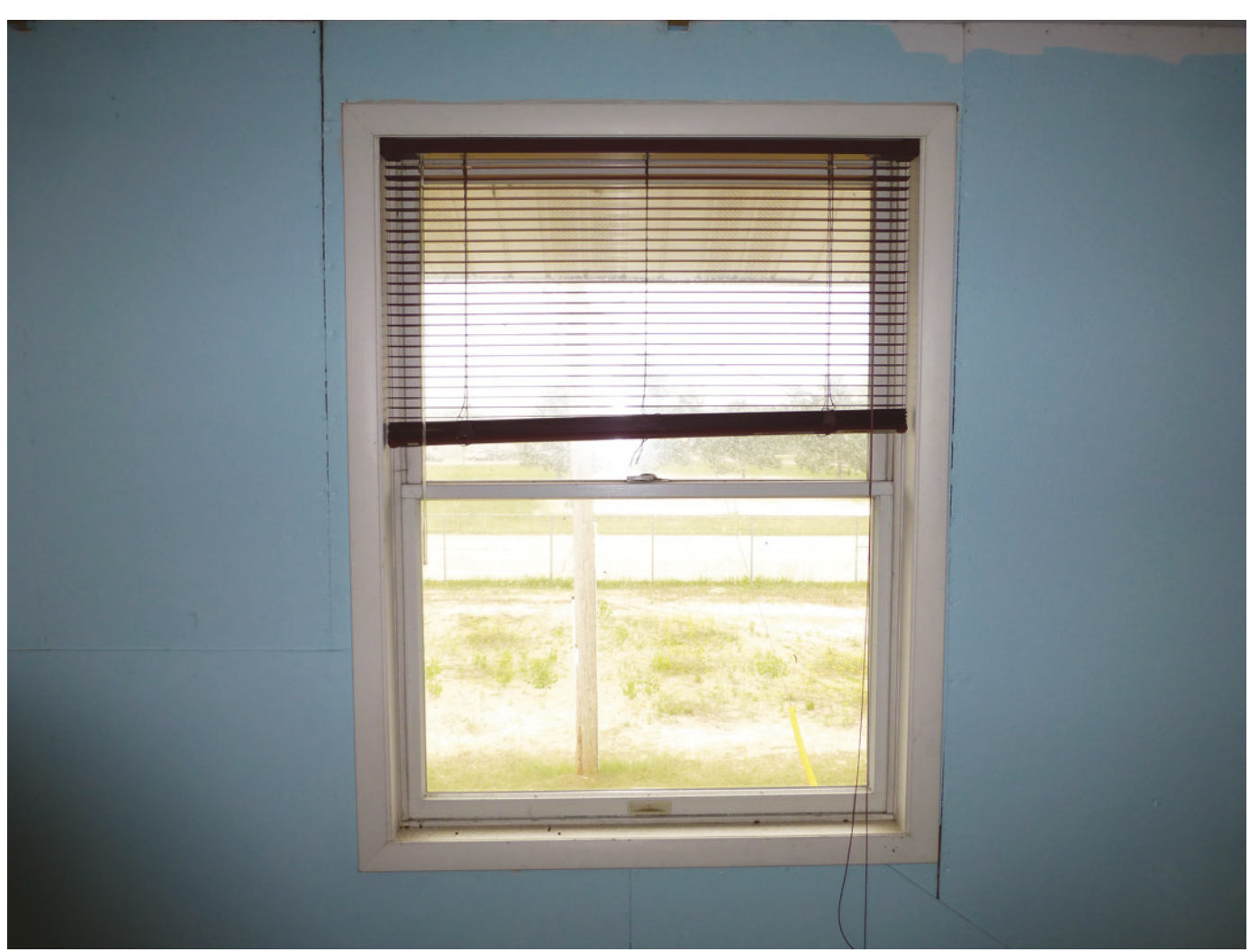

Photo 54. Replacement wood window trim in Building 2000 (ERDC-CERL, 2018).

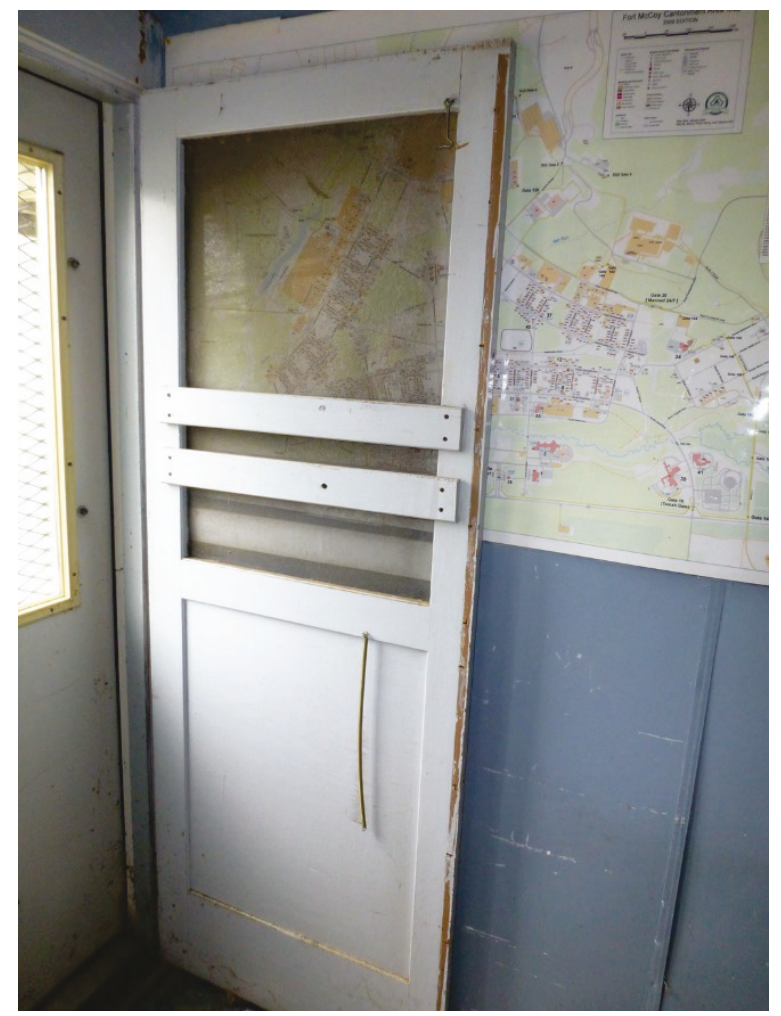

Photo 55. Original wood screen door on the south wall of the 1943 addition to Building 2000 (ERDCCERL, 2018). 


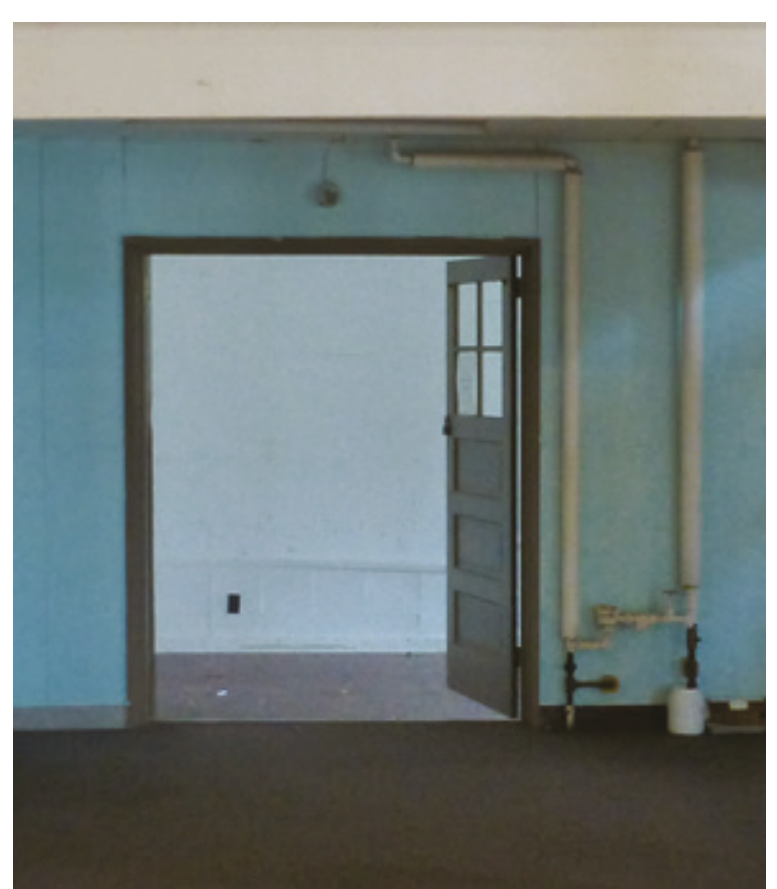

Photo 56. Original four-light, three-panel, wood interior door on the west wall of the dance hall in Building 2000 (ERDC-CERL, 2018). 


\begin{tabular}{|l|l|l|}
\hline COORDINATES & USGS QUAD & CATEGORY CODE \\
UTM $15 \mathrm{~N}$ & Alderwood Lake & \\
$6875897 \mathrm{~N}$ & & \\
\hline
\end{tabular}

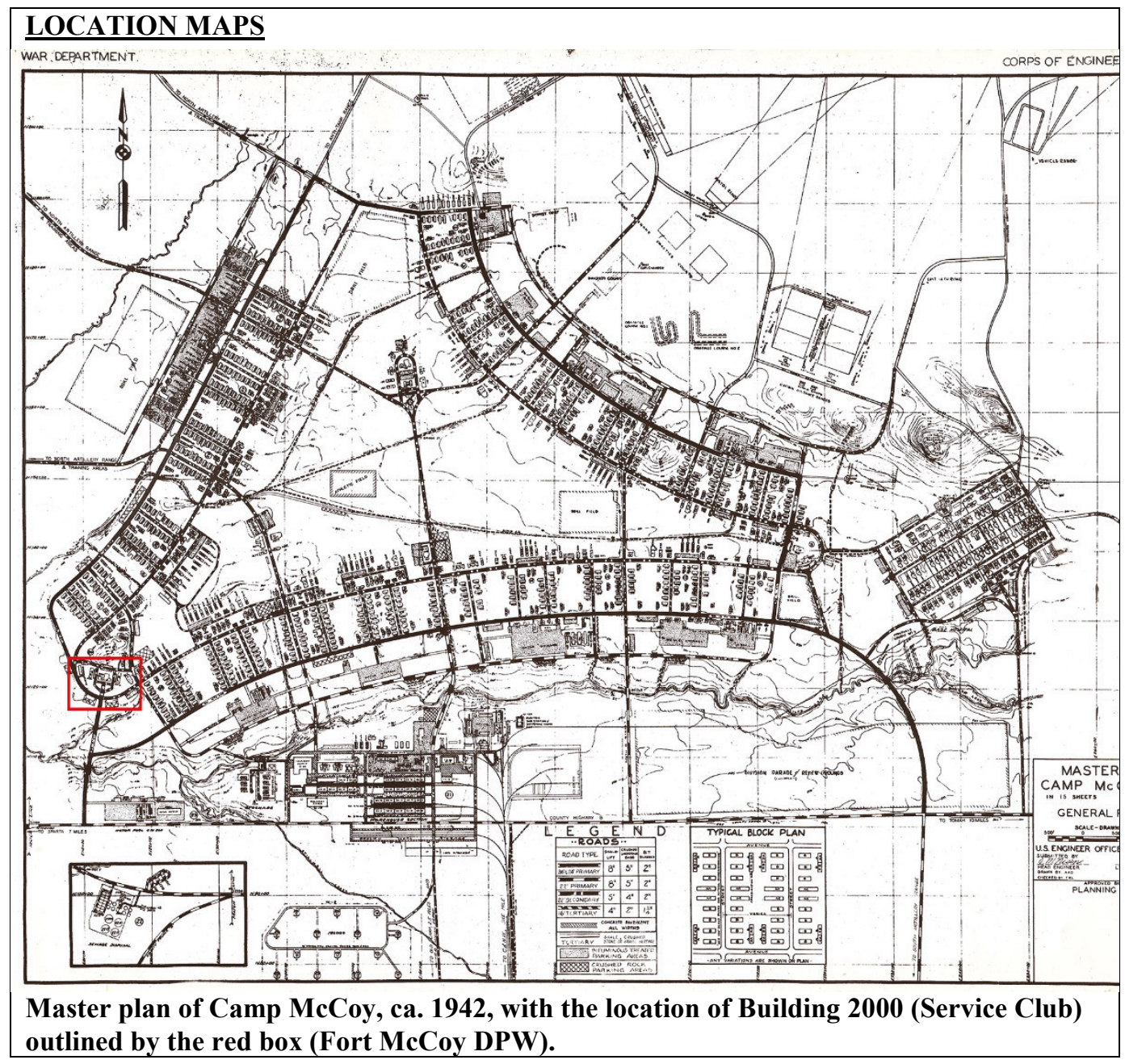




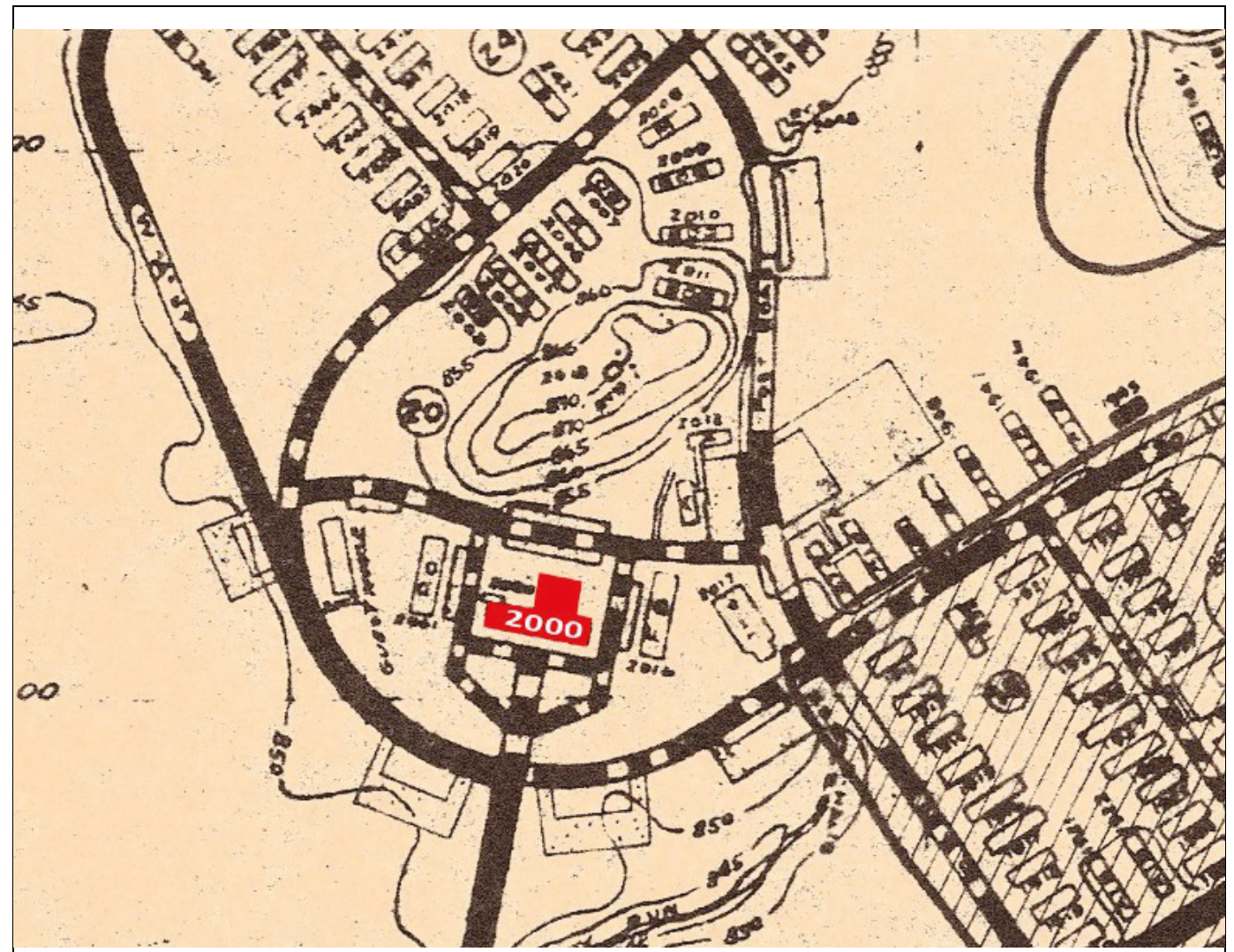

Portion of the General Site Map Camp McCoy with the location of Building 2000 (Service Club) color-coded in red, 1947 (Fort McCoy DPW).

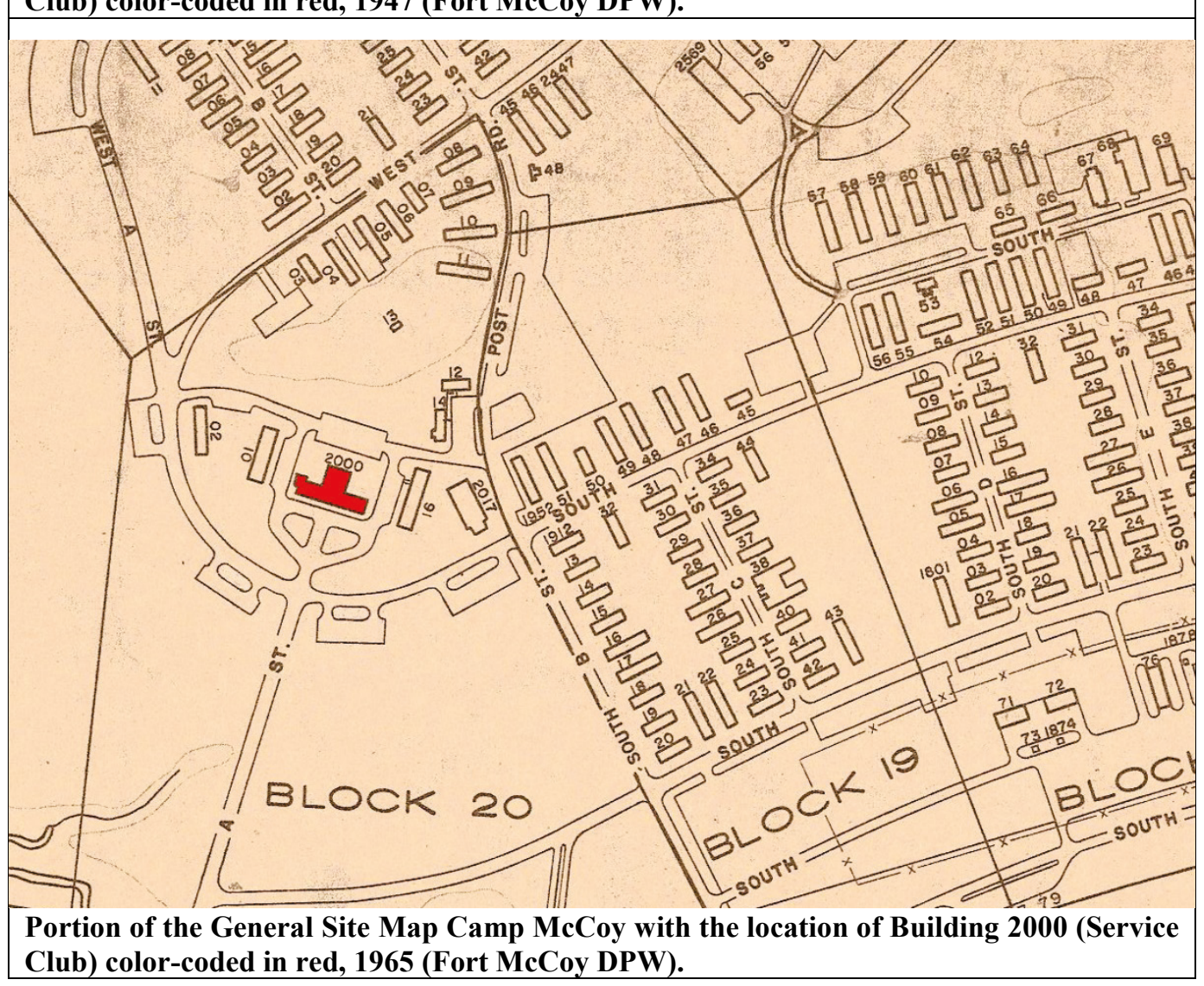




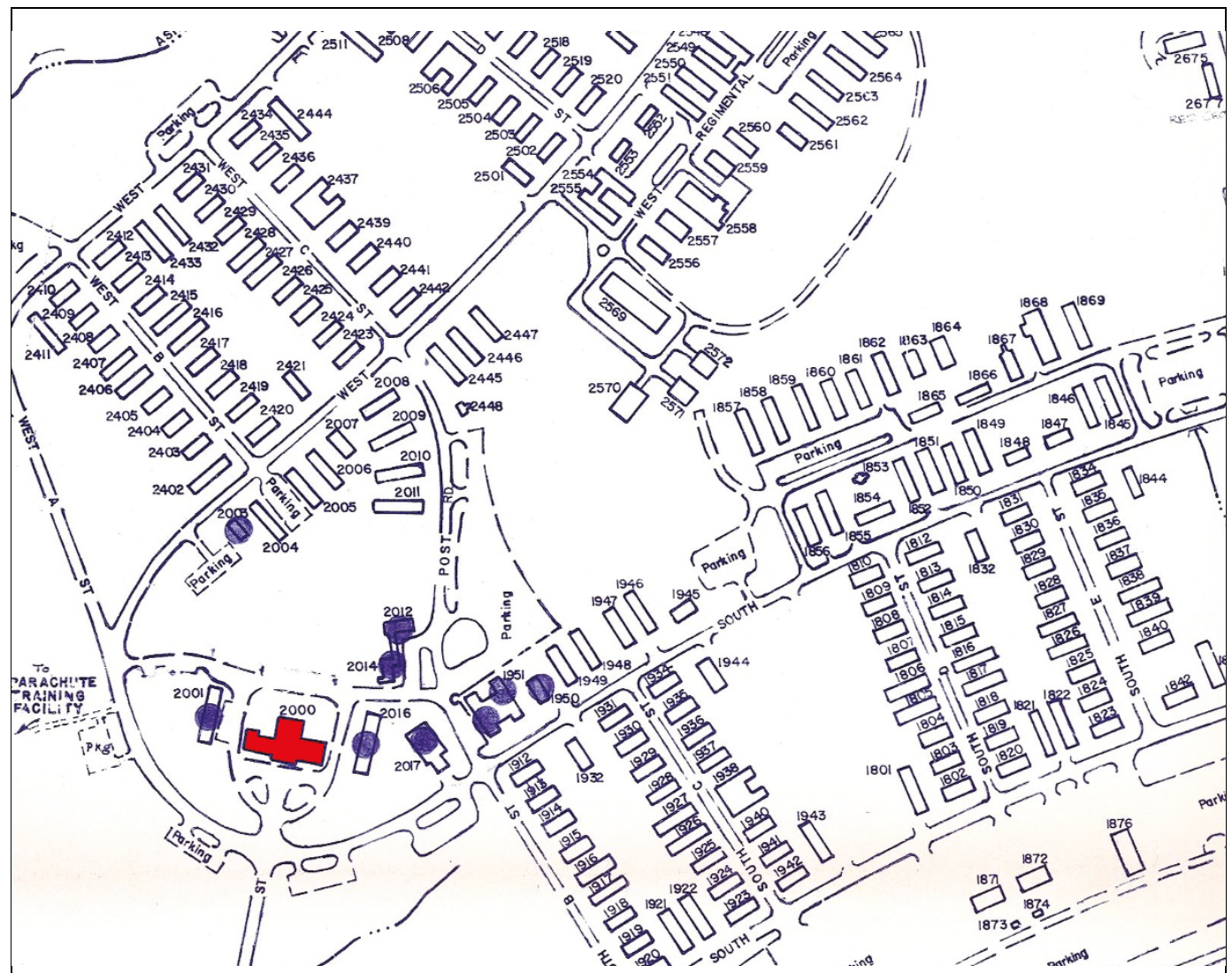

Portion of the General Site Map Fort McCoy with the location of Building 2000 (Service Club) color-coded in red, 1993 (Fort McCoy DPW).

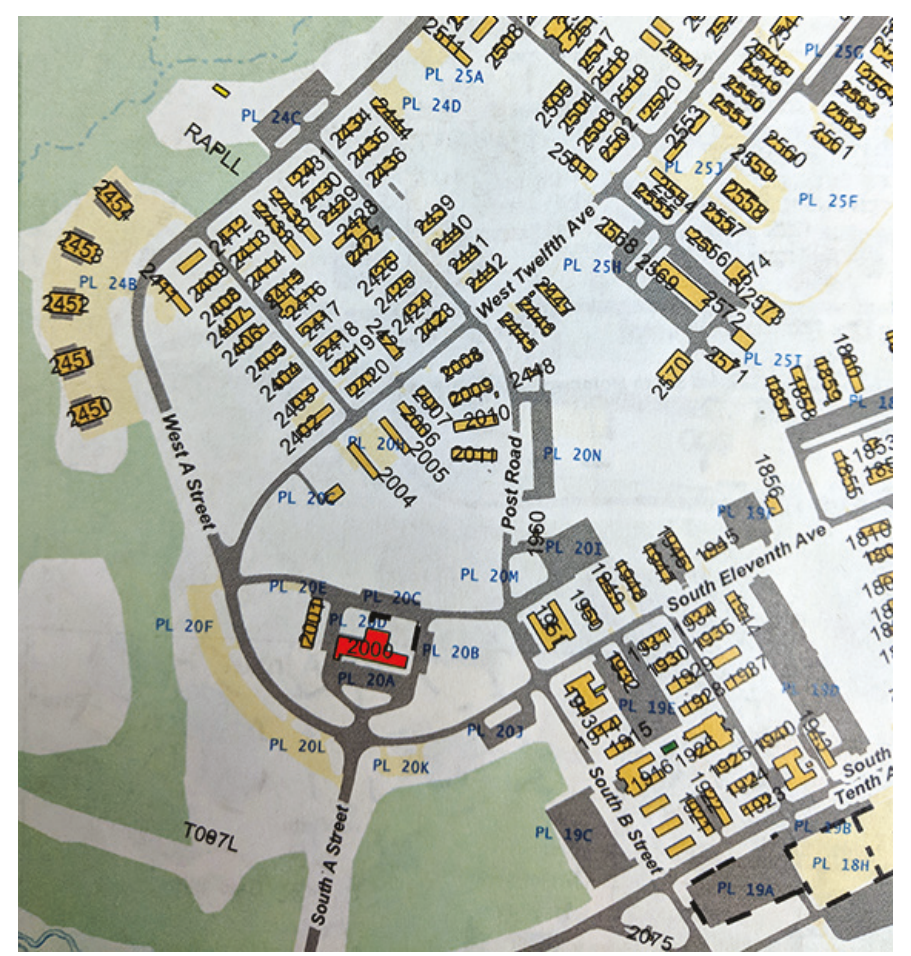

Portion of the General Site Map Fort McCoy with the location of Building 2000 (Service Club) color-coded in red, 2014 (Fort McCoy DPW). 


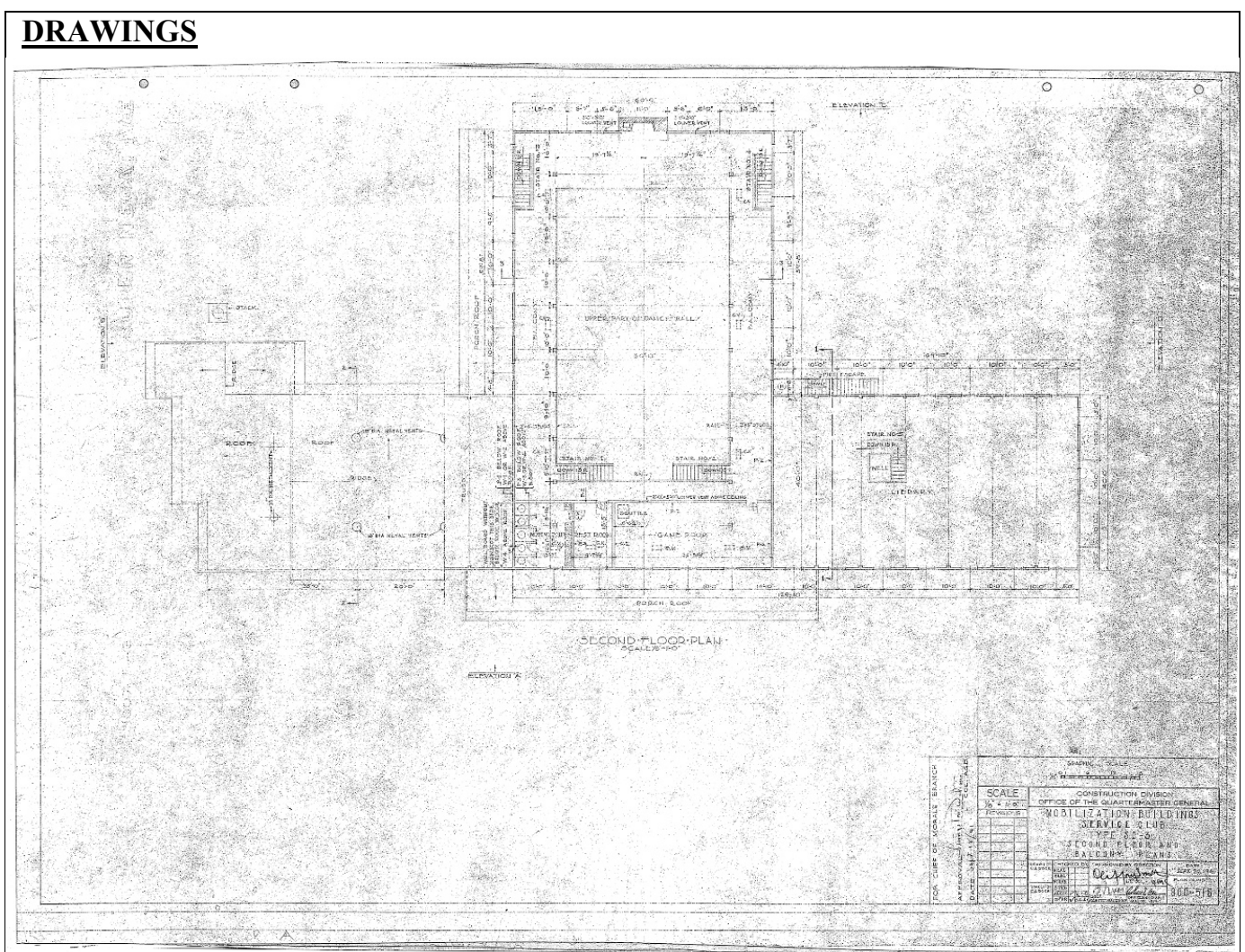

First-floor plan for Building 2000 (Service Club), Drawing 800-517, 1941 (Fort McCoy DPW).

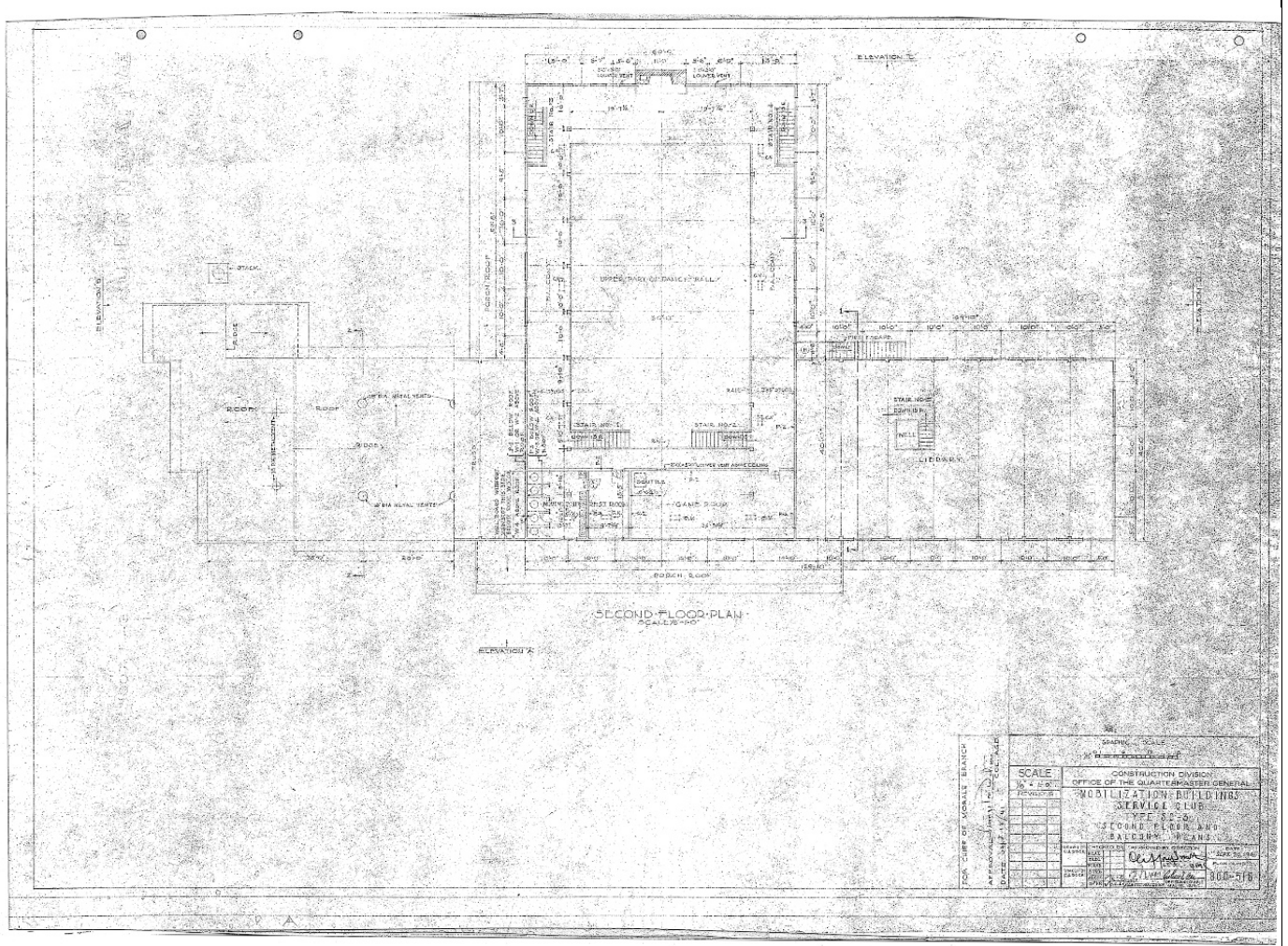

Second-floor plan for Building 2000 (Service Club), Drawing 800-518, 1941 (Fort McCoy DPW). 


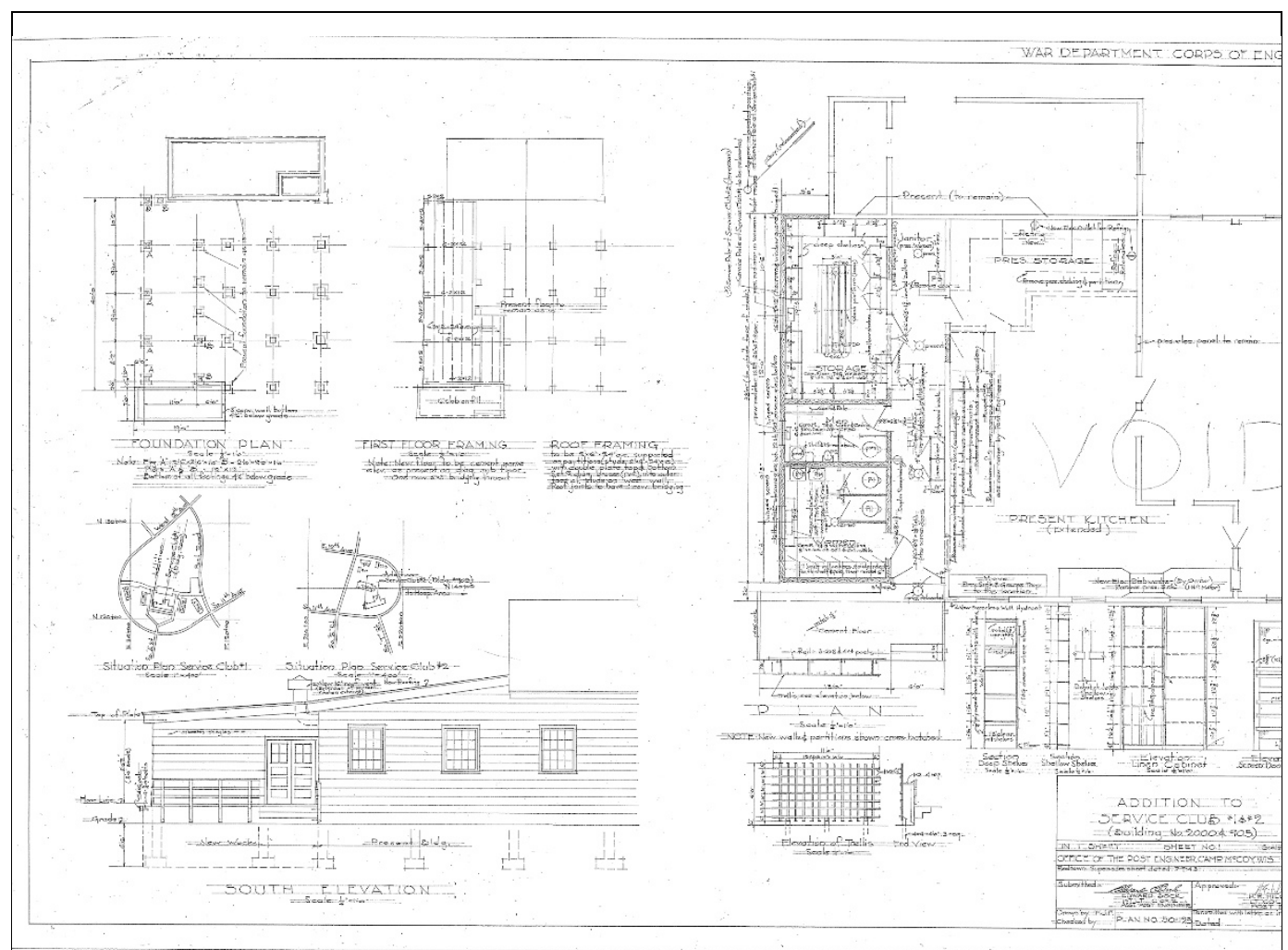

Floor plan, elevation, and details for addition constructed on the west side of the west wing of Building 2000 (Service Club), 1943 (Fort McCoy DPW).

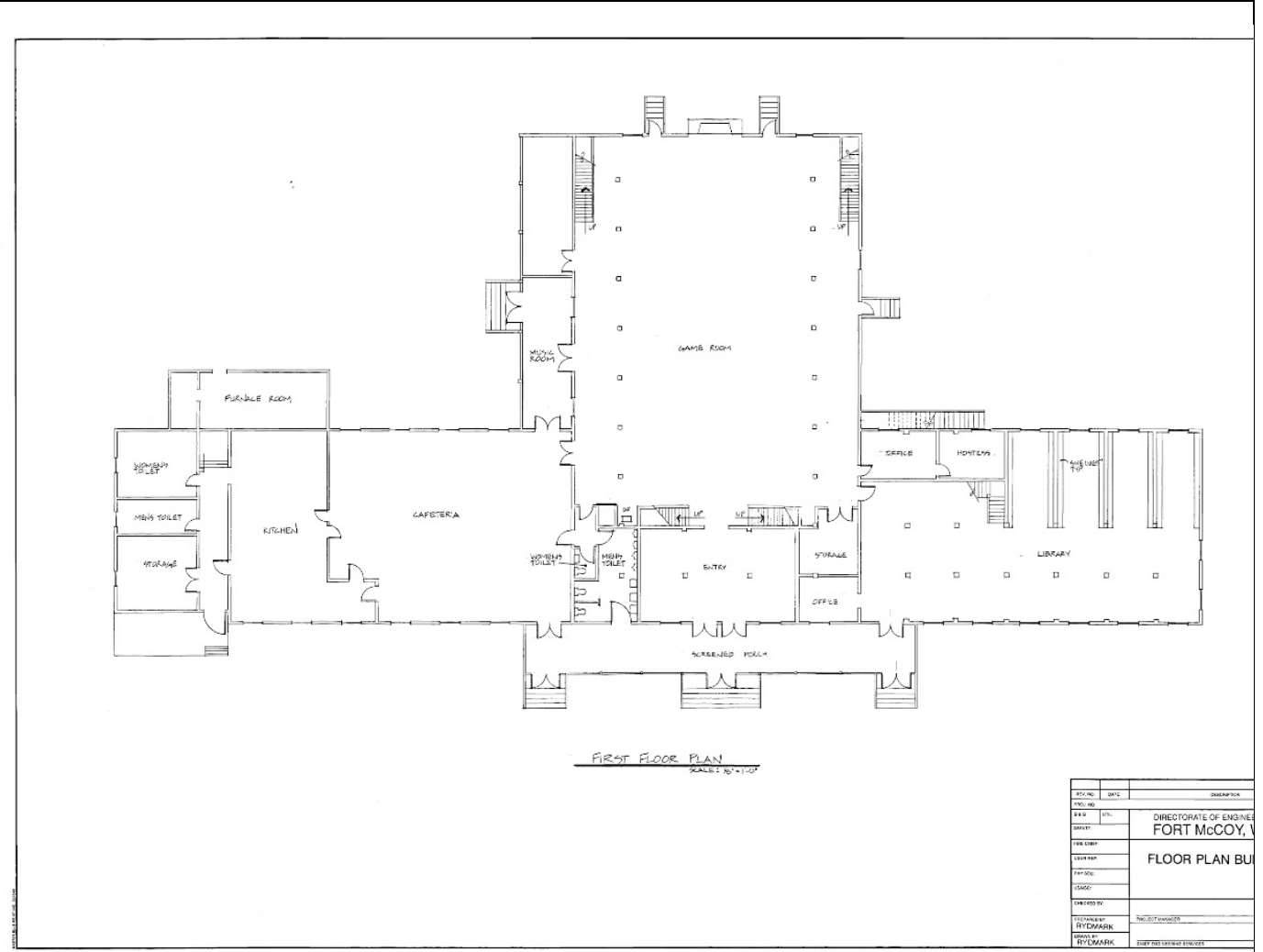

Floor plan for Building 2000 (Service Club) with 1943 addition, NO DATE (Fort McCoy DPW). 


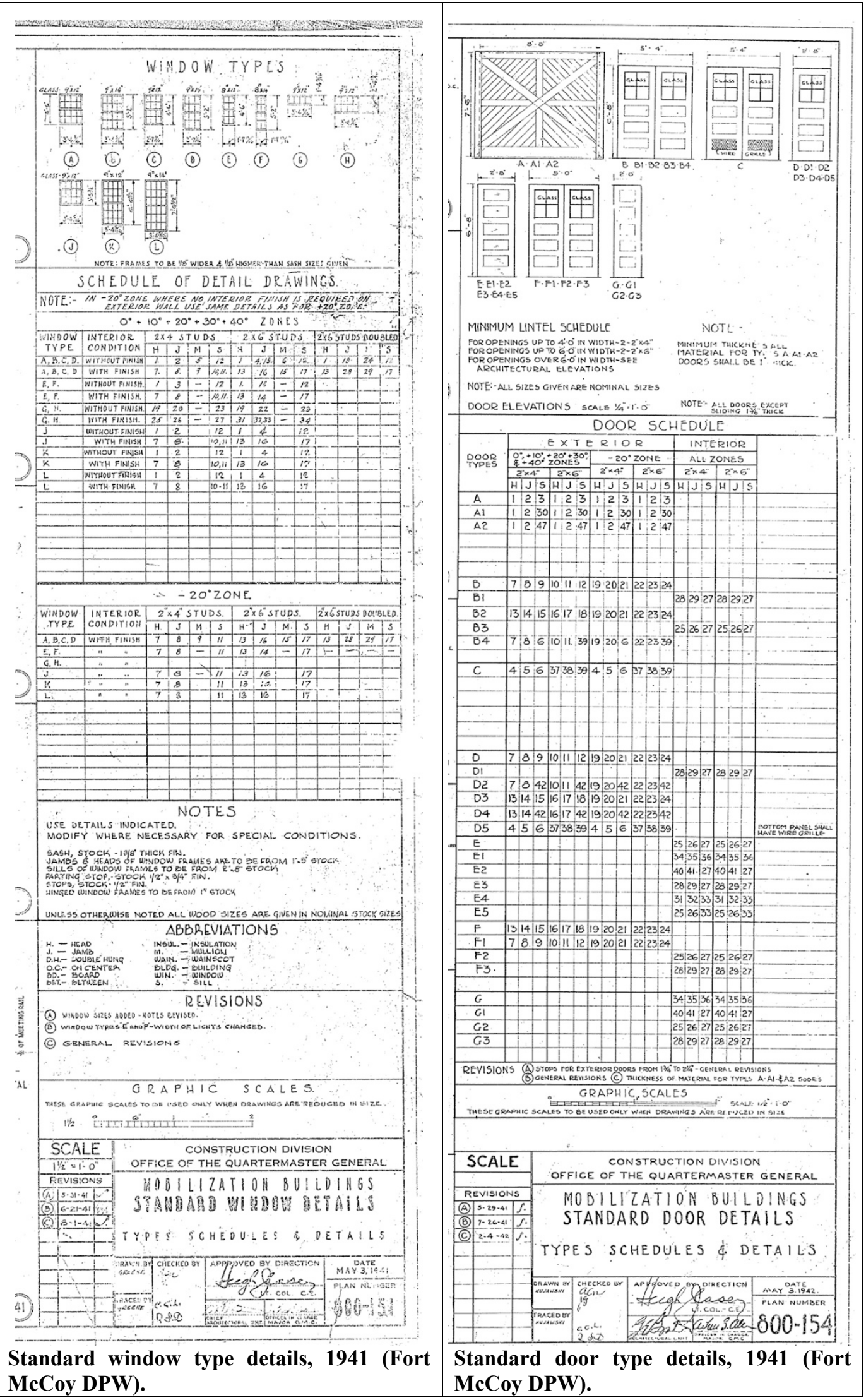




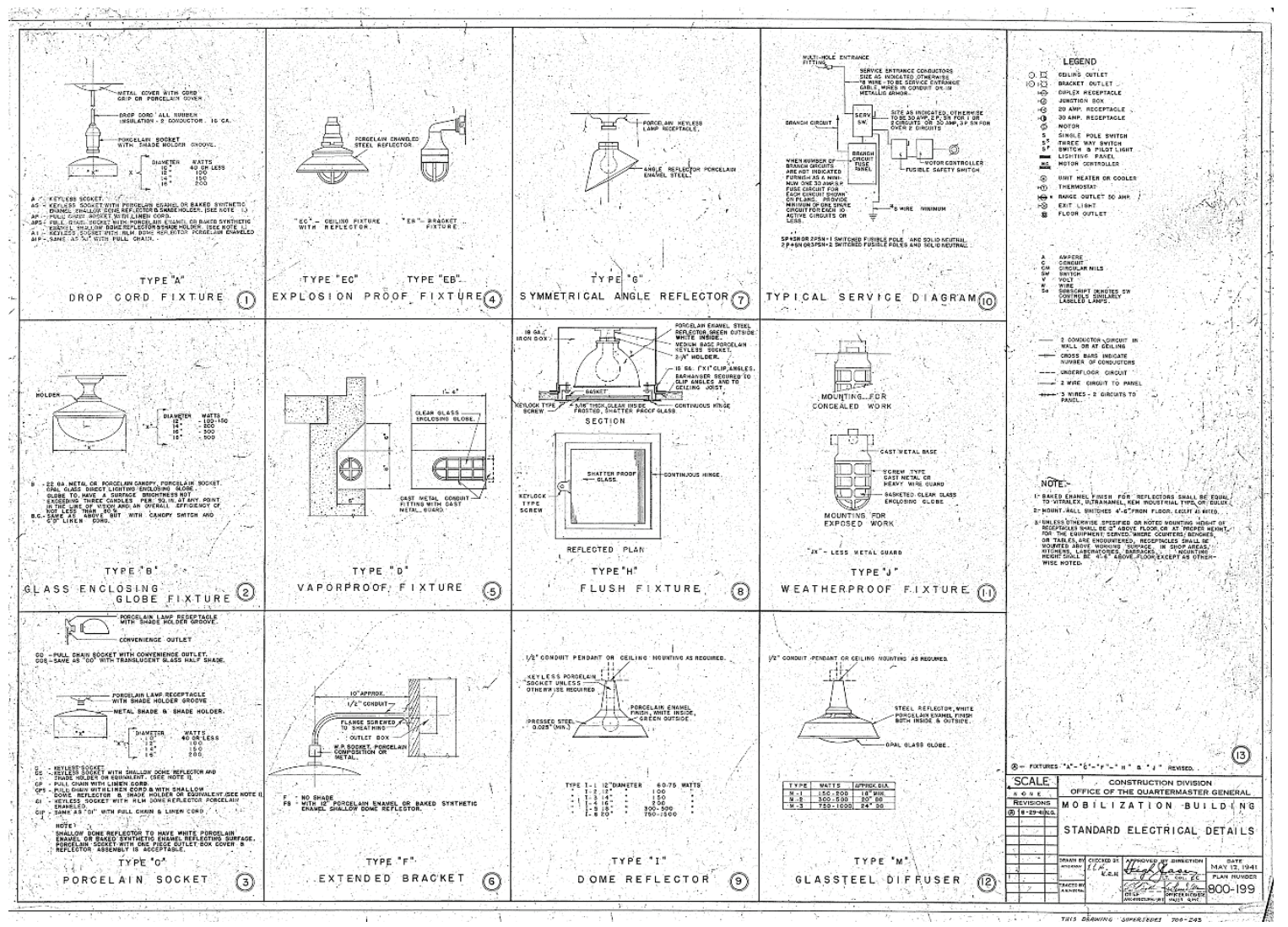

Standard electrical details, 1941 (Fort McCoy DPW).

\section{PRESENT OWNER}

Fort McCoy Commander

\section{OWNER ADDRESS}

Department of the Army US Army Garrison, Fort McCoy

100 East Headquarters Road

Fort McCoy, WI 54656

ADDITIONS/ALTERATIONS

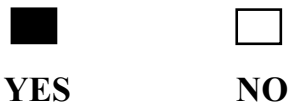

IF YES, SEE HISTORY

\section{BIBLIOGRAPHIC SOURCES}

HABS No. WI-308-J. "Fort McCoy, Building T-2000 (Service Club)." (Washington, DC: Historic American Buildings Survey, National Park District, Department of the Interior, 1988). Cataloged by Library of Congress as HABS WIS, 41-SPAR.V,1-J-7. Also in unmarked wooden container in Meatlocker storage room, Building 2145, Fort McCoy, Wisconsin.

\section{ARCHIVAL SOURCES}

Real Property Record Cards on file at Fort McCoy, Wisconsin

Drawing documentation on file at Fort McCoy, Wisconsin

NARA, College Park, Maryland 


\begin{tabular}{|l|l|}
\hline $\begin{array}{l}\text { PRELIMINARY NATIONAL REGISTER } \\
\text { DETERMINATION OF ELIGIBILITY }\end{array}$ & $\begin{array}{l}\text { FORM PREPARED BY: } \\
\text { ELIGIBLE/CONTRIBUTING NOTny Adams } \\
\text { NON-CONTRIBUTING }\end{array}$ \\
& Engineer Research and Development \\
& Center \\
& Construction Engineering Research \\
& Laboratory \\
& 2902 Newmark Drive \\
& Champaign, IL 61822 \\
& DATE: September 2018 \\
\hline
\end{tabular}

\section{DESCRIPTION}

Building 2000 is located in the southwest corner of the triangular cantonment layout just north of where South A Street intersects with West A Street and South Eleventh Avenue. A paved circular drive is located on the south side of the building. Open mowed lots are located on the east and west side of the building and Building 2001 is adjacent Building 2000 on the west side.

Building 2000 has a T-shaped footprint, concrete pier foundation with wood foundation skirting, wood frame construction clad with cement asbestos siding that has a scalloped bottom edge detail, a cross-gable roof clad with red asphalt shingles, and metal fascia, and soffit (see Photos 1, 19, and 21). There are two types of replacement windows; one-over-one vinyl windows (see Photo 17) and a small single-pane vinyl hopper window (see Photo 18). The doors are replacement metal doors, either solid metal, metal with a large light, or plate glass or metal (see Photos 22-25). All but one light fixture are replacement (see Photo 26). The building has an addition located on the west side of the west wing. The addition is one-story tall, has a concrete pier foundation, and exterior walls clad with the same cement asbestos siding as the original building. The building has two roof forms; a shed roof on the south end and a gable roof on the north end.

The south (front) elevation is defined by a long covered concrete porch that stretches out along the center part of the elevation (see Photo 15). The porch has wood railings and wood posts supporting the overhanging wood roof of the porch (see Photos 15 and 16). The middle section of the south elevation is two-stories tall and is where the main entry is located. Two sets of replacement metal doors with large lights are located in the center of the elevation under the porch (see Photo 22). Also under the porch roof are two other sets of entry doors. The one on the left is metal and plate glass (see Photo 24) and the other on the right side is metal with a large light (see Photo 23). Also under the porch roof are two small replacement single-pane windows (see Photo 18). Above the porch roof are four evenly spaced replacement one-over-one windows. Above the windows are two large signs attached to the exterior wall and in the gable end is a louvered vent (see Photo 15). The left side of the elevation is one-story tall. There are four replacement one-over-one windows on this part of the elevation. On the far left, attached to the west wall of the west wing, is where an addition is located (see Photos 2 and 12). There are two smaller one-over-one replacement windows and a recessed entry of replacement metal and large pane doors (see Photo 25). A large refrigeration enclosure is placed in front of the majority of the south elevation of the addition (see Photo 11). The right side of the south elevation is two-stories tall (see Photo 3). There are six one-over-one replacement windows on both the first and second floors.

The east elevation is two part. The left side is the east wing and the right side is recessed and is the north wing of the building (see Photo 4). The left side has three replacement one-over-one windows and a single entry metal fire escape door on the second floor (see Photo 4). A set of metal stairs provides access to the exit door. A louvered vent is set into the gable end. The right side is the east elevation of the north wing (see Photo 6). There are two replacement one-over-one windows, a small single-pane replacement window, and a replacement entry door with a large light on the first floor of this elevation. A small pent roof wood canopy is above the entry. There are five replacement one-over-one windows on the second floor. A wood deck area is located in front of this part of the building.

The north elevation has several parts. The left side (east wing) is recessed from the middle section and is two stories tall (see Photo 5). There are six replacement one-over-one windows on the first 
floor. There are six replacement one-over-one windows and a replacement metal and large pane fire exit door on the second floor (see Photo 6). A set of wood fire escape stairs provides access to this entry. The middle section (north wing) of the north elevation projects outward from the right and left sides and is defined by a large brick chimney that extends from the ground past the roof line (7). The elevation is symmetrical. On either side of the chimney are two replacement one-over-one windows (one per floor), a replacement metal and large glass door, and a louvered vent. A wood deck stretches out in front of this elevation. On the right side of the middle section is a one-story appendage (original was a screen porch but has since then been enclosed with the same cement asbestos siding). This appendage has a shed roof. There are two small windows on the north side of the appendage (see Photo 7). The right side (west wing) of the north elevation is one-story tall (see Photo 8). A wood porch is covered by an overhanging eave. There are three replacement windows and a single entry metal and large glass door under the porch roof. On the far right, attached to the west wall of the west wing, is the addition is located. This part of the addition has a gable roof, a replacement window, a set of metal doors, and small louvered vent. To the right of the addition is a small appendage with a shed roof and a wood entry door.

The west elevation is two part. The left side (north wing) is recessed from the right side (west wing elevation wall no longer visible due to the construction of the addition) (see Photo 10). The left side is also two part. The foreground is one-story tall and is the enclosed porch area that stretches along the wall. There are two small windows on the left side of the enclosed porch (see Photo 10). The background is two-stories tall and is the west wall of the north wing and there are six replacement one-over-one windows on this part of the wall (see Photo10). The right side of the west elevation is the addition. There are three replacement windows covered with metal security screens (see Photo $11)$.

The interior of Building 2000 has undergone some renovations but for the most part, the layout and use of spaces are intact. Few partitions walls have been constructed to enclose what was original open interior spaces. There are a few newer door openings cut into original walls. All of the original wood work, including exposed structural members have been painted. All of the original wood panel doors have been removed. A four-pane wood door located on the west wall of the hall space would have originally been an exterior door leading out to the west screened porch, however, this porch has since been enclosed making this door an interior door (see Photo 56).The majority of the interior wood screen doors have been removed, with the exception of the doors on the south side of the addition (see Photo 55). All of the simple wood window trim has been removed and replaced (see Photo 54).

The main entry hall is located on the south side. It has new carpet and light fixtures (see Photo 27). From the entry hall to the north it opens up into a large two-story space. A balcony surrounds the perimeter of the space and exposed wood trusses from the roof of the space (see Photos 28-31). The hall has a wood floor, except underneath the balcony where carpet has been added. A large twostory brick fireplace wall is located on the north side of the hall creating a fireplace on the main floor (see Photo 32) and one on the balcony level (see Photo 38). All of the original pendent light fixtures hanging from the trusses have been replaced. An original blower heater fan mechanism is attached to the trusses and is intact (see Photo 39). It is unclear if the metal sconces attached to the wood columns in the hall are original or replacement (see Photo 40). There are four sets of wood stairs, one located at each corner of the hall space that provide access to the balcony (see Photo 33). A simple wood balustrade is used for the balcony (see Photo 34). The balcony floor is covered with carpet (see Photo 36). The east balcony has been enclosed with the addition of partition walls (see Photos 31 and 53).

From the entry hall to the east is the two-story east wing. The first floor is dotted with a wood column grid system (see Photos 41 and 42). The area is covered with carpet. A new door opening has been cut into the east wall leading to the exterior. An interior wood staircase provides access to the second floor of the east wing, which is a large open space define by exposed wood trusses used to support the gable roof above (see Photos 43 and 44). The space is covered with carpet. There is one fire exit door located on the north wall. 
From the southwest corner of the hall is a set of metal and plate glass doors leading into the café space (west wing) (see Photo 45). This space has been remodeled over the years and has no original features intact (see Photos 46 and 47). To the west of the cafe is the original space for the kitchen, storage, and service areas; however, this space has been completely remodeled (see Photo 48). A to the west of the original kitchen space is the one-story addition, which has a long, north-south corridor that provides access to two restrooms and a larger storage room (see Photos 48-50). The restrooms have no original features.

\section{HISTORY (excerpt taken from HABS data sheet)}

The construction of Building 2000 was part of a massive, nation-wide mobilization program designed to build cantonments in which to house and train the expanded WWII Army.

Building 2000 was erected in 1942 using the Construction Division Office of the Quartermaster General, Mobilization Building, Service Club Type SC-3, Plan Number 800-517 standardized plan of the War Department. The 800 Series plans featured well-constructed wooden buildings with ample structural members and such comforts as indoor plumbing and forced, hot-air furnaces. Building 2000 was one of two SC-3 Service clubs constructed in the main cantonment area of the "New Camp McCoy" and was assigned to Special Services from January 26, 1943, until September 26, 1963.

\section{Exterior:}

Overall dimensions: Building 2000 was built as a T-shaped building with a main hall and two wings. The main structure measured 40'-0" x 199'-8" and the wings measured 70'-0" x 59'-8" with an approximate area of 18,791 square feet.

Foundation: Building 2000 had a concrete pier foundation system with wood foundation skirting.

Walls: The exterior wall consisted of wooden sheathing composed of 7-1/8", tongue and groove boards, a black construction paper which acts as a vapor barrier, and siding composed of cement asbestos pieces measuring 11 " $\mathrm{x} 24$ ", the standard size used throughout the cantonment.

Structural system: The building was built of light wood frame construction consisting of 2' $\mathrm{x} 4$ "' studs at 2'-0" on center. The roof was supported by a pitched truss which were supported by wood columns.

Porches/stoops: The building had a long screened wooden porch that stretched across the south (front) elevation measuring $80^{\prime}-0$ " in length. Three sets of wood stairs provided access to this porch with the center set being the widest. A screened porch located on the west wall of the north wing measured 59'-8" in length was modified in 1943 to be an enclosed porch.

Chimneys: Building 2000 was designed with two chimneys. One was an end chimney wall at the center of the north elevation in the dance hall wing. It had two fireplaces attached to it; one on the first floor and one on the balcony of the dance hall. This chimney was approximately 30 -feet in height (approximately 4-foot over the roof ridge). The second chimney was located outside the boiler room of the west wing and it ascended approximately 65 -feet above grade. Both chimneys were constructed of brick.

Windows: There were two types of windows used on Building 2000. The one used the most was an eight-over-eight double-hung wood sash and the other was an eight-pane fixed sash wood window. The architraves of the opening was of the same simple board design found in the other mobilization building types.

Doors: There were three sets of wood screen doors that provided access to the porch on the south (front) elevation. At the south wall (front entrance), there were two pairs of doors, side-by-side, with four-light three panel wood doors that lead into the main entry hall flanked on either side by a set of four-light three panel wood doors; one lead into the café and the other into the library. There was one set of wood screen doors leading to the porch on the west wall of the north addition. Also there were two sets of four-light three panel wood doors lead out from the dance hall on the west wall onto the screen porch and one set lead from the north wall of the café to the porch. There was a set 
of wood doors on the north wall of the boiler room. Two single entry four-light wood doors flanked either side of the chimney on the north wall of the north wing. There was one fire exit door from the second floor on the east wall of the north wing.

\section{Interior:}

Floor plan: The T-shape of the main floor consisted of an entry hall flanked on one side by a men's toilet room and the other by a storage room, and librarian's office, a café, kitchen area with storage rooms, and a boiler room in the west wing, a library, a storage room, and an office in the east wing, and a dance hall in the north wing. The middle section of the second floor had a women's restroom and toilet, and a game room. The east wing was the second floor for the library (billiard room). There was no second floor over the west wing and the majority of the second level of the north wing was open to the dance hall below.

Entry hall: The entry hall had a wood floor, insulation boards covered the walls, and the space was filled with built-in coat racks.

Library: The library was a two-story space. On the first floor, a grid pattern of wood columns supports dotted the open space. The floor of the library was wood. An interior wood staircase lead up to the second floor where exposed wood trusses highlighted the vaulted ceiling.

Dance hall: The dance hall was an open two-story space with a wood balcony that encompassed the perimeter of the space. The balcony had a simple wood balustrade. The floor of the hall and balcony was wood. Exposed wood trusses highlighted the vaulted ceiling. The room had metal and porcelain light fixtures. A fire place was located on the north wall on both the main floor and the balcony level. Four wood staircases, one at each corner of the dance hall provided access to the balcony.

Café: A café was located in the west wing with an adjacent kitchen space. The café had a wood floor.

Flooring: The flooring in the kitchen, toilet rooms, and boiler room was concrete. The remainder of the structure had wood floors.

Wall and ceiling finishes: The ceiling and walls are finished with Masonite presswood (fiberboard) and painted.

Doors and trim: There were two type of doors used in Building 2000; one was a four-light threepanel wood door and the other was a five panel wood door. Both were of standard types used throughout the WWII cantonment construction.

Lighting: The lighting in the dance has been replaced with pendant light fixtures. The lighting in the library has been replaced with fluorescent fixtures and globe fixtures.

In 1943, new addition was constructed on the west side of the west wing. This addition measured 38 'x $22^{\prime}$ and housed a corridor that provided access to a women's restroom, a men's restroom, and a large storage room. The addition had a concrete pier foundation, exterior walls clad with the same cement asbestos siding as found on the original structure, and a sloped shed roof clad with asphalt shingles. There were three eight-over-eight double-hung wood windows on the west elevation of the addition and a set of four-light wood panel doors on the south elevation near the connection to the original west wall of Building 2000. These doors provided access to the corridor.

In 1951, the original open screened porch on the west side of the north wing was enclosed. The exterior was clad with the same type of cement asbestos siding as found on the original part of the building. Also in 1951, a checkerboard tile was installed in the entry hall, underneath the balcony on the first floor of the dance hall, the second floor balcony, and the library, ultimately cover up the original wood flooring used in these spaces.

Sometime between 1965 and 1978, the screens were removed on the south porch.

In 2003, all of the original multi-pane wood windows and four-light wood panel doors exterior doors were removed and replaced with one-over-one vinyl windows and metal and glass entry doors. 
At an unknown date(s), the tall brick chimney stack located adjacent the boiler room in the west wing was demolished, two new door openings were cut into the north wall of the north wing; one on either side of the chimney, all the exposed wood of the balcony, trusses, and staircases have been painted in the dance hall, carpet has been in the library, balcony, and second floor spaces. Tile has been installed in the café, all of the original pendent light fixtures in the dance hall, library, and café have been removed and replaced. The wood floor of the porch on the south (front) was replaced with a concrete floor.

\section{HISTORIC PHOTOS}

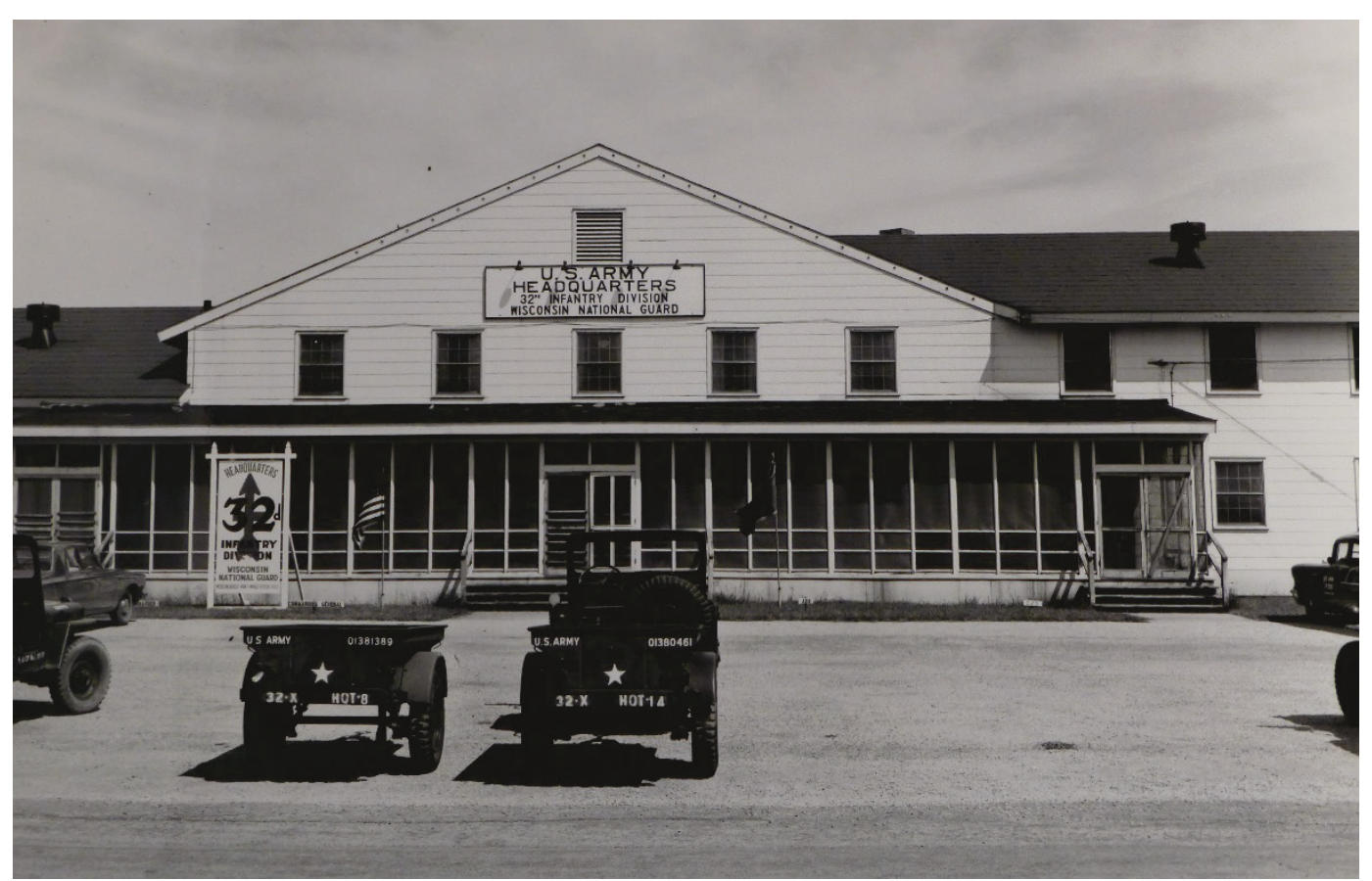

Close-up view of the south (front) elevation showing the front porch of Building 2000, 1965 (NARA College Park, RG 111-SC). 


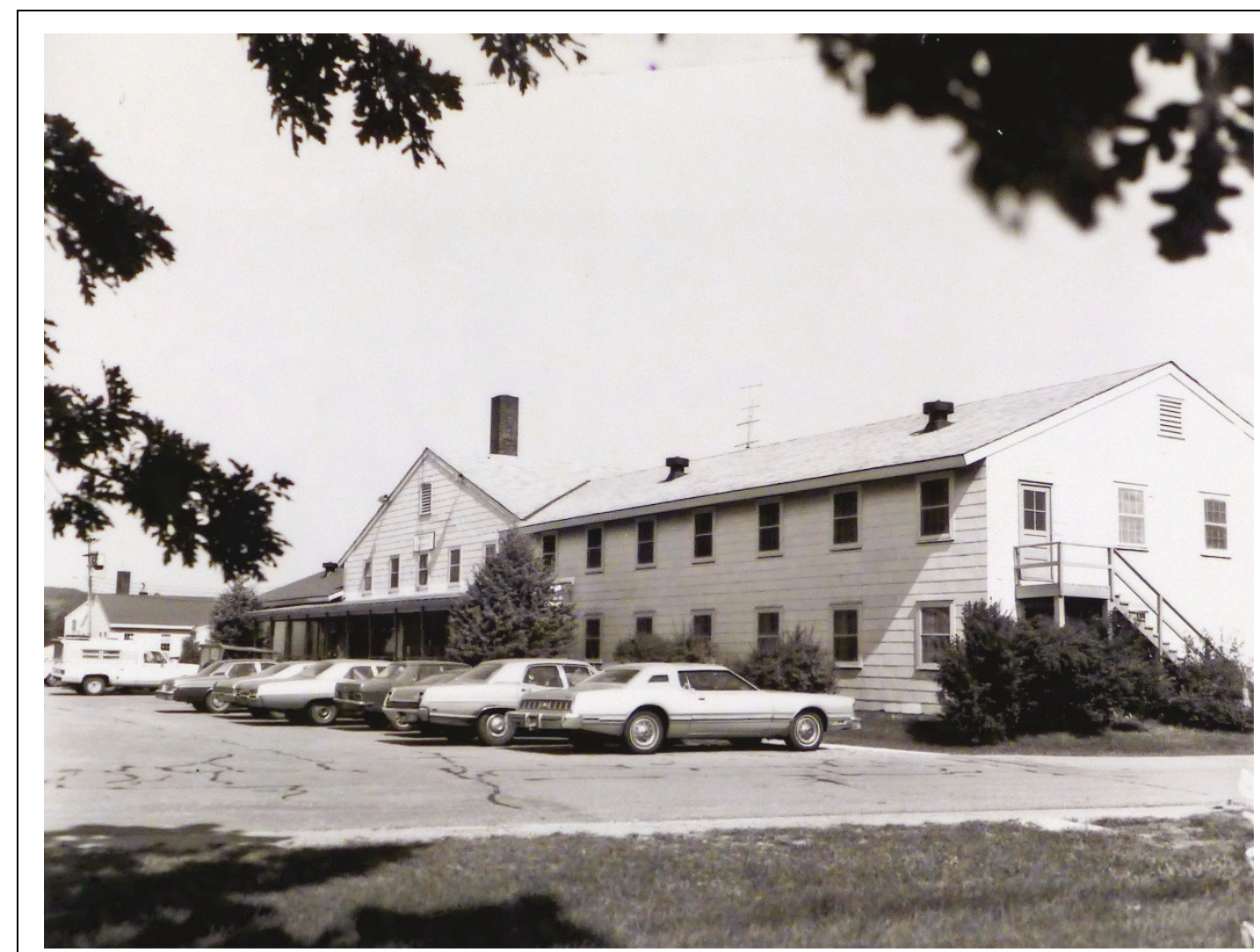

Southeast oblique of Building 2000, 1978 (NARA College Park, RG 111-SC).

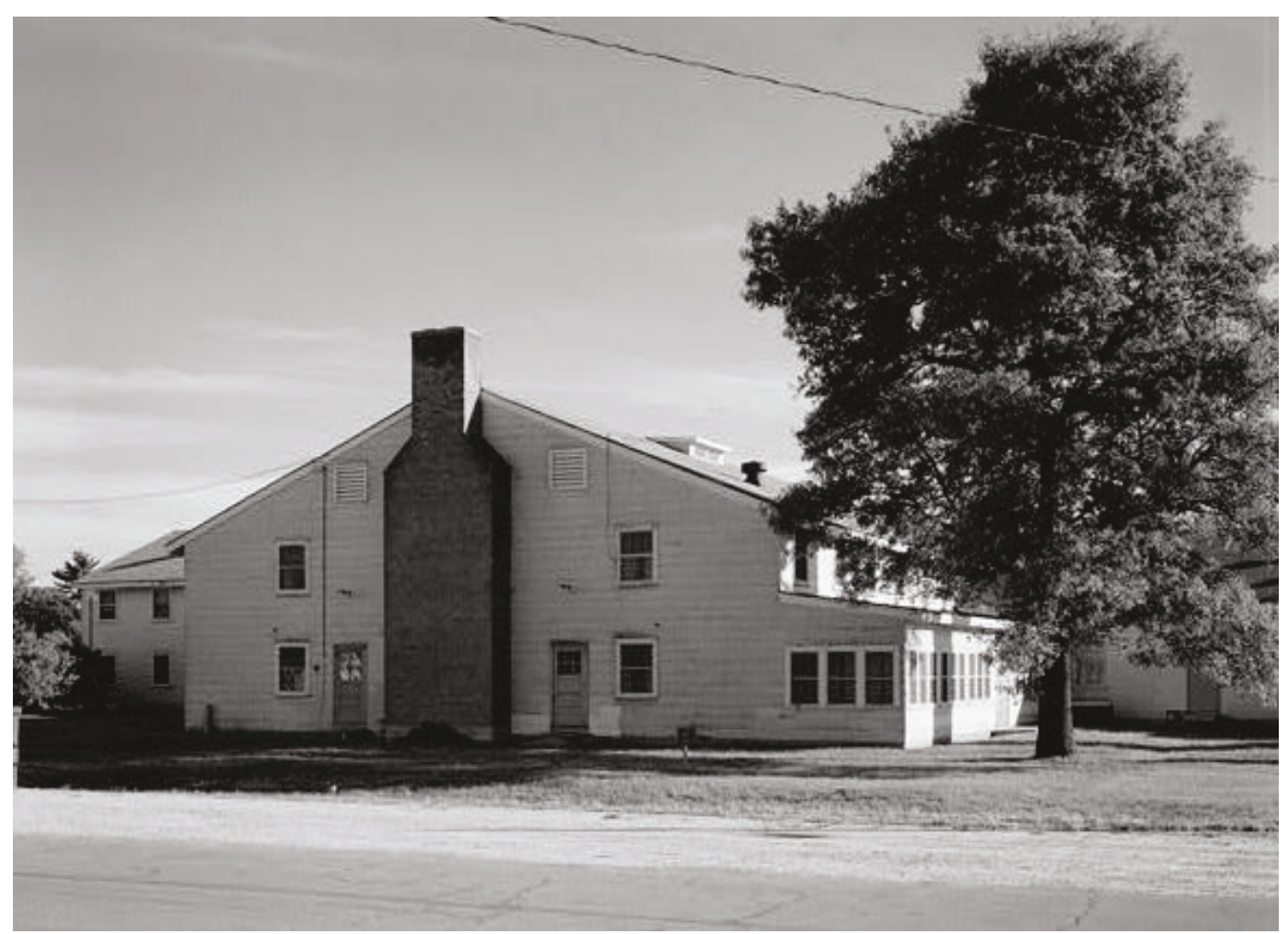

Northwest oblique of the north wing of Building 2000, 1988 (Library of Congress, HABS WIS, 41-SPAR.V,1-J-6). 


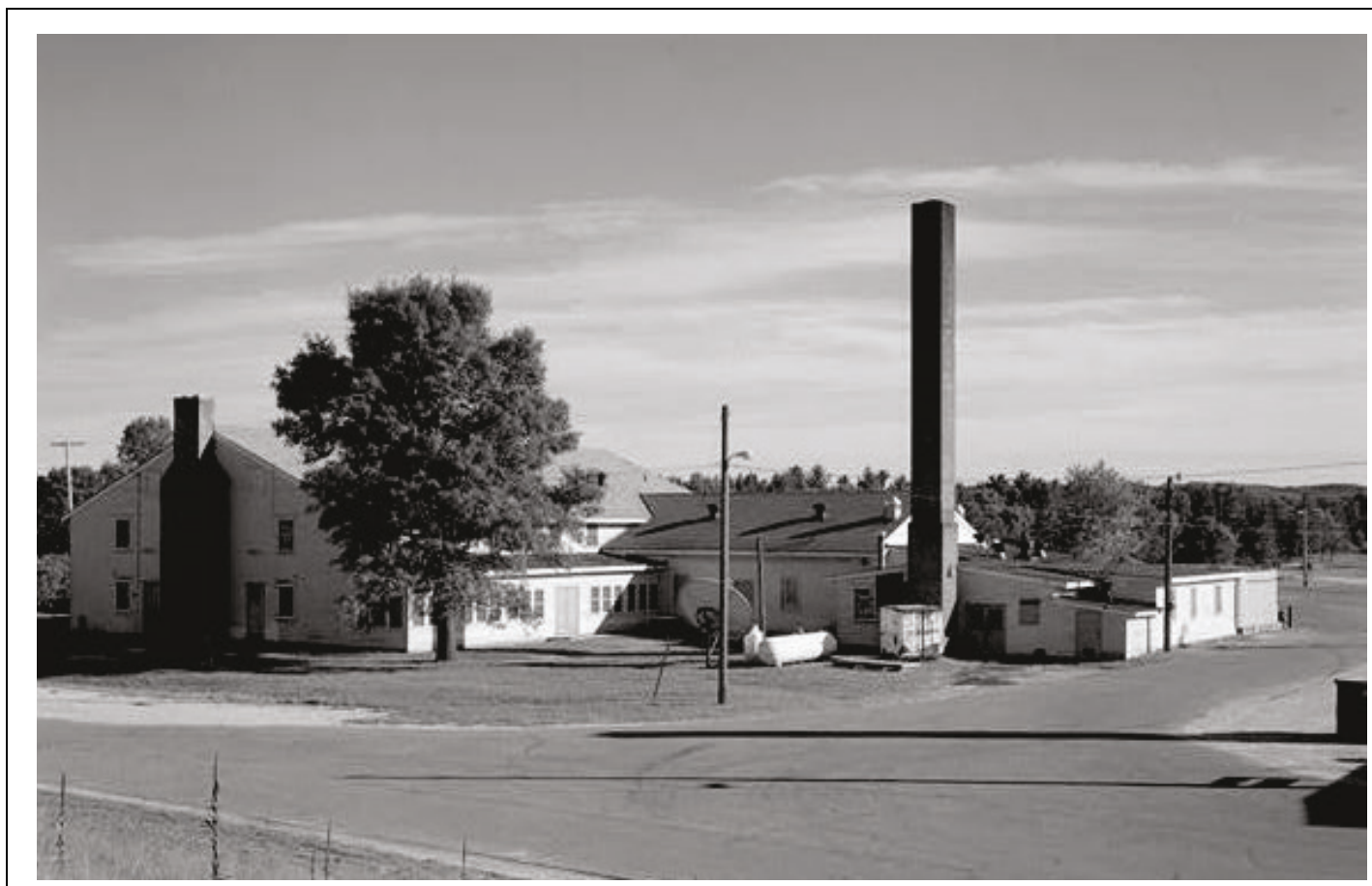

Northwest oblique of Building 2000, 1988 (Library of Congress, HABS WIS,41-SPAR.V,1-J2).

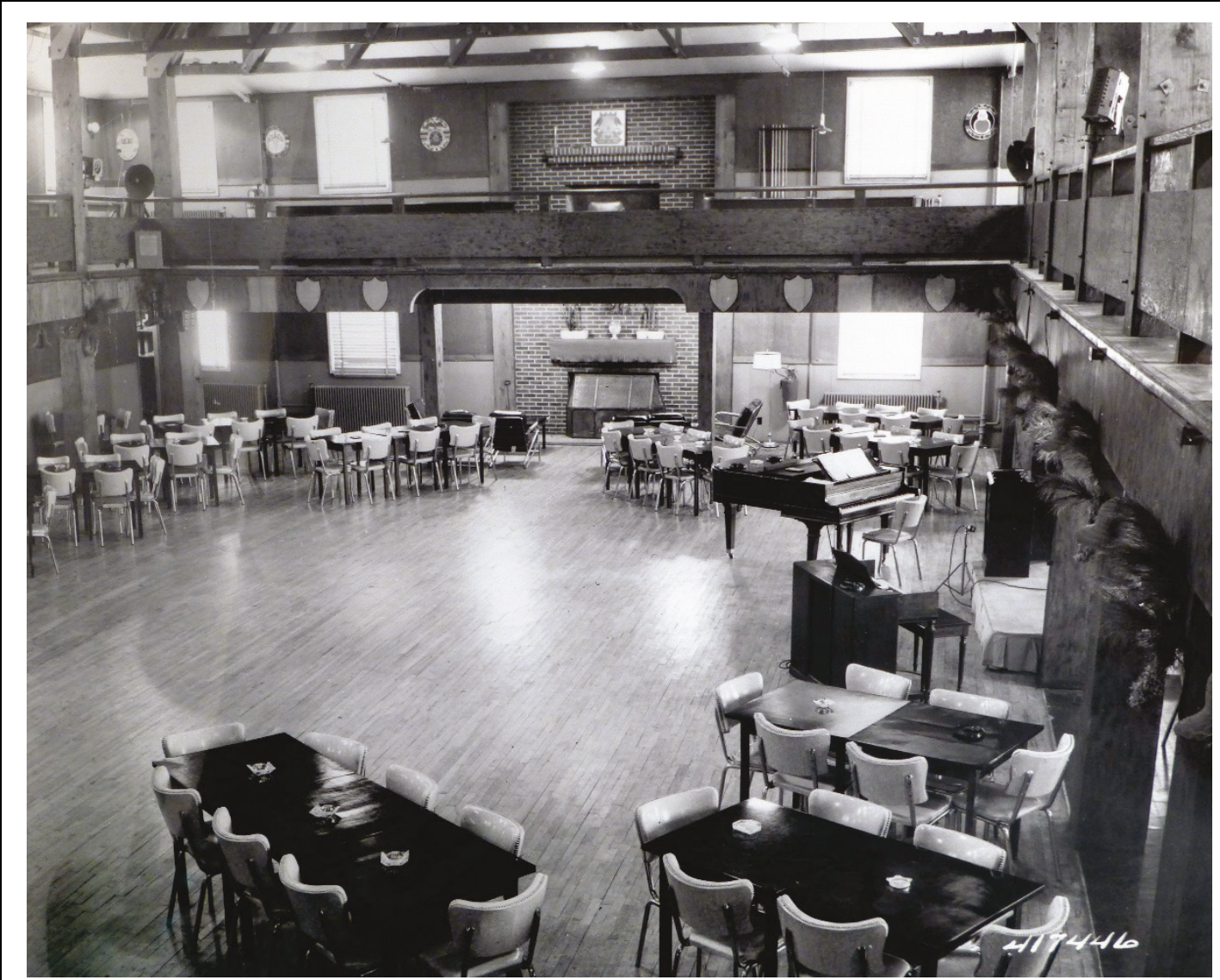

Interior view of the dance hall looking north towards the fireplaces in Building 2000, 1952 (NARA, College Park, RG 111-SC). 


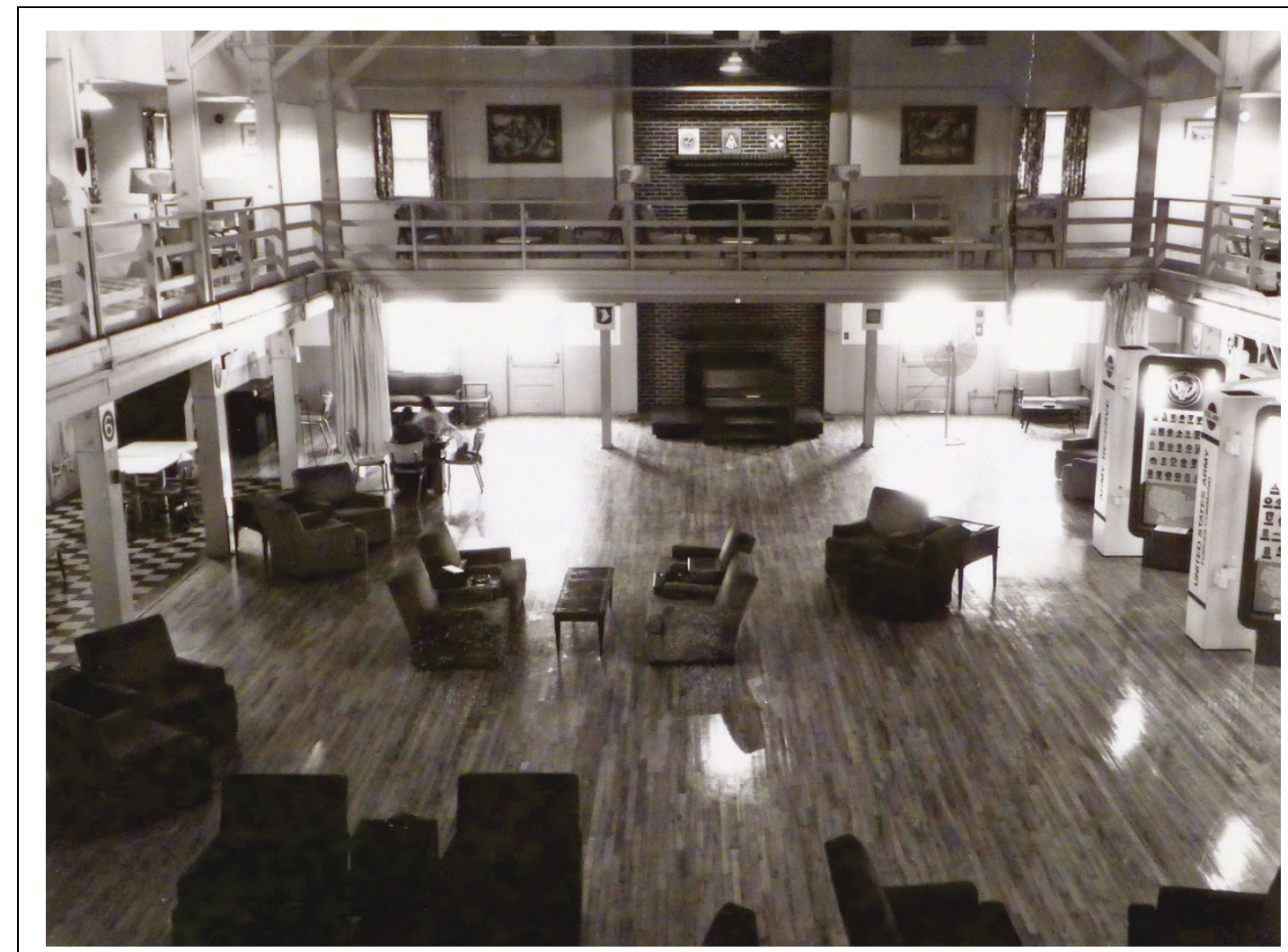

Interior view of the dance hall in Building 2000, looking north, 1978 (NARA, College Park, RG 111-SC).

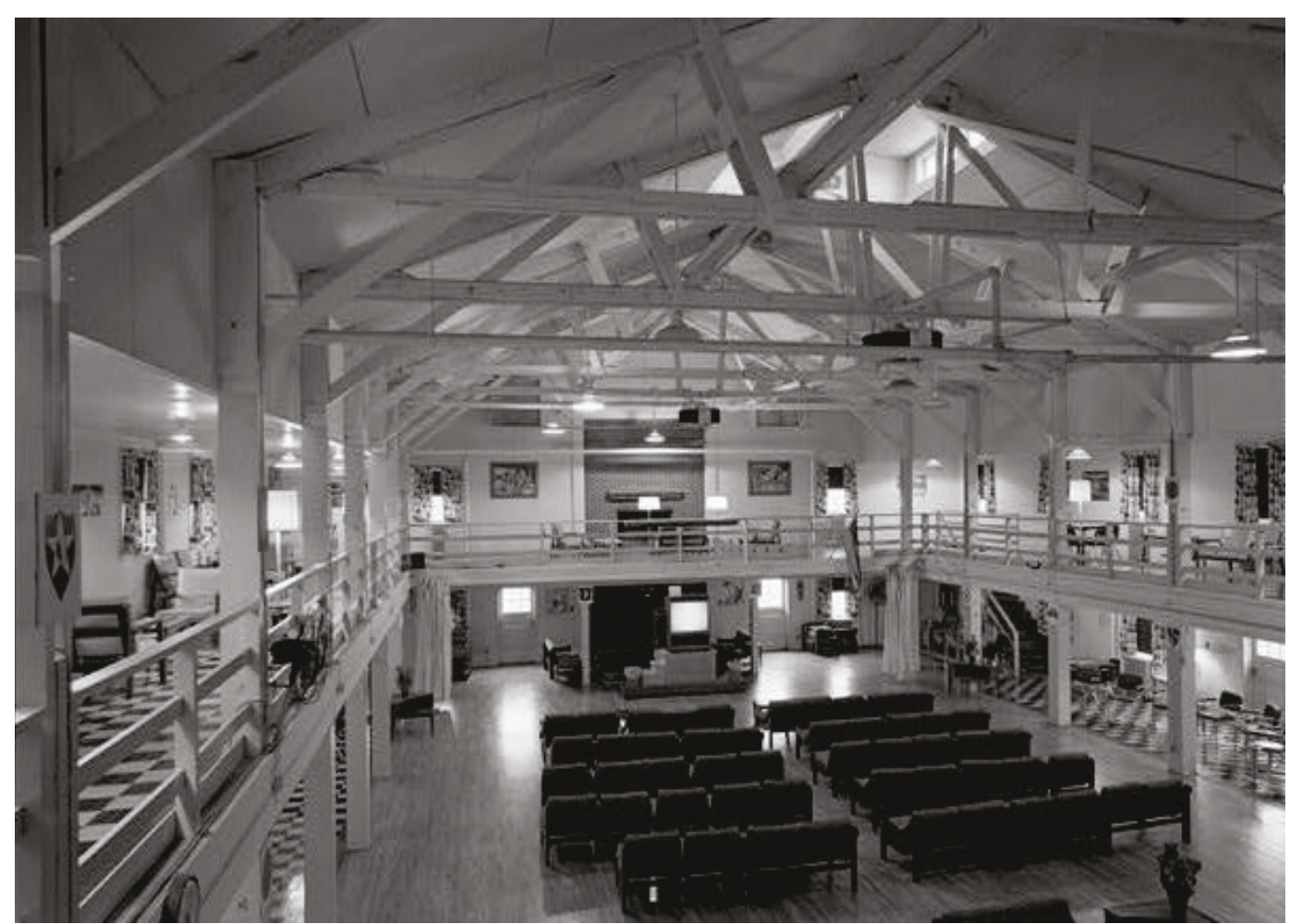

Interior view of the dance hall from the balcony looking north in Building 2000, 1988 (Library of Congress, HABS WIS,41-SPAR.V,1-J-8). 


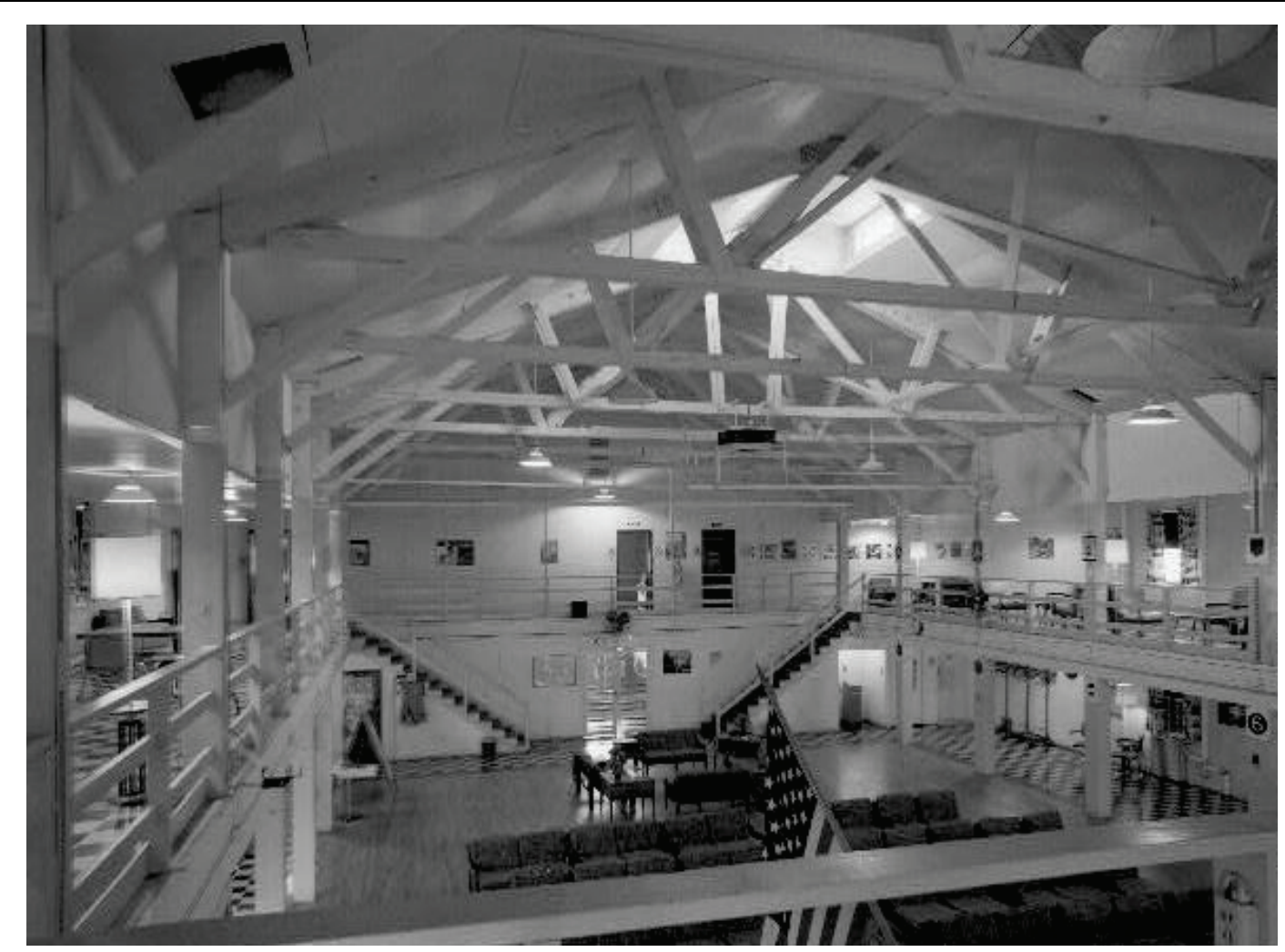

Interior view of the dance hall from the balcony looking southwest in Building 2000, 1988 (Library of Congress, HABS WIS,41-SPAR.V,1-J-7).

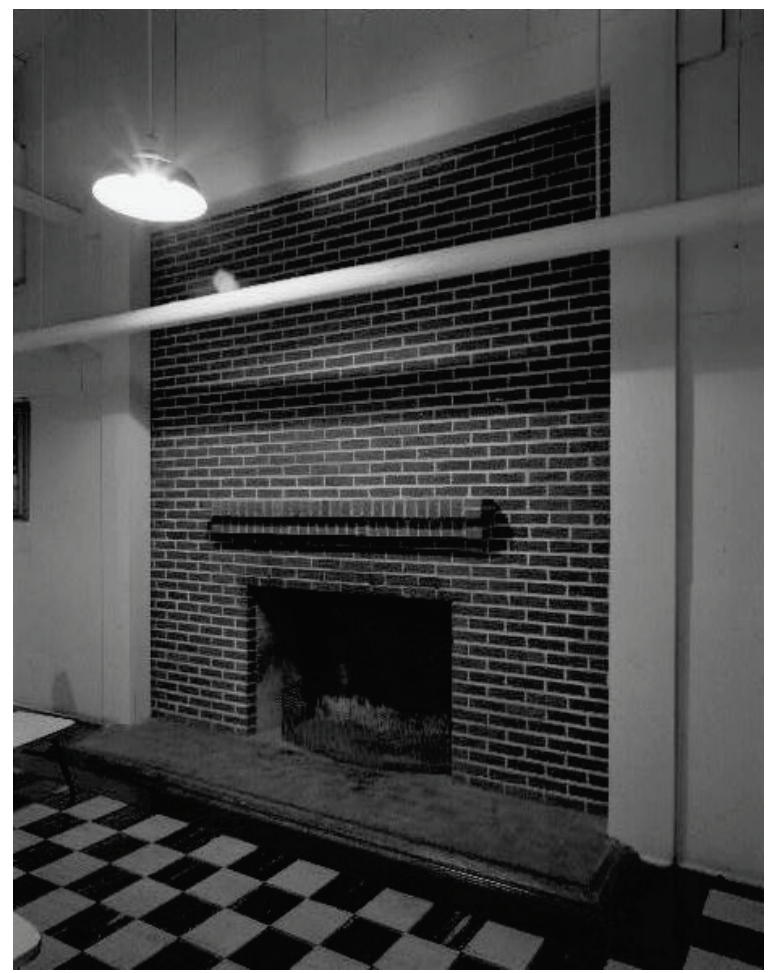

Close-up of the fireplace, hearth, and mantle on the balcony level of the dance hall in Building 2000, 1988 (Library of Congress, HABS WIS,41-SPAR.V,1-J-12). 


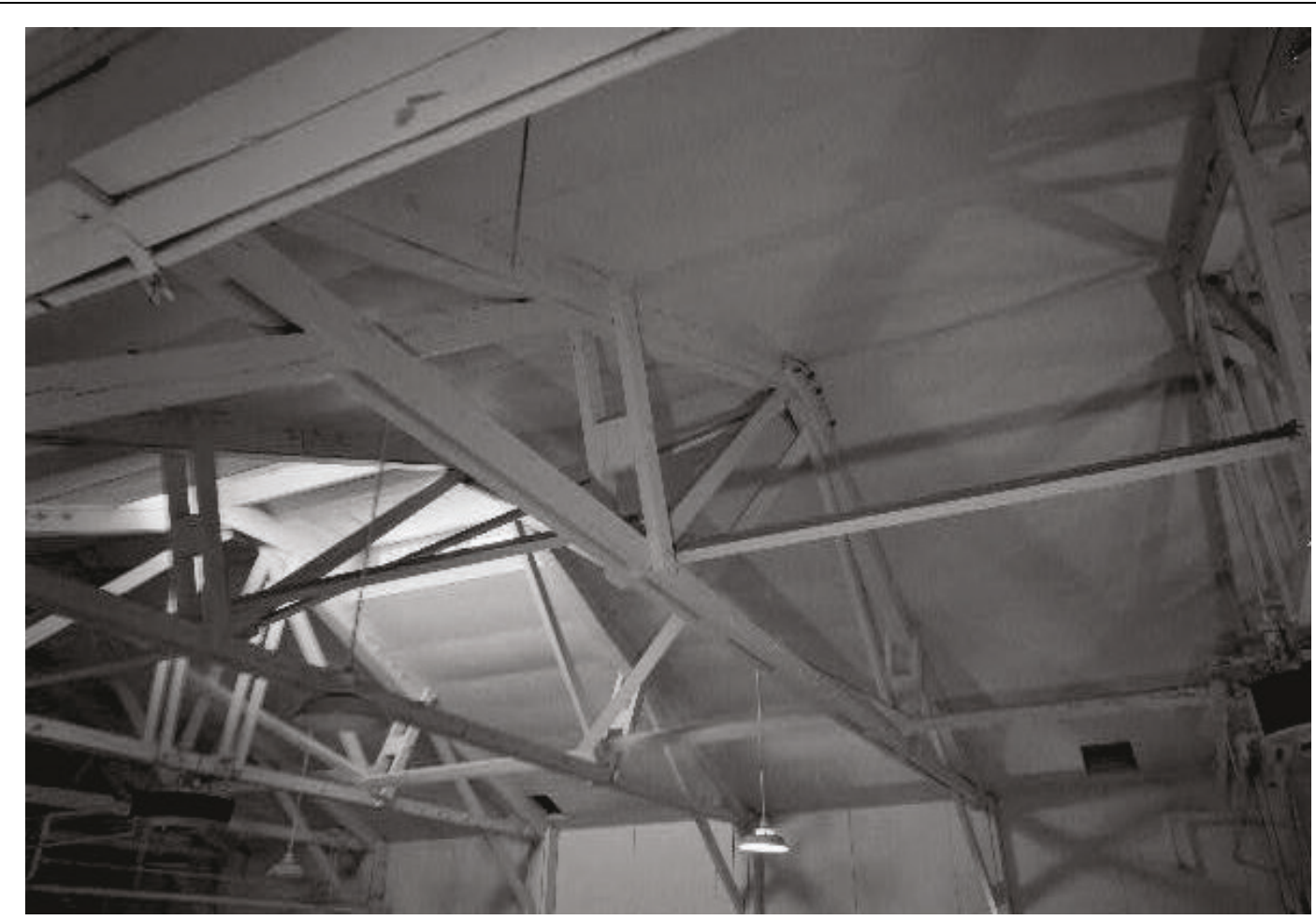

Interior view of truss in main roof of the dance hall in Building 2000 showing the skylight, 1988 (Library of Congress, HABS WIS,41-SPAR.V,1-J-10).

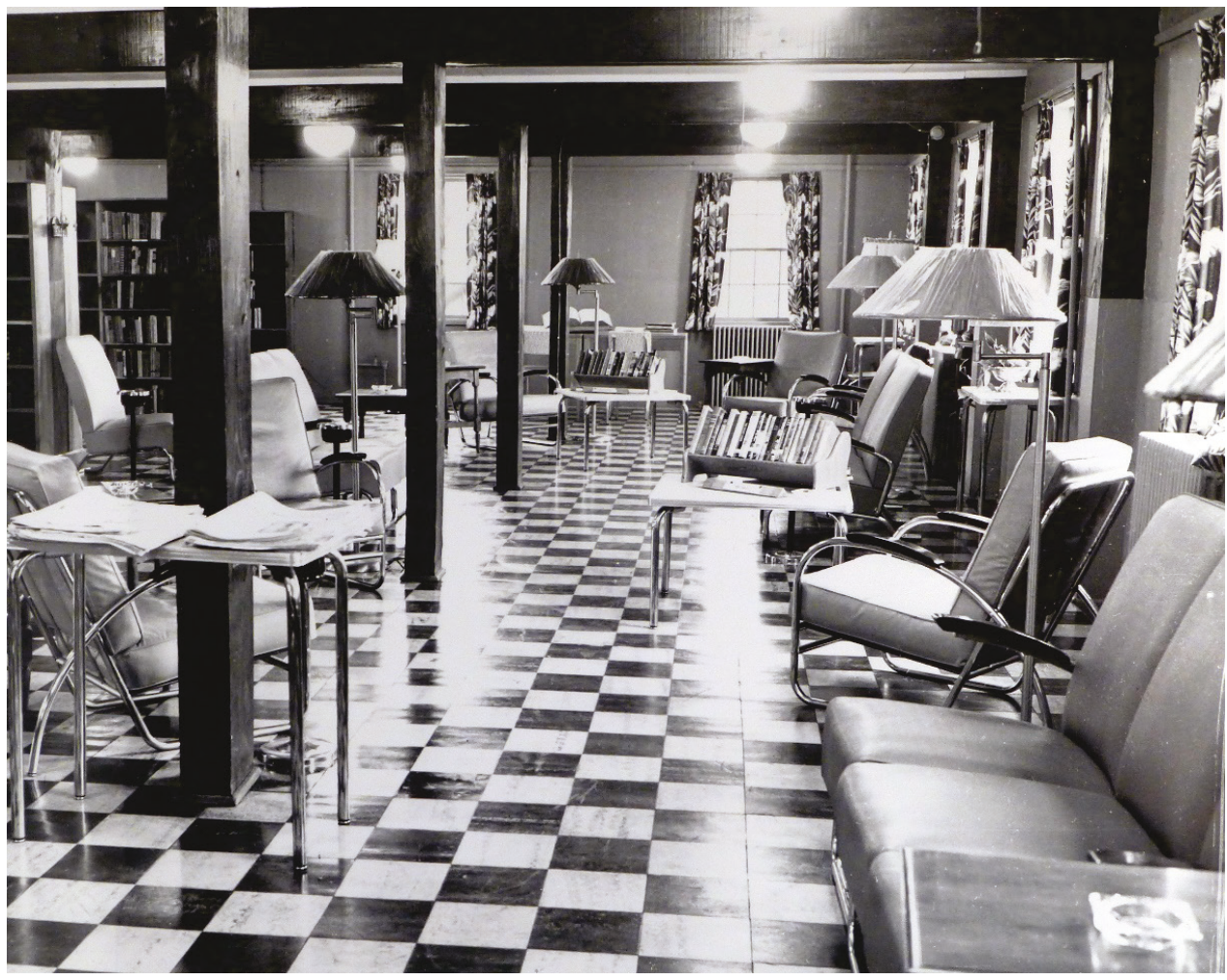

Interior view of the first floor library in the east wing of Building 2000, 1952 (NARA College Park, RG 111-SC). 


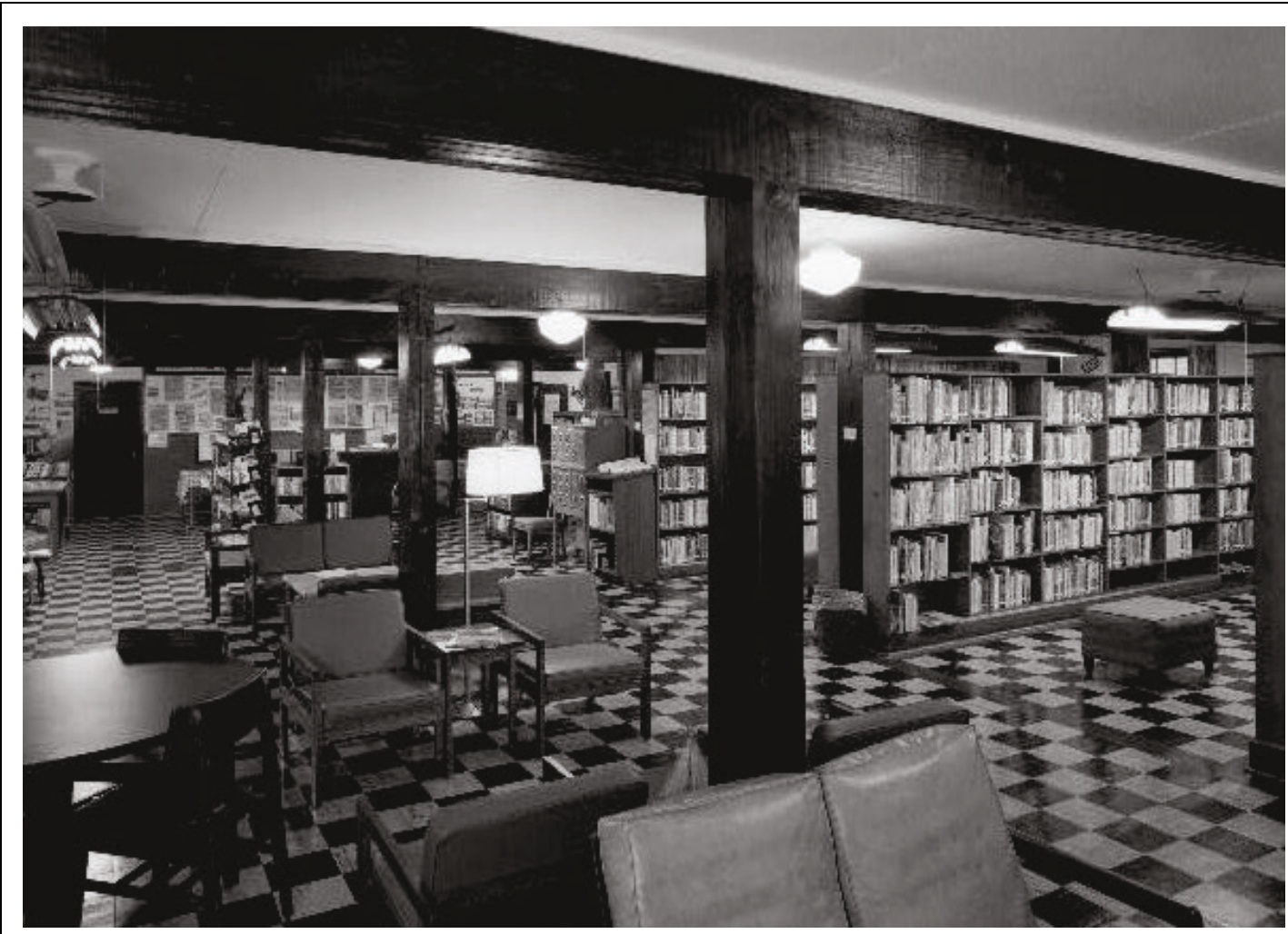

Interior view of the library, first floor of Building 2000, 1988 (Library of Congress, HABS WIS,41-SPAR.V,1-J-9).

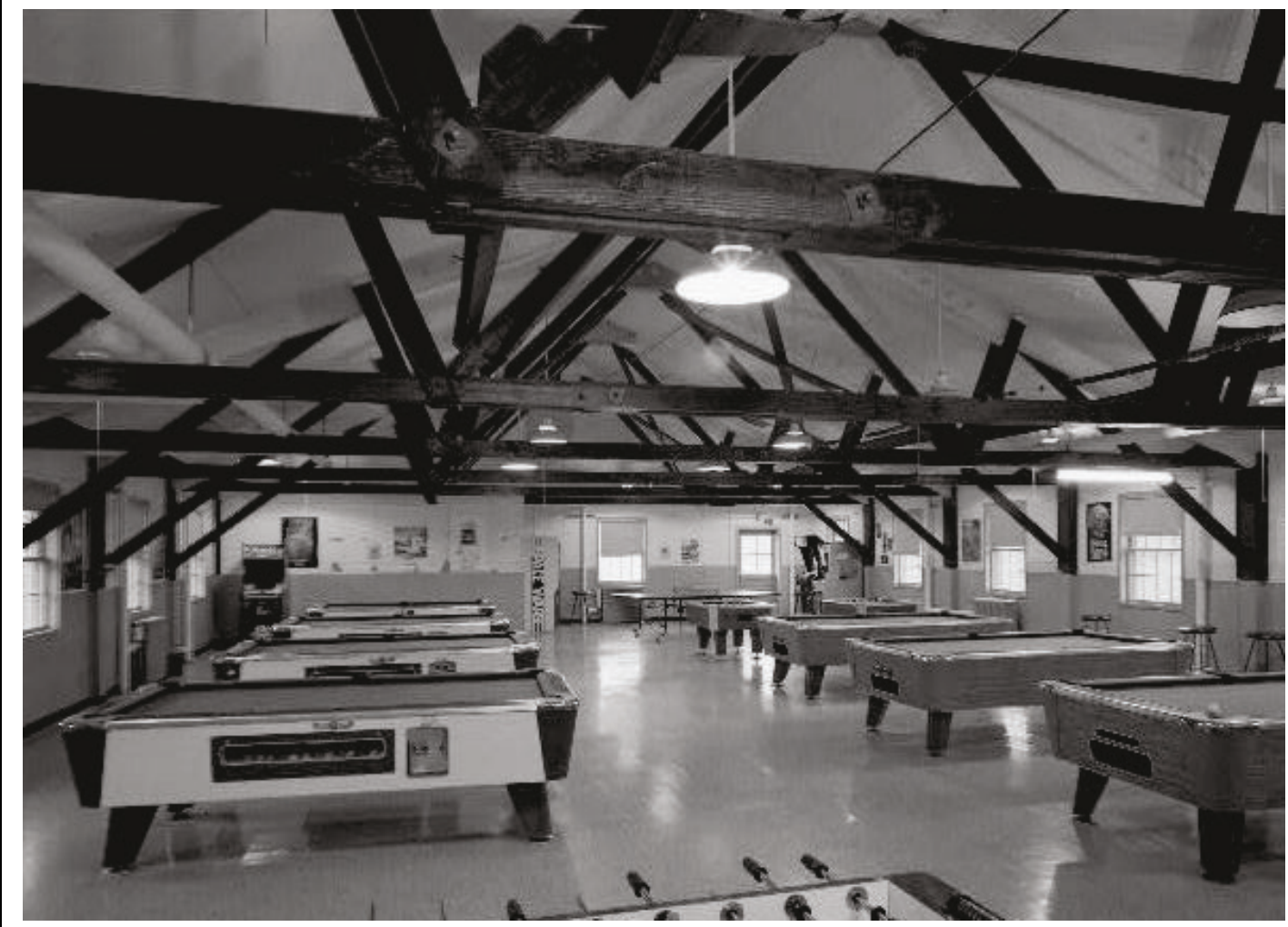

Interior view of the second floor of the billiards room; in the plans, this was originally the second floor of the library, 1988 (Library of Congress, HABS WIS,41-SPAR.V,1-J-11). 


\section{CHARACTER-DEFINING FEATURES}

- Massing

- T-shape footprint

- Wood frame structure with textured asbestos cement siding with scalloped bottom edge detail

- Vertical line definition between each siding piece

- Cross-gable roof with red asphalt shingles (replaced in-kind)

- Wood fascia and soffit detail (covered with metal)

- Concrete pier foundation system with wood foundation skirting

- Wood screened porch on front elevation (screens removed)

- Wood screened porch on the west side of the north wing (enclosed)

- Multi-pane wood double-hung windows with wood screens (replaced with one-over-one vinyl windows)

- Wood trim size and profile around window and door openings (replaced)

- Four-light with three recessed panels exterior doors (replaced with metal) with wood interior screen doors (removed)

- Brick chimney on the north wall of the north wing

- Tall brick chimney stack near the boiler room on the north side of the west wing (demolished)

- T-shaped floor plan with main interior spaces including dance hall, library, and café

- Wood flooring in entry, dance hall, balcony, library (both first and second floor), and café (covered with tile then carpet)

- Two-story open interior of the dance hall with encircling balcony with wood balustrade and exposed wood truss structural system (balcony slightly modified with the enclosure of the east side with partition walls)

- Multiple interior wood staircases providing access to balcony

- Large two story brick chimney provides flue for two fireplaces in the dance hall; one on the main floor and one on the balcony

- Exposed wood truss structural system on second floor of library wing

- Café in west wing with wood floors (replaced floors) adjacent a kitchen space with concrete floors

- Toilet room with fixtures such as urinals, sinks, mirrors, light fixtures, and concrete floor (removed fixtures and/or replaced)

- Four-light with three-recessed panels interior doors (removed or replaced)

- Interior pendent light fixtures in dance hall (replaced with newer fixtures)

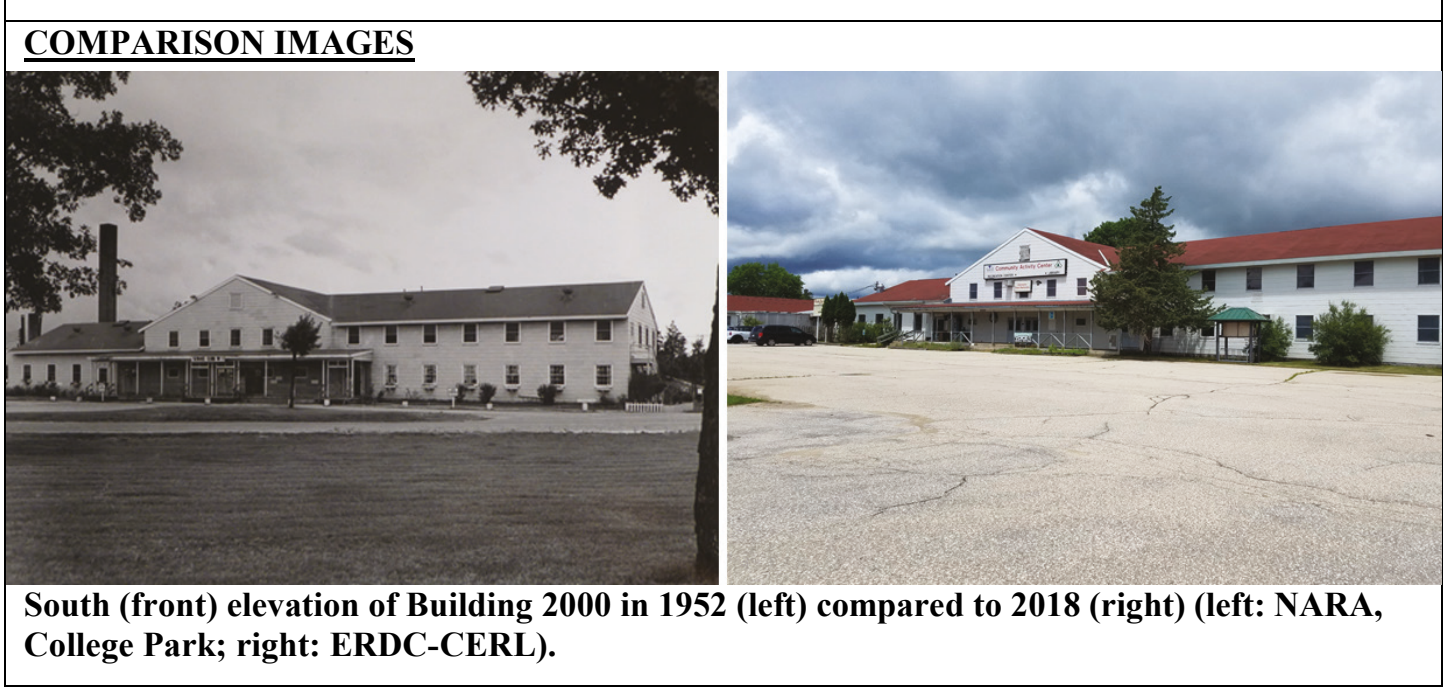



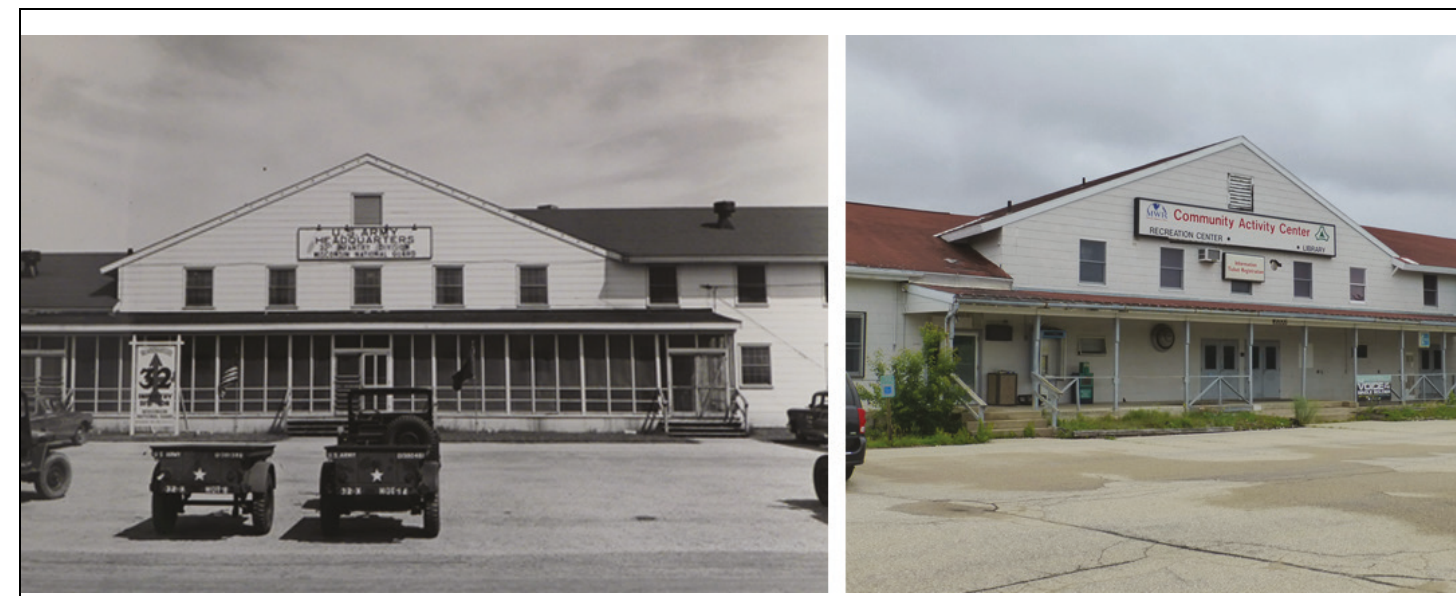

Main porch on the south (front) elevation of Building 2000 in 1965 (left) compared to 2018 (right) (left: NARA, College Park; right: ERDC-CERL).
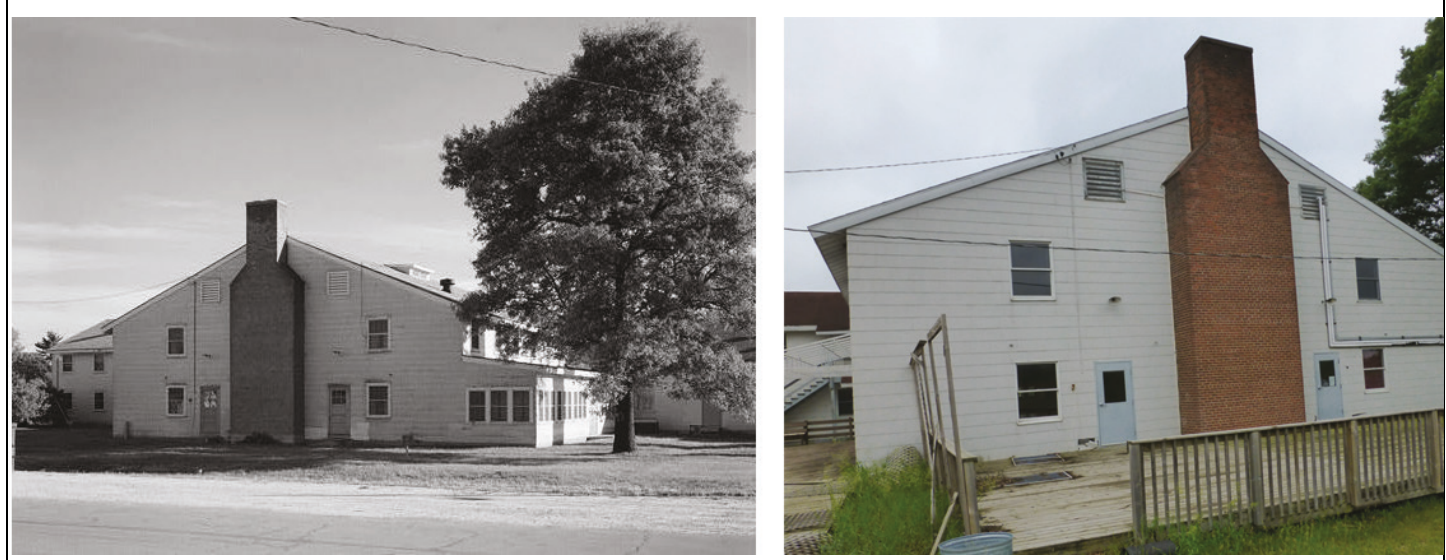

North elevation of the north wing of Building 2000 in 1988 (left) compared to 2018 (right) (left: Library of Congress, HABS; right: ERDC-CERL).
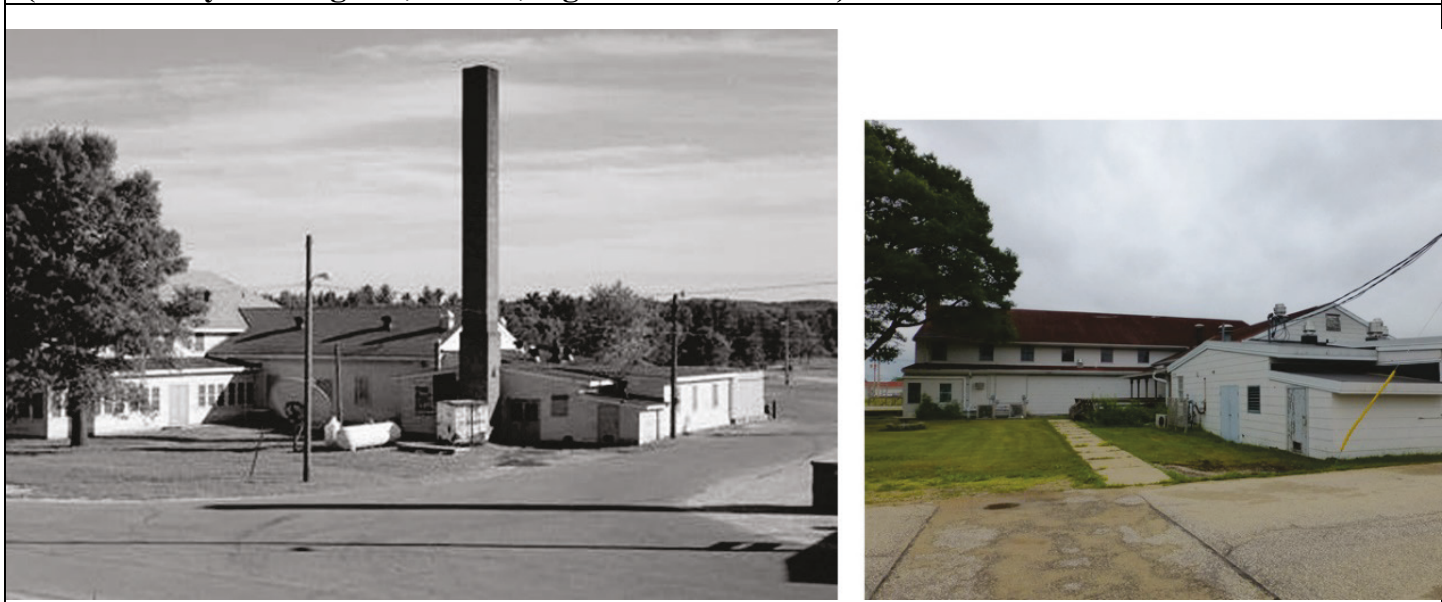

Northeast oblique of Building 2000 in 1988 (left) compared to 2018 (right) (left: Library of Congress, HABS; right: ERDC-CERL). 


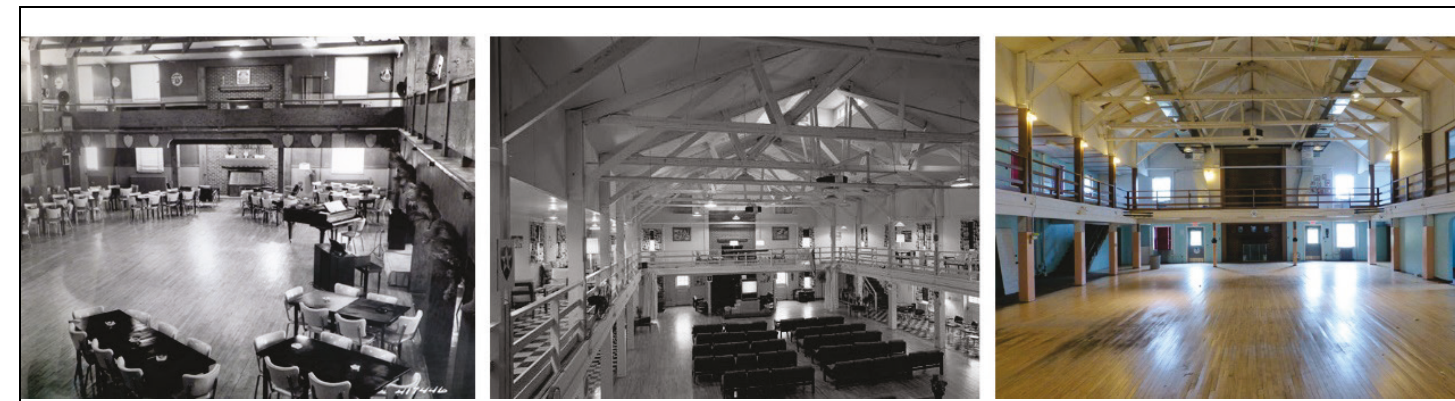

Interior view of the dance hall looking north in Building 2000 in 1952 (left), 1988 (middle), and 2018 (right) (left: NARA College Park; middle: Library of Congress, HABS; right: ERDC-

CERL).
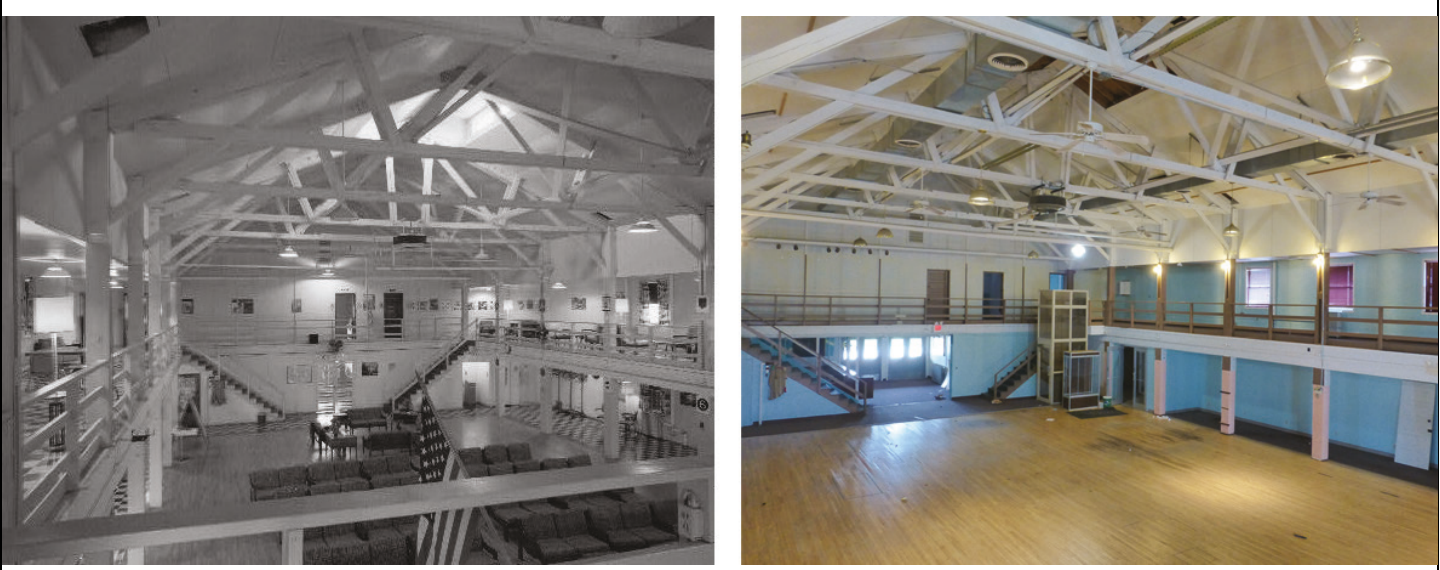

Interior view of the dance hall looking southwest in Building 2000 in 1988 (left) compared to 2018 (right) (left: Library of Congress, HABS; right: ERDC-CERL).
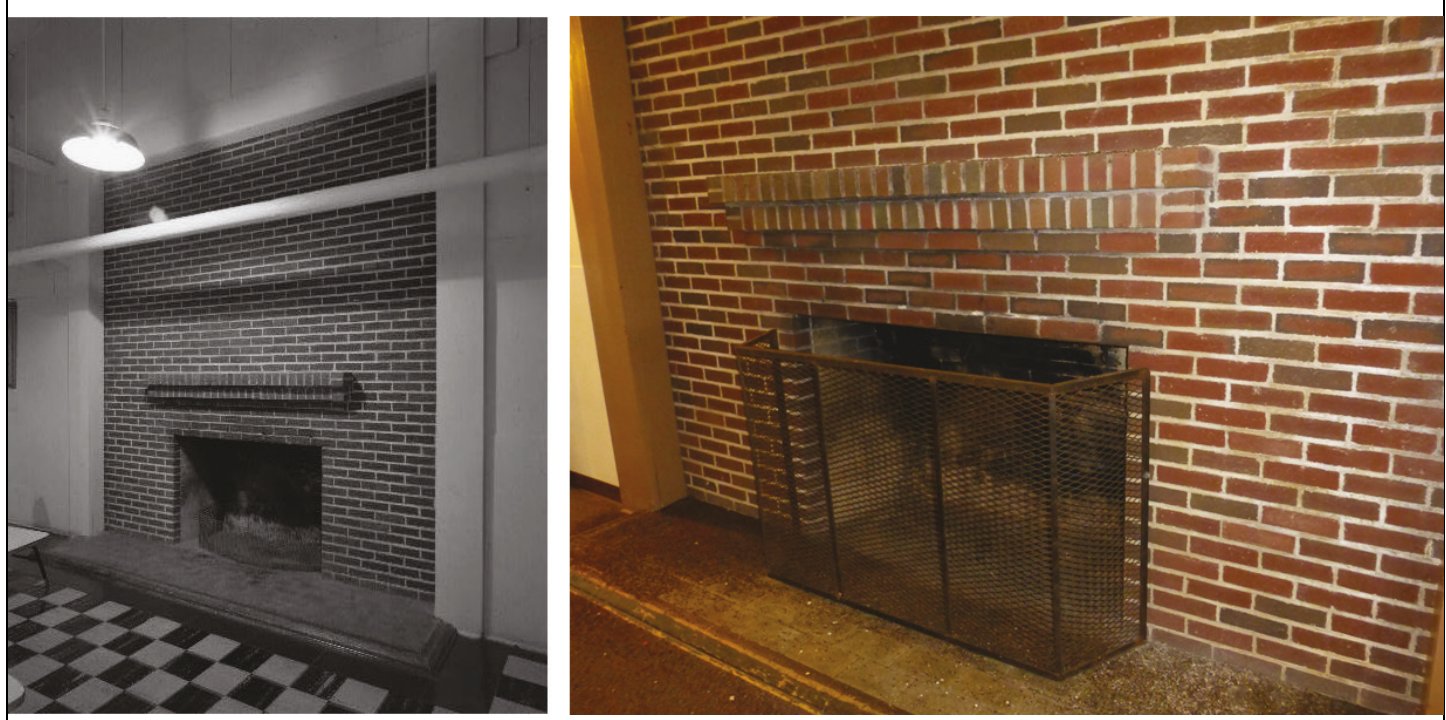

Close-up of the fireplace on the balcony level in the dance hall in Building 2000 in 1988 (left) compared to 2018 (right) (left: Library of Congress, HABS; right: ERDC-CERL). 


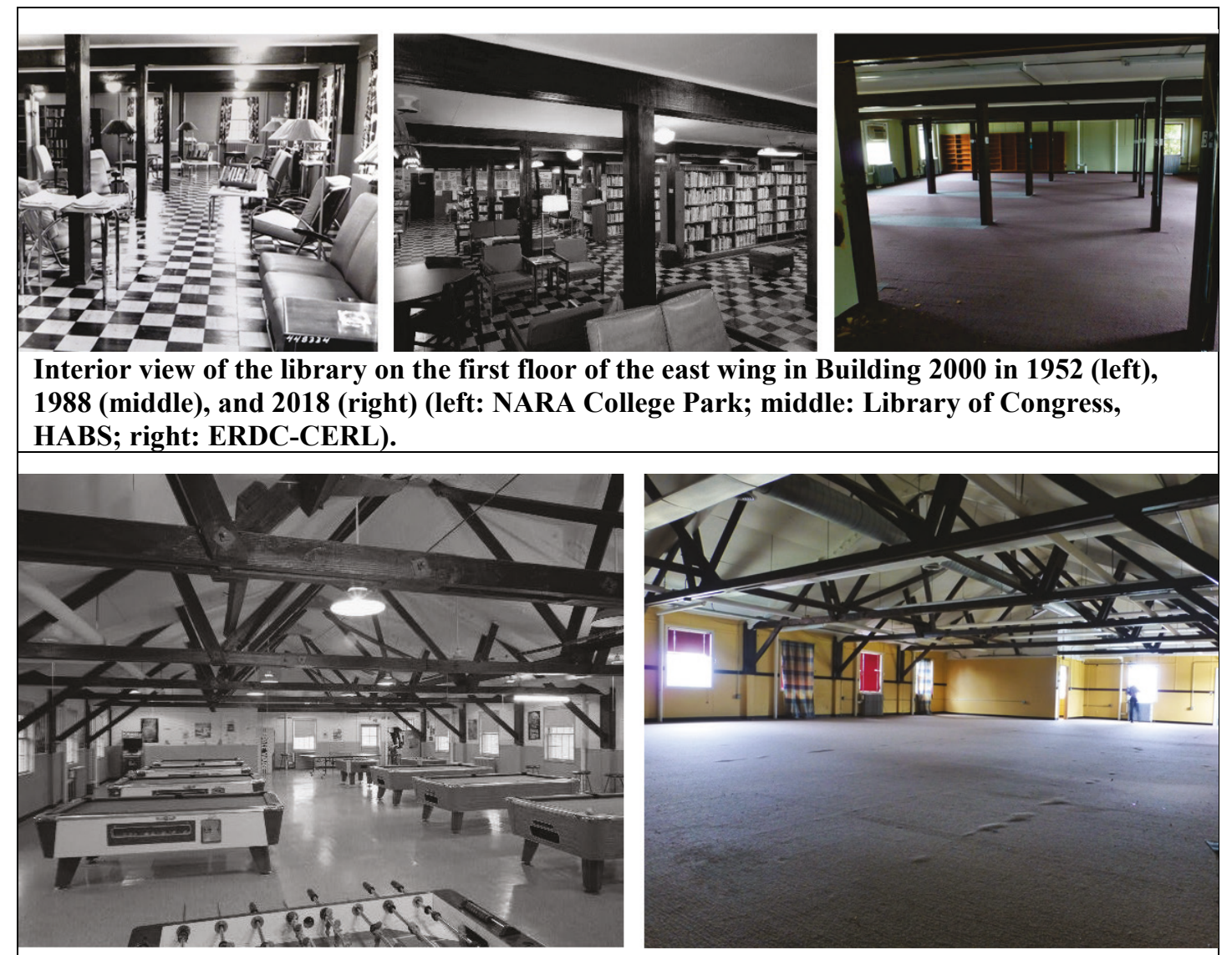

Interior view of the second-floor library, looking east in the east wing of Building 2000 in 1988 (left) compared to 2018 (right) (left: Library of Congress, HABS; right: ERDC-CERL).

\section{SIGNIFICANCE}

The 800 Series (and the 700 Series that preceded it), was a comprehensive set of drawings which could be used interchangeably in creating the various building types. War mobilization buildings are significant for their construction and technological innovation. Techniques such as the standardization of plans, prefabrication of units, and assembly-line approach to construction were largely pioneered in the construction of these mobilization structures.

The temporary wood buildings constructed with the 700 series or 800 series on Fort McCoy during World War II (WWII) during 1939 to 1946 were determined significant for the National Register of Historic Places (NRHP) in 1986 when the Programmatic Memorandum of Agreement (PMOA) was signed between the Department of Defense (DoD), the Advisory Council on Historic Preservation (ACHP), and the National Council of State Historic Preservation Officers (NCSHPO). In the early 1990s, this significance was reaffirmed by the writing of "World War II and the U.S Army Mobilization Program: A History of the 700 and 800 Series Cantonment Program" and the performance of the Historic American Buildings Survey (HABS) on a variety of the 700 and 800 series planned buildings across the country. Many of the 800 series buildings at Fort McCoy were utilized for the HABS.

Building 2000, WWII Service Club Type SC-3, is significant under Criterion A for WWII temporary building construction (1939-1946).

The design and construction of the WWII temporary buildings could not be linked to a specific architect due to their construction from standardized War Department temporary building plans. They do not possess high artistic values; however, WWII temporary buildings in general were found to be significant for their design, construction, and technological innovation under Criterion $\mathrm{C}$. 


\section{INTEGRITY}

Location - Building 2000 retains its integrity of location.

Design - Building 2000 retains the key elements of its WWII design.

Setting - Building 2000 retains integrity of setting.

Materials - Building 2000 retains the key elements of its WWII architectural materials such as exterior cladding material, and asphalt roofing material on the exterior; and wood floors, concrete floors, fiberboard walls, fiberboard ceilings, and the brick fireplaces,

Workmanship - Workmanship is not part of integrity for WWII temporary buildings.

Feeling - Building 2000 retains its integrity of a WWII temporary building.

Association - Building 2000 retains its integrity of association.

RECOMMENDATION OF CONTRIBUTING/NONCONTRIBUTING STATUS

It is the recommendation of this report that Building 2000, Service Club, is Eligible for the National Register of Historic Places (NRHP) at the national level due to its significance under Criteria A and $\mathrm{C}$ and its integrity from the period of significance of 1939 to 1946. 
Building 2159

\begin{tabular}{|c|c|c|c|}
\hline \multicolumn{4}{|c|}{$\begin{array}{c}\text { FORT MCCOY } \\
\text { HISTORIC PROPERTY INVENTORY FORM }\end{array}$} \\
\hline $\begin{array}{l}\text { PROPERTY BOUNDARIES } \\
\text { - Fort McCoy in the } 2100 \text { block } \\
\text { area on the south side of the } \\
\text { triangular cantonment plan } \\
\text { - Sparta vicinity } \\
\text { - Monroe County, Wisconsin }\end{array}$ & \multicolumn{2}{|c|}{$\begin{array}{l}\text { COMMON/HISTORIC NAME } \\
\text { Building } 2159 \\
\text { Flammable Material Storage Building }\end{array}$} & $\frac{\text { STATUS }}{\text { Usable }}$ \\
\hline$\frac{\text { ARCHITECT/BUILDER }}{\text { Unknown }}$ & $\begin{array}{l}\text { DATE OF CONSTRUCTION } \\
1947 \\
\text { DATE OF ALTERATIONS } \\
\begin{array}{l}\text { Unknown - removed original } \\
\text { windows and filled openings } \\
\text { with brick }\end{array}\end{array}$ & $\frac{\text { NO. OF STORIES }}{1}$ & $\frac{\text { FOOTPRINT }}{\text { Square }}$ \\
\hline$\frac{\text { ROOF FORM }}{\text { Front gable }}$ & $\frac{\text { FOUNDATION }}{\text { Concrete }}$ & $\begin{array}{l}\text { WALLS } \\
\text { Structural terra cotta } \\
\text { tiles }\end{array}$ & 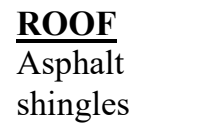 \\
\hline HISTORIC USFIS PROPERT & $\frac{\text { FUNCTION }}{\text { CURRENT USE }}$ & \multirow{3}{*}{\multicolumn{2}{|c|}{$\begin{array}{l}\text { NOTABLE FEATURES } \\
\text { - Square footprint } \\
\text { - Shallow gable roof with exposed } \\
\text { overhanging eaves and rafters } \\
\text { - Structural terra cotta tile walls with } \\
\text { brick quoins } \\
\text { - Concrete windowsills } \\
\text { - Open interior with exposed structural } \\
\text { members } \\
\text { - Original interior light fixture }\end{array}$}} \\
\hline Storage & Vacant & & \\
\hline \multicolumn{2}{|c|}{$\begin{array}{l}\text { RELATIONSHIP TO OTHER BUILDINGS } \\
\text { Building } 2159 \text { is located on the south side of the Triad in the } 2100 \\
\text { industrial block. It is located on the west side of the block, and } \\
\text { south of the intersection of South Fifth Avenue and South E Street. } \\
\text { Building } 2138 \text { is directly to the west. }\end{array}$} & & \\
\hline
\end{tabular}




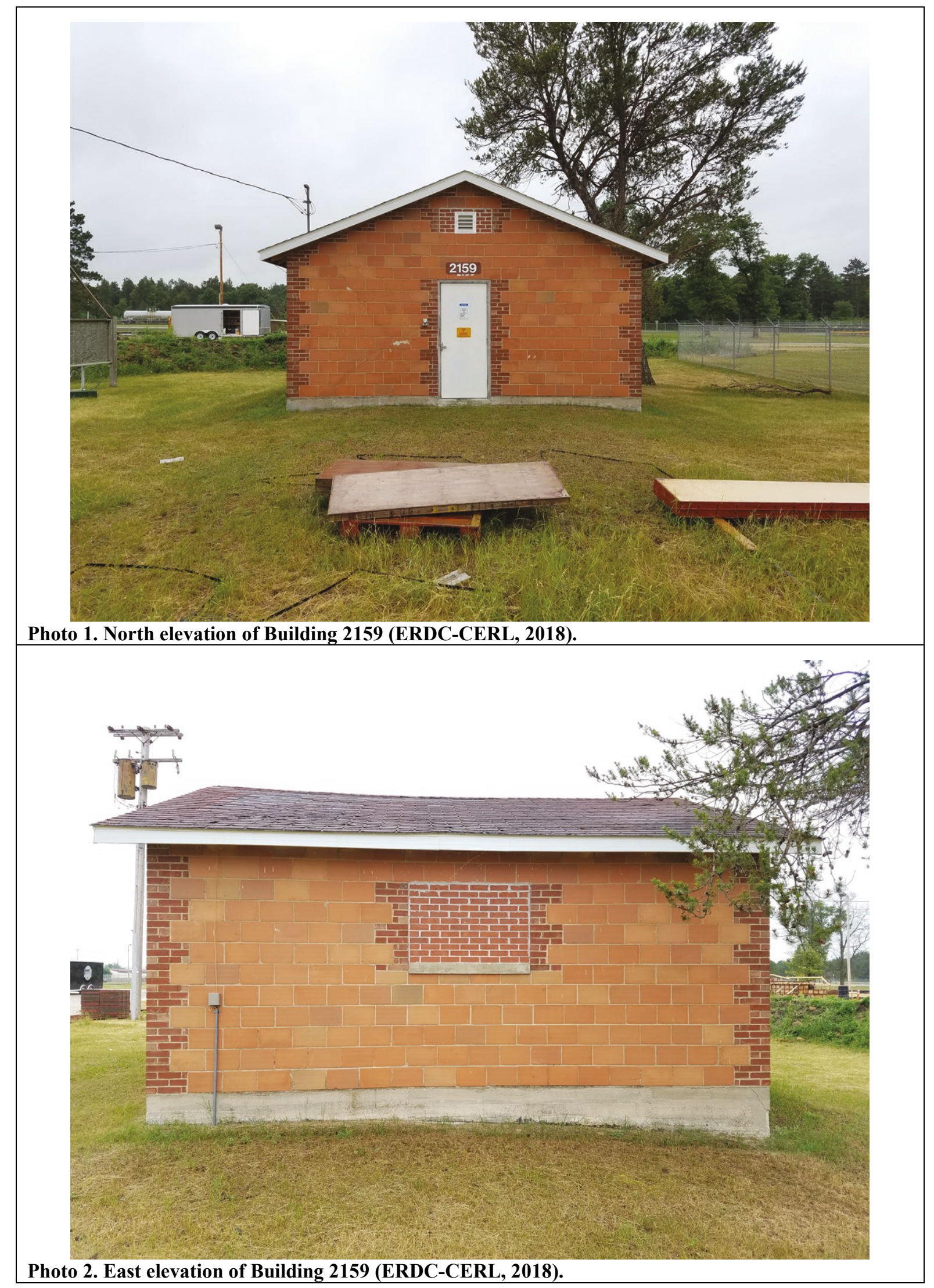




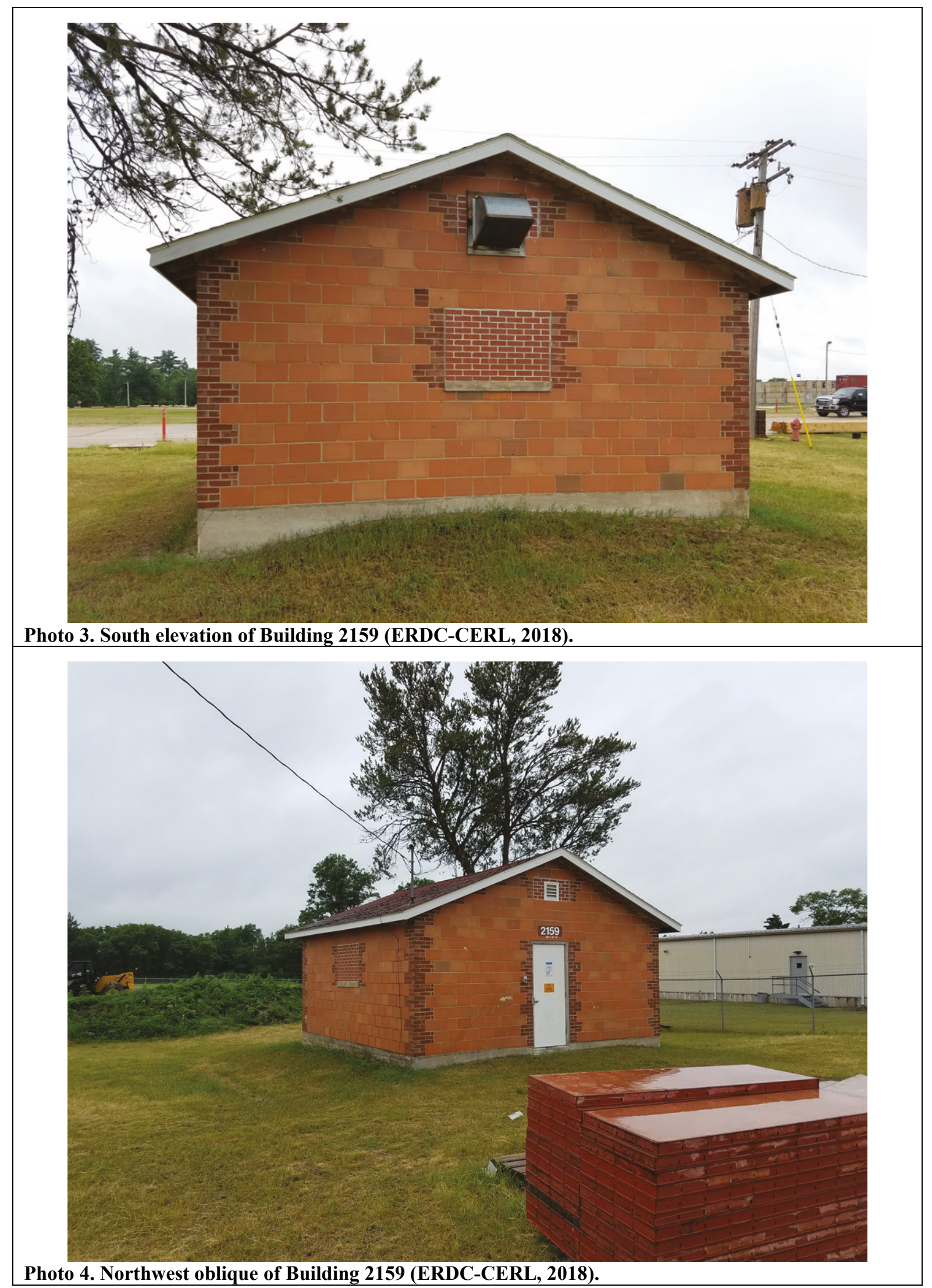




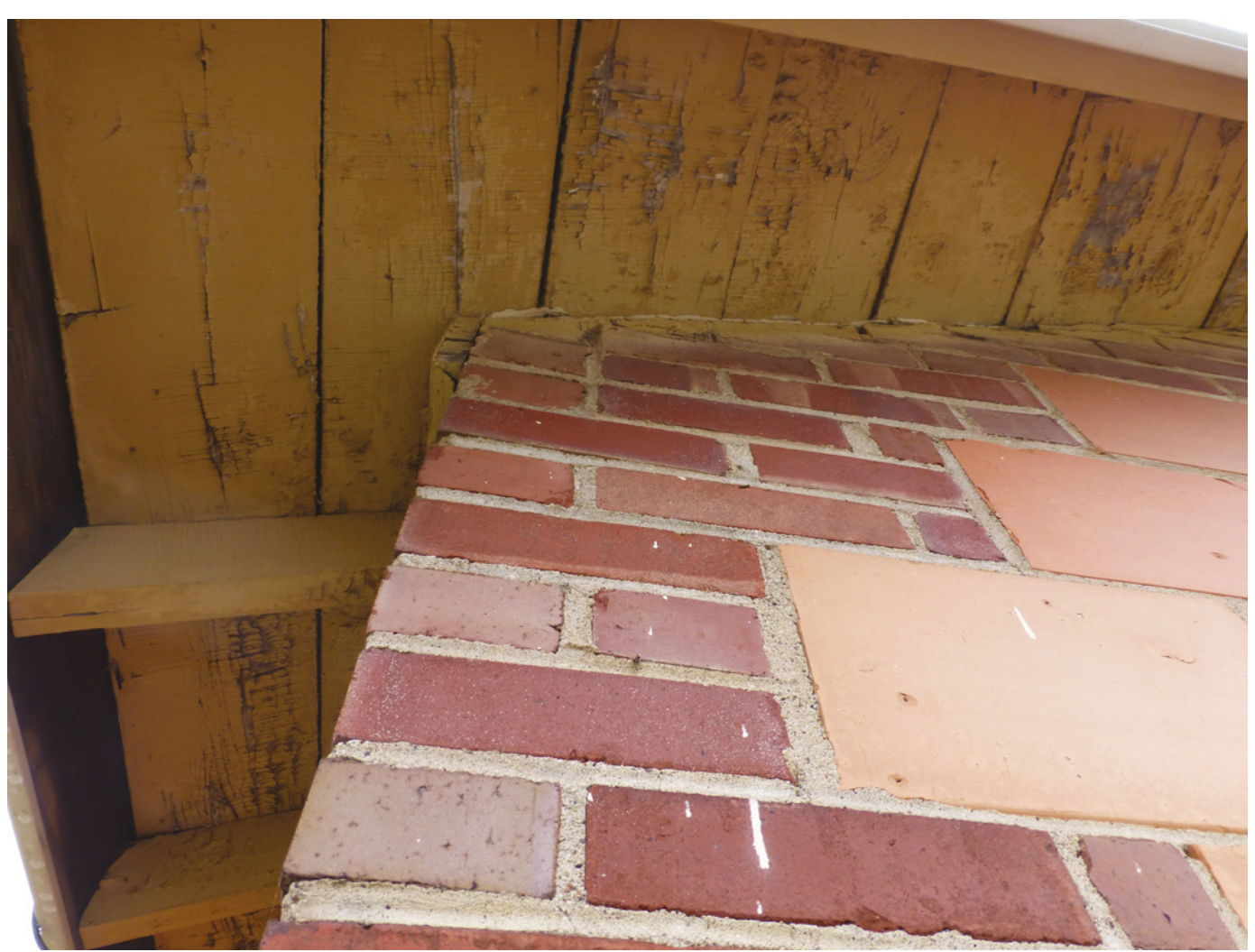

Photo 5. Close-up detail of exposed wood overhang eaves and rafters, and the brick and structural terra cotta tile wall in Building 2159 (ERDC-CERL, 2018).

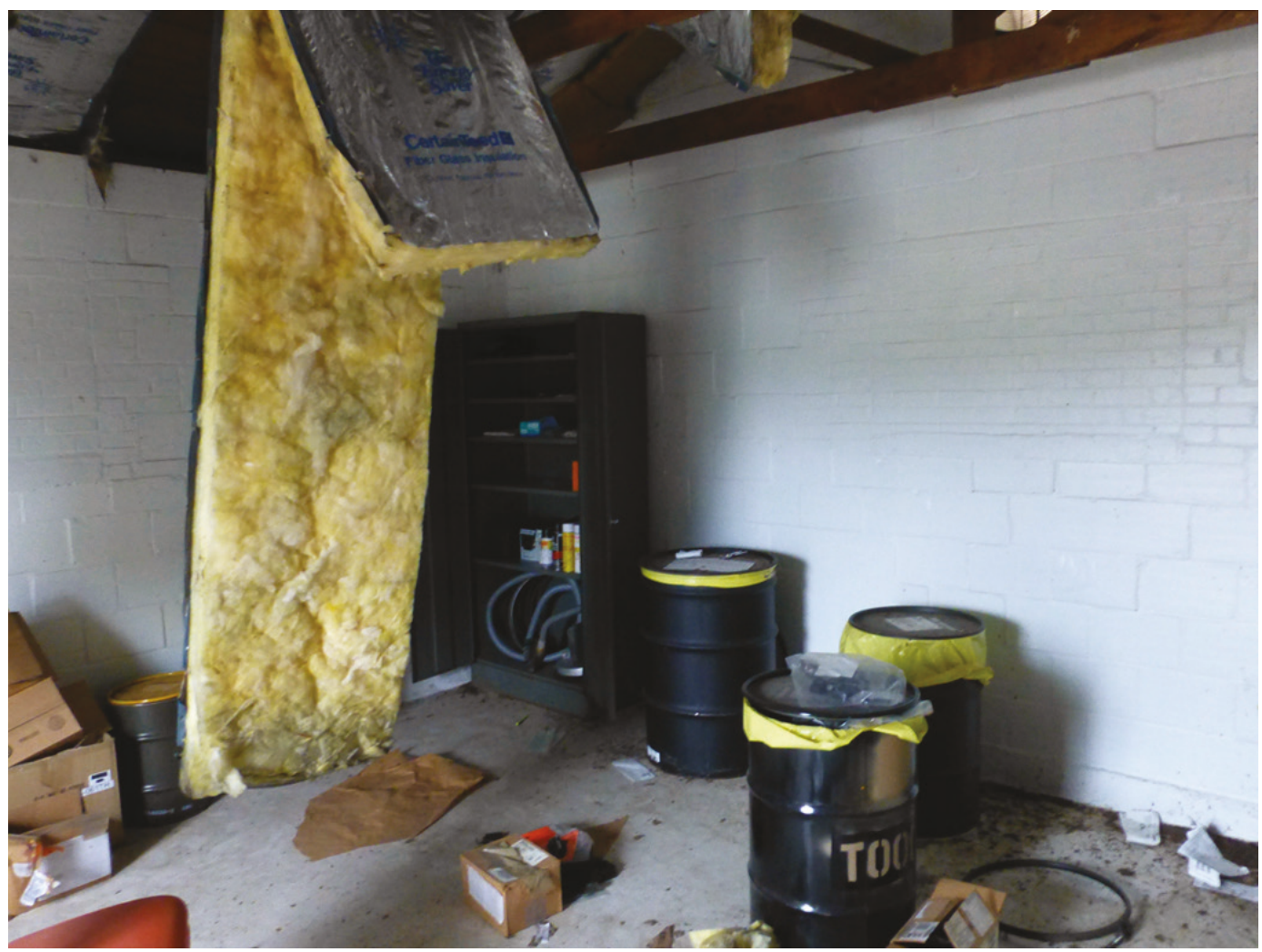

Photo 6. Interior view of Building 2159 (ERDC-CERL, 2018). 


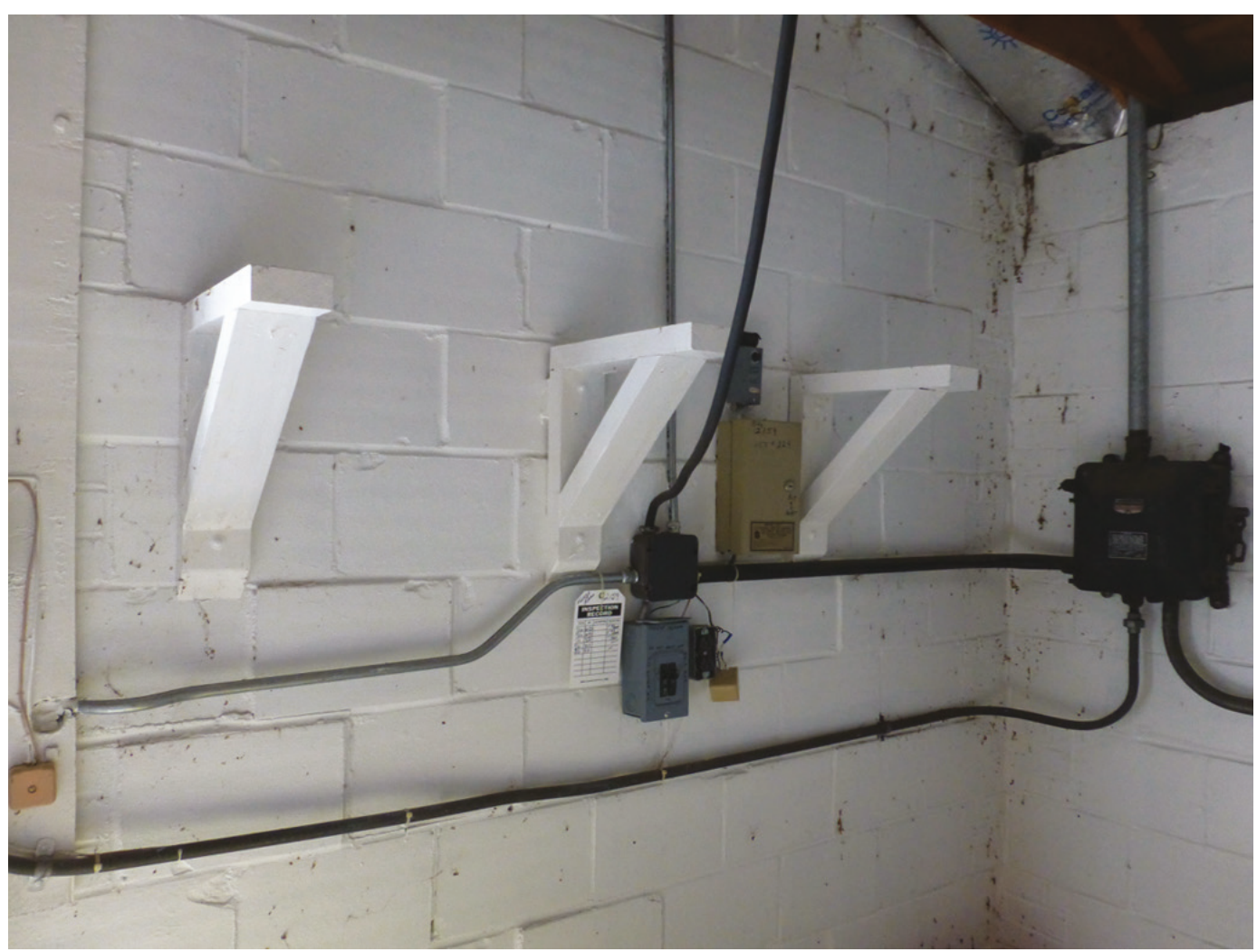

Photo 7. Original brackets in Building 2159 (ERDC-CERL, 2018).

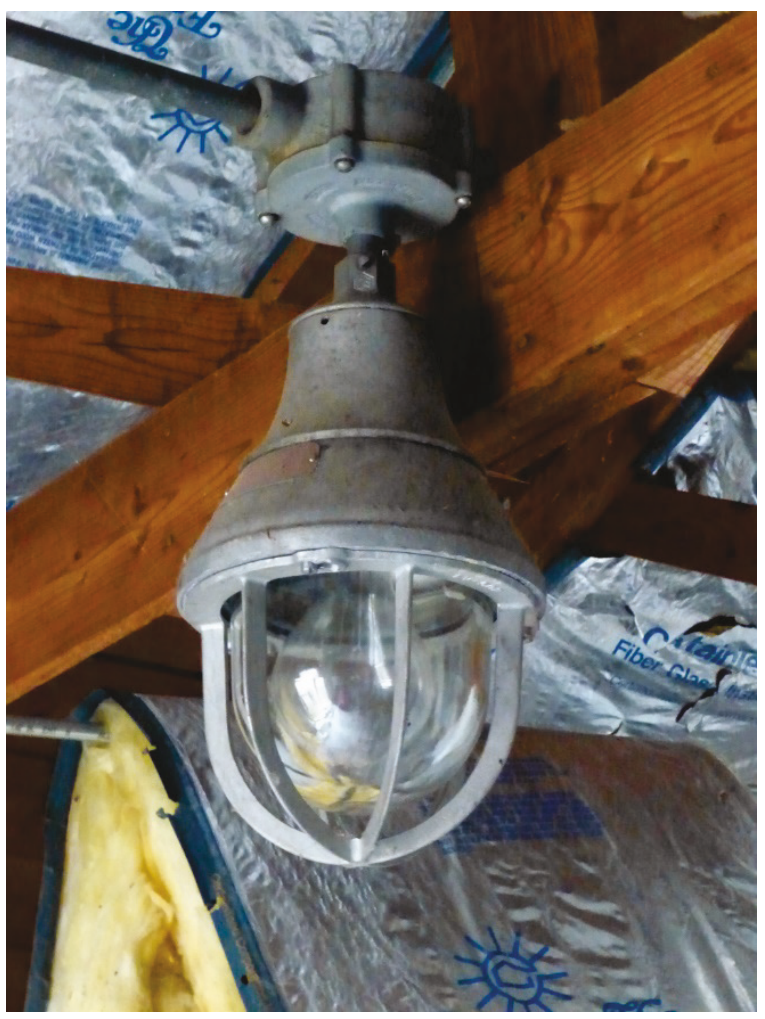

Photo 8. Original light fixture in Building 2159 (ERDC-CERL, 2018). 


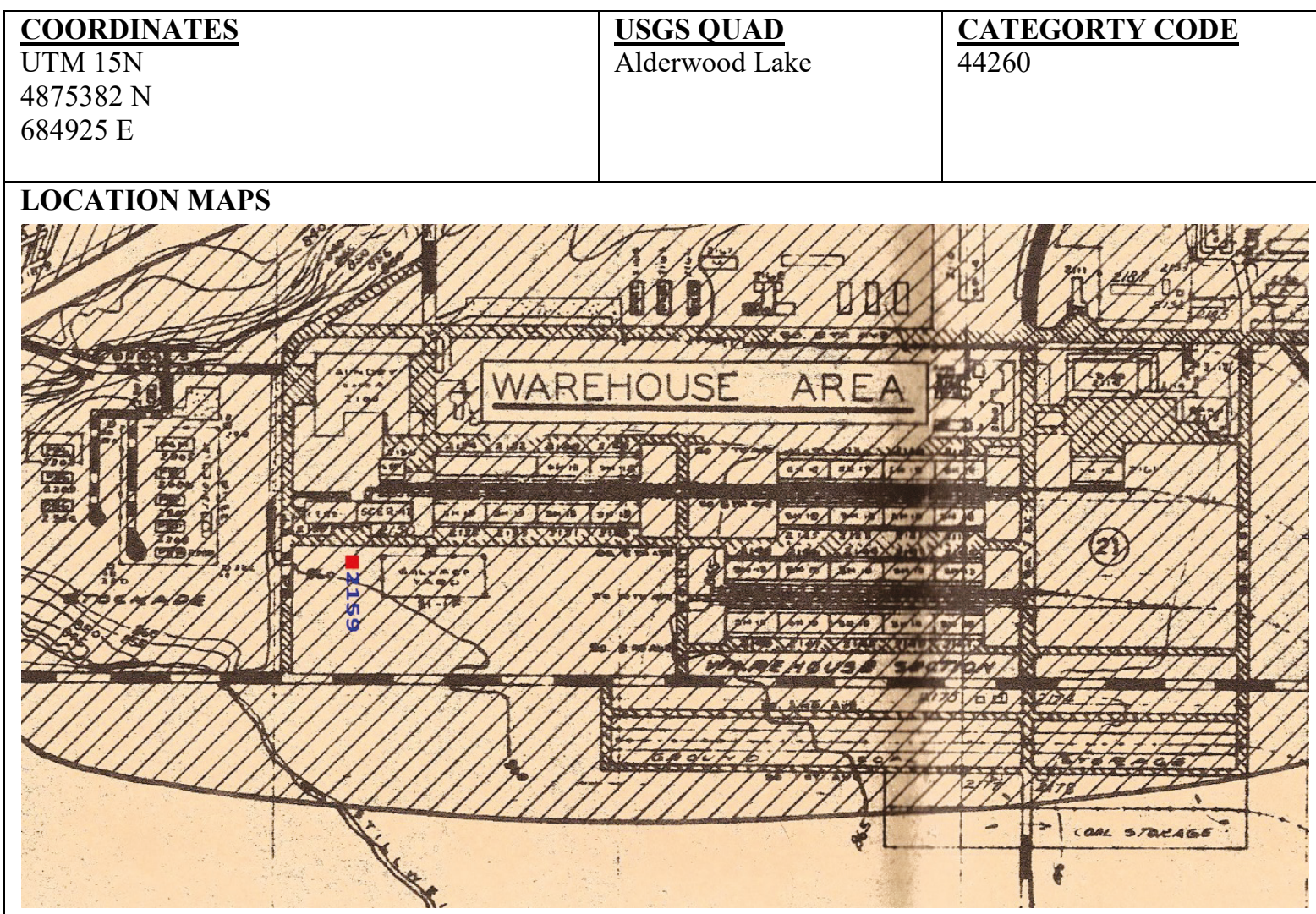

Portion of the General Site Map Camp McCoy with the location of Building 2159, Flammable Material Storage Building, color-coded in red, 1947 (Fort McCoy DPW).

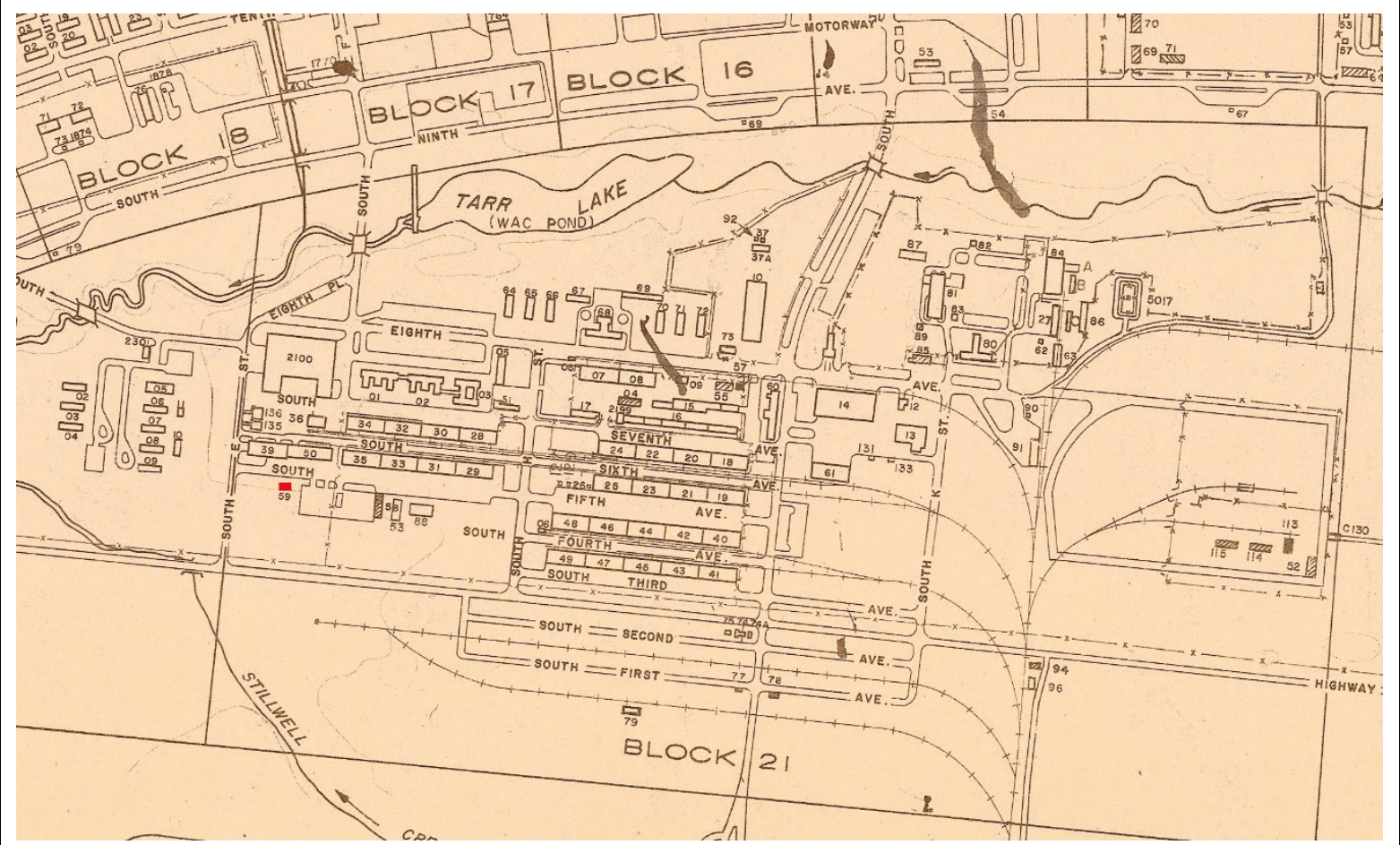

Portion of the General Site Map Camp McCoy with the location of Building 2159, Flammable Material Storage Building, color-coded in red, 1965 (Fort McCoy DPW). 


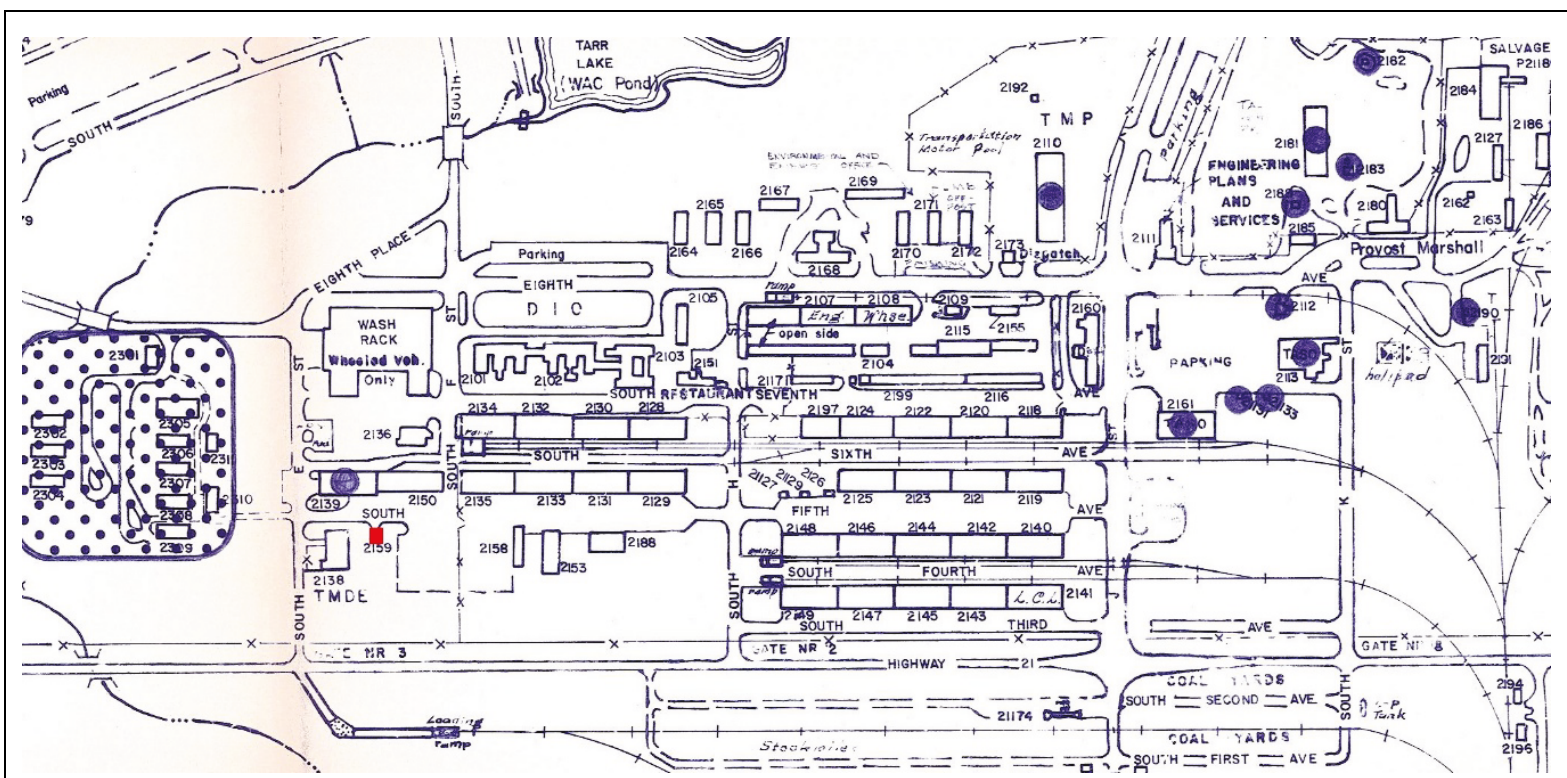

Portion of the General Site Map Fort McCoy with the location of Building 2159, Flammable Material Storage Building, color-coded in red, 1993 (Fort McCoy DPW).

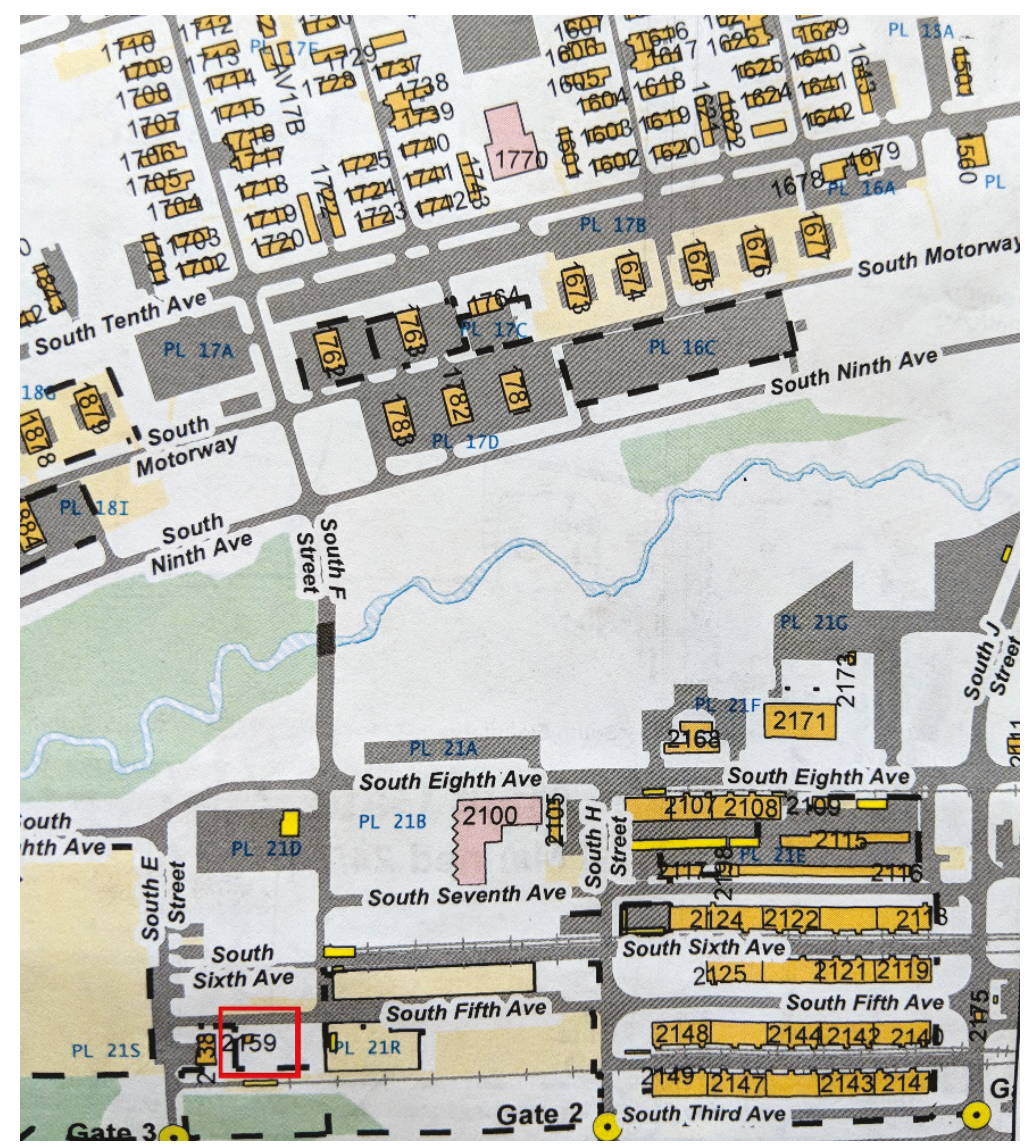

Portion of the General Site Map Fort McCoy with the location of Building 2159, Flammable Material Storage Building, color-coded in red, 2014 (Fort McCoy DPW). 


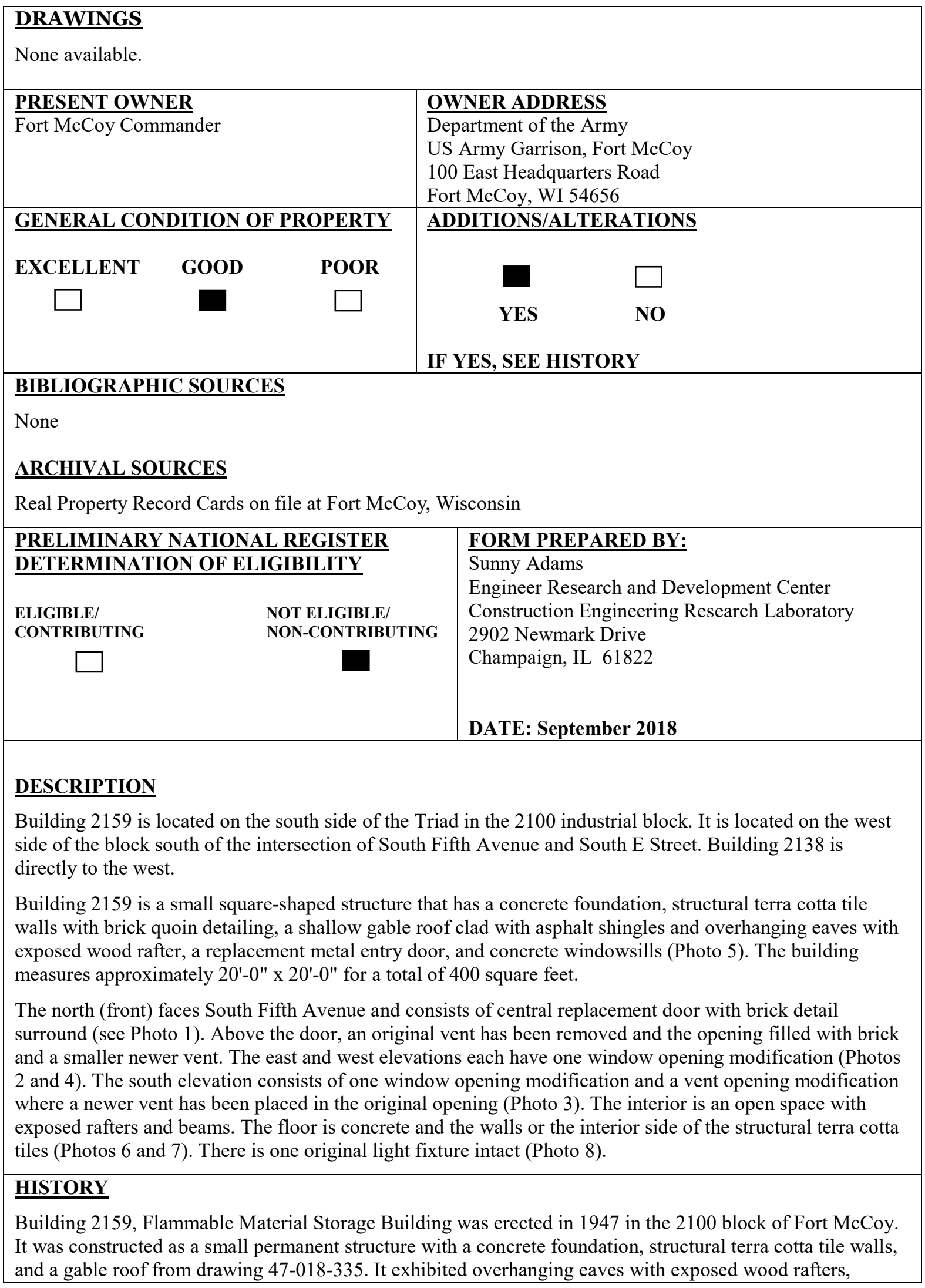


concrete block windowsill, metal sash windows, and brick quoins. The interior was an open space with exposed structural members, concrete floor, and light fixtures.

At an unknown date the original windows were removed and the openings were filled in with brick. In 2001 the category code changed to 44260 . It is currently vacant.

\section{HISTORIC PHOTOGRAPHS}

None available.

\section{CHARACTER-DEFINING FEATURES}

Not applicable.

\section{SIGNIFICANCE}

The researchers determined that Building 2159 was not significant for the National Register of Historic Places (NRHP) due to its construction outside of the period of significance for WWII temporary buildings or for a significant period in the history of Fort McCoy. Its design and construction was not significant at the state or local level.

Building 2159 (paint storage) was looked at for local or state significance, but none could be found for its design and construction is typical of the era and location.

\section{INTEGRITY}

Not applicable.

\section{RECOMMENDATION OF CONTRIBUTING/NONCONTRIBUTING STATUS}

Building 2159 , constructed in 1947 , is outside the WWII temporary building period of significance. As a paint storage building, it does not in and of itself have significance as a building type, and its design and construction is typical of the era and is not considered significant to explore further for NRHP eligibility. 
Building 2668

\begin{tabular}{|c|c|c|c|}
\hline \multicolumn{4}{|c|}{$\begin{array}{c}\text { FORT McCOY } \\
\text { HISTORIC PROPERTY INVENTORY FORM }\end{array}$} \\
\hline $\begin{array}{l}\text { PROPERTY BOUNDARIES } \\
\text { - Fort McCoy in the } 2600 \text { block } \\
\text { area on the west side of the } \\
\text { triangular cantonment plan } \\
\text { - Sparta vicinity } \\
\text { - Monroe County, Wisconsin }\end{array}$ & $\begin{array}{l}\text { COMMON/HISTORIC NAME } \\
\text { - Building } 2668 \\
\text { - Administration Building } \\
\text { - Recreation Center } \\
\text { - Administration and Supply Buil }\end{array}$ & & $\frac{\text { STATUS }}{\text { Usable }}$ \\
\hline $\begin{array}{l}\text { ARCHITECT/BUILDER } \\
\text { Construction Division, Office of } \\
\text { the Quartermaster General } \\
\text { - Series } 800-222\end{array}$ & $\begin{array}{l}\text { DATE OF CONSTRUCTION } \\
1942 \\
\text { DATE OF ALTERATIONS } \\
\text { Unknown - remodeled the } \\
\text { entire structure to include new } \\
\text { vinyl siding, new windows, } \\
\text { new doors, new porch stoops, } \\
\text { removed light fixtures, } \\
\text { modified the interior floor plan } \\
\text { with new partition walls }\end{array}$ & $\frac{\text { NO. OF STORIES }}{1}$ & $\frac{\text { FOOTPRINT }}{\text { Rectangular }}$ \\
\hline$\frac{\text { ROOF FORM }}{\text { Side gable }}$ & $\frac{\text { FOUNDATION }}{\text { Concrete piers }}$ & $\begin{array}{l}\text { WALLS } \\
\text { Wood frame } \\
\text { structure clad with } \\
\text { vinyl siding }\end{array}$ & $\begin{array}{l}\frac{\text { ROOF }}{\text { Asphalt }} \\
\text { shingles }\end{array}$ \\
\hline $\begin{array}{l}\text { PROPERTY } \\
\text { HISTORIC USE(S) } \\
\text { Administration }\end{array}$ & $\begin{array}{l}\frac{\text { FUNCTION }}{\text { CURRENT USE }} \\
\text { Administration }\end{array}$ & \multirow{2}{*}{\multicolumn{2}{|c|}{$\begin{array}{l}\text { NOTABLE FEATURES } \\
\text { - Rectangular one-story massing } \\
\text { - Gable roof clad with red asphalt } \\
\text { shingles }\end{array}$}} \\
\hline \multicolumn{2}{|c|}{$\begin{array}{l}\text { RELATIONSHIP TO OTHER BUILDINGS } \\
\text { Building } 2668 \text { is located on the west side of the Triad in the } 2600 \\
\text { WWII block. It is located to the east of the intersection of South F } \\
\text { Street and West Twelfth Street. Buildings } 2658,2659 \text {, and } 2669 \text { are } \\
\text { to the north, and Buildings } 2661,2662 \text {, and } 2667 \text { are to the south. } \\
\text { A paved lot is located on the east side of the structure. }\end{array}$} & & \\
\hline
\end{tabular}




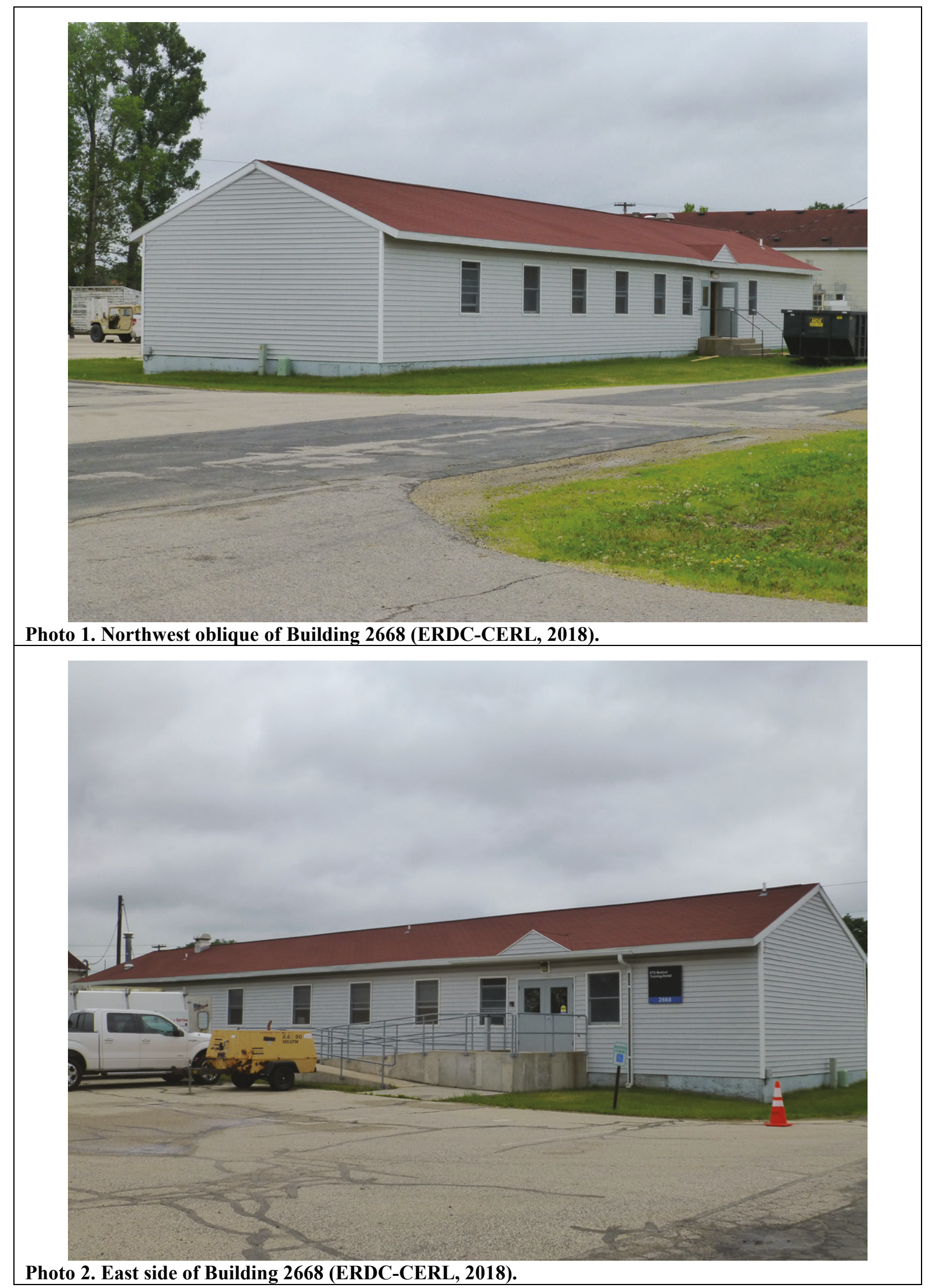




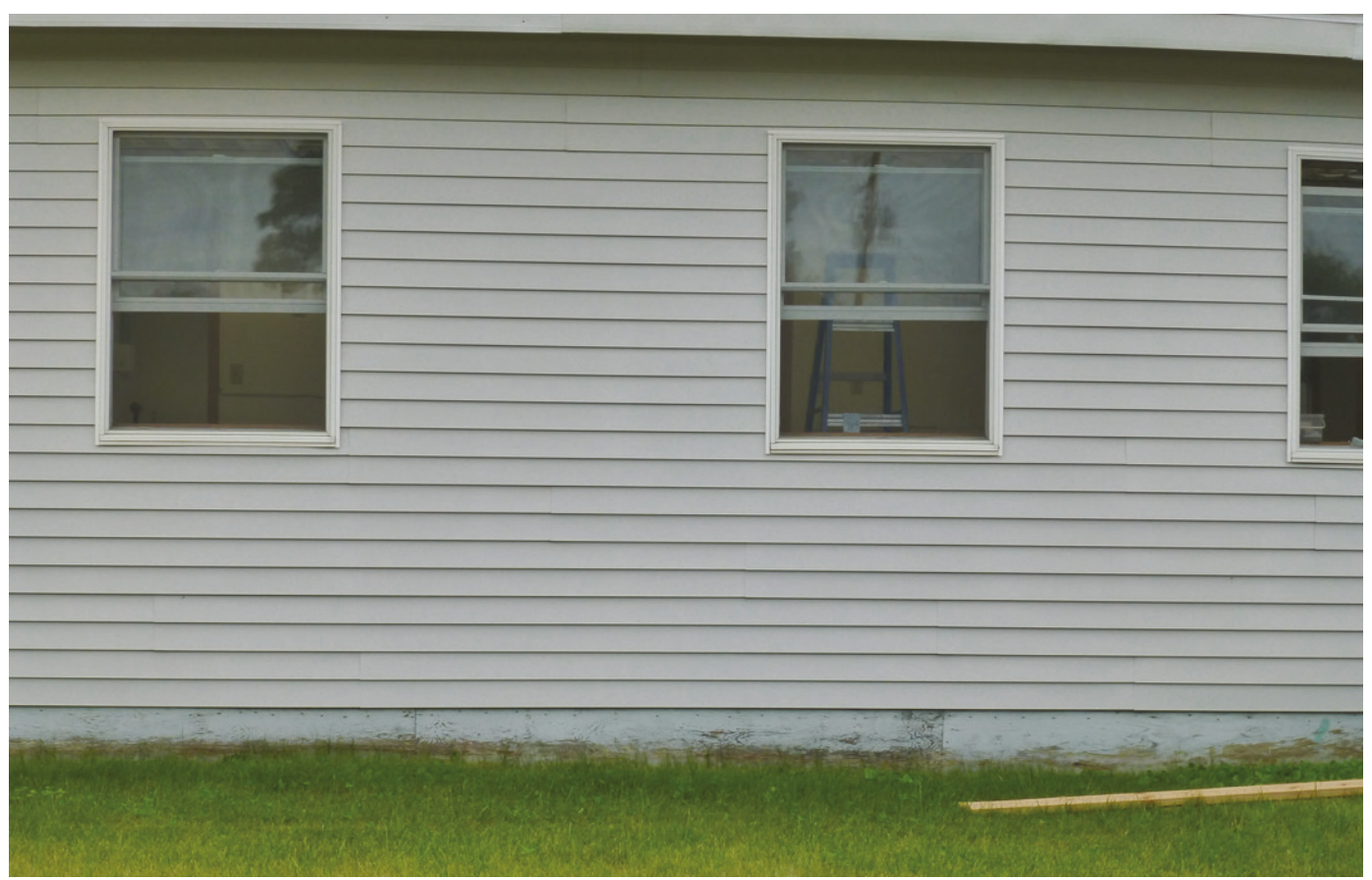

Photo 3. Close-up of the new vinyl siding, new wood foundation skirting, and replacement windows of Building 2668 (ERDC-CERL, 2018).

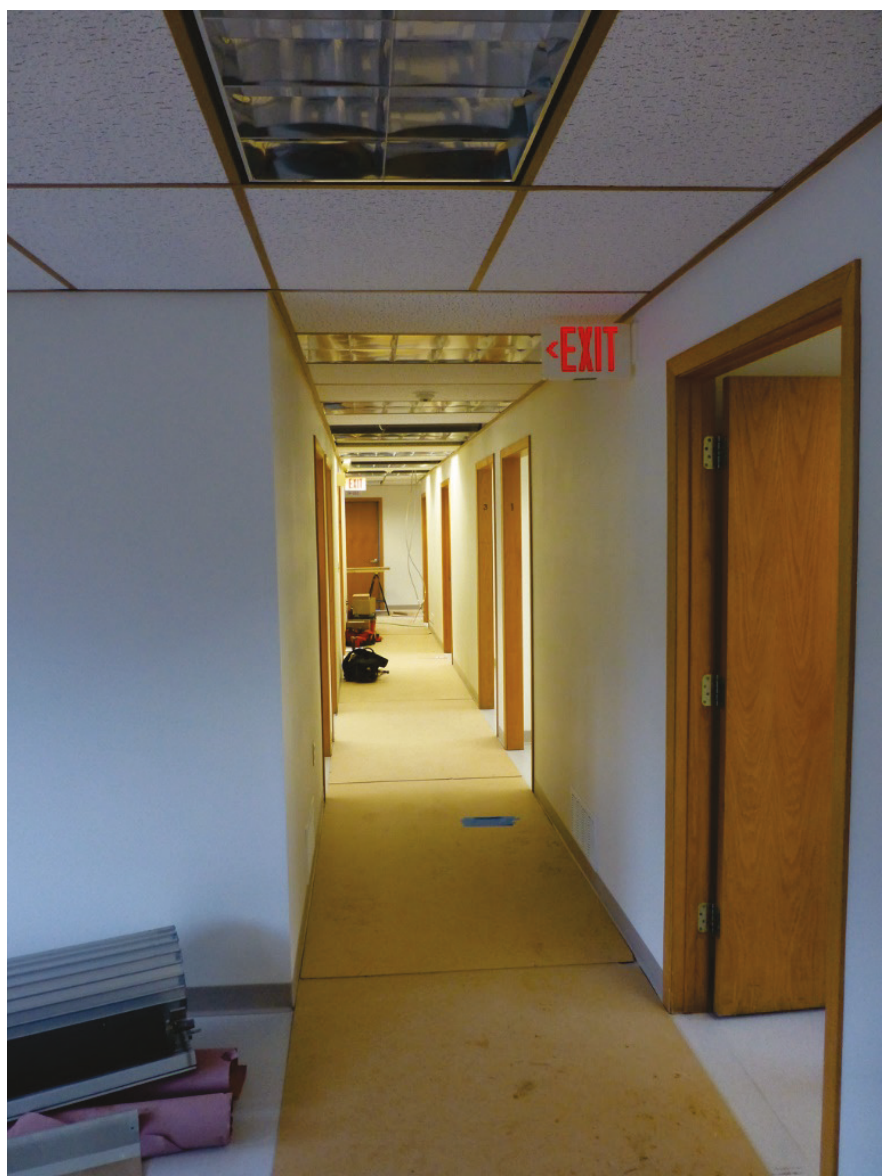

Photo 4. View of the modified interior spaces of Building 2668 with new partition walls, ceiling, floors, and doors (ERDC-CERL, 2018). 


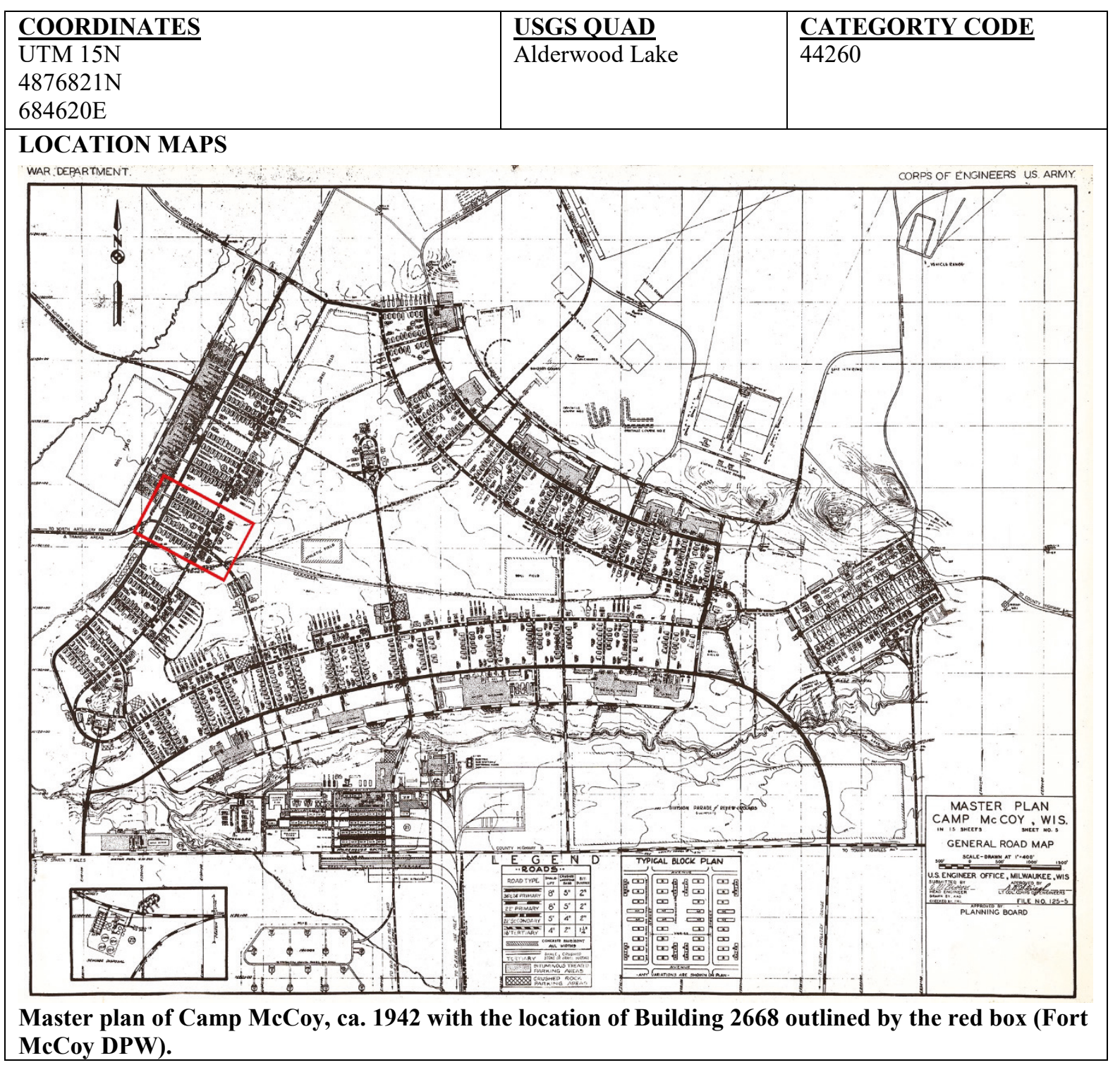




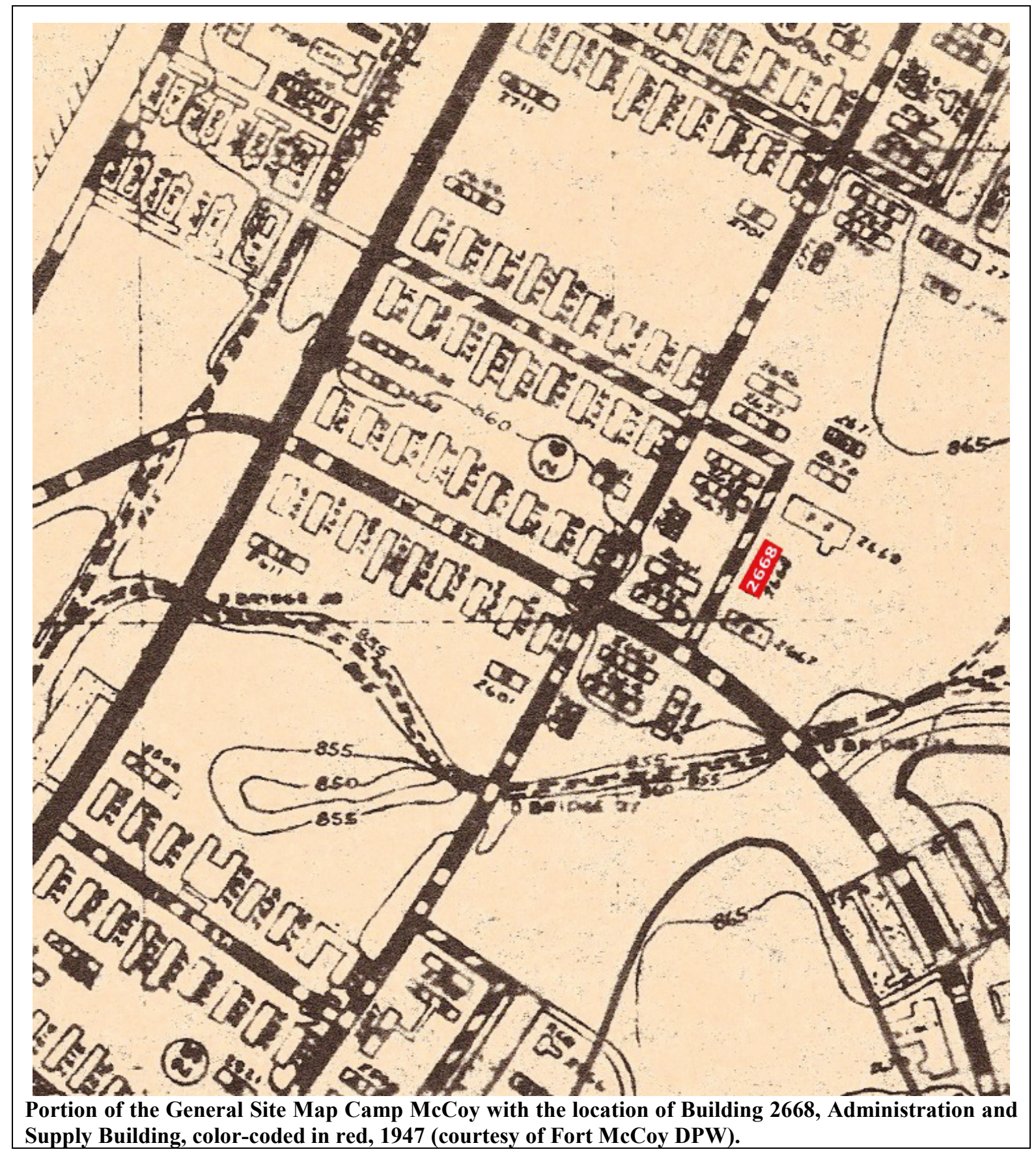




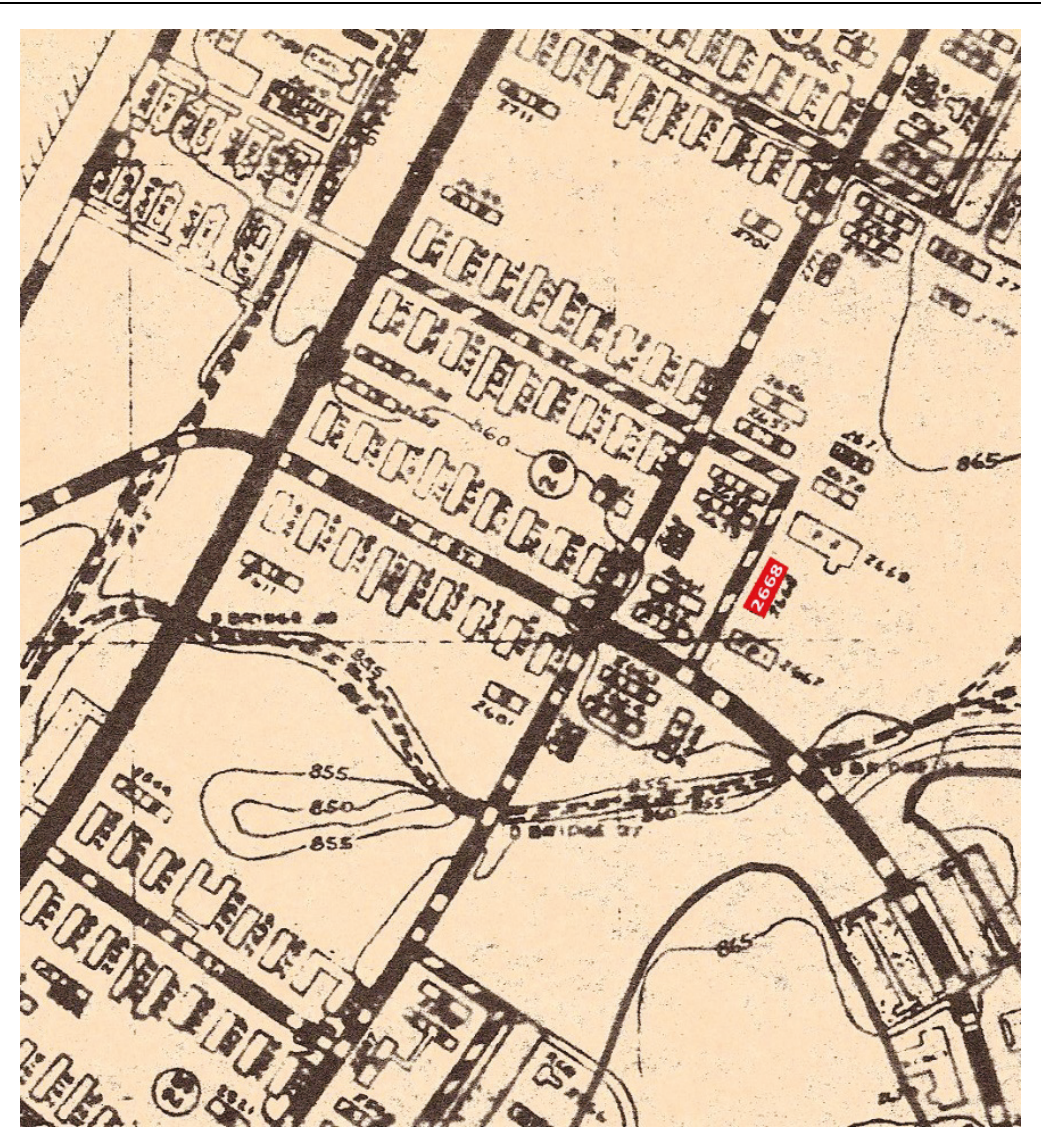

Portion of the General Site Map Camp McCoy with the location of Building 2668, Administration and Supply Building, color-coded in red, 1965 (courtesy of Fort McCoy DPW). 


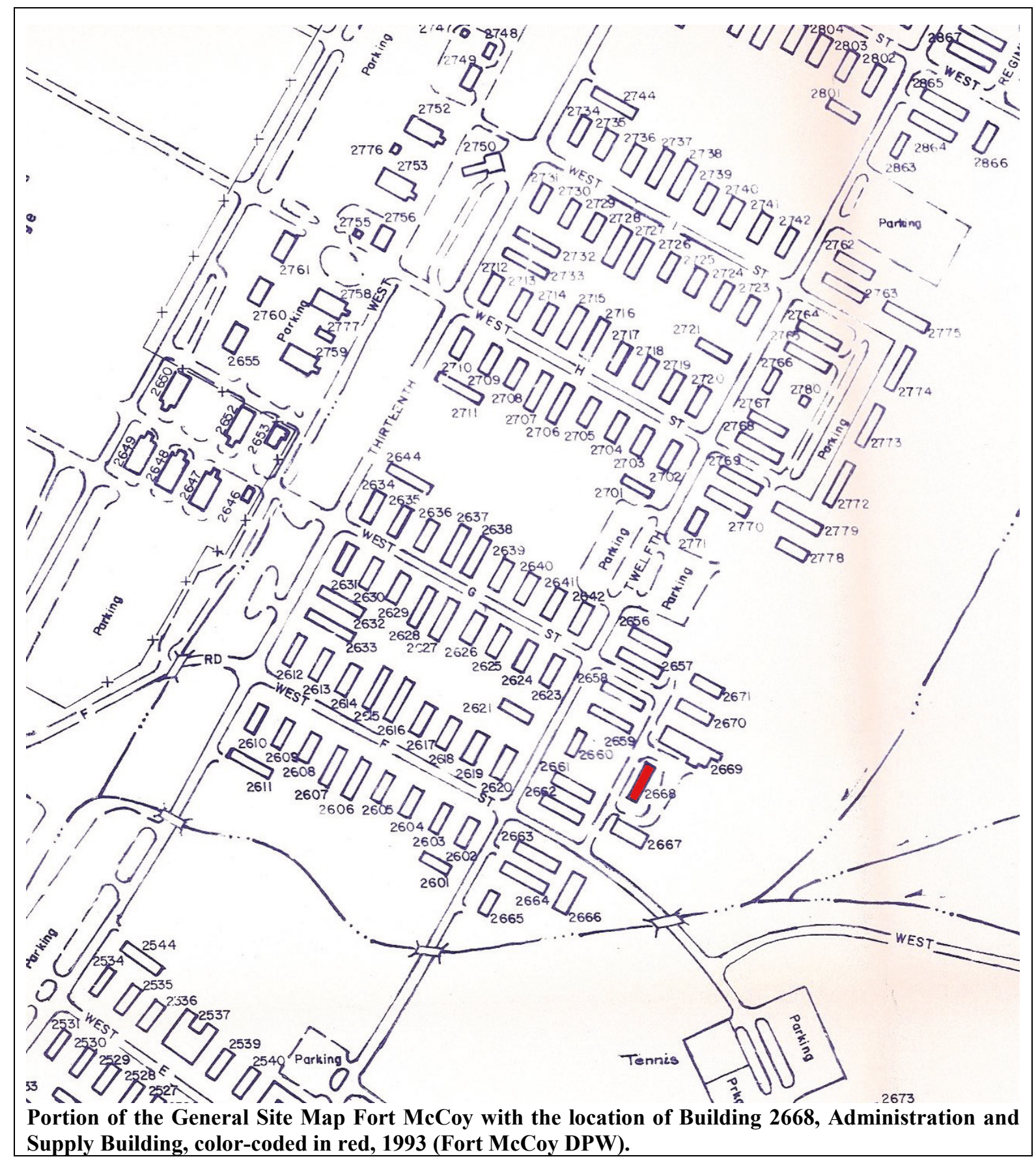




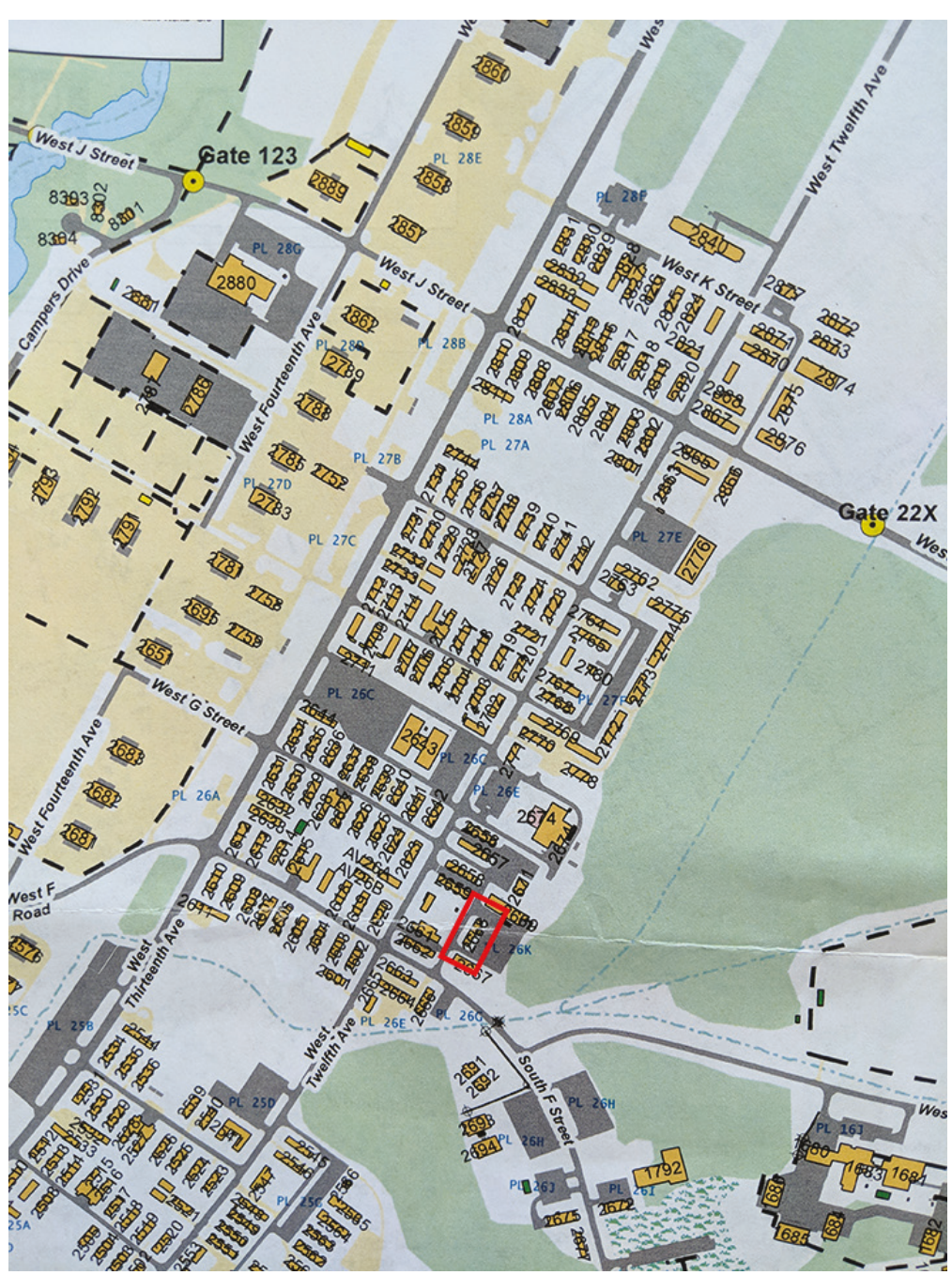

Portion of the General Site Map Fort McCoy with the location of Building 2668, Administration and Supply Building, outlined in red, 2014 (courtesy of Fort McCoy DPW). 


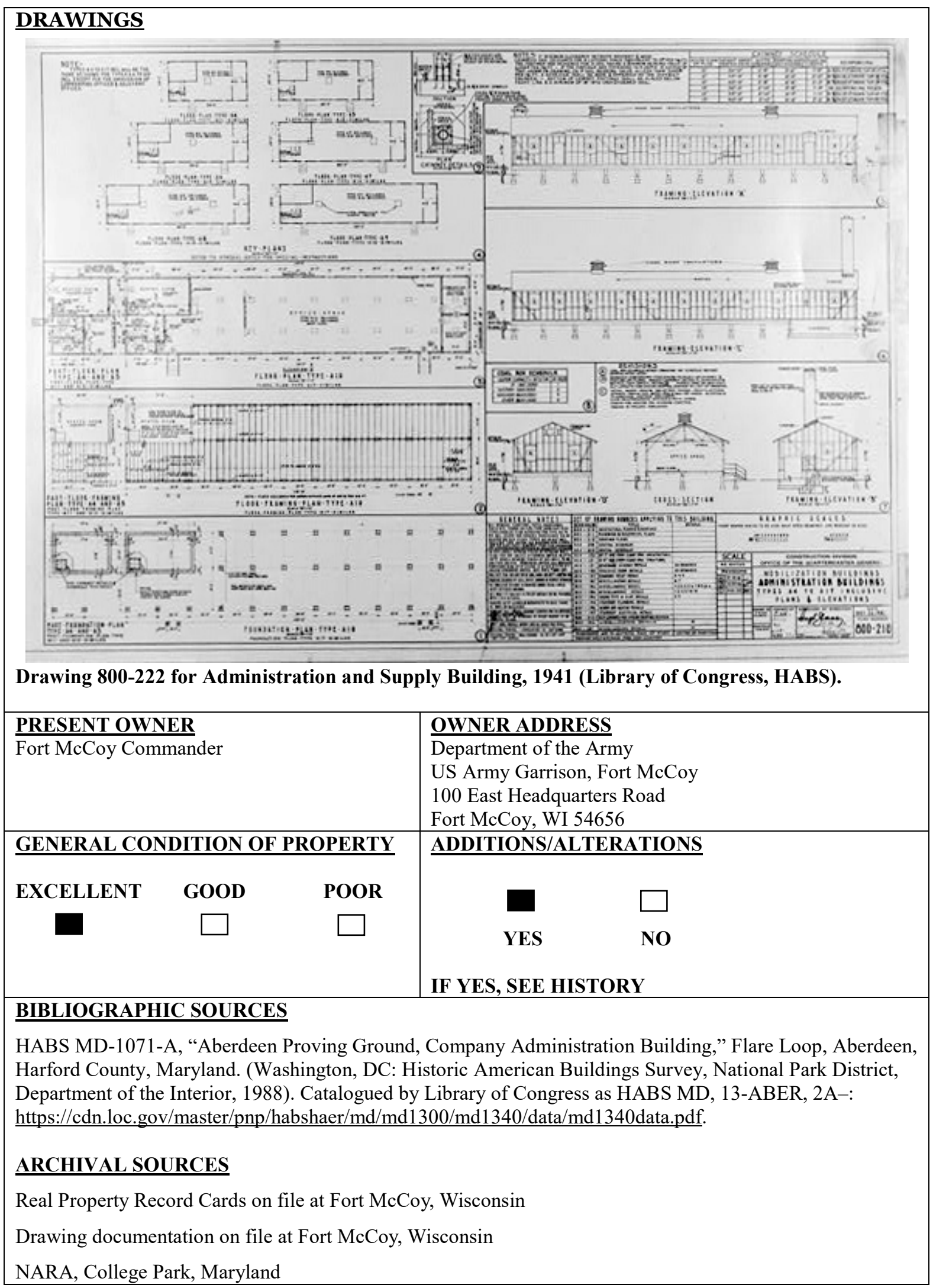




\section{PRELIMINARY NATIONAL REGISTER DETERMINATION OF ELIGIBILITY}

ELIGIBLE/ CONTRIBUTING
NOT ELIGIBLE/ NON-CONTRIBUTING

\section{FORM PREPARED BY:}

Sunny Adams

Engineer Research and Development Center

Construction Engineering Research Laboratory

2902 Newmark Drive

Champaign, IL 61822

DATE: September 2018

\section{DESCRIPTION}

Building 2668 is located on the west side of the Triad in the 2600 WWII block. It is located to the east of the intersection of South F Street and West Twelfth Street. Buildings 2658, 2659, and 2669 are to the north and Buildings 2661, 2662, and 2667 are to the south. A paved lot is located on the east side of the structure.

Building 2668 is a long rectangular temporary structure that has a concrete pier foundation system encased in replacement wood foundation skirting, vinyl clad exterior walls, a side gable roof clad with red asphalt shingles, replacement one-over-one vinyl windows, and replacement metal and glass entry doors. The building measures approximately $110^{\prime}-0$ " long by $25^{\prime}-0$ " wide with an approximate area of 2,750 square feet. A newly constructed concrete ramp system is located on the east side of the structure.

The west (front) elevation faces South Twelfth Street. There are seven replacement windows and a set of elevated replacement doors. Concrete steps and stoop with metal handrails provide access to this entry. Above the door is a front-gable roof detail. The south elevation consists of a set of replacement metal doors, and the concrete block foundation wall for the heater room is exposed on the right side of this elevation. The east elevation faces a paved lot. There are six replacement windows and a set of elevated metal replacement doors. A poured concrete ramp with metal handrails provides access to this entry. The elevation is void of any fenestration.

The interior of Building 2668 has been completely remodeled, and nothing of the original layout and finishing materials exists. All new materials including drywall, flooring, partition walls, drop-ceilings, lighting, doors, and window trim have been recently added.

\section{HISTORY}

Typical blocks within the general layout were based both on military organizational requirements and city planning principles. Each block was to be occupied by a battalion of troops. Two blocks comprised a regiment. Within a block were six companies, depending on the type of battalion involved. Along each street in a block were four mess halls at center and ten or more barracks, with a company usually occupying three barracks and eating in one of the mess halls. To the rear of the barracks at either end of each street were company administration buildings, one for each company.

Building 2668 was erected as an administration and supply building in 1942, using standardized 800 Series plans from the War Department, Drawing 800-222.

Walls: The exterior wall consists of wooden sheathing composed of 7-1/8" tongue and groove boards, black construction paper which acts as a vapor barrier, and siding composed of cement asbestos pieces measuring $11 " \mathrm{x} 24$ ", the standard size used throughout the cantonment. One-story buildings erected from the 800 Series standard plans are of balloon construction.

Foundation: The buildings had longitudinal rows of square concrete piers. A wooden foundation skirting encompassed this foundation system.

Roof: A low-pitched gable roof clad red asphalt shingles. The overhanging eaves had wood fascia and soffits.

Exterior Doors: The doors were of standard design, and each contained four lights in its upper half and three horizontal recessed panels in its lower section.

Windows: The windows were multipane wood double-hung. The architrave of the opening was of the same simple board design found in the other mobilization building types. The surrounds and sash were both painted a yellow color. Wire insect screen hung on the outside of all the windows. 
Flooring: A wooden floor.

Walls and ceiling finishes: Insulation boards on the lower part of the walls, and fiber board on the upper portion of these walls. The ceiling panels were insulation boards nailed in place by battens.

Interior doors: The interior doors were standard-issue solid-wood doors constructed in the typical interior pattern: five, horizontal, recessed panels.

Lighting: The original were metal bases with glass globes.

The building was heavily modified in 2004. The only original feature intact is the overall one-story massing. The siding, roofing (in-kind), foundation skirting, brick chimney stack, multipane wood double-hung windows, wood panel and divided light doors, and porch stoops were all removed at this time. The interior of the building also underwent major modification with all-new interior finishes. The original floor was modified with the construction of several partition walls.

Its category code was changed to a recreation center in 1991. The building is currently again being utilized as an administration building.

\section{HISTORIC PHOTOGRAPHS}

None available.

\section{CHARACTER-DEFINING FEATURES}

- One-story massing

- Rectangular footprint

- Side gable roof clad with red asphalt shingles (replaced roof in-kind)

- Overhanging eaves with wood fascia and soffit (modified with metal soffits)

- Textured cement asbestos siding with a scalloped bottom edge detail (replaced with vinyl siding)

- Concrete pier foundation with wooden foundation skirting (replaced)

- Window pattern

- Multipane wood double-hung windows (replaced with one-over vinyl windows)

- Wood trim, surround, and profile of windows (removed)

- Wood panel and divided light doors (replaced with newer metal doors)

- Room arrangement (modified with partition walls)

- Exposed softwood floors (replaced)

- Wood 5-panel interior doors (replaced)

- Wood trim around windows (replaced)

- Interior light fixtures (replaced)

- Insulation board and batten details on walls and ceiling (replaced)

\section{COMPARISON IMAGES}
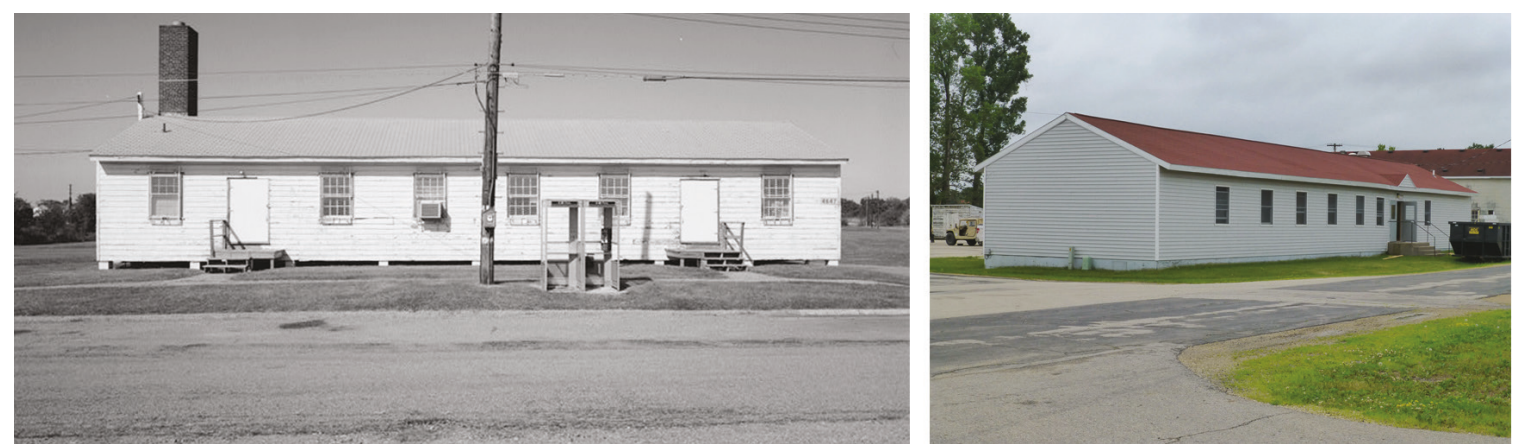

South (front) elevation of Building 4647 at Aberdeen Proving Ground, MD in 1988 (left) compared to 2018 (right) (left: Library of Congress, HABS; right: ERDC-CERL). 


\section{SIGNIFICANCE}

The 800 Series (and the 700 Series that preceded it), was a comprehensive set of drawings which could be used interchangeably in creating various building types. War mobilization buildings are significant for their construction and technological innovation. Techniques such as the standardization of plans, prefabrication of units, and assembly-line approach to construction were largely pioneered in the construction of these mobilization structures (from the HABS caption: http://www.loc.gov/pictures/collection/hh/item/wi0557/).

The temporary wood buildings constructed with the 700 Series or 800 Series plans on Fort McCoy during World War II (WWII) between 1939 and 1946 were determined significant for the National Register of Historic Places (NRHP) in 1986, when the Programmatic Memorandum of Agreement (PMOA) was signed between the Department of Defense (DoD), the Advisory Council on Historic Preservation (ACHP), and the National Council of State Historic Preservation Officers (NCSHPO). In the early 1990s, this significance was reaffirmed by the writing of "World War II and the U.S. Army Mobilization Program: A History of 700 and 800 Series Cantonment Construction" and Historic American Buildings Survey (HABS) performed on a variety of the 700 and 800 Series planned buildings across the country. Many of the 800 Series buildings at Fort McCoy were utilized for the HABS.

Building 2668, Administration and Supply Building, a WWII temporary building, is significant under Criterion A for WWII temporary building construction (1939-1946).

The design and construction of the WWII temporary buildings could not be linked to a specific architect due to their construction from standardized War Department temporary building plans. These buildings do not possess high artistic values; however, WWII temporary buildings in general were found to be significant for their design, construction, and technological innovation under Criterion $\mathrm{C}$.

\section{INTEGRITY}

Location - Building 2668 retain its integrity of location.

Design - Building 2668 retains the key elements of its WWII design.

Setting - Building 2668 retains its integrity of setting.

Materials - Building 2668 does not retain its integrity of materials. The building has been completely modified with newer materials. No original material elements are intact.

Workmanship - Workmanship is not part of integrity for WWII temporary buildings, including Building 2668.

Feeling - Building 2668 does not retain its integrity. It has been heavily modified with modern materials. Association - Building 2668 retains its integrity of association.

\section{RECOMMENDATION OF CONTRIBUTING/NONCONTRIBUTING STATUS}

It is the recommendation of this report that Building 2668, Administration and Supply Building, is NOT Eligible for the NRHP at the national level due to the lack of integrity from changes in floor plan, changes in siding, changes in window pattern and type, changes in doors, and dismantled chimney stack. 
[Intentionally blank.] 


\section{Bibliography}

“22 Million Dollar Improvement for McCoy.” Monroe County Democrat July 31, 1941.

“All Right, You Guys, We're Moving-On to New Site.” The Real McCoy, Vol. 1, No. 6, August 28, 1942.

"Bids on McCoy Work Started February 14." Monroe County Democrat, February 16, 1942.

“Camp McCoy Cost Is Increased Seven Million.” Sparta Herald, March 23, 1942.

“Camps Awarded and/or Underway [and] Advanced Planning - Camps." National Archives, 107-23-894; as quoted in Historic American Building Survey, HABS 41308. Washington, DC: NARA, January 22, 1942.

“Closing Date for McCoy Bids Nears.” Sparta Herald, March 16, 1942.

“Complete One McCoy Survey.” Monroe County Democrat, September 4, 1941.

"Construction at Camp McCoy Getting Along, The Place Is Seething with Activity." Monroe County Democrat, April 16, 1942.

“Construction Division Expansion.” Civil Engineering, Vol. II, No. 3 (March 1941).

“Construction Is Authorized for Camp McCoy.” Monroe County Democrat, February 12, 1942.

“Construction QM Office at McCoy,” Monroe County Democrat, July 31, 1941.

“The 'Daddy' of Camp McCoy to New Fields.” The Real McCoy, October 16, 1942.

"Doubled Population Predicted for Sparta, Tomah, Districts." Monroe County Democrat, August 14, 1941.

Elkin, Sgt. Lew. "Post Headquarters in New Camp Now.” The Real McCoy, September 25, 1942.

“Files Tell Events Leading to McCoy Expansion.” Monroe County Democrat July 31, 1941.

Fine, Lenore, and Jesse A. Remington. The Corps of Engineers: Construction in the United States [volume in the series, United States Army in World War II: The Technical Services]. Washington, DC: Office of the Chief of Military History, United States Army, 1972.

“Government Buys Lumber for Army Cantonment.” Monroe County Democrat, April 23, 1942. 
HABS No. WI-308. "Fort McCoy (Camp McCoy)." (Washington, DC: Historic American Buildings Survey, National Park District, Department of the Interior, 1988). Catalogued by Library of Congress as HABS WIS, 41-SPAR.V, 1-: https://cdn.loc.gov/master/pnp/habshaer/wi/wi0200/wi0229/data/wi0229data.pdf.https:// cdn.loc.gov/master/pnp/habshaer/wi/wi0200/wi0229/data/wi0229data.pdf.

HABS No. WI-308-A. "Fort McCoy, Building T-1129, Sparta, Monroe County, Wisconsin.” (Washington, DC: Historic American Buildings Survey, National Park District, Department of the Interior, 1988). Catalogued by Library of Congress as HABS WIS, 41-SPAR.V, 1-A-: https://cdn.loc.gov/master/pnp/habshaer/wi/wi0200/wi0261/data/wi0261data.pdf.

HABS No. WI-308-C. "Fort McCoy, Building T-801 (Storehouse, Administration \& Recreation Building), Sparta vicinity, Monroe County, Wisconsin.” (Washington, DC: Historic American Buildings Survey, National Park District, Department of the Interior, 1988). Catalogued by Library of Congress as HABS WIS, 41-SPAR.V, 1-B-: https://cdn.loc.gov/master/pnp/habshaer/wi/wi0200/wi0262/data/wi0262data.pdf.

HABS No. WI-308-FD. "Fort McCoy, Building No. T-1555, Intersection of South Tenth Avenue \& South "J" Street, Sparta, Monroe County, Wisconsin." (Denver, CO: Historic American Buildings Survey, National Park Service, Department of the Interior, 1988). Catalogued by Library of Congress as HABS, WIS, 41-SPAR.V, 1FD-: https://cdn.loc.gov/master/pnp/habshaer/wi/wi0500/wi0557/data/wi0557data.pdf.

HABS No. WI-308-J. "Fort McCoy, Building T-2000 (Service Club).” (Washington, DC: Historic American Buildings Survey, National Park District, Department of the Interior, 1988). Cataloged by Library of Congress as HABS WIS, 41-SPAR.V,1-J7. Copy in unmarked wooden container in Meatlocker storage room, Building 2145, Fort McCoy, Wisconsin.

HABS No. MD-1071-A. "Aberdeen Proving Ground, Company Administration Building (Building \#4647),” Flare Loop, Aberdeen, Harford County, Maryland (Philadelphia, PA: Historic American Buildings Survey, National Park Service Northeast Region, Department of the Interior, 1988). Catalogued by Library of Congress as MABS MD 13-ABER, 2A-: https://cdn.loc.gov/master/pnp/habshaer/md/md1300/md1340/data/md1340data.pdf.

"Historical Summary." Typescript release prepared by and on file at Public Affairs Office, Fort McCoy, ca. 1985.

“Maj. Gen. Cummins Sees McCoy Possibilities.” Monroe County Democrat, August 7, 1941.

“McCoy Land Appraisal Opens; Begin Activity.”. Sparta Herald, August 11, 1941.

"McCoy Survey Project on Schedule, Power Surveyed." Monroe County Democrat, August 21, 1941.

Mittelstaedt, Lou Ann. “McCoy’s History, 1947-Present.” Triad, Vol. 3, No.11, May 29, 1986.

"More Contracts Being Let at McCoy Cantonment." Monroe County Democrat, March 26, 1942. 
"More Wisconsin Concerns Get Contracts at McCoy." Monroe County Democrat, April 2, 1942.

“New Camp McCoy Open Sunday.” Monroe County Democrat, August 27, 1941.

Nelson, Lee H. National Park Service Preservation Brief 17: Architectural CharacterIdentifying the Visual Aspect of Historic Buildings as an Aid to Preserving their Character. Washington, DC: U.S. Department of the Interior, National Park Service, 1988.

NPS. National Register Bulletin \#15: How to Apply the National Register Criteria for Evaluation. Washington, DC: U.S. Department of the Interior, 1997 (rev.).

. National Register Bulletin \#16A: How to Complete the National Register Registration Form. Washington, DC: U.S. Department of the Interior, National Park Service, 1997.

. National Register Bulletin: How to Prepare National Historic Landmark Nominations. Washington, DC: U.S. Department of the Interior, National Park Service, 1999.

“Officer Who Helped Build McCoy in '42 Recalls Post's Early Construction Days.” Undated, ca. 1950s newspaper clipping regarding Daniel C. Lamoreaux, found in the Public Affairs Office archive, Fort McCoy.

"Picture Taking Now Permitted, But Cautiously." The Real McCoy, October 9, 1942.

“Prospects for McCoy Post Looking Bad.” Sparta Herald, October 6, 1941.

Scott, Mel. American City Planning Since 189o. Berkeley, CA: University of California Press, 1969.

Sorenson, Martha. "Post Becomes a Reality in 1909." Triad, 3:11, May 29, 1986.

"Success at Last." Sparta Herald, August 4, 1941.

“To Condemn 9600 Acres for McCoy, Petition to Be Filed Monday.” Sparta Herald, February 9, 1942.

“Triangular McCoy Site Plan Approved by 6th Corps Area.” Sparta Herald.September 29, 1941.

"U. S. to Receive Bids for Camp McCoy Project." Monroe County Democrat, February 5, 1942.

Wasch, Diane Shaw, Perry Bush, Keith Landreth, and James Glass. World War II and the U.S Army Mobilization Program: A History of the 700 and 800 Series Cantonment Program. Prepared for and funded by Legacy Resources Management Program. Washington, DC: Joint effort of HABS/HAER of National Park Service, Department of Interior; and DoD Legacy Resources Management Program of the Department of the Army Engineering and Housing Support Center, 24 March 1992. http://archive.org/details/worldwariiusarmyOOwasc. 
"Work at McCoy Scheduled to Start About March 20; Bids to Close March $7^{\text {th." Monroe }}$ County Democrat, February 26, 1942.

“Work Started on McCoy Building.” Monroe County Democrat, February 19, 1942.

“Where Soldiers Will Live at New McCoy.” Sparta Herald, August 31, 1942.

\section{Archival resources - Camp McCoy area}

\section{Meat Locker storage room, Camp McCoy}

Boxes of archival files, photographs, inventories, etc., marked "Historical Records," Meatlocker.

"Buildings \& Structures Description."-An inventory of Camp McCoy buildings prepared by the Post Engineer Office, ca. 1945. Now in box marked "Historical Engineering Records," Meatlocker storage room, Fort McCoy.

"Index, Drawings from Area Engineer." February 1944. Prepared by Area Engineer and now in "Historical Engineering Records" box, Meatlocker storage room, Fort McCoy.

Original plans prepared by the Office of Area Engineer at Camp McCoy, 1942, now stored in map files in Meatlocker-storage room, Building 2145, and in entry hall, Building 2111, Fort McCoy.

Post Engineer Office, Camp McCoy, Wisconsin. "Historical Data" [typescript copy of original ditto version], January 15, 1946 (both versions are in the "Historical Engineering Records” box, Meatlocker).

Vandyke master copies of standard War Department plans used in the construction of Camp McCoy, now stored in map files in the "Meatlocker."

\section{Public Affairs Office}

Archive, Public Affairs Office, Fort McCoy, Wisconsin.

\section{Sparta Free Library}

Camp McCoy photograph collection, Monroe County Local History Room, Sparta Free Library, Sparta, Wisconsin.

Clippings files on Fort McCoy at Sparta Free Library, Sparta, Wisconsin.

\section{Archival resources - other}

ERDC-CERL Library, Champaign, IL.

Library of Congress, Historic American Buildings Survey collection. 
NARA, College Park, RG111-SC and RG111-CCS.

NARA, Washington, DC. Various collections.

Office of the Chief of Engineers [engineering manuals issued in chapters dated from March 1942 to February 1943] .Washington, DC: Corps of Engineers, 1942-43. 


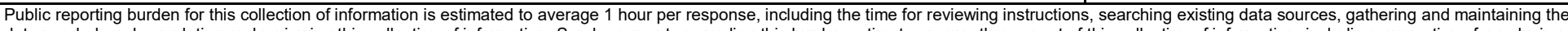

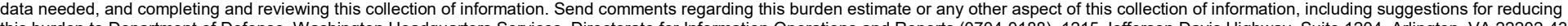

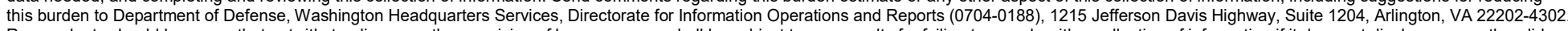

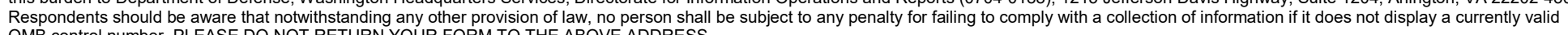
OMB control number. PLEASE DO NOT RETURN YOUR FORM TO THE ABOVE ADDRESS.
1. REPORT DATE (DD-MM-YYYY)
2. REPORT TYPE

December 2018

\section{TITLE AND SUBTITLE}

Final Technical Report

Determination of NRHP Eligibility for 26 Buildings at Fort McCoy, Wisconsin

3. DATES COVERED (From - To)

5a. CONTRACT NUMBER

5b. GRANT NUMBER

5c. PROGRAM ELEMENT NUMBER

6. AUTHOR(S)

Adam D. Smith and Sunny E. Adams 5d. PROJECT NUMBER

474178

5e. TASK NUMBER

5

f. WORK UNIT NUMBER

8. PERFORMING ORGANIZATION REPORT NUMBER

ERDC/CERL TR-18-38
7. PERFORMING ORGANIZATION NAME(S) AND ADDRESS(ES)

U.S. Army Engineer Research and Development Center (ERDC)

Construction Engineering Research Laboratory (CERL)

PO Box 9005

Champaign, IL 61826-9005

\section{SPONSORING / MONITORING AGENCY NAME(S) AND ADDRESS(ES)}

Cultural Resources Manager

Directorate of Public Works

Fort McCoy, WI 54656
10. SPONSOR/MONITOR'S ACRONYM(S)

11. SPONSOR/MONITOR'S REPORT NUMBER(S)

\section{DISTRIBUTION / AVAILABILITY STATEMENT}

Approved for public release. Distribution is unlimited.

\section{SUPPLEMENTARY NOTES}

\section{ABSTRACT}

The U.S. Congress codified the National Historic Preservation Act of 1966 (NHPA), the nation's most effective cultural resources legislation to date, mostly through establishing the National Register of Historic Places (NRHP). The NHPA requires federal agencies to address their cultural resources, which are defined as any prehistoric or historic district, site, building, structure, or object. Section 110 of the NHPA requires federal agencies to inventory and evaluate their cultural resources, and Section 106 requires them to determine the effect of federal undertakings on those potentially eligible for the NRHP.

Fort McCoy is in west-central Wisconsin, entirely within Monroe County. It was first established as the Sparta Maneuver Tract in 1909. The post was renamed Camp McCoy in 1926. Since 1974, it has been known as Fort McCoy. It has one of the largest surviving collections of World War II (WWII) mobilization buildings. This report provides historic context and determinations of eligibility for 26 of those buildings and concludes that only two (fire station and service club) are eligible for the NRHP at the national level, under Criteria A and C. In consultation with the Wisconsin State Historic Preservation Officer, this work fulfills Section 106 and Section 110 processes for these buildings.

\section{SUBJECT TERMS}

Fort McCoy (Wisc.), Military bases, Architectural surveys, Historic preservation, Historic buildings, National Register of Historic Places (NRHP)

\begin{tabular}{|c|c|c|c|c|c|}
\hline \multicolumn{3}{|c|}{ 16. SECURITY CLASSIFICATION OF: } & \multirow{2}{*}{$\begin{array}{l}\text { 17. LIMITATION } \\
\text { OF ABSTRACT } \\
\text { UU }\end{array}$} & \multirow{2}{*}{$\begin{array}{l}\text { 18. NUMBER } \\
\text { OF PAGES } \\
418\end{array}$} & 19a. NAME OF RESPONSIBLE PERSON \\
\hline $\begin{array}{l}\text { a. REPORT } \\
\text { Unclassified }\end{array}$ & $\begin{array}{l}\text { b. ABSTRACT } \\
\text { Unclassified }\end{array}$ & $\begin{array}{l}\text { c. THIS PAGE } \\
\text { Unclassified }\end{array}$ & & & $\begin{array}{l}\text { 19b. TELEPHONE NUMBER } \\
\text { (include area code) }\end{array}$ \\
\hline
\end{tabular}

